

Universidade de Brasília

Faculdade de Economia, Administração e Contabilidade

Programa de Pós-graduação em Administração

Doutorado em Administração

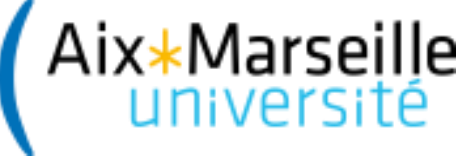

Université d'Aix-Marseille

École Doctorale de Sciences Economiques et de Gestion Centre d'Études et de Recherche en Gestion

Doctorat en Sciences de Gestion

\title{
DESEMPENHO PROFISSIONAL: RELAÇÕES COM VALORES, PRÁTICAS E IDENTIDADE NO SERVIÇO POLICIAL
}

\author{
PERFORMANCE COMPÉTENTE: RELATIONS AVEC VALEURS, \\ PRATIQUES ET IDENTITÉ DANS LE SERVICE DE POLICE
}

THIAGO GOMES NASCIMENTO

Brasília - DF 
Universidade de Brasília

Faculdade de Economia, Administração e Contabilidade Programa de Pós-graduação em Administração

Doutorado em Administração
Université d'Aix-Marseille

École Doctorale de Sciences Economiques et de Gestion Centre d'Études et de Recherche en Gestion

Doctorat en Sciences de Gestion

\title{
DESEMPENHO PROFISSIONAL: RELAÇÕES COM VALORES, PRÁTICAS E IDENTIDADE NO SERVIÇO POLICIAL ${ }^{1}$
}

\author{
PERFORMANCE COMPÉTENTE: RELATIONS AVEC VALEURS, \\ PRATIQUES ET IDENTITÉ DANS LE SERVICE DE POLICE ${ }^{2}$
}

\section{THIAGO GOMES NASCIMENTO}

\author{
Brasília - DF
}

2014

\footnotetext{
${ }^{1}$ Este trabalho foi realizado com apoio da Coordenação de Aperfeiçoamento de Pessoal de Nível Superior (CAPES/Brasil) e com apoio do Comitê Francês de Avaliação da Cooperação Universitária com o Brasil (COFECUB/França).

${ }^{2}$ Cette thèse a été réalisée avec le soutien de la Coordination pour le Perfectionnement du Personnel de l'Enseignement Supérieur (CAPES/Brésil) et avec le soutien et d'évaluation du Comité Français de la Coopération Universitaire et Scientifique Avec le Brésil (COFECUB/France).
} 


\section{DESEMPENHO PROFISSIONAL: RELAÇÕES COM VALORES, PRÁTICAS E IDENTIDADE NO SERVIÇO POLICIAL}

\section{PERFORMANCE COMPÉTENTE: RELATIONS AVEC VALEURS, PRATIQUES ET IDENTITÉ DANS LE SERVICE DE POLICE}

Tese de Doutorado submetida ao Programa de pós-graduação em Administração da Universidade de Brasília (UnB) como requisito parcial para obtenção do grau de Doutor em Administração.

Thèse présentée au Centre d'Études et de Recherche en Gestion - CERGAM de l'École Doctorale de Sciences Économiques et de Gestion de l'Université d'Aix-Marseille - dans le cadre d'une cotutelle pour l'obtention du titre de Docteur en Sciences de Gestion.

Orientadora / Directrice de Recherche: Prof. Dra. Eda Castro Lucas de Souza

Orientador / Directeur de Recherche: Prof. Dr. Jean Philippe 
DESEMPENHO PROFISSIONAL: RELAÇÕES COM VALORES, PRÁTICAS E IDENTIDADE NO SERVIÇO POLICIAL

PERFORMANCE COMPÉTENTE: RELATIONS AVEC VALEURS, PRATIQUES ET IDENTITÉ DANS LE SERVICE DE POLICE

Apresentada e aprovada publicamente em 01 de dezembro de 2014 por: Présentée et soutenue publiquement le 01 de décembre 2014 par:

Profa. Dra. Eda Castro Lucas de SOUZA - Orientadora / Directrice de Recherche Programa de Pós-graduação em Administração Universidade de Brasília, Brasil

Prof. Dr. Jean PHILIPPE - Orientador / Directeur de Recherche

Centre d'Études et Recherche en Sciences de Gestion de Aix-Marseille

Université d'Aix-Marseille, França

Prof. Dr. Faïz GALLOUJ - Membro Externo / Rapporteur

Centre Lillois d'Études et de Recherches Sociologiques et Economiques

Université de Sciences et Techniques de Lille 1, França

Prof. Dra. Solange ALFINITO - Membro Interno / Rapporteuse

Programa de Pós-graduação em Administração

Universidade de Brasília, Brasil

Prof. Dra. Maria Cristina FERREIRA - Membro Externo / Membre du Jury

Programa de Pós-graduação em Psicologia

Universidade Salgado de Oliveira, Brasil

Prof. Dr. Francisco Antônio COELHO Jr. - Membro Interno / Membre du Jury Programa de Pós-graduação em Administração

Universidade de Brasília, Brasil

Brasília, 01 de dezembro de 2014. 
L'Université de Brasília et l'Université d'Aix-Marseille n'entend donner aucune approbation ni improbation aux opinions émises dans les thèses ; ces opinions doivent être considérées comme propres à leur auteur. 
À Daniele Alcântara, por todo amor e apoio irrestrito.

Aos meus pais, Manoel Pinheiro e Liduina Gomes, pelo afeto e fraternal amor. 
"O mais competente não discute, domina sua ciência $e$ cala-se" (Voltaire).

Enquanto a polícia não deixar de ser empírica, os avanços em sua função de servir e proteger serão incipientes (Thiago Gomes Nascimento).

"A Farda não é uma veste, que se despe com facilidade e até com indiferença, mas uma outra pele, que adere à própria alma, irreversivelmente para sempre" (General Octávio Costa). 


\section{Agradecimentos}

Uma tese de doutorado não é um empreendimento construído de forma exclusiva por uma única pessoa, seu autor. Antes disso, trata-se de um trabalho que envolve diversos colaboradores. Nesta, em especial, vários sãos aqueles, que, de forma direta ou indireta, tornaram possível este trabalho. A cada um, deixo meus sinceros agradecimentos:

À Coordenação de Aperfeiçoamento de Pessoal de Nível Superior (CAPES/Brasil) e ao Comitê Francês de Avaliação da Cooperação Universitária com o Brasil (COFECUB/França), pela concessão da bolsa de estudos, que me permitiu realizar o doutorado em cotutela.

Ao Programa de Pós-graduação em Administração da Universidade de Brasília e ao Centre d'Études et de Recherche en Gestion de Aix-Marseille de l'Université de AixMarseille, que me receberam e possibilitaram a construção deste trabalho.

À minha orientadora no Brasil, professora Eda Castro Lucas de Souza, pelo afeto, dedicação e competência com que me conduziu durante a elaboração deste trabalho. Sou particularmente grato pela confiança, respeito e incentivo que semprese fez presente em suas palavras e ações. Poucos são os alunos que têm a sorte de desfrutar de tantos momentos agradáveis quanto os nossos. Obrigado!

Ao meu orientador na França, professor Jean Philippe, por ter me mostrado a ordem, quando tudo parecia o caos. Merci beucoup pour votre accueil et pour votre orientation dans ce travail. Je lui suis particulièrement reconnaissant de sa rigueur, de ses conseils, ainsi que de la liberté et de la confiance qu'il m'a accordées pendant cette thèse.

Aos membros de minha banca de qualificação e de tese: Prof. Dr. Cláudio Vaz Torres, Profa. Dra. Denise Del Prá Netto Machado, Prof. Dr. Faiz Gallouj, Prof. Dr. Francisco Antônio Coelho Jr., Profa. Dra. Maria Cristina Ferreira, Prof. Dra. Solange Alfinito e Prof. Dr. Tomás de Aquino Guimarães. Suas contribuições foram imprescindíveis para o resultado deste trabalho. Muito Obrigado!

A todos os professores do PPGA, do PSTO e do CERGAM, que muito contribuíram para minha formação. E a todos os juízes e especialistas, que se dedicaram a avaliar partes substanciais deste trabalho.

Ao amigo e professor, Cláudio Torres, por todos os comentários e sugestões para o aperfeiçoamento da tese. Serei sempre grato!

À Professora Marina Moreira, pelas valiosas dicas e pelo auxílio com a documentação necessária para a realização da cotulela junto à Université d'Aix-Marseille. 
Aos amigos Breno Adaid e Eluiza Watanabe, por repartirem comigo as alegrias, os anseios e as frustrações durante o período do doutorado. E pela importante contribuição na leitura atenta e nas sugestões apontadas. Meus sinceros agradecimentos!

Ao Professor Pierre-Yves Léo, por sua ajuda durante a construção do modelo teórico e ao professor Armand Taranco por ter possibilitado e ministrado o seminário de estatística avançada quando de minha estadia em Aix-en-Provence.

Ao Professor Naliel Paixão, por ter me guiado no aprendizado do francês.

À Magdalena Depieri pela revisão do texto. À Karen Stadler pela tabulação dos dados. Ao Bruno Guérard pelo auxílio na tradução do texto.

À Policia Militar do Distrito Federal, pela autorização e apoio em todas as fases desta tese. Seria impossível nominar todos os policiais que contribuiram com este trabalho; agradeço, portanto, aos Comandantes-Gerais (CEL Suamy e CEL Anderson) e chefes do Estado-Maior (CEL Niño e CEL Venturim), ao CEL Nunes e aos demais oficiais e às praças da PMDF, que diretamente dedicaram seu tempo para participar desta pesquisa.

Aos funcionários do PPGA e do CERGAM, que tanto contribuíram com documentações e processos. Em especial à Sonária Lucia e à Armande Poret, obrigado!

Aos colegas do grupo de pesquisa em Cultura e Internacionalização da UnB, que tantas vezes viram e reviram este trabalho, sou muito grato!

Aos colegas do CULTI/UnB por nossas intensas discussões e às colegas do CERGAM/AMU, que tornaram minha estadia em Aix-en-Provence acolhedora.

Aos amigos que se preocuram e mesmo à distância torciam para meu sucesso.

Aos meus sogros, Sueli e José Alcântara, pelo carinho e acolhida, mesmo passando horas em frente ao computador nos finais de semana. Muito obrigado!

A toda minha família, que sofreu com tantas ausências, durante estes quase seis anos de pós-graduação. Vó, tios, tias, primos, irmão, cunhada saibam que sempre estavam em meus pensamentos e em meu coração; só assim, foi possível terminar este trabalho.

A meus pais, Liduina e Manoel (Mazinho), pelo amor fraterno e por todas as oportunidades que me proporcionaram. Serei eternamente grato!

À Daniele. Sem sua força, companheirismo, dedicação e intenso amor, isto não seria possível. Obrigado por fazer parte de minha vida. Amo-te!

Ao Grande Arquiteto do Universo, por ter me dado a sabedoria, a força e a serenidade necessárias para terminar este trabalho. 


\section{SUMÁRIO}

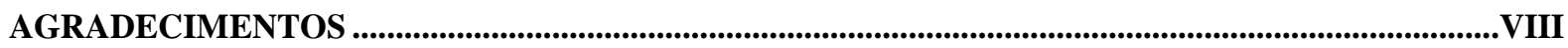

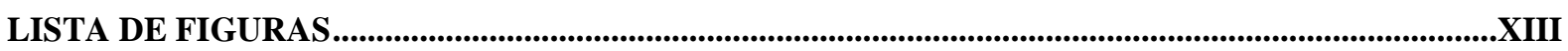

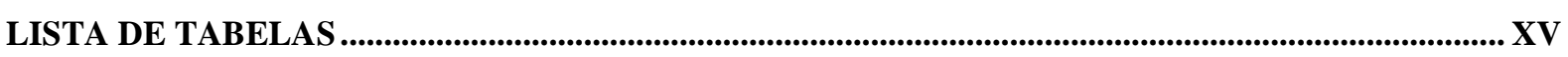

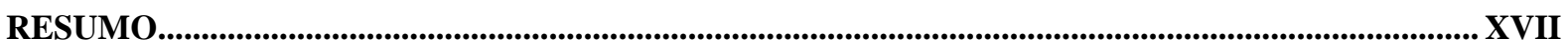

ABSTRACT ...................................................................................................................................................XVIII

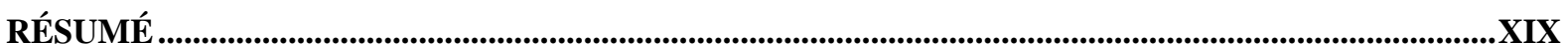

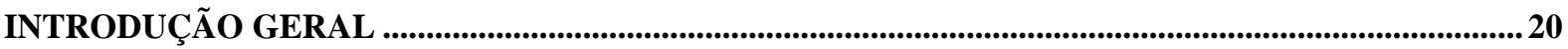

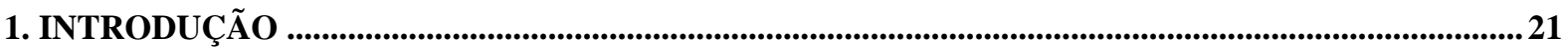

1.1 OBJETIVO GERAL

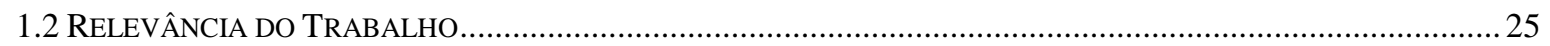



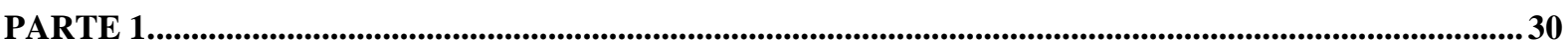

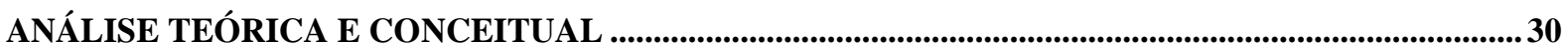

CAPÍTULO I. DESEMPENHO NO TRABALHO E DESEMPENHO POR COMPETÊNCIAS................33

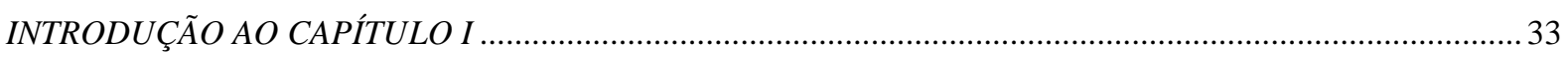

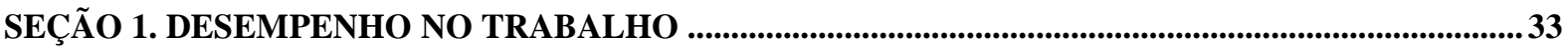

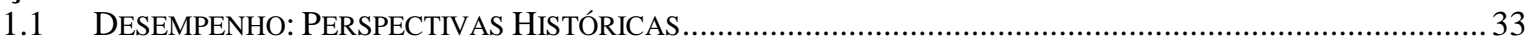

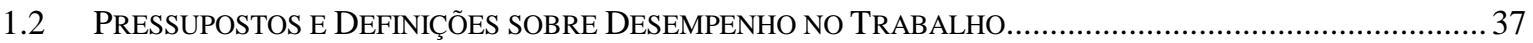

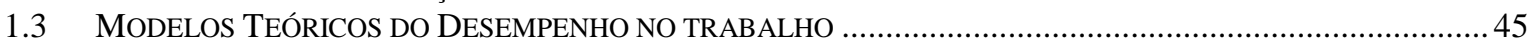

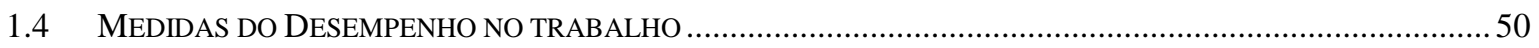

SEÇÃO 2. DESEMPENHO PROFISSIONAL POR COMPETÊNCIAS......................................................56

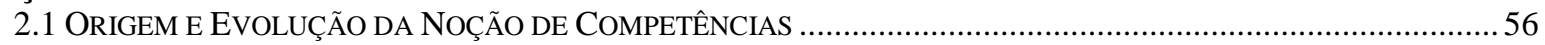

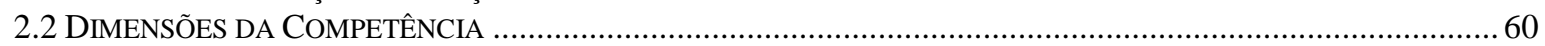

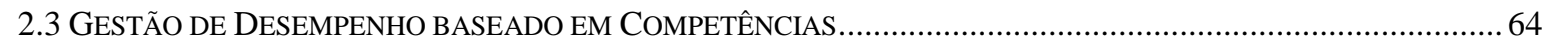

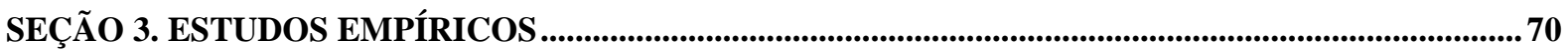

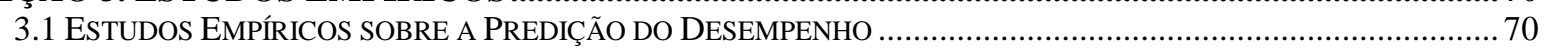

3.2 ESTUdos EMPÍRICOS SOBRE A RELAÇÃO ENTRE COMPETÊNCIA E DESEMPENHO........................................... 74

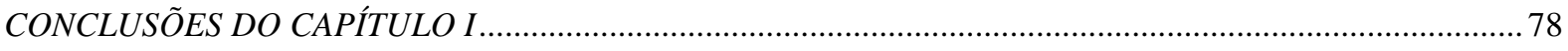

CAPÍTULO II. CULTURA, VALORES E PRÁTICAS ORGANIZACIONAIS ...........................................8

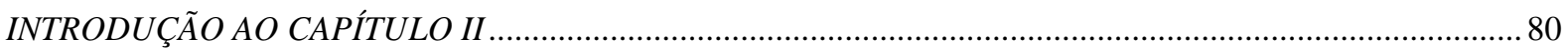

SEÇÃO 1. CULTURA NACIONAL E CULTURA ORGANIZACIONAL ................................................80

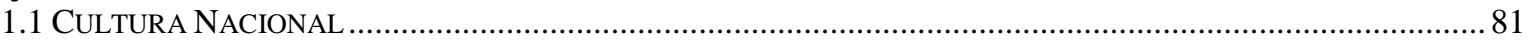

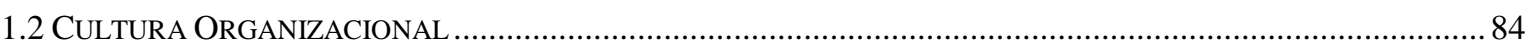

SEÇÃO 2. VALORES HUMANOS E VALORES ORGANIZACIONAIS..............................................108

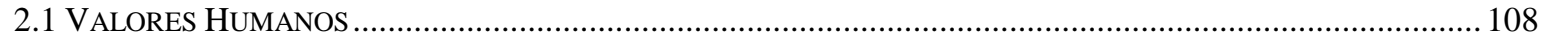

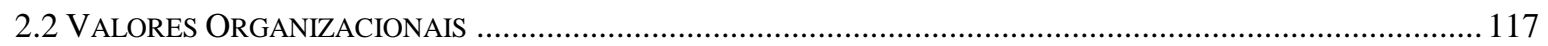

SEÇÃO 3. PRÁTICAS SOCIAIS E PRÁTICAS ORGANIZACIONAIS ...............................................133

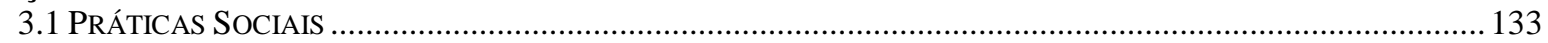

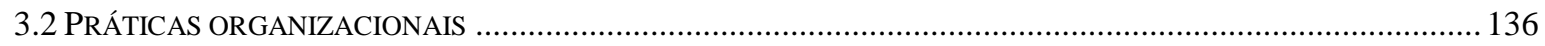

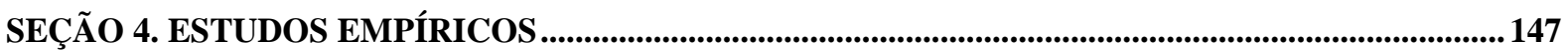

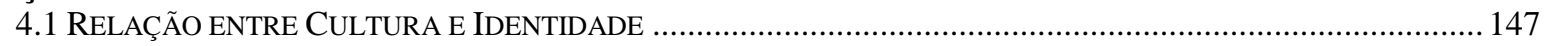

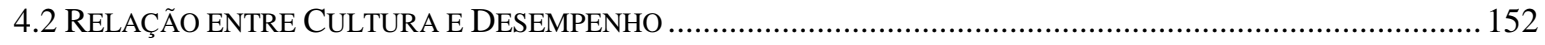

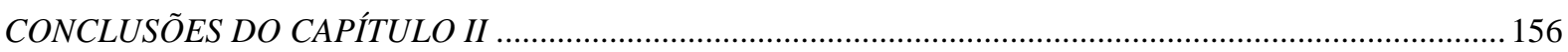


CAPÍTULO III. IDENTIDADE NO CONTEXTO DO TRABALHO E DA ORGANIZAÇÃO...............159

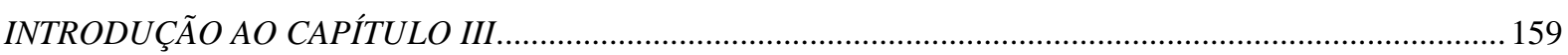

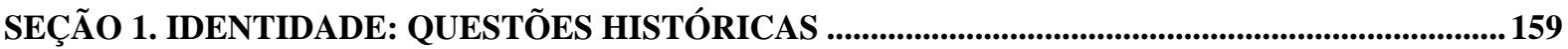

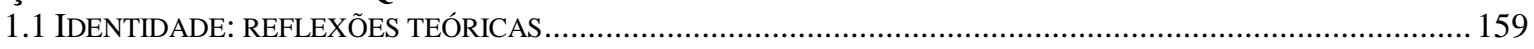

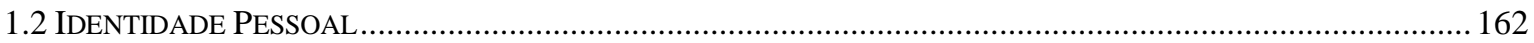

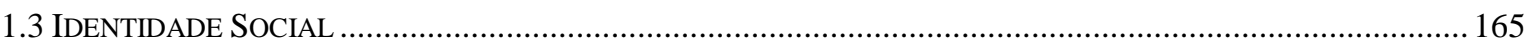

SEÇÃO 2. IDENTIDADE SOCIAL POR INTERMÉDIO DA TEORIA DA IDENTIDADE SOCIAL .. 168

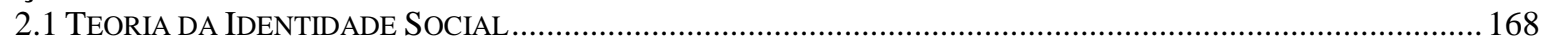

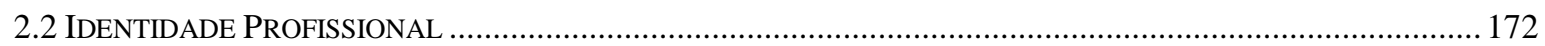

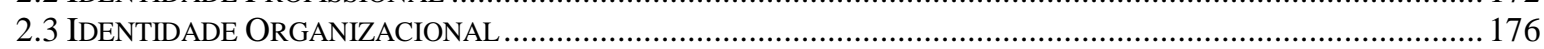

2.4 DisTINÇão E INTEGRAÇÃo ENTRE OS NÍVEIS DE ANÁLISE DA IDENTIDADE .............................................. 179

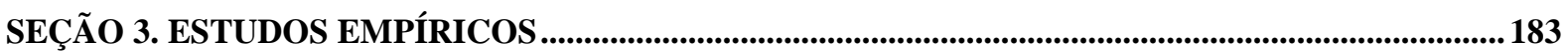

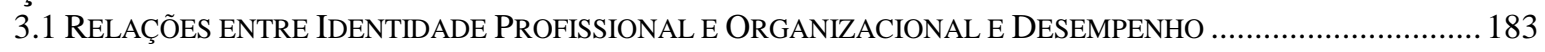

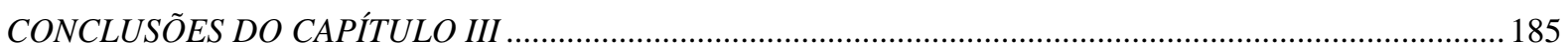

CAPÍTULO IV. MODELO CONCEITUAL E HIPÓTESES DE PESQUISA ..............................................188

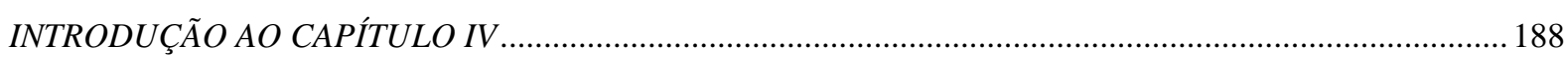

SEÇÃO 1. MODELO CONCEITUAL E HIPÓTESES DE PESQUISA ....................................................188

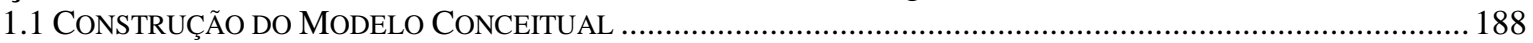

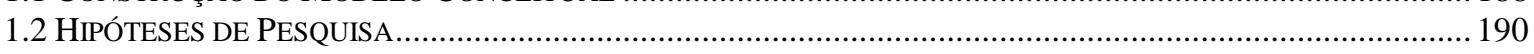

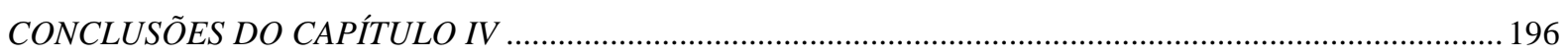

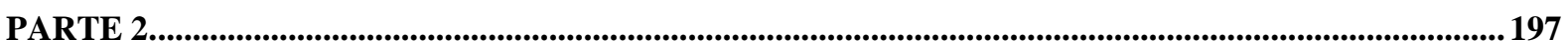

ESTUDOS EMPÍRICOS E RESULTADOS DA PESQUISA .............................................................. 197

CAPÍTULO V. MÉTODO E CONCEPÇÃO DO ESTUDO EMPÍRICO.....................................................200

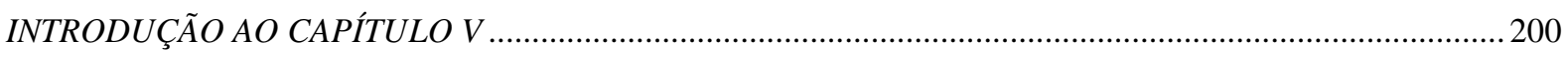

SEÇÃO 1. ESCOLHAS METODOLÓGICAS DE INVESTIGAÇÃO............................................................200

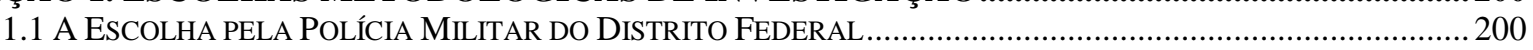

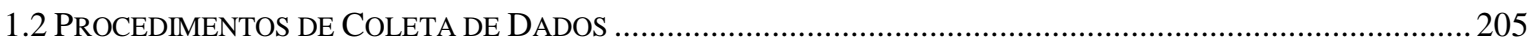

SEÇÃO 2. OPERACIONALIZAÇÃO DOS CONSTRUTOS ……...................................................................208

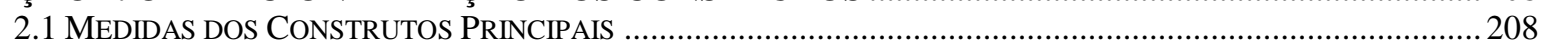

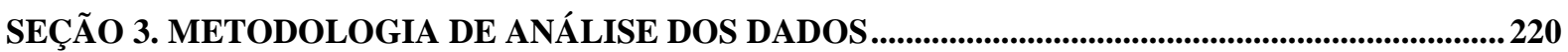

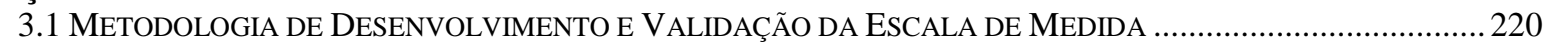

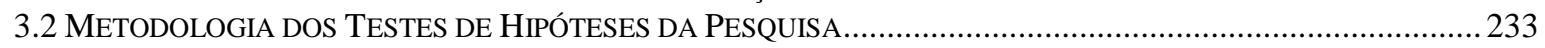

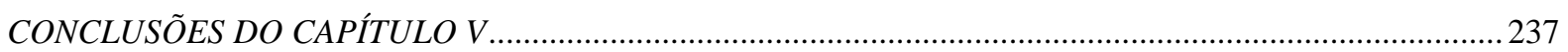

CAPÍTULO VI. EVIDÊNCIAS DE VALIDADE DOS INSTRUMENTOS DE MEDIDA..........................239

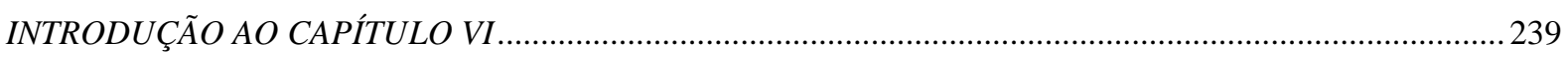

SEÇÃO 1. APRESENTAÇÃO DAS AMOSTRAS E ANÁLISES PRELIMINARES...................................239

1.1 ANÁLISES PRELIMINARES DE ADEQUAÇ̃̃o DOS DADOS ÀS ANÁLISES MUlTIVARIADAS ............................2.240

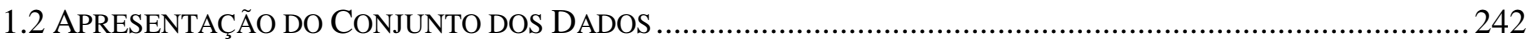

SEÇÃO 2. EVIDÊNCIAS DE VALIDADE DAS ESCALAS DE MEDIDAS DOS CONSTRUTOS DO

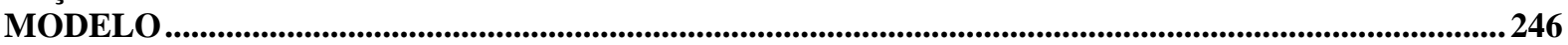

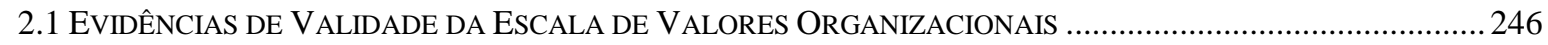

2.2 EVIDÊNCIAS DE VALIDADE DA ESCALA DE PRÁTICAS ORGANIZACIONAIS ..................................................25

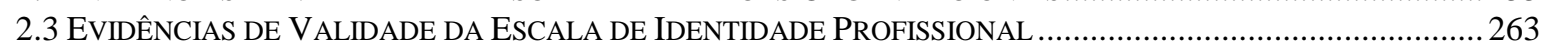

2.4 EVIDÊNCIAS DE VALIDADE DA ESCALA DE IDENTIDADE ORGANIZACIONAL .............................................22

2.5 EVIDÊNCIAS DE VALIDADE DA ESCALA DE DESEMPENHO PROFISSIONAL POR COMPETÊNCIAS ................. 275

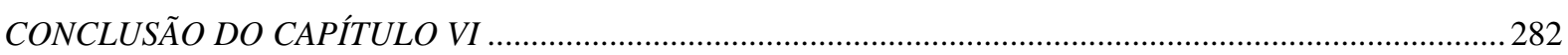




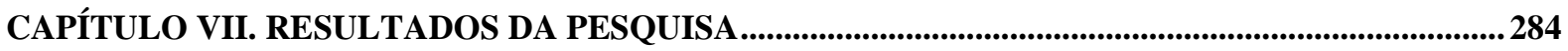

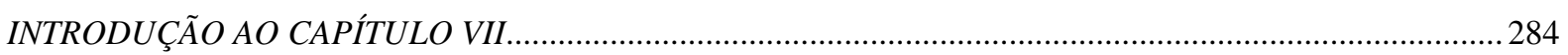

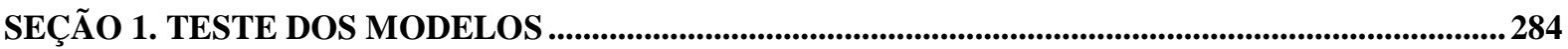

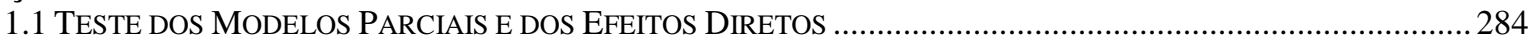

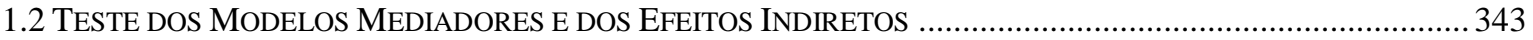

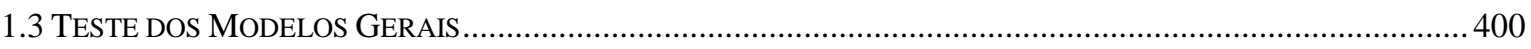

SEÇÃO 2. TESTE DAS HIPÓTESES DE PESQUISA ................................................................................427

2.1 TESTE DAS HIPÓTESES DOS RELAÇÕES ESTRUTURAIS DiRETAS ..........................................................427

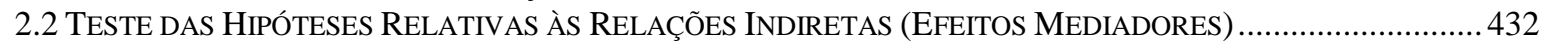

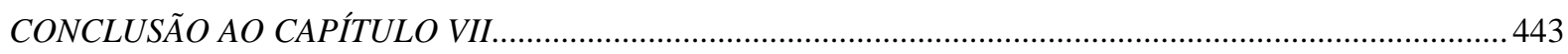

CAPÍTULO VIII. DISCUSSÃO DOS RESULTADOS DA PESQUISA .....................................................445

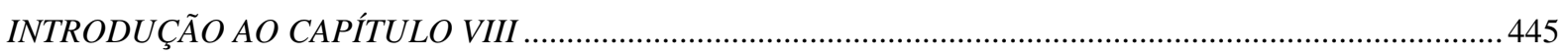

SEÇÃO 1. DISCUSSÃO DOS RESULTADOS DOS MODELOS DE MEDIDA ….....................................445

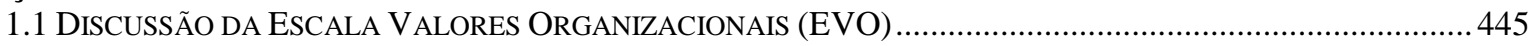

1.2 DISCUSSÃO DA ESCALA DE PRÁTICAS ORGANIZACIONAIS (EPO) ...........................................................4 447

1.3 DISCUSS ÃO DA ESCALA DE IDENTIDADE PROFISSIONAL (EIP) ................................................................. 450

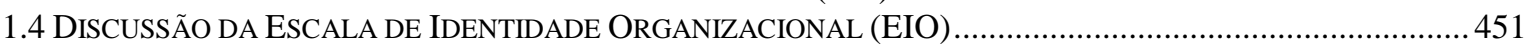

1.5 DisCuSS Ão DA ESCALA DE DESEMPENHO PROFISSIONAL POR COMPETÊNCIAS (EDC) ................................ 451

SEÇÃO 2. DISCUSSÃO DOS RESULTADOS DOS MODELOS ESTRUTURAIS.......................................453

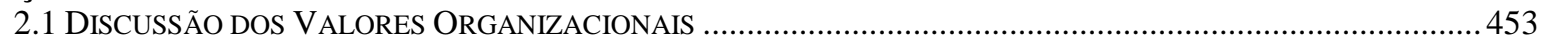

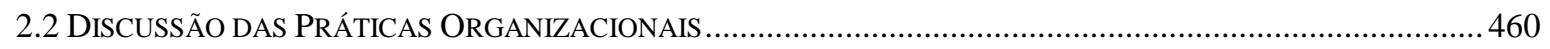

2.3 DISCUSS ÃO DA IDENTIDADE PROFISSIONAL E DA IDENTIDADE ORGANIZACIONAL ……............................470

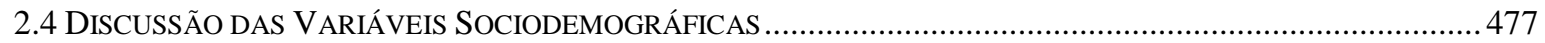

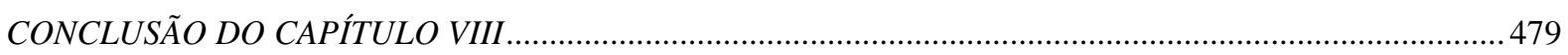

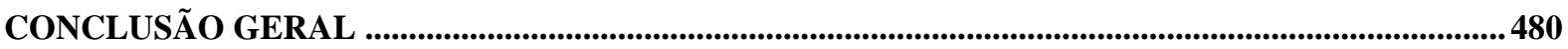

1. SÍNTESE DAS RESPOSTAS ÀS QUESTÕES DE PESQUISA ...........................................................481

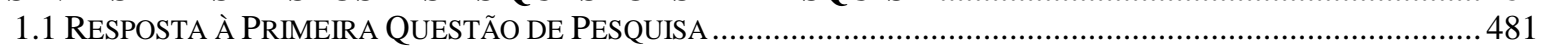

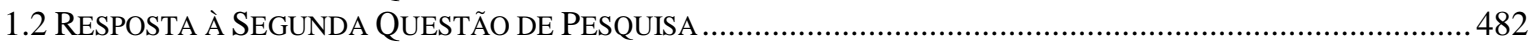

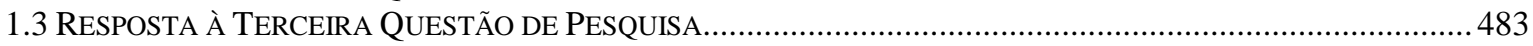

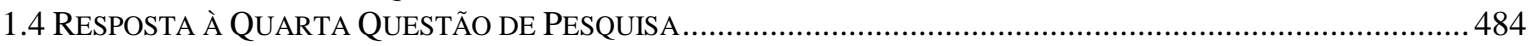

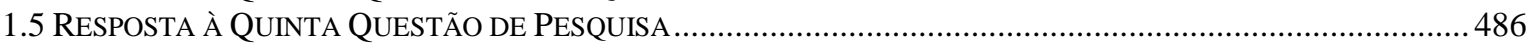

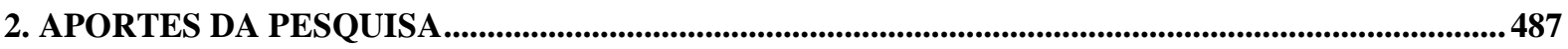

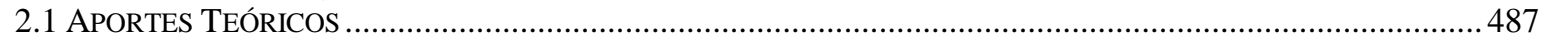

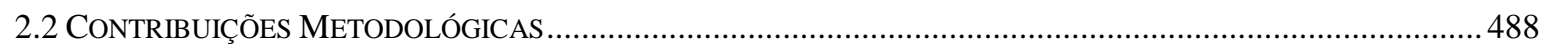

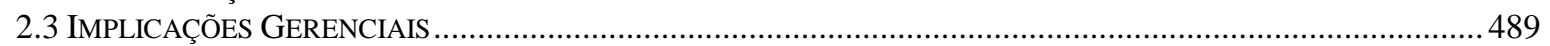

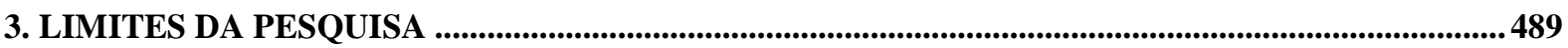

4. AGENDA DE PESQUISA …....................................................................................................................... 490

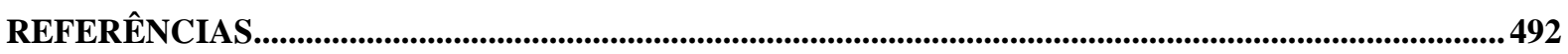

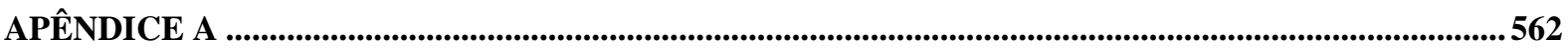

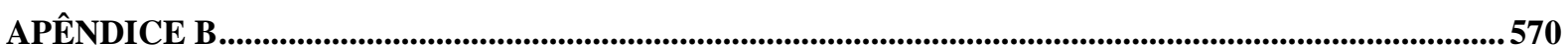

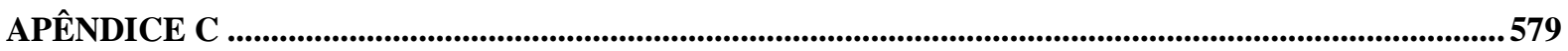




\section{Lista de Figuras}

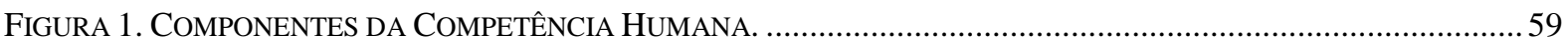

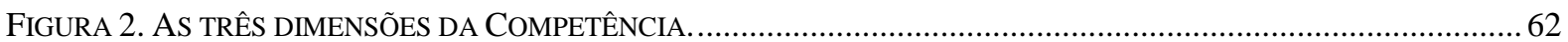

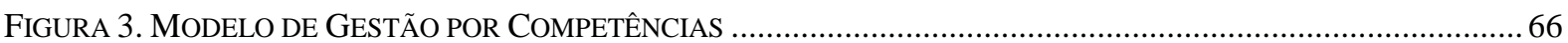



Figura 5. INTERSEÇão dA CULTURA COM A TEORIA DAS ORGANIZAÇÕES (ADAPTADO DE SMIRCICH, 1983, P.

342)

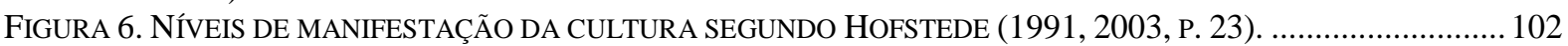

FIGURA 7. ESTRUTURA TEÓRICA DE RELAÇÕES ENTRE VALORES DE SCHWARTZ (2005A) .................................... 113

FIGURA 8. CÍRCULO MOTIVACIONAL DE ACORDO COM A TEORIA DE VALORES BÁSICOS REFINADA, ADAPTADA DE

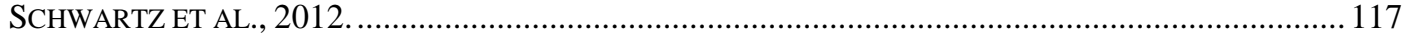

FIGURA 9. MODELO DOS VALORES CONCORRENTES ADAPTADO DE QUINN E RORHBAUGH (1983)....................... 122

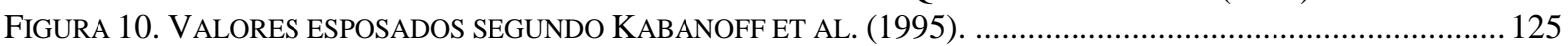

FIGURA 11. ESTRUTURA DOS VALORES ORGANIZACIONAIS SEGUNDO TAMAYO (1996)...................................... 127

FIGURA 12. INTERAÇão ENTRE OS NÍVEIS DE ESTUDO DA IDENTIDADE (MACHADO, 2003, P. 65)........................1 181

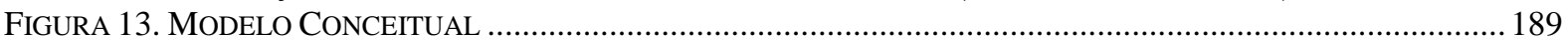

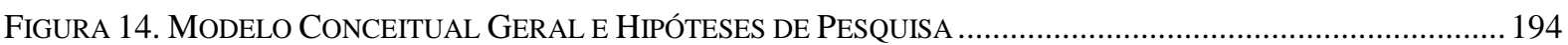

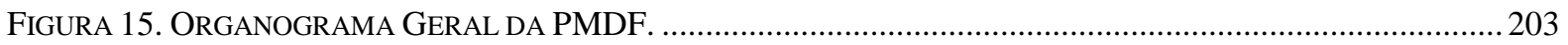

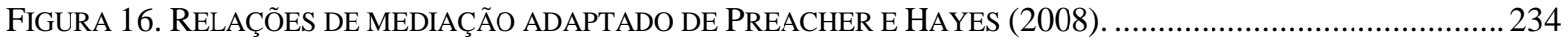

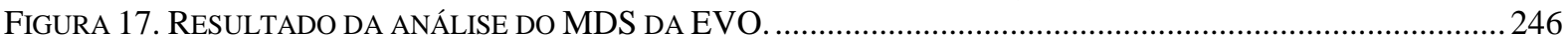

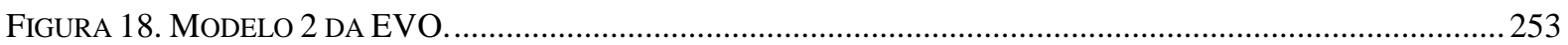

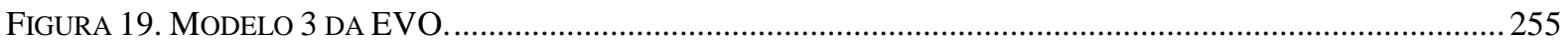

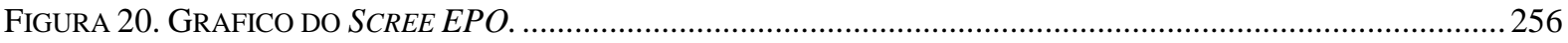

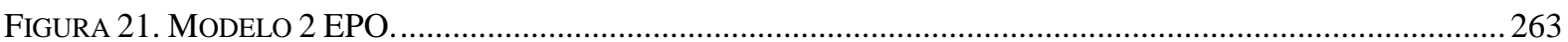

FIGURA 22. GRÁFICO DO SCREE DA EIP

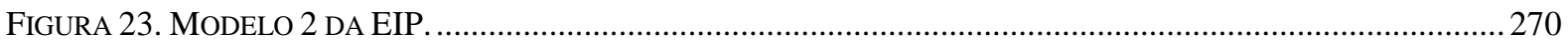

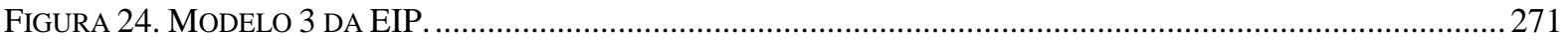

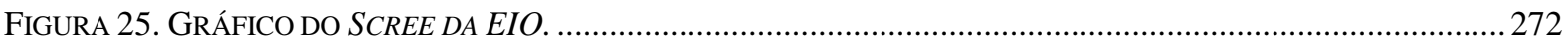

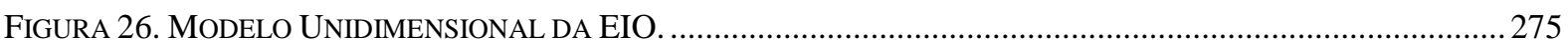

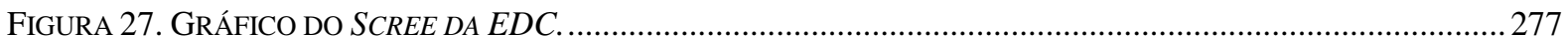

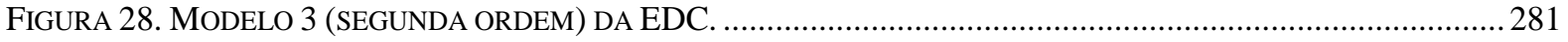

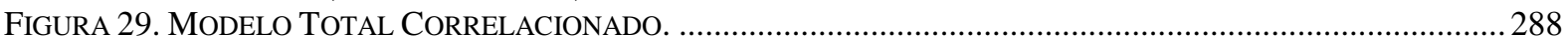

Figura 30. MODELO COM TIPOS MOTIVACIONAIS CORRELACIONADOS PREDIZENDO A IDENTIDADE PROFISSIONAL (IP).

291

FigURA 31. Modelo AUTONOMIA X CONSERVAÇÃO $\rightarrow$ IP (IDENTIDADE PROFISSIONAL)......................................292

FIGURA 32. MODELO HIERARQUIA X IGUALITARISMO $\rightarrow$ IP (IDENTIDADE PROFISSIONAL) ..................................... 293

FIGURA 33. MODELO DOMÍNIO X HARMONIA $\rightarrow$ IP (IDENTIDADE PROFISSIONAL). ................................................ 294

Figura 34. MOdelo COM TIPOS Motivacionais CorRelacionados PREDIZENDO A IDENTIDADE

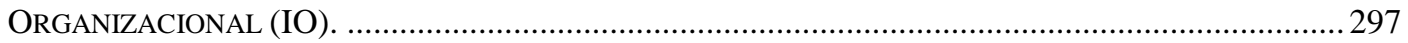

FIGURA 35. MODELO AUTONOMIA X CONSERVAÇÃO $\rightarrow$ IO (IDENTIDADE ORGANIZACIONAL). ...................................29

FigURA 36. MODELO HIERARQUIA X IGUALITARISMO $\rightarrow$ IO (IDENTIDADE ORGANIZACIONAL)...............................2 299

FIGURA 37. MODELO DOMÍNIO X HARMONIA $\rightarrow$ IO (IDENTIDADE ORGANIZACIONAL).......................................... 300

Figura 38. MODELO COM TiPOS MOTIVACIONAIS CORRELACIONADOS PREDIZENDO O DESEMPENHO POR

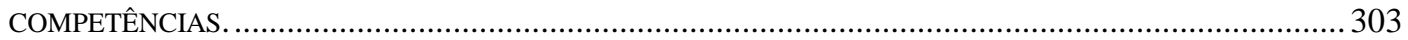

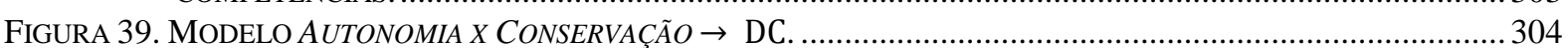

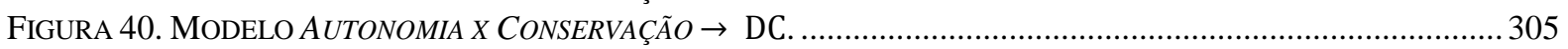

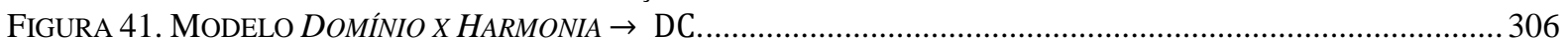

FigURA 42. MODELO $P O \rightarrow$ IP (CENTRALIDADE, AFETO, LAÇOS). .................................................................. 310

FigURA 43. MODELO RECOMPENSAS E PUNIÇÕES $\rightarrow$ IP (CENTRALIDADE, AFETO, LAÇOS)................................... 311

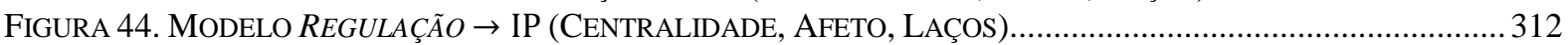

Figura 45. Modelo SENSO DE DEVER $\rightarrow$ IP (CENTRALIDADE, AfETO, LaÇOS) ............................................... 313

Figura 46. Modelo RELAÇõ ES DE AUTORIDADE $\rightarrow$ IP (CENTRALIDADE, AFETO, LAÇOS)................................... 314

Figura 47. MODELO QUALIDADE DA COOPERAÇÃO $\rightarrow$ IP (CENTRALIDADE, AFETO, LAÇOS)............................... 315

Figura 48. MODELO DEFINIÇÃO DE RESPONSABILIDADE $\rightarrow$ IP (CENTRALIDADE, AFETO, LAÇOS), ........................ 316

FIGURA 49. MODELO $P O \rightarrow$ IO

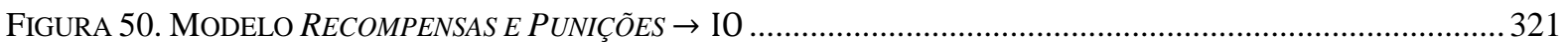

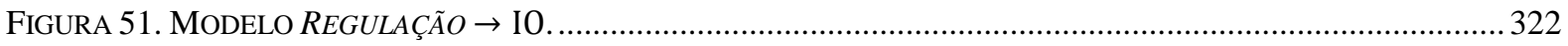

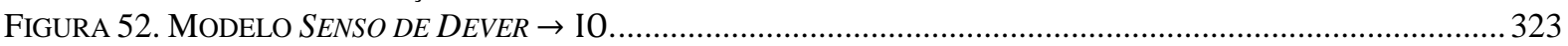

FIGURA 53. MODELO RELAÇÕES DE AUTORIDADE $\rightarrow$ IO 


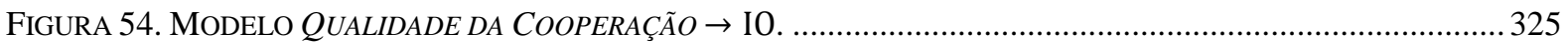

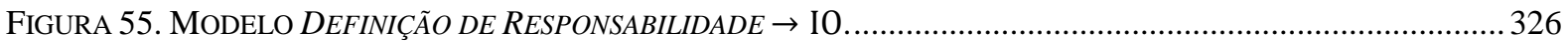

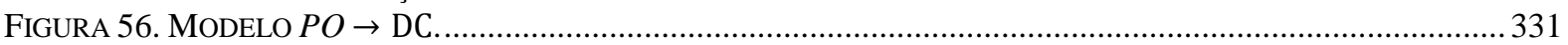

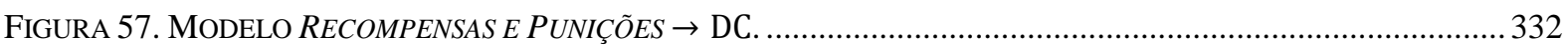

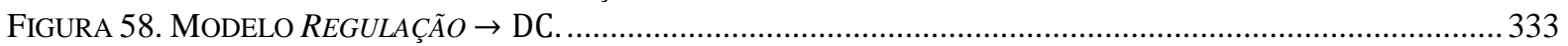



FIGURA 60. MODELO RELAÇÕES DE AUTORIDADE $\rightarrow$ DC .

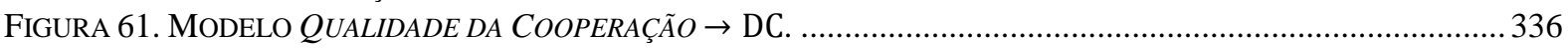

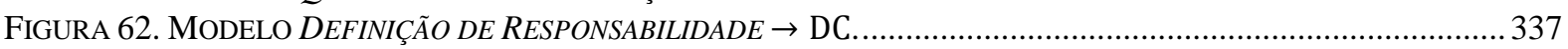

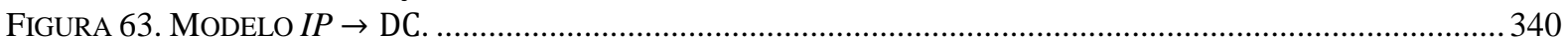

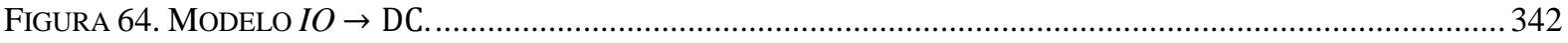

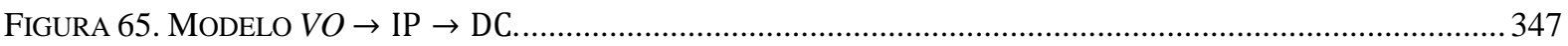

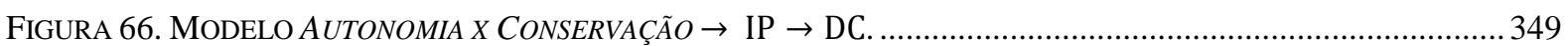

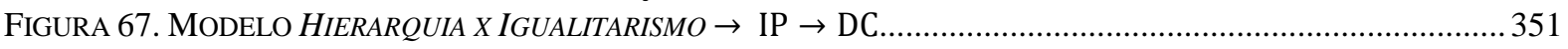

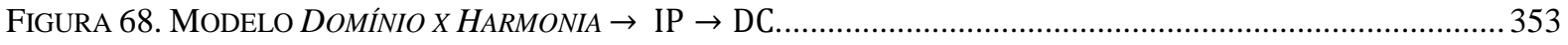

FIGURA 69. MODELO $V O \rightarrow$ IO $\rightarrow$ DC.

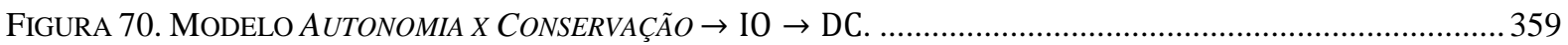

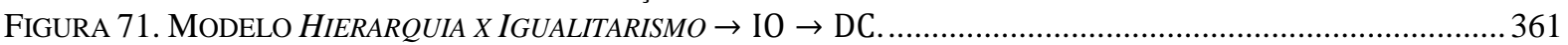

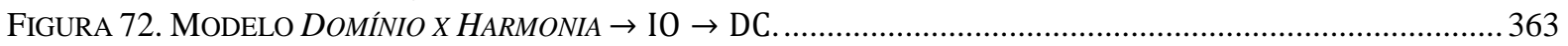

FIGURA 73. MODELO $P O \rightarrow$ IP $\rightarrow$ DC

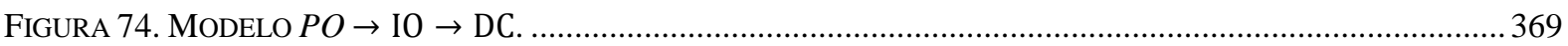

FIGURA 75. MODELO $V O \rightarrow \mathrm{IP} \rightarrow \mathrm{IO} \rightarrow \mathrm{DC}$

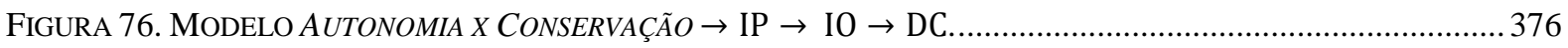

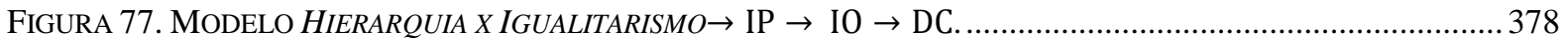

FIGURA 78. MODELO DOMÍNIO X HARMONIA $\rightarrow \mathrm{IP} \rightarrow \mathrm{IO} \rightarrow \mathrm{DC}$

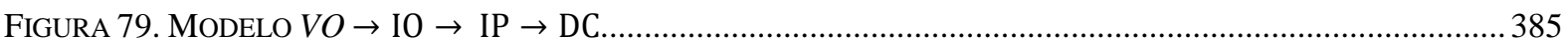

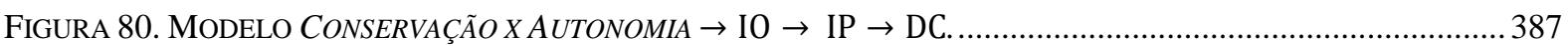

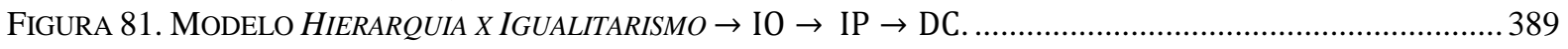

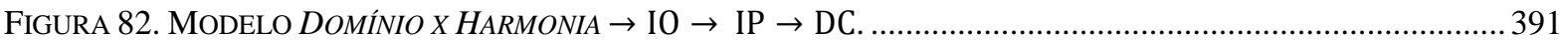

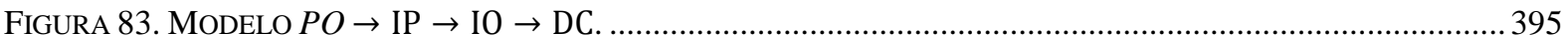

FIGURA 84. MODELO $P O \rightarrow I O \rightarrow I P \rightarrow$ DC.

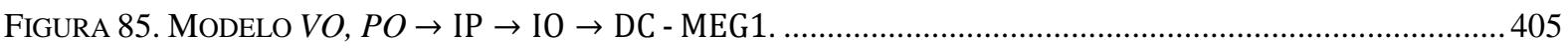

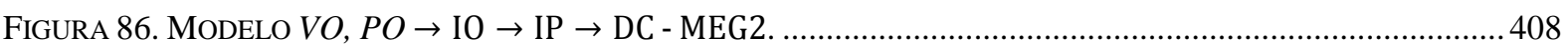

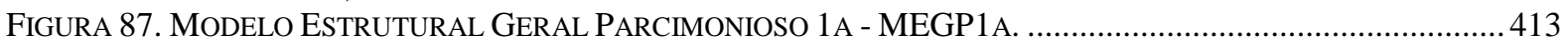

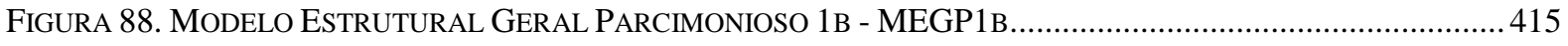

FIGURA 89. MODELO ESTRUTURAL GERAL PARCIMONIOSO 1C - MEGP1C........................................................ 417

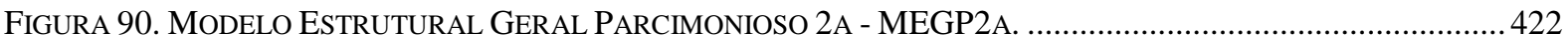

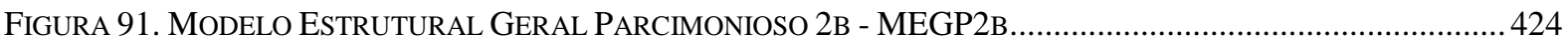

FigURA 92. Modelo ESTRUTURAL GERAL PARCIMONIOSO 2C - MEGP2C....................................................... 426 


\section{Lista de Tabelas}

TABELA 1. MEDIDAS DE DESEMPENHO EM PESQUISAS EMPÍRICAS..................................................................52

TABELA 2. ABORDAGENS TEÓRICAS PROPOSTAS POR SCHULTZ PARA A CULTURA ORGANIZACIONAL ....................89

TABELA 3. TIPOLOGIA DE AlVESSON E BERG PARA O ESTUDO DA CULTURA ORGANIZACIONAL ............................90

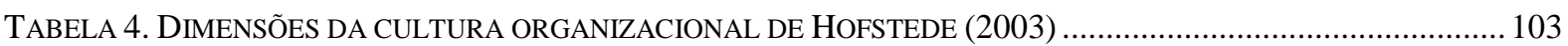

TABELA 5. DESCRITORES DAS CATEGORIAS DE ANÁLISE DO MODELO DE D'IRIBARNE .......................................105

TABELA 6. TIPOS MOTIVACIONAIS DE VALORES DO MODELO DE SCHWARTZ ................................................. 112

TABELA 7. OS 19 VALORES DA TEORIA REFINADA, DEFINIDOS EM TERMOS DE METAS MOTIVACIONAIS ............ 116

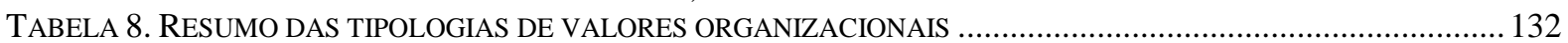

TABELA 9. TIPOS DE CONFLITOS SEGUNDO ARGOTE E MCGRATH (1993) .....................................................145

TABELA 10. DIFERENCIAÇÃO ENTRE OS NÍVEIS DE ESTUDO DA IDENTIDADE SEGUNDO MACHADO (2003, P. 64). 180

TABELA 11. VARIÁVEIS ANTECEDENTES E MEDIADORAS E HiPÓTESES DE PESQUISA ......................................... 195

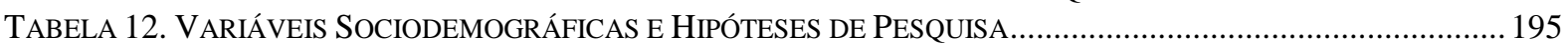

TABELA 13. NÚMERO DE POLICIAIS POR POSTOS E GRADUAÇÕES ..................................................................204

TABELA 14. DIMENSÕES E ITENS DA ESCALA DE VALORES ORGANIZACIONAIS ...........................................210

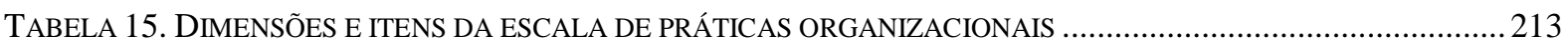

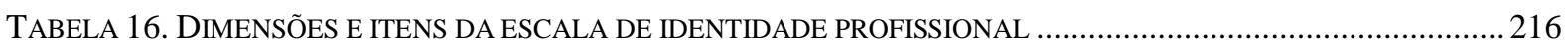

TABELA 17. DIMENSÕES E ITENS DA ESCALA DE IDENTIDADE ORGANIZACIONAL ............................................217

TABELA 18. DIMENSÕES E ITENS DA ESCALA DE DESEMPENHO PROFISSIONAL POR COMPETÊNCIAS ...................218

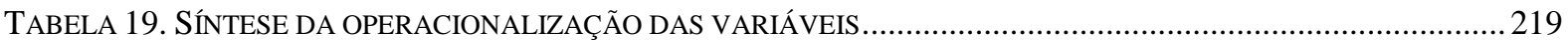

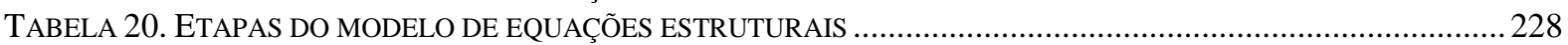

TABELA 21. ÍNDICES DE QUALIDADE DOS AJUSTES E VALORES DE REFERÊNCIA ..........................................230

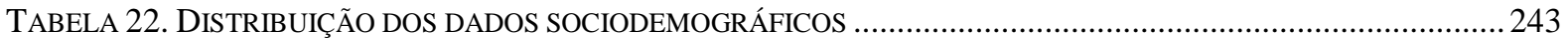

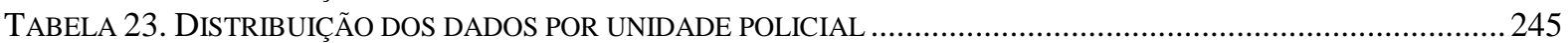

TABELA 24. ITENS POR TIPO MOTIVACIONAL E ÍNDICES DE PRECISÃO DA EVO …..........................................24

TABELA 25. ÍNDICES DE AJUSTAMENTO DOS MODELOS DE MEDIDA CONFORME MODELOS 1 E 2 DA EVO ...........248

TABELA 26. ÍNDICES DE AJUSTAMENTO DAS DIMENSÕES BIPOLARES CONFORME MODELO 3 DA EVO ...............249

TABELA 27. CONFIABILIDADE E VALIDADE DAS TIPOLOGIAS CONFORME MODELO 2 DA EVO ...........................251

TABELA 28. CONFIABILIDADE E VALIDADE DAS TIPOLOGIAS CONFORME MODELO 3 DA EVO ...........................252

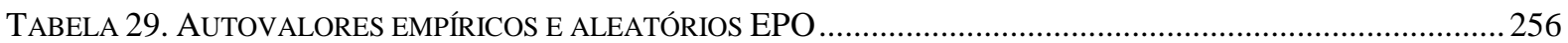

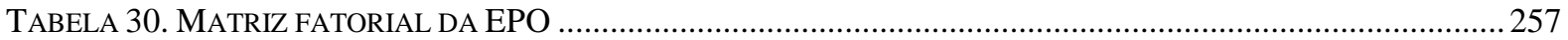

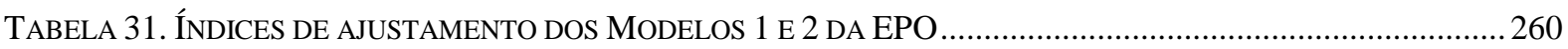

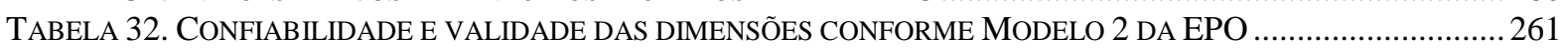

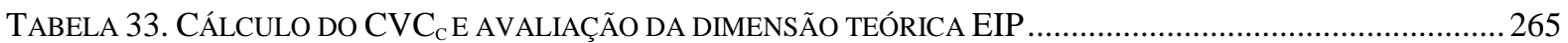

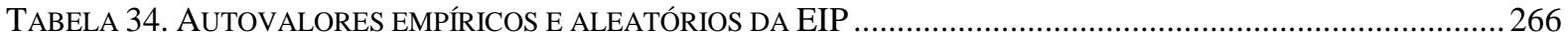

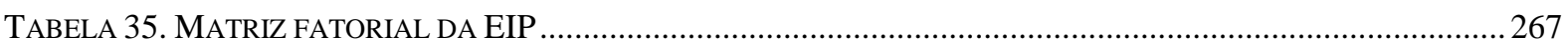

TABELA 36. ÍNDICES DE AJUSTAMENTO DOS MODELOS DE MEDIDA CONFORME MODELOS 1, 2 E 3 DA EIP …........268

TABELA 37. CONFIABILIDADE E VALIDADE DAS DIMENSÕES CONFORME MODELO 2 DA EIP.............................269

TABELA 38. CONFIABILIDADE E VALIDADE DAS DIMENSÕES CONFORME MODELO 3 DA EIP ...........................270

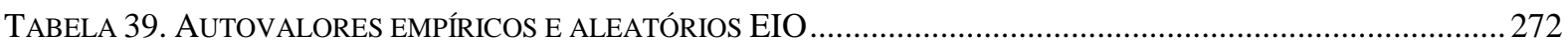

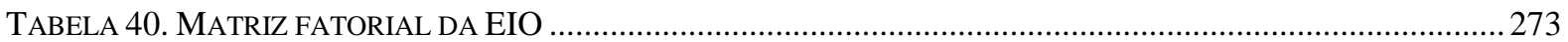

TABELA 41. ÍNDICES DE AJUSTAMENTO DO MODELO UNIDIMENSIONAL DA EIO ..........................................2 274

TABELA 42. CONFIABILIDADE E VALIDADE DA DIMENSÃO CONFORME MODELO DA EIO ...............................2274

TABELA 43. COMPETÊNCIAS TÉCNICAS E COMPORTAMENTAIS POR IMPORTÂNCIA ...........................................2276

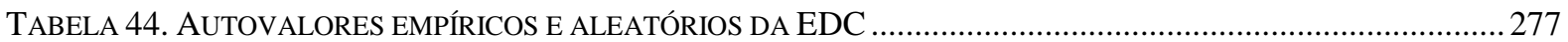

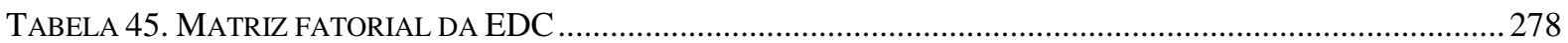

TABELA 46. ÍNDICES DE AJUSTAMENTO DOS MODELOS DE MEDIDA CONFORME MODELOS 1, 2 E 3 DA EDC .......2 279

TABELA 47. CONFIABILIDADE E VALIDADE DAS DIMENSÕES CONFORME MODELO 3 ( $2^{\circ}$ ORDEM) DA EDC ......... 280

TABELA 48. ÍNDICES DE AJUSTAMENTO DOS MODELOS GERAIS CORRELACIONAIS ….........................................286

TABELA 49. ÍNDICES DE AJUSTAMENTO DA RELAÇÃO ENTRE VO $\rightarrow$ IP, COMPLETO E POR DIMENSÕES ................290

TABELA 50. ÍNDICES DE AJUSTAMENTO DA RELAÇÃO ENTRE VO $\rightarrow$ IO, COMPLETO E POR DIMENSÕES ...............296

TABELA 51. ÍNDICES DE AJUSTAMENTO DA RELAÇÃO ENTRE VO $\rightarrow$ DC, COMPLETO E POR DIMENSÕES ................ 302

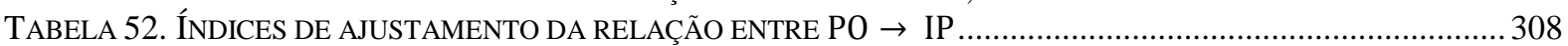

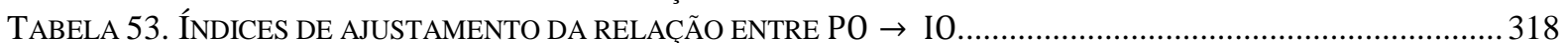



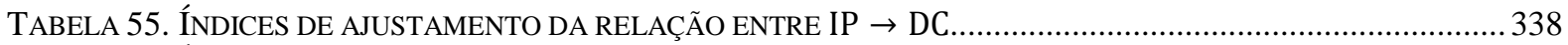

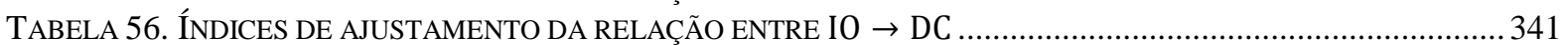

TABELA 57. ÍNDICES DE AJUSTAMENTO DA RELAÇÃO ENTRE VO $\rightarrow$ IP $\rightarrow$ DC, COMPLETO E POR DIMENSÕES ... 345

TABELA 58. ÍNDICES DE AJUSTAMENTO DA RELAÇÃO ENTRE VO $\rightarrow$ IO $\rightarrow$ DC, COMPLETO E POR DIMENSÕES ... 356 
TABELA 59. ÍNDICES DE AJUSTAMENTO DA RELAÇÃO ENTRE PO $\rightarrow$ IP $\rightarrow$ DC. 364

TABELA 60. ÍNDICES DE AJUSTAMENTO DA RELAÇÃO ENTRE PO $\rightarrow$ IO $\rightarrow$ DC

TABELA 61. ÍNDICES DE AJUSTAMENTO DA RELAÇÃo ENTRE VO $\rightarrow \mathrm{IP} \rightarrow \mathrm{IO} \rightarrow \mathrm{DC}$, COMPLETO E POR

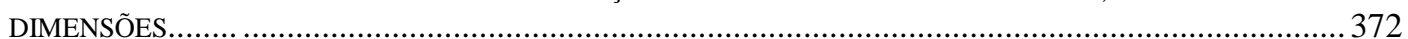

TABELA 62. ÍNDICES DE AJUSTAMENTO DA RELAÇÃO ENTRE VO $\rightarrow$ IO $\rightarrow \mathrm{IP} \rightarrow \mathrm{DC}$, COMPLETO E POR

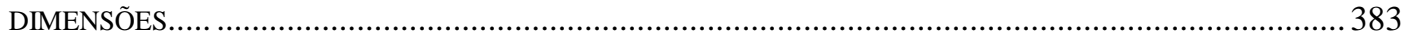

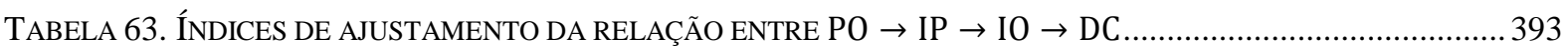

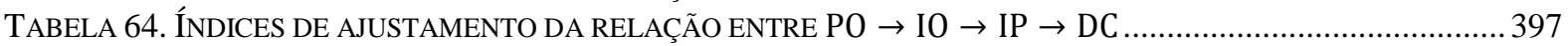

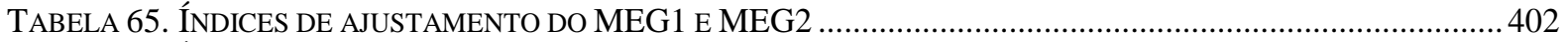

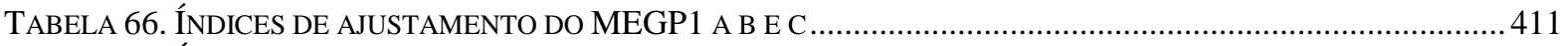

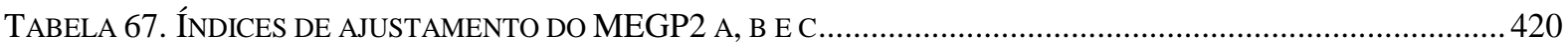

TABELA 68. TESTE DOS EFEITOS DOS VALORES ORGANIZACIONAIS (TIPOS MOTIVACIONAIS) ............................... 428

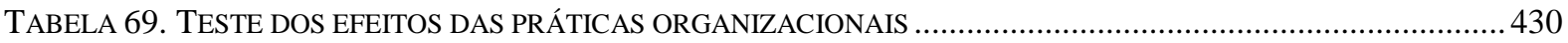

TABELA 70. TESTE DOS EFEITOS DAS IDENTIDADES PROFISSIONAL E ORGANIZACIONAL SOBRE O DESEMPENHO

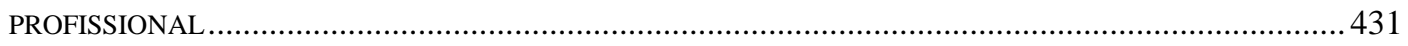

TABELA 71. TESTE DE MEDIAÇÃO SIMPLES DAS IDENTIDADES PROFISSIONAL E ORGANIZACIONAL NA RELAÇÃO ENTRE OS TIPOS MOTIVACIONAIS E O DESEMPENHO PROFISSIONAL

TABELA 72. TESTE DE MEDIAÇÃO SIMPLES DAS IDENTIDADES PROFISSIONAL E ORGANIZACIONAL NA RELAÇÃO PRÁTICAS ORGANIZACIONAIS E O DESEMPENHO PROFISSIONAL ………………………................... 434

TABELA 73.TESTE DE MEDIAÇÃO EM CADEIA DA IDENTIDADE ORGANIZACIONAL E DA IDENTIDADE PROFISSIONAL NA RELAÇÃO ENTRE OS TIPOS MOTIVACIONAIS E O DESEMPENHO PROFISSIONAL ...............................435

TABELA 74. TESTE DE MEDIAÇÃO EM CADEIA DA IDENTIDADE PROFISSIONAL E DA IDENTIDADE ORGANIZACIONAL NA RELAÇ̃̃O ENTRE OS TIPOS MOTIVACIONAIS E O DESEMPENHO PROFISSIONAL ................................ 436

TABELA 75.TESTE DE MEDIAÇÃO SIMPLES DAS IDENTIDADES ORGANIZACIONAL E PROFISSIONAL NA RELAÇÃO PRÁTICAS ORGANIZACIONAIS E O DESEMPENHO PROFISSIONAL ………….......................................437

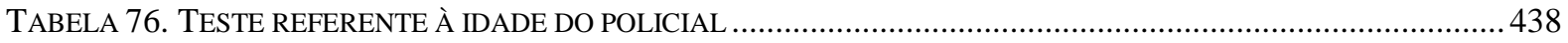

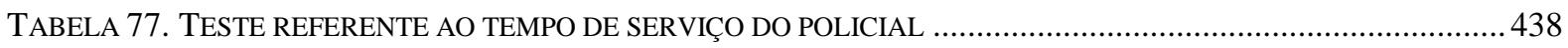

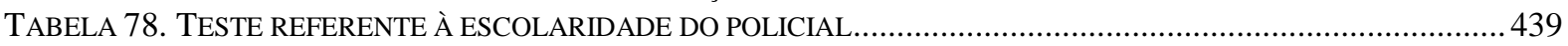

TABELA 79. TESTE REFERENTE À ÁREA DE LOTAÇÃO DO POLICIAL POR ATIVIDADE ……………………..............440

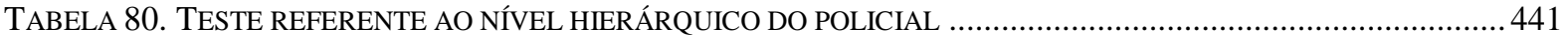

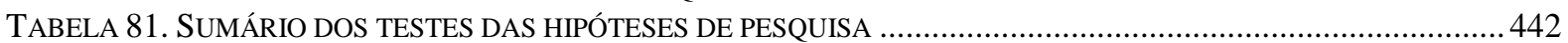




\section{RESUMO}

O objetivo geral desta tese é identificar e descrever a influência das manifestações da cultura da organização, em termos de valores e práticas organizacionais, e da identidade profissional e organizacional sobre o desempenho profissional por competências no serviço policial. Para isso, foi elaborada uma revisão teórica sobre os temas: cultura, valores e práticas organizacionais; identidade profissional e identidade organizacional; desempenho no trabalho e desempenho profissional por competências. Participaram desta pesquisa 916 policiais militares do Distrito Federal de todos os níveis hierárquicos. As análises fatoriais exploratória e confirmatória foram utilizadas para a verificação de evidências de validade das medidas dos seguintes construtos, que compõem o modelo teórico: valores organizacionais, práticas organizacionais, identidade organizacional, identidade profissional (variáveis antecedentes e mediadoras) e desempenho profissional por competências (variável critério). Para os testes desses modelos foram realizadas análises por intermédio de modelagens por equações estruturais. Os resultados sugerem que as variáveis antecedentes (valores organizacionais, práticas organizacionais, identidade profissional e identidade organizacional) são preditoras do desempenho profissional por competências. Tanto a identidade organizacional quanto a identidade profissional mediaram (mediação simples e em cadeia) a relação entre dimensões subjacentes aos valores e às práticas organizacionais sobre o desempenho profissional por competências. As práticas organizacionais apresentaram maior poder de predição sobre o desempenho profissional relativamente aos tipos motivacionais. O teste de modelos gerais e modelos parcimoniosos (modelos concorrentes) demostrou a estabilidade e a invariância dos construtos do modelo, permitindo sua aplicação em diversos contextos. Ao final, são apontadas limitações da pesquisa, implicações de ordem teórica, metodológica e gerenciais e uma agenda para realização de novas pesquisas é estabelecida.

Palavras-chave: manifestações culturais, desempenho profissional por competências, valores organizacionais, práticas organizacionais, identidade organizacional, identidade profissional, polícia. 


\begin{abstract}
The purpose of this research was to identify and describe the influence of the manifestations of the culture, represented in this work by organizational values and practices, organizational and professional identity regarding the professional performance competencies of the professional in his service as a policeman. In order to achieve this objective a theoretical background was constructed using culture, values, practices, identity, performance at work and professional performance competencies. In total, 916 military police officers from Distrito Federal of all hierarchical levels of the police organization were questioned about organizational values, organizational practices, professional identity, organizational identity and professional performance competencies. The scales were tested using exploratory factorial analysis and confirmatory factorial analysis in order to validate the theoretical model using structural equation modeling. The results suggest that the variables of organizational values, organizational practices, professional identity and organizational identity can predict professional performance competencies. Organizational identity and professional identity have mediated (simple mediation and chain mediation) the relation between subjacent dimensions of values and organizational practices regarding performance at work. The organizational practices have predicted the professional performance competencies better than the organizational values subtypes. The tests of the general model and the parsimonious models (concurrent models) have demonstrated the stability and the invariance of the constructs of the model, indicating their usability in other contexts. After the conclusion are proposed the research limitations, theoretical, methodological and managerial implications, as well as an agenda to attend the gaps of the research.
\end{abstract}

Keywords: cultural manifestations, professional performance competencies, organizational values, organizational practices, organizational identity, professional identity, police. 


\section{RÉSUMÉ}

L'objectif général de cette thèse est d'identifier l'influence des manifestations de la culture de l'organisation, en matière de valeurs et de pratiques organisationnelles, ainsi que de l'identité professionnelle et organisationnelle sur la performance professionnelle par les compétences au sein de la police. Pour cela, une étude théorique a été faite sur les thèmes de : la culture, des valeurs et des pratiques organisationnelles, de l'identité professionnelle et de l'identité organisationnelle, de la performance au travail et de la performance professionnelle. 916 policiers militaires du District Fédéral de tous les niveaux hiérarchiques ont participé à cette recherche. Des analyses factorielles exploratoires et de confirmation ont été utilisées pour vérifier les évidences de la validité des mesures des constructions qui composent le modèle théorique comme suit : valeurs organisationnelles, pratiques organisationnelles, identité organisationnelle, identité professionnelle (variables antécédentes et médiatrices) et performance professionnelle (variable critère). Pour pouvoir tester ces modèles, des analyses ont été réalisées par le biais de modélisations d'équations structurelles. Les résultats trouvés suggèrent que les variables antécédentes (valeurs organisationnelles, pratiques organisationnelles, identité professionnelle et identité organisationnelle) permettent de faire des prédictions quant à la performance professionnelle. Aussi bien l'identité organisationnelle que l'identité professionnelle ont permis de faire une médiation (médiation simple et en chaîne) entre les dimensions sous-jacentes aux valeurs et aux pratiques organisationnelles et la performance au travail. Les pratiques organisationnelles ont plus de pouvoir de prédiction que les types de motivations par rapport à la performance professionnelle. Le test des modèles généraux et des modèles détaillés (modèles concurrents) a démontré que les constructions du modèle étaient stables et invariantes, ce qui permet leur utilisation dans différents contextes. Enfin, des limitations de recherche ont été montrées, leurs implications sont d'ordre théorique, méthodologique et de gestion, ce qui demande la mise en place de nouvelles recherches.

Mots-clés : manifestations culturelles, performance professionnelle, valeurs organisationnelles, pratiques organisationnelles, identité organisationnelle, identité professionnelle, police. 
INTRODUÇÃO GERAL 


\section{Introdução}

No campo da gestão, o indivíduo exerce papel central no desempenho organizacional, pois as organizações dependem da perícia humana (Swanson, 1996). Enquanto o grau de importância das pessoas para as organizações é variável e discutível (Collin, 1996), a importância do indivíduo para a organização, que se manifesta na forma de satisfação, identificação e comprometimento, é frequentemente assumida a afetar o desempenho (Alvesson, 2000; Ashforth \& Mael, 1989; Stets \& Burke, 2000; Stryker \& Serpe, 1994).

A literatura é rica em definições, modelos e métodos para a avaliação e compreensão do desempenho no trabalho (Ţuţu \& Constantin, 2012). Teorias e práticas foram desenvolvidas para permitir aumentar o desempenho do trabalho (Holton \& Yamkovenko, 2008), cuja natureza é tratada em duas abordagens: a que entende o desempenho como resultados, e a que o considera como a soma dos comportamentos que controlam os indivíduos em um determinado contexto (Bartram, 2000; Campbell, McCloy, Oppler, \& Sager, 1993; Robertson, Callinan \& Bartram, 2002).

A primeira abordagem possui definição alicerçada no histórico de resultados, produzidos por uma determinada atividade ou em uma determinada posição (Robertson, Callinan \& Bartram, 2002). Com base nessa abordagem, o desempenho no trabalho é a soma (ou média) dos resultados do trabalho (Ţuţu \& Constantin, 2012). Na segunda abordagem, partindo-se de que os comportamentos são relevantes para os objetivos organizacionais (Schmitt \& Chan, 1998) e, considerando que podem ser avaliados separadamente, o desempenho é entendido como uma série interligada de comportamentos (Robertson et al., 2002).

Em um mesmo processo de ação, o desempenho é capaz de agregar distintas dimensões, como a individual (habilidades, competências, disposições, afetos), a interpessoal (identidade e identificação) e a situacional (cultura, valores e práticas) (Bendassolli, 2012). Nesse sentido, existe consenso de que as competências estão ligadas ao desempenho no trabalho, sendo que a concepção integradora da noção de competências associa atributos individuais ao contexto em que são empregados, caracterizando o próprio desempenho no trabalho (Gonczi, 1999). Essa concepção de competência aproxima-se, de forma determinante, dos conceitos e pressupostos centrais relacionados ao desempenho no trabalho (Santos, 2012).

Desempenho, por se tratar de um conceito multidinâmico e multidimensional, pode ser descrito por dois aspectos: o desempenho voltado para a tarefa, no que se refere às atividades desempenhadas pelos sujeitos que contribuem com as questões técnicas ou centrais 
da organização, e o desempenho voltado ao contexto, em que as atividades fazem parte do suporte organizacional, tanto no ambiente social quanto no psicológico (Sonnentag \& Frese, 2002).

Os conhecimentos específicos ou habilidades tendem a predizer o desempenho na tarefa, enquanto personalidade, motivação e fatores relacionados tendem a predizer o desempenho no contexto (Sonnentag \& Frese, 2002). A literatura vem demostrando o estabelecimento de vínculos com a organização como um importante desses antecedentes disposicionais (Santos, 2012), como, por exemplo, a identificação organizacional. Além desses aspectos, são crescentes os estudos sobre vínculos com a carreira e identidade profissional (Meyer, Stanley, Herscovitch \& Topolnyutsky, 2002), em virtude das alterações sofridas pelo vínculo, que estão migrando da organização para a carreira (Blau, 2003; Cohen, 2003).

Cultura organizacional, identidade no trabalho e organizacional (vínculos) e competência passaram a constituir temáticas importantes para a explicação do desempenho no trabalho e nas organizações (Brandão, 2007; Brandão, 2009; Santos, 2012). Entretanto, muitas questões permanecem sem solução, mesmo que no campo teórico tenha havido certo esforço, no sentido de explicar a natureza do desempenho profissional por competências, ou simplismente desempenho competente, e de seus componentes (Brandão, 2009; Coelho Jr., 2009; Santos, 2012).

Esses pontos demonstram que faltam pesquisas reservadas à investigação das relações entre as variáveis antecedentes e consequentes do desempenho profissional por competências de maneira empírica, principalmente no contexto brasileiro (Brandão, 2009; Coelho Jr., 2009; Santos, 2012). Mesmo que existam hipóteses e pressuposições desenvolvidas por teorias da administração ou da psicologia, são escassos os estudos empíricos (Brandão, 2007).

Diante disso, características pessoais e organizacionais passam a ser consideradas essenciais para se investigar o desempenho (Brandão, Borges-Andrade, Puente-Palacios \& Laros, 2012b; Brandão, Borges-Andrade \& Guimarães, 2012a; Coelho Jr., 2009; Santos, 2012; Sonnentag \& Frese, 2002). Contudo, é precária a atenção dada à investigação do efeito de variáveis de contexto na explicação do desempenho no trabalho, nas pesquisas em comportamento organizacional (Bendassolli, 2012; Coelho Jr., 2009; Fuller, Munro, \& Rainbird, 2004; Gubbins \& MacCurtain, 2008). Ainda, menor produção empírica em comportamento organizacional, especialmente na literatura brasileira, tem sido encontrada investigando as relações preditivas entre os componentes da cultura organizacional (valores e 
práticas organizacionais) e da identificação do indivíduo com a organização e com o seu trabalho, e seu impacto no desempenho. Embora esses estudos demonstrem a importância de se compreender, por exemplo, a influência da cultura sobre a identidade, seja ela organizacional (Chen, 2011), seja profissional (Ruiz Castro, 2012), bem como o impacto que a identidade exerce sobre o desempenho no trabalho (He \& Brown, 2013; Kira \& Balkin, 2014; Mitchell, Parker \& Giles, 2011), são poucos os relatos empíricos que buscam entender a lógica em que se processam essas relações.

Estudos que apresentam a ligação entre cultura de uma organização e seu desempenho (Schneider, Ehrhart \& Macey, 2013; Sackmann, 2011), em parte expressam essa cultura pelos valores organizacionais (Gregory, Harris, Armenakis \& Shook, 2009; Hartnell, Ou \& Kinicki, 2011; Tomczyk, Lee \& Winslow, 2013) e pelas práticas organizacionais (Chan, Shaffer \& Snape, 2004; Peltier, Zahay \& Lehmann, 2013).

As práticas e os valores organizacionais são fundamentais para ocasionar impacto nos resultados no trabalho e na organização, ao sustentar os objetivos e metas da organização (Abbad \& Borges-Andrade, 2004). Entretanto, são escassos os estudos empíricos que testam o impacto dos valores e das práticas organizacionais sobre o desempenho, especialmente no Brasil.

Ao investigar as publicações empíricas dos preditores de natureza contextual e individual, que poderiam influenciar a expressão do desempenho profissional por competências, lacunas são encontradas no cenário brasileiro (Brandão, 2007; Brandão, 2009; Brandão et al., 2012a; Brandão et al., 2012b; Coelho Jr., 2009; Santos, 2012); maiores ainda são as omissões nos estudos, cujo segmento é a administração pública, tanto no Brasil quanto no exterior (Santos, 2012; Santos \& Borges-Andrade, 2012).

A revisão de literatura realizada para esta tese corroborou a escassez dos estudos na administração pública brasileira, salvo estudos em administrações públicas federais (Santos, 2012) e instituições bancárias estatais (Brandão et al., 2012a; Coelho Jr., 2009; Coelho Jr. \& Borges-Andrade, 2011a). Não foram localizadas investigações, cujo objeto fossem organizações policiais, no exame das variáveis contextuais e individuais que afetam o desempenho profissional por competências no serviço policial.

O serviço policial pode ser entendido como o conjunto de atributos técnicos e comportamentais necessários para o cumprimento das funcões constitucionais da polícia. No caso da policia militar, alvo desta tese, sua atividade ou seu serviço vão, entre outros aspectos, do policiamento preventivo, quando se presume possível a perturbação da ordem pública, e de sua vertente repressiva, quando da ruptura dessa ordem pública, com o emprego 
escalonado da força. Por todas estas razões, e como forma de preencher parte das lacunas elencadas, é essencial compreender a influência de variáveis contextuais e individuais sobre o desempenho profissional por competências policiais.

Nessa linha, surgem questões: os valores e as práticas, como manifestação da cultura organizacional, e a identidade organizacional e profissional são variáveis antecedentes e explicativas do desempenho profissional por competências? Caso sejam, que dimensões emergem dos valores e das práticas organizacionais para explicar o desempenho profissional por competências? Que dimensões emergem dos valores e das práticas organizacionais para explicar a identidade profissional e a identidade organizacional? A identidade atua como mediadora da relação entre as manifestações da cultura e o desempenho profissional por competências? São encontradas diferenças em função das variáveis biográficas (idade, grau de escolaridade) e profissionais (tempo de serviço, nível hierárquico) em relação ao desempenho?

Com base nesses questionamentos, este trabalho propõe-se a identificar as variáveis preditoras do denominado desempenho profissional por competências. Para isso, evidenciamse características do contexto organizacional, notadamente, a cultura organizacional, por meio dos elementos que a compõem, valores e práticas organizacionais, bem como atributos individuais, em especial, os vínculos que o indivíduo desenvolve com a carreira (identidade profissional) e com a organização (identidade organizacional).

\subsection{Objetivo Geral}

A presente pesquisa tem como objetivo geral identificar e descrever a influência das manifestações da cultura da organização, em termos de valores e práticas organizacionais, e da identidade profissional e organizacional sobre o desempenho profissional por competências no serviço policial.

\subsubsection{Objetivos Específicos}

Especificamente, visa-se descrever:

a) A influência dos valores organizacionais e dos tipos motivacionais decorrentes sobre o desempenho profissional por competências;

b) A influência das práticas organizacionais e de suas dimensões subjacentes sobre o desempenho profissional por competências;

c) A influência da identidade organizacional sobre o desempenho profissional por competências; 
d) A influência da identidade profissional sobre o desempenho profissional por competências;

e) A influência dos valores organizacionais e dos tipos motivacionais decorrentes sobre a identidade profissional e sobre a identidade organizacional;

f) A influência das práticas organizacionais e de suas dimensões subjacentes sobre a identidade profissional e sobre a identidade organizacional;

g) A influência da identidade organizacional na relação entre valores e práticas organizacionais e o desempenho profissional por competências;

h) A influência da identidade profissional na relação entre valores e práticas organizacionais e o desempenho profissional por competências;

i) As diferenças no desempenho profissional por competências em função das variáveis sociodemográficas, caso existam.

\subsection{Relevância do Trabalho}

\subsubsection{Nível Teórico}

A relevância desta pesquisa está na contribuição que apresenta aos trabalhos empíricos em comportamento organizacional, sobretudo na descrição dos fatores explicativos do desempenho profissional por competências no trabalho, por intermédio de diversos aportes teóricos, gerencias e metodológicos. Espera-se avançar teoricamente nesse campo ao descrever e modelar a influência dos valores e das práticas organizacionais sobre o desempenho profissional por competências.

Contribuição importante é a pesquisa ser realizada no contexto de uma organização pública, especificamente no setor de segurança, onde os estudos são escassos, abrindo, com isso, novas possibilidades de investigação e discussão sobre o tema. Ressalta-se a importância de serem descritos os vínculos que os profissionais estabelecem com a carreira e com a organização - identidade profissional e organizacional - os valores e as práticas organizacionais e a relação desses com o desempenho profissional por competências, principalmente ao explicar a influência das características profissionais e individuais nesse desempenho. 


\subsubsection{Nível Metodológico}

Os aportes metodológicos desta pesquisa contribuem de maneira significativa aos estudos do comportamento organizacional, em virtude da utilização de uma abordagem quantitativa que permitiu o emprego de recursos estatísticos modernos, notadamente no contexto brasileiro de pesquisa:

Validando o construto das escalas utilizadas na tese, tanto de forma exploratória, quanto de forma confirmatória, sendo parte delas (escala de identidade profissional, escala de práticas organizacionais e escala de desempenho profissional por competências) inéditas em pesquisas realizadas no Brasil.

Testando, simultaneamente, diversos tipos de efeitos (diretos e indiretos) com a utilização de diferentes métodos, o que propiciou um modelo estrutural robusto.

\subsubsection{Nível de Aplicação}

Por outro lado, do ponto de vista da contribuição prática/gerencial, a descrição dos fatores que explicam o desempenho no trabalho é elemento importante para todo o processo de gestão das organizações. Isso é reforçado pelos trabalhos de Brandão (2009), Coelho Jr. (2009) ou, mais recentemente, de Hartnell et al. (2011), Santos (2012) e Triguero-Sánchez et al. (2013).

Determinar os fatores que influenciam o desempenho profissional por competências do serviço policial, medido por competências técnicas e comportamentais, consideradas essenciais para o bom desempenho no trabalho, é dos primeiros passos a ser dado para o diagnóstico organizacional. Além disso, o papel da identidade profissional e da identificação organizacional para o indivíduo e para a organização é imprescindível para a modelagem de gestões, que objetivem maior identificação das pessoas com suas carreiras e com sua organização.

Finalmente, a introdução de variáveis sociodemográficas dentro do modelo fornece critérios de segmentação relevantes para que se expliquem diferenças no comportamento organizacional, bem como a identificação de alavancas operacionais que possibilitem aos policiais agirem no sentido de aumentar seu desempenho no trabalho. 


\subsection{Arquitetura da Pesquisa}

Esta tese está articulada em duas partes: a primeira composta por quatro capítulos e a segunda por três capítulos. Como o objetivo desta pesquisa encontra-se na descrição de fatores explicativos do desempenho profissional por competências, em uma organização de segurança pública, para tanto, diversas etapas foram seguidas. Na primeira, descrevem-se os conceitos e fatores explicativos, relativos ao desempenho profissional por competências e às variáveis que o antecedem, adotando-se uma abordagem histórica, conceitual e pluridisciplinar (Capítulos I, II e III) e uma abordagem que integra as variáveis estudadas (Capítulo IV).

O primeiro capítulo aborda o desempenho profissional por competências no trabalho, variável critério da pesquisa, em três seções. Na primeira, foi apresentada a noção de desempenho no trabalho, baseada em uma análise histórica e conceitual, suas definições e medidas associadas. Na segunda seção, o foco recaiu sobre a variável competência e sua concepção integradora. Por fim, a terceira seção apresentou o estado da arte de pesquisas empíricas sobre preditores de desempenho no trabalho, competências no trabalho e a relação entre competências e desempenho no trabalho.

O segundo capítulo é consagrado ao estudo da cultura organizacional e suas dimensões principais, assim como suas relações com o desempenho competente. A primeira seção abordou a noção de cultura, com destaque para a cultura organizacional. Na segunda seção, foi apresentada a temática dos valores organizacionais. A terceira seção vinculou-se ao tema práticas organizacionais como elemento manifesto da cultura organizacional. Cada uma das seções inicia-se por uma perspectiva histórica relativa aos estudos das variáveis, passando, em seguida, para as definições e descrições dos principais modelos teóricos. Por fim, esse capítulo foi finalizado por uma revisão de estudos empíricos sobre cultura, valores, práticas organizacionais, identidade e desempenho no trabalho.

O terceiro capítulo apresenta o fenômeno da identidade, apontando suas interfaces com o ambiente organizacional. Duas dimensões sociais da identidade receberam maior atenção, a profissional ou no trabalho e a organizacional, evidenciando a importância da identidade para o desempenho no trabalho.

O quarto capítulo constitui-se do modelo conceitual e das hipóteses que procuram responder às questões teóricas e práticas sobre os determinantes do desempenho profissional por competências. O modelo conceitual é derivado da revisão da literatura, sendo que as hipóteses de pesquisa declinam-se em suposições sobre os efeitos diretos e indiretos (mediadores). 
A segunda parte desta tese, que testou empiricamente o modelo proposto e as hipóteses de pesquisa e discutiu os resultados encontrados, estrutura-se em quatro capítulos (Capítulos V, VI, VII e VIII).

O quinto capítulo, com três seções, é consagrado à metodologia e à concepção do estudo empírico. Na primeira seção, são detalhadas as escolhas metodológicas de investigação, justificando-se a escolha da organização, os procedimentos de coleta e análises dos dados. Na segunda seção, foram operacionalizados os diferentes construtos apresentados no modelo de pesquisa proposto. Por fim, a terceira seção, descreveu a metodologia para a adaptação, o desenvolvimento, a validação de instrumentos de medida e o teste das hipóteses de pesquisa.

No sexto capítulo, são validadas as escalas de medida dos construtos. A primeira seção apresenta as amostras utilizadas e as análises preliminares de adequação dos dados para a realização das análises multivariadas. A segunda seção apresenta as evidências de validação das escalas de medida dos construtos centrais do modelo de pesquisa. E, por último, a terceira seção discutiu a medida das variáveis individuais no modelo de pesquisa. Essas análises foram efetuadas com os programas PASW Statistics18 e AMOS 18.

O sétimo capítulo apresenta os resultados da pesquisa. Na primeira seção, apresentamse os testes dos efeitos diretos, o teste dos efeitos indiretos, os testes dos modelos gerais e o teste dos efeitos das variáveis sociodemográficas. Na segunda seção, as relações hipotéticas da pesquisa, confirmadas ou refutadas, são apresentadas e sumarizadas.

No oitavo capítulo discutem-se, interpretam-se e colocam-se em perspectivas os resultados da pesquisa. $\mathrm{O}$ foco principal encontra-se na discussão dos resultados do modelo de medida, das relações do modelo estrutural e da influência das variáveis sociodemográficas.

Finalmente, na conclusão da tese, retomam-se o objetivo geral e as questões de pesquisa, as contribuições teóricas, metodológicas e as implicações gerenciais do estudo, apresentando, igualmente, as limitações da pesquisa e uma agenda para futuras investigações. 


\section{INTRODUÇÃO GERAL}
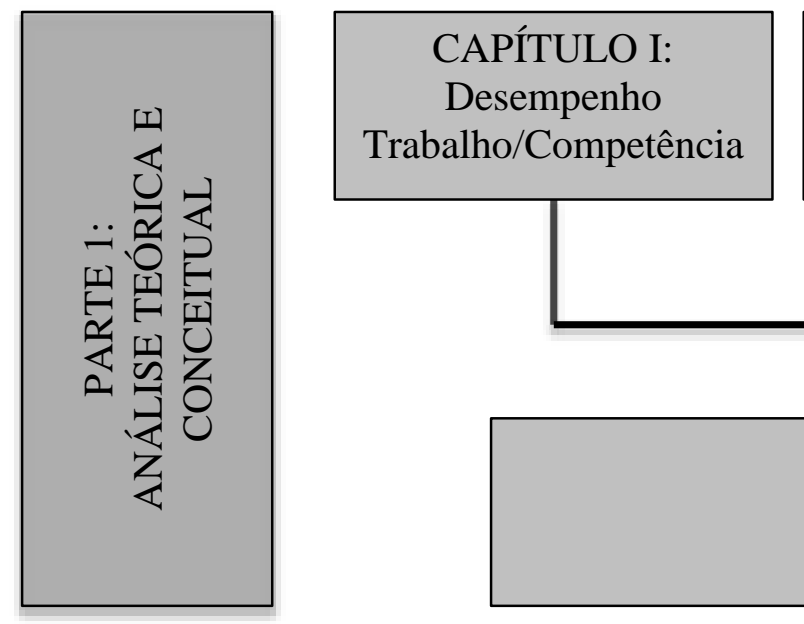
CAPÍTULO II: Cultura Organizacional Identidade Trabalho/Organização
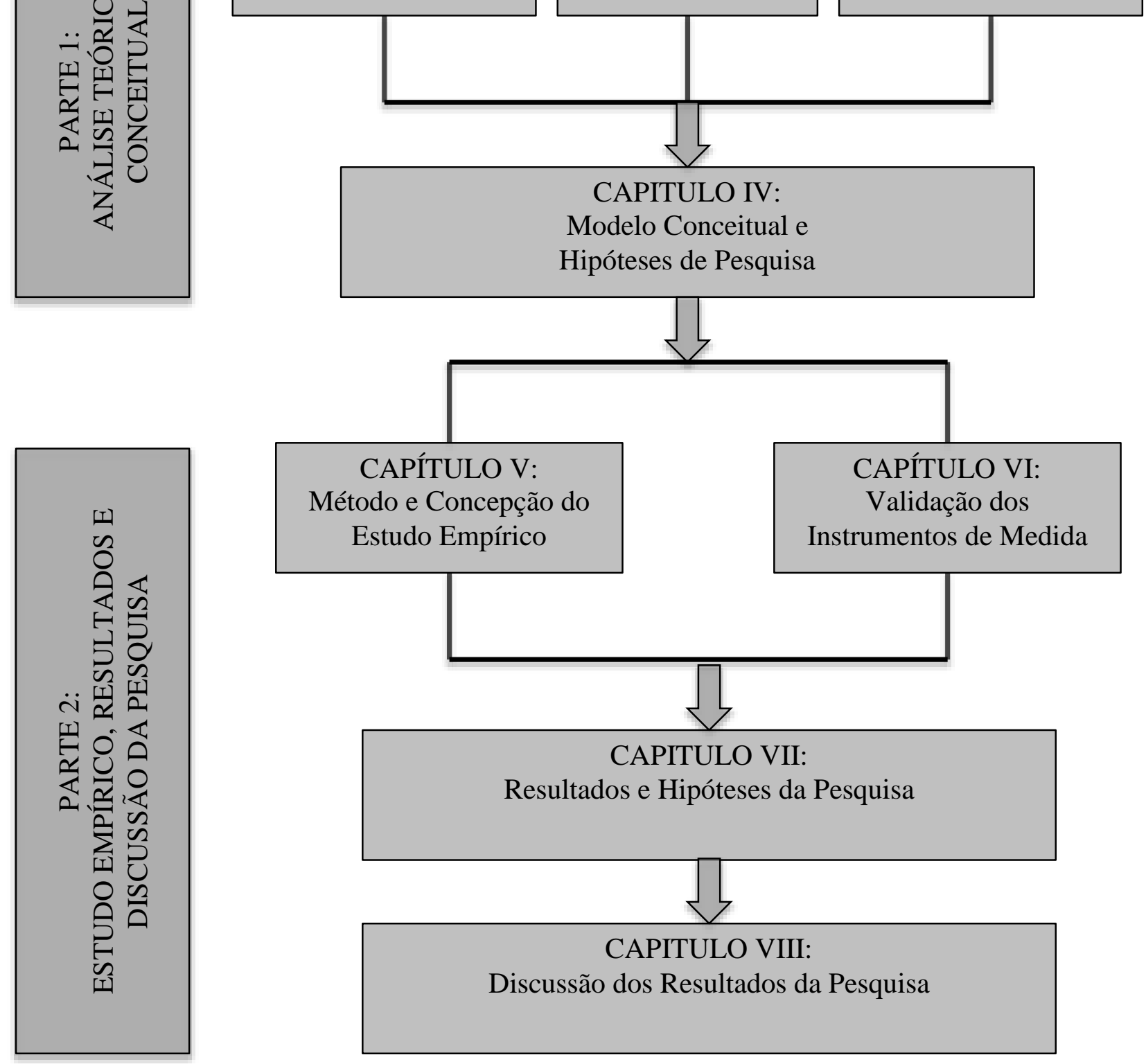

CAPÍTULO V: Método e Concepção do Estudo Empírico
CAPÍTULO VI: Validação dos Instrumentos de Medida

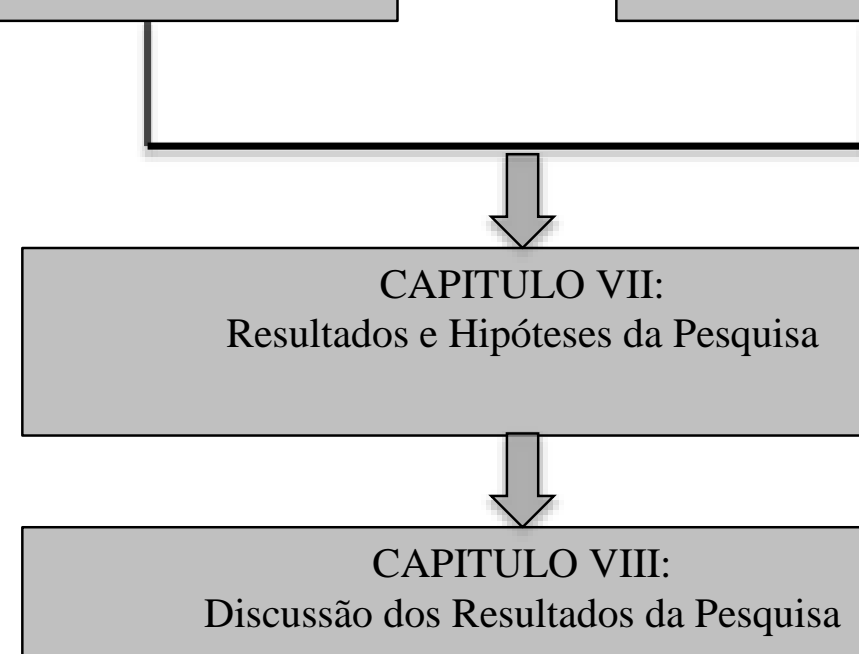


PARTE 1.

ANÁLISE TEÓRICA E CONCEITUAL 


\section{INTRODUÇÃO GERAL}
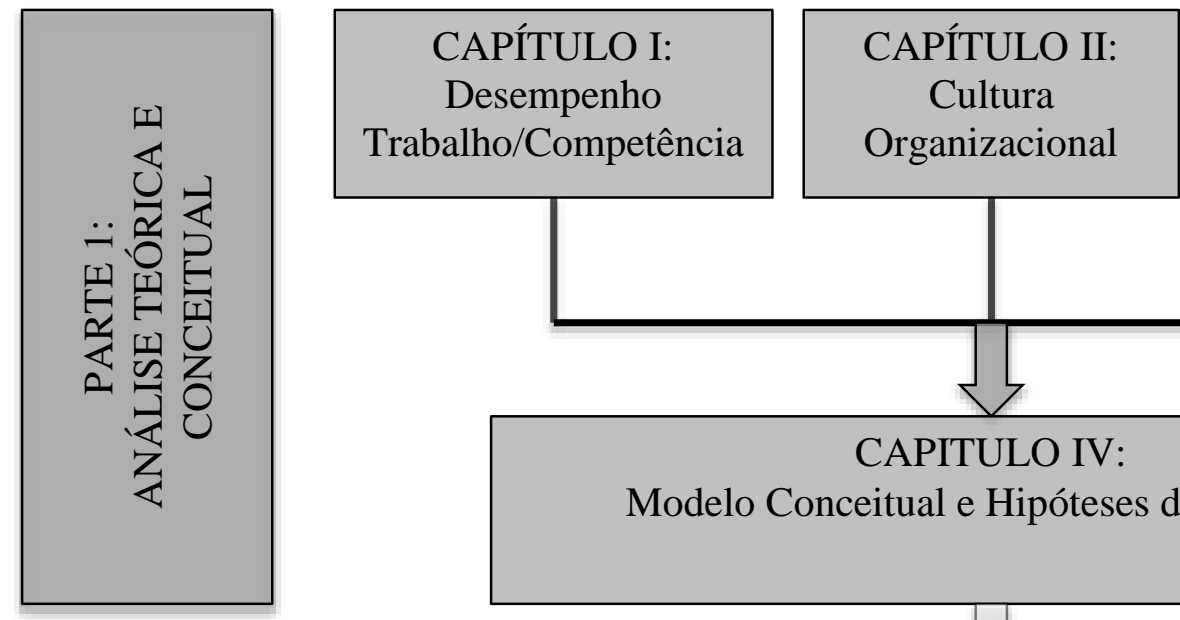
CAPÍTULO III: Identidade
Trabalho/Organização

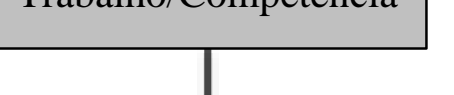

Organizacional
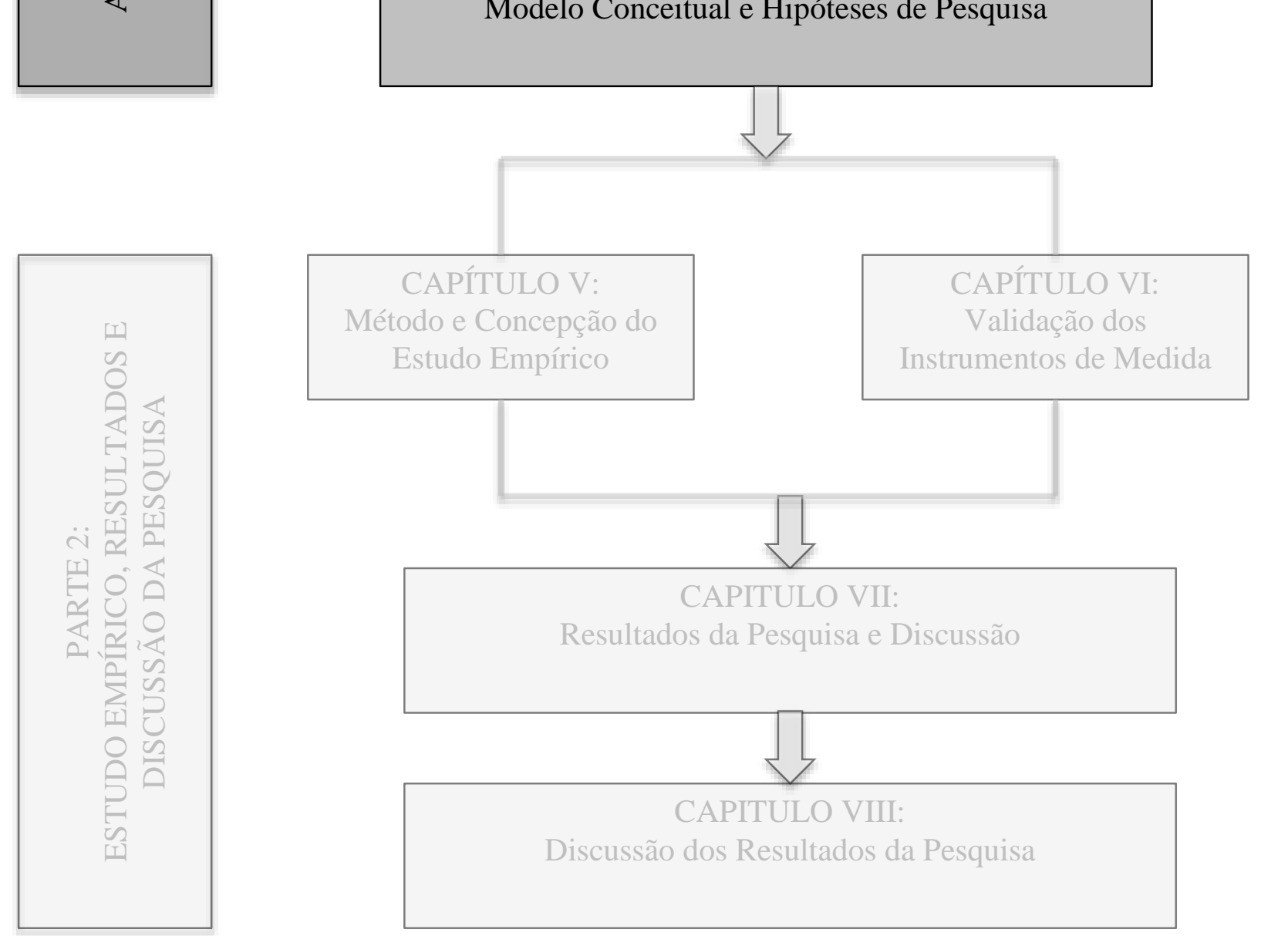

CAPITULO IV:

Modelo Conceitual e Hipóteses de Pesquisa

CONCLUSÃO GERAL 


\section{PARTE 1}

ANÁLISE TEÓRICA E CONCEITUAL

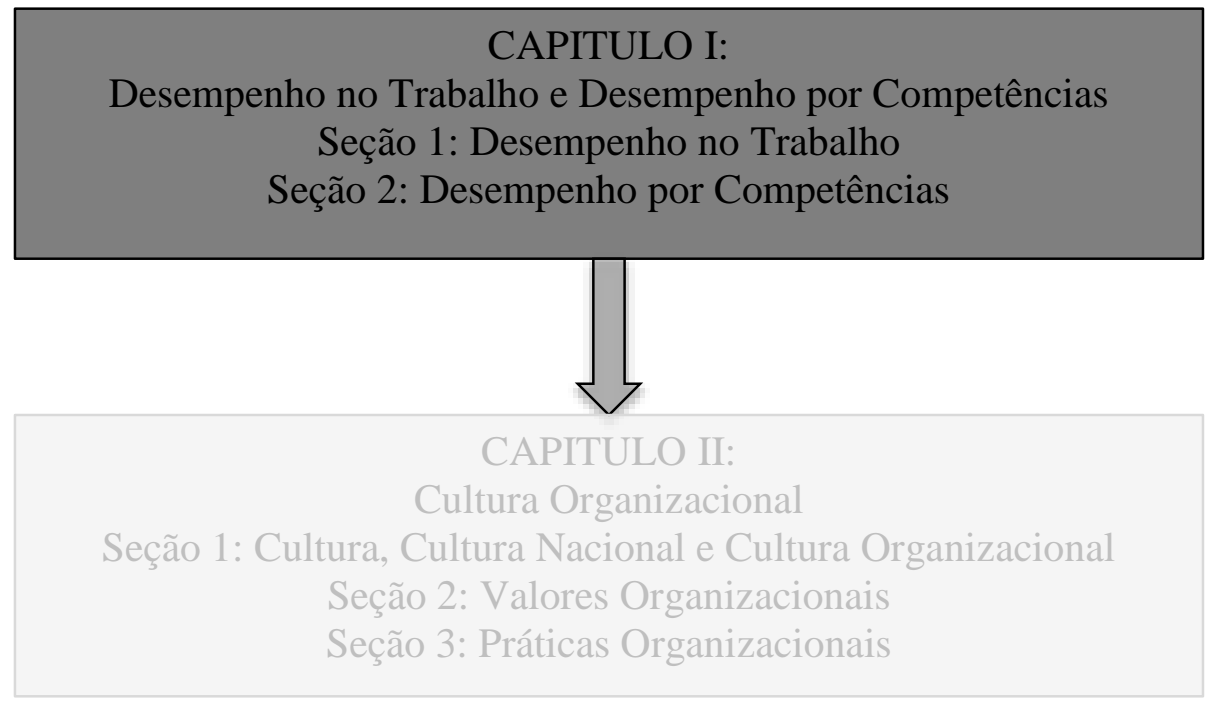

\begin{tabular}{|c|} 
CAPITULO III: \\
Identidade no Contexto do Trabalho e da Organização \\
Seção 1: Identidade: Discussões Teóricas \\
Seção 2: Teoria da Identidade Social \\
Seção 3: Identidade no Trabalho \\
Seção 4: Identidade na Organização
\end{tabular}

\section{CAPITULO IV:}

Modelo Conceitual e Hipóteses de Pesquisa

Seção 1: Fase Qualitativa Exploratória

Seção 2: Modelo Conceitual e as Hipóteses de Pesquisa 


\section{CAPÍtULO I. DESEMPENHO NO TRABALHO E DESEMPENHO POR COMPETÊNCIAS}

\section{Introdução ao Capítulo I}

Este capítulo tem por objetivo abordar a variável desempenho. No primeiro momento será abordada a noção de desempenho no trabalho, umas das variáveis mais investigadas na área do comportamento organizacional. As diversificadas definições e medidas associadas refletem-se na disparidade teórica e metodológica relacionada ao estudo do desempenho no trabalho e na organização. Em um segundo momento, será focada a variável competência, examinada como associação de atributos individuais ao contexto em que são utilizados, caracterizando o próprio desempenho no trabalho, aqui denominado desempenho profissional por competências, ou simplismente desempenho competente. Por fim, será apresentado o estado da arte de pesquisas empíricas sobre preditores de desempenho no trabalho, de competências no trabalho e da relação entre competências e desempenho no trabalho.

\section{Seção 1. Desempenho no Trabalho}

Recentemente, o capital intelectual tem sido alvo de constantes investimentos, que, entre outras razões, visam à maximização do desempenho individual, tornando-o um dos pilares que norteiam as ações de gerenciamento de pessoas (Coelho Jr., 2009), com prováveis reflexos sobre os resultados organizacionais. O elevado impacto prático e acadêmico do desempenho no trabalho estabelece-se como mecanismo gerador de inputs, que agregam valor a indivíduos e a organizações (Bendassolli, 2012). Diante disso, a primeira parte dessa seção (1.1) apresenta aspectos relativos à perspectiva histórica dos estudos sobre desempenho. A segunda parte (1.2) apresenta alguns aspectos preliminares e as principais definições do desempenho no trabalho; a terceira parte (1.3) se encarregará dos modelos de desempenho. E, por fim, a quarta parte (1.4) abordará as medidas de desempenho no trabalho.

\subsection{Desempenho: Perspectivas Históricas}

Os estudos sobre desempenho no trabalho, das variáveis que o antecedem e o predizem, ocorrem de forma sistemática há décadas (Austin \& Villanova, 1992; Cropazano, James \& Konovsky, 1993; Oliveira-Castro, 1994). No tocante à aferição do desempenho, diversas métricas foram desenvolvidas e utilizadas no contexto das organizações, com foco específico em sua aplicação (Netto, 2007). Entretanto, Coelho Jr. (2009) pondera que, no início século XIX, não se podia falar em medidas de desempenho validadas 
psicometricamente, nem, tampouco, possíveis de serem generalizadas para outras organizações. Para esse autor, o desempenho apresentava um entendimento prático, de utilização imediata às demandas da organização, sem contudo, maior rigor teórico ou metodológico capaz de gerar conhecimento, no que se refere ao desenvolvimento de medidas que apresentassem evidências de validade para a aferição do desempenho.

Coube à Escola de Administração Científica, na primeira década do século XX, um crescente interesse pela padronização dos processos de trabalho, principalmente os voltados à identificação do modo mais eficaz de executar as tarefas (Martins \& Santos, 2007; Willians, 2004). Essa uniformização possibilitaria, segundo os autores, a padronização dos recursos a serem utilizados nas tarefas e os resultados alcançados. Isso acarretou uma forma específica de se avaliar o desempenho das pessoas, em virtude do prévio planejamento e da padronização das tarefas e rotinas, o que, de certa forma, ratifica o exposto por Brandão e Guimarães (2001) ao colocarem que não é recente a preocupação das organizações em dispor de indivíduos capacitados para o desempenho eficiente de certas funções.

As empresas necessitavam de homens eficientes; entretanto, a busca por indivíduos competentes, na visão de Taylor (1970), excedia a oferta. Nessa época, ressalta Taylor (1980), buscava-se a padronização, que trazia o parcelamento e a separação entre a compreensão e a execução do trabalho, o que garantiria os principais recursos instrumentais para aumentar tanto a produção quanto o controle sobre ela.

O foco recaia sempre no aumento da produtividade; para tanto, partia-se do pressuposto de que os homens não eram capazes de se autosselecionar, nem de se autoaperfeiçoar, o que fez Taylor (1980) propor a seleção científica de empregados e o treinamento sistemático. De acordo com Coelho Jr. (2009), coube a Taylor, a partir de 1914, o papel de influenciar as organizações, no sentido de planejarem seus sistemas de avaliação, levando em consideração os esforços do gerenciamento científico do desempenho.

A seleção e o treinamento do trabalhador, com base no princípio taylorista, visavam o aperfeiçoamento dos empregados em habilidades indispensáveis para o exercício de atividades específicas, limitando-se às questões técnicas pertinentes ao trabalho e às especificações de cada cargo (Coelho Jr., 2009).

Posteriormente, em decorrência de pressões sociais e do aumento da complexidade das relações de trabalho, as organizações passaram a considerar, no processo de desenvolvimento profissional de seus empregados, não somente questões técnicas mas também aspectos sociais e comportamentais relacionados ao trabalho. 
Pode-se perceber que a utilização de processos de avaliação do desempenho dos trabalhadores tornou-se maior com o advento do taylorismo, no início do século passado. As pesquisas sobre racionalização do trabalho, a origem e as primeiras escalas de avaliação de mérito, aplicadas com o objetivo de disciplinar o trabalhador e interferir na maneira como realiza o trabalho, também se deve a Taylor (Brandão \& Guimarães, 2001). Poucas organizações efetivamente utilizaram essas avaliações de desempenho antes da Segunda Guerra Mundial; somente, empresas estatais e as forças armadas valiam-se regularmente desses procedimentos (Coelho Jr., 2009).

Essas primeiras medidas de desempenho apresentavam dois objetivos centrais: o primeiro de fornecer aos gestores informações referentes à natureza e ao status do trabalho realizado pelos subordinados, o que acabava por aumentar a produtividade; e o segundo, como mecanismo de apoio à tomada de decisões, baseadas nas constantes reavaliações das informações do trabalho executado pelos empregados (Willians, 2004).

A utilização de medidas para aferir o desempenho nas organizações apresentava, pois, como objetivo, o provimento de insumos consistentes à delimitação de práticas e procedimentos organizacionais, o que justificaria o enfoque, desde sua origem, dada a avaliação, no que se refere ao gerenciamento do desempenho, dando menor evidência às etapas de planejamento, acompanhamento e revisão, conforme apontado por Lucena (1992) e Sonnentag e Frese (2002). Esse fato, na visão de Coelho Jr. (2009), historicamente forneceu à avaliação do desempenho um caráter punitivo devido ao controle do que era executado pelo empregado, além de promover um ranqueamento entre os indivíduos com melhor desempenho, o que ocasionava uma intensa competição entre os trabalhadores.

Ao analisar as medidas de desempenho utilizadas até a década de 1930, Willians (2004) constatou que a origem do desenvolvimento e aplicação de medidas de desempenho remonta à necessidade de os chefes de órgãos do governo investigarem o cumprimento dos objetivos da organização e da avaliação do nível do esforço dispensado pelos empregados para a execução. Por intermédio de feedbacks aos gestores, diz esse autor, as medidas de desempenho eram desenvolvidas para informarem sobre o comportamento dos trabalhadores no exercício de suas funções, apresentando o impacto dos resultados de trabalho para o cumprimento dos objetivos e da missão da organização.

No entanto, a base de sistemas ancorados em aspectos de personalidade encontrava respaldo na crença de que ações de feedback se apresentavam como fonte de aprendizagem e mecanismo de motivação para os indivíduos. Entretanto, o feedback emanado pelo chefe refletia o comportamento da pessoa em termos de suas atitudes (extroversão, bom 
relacionamento interpessoal) e não em função dos resultados do seu trabalho, o que representa uma vulnerabilidade dos sistemas de avaliação do desempenho, denominados tradicionais (Coelho Jr., 2009). Em virtude do enfoque dado às questões relativas à personalidade do sujeito, que estabeleciam um escalonamento entre os mesmos, o que provocava consequências relativas ao posicionamento do indivíduo nessa classificação. No início do século $\mathrm{XX}$, as avaliações de desempenho refletiam mais a personalidade e as características do indivíduo do que os próprios resultados relacionados às metas e a comportamentos que acarretavam tais resultados (Coelho Jr, 2009).

Com o advento da realização de estudos empíricos, os pesquisadores passaram a questionar a avaliação de desempenho que utilizava fatores de personalidade. A partir da década de 1960, estes pesquisadores, por influência da administração por objetivos, passaram a avaliar o desempenho por metas e pelas capacidades do indivíduo, dada a complexidade em se mensurar desempenho somente por intermédio de características de personalidade (Coelho Jr., 2009).

Considerando a evolução histórica da avaliação do desempenho, Coelho Jr. (2009) relata que, na década de 1970, as práticas de mensuração do desempenho sofreram influência da legislação americana, que forneciam as mesmas oportunidades aos indivíduos. Nas décadas posteriores, 1980 e 1990, mudanças consecutivas promoveram a utilização de práticas organizacionais consideradas drásticas, como, por exemplo, o downsizing, o que afetou o sistema de avaliação de desempenho, com as necessárias adaptações (Coelho Jr., 2009).

Ainda, na década de 1990, as ações vinculadas ao desempenho (ato de desempenhar) tornaram-se fundamentais no trabalho, estabelecendo objetivos prévios e contextos específicos para o desenvolvimento, integrando características individuais, relativas às tarefas que dizem respeito ao contexto, deixando, assim, de estarem vinculadas a aspectos de controle e punição dos indivíduos, tornando-se um processo estratégico para as organizações (Coelho Jr., 2009).

Em síntese, no decorrer do século XX, a avaliação de desempenho deixou de lidar somente com aspectos relacionados ao controle dos tempos e movimentos para tratar de processos em que o empregado e seu trabalho eram considerados como parte de um contexto social e organizacional mais amplo (Guimarães, Nader \& Ramagem, 1998). A partir de 2000, a esse processo de avaliação do desempenho incorporou-se um status de gestão estratégica, além de realizar ações de planejamento, acompanhamento e revisão de desempenho (Coelho Jr., 2009). 
Para Coelho Jr. (2009), as organizações, mais recentemente, vêm desenvolvendo sistemas de avaliações de desempenho por intermédio de competências, apresentando-se como um diferencial competitivo. Mesmo assim, ressalta o autor, há existência de certa insatisfação dos gestores com os sistemas de avaliação de desempenho, em virtude da ausência de neutralidade na atribuição de escores de desempenho e pelas distintas motivações envolvidas no ato de avaliar.

Diante dessas ponderações, Brandão e Guimarães (2001) apontam que as necessidades de as organizações contarem com instrumentos para estimular o trabalhador a adotar ou reforçar determinadas atitudes fizeram com que as técnicas de avaliação de desempenho fossem aperfeiçoadas, restando às ciências sociais o papel de destaque neste processo. Ainda assim, Coelho Jr. (2009) coloca que proporcionar avaliações menos negativas sob a ótica dos avaliados é o grande desafio da temática acadêmica que trata do desempenho, ou seja, deve-se considerar a magnitude de motivos, disposições, intenções e ações da organização, de avaliadores e dos indivíduos que são avaliados ao se medir desempenho.

$\mathrm{Na}$ parte seguinte, serão discutidos os principais conceitos e pressupostos que norteiam a literatura sobre desempenho.

\subsection{Pressupostos e Definições sobre Desempenho no Trabalho}

O desempenho no trabalho vem sendo uma das variáveis mais investigadas na área do comportamento organizacional, sobretudo no cenário internacional (Bourne, Mills, Wilcox, Neely, Platts, 2000; Coelho Jr., 2009; Godard, 2001, Iaffaldano \& Muchinsky, 1985; Mair, 2005; Manning \& Barrete, 2005; Rousseau, 1997). No entanto, no contexto brasileiro, cabe salientar que o quantitativo de publicações são inferiores às estrangeiras, tanto no campo da psicologia organizacional e do trabalho quanto no campo da administração (Borges-Andrade, Coelho Jr. \& Queiroga, 2006; Borges-Andrade \& Pagoto, 2010). Mais recentemente, contudo, alguns esforços foram realizados e um certo número de trabalhos vieram a impulsionar a produção brasileira, sobre desempenho, sobretudo os trabalhos de Bendassolli e Borges-Andrade (2013), Brandão, Borges-Andrade, Puente-Palácios e Laros (2012), Brandão, Borges-Andrade e Guimarães (2012), Gondim, Puente-Palácios e Borges-Andrade (2011) e Santos (2012), mesmo assim, essas publicações não suprem as lacunas existentes.

Os estudos de desempenho no trabalho no Brasil, dizem respeito a etapa de avaliação, negligenciando o planejamento, o acompanhamento e a revisão, como pode ser comprovado pelos estudos de Borba, Pagotto e Martins (2008), Coelho Jr. (2009), Coelho Jr. e Queiroga 
(2008), Macedo (2007), Melo (2008), Oliveira, Vieira, Oliveira, Vieira e Brixi, (2008), Peixoto, (2008), Sanzi (2008). Estudos mais atuais ainda mantêm essa tendência, como por exemplo, as pesquisas conduzidas por Bendassolli e Borges-Andrade (2013), Brandão et al. (2012a) e Santos (2012).

Como estratégia para superar essa limitação, Coelho Jr. (2009) expõe a necessidade de se investigar as variáveis referentes às dimensões psicológicas do desempenho em comportamento organizacional. Tal demanda, justifica-se na medida em que se busca o objetivo de promover um avanço teórico e empírico mais efetivo e de forma mais concreta nos estudos do desempenho no trabalho.

Como objeto de estudo da administração e da psicologia, essa análise recaí sobre sobre o desempenho humano no trabalho, dizendo respeito à identificação de dimensões psicológicas e de variáveis antecedentes ao desempenho, como valores organizacional, práticas organizacionais (como manifestação da cultura organizacional), identidade profissional e identidade organizacional, conforme tratado neste trabalho. Assim sendo, a administração e principalmente a psicologia, com foco nos estudos do comportamento humano, não abordam temas de desempenho que são recorrentes à outras tradições de pesquisa, tais como, a econometria.

A contribuição da psicologia e da administração, nos estudos sobre o desempenho que se referem aos processos comportamentais no ato de desempenhar, está na investigação dos preditores das variáveis psicológicas responsáveis pela explicação de variância de desempenho o que corresponde a importante contribuição para o avanço teórico e empírico do desempenho no trabalho nos estudos organizacionais (Coelho, Jr, 2009).

No que se refere à literatura sobre desempenho, pouco esforço vem sendo dispendido para se definir e se integrar os múltiplos aspectos teóricos associados ao desempenho, como pode ser verificado em Sonnentag e Frese (2002). Segundo esses autores, duas abordagens teóricas são encontradas. A primeira trata do aspecto comportamental relativo ao desempenho, e a segunda, é responsável por investigar o resultado do desempenho. De forma similar, Ţuţu e Constantin (2012), referem-se a essas duas abordagens. A primeira parte do princípio que o desempenho é visto como sendo desfechos e resultados, definindo como o histórico de resultados produzidos de uma certa atividade ou em uma determinada posição (Robertson, Callinan \& Bartram, 2002). Nessa abordagem o desempenho do trabalho global deve ser a soma (ou média) dos resultados do trabalho. Já a segunda abordagem, mais empregada por esses autores, considera o desempenho no trabalho como a soma de comportamentos que regem os empregados em um determinado contexto (Bartram, 2000; 
Campbell, McLoy, Oppler, Sager \& Frese, 1993, Robertson et al., 2002), sendo relevantes para os objetivos organizacionais (Schmitt \& Chan, 1998). Se comportamentos podem ser avaliados separadamente, o desempenho é entendido como uma série interligada de comportamentos (Robertson et al., 2002).

As pesquisas empíricas mostram, de forma recorrente, que os temas referentes ao desempenho humano no trabalho são os mais desenvolvidos (Coelho Jr., 2009). Diversas investigações dão conta do impacto produzido pela avaliação de desempenho no contexto da organização, como por exemplo, Brandão et al. (2012a), Brandão et al. (2012b), Nankervis e Compton (2006), além do impacto sobre os processos vinculados à própria avaliação (Coelho Jr., 2009).

Assim sendo, se há determinado consenso nos estudos sobre o desempenho, este se dá no que se refere a seu significado. O pressuposto central é de que o desempenho é um construto comportamental, significa dizer que, existe uma ação ou um conjunto de ações realizadas pelos indivíduos direcionadas ao alcance dos objetivos relevantes para a organização (Campbell, et al., 1993; Sonnentag \& Frese, 2002).

Para Ferreira (1999) o desempenho representa o produto de uma ação, isto é, o ato ou efeito de concretizar algo ou a manifestação de certo comportamento. O que para Lucena (1992) se refere à consecução de tarefas, responsabilidades e deveres que são imputadas aos indivíduos e por eles manifestadas. Trata-se da expressão de comportamentos conexos a atividades, papéis, normas, metas, padrões de eficiência e eficácia constituídos no trabalho (Abbad, 1999). Para Abbad e Borges-Andrade (2004, p. 256) são o "o quê, como, onde, quando, para que e com que padrões as tarefas são executadas pelas pessoas".

Percebe-se, então, que o desempenho está atrelado ao esforço em se realizar certa atividade ou trabalho, com o objetivo de se entregar resultados específicos ou determinado saldo em torno de algo esperado. Para tanto, existe um executante, que assume uma ação ou comportamento, perante determinada situação ou contexto, com vistas à atingir resultados (Caetano, 1996). Não constituindo, portanto, o desempenho uma qualidade ou atributo do indivíduo, mas sim, certa ação ou conjunto de ações observáveis, mensuráveis e dinâmicas (Abbad, 1999).

Em síntese, na linguagem cotidiana a definição de desempenho está atrelada ao empreendimento de esforços dos indivíduos para a consecução de determinados tipos de comportamentos esperados e previamente planejados. Para tanto, o desempenho conta com características e aspectos específicos, tais como motivação e contexto, pautados pela sua execução (Coelho Jr., 2009; Coelho Jr. \& Borges-Andrade, 2011a). 
Três são as perspectivas conceituais ao se estudar empiricamente o desempenho no trabalho (Sannentag \& Frese, 2002). A primeira, perspectiva individual, na qual o foco recai na investigação de características individuais relacionadas ao desempenho. Nessa perspectiva, o bom desempenho está atrelado à pré-requisitos pessoais ou profissionais, sendo comumente investigadas variáveis individuais referentes à fatores de personalidade, habilidades técnicas e variáveis demográficas, como grau de escolaridade e idade (Coelho Jr., 2009).

A segunda, perspectiva contextual ou situacional, apresenta ênfase no contexto, referente ao ambiente de trabalho do sujeito. Para Sonnentag e Frese (2002) são duas as linhas de investigação, quando se trata dos fatores situacionais. A primeira, vem analisar os fatores situacionais facilitadores do desempenho e a segunda os fatores que dificultam o desempenho. Na pesquisa conduzida por Hackman e Oldman (1976), as características do trabalho são analisadas, admitindo-se que certos fatores relativos à tarefa (identidade com a tarefa, significado do trabalho, autonomia, variedade de habilidades necessárias) produzem impacto sobre o estado psicológico do indivíduo (por exemplo, conhecimento dos resultados do trabalho, responsabilidade pelos resultados do trabalho) e nos resultados de seu trabalho. No segundo caso, a investigação se dá sobre as características organizacionais que restringem o bom desempenho, como por exemplo, ausência de suporte da chefia à execução das tarefas e suporte à aprendizagem. De acordo com Coelho Jr. (2009), são escassos os estudos que se referem a esta segunda vertente.

A terceira perspectiva, perspectiva da regulação do desempenho, analisa os processos que envolve à manutenção do desempenho. Nesta linha, o desempenho é considerado um processo ativo, isto quer dizer que, encontra-se vinculado ao interesse do indivíduo para sua manutenção (Coelho Jr., 2009). Para esse autor, o pesquisas desta perspectiva abordam a forma dos indivíduos executarem seu trabalho e quais os processos individuais que estão envolvidos quando ocorre o desempenho, distinguindo os sujeitos entre si a partir da avaliação de seu desempenho. Os exemplos desta linha de pesquisa refletem a identificação dos processos cognitivos relacionados ao ato de desempenhar (como a função conferida à memória e a função da teoria do processamento da informação) e a teoria da ação, cuja ênfase está no quanto o sujeito se engaja e quais processos seguintes relacionados quando está desempenhando (Coelho Jr., 2009).

De acordo com Coelho Jr. (2009) os antecedentes do desempenho são investigados, na perspectiva de regulação, a partir de variáveis individuais. Ainda de acordo com o autor, expertise e o grau de excelência são os principais temas investigados na literatura 
internacional, que contempla esta perspectiva, nos estudos do comportamento humano na organização.

O objetivo da pesquisa em expertise do desempenho é a distinção entre o que induz o bom e o mau desempenho. Ou seja, busca os processos de cognição envolvidos, bem como o tipo de compreensão que utiliza ou integra, por intermédio da análise das características relativas à tarefa abrangidas no ato de desempenhar. A partir da teoria da ação em desempenho, Sonnentag e Frese (2002) descrevem o processo de desempenhar a partir de seu grau de excelência, considerando o processo e a estrutura deste ato. O processo, enseja a sequência de aspectos envolvidos numa ação e diferencia o desenvolvimento de metas, a pesquisa de informações relacionadas ao trabalho assim como o planejamento, execução e monitoramento da ação e processamento de feedback (Coelho Jr., 2009). O ponto de vista da estrutura se refere à organização hierárquica destes aspectos. Além de tudo, as duas formas se apresentam como complementares.

Os estudos desenvolvidos por Seifert, Yukl e McDonald (2003) relacionam a regulação de desempenho e o contínuo estabelecimento de intervenções planejadas de maneira antecipada. De acordo com esses autores, as interposições mais eficazes dizem respeito a orientação por metas e o provimento contínuo de ações de feedback que estejam relacionadas à tarefa. Coelho Jr. (2009) esclarece que a teoria de orientação por metas assume que as metas impactam o desempenho por intermédio de quatro mecanismos mediadores (esforço, persistência, direção e adoção de estratégias relacionadas à tarefa). O efeito favorável, provocado pelas ações de feedback sobre o desempenho, ocorre na medida em que este se apresente de forma direta e relacionado à tarefa e não aos processos individuais (e.g., personalidade) subjacentes à mesma (Coelho Jr., 2009). Para Sonnentag e Frese (2002) a combinação de uma intervenção por intermédio de orientação por metas com uma intervenção por intermédio de feedback resultaria em um melhor desempenho do que quando estas intervenções são realizadas isoladamente.

A modelagem comportamental surge como outra linha da perspectiva de regulação de desempenho. O reforço ao indivíduo, por meio de, reconhecimento social, elogios e atitudes favoráveis, é capaz de regular o desempenho. A partir da meta-análise feita por Sonnentag e Frese (2002) foi possível observar que as intervenções com fundamento na modificação de comportamentos apresentam efeitos positivos sobre o desempenho na tarefa, ou seja, a forma como certas atividades desempenhadas pelos sujeitos possibilitam a contribuição com as questões técnicas da organização, relacionando, portanto, ao exercício da descrição de cargos (Coelho Jr., 2009). 
Entretanto, ressaltam Sonnentag e Frese (2002) que não houve um efeito favorável com base na modificação de comportamentos sobre desempenho contextual, compreendido como às atividades contidas no suporte da organização e no ambiente social e psicológico da organização (nível Macro). Cabe ainda salientar, segundo Coelho Jr. (2009, p. 23) que, as atividades consideradas relevantes para o desempenho na tarefa são variáveis entre as ocupações, ao contrário, as atividades de desempenho contextual se assemelham, de forma relativa, entre os tipos de trabalho.

Em resumo, Sonnentag e Frese (2002) apresentam diversificadas linhas de investigação sobre o desempenho no trabalho a partir das três perspectivas elencadas. A combinação entre duas ou mais perspectivas visando a predição do desempenho é comum na literatura, conforme observa Coelho Jr. (2009). Assim, as pesquisas realizadas por Brandão (2009), Brandão e Borges-Andrade (2012a), Coelho Jr. (2009), Santos (2012) e Waldman (1994) mostram que fatores pessoais e contextuais apresentam efeito significativo na predição de variância de desempenho no trabalho.

Quando se trata da definição de desempenho nos estudos organizacionais, Eccles (1991), Grote (2003), Starbuck (2005), Bendassolli (2012) e Țuţu e Constantin (2012), atribuem a vinculação do desempenho ao comportamento manifesto pelo sujeito no exercício de suas atribuições e responsabilidades. Tratam-se dos conhecimentos e habilidades, segundo Oliveira-Castro (1994), que se dirigem ao contexto do cargo à execução de uma obrigação ou tarefa, ou à maneira como um indivíduo se comporta ou atua em termos de eficiência, rendimento e atuação em relação a algo (Houaiss, 2001), o que resulta no alcance de resultados organizacionais efetivos.

Para determinados autores, como no caso de Toro (1996), o desempenho está dirigido ao resultado, por intermédio de uma ação, de um empreendimento intencional realizado pelo sujeito. Para outros, como Pontes (2002) e Grote (2003), esse desempenho vincula-se à qualidade e quantidade de trabalho realizado, levando-se em consideração tempo e custo de sua execução. No primeiro caso, há influência de fatores relacionados ao contexto de trabalho do indivíduo, ou seja, as condições culturais e sociais. No segundo, abarca fatores de eficácia, que dizem respeito aos resultados, e fatores de eficiência, relativos a meios ou processos, na esfera organizacional.

A definição do desempenho em termos comportamentais gera uma série de implicações. A primeira delas diz respeito à sua diferenciação de outros termos como eficiência e resultado. Para Bendassolli (2012) o resultado não é o desempenho, mas sim, estados ou condições de indivíduos ou coisas que são modificados pelo desempenho, que por 
conta disso, passam a contribuir para o alcance dos objetivos organizacionais, ou seu contrário, chamado por alguns autores de desempenho contra-produtivo (por exemplo, Dunlop \& Lee, 2004; Rotundo \& Sackett, 2002). O resultado pertence às consequências do desempenho. A diferenciação apresentada por Bendassolli (2012) estabelece que o desempenho é regulado por aspectos psicossociais, cognitivos e afetivos, enquanto o resultado sofre influência de fatores de maior amplitude, como por exemplo, demanda de consumidores, oferta de insumos, crises econômicas, mudanças tecnológicas, entre outros.

No que se refere a eficiência, está é apresentada como à avaliação do resultado do desempenho (Bendassolli, 2012), para tanto, critérios devem ser selecionados, como por exemplo critérios de qualidade. Segundo o autor, essa interseção entre desempenho e eficiência acarreta a existência de uma zona crítica, isto é, por um lado a colocação de ações no ambiente por parte do sujeito (sequência de movimentos intencionais, dependentes de fenômenos psicossociais, intra e interindividuais e situacionais de alta complexidade. Tais ações provocam mudanças no ambiente, nos indivíduos e nas coisas, isto é, no resultado. $\mathrm{E}$ por outro lado, há a necessidade do processo de avaliativo. Por conta disso, Bendassolli (2012) estabelece que a eficiência não possui uma faceta estritamente objetiva, ou seja, ela depende de processos de interação social mediados por elementos organizacionais, e como acontece com o resultado, a eficiência é afetada por certas variáveis que não são controladas pelo indivíduo.

A segunda implicação de se definir desempenho como comportamento, segundo Bendassolli (2012), é a decisão de quais comportamentos estão efetivamente relacionados a resultados organizacionais relevantes. Deve-se esclarecer quais são as metas, tarefas e objetivos principais da organização, com vistas à avaliação e desenvolvimento do desempenho dos indivíduos. Dentre outros aspectos, esse pressuposto se liga ao fato do desempenho ser um construto multidimensional (Sonnentag \& Frese, 2002). O que impossibilita seu tratamento somente como uma medida global.

A esse respeito Bendassolli (2012) comenta que, por se referir a um conjunto de ações que abrange uma complexa interação com a realidade, o desempenho integra diferentes facetas psicológicas (cognitivas e afetivas, entre outras), materiais e interpessoais, refletindo uma diversidade de códigos. Continua o autor afirmando que tais códigos estão em relacionamento, não só com a ação dirigida ao próprio comportamento do indivíduo, mas também à ação sobre outros sujeitos, guiada para recursos físicos ou imateriais presentes no ambiente, para os próprios conjuntos normativos que delimitam a tarefa, para a própria tarefa e finalmente, dirigida para a organização. 
Duas meta-dimensões do desempenho são frequentemente encontradas na literatura. Borman e Motowidlo (1993) foram os responsáveis pela identificação dessas duas grandes classes de comportamento dos funcionários: o desempenho da tarefa e desempenho contextual. A distinção entre o desempenho da tarefa e o desempenho contextual ganhou projeção e aceitação na literatura ao investigar o comportamento no trabalho (por exemplo, Conway, 1999; Griffin, Neal \& Neale, 2000; Van Scotter \& Motowidlo, 1996).

O desempenho de tarefas, de acordo com Kahya (2008), envolve padrões de comportamentos que estão diretamente envolvidos na produção de bens ou serviços, ou atividades que dão suporte indireto para os processos técnicos do núcleo da organização. $\mathrm{O}$ que Campbell et al. (1993) tratou como sendo à proficiência do indivíduo em contribuir com o núcleo técnico do cargo ou da ocupação.

O desempenho contextual é definido como os esforços individuais que não estão relacionados diretamente com a sua função principal da tarefa, porém, são importantes na medida em que moldam o contexto organizacional, social e psicológico, que serve como catalisador crítico para atividades e processos de tarefas (Werner, 2000). Ou seja, são as atividades que não contribuem de forma direta para o núcleo técnico, para o atingimento dos objetivos organizacionais. A ajuda fornecida por um funcionário para que outro complete sua tarefa, a colaboração com supervisores, ou a simples sugestão de formas de melhorar os processos organizacionais, fazem com que haja um engajamento para realizar o desempenho contextual (Van Scotter, Motowidlo \& Cross, 2000). Neste sentido, conforme destaca Van Scotter et al. (2000), cresce o interesse no tipo de comportamento útil, cooperativo e inovador para o desempenho no trabalho, tornando-se mais importante para a compreensão de sua influência sobre os resultados individuais e organizacionais.

O terceiro pressuposto apresentado por Bendassolli (2009) remete-se ao fato de o desempenho ser um fenômeno multinível, dada a complexa interações entre as dimensões psicológicas, sociais, organizacionais e situacionais que se vinculam ao desempenho. A literatura, sobretudo no campo da psicologia organizacional e da administração, vem buscando combinar construtos inerentes a estas tradições com o objetivo de se predizer o desempenho em uma perspectiva multinível. Como exemplos, os estudos de Tesluk, Hofmann \& Quigley (2002), baseados na cultura organizacional, os de satisfação e aprendizagem, de Coelho Jr. (2009), os de aprendizagem, contexto e competência de Brandão (2009) e, mais recentemente, o estudo de competências, carreiras e contexto, de Santos (2012). 
O quarto e último pressuposto vai tratar da origem do desempenho, o que remete à ideia de que o conjunto de ações que estabelece o desempenho está sob o controle do indivíduo (Bendassolli, 2011). Assim sendo, o desempenho é intencional, mesmo que seu conjunto de ações seja automático. Para Campbell (1990) e Campbell et al. (1993), a implicação mais direta desse pressuposto é a que remete à avaliação do desempenho somente em função da cadeia de eventos e da interdependência de ações que estão sob o efetivo controle do indivíduo.

Diante de todo o exposto, a definição operacional de desempenho utilizada nesta tese refere-se ao conjunto de comportamentos do indivíduo, manifestadamente expressos no exercício de seu trabalho, refletindo suas atribuições e responsabilidades.

A próxima seção tratará do modelos sobre desempenho no trabalho mais comumente encontrados na literatura.

\subsection{Modelos Teóricos do Desempenho no trabalho}

O primeiro modelo teórico, entre os mais referenciados na literatura, é proposto por Campbell (1990), que definiu desempenho como um comportamento ou ação proeminente para os objetivos organizacionais. A mensuração do desempenho para esse modelo ocorre em termos de níveis ou margens de contribuições para os objetivos da organização.

Para Bendassolli (2012), o aspecto mais importante do modelo de Campbell (1990) é sua proposta de componentes (dimensões) e antecedentes (determinantes e preditores) para o desempenho. Três são os determinantes propostos. O primeiro nominado conhecimento declarativo (Campbell, 1990; Campbell et al. 1993), definido como o conhecimento sobre fatos, regras, princípios e sobre o self, referindo-se a o que fazer. O segundo, conhecimentos $e$ habilidades procedimentais, incluindo-se, aqui, habilidades psicomotoras e psicoafetivas, diz respeito a como fazer, à capacidade prática de integrar conhecimento e ação. O terceiro trata da motivação, que versa sobre as escolhas referentes à definição do tempo e da investigação de dado comportamento, além de se referir à sua intensidade e à persistência nessa conduta.

No que concerne às dimensões do desempenho, estas são tratadas como categorias que se diferenciam de eventos que se espera que as pessoas façam em um cargo ou ocupação. Para Campbell et al. (1993), as dimensões do desempenho representam inter-relações e padrões de variação com outras variáveis, as quais dependem do cargo ou função considerados. São representadas, segundo Bendassolli (2012), por: proficiência em tarefas específicas e não específicas ao cargo; comunicação oral e escrita; demonstração de esforço; manutenção da disciplina pessoal; facilitação para pares e desempenho de equipe; supervisão 
e liderança e gestão. As cinco primeiras são relacionadas ao desempenho de tarefa (Sonnentag \& Frese, 2002). A lacuna apontada por Hesketh e Neal (1999) para o modelo versa sobre sua negligência às variáveis situacionais.

Para Bendassolli (2012), o modelo apresenta certas implicações, entre as quais se mostra relevante a postulação que o desempenho seja somente diretamente determinado por uma combinação dos três determinantes. Entretanto, conforme destacam Campbell (1990), Campbell (1999), Campbell et al. (1993), Campbell et al. (1996) e McCloy et al. (1994), existem antecedentes (treinamento e experiência do indivíduo, por exemplo), que podem dificultar ou facilitar a ação desses determinantes.

De acordo com o modelo, as variáveis individuais e situacionais vão ser mediadas (efeitos mediados) pelos determinantes, aconselhando-se o isolamento entre os efeitos indiretos dos antecedentes e efeitos diretos dos determinantes (Bendassolli, 2012). Para Campbell (1990) e Campbell et al. (1993), a motivação sempre será um determinante do desempenho, independente da função ou do cargo exercido pelo indivíduo, sendo o conhecimento declarativo um pré-requisito para os conhecimentos e habilidades em termos de procedimentos.

O segundo modelo de desempenho foi elaborado por Borman e Motowidlo (1993). De acordo com esses autores, o desempenho é dividido em duas vertentes: a primeira referese ao desempenho de tarefa, ou seja, associada ao papel formal; e a segunda ao desempenho contextual (não relacionado à tarefa em si, mas catalisador para as tarefas), cuja ênfase recai sobre a iniciativa do indivíduo e não sobre sua proficiência.

A distinção em duas dimensões do desempenho buscou solucionar o problema de se tratar a contribuição do indivíduo à organização como um valor agregado único, sendo avaliado por uma única medida, o que para Motowidlo et al. (1997) é uma limitação. Considerando-se que o comportamento do indivíduo no trabalho não é homogêneo e, por conta disso, não pode ser expresso em uma única medida global (Bendassolli, 2012). Propõese, então, duas formas de se analisar as contribuições e os comportamentos dos sujeitos no trabalho: pela categoria da tarefa e pela categoria de comportamentos expressos no contexto

Em virtude de o modelo de Borman e Motowidlo (1993) já ter sido alvo de discussão nesta tese, outras colocações serão apresentadas. A primeira reflete que o comportamento contextual está relacionado a comportamentos imprevistos que podem assumir categorias pró-sociais, conforme observa Brief e Motowidlo (1986), o que pode acarretar o bem-estar de indivíduos, de grupos e da organização (Bendassolli, 2012), ou assumir características de comportamento de cidadania organizacional (Organ, 1988; Podsakoff, MacKenzie, Paine \& 
Bachrach, 2000), ou se apresentar como comportamentos desviantes, roubo, absenteísmo, sabotagem, o que é maléfico para a organização (Murphy, 1990).

A segunda colocação, apresentada por Viswersvaran e Ones (2005), trata dos preditores de desempenho. Para Motowidlo et al. (1997), as variáveis de personalidade são preditoras mais eficientes do desempenho se comparadas às habilidades cognitivas, sobretudo no desempenho da tarefa. Para o desempenho contextual, as variáveis de personalidade, predisposição, volição e motivos são as responsáveis por explicar variância do desempenho (Borman \& Motowidlo, 1993; Motowidlo et al., 1997).

O terceiro modelo, desenvolvido por Murphy (1989a, 1989b), enfatiza a natureza dinâmica do desempenho, não confundindo o seu domínio como domínio da tarefa. Para o autor, o desempenho apresenta dimensões vinculadas à tarefa e aos relacionamentos (outputs, como define o autor), além das dimensões nocivas, como por exemplo, comportamentos de indisponibilidade (absenteísmo) e destrutivos (imputs, como define o autor).

Para Murphy (1989b), a dinâmica do desempenho pode ser observada no transcurso do tempo, pelo efeito da aprendizagem e por intermédio de estágios de desempenho. $\mathrm{O}$ primeiro é o estágio de transição, ou seja, ele ocorre na medida em que o sujeito se encontra frente a uma tarefa ou a um novo trabalho, dependendo o desempenho, principalmente, de habilidades cognitivas, considerando a necessidade de o indivíduo obter novas informações e referências ainda desconhecidas. O estágio de manutenção estabelece a menor evidência dada ao peso dos conhecimentos e das habilidades, porque o desempenho do indivíduo ocorre de forma automática e estável. Entretanto, cabe salientar, que a motivação, os interesses e os valores são primordiais para o desenvolvimento de novos estágios de desempenho.

O desempenho ativo, quarto modelo analisado, parte de sua concepção teórica de base, a denominada regulação da ação (Frese \& Zaptf, 1994). Dois são os postulados principais para o modelo. O primeiro atribui uma ação natural ao seres humanos, ou seja, é da natureza do homem ser ativo. O segundo diz que essa ação é orientada sempre por um objetivo; diante disso, o sujeito da ação é um sujeito intencional capaz de se autorregular na busca por esse objetivo.

É importante também salientar que a teoria estabelece que a ação é organizada em função de uma continuidade que tem início na escolha de um objetivo, segue pela busca de informações relativas ao contexto desse objetivo por parte do indivíduo, de forma ativa, perpassa a elaboração de um plano ou de um projeto de ação, que culmina em sua execução e monitoramento. Por fim, ocorre o feedback como forma de completar o ciclo, em virtude da realização do plano (Bendassolli, 2012; Frese \& Zaptf, 1994). 
Bedassolli (2012) ressalta que o modelo do desempenho ativo é de base cognitiva, sendo que o desempenho é um processo de ação regulado e interligado pela cadeia sequencial. Não há, segundo o autor, um sujeito passivo, que reage às forças do meio, mas, sim, um sujeito ativo. Por esse motivo, Frese e Fay (2001) questionam o motivo pelo qual um indivíduo inicia um desempenho e prossegue nele, mesmo lidando com as restrições do meio, ao contrário de outros que adotam uma postura reativa. A resposta a esse questionamento está na iniciativa pessoal (Frese \& Fay, 2001). Para os autores, essa iniciativa baseia-se em três elementos: a autoiniciação de uma ação ou atividade pelo indivíduo; ser proativo, isto é, vislumbrar o longo prazo e se antecipar às eventualidade para lidar com imprevistos; persistir no curso de sua ação ou desempenho.

Segundo Frese e Fay (2001), a ativação do ciclo de ação é necessária para que um objetivo externo se transforme em um objetivo interno. Esse fenômeno é definido pelos autores como processo de redefinição ativa, ou seja, quando o indivíduo, perante uma distância psicológica considerável entre objetivos previsíveis e estabelecidos e objetivos imprevisíveis, necessita assumir uma postura ativa pela qual o objetivo, com certo grau de dificuldade, determina a elaboração e execução de um plano de ação. Em síntese, o desempenho ativo resulta de ações por parte do indivíduo que, necessita de uma autoiniciativa, de proatividade e de persistência.

No que se refere ao quinto modelo, nomeado desempenho adaptativo (Pulakos et al., 2000; Pulakos et al., 2002). O surgimento deste modelo buscou introduzir novos elementos à taxonomia proposta por Campbell et al. (1993), notadamente, os que se referissem às estratégias de adaptação dos indivíduos às novas condições de trabalho. $\mathrm{O}$ mesmo foi proposto por London e Mone (1999), com vistas a incluir elementos de desempenho adaptativo ao desempenho contextual e da tarefa.

Após uma análise da literatura, Pulakos et al. (2000) encontraram seis dimensões, e, posteriormente, mais duas, baseadas em suas pesquisas. Assim, o modelo do desempenho adaptativo conta com oito dimensões (lidar com situação de crise ou com emergência; lidar com estresse no trabalho; resolver criativamente os problemas; lidar com situações de trabalho imprevisíveis e incertas; aprender tecnologias, tarefas e procedimentos relativos ao trabalho; demonstrar adaptabilidade interpessoal; demonstrar adaptabilidade cultural; e demonstrar adaptabilidade física), encontradas em diversos cargos e ocupações (Bendassolli, 2012).

Estudos recentes realizados por Pulakos et al. (2002) demostraram que a habilidade cognitiva e a personalidade são responsáveis por explicar variância significativa do 
desempenho adaptativo. A experiência, entretanto, apenas mostrou uma influência incremental sobre as dimensões analisadas do desempenho. Esse estudo bem como a teoria em si visam estabelecer que o desempenho não é estático. O sujeito necessita de adaptações contínuas em seu desempenho, sobretudo as relativas às situações e ao conteúdo do trabalho, e que advenham de mudanças tecnológicas. Assim, podem-se entender as transformações nas fronteiras dos cargos e das ocupações e seus impactos sobre o desempenho (Bendassolli, 2012). Outros autores, como, por exemplo, Griffin, Neal e Parker (2007), propuseram formas semelhantes de se avaliar o desempenho relacionado ao trabalho, seu conjunto de papéis, contextos, não exclusivamente ligados ao cargo ou ocupação. Para esses autores, o desempenho depende de papéis diferenciados, influenciados por contextos incertos e interdependentes.

O último modelo analisado é o do desempenho episódico (Beal, Weiss, Barros, MacDermid, 2005). Este modelo apoia-se na da ligação individual entre estados afetivos e desempenho. De acordo com os autores, em virtude do caráter transitório e dinâmico dos estados afetivos, buscou-se uma definição de desempenho que fosse, também, dinâmico. Esta necessidade se justifica na medida em que estados afetivos não podem afetar o desempenho global de um indivíduo, somente episódios específicos. Assim, Beal et al. (2005) definem desempenho episódico como a progressão das atividades de trabalho do indivíduo, no tempo e no transcurso do dia. Esses episódios associam-se a unidades de tempo balizadas pela segmentação de tarefas e por objetivos específicos a serem atingidos (Bendassolli, 2012).

De acordo com Beal et al. (2005), os recursos cognitivos e sua forma de alocação são elementos-chave no desempenho episódico. Entre esses recursos, encontram-se as habilidades cognitivas gerais, os conhecimentos relativos às tarefas e ao fator conscienciosidade, presente no modelo dos cinco grandes fatores (big five). O foco da atenção necessário à realização das tarefas é determinado pela alocação desses recursos. Para os autores, os indivíduos sofrem, ainda, influência de demandas de atenção não relacionadas às tarefas, como por exemplo, conflitos internos, tensões excessivas (afetivas), pensamentos ruminativos ou lembranças (cognitivos). Tais demandas podem influenciar o sujeito e retirar o foco de sua atenção, o que culmina num desempenho inferior, comparado à alocação de recursos cognitivos que estivesse voltada para os aspectos específicos, ou seja, para a tarefa, o que garante o desempenho.

Para que a atenção esteja na tarefa, necessita-se de recursos regulatórios, definidos como uma competência destinada à autorregulação da atenção, nomeadamente quando da presença de distúrbios e interferências (Beal et al., 2005). Essa regulação sofre influência da 
motivação intrínseca do indivíduo e do significado atribuído ao objetivo. Destaca-se, ainda, no modelo, a segmentação do fluxo de comportamentos no trabalho, vivenciados do início ao fim de forma subjetiva e que se organizam entre objetivos imediatos ou de estados-fins desejados. Além da relação entre os estados afetivos e os episódios de desempenho, orientados pelo decorrer do tempo, os primeiros interferem no foco da atenção, competindo por recursos, com o objetivo de se determinar os estilos de comportamentos relevantes para a realização das tarefas (Beal et al., 2005; Bendassolli, 2012).

Em síntese, os modelos apresentados fornecem um arcabouço teórico para o desenvolvimento e a utilização de medidas do desempenho. Com base em estudos empíricos, pode-se identificar e operacionalizar preditores para o desempenho, sejam eles individuais, sejam situacionais, vinculados à tarefa e/ou contexto, apresentando-se como um conceito multidimensional e dinâmico.

A próxima parte apresentará as medidas do desempenho, entendidas como responsáveis pela realização de diagnósticos objetivos sobre os comportamentos manifestados pelos indivíduos na execução de suas atividades.

\subsection{Medidas do Desempenho no trabalho}

Nas seções anteriores foi possível verificar que o desempenho no trabalho tem sido investigado, teórica e metodologicamente, além de ser operacionalizado, de diversas formas. Essa constatação, também, foi observada por autores que trataram as medidas do desempenho como heterogêneas e de multicritérios (Bose, 2004; Brandão 2009; Carneiro, Silva, Rocha \& Dib, 2007; Coelho Jr., 2009; Sellito, Borchardt \& Pereira, 2006). Assim, a operacionalização deste construto tornou-se, segundo Oliveira-Castro (1994), uma das mais importantes questões teóricas e empíricas no contexto organizacional.

O debate controverso presente na literatura sobre qual tipo de medida e critério mais adequados para mensurar e demonstrar a validade do construto desempenho no trabalho foi apontado por Coelho Jr. (2009) em sua revisão. Comumente, encontram-se medidas de autorrelato e autoavaliação nos estudos empíricos, como no caso das investigações conduzidas por Gava e Silveira (2007), Brandão (2009) e Santos (2012). Uma segunda forma de se avaliar o desempenho é por intermédio de medidas de heteroavaliação, entre as quais destaca-se a avaliação 360 graus (Birkeland, Borman \& Brannick, 2003; Brito, Bastos, Oliveira \& Sant'anna, 2008; Grote, 2003). Outro grupo responde pela utilização de medidas objetivas ou quantitativas como forma de se medir o desempenho, tanto na literatura 
internacional (Collins, 2002; Chaddad, 2006) quanto na literatura brasileira (Bandeira-deMello \& Marcon, 2004; Coelho Jr., 2009; Gonçalves, Dias \& Muniz, 2008; Macedo, 2007).

Existem ainda classificações que levam em consideração os comportamentos adotados pelos indivíduos no trabalho e os centrados nos resultados decorrentes desses comportamentos (Brandão, 2009; Brandão \& Guimarães, 2001; Caetano, 1996; Carbone et al., 2005; Gilbert, 1978; Santos, 2012). Estes indicadores, segundo Guimarães (1998), são parâmetros quantificáveis, advindos de informações básicas, utilizados para mensurar o desempenho da organização, de suas unidades produtivas, das equipes e dos indivíduos em si, a depender do nível que estas informações representam. Descrevem e refletem uma gama de variáveis mensuráveis, que apresenta como função indicar, com a utilização de escalas específicas, certo estágio de desenvolvimento para parte da organização ou para ela como um todo.

De acordo com Coelho Jr. (2009), há vasta variedade de medidas associadas ao desempenho no trabalho e na literatura. Parte destas medidas é chamada, pelo autor, de medidas duras ou quantitativas, pertencentes aos níveis individual ou organizacional, orientados por resultados. Por outro lado, há medidas que cunho processual ou subjetiva, em que a avaliação se fundamenta em julgamentos. A sistematização dessas medidas foi realizada por Coelho Jr. (2009) com base em outros autores, notadamente, Gonçalves et al. (2008) e Schiehll e Morissette (2000), conforme apresentada no Tabela 1. 
Tabela 1

Medidas de Desempenho em Pesquisas Empíricas

\begin{tabular}{ll}
\hline Área de Investigação & Medidas de Desempenho \\
\hline $\begin{array}{l}\text { Comportamento } \\
\text { Organizacional }\end{array}$ & $\begin{array}{l}\text { Satisfação no trabalho; envolvimento; comprometimento, } \\
\text { centralidade, turn-over, competências, aprendizado, significado do } \\
\text { trabalho absenteísmo, produtividade tangível. }\end{array}$ \\
$\begin{array}{l}\text { Administração } \\
\text { Estratégica }\end{array}$ & $\begin{array}{l}\text { Orientação para o concorrente, orientação para o cliente, } \\
\text { redimensionamento da visão, dos objetivos e processos } \\
\text { organizacionais, redirecionamento da estratégia e visões, } \\
\text { endividamento de longo prazo, nível de exposição ao risco, foco } \\
\text { no longo prazo, intensidade da concorrência. }\end{array}$ \\
Marketing & $\begin{array}{l}\text { Exposição ao risco, crescimento de vendas, participação no } \\
\text { mercado. }\end{array}$ \\
Finanças & $\begin{array}{l}\text { Lucratividade, retorno sobre investimento, custos logísticos e } \\
\text { operacionais, controle financeiro, variação da receita bruta, }\end{array}$ \\
variação da relação entre custo do produto vendido e o \\
faturamento bruto (anual), alavancagem financeira. \\
Produção & $\begin{array}{l}\text { Horas trabalhadas pelos empregados, custos diversos, material } \\
\text { utilizado, quantidade de produtos, percentual de acidentes de } \\
\text { trabalho. }\end{array}$ \\
Recursos financeiros, capital de giro, volume de entradas e saídas, \\
retorno sobre o ativo. \\
Relação entre custo e benefício, rentabilidade, crescimento de \\
vendas, crescimento do setor e do subsetor de atuação, recursos \\
disponibilizados e utilizados.
\end{tabular}

Fonte. Adaptado de Coelho Jr. (2009), Gonçalves et al. (2008) e Schiehll e Morissette (2000).

A análise da Tabela 1 demonstra que o construto desempenho é trabalhado em diversas disciplinas, o que lhe fornece uma característica multidisciplinar. As avaliações que utilizam instrumentos voltados ao comportamento humano nas organizações são representadas por expectativas ou padrões comportamentais passíveis de observação no trabalho, ou seja, indicadores de desempenho que refletem as competências profissionais mais importantes para a organização (Brandão, 2009). Assim, busca-se a otimização do desempenho profissional e organizacional, no entendimento de que o domínio de certas competências é imprescindível para o desempenho de tarefas de um cargo (Brandão \& Borges-Andrade, 2007; Brandão, Guimarães \& Borges-Andrade, 2002; Dutra, Hipólito, \& Silva, 2000).

Com a utilização de instrumentos centrados nos resultados advindos de certos comportamentos, tem-se a avaliação objetiva em que há a comparação entre metas 
quantificáveis, anteriormente estipuladas, e resultados obtidos (Brandão, 2009; Guimarães, 1998). Assim sendo, o estabelecimento de metas, objetivos e diretrizes para a organização (índices ou padrões) permite que indicadores de desempenho sejam definidos, e, com isso, desdobre-se a avaliação. De acordo com Guimarães (1998), os índices dizem respeito à quantificação do indicador, por intermédio de uma relação matemática, sendo seu resultado numérico; já o padrão constitui um referencial de comparação, isto é, representa a meta de desempenho a ser atingida.

Seja a avaliação de desempenho mensurada pelo comportamento do indivíduo no trabalho, seja relativa aos resultados decorrentes desses comportamentos, as organizações necessitam de modelos de gestão que utilizem os dois tipos de indicadores (comportamentos e resultados). De acordo com Brandão et al. (2008), só a avaliação do comportamento do indivíduo no trabalho não assevera que o resultado seja realizado; por outro lado, medir unicamente os resultados pode fazer com que os sujeitos adotem comportamentos impróprios na tentativa de obter a meta, diretriz ou objetivo estipulado.

Ao se vislumbrar o cenário das medidas de desempenho nas organizações, nota-se, claramente, uma profusão de avaliações heterogêneas, que utilizam desde observação direta de certos cargos, aplicação de questionários (ou surveys) para os indivíduos na organização, além das medidas quantitativas e objetivas dos resultados, que podem ser utilizados para se relacionar aos planos dos indivíduos no trabalho, como, por exemplo, comparações entre períodos, índices de satisfação com o trabalho, absenteísmo ou rotatividade, cálculos percentuais, comparação de resultados por períodos, entre outros. Esta complexidade de medidas pode ser encontrada nas revisões de Brandão (2009), Coelho Jr. (2009), Brandão e Guimarães (2001), Santos (2012), Sonnentag e Frese (2002), conforme anteriormente relatado.

As medidas financeiras, também nominadas medidas numéricas, serviam para a avaliação do desempenho do empregado no trabalho, como observam Collins (2002), Combs, Liu, Hall e Ketchen (2006), Eckes (1994), Hanges, Schneider e Niles (1990) e Manning e Barrette (200). Relacionando-se, essas medidas, à eficácia do trabalho realizado pelo sujeito (Grote, 2003), sendo mais comum os indicadores de efetividade e produtividade no trabalho (Bandeira-de-Mello \& Marcon, 2004; Lucena, 1992; Oliveira-Castro, Lima \& Veiga, 1996).

De acordo com Coelho Jr. (2009), medidas perceptuais têm sido utilizadas para se avaliar o desempenho no trabalho. Essa constatação também foi mencionada, anteriormente, por autores como Viswervaran, Ones e Schmidt (1996), Fonseca (2001), Guimarães e Brandão (2001) e Gava e Silveira (2007). A contribuição da utilização de medidas de 
percepção reside no fato de investigarem fatores situacionais que não são comumente investigados, conforme observa Gerhart, Wright, McMahan e Snell (2000) e Joudern e Heath (1996).

As críticas relacionadas às medidas perceptuais também foram alvos da revisão elaborada por Coelho Jr. (2009). A primeira diz respeito à validade; assim sendo, questionase se a percepção dos indivíduos corresponde, de forma efetiva, ao seu comportamento real manifestado em suas rotinas e tarefas organizacionais, de forma a garantir esta validade com um mínimo de segurança e imparcialidade. Em segundo lugar, leva-se em consideração a possibilidade de ocorrer, de forma fidedigna, o transporte da avaliação do desempenho, por uma medida subjetiva, para a realidade de comportamentos que os sujeitos apresentam no exercício de seu cargo de maneira efetiva. Para Coelho Jr. (2009), outro problema das medidas de desempenho atreladas ao comportamento organizacional é a ausência de evidências de sua adequação psicométrica, o que compromete a fidedignidade e a precisão do instrumento.

Tais discussões foram alvo de interpelações de vários autores, tanto no contexto brasileiro quanto no cenário internacional (Brandão, 2009; Coelho Jr., 2009; Fonseca, 2001; Gava \& Silveira, 2007; Hodgkinson, 2002; Mezias \& Starbuck, 2003; Vasconcelos, 2005; Walton \& Dawson, 2001; Winter, 2003; Wright, Gardner, Moynihan, Park, Gerhart \& Derley, 2001; Wright, Manigault \& Black, 2004). Coelho Jr. (2009) destaca que não há consenso entre os estudiosos a respeito da melhor forma de se integrar as medidas objetivas e subjetivas, de maneira otimizada, para se aferir o desempenho.

Mesmo com todas as ponderações apontadas, a utilização de medidas quantitativas de percepção para a aferição do desempenho do trabalho deve ser encorajada. Essa recomendação é respaldada, de acordo com Coelho Jr. (2009), pela ausência de indicadores de desempenho dos indivíduos no trabalho, em grande parte das pequenas empresas, sendo que a utilização dessas medidas pode apontar para o avanço da organização, ao sistematizar um programa de gestão de desempenho.

Outra medida vinculada à análise dos resultados organizacionais é o Balanced Scorecard, proposto por Kaplan e Norton (1994), em decorrência da escassez do emprego estrito de indicadores financeiros para a gestão organizacional. Esse instrumento despontou como uma alternativa para aprimorar a gestão e o acompanhamento dos resultados da organização, uma vez que é focado no planejamento estratégico e no desempenho (Oliveira, Martins, Oliveira \& Pinto, 2012). 
Consiste, diante disso, em um dos enfoques sugeridos, frequentemente, para aperfeiçoar o desempenho organizacional (Coad, 1999), baseado na perspectiva financeira de processos internos de aprendizado e de crescimento e do cliente, criando um modelo teórico cujo foco recai na operacionalização da missão e estratégia da organização, ao redor de objetivos e medidas não financeiras e financeiras de desempenho (Kaplan \& Norton, 1994). Neste contexto, a aferição dos resultados é primordial para a gestão organizacional porque confere efetividade às metas e aos objetivos estabelecidos, auxiliando o processo decisório no que concerne aos ajustes e medidas que precisam ser tomadas (Kaplan, 2012).

A seção seguinte abordará uma medida perceptual de desempenho, alvo de investigação desta tese, o desempenho profissional por competências, ou simplismente, desempenho competente, definido como o conjunto de conhecimentos, habilidades e atitudes que o indivíduo emprega para a realização de suas metas de trabalho e que devem estar alinhados ao perfil almejado pela organização, impactando tanto o nível micro quanto o macro-organizacional. 


\section{Seção 2. Desempenho Profissional por Competências}

Diversos autores (Abbad \& Borges-Andrade, 2004; Brandão \& Guimarães, 2001; Brandão, 2009; Carbone et al., 2005; Coelho Jr, 2009; Nisembaum, 2000; Santos, 2012, Silva \& Luz, 2010, entre outros) vêm nos últimos quinze anos associando competência à noção de desempenho, reconhecendo que a utilização de conhecimentos, habilidades e atitudes no trabalho (elementos que formam a competência) resulta em um desempenho profissional, com evidenciáveis reflexos sobre os resultados organizacionais (Brandão, 2009). Diante disso, o desempenho da pessoa representaria uma manifestação de suas competências, expressas em razão dos comportamentos que o indivíduo adota no trabalho e de resultados decorrentes (Gilbert, 1978).

Em vista disso, a primeira parte dessa seção (2.1) apresenta aspectos relativos à origem e expansão do conceito de competências. A segunda parte apresenta as dimensões da competência (2.2). E, por fim, a terceira parte (2.3) que se encarregará da noção de gestão por competência e gestão por desempenho.

\subsection{Origem e Evolução da Noção de Competências}

Dentro da temática dos estudos sobre o comportamento organizacional, a noção de competência tem alcançado grande relevo, devido ao interesse de pesquisadores e organizações, nos últimos anos (Brandão 2009; Santos, 2012). Migrando da forma discursiva para a forma operativa, as competências passam a ser utilizadas para promover transformações no ambiente organizacional, em diversas áreas, como forma de resolução de problemas que incluem remuneração, avaliação do desempenho, programas de capacitação, entre outros. O impulso da literatura acerca desse tema ocorreu na década de 2000, com a emergência do modelo de gestão por competências, propiciando, assim, a ocorrência de discussões sobre a noção de competência, suas dimensões, antecedentes e implicações (Brandão \& Guimarães, 2001; Brandão, 2009; Gonczi, 1999; McLagan, 1997).

Ao percorrerem a historiografia, Isambert-Jamati (1997) observa que a expressão competência estava associada à linguagem jurídica, primeiramente. Referia-se à faculdade, atribuída ao indivíduo ou à instituição de apreciar e julgar determinadas questões. Por influência, o conceito de competência se destinou ao reconhecimento social sobre a capacidade de o sujeito pronunciar-se relativamente a um assunto determinado; posteriormente, foi utilizado, de forma mais geral, como forma de qualificar a pessoa capaz de realizar determinado trabalho. 
A incorporação do termo competência pela linguagem organizacional ocorreu no começo do século passado. A utilização desse termo estava ligada ao processo de qualificação do indivíduo capaz de desempenhar de forma eficiente certo papel (Carbone et al., 2005). Neste contexto, em que se experimentavam os princípios do taylorismo de seleção e treinamento do trabalhador, as organizações buscavam aperfeiçoar seus indivíduos para as habilidades indispensáveis à realização de determinadas tarefas, limitando-se a assuntos operacionais relativos ao trabalho e à especificação do cargo. Por essa perspectiva, a competência era referenciada como um conjunto de conhecimentos e habilidades que credenciavam o profissional a desempenhar determinada função (Bruno-Faria \& Brandão, 2003).

Em consequência de pressões sociais e do aprofundamento da complexidade das relações de trabalho, as organizações passaram a ponderar, no processo de desenvolvimento de seus empregados, sobre questões sociais e atitudinais relativas ao trabalho, não somente a respeito de conhecimentos e habilidades (Brandão \& Guimarães, 2001). Foram reconhecidos, portanto, os aspectos emocionais, além do cognitivo ou do psicomotor, associado aos indivíduos competentes (Santos, 2001).

Ocorreu, então, a valorização da atitude como importante dimensão da competência. A explicação para a natureza da competência está na premissa de que não se pode considerar o trabalho como um conjunto de atividades ou tarefas predefinidas e estáticas, em virtude da dinamicidade e competitividade do ambiente (Zarifian, 1996). Competência, para esse autor, significa a assunção de responsabilidades diante de situações complexas de trabalho, ligado ao exercício sistemático de uma reflexividade no trabalho, o que possibilita ao indivíduo lidar com eventos surpreendentes, inéditos e de natureza singular, em seu local de trabalho.

A frequente utilização do termo competência nas últimas décadas, no campo da gestão organizacional, fez com que diferentes conotações fossem atribuídas a esse termo (Brandão \& Guimarães, 2001; McLagan, 1997; Ruas, Ghedine, Dutra, Becker \& Dias, 2005). Diante do aumento do interesse pelo assunto, debates teóricos e pesquisas empíricas foram estimuladas, com o objetivo de se definir e identificar suas dimensões e seus aspectos variados (Brandão, 2009). Entretanto, segundo esse último autor, o interesse pela questão da competência é mais longínquo.

Autores como Gilbert (1978) preocuparam-se com o estudo da competência, destacando-a como a expressão do desempenho ou comportamento do indivíduo no trabalho. De forma similar, Sparrow e Bognanno (1994) observam que competência representa atitudes identificadas, isto é, comportamentos para a obtenção de alto desempenho em um trabalho 
específico, não podendo ser, a competência, dissociada da ação para sua compreensão (Ropé \& Tanguy, 1997). Durand (2000) e Bruno-Faria e Brandão (2003) enfatizam os elementos constituintes da competência, isto é, conhecimentos, habilidades e atitudes de um indivíduo, observando que a definição de competência passa, necessariamente, pela combinação desses três elementos.

A ponderação realizada por Brandão e Borges-Andrade (2007) ao visitar certas concepções como, por exemplo, a de Sparrow e Bognanno (1994), expressa que esta pode ser a base teórica influenciada pelo "movimento S-R", em que a compreensão do comportamento necessita estar vinculada à investigação das relações estabelecidas entre estímulos (S) e respostas (R). Outras concepções como as de Durand (2000), por seu turno, parecem influenciadas pelo "movimento S-O-R", considerando que basearam-se na premissa de que tais relações, para serem compreendidas em sua plenitude, necessitam considerar o que ocorre com o sujeito ou organismo $(\mathrm{O})$, que medeia as relações entre estímulos (S) e respostas (R). Esse último movimento, segundo Abbad e Borges-Andrade (2004), estabelece a base sobre a qual estão amparados os enfoques cognitivistas e pressupõe que a interação do indivíduo com o ambiente resulta em processos cognitivos ou na aquisição de conhecimentos, habilidades e atitudes.

Mesmo com a possibilidade de se interpretar a competência de diversas, ou melhor, de múltiplas maneiras, conforme estabelecem Bitencourt e Barbosa (2004), Mclagan (1997) e Ruas et al. (2005), duas grandes correntes teóricas são encontradas (Dutra, 2004). A primeira, de representação estadunidense (por exemplo, Boyatzis, 1982; McClelland, 1973) considera a competência como um conjunto de qualificações ou características subjacentes ao indivíduo, que lhe possibilitam a realização de determinado trabalho ou dada situação. A segunda, de representação francesa (como exemplo, Le Boterf, 1999; Zarifian, 1999), associa a competência não a um conjunto de atributos do indivíduo, mas sim às suas realizações em determinado contexto, isto é, àquilo que o sujeito realiza ou produz no trabalho (Dutra, 2004; Brandão \& Borges-Andrade, 2007). Para Le Boterf (1999), a ação competente é a combinação e mobilização de recursos. Dois elementos estão presentes neste conceito: capacidades necessárias ao sujeito para um desempenho competente e efetiva aplicação dessas capacidades para lidar com qualquer assunto em sua área de atuação.

Conforme salienta Brandão (2009), nos últimos anos, o destaque tem sido atribuído a uma terceira vertente integradora, que, baseada na conexão das correntes referenciadas, busca definir a competência. Gonczi (1999) foi responsável pela defesa dessa posição. Para esse autor, a competência associa atributos pessoais ao contexto em que são utilizados. Assim, a 
competência é compreendida como o desempenho expresso pelo indivíduo em contexto determinado, em termos de comportamentos adotados no trabalho e realizações decorrentes, e não somente a um conjunto de conhecimentos, habilidades e atitudes (Carbone et al., 2005).

De acordo com essa ótica, alinhada ao "movimento S-O-R" (cognitivista), as competências são entendidas como combinações de conhecimentos, habilidades e atitudes estabelecidos de forma sinérgica. Expressas pelo desempenho profissional dentro do contexto organizacional determinado, agregam valor a pessoas e organizações (Durand, 1998; Freitas \& Brandão, 2006; Nisembaum, 2000; Santos, 2001). Essas combinações referem-se ao "O”, que sugestiona ser o sujeito capaz de desenvolver conhecimentos, habilidades e atitudes de forma a mediar as relações que seu comportamento (R) estabelece com o ambiente (S) (Brandão \& Borges-Andrade, 2007).

A aceitação dessas definições, tanto no ambiente acadêmico quanto no organizacional, de maneira mais ampla, na medida em que reflete a diversidade de dimensões do trabalho (psicomotora, cognitiva e afetiva) e associa a competência ao desempenho, pertence a um contexto ou à esfera de uma estratégia organizacional (Carbone et al., 2005). As competências, neste aspecto, manifestam-se no momento em que os indivíduos agem diante das situações profissionais com as quais se deparam (Zarifian, 1999), além de agregarem valor (econômico ou social) a indivíduos e a organizações, reconhece-se a contribuição para a consecução de estratégias organizacionais, bem como propalar o reconhecimento social sobre a capacidade de sujeitos, equipes e organizações (Brandão \& Guimarães, 2001; Zarifian, 1999). Conhecimentos, habilidades e atitudes, como elementos constitutivos da competência, agregam valor, por intermédio do desempenho no trabalho. A Figura 1 sugere a complementaridade desses três elementos, além de mostrar que a aplicação dos mesmos gera um desempenho profissional no trabalho (Gonczi, 1999; Durand, 2000).

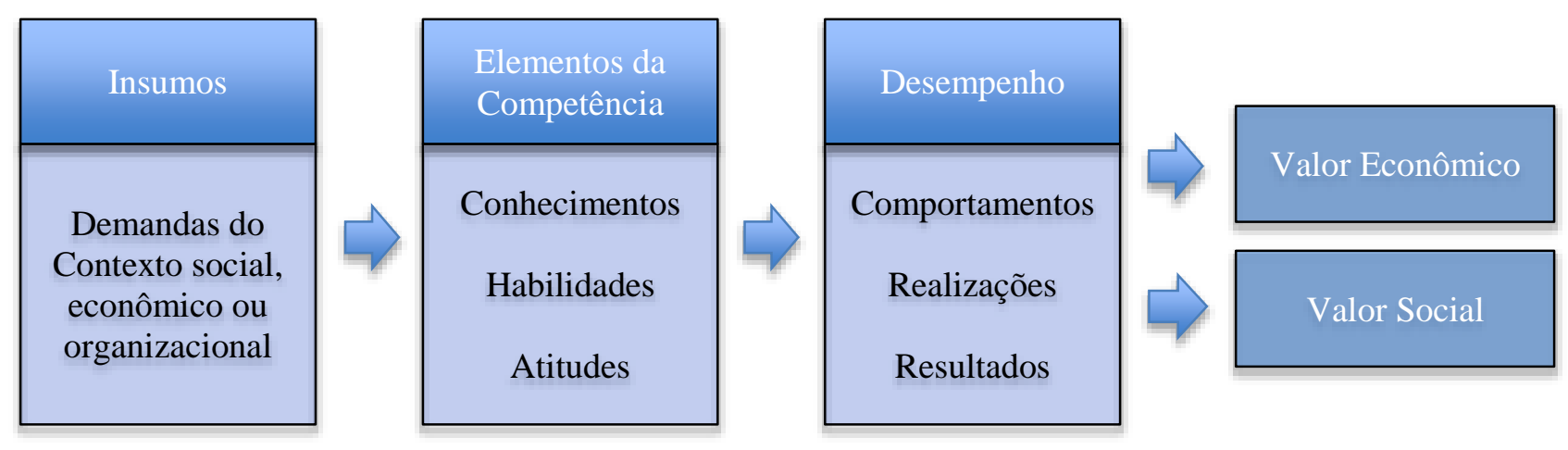

Figura 1. Componentes da Competência Humana. Fonte. Adaptado de Carbone et al., (2005) e Fleury e Fleury (2001, p. 21). 
O desempenho é expresso pelos comportamentos que o indivíduo manifesta no trabalho bem como pelas consequências de tais comportamentos, no que se refere a realizações ou resultados (Gilbert, 1978). Dessa maneira, o desempenho profissional por competências possui valor para o sujeito que o produz e para a organização à qual se vincula.

O desempenho profissional por competências será definido nesta tese, referindo-se ao conjunto de conhecimentos, habilidades e atitudes que o sujeito utiliza para a realização de seus planos de trabalho e que deve estar relacionado ao perfil almejado pela organização. Para ser competente, o desempenho necessita gerar impacto nos resultados do trabalho do indivíduo (nível micro) e na organização, pela abrangência dos resultados individuais (nível macro). Deve, ainda, para ser competente, estar em conformidade com objetivos, metas e valores organizacionais de eficiência e eficácia (Abbad \& Borges-Andrade, 2004). Por outro lado, o desempenho incompetente está relacionado ao conjunto de comportamentos, manifestado pelo indivíduo que está aquém do que é esperado pela organização (Coelho Jr., 2009). Trata-se, portanto, segundo este autor, do tipo de lacuna identificada no trabalho do indivíduo, que é provocada por fatores de ordem individual (ausência de motivação no trabalho), relacionados às tarefas (desconhecimento de como desempenhar certa atribuição) ou ao contexto de trabalho (impossibilidade de realizar determinada tarefa por fatores ligados ao ambiente de trabalho, como falta de material ou recurso, falta de suporte à aprendizagem, entre outros).

Como se pode observar, a competência apresenta-se como um fenômeno de conceituação complexa, diversa e fragmentada, que acarreta uma profusão de maneiras de se analisar este tema. A compreensão da noção de competência passa pela análise de suas dimensões, conhecimentos, habilidades e atitudes, em seguida, apresentada.

\subsection{Dimensões da Competência}

Conhecimentos, habilidades e atitudes (CHAs) são considerados elementos constitutivos ou dimensões da competência (Brandão, 2009; Bruno-Faria \& Brandão, 2003; Carbone et al., 2005; Coelho Jr., 2009; Durand, 2000; Gonczi, 1999; Fleury \& Fleury, 2001; Santos, 2012, entre outros). Brandão e Borges-Andrade (2007) observam que esses elementos são propriedades disposicionais do indivíduo, ou seja, o comportamento no trabalho sofre influência desses fatores, de tal maneira que teorias e estudos conexos à cognição social e de enfoques instrucionais auxiliam na compreensão da natureza desses componentes.

Estudos sobre o comportamento interpessoal, como os realizados por Heider (1958), influenciaram diversos autores e pesquisadores, o que culminou com Teoria da Atribuição de 
Causa Em suas pesquisas, este autor buscou avaliar os elementos constitutivos de uma ação, como forma de interpretar ou predizer essa ação.

Esses estudos indicam que o comportamento do indivíduo depende de aspectos disposicionais e situacionais. Os primeiros representam as propriedades (por exemplo, capacidades) de que os indivíduos dispõem sob determinadas condições, ao se comportarem de certa maneira. Os segundos refletem as propriedades mais variáveis, presentes no ambiente, que influenciam o arranjo entre a ação e as propriedades disposicionais do indivíduo, tendo em vista que podem aumentar ou reduzir a possibilidade de manifestação das capacidades pelos indivíduos.

Dois são, segundo Heider (1958), os elementos que determinam a disposição para a ação. Um fator de poder, que se refere à capacidade, e um fator de intencionalidade. A capacidade é condicionada por conhecimentos e habilidades que tornam o indivíduo capaz de realizar algo. $\mathrm{O}$ fator de intencionalidade diz respeito à tentativa de o indivíduo fazer algo e à intensidade com que busca fazê-lo. Heider (1958) observa que a manifestação se estabelece na tentativa, impulsionando e orientando a ação, dando-lhe caráter intencional. Capacidade e intenção são os fatores necessários para a determinação da ação; entretanto, isoladamente, nenhum deles, é suficiente. Assim sendo, se um indivíduo apresenta capacidade, porém não tem intenção (ou motivação), ou tem intenção, mas não capacidade, não progredirá em direção do objetivo; é imperativo ser capaz e desejar, para se alcançar o êxito em uma ação (Heider, 1958).

Para Brandão (2009), conhecimentos, habilidades e atitudes podem ser entendidos como fatores disposicionais do indivíduo, estabelecendo bases para seu desempenho ou para a manifestação de competências no trabalho, conforme ilustra a Figura 2. 


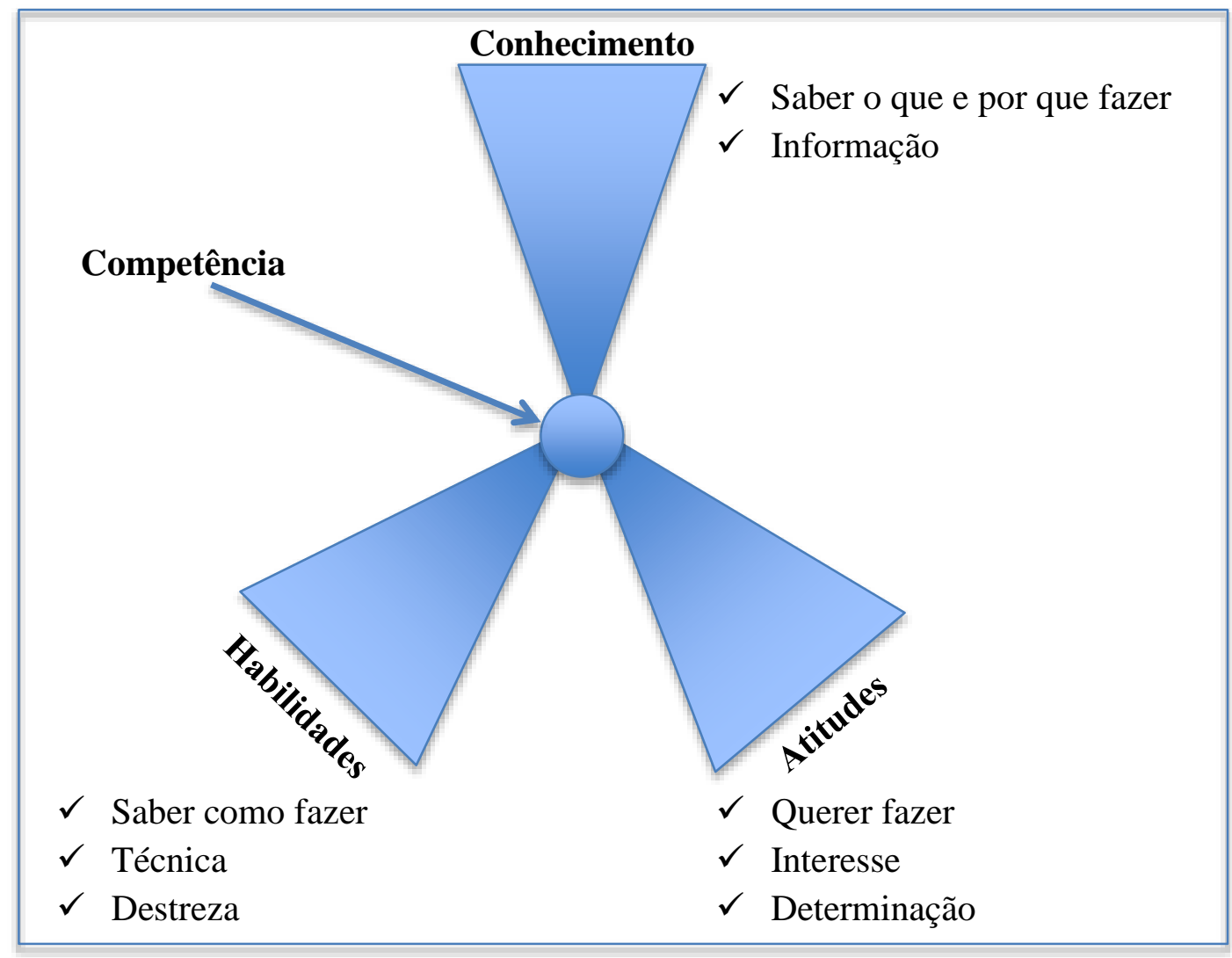

Figura 2. As três dimensões da Competência.

Fonte. Adaptado de Duran (2000, p. 10.).

O conhecimento representa um conjunto de informações assimiladas e estruturadas pelo indivíduo, as quais lhe possibilitam "entender o mundo" (Durand, 2000). Diz respeito, portanto, ao saber acumulado pelo sujeito ao longo da vida. Esse conhecimento é derivado da informação, que, por seu turno, deriva de conjuntos de dados (Davis \& Botkin, 1994; Davenport \& Prusak, 1998). Para esses autores, os dados são considerados séries de eventos ou fatos isolados; informações são dados que, ao serem agregados a outros dados, obtêm relevância e significado; e conhecimentos são uma série de informações, reconhecidas e integradas pelo indivíduo em um esquema cognitivo preexistente, que produzem impacto sobre seu julgamento ou comportamento. Para autores de teorias instrucionais (Bloom, Englhart, Furst, Hill \& Krathwohl, 1979; Gangné, Briggs \& Wager, 1988), o conhecimento significa algo relacionado à lembrança de ideias ou fenômenos, ou seja, algo retido na memória do indivíduo por intermédio de processos psicológicos de aquisição e interpretação de informações.

A habilidade alude ao saber como fazer alguma coisa (Gangné et al., 1988). Representa a capacidade que o indivíduo tem de usar de maneira produtiva o conhecimento que detém, instaurando conhecimentos guardados em sua memória e utilizando-os em uma 
ação (Durand, 2000). Essa dimensão, de acordo com o que observa Primi et al. (2001), relaciona-se à capacidade cognitiva de processamento de informações como forma de resolver problemas ou para lidar com uma situação determinada.

A definição de habilidade pode ser entendida, de acordo com Bloom et al. (1979), como a busca, pelo indivíduo, de suas experiências anteriores, conhecimentos, de fatos ou princípios, e técnicas adequadas para examinar e solucionar certo problema. Duas podem ser as classificações atribuídas às habilidades, as intelectuais, que abarcam, basicamente, processos mentais de organização e reorganização de informações (por exemplo, na execução de uma operação matemática) e as motoras ou manipulativas, que essencialmente exigem uma coordenação neuromuscular (Bloom et al., 1979; Gangné et al., 1988), como, por exemplo, na colocação de peças em uma linha de produção.

Quando se abordam os conhecimentos e as habilidades (elementos ou dimensões da competência), Durand (2000) emprega a estrutura de análise do conhecimento proposta por Sanchez (1997), esclarecendo que a habilidade diz respeito ao saber como fazer algo em determinado processo (know-how), enquanto o conhecimento refere-se ao saber o que e por que fazer (know-whate know-why), isto é, o entendimento do princípio teórico que dirige esse processo e seu propósito. A agregação de conhecimentos e habilidade parece constituir o que Heider (1958) chamou capacidade, como já referido.

O terceiro elemento ou dimensão da competência, a atitude, pode ser definida como uma predisposição do sujeito para reagir (negativa ou positivamente) a um estímulo (Bowditch \& Buono, 1992). Atitude, portanto, é uma constatação avaliadora (favorável ou desfavorável) em relação a objetivos, pessoas ou eventos (Robbins, 1999). De forma conceitual, atitude apresenta-se como propriedade do sujeito que influencia, em alguma medida, seu comportamento (Eiser, 1987; Martin-Baró, 1985). Ao se considerar essa perspectiva, Gangné et al. (1988) expõem que atitudes são estados complexos do ser humano, capazes de afetar o comportamento em relação a pessoas, objetos e eventos, causando a escolha de um curso de ação pessoal. Para esses autores, os indivíduos apresentam preferências por certos tipos de atividades e demonstram interesse por alguns eventos mais que por outros. O efeito da atitude é exatamente ampliar a reação positiva ou negativa de um indivíduo, ou seja, sua intenção ou predisposição em relação à adoção de uma ação específica (Bedani, 2009).

Autores como Bloom, Krathwohl e Masia (1973) e Gondim e Siqueira (2004) observam que a atitude (como componente da competência) se vincula a um sentimento ou a um grau de aceitação ou rejeição do sujeito em relação aos outros, a objetos ou a situações. 
Por analogia, a atitude refere-se ao que Heider (1958) batizou desejar e ao qual Durand (2000) denominou de querer fazer. Constitui-se, portanto, em uma propriedade relativa ao desejo, à disposição, à intenção, que influencia a tendência de o indivíduo adotar certo comportamento.

Cabe ainda destacar que esses três elementos constitutivos da competência (conhecimentos, habilidades e atitudes) têm caráter complementar e interdependente, de maneira que haveria uma influência mútua entre eles, conforme aponta a literatura. A esse respeito, o estudo conduzido por Sansone (1986) identificou que o conhecimento do indivíduo acerca dos padrões de competência exigidos em seu trabalho afetava sua disposição no trabalho (isto é, suas atitudes) para demonstrar as competências requeridas, e não somente a percepção sobre sua competência (autoeficácia ou competência percebida). De maneira similar, a habilidade pressupõe o domínio de conceitos, técnicas ou princípios (Brandão et al., 2001) e o interesse do sujeito pelo trabalho influencia a aprendizagem de novos conhecimentos e habilidades (Pozo, 2002).

A competência é tratada como um preditor do desempenho (Brandão \& Guimarães, 2001). Esses autores compreendem o desempenho como resultado da articulação entre competência individual (conhecimentos, habilidades e atitudes mobilizados nas tarefas e comportamentos desempenhados), características pessoais (idade, grau de instrução, motivação, estratégias de aprendizagem, entre outros) e o suporte, material e psicossocial recebido da organização.

Nessa forma integrada, a competência é entendida como comportamento adotado no trabalho e as realizações dele decorrentes e não apenas como o conjunto de conhecimentos, habilidades e atitudes necessários para a realização de uma atividade (Brandão \& BorgesAndrade, 2007). Dessa forma, a competência é compreendida como associação de atributos individuais ao contexto em que são empregados, referindo-se desta forma, ao desempenho do indivíduo no trabalho (Gonczi,1999).

\subsection{Gestão de Desempenho baseado em Competências}

Questões relativas à gestão por competências e gestão por desempenho têm sido consideradas tecnologias gerenciais interdependentes de um mesmo construto (Brandão \& Guimarães, 2001; Brandão, 2009), no contexto mais amplo da gestão organizacional.

Considerada como uma tecnologia derivada da Resource-Based Management Theory, a gestão por competências destaca que recursos organizacionais são condicionantes do sucesso da empresa com relação à concorrência (Leite \& Porse, 2003; Taylor, Beechler \& 
Napier, 1996). Essa teoria ressalta que desempenho organizacional não é decorrente exclusivamente da competição entre empresas e das forças que exercem no ambiente externo, mas, sim, da forma como a empresa descobre e alavanca recursos para satisfazer as necessidades dos indivíduos que utilizam o serviço ou consomem o produto dessa organização, em um mercado específico (Durand, 2000).

O domínio de recursos raros, valiosos e de difícil imitação apresenta-se como o pressuposto para que a organização obtenha certa vantagem competitiva presente e futura (Raub, 1998). Para essa corrente, a gestão estratégica de recursos humanos colabora para a geração de vantagem competitiva sustentável, na medida em que promove o desenvolvimento de habilidades, produz um complexo de relações sociais e gera conhecimento, isto é, desenvolve competências (Brandão \& Guimarães, 2001).

Diversas organizações recorrem a modelos de gestão por competência com o objetivo de planejar, selecionar, desenvolver e avaliar as competências necessárias, nos diferentes níveis (individual, grupal e organizacional) da empresa (Bitencourt \& Barbosa, 2004; Brandão \& Guimarães, 2001; Whiddett \& Hollyforde, 1999). As análises e implicações organizacionais desses modelos ficaram por conta de Brandão e Guimarães (2001). Segundo esses autores, trata-se de um processo contínuo, cuja referência se encontra na estratégia organizacional com vistas à orientação dos esforços em torno da captação e do desenvolvimento de competências (humanas e organizacionais) relevantes para a organização.

A Figura 3 apresenta o diagrama que ilustra as principais fases desse processo, conforme proposto por Brandão e Guimarães (2001) e Brandão e Bahry (2005). 


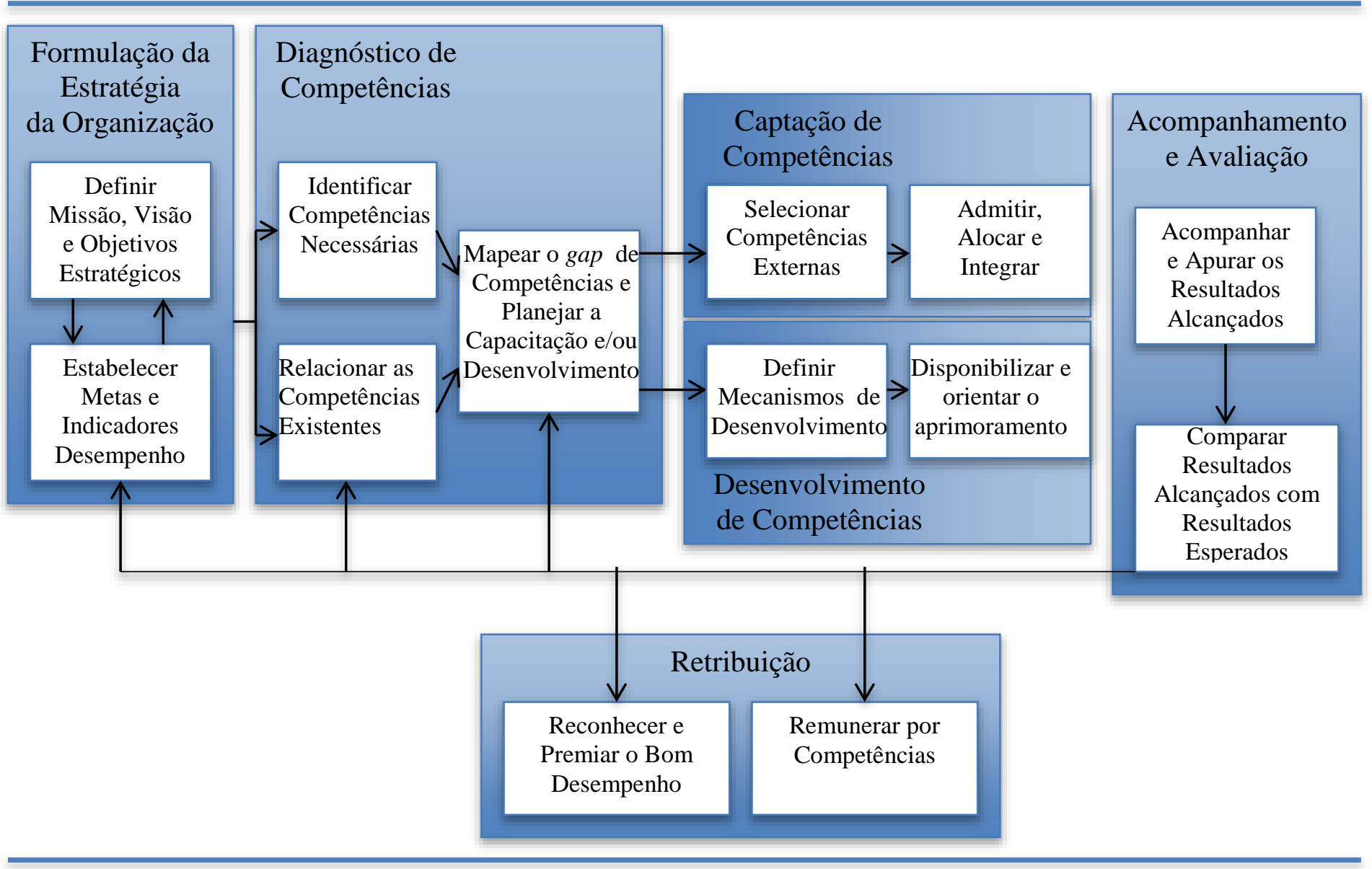

Figura 3. Modelo de Gestão por Competências

Fonte. Adaptado de Brandão e Bahry (2005, p. 181).

O processo inicia-se com a formulação da estratégia organizacional, em que são definidos a missão, a visão de futuro e os objetivos estratégicos. Souza (2001) ressalta que a missão da organização é o propósito principal da existência da organização. A visão trata do estado de futuro almejado pela organização, isto é, o que ela quer ser no futuro próximo. Os objetivos estratégicos versam sobre os desígnios a alcançar ou a situação a ser perseguida pela organização em um dado período de tempo.

Após a formulação da estratégia da organização, parte-se para o mapeamento de competências, segunda etapa do processo. O mapeamento apresenta como objetivo a identificação do gap ou lacuna de competência, conforme proposto no modelo de Ienaga (1998). Esse processo consiste em estabelecer os objetivos e as metas a serem obtidos de acordo com a intenção estratégica da organização e, depois, identificar a lacuna entre as competências necessárias à concretização desses objetivos e as competências internas disponíveis na organização (Brandão \& Guimarães, 2001; Brandão, 2009), conforme apresentado na Figura 4. 


\section{Competência Mapeada}

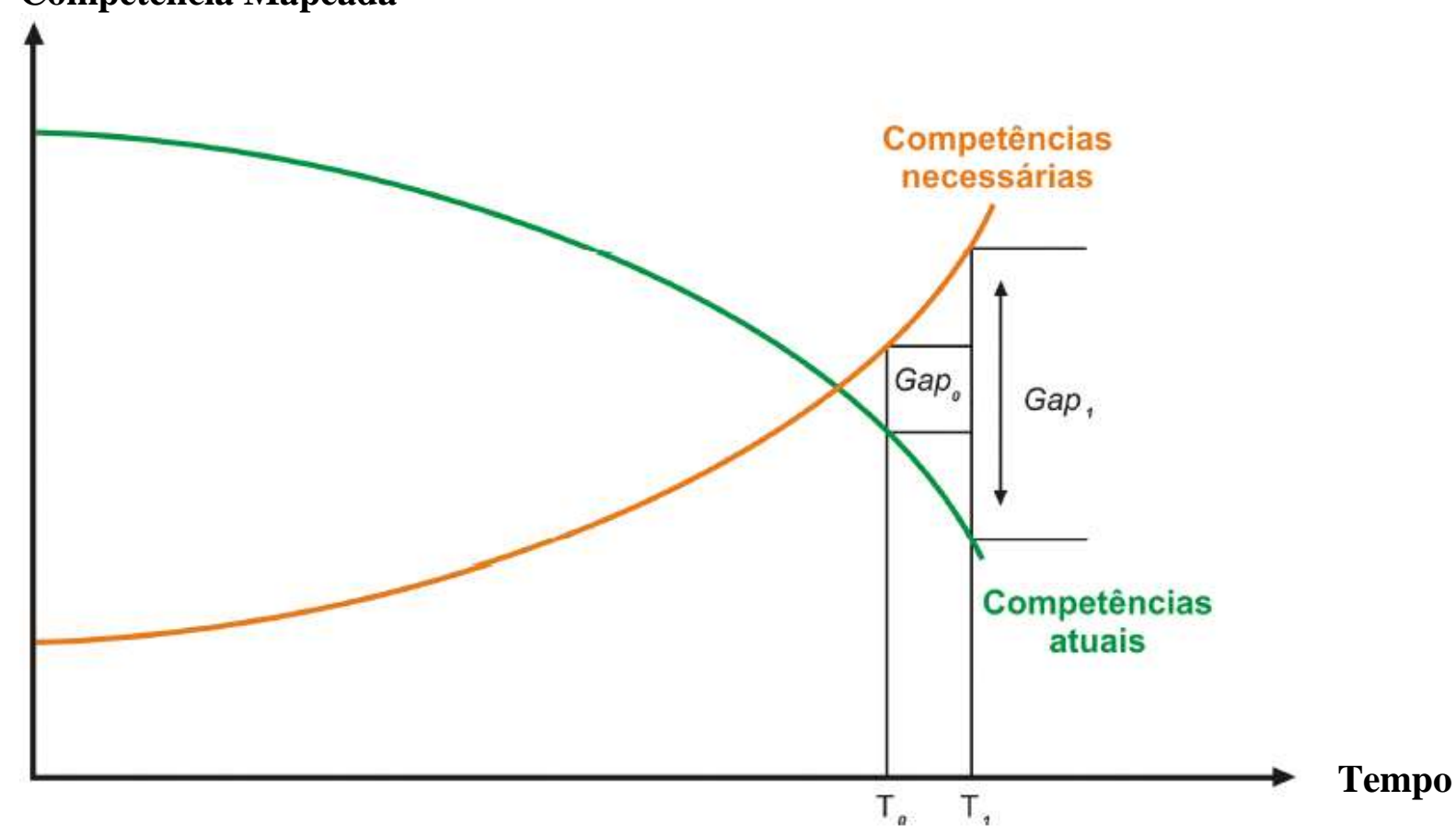

Figura 4. Determinação do GAP de Competência. Fonte. Adaptado de Ienaga (1998)

O dinamismo das organizações atuais faz com que novas competências sejam exigidas a cada instante. Diante disso, as ações de seleção (captação) ou desenvolvimento de competências são de extrema importância para as organizações, reconhecendo que na ausência dessas ações a lacuna entre a competência necessária e a atual tende a aumentar (Brandão \& Bahry, 2005), conforme pode-se observar na Figura 4.

A captação diz respeito à seleção de competências existentes e sua integração ao ambiente da organização. No nível individual, estabelece-se por intermédio de ações de recrutamento e seleção de pessoal e, no nível organizacional, por meio de parcerias ou alianças estratégicas (Brandão, 2009). O desenvolvimento, por seu turno, refere-se ao aprimoramento interno de competências na organização, que no nível individual ocorre pela aprendizagem e, no nível organizacional, por meio de investimentos em pesquisa (Brandão \& Guimarães, 2001).

No que se refere à etapa de acompanhamento e avaliação, é realizado o monitoramento da execução dos planos de gestão e operacionais e os indicadores de desempenho respectivos, com vistas à identificação e correção de eventuais falhas (Brandão, 2009). Dentro de uma abordagem sistêmica, essa fase funciona como mecanismo de feedback, em virtude da comparação entre os resultados alcançados e esperados, em um processo de gestão do desempenho (Guimarães et al., 2001). 
A etapa de acompanhamento e avaliação aponta a relação interdependente entre a gestão por competências e a gestão de desempenho. Sobre esse ponto, Brandão e Guimarães (2001) observam que o desempenho expressa, em última instância, a competência de indivíduos, equipes e organizações. Esses dois modelos ou tecnologias de gestão, portanto, complementares e não independentes, encontram-se dentro de um amplo contexto de gestão estratégica da organização (Brandão \& Guimarães, 2001).

A etapa de retribuição, por fim, reconhece, premia ou remunera, de maneira diferenciada, os indivíduos, as equipes de trabalho e as unidades produtivas que mais contribuíram para a concretização dos resultados planejados (Wood Jr., Pereira Filho \& Picarelli Filho, 1997), o que serviria de estímulo à manutenção de comportamentos esperados e à correção de desvios ocasionais (Brandão \& Bahry, 2005).

O alinhamento entre a estratégia da organização e as práticas de gestão de pessoas, adicionado a sinergia, acarreta a consistência interna da estratégia (Tilles, 1963). Assim essas ações impactam positivamente e de forma cumulativa o desempenho organizacional.

As duas tecnologias (gestão por competências e gestão do desempenho) recomendam a necessidade de associar a performance às competências da organização com as de seus membros (Brandão \& Guimarães, 2001). Tanto na gestão de desempenho, quanto na gestão por competências, diversos autores (Brandão \& Guimarães, 2001; Brandão, 2009; Durand, 2000; Oliveira-Castro et al., 1996; Prahalad \& Hamel, 1990) são unânimes em relatar que as organizações deveriam dispor de instrumentos de avaliação de desempenho em seus diversos níveis (individual, de equipe e organizacional).

O pressuposto que serve de alicerce para ambas as tecnologias parece ser o mesmo, ou seja, a competência ou o desempenho do indivíduo exercem influência na competência ou no desempenho organizacional, sendo por ela influenciados (Brandão \& Guimarães, 2001). Para esses autores, o argumento da corrente da gestão de competências é de que a competência humana, aliada a outros recursos, origina e sustenta a competência organizacional. No que se refere à gestão de desempenho, a performance no trabalho é resultado das competências inerentes ao indivíduo adicionados os atributos da organização.

Observa-se, ainda, que é possivel utilizar indicadores relacionados tanto ao resultado do trabalho quanto ao comportamento ou processo utilizado para seu atingimento. Exemplificando essa questão, Brandão e Guimarães (2001) esclarecem que, quando a gestão de desempenho se realiza no nível individual, é possível avaliar o indivíduo, assumindo como parâmetro não somente os resultados decorrentes do trabalho efetuado, mas também a manifestação, por parte do sujeito, de conhecimentos, habilidades e atitudes que se pressupõe 
serem proeminentes para a consecução dos objetivos da organização. De forma análoga, na gestão por competências, uma competência exprime-se tanto pelo resultado conseguido como pelo conjunto de conhecimentos, habilidades e atitudes necessários para atingi-lo, revelando, portanto, as semelhanças conceituais entre desempenho e competências, tendo em vista que o resultado alcançado (desempenho) representa a própria competência do sujeito (Brandão \& Guimarães, 2001).

Mesmo que a gestão por competências e a gestão de desempenho pertençam a um mesmo contexto de fragmentação teórica, a relação de interdependência entre as duas tecnologias é percebida (Brandão \& Guimarães, 2001). Nesse sentido, apresenta-se como imprescindível a ampliação (concomitante) dos pressupostos e processos subjacentes a ambos os instrumentos para integrar e direcionar energias, principalmente as relacionadas à gestão de recursos humanos.

Como instrumentos de um mesmo construto, Brandão e Guimarães (2001) sugerem a unificação de ambas as tecnologias sobre um novo termo, gestão de desempenho baseado nas competências, dado que este considera o caráter complementar e interdependente entre desempenho e competência. O desempenho profissional por competências, ou desempenho competente, portanto, pode ser entendido como o conjunto de conhecimentos, habilidade e atitudes que o sujeito utiliza para concretizar seus planos de trabalho e que deve estar atrelado ao perfil almejado pela organização. Constituindo-se como condições ou requisitos necessários para que alguém apresente um desempenho competente, o domínio da tarefa, a motivação para sua realização e o suporte da organização (condições adequadas de trabalho) são fundamentais, conforme ressaltam Abbad e Borges-Andrade (2004). 


\section{Seção 3. Estudos Empíricos}

Esta seção tem como finalidade apresentar os resultados de uma revisão de literatura, nas principais bases de dados (ABI/Inform Global - Proquest; Scopus; ISI Web of Knowledgement; Science Direct; Periódicos CAPES, Scielo, Pepsic, Spell, entre outras) sobre os temas abordados no capítulo e suas relações empíricas com as outras variáveis (predição de desempenho e competências no trabalho) que serão investigadas na presente tese. As buscas foram orientadas pela combinação das palavras chave "desempenho" e/ou "desempenho no trabalho" e/ou "competência" e/ou "competência no trabalho" e "gestão por competência" e/ou "competência gerencial", e pelas suas respectivas versões em inglês. A primeira parte da seção (3.1) apresentará os estudos empíricos que se relacionam à variável desempenho. A segunda (3.2) parte exporá os estudos empíricos que relacionam competência e desempenho no trabalho.

\subsection{Estudos Empíricos sobre a Predição do Desempenho}

Três classes de variáveis preditoras de desempenho no trabalho são comumente encontradas na literatura, conforme destacam diversos autores (Beersma, Hollenbeck, Humprey, Moon, Conlon \& Ilgen, 2003; Bendasolli, 2012; Borman \& Motowidlo, 1993; Coelho Jr., 2009; Fonseca, 2001; Grund \& Nielsen, 2008; Oliveira-Castro et al., 1996; Sackett, 2002; Wood, 1999), na presente revisão. De acordo com Coelho Jr. (2009), a primeira classe trata das variáveis relativas a características organizacionais ou fatores de contexto (abarca variáveis, como, por exemplo, ambiente de suporte à aprendizagem, tipo de gestão empregado, políticas de macrogestão estratégica, direcionamento de ações de recursos humanos, políticas e práticas organizacionais e de recursos humanos, valores organizacionais, clima e cultura organizacional). A segunda trata da tarefa (variáveis que refletem características do trabalho, disponibilidade de material e equipamento, qualidade no gerenciamento de desempenho, tipos de interações sociais no trabalho, ações de feedback ao desempenho, entre outros). E, por fim, a terceira apresenta características individuais (idade, tempo de serviço na organização, motivações, traços de personalidade, nível de conhecimento da tarefa são os mais referenciados).

Conforme observado por Bendassolli (2012) e Coelho Jr. (2009) em suas recentes revisões, essas variáveis são habitualmente investigadas em termos de sua relação direta com desempenho no trabalho, ou de forma associada, conforme o modelo teoricamente hipotetizado. De acordo com esses autores e com a revisão realizada nessa tese, a maior parte 
dos estudos encontrados diz respeito às características individuais como preditoras do desempenho, sendo que uma menor parcela investigou fatores contextuais.

Nos relatos empíricos examinados, fica evidente que parte significativa dos trabalhos utiliza a combinação de distintas classes de variáveis pertencentes a estes três grupos de preditores, relacionando-os com a predição de desempenho no trabalho e com a variância, ou seja, o tamanho do efeito associado (Coelho Jr., 2009). Segundo esse autor, nesses estudos encontram-se variáveis individuais e de contexto na predição do desempenho, ou mesmo variáveis conexas à tarefa, características individuais e desempenho no trabalho.

Investigações empíricas também dão conta que o desempenho no trabalho é considerado como variável critério (Bates, 1999; Delery \& Shaw, 2001; Collins, 2002; Grund \& Nielsen, 2008), conforme a clássica análise realizada por Campbell (1990), em que foram verificados os principais preditores de desempenho, destacadamente, idade, tempo de serviço na organização, motivação, satisfação e comprometimento, responsáveis por explicar quantia significativa de desempenho.

Quando o foco recai sobre os estudos do comportamento organizacional, as investigações sobre predição do desempenho, tradicionalmente, encontram-se no nível individual (Jones, Buerkle, Hall, Rupp \& Matt, 1993; Eckes, 1994; Ghorpade \& Chen, 1995; Lam \& Schaubroek, 1999). Ou ainda, conforme encontrado na literatura, em que as variáveis de nível individual ou organizacional são empregadas para predizer desempenho no trabalho, conforme ressaltam Parker et al. (2003) e Wallace e Chen (2006).

No que se refere às relações entre características individuais e desempenho, encontram-se numerosos estudos em comportamento organizacional, entre outros, Albuquerque (2004), Brandão (2009), Coelho Jr. (2009), Coelho Jr. e Borges-Andrade (2011a), Coelho Jr. e Borges-Andrade (2011b), Judge, Heller e Mount, (2002), Salgado (2003), Santos (2012), Tett e Burnett (2003), Tett, Jackson e Rothstein (1991), Vasconcelos (2005). Já para a relação entre preditores de desempenho e características individuais verifica-se que, variáveis profissionais, demográficas e atributos de personalidade predizem o desempenho no trabalho (Hanges, Schneider \& Niles, 1990). Características individuais refletem informações pessoais relativas ao indivíduo (gênero, idade, grau de escolaridade), profissionais (natureza do cargo, tempo de serviço, natureza do cargo, comprometimento, motivação, envolvimento, níveis de estresse, setor de locação, entre outros) e características de personalidade (comportamentos de extroversão, introversão, sociabilidade, lócus de controle, bem-estar psicológico, percepção de auto-eficácia, por exemplo), conforme assinala Coelho Jr. (2009). 
Exemplos da influência direta da idade sobre o desempenho foram relatados por Waldman e Avolio (1986) em sua clássica meta-análise. De forma similar, Treadway, Ferris, Hochwarter, Perrewe, Witt e Goodman (2005) e West e Anderson (1996) encontraram correlações significativas entre o tempo de serviço na organização e a efetividade da equipe.

Para o grau de escolaridade, Russel (2001) encontrou relação positiva com desempenho no trabalho, e o mesmo resultado para tempo de serviço, ou seja, quanto maior a escolaridade e maior o tempo de serviço, mais positiva a percepção do sujeito sobre o desempenho. Fonseca (2001) também verificou maior percepção média de desempenho com o maior grau de escolaridades dos sujeitos da organização. Já Coelho Jr. (2009) e Coelho Jr. e Borges-Andrade (2011b) mostraram que essa relação (grau de escolaridade e desempenho) é positiva considerada variável de contexto.

Outra relação entre idade e desempenho foi descrita por Michel, Leschinsky e Gagnon (2006). A investigação desses autores mostrou que, quanto maior a idade e menor a percepção de estabilidade no trabalho, mais insatisfatório era considerado o desempenho. Resultado semelhante foi descrito mais recentemente por Coelho Jr. e Borges-Andrade (2011b), em que empregados com ensino médio, superior e superior com especialização obtiveram maiores notas em relação aos demais.

Para Macedo (2007), o tempo médio de trabalho estava positivamente relacionado com os resultados da organização, isto é, evidencia-se que a experiência profissional é responsável por parcela de contribuição no incremento dos resultados organizacionais. Outro resultado encontrado no estudo de Macedo (2007) demostrou que variáveis individuais relacionam-se com os resultados da organização, ao se aumentar a dependência da ação direta do indivíduo. A quantidade de indivíduos lotados nas unidades organizacionais e o tempo médio de trabalho foram responsáveis por influenciar de forma direta o resultado da organização. Ainda, segundo o autor, os empregados que não participaram de ações induzidas de aprendizagem, o nível educacional, a quantidade de indivíduos por unidade e o tipo de unidade organizacional predisseram melhor o resultado da organização.

Michael et al. (2006) e Grund e Nielsen (2008), de forma análoga, constataram que a variável gênero foi responsável por explicar importante variância de desempenho no trabalho. De acordo com esses autores, comparativamente em relação aos homens, as mulheres percebiam que o suporte fornecido pelos superiores era mais insatisfatório, o que gerou impacto na diferença de desempenho entre homes e mulheres (mulheres eram avaliadas de maneira pior em termo de seu desempenho e associavam esse fato à ausência de suporte dos superiores). Entretanto, Ali e Davis (2003) encontraram resultados opostos, em que as 
mulheres obtiveram escores de desempenho superiores aos dos homens, restando inconclusivos os resultados empíricos relativos à variável gênero, conforme destacou Coelho Jr. (2009).

As evidências empíricas dos estudos de Ali e Davies (2003), Avolio, Waldman e Mc Daniel (1990), Coelho Jr. (2009) apontam para a predição do desempenho das variáveis idade e tempo de serviço. Outros estudos, como os de Vasconcelos (2005) e Pema e Mehay (2010) mostram que o gênero prediz o desempenho, mesmo que em menor quantidade (Coelho Jr., 2009).

Coelho Jr. (2009), ao citar as pesquisas de Albuquerque (2004) e Vasconcelos (2005), constataram o desempenho no trabalho explicado pelos comportamentos dos empregados em virtude da natureza do cargo; assim, indivíduos lotados na área fim apresentaram melhores escores de desempenho se comparados com os da área meio. Parte da explicação da diferença na atribuição de escores entre cargos meio e fim pode ser encontrada nas meta-análises realizadas por Sonnentag e Frese (2002), que indicam que existe uma relação positiva de predição entre características e finalidade do trabalho (como a configuração de tarefas, por exemplo) e desempenho, conforme destacam Coelho Jr. e Borges-Andrade (2011b).

Em outras meta-análises, encontraram-se correlações positivas entre influências no contexto organizacional (como o redesenho sucessivo das tarefas de um cargo entre chefia e subordinados, segundo Morgeson \& Humphrey, 2006) e seu impacto no desempenho. Entretanto, nas meta-análises não se pode estabelecer uma interpretação causal, pois tratamse de estudos correlacionais (Coelho Jr. \& Borges-Andrade, 2011b).

Outras variáveis independentes relativas às tarefas são preditoras do desempenho no trabalho, conforme destaca Coelho Jr. (2009): cidadania organizacional (Willians \& Anderson, 1991), comprometimento (Armeli, Eisenberger, Fasolo \& Lynch, 1998, Bandura \& Jourden, 1991; Fonseca \& Bastos, 2003; Bishop \& Scott, 1997; Jourden \& Health, 1996; Keller, 1997; Riketta, 2002; Settoon, Bennett \& Liden, 1996; Reis Neto, Kilimnik, Melo, \& Theotônio, 2012; Yeh, 2009), comunicação no trabalho (Goris, Vaught \& Petit Jr., 2000), envolvimento com o trabalho (Babin \& Boles, 1996; Cropanzano, Howes, Grandey \& Toth, 1997), estresse (Babin \& Boles, 1996; Mohr \& Puck, 2007; Zonatto \& Lavarda, 2013) e percepção de estilos de liderança e participação em tomadas de decisão (Scott-Ladd, Travaglione \& Marshall, 2006; Suar et al., 2006; Wright \& Kim, 2004). Mesmo como preditoras, essas variáveis não comporão o modelo de pesquisa hipotetizado no Capítulo IV deste trabalho. 
Alguns dos estudos analisados mostram que a variável desempenho no trabalho é mensurada no nível organizacional (Anselmo, 2007; Bedani, 2007, 2009; Dias Gonçalves \& Coleta, 2007; Freitas \& Medeiros, 2004, Pires \& Kato, 2007; Zonatto \& Lavarda, 2013), que utilizaram medidas de resultado econômico, lucro, participação de mercado, alcance de estratégias, entre outros, conforme também observado por Coelho Jr. (2009). Nesta tese, a variável desempenho será mensurada em nível individual, medidas por competências, aqui tratadas como desempenho competente, relacionadas a variáveis antecedentes, valores organizacionais, práticas organizacionais e mediadas pela identidade profissional e organizacional, que vêm explicando importante variância significativa de desempenho no trabalho, conforme discutidos no tópico e capítulos seguintes.

\subsection{Estudos Empíricos sobre a Relação entre Competência e Desempenho}

Nesta parte, busca-se examinar os efeitos da competência ou de seus elementos constitutivos (conhecimentos, habilidades e atitudes) sobre o desempenho. Parte dos estudos revisados (Brandão, 2009) mostrou a relação com o desempenho organizacional (Almeida \& Fernandes, 2006; Baum, Locke \& Smith, 2001; Borges-Andrade, Rocha \& Punte-Palacios, 2002; Brandão, Borges-Andrade, Puente-Palacios \& Laros, 2012; Brandão, Borges-Andrade \& Guimarães, 2012a; Castro \& Figueiredo, 2005; Fernandes, Fleury \& Mills, 2006; Gondim, Melo, Rodrigues \& Barbosa, 2003; Greatti \& Previdelli, 2004; Laverson, Van der Stede \& Cohen, 2006; Martins 2004; Omaki, 2005; Peinado \& Fernandes, 2012).

Outros artigos (Cavazotte, Humphrey \& Sleeth, 2004; Gondim, Puente-Palacios \& Borges-Andrade, 2011; Hertel, Konradt \& Voss, 2006; Puente-Palacios, Almeida \& Rezende, 2011) investigaram o desempenho no nível de equipes de trabalho. E, por fim, os artigos que averiguam o desempenho no nível individual (Alge, Gresham, Heneman, Fox \& McMasters, 2002; Borges-Andrade et al., 2002; Hertel et al., 2006; Leverson et al., 2006; Mulder, Lans, Verstengen, Biemans, \& Meijer, 2007; Pimenta \& Paula, 2012; Riggio \& Taylor, 2000;

Shaffer, Harrison, Gregerson, Black \& Ferzandi, 2006; Steel \& Scotter, 2003). Brandão (2009) encontrou em sua revisão dezesseis artigos. Parte desses artigos, e outros, serão a seguir apresentados.

Entre os estudos que se dedicaram a examinar a relação entre competências e desempenho na organização, os de Baum et al. (2001) encontraram que o domínio de competências técnicas pelos dirigentes, motivações e estratégias competitivas impactaram de forma direta o crescimento organizacional. Além disso, as competências gerais, os traços de personalidade dos dirigentes e as características do contexto do negócio apresentaram efeitos 
sobre o desempenho da organização de forma indireta. Já, a investigação de Almeida e Fernandes (2006), por meio de entrevistas com dirigentes e fundadores, verificou a influência de competências empreendedoras sobre o desempenho do negócio.

Por intermédio de aspectos de desempenho do Balanced Scorecard, Fernandes et al. (2006) investigaram o relacionamento entre competências profissionais e desempenho da organização. As variáveis antecedentes foram a satisfação e as competências dos empregados sobre a predição do desempenho de unidades produtivas. De forma semelhante, Gondim et al. (2003) analisaram a relação entre domínio e habilidades cognitivas, interpessoais e psicomotoras por parte dos empregados e a adoção de práticas inovadoras.

Mais recentemente, Brandão et. al (2012a) pesquisaram a possível existência de relações preditivas entre as competências expressas por gerentes de agências bancárias, sua percepção sobre o suporte organizacional, o número de horas destinadas a treinamentos e o desempenho das agências em que trabalham. Segundo os autores, os resultados apontaram que as competências relativas à gestão estratégica e à gestão financeira mostraram-se preditoras de distintas dimensões do desempenho das agências. Enquanto isso, outras competências, tais como, gestão de processos e gestão socioambiental, bem como o número de horas destinadas a treinamentos e a percepção dos gestores acerca das práticas de gestão de desempenho da empresa (dimensão do suporte organizacional), apresentaram efeitos menos abrangentes (Brandão et al., 2012a).

Em uma segunda investigação, Brandão et al. (2012b) identificaram as variáveis preditoras para três tipos de competências gerenciais (gestão empresarial financeira, gestão de processos e gestão socioambiental). Confirmaram, ainda, a hipótese de que os atributos de gerentes de agências bancárias (como as estratégias de aprendizagem utilizadas) e as dos setores de atuação (como suporte organizacional) estão associados com a expressão de competências gerenciais no trabalho.

Dos artigos revisados, cujo foco recaiu sobre o desempenho no nível de equipes de trabalho, Cavazotte et al. (2004) buscaram evidências da relação de predição entre adversidade racial e competência emocional, variáveis antecedentes, e a cooperação interpessoal em equipes, variável critério e medida associada ao desempenho do grupo. Os resultados indicam que os indivíduos com maiores habilidades para expressar emoções e empatia com seus pares apresentaram maior sinergia, o que leva à maior cooperação na equipe (desempenho). A diversidade racial do grupo, em contrapartida, não predisse a cooperação interpessoal (Cavazotte et al., 2004). 
Com base no desenvolvimento e na validação de uma escala com dez fatores (comunicação, confiança, consciência, cooperação, criatividade, independência, integridade, fidelidade, motivação para aprender, persistência), que refletem conhecimentos, habilidades e atitudes relevantes a equipes virtuais, Hertel et al. (2006) mostraram que o fator criatividade (média da equipe) estava positivamente relacionado à efetividade da equipe. No nível individual, os autores encontraram quatro fatores de competências (comunicação, cooperação, fidelidade e integridade) como preditores do desempenho no trabalho.

De forma similar, Gondim et al. (2011) realizaram uma análise de equipes virtuais no Brasil e Argentina. Os resultados demostraram a ocorrência de diferenças significativas no uso de estratégias de aprendizagem, na necessidade de treinamento em relação à percepção da qualidade das interações, e na eficácia no desempenho. Ainda, segundo os autores, a crença de que as diferenças são mais facilmente superadas em equipes virtuais do que em presenciais é responsável por explicar a maior variação encontrada nas respostas do Brasil em comparação com as da Argentina.

Equipes de trabalho guardam estreita relação com efetividade organizacional. Examinando o efeito da interdependência de tarefas e de resultados sobre a satisfação e o comprometimento de membros de equipes, Puente-Palacios et al. (2011) revelaram que os resultados foram responsáveis por explicar $15 \%$ da satisfação e $14 \%$ do comprometimento. De forma adicional, as autoras verificaram efeitos diferentes de cada preditor analisado, com vistas a uma gestão específica para os impactos de cada tipo de dependência na satisfação e no comprometimento.

Dos estudos que se preocuparam com o nível individual, Alge et al. (2002) investigaram a relação entre domínio de competências interpessoais, definidas como a capacidade de interagir com outros indivíduos de forma eficaz, e o desempenho no trabalho. Já, Riggio e Taylor (2000) identificaram quais competências profissionais e dimensões de personalidade são preditoras do desempenho de enfermeiras. Os resultados observaram que o domínio de competências sociais e de comunicação e a posse de determinadas dimensões positivas de personalidade (empatia) foram responsáveis por predizer o desempenho.

A pesquisa conduzida por Borges-Andrade et al. (2002) estudou o impacto da disseminação de informações sobre competência (capacidades) e o desempenho individual e organizacional. Os resultados demostraram que as informações difundidas impactaram fortemente a motivação e a capacidade (competência) dos leitores em planejar, acompanhar e avaliar o desempenho da organização (Borges-Andrade et al., 2002). Ainda, segundo os autores, em relação aos indicadores de desempenho (aplicação de técnicas de treinamento, 
desenvolvimento de planos para a instituição e de programas e projetos de pesquisa, por exemplo), o impacto foi menor, o que sugere certa influência das informações disseminadas sobre os conhecimentos e habilidades, necessitando-se, ainda, de suporte organizacional para se alcançarem efeitos significativos sobre o desempenho dos indivíduos e das organizações (Borges-Andrade et al., 2002).

Mulder et al. (2007) investigaram as competências desenvolvidas em empresas que empreendem. Os resultados descrevem que o desenvolvimento de competências é responsável por maior nível de significância durante o desempenho no trabalho se comparado às ações formais de aprendizagem.

Ao descrever os sentidos que os sujeitos da organização atribuem a um sistema de avaliação de desempenho por competências, Pimenta e Paula (2012) buscaram compreender a influência desse sistema na relação de prazer ou sofrimento que os funcionários estabelecem com o trabalho. Os resultados, segundo as autoras, sugerem que o reconhecimento da avaliação é uma prática importante, apropriada para direcionar do desenvolvimento profissional. Adicionalmente, a ênfase atribuída à melhoria do processo de feedback corrobora a importância da avaliação de desempenho para os indivíduos na organização (Pimenta \& Paula, 2012).

O estudo de Santos (2012) objetivou identificar os preditores do desempenho no trabalho, por meio de variáveis dos níveis individual e organizacional. Para tanto, a autora examinou duas dimensões relativas ao desempenho por competências (voltado para a tarefa e para o contexto). Os questionários mensuraram, em duas ocasiões: a expressão de competências no desempenho, orientação cultural para aprendizagem, comprometimentos organizacional e com a carreira e entrincheiramento na carreira. Os resultaram apontaram que, as percepções individual e agregada, de orientação cultural para aprendizagem e comprometimento organizacional afetivo foram responsáveis por explicar o desempenho voltado para o contexto. E, investimentos em ações de TD\&E e percepções de orientação cultural para aprendizagem (presentes nos níveis individual e organizacional) responsáveis por explicar o desempenho voltado para a tarefa (Santos, 2012).

A presente revisão de literatura mostrou a relação entre competência e desempenho. Entretanto, pode-se perceber que alguns estudos não descreveram de maneira clara, objetiva e completa as competências, nem mesmo os procedimentos e análises estatísticas envolvidas, com vistas a subsidiar as conclusões (ver Greatti \& Previdelli, 2004), nem mesmo descreveram as características amostrais (Castro \& Figueiredo, 2005), as propriedades de 
certas medidas utilizadas (Fernandes et al., 2006), o que se constitui em importante limitação para os estudos apresentados.

A lacuna apresentada por Brandão (2009) sobre a necessidade de investigações a respeito das influências de variáveis contextuais, oriundas dos níveis de equipe e de unidades de trabalho, sobre o desempenho de indivíduos, no nível individual, parece começar a ser preenchida. Os estudos de Puente-Palacios et al. (2011), Brandão et al. (2012a), Brandão et al. (2012b) e Santos (2012) são alguns dos responsáveis pelas análises multiníveis.

\section{Conclusões do Capítulo I}

As investigações sobre desempenho no trabalho mostram que seu conceito é plural e de múltiplas causas, sendo, portanto, constituído por diversas dimensões ou fatores que se relacionam aos níveis individual, de equipe e organizacional, conforme referenciado no presente capítulo.

Abordaram-se, diante disso, aspectos históricos, teóricos, metodológicos da noção de desempenho no trabalho e do desempenho profissional por competências. No primeiro momento, o desempenho no trabalho foi abordado, suas perspectivas históricas, definições, modelos e medidas. Posteriormente, reservou-se espaço especial para o desempenho profissional por competências. Além do histórico e da conceituação, foram apresentadas tanto as dimensões da competência como a gestão do desempenho baseada em competências. Por fim, uma revisão da literatura mostrou os principais estudos publicados no Brasil e no exterior que tratavam dos preditores do desempenho e da relação entre competência e desempenho.

A análise das investigações revisadas permitiu concluir que, em geral, três são as classes de variáveis preditoras de desempenho (características organizacionais ou de contexto, características da tarefa e características individuais) sendo que o desempenho profissional por competências apresenta a mesma estrutura, ou seja, é estudado em três níveis (organizacional, de equipes, e individual), prioritariamente.

As principais lacunas dos estudos sugerem a importância de serem descritas, de maneira clara, objetiva e completa, as competências, bem como a necessidade de investigar a influência de variáveis contextuais sobre o desempenho individual. Outra lacuna apresentada pela revisão refere-se à utilização de análises mais robustas como modelagem por equações estruturais ou análise multinível, ainda incipientes no cenário brasileiro de pesquisa. 
PARTE 1

ANÁLISE TEÓRICA E CONCEITUAL

\section{CAPITULO I:}

Desempenho no Trabalho e Desempenho por Competências

Seção 1: Desempenho no Trabalho

Seção 2: Desempenho por Competências

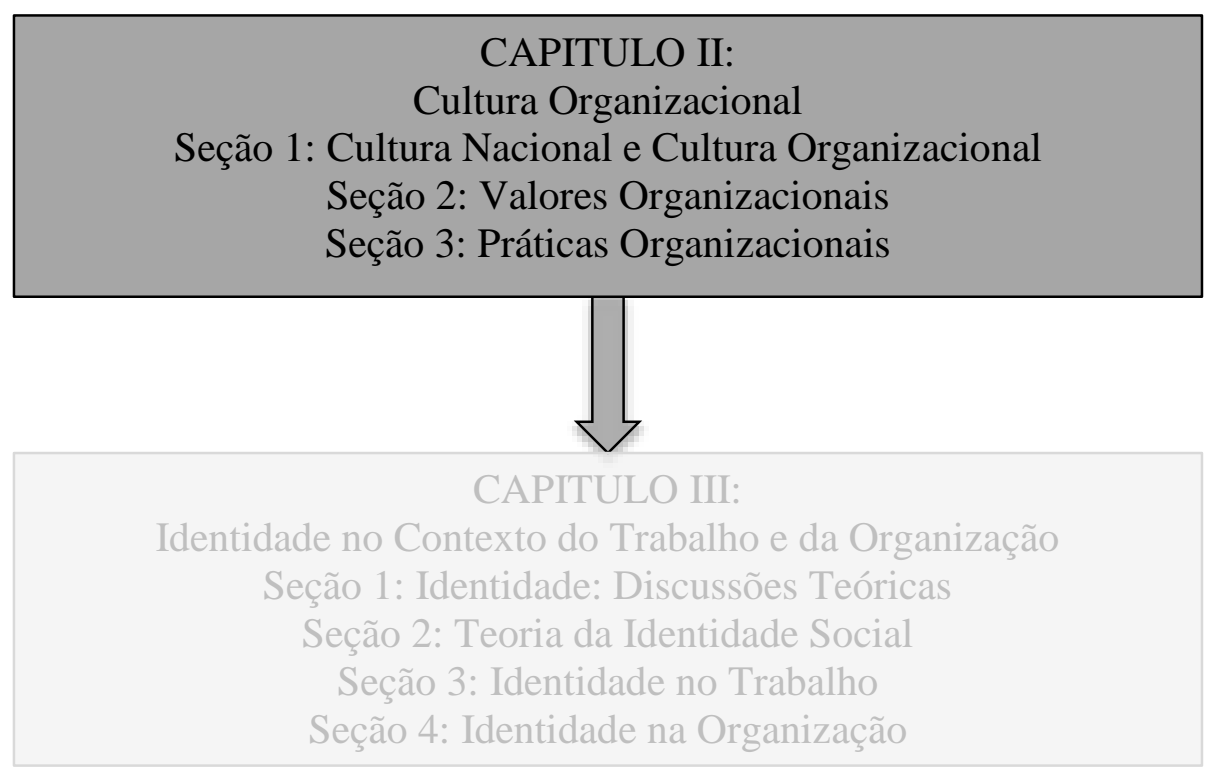

CAPITULO IV:

Modelo Conceitual e Hipóteses de Pesquisa

Seção 1: Modelo Conceitual e as Hipóteses de Pesquisa 


\section{CAPÍTULO II. CULTURA, VALORES E PRÁTICAS ORGANIZACIONAIS}

\section{Introdução ao Capítulo II}

O presente capítulo tem por finalidade apresentar uma revisão do complexo e polissêmico tema cultura e, especificamente, cultura organizacional. A Cultura, construção simbólica das práticas sociais, possui sua origem em diversos campos como o da antropologia, da sociologia, da psicologia e, mais recentemente da administração, o que provoca divergências nos debates sobre o tema entre os diferentes autores.

A primeira seção trata, inicialmente, das origens, definições e perspectivas teóricas relativas aos estudos sobre cultura nacional e cultura organizacional. Em seguida, apresenta a influência da cultura nacional na cultura organizacional. E, por fim, propõe um diálogo entre dois autores de tradições metodológicas distintas nos estudos culturais - Hofstede e D'Iribarne.

A segunda seção apresenta a temática dos valores organizacionais, constantemente referenciada na literatura sobre cultura organizacional como um dos seus principais componentes. Inicia-se por uma perspectiva histórica relativa aos estudos dos valores, passando, em seguida, para a descrição do modelo teórico proposto por Schwartz, que tem como ponto de referência um dos instrumentos utilizado nesta tese. Por fim, descreve a abordagem sobre valores organizacionais, apresentando os principais autores, suas definições e perspectivas para o tema.

A terceira vincula-se ao tema práticas organizacionais como elemento manifesto da cultura organizacional e trata as práticas sociais, anteriormente às práticas da organização, as quais são apresentadas com base em questões conceituais e perspectivas de estudo. Por fim, uma revisão de estudos empíricos integrará os estudos sobre cultura, valores, práticas organizacionais, identidade e desempenho no trabalho.

\section{Seção 1. Cultura Nacional e Cultura Organizacional}

Embora haja similaridade entre os termos cultura de uma nação e cultura de uma organização, esse fenômeno possui naturezas distintas. A diferença reside nos papéis representados em cada cultura, por suas manifestações, em termos de aspectos objetivos e subjetivos. Nessa concepção, essa seção será dividida em duas partes: a primeira (1.1) que versa sobre os aspectos históricos e conceituais de cultura nacional e a segunda parte, composta das abordagens teóricas, conceituais e formas de investigação de cultura organizacional (1.2). 


\subsection{Cultura Nacional}

É longa a tradição histórica do conceito de cultura, que nem sempre apresentou o mesmo significado (Souza, 2009). Nesse sentido, ao longo dos séculos passados, com destaque para o século XX, ocorreu amplo debate sobre a forma mais adequada para se definir esse conceito. Com o atraso da participação de psicólogos e administradores, que se aproveitaram de trabalhos anteriores realizados por antropólogos, coube aos antropólogos encontrar um valor particular no conceito de cultura como uma forma de encapsular seus entendimentos dos grupos de pessoas relativamente pequenos e isolados. Dessa forma, muitos de seus primeiros estudos se concentraram, mesmo não havendo acordo quanto à melhor forma de definir o que uma cultura é conceitualmente (Smith, Bond \& Kağitçibasi, 2006).

\subsubsection{Cultura Nacional: aspectos históricos e conceituais}

Ao longo dos séculos, com destaque para o século XX, tem sido amplo o debate sobre a forma mais própria de definir o conceito cultura. O vocábulo germânico Kultur, no final do século XVIII, era utilizado para designar os aspectos espirituais de uma comunidade, enquanto a palavra francesa Civilization definia aspectos materiais de um povo. A síntese dos termos coube a Tylor (1871), que propôs uma definição ao empregar o termo inglês Culture em um amplo sentido etnográfico. Cultura, para Tylor (1871), significa "este todo complexo que inclui conhecimentos, crenças, arte, moral, leis, costumes ou qualquer outra capacidade ou hábitos adquiridos pelo homem como membro de uma sociedade", abrangendo todas as possibilidades de realização humana, além do forte caráter de aprendizado da cultura em contraposição à ideia de aquisição inata.

Em seus estudos, Kroeber e Kluckhohn (1963) conseguiram identificar cerca de 160 acepções de cultura, sendo algumas apresentadas a seguir.

De forma pragmática, Frans Boas (1911) foi o primeiro antropólogo a realizar pesquisas de campo para observar diretamente as culturas primitivas. Esse autor definiu cultura como todo o complexo de comportamento tradicional que vem sendo desenvolvido pela raça humana e é sucessivamente aprendido por cada geração, podendo significar não apenas as formas de comportamento tradicional, que são características de uma dada sociedade ou grupo de sociedades, mas, também determinada raça ou área definida ou certo período de tempo.

Seguindo a tradição de Boas (1911), para quem as diferenças entre os grupos são de ordem cultural e não racial, Benedict (1934) refere-se à cultura como um fenômeno que 
agrega os homens em torno de ideias e normas compartilhadas, significando todo o complexo de comportamento tradicional que vem sendo desenvolvido pela raça humana e é sucessivamente aprendido por cada geração.

Kluckhohn (1962) dividiu o conceito de cultura em duas partes, a primeira referindose aos elementos objetivos (por exemplo, artesanato produzido por grupos sociais) e a segunda aos elementos subjetivos (valores, crenças e normas sociais). A análise desses elementos subjetivos permite a compreensão de como as pessoas percebem, fazem categorizações sociais, formulam crenças, e valorizam aspectos específicos do ambiente social ao seu redor (Triandis 1994).

A responsabilidade de tratar da coesão entre os diversos conceitos de cultura foi assumida por Kluckhohn (1951) e Kroeber e Kluckhohn (1963), resultando na definição de que cultura consiste em padrões explícitos e implícitos, de e para comportamentos adquiridos e transmitidos por símbolos, constituindo a realização distintiva dos grupos humanos. Assim, sistemas de cultura podem, por um lado, ser considerados como produtos de ação e, por outro lado, como elementos de condicionamento de ação adicional (Kroeber \& Kluckhohn, 1963).

Parsons e Shils (1951) afirmam que a cultura diferencia-se dos outros elementos de ação pelo fato de ser intrinsecamente transmissível de um sistema de ação para o outro, por intermédio da aprendizagem e pela difusão, ou seja, uma definição multidisciplinar da cultura como conteúdo transmitido e criado por padrões de valores, ideias e outros sistemas simbólico-significativos como fatores na formação do comportamento humano (Kroeber \& Parsons, 1958).

Por sua vez, Levi-Strauss (1949) apresentou seu conceito de cultura baseado na definição do homem como um ser biológico e social, estando a cultura na síntese das respostas do indivíduo aos estímulos externos, mesmo que sejam produto de sua natureza ou de sua condição social.

A definição de cultura elaborada por Geertz $(1973,1989,2009)$ leva em consideração diversos aspectos que vão do completo modo de vida de um povo até o compartilhamento de formas de sentir, pensar e acreditar. Associado a isso, afirma esse autor, apresenta-se o legado social adquirido pelo individual em seu grupo, levando em conta a abstração do comportamento, compreendido como um depósito de aprendizagem compartilhada, ou mesmo um conjunto de orientações padronizadas para os problemas recorrentes, ou seja, um comportamento aprendido, que passa por mecanismos de regulamentação normativa. Assim, cultura expressa um conjunto de técnicas que ajustam o homem ao ambiente externo ou em relação aos outros homens. 
Quando se analisa o termo cultura com base na multiplicidade de conceitos apresentados, verifica-se a existência de aspectos teóricos diferenciados. Para Noriega e Carvajal (2009), de maneira geral, o entendimento do conceito de cultura refere-se às práticas materiais e de significação, ao mesmo tempo em que garante contínua produção, reprodução e transformação das estruturas materiais e de significação que organizam a ação humana.

A definição de cultura elaborada por Dupuis (2008) trata tanto da ligação inseparável entre modelos, valores, símbolos como de comportamentos, ações e práticas, que estabelecem juntas as configurações culturais, ou seja, cultura. Neste sentido, cultura é considerada "constituída pela interação de elementos estruturais" como economia, administração, práticas e representações sociais que estabelecem as "manifestações da cultura" de um grupo social (Dupuis, 2008, p. 202). D’Iribarne (1983) afirma ser cultura um recurso, ou mesmo, um ponto de apoio para o estabelecimento de relação e cooperação entre atores sociais.

Nessa linha, Souza, Castro-Lucas e Torres (2011) comentam que cultura pode ser a forma pela qual os indivíduos e os grupos sociais se relacionam e agem, sendo fundamental para se identificar o conjunto de valores, estilos, formas de pensar, que se expande a uma variedade de grupos sociais vistos e compreendidos como integrantes da mesma cultura ou subcultura.

Dada a grande variedade de definições utilizadas para o termo cultura, Gelfand, Erez e Aycan (2007), de forma organizada, apresentam a ligação entre as definições. Assim, pode-se referenciar cultura como a parte do ambiente de origem humana (Herkovits, 1955), que inclui elementos objetivos e subjetivos (Triandis, 1972), como um conjunto de reforços (Skinner, 1981), como a programação coletiva da mente (Hofstede, 1991), como um sistema de significado compartilhado (Shweder \& LeVine, 1984); como maneiras padronizadas de pensamento (Kluckhohn,1954), e como padrões de procedimentos operacionais não declarados ou maneiras de fazer as coisas (Triandis, 1994). Mesmo que ocorram variações nas definições de cultura, pesquisadores enfatizam que a cultura é compartilhada, adaptativa ou tem sido adaptativa, em alguma ocasião no passado, e é transmitida por meio do tempo e das gerações (Triandis, 1994).

Um último, mas não menos importante ponto que se estabelece diz respeito ao nível de análise ou de estudo que o conceito de cultura pode apresentar. A cultura é um constructo de carácter multinível (Gelfand et al., 2007; Erez \& Gati, 2004; Chao, 2000; Dansereau \& Alutto, 1990), logo, o posicionamento do estudo em determinado nível, ou na relação entre os níveis, remete para diversificadas formas de investigação (Rebelo, 2006). Disso, resulta que a opção pelo nível (ou níveis) de cultura a estudar (nacional, organizacional, departamental, 
profissional) é uma questão crítica e fundamental, pois dessa escolha, decorre a possibilidade de se obterem resultados confiáveis (De Witte \& van Muijen, 1999a). Para essa tese, a escolha do nível recai sobre a organização; em outras palavras, incide na cultura organizacional, que será tratada no tópico seguinte.

\subsection{Cultura Organizacional}

Diferentemente de outros conceitos aplicados às organizações, a cultura organizacional já atravessou a etapa de ser encarada como uma moda gestionária (Rebelo, 2006). Diametralmente oposta a isso, cultura organizacional apresenta-se como um conceito reconhecido, com estabilidade conceitual razoável, complexo, para o qual diversas revisões de literatura como também várias investigações e discussões em torno de distintas perspectivas ou quadros teóricos muito têm colaborado (e.g., Allaire \& Firsirotu, 1984; Bedani, 2008; Brown, 1998; Coelho Jr. \& Borges-Andrade, 2004; De Witte \& van Muijen, 1999b; Gelfand et al., 2007; Gomes, 1990, 2000; Martin, 2002; Neves, 1996, 2000; Reichers \& Schneider, 1990; Sackmann, 1991; Smircich, 1983).

\subsubsection{Abordagens teóricas em cultura organizacional}

O tema cultura organizacional ganha relevância no final década de 1970 e início da década de 1980, especialmente pelos teóricos organizacionais (Bedani, 2008). O interesse em questões intangíveis e simbólicas que constituem as organizações foi mencionado por Barbosa (1996) e Hofstede (2003), tendo esse assunto um papel importante, ao influenciar a forma de pensar, sentir e agir das pessoas que fazem parte das organizações.

Diante dessa importância, Schultz (1994) propõe a operacionalização do conceito de cultura para os estudos organizacionais. Assim, em um primeiro momento, são consideradas as perspectivas que fundamentam cada abordagem teórica, sendo possível analisar as distintas visões e conceitos, desvendar as várias implicações teóricas decorrentes de cada enfoque e compreender adequadamente os resultados originados pela análise desse tipo de cultura (Bedani, 2008).

Smircich (1983) buscou explicar como se operacionaliza a cultura nos estudos organizacionais, com o cruzamento entre o arcabouço antropológico e a teoria das organizações dando origem à estrutura conceitual dos cinco principais modelos que orientam esses estudos (Figura 5). 
Assim, os enfoques resultantes de cada associação engendram variados entendimentos de cultura organizacional, que proporcionam distintas questões de pesquisa e interesses teóricos, conforme assinala Bedani (2008).

\section{Concepçōes de cultura advindas da antropologia}
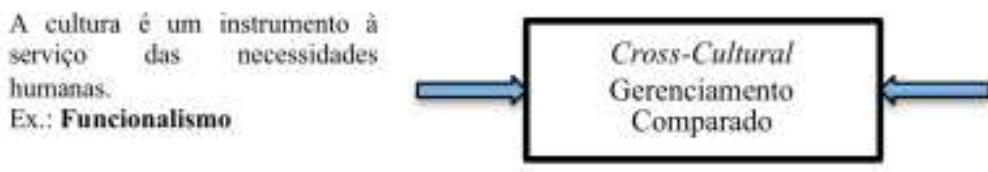

Temas em pesquisas organizacionais

As organizações ș̃o instrumentos sociais para a realizaçầo de tarefas.

Ex.: Teoria Clássica da Administraçâe.

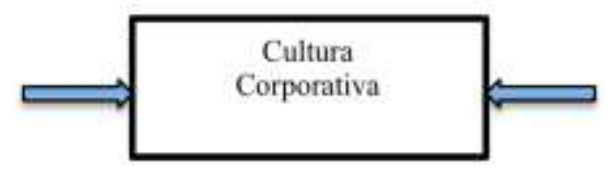

As organizaçōes sẫo organismos adaptativos existindo pelo processo de trocas com o ambiente.

Ex.: Teoria Contingencial

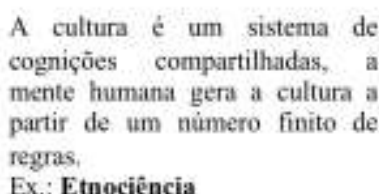
regras.

Ex.: Etnociênci:
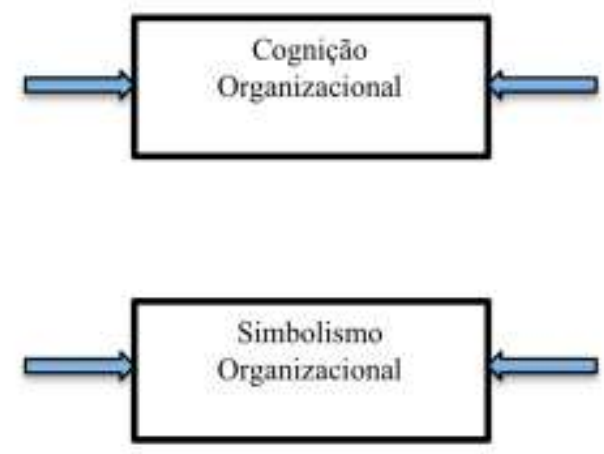
significados compartilhados que precisam ser interpretados ou decifrados para serem entendidos.

Ex: Antropologia Simbólica
As organizaçōes são sistemas de conhecimento e significados compartilhados entre seus membros.

Ex: Teoria Cognitiva da Organização

As organizações sâo padrỏes de discurso simbólico, como a linguagem que facilita o compartilhamento de significados e realidades.

Ex. Teoria do Simbolismo Organizacional

As formas e r práticas
organizacionnis
manifestaçōes de
inconscientes.
Ex.: Teoria da Transformaçã̃o
Organizacional

Figura 5. Interseção da cultura com a teoria das organizações (adaptado de Smircich, 1983, p. 342).

Ao servir de instrumento a serviço das necessidades humanas, atribui-se à cultura certa instrumentalidade (Carrieri, 2002). Para Smircich (1983), essa instrumentalidade pode ser observada nas duas seguintes concepções: a da Gerência comparada, que procura organizar padrões culturais gerais ou homogêneos e vislumbra cultura como uma variável externa à organização, e a da Cultura corporativa, igualmente conhecida como Cultura organizacional. Essa acepção da cultura como variável, segundo Barley e Kunda (1992), 
emerge no sentido de auxiliar os estudos estadunidenses que priorizavam apenas as questões técnicas e econômicas.

Quando se observa a cultura na perspectiva da Gerência comparada, essa é tratada como uma variável independente, resultante da soma de diversas variáveis dependentes que podem ser racionalmente equacionadas, introduzidas na organização pelos seus membros, podendo ser revelada pelos padrões de atitudes (possíveis de ser mensuradas nas escalas), bem como pelas ações dos membros organizacionais (Bedani, 2008; Carrieri, 2002). Dessa forma, a cultura funciona como um adesivo, com a finalidade de manter a unidade dos grupos, informando, ainda, o estilo de gerenciar mais favorável para a organização.

Diversos trabalhos podem refletir de forma significativa essa concepção apresentada. São eles, segundo Oliveira, Drummond e Rodrigues (1999), os trabalhos de Hofstede (1991), Hampden-Turner e Trompenaars (1993), que buscam a eleição de grupos de valores relevantes para a realidade dos negócios (internacionais) e situam os gerentes de diversas culturas diante desses valores, estabelecendo escalas e tipificações. Søndergaard (1994) observa que os estudos de Hofstede (1980; 1991) e Hofstede, Neuijen, Ohavy e Sanders (1990) são clássicos, em concordância com a perspectiva de se observar a cultura como variável, e os considera fundadores de uma abordagem bastante popular sobre tipologias culturais. Contudo, autores como Yeh e Lawrence (1995) fazem duras críticas aos estudos referenciados, inclusive quanto ao aspecto metodológico. A abordagem das pesquisas que se debruçam sobre essa aproximação procura identificar as contestações e clusters de similitudes entre culturas nacionais e como estes elementos influenciam a produtividade organizacional (como exemplo, ver Van der Zee, Astma, \& Brodbeck, 2004).

Quanto à Cultura corporativa, a definição utiliza a metáfora da cola (Carrieri, 2002), que mantém a organização unida. A cultura apresenta-se como responsável por desempenhar um papel de cola social ou normativa, responsável pela unificação da organização, expressa os valores, crenças e ideais compartilhados por todos os atores organizacionais. Esse conceito, aqui, é estudado como uma variável (interna da organização) que possibilita evidenciar, decifrar e até controlar a concepção de verdades, valores e crenças que ocorrem na organização; esses padrões manifestam-se pelo aparato simbólico verificado em mitos, rituais, histórias, lendas, cerimônias, entre outros.

Disso resulta que certo número de determinantes do comportamento organizacional pode ser manipulado pelos gestores por intermédio da dimensão simbólica, com vistas à melhoria do desempenho, ao aumento da socialização entre os sujeitos organizacionais, gerando maior comprometimento, identificação, motivação e desempenho. Como exemplo 
disso, pode-se verificar o estudo de Van der Zee et al. (2004) que examina, entre outros aspectos, a influência da diversidade cultural, a identificação organizacional e a personalidade sobre os resultados organizacionais.

Os estudos sobre cultura corporativa, claramente influenciados pela abordagem funcionalista, normativa e instrumentalista, focalizam a estrutura, a tecnologia e os padrões de liderança bem como a relação dessas variáveis com a sobrevivência e a produtividade das organizações. Com uma visão utilitarista de cultura, como variável interna da organização, passível de ser controlada ou moldada, dependendo dos interesses dos gestores, o enfoque de cultura organizacional despertou imenso entusiasmo entre acadêmicos e profissionais, porque se constituiria em um componente conceitual entre o comportamento organizacional e as questões estratégicas das empresas (Bedani, 2008).

Por outro lado, a perspectiva que identifica cultura como uma metáfora busca determinar uma visão das organizações como expressão de formas e manifestações da consciência humana (Carrieri, 2002). As organizações, por conta disso, passam a ser analisadas e compreendidas em termos de aspectos simbólicos como, por exemplo, o uso da linguagem e o desenho dos discursos organizacionais.

Na verdade, ressalta Carrieri (2002), a rede de discursos simbólicos é que dá origem à organização como conjunto, resultando na forma de ler, interpretar e compreender a cultura, assim como a organização. De acordo com essa perspectiva, a possibilidade de enxergar o mundo social e organizacional apresenta-se pela avaliação da cultura como metáfora da organização. Isso acontece em contraponto à visão da organização como dado concreto, como a invenção das interações humanas, das quais as inúmeras significações simbólicas são manifestadas.

Outra diferenciação é que, pela linguagem, a identidade, os mitos, os ritos, as histórias, entre outros elementos, deixam de ser simplesmente artefatos culturais e passam a existir como processos produtores e formadores de significações as quais dão sentido à existência da organização (Smircich, 1983). Três abordagens são elencadas nessa perspectiva: a Cognitiva, a Simbólica e a Psicoestruturalista, intensamente influenciadas pela abordagem antropológica do idealismo cultural e pela teoria institucional.

Na perspectiva da cognição organizacional, a cultura é exteriorizada como um sistema de conhecimentos e crenças compartilhadas na organização. Nessa perspectiva, vinculada aos princípios da etnociência, as organizações são examinadas como redes de significados subjetivos, diferentemente compartilhados e criados pela mente de seus membros, ou seja, a abordagem cognitiva entende cultura como um sistema de conhecimentos, com padrões de 
percepção e crenças, cujos modelos de avaliação são aprendidos e norteiam o modo de agir dos sujeitos organizacionais.

Uma consequência prática, que resulta da abordagem cognitiva, na visão de Bedani (2008), é a compreensão da relação entre cognição e o comportamento dos indivíduos da organização. Essa consequência deve passar pelo entendimento da rede de significados que estrutura a organização, ou seja, que revela a sua cultura, bem como a identificação das estruturas de conhecimento que operam na organização e do sistema de regras, que guiam a ação dos indivíduos, permitindo o diagnóstico e a promoção de alterações na forma de a organização agir.

A concepção Simbólica, ou simbolismo organizacional, diretamente influenciado pelas ideias de Geertz (1973, 1989) estuda a cultura como um sistema de símbolos e significados. Dessa forma, as organizações são apreciadas pelos padrões de discursos simbólicos, que necessitam ser interpretados e decifrados para serem compreendidos. Essa abordagem representa o compartilhamento de símbolos e significados, resultantes da interação social, em que os membros da organização interpretam e compreendem suas experiências, suas realidades, bem como o significado atribuído e a experiência desse processo com estabelecimento de critérios orientadores para a ação. Nesse aspecto, a análise organizacional enfoca a maneira como os sujeitos entendem suas experiências e como essas interpretações se relacionam com a ação. Assim, o simbolismo organizacional especifica as ligações desses temas com os valores, crenças e ações dos indivíduos da organização. Os temas expressos nos diversos sistemas simbólicos representam o coração da organização como uma cultura (Smircich, 1983).

Por fim, para os psicoestruturalistas, a cultura é investigada como expressão manifesta do inconsciente humano. As análises acerca da cultura organizacional seriam superficiais, porque se referem aos aspectos manifestos do fenômeno cultural (valores, práticas, normas, regras, estrutura formal da organização) e a sua relação com o comportamento. A proposta desse ponto de vista é o estudo da cultura como expressão do inconsciente e como revelação das grandes dimensões (estruturas) da mente humana (Carrieri, 2002). A finalidade desses estudiosos é romper com a superficialidade, revelando a realidade escondida ou os fundamentos inconscientes que dariam origem à cultura organizacional.

Em síntese, encontra-se nas duas primeiras correntes o conceito de cultura como uma variável (independente, dependente, externa ou interna à organização) e, por contraposição, nas três últimas, a cultura, não sendo vista como uma variável, mas sim concebida como uma metáfora fundadora para conceituar a organização (Rebelo, 2006). Os autores vinculados às 
perspectivas cross-cultural e da cultura corporativa compreendem a cultura como algo que a organização "tem". Já os autores das demais abordagens qualificam a cultura como algo que a organização "é” (Bedani, 2008). Apresenta-se uma forma viável de estudar e investigar cultura organizacional por meio de cada uma dessas cinco perspectivas, demonstrando-se o potencial rico e variado do conceito de cultura aplicado às organizações.

O tema cultura, contrapondo-se às metáforas da máquina (abordagem racionalista) e do organismo (abordagem sistêmica), de acordo com a perspectiva de Schultz (1994), introduz novas questões no estudo das organizações. Entretanto, cabe ressaltar o aprofundamento da inserção na teoria organizacional, cujas pressuposições básicas inerentes a estas duas últimas metáforas, igualmente incidiram sobre a cultura organizacional (Bedani, 2008).

Considerando a influência da teoria organizacional sobre a cultura, Schutlz (1994) identifica três perspectivas centrais, que norteiam os estudos sobre cultura organizacional, apresentadas na Tabela 2 .

Tabela 2

Abordagens teóricas propostas por Schultz para a cultura organizacional

\begin{tabular}{lll}
\hline Perspectivas & Paradigma Organizacional & Cultura Organizacional \\
\hline Racionalista & $\begin{array}{l}\text { A organização é constituída como um meio } \\
\text { eficiente para a obtenção de resultados. }\end{array}$ & $\begin{array}{l}\text { A cultura é uma ferramenta para a obtenção } \\
\text { dos resultados organizacionais. }\end{array}$ \\
Funcionalista & $\begin{array}{l}\text { A sobrevivência organizacional vincula-se ao A cultura é um padrão de valores } \\
\text { desempenho de funções essenciais, já que a } \\
\text { organização é uma coletividade. }\end{array}$ & $\begin{array}{l}\text { compartilhados e pressupostos básicos cuja } \\
\text { função é provocar a adaptação e integração da } \\
\text { organização ao seu ambiente. }\end{array}$ \\
Simbólica & $\begin{array}{l}\text { Vista como um sistema humano, a organização } \\
\text { expressa os padrões complexos da ação } \\
\text { simbólica. }\end{array}$ & $\begin{array}{l}\text { A cultura constitui-se como um padrão de } \\
\text { símbolos e significados. }\end{array}$ \\
\hline Fonte: Schultz (1994, p. 14).
\end{tabular}

As abordagens expostas por Schultz (1994) aproximam-se das colocadas por Smircich (1983). Tanto na perspectivas racionalista como na funcionalista, a cultura é compreendida como uma variável organizacional; já no enfoque simbólico, a cultura é assimilada como uma metáfora organizacional.

A abordagem da cultura organizacional como uma variável de perspectiva funcionalista é retomada por autores como Deal e Kennedy (1982) e Peters e Waterman (1982), que referenciam a eficiência e o desempenho nas organizações. A perspectiva funcionalista, aprofundada nas proposições de Parsons (1960), caracteriza a abordagem proposta por Schein (1985), que procura revelar qual a função da cultura para a organização. Já a perspectiva simbólica encontra nos trabalhos de Trice e Beyer (1986), Frost, Moore, 
Louis, Lundberg e Martin (1991), Aktouf (2001) a visão compartilhada dos cientistas sociais, que buscam entender o significado da organização para seus membros.

Ao estudarem as raízes teóricas das pesquisas sobre cultura, Alvesson e Berg (1992) sinalizaram para a existência de doze perspectivas de estudos sobre cultura na teoria organizacional. Esses autores julgaram inadequada a separação dos estudos sobre cultura organizacional em abordagens que se excluíam mutuamente, tendo em vista a complementariedade que teriam na explicação da realidade organizacional. É preciso salientar que, na época em que Smircich (1983) realizou sua tipologia, poucos estudos sobre cultura existiam, o que não ocorreu com Alvesson e Berg (1992). Com a denominação de convenções, esses autores agruparam as doze perspectivas em cinco categorias, que apresentam uma designação coletiva para um grupo de perspectivas referentes ao elemento principal que cada perspectiva aborda, conforma descrito na Tabela 2.

Cabe ressaltar que as doze perspectivas alinhadas em cinco grupos representam a visão comum de um grupo de pesquisadores na caracterização e construção de um objeto de pesquisa. Entretanto, tais caracterizações não são estanques, ou seja, as perspectivas podem sobrepor-se ou mesclar-se, a depender do tipo de abordagem da investigação (Carrieri, 2002). Tabela 3

Tipologia de Alvesson e Berg para o estudo da cultura organizacional

\begin{tabular}{ll}
\hline Convenções & Perspectivas \\
\hline Cultura & Cultura corporativa \\
& Cultura como sistema de valores e crenças \\
& Cognitivismo cultural \\
& Cultura como sistema de símbolos \\
Construção de significados & Significados compartilhados \\
& Construção e desconstrução de significados \\
Ideologia & Ideologia corporativa \\
Ideologia política \\
Psicodinâmica & Fantasias compartilhadas \\
& Cultura como arquétipos \\
\hline Fonbolismo & Universalismo simbólico \\
& \\
& \\
&
\end{tabular}

Fonte: Adaptado de Alvessom e Berg (1992). 
Na Tabela 3, a primeira convenção, denominada cultura, agrupa as perspectivas cultura corporativa, cultura como sistema de valores e crenças, cognitivismo cultural e cultura como sistema de símbolos. Essa convenção assume que as organizações apresentam uma cultura única de aspecto eminentemente instrumental, com clara aproximação da abordagem funcionalista. A segunda convenção, com a perspectiva de construção de significados, fortemente influenciada pela abordagem hermenêutica de Geertz (1973, 1989), procura compreender a realidade social e organizacional baseada em aspectos históricos e busca a interpretação dos elementos subjetivos da cultura. Próxima da abordagem que estuda a cultura como metáfora das organizações, acolhe duas perspectivas ligadas à visão subjetiva da realidade e com intensas influências do paradigma interpretativo: organização como significados coletivamente compartilhados; e organização como construção e desconstrução de significados, tomando esta como metáfora organizacional (Carrieri, 2002).

A terceira convenção, denominada ideologia, apresenta-se como elemento central dos estudos sobre cultura e não somente como mais um elemento qualquer como ritos, mitos, cerimônias, entre outros. Essa concepção traz a perspectiva de que existe uma durabilidade e uma estabilidade dos valores organizacionais e que esses ordenam a realidade e trazem significações nas ações da organização. Na quarta concepção, retratada pelos autores como produto do inconsciente dos membros da organização, a cultura é estudada na convenção psicodinâmica, onde a ênfase e a instrumentalização recaem sobre os elementos culturais com o objetivo de identificar as ansiedades e impulsos que influenciam no comportamento dos indivíduos no ambiente organizacional.

Os estudos agrupados na última convenção, denominada simbolismo, fundamentamse no princípio de que há muita confusão e ambiguidade na realidade organizacional. Os parâmetros pelos quais a realidade pode ser moldada não são claros, e muitas vezes considerados insuperáveis; entretanto, são os responsáveis para que os indivíduos percebam a realidade e construam significados dentro das organizações.

Como já mencionadas e reafirmadas, também por Alvesson e Berg (1992), essas abordagens não são excludentes. Ao contrário, existe a possibilidade de sua sobreposição ou combinação nos estudos organizacionais, pois todas as perspectivas abordam os mesmos elementos do ambiente organizacional como: normas, atitudes, valores, emoções, cognição, significados, suposições, fantasias e símbolos. A diferença reside no grau dessa abordagem, ou seja, determinados elementos são mais intensamente e profundamente estudados, enquanto outros são abandonados. 
Um dos argumentos utilizados por Alvesson (1993) para a abundância de perspectivas, tanto teóricas como metodológicas, pode ser atribuída à falta de definição sobre o objeto de estudo empírico das pesquisas realizadas sob o domínio da cultura organizacional. A sugestão desse e de outros autores, nesse caso, é substituir o termo cultura por outros mais precisos e que verdadeiramente reflitam o objeto estudado, tais como: ideologia corporativa, particularismo simbólico, padrões informais de comportamento ou sistema de normas (Bedani, 2008; Alvesson, 1993). Argumentam, ainda, os autores que a cultura organizacional é empregada como um verdadeiro guarda-chuva conceitual. Dessa forma, existiria a possibilidade de não se fazer referência a nenhum objeto empírico específico, o que configuraria mais uma maneira de pensar na realidade social.

Como forma de realizar uma síntese das abordagens apresentadas, Alvesson (1993) finaliza observando que a principal diferenciação conceitual estaria entre a visão de cultura baseada nas abordagens objetivo-funcionalista versus subjetivo-interpretativa. Observa-se que essa síntese apresentada converge, de forma parcial, para a tipologia proposta por Schultz (1994). Ademais, para Carrieri (2001) existe uma relação entre as duas perspectivas resumidas por Alvesson (1993), respectivamente, aos conceitos de cultura organizacional e de cultura nas organizações, que tangenciam as três perspectivas propostas por Martin (1992) para o estudo da cultura: integração, diferenciação e fragmentação cultural.

Integração, na visão de Martin (1992), considera a cultura organizacional como um todo unitário (formal e informal), consistente e universalmente aceito por todos os sujeitos da organização, incumbindo aos gestores a função de atores de formação, disseminação e transformação cultural. Nessa perspectiva, o papel da cultura é de imprimir consenso ou conformidade à organização, na medida em que reflete os valores e pressupostos básicos compartilhados de maneira uniforme por todos os seus membros, atuando de forma a reprimir as ambiguidades e contradições, com vistas a guiar e direcionar a ação e o comportamento das pessoas de forma conveniente. Das três perspectivas de Martin (1992), a de enfoque integrador propõe uma pesquisa sobre cultura organizacional, em contrapartida às demais que propõem cultura sob o aspecto da diferenciação ou fragmentação ao efetuar pesquisas sobre cultura na organização.

Martin (1992) defende, ainda, que o maior comprometimento e a produtividade dos indivíduos, bem como seu pertencimento a organizações mais eficientes e lucrativas, estão diretamente ligados a culturas caracterizadas pela consensualidade. Ideias, opiniões e interesses desviantes são, conforme observados pela autora, ignorados nos julgamentos motivados por esta perspectiva. Privilegia-se, então, uma acepção de cultura organizacional 
estabelecida de forma homogênea e harmônica que, na prática, nutriria um "hegemônico vicioso" (p. 68), o que, por sua vez, reforçaria os interesses dos grupos dominantes no interior da organização, conferindo legitimidade às relações de autoridade instituídas. De modo próximo ao destacado por Aktouf (2001), Martin e Frost (2002) sinalizam que os atraentes compromissos, advindos especialmente do hipotético relacionamento entre cultura e desempenho organizacional, fizeram do aspecto da integração a abordagem dominante nos estudos realizados sobre cultura organizacional.

Em contrapartida, quando se analisa a cultura sob o aspecto da diferenciação ou fragmentação, Bedani (2008) propõe que a unidade cultural de uma organização seja apenas aparente, pois mascara uma série de subculturas que coexistiriam de forma harmônica, conflituosa ou indiferente dentro do contexto organizacional. Essa abordagem explora em suas análises os conflitos de interesse, a divergência, a diversidade, a inconsistência e outros influenciadores culturais internos e externos à organização, minimizando o papel dos gestores como fonte primária de conteúdo cultural. Além disso, apesar de não negar completamente a existência de uma cultura dominante ou de que alguns aspectos culturais seriam comuns e consensuais a toda organização, essa abordagem, diferentemente da integradora, considera que a concordância cultural existe somente nos limites de pequenos grupos, ou seja, restringe-se às subculturas organizacionais.

Para Martin (2002), a abordagem de mais difícil articulação nos estudos culturais é a da fragmentação, que apresenta seu foco na ambiguidade, cuja definição em si é confusa. Nessa visão, não se confirmam as consistências peculiares da perspectiva da integração ou as discordâncias inerentes da perspectiva da diferenciação. Ao contrário, a fragmentação ultrapassa a ambiguidade emanada da ignorância ou confusão ao abarcar ironias, paradoxos e contradições que permeiam o contexto cultural (Bedani, 2008). Ao se aproximar dos postulados pós-modernistas, para esse ponto de vista, a ambiguidade seria um elemento intrínseco à organização e à sociedade contemporânea. A recomendação é de que o equívoco, a imprecisão, a incerteza e a falta de consenso sejam focados pelas análises culturais. Mesmo reconhecendo a cultura como um fenômeno multinível (individual, grupal, organizacional, nacional), as investigações que possuem alicerce na teoria da fragmentação admitem que o perímetro entre cultura e subculturas organizacionais seria amorfo, ficando seus limites imprecisos e permeáveis entre si.

As três abordagens propostas por Martin (1992), ao comporem um sistema fechado para o entendimento da cultura organizacional, podem ser descritas como o relacionamento organizado entre as manifestações culturais (consistência, inconsistência e complexidade); o 
grau de consonância cultural (amplo consenso organizacional, consenso subcultural e coexistência de multiplicidade de visões); a orientação com relação à ambiguidade (negação, aceitação e priorização) (Bedani, 2008).

Um aspecto importante a ser observado com relação a essas três perspectivas refere-se à sua complementaridade. Isso se dá, em virtude da apreciação de determinado contexto organizacional ao expor alguns elementos consistentes, que apresentam relação direta para o estabelecimento de certo consenso cultural. Concomitantemente, distintos aspectos culturais se mostrariam radicados nas subculturas organizacionais ou, até, diluídos em um fluxo constante de incertezas, confusão e ambiguidades. Desse modo, as sugestões de Meyerson e Martin (1987) e Martin (1992) apontam para a utilização conjunta das perspectivas de integração, da diferenciação e da fragmentação, o que estabeleceria uma visão abrangente e meta-teórica do fenômeno cultural.

Ao analisar as alternativas que os pesquisadores têm à disposição em relação às perspectivas de estudo da cultura organizacional, nota-se que as opções vão desde aspectos que privilegiam descrições densas e profundas do constructo cultura, até aquelas que se preocupam com os elementos mais superficiais do fenômeno. Dessa forma, considerando-se a abrangência em que as pesquisas se mostram substancialmente diferentes, observa-se que cada enfoque, apesar de possuir bases e características diferentes, atende inteiramente aos interesses específicos de cada investigação. Em contrapartida, cabe salientar que essas abordagens não são autoexcludentes; ao contrário, admitem sua combinação como forma de buscarem uma sinergia ao se complementarem para o melhor entendimento da cultura organizacional.

Assim, a perspectiva mais adequada para o estabelecimento da investigação do fenômeno cultural é enunciada levando-se em consideração a acepção de cultura e os objetivos de cada pesquisa. A cultura será entendida como uma variável ou um subsistema da organização sendo a organização um local gerador ou produtor de uma cultura (e.g., Deal \& Kennedy, 1982). Isso resulta no entendimento de que cultura, baseada na escolha teórica, representa uma variável interna da organização, responsável por desempenhar um papel normativo que garante a estabilidade e a coesão do sistema social, bem como motiva os comportamentos considerados adequados a cada contexto organizacional. Ademais, a cultura é o construto responsável por fornecer os padrões básicos que determinam o que é adequado ou inadequado, além da maneira correta de realizar as atividades e a forma de conduzir os negócios em cada organização, sendo influenciada ou mesmo administrada pelos dirigentes organizacionais. Cabe, ainda, salientar que a cultura é constituída dos elementos latentes 
(como os valores compartilhados) e manifestos (como as práticas); assim, além de sua natureza privilegiar a estabilidade, não elimina a possibilidade de mudança, facilitando a transformação temporal, com a finalidade de incentivar a adaptação e a sobrevivência do sistema organizacional. Finalmente, trata-se de um construto qualitativa e quantitativamente mensurável, além de influenciar o comportamento de outras variáveis organizacionais, como, por exemplo a identidade no trabalho (profissional / organizacional) e o desempenho (Coelho Jr \& Borges-Andrade, 2004; Van der Zee et al., 2004; Gelfand et al. 2007; Hartnell, Ou \& Kinicki, 2011; Jacobs et al., 2013; Schneider, Ehrhart \& Macey, 2013).

Com referência às demais perspectivas, que levam em consideração a consistência cultural, a abordagem privilegiada será a da diferenciação, o que se liga ao conceito de culturas fortes, ou seja, admite-se o compartilhamento entre todos os indivíduos da organização de determinados elementos culturais; entretanto, igualmente, aceita-se o estabelecimento de subculturas no contexto organizacional, que podem conviver com relativa harmonia.

Finalmente, postula-se que o estudo da cultura possa ser realizado por meio de entrevistas semiestruturadas, análise de documentos da organização (D’Iribarne, 1989, 2003), bem como questionários autoaplicáveis (Hofstede, 1980, 1991, 2001), levando-se em consideração amostras representativas das populações pesquisadas. Com base nesses levantamentos, os resultados permitem a elaboração de diagnósticos sobre as principais particularidades da cultura de cada organização e o delineamento de estudos comparativos e correlacionais.

\subsubsection{Questões conceituais em cultura organizacional}

As definições de cultura organizacional apresentam-se, usualmente, fragmentadas, o que é consoante ao corpo teórico multidisciplinar no qual se estruturam. A formulação dessas definições reflexiona os limites infligidos pelos dogmas característicos da abordagem teórica da qual se originam. Desse modo, a centralidade da definição de cultura organizacional é utilizada de formas distintas pelos diversos autores, originando ainda mais confusões e equívocos conceituais. Talvez por isso, Sackmann (1991) tenha escrito que existem tanto definições e entendimentos de cultura quanto pessoas escrevendo sobre elas (p. 2).

Da mesma forma, refletindo essa condição de atomização teórica do constructo, Coelho Jr. e Borges-Andrade (2004), Gelfand et al. (2007), Ferreira e Assmar (2008), Ashkanasy, Wilderom e Peterson (2011) e Schneider et al. (2013) sinalizam para uma pluralidade conceitual nas definições de cultura organizacional e hipotetizam o motivo dos 
diferentes e diversificados recortes do tema, ao levarem em conta a própria conceituação de cultura, a metodologia de investigação, os níveis de análise e a abrangência que tais estudos pretendem atingir. Além disso, também foram consideradas a interdependência existente entre os artifícios históricos, as estruturas sociais e as experiências subjetivas que estão arraigados em sua concepção. Desses recortes, resulta a necessidade de compreender adequadamente os resultados produzidos pela análise da cultura organizacional.

Resumindo este contexto de verdadeira anomia teórica com relação à cultura organizacional, Fleury (1992 verifica uma "bricolagem de elementos teóricos e empíricos" (p. 10), no qual a forma se elabora conjuntamente com o conteúdo. Nessa linha, são apresentadas algumas das definições encontradas na literatura, não como forma de esgotar o assunto, mas, somente como forma de solidificar o referencial teórico proposto para este trabalho.

Assim, com base na definição de cultura organizacional dada por Prettigrew (1979, p.574) "como um sistema de significados aceitos, pública e coletivamente, operando para um dado grupo em um dado tempo", encontra-se um sistema de termos, formas, categorias e imagens interpretáveis para os sujeitos sobre suas experiências e estados.

Para outros autores como, por exemplo, Alvesson (1993), a cultura é compreendida como a forma de considerar a realidade social que não se correlaciona com um determinado objeto empírico. Trice e Beyer (1993) definem cultura organizacional como um conjunto de ideologias, de elevada carga emocional, que resiste a mudanças, auxiliando os sujeitos da organização a lidarem com incertezas e ambiguidades.

Uma das definições recorrentemente encontrada na literatura de cultura organizacional é a construída por Schein (2004), para quem o termo deve ser utilizado para o desígnio das crenças e dos pressupostos básicos compartilhados pelos indivíduos de uma organização, os quais atuam inconscientemente e limitam a visão que a organização tem de seu ambiente e de si própria. Nesse sentido, o autor afirma que a cultura organizacional consiste em um conjunto de pressupostos básicos, que os sujeitos organizacionais utilizam para resolver de forma eficaz os problemas de adaptação externa e integração interna, motivo que leva a serem ensinados aos novos membros da organização, como forma de perceber, pensar e sentir esses problemas, passando a fazer parte da cultura da organização.

Três diferentes níveis são utilizados por Schein (2004) para a caracterização da cultura, respectivamente, artefatos visíveis, valores e pressupostos básicos. Os primeiros referem-se à arquitetura, à linguagem, à tecnologia, à forma de vestuário, aos documentos públicos, ou seja, os aspectos visíveis da organização caracterizam os artefatos. Nesse nível, 
os elementos culturais são de fácil obtenção e de simples observação, contudo, são dificilmente interpretáveis, em virtude da ausência de coerência a eles subjacente.

No segundo nível, encontram-se os valores que refletem a cultura organizacional ao orientar a vida da organização e direcionar o comportamento dos indivíduos organizacionais. Esses valores são justificativas empregadas para esclarecer e predizer os atos dos sujeitos da organização. A visibilidade adquirida por tais valores advém por intermédio das metas, filosofias, normas e regras de comportamento que explicitam como as "coisas" devem ser (Ferreira \& Assmar, 2008).

No último nível da cultura organizacional estão os pressupostos básicos, de difícil acesso, que representam as crenças, as percepções e os sentimentos inquestionáveis, na maioria das vezes inconscientes, responsáveis pela forma como os membros da organização sentem, percebem e analisam a organização. O processo de introjeção desses pressupostos, segundo Ferreira e Assmar (2008), é extenso e é proveniente do enfrentamento de problemas e de sua apropriada solução. Surgem após um longo processo de aprendizagem e constituem a visão de mundo dos sujeitos da organização. Segundo Schein (1992), este nível é de difícil interpretação, mesmo constituindo a essência da cultura, tendo em vista sua associação a elementos menos discutíveis e confrontáveis que os valores esposados e os artefatos.

Baseado na ampliação do modelo proposto por Schein (1985), Rousseau (1990) pontua que a cultura organizacional anuncia-se por intermédio de cinco dimensões: artefatos, padrões de comportamento, normas comportamentais, valores e pressupostos fundamentais; desse modo, ela acrescenta aos elementos culturais do modelo anterior padrões de comportamento (mecanismos de coordenação, comunicação e tomada de decisão, utilizados na solução de problemas) e as normas comportamentais (perspectivas da organização acerca de como seus indivíduos devem comportar-se e interagir com os outros no que tange, por exemplo, às relações de cooperação ou à competição entre colegas). Cabe salientar, que, ao descrever a cultura de uma organização, Rousseau (1990) prioriza as normas comportamentais (Ferreira \& Assmar, 2008).

Para Hofstede (1980, 2005, p. 4), a cultura é entendida como “a programação coletiva da mente que diferencia os membros de um grupo humano de outros". Segundo Hofstede (2001), esta é uma definição abreviada que implica tudo na mais extensa definição de Kluckhohn (1962), ou seja, a mente está para a cabeça, o coração e as mãos, isto é, para o pensamento, o sentimento e as habilidades. Nesse sentido, Kluckhohn (1962) afirmou que cultura inclui valores e sistemas de valores que são elementos centrais da cultura. Disso 
resulta que a cultura é estabelecida pelas interações sociais, por meio das quais se processa o aprendizado do sistema de valores culturais (Sousa, 2009).

Em sua definição, Hofstede (1980, 2001, 2005) divide a cultura em dois níveis: valores e práticas. Os primeiros refletem a propensão para se eleger certo estado de coisas a outro, respeitando-se as diferenças entre os valores desejáveis e os desejados. Valores desejáveis referem-se à forma como os indivíduos pensam que o mundo deveria ser; valores desejados dizem respeito aos desejos das pessoas (Sousa, 2009). Já as práticas, que, para Hofstede (1980), são estabelecidas pelos fundadores da organização ou por figuras significativas, englobam os símbolos (palavras, gestos, figuras ou objetos que carregam significados aos que compartilham a mesma cultura), os heróis (pessoas que carregam características valorizadas e que moldam o comportamento das pessoas em determinadas culturas) e os rituais (atividades essenciais, realizadas de forma coletiva, para atingir determinados fins). Para Hofstede (2005, os valores moldam a cultura da organização, mas é pela intervenção das práticas que a tipificam, que a cultura é operacionalizada, sendo repassadas pelos processos de socialização (Hofstede, 2005).

A respeito das práticas organizacionais, Dupuis (2007) as define como molas propulsoras da cultura, que devem, portanto, vislumbrar as práticas reais dos indivíduos bem como os contextos de interação social, que são as representações da organização, ou mesmo para discutir as práticas sociais como manifestações culturais e seu significado nos contextos organizacionais, conforme proposto por D’Iribarne (1983).

Em síntese, a cultura organizacional, para essa tese, pode ser definida como os pressupostos básicos compartilhados (Schein, 2010), isto é, as crenças, os valores e sistemas de valores (Hofstede, 1980, 2001) que caracterizam um ambiente e são ensinados aos novos membros da organização, como a maneira correta de pensar e sentir, comunicados e manifestados pelas práticas da organização (D’Iribarne, 1983; Dupuis, 2007), pelos símbolos, heróis, ritos (Hofstede, 1980, 2001), mitos e histórias que as pessoas contam sobre como a organização veio a concretizar seu objetivo, em virtude da resolução dos problemas associados com a adaptação externa e a integração interna (Trice \& Beyer, 1993; Zohar \& Hofmann, 2012).

\subsubsection{A Influência da cultura nacional na cultura organizacional}

Diversos são os autores a discutir o conceito de cultura nacional (D’Iribarne, 2009; Dupuis, 2007; Hofstede, 1980; Huang \& Van de Vliert, 2004; Smith \& Bond, 1999; Smith et al., 2006; Souza et al., 2011; Torres, 1999; Triandis, 1994). 
Para cada grupo social, estão presentes as formas de continuidades e de mudanças, que tornam possível a conceituação da cultura, respeitando-se a imposição entre o que se modifica e o que permanece, ou seja, o "que é diverso e o que é compartilhado" (D'Iribarne, 2003, p. 328). Na visão de Dupuis (2007), a cultura chamada nacional, de forma geral, fornece a principal explicação das práticas organizacionais observadas como manifestações culturais das organizações. Para Hofstede (2005), a diferença entre as culturas nacional e organizacional reside no fato dos diversificados papéis representados em cada uma pelas manifestações da cultura, consideradas pelos valores centrais e pelas práticas, representadas pelos símbolos, heróis e rituais.

Assim a organização, sendo um sistema social, é um sistema aberto inserido em um contexto específico, composto por vários subsistemas, em que ocorrem trocas, que acarretam influências entre os diversos níveis da cultura (nacional, organizacional, departamental, entre outros) (Rebelo, 2006). A referida autora aponta que as organizações inserem-se em um meio externo, no qual interagem constantemente, gerando modificações internas, como forma de adaptação, e externas por intermédio de seus outputs (novas tecnologias, novas práticas compartilhadas e produtos inovadores).

Nesse contexto, as organizações possuem uma cultura (nível organizacional) e encontram-se vinculadas a uma comunidade, dentro de uma sociedade, dependendo, em parte, da cultura da comunidade na qual se inserem (nível nacional) (Rebelo, 2001), cabendo aos stakeholders externos à organização (governos, imprensa, sociedade em geral, entre outros) influenciar sua cultura, como atores que o são (DeWitte \& Van Muijen, 1999b).

De uma forma ou de outra, nas pesquisas sobre a cultura, o carácter multinível do constructo sempre esteve presente (Gelfande et al., 2007; Ashkanasy et al., 2011; Schneider et al., 2013). A este respeito, van Den Berg e Wilderom (2004) apontam que a relação entre cultura e organização é estudada em diferentes níveis de análise, desde o nacional até o individual. De acordo com esses autores, a cultura organizacional foi estudada em relação à cultura nacional, num primeiro momento e, em um segundo momento, utilizada para descrever e fundamentar as organizações; posteriormente, surgiu o conhecimento de subculturas, ou seja, a existência de diversas culturas no âmbito de uma mesma organização; e, recentemente, a cultura tem sido estudada, também, no nível da equipe ou do grupo de trabalho.

A discussão sobre a distinção entre cultura organizacional e outros níveis da cultura (como, por exemplo, a nacional) remete, segundo Rebelo (2006), a várias formas plausíveis de relacionar cultura e organização. Assim, ao comparar organizações, não se pode esquecer 
a coexistência de (sub)culturas mais ou menos convergentes entre si com a cultura da “coligação no poder", o que vem a influenciar o caráter unitário, forte e coeso da cultura de cada organização investigada, pelo que se torna indispensável avaliar o seu grau de homogeneidade cultural. Se a investigação ou a intervenção centrar-se em apenas um caso (uma organização), faz-se necessário decidir o objeto, ou seja, a cultura da organização, as subculturas ou mesmo a forma como elas se cruzam e interagem. Assim, segundo Rebelo (2006), no domínio da temática cultural e de sua relação com as organizações, é fundamental definir as questões de investigação e, com base nelas, o nível ou os níveis de análise em que a investigação se situa, porque este posicionamento tem consequências tanto no nível teórico como no nível metodológico.

Vários são os autores que estudam as relações entre a cultura nacional e a cultura organizacional, destacando-se, entre outros, Hofstede (1980, 1990, 1991, 2001) e D'Iribarne (1983, 2009), que verificaram o impacto da cultura nacional sobre a cultura organizacional. Outros como van Muijen et al. (1999) estudaram a influência do setor da atividade na cultura organizacional bem como na cultura nacional. D'Iribarne (1983, 2009a), por sua vez, pesquisou as relações da cultura nacional, em uma abordagem etnográfica destacando a interpretação histórica, e a cultura organizacional em mais de 20 países.

Nesse sentido, serão apresentadas, a seguir, reflexões acerca dos modelos da lógica cultural das organizações de D'Iribarne (1989) e da tipologia cultural de Hosftede (2003), nas quais, mesmo com a utilização de métodos de pesquisa diferenciados, ambos concordam com a importância das práticas organizacionais para o entendimento da cultura organizacional.

\subsubsection{Cultura organizacional: visões de D'Iribarne e de Hofstede?}

Ao considerar formas de estudar cultura organizacional, verifica-se que dois autores distinguem-se ao focarem seus estudos nas culturas nacionais: Hofstede (1980, 2001), com suas investigações que utilizaram escalas de atitudes, e D’Iribarne (1989, 2003) com seu método baseado na história e na etnografia. Com a combinação de abordagens qualitativas ou quantitativas, esses autores identificaram significados das práticas locais dos países estudados.

Ao longo dos últimos 20 anos, D’Iribarne (1989), fazendo uso de técnicas etnográficas de pesquisa e da interpretação histórica de culturas nacionais, com base em estudos de caso de organizações, vem pesquisando em mais de vinte distintos países as relações entre cultura nacional e cultura organizacional. Em suas pesquisas, dedica importante atenção à descrição das dinâmicas das organizações e suas práticas concretas de 
gestão, vinculando a relação da cultura nacional com a gestão dessas organizações (Souza et al., 2011), ou seja, como a cultura nacional influencia o funcionamento das organizações (Dupuis, 2004).

A lógica dos estudos de D’Iribarne (1983, p.131) propõe a análise das empresas e seus estilos de gestão, com ênfase incidindo em como os atores "definem precisa e explicitamente as responsabilidades de cada um; formulam claramente seus objetivos; deixam livres as escolhas dos meios; avaliam com atenção seus resultados, recompensas e sanções, considerando sucessos e fracassos".

As pesquisas realizadas por D'Iribarne (2003) utilizaram observação e entrevistas com os sujeitos das organizações em estudo, como forma de entender o funcionamento de cada empresa. $\mathrm{O}$ autor, por intermédio de pesquisa comparativa entre as filiais, em diferentes países, estudou as variáveis, tais como: tipo de produção, modelo de gestão, formação exigida dos funcionários, entre outras.

Por outro lado, utilizando a abordagem quantitativa, Hofstede (1991, 2003) realiza estudos sobre cultura organizacional, entendida como a programação coletiva da mente, que distingue os indivíduos de uma organização da outra. Ou seja, para esse autor, cada sujeito pertence, simultaneamente, a diversos grupos ou categorias distintas, o que os leva a diferenciados níveis de programação mental, que correspondem a diferentes níveis de cultura, tais como, nacional, étnico, religioso, linguístico, gênero, classe social, profissional, familiar, organizacional, entre outros, o que não significa dizer que existe harmonia entre os diferentes níveis culturais, ou seja, os programas mentais enfrentam conflitos frequentes entre valores (religiosos, gerenciais ou de gênero) e as práticas (Bedani, 2008).

Entre os diversos elementos que constituem a cultura organizacional, Hofstede (2003) classifica-os em duas categorias: (1) valores (que representam a parte invisível da cultura) e símbolos, rituais e heróis, que refletem a parte manifesta da cultura, agrupada sob o termo práticas (2). Para Hofstede (1994), as diferenças culturais estão nas práticas, quando se observa o nível organizacional, enquanto, no nível nacional, as diferenças culturais residem principalmente nos valores. Disso resulta que é pelas práticas compartilhadas cotidianamente nas organizações que se constitui a essência da cultura organizacional, conforme Figura 6. 


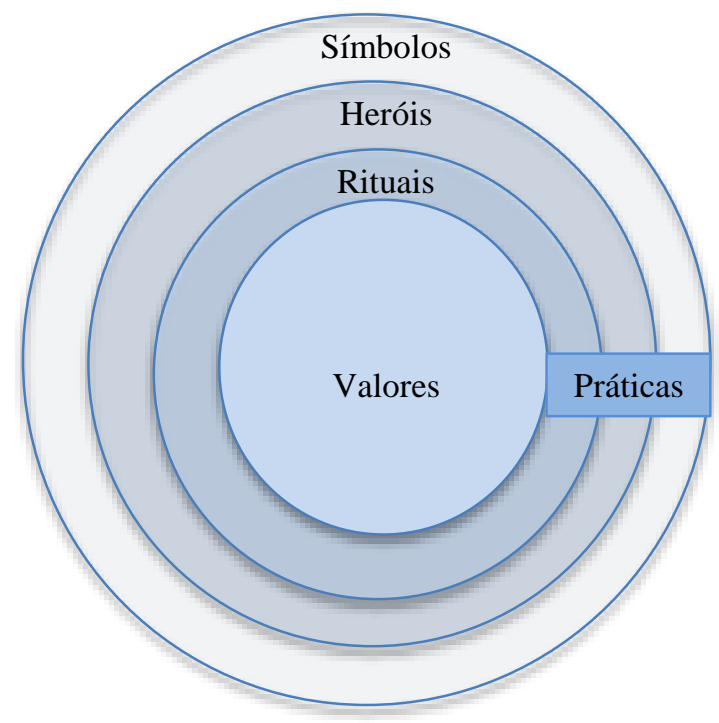

Figura 6. Níveis de manifestação da cultura segundo Hofstede (1991, 2003, p. 23).

Ainda, de acordo com Hofstede (1994), o que os indivíduos necessitam aprender quando se inserem em um contexto organizacional, está relacionado principalmente às práticas, o que permite afirmar que o ambiente de trabalho apresenta uma limitada capacidade de promover a mudança dos valores pessoais dos servidores.

O modelo para análise das diferenças culturais foi proposto em estudos realizados por Hofstede (1980), entre os anos de 1967 e 1973, com funcionários da empresa IBM, em 72 distintos países. Esse autor identificou que, de acordo com a nacionalidade dos empregados, houve diferenças significativas entre as unidades organizacionais com relação aos símbolos, heróis e rituais, ou seja, as práticas. Embora as culturas organizacionais apresentem-se como constituídas principalmente pelas práticas, Hofstede (1991, 2003) afirma serem também constituídas por valores, fortemente associados com a cultura nacional da unidade organizacional, complementando as dimensões culturais, conforme Tabela 4. 
Tabela 4

Dimensões da cultura organizacional de Hofstede (2003)

\begin{tabular}{|c|c|}
\hline Dimensões & Definições \\
\hline $\begin{array}{l}\text { Orientação para processos } \\
\text { versus Orientação para } \\
\text { resultados }\end{array}$ & $\begin{array}{l}\text { Opõe uma preocupação com os meios (orientação para processos) a } \\
\text { uma preocupação com os objetivos (orientação para os resultados). } \\
\text { Organizações orientadas para processo, comumente, são estabelecidas } \\
\text { por rotinas técnicas ou burocráticas, ao passo que a segunda } \\
\text { orientação enfoca a obtenção de resultados. Associada com o grau de } \\
\text { homogeneidade cultural da unidade, esta dimensão, estabelece que, } \\
\text { em unidades orientadas para resultados, os indivíduos perceberiam as } \\
\text { práticas organizacionais de maneira uniforme; nas unidades } \\
\text { orientadas para processo, grandes diferenças nas abordagens acerca } \\
\text { das práticas dentro de cada unidade. Para Hofstede (2003), a } \\
\text { homogeneidade de uma cultura refletiria a medida de sua força, } \\
\text { culturas fortes seriam mais orientadas para resultados do que as } \\
\text { culturas fracas e vice-versa (Bedani, 2008; Hofstede, 2003). }\end{array}$ \\
\hline
\end{tabular}

Orientação para o trabalho Culturas orientadas para o trabalho, a pressão sentida pelos indivíduos versus Orientação para o está na realização do trabalho, não no seu bem estar ou de sua família; empregado as culturas orientadas para o empregado, os problemas pessoais são considerados e as organizações assumem responsabilidades mais amplas pelo bem estar dos seus empregados. A orientação resulta de fatores históricos: a filosofia dos fundadores; a presença ou ausência deles na história recente; e, a ocorrência de crises econômicas com demissões coletivas (Bedani, 2008; Hofstede, 2003).

Profissional versus Paroquial Nas organizações ou unidades profissionais, a vida profissional interessa somente aos próprios membros, habitualmente com elevado nível educacional, primariamente identificam-se com a sua própria profissão. Nas culturas paroquiais, os indivíduos derivam sua identidade da organização na qual trabalham, seu comportamento é pautado interna e externamente pelas normas organizacionais (Bedani, 2008; Hofstede, 2003).

Sistema aberto versus Sistema Ao tratar do estilo de comunicação interna e externa escolhido pela fechado organização, esta dimensão refere-se à facilidade com que pessoas externas e recém-chegados são aceitos pelos demais sujeitos (Bedani, 2008; Hofstede, 2003).

Controle rígido versus Esta dimensão refere-se ao grau de estruturação interna da Controle flexível organização, lidando com o nível de formalidade e pontualidade interna a organização. Os indivíduos de unidades de controle rígido percebem a preocupação com os custos, horários das reuniões (Bedani, 2008; Hofstede, 2003).

Normativo versus Pragmático Relacionada com a vinculação da organização com o ambiente e particularmente com seus clientes. As unidades pragmáticas são orientadas para o mercado, já as unidades normativas percebem o seu papel face ao mundo exterior como a implementação de regras invioláveis (Bedani, 2008; Hofstede, 2003).

Adaptado de Hofstede (2003) e Bedani (2008).

Nos estudos de D’Iribarne (1993), baseados em categorias de análise desenvolvidas em função de lógicas culturais dos contextos nacionais das organizações, diferenças importantes foram apresentadas quando verificadas as práticas em uso nas organizações. Considerando que os modelos de gestão adotados são comuns nos diferentes contextos culturais estudados, foi possível afirmar que as práticas organizacionais adquirem significado nas leituras apontadas pelas visões particulares de cada cultura, pela maneira como as 
pessoas vivem em coletividade (Souza et al., 2011). É em função do nível de análise adotado que o aspecto universal ou, ao contrário, o aspecto local da administração ocupa a frente da cena (D'Iribarne, 2003), ou seja, as regras das empresas bem como as estratégias dos diversos sujeitos variam entre as organizações, o que significa que as regras sociais são próprias de cada cultura (Dupuis, 2009).

Ao buscar as manifestações culturais das organizações em função da cultura nacional, e passando pela identificação das relações entre cultura nacional, cultura organizacional e gestão das organizações, D’Iribarne (1989) identifica as lógicas de gestão de empresas em função de suas lógicas culturais. Assim, ao analisar categorias que o autor denominou como: senso de dever, relações hierárquicas, percepção de controle, definição de responsabilidades, sanções e qualidade da cooperação, elas foram atribuídas às manifestações culturais das organizações em função dos contextos nacionais. De mais, os problemas próprios a cada contexto e os modos de regulação desses problemas são identificados nas próprias empresas. Philippe D’Iribarne (1989) explica essas diferenças pelas maneiras de viver e compartilhar as relações entre os diversos países.

Com base nos estudos de D’Iribarne (1989) que compararam as lógicas culturais de gestão em três países, França, Estados Unidos e Países Baixos, Souza (2009) descreveu as sete categorias de estudo de D'Iribarne (1989), na Tabela 5. Essas categorias, assim descritas, serviram de base para a construção da escala de medida de práticas organizacionais, que foi adotada nesta tese. 


\section{Tabela 5}

Descritores das categorias de análise do modelo de D'Iribarne

\begin{tabular}{|c|c|}
\hline Categorias de análise & Definições \\
\hline Senso de dever & $\begin{array}{l}\text { Refere-se ao exercício de procura de direitos e execução de deveres. Inclui } \\
\text { aspectos de motivação na execução do trabalho (obrigação versus } \\
\text { compromisso), adesão a valores organizacionais ou prevalência de } \\
\text { interesses individuais nas relações de trabalho; sentimentos de orgulho e de } \\
\text { pertencimento à organização, compromisso com a obtenção de resultados. }\end{array}$ \\
\hline $\begin{array}{l}\text { Relações de } \\
\text { Autoridade }\end{array}$ & $\begin{array}{l}\text { Relação entre os diferentes níveis de gestão e entre profissionais, tomada } \\
\text { de decisão na organização, percepção de controle. }\end{array}$ \\
\hline $\begin{array}{l}\text { Definição de } \\
\text { responsabilidades }\end{array}$ & $\begin{array}{l}\text { Refere-se à forma das funções/tarefas serem atribuídas (segundo critérios } \\
\text { normativos, por fidelidade, por amizade, por interesses privados) e } \\
\text { avaliadas, ao estabelecimento e à difusão das responsabilidades individuais } \\
\text { e dos grupos, aos critérios formais, definidos pelos superiores } \\
\text { (responsabilidade objetiva), aos critérios informais de acordo com as } \\
\text { relações pessoais ou às crença dos profissionais subordinados } \\
\text { (responsabilidade subjetiva), utilização de regras mais formalizadas. }\end{array}$ \\
\hline Regulação & $\begin{array}{l}\text { Refere-se ações de moderação e de acordos que regem as atividades dos } \\
\text { profissionais, o cumprimento de contratos, gestão de interesses } \\
\text { organizacionais e individuais. }\end{array}$ \\
\hline $\begin{array}{l}\text { Recompensas e } \\
\text { Punições (Sanções) }\end{array}$ & $\begin{array}{l}\text { Refere-se às recompensas e/ou punições aplicadas em função de } \\
\text { comportamentos no trabalho; à concessão de benefícios ou punições } \\
\text { decorrentes da obtenção de resultados ou objetivos propostos; à existência } \\
\text { de políticas organizacionais de sanções (benefícios ou punições), e à } \\
\text { utilização de critérios para a aplicação de sanções. }\end{array}$ \\
\hline $\begin{array}{l}\text { Qualidade da } \\
\text { cooperação }\end{array}$ & $\begin{array}{l}\text { Refere-se às características das relações interpessoais entre funcionários } \\
\text { no trabalho individual ou em grupo, à disponibilidade dos profissionais } \\
\text { para trabalharem em equipe; à forma como são gerenciados os conflito no } \\
\text { e pelo grupo; à tendência ao individualismo ou ao coletivismo das } \\
\text { relações profissionais; à base em que ocorrem laços de cooperação } \\
\text { (profissionais, sociais, familiares). }\end{array}$ \\
\hline Percepção de controle & $\begin{array}{l}\text { Refere-se à percepção que o profissional possui sobre as medidas de } \\
\text { controle da organização; aos níveis de consentimento e de conformidade } \\
\text { com as normas estabelecidas e com a autoridade; à percepção sobre a } \\
\text { liberdade de atuação; à percepção sobre atos arbitrários. }\end{array}$ \\
\hline
\end{tabular}

Fonte. Adaptado de Souza (2009).

No Brasil, Souza, Castro-Lucas e Fenili (2012), Souza e Fenili (2012) e Souza, CastroLucas, Fenili e Chaves Farias (2013) realizaram pesquisas, apoiadas nos estudos de D’Iribarne (1989, 1998, 2003) com suas categorias descritas por Souza (2009). Na pesquisa de Souza e Fenili (2012), o objetivo foi identificar manifestações culturais de uma empresa estadunidense, fornecedora global de componentes e sistemas automotivos, foi estudada a sede na América do Sul, localizada no Brasil, em São Paulo, que congrega 11 (onze) polos e um centro de atendimento ao cliente, situados em diferentes estados brasileiros. Nessa pesquisa as práticas de gestão foram consideradas por níveis, dentro da organização, e revelaram que as manifestações culturais da empresa, no Brasil, apesar da forte relação entre as práticas da empresa matriz, apresentaram fortes traços culturais brasileiros. 
Na pesquisa de Souza, Castro-Lucas e Chaves Farias (2013), foi realizada uma revisão da produção científica sobre a internacionalização de bancos e a análise das práticas percebidas pelos gestores de dependências de um banco brasileiro no exterior. Na visão dos gestores, além da lógica cultural de sentimentos de orgulho profissional, as agências bancárias no exterior apresentam manifestações culturais com tendência à autonomia, informalidade, moderação, responsabilidade com o trabalho e respeito à cultura local.

Um ponto que merece destaque nos estudos de D’Iribarne (1989) e de Dupuis (2009) é o que trata da combinação entre a historicidade e as lógicas da cultura nacional para a identificação das manifestações culturais das organizações, baseadas em suas práticas cotidianas, já que o desenvolvimento das perspectivas interpretativistas da cultura produziu o abandono da noção de cultura nacional, porque a cultura tende a ser vista como uma realidade local e transitória, o que levou à supressão da ideia de cultura nacional capaz de subsistir no tempo (D'Iribarne, 2009).

A abordagem de D'Iribarne $(1989,1998)$ estuda em maior profundidade as culturas e busca entender a lógica cultural específica de um país, mas o seu âmbito é mais limitado, já que abrange menos países. Sua abordagem é menos sistematizada, pois as empresas não abordam a cultura da mesma maneira, às vezes concentrando-se em aspectos de gestão, outras vezes na dinâmica da empresa (Dupuis, 2009).

Ao considerar as abordagens de estudos de cultura organizacional apresentadas por D'Iribarne (1989, 2003), que se baseia na história e na etnografia, e por Hofstede (1980, 2001), que utiliza escalas de atitudes, verifica-se que as culturas organizacionais podem ser um reflexo da cultura nacional, podendo suas diversidades explicar os significados das práticas das organizações.

Para este trabalho, no sentido de estudar as práticas como manifestações culturais, serão considerados os estudos de D'Iribarne (1989, 2003), embora a escolha de uma abordagem particular não signifique a condenação das perspectivas alternativas como os estudos de Hofstede (2000). Com a utilização de enfoques diversificados, como, por exemplo, os de D’Iribarne (1989, 2003), que utilizam entrevista comparativa, busca-se complementar a compreensão da lógica subjacente de estudos como os realizados por Hofstede (1980, 2001). Abordagens qualitativas ou quantitativas representam duas faces da mesma moeda, duas maneiras de descobrir a mesma realidade, ou seja, ambas são igualmente necessárias e complementares

Sob a influência dos estudos aqui apresentados, optou-se por estudar cultura organizacional por dois de seus elementos, a saber, as práticas organizacionais e os valores 
organizacionais. Os valores refletem os princípios norteadores da organização, e as práticas representam um aspecto manifesto, mais facilmente observado. Porém, ressalta-se que existe divergência acerca de qual desses componentes constitui o núcleo da cultura organizacional, sendo, para alguns, os valores organizacionais (Schein, 2010; Paz \& Tamayo, 2004); enquanto que outros propagam que são as práticas (e.g., D’Iribarne, 1983; Hofstede et al., 1990).

As duas seções seguintes têm por objetivo realizar a discussão dessas duas dimensões (valores e práticas organizacionais), percorrendo a trajetória histórica, a definição do construto e a discussão de modelos mais comumente utilizadas para sua mensuração. 


\section{Seção 2. Valores Humanos e Valores Organizacionais}

Esta seção refere-se a valores organizacionais, considerados, neste trabalho, como uma das dimensões utilizadas para identificar as manifestações culturais da organização. Cabe salientar que a abordagem a ser utilizada reflete o isomorfismo entre a estrutura dos valores humanos e organizacionais. Inicialmente será apresentada uma breve perspectiva histórica do estudo dos valores humanos (2.1), com destaque para a teoria de valores humanos, de Schwartz, referência para o instrumento de medida de valores a ser aqui utilizado. Em um segundo momento, serão considerados os valores organizacionais (2.2).

\subsection{Valores Humanos}

É crescente a importância dos valores na psicologia social, fato esse que pode ser comprovado pela presença de um capítulo exclusivo designado à temática na última versão do Handbook of Social Psychology (Ros, 2006). Conforme ressalta Ros (2006), isso só foi possível graças aos esforços de pesquisadores, durante os anos de 1980 e 1990, no desenvolvimento e na verificação de teorias que permitiram o conhecimento das dimensões básicas da cultura.

\subsubsection{Valores Humanos: uma perspectiva histórica e conceitual}

O constructo valores já circundava o imaginário de diversos pensadores, como é o caso de Aristóteles, que o definia como aquilo que todos desejam em contraponto ao que deveriam desejar; logo, a ênfase que se estabelecia recaía sobre a concretização de uma natureza, já que o ser humano carecia de uma realização virtuosa no que lhe é natural, a sua razão, o modo pelo qual a pessoa floresce, ou seja, torna-se ela mesma (Aristóteles, 2001). Cabe salientar que não havia consenso entre Sócrates, Platão e os sofistas sobre o significado do termo valor. Assim, para os sofistas, na subjetividade e na relatividade os valores eram depositados; advinha a ideia de que "o homem é a medida de todas as coisas, das que são como são e das que não são como não são", conforme o pensamento de Protágoras de Abdera. Disso resulta a subordinação dos valores ao julgamento do homem. Para Sócrates, a noção de valore vinculava-se a um juízo de verdade, que continha validade universal. E, por fim, Platão, abordava a ideia de que no bem estaria o caminho para todas as coisas.

Ao caminhar pelo horizonte da história, a concepção moderna do valor, definida por Kant (1724-1804/2002), passa pela possível realização prática advinda de uma norma priorizada, desde que vincule verdade, bondade e beleza às coisas passíveis de seleção 
(Goergen, 2005). Para Durkheim (1897/1964) e Weber (1905/1958), os valores são cruciais para explicar a organização social e pessoal bem como a mudança.

As contribuições sociológicas e psicológicas encontram em Thomas e Znaniecki (1918-1920 citado por Ros, 2006) expoentes do legado sobre o qual foram estabelecidos os desenvolvimentos teóricos dos anos de 1970 até o final dos anos de 1990 (Ros, 2006). A contribuição dos autores perpassa dois temas considerados centrais, atitude e a relação entre atitude e valores. Assim, enquanto a atitude é considerada intrasubjetiva, o valor passa pelo intersubjetivo e extrasubjetivo. Para tanto, são estabelecidas cinco motivações subjacentes aos valores: reconhecimento social, segurança, resposta, domínio ou competência e novas experiências. Se o desejo de se relacionar com os outros for a consequência da motivação subjacente nos valores, tem-se a relativização da motivação, fato análogo quando se refere à definição da situação (Ros, 2006).

Outro expoente da tradição sociológica foi Parsons (1937), que observava a importância do sistema cultural para tornar possível o sistema social e o pessoal. Segundo esse autor, as pessoas agiam motivadas por três categorias (cognitivas, catécticas (ou catéxicas) e avaliativas) adicionadas às orientações de valor que obrigavam o indivíduo a respeitar determinadas normas que limitariam as escolhas. Assim, a definição de valor pessoal apresentava-se como os compromissos com os critérios normativos relacionados a três critérios (cognitivo, avaliativo e de responsabilidade pessoal), perante as implicações de suas ações, tanto para o sujeito que age como para o sistema social (Ros, 2006). Segundo a concepção de Parsons (1951), os valores têm um caráter normativo que proveem critérios orientadores da ação, motivando as expectativas e sanções sociais.

Os dois conceitos apresentados anteriormente são distintos. Parson (1961) adota o conceito concebido por Kluckhohn (1951, p. 395) que o estabelece como uma “concepção, explícita ou implícita, distintiva de um indivíduo ou característico de um grupo, do desejável que vai influenciar a seleção entre os modos, meios e finalidades de ação disponíveis". Nessa definição, fica evidente o papel de influência dos valores sobre o comportamento da pessoa, além de estarem internalizados pelo praticante da ação. Ademais, Kluckhohn (1951) observa que os valores estão hierarquicamente organizados.

No ramo da psicologia, destaca-se a contribuição de Lewin (1942) e sua observação sobre a influência dos valores no comportamento, o que significa dizer que os valores definem quais atividades são relevantes, negativa ou positivamente, para um indivíduo em um contexto definido. Ao classificar valores como a crença sobre a qual o indivíduo se baseia para atuar por preferência, que, assim, acabam por influenciar o modo como os 
indivíduos percebem a realidade, Allport (1955) reforça a ideia de que valores influenciam o comportamento, como preconizado por Lewin (1942).

Mesmo com os trabalhos apresentados por Allport (1955) e Lewin (1942), de tradição da psicologia, dois outros nomes aparecem em destaque, ao se tratar a temática dos valores: o primeiro é Maslow (1959) e sua hierarquia e dinâmica das necessidades humanas, que escalona em uma pirâmide cinco tipos de necessidades (fisiológicas, segurança, sociais, autoestima e autorrealização). Segundo o autor, as necessidades mais básicas referem-se aos valores comuns compartilhados por toda a sociedade. Em contrapartida, as necessidades ou valores mais elevados não se apresentam plenamente compartilhados, tendo em vista que sua manifestação depende de questões relativas a escolhas pessoais, condições econômicas, sociais e culturais. Apesar disso, ambas as categorias de necessidades ou valores permaneceriam inter-relacionadas, já que conceberiam metas que o indivíduo busca alcançar.

O segundo nome de relevo no estudo dos valores é o de Rokeach (1973), que os define como crenças transituacionais, hierarquicamente organizadas, que atuam como critério para orientar o comportamento. Segundo Ros (2006), vários elementos que estão presentes nessa definição merecem destaque: o primeiro é que valores não são crenças descritivas ou avaliativas, são prescritivas, ou seja, aquelas que revelam o que é adequado ou não atingir. Segundo, organizam-se com um critério de importância; e terceiro, os valores estáveis orientam as decisões dos indivíduos, devido à interiorização ocasionada pelos processos de socialização, pela convergência das instituições sociais (e.g família, escola, amigos), que são a base de seu autoconceito.

Dois tipos de valores foram descritos por Rockeach (1973): os terminais e os instrumentais; os primeiros dizem respeito às necessidades de existência do homem, podendo ser pessoais (autorrealização, felicidade, harmonia interna) e sociais ou interpessoais (segurança familiar e nacional, igualdade). Já os segundos são valores que compõem o meio para o alcance dos fins da existência do homem. Os valores instrumentais exibem-se como morais (ser honesto, responsável), que se apresentam como interpessoais, cuja falta de realização provoca culpa e, por fim, de competência (autorrealização, ser eficaz, ser imaginativo), em que a falta de cumprimento acende sentimentos de ineficiência pessoal.

Rokeach $(1968,1981)$ e Feather (1995) partilham a ideia de que um indivíduo pode possuir uma infinidade de crenças e atitudes, todavia, apenas um reduzido número de valores, cuja importância atribuída varia entre as pessoas. Assim, Feather (1995) define valores como estruturas abstratas que transcendem objetos específicos e posições específicas; além de 
serem dotados de atributo normativo e impregnados de moral, influenciam escolhas e comportamentos, dada a organização prioritária relacionada com o self do sujeito.

O modelo elaborado por Schwartz (2005a), baseado teoricamente nos estudos de Rokeach $(1968,1973,1981)$, tinha por finalidade unificar as distintas teorias no campo da motivação humana, organizando as diversas necessidades, motivos e objetivos propostos nas teorias anteriores. Com isso, o autor procurou desenvolver um sistema universal de valores humanos, em que se consideram os principais valores compartilhados por todas as culturas (Blackwell, Miniard \& Engel, 2005, Schwartz, 2005a).

Essa característica transcultural dos valores foi explicada por Schwartz e Bilsky (1987), levando em consideração as representações cognitivas de três tipos de necessidades humanas universais: necessidades biológicas do organismo; necessidades de interação social para a regulação das relações interpessoais; e necessidades sócio-institucionais que buscam o bem-estar e a sobrevivência do grupo. A ampliação do modelo proposto por Schwartz (1992, 1994, 1996, 2005b) decorreu de um processo de avaliação empírica da teoria, no qual os tipos de valores ou tipos motivacionais básicos e as relações que se estabelecem entre eles foram confirmados ao longo de várias pesquisas transculturais.

\subsubsection{Modelo Teórico dos Valores Humanos de Schwartz}

Com base na compreensão de Schwartz (1992, 2005a), os valores humanos podem ser definidos como: (1) crenças ligadas à emoção de forma intrínseca que, quando ativadas, geram sentimentos positivos e negativos; (2) um construto motivacional que orienta pessoas para agirem de forma adequada; (3) transcendem situações e ações específicas, diferindo das atitudes e normas sociais, além de orientar as pessoas em diversos contextos sociais; (4) guiam a seleção e avaliação de ações, políticas, pessoas e eventos e compõem critérios para julgamentos; e (5) aqueles que se organizam de acordo com a importância relativa dada aos demais valores e, assim, formariam um sistema ordenado de prioridades axiológicas.

Dessa forma, existe uma variação do grau de importância que cada indivíduo atribui aos valores. Schwartz (2005a) propõe a existência de uma organização universal das motivações humanas, sustentada na semelhança das estruturas axiológicas, mesmo entre indivíduos de grupos de culturas diversificadas. Os indivíduos e grupos não diferem em relação aos tipos motivacionais (valores), mas, sim, em relação importância relativa atribuída a seus valores, ou seja, às prioridades axiológicas dos indivíduos ou grupos. Em síntese, a diferença entre indivíduos e grupos reside em suas prioridades axiológicas, o que distinguiria um valor de outro, ou seja, seria o tipo de objetivo ou tipo de meta motivacional que o valor 
expressa. Com isso, a Tabela 6 descreve os dez tipos motivacionais contemplados na Teoria de Valores de Schwartz, suas metas e como são compostos em termos de valores.

Tabela 6

Tipos motivacionais de valores do modelo de Schwartz

\begin{tabular}{|c|c|c|}
\hline Tipo Motivacional & Metas / Objetivos que definem os valores & Serve a interesses \\
\hline Segurança & $\begin{array}{l}\text { Segurança, harmonia e estabilidade da sociedade, dos } \\
\text { relacionamentos e de si mesmo }\end{array}$ & Mistos \\
\hline Tradição & Respeito, compromisso e aceitação dos costumes & Coletivos \\
\hline Conformidade & $\begin{array}{l}\text { Advertência das ações, inclinações e impulsos que } \\
\text { incomodam, prejudicam ou que violam as expectativas ou } \\
\text { normas sociais }\end{array}$ & Coletivos \\
\hline Benevolência & $\begin{array}{l}\text { Preocupação com a preservação e fortalecimento do bem- } \\
\text { estar de pessoas próximas }\end{array}$ & Coletivos \\
\hline Universalismo & $\begin{array}{l}\text { Compreensão, apreço, tolerância e proteção do bem-estar } \\
\text { de todas as pessoas e da natureza }\end{array}$ & Mistos \\
\hline Autodeterminação & $\begin{array}{l}\text { Independência de ação e pensamento - escolher, criar, } \\
\text { explorar }\end{array}$ & Individuais \\
\hline Estimulação & Excitação, novidade, desafio & Individuais \\
\hline Hedonismo & Prazer ou gratificação sensual & Individuais \\
\hline Realização & $\begin{array}{l}\text { Sucesso pessoal por intermédio da demonstração de } \\
\text { competência de acordo com padrões sociais }\end{array}$ & Individuais \\
\hline Poder & $\begin{array}{l}\text { Controle ou domínio sobre pessoas ou recursos, status } \\
\text { social e prestígio }\end{array}$ & Individuais \\
\hline
\end{tabular}

Fonte. Schwartz (2005a, p. 24-27).

O modelo apresentado, na visão de Schwartz e Bilsky (1990), representa a possibilidade de revelar a estrutura dinâmica das relações entre os tipos motivacionais (Schwartz, 2005a). Essa estrutura decorre do fato de as ações, na busca de qualquer valor, produzirem consequências que poderiam conflitar ou ser congruentes com a busca de outros valores; assim, alguns pares de tipos motivacionais concorreriam entre si, enquanto outros seriam complementares (Schwartz, 2005a). A explicação do que são valores congruentes ou conflitantes foi trazida por Bardi e Schwartz (2003). Para esses autores, dois valores expressariam congruência quando as ações normalmente utilizadas para expressá-los fossem compatíveis com as metas motivacionais que representam. Por exemplo, benevolência e universalismo são valores congruentes, porque ambos promulgam ações relacionadas à promoção do bem-estar de terceiros.

Dessa congruência e conflitualidade resulta que determinados indivíduos apresentam alta preferência para tipos motivacionais mutuamente compatíveis e baixa prioridade para 
tipos motivacionais incompatíveis (Schwartz \& Bilsky, 1987). É bem verdade que as pessoas poderiam buscar valores antagônicos, porém, não em uma única ação. Ao contrário, buscariam em relação a atos separados, em ocasiões e conjunturas diferentes. A priorização concomitante de valores de domínios incompatíveis poderia gerar o conflito (Schwartz \& Bilsky, 1987).

A estrutura circular proposta por Schwartz (1994, 2005a), disponível na Figura 7, refere-se ao padrão total de relações teóricas de conflito e congruência entre os tipos motivacionais, bem como tipos motivacionais de segunda ordem. Quanto mais próximo um tipo motivacional estiver de outro, em qualquer uma das direções do círculo, mais compatibilizados são suas motivações subjacentes. Quanto mais afastados os valores se localizarem no círculo, mais antagônicas são suas motivações subjacentes.

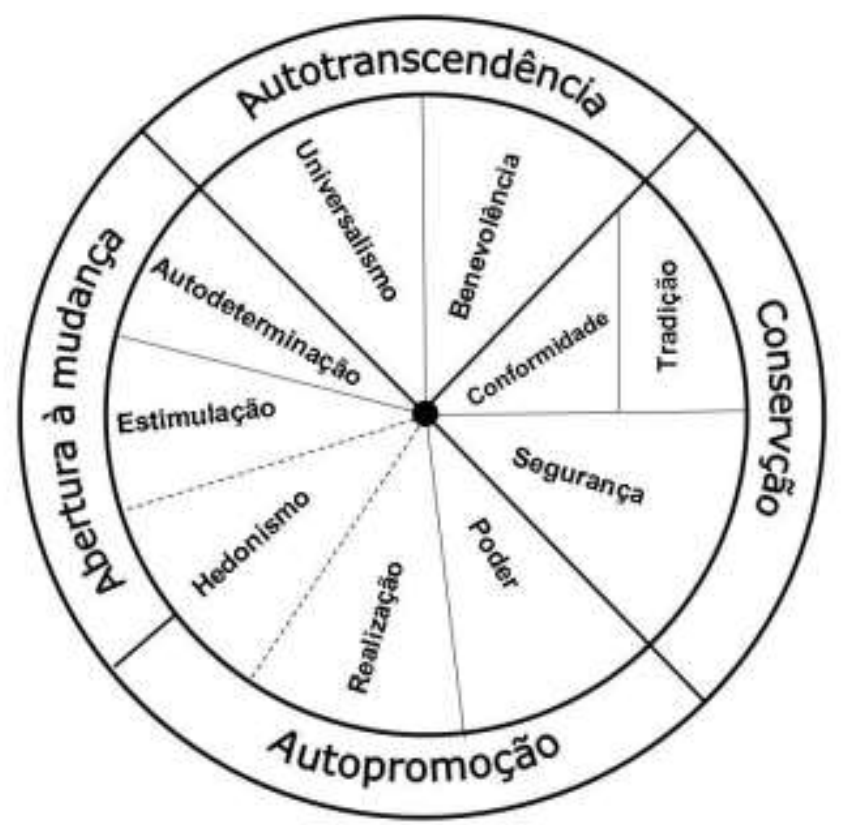

Figura 7. Estrutura teórica de relações entre valores de Schwartz (2005a).

A seguinte compatibilidade entre os pares de tipos motivacionais são indicados por Schwartz (1994, 2005a), baseada na verificação da Figura 7:

poder e realização: ênfase na superioridade social e estima;

$>$ realização e hedonismo: satisfação situada no indivíduo;

$>$ hedonismo e estimulação: presumem o desejo por experiências afetivas prazerosas;

$>$ estimulação e autodeterminação: envolvem o interesse pela novidade e abertura à mudança;

$>$ autodeterminação e universalismo: expressam a confiança no próprio julgamento e bem-estar com relação à diversidade; 
$>$ universalismo e benevolência: referem-se à preocupação com as outras pessoas e superação dos interesses individuais;

> tradição e conformidade: manifestam a subordinação do indivíduo em favor de expectativas socialmente impostas;

$>$ conformidade e segurança: relativos à proteção da ordem e da harmonia nas relações;

> segurança e poder: destacam a evitação e a superação de ameaças, controlando relacionamentos e recursos.

Ao vislumbrar as oposições entre os tipos motivacionais contrastantes, verifica-se que estão organizadas em duas dimensões bipolares. Conforme se pode verificar na Figura 7, uma dimensão contrasta abertura à mudança e conservação, que enlaça o conflito entre a evidência no pensamento e nas ações independentes do sujeito, que beneficiam a mudança (autodeterminação e estimulação) e autorrestrição submissa, preservação de práticas tradicionais e proteção da estabilidade (segurança, conformidade e tradição). A segunda dimensão afronta autopromoção e autotranscedência, que capta o conflito entre a ostentação na aceitação dos outros como iguais e a preocupação com seu bem-estar (universalismo e benevolência) e a busca pelo próprio sucesso relativo e domínio sobre os outros (poder e realização) (Schwartz, 2005a). Ainda, segundo o autor, o hedonismo apresenta elementos comuns tanto à abertura à mudança quanto à autopromoção.

Em síntese, ao se organizar em distintos sistemas psicológicos de semelhanças e opostos, Schwartz $(1992,2005 a)$ observa que os tipos motivacionais formam um continuum ou hierarquia de motivações. Esse continuum motivacional compõe-se de duas dimensões basilares, designadas dimensões de ordem superior (Mendonça \& Tamayo, 2008). Apesar de a teoria reunir e distinguir os valores em dez tipos motivacionais, Schwartz (2005a) afirma que, em nível mais fundamental, os valores formam um continuum de motivações relacionadas (Blackwell et al., 2005; Schwartz, 2005a). Tal exposição reflete o fato de que algumas ações que são equivalentes com algum valor e seu tipo motivacional ocasionam consequências que podem ser complementares e congruentes, ou conflitantes, com os objetivos de outros tipos motivacionais que estejam próximos ou opostos (Schwartz, 2005a).

Examinando a estrutura circular, nota-se que os cinco tipos motivacionais que exprimem interesses individuais ocupam uma área adjacente que se contrasta aos três conjuntos de valores que expressam interesses coletivos. Os tipos de valores que expressam 
interesses mistos sãoopostos, situando-se na fronteira entre as duas áreas anteriores (Tamayo \& Schwartz, 1993).

De forma contrária às demais propostas para o estudo dos valores, que buscam o exame das relações entre valores isolados e atitudes ou comportamento, no modelo de Schwartz (1996), a estrutura do sistema de valores capta o relacionamento dinâmico (compatível ou antagônico) entre os dez tipos motivacionais, permitindo pesquisar as relações dos valores com atitudes, comportamentos ou outras variáveis de maneira integrada.

A abordagem proposta pelo modelo de Schwartz (1996) implicaria em uma associação entre os tipos motivacionais adjacentes de maneira similar com outras variáveis, bem como uma previsível redução do nível de correlação dos valores com outras variáveis. Assim, espera-se um decréscimo contínuo ao longo dos tipos motivacionais nas direções horárias e anti-horárias da estrutura circular, apresentando desde o tipo motivacional com maior correlação até o mais negativamente relacionado a determinada variável, o que resulta em um padrão previsível entre a ordem de associações para o conjunto dos dez tipos motivacionais (Bedani, 2008). Portanto, quando se tem uma correlação positiva entre uma atitude ou comportamento e um tipo motivacional específico, deseja-se uma correlação negativa no tipo motivacional oposto, espera-se que o modelo de associações seja o mesmo entre os tipos motivacionais ao longo da estrutura circular em consonância com o conteúdo da meta que expressa. A consequência do modelo apresentado reside na possibilidade de elaboração de hipóteses lógicas acerca dos relacionamentos entre os tipos motivacionais e alguma outra variável, em virtude do tratamento do sistema de valores como estruturas integradas, que indica um comportamento previsível, e assim facilitaria a explicação dos resultados das investigações conduzidas com base neste modelo teórico (Schwartz, 1996).

Recentemente, a Teoria de Valores foi revisada e Schwartz et al. (2012) propuseram o refinamento dos tipos motivacionais de valores com o objetivo de obter um contínuo de valores mais significativo, com melhor confiabilidade entre os itens e menor multicolinearidade entre valores adjacentes (Schwartz et al., 2012). Os dez tipos motivacionais inicialmente propostos foram desdobrados em 19 potenciais valores, conceitualmente distintos, que representam um contínuo de motivações de maneira mais particularizada. As análises do escalonamento multidimensional e confirmatórias dos 57 itens produzidos para medir esses valores forneceram suporte tanto à distinção entre eles, quanto ao seu ordenamento. A avaliação do grau de distinção destes 19 valores e seu ordenamento circular se deu em 15 amostras de 10 diferentes países. A Tabela 7 apresenta como os 19 valores capturam diferenças motivacionais substanciais no contínuo de valores. 


\section{Tabela 7}

Os 19 Valores da Teoria Refinada, definidos em termos de Metas Motivacionais

\begin{tabular}{ll}
\hline Valor & Definições Conceituais em Metas Motivacionais \\
\hline Autodireção de Pensamento & Liberdade para cultivar suas próprias ideias e habilidades. \\
Autodireção de Ação & Liberdade para determinar suas próprias ações. \\
Autodireção de Estimulação & Excitação, novidade e mudança. \\
Hedonismo & Prazer e gratificação sensual para si mesmo. \\
Poder de Realização & Sucesso de acordo com os padrões sociais. \\
Poder de Domínio & Poder pelo exercício de controle sobre outras pessoas. \\
Poder sobre Recursos & Poder pelo controle sobre materiais e recursos sociais. \\
Face & Manutenção da sua imagem pública e evitar humilhações. \\
Segurança Pessoal & Segurança em seu ambiente imediato. \\
Segurança Social & Segurança e estabilidade da sociedade (mais ampla). \\
Tradição & Manutenção e preservação da cultura, família ou religião. \\
Conformidade com Regras & Conformar-se com regras, leis e obrigações formais. \\
Conformidade Interpessoal & Evitar chatear ou machucar outras pessoas. \\
Humildade & Reconhecimento da própria insignificância em um contexto amplo. \\
Benevolência Dependência & Ser um membro confiável e fidedigno do endogrupo. \\
Benevolência Cuidado & Devoção ao bemestar dos membros do endogrupo. \\
Universalismo Compromisso & Comprometimento com igualdade, justiça e proteção de todas as \\
& pessoas. \\
Universalismo Natureza & Preservação do ambiente natural. \\
Universalismo Tolerância & Aceitação e compreensão daqueles que são diferentes de si mesmo. \\
\hline Fonte. Adaptada de Schwartz et al. (2012).
\end{tabular}

Como já observado, a ordem circular no contínuo, proposta pela teoria original, reflete conflitos ou compatibilidades motivacionais entre eles (Schwartz, 1992). Esse princípio também se confirmou e está inserido na teoria refinada. A argumentação necessária para justificar a nova ordem proposta na teoria refinada foi apresentada e detalhada por Schwartz et al. (2012). A compatibilidade entre os valores se estabelece, quando os comportamentos promovem ou expressam metas de um par de valores. Na medida em que esses comportamentos apresentam consequências opostas para dois valores, originando a meta de um deles em detrimento do outro, estes valores estão em conflito. Quanto maior a compatibilidade entre dois valores, mais próximos eles estão no ordenamento circular. Quanto maior o conflito entre os valores, mais distantes eles estão no círculo. A Figura 8 ilustra o ordenamento dos 19 valores na estrutura circular da teoria refinada. 


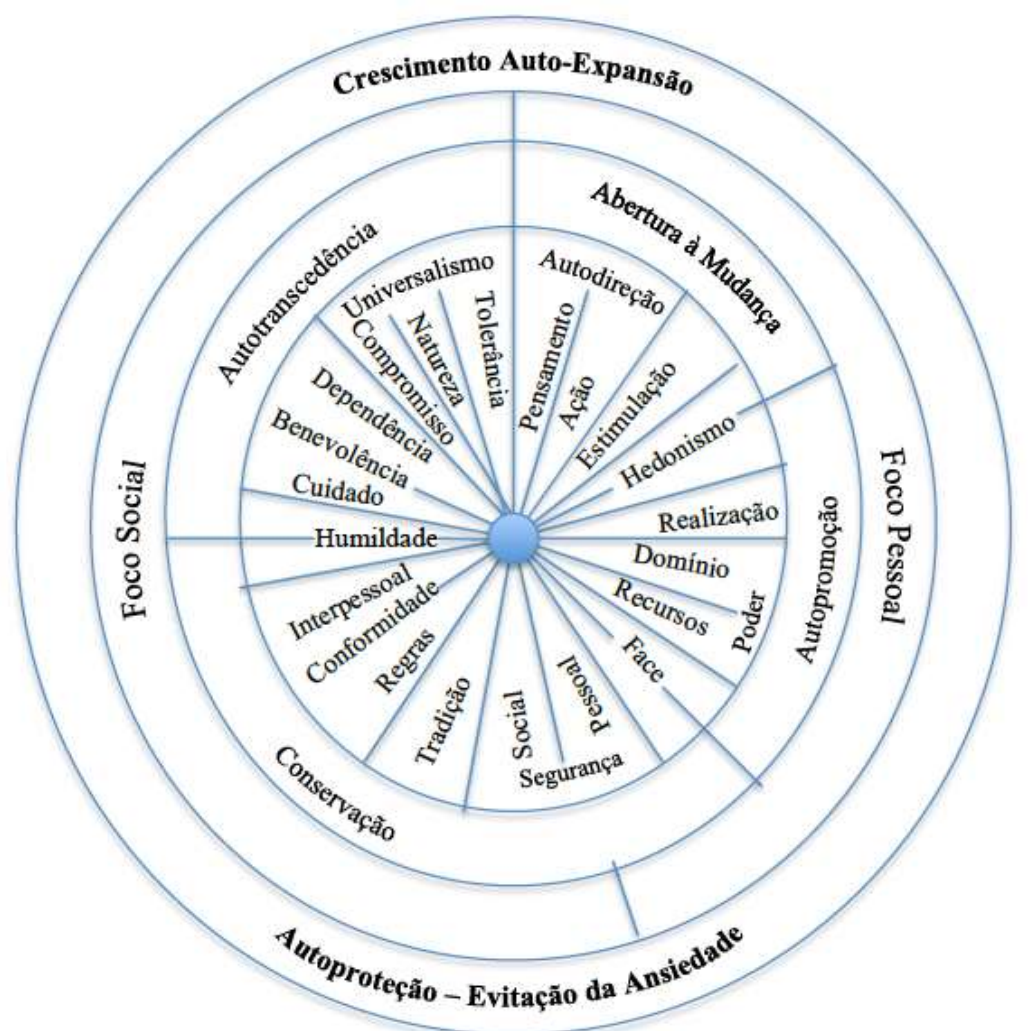

Figura 8. Círculo motivacional de acordo com a teoria de valores básicos refinada, adaptada de Schwartz et al., 2012.

Ainda assim, a teoria refinada não invalidou a estrutura dos 10 tipos motivacionais supramencionados, em virtude da possibilidade da nova estrutura de valores em agrupar os valores de forma similar ao da teoria original (Schwartz et al., 2012; Sousa, 2013), conforme se mostrar mais útil para o pesquisador.

\subsection{Valores Organizacionais}

Os estudos sobre valores organizacionais são reconhecidos pelo lugar central em diversos fenômenos organizacionais (Bourne \& Jenkins, 2013), incluindo identidade (Ashforth \& Mael, 1989; Canova \& Porto, 2010), cultura (Schein, 1985), compatibilidade indivíduo-organização (Cable \& Edwards, 2004; Sousa, 2013), e socialização (Dose, 1997). Outros autores enfatizam o papel dos valores como elemento central da cultura organizacional (Champy, 1995; Deal \& Kennedy, 1982; O’Reilly \& Chatman, 1996), que defendem o melhor desempenho organizacional e empresas com culturas fortes (Payne, 2000).

Os valores organizacionais apresentam-se como um instrumento de relevância para a compreensão da cultura organizacional (Mendes \& Tamayo, 2001). Soma-se a isso a relevância do tema, que se dá tanto na área de pesquisa quanto na área do diagnóstico da 
gestão organizacional (Tamayo, 2008). Assim, o estudo da conformidade com os valores organizacionais é oferecido como uma alternativa ao controle burocrático (Ouchi, 1980), possibilitando o gerenciamento remoto de filiais (Nohria \& Ghoshal, 1994) ou atividades funcionais como, por exemplo, a produtividade do serviço (Dobni, Ritchie \& Zerbe, 2000).

Os valores organizacionais também exercem influência sobre questões estratégicas (Bansal, 2003), escolha estratégica (Pant \& Lachman, 1998), mudança estratégica (Carlisle \& Baden-Fuller, 2004) e gestão de tomada de decisão (Liedtka, 1989), bem como a chamada teoria dos escalões superiores (Hambrick \& Mason, 1984) baseada na ligação entre os resultados organizacionais e valores gerenciais. Questões vinculadas à posição ética de uma organização também são afetas aos valores organizacionais, ou seja, são por eles moldadas (Finegan \& Theriault, 1997), ao comprometimento dos empregados (Ostroff, Shin \& Kinicki, 2005) e às relações com elementos externos (Voss, Cable \& Voss, 2000).

Os valores têm um longo alcance e uma grande extensão de influência sobre os processos críticos e características nas organizações (Bourne \& Jenkins, 2013), servindo de guias implícitos para a ação, compartilhados pelos sujeitos da organização, e apresentando-se como alicerce para o comportamento individual no ambiente de trabalho (Quenneville, Bentein \& Simard, 2010).

\subsubsection{Valores Organizacionais: abordagens históricas e suas definições}

Os valores, os papéis e as normas são, segundo Katz e Kahn (1978), os componentes fundamentais das organizações, em virtude da direção e do o funcionamento que impõem à organização. Os valores organizacionais refletem as crenças sobre o que é bom e desejável no contexto organizacional e compõem o núcleo da cultura organizacional. Dito de outra maneira, as normas definem explicitamente o comportamento esperado dos sujeitos de uma organização, e os valores propiciam uma justificativa mais elaborada e generalizada, tanto para o comportamento apropriado como para as atividades e funções do sistema (Katz \& Kahn, 1978).

A definição dos valores organizacionais é construída sobre princípios ou crenças, hierarquicamente organizados, relativos a metas e a comportamentos organizacionais desejáveis, que orientam a vida da empresa e estão a serviço de interesses individuais, coletivos ou mistos (Tamayo, 1996). Assim, como guia da vida diária da organização, pois são crenças sobre o que é ou não desejável na organização (Tamayo \& Gondim, 1996), os valores são percebidos facilmente pelos membros da organização com clara função de integração organizacional (Tamayo \& Borges, 2006), em virtude de promoverem a adaptação 
das pessoas ao ambiente (Stainer \& Stainer, 1996), além de influenciar comportamentos dos membros da organização (McNeely \& Meglino, 1994).

Os valores organizacionais são normalmente introduzidos pelo criador da empresa ou por indivíduos com forte influência dentro da organização (Bansal, 2003). O estabelecimento do que é ideal, valorizado e quais os princípios motivacionais e as metas organizacionais são definidos por este grupo dominante. Cabe ao fundador ou a outro sujeito organizacional, detentor de poder de decisão na organização, encontrar a solução para determinado problema decorrente de uma nova situação, apontando a adequada forma de se lidar com o problema (Tamayo \& Borges, 2006).

Os valores organizacionais, de reconhecida relevância para a organização (prioridade axiológica da organização), não são essencialmente idênticos aos dos seus componentes, podendo, essa relação ser conflituosa (Veiga, 2010), ou seja, o grupo e os valores organizacionais possuem características particulares que fazem o nível de análise ser de difícil isolamento (Bourne \& Jenkins, 2013). O ideal do grupo dominante é reflexo do sistema de valores da organização; assim, os exemplos desse grupo e os valores são aprendidos. Faz-se necessário o compartilhamento dos valores organizacionais entre os sujeitos da organização, em virtude da harmonia ou desarmonia que pode ocorrer entre os valores pessoais e os organizacionais. A convergência na apreensão dos valores organizacionais é o reflexo do compartilhamento dos valores entre os diversos atores da organização e funcionam como guias do comportamento, baseados em modelos mentais (Tamayo \& Borges, 2006).

O paralelismo entre os valores pessoais e os valores organizacionais é defendido por Tamayo (2005), na medida em que os fundadores da organização ou aqueles membros de forte influência estabelecem o que é seguro e desejável para a organização; assim, utiliza-se de princípios e metas idênticas que orientam o comportamento individual, de forma que as motivações que apoiam os valores pessoais e organizacionais se assemelhem.

Os componentes motivacional, cognitivo, hierárquico e funcional estão presentes em ambos os marcos conceituais dos valores pessoais e organizacionais (Tamayo \& Gondim, 1996). O primeiro componente (motivacional) diz respeito às metas necessárias à organização, o que implica que na atribuição de importância a determinado valor vincula-se a quantidade de esforço a ser empreendido pelos sujeitos da organização. $\mathrm{O}$ aspecto cognitivo refere-se às crenças sobre o que é desejável ou não na organização e representa a maneira de se conhecer a identidade organizacional, considerando o funcionamento dos valores como padrão cognitivo para a seleção dos comportamentos apropriados no contexto 
intraorganizacional. O terceiro componente (hierárquico) aponta que a diferenciação existente entre os indivíduos e a organização, do ponto de vista axiológico, está na prioridade dada a cada um dos valores e não aos valores em si, ou seja, está no continuum de importância que é atribuído. Por último, a dimensão funcional salienta que os valores norteiam o comportamento de seus membros e o julgamento feito do comportamento, apresentando-se como extremamente relevantes para o dia a dia da organização.

Em resumo, os valores baseiam-se em requisitos humanos potencialmente incompatíveis (Rokeach, 1973). Os valores organizacionais podem ser entendidos em diferentes níveis e em contextos presentes e futuros, e, ainda assim, eles são assumidos para orientar os membros da empresa em sua seleção ou avaliação de comportamento.

Para esta tese, os valores organizacionais são definidos, conforme Porto, Ferreira, Brandão, Freitas e Pereira (2012), como representações mentais compartilhadas coletivamente (Tindale, Smith, Thomas, Filkins, \& Sheffey, 1996). São compartilhados pelos membros da organização, que convivem dentro do mesmo ambiente, em um espaço de tempo consideravelmente duradouro, consistindo em cognições dos princípios que orientam práticas e normas organizacionais (Katz \& Kahn, 1974). Estão hierarquicamente organizados (Tamayo, et al., 2000) e transcendem práticas ou normas específicas (Porto et al., 2012). É compreensível, portanto, que os estudiosos tenham adotado diferentes abordagens para definir, descrever e operacionalizar os valores organizacionais (Bourne \& Jenkins, 2013).

\subsubsection{Valores Organizacionais: Dimensões e Tipologias}

A literatura tem apontado, conforme destacam Ferreira, Fernandes e Corrêa-e-Silva (2009), que parte das preocupações dos pesquisadores dos valores organizacionais diz respeito à descrição de dimensões e tipologias adequadas para a aplicação na caracterização da cultura de uma extensa gama de organizações (Ferreira et al., 2009). As dimensões, na maioria dos casos, são derivadas empiricamente da utilização de instrumentos de medida quantitativos (Cameron \& Quinn, 2011; Hartnell, Ou \& Kinicki, 2011). As tipologias, por seu lado, partem de certas dimensões básicas para identificar determinados tipos, nos quais as culturas podem ser classificadas, apesar de os tipos puros dificilmente serem encontrados (Ferreira et al, 2009), como, por exemplo, fizeram Cameron e Quinn (1999, 2011) na estrutura de valores competitivos.

O exame da literatura de valores organizacionais revela que somente alguns autores propuseram um modelo ou taxonomia para os valores organizacionais. Os postulados por Quinn e Rohrbaugh (1983), Weiner (1988), O’Reilly, Chatman e Caldwell (1991), Kabanoff 
(1994), Tamayo (1996), Tamayo e Gondim (1996), Cameron e Quinn (1999), Rousseau (1992), Ashkanasy, Broadfoot e Falkus (2000), Detert, Schroeder e Mauriel (2000), Dobni, Ritchie e Zerbe (2000), Tamayo, Mendes e Paz (2000) e Oliveira e Tamayo (2004) são expostas.

Com o objetivo de compreender a eficácia organizacional, Quinn e Rorhbaugh (1983) desenvolveram o modelo dos valores concorrentes (CVF - Competing Values Framework), que, posteriormente, serviu para explorar fenômenos organizacionais como cultura e mudança, ou, como o mais abrangente teste (Schneider et al., 2013) sobre a relação entre cultura e desempenho organizacional (Hartnell et al., 2011).

O modelo sugerido por Quinn e Rorhbaugh (1983) apresenta duas dimensões ortogonais; a primeira, referenciada no eixo vertical, contempla flexibilidade versus estabilidade e, no eixo horizontal, orientação interna versus orientação externa. Da união entre os eixos, emergem quatro quadrantes, que dizem respeito às relações humanas, aos sistemas abertos, às metas racionais e aos processos internos. Esses quadrantes remetem a valores organizacionais inerentes à organização que ocasionam o processo de integração (Kalliath, Bluerdorn \& Gillespie, 1999). A justaposição das duas dimensões em quadrantes opostos confirma a estrutura de valores concorrentes (Belasen, 1997), como previram Quinn e Rohrbaugh (1983).

Segundo Veiga (2010), cada uma das dimensões remete a uma determinada característica da organização. A dimensão relações humanas caracteriza organizações cuja ênfase recai sobre a confiança, participação, delegação de poder, cujas ideias dos colaboradores são valorizadas. Na dimensão sistema aberto, valores como flexibilidade e foco externo são apreciados. Quando o destaque se insere sobre a eficiência, desempenho, foco no resultado, a dimensão das metas racionais é representada. Por fim, organizações que enfatizam os processos internos apresentam alto controle, rotinização, estabilidade e ordem (Quinn et al., 2003). As recompensas são devidas aos trabalhadores que seguem as normas e rotinas, conforme Figura 9. 


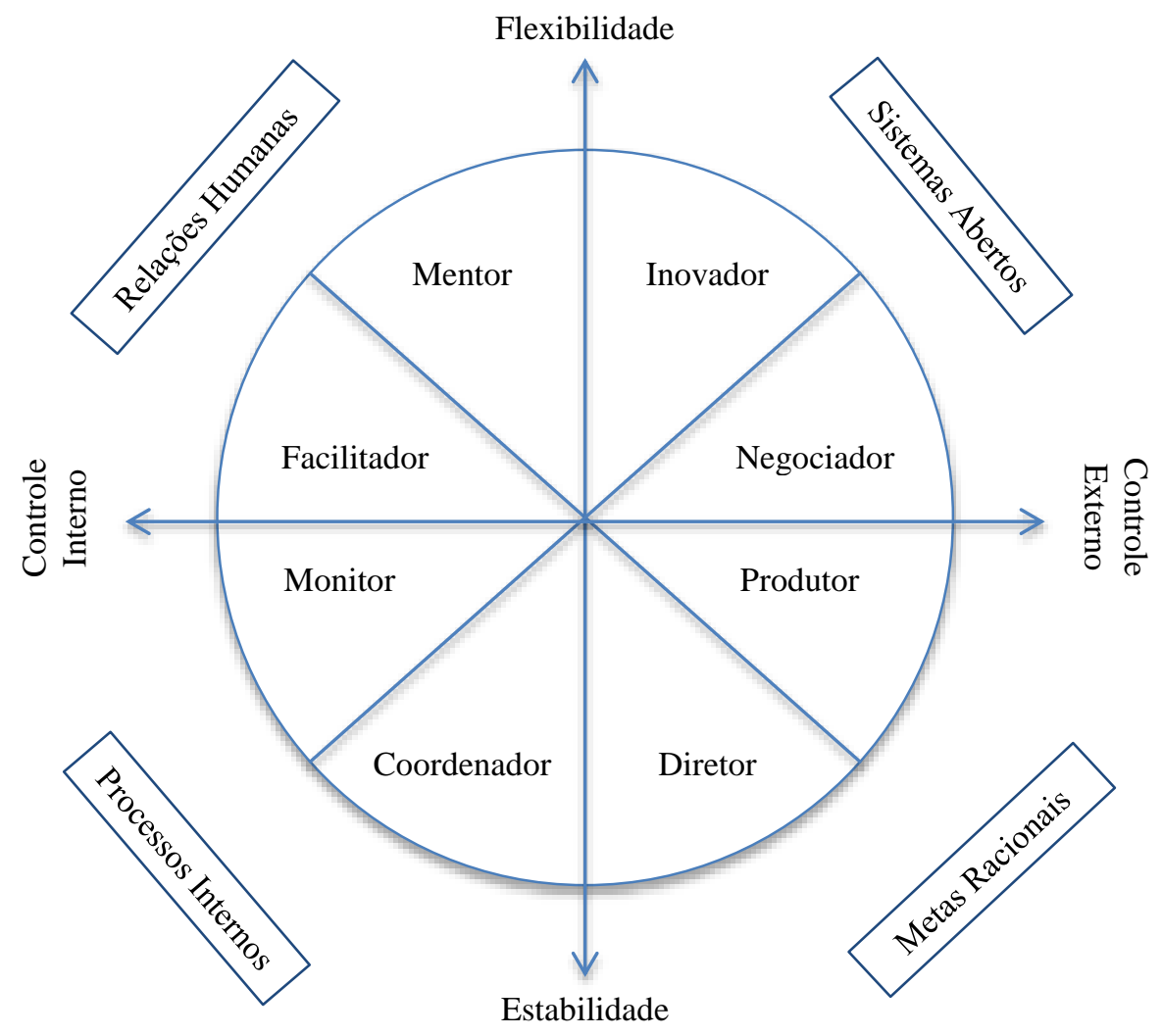

Figura 9. Modelo dos valores concorrentes adaptado de Quinn e Rorhbaugh (1983).

Os valores organizacionais são apontados por Wiener (1988) como pertencentes ao centro da cultura organizacional, pois auxiliam a definição dos objetivos, as políticas e as práticas organizacionais. Para a mensuração dos valores organizacionais, o autor recomenda uma tipologia fundamentada no conteúdo e na fonte dos valores organizacionais.

O conteúdo do valor versa sobre o objetivo subjacente, que pode ser funcional (com ênfase no alcance de um objetivo em particular) ou elitista (que destaca as comparações; por exemplo, essa organização é a número um). Já a fonte do valor fala da origem do valor que se estabelece na tradição ou na liderança. Se determinado valor está embasado na tradição, sua difusão ocorrerá de maneira ampla e sofrerá pouca influência, em virtude das diferenças individuais. Logo, esses valores aparentam ser mais estáveis. Em contrapartida, quando os valores estão alicerçados nos líderes, a identificação do subordinado com o seu gestor afetará na manutenção desses valores, tornando-os menos estáveis (Veiga, 2010). Ao considerar as duas dimensões (conteúdo e fonte), apresenta-se uma tipologia de quatro valores: elitistas, funcionais, tradicionais e carismáticos.

A transmissão e a manutenção dos valores organizacionais também são apresentadas por Wiener (1988), que atribui às primeiras socializações o papel de transmitir aos novos 
empregados os valores da organização. Em um segundo momento, a identificação dos membros com os valores da organização também influenciará na manutenção dos valores.

Duas perspectivas são responsáveis pela aceitação dos valores organizacionais. A primeira refere-se à crença de que os indivíduos têm um dever moral de se comportar de certo modo - essas crenças são oriundas do processo de socialização. A segunda perspectiva versa sobre a compatibilidade entre os valores dos empregados e os defendidos pela organização. Disso resulta, que quanto maior a congruência entre os valores, mais fácil é a adaptação do empregado. Veiga (2010) ainda ressalta que os processos de recrutamento e seleção podem afetar a adequação dos trabalhadores aos valores defendidos na organização. O autor ressalta, ainda, que cabe à socialização e aos ritos o papel de sinalizar o que é adequado ao indivíduo no local de trabalho.

Construído para avaliar a congruência entre os valores individuais e organizacionais, o modelo de O'Reilly et al. (1991), denominado mapeamento da cultura organizacional (OCP - Organizational Cultural Profile), reflete, em seus fatores, um padrão de relacionamento sustentado nos interesses individuais (apoio, ênfase no reconhecimento, orientação para equipes, decisão) e interesses organizacionais (inovação, atenção a detalhes, orientação para desempenho, agressividade).

O instrumento original de O'Reilly et al. (1991) é composto de 54 valores organizacionais, oriundos de uma revisão elaborada por pesquisadores focados em valores e cultura da organização, após a eliminação de redundâncias, irrelevâncias e dificuldades de compreensão dos itens. O OCP foi construído utilizando-se da técnica do Q-sort (Block, 1978). Para a aplicação do instrumento, os respondentes deviam classificar os 54 valores em 9 categorias responsáveis por quanto cada valor é desejável na organização em que trabalham (O’Reilly et al., 1991).

Apos uma série de análises, a estrutura final ficou composta por sete dimensões de valores: inovação, estabilidade, respeito às pessoas, orientação para resultados, orientação aos detalhes, orientação para equipes e agressividade. Outros estudos buscaram comparar o modelo entre nações e indústrias (Vandenberghe, 1999), analisar a adequação em amostras específicas (Windsor \& Ashkanasy, 1996), bem como estudos que buscavam novas evidências de validação do modelo (Cable \& Judge, 1996; Vandenberghe, 1999; Sarros, Cinza, Densten \& Cooper, 2005).

Os estudos preliminares de Kabanoff (1991) resultaram em uma tipologia de estratégias organizacionais. Em pesquisas posteriores, Kabanoff (1995) apresenta o conceito 
de valores como um poderoso construto, em virtude de seu emprego em todos os níveis de análise: cultural, social, institucional, organizacional, grupal e individual.

Kabanoff, Waldersee e Cohen (1995) partiram, então, de um novo método para a investigação dos valores esposados em organizações australianas. Esses autores analisaram o conteúdo dos anuários, revistas internas e missão de diversas organizações no período de 1986 a 1990, com a meta de examinar com que frequência eram mencionados os valores de autoridade, liderança, desempenho, recompensa, participação, afiliação, comprometimento, trabalho em equipe, equidade e controle normativo (Veiga, 2010). Desses resultados, apontam-se quatro tipos de valores organizacionais (elitista, liderança, meritocracia e colegial), que decorrem da combinação das dimensões estrutura (poder descentralizado versus poder centralizado) e processo (igualdade versus equidade).

Essa tipologia de quatro tipos ideais de organização em que se acrescentam os valores organizacionais, descrita por Kabanoff (1995), representam diferentes formas de lidar com o conflito entre equidade e igualdade. Quanto mais desigual ou centralizada for a estrutura de poder de uma organização, mais os valores de equidade sobressairão e mais desigual será a distribuição de recursos e recompensas. Em organizações cujo poder é descentralizado e existem estruturas mais democráticas, a orientação será mais igualitária e as alocações de recursos serão mais bem distribuídas.

Ao analisar as estruturas, Veiga (2010) observa que a primeira delas (valor elitista) valoriza as relações desiguais de poder (autoridade), a escassa ênfase no igualitarismo (participação) e a importância elevada nas recompensas. O poder desigual também é valorizado pela estrutura de valor liderança, todavia distingue valores como liderança, trabalho em equipe e coesão. Em lados opostos, apresentam-se os valores meritocracia e colegial, em que uma distribuição menos desigual de poder é valorizada, além de se alternarem os processos equitativos e igualitários como nas estruturas anteriores, conforme a Figura 10. 


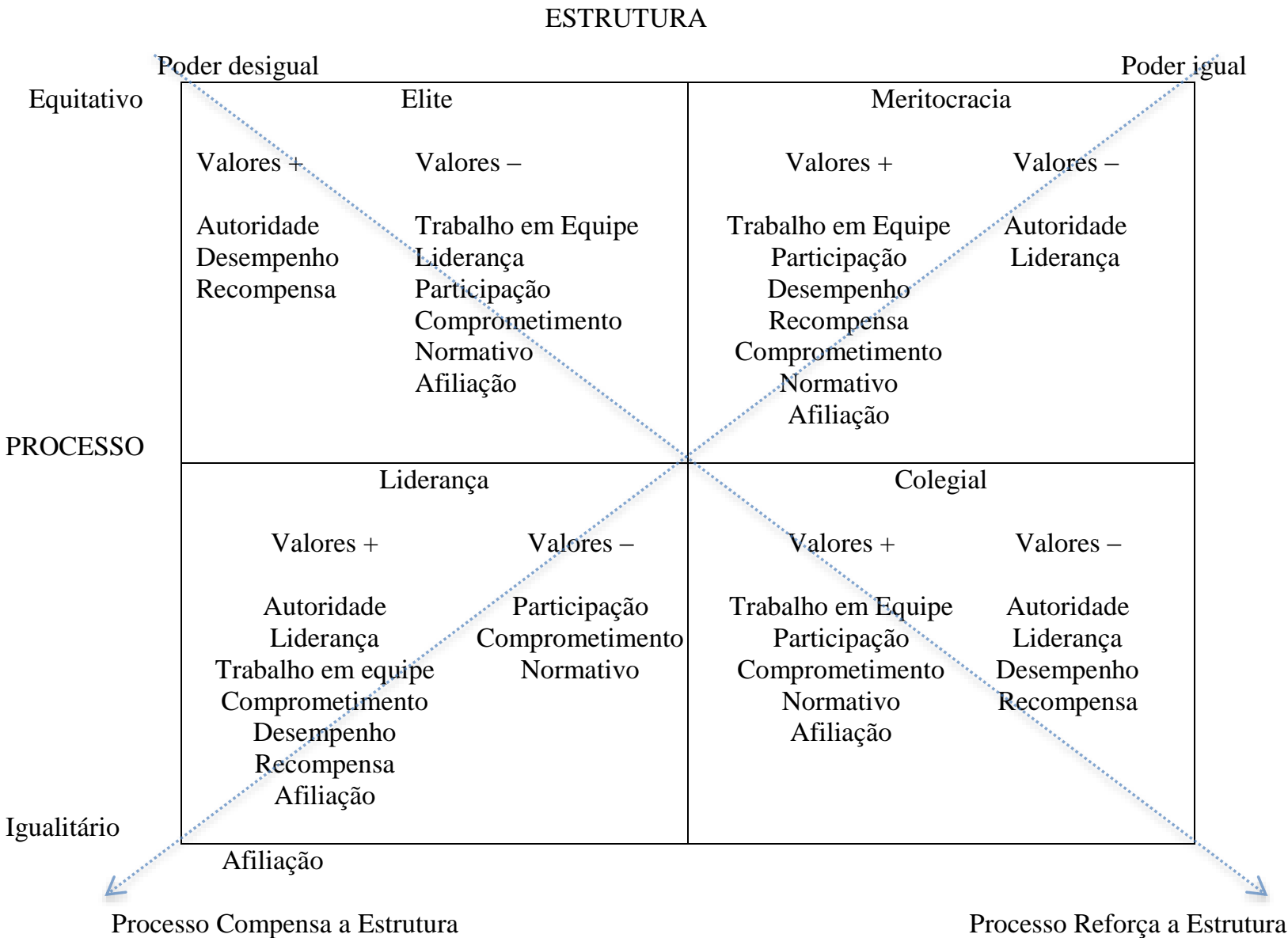

Figura 10. Valores esposados segundo Kabanoff et al. (1995).

De forma similar e utilizando a mesma estratégia, Kabanoff e Daly (2000; 2002) confirmaram a taxonomia anteriormente apresentada. $\mathrm{O}$ resultado demonstrado no trabalho de Kabanoff, Walderse e Cohen (1995) informa que o valor organizacional preponderante influencia a maneira como sujeitos percebem a mudança organizacional. Os defensores dessa tipologia observam que para julgar os valores de uma organização é fundamental a análise dos documentos produzidos por tal organização, seja porque exibem o que é valorizado pela organização, seja porque refletem a visão do corpo diretivo. Assim, defendem o estudo dos valores presentes nos documentos oficiais, isto é, os valores esposados (Kabanoff \& Daly, 2002).

Quando se busca no contexto brasileiro os pesquisadores que contribuíram com a literatura dos valores organizacionais, o primeiro nome que surge é de Álvaro Tamayo, que iniciou, em 1986, sua primeira pesquisa na área de valores por intermédio do inventário de valores de Rokeach (IVR), adaptado para o Brasil por Günther (1981). Tamayo (1996) observa que as organizações, da mesma maneira que ocorre com as pessoas e os grupos sociais, apresentam necessidades universais que precisam ser satisfeitas, com a finalidade de 
garantir a sobrevivência. Os valores organizacionais, então, originam-se em resposta a estas exigências ou problemas eminentemente organizacionais (Tamayo \& Borges, 2001). Caberia aos fundadores ou pessoas de alta influência na organização a introdução dos valores organizacionais; entretanto, seu processo de desenvolvimento levaria em consideração as interações entre necessidades internas e externas da organização

Disso resulta que as necessidades a serem satisfeitas devem considerar três exigências fundamentais ou problemas, seguindo as referências de Schwartz e Ros (1995): (1) a relação do indivíduo com o grupo (relação que sempre se apresenta como conflituosa, porque é difícil harmonizar os interesses do indivíduo com os da organização); (2) a necessidade de estabelecer uma estrutura (para sobreviver, a organização necessita definir as normas, papéis, subsistemas organizacionais, relações de trabalho, entre outros); (3) a relação entre a organização e o meio ambiente natural e social (para continuar existindo, a organização tem que interagir ininterruptamente com o ambiente externo, com o objetivo de identificar e planejar as respostas adequadas).

Fundamentado nas necessidades (três exigências) e na abordagem cultural de valores de Schwartz e Ros (1995), Tamayo (1996) sugere um modelo para o estudo dos valores organizacionais, com base na existência de três dimensões bipolares (formadas por seis tipos motivacionais) como resposta das organizações, que são: (1) relação do indivíduo-grupo (autonomia versus conservadorismo), (2) relação estrutural (hierarquia versus igualitarismo) e (3) relação com o meio ambiente natural e social (domínio versus harmonia). Tamayo (1996) sugere, ainda, a existência de uma relação dinâmica de compatibilidade e ou conflito entre as dimensões, que se vislumbraria pelo grau de proximidade ou afastamento entre os polos motivacionais, conforme exposto Figura 11. 


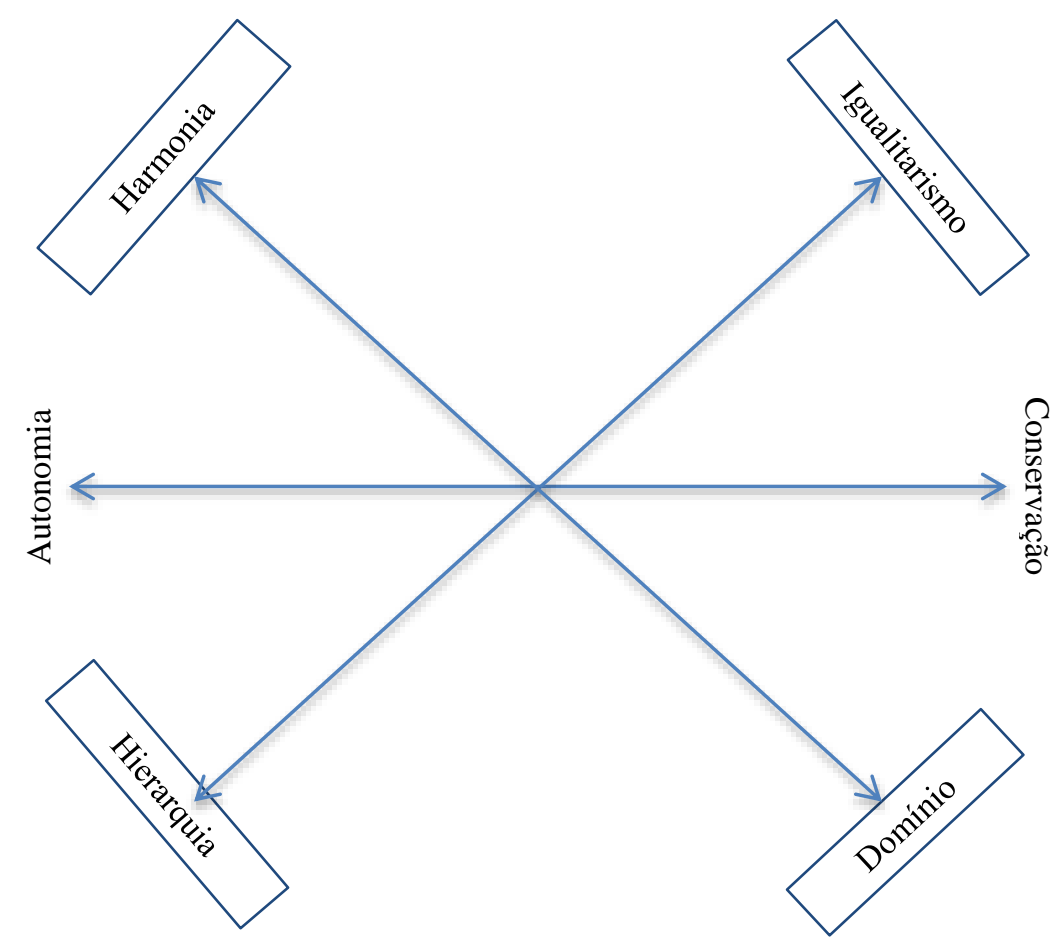

Figura 11. Estrutura dos valores organizacionais segundo Tamayo (1996).

A primeira dimensão, autonomia versus conservação, versa sobre as alternativas existentes de compatibilização entre os interesses do indivíduo e da organização. Quando a ênfase da organização recai sobre o polo de autonomia, existe liberdade paro o indivíduo estabelecer metas em harmonia com as da organização. Tais organizações são caracterizadas por valorizarem a inovação, a criatividade bem como a promoção de mudanças e originais formas de agir, pensar, produzir e trabalhar. No extremo oposto dessa dimensão, tem-se a ostentação da manutenção do status quo, com a preferência pela implementação das soluções já existentes dentro do contexto organizacional, com o desencorajamento de comportamentos que perturbem as normas e as tradições.

A segunda dimensão abrange a hierarquia versus o igualitarismo e trata da estrutura assumida, que define o sistema social da organização. Organizações que privilegiam a hierarquia buscam assegurar o comprometimento dos membros com a missão e os valores da organização bem como sua manutenção; há ênfase na autoridade, poder social, influência, fiscalização e controle.O polo oposto, a dimensão do igualitarismo, ressalta o bem-estar dos membros da organização, de forma geral; os sujeitos são tratados como iguais; existem poucos níveis hierárquico e ocorre o predomínio do consenso. A ênfase recai sobre valores que expressam justiça social, equidade e responsabilidade. 
A terceira dimensão trata das relações entre harmonia versus domínio, representando a relação entre a organização e o ambiente físico e social em que se insere, adicionando a forma de como a empresa solucionará os problemas dessa interação. No primeiro polo, apresenta-se a harmonia, que se caracteriza por valores como proteção da natureza, cooperação, integração no relacionamento interorganizacional e tolerância, os quais buscam a experiência de um relacionamento harmonioso com o ambiente. No polo oposto, tem-se o domínio, representado por uma relação desequilibrada com o meio ambiente. Assim, as prioridades axiológicas refletem a supremacia dos interesses e sucesso da organização em detrimento do meio ambiente, ou seja, valores ligados a esforços para obtenção de controle e exploração do meio ambiente são salientados. Essas dimensões propostas por Tamayo (1996) podem "constituir os pilares teóricos para o estudo empírico da estrutura de valores organizacionais tal como são percebidos pelos empregados" (Ros, 2006a, p. 425).

As prioridades axiológicas de uma organização especificam a natureza dos valores dominantes da organização (tipos motivacionais dominantes), podendo ser consideradas um sistema com relativa estabilidade dos valores, os quais determinam e sustentam o clima e a cultura organizacional (Tamayo, 1996). O autor destaca, ainda, que o papel dos valores organizacionais compartilhados é produzir modelos mentais análogos sobre o funcionamento e a missão da organização, ou seja, tais modelos mentais orientam o comportamento dos membros da organização. "O comportamento dos empregados na organização, as explicações que eles dão da rotina organizacional e possivelmente seu comprometimento com a empresa são determinados pela percepção que eles têm dos valores organizacionais" (Tamayo, 1996, p. 189).

Soma-se a isso o fato de os valores organizacionais auxiliarem na constituição da identidade organizacional, o que origina a diferenciação organizacional (Tamayo, 1998). Dois papéis são atribuídos ao compartilhamento dos valores, um externo e um interno. O externo propicia a adaptação e sobrevivência da organização ao ambiente. O papel facilita as relações intraorganizacionais (O’Reilly et al. 1991).

A defesa realizada ao propor a existência de prioridades axiológicas da organização não significa dizer que uma entidade tenha valores, porque os valores da organização "só existem na mente de seus membros" (Tamayo, 2008, p. 310). Os valores que são considerados importantes e desejáveis pelos fundadores ou membros influentes foram registrados nos documentos, discursos oficiais da organização, ou mesmo apresentados no ambiente de trabalho. 
O reforço de tais valores é facilitado por meio de experiências cotidianas, das atitudes dos gestores e das práticas adotadas, de forma que esses valores passam a ser reconhecidos e apreciados dentro da organização. Assim, as recompensas para os sujeitos da organização são dadas quando algo de correto é realizado, ou quando o processo de socialização, no qual ocorre um compartilhamento sobre o que é avaliado como adequado neste contexto, ou seja, o funcionamento da organização é pautado por esses valores, o que implica em uma identidade própria, diferenciando uma organização das demais existentes (Veiga, 2010).

Embasados no modelo teórico proposto por Tamayo (1996), dois novos instrumentos foram desenvolvidos: o Inventário de Valores Organizacionais - IVO (Tamayo et al., 2000) e o Inventário de Perfis de Valores Organizacionais - IPVO (Oliveira \& Tamayo, 2004). Entretanto, anteriormente às duas escalas referenciadas, Tamayo e Gondim (1996) elaboraram a Escala de Valores Organizacionais - EVO. Para a construção do instrumento, os autores utilizaram uma estratégia exclusivamente empírica, ou seja, não houve a utilização de um modelo para representar a estrutura dos valores organizacionais. Para tanto, foi aplicado um questionário a 113 funcionários de 5 diferentes organizações (públicas e privadas), por meio do qual os respondentes citavam cinco valores que, na concepção destes, representassem os princípios e crenças que orientam a organização (Tamayo \& Gondim, 1996). Além disso, os inquiridos definiam, de maneira geral, cada valor citado no questionário. Como resultado, obteve-se uma lista com 565 valores, dos quais foram obtidos 48 valores finais. Ocorre que, após a análise das cargas fatoriais, 10 itens (valores) foram eliminados, restando um total de 38 itens que foram distribuídos em cinco dimensões de valores: eficácia/eficiência, interação no trabalho, gestão, inovação e respeito ao empregado.

Construído com base no modelo dos valores culturais (Schwartz, 1999; Schwartz \& Ros, 1995), o Inventário de Valores Organizacionais - IVO (Tamayo et al., 2000) utilizou-se, ainda, de alguns dos itens da Escala de Valores Organizacionais (Tamayo \& Gondim, 1996), e os demais itens foram construídos de forma a contemplar todas as dimensões (igualitarismo e autonomia, que possuíam menos representações na EVO). Os resultados revelaram que as medidas obtidas não foram perfeitas, mas garantiam uma solução satisfatória bem como a confirmação dos pressupostos teóricos.

Foi encontrada a estrutura de três dimensões; entretanto, apenas na dimensão hierarquia versus igualitarismo, encontrou-se a relação de conflito hipotetizada; nas outras duas, os polos eram adjacentes. Em complemento à análise, rememora-se que os itens foram distribuídos nos 6 tipos: motivacionais, autonomia, conservadorismo, hierarquia, igualitarismo, e harmonia. Uma peculiaridade dessa escala é que ela possibilita avaliar os 
tipos motivacionais de valores em dois níveis (real e desejado), o que permite mensurar a descompensação axiológica, isto é, o grau de satisfação/insatisfação do empregado com as prioridades da organização (Veiga, 2010).

Para a elaboração do IPVO - Inventário de Perfis de Valores Organizacionais Oliveira e Tamayo (2004) admitiram como premissa a similaridade entre a estrutura e o conteúdo dos valores organizacionais e dos valores pessoais. De acordo com Tamayo (2007), existiria uma correspondência biunívoca entre os valores pessoais e os valores da organização. Cabe, ainda, destacar que os aspectos cognitivo, motivacional e organização hierárquica dos valores foram considerados. $\mathrm{O}$ aspecto cognitivo reflete às crenças do que é desejável para a organização. A perspectiva motivacional diz respeito à expressão das metas essenciais da organização. Ademais, os valores estão organizados de forma hierárquica, mostrando quais são os comportamentos mais desejados dentro da organização. Dessa forma, as prioridades axiológicas determinam a quantidade de esforço a ser empreendido por cada trabalhador e diferencia as organizações.

A primeira etapa no desenvolvimento do IPVO levou em consideração a confecção das definições constitutivas e operacionais de cada um dos tipos motivacionais de valores organizacionais, fundamentando-se na teoria de valores pessoais. Os resultados revelaram 8 fatores: autonomia, bem-estar, realização, domínio, prestígio, conformidade, tradição e preocupação com a coletividade.

A especificidade que algumas dimensões de valores apresentaram frente a certo instrumento ou tipologia demonstra uma justaposição entre elas, o que se reflete na tentativa de obter um conjunto básico de dimensões para a caracterização dos valores organizacionais (Ferreira et al., 2009). Fundamentado nesse posicionamento, Rousseau (1992) revisou conceitualmente sete instrumentos, em suas dimensões subjacentes, que avaliavam a cultura organizacional. Sua conclusão sugeriu que, mesmo havendo uma variação das dimensões desses instrumentos, determinado número de dimensões se sobrepunham e que podiam ser resumidas em três categorias básicas: tarefa, interpessoal e individual. Rousseau (1992) validou, assim, uma escala com três categorias que descreve os focos das organizações.

A busca por dimensões básicas foi, posteriormente, realizada por Ashkanasy et al. (2000) que, ao revisarem de forma ampla as dimensões surgidas nos instrumentos de medida da cultura organizacional, obtiveram 10 dimensões de valores: liderança, estrutura, inovação, desempenho no trabalho, planejamento, comunicação, ambiente, local de trabalho humanizado, desenvolvimento do indivíduo e socialização na entrada na organização. 
Em um estudo dirigido para investigar as relações entre valores organizacionais e a produtividade de trabalhadores, Dobni et al. (2000) elaboraram uma taxonomia de valores organizacionais, originadas de análises de conteúdo de trabalhos escritos por acadêmicos e gestores, em que foram encontrados 31 valores. Para os autores, os valores organizacionais são estados de opção por determinados modos de conduta, que se direcionam para diversas decisões a serem tomadas na organização em distintos níveis; ademais, apresentam-se como um componente central da cultura organizacional. Quando se referiam à medida de produtividade, havia a compreensão de comportamentos de trabalho valorizados na organização (quantidade versus qualidade, criativo e inovador versus confiável e previsível), bem como o comprometimento organizacional e o afeto. Foram aplicados 415 questionários em trabalhadores do Canadá procedentes de quase uma centena de organizações da área de serviços. Quatro tipos de valores foram encontrados na taxonomia: empreendedorismo, pressão para o desempenho, integração e temperança. Esses tipos motivacionais apresentaram-se preditores das medidas de produtividade (Veiga, 2010).

As considerações sobre valores e as investigações sobre as dimensões e tipologias possibilitam, tanto em estudos nacionais quanto nos internacionais, a realização de uma análise da forma como os pesquisadores orientam o estudo dos valores organizacionais e sua associação com outros temas, com vistas ao aprofundamento teórico, empírico, de diagnóstico e de gestão organizacional. A Tabela 8 apresenta uma síntese das tipologias e dimensões de valores organizacionais referenciados na presente tese. 
Tabela 8

Resumo das tipologias de valores organizacionais

\begin{tabular}{|c|c|c|}
\hline Autores & $\begin{array}{l}\text { N. de } \\
\text { Dimensões }\end{array}$ & Tipologias de Valores Organizacionais \\
\hline $\begin{array}{l}\text { Quinn e } \\
\text { Rohrbaugh (1983) }\end{array}$ & $\begin{array}{l}\text { Duas } \\
\text { ortogonais }\end{array}$ & $\begin{array}{l}\text { Flexibilidade versus Estabilidade; Orientação interna versus } \\
\text { Orientação externa. }\end{array}$ \\
\hline Wiener (1988) & $\begin{array}{l}\text { Duas } \\
\text { dimensões }\end{array}$ & Elitistas, funcionais, tradicionais e carismáticos. \\
\hline $\begin{array}{l}\text { O’Reilly, et al. } \\
\text { (1991) }\end{array}$ & Sete Categorias & $\begin{array}{l}\text { Inovação, estabilidade, respeito às pessoas, orientação para } \\
\text { resultados, orientação aos detalhes, orientação para equipes e } \\
\text { agressividade. }\end{array}$ \\
\hline Kabanoff (1994) & $\begin{array}{l}\text { Duas } \\
\text { dimensões }\end{array}$ & Elitista, liderança, meritocracia e colegial. \\
\hline Tamayo (1996) & $\begin{array}{l}\text { Três dimensões } \\
\text { bipolares }\end{array}$ & $\begin{array}{l}\text { Autonomia versus conservadorismo, hierarquia versus } \\
\text { igualitarismo, domínio versus harmonia. }\end{array}$ \\
\hline $\begin{array}{l}\text { Tamayo e Gondim } \\
\text { (1996) }\end{array}$ & $\begin{array}{l}\text { Cinco } \\
\text { Categorias }\end{array}$ & $\begin{array}{l}\text { Eficácia/eficiência, interação no trabalho, gestão, inovação e } \\
\text { respeito ao empregado. }\end{array}$ \\
\hline $\begin{array}{l}\text { Cameron e Quinn } \\
\text { (1999) }\end{array}$ & Duas bipolares & $\begin{array}{l}\text { Flexibilidade versus estabilidade e foco interno versus foco } \\
\text { externo. }\end{array}$ \\
\hline Rousseau (1992) & Três categorias & Tarefa, interpessoal e individual. \\
\hline $\begin{array}{l}\text { Ashkanasy et al. } \\
(2000)\end{array}$ & Dez Categorias & $\begin{array}{l}\text { Liderança, estrutura, inovação, desempenho no trabalho, } \\
\text { planejamento, comunicação, ambiente, local de trabalho } \\
\text { humanizado, desenvolvimento do indivíduo e socialização na } \\
\text { entrada na organização. }\end{array}$ \\
\hline Detert et al. (2000) & $\begin{array}{l}\text { Oito } \\
\text { Categorias }\end{array}$ & $\begin{array}{l}\text { Bases da confiança e da racionalidade na organização; } \\
\text { natureza do tempo; motivação; estabilidade versus inovação; } \\
\text { orientação para o trabalho, tarefa ou colegas; isolamento } \\
\text { versus colaboração/cooperação; controle, coordenação e } \\
\text { responsabilidade; orientação e foco interno e/ou externo. }\end{array}$ \\
\hline Dobni et al. (2000) & $\begin{array}{l}\text { Quatro } \\
\text { Categorias }\end{array}$ & $\begin{array}{l}\text { Empreendedorismo, pressão para o desempenho, integração e } \\
\text { temperança. }\end{array}$ \\
\hline $\begin{array}{l}\text { Tamayo et al. } \\
(2000)\end{array}$ & $\begin{array}{l}\text { Três dimensões } \\
\text { bipolares }\end{array}$ & $\begin{array}{l}\text { Autonomia versus conservadorismo, hierarquia versus } \\
\text { igualitarismo e harmonia versus domínio. }\end{array}$ \\
\hline $\begin{array}{l}\text { Oliveira e Tamayo } \\
(2004)\end{array}$ & $\begin{array}{l}\text { Oito } \\
\text { Categorias }\end{array}$ & $\begin{array}{l}\text { Autonomia; bem-estar; realização; domínio; prestígio; } \\
\text { tradição; conformidade; preocupação com a coletividade. }\end{array}$ \\
\hline
\end{tabular}

Fonte. Adaptado de Ferreira et al. (2009).

Os estudos nacionais e internacionais sobre valores organizacionais vêm demonstrando que a apreciação das diversas dimensões e tipologias, adotadas como referencial teórico, têm evidenciado certa complexidade dessa temática, por um lado vista, e, por outro, o avanço verificado no conhecimento sobre valores organizacionais, especialmente no Brasil, nas últimas décadas (Ferreira et al., 2009). 


\section{Seção 3. Práticas Sociais e Práticas Organizacionais}

Este seção tem por escopo a contextualização e a definição das práticas organizacionais em consonância com as práticas sociais, como forma de mapear as manifestações da cultura da organização. Após um resumido retrospecto, apresenta-se como os autores definem as práticas, algumas abordagens teóricas para seu estudo e modelos que tentam explicitar quais fatores determinam as práticas adotadas pelas organizações. A primeira parte da seção (3.1) aborda as práticas sociais, ficando a segunda parte (3.2) responsável pelas práticas organizacionais.

\subsection{Práticas Sociais}

O estudo das práticas sociais tem ganhado relevo nos últimos anos (Guarido Filho \& Machado-da-Silva, 2009). Essas práticas podem ser compreendidas como construções dos atores sociais em seus contextos de interação, como, por exemplo, a organização (Souza et al., 2011).

\subsubsection{Práticas Sociais: uma abordagem preliminar}

Na visão de Bourdieu (1989, p. 261), a prática é definida como o produto de uma relação dialética entre a situação e o habitus, compreendido como um sistema de disposições duráveis e transponíveis que, agregando todas as experiências passadas, trabalham em cada momento como uma "matriz de percepções, apreciações e ações", que torna possível cumprir tarefas imensamente distintas graças à transferência analógica de esquemas concebidos numa prática anterior.

A síntese de Bourdieu (2004) centra-se no indivíduo socializado, entendendo o habitus como a manifestação das coerções e necessidades da vida social no indivíduo - a exata incorporação dessas necessidades pelo ator (Suassuna, 2008). Assim, ele concebe o habitus como "o social inscrito no corpo, no indivíduo biológico" (p. 82), ou ainda, "uma subjetividade socializada" (Bourdieu \& Wacquant, 1992, p. 126). De forma mais clara, o conceito de habitus pode ser entendido como habilidades treinadas e disposições estruturadas para pensar, sentir e agir de modos produzidos, ou seja, a maneira como a sociedade sente-se representada nos indivíduos de maneira durável, dirigindo suas ações e respostas às pressões e demandas do meio social (Bourdieu, 1989). Destaca esse autor que as características "criativas, ativas e inventivas" do habitus, aponta "a disposição incorporada, quase postural" de um sujeito em ação, focando com isso o "lado ativo do conhecimento prático" (p. 64). 
Ainda sobre o habitus, Bourdieu (1989, p. 64) ressalta que pode ser entendido como o aglomerado sistematizado de princípios substituíveis, geradores e organizadores de práticas e de representações, por meio das quais podem ser originadas soluções "que não se deduzem diretamente das condições de produção".

O habitus, em síntese, pode ser apresentado como um sistema relativamente durável, embora, modificável de forma incremental, de arranjos práticos de conduta e de esquemas de percepção e classificação, por meio dos quais os agentes concebem suas ações e representações de ações e instituições no mundo social (Bourdieu, 1989). O sistema, adicionado por um processo implícito de aprendizagem, é resultante das experiências adquiridas ao longo de uma trajetória biográfica privada, em um universo social definido de atuação, universo cujas obrigações particulares tornam-se, por assim dizer, alocadas ou sedimentadas nos corpos e mentes dos atores sob o formato de uma matriz durável gerativa de práticas e representações implicitamente adaptativas às exigências das condições sociais das quais ela é produto (Peters, 2006).

Para Bourdieu (2004), a tentativa de superação da oposição indivíduo e sociedade, agente e estrutura, subjetivo e objetivo, aparece por intermédio das características do habitus, ou seja, não se constitui de ações individuais sempre conscientes e consequentes; e não pode ser lido como simples adaptação às estruturas sociais. O habitus afigura-se, em outra medida, como incorporação, por parte do indivíduo biológico, das necessidades práticas imanentes à vida social (Bourdieu 2004; Bordieu \& Wacquant, 1992).

Com base nesse pensamento, distintas estratégias são lançadas, levando os sujeitos ao exercício de práticas sociais em diferentes contextos (Souza et al., 2011). Esses contextos são preexistentes aos próprios indivíduos e, portanto, norteiam o sentido de suas ações, inclinando-os a pensar, sentir e agir de modos definidos em todos os níveis de interação. Por outro lado, as práticas “concernem aos atores, pois toda a questão está na prática destes”, ou seja, cabe aos atores agir e modificar seus contextos, por intermédio de suas práticas incessantes (Dupuis, 1996, p. 239).

Segundo Cohen (1999), cabem às práticas a capacidade de intervenção para o curso e os resultados das atividades sociais, as quais podem compreender a organização sequencial e interativa de diversas práticas exploradas por outros. Se a vida social se diferencia da natureza pela execução das práticas sociais, então a base dessa diferenciação consiste nas habilidades e recursos requeridos para se desempenhar uma dada prática (Cohen, 1999).

As práticas sociais são assistidas como construções dos atores sociais em seus contextos de interação, afirmam Souza et al. (2011), podendo esse contexto ser ou não uma 
organização. Os termos práticas sociais e organização, segundo os autores, apresentam-se interligados, ficando as práticas entendidas como ações nas organizações, mesmo antes de serem princípios administrativos. Dupuis (1996, p. 238), ao estudar as práticas, faz referência à "essência da tese de Bourdieu", na qual esse "recusa reduzir as ações dos indivíduos a atos puramente racionais ou a atos puramente mecânicos", acolhendo, com isso, a ideia de "ações voluntárias dos indivíduos e das pressões objetivas que limitam essas ações". Parte dessa construção o conceito de habitus de Bourdieu, de extrema importância, segundo o autor, para o "funcionamento sistemático do corpo socializado" (Bourdieu, 1989, p. 64).

As práticas, diz Accardo (1991, p. 133), são difundidas em "graus diversos entre dois polos opostos". No primeiro polo, as práticas parecem operar de maneira completamente livre, por serem conduzidas por uma lógica "que nos escapa que é a do habitus", ficando evidentes, sem indigência de serem explicadas. No segundo polo, estão "as práticas conscientes e expressamente regradas, codificadas por regras gramaticais, técnicas, morais, jurídicas etc.", ou seja, aquelas que "somente a razão e a regra podem impor".

O conjunto de regras e normas de conduta empregadas para a representação regular da práxis social toma por base um conjunto de propriedades estruturais, de sistemas sociais, que se desenvolvem ao longo do tempo e do espaço devido à sua natureza institucionalizada. Explicam-se, dessa maneira, a relação entre as práticas sociais e o conhecimento mútuo dessas práticas (Oliveira \& Segatto, 2009).

Para Souza et al. (2011), existe uma concordância dos autores ao definirem práticas sociais, especialmente no que se refere à regularidade que lhes é peculiar. Isso é reforçado por Cohen (1999), que qualifica práticas sociais como atividades humanas recorrentes, estabelecidas por significados institucionalmente compartilhados.

Vale ressaltar que qualquer mudança ou manutenção de práticas sociais é sensível à cultura. Essa afirmação pode ser justificada por Torres (2009) ao se referir à necessidade de indivíduos que realizam negócios entenderem a cultura dos contextos em que atuam, no sentido de apreender suas práticas.

A definição proferida por Bourdieu (2009) sobre práticas sociais revela que essas são capacidades sociais, que variam no tempo e no espaço, possíveis de serem transferidas, ou seja, não são estáticas, encontram-se no interior e entre sujeitos da mesma classe e que fundamentam os diferentes estilos de vida. As práticas sociais caracterizam-se, segundo esse autor, como duráveis, dinâmicas, estabelecidas socialmente, podendo ser desgastadas, contraditas, ou mesmo arruinadas pela exposição a novas forças externas, com relativa autonomia no que se refere às determinações externas do agora. 
A explicação fornecida por Cohen (1999) para as relações entre práticas sociais e instituições diz respeito às propriedades estruturais, que são instituídas pela reprodução das práticas, sendo que, ao mesmo tempo, permitem essa reprodução. Essa resultante (meio e resultado da reprodução das práticas), segundo Dupuis (1996), é o contexto de interação social, no qual são desenvolvidas pressões, autorizadas as ações, fixadas e desenvolvidas as práticas dos indivíduos de uma sociedade, ou mesmo de uma organização.

Na visão de Dupuis (1996), contextos de interação social (por exemplo, organizações) são ambientes propícios para se originarem práticas sociais, que, com o transcurso do tempo, passam a configurar a cultura. Essas práticas contextualizadas contêm uma cultura, na medida em que comunicam sentidos e significados para os sujeitos dos ambientes em que as práticas se desenvolvem. É feita a afirmação de que o conceito de cultura permeia contextos de interação social (organizações, igrejas, grupos políticos), práticas dos indivíduos e significações das ações (Dupuis, 1996).

\subsection{Práticas organizacionais}

O interesse pelas práticas organizacionais ocorreu de forma análoga ao que aconteceu com os valores organizacionais, que ganharam interesse por meio dos estudos de cultura organizacional, a partir da década de 1980. Embora exista uma larga utilização do termo práticas organizacionais e de sua reconhecida importância para as análises organizacionais, Kostova $(1996,1999)$ faz uma ressalva no sentido de que tal construto carece de definições mais estruturadas e generalizáveis. Normalmente, os conceitos, quando disponibilizados, enfocariam apenas algumas precárias características das práticas organizacionais, perspectivas consonantemente alinhadas e demarcadas pela abordagem teórica, seguida pelos respectivos autores ou pelo interesse específico relativo a cada pesquisa executada.

\subsubsection{Práticas organizacionais: uma abordagem preliminar}

As organizações e suas práticas são formadas de interações e a cultura presente na organização é o sistema estruturante dessas inter-relações (Souza et al., 2011).

Desse fato resulta que as relações entre modelos mentais e comportamentos dos sujeitos sociais com o contexto em que está inserida a organização é o ambiente propício para serem consideradas as práticas sociais, constituídas de ações e atividades (Souza et al., 2008). Essas práticas, por seguirem padrões de regularidade e relações recíprocas entre os indivíduos organizacionais, e por serem características à organização, são denominadas de administrativas. 
As práticas administrativas, assim vistas, são sociais por não serem orientadas isoladamente e por estarem permanentemente relacionadas com outras variáveis, sendo delimitada "ao âmbito da organização e do espaço existencial humano que lhe corresponde". Práticas que, mesmo sendo condicionadas à eficiência e à produtividade, são avaliadas em relação a intenções, motivos, atitudes, valores e crenças dos atores (Guerreiro Ramos, 1966, p. 94).

As ações humanas, inseridas em contextos socioculturais (organizações), coordenam as práticas organizacionais, que estão sob a influência da lógica e da dinâmica da organização, e de pressões externas, advindas do contexto global. Essas práticas incluem conjuntos de tarefas individuais, diariamente realizadas, e conjuntos de tarefas coletivas, mais complexas e demoradas (Souza et al., 2011).

Por acontecerem de acordo com padrões regulares e serem compartilhadas entre os atores organizacionais, além de serem peculiares à organização, essas práticas são denominadas de administrativas. As práticas e representações de atores organizacionais incorporam o modo habitual de pensar e de agir, que necessitam ser apreendidas e aceitas, sendo compartilhadas pelos atores sociais das organizações (Dupuis, 2007).

\subsubsection{Práticas organizacionais: questões conceituais e perspectivas de estudo}

Assim como Kostova (1999), ao elencar as deficiências epistemológicas relativas às definições de práticas organizacionais na literatura internacional, Bedani (2008) e Demo (2004) relataram semelhantes carências nos escassos trabalhos sobre a temática, realizados no contexto brasileiro. Esses relatos apontam para a pouca atenção que os estudos das práticas organizacionais, face à sua importância teórica, têm recebido da literatura organizacional (Verbeke, 2000). Entretanto, autores como Fisher et al. (2013) acreditam que essa importância pode ser adquirida pelo estudo da cultura organizacional por meio das lentes de práticas que caracterizam a organização.

No contexto de estudos brasileiros, Demo (2004) explica que o termo práticas é utilizado com a acepção de hábito, rotina, ação ou atividades introduzidas pelas políticas de gestão de pessoas reconhecidas pela organização ou dela derivadas. De forma semelhante, Bedani (2008) constata que, a maior parte da literatura, utiliza termos como rotina, ação, procedimento, processo, programa, política, técnica,tarefa, atividade, entre outros, de maneira equivocada, muitas vezes como sinônimo da expressão prática organizacional, o que pode ser explicado pelacarência deuma estrutura teórica mais consistente e de uma definição para o termo práticas. 
Outros autores versaram sobre práticas, sem, no entanto apresentarem uma definição para o construto. Por exemplo, Paczkowski (2003) escreveu acerca das práticas de responsabilidade social em organizações produtivas; Carvalho (2004) tratou, dentro de organizações do terceiro setor, das práticas de planejamento estratégico; Cunha (2005) categorizou cinco grupos de práticas (de favorecimento ou contribuição) para inovação organizacional; Caridade (2006) trabalhou com as práticas de gestão (estratégica e socioambiental); Zan (2006) focou as práticas de contabilidade gerencial, e Bridger (2006) dissertou sobre práticas de governança corporativa. Recentemente, Oliveira, Oliveira e Almeida (2010) trataram das práticas de gestão, Souza et al. (2011), Neumann et al. (2012) das práticas de inovação e Souza et al. (2013) de práticas de internacionalização.

A sistematização de uma definição abrangente que considerasse as características mais significativas do construto foi o objetivo de Kostova (1996), ao buscar uma conceituação "mais técnica e trivial" (p. 13). Entretanto, esse autor acaba por fornecer uma definição geral para as práticas organizacionais, que se assemelha à definição de cultura organizacional proposta por Schein (1985).

A definição de Kostova (1999) diz que as práticas organizacionais são formas evolutivas e particulares de reger as funções organizacionais, que recebem influência da história da organização, das pessoas, de interesses e ações que se tornaram institucionalizadas na organização, fato esse que reflete o conhecimento compartilhado e as competências da organização. As práticas, por conta disso, tendem a ser aceitas e aprovadas pelos membros, pois são percebidas como a maneira correta para a realização de determinadas tarefas.

$\mathrm{O}$ estilo multifacetado das práticas origina dois elementos diferenciados. $\mathrm{O}$ primeiro retrata uma reunião de regras escritas ou implícitas acerca de como as funções organizacionais devem ser administradas. E o segundo é constituído por elementos cognitivos (valores e crenças), que determinam como interpretar e compreender essas regras (Kostova, 1999). Três outros atributos das práticas organizacionais são ressaltados pela autora: (1) a abrangência das práticas no ambiente organizacional, ou seja, determinadas práticas apresentam-se mais limitadas, referindo-se a ocupações peculiares, dirigidas por uma área ou departamento da organização, enquanto outras práticas tratam de tarefas mais amplas, como, por exemplo, o gerenciamento de um programa para qualidade total; (2) o grau de formalização das práticas, que varia desde a alta formalização em um extremo até as práticas totalmente informais; (3) a característica referente ao conteúdo das práticas (técnicas, sociais, promotoras de relacionamento interpessoal) no contexto da organização. 
Algumas práticas são prioritárias para a organização, principalmente quando contribuem para o alcance dos objetivos estratégicos (Kostova, 1999). Essas práticas principais refletem as competências fundamentais da organização e fornecem uma fonte diferenciada de vantagem competitiva, o que possibilita à organização se diferenciar de suas concorrentes. O foco de tais práticas recai sobre os indivíduos da organização, devido à sua ampla abrangência, complexidade e formalização, reservando menor incidência à tecnologia, o que dificulta a possibilidade de replicação e de aplicação integral a outros ambientes organizacionais.

As práticas organizacionais podem ser definidas como "teorias em uso que representam os comportamentos e procedimentos típicos, adotados pelos membros de uma organização" (Verbeke, 2000, p. 589). É durante a realização conjunta das atividades que as práticas organizacionais são repassadas aos sujeitos na organização, sendo por eles compartilhadas. Nessa concepção, as práticas significam prioritariamente um conjunto de conhecimentos tácitos, situação que dificulta sua comunicação verbal entre os indivíduos da organização. A aprendizagem das práticas depende do engajamento dos trabalhadores na realização das atividades e da participação do grupo na resolução dos problemas organizacionais.

Contrastando com os valores e crenças organizacionais, Verbeke (2000) observa que as práticas organizacionais são flexíveis, permitindo alterações no ambiente, além de refletir as características da organização no que diz respeito à sua interação com os diferentes públicos. Essas práticas transformam-se em função dos sistemas internos de controle e das pressões oriundas do ambiente externo da organização e são relativamente autônomas dos valores organizacionais. Dessa maneira, duas organizações com perfil axiológico análogo poderiam produzir práticas completamente diferentes. Em resumo, para Verbeke (2000), a cultura significaria algo que a organização "é" e as práticas constituiriam aquilo que a organização efetivamente "tem".

O ambiente interno e externo da organização é influenciador das práticas organizacionais (Verbeke, 2000), o que proporciona um constante estado de evolução, bem como a possibilidade de ser alterado de forma mais simples em comparação aos valores organizacionais, que são mais difíceis de mudar (Fisher et al., 2013). A aprendizagem das práticas organizacionais ocorre por processos de socialização, o que garante aos indivíduos como agir e experimentar a vida dentro do ambiente organizacional (Karahanna, Evaristo \& Srite, 2005).

As práticas e as normas refletem as regras que permeiam os comportamentos dos 
membros de uma organização. Apresentam-se como fundamentais para o entendimento das características da cultura, ao lado de outros aspectos da organização, como por exemplo, os valores pessoais dos líderes; as histórias e lendas relatadas, vinculadas a tradição e ao passado organizacional; os rituais formais, que envolvem atividades e eventos recorrentes e persistentes; e os símbolos presentes em seu ambiente interno (Levin, 2000).

O elemento mais complexo da cultura organizacional pode ser considerado como as práticas organizacionais e abarca comportamentos, rituais e cerimônias (como por exemplo, reuniões, encontros sociais dos membros da organização, controle diário de e-mails, entre outros) (Mallak, 2001). Essas práticas são implementadas por razões instrumentais, com o objetivo de transmitir aos sujeitos da organização mensagens sobre a cultura, ou seja, sobre os valores que a tipificam, e que são reforçados todas as vezes que uma determinada prática é colocada em ação (Ferreira \& Assmar, 2008).

Para Hofstede (2005), os valores organizacionais moldam a cultura organizacional, mas é, por intermédio da adesão às práticas, que os membros da organização são influenciados por essa cultura. Como consequência, o compartilhamento das percepções das práticas organizacionais constitui a essência da cultura da organização (Fischer et al., 2013). Ocorre ainda, que as práticas da organização são capazes de influenciar as atitudes e comportamentos dos sujeitos da organização (Ogaard 2006; Singh, Verbeke \& Rhoads, 1996; Tuomi, Vanhala, Nykyri \& Janhonen, 2004; Verbeke, 2000). Cumprem, assim, um papel fundamental que estabelece um laço entre o ambiente organizacional e os resultados dos indivíduos no trabalho (Poole, 1985).

Com relação às perspectivas de estudo das práticas organizacionais, Bedani (2008), ao revisar a literatura sobre o construto, observou a distinção entre três vertentes: a primeira referencia trabalhos sob o enfoque da perspectiva evolucionária das organizações e a teoria da agência, cujo interesse se insere nas rotinas organizacionais e compliance, afastando-se do escopo desta pesquisa. Segundo, trabalhos dirigidos sob a perspectiva cultural, os quais se subdividem entre os estudos da cultura organizacional e os que utilizam a abordagem transcultural. E, por fim, trabalhos apoiados pela teoria institucional. Dessa divisão, revela-se que os dois últimos enfoques compartilham a visão de inter-relacionamento das práticas com a cultura organizacional, bem como sua influência sobre o comportamento.

Quando a ênfase recai na perspectiva da cultura organizacional, as práticas são estudadas em paralelo aos valores e pressupostos básicos. A cultura, de acordo com a observação de Trice e Beyer (1986) e Beyer e Trice (1987), constitui-se de dois elementos fundamentais, a rede de significados composta pelos valores, ideologias e normas, e as 
práticas que possuem a função de propagar, afirmar e comunicar o teor dessa rede de significados aos indivíduos da organização. Com base na materialização da dimensão mais manifesta da cultura organizacional, é que os autores propõem a possível revelação dos aspectos mais latentes da cultura organizacional, por intermédio da averiguação das práticas. Da mesma forma, Hofstede $(1991,2003)$ aconselha o estudo da cultura organizacional por meio das práticas, o que possibilita a análise por observadores externos. As práticas constituem-se em um aspecto mais facilmente observável do fenômeno cultural, pois ocupam o nível mais superficial da cultura e, por meio delas, é possível identificar as manifestações culturais de uma organização (D’Iribarne, 1989).

Entretanto, apesar de as práticas apresentarem maior superficialidade quando comparadas aos valores, revelariam um impacto emocional imediato sobre os sujeitos da organização e, consequentemente, sobre seu comportamento (Schein, 1985). Para Hofstede et al. (1990), os valores e as crenças dos fundadores e das pessoas com poder de influência na organização moldariam a cultura organizacional; apesar disso, é por intermédio das práticas que a cultura pode influenciar o comportamento dos demais indivíduos da organização.

$\mathrm{Na}$ visão de Bedani (2008), os teóricos transculturais e institucionais procuram entender a influência de variáveis externas sobre variáveis intraorganizacionais específicas. A cultura nacional constitui a variável externa de interesse, nos estudos transculturais, que buscam avaliar a influência da cultura nacional sobre a cultura organizacional e, por conseguinte, esclarecer como esta relação interfere nas práticas organizacionais e no comportamento dos atores.

Na perspectiva dos estudos transculturais, são recorrentes as investigações acerca do processo de transferência de práticas entre organizações sediadas em países distintos (Kogut \& Zander, 1993; Kostova, 1999; Szulanski, 1996; Van der Zee et al., 2004). O pensamento humano, as instituições sociais e as organizações são afetados pelos componentes políticos, sociológicos e psicológicos da cultura nacional (Hofstede, 1983). Mesmo que as organizações estejam sujeitas a forças ambientais diversificadas, a cultura nacional, segundo Sagiv e Schwartz (2000) é o único objeto capaz de influenciar os símbolos, as ideologias e as práticas organizacionais e, concomitantemente, influenciar a percepção, o entendimento e o comportamento dos indivíduos.

Para a teoria institucional, a ênfase está no estudo das pressões sociais e culturais no cotidiano da organização, bem como na influência destes fatores sobre práticas e estruturas organizacionais. Para DiMaggio e Powell (1983), as forças ambientais influenciariam as decisões gerenciais que, conformando uma fonte de pressões regulatórias e coercitivas, 
originariam e difundiriam um agregado comum de valores, normas e regras responsáveis pelo cultivo de práticas e estruturas análogas entre organizações que atuam em um mesmo segmento. Todavia, as pressões institucionais não impactam a totalidade das organizações da mesma maneira. Cada cultura organizacional pondera um elemento moderador que, referenciando sua história e seus valores, provê interpretações diferenciadas para estas pressões, possibilitando o aparecimento de práticas significativamente heterogêneas, mesmo em organizações semelhantes (Bedani, 2008).

No contexto da organização, deve-se dar importância relação de interdependência existente entre práticas e valores, na qual o comportamento organizacional é orientado pela pré-consciência de valores e práticas já institucionalizadas. Os valores culturais acabam por orientar as práticas consideradas numa organização de forma preponderante no tocante aos critérios racionais de eficiência. $\mathrm{O}$ valor abstrato dos significados é agregado pelas práticas num processo de ratificação da própria cultura organizacional (DiMaggio,1988).

As práticas possuem aspectos simbólicos inseridos na organização e estão ligadas ao cotidiano e à historicidade que se constrói. Uma organização possui valores que não se restringem às necessidades técnicas do trabalho em si, atingindo as pessoas que compõem a mesma (Selznick, 1957, 1971). Os membros de uma organização são dotados de valores que ligam as dimensões simbólicas e normativas das práticas organizacionais, mesmo que se tenha a materialização de um conjunto de regras e procedimentos.

As práticas de uma organização permitem diferenciar tanto a adoção como a internalização, na medida em que a primeira faz referência direta à seleção e ao uso de uma prática não recorrente na organização. O segundo termo evidencia em seu significado que as práticas não são abandonadas pela organização, ainda que sob pressões externas (Zeitz, Mittal \& McAulay, 1999). Práticas que não apresentam em seu caráter a historicidade de uma organização, não perduram. Significa dizer que, adotar uma prática não implica em sua consolidação, deixando uma lacuna. Ocorre que as práticas necessitam ser internalizadas, para expressarem os aspectos latentes da cultura organizacional (Christensen \& Gordon, 1999).

O fato de serem internalizadas faz com que as práticas representem as características vigentes na organização em todos os níveis (Zeitz et al., 1999). Essa dinâmica permite o equilíbrio entre a organização e o seu ambiente, envolvendo todos os membros, a tecnologia, aspectos legais e financeiros. A internalização torna-se um processo complexo que envolve muitos fatores da cultura organizacional, exigindo coerência entre os valores partilhados e o uso de recursos. 
Para esta pesquisa, serão consideradas as sugestões de Orr (1996), para quem o estudo mais cuidadoso das práticas (fator de extrema complexidade) possibilita o aprofundamento do entendimento sobre as relações de trabalho e o papel desempenhado por ele na constituição da identidade do trabalhador, fundamentado na premissa de que as práticas merecem uma descrição mais profunda que referencie a percepção dos trabalhadores e o contexto onde são realizadas.

Assim, para esta tese, as práticas organizacionais são entendidas como, atividades reais da organização, desde as cotidianas até as mais inovadoras (Souza et al., 2011), podendo variar no espaço e no tempo, sendo compartilhadas pelos membros da organização e capazes de modificar atitudes e comportamentos (Ogaard, 2006; Singh et al., 1996; Tuomi et al., 2004; Verbeke 2000), tornando os comportamentos definidos pelos habitus (Dupuis, 2007), e criando um laço entre o ambiente organizacional e o desempenho dos indivíduos no trabalho (Poole, 1985). Representam, assim, as manifestações da cultura organizacional (D’Iribarne, 1989; Souza, 2009).

\subsubsection{Práticas Organizacionais: dimensões e tipologias}

O estudo das práticas tem recebido maior crédito dos teóricos organizacionais, conforme observa Verbeke (2000), fato esse, que pode ser explicado pela representatividade que o construto apresenta, em virtude do relacionamento tanto com o comportamento dos membros (influenciando desempenho e atitudes) quanto com a performance integral da organização. Entretanto, conforme salientam Bedani (2008) e Veiga (2010), são escassos os instrumentos disponibilizados na literatura com a capacidade específica para mapear as práticas organizacionais e que sejam capazes de fazê-lo de modo consistente e sistemático.

Cabe salientar que em algumas tipologias, dimensões e escalas construídas para o estudo da cultura, como os de D’Iribarne (1989), Hofstede et al. (1990), Calori e Sarnin (1991), Ferreira, Assmar, Estol, Helena e Cisne (2002), encontram-se fatores reservados à avaliação das práticas organizacionais. A ressalva feita por Bedani (2008) a esse respeito refere-se ao número de trabalhos acerca do tema que utilizam de forma restritiva, aos estudos descritivos de práticas específicas, em que, rotineiramente, o método privilegiado é o estudo de caso.

Diferentes tipologias e dimensões têm sido apresentadas na literatura (Fischer, et al., 2013) para descrever a cultura organizacional. Estudos clássicos têm conceituado cultura organizacional como valores (OCP, O’Reilly et al., 1991; Sarros et al., 2005). Outros avaliam a eficácia organizacional (Cameron \& Quinn, 1999; Quinn \& Spreitzer, 1991), por meio de 
uma tipologia da cultura organizacional bidimensional, separadas por: (1) flexibilidade versus estabilidade e (2) foco interno versus foco externo. Estas duas dimensões levam a quatro tipos centrais da cultura: clã (ênfase na flexibilidade e foco interno), adhocracia (ênfase na estabilidade e foco externo), hierarquia (ênfase na estabilidade e foco interno) e mercado (ênfase na estabilidade e foco externo). Ao avaliar sete instrumentos que mensuram a cultura organizacional, Rousseau (1990) concluiu que as suas dimensões podem ser resumidas em três categorias básicas: tarefas, interpessoais e individuais.

Posteriormente, Ashkanasy et al. (2000) identificaram dez dimensões empíricas, baseadas na revisão de 18 instrumentos de cultura. Essas dimensões incluíam liderança, estrutura, inovação, desempenho no trabalho, planejamento, comunicação, meio ambiente, trabalho humanista, desenvolvimento individual e processos de socialização. Cabe aqui salientar que essas dez dimensões foram, em parte, encontradas em uma revisão independente elaborada por Fischer et al. (2005). A conclusão a que chegam Fischer et al. (2013) é que grande parte dos instrumentos e dimensões desenvolvidas para mensurar a cultura organizacional são focados em valores. Outro ponto refere-se à escassez de pesquisas que utilizam amostras da América Latina e Ásia, como sinalizam os autores.

Com vistas a suprimir essa lacuna, Fischer et al. (2013) propuseram um estudo com vistas em uma abordagem teórica focada nas dimensões subjacentes de práticas organizacionais. Para tanto, utilizaram diversas amostras de incluíam a América Latina, a Ásia e os países ocidentais. Por fim, realizaram previsões de teste sobre covariação das dimensões práticas organizacionais com variáveis econômicas e culturais.

Como forma de subsidiar a pesquisa, Fischer et al. (2013) exploraram as dimensões universais das práticas organizacionais. Primeiramente, utilizaram a referência de Katz \& Kahn (1978) para quem as organizações são sistemas abertos, que se constituem em partes separadas ou subsistemas que interagem de forma dinâmica. Essa interação leva a diversos tipos de conflito entre os seus componentes, em virtude da impossibilidade lógica de todos utilizarem os mesmos recursos ou obterem os mesmos ganhos.

Para Argote e McGrath (1993), se um sistema aberto quiser continuar em operação, qualquer que seja ele, faz-se necessário resolver três conflitos principais: conflitos de interesse, conflitos de controle e os conflitos de estabilidade versus mudança. Desse fato, Fischer et al. (2013) presumem que esses são evidentes em todas as organizações em todo o mundo e podem fornecer a estrutura básica para a experiência de práticas organizacionais pelos funcionários. A Tabela 9 descreve esses três tipos de conflito e como eles podem dizer respeito às práticas organizacionais. 
Tabela 9

Tipos de Conflitos segundo Argote e McGrath (1993)

\begin{tabular}{|c|c|c|}
\hline $\begin{array}{l}\text { Tipos de } \\
\text { Conflito }\end{array}$ & Descrição & $\begin{array}{l}\text { Relacionamento com outras } \\
\text { práticas }\end{array}$ \\
\hline $\begin{array}{l}\text { Conflito de } \\
\text { interesse }\end{array}$ & $\begin{array}{l}\text { Incompatibilidade entre os interesses do } \\
\text { indivíduo, com os interesses dos membros } \\
\text { da organização e da organização como um } \\
\text { todo. Conflito entre bem-estar dos } \\
\text { empregados e as metas da organização, ou } \\
\text { seja, ênfase principal na produção (Argote } \\
\text { \& McGrath, 1993). }\end{array}$ & $\begin{array}{l}\text { Fischer et al. (2005); } \\
\text { Ashkanasy et al. (2000); } \\
\text { Detert et al. (2000); Hofstede } \\
\text { et al. (2000); House, Hanges, } \\
\text { Javidan, Dorfman e Gupta } \\
\text { (2004); O'Reilly et al. } \\
\text { (1991). }\end{array}$ \\
\hline $\begin{array}{l}\text { Conflito de } \\
\text { foco }\end{array}$ & $\begin{array}{l}\text { Equilíbrio entre a necessidade de } \\
\text { diferenciação e especialização nos } \\
\text { subsistemas e da necessidade de } \\
\text { coordenação e integração das funções do } \\
\text { sistema. Necessidade de autonomia e } \\
\text { descentralização dos funcionários versus } \\
\text { necessidade de controle da gestão e } \\
\text { centralização Argote \& McGrath, 1993). }\end{array}$ & $\begin{array}{l}\text { Fisher et al. (2005); } \\
\text { Ashkanasy et al. (2000); } \\
\text { Dellobbe, Haccoun e } \\
\text { Vandenberghe (2002); House } \\
\text { et al. (2004). E a definição do } \\
\text { clássico de Burns e Stalker } \\
\text { (1961), de organizações } \\
\text { como mecanicista e orgânica. }\end{array}$ \\
\hline $\begin{array}{l}\text { Conflito entre } \\
\text { estabilidade e } \\
\text { mudança }\end{array}$ & $\begin{array}{l}\text { Ênfase na manutenção do status quo ante } \\
\text { uma ênfase na mudança proativa e na } \\
\text { inovação. }\end{array}$ & $\begin{array}{l}\text { Fisher et al. (2005); } \\
\text { Ashkanasy et al. (2000); } \\
\text { Hofstede et al. (2000); } \\
\text { O'Reilly et al. (1991); van } \\
\text { Muijen et al. (1999). }\end{array}$ \\
\hline
\end{tabular}

Fonte. Adaptado de Fischer et al. (2013).

Diante dos tipos de conflitos e sustentado por revisões teóricas (Fischer et al., 2005) e empíricas (Ashkanasy et al., 2000), Fischer et al. (2013) propuseram três dimensões para abranger as práticas organizacionais. São elas: orientação para o empregado, formalização e práticas de inovação, com estrutura semelhante à desenvolvida por Wallach (1983), em que perfis de culturas organizacionais são percebidos por três dimensões estereotipadas: de apoio, burocráticas e inovadoras.

Mesmo com a estabilidade dos diferentes conflitos para se atingir as práticas organizacionais, Fischer et al. (2013) sugerem que outras características possam afetar e moldar as práticas organizacionais. Para isso, os autores exploraram as diferenças de percepções das práticas organizacionais entre as culturas, as indústrias, os setores e as posições organizacionais. Diante disso, serão detalhados dois níveis, que guardam relação com essa tese, ao focar no nível do indivíduo, isto é, na forma como ele percebe as práticas organizacionais pertencentes a uma organização do setor público.

Os resultados encontrados por Fisher et al. (2013), no que se refere às percepções das práticas organizacionais no nível do indivíduo, corroboram outros estudos, entre os quais 
destaca-se o de Fischer et al. (2007) sobre tomada de decisão, cujos resultados apontam para visões mais favoráveis dos gestores da empresa. Tal fato pode ser particularmente aplicável aos aspectos da organização relacionados ao desempenho (Fischer et al., 2013). A esse respeito, Erez (1994) observou que investigadores estadunidenses se preocupam mais com os gestores do que com funcionários de nível mais baixo que, não são frequentemente estudados.

Ao tratar da diferença entre o setor público e o setor privado, Fischer et al. (2013) hipotetizam que as organizações do setor público são mais propensas a exercer o controle e a formalização. De fato, os resultados encontrados pelos autores confirmam a hipótese de o setor exercer certa influência sobre as práticas organizacionais. Outras pesquisas demonstraram que o setor público é mais burocrático (Kabanoff \& Daly, 2001) do que o setor privado, em virtude da centralização e da formalização, o que dificulta o início de processos de mudança, isto é, confiar mais nos procedimentos que aumentam a estabilidade (Fischer, 2008). Além disso, o setor privado é mais competitivo (Mathur, Aycan \& Kanungo, 1996) e seus funcionários são mais participativos, dispostos a mudar e a assumir riscos, enquanto os do setor público, em geral, tendem para a participação submissa e a aversão ao risco (Mathur et al., 1996).

Como forma de apresentar as relações existentes, oriundas de estudos empíricos, entre cultura, valores, práticas organizacionais, identidade no contexto do trabalho e das organizações, bem como atinentes ao desempenho no trabalho, a seção seguinte se destinará à revisão da literatura. 


\section{Seção 4. Estudos Empíricos}

Esta seção tem como finalidade apresentar os resultados de uma revisão de literatura, nas principais bases de dados (ABI/Inform Global - Proquest; Scopus; ISI Web of Knowledgement; Science Direct; Periódicos CAPES, Scielo, Pepsic, Spell, entre outras), sobre os temas abordados no capítulo e suas relações empíricas com as outras variáveis (identidade profissional/organizacional e desempenho no trabalho), que serão investigadas na presente tese. As buscas foram orientadas pela combinação das palavras-chave "identidade organizacional" e/ou "identificação organizacional" e/ou "identidade profissional" e/ou "identidade no trabalho" e "cultura organizacional" e/ou "valores organizacionais" e/ou "práticas organizacionais" e "desempenho" e/ou "desempenho no trabalho", e pelas suas respectivas versões em inglês. A primeira parte da seção (4.1) apresentará os estudos empíricos que relacionam as variáveis de cultura e identidade no contexto do trabalho e da organização. A segunda parte exporá os estudos empíricos que relacionam cultura e desempenho no trabalho.

\subsection{Relação entre Cultura e Identidade}

Cultura e identidade são construtos atrelados (Dutton \& Dukerich, 1991; Hatch, 1993; Fiol, Hatch \& Golden-Biddle, 1998; Schein, 1985), de forma mais enfática, à cultura da identidade da organização (Cheung, Wong, \& Wu, 2011). Recentemente alguns autores têm se esforçado para conceituar (Hatch \& Schultz, 2002; Prati, McMillan-Capehart \& Karriker, 2009) e investigar (Millward \& Haslam, 2013; Ravasi \& Schultz, 2006), de forma precisa, essa inter-relação.

Por intermédio de valores tácitos ou esposados, crenças, práticas normativas e prescritivas, a cultura organizacional auxilia os funcionários a criar um sentido de si-mesmo em relação à organização, e como tal, fornecer uma base ideal para que certas identidades se tornem acessíveis e significativas (Cornelissen et al, 2007; Millward, 1995; Millward \& Haslam, 2013). Por exemplo, nos estudos de Prati et al. (2009) a concretizar seu objetivo, as culturas que expressam valores e práticas coletivistas são mais propensas a manter as normas de trabalho em equipe e a coordenação relacional (Millward \& Haslam, 2013; Prati et al., 2009) e, assim, aumentam a acessibilidade relativa do nível de equipe. Em contraste, as culturas que promulgam valores e práticas individualistas tendem a incentivar a identificação focada na carreira (Millward \& Haslam, 2013; van Dick et al., 2005). 
Os estudos que enfatizam a relação entre trabalho e identidade estão entre os celebrados nas pesquisas internacionais (Kira \& Balkin, 2014). Os resultados positivos dessa relação estabelecem-se quando os funcionários percebem seu trabalho como significativo (Ménard \& Brunet, 2011; Pratt \& Ashforth, 2003; Scroggins, 2008) e capaz de promover bem-estar (Kernis \& Goldman, 2006), resultando em um melhor desempenho do indivíduo no trabalho (Kira \& Balkin, 2014). Para tanto, os sujeitos da organização moldam suas identidades, de tal forma que ocorra um alinhamento entre as identidades e a situações de trabalho (Ibarra, 1999; Ibarra \& Barbulescu, 2010; Pratt, Rockmann \& Kaufmann, 2006).

Uma parte significativa das investigações, entretanto, tem recaído mais sobre os desalinhamentos entre o trabalho e as identidades do que aos seus alinhamentos (por exemplo, Ibarra \& Barbulescu, 2010; Pratt et al., 2006; Sveningsson \& Alvesson, 2003). Cabe ainda salientar que não só os desalinhamentos, mas, também, os alinhamentos influenciam a cognição, as emoções, a motivação e o desempenho dos trabalhadores (Kira \& Balkin, 2014).

Os estudos empíricos mais recentes que tratam da relação entre cultura organizacional e identidade têm apontado que a identidade sofre influência tanto dos valores organizacionais (que afetam a acessibilidade da identidade), quanto da maneira como essas identidades são enquadradas localmente, isto é, sob influência direta das práticas organizacionais, o que afeta o ajuste da identidade (Millward \& Haslam, 2013).

Cumpre salientar que a identificação necessita de expectativas anteriores, metas e valores (Oakes, Haslam \& Turner, 1994; Turner, Oakes, Haslam, McGarty, 1994). Essas predisposições podem derivar de crenças compartilhadas e influências de grupos que conferem estabilidade, previsibilidade e continuidade à experiência (Barreto, Ellemers \& Palacios, 2004; Fiol \& O’Connor, 2005; Haslam \& Ellemers, 2005; Peteraf \& Shanley, 1997; Riketta, van Dick \& Rousseau, 1998; Rousseau, 1998). Desta forma, a hipótese de acessar a identidade implica em tendências dos indivíduos para organizar e interpretar o mundo de maneira a refletir suas experiências anteriores com determinadas categorias sociais (Millward \& Haslam, 2013).

Para Millward e Haslan (2013), esse fato se deve aos estudos empíricos que evidenciam que, na medida em que o self pessoal é definido em termos da sua pertença a um grupo específico (ou seja, a identificação organizacional, ou identidade profissional), a identidade se torna um poderoso preditor de uma gama de comportamentos organizacionais, de comunicação e conformidade à liderança e lealdade (para revisões recentes ver, por exemplo, Akerlof \& Kranton, 2009; Ellemers, Gilder \& Haslam, 2004). A identidade, afeta o 
modo como a pessoa se sente a respeito de sua participação na organização, além de determinar o comportamento dentro do ambiente organizacional (Prati, McMillan-Capehart $\&$ Karriker, 2009). Ainda mais, a identificação organizacional é capaz de oferecer benefícios materiais para as organizações (van Dick, Stellmacher, Wagner, Lemmer \& Tissington, 2009; Millward \& Postmes de 2010; Wieseke, Ahearne, Lam \& van Dick, 2009).

Para estudar como a acessibilidade à identidade funciona em contextos organizacionais, Millward e Haslam (2013) investigaram a influência potencial de diferentes culturas organizacionais sobre as identidades dos indivíduos. O estudo, que utilizou abordagens experimentais e quase-experimentais, mediu três focos de identificação (com a organização, com o grupo de trabalho, com a carreira), sob três condições de ajuste de identidade (organizacional, grupo de trabalho, carreira), em duas organizações de saúde, uma do setor público (coletivista) e outra do setor privado (individualista).

Os resultados mostraram que os valores coletivistas com foco na identificação com o grupo de trabalho foi maior quando o ajuste da identidade residiu sobre grupo de trabalho, no setor público (ou seja, em que os valores coletivistas foram previstos para fazer a identidade do grupo de trabalho mais significativa). Por outro lado, a identificação com a carreira foi maior quando a manipulação do ajuste foi executada para a identidade com a carreira, notável na organização do setor privado (isto é, em que os valores individualistas foram previstos para fazer a identidade com a carreira mais significativa) (Millward \& Haslam, 2013).

Na pesquisa conduzida por Chen (2011), a cultura organizacional está positivamente relacionada com a identidade organizacional; além disso, a identidade organizacional teve um efeito de mediação entre a cultura organizacional e a vantagem competitiva, ou seja, nos resultados da organização. Sua pesquisa sugere que o fortalecimento da cultura organizacional verde e da liderança ambiental impacta no aumento da identidade organizacional verde, aumentando as vantagens competitivas das empresas. Os efeitos foram maiores para grandes empresas se comparados com as médias e pequenas organizações.

As entrevistas realizadas por Ruiz Castro (2012), em seu estudo, constataram que a identidade profissional é influenciada pela cultura organizacional. Com base nas diferenças de gênero, em que a vinculação a longas jornadas significa, segundo a investigação, comprometimento com a organização e progressão na carreira, as entrevistas são permitidas somente a homens, mesmo prejudicando a relação trabalho-vida para todos na organização. Outros autores, que trataram da perspectiva temporal, mas, dessa vez, atrelada ao processo de construção e reconstrução da identidade organizacional, foram Schultz e Hernes (2013). Para eles, o passado influencia a articulação e as reivindicações para a reconstrução da identidade 
futura. Assim, quanto maior o tempo da memória ativa, maior o prazo para formular os pedidos para uma identidade futura. A identidade, partindo de perspectiva de um presente contínuo, acrescenta uma nova dimensão para a compreensão da dinâmica temporal da identidade organizacional.

No artigo de Prati et al. (2009) são discutidas as relações de inteligência gerencial emocional, coordenação relacional e cultura organizacional do clã no estabelecimento da identidade organizacional dos subordinados. A administração das funções organizacionais é influenciada pela inteligência emocional dos gestores. A teorização realizada estabelece que o gestor emocionalmente inteligente possa usar a ferramenta estratégica de coordenação relacional para influenciar a cultura da organização e para a criação de uma forte identidade organizacional aos seguidores.

O modelo proposto por Brickson (2013) observa que os membros da organização realizam duas comparações de identidades para avaliar o valor da filiação organizacional para fins de identificação. Na primeira, compara-se a identidade atual da organização com a identidade do sujeito, o que lhes permite avaliar a capacidade da organização para atender a sua motivação para a autocontinuidade. Na segunda, comparam-se a identidade atual da organização com a identidade esperada do sujeito, permitindo-lhes avaliar a capacidade da organização para atender a sua motivação para a autoestima. Os autores discutem se a congruência da identidade indivíduo-organização pode ser considerada um precursor dinâmico para a identificação, em vez de um indicador estático.

Ao testar as diferenças de gênero, experiência profissional e escolaridade, na opinião de professores, sobre percepção da identidade organizacional, Özan e Şener (2013) não encontraram diferenças significativas para gênero, mesmo as médias sendo maiores para professores do sexo masculino. No que se refere à diferença na experiência profissional, o estudo mostrou que quanto maior o tempo de experiência, maior a identificação organizacional. E por fim, não há diferenças significativas na percepção da identidade organizacional sobre o nível de escolaridade, mesmo os resultados indicando que quanto mais altos são os níveis de ensino dos professores, menores são as percepções de identidade que eles desenvolvem em relação a suas próprias instituições, em virtude alto nível de expectativas. Relações como essas foram testadas por Nascimento, Torres, Souza, Nascimento e Adaid-Castro (2013), que encontraram predições positivas relativas a sexo, idade, tempo no trabalho, nível hierárquico, e negativas relacionadas ao nível de escolaridade, sobre a identidade profissional de policiais. Hsu e Elsbach (2013) também encontraram predições positivas da idade e do sexo sobre a identidade organizacional. 
No estudo conduzido por Chang e Wu (2013), testou-se a relação de mediação da identificação organizacional entre tarefas e o compartilhamento do conhecimento. Os resultados demonstraram que a identificação organizacional mediou totalmente a relação entre o feedback de tarefas e o compartilhamento de conhecimento, e, parcialmente as relações entre o apoio social, a autonomia de tarefas e o compartilhamento de conhecimento.

Ao analisar a influência da cultura organizacional na identidade organizacional, Bingöl, Şener e Çevik (2013) encontraram uma influência positiva dos valores sobre a identidade. Por intermédio de sete indicadores (configurações de metas e realização, orientação da equipe, coordenação e integração, ênfase no desempenho, orientação para inovação, participação dos membros, e orientação para recompensa), Cheung et al. (2011) observaram que a cultura organizacional é responsável por formar a identidade organizacional. Outro resultado mostrou o papel de moderador que a identidade apresenta entre a cultura organizacional e a imagem organizacional percebida.

De forma similar, Smith, Cunha, Giangreco, Vasilaki e Carugati (2013) e Tataw (2012) mostram a influência direta das práticas de recursos humanos sobre a identidade. He e Baruch (2009) também salientam as implicações de mudanças nas práticas organizacionais na identidade organizacional, o que estabelece uma relação direta entre esses construtos. Outros autores (Bradford, Quinton, Myhill \& Porter, 2014) identificaram o papel da justiça organizacional sobre a identidade e a motivação da atividade policial. Os resultados sugerem que a justiça organizacional melhore a identificação com a organização policial, incentive os funcionários a assumir novos papéis (modificando as práticas), aumente as opiniões positivas de policiamento comunitário, e esteja associada com maior adesão autorrelatada.

As pesquisas revisadas nesta seção corresponderam à forma que Ravise e Canato (2013) utilizaram para sintetizar as principais abordagens metodológicas utilizadas nas pesquisas de identidade organizacional. Esses autores categorizaram os estudos em cinco métodos fundamentais, divididos em duas categorias. A primeira apresenta os estudos baseados em avaliação quantitativa e a segunda apresenta as abordagens baseadas em pesquisa qualitativa, o que, de forma similar, foi encontrado no contexto brasileiro, conforme revisão de Beyda e Macedo-Soares (2010) e Martins (2013).

Nos estudos ora revisados, buscou-se a relação entre cultura, valores, práticas organizacionais e identidade; entretanto, poucos foram os estudos que especificavam quais valores (e.g., Bingöl et al., 2013) e quais práticas (Smith et al., 2013) influenciam a identidade profissional e organizacional dos indivíduos no contexto do trabalho. Diante disso, esta tese contribuirá com a literatura, entre outros aspectos, com os estudos referentes à 
influência dos valores e das práticas (utilizando-se modelos teóricos específicos) sobre a identidade profissional/organizacional, bem como com o impacto no desempenho no trabalho, cumprindo parte da agenda proposta por Beyda e Macedo-Soares (2010).

O próximo tópico cuidará da relação entre cultura organizacional e desempenho, que expões os principais resultados empíricos encontrados na literatura.

\subsection{Relação entre Cultura e Desempenho}

A representação de que as organizações possuem culturas origina um foco de investigações sobre a relação entre cultura organizacional e eficácia (Schneider et al., 2013). Em recente revisão, Sackmann (2011) esclarece que as investigações dessa relação baseiamse em medidas de cultura organizacional. Dificuldades para a realização dessas pesquisas são apresentadas pelo autor, entre elas: (1) quais níveis da cultura devem ser foco da avaliação (por exemplo, os mitos, histórias, valores, práticas, comportamentos); (2) em qual unidade de análise deve ser avaliada (subcultura versus a cultura como um todo); e (3) o conteúdo das dimensões ao longo do qual as avaliações podem ser melhor realizadas (por exemplo, experiências de funcionários, táticas de socialização, ações de liderança). Em virtude destas dificuldades, Wilderom, Glunk e Mazlowski (2000) apontam a falta de consistência dessa relação. Entretanto, ao se compararem as revisões de Wilderom et al. (2000) e Sackmann (2011) com a revisão de Schneider et al., (2013) evidencia-se que o interesse no

relacionamento entre cultura e desempenho persiste e está em desenvolvimento, com resultados significativos consistentes, justificando-se, novamente, o objetivo desta tese em testar a relação entre esses construtos.

Os estudos descritos por Schneider et al. (2013) encontraram evidências de impacto no desempenho, utilizando medidas tradicionais. Entre essas, destacam-se medidas de desempenho financeiro (Gregory, Harris, Armenakis \& Shook, 2009; Kotrba et al. 2012; Lee \& Yu, 2004; Yesil \& Kaya, 2013), as de satisfação do cliente (Gillespie, Denison, Haaland, Smerek \& Neale, 2008), as de realização do objetivo (Xenikou \& Simosi, 2006) e os relatórios de gestão de topo (por exemplo, Chan, Shaffer \& Snape, 2004, Glisson et al. 2008). Recentemente, pesquisas conduzidas, no Brasil, por Coelho Jr. (2009), Brandão (2009) e Santos (2012) testaram o impacto da cultura organizacional sobre o desempenho por competências, isto é, para ser competente, o desempenho dever estar em consonância com os objetivos, metas e valores organizacionais de eficiência e eficácia (Abbad \& BorgesAndrade, 2004). 
Foram também estudados outros índices menos tradicionais de eficácia, por exemplo, o percentual de mulheres na gestão (Bajdo \& Dickson, 2001). O estudo proposto por Shim (2010) analisou a eficácia organizacional baseada no bem-estar das crianças, filhos dos empregados, bem como a relação entre cultura e o clima organizacional na intenção do funcionário de deixar a empresa. Os resultados mostraram que a cultura organizacional e o clima são os fatores significativos para explicar a intenção da rotatividade do empregado. Assim, quando a ênfase nas recompensas na cultura organizacional for significativa, percebese melhor bem-estar infantil nos filhos dos funcionários, o que resulta em mais eficácia e melhor desempenho do trabalho, bem como menor intenção de deixar o emprego, comparados às empresas em que os incentivos e recompensas são menos claros e eficazes. Resultados semelhantes a esses foram encontrados na pesquisa de Westbrook, Ellett e Asberg (2012).

Parte dos estudos encontrados na literatura incluiu mediadores da relação cultura e performance (por exemplo, as atitudes em Gregory et al. 2009), enquanto que outros incluídos foram os efeitos interativos entre as dimensões da cultura (Kotrba et al. 2012), com práticas organizacionais (Chan et al., 2004; Peltier, Zahay \& Lehmann, 2013), valores (Gregory et al., 2009; Tomczyk, Lee \& Winslow, 2013) ou com as características da indústria (Sørensen, 2002).

A variedade de medidas de cultura também tem sido abordada pelos estudiosos. Entre as medidas, destacam-se: o inventário de cultura organizacional (Cooke \& Lafferty, 1989), o Denison Survey de cultura organizacional (Denison, 1990), e o perfil da cultura organizacional (OCP; O’Reilly et al., 1991), que são frequentemente encontrados na literatura (Schneider et al., 2013).

Como foi acima observado, as estratégias para se mensurar o impacto da cultura organizacional sobre o desempenho são diversas. Ao se analisarem os estudos publicados nos últimos cinco anos em periódicos científicos, encontram-se investigações que vão desde diferenças na cultura de organizações sobre o desempenho no relacionamento de duplas de empregados (Beugelsdijk, Koen \& Noorderhaven, 2008), prioridades estratégicas sobre medidas de desempenho e do próprio desempenho da firma (Verbeeten, Arnick \& Boons, 2009, Yarbrough, Morgan \& Vorhies, 2011) até o impacto da orientação para serviços na cultura corporativa (medida pelos valores dos gestores e dos empregados) sobre o desempenho dos negócios em empresas de manufatura (Gebauer, Edvardsson \& Bjurko, 2010). 
Liderança tem sido outra variável que aparece com frequência nos estudos da relação entre cultura organizacional e desempenho. Investigações que tratam as percepções de quais facetas da cultura organizacional estão relacionadas à liderança e eficácia pessoal (Kwantes \& Boglarsky, 2007), influência da competência de liderança e da cultura organizacional na capacidade de resposta e desempenho das empresas (Asree, Zain \& Razalli, 2010), a liderança como variável antecedente da relação entre cultura organizacional e desempenho (Chen, 2004) ou mesmo, dos estilos de liderança e da cultura organizacional no desempenho das empresas (Wilderom, Van der Berg \& Wiersma, 2012; Yildirim \& Birinci, 2013; Zehir, Ertosun, Zehir \& Mueldili, 2011) estão entre as pesquisas mais celebradas.

Encontram-se, ainda, estudos que abordam a relação entre subculturas organizacionais e desempenho (Li \& Jones, 2010), a correlação entre a cultura organizacional e a conversão do conhecimento sobre o desempenho corporativo (Tseng, 2009). Espaço também tem sido reservado para a relação entre cultura organizacional, os valores sobre os resultados dos colaboradores, mediada pelo conflito da tarefa (McMillan, Chen, Richard \& Bhuian, 2012), ou somente a relação entre cultura e desempenho (Agbényiga, 2011; Cheung, Wong \& Lam, 2012; Jacobs et al., 2013; Mathew, Ogbonna \& Harris, 2011; Murphy, Cooke \& Lopez, 2013; Prajogo \& McDermott, 2010; Yazici, 2010, Yilmaz \& Ergun, 2008).

Práticas de inovação e desempenho representam importantes pesquisas realizadas no cenário atual. Entre outras, destacam-se as investigações sobre a relação entre cultura de inovação, programas de inovação e desempenho (Stock, Six \& Zacharias, 2013), fatores ambientais e organizacionais como moderadores da relação multidimensional da inovação e o desempenho (García-Zamora, González-Bento \& Muñoz-Gallego, 2013). Para o maior aprofundamento entre cultura e inovação, recorre-se à recente revisão elaborada por Buschgens, Bausch e Balkin, (2013).

O trabalho desenvolvido por Hartnell et al. (2011) utilizando a estrutura de valores concorrentes (Competing Values Framework - CVF; Quinn \& Rohrbaugh, 1983) é apresentado como um dos mais abrangentes testes da relação entre cultura e desempenho organizacional. Em sua meta-análise, Hartnell et al. (2011) exploraram a estrutura da CVF, bem como a relação entre suas dimensões e três indicadores de eficácia organizacional (atitudes dos funcionários, o desempenho operacional e desempenho financeiro). Os resultados da pesquisa de Hartnell et al. (2011) apontaram que a estrutura dos valores concorrentes se comportou como o previsto. A cultura de clã apresentou os funcionários mais satisfeitos e comprometidos, enquanto aqueles com maior orientação de mercado obtiveram um desempenho operacional e financeiro superior. 
Outro importante estudo do impacto da cultura, que utilizou a estrutura de valores concorrentes na eficácia da empresa foi o de Gregory et al. (2008). Esses autores examinaram as atitudes dos funcionários (satisfação dos médicos e dos outros empregados) como um mediador potencial da relação entre a cultura organizacional e diversas medidas de eficácia organizacional (despesas controláveis e satisfação do paciente). Os resultados forneceram evidências de que as atitudes dos funcionários mediam a relação cultura-efetividade.

Como já relatado na presente revisão, valores e práticas organizacionais apresentam um importante papel na predição do desempenho. Estudos como o de Triguero-Sánchez, Peña-Vinces \& Sánchez-Apellániz (2013) mostram que práticas de recursos humanos relacionam-se com o desempenho organizacional (percebido e financeiro), sendo essa relação moderada pela distância hierárquica, encerrando uma lacuna na literatura, em que até o momento não havia nenhuma evidência empírica que demonstrasse que a distância hierárquica afetasse esta relação. Os resultados mostram que a distância hierárquica é uma dimensão cultural que modera a relação entre práticas de recursos humanos e o desempenho organizacional. Além disso, os autores observam que, ao se estudar o desempenho em relação às práticas organizacionais, o uso de medidas de percepção são consideradas mais apropriadas $\left(\mathrm{R}^{2}=0,48\right)$, como indicaram a opinião de funcionários e gestores se comparadas ao desempenho financeiro $\left(\mathrm{R}^{2}=0,07\right)$ (Triguero-Sánchez et al., 2013) na relação direta entre práticas e desempenho.

Na mesma direção, a pesquisa conduzida por Nicolau e Musetescu (2012) tratou de práticas de recursos humanos, especificamente, programas que oferecem aprendizagem ao longo da vida. O papel desses programas ficou claro, e, segundo os autores, gera o desenvolvimento da capacidade de pessoal, o que se reflete no desempenho futuro da organização.

Anderson, Spataro e Flynn (2008) investigaram a influência de pessoas na organização. Os autores testaram se a influência pode ser resultado da compatibilidade indivíduo-organização. Os resultados demonstraram que pessoas extrovertidas revelam maior influência em uma organização orientada para a equipe. Ao contrário, indivíduos conscienciosos apresentam maior influência em organizações em que os indivíduos trabalham sozinhos, em tarefas técnicas. Além disso, estes efeitos impactaram no desempenho no trabalho e sofreram influência de características demográficas, como sexo, etnia e nível socioeconômico.

A presente revisão de literatura mostrou a influência da cultura organizacional ou de seus componentes (valores e práticas organizacionais) sobre o desempenho. Entretanto, pode- 
se perceber que os estudos, salvo algumas exceções (ver Hartnell et al., 2011; TrigueroSánchez et al., 2013), não especificam quais valores e quais práticas predizem o desempenho, expondo, assim, uma importante lacuna para estudos que tratam da relação entre estas variáveis.

Mesmo que diversos estudos aqui relatados tenham apresentado análises robustas como, por exemplo, modelagem por equações estruturais (Kwantes \& Boglarsky, 2007; Murphy et al., 2013) ou análise multinível (Kull \& Narasimhan, 2010), o contexto de pesquisas brasileiro ainda é incipiente para pesquisas que utilizem análises de ponta, que indicam outra lacuna. Ademais, são escassos os estudos que trabalham com todas as dimensões aqui apresentadas, que serão objeto de investigação da presente tese.

Diante das lacunas apresentadas, esta tese contribuirá com a literatura, entre outros aspectos, no que se refere ao estudo da influência dos valores e das práticas especificas (utilizando-se modelos teóricos definidos) sobre o desempenho no trabalho. Além disso, testará um modelo em que a relação entre cultura organizacional e desempenho é comprovada com a identidade no contexto do trabalho e da organização.

\section{Conclusões do Capítulo II}

As investigações sobre cultura organizacional no campo dos estudos organizacionais apresentam-se polissêmicas, conforme referenciado no presente capítulo. Desse fato, aflorou a diversificação e a diferenciação que caracterizam a conceituação, a metodologia e a abrangência das pesquisas sobre cultura organizacional. A complexidade polissêmica que caracteriza a cultura organizacional também se reflete na forma de mensurar este construto. Não existe consenso, conforme já salientado, entre os autores a respeito da maneira de se medir cultura organizacional, o que gera uma controvérsia epistemológica. Além desses aspectos, foi abordada outra contestação, que se refere aos principais elementos constitutivos da cultura organizacional, sendo para alguns autores os valores organizacionais, e, para outros, as práticas organizacionais.

Neste capítulo, abordaram-se aspectos históricos, teóricos, metodológicos da noção de cultura, valores e práticas organizacionais. No primeiro momento, a cultura nacional e a cultura organizacional foram abordadas, assim como suas definições, tipologias e limites conceituais, bem como a relação entre os dois níveis culturais. Posteriormente, reservou-se espaço especial para os valores humanos e os valores organizacionais. Além do histórico e da conceituação, foi apresentada a teoria que referenciará os estudos posteriores desta tese. Em seguida, as práticas sociais e organizacionais foram retratadas. Novamente, aspectos da 
história, definições e tipologias foram apresentados, tendo lugar especial a discussão das práticas organizacionais vinculadas às práticas sociais. Por fim, uma revisão da literatura mostrou os principais estudos publicados no Brasil e no exterior que tratavam das relações entre cultura, valores, práticas organizacionais, identidade no contexto do trabalho e das organizações e desempenho.

A análise dos estudos revisados permitiu concluir que, em geral, existe uma diversidade de estudos que contemplam as variáveis revisadas. Entretanto, quando se analisaram os estudos entre cultura organizacional e identidade, seja no contexto do trabalho, seja na organização, poucos estudos apresentaram uma especificação de quais valores e quais práticas influenciam a formação da identidade. Outro aspecto observado trata da condição de a identidade ser utilizada como variável mediadora ou moderadora da relação entre cultura e outro construto (por exemplo, desempenho). Nos estudos sobre cultura, valores, práticas e desempenho, novamente não se especificaram quais são os valores e práticas que influenciam essa relação. Outra lacuna trazida pela revisão refere-se à utilização de análises mais robustas como modelagem por equações estruturais ou análise multinível, ainda incipientes no cenário brasileiro de pesquisa. 
PARTE 1

ANÁLISE TEÓRICA E CONCEITUAL

\section{CAPITULO I:}

Desempenho no Trabalho e Desempenho Competente

Seção 1: Desempenho no Trabalho

Seção 2: Desempenho Competente

CAPITULO II:

Cultura Organizacional

Seção 1: Cultura, Cultura Nacional e Cultura Organizacional

Seção 2: Valores Organizacionais

Seção 3: Práticas Organizacionais

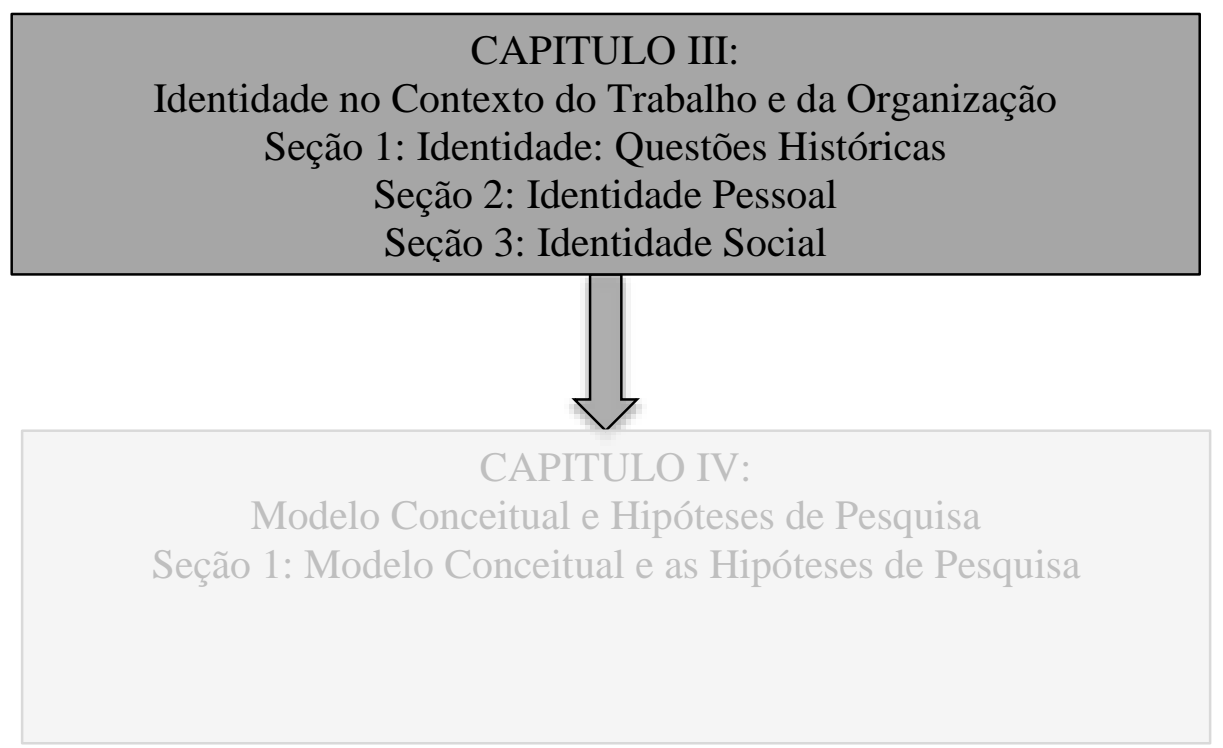




\section{CAPÍtULO III. IDENTIDADE NO CONTEXTO DO TRABALHO E DA ORGANIZAÇÃO}

\section{Introdução ao Capítulo III}

Este capítulo tem por objetivo abordar o fenômeno da identidade apontando suas interfaces com o ambiente organizacional. Busca-se esquematizar os diferentes níveis desse fenômeno, apresentar delimitações para o estudo de suas categorias, identificando possibilidades de integração entre elas e sua aplicabilidade aos estudos organizacionais. Evidencia-se a importância da identidade para o desempenho no trabalho e analisam-se algumas de suas características desde seu nível pessoal até o nível social, à luz da Teoria da Identidade social e de abordagens sobre identidade no trabalho (profissional) e identidade organizacional no desempenho no trabalho.

\section{Seção 1. Identidade: questões históricas}

Desde o início das ponderações no domínio das ciências humanas e sociais contemporâneas a questão da identidade foi abordada por intermédio da noção do si-mesmo, idealizada como capaz de remeter a perspectivas coletivas para uns e perspectivas mais pessoais para outros (Cerulo, 2007; Ellemers, Spears \& Doosje, 2002; Stets \& Burke, 2000), sendo discutida desde o seu ponto de vista individual, ou pessoal, até o aspecto social. Diante disso, a primeira parte dessa seção (1.1) apresenta aspectos relativos à origem e discussão epistemológica, ou seja, do papel da psicologia social psicológica e da psicologia social sociológica para os estudos da identidade, além de tratar de sua vertente pessoal e social. A segunda parte apresenta a vertente pessoal da identidade (1.2). E por fim, a terceira parte (1.3) que se encarregará da vertente social da identidade.

\subsection{Identidade: reflexões teóricas}

A origem do termo identidade é latina, constituída pela derivação do termo idem, que tem a acepção de mesmo, ao passo que o verbo identificar significa tornar-se igual, idêntico a algo ou alguém, podendo ainda representar separar indivíduos de outros com base em características que tornam algo ou alguém diferente, referindo-se a perspectivas individuais que fazem cada pessoa sentir-se única, singular (Galinkin \& Zauli, 2010). Coube a Sumner (1906) cunhar e utilizar pela primeira vez o termo identidade.

O significado de unicidade refere-se a perspectivas individuais, embora o fenômeno identidade possa ser abordado ora na perspectiva social, ora na individual (Cerulo, 2007; 
Ellemers et al., 2002; Stets \& Burke, 2000). Essa dicotomia relaciona-se ao binômio indivíduo-sociedade, sobre as relações que os indivíduos mantêm com a sociedade ou cultura (Ferreira, 2010). As sociedades ocidentais, responsáveis pela teorização e pelo maior volume de pesquisas sobre identidade (Ellemers et al., 2002), são caracterizadas como contextos culturais com forte ênfase em identidades pessoais e realizações individuais (Hofstede, 1980; Triandis, 1989).

Introduzido pelas obras de Cooley $(1902,1922)$ e Mead $(1909,1910,1934)$, o estudo da identidade constitui-se em um pilar no pensamento moderno (Cerulo, 1997), que vem crescendo em importância para o entendimento das práticas singulares ou coletivas que permeiam as organizações. Nesse sentido, para melhor compreender o conceito, na sequência, apresentam-se contornos históricos da psicologia social.

Dando a maior ênfase, ora a aspectos relacionados ao indivíduo, ora à sociedade, estabeleceu-se, segundo alguns autores (House, 1977; Stephan \& Stephan, 1985), duas modalidades de psicologia social: a social psicológica e a social sociológica.

Na clássica visão de Allport (1954), a psicologia social psicológica buscou explicar os sentimentos, pensamentos e comportamentos do indivíduo na presença real ou imaginada de outras pessoas. Sobre esse aspecto, o próprio Allport (1924) deixou clara a orientação comportamental ao referenciar que não existe qualquer psicologia de grupo que não seja em sua essência e totalidade uma psicologia de indivíduos. Essa linha da psicologia social é uma componente da psicologia do indivíduo, cujo comportamento é pesquisado em relação ao ambiente que compreende seus semelhantes. Segundo Allport (1924, p. 4), "a psicologia, em todas suas ramificações, é uma ciência do indivíduo”.

Por outro lado, a psicologia social sociológica, conforme Stephan e Stephan (1985), apresenta como foco o estudo da experiência social que o indivíduo obtém sustentado por sua participação nos diferentes grupos sociais, com os quais convive. Essa abordagem está presente nas colocações de Mead (1934) que contribuem ao entendimento de que o self é socialmente produzido como expressão da interação social.

Nos ensinamentos de Mead (1934), o self decorre do processo de experiências e atividades sociais, desenvolve-se no indivíduo por meio de suas interações com a totalidade desse processo e com outros indivíduos no interior desse processo (Morris, 2010). Para González Rey (2009), um aspecto importante na definição do self, categoria central proposta por Mead (1964), é a que trata do caráter processual da relação do homem com o meio social, que rebate o caráter descritivo e estático que caracterizava o tipo de unidades conceituais 
predominantes em um setor importante da psicologia social comportamental (atitudes, valores, crenças, entre outros).

A abordagem social psicológica enfatiza os processos intraindividuais responsáveis pelo modo como os indivíduos respondem aos estímulos sociais, enquanto que a social sociológica tende a privilegiar os fenômenos que emergem dos diferentes grupos e sociedades (Ferreira, 2010). Diante disso, cabe ressaltar que a separação da psicologia social em duas vertentes, psicológica e sociológica, perpetuou uma dicotomia que só teve valor em um contexto histórico determinado e sob certa representação da ciência, a positivista (González Rey, 2009), podendo, essa dicotomia impedir o desenvolvimento de um espaço integrador. Ao invés de tentar decidir se o self individual ou o self coletivo é mais adequado, Ellemers et al. (2002) julgam pertinente especificar as condições de uma provável precedência de um determinado self (individual ou social) sobre o outro, especificando as condições em que cada identidade (pessoal ou social) é susceptível de ter precedência sobre a outra, e com que efeito.

Assim, os estudos sobre o tema identidade, conforme observa Machado (2003), envolvem múltiplos níveis de análise. Ao considerar o aspecto geral, os dois níveis encontrados são o pessoal e o social (Antaki \& Widdicombe, 1998; Beyda \& Macedo-Soares, 2010; Brown \& Starkey, 2000; Castells, 1999; Cerulo, 1997; Ellemers et al., 2002; Gioia, 1998; Howard, 2000; Machado, 2003; Ruano-Borbalan, 1998). Quando o foco é direcionado aos estudos organizacionais, outras categorizações têm sido evidenciadas: a de identidade no contexto do trabalho (Dubar, 2005, 2009; Sainsaulieu, 1977) e a de identidade organizacional (Albert, Ashforth \& Dutton, 2000; Brown \& Starkey, 2000; Gioia, Schultz \& Corley, 2000; Machado, 2003; Pratt \& Foreman, 2000; Scott \& Lane, 2000; Whetten \& Godfrey, 1998).

Ainda que se constitua essa distinção para fins de pesquisa, pesa o fato de existir uma ligação entre as diferentes formas constituídas da identidade, pois todas estão alicerçadas no comportamento de indivíduos ou grupos. A justificativa para a segmentação reside nas análises, pois cada uma das classificações contém subsídios próprios, que melhor possibilitam a compreensão do construto (Machado, 2003).

Uma importante contribuição para o entendimento dessas questões é encontrada na teoria da identidade social (Tajfel, 1978; Tajfel \& Turner, 1979) e na teoria da autocategorização (Turner, 1987). Esse quadro teórico enfatiza a interação entre a identidade social como percepção de um fator, implicando diferentes aspectos do self (ou diferentes eus sociais - selves) e fatores sociais contextuais, que buscam aumentar ou diminuir o significado da identidade pessoal, bem como das identidades sociais (Ellemers et al., 2002). 
Esta tese utiliza o enfoque da identidade social adotando, pois, uma visão oriunda da corrente que trata dos aspectos da identidade social, que faz referência a um sentimento de semelhança com (alguns) outros (Deschamps \& Moliner, 2009), a partir da vinculação da pessoa a grupos sociais.

\subsection{Identidade Pessoal}

A identidade apresenta-se como um processo em edificação, demarcado pela intermediação constante das identidades assumidas e das identidades visadas (Dubar, 1996). Essa extensão existente entre tais tipos de identidades é o que se configura como espaço de conformação do eu, ou seja, da construção da identidade. É sob esse ambiente que se processam as interações sociais e se estabelece a participação dos outros na construção da própria identidade.

Para Dubar (2005), a identidade para si e a identidade para o outro são, ao mesmo tempo, inseparáveis e ligadas de maneira problemática. Inseparáveis, no sentido de que a identidade para si correlaciona-se com o outro e com seu reconhecimento, "nunca sei quem sou a não ser pelo olhar do outro" (Dubar, 2005, p. 135). Problemáticas, em virtude da dependência de uma comunicação para saber qual identidade o outro nos atribui e, assim, formar nossa própria identidade, dado que a experiência do outro não pode ser vivida de forma direta pelo eu (Laing, 1961, 1986).

Entre outros autores, coube a Ciampa (2007) tratar dos aspectos mais pessoais da identidade; assim, para esse autor a compreensão da identidade é imediata e imutável, estabelecida como um traço estatístico que define o ser, mesmo que essa estabilidade da identidade não seja aceita por outros autores (Tajfel, 1978; Ellemers et al., 2002, Nascimento, 2010). A marca primeira desse traço é o nome, dado à pessoa por ocasião de seu nascimento, elemento diferenciador, que num primeiro momento o identifica e, em segundo momento, faz com que, com o nome, possa ocorrer a autoidentificação. "O nome é mais que um rótulo ou etiqueta: serve como uma espécie de síntese ou chancela, que confirma e autentica nossa identidade. É o símbolo de nós mesmos" (Ciampa, 2007, p. 131). Entretanto, cabe destacar que o próprio Ciampa (2007) reviu essa imutabilidade da identidade, sinalizando a constituição de fluída e transitória.

Ao estabelecer sua corrente teórica para o estudo da identidade, Ciampa (2007) esclarece que o nome não é a identidade, mas sim sua representação (Goffman, 1959, 2011), que, atualmente, vem precedido por uma atividade, conceito traduzido por proposições substantivas, já que o ser se manifesta por intermédio dela. Ferdman (2003) observa que cada 
indivíduo apresenta variadas fontes para constituir sua identidade, por aspectos ligados a religião, espiritualidade, saúde, educação, habilidade física ou mental, fatores geográficos e políticos, características fenotípicas ou genotípicas, ordem de nascimento, idiomas, experiência de vida, raça, etnia, nacionalidade, gênero, família orientação sexual, identidade profissional, classe social e idade, dentre outras fontes.

Para Erickson (1994), a formação da identidade opera em diferentes fases do ciclo de vida, ou seja, a infância e a adolescência são períodos em que influência dos outros na definição das identidades é mais forte. Na idade adulta, os espelhos que norteiam as escolhas não estão tão disponíveis como na infância ou na adolescência; mesmo assim, o indivíduo continua buscando referências, protótipos e modelos até atingir determinado nível de composição entre a sua interioridade e a exterioridade, que corresponde ao processo de individuação. Assim, a identidade, que assume a forma de um nome próprio, vai adotando novas predicações e assumindo personagens. O indivíduo deixa de ser algo, ele se torna o que ele faz, onde vive, como se estabelece dentro de determinados grupos e categorias sociais.

Nesse ponto, para Ciampa (2007), o indivíduo sai de sua individualidade e passa a ser relacionado com os outros; por isso, recebe um sobrenome, que o torna parte de algo, que os une a outras pessoas, constituindo uma família. Fica clara a necessidade de se estabelecer uma dialética, em que o igual e o diferente se combinam para a construção da identidade, mostrando a articulação da igualdade e da diferença.

A identidade, como descreve Anchieta (2003), refere-se à representação em um dado período da história do indivíduo, atrelada a certo contexto social, que carrega um sistema de características físicas, psicológicas, morais, jurídicas, sociais e culturais, sistema esse que institui a definição da pessoa feita por ela mesma ou por outro.

Não se pode isolar, de um lado, todo um conjunto de elementos (biológicos, psicológicos, sociais, entre outros) que podem caracterizar um indivíduo, identificando-o, e, de outro lado, a representação desse indivíduo, como uma espécie de duplicação mental ou simbólica, que expressaria a identidade do mesmo. Isto porque há uma espécie de interpretação desses dois aspectos, de tal forma que a individualidade dada já pressupõe um processo anterior de representação, que faz parte da constituição do indivíduo representado (Ciampa, 2007).

Identidade, como se vê, é ao mesmo tempo a inter-relação que existe entre igualdade e desigualdade, evocando, tanto a qualidade do que é idêntico como a noção de um conjunto de caracteres que fazem reconhecer um indivíduo como diferente dos demais (Jacques, 1998). 
Portanto, a identidade implica tanto no reconhecimento de que um indivíduo é o próprio como, também, pertence a um todo, confundindo-se com outros, seus iguais.

Ciampa (2007) conclui que a identidade é fluida, já que a realidade está sempre em movimento. A análise da estrutura social, fator preponderante para a definição dos padrões de identidade, articula-se entre as diferenças e igualdades, determinando a existência do ser, por meio da unidade dessa multiplicidade.

A ideia de identidade, tratada como um processo construído individualmente, implicando em um sujeito autônomo e unitário, vem sendo questionada por teóricos do campo dos estudos culturais (Guareschi, Medeiros \& Bruschi, 2003; Hall, 2000; Silva, 2004; Woodward, 2004). Para esses autores, as identidades modernas estão entrando em esgotamento, em virtude de um tipo diferente de mudança estrutural que está modificando as sociedades desde o final do século passado, apresentando como resultado a fragmentação das paisagens culturais de classe, sexualidade, nacionalidade, entre outras, que, no passado, forneciam sólidas localizações como indivíduos sociais (Machado, 2003).

A centralidade da cultura na constituição da subjetividade, da própria identidade e do indivíduo como um ator social é apontada pelos teóricos culturalistas. A ênfase na cultura, como elemento das identidades e dos processos de subjetivação, provoca uma compreensão de identidade como algo múltiplo, instável e dependente da adesão a grupos, asseverando uma identidade coletiva e não mais como uma realização individual. Para essa perspectiva, a cultura é refletida no domínio simbólico, na constituição de significações, organizando visões de mundo que, nesse processo, constituem também posições-de-sujeito (Bernardes \& Hoenisch, 2003).

Portanto, compreende-se que o conceito do eu, ou self, é uma construção mental complexa, fruto de uma relação dialética que considera o indivíduo igual a seus pares, mas único na sua existência, na sua experiência e vivência pessoal. Assim, uma identidade bem construída é aquela em que existe o delineamento e se impõem os limites entre a individualidade e os grupos aos quais a pessoa está vinculada. Disso resulta que, mesmo reunidos na presença física, o eu e o grupo encontram-se separados nos processos psíquicos (Machado, 2003).

As dificuldades encontradas no percurso de formação da identidade, que levavam em conta uma excessiva ênfase, ora no aspecto individual, ora no social, são também constatadas na atualidade sob formas diferentes, embora no cerne ainda carreguem o problema de origem, referente à demarcação do território limítrofe do social e do individual (Laurenti \& Barros, 2000). 


\subsection{Identidade Social}

Para Tajfel (1981), a identidade social pode ser definida como uma representação que um indivíduo dá a si mesmo por pertencer a um grupo. Complementando essa definição, Brewer (1997) esclarece que a identidade social de um indivíduo é constituída por uma série de identificações sociais que esse indivíduo tem com várias categorias sociais. Ressalta, ainda, esse autor que nem todas as identificações são privilegiadas, ativadas ou salientadas a qualquer momento. Em um dado momento, a identidade social é composta de poucas identificações selecionadas para servir a um contexto social particular.

Identidade, seja pessoal, seja social, é um fenômeno que pode ser percebido tanto como diferenças, que levam a distintas categorias sociais e individuais, como semelhanças, que unem pessoas numa mesma categoria social. A única diferenciação é que a identidade social é dirigida por dois motivos sociais opostos ao nível individual: a necessidade de inclusão e a necessidade de diferenciação (Brewer, 1997).

Diante dessa diversidade de qualificações e predicativos atribuídos à identidade, Laurente e Barros (2000) observam que o termo identidade social se destaca, em virtude dos elementos que o compõem, ao apontar, de forma mais evidente, as duas instâncias individual e social - que enriquecem a discussão da problemática conceitual, referindo-se à origem individual ou coletiva da identidade. As reflexões que aqui podem ser feitas levam à concepção de homem subjacente, no que se refere à interpretação do termo; assim, é possível superar a errônea dicotomia (individual e social), para mostrar que é na articulação destas que é tecida a identidade.

Quando se trata dos termos identidade e social, surge a necessidade de um conceito que "explique, por exemplo, o sentimento pessoal e a consciência da posse de um eu" (Brandão, 1990, p.37) estando, de um lado, o indivíduo como privilegiado, e, de outro lado, a coletividade, resultando numa disposição na qual se assegura o homem inserido na sociedade, bem como a dinâmica das relações sociais (Laurenti \& Barros, 2000).

A identidade de um grupo assenta-se sobre uma representação social construída, sobre a qual uma coletividade toma consciência de sua unidade pela diferenciação dos outros (Dubar, 1996), porque a vida no grupo cria um imaginário social (Maffesoli, 2000). Dessa forma, a identidade social é estabelecida não somente pela representação que o sujeito faz dele mesmo no seu ambiente social, referindo-se a distintos grupos aos quais ele pertence, mas, também, aos grupos de oposição, aos quais ele não pertence (Chauchat \& DurandDelvigne, 1999). Vista dessa forma, conforme Berger e Luckmann (2002), o sujeito como 
membro da sociedade exterioriza seu modo de ser no mundo e o interioriza, por intermédio dos processos de socialização primária e secundária. Isso ocorre em virtude da definição do outro e de si mesmo que é largamente relacional e comparativa (Ashforth \& Mael, 1989).

Sob a ótica da identidade social, membros de todas as sociedades encaixam-se em categorizações e recategorizações sociais (Brewer, 1991; Tajfel, 1978). Tajfel (1978) estabelece, ainda, que a identidade social é construída levando-se em conta o contexto das atividades de um grupo e está relacionada com o preconceito, o conflito intergrupo, a cultura e a aculturação. A motivação individual para defender e expressar a identidade social depende das necessidades concorrentes para atingir a unidade, na qual a pessoa obtém um nível ótimo de diferenciação (Brewer, 1991). Tem-se, então, que os sinais podem mudar o que especifica a identidade proeminente, mas as pessoas enxergam a si mesmos e aos outros em termos consistentes e criam situações para respaldar esta visão.

Deschamps e Moliner (2009) estabelecem que o ponto de pesquisa de identidade trate da integração dos agentes sociais no espaço social, o que gera o reconhecimento de uma pertença, e, ao mesmo tempo, leva em conta o fato de que esses indivíduos procuram um lugar específico nesse mesmo espaço social, no qual se busca tanto a diferenciação como a singularização.

Assim, como as identidades sociais são partilhadas por aqueles que ocupam posições semelhantes, que têm pertenças comuns, é precisamente ao fator semelhança que é remetida a ideia de identidade social. Entretanto, esse sentimento de pertença bem como a identificação não são possíveis, a não ser em relação a outros grupos ou categorias sociais de não pertença (Deschamps \& Moliner, 2009).

Os processos acima descritos relacionam-se com a forma de os indivíduos organizarem conhecimentos sobre si mesmos e sobre o grupo ao qual pertencem. Vários são os modelos teóricos que permitem prever os efeitos advindos dessas formas de organização. Entretanto, além do caráter explicativo ou previsível, todos esses modelos levantam à questão da relação entre identidade social e pessoal (Deschamps \& Moliner, 2009).

O sociocentrismo nas relações entre grupos, integrando teoricamente a noção de identidade e o processo de categorização social, foi explicado por Tajfel (1972) ao proferir determinadas proposições.

Com base na teoria da comparação social de Festinger (1957, 1971), na qual o autor afirma que a avaliação das opiniões e aptidões dos indivíduos ocorre pela comparação com as de outros indivíduos, Tajfel (1972) propõe uma extensão mais social dessa teoria. A avaliação de si mesmo, preferencialmente, acontece alicerçada numa comparação entre 
indivíduos que se assemelham. Por outro lado, para Tajfel (1972), com base na avaliação de si mesmo encontra-se a identidade social.

No plano comportamental, a categorização social leva também à discriminação comportamental, o que induziu Tajfel (1970) a desenvolver as célebres pesquisas que tendem a isolar as condições mínimas que provocam uma atitude de discriminação sistemática do exogrupo em relação ao endogrupo. Para testar os efeitos da categorização sobre os comportamentos discriminatórios, Tajfel (1970) e Tajfel, Billing, Bundy \& Flament (1979) utilizaram o paradigma chamado dos grupos mínimos, ou seja, a indução experimental da clivagem de uma população em dois grupos mínimos e de importância reduzida impele os indivíduos a comportarem-se de maneira diferente para com seu grupo e para com o outro grupo.

Tajfel (1970) percebeu que normas de favoritismo em relação a membros do grupo de pertença exercem influência sobre os comportamentos. A pertença a dois grupos distintos, ao passar por uma atualização ao nível representacional, leva a uma discriminação em favor dos membros do intragrupo. Isso, de modo geral, é denominado de "sociocentrismo" e explica, de um lado, o fato de os membros de um grupo instituírem uma distinção simplificadora entre eles e os dos outros grupos e, de outro lado, os efeitos discriminatórios dessa distinção, tanto em nível dos valores como em nível dos comportamentos (Deschamps \& Moliner, 2009, p. $37)$.

A ideia de Tajfel (1970) baseia-se, neste aspecto, em considerar o processo de categorização social, que conduz os indivíduos a dicotomizar o espaço social com base na dimensão nós/eles, o que constitui a origem essencial da discriminação, pois o autor propõe uma norma de interação competitiva. No momento da repartição ou da atribuição de recursos, esta norma induziria os indivíduos a querer ganhar e, portanto, a discriminar os outros. Essa hipótese, que foi, posteriormente, abandonada por Tajfel (1970), serviu de alicerce para o desenvolvimento da teoria da identidade social, utilizada para explicar a discriminação. 


\section{Seção 2. Identidade Social por intermédio da Teoria da Identidade Social}

Os estudos sobre a identidade social, no campo de abrangência da psicologia social, encontram em Henri Tajfel um de seus principais teóricos (Galinkin \& Zauli, 2011). A definição proposta por Tajfel (1978) para identidade social inicia-se pelo autoconceito, que deriva da pertença a um ou mais grupos, associado ao valor e ao significado emocional que tal agregação traz para a pessoa. Esse autor afirma que essa definição tem como propósito abranger os efeitos da natureza e a importância subjetiva do comportamento dos indivíduos em suas relações interpessoais, mesmo admitindo os limites da definição e a complexidade da forma como o indivíduo se enxerga em relação ao ambiente físico e social (Tajfel, 1978, 1982).

A primeira parte da seção aprofundará as discussões sobre a Teoria da Identidade Social (2.1). Em segundo lugar, será abordada a identidade social no contexto do profissional (2.2). Posteriormente a seção reserva espaço para a identidade organizacional (2.3). Passa-se, então, para a distinção e integração entre os níveis de análise da identidade (2.4). E, por fim, analisam-se os estudos que tratam da identidade no contexto do trabalho e da organização com o desempenho (2.5).

\subsection{Teoria da Identidade Social}

$\mathrm{Na}$ visão da teoria da identidade social (TIS), a constituição do autoconceito do indivíduo é, em alguns aspectos, formada por uma identidade pessoal que abrange seus atributos idiossincráticos (como habilidades, jeito de ser, preferências) e, em outros, pelas identidades sociais provenientes da sua autoclassificação nos grupos nos quais se considera inserido (como nacionalidade, sexo, raça, profissão, religião) (Rocha \& Silva, 2007).

Rocha e Silva (2007) apontam para duas funções básicas dessa classificação: a primeira possibilita o ordenamento do ambiente social por intermédio de um processo de segmentação cognitiva, munindo o indivíduo de uma estrutura sistematizada para a definição do outro; e a segunda capacita o indivíduo a se estabelecer e se autodefinir diante da sociedade. A identificação social originaria, então, respostas para a pergunta: quem sou eu? (Ashforth \& Mael, 1989).

Com base nas referências da sociologia, Tajfel (1978) assume a perspectiva intergrupal da identidade social e passa a considerar a categorização como um sistema de orientação que vai auxiliar cada indivíduo a criar e definir seu lugar na sociedade. Nessa perspectiva, conforme advertem Galinkin e Zauli (2011), nenhum grupo existe sozinho, uma vez que há necessidade da presença de outros grupos e é justamente nas ligações ou nas 
comparações entre grupos que os aspectos positivos da identidade social e o engajamento na ação social ganham sentido.

A estrutura da TIS (Tajfel, 1982; 1983; Tajfel \& Turner, 1979), uma das mais importantes teorias no conjunto atual dos modelos sobre as relações intergrupais em psicologia social (Amâncio, 1993), parte da ligação de três conceitos essenciais: categorização social, identidade social e comparação social.

Categorização social é revelada como um instrumento que segmenta, classifica e ordena o ambiente social, servindo como um sistema de orientação que ajuda a criar e definir o lugar do indivíduo na sociedade. Assim, os grupos sociais contribuem para a construção da identidade social dos seus membros. A sociedade é a responsável não só pela definição, mas, também, pela criação da realidade psicológica (Tajfel, 1983). A identificação grupal é um construto cognitivo, ou um processo cognitivo básico (Galinkin e Zauli, 2011; Oliveira, 2008), que se liga à aquisição de conhecimento por intermédio da percepção do indivíduo. Disso resulta que o construto (cognitivo) identificação organizacional não é obrigatoriamente comportamental, nem necessita ser equiparado à internalização, processo individual, no qual uma pessoa se apropria dos valores e modos de conduta de outro indivíduo. Em seguida ao processo de identificação grupal, o indivíduo assume os sucessos e fracassos desse grupo, o que acarreta prazeres e sofrimentos, que são sentidos pelo indivíduo (Torres \& Pérez-Nebra, 2004).

Assim, o componente cognitivo refere-se à autocategorização e à autodefinição do sujeito, ou seja, conforme observa Fernandes, Marques e Carrieri (2009), ao instituir um senso de pertencimento a determinado grupo ou categoria social, o indivíduo tende a assumir seus protótipos e estereótipos, vindo a expressar moldes e atributos responsáveis pela caracterização e distinção de um grupo frente aos demais. Segundo esses autores, constituemse nessa dimensão as crenças, atitudes, os sentimentos e o comportamento dos seus membros, maximizando as similaridades e as diferenças entre os grupos (Adarves-Yorno, Postmes \& Haslam, 2006; Brewer \& Gardner, 2004; Hogg \& Terry, 2000; Howard, 2000; Silva, 2002; Tajfel, 1981; Turner et al, 1987). A identidade social é, em larga medida, relacional e comparativa. Neste sentido, na acepção de Tajfel (1983), "o reconhecimento da identidade em termos socialmente definidos tem várias consequências ao nível de pertença de grupo" (p.291).

A primeira dessas consequências, segundo Tajfel (1983), diz respeito a um indivíduo manter-se em um grupo e a buscar novos grupos que contribuam para alguns aspectos da sua identidade que gerem satisfação. Se ao contrário, o grupo não preencher este requisito, o 
indivíduo tenderá a abandoná-lo, a não ser que seja impossível, por razões objetivas ou, por colocar em conflito valores importantes, parte da autoimagem ser aceita socialmente. Se o abandono do grupo apresentar as dificuldades referidas, então há pelo menos duas soluções possíveis: 1) mudar a interpretação individual pessoal dos atributos do grupo, de modo que suas características indesejáveis se tornem justificáveis, ou aceitáveis por meio de reinterpretação; ou 2) aceitar a situação tal como é e empenhar-se na ação social que possa levar às mudanças desejáveis na situação (Tajfel, 1983).

Os sentimentos que os indivíduos estabelecem ao fato de pertencerem a determinado grupo social, segundo Fernandes et al. (2009), retratam o componente afetivo, incorporado ao componente cognitivo do processo de identificação. Esses autores sinalizam que a maior percepção atribuída às similaridades, equivalências, intenções e aos comportamentos, propiciadas pela comparação com outros grupos, ocasiona a tendência de o sujeito manter-se como membro do grupo que lhe proporcione uma autodefinição positiva. De outra forma, características do grupo que afetem de forma negativa a autodefinição do sujeito ocasionam o seu desligamento do grupo, passando a se condicionar pela permeabilidade dos limites do grupo social, tendo como alternativa desenvolver estruturas de aceitação (Hogg \& Terry, 2000; Reade, 2001; Tajfel, 1981).

Outra consequência do reconhecimento da identidade em termos socialmente definidos leva em conta que nenhum grupo vive sozinho em determinada sociedade; disso resulta que a reinterpretação dos atributos e o empenho na ação social só fará sentido, quando ocorrer a comparação com outros grupos. Os indivíduos, segundo a TIS, buscam uma identificação social positiva no procedimento de comparação com outros grupos. Logo, surge a necessidade de uma identidade pessoal e de uma identidade social positiva, ou seja, as pessoas procuram pertencer a grupos valorizados socialmente (Galinkin \& Zauli, 2011).

$\mathrm{Na}$ percepção do sujeito, o componente valorativo é atrelado à maneira como se estabelece a valorização de seu grupo social pelos outros grupos. A percepção pode ser positiva ou negativa, o que demonstra o valor e o prestígio do seu grupo social, bem como a crítica dos demais grupos (Fernandes et al., 2009). O componente valorativo implica na intensa motivação para os membros do grupo assumirem comportamentos causadores de uma percepção positiva (Reade, 2001; Tajfel,1981). Em vista disso, ocorre acentuada propensão de os sujeitos compartilharem valores, crenças, normas e regras dos grupos e das organizações consideradas detentoras de maior prestígio, o que poderia afetar de forma positiva a sua autoestima e autodefinição (Ashforth, 2001; Corley \& Gioia, 2004; Gioia et al., 2000; Hogg \& Abrams, 1988; Pratt \& Foreman, 2000). 
Outros entendimentos sobre a autocategorização são elaborados em fatores contextuais sociais mais imediatos que podem influenciar as autodefinições e as preocupações de identidade (Turner, 1987). O pressuposto básico é que o contexto social relevante determine que a categorização pareça mais adequada para proporcionar uma organização significativa de estímulos sociais e, portanto, que os aspectos de identidade tornem-se salientes como diretrizes para as percepções e comportamentos das pessoas que operam dentro desse contexto (Oakes 1987; Deaux \& Major, 1987). Assim, pesquisas demonstram que as pessoas percebem seus próprios e outros grupos em termos de características diferentes, dependendo de qual grupo de comparação ou domínio comparativo forneça a moldura para seus julgamentos (Doosje, Haslam, Spears, Oakes \& Koomen, 1998; Haslam \& Turner, 1992; Van Rijswijk \& Ellemers, 2001) .

As consequências sugeridas por Tajfel (1983), em relação ao reconhecimento da identidade, podem ser compreendidas de forma mais explícita. Como relata Brandão (1990), as identidades apresentam-se como representações marcadas pelo confronto com o outro. Isso, diz o autor, pressupõe a existência do contato entre as partes, a exposição, a dominação ou submissão, resultando em maior ou menor liberdade, poder ou a não construção, por conta própria, do universo simbológico e, no seu interior, daqueles que identificam e qualificam a pessoa, o grupo, a minoria, a raça, o povo. Identidades podem ser resumidas como o conhecimento social da diferença, não apenas o produto inevitável da oposição por contraste.

O último conceito pilar da TIS trata da comparação social, que se estabelece na medida em que dois ou mais indivíduos, que compartilham uma identificação social comum, consideram a si mesmos como pertencendo à mesma categoria social. As comparações sociais entre grupos baseiam-se na percepção da legitimidade das relações percebidas entre eles. Assim, a identidade social não se estabelece apenas como resultado da pertença a determinados grupos, mas, principalmente da comparação entre os grupos internos e os externos, ou seja, de "um mecanismo causal que determina as relações entre grupos" (Álvaro \& Garrido, 2006, p. 278).

Dessa forma, o conceito de identidade social está ligado à necessidade de se obter uma imagem positiva e diferente do grupo próprio, razão pela qual a percepção da ilegitimidade em uma relação transcende os limites da semelhança intergrupo no plano das comparações sociais relevantes, buscando, com isso as causas da ilegitimidade. Ou, conforme esclarece Tajfel (1983), a percepção da ilegitimidade numa relação intergrupo é social e psicológica, é a alavanca aceitável da ação de mudança social no comportamento intergrupo. 
Portanto, conforme encerra Souza (2005), a identidade social constrói-se pautada sobre inúmeras outras características estudadas pela Psicologia, no plano que se desenvolve entre estabilidade e transformação, a qual decorre do fato de que a identificação social é um processo psicológico que pressupõe primordialmente em "sentir-se identificado" (p.132) - o que pode ser considerado bastante variável de um contexto para outro.

Apesar de os componentes da TIS estarem inter-relacionados, o componente cognitivo apresenta-se como o primeiro no processo de identificação do sujeito com o grupo. Somente no momento em que o indivíduo se sente pertencente a um determinado grupo social é que os outros membros do grupo entrariam no jogo, não existindo, todavia, uma sequência entre os componentes (Van Dick, 2001).

Logo, a identificação, a categorização social e a comparação social apresentam-se como dimensões essenciais para se analisarem as relações entre grupos, bem como para a formação da identidade social, conforme estabelece a Teoria da Identidade Social (Galinkin \& Zauli, 2011). Ou seja, de acordo com Galvão (2009), existe uma reservada relação entre os processos de categorização e comparação social, na qual o papel da categorização é a concepção e a definição do lugar do indivíduo na sociedade, e a comparação estabelece um caráter de realidade objetiva a essa categorização ao se fundamentar na pertença da pessoa a um grupo concreto.

Resumidamente, a definição de identidade social articula o processo cognitivo de categorização e vinculação social, apresentando-se como a estrutura psicológica que efetua a ligação entre o indivíduo e o grupo (Baugnet, 1998). Sua importância reside no fato que sempre haverá uma conexão entre a experiência afetiva, oriunda dos relacionamentos, e a experiência cognitiva da descoberta de um sentido ao mundo, às coisas e à ação (Machado, 2003).

Diante disso, cabem algumas indagações acerca de como se estabelece a identidade, relativa ao contexto do trabalho e da organização em que o indivíduo está inserido, pois organizações e o trabalho constituem um lugar privilegiado para o entendimento das relações entre as dimensões da identidade.

\subsection{Identidade Profissional ${ }^{3}$}

A noção de trabalho apresenta-se na história da humanidade como forma de conceber o atendimento às necessidades de sobrevivência dos indivíduos, passando, nos últimos

\footnotetext{
${ }^{3}$ Nesta tese a noção de identidade no trabalho foi considerada como sinônimo de identidade profissional. Para maiores esclarecimentos as referências de Dubar (2005) e Sainsanlieu (1977) podem ser esclarecedoras.
} 
séculos, em virtude de algumas circunstâncias históricas, à forma de criar riquezas e investir no sentido econômico (Coutinho, Krawuslki \& Soares, 2007). Nesse sentido, o homem passou a ser enxergado como um elemento de força de trabalho e se viu transformado de indivíduo em trabalhador, ou seja, o trabalho passou a significar um instrumento do valor e da dignidade humana (Krawulski, 1998).

Ao desempenhar papéis, ou melhor, pelo seu exercício é que os indivíduos constroem ativamente suas identidades (Baugnet, 1998). No mesmo sentido, os papéis vinculados ao mundo do trabalho compõem uma faceta da estrutura identitária dos indivíduos, de acordo com Sainsanlieu (1995), e a empresa apresenta-se como um lugar importante para a socialização dos indivíduos que nela trabalham. A organização, para Sainsanlieu (1995), apresenta-se como uma instituição de socialização secundária, a qual, depois da escola e da família, modela atitudes, comportamentos, a ponto de produzir uma identidade profissional e social.

A identidade profissional básica, como aponta Dubar (2005), leva em consideração não somente uma identidade no trabalho, mas, também, uma projeção da pessoa no futuro, a antecipação de um caminho de emprego e a preparação de uma lógica de aprendizagem, ou melhor, de formação.

A visão de identidade profissional de Dubar (2005) é próxima da noção de identidade no trabalho de Sainsanlieu (1977), que designa modelos culturais ou lógicas de atores em organização, restando a distinção entre as duas acepções da identidade em um importante aspecto, as formas visadas não são relacionais, ou seja, as identidades dos atores em um sistema de ação são também biográficas, referindo-se às trajetórias do indivíduo no transcurso de sua vida no trabalho. Para Dubar (1994), as identidades profissionais são formas reconhecidas socialmente, em que os indivíduos identificam-se uns com os outros no espaço do trabalho e do emprego.

Ao tratar dos processos de socialização dos indivíduos no mundo do trabalho, Sainsanlieu (1995) esclarece que esses são frutos da experiência das relações de poder, vivenciadas no universo produtivo, as quais geram normas coletivas de comportamento e geram a possibilidade de construir uma identidade no trabalho, entendida como a forma de constituir um sentido para si mesmo na multiplicidade de papéis sociais, e de fazê-la ser reconhecida por seus colegas de trabalho.

Verifica-se então, que as identificações plausíveis por parte do indivíduo na organização estão vinculadas, em primeiro lugar, ao trabalho realizado, no qual se verifica que quanto maior a intensidade, maior a possibilidade de progressão profissional; em 
segundo lugar, com a empresa, resultado de um sentimento de proteção por parte do indivíduo; e, por último, formando uma identidade pretendida, por meio de uma trajetória regulada em um projeto, em que o indivíduo vislumbra para si no trabalho, ou seja, sua provável identidade (Sainsanlieu, 1995).

Os tipos de relacionamentos, para Sainsanlieu, (1995), aos quais os sujeitos estão submetidos na organização, devem ser igualmente importantes na construção das identidades no trabalho; tal aspecto geralmente é mantido numa hierarquia, que leva em conta a relação entre colegas ou com outras pessoas na empresa. Os sistemas de representação existentes nas organizações tornam-se importantes variáveis no processo de construção das identidades na esfera organizacional. Para Sainsanlieu (1995), as representações, que estão ligadas à legitimação da autoridade na organização, às finalidades do trabalho e da empresa, encontram-se entre as diretamente relacionadas com o autoconceito no trabalho.

Assim, ao examinar a identidade em um espaço com rígida estrutura hierárquica, Sainsanlieu (1977) observou que, em circunstâncias de alta dependência e de inaptidão para a oposição aos outros, colegas ou chefes, os indivíduos só conseguem interpretar sua existência de trabalho de maneira imaginária. Ocorre uma disposição de os indivíduos se diferenciarem de seus inferiores e se identificarem com seus superiores, com vistas à busca de reduzir a sua distância social. Essa identificação com os mais importantes, ou que gozam de maior poder, pode ser explicada como produto de uma avaliação permanente dos meios, de que o indivíduo dispõe para se engajar na luta à ordem estabelecida, escorando a sua diferença no sistema social no qual se insere. Entretanto, Sainsanlieu (1977) alerta que esses processos são obstáculos para o avanço e a igualdade entre pares, em face ao desejo permanente do favoritismo, que, porventura, se estabeleça entre os membros da organização, numa busca de reduzir as desigualdades e dissonâncias.

A identidade no trabalho processa-se nos níveis afetivo e cognitivo (Machado, 2003). Como o indivíduo está envolto em uma estrutura, forma-se uma espécie de mentalidade coletiva, na qual o indivíduo se conforma, assimila suas regras e normas de comportamento e, assim, estabelece vínculos afetivos com as pessoas com as quais coexiste nesse ambiente. Os significados distorcidos, portanto, são oriundos do processo de identificação por parte dos indivíduos. Isto ocorre principalmente quando no ambiente organizacional os indivíduos têm seus espaços de autonomia restringidos, momento em que existe a possibilidade de conceber os procedimentos de identificação que tenham natureza projetiva, isto é, aqueles em que o indivíduo se projeta no lugar do outro. Nessa busca, realiza-se a destituição do lugar ocupado, 
ou o de natureza introjetiva e imitativa, perante o qual o indivíduo copia o outro e busca viver a vida do outro.

Ao considerar a identidade no trabalho, notadamente em modelos organizacionais com preponderância de relações de trabalho modernas, os quais pressupõem uma determinada autonomia dos indivíduos, Sainsanlieu (1995) verificou que existe multiplicidade de modelos identitários no universo do trabalho, que se diferenciam, sobretudo, pelos tipos de socialização que os indivíduos compartilham e por suas formas de integração na empresa. $\mathrm{O}$ fato de haver diversas formas de se definir o indivíduo em relação às situações de trabalho, ou seja, dada essa variedade de lógicas, existe a possibilidade de diversos tipos de motivação afetarem os indivíduos.

A identidade pessoal e a social, quando se olha o ambiente de trabalho, pode ser construída, ao levar em conta as modalidades de experiência concretas (Dubar, 2005; Machado, 2003). Assim, Sainsanlieu (1995) sustenta que, quando os meios de reconhecimento do indivíduo como autor do resultado do trabalho não são acessíveis a não ser pelo coletivo, a julgar pela fraqueza do sujeito em sustentar sozinho uma relação de desafio, a racionalidade só é acessível quando ocorre certo grau de fusão entre os desejos realizados por meio dos processos de identificação projetiva recíproca entre os pares. No momento em que cada indivíduo dispõe de meios suficientes para obter por conta própria o reconhecimento de suas ações pelos outros, ocorre a conciliação individual do desejo, da reflexão e da ação, a ponto de edificar uma lógica pessoal e particular.

A identidade no trabalho, ou sua constituição, não está desvinculada de interesses pessoais e coletivos, que estão em constante articulação no seio das organizações. Diversos arranjos sociais se desdobram, com suas características e dinâmicas peculiares, permeando a memória dos membros da organização. Ocorre uma seleção, por parte dos indivíduos, daqueles relacionamentos que formarão parte de seu universo relacional, para que, a partir daí, estabeleçam as experiências e os relacionamentos com os quais enfrentarão as pressões pela conquista de espaços de poder na organização (Machado, 2003).

A identidade no trabalho constitui um importante elemento do processo motivacional, que converge para a construção de uma autoestima positiva. Essa constatação não se vincula apenas à realização do trabalho, mas, também, ao domínio social organizacional, o qual é positivamente afetado, levando a maneiras mais criativas de se realizar o trabalho, que integram a subjetividade, a socialização e o trabalho (Machado, 2003), com vistas a serem obtidos melhores desempenhos (Van der Zee, Atsma, \& Brodbeck, 2004). 
O papel da identidade social em sua vertente profissional ou no trabalho tem sido apresentado em pesquisas com vistas ao seu efeito em equipes interprofissionais (Nishii \& Mayer, 2009), havendo evidências de impacto dessa identidade no desempenho de equipes demograficamente diversas (Van Knippenberg \& Schippers, 2007; Van Dick et al, 2008), bem como de influência da identidade profissional na interação interprofissional (Fitzgerald \& Teal , 2003; Helmreich \& Schaefer , 1994), sugerindo mérito na investigação da influência da identidade, vinculado ao desempenho no trabalho (Mitchell, Parker \& Giles, 2011).

Na visão de Machado (2003), existe a força dos processos de categorização na organização, que colaboram para maior consolidação da identidade no trabalho, resultando em sentimentos de vinculação e diferenciação, que favorecem uma visão simbólica do indivíduo como integrante de um espaço imaginário maior na organização. Nesse ambiente, concomitantemente, ocorre um fenômeno responsável pela ligação psíquica do indivíduo à organização, ou seja, a identidade organizacional.

\subsection{Identidade Organizacional}

A Identidade organizacional tornou-se um campo de investigação cada vez mais importante para alguns estudiosos (Brown, 2006; Corley et al., 2006) e também uma questãochave para os gestores (Cheney, 1991). Desde o trabalho seminal de Albert e Whetten (1985), o interesse em identidade no nível da organização tem sido acompanhado por um vigoroso foco no coletivo, em particular, nos eus organizacionais e suas implicações para a teoria e a prática (He \& Brown, 2013). O reconhecimento atual da identidade organizacional torna-se fundamental para o entendimento de questões que levam em consideração a mudança estratégica (Ravasi \& Phillips, 2011), a tomada de decisão (Riantoputra, 2010), os conflitos internos (Humphreys \& Brown, 2002), a comunicação (Fombrun, 1996), a interpretação e edição de resposta (Dutton \& Dukerich, 1991; Gioia \& Thomas, 1996), e fundamental para a teorização de questões centradas na legitimidade (He \& Baruch, 2010; Sillince \& Brown, 2009), bem como no desempenho (Ashforth et al., 2008; Riketta, 2005; Rao, Monim, \& Durand, 2003; Smith, 2011).

Buscando explicar essa tendência, estudiosos como Ashforth \& Mael (1996, p. 4) e Polzer (2000, p. 628) apontam para a utilidade do conceito de identidade nos níveis de pontes de análise, ligação, estruturas e processos de nível micro e nível macro e, assim, coerentes fios de outra forma díspar de pesquisa baseada em organização. Em última análise, existe um consenso emergente de que é "porque a identidade é problemática e ao mesmo tempo tão crítica que a dinâmica da identidade precisa ser melhor compreendida" (Albert, Ashforth, \& 
Dutton, 2000, p. 14).

A identidade organizacional abrange o processo, a atividade e o acontecimento em que a organização se torna presente na mente de seus integrantes (Scott \& Lane, 2000), compreendendo as crenças compartilhadas pelos sujeitos da organização sobre o que é fundamental, o que a distingue e é duradouro (Whetten \& Godfrey, 1998). Sua constituição é realizada todos os dias, quando o indivíduo vai internalizando a crença de que a organização de pertença é a mesma que era no passado, simbolizando a sua existência temporal (Machado, 2003).

Albert e Whetten (1985) ressaltam que a identidade organizacional tem três dimensões: (1) a definida pelos membros da organização, que é a central; (2) a que distingue a organização de outras; e (3) a que é percebida como traço contínuo, ligando o passado ao presente. Entretanto, não foram claros os critérios para a especificação dessas afirmações, reconhecendo esses autores que as organizações podem ser caracterizadas por múltiplas identidades e que as reivindicações das identidades são, muitas vezes, atos políticos, podendo ser ambíguas, complementares, não relacionadas e contraditórias (He \& Brown, 2013).

Fernandes e Zanelli (2006) mostram que toda organização é composta por ritos, crenças, valores, rituais, normas, rotinas e tabus, que contribuem para a formação da identidade profissional de seus trabalhadores. Quando essa composição é apresentada aos funcionários, o que se pretende, em linhas gerais, é buscar a sua identificação com os padrões a serem seguidos na instituição. Segundo Machado (2003), os interesses pessoais e coletivos estão vinculados ao processo de construção das identidades, que passam por constantes articulações no ambiente organizacional. Sendo assim, verifica-se que os arranjos sociais das organizações permeiam a memória de seus indivíduos, os quais selecionam os relacionamentos que constituirão o universo relacional, com o objetivo de construir as experiências e os relacionamentos que irão fazer frente às pressões que objetivam aumentar os espaços de poder organizacional. O processo motivacional sofre, então, influência direta da identidade no trabalho, colaborando para o surgimento de uma autoestima positiva. A identidade no trabalho constitui, dessa forma, componente importante no processo motivacional, que concorre também para a construção de uma autoestima positiva. Como consequência, têm-se melhorias na realização do trabalho, bem como na esfera social da organização, o que pode gerar inovação e criatividade laborais, importantes para a integração da subjetividade, o processo de socialização e o trabalho em si.

Assim, percebe-se que os processos de categorização no ambiente da organização exercem forte influência e contribuem para concretizar a identidade no trabalho, 
reconhecendo que tais processos derivam em sentimentos de vinculação e diferenciação, que estimulam uma visão simbólica do indivíduo como integrante de um espaço imaginário maior na organização, conforme observado por Tajfel (1983). Disso, surge a identidade organizacional, fenômeno que une o indivíduo à organização.

No que se refere à vida organizacional, Faria (2000) observa que somente se pode aprender e analisar se for utilizado um processo interacionista. $\mathrm{O}$ ambiente não determina $\mathrm{O}$ ser da organização e tampouco é o indivíduo da organização que define o ambiente, porém é na relação entre ambiente e indivíduo que se determina o que, como e por que da organização.

Ao se tratar do ambiente da organização em si, como formador da identidade, Fernandes e Zanelli (2006) percebem nuances do processo, ao identificarem que indivíduos com características distintas unem-se ao ingressarem em uma organização, atuando em um mesmo sistema sociocultural, sempre à procura de objetivos determinados. O que, por fim, resulta no compartilhamento de hábitos, crenças, valores, entre outros, que servirão como suporte de orientação de ações dentro do contexto organizacional, definindo assim as suas identidades.

Na definição proposta por Hatch e Schultz (1977), a identidade organizacional referese a um produto reflexivo do processo dinâmico da cultura organizacional. A cultura disponibiliza o material simbólico em que as imagens são construídas e comunicadas. Ao relacionar cultura, identidade e imagem, os autores expõem que a experiência de trabalho dos sujeitos da organização e a visão da capacidade de liderança dos níveis estratégicos da organização são os elementos determinantes. Contudo, para esses autores, a identidade organizacional recebe influências externas, por intermédio do processo de formação de imagens.

Para Machado (2003), enquanto a identidade é associada à visão interna na empresa, a imagem está ligada também a uma visão externa. Por isso, qualquer desgaste da imagem pode constituir um risco para a identidade organizacional. Por outro lado, a imagem está associada à identidade corporativa (Gioia et al., 2000).

Ao discutir a identidade organizacional, a identificação está presente, pois, conforme concebe Pratt (2000), não existe identidade sem identificação. A identificação é estabelecida sob identidades projetadas, especialmente em termos de aspirações pessoais, que constituem a ligação mental entre os elementos e a companhia, buscando uma vinculação e ratificação do desejo de afiliação, na medida em que a realização dos desejos está atrelada à vinculação organizacional. Identidade e identificação são termos que se deslocam facilmente entre os 
diferentes níveis de análise, transmitindo, simultaneamente especificidade e unicidade (de uma organização, grupo ou indivíduo), e permitindo a indefinição, a multiplicidade, a dinamicidade e o processo de identidade (Albert et al., 2000).

A complexidade da identidade organizacional está vinculada à multiplicidade de identidades dos indivíduos, bem como à forma de interação dessas identidades, que abrange as crenças compartilhadas pelos indivíduos da organização sobre o que é central, o que a diferencia e o que é duradouro na organização (Machado, 2003, p. 61).

Machado (2003), ao analisar a identidade organizacional, afirma que a partir da ação e da interação é que se formam às identidades. A todo instante, portanto, realizar e pertencer são condições para que os processos de identificação sejam desencadeados e provoquem estímulos, novas descobertas e modos de realizar as atividades, transformando o espaço organizacional em importante local para a potenciação das existências. Desse modo, o grupo, o trabalho e a organização passam a constituir as bases centrais de representação do eu para o indivíduo.

Assim, a identidade organizacional remete o indivíduo ou os indivíduos ao vivido e à subjetividade, orientando suas ações, construídas pelas dinâmicas das interações sociais, pelo processo de identificação e por suas afiliações. Dessa forma, no ambiente organizacional, a identidade é constituída pelo indivíduo, pelo grupo e pela organização.

\subsection{Distinção e Integração entre os Níveis de Análise da Identidade}

A identidade apresenta níveis que se ligam a um autoconceito formado pelo indivíduo e que resultam em influências nas esferas pessoal, social, no trabalho e na organização. Isso faz emergir múltiplas identidades construídas concomitantemente, o que colabora para a complexidade desse fenômeno (Machado, 2003). Entretanto, é possível destacar e delimitar fronteiras entre cada uma das categorizações e, assim, verificar o impacto de cada uma delas. Machado (2003) reuniu os aspectos principais de cada uma das abordagens (pessoal, social no trabalho e organizacional, conforme Tabela 10), apresentando suas diferenças. Apesar de os níveis estarem centrados na conformação do self, sua manifestação ocorre de maneiras diversas, em momentos específicos, bem como leva em consideração a variedade de relacionamentos presentes em todas as identidades, fundamental aos processos cognitivos e afetivos, imperiosos para uma coerência identitária (Machado, 2003). 


\section{Tabela 10}

Diferenciação entre os níveis de estudo da identidade segundo Machado (2003, p. 64)

\begin{tabular}{|c|c|c|c|c|}
\hline $\begin{array}{l}\text { Tipo de } \\
\text { Identidade }\end{array}$ & Pessoal & Social & $\begin{array}{l}\text { Identidade no } \\
\text { Trabalho }\end{array}$ & $\begin{array}{l}\text { Identidade } \\
\text { Organizacional }\end{array}$ \\
\hline $\begin{array}{l}\text { Objeto de } \\
\text { Estudo }\end{array}$ & $\begin{array}{l}\text { A construção do } \\
\text { autoconceito ao } \\
\text { longo da vida do } \\
\text { sujeito. }\end{array}$ & $\begin{array}{l}\text { A construção do } \\
\text { autoconceito pela } \\
\text { vinculação a } \\
\text { grupos sociais. }\end{array}$ & $\begin{array}{l}\text { A construção do eu } \\
\text { pela atividade que } \\
\text { realiza e pelas } \\
\text { pessoas com as } \\
\text { quais tem contato } \\
\text { no trabalho. }\end{array}$ & $\begin{array}{l}\text { A construção do } \\
\text { conceito de si } \\
\text { mesmo vinculado à } \\
\text { organização na } \\
\text { qual trabalha. }\end{array}$ \\
\hline $\begin{array}{l}\text { Meios de } \\
\text { Construção }\end{array}$ & $\begin{array}{l}\text { Diversos } \\
\text { relacionamentos } \\
\text { sociais, em } \\
\text { diferentes esferas, } \\
\text { bem como } \\
\text { desempenho de } \\
\text { papéis. }\end{array}$ & $\begin{array}{l}\text { Interação a grupos } \\
\text { sociais com } \\
\text { finalidades } \\
\text { diversas. }\end{array}$ & $\begin{array}{l}\text { Interação com a } \\
\text { atividade e com as } \\
\text { pessoas no } \\
\text { trabalho. }\end{array}$ & $\begin{array}{l}\text { Interação com uma } \\
\text { instituição (com } \\
\text { seus valores, } \\
\text { objetivos, missão e } \\
\text { práticas). }\end{array}$ \\
\hline $\begin{array}{l}\text { Período de } \\
\text { Ocorrência }\end{array}$ & $\begin{array}{l}\text { Permanente, } \\
\text { ocorrendo em } \\
\text { todas as fases da } \\
\text { vida. }\end{array}$ & $\begin{array}{l}\text { Permanente na } \\
\text { vida do indivíduo. }\end{array}$ & $\begin{array}{l}\text { Na juventude, na } \\
\text { idade adulta até a } \\
\text { aposentadoria. }\end{array}$ & $\begin{array}{l}\text { A partir da } \\
\text { juventude, } \\
\text { enquanto estiver } \\
\text { vinculado a alguma } \\
\text { instituição. }\end{array}$ \\
\hline $\begin{array}{l}\text { Espaços de } \\
\text { Construção }\end{array}$ & $\begin{array}{l}\text { Múltiplos } \\
\text { relacionamentos e } \\
\text { papéis. }\end{array}$ & Múltiplos grupos. & $\begin{array}{l}\text { Múltiplas } \\
\text { atividades e grupos } \\
\text { profissionais. }\end{array}$ & $\begin{array}{l}\text { Pode ocorrer em } \\
\text { uma ou em } \\
\text { múltiplas } \\
\text { organizações. }\end{array}$ \\
\hline Finalidades & $\begin{array}{l}\text { Conformação do } \\
\text { eu, em direção ao } \\
\text { processo de } \\
\text { individuação. }\end{array}$ & $\begin{array}{l}\text { Orientar e } \\
\text { legitimar a ação, } \\
\text { por meio do } \\
\text { reconhecimento e } \\
\text { da vinculação } \\
\text { social. }\end{array}$ & $\begin{array}{l}\text { Contribuir para a } \\
\text { formação da } \\
\text { identidade pessoal } \\
\text { e atuar como fator } \\
\text { motivacional. }\end{array}$ & $\begin{array}{l}\text { Incorporar as } \\
\text { instituições no } \\
\text { imaginário, de } \\
\text { forma a orientar } \\
\text { ações nessas } \\
\text { organizações. }\end{array}$ \\
\hline
\end{tabular}

Como pode ser observado na Tabela 10, cada um dos níveis que define a identidade, apresenta particularidades; entretanto, podem-se verificar complementaridades, resultando que a constituição da identidade pessoal, por intermédio do grupo, do trabalho ou da organização envolve a todo momento construção e desconstrução, a julgar pela mobilidade, dinamicidade e complexidade do contexto social, conforme descreve Machado (2003).

A TIS tem sido largamente aplicada para explicar as relações entre o empregado e a organização (Ashforth et al., 2008; Ashforth \& Mael, 1989; Dutton et al., 1994; Hogg \& Terry, 2001). A organização atua como uma categoria social potencialmente saliente (He \& Brown, 2013) com a qual os indivíduos podem desenvolver identificação (Ashforth \& Mael, 1989; Hogg \& Terry, 2000). A identificação organizacional estabelece-se quando os 
colaboradores consideram a unidade com uma organização empregadora e sentem-se pertencentes a ela (Ashforth \& Mael, 1989), definindo-se como um membro da organização (Ashforth \& Mael, 1989). Sendo assim, a identificação organizacional apresenta uma capacidade potencial de gerar no colaborador da organização uma série de resultados positivos, como, por exemplo, baixa intenção de rotatividade, comportamento de cidadania organizacional, satisfação dos indivíduos e bem-estar, além de impactar positivamente no desempenho dos funcionários (Ashforth et al, 2008; Riketta , 2005, He \& Brown, 2013).

Dessa maneira, a concepção do autoconceito, levando em consideração a ideia de grupo, reunindo o trabalho e as organizações, fundamenta-se em fases gradativas, elaboradas sobre processos de identificação, originalidade e conformação, permeados pela cognição e pela emoção, conforme apresentado na Figura 12. O resultado, segundo Machado (2003), é que o indivíduo identifica-se com o grupo ou os grupos a que pertence, com o trabalho que realiza e com a organização da qual faz parte. Esses elementos relacionam-se na configuração da autorrepresentação do indivíduo. Ademais, a organização reflete o trabalho realizado em seu interior, bem como os grupos que a compõem. O grupo ou grupos podem ser reconhecidos pela imagem do trabalho que executam; o trabalho, por sua vez, também engloba o imaginário do grupo.

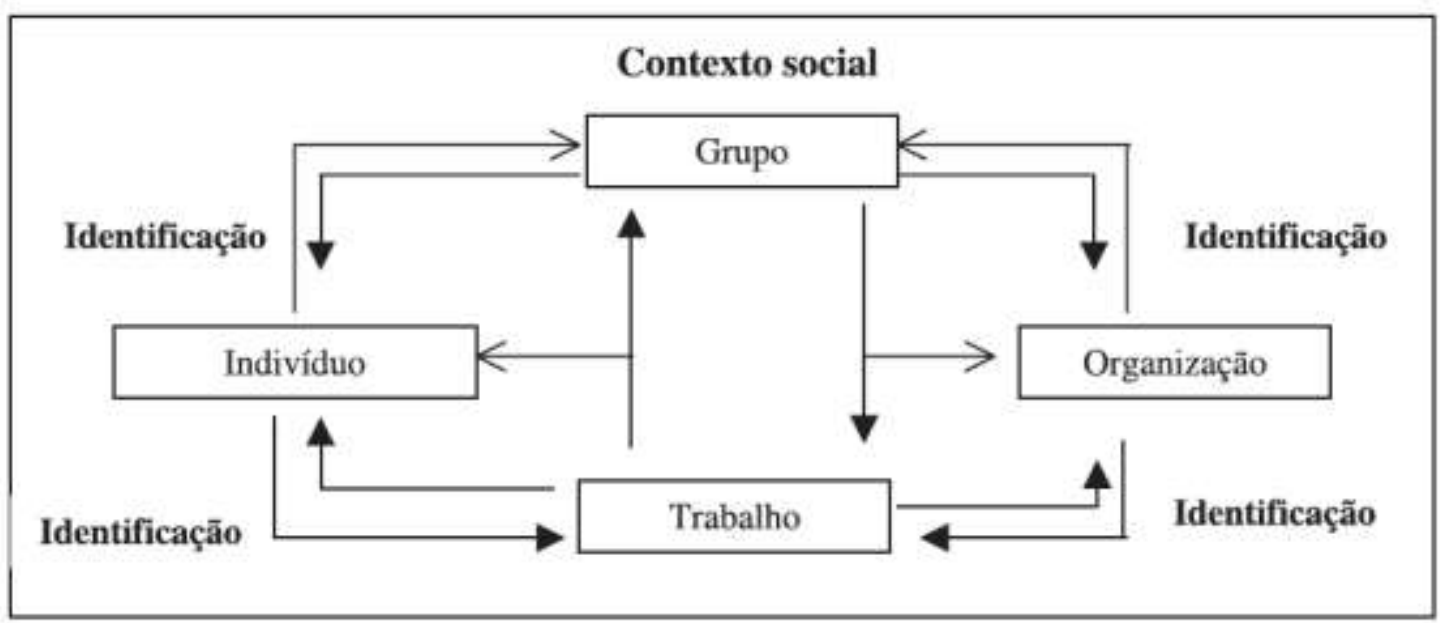

Figura 12. Interação entre os níveis de estudo da identidade (Machado, 2003, p. 65).

Quando se leva em consideração o contexto organizacional, a ação e a interação são as responsáveis por moldar as identidades. As condições para o desencadeamento dos processos de identificação (Pratt, 2000), de geração de estímulos, de novas descobertas e maneiras de concretizar as atividades (Machado, 2003), passam pelo pertencimento e realização, o que acarreta a transformação do espaço organizacional em um importante campo para potenciação das existências. 
Por essa forma de compreensão, o grupo, o trabalho e a organização constituem-se como bases centrais de representação do eu para o indivíduo (Ashforth \& Mael, 1989; Erickson, 1972; Machado, 2003; Pratt, 200; Dubar, 2005, 2009; Scott \& Lane, 2000; Tajfel \& Turner, 1979). Por fim, quanto maior o reconhecimento do indivíduo em todas as esferas, ou seja, no trabalho desempenhado, no grupo ou na organização de pertença, maior é a força desses elementos na constituição do conceito de si (Dubar, 2005; Machado, 2003; Oliveira, 2008; Van Der Zee et al., 2004).

Em resumo, para esta tese, a identidade será entendida numa perspectiva social, em que se articula o processo cognitivo de categorização e vinculação social, apresentando-se como estrutura psicológica que efetua a ligação entre o indivíduo e o grupo (Baugnet, 1998), A importância dessa definição, respaldada na TIS (Tajfel, 1978), reside na conexão entre a experiência afetiva proveniente dos relacionamentos e a experiência cognitiva da descoberta de um sentido ao mundo, às coisas e à ação (Machado, 2003).

A identidade profissional será compreendida como o modo de elaborar um sentido para si na pluralidade de papéis sociais, bem como em seu reconhecimento pelos outros indivíduos no contexto do trabalho (Sainsanlieu, 1995), ou seja, baseada na configuração eunós vinculada ao campo das atividades de trabalho (Dubar, 2005). No que se refere à identidade organizacional, essa será entendida como a expressão das percepções dos indivíduos sobre o significado da organização. 


\section{Seção 3. Estudos Empíricos}

Analisa-se, nessa seção, os estudos que tratam da identidade no contexto do trabalho e da organização com o desempenho (3.1).

\subsection{Relações entre Identidade Profissional e Organizacional e Desempenho}

Compreender o impacto da identidade no contexto profissional e organizacional, bem como da identificação indivíduo-organização sobre o desempenho dos colaboradores é uma questão primordial para a pesquisa (He \& Brown, 2013; Mitchell et al, 2011). Algumas metaanálises mostraram que há relação positiva de moderação entre identidade e desempenho do indivíduo no trabalho (Riketta, 2005; van Knippenberg, 2000; van Knippenberg \& Van Schie, 2000; He \& Brown, 2013). De fato, alguns estudos recentes sobre identificação organizacional têm demonstrado relação positiva da identidade sobre o desempenho tanto nas tarefas quanto no trabalho (Walumbwa, Avolio, \& Zhu, 2008; Weiseke, Ahearne, Lam \& Von Dick, 2008).

O cenário atual de pesquisas tem analisado o impacto da identidade no contexto do trabalho e da organização sobre o desempenho dos colaboradores, seja de um funcionário específico, seja de comportamentos relacionados ao desempenho (Chen, Chi \& Friedman, 2013; He \& Brown, 2013, Mitchell et al., 2011; Smith, 2011). Entre esses estudos, ressaltamse os que envolvem um efeito positivo da identidade na criatividade dos funcionários (Hirst, van Dick, \& van Knippenberg, 2009; Madjar, Greenberg, \& Chen, 2011), acarretando maior propensão dos funcionários a dedicar mais esforço criativo, portanto, maior criatividade, ao seu trabalho, devido ao alinhamento entre os seus próprios interesses e o interesse da organização. Nesse contexto, se a organização possuir valores e práticas organizacionais que incentivem a inovação, já que esses são antecedentes da formação da identidade (Hall, Schneider, \& Nygren, 1970; D’Iribarne, 1980; Pratt, 1998), ocorrerá um impacto positivo no desempenho desse trabalho (Van der Zee et al., 2004; Riketta, 2005; He \& Brown, 2013). Da mesma forma, Lipponen, Bardi e Haapamaki (2008) mostraram que a identificação organizacional interage com os valores pessoais de abertura à mudança na previsão de comportamento inovador entre os funcionários. Outros estudos, menos frequentes, são os que tratam das implicações entre identificação organizacional e desempenho financeiro, especificamente sobre o efeito positivo da identificação, agregado ao nível organizacional no desempenho financeiro (Homburg, Wieseke \& Hoyer, 2009; Weiseke et al., 2008), demonstrando o papel central que a identidade apresenta no contexto do trabalho e da organização. 
Equipes organizacionais são contempladas nos estudos que investigam o impacto da identidade social sobre o desempenho (Van Knippenberg \& Schippers, 2007; Van Dick et al., 2008). As investigações realizadas por Van der Zee et al. (2004) mostram que equipes formadas por indivíduos de contextos culturais diversos, que compartilharam e constituíram uma identidade com seu grupo de pertença, apresentaram melhor desempenho em comparação aos grupos em que a formação da identidade não ocorreu ou demorou a ocorrer. Estudos anteriores também demonstraram que a identidade profissional pode influenciar a interação interprofissional (Fitzgerald \& Teal, 2003; Helmreich \& Schaefer, 1994), o que acarreta melhor desempenho. Isso pode ser verificado no trabalho de Morash e Haarr (2012), sobre a variação de gênero na identidade profissional em policiais e sua influência no desempenho. Assim, a incorporação da diversidade na identidade organização reflete a adoção de um valor social favorável (Cole \& Salimath, 2013; Richard, Murthi \& Ismail, 2007), propondo, então, que os efeitos da diversidade exerçam interação no conhecimento e na identidade relacionada a influenciar o desempenho (Van Knippenberg et al. , 2004).

Outra temática na literatura sobre identidade é a que trata da centralidade do controle das identidades sociais, apresentando-se, na visão de Karreman e Alvesson (2004), como uma questão central para as organizações. Na visão desses autores, duas formas de controle são relacionadas no contexto organizacional. A primeira diz respeito ao controle tecnocrático, que abrange o aparato burocrático, ou seja, as questões ligadas à hierarquia, divisão e padronização das tarefas, aferição do desempenho, com vistas a controlar o comportamento dos sujeitos. A segunda versa sobre o controle social-ideológico, responsável pela manipulação de valores significados e ideias por meio do controle das identidades sociais, evidenciando a dimensão do poder subjacente à questão da identidade, segundo referenciado pelos estudos culturais (Martins, 2013).

Múltiplas identidades têm se destacado no cenário acadêmico, com uma recente necessidade de mais investigações sobre essa temática (Ashforth, Harrison \& Corley, 2008; George \& Chattopadhyay, 2005; van Knippenberg \& van Schie, 2000). Os estudos conduzidos por Chen et al. (2013) exploram os efeitos conjuntos de dupla identificação sobre os resultados organizacionais (por exemplo, satisfação no trabalho, desempenho). A questão das identificações duplas ou múltiplas ganha, cada vez mais, relevo nas investigações (Riketta, 2005). Em alguns casos, a preocupação tem sido com múltiplas identidades dentro das organizações (por exemplo, grupos de trabalho e departamentos; Riketta \& van Dick, 2005), enquanto, em outros casos, a preocupação incide na tensão entre identidades intraorganizacionais e extraorganizacionais (por exemplo, identidades dos funcionários como 
funcionários da empresa e como sindicalistas; Angle \& Perry, 1986). Chen et al. (2013) focaram, entre outros aspectos, no potencial de identificação com o local de trabalho para ampliar ou diminuir a influência das identificações com o empregador sobre as atitudes relacionadas com o trabalho e desempenho no trabalho. Assim, Chen et al. (2013) concentraram-se em estudar os efeitos moderadores da identificação da organização e dos diversos departamentos sobre o impacto da identificação empregando-empresa. A identidade de uma organização reflete seus atributos centrais e distintivos, incluindo seus principais valores, a cultura organizacional, modos de desempenho, e seus produtos (Elsbach \& Kramer, 1996).

Por fim, a revisão elaborada por He e Brown (2013) evidencia que o impacto relativamente moderado da identificação organizacional sobre o desempenho do empregado pode sugerir algumas condições de contorno relevantes para este relacionamento. Entretanto, os autores sinalizam para a escassez de pesquisas que examinam os fatores moderadores sobre essa relação, que podem ser relacionados com a pessoa ou como contexto (cultura da organização).

Para He e Brown (2013), Mitchell et al. (2011), Xenikou (2011), Riketta (2005), existe um impacto positivo no desempenho com indivíduos que apresentam alta identificação organizacional e profissional, em virtude do maior esforço, mesmo que a capacidade para fazer seja inexistente. Portanto, os potenciais moderadores podem, na visão de $\mathrm{He}$ e Brown (2013), estar relacionados com (1) o grau em que os colaboradores acreditam que o seu próprio desempenho pode fazer a diferença para o desempenho global da organização, e (2) a medida em que os indivíduos são (ou pensam que são) capazes para oferecerem o melhor desempenho no trabalho.

\section{Conclusões do Capítulo III}

Os estudos sobre identidade no campo do comportamento humano no trabalho vêm passando por transformações ao longo do tempo. A identidade, que era tratada como remetendo a características de essência, de imutabilidade, algo fixo e duradouro, parece ter se esgotado, como foi discutido no capítulo. O novo paradigma passa a tratar a identidade como algo transitório, dinâmico, que é constantemente construído e desconstruído.

Neste capítulo, foram abordados aspectos históricos e conceituais da noção de identidade. Para tanto, os níveis (pessoal e social) de estudo da identidade foram abordados, bem como as definições e os limites conceituais de cada uma das abordagens. Posteriormente, reservou-se espaço especial para a Teoria da Identidade Social, que 
referenciará os estudos posteriores desta tese. Em seguida, a identidade social foi retratada em duas vertentes ligada ao contexto do trabalho e da organização, a identidade no trabalho e a identidade (identificação) organizacional. Uma seção cuidou de relacionar os diferentes níveis da identidade, apresentando similaridades e diferenças, bem como a interação entre seus níveis (pessoal, social, no trabalho/profissional e organizacional). Por fim, uma revisão da literatura mostrou os principais estudos publicados no Brasil e no exterior que tratavam das relações entre identidade no contexto do trabalho e das organizações.

A análise dos estudos revisados permitiu concluir que, em geral, a categoria identidade, seja no contexto do trabalho, seja no contexto da organização, relacionada ao desempenho no trabalho, foi pouco estudada por pesquisadores com formação em psicologia ou administração. Contudo, os estudos mostraram a importância da identidade como variável moderadora do desempenho no trabalho, além de indicar a relevância das investigações sobre identidade no que se refere aos valores e às práticas da organização, bem-estar, comprometimento e desempenho, para os indivíduos e grupos sociais. 
PARTE 1

ANÁLISE TEÓRICA E CONCEITUAL

\section{CAPITULO I:}

Desempenho no Trabalho e Desempenho por Competências

Seção 1: Desempenho no Trabalho

Seção 2: Desempenho por Competências

\section{CAPITULO II}

Cultura Organizacional

Seção 1: Cultura, Cultura Nacional e Cultura Organizacional

Seção 2: Valores Organizacionais

Seção 3: Práticas Organizacionais

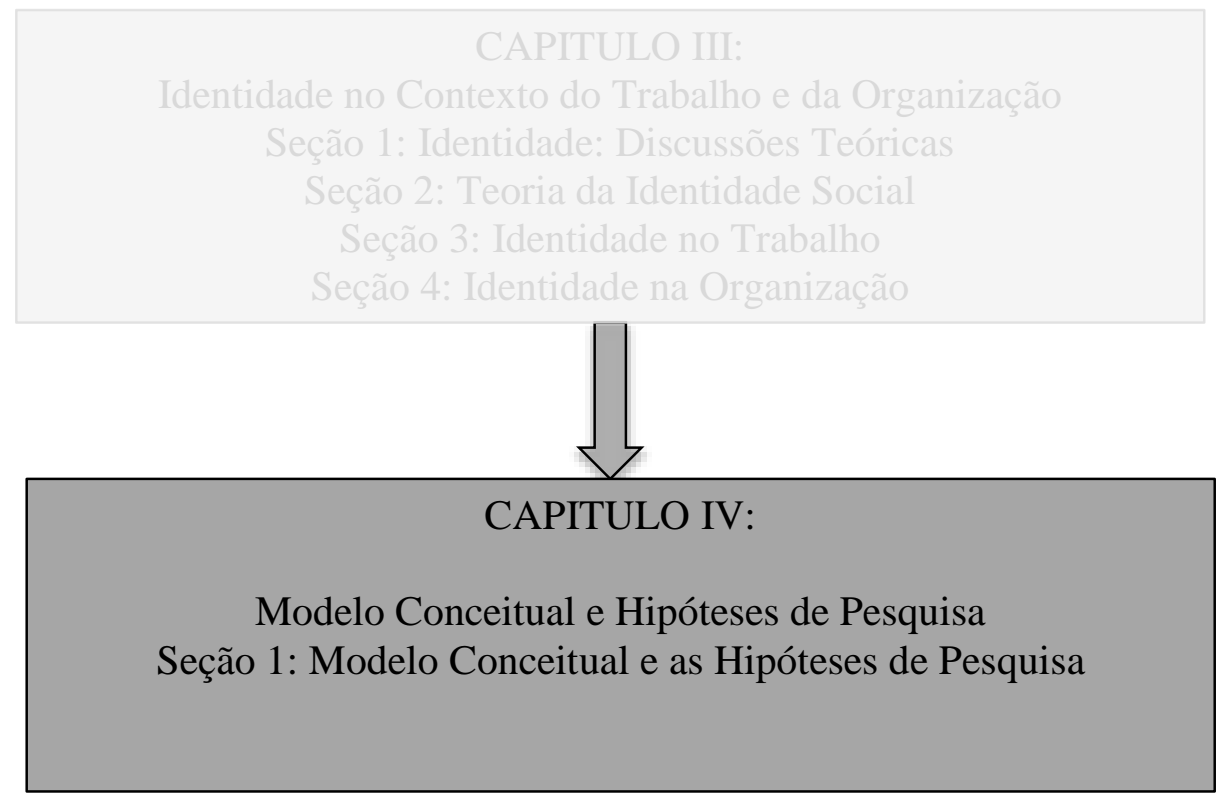




\section{CAPÍTULO IV. MODELO CONCEITUAL E HIPÓTESES DE PESQUISA}

\section{Introdução ao Capítulo IV}

O objetivo principal desta pesquisa é examinar as relações preditivas entre valores organizacionais, práticas organizacionais, identidade profissional e organizacional sobre o desempenho profissional por competências do policial. Para tanto, a ampla revisão da literatura, tanto brasileira quanto internacional, serviu de alicerce para a construção de um modelo integrador, que contém as relações hipotetizadas para a pesquisa.

O marco teórico desenvolvido possibilitou identificar variáveis, que influenciam o desempenho, relacionadas ao contexto, à tarefa e ao indivíduo (idade, nível de escolaridade, tempo de serviço, por exemplo). Além disso, o modelo permitiu clarificar os conceitos sobre o desempenho profissional por competências e possibilitou a seleção e integração de variáveis antecedentes do modelo conceitual para a predição do desempenho no serviço policial. A partir dessa etapa, foram identificadas as hipóteses teóricas do estudo.

Assim, nesse capítulo serão apresentados o modelo conceitual e as hipóteses de pesquisa. Essas hipóteses desenvolvem-se sobre as relações entre o modelo principal construído (efeitos diretos, indiretos e mediadores) e as suposições sobre os efeitos das variáveis individuais (efeitos diretos e mediação).

\section{Seção 1. Modelo Conceitual e Hipóteses de Pesquisa}

Essa seção apresentará o processo de desenvolvimento do modelo conceitual (1.1) e as hipóteses de pesquisa (1.2). O modelo proposto apresenta os fatores que, advindos da base conceitual, podem ser considerados como influenciadores do desempenho profissional por competências do trabalho policial, possibilitando o estudo dos efeitos das variáveis antecedentes (valores, práticas e identidade), além das sociodemográficas.

\subsection{Construção do Modelo Conceitual}

O modelo conceitual é construído levando-se em consideração que o desempenho por competências é antecedido pelas seguintes variáveis: valores organizacionais, práticas organizacionais, identidade profissional e organizacional. Essas variáveis serão mensuradas: pela escala de valores organizacionais, desenvolvida por Porto et al. (2012), construída com base no modelo de valores humanos de Schwartz (1999); pela escala de manifestações culturais (pelas práticas organizacionais), construída por Souza (2014), fundamentada nos estudos de D’Iribarne (1989); pela escala de identidade profissional, adaptada de Cameron 
(2004), construída baseada na Teoria da Identidade Social (Tajfel, 1981); e pela escala de identidade organizacional, desenvolvida por Mael e Ashforth (1992), com vários modelos de predição do desempenho e variáveis identificadas em pesquisas anteriores.

$\mathrm{Na}$ revisão da literatura, identificaram-se variáveis que podem influenciar o desempenho profissional por competências. Além das variáveis antecedentes, acima mencionadas, o modelo contemplará variáveis sociodemográficas como preditoras do desempenho, conforme mostrado por pesquisas anteriores (Albuquerque, 2004; Bedani, 2009; Coelho Jr., 2009; Coelho Jr. \& Borges-Andrade, 2011a; Coelho Jr. \& Borges-Andrade, 2011b; Judge et al., 2002; Salgado, 2003; Santos, 2012; Tett \& Burnett, 2003; Tett, Jackson \& Rothstein, 1991; Vasconcelos, 2005).

O modelo conceitual, formulado com base nos referenciais teóricos e empíricos revisados, possui os componentes dispostos na Figura 13.

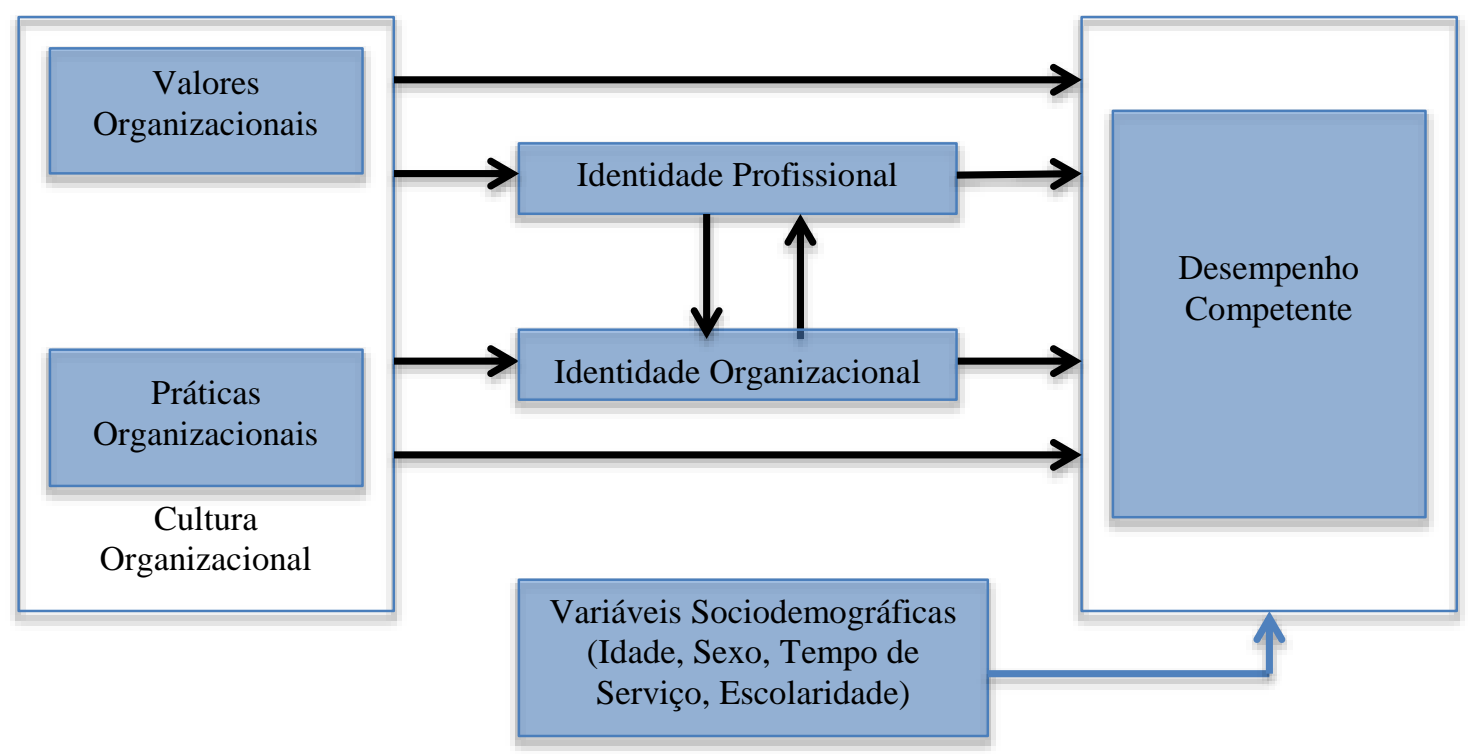

Figura 13. Modelo Conceitual

O quadro geral apresentado pela Figura 13 é o resultado da revisão de literatura, em que as variáveis antecedentes (valores e práticas organizacionais) impactam o desempenho profissional por competências. Cabe salientar que a identidade profissional e organizacional serão analisadas não só como antecedentes do desempenho, mas também, como variáveis mediadoras da relação entre os valores e as práticas organizacionais e o desempenho profissional por competências. Por fim, a essas variáveis incorporam-se o modelo conceitual e as variáveis sociodemográficas.

A seção seguinte apresentará as hipóteses de pesquisa, especificando-se as relações entre os diferentes construtos identificados. 


\subsection{Hipóteses de Pesquisa}

Nessa seção serão apresentadas as hipóteses de pesquisa que distinguem as hipóteses relativas às variáveis preditoras principais do modelo e, posteriormente, as variáveis sociodemográficas. Por fim, o modelo conceitual geral é apresentado com as hipóteses referenciadas.

\subsubsection{Hipóteses relativas às variáveis principais}

O interesse, nesse momento, recai sobre as variáveis centrais do modelo e suas relações com o desempenho profissional por competências.

Efeito da cultura organizacional sobre o desempenho profissional por competências

Nesse ponto, serão construídas as hipóteses levando-se em conta o efeito da cultura organizacional, por meio dos valores organizacionais e das práticas organizacionais, sobre o desempenho profissional por competências no serviço policial. Conforme visto, a cultura organizacional é definida, nessa tese, como os pressupostos básicos compartilhados (Schein, 2010), ou seja, crenças, valores e sistemas de valores que (Hofstede, 1980, 2000) caracterizam um ambiente e são ensinadas aos novos membros da organização, como a maneira correta de pensar e sentir, comunicadas e manifestadas pelas práticas da organização (D’Iribarne, 1983; Dupuis, 2007), pelos símbolos, heróis, ritos (Hofestede, 1980, 2000), mitos e histórias que as pessoas contam sobre como a organização veio a ser do jeito que é, em virtude da resolução dos problemas associados com a adaptação externa e a integração interna (Trice \& Beyer, 1993; Zohar \& Hofmann, 2012). Além disso, diversas pesquisas têm mostrado o efeito direto da cultura organizacional ou de suas principais dimensões (valores e práticas) sobre o desempenho (Agbényiga, 2011; Cheung et al. 2012; Jacobs et al., 2013; Mathew et al., 2011; Murphy et al., 2013; Prajogo \& McDermott, 2010; Yazici, 2010, Yilmaz \& Ergun, 2008). As hipóteses sobre cultura organizacional serão apresentadas, com base nos valores organizacionais e nas práticas organizacionais, construtos mensurados no presente trabalho.

Valores organizacionais são compreendidos, conforme Porto et al. (2012), como representações mentais compartilhadas coletivamente (Tindale et al., 1996) pelos membros da organização, que convivem dentro do mesmo ambiente em um espaço de tempo consideravelmente duradouro, consistindo em cognições dos princípios que orientam práticas e normas organizacionais (Katz \& Kahn, 1974). Os valores organizacionais hierarquicamente organizados (Tamayo, et al., 2000), transcendem práticas ou normas específicas (Porto et al., 2012), influenciando o desempenho no trabalho (Gregory et al., 2008; Hartnell et al., 2011; 
Tomczyk et al., 2013). Assim, os valores organizacionais apresentam-se como um construto importante para a predição do desempenho.

Práticas organizacionais são definidas como atividades reais da organização, desde as cotidianas até as mais inovadoras (Souza et al., 2001), podendo variar no espaço e no tempo, sendo compartilhadas pelos membros da organização, capazes de modificar atitudes e comportamentos (Ogaard 2006; Singh, Verbeke \& Rhoads 1996; Tuomi et al., 2004; Verbeke 2000), criando um laço entre o ambiente organizacional e os desempenhos dos indivíduos no trabalho (Poole, 1985). Dessa forma, representam as manifestações da cultura organizacional (Dupuis, 2007), ou sua essência (Fischer et al., 2013). Como componente da cultura organizacional, as práticas organizacionais são estudadas como variáveis antecedentes do desempenho no trabalho, como dito em estudos, entre os quais, os de Anderson, et al. (2008), Nicolau e Musetescu (2012) e Triguero-Sánchez et al. (2013).

Contudo, ressalta-se a discordância sobre quais componentes (valores ou práticas) constituem o núcleo da cultura organizacional, sendo, para alguns, os valores organizacionais (Schein, 1988; Paz \& Tamayo, 2004), enquanto, para outros, as práticas organizacionais (D’Iribarne, 1983; Hofstede et al., 1990). Além disso, os valores antecedem as práticas da organização.

Com base nessas discussões, e na literatura revisada nesta tese, as seguintes hipóteses são formuladas:

\section{H1: Os valores organizacionais influenciam de forma direta e positiva o desempenho profissional por competências.}

H2: As práticas organizacionais influenciam de forma direta e positiva o desempenho profissional por competências.

H3: As práticas organizacionais têm um maior poder de predição sobre o desempenho em comparação com os valores organizacionais.

Efeito da cultura organizacional sobre identidade e o posterior efeito da identidade sobre o desempenho

As hipóteses aqui apontadas, referem-se à relação entre a cultura organizacional (mensurada por valores e práticas organizacionais) e a identidade (no trabalho e organizacional), e o efeito da identidade (no trabalho e organizacional) sobre o desempenho. A identidade no trabalho será entendida como o modo de elaborar um sentido para si napluralidade de papéis sociais, bem como em seu reconhecimento pelos outros indivíduos no contexto do trabalho (Sainsanlieu, 1995). A identidade organizacional é definida como a expressão das percepções dos indivíduos sobre o significado da organização, sendo 
considerada predição positiva entre cultura organizacional e identidade (Bingöl et al., 2013; Cheung et al., 2011; He \& Baruch, 2009; Ruiz Castro, 2012; Smith et al., 2013; Tataw, 2012). Especificamente, algumas pesquisas analisam a influência direta e positiva da cultura organizacional sobre a identidade profissional (Millward \& Haslam, 2012; Ruiz Castro, 2012; van Dick et al., 2005), sendo que outras investigam a relação de predição entre cultura organizacional e identidade organizacional (Bingöl et al., 2013; Chen, 2011; Cheung et al., 2011; Prati et al., 2009).

Parte dos estudos empíricos revisados abordaram a relação entre cultura organizacional e identidade. Essas investigações apontaram que a identidade sofre influência dos valores organizacionais e das práticas organizacionais (Millward \& Haslam, 2012). Os estudos de Bingöl et al. (2013) e Cheung et al. (2011) encontraram influência positiva dos valores sobre a identidade. De forma similar, Smith et al. (2013) e Tataw (2012) mostram a influência direta das práticas de recursos humanos sobre a identidade. He e Baruch (2009) também apresentam as implicações de mudanças nas práticas organizacionais na identidade, o que estabelece uma relação direta entre esses construtos.

No que se refere à relação entre identidade e desempenho, He e Brown (2013), Mitchell et al. (2011), Xenikou (2011), Riketta (2005) observam que existe impacto positivo no desempenho com indivíduos que apresentam alta identificação organizacional e profissional. Além disso, a identidade vem sendo estudada como variável mediadora da relação entre cultura e desempenho (Chang \& Wu, 2013; Chen, 2011).

Diante disso, são apresentadas as seguintes hipóteses de pesquisa:

H4: Os valores organizacionais, expressos pelos tipos motivacionais, influenciam de forma direta e positiva a identidade profissional (H4a) e a identidade organizacional (H4b).

H5: As práticas organizacionais influenciam de forma direta e positiva a identidade profissional (H5a) e a identidade organizacional (H5b).

H6: As práticas organizacionais têm um maior poder de predição sobre a identidade profissional (H6a) e identidade organizacional (H6b) em comparação com os valores organizacionais.

H7: A identidade profissional (H7a) e a identidade organizacional (H7b) mediam a relação entre os valores organizacionais e o desempenho profissional por competências. A identidade organizacional antecede a identidade profissional (H7c) na mediação da relação entre os valores organizacionais e o desempenho profissional por competências. $A$ identidade profissional antecede a identidade 
organizacional (H7d) na mediação da relação entre os valores organizacionais e o desempenho profissional por competências.

H8: A identidade profissional (H8a) e a identidade organizacional (H8b) mediam a relação entre as práticas organizacionais e o desempenho profissional por competências. A identidade organizacional antecede a identidade profissional (H8c) na mediação da relação entre as práticas organizacionais e o desempenho profissional por competências. $A$ identidade profissional antecede a identidade organizacional (H8d) na mediação da relação entre as práticas organizacionais e o desempenho profissional por competências.

H9: A identidade profissional (H9a) e a identidade organizacional (H9b) influenciam de forma direta e positiva o desempenho profissional por competências.

\subsubsection{Hipóteses relativas às variáveis individuais}

Nesta parte, concentram-se as hipóteses relativas à influência das variáveis individuais na predição do desempenho.

A influência das variáveis sociodemográficas

Diversos estudos mostram a relação das características individuais no desempenho (Albuquerque, 2004; Bedani, 2009; Coelho Jr., 2009; Coelho Jr. \& Borges-Andrade, 2011a; Coelho Jr. \& Borges-Andrade, 2011b; Judge et al., 2002; Salgado, 2003; Santos, 2012; Tett \& Burnett, 2003; Tett et al., 1991; Vasconcelos, 2005, por exemplo).

Segundo a literatura analisada, verifica-se que a idade vem se associando positivamente como desempenho no trabalho (Coelho Jr., 2009; Michel et al., 2006; Waldman \& Avolio, 1986). Assim, à medida que o sujeito envelhece na organização, seu desempenho no trabalho aperfeiçoa-se em termos de eficácia e qualidade na execução de tarefas (Coelho Jr., 2009).

As variáveis tempo de serviço e escolaridade vêm apresentando relação preditiva significativa com o desempenho, conforme a revisão realizada (Ali \& Davies, 2003; Coelho Jr., 2009; Coelho Jr. \& Borges-Andrade, 2011b; Fonseca, 2001; Macedo, 2007; Russel, 2001; Waldman \& Mc Daniel, 1990). Outros estudos, como os de Grund e Nielsen (2008), Michael et al. (2006), Pema e Mehay (2010) e Vasconcelos (2005), mostram que o gênero prediz o desempenho, mesmo que em menor grau (Coelho Jr., 2009).

Além dessas variáveis, a finalidade do cargo mostrou ter predição positiva sobre o desempenho (Albuquerque, 2004; Coelho Jr. \& Borges-Andrade, 2011b; Fonseca, 2001; 
Macedo, 2007; Morgeson \& Humphrey, 2006; Vasconcelos, 2005). Indivíduos lotados na área fim apresentaram melhores escores de desempenho se comparados com os da área meio.

Após tais análises, hipotetizam-se:

H10: Existe uma diferença no desempenho profissional por competências em função da idade do policial.

H11: Existe uma diferença no desempenho profissional por competências em função do tempo de serviço do policial.

H12: Existe uma diferença no desempenho profissional por competências em função da escolaridade do policial.

H13: Existe uma diferença no desempenho profissional por competências em função da área de lotação (atividade fim versus atividade meio) do policial.

H14: Existe uma diferença no desempenho profissional por competências em função do nível hierárquico (oficiais e praças) do policial.

Apresentadas as hipóteses de pesquisa, parte-se para a configuração do modelo conceitual geral com as hipóteses de pesquisa, conforme Figura 14, bem como para a recapitulação dessas hipóteses.

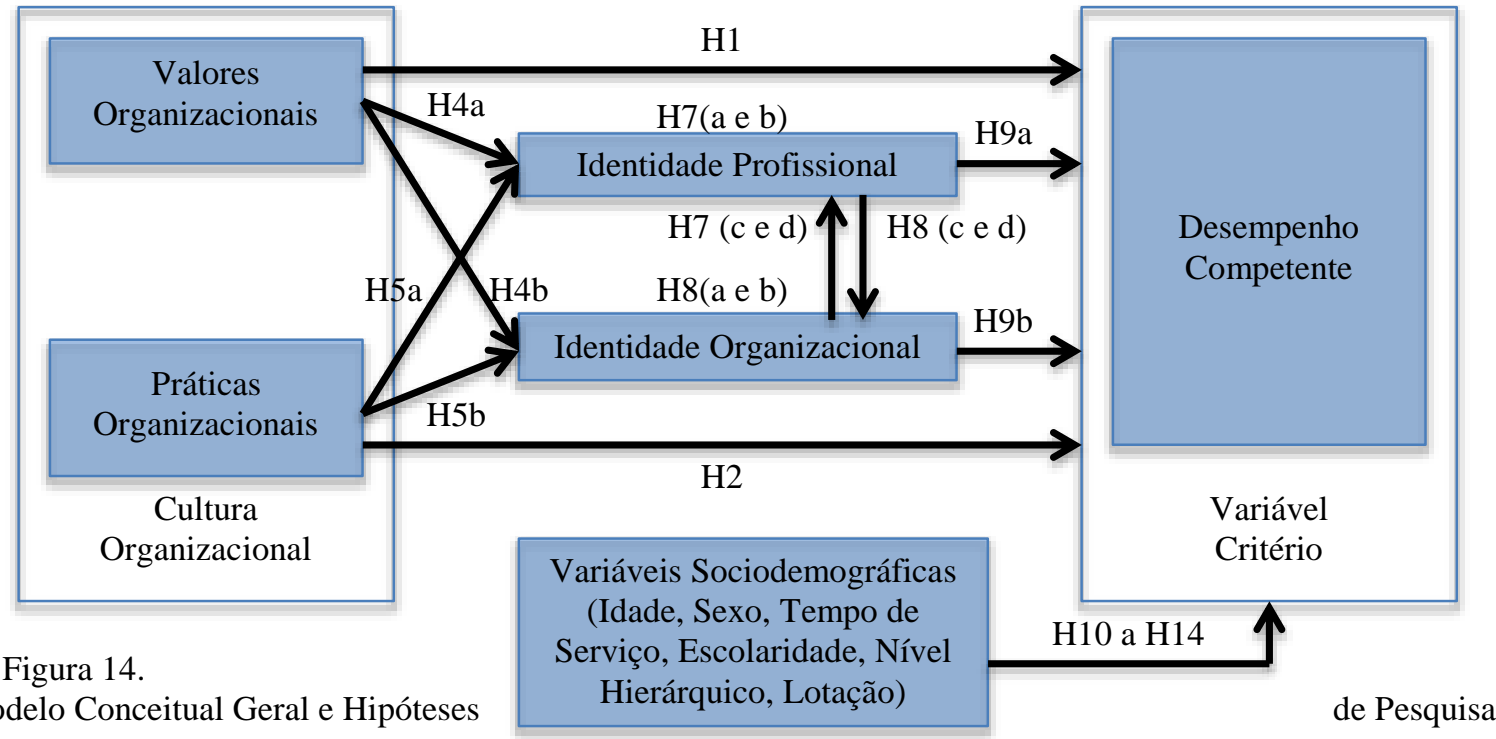

A Tabela 11 sintetiza as hipóteses de pesquisa de $\mathrm{H} 1$ a H10, que refletem o impacto das variáveis principais (antecedentes e mediadoras) e a Tabela 12 as hipóteses de H11 a H14, que referem-se as variáveis individuais (sociodemográficas) sobre desempenho profissional por comeptências. 
Tabela 11

Variáveis Antecedentes e Mediadoras e Hipóteses de Pesquisa

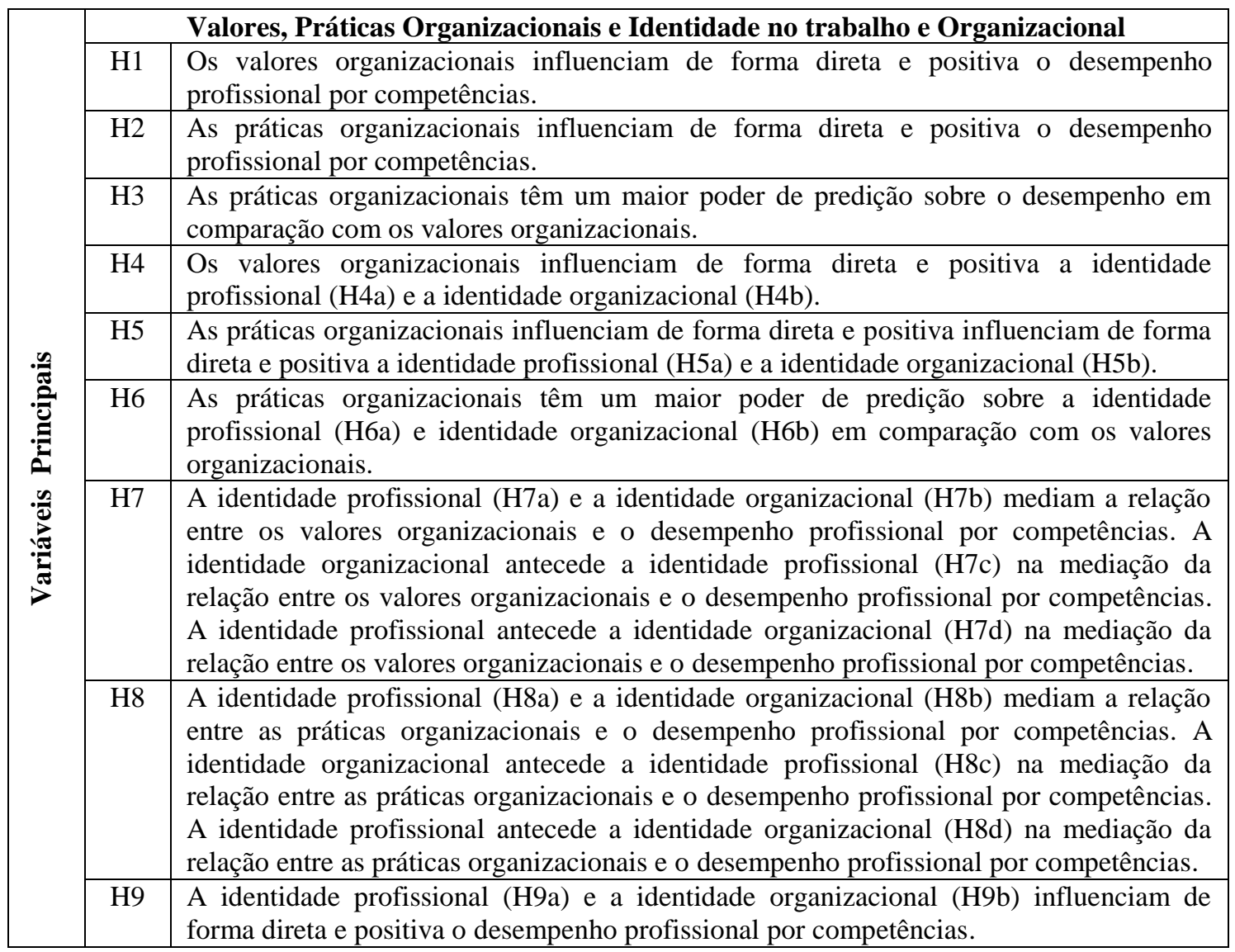

Tabela 12

Variáveis Sociodemográficas e Hipóteses de Pesquisa

\begin{tabular}{|l|c|l|}
\hline \multirow{2}{*}{} & \multicolumn{3}{|c|}{$\begin{array}{l}\text { Variáveis Sociodemográficas } \\
\text { (idade, sexo, escolaridade, tempo de serviço, nível hierárquico, lotação) }\end{array}$} \\
\cline { 2 - 3 } & $\mathrm{H} 10$ & $\begin{array}{l}\text { Existe uma diferença no desempenho profissional por competências em função da idade } \\
\text { do policial. }\end{array}$ \\
\cline { 2 - 3 } & $\mathrm{H} 11$ & $\begin{array}{l}\text { Existe uma diferença no desempenho profissional por competências em função do } \\
\text { tempo de serviço do policial. }\end{array}$ \\
\cline { 2 - 3 } & $\mathrm{H} 12$ & $\begin{array}{l}\text { Existe uma diferença no desempenho profissional por competências em função da } \\
\text { escolaridade do policial. }\end{array}$ \\
\cline { 2 - 3 } & $\mathrm{H} 13$ & $\begin{array}{l}\text { Existe uma diferença no desempenho profissional por competências em função da área } \\
\text { de lotação (atividade fim versus atividade meio) do policial. }\end{array}$ \\
\cline { 2 - 3 } & $\mathrm{H} 14$ & $\begin{array}{l}\text { Existe uma diferença no desempenho profissional por competências em função do nível } \\
\text { hierárquico do policial. }\end{array}$ \\
\hline
\end{tabular}

Apresentados o modelo conceitual e as hipóteses de pesquisa, o capítulo seguinte abordará o método de pesquisa. Para tanto, serão apresentados o local da pesquisa, os participantes, instrumentos de medida, procedimentos de coleta e análise de dados. 


\section{Conclusões do Capítulo IV}

O objetivo do capítulo foi propor um modelo conceitual integrador, bem como apresentar as hipóteses de pesquisas, construídas com base na revisão de literatura. Com base nessa revisão, foi proposto um modelo conceitual geral que contemplou as variáveis antecedentes e individuais que influenciam o desempenho no trabalho.

As variáveis principais são: valores organizacionais, práticas organizacionais, identidade no trabalho e identidade organizacional. Variáveis individuais (sociodemográficas) foram, igualmente, integradas ao modelo proposto (idade, sexo, escolaridade, tempo de serviço, nível hierárquico, lotação).

Foram propostas quatorze hipóteses de pesquisa, que correspondem às relações diretas e mediadoras das variáveis estudadas, sendo que certas hipóteses subdividem-se em subhipóteses. 
PARTE 2.

ESTUDOS EMPÍRICOS E RESULTADOS DA PESQUISA 


\section{INTRODUÇÃO GERAL}
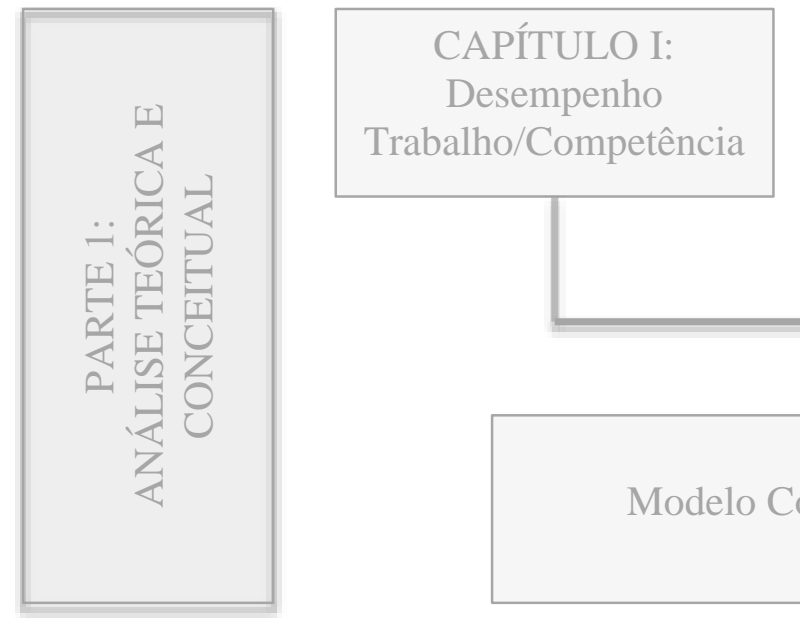
CAPÍTULO II:
Cultura
Organizacional

CAPÍTULO III:

Identidade

Trabalho/Competência

Trabalho/Organização

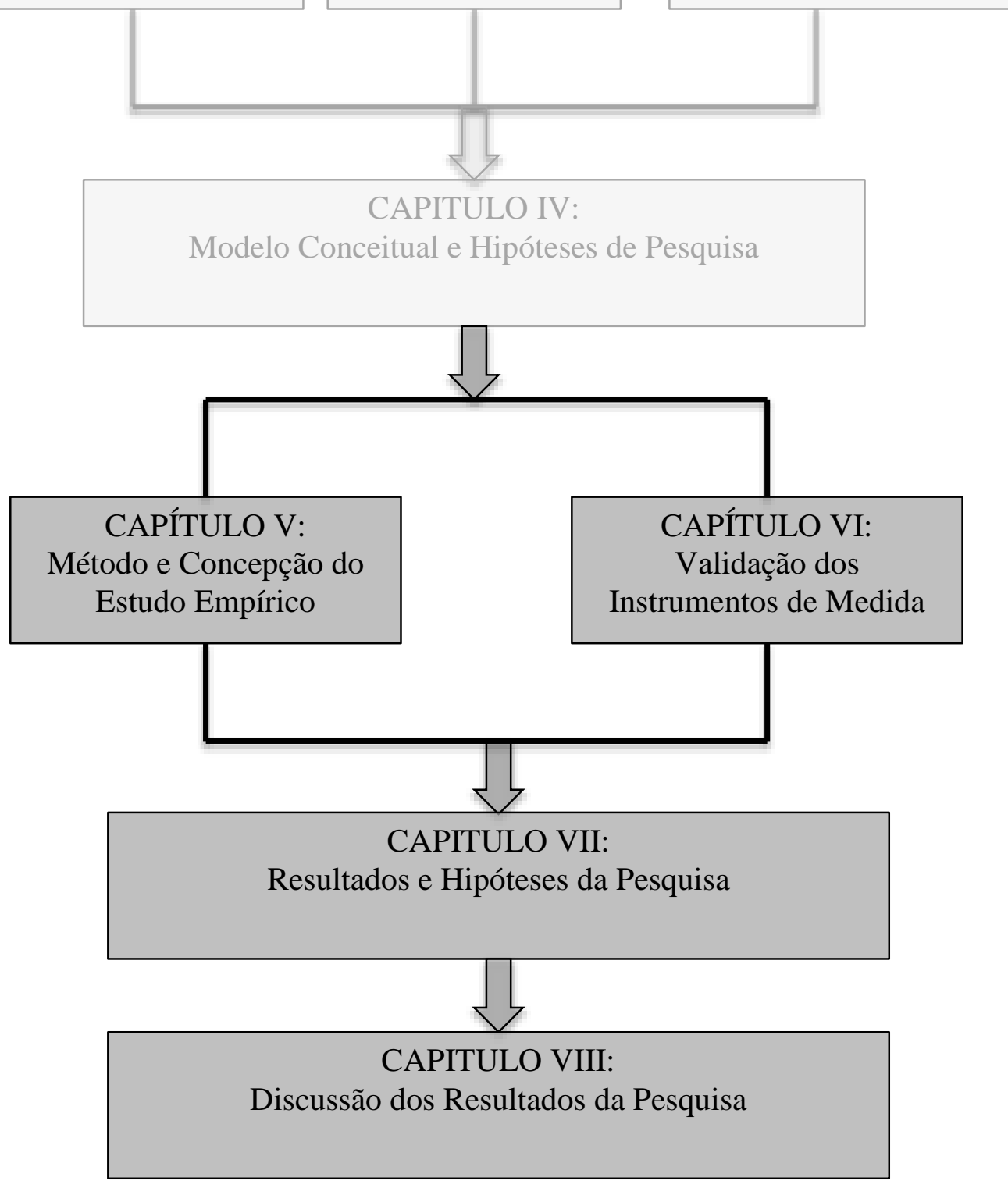

CONCLUSÃO GERAL 
PARTE 2

ESTUDO EMPÍRICO E RESULTADO DA PESQUISA
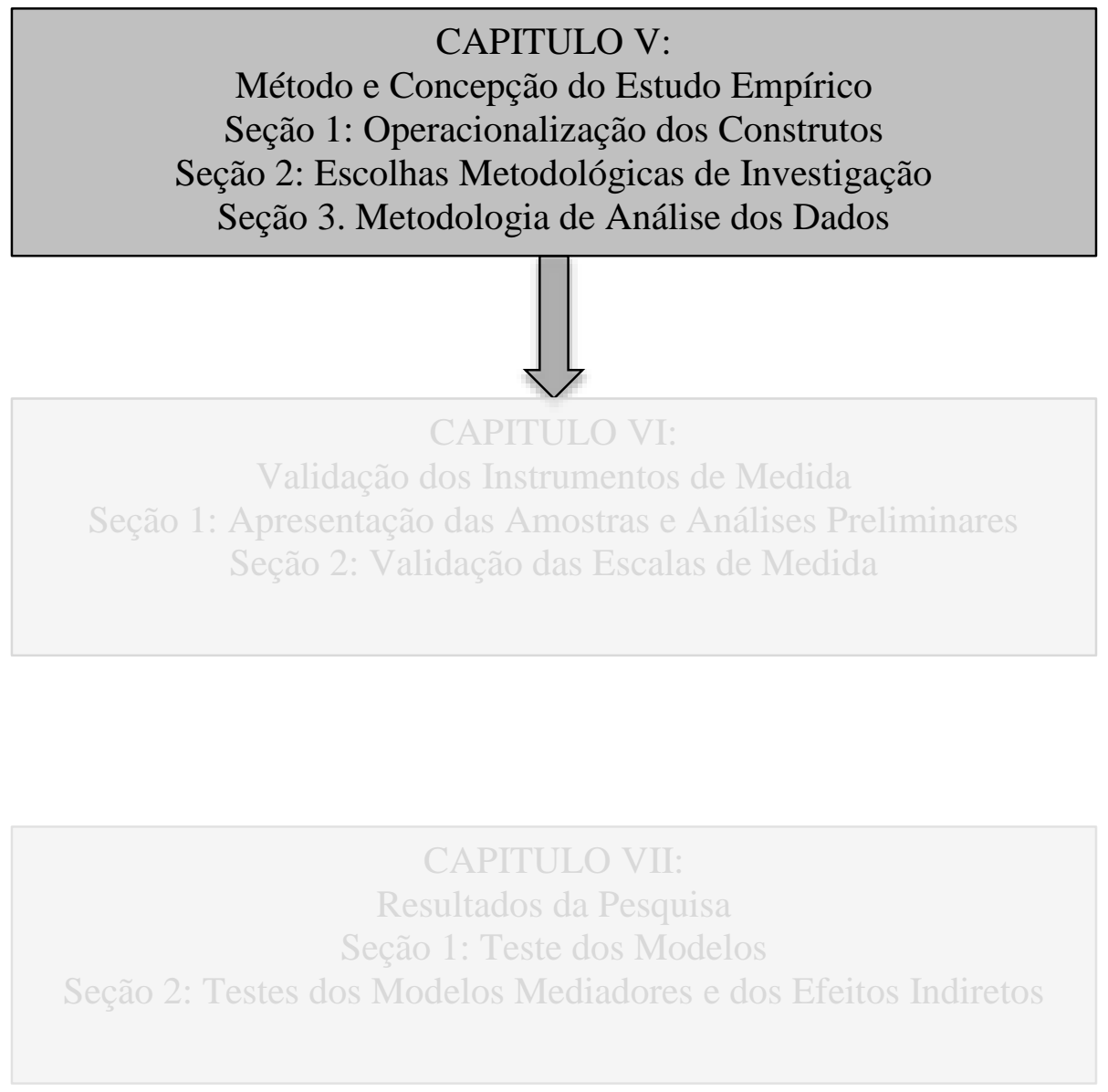

CAPITULO VIII

Discussão dos Resultados da Pesquisa

Seção 1: Discussão dos Resultados do Modelos de Medida

Seção 2: Discussão dos Resultados dos Modelos Estruturais 


\section{CAPÍTULO V. MÉTODO E CONCEPÇÃO DO ESTUDO EMPÍRICO}

\section{Introdução ao Capítulo $V$}

A revisão de literatura apresentada nos capítulos precedentes conduziram à construção de um modelo conceitual de predição do . Esse capítulo descreve os procedimentos metodológicos utilizados para alcançar os objetivos propostos pelo estudo. Conforme observam Demo (1983) e Giroux e Tremblay (2004), o método explicita o modo de operacionalização, o locus e o focus da pesquisa. Descreve, portanto, como as variáveis foram definidas, mensuradas, a forma de seleção da amostra e os procedimentos empregados para a análise dos dados (Seltizz, Wrightsman \& Cook, 1987).

São especificadas as escolhas metodológicas de investigação (seção 1), como o detalhamento da organização, a organização estudada, os procedimentos de coleta e análises dos dados e, em continuidade, especificando a forma de operacionalizar os diferentes construtos do modelo de pesquisa proposto (seção 2). Por fim, apresenta-se a metodologia para a adaptação, o desenvolvimento, a validação de instrumentos de medida e o teste das hipóteses de pesquisa (seção 3).

\section{Seção 1. Escolhas Metodológicas de Investigação}

A pesquisa científica baseia-se nas escolhas metodológicas ligadas ao campo relacionado. Essa seção apresentará a escolha dos atores, os policiais militares e a organização estudada, a Polícia Militar do Distrito Federal (1.1), bem como os procedimentos de coleta de dados (1.2).

\subsection{A Escolha pela Polícia Militar do Distrito Federal}

A escolha pela investigação que utiliza como respondentes os policiais militares é explicada pela natureza do objeto estudado e pelos objetivos da pesquisa. No que se refere ao objeto estudado, diversas pesquisas vêm mostrando a importância do desempenho no trabalho, que é influenciado por variáveis contextuais e individuais (Bendassoli \& BorgesAndrade, 2013; Brandão et al., 2012a; Brandão et al., 2012b; Coelho Jr. et al., 2011, por exemplo). Entretanto, como observa Santos (2012), os estudos sobre desempenho por comeptências no setor público ainda são escassos. Nesse sentido, a revisão de literatura realizada não encontrou investigações, cujo objeto fosse as organizações de segurança pública que se preocuparam com o desempenho no trabalho e com variáveis que o antecedem e predizem, mostrando que essa lacuna ainda é maior ao se tratar de organizações policiais. 
No que concerne aos objetivos desta pesquisa, busca-se estudar os fatores explicativos do dos policiais militares, no intuito de compreender a influência das variáveis antecedentes e mediadoras (valores organizacionais, práticas organizacionais, identidade profissional e identidade organizacional) sobre o do serviço policial. Assim, o universo deste estudo passa a ser o policial militar e a instituição Polícia Militar do Distrito Federal.

Duas razões principais levaram a escolha da Polícia Militar do Distrito Federal (PMDF) como organização a ser estudada.

A primeira está ligada à sua reconhecida receptividade em auxiliar pesquisadores de diversos campos de investigação, entre os quais se destacam os da psicologia, da administração e da sociologia. A esse respeito, diversos estudos, tendo como amostra os policiais militares, apontam: identidade profissional (Nascimento, 2010; Nascimento et al., 2013), qualidade do serviço policial (Faiad, Delabrida \& Nascimento, 2011), atitudes frente à polícia (Nascimento, Torres \& Pimentel, 2011), educação policial (Nascimento, 2012; Nascimento \& Cerqueira, no prelo), novos padrões de seleção de policiais militares (Costa, Mattos \& Santos, 2012) e valores organizacionais e atitudes frente à mudança (Rodrigues, Nascimento \& Neiva, no prelo).

A segunda razão para a escolha dessa organização reside no fato da atribuição de um status de pesquisa institucional por parte da PMDF, o que possibilitou acesso aos documentos, aos próprios policiais e a outros elementos julgados pertinentes para o desenvolvimento deste trabalho.

As atribuições da PMDF são definidas pela Constituição Federal e por legislações específicas. De maneira geral:

Art. $1^{\circ}$. A Polícia Militar do Distrito Federal, instituição permanente, fundamentada nos princípios da hierarquia e disciplina, essencial à segurança pública do Distrito Federal e ainda força auxiliar e força reserva do Exército nos casos de convocação ou mobilização, organizada e mantida pela União nos termos do inciso XIV do art. 21 e dos $\S \S 5^{\circ}$ e $6^{\circ}$ do art. 144 da Constituição Federal, subordinada ao Governador do Distrito Federal, destina-se à polícia ostensiva e à preservação da ordem pública do Distrito Federal (redação dada pela Lei nº. 12.086, de 2009).

Art. $2^{\circ}$. Compete à Polícia Militar do Distrito Federal (redação dada pela Lei $n^{\circ}$. 7.457, de 1986):

I - executar com exclusividade, ressalvadas as missões peculiares das Forças Armadas, o policiamento ostensivo, fardado, planejado pela autoridade competente, a fim de assegurar o cumprimento da Lei, a manutenção da ordem pública e o exercício dos poderes constituídos (redação dada pela Lei no ${ }^{\circ}$ 7.457, de 1986); 
II - atuar de maneira preventiva, como força de dissuasão, em locais ou áreas específicas, onde se presuma ser possível a perturbação da ordem pública;

III - atuar de maneira repressiva, em caso de perturbação da ordem, precedendo o eventual emprego das Forças Armadas; e

IV - atender à convocação, inclusive mobilização, do Governo Federal em caso de guerra externa, ou para prevenir ou reprimir grave perturbação da ordem ou ameaça de sua irrupção nos casos previstos na legislação em vigor, subordinando-se à Força Terrestre para emprego em suas atribuições específicas de polícia militar e como participante da Defesa Interna e da Defesa Territorial (redação dada pela Lei $\mathrm{n}^{\mathbf{o}}$. 7.457, de 1986) (Brasil, 2010).

Duas outras legislações buscaram mais recentemente tratar da PMDF: a primeira é a Lei $n^{\circ} .12 .086$ de 2009, que dispõe sobre os militares da PMDF, e a segunda é o Decreto Federal $n^{\circ}$. 7.165 de 2010, que dispõe sobre sua organização básica. Esses instrumentos trazem o novo contingente e a nova estrutura organizacional da PMDF, com um modelo baseado na organização funcional e departamental.

De acordo com seu plano estratégico (Plano Estratégico 2011-2022, 2011), o objetivo do modelo empregado visa orientar os processos corporativos para uma gestão mais ágil e direcionada a resultados, alcançando a missão da organização. Sendo a Missão da PMDF promover a segurança e o bem-estar social por meio da prevenção e repressão imediata da criminalidade e da violência, baseando-se nos direitos humanos e na participação comunitária.

Para cumprir sua missão, a PMDF está dividida, segundo seu organograma, em comando-geral, órgãos de apoio ao comando-geral, órgão de planejamento estratégico, órgãos de direção geral e órgãos de direção setorial. O organograma indica que a estrutura da organização é tradicional e verticalizada, com foco na hierarquização dos cargos e departamentalização, conforme a Figura 15. 


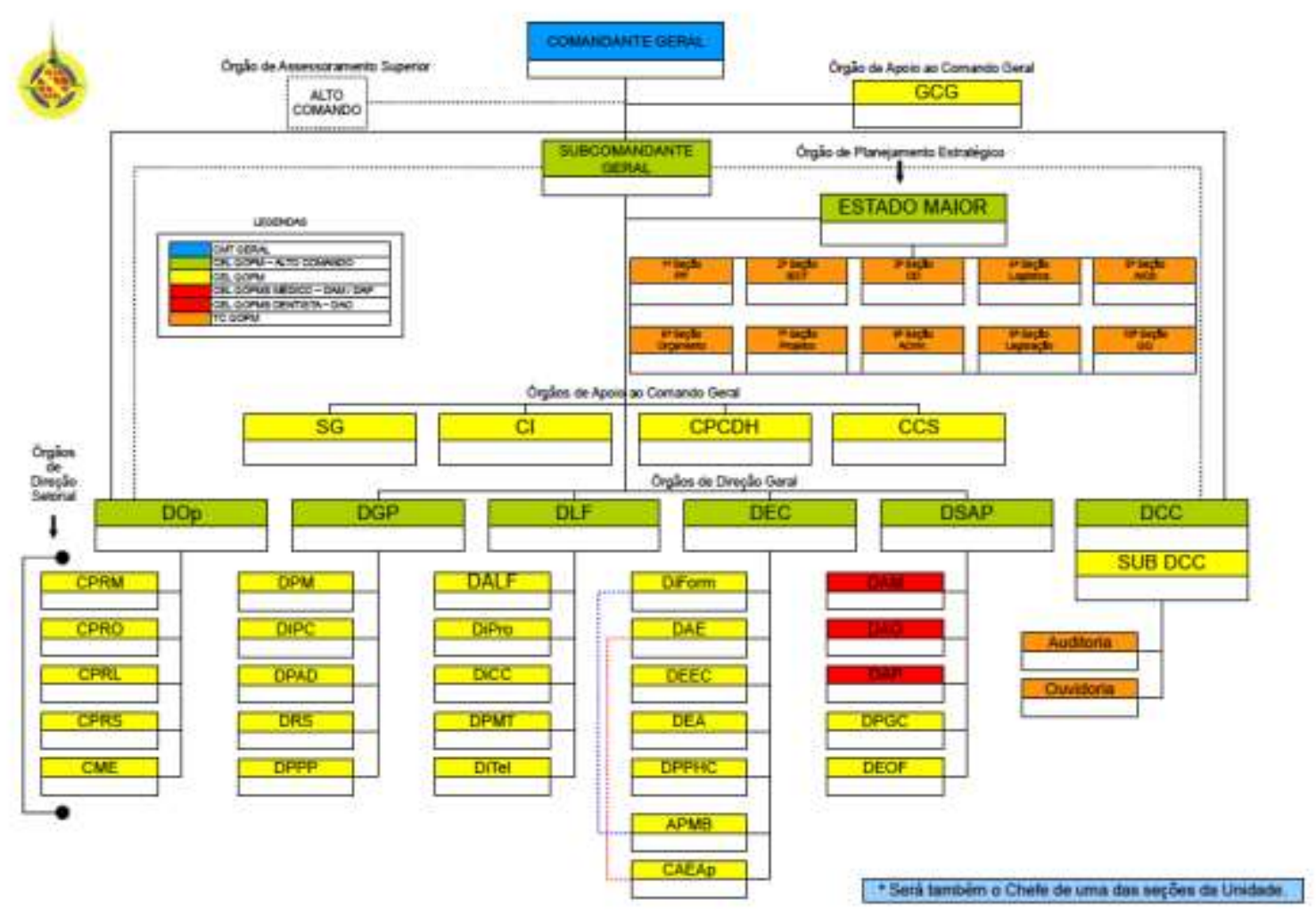

Figura 15. Organograma Geral da PMDF.

Fonte. Planejamento Estratégico 2011-2022 (2010).

O órgão de direção geral, intitulado Departamento Operacional (DOP) é o responsável pelo policiamento ostensivo no âmbito do Distrito Federal (DF), ao qual compete planejar, coordenar, fiscalizar e controlar os comandos de policiamento que lhe são diretamente subordinados, visando manter a indispensável unidade de instrução, disciplina e emprego operacional (Decreto $\mathrm{n}^{\circ} .31 .973,2010$ ). Para tanto, o DOP se divide em quatro órgãos setoriais com responsabilidade de atuação em áreas específicas do DF, conforme segue:

$>$ Comando de Policiamento Regional Metropolitano (CPRM) - compreende o Plano Piloto, Guará, SIA, Estrutural, Lago Sul, Esplanada, Cruzeiro e Sudoeste;

Comando de Policiamento Regional Oeste (CPRO) - compreende as cidades de Taguatinga, Ceilândia, Brazlândia, Samambaia, Águas Claras e Vicente Pires;

Comando de Policiamento Sul (CPRS) - compreende as cidades Gama, Núcleo Bandeirante, Candangolândia, Riacho Fundo, Recanto das Emas e Santa Maria; 
Comando de Policiamento Regional Leste (CPRL) - compreende as cidades de Sobradinho, Planaltina, Paranoá, São Sebastião, Complexo Penitenciário da Papuda e Lago Norte.

As Unidades Policias Militares (UPM's) subordinadas a cada Comando Regional são designadas de Batalhões de Polícia Militar (BPM). Atualmente, a PMDF conta com 21 BPM's.

O DOP dispõe, ainda, de um quinto órgão setorial, o Comando de Missões Especiais (CME), responsável por planejar, coordenar e fiscalizar as atividades operacionais desenvolvidas pelas unidades de missões especiais. Fazem parte desse comando o Batalhão de Operações Especiais (BOPE), o Batalhão de Policiamento com Cães (BPCÃES), o Batalhão de Policiamento de Choque (BPCHOQUE), o Batalhão de Aviação Operacional (BAVOP), o Batalhão de Polícia Militar Ambiental (BPMA), o Regimento de Polícia Montada (RPMON), o Batalhão Judiciário, o $1^{\circ}$ Batalhão de Policiamento de Trânsito $\left(1^{\circ}\right.$ BPTRAN $)$ e o $3^{\circ}$ Batalhão de Policiamento de Trânsito, mais conhecido como Batalhão de Policiamento Rodoviário (BPRV / $3^{\circ}$ BPTRAN), com atribuições em todas as regiões do DF.

O quadro de pessoal da PMDF é dividido entre os oficiais, que compõem os postos de coronel, tenente-coronel, major, capitão, $1^{\circ}$ tenente, $2^{\circ}$ tenente, além dos aspirantes a oficial e cadetes. E os praças, que compreendem as seguintes graduações: subtenente, $1^{\circ}$ sargento, $2^{\circ}$ sargento, $3^{\circ}$ sargento, cabo, soldado e soldado $2^{\mathrm{a}}$ classe. Atualmente, a PMDF conta em seus quadros com 1.406 oficiais e 13.772 praças, perfazendo um total de 15.178 policiais militares, descriminados na Tabela 13.

Tabela 13

Número de policiais por postos e graduações

\begin{tabular}{|c|c|c|c|}
\hline Postos & Número de Policiais & f em relação ao total de oficiais & f em relação ao total de policiais \\
\hline Coronel & 66 & $4,69 \%$ & $0,43 \%$ \\
\hline Tenente Coronel & 127 & $9,03 \%$ & $0,84 \%$ \\
\hline Major & 327 & $23,26 \%$ & $2,15 \%$ \\
\hline Capitão & 396 & $28,17 \%$ & $2,61 \%$ \\
\hline $1^{\mathrm{o}}$ Tenente & 120 & $8,53 \%$ & $0,79 \%$ \\
\hline $2^{\circ}$ Tenente & 138 & $9,82 \%$ & $0,91 \%$ \\
\hline Aspirante a Oficial* & 180 & $12,80 \%$ & $1,19 \%$ \\
\hline Cadetes** & 52 & $3,70 \%$ & $0,34 \%$ \\
\hline Total & 1.406 & $100,00 \%$ & $9,26 \%$ \\
\hline
\end{tabular}


continua

\begin{tabular}{lccc}
\hline continua & & \\
Graduações & Número de Policiais & f em relação ao total de praças & f em relação ao total de policiais \\
\hline Subtenente & 656 & $4,76 \%$ & $4,32 \%$ \\
$1^{\circ}$ Sargento & 2.350 & $17,06 \%$ & $15,48 \%$ \\
$2^{\circ}$ Sargento & 2.278 & $16,54 \%$ & $15,01 \%$ \\
$3^{\circ}$ Sargento & 2.946 & $21,39 \%$ & $19,41 \%$ \\
Cabo & 3.277 & $23,80 \%$ & $21,59 \%$ \\
Soldado & 1.194 & $8,67 \%$ & $7,87 \%$ \\
Soldado 2 & 1.071 & $7,78 \%$ & $7,06 \%$ \\
Total & 13.772 & $100,00 \%$ & $90,74 \%$ \\
\hline
\end{tabular}

Fonte: Diretoria de Promoção e Avaliação do Desempenho, atualizada em 13 de junho de 2014.

*Os aspirantes a oficial são alunos que concluíram o curso de formação de oficiais e estão em estágio probatório.

** Os cadetes são alunos do curso de formação de oficiais.

*** Os Soldados $2^{\text {a }}$ Classe são alunos do curso de formação de praças.

$\mathrm{Na}$ parte seguinte, serão apresentados os procedimentos utilizados para a coleta dos dados utilizados nessa pesquisa.

\subsection{Procedimentos de Coleta de Dados}

Os dados do estudo quantitativo foram coletados por intermédio de um questionário (Apêndice A). Cada um deles passou por uma validação de juízes e semântica antes de sua aplicação.

\subsubsection{Elaboração do Questionário}

A elaboração do questionário apresenta a técnica de interrogatório individual, padronizado, que consiste de uma série de perguntas em uma ordem predefinida (Diallo, 2011). Ainda, segundo o autor, sua construção é uma fase delicada, na medida em que deve conciliar os objetivos de simplicidade e clareza para motivar os entrevistados, bem como a necessidade do rigor e precisão para minimizar os erros de medição. Quatro pontos foram considerados e discutidos no desenvolvimento dos questionários desta tese, conforme colocado por Diallo (2011).

Objetivos do questionário: coletar as informações primárias sobre:

$\checkmark$ a percepção sobre os valores organizacionais;

$\checkmark$ a percepção sobre as práticas organizacionais;

$\checkmark$ a percepção sobre a identidade profissional e organizacional;

$\checkmark$ a percepção sobre o ;

$\checkmark$ as variáveis sociodemográficas. 
Formulação das questões: os questionários necessitam apresentar questões simples e precisas para que todos os respondentes as compreendam da mesma forma (Diallo, 2011; Pasquali, 2010). Como os questionários encontravam-se previamente construídos e validados, buscaram-se as seguintes estratégias para evitar o viés semântico: validação semântica por uma amostra representativa dos participantes, isto é, de todos os níveis hierárquicos; e 2) envolvimento de peritos para validar o questionário.

> Estruturação do questionário: a estrutura do questionário é um fator motivacional para os participantes; diante disso, houve o cuidado de apresentar a ordem das perguntas. Os questionários, apresentados no Apêndice A, são divididos em duas partes. A primeira parte contém as escalas de medida dos construtos e a segunda parte agrupa as questões ligadas às variáveis sociodemográficas. Os instrumentos são mensurados por escalas tipo Likert, de 5 pontos, exceção feita à escala de valores organizacionais, que é do tipo osgood. O questionário apresenta, também, uma introdução sobre o objetivo da enquete, um termo de consentimento e os agradecimentos pela participação.

Tradução, retradução e validação do questionário: O questionário de identidade profissional passou pelo procedimento de tradução e retradução de Brislin (1970) e Vallerand (1979) e a validação de conteúdo de Henández-Nieto (2002), com o cálculo do índice de validação de conteúdo. Todos os outros questionários tiveram seus itens verificados por juízes para garantir que correspondiam ao construto e as dimensões especificadas, bem como uma validação semântica, com policiais militares, para verificar que todos os participantes compreendiam da mesma forma os itens.

\subsubsection{Aplicação dos Questionários}

Os questionários foram administrados à PMDF no período compreendido entre os meses de março e abril de 2014, sendo aplicados face a face por diversas razões, entre as quais a possibilidade: de motivar o respondente; de elucidar perguntas que gerem confusão; de fornecer detalhes necessários para o entrevistado. Além disso, a coleta direta pode reduzir a ocorrência de erros de resposta e não resposta, isto é, valores ausentes (Diallo, 2011).

$\mathrm{O}$ risco desse tipo de aplicação reside tanto na possibilidade de o aplicador vir a influenciar o respondente, como de problemas no controle da eficácia do trabalho. Para minimizar tais inconvenientes, foram utilizados os procedimentos recomendados por Diallo (2011): 
Treinamento dos indivíduos requisitados para a aplicação dos questionários;

> Instruções prévias aos aplicadores, com vistas a precisar os objetivos da pesquisa e a evitar a influência sobre os respondentes;

Controles posteriores dos questionários efetuados pelos próprios aplicadores e pelo pesquisador principal, com o objetivo de verificar a eficácia dos questionários.

\subsubsection{Amostragem e Segmentação dos Respondentes}

Os métodos de amostragem existentes são diversos. Entre as divisões reconhecidas, encontram-se os métodos probabilísticos (amostragem aleatória) e os métodos empíricos (escolha do pesquisador). Conforme observam Evrard, Pras e Roux (2009), a escolha por um desses métodos envolve questões orçamentárias e o tempo disponível para a realização da pesquisa. Nessa pesquisa, optou-se pelo método de amostragem no local (no lugar de trabalho, UPM), que é um método empírico.

Conforme observa Diallo (2011), o método de amostragem utilizado nesse trabalho não respeita os princípios da lei dos grandes números. Entretanto, como pondera o autor, existe a vantagem do custo aceitável e, também, para suprir a falta de uma base de amostragem disponível. No sentido de limitar os vieses, ao utilizar métodos empíricos de amostragem, foi dada especial atenção à segmentação dos entrevistados.

A segmentação dos respondentes obedeceu a três parâmetros: a seleção dos entrevistados, o lugar do questionário e o período de realização. Quanto à seleção dos respondentes, buscou-se uma diversificação, de tal forma que eles pertencessem a todos os postos e graduações da polícia e que trabalhassem em atividades administrativas e operacionais, sendo convidados a participar da pesquisa no sentido de verificar a motivação. No que diz respeito ao local, foi utilizado o de trabalho. A pesquisa foi realizada durante 30 dias, o que permitiu uma coleta ampla, contando com membros de todos os níveis hierárquicos da PMDF.

A seção seguinte apresenta os instrumentos de medida utilizados na pesquisa, apontando suas principais características. 


\section{Seção 2. Operacionalização dos Construtos}

O modelo conceitual desenvolvido nesse trabalho não é observado diretamente. Sua proposta de operacionalização é resolvida nessa seção, ou seja, de forma concreta e compreensível. Antes, porém, faz-se necessária a distinção entre os modelos formativos e reflexivos, envolvidos no desenvolvimento de um construto (Crié, 2005; Marôco, 2010). Os modelos, cujas variáveis latentes manifestam-se ou refletem-se nas variáveis manifestas, são ditos reflexivos, isto é, um construto em que as variáveis manifestas são efeito da variável latente. Por outro lado, nos modelos formativos, as variáveis latentes são formadas pelas variáveis manifestas, ou seja, seus indicadores são a causa (Javis, Mackenzie \& Podsakoff, 2003; Marôco, 2010; Crié, 2005). Nessa tese, todos os construtos utilizados são reflexivos, conforme sua operacionalização e utilização em pesquisas anteriores.

Serão apresentados, a seguir, os instrumentos que viabilizaram o alcance dos objetivos da pesquisa (2.1).

\subsection{Medidas dos Construtos Principais}

Serão apresentadas as escalas de medida dos diferentes construtos abordados nesta pesquisa. Cada instrumento de medida apresentou uma especificidade (análise por juízes e análise semântica) em seu processo de operacionalização e/ou adaptação para sua utilização.

\subsubsection{Escala de Valores Organizacionais}

Diversas são as escalas que tratam dos valores organizacionais, seja na literatura brasileira (Oliveira \& Tamayo, 2004; Porto et al., 2012; Tamayo et al., 2000), seja na internacional (Cameron \& Quinn, 2011, Hofstede et al.,1990; O’Reilly et al., 1991). Parte dessas escalas é construída sobre teoria de valores culturais, de Schwartz (1999); Tamayo et al. (2000); Oliveira e Tamayo (2004) e Porto et al. (2012), sendo algumas baseadas em tipologias, afastando-se das medidas que tratam das dimensões que constituem a cultura, como a escala de Cameron e Quinn (2011).

Para mensurar os valores, esta pesquisa utilizará uma adaptação da escala proposta por Porto et al. (2012), que se apresenta adequada aos objetivos propostos. Com base na teoria de Schwartz (1999), os autores realizaram uma sistematização das dimensões encontradas nas principais escalas de valores organizacionais disponíveis na literatura (Cameron \& Quinn, 2011; Hofstede et al., 1990; Oliveira \& Tamayo, 2004; O'Reilly et al., 1991; Tamayo, 2000). Diante disso, foram identificadas 14 dimensões (inovação, autonomia, 
bem-estar, conformidade, tradição, orientação para resultados, perfeccionismo, valorização do empregado, orientação para o grupo, distância do poder, integridade, harmonia, domínio, prestígio com foco no cliente) e apontadas suas semelhanças e o ajustamento ao modelo teórico de Schwartz (1999), à exceção da dimensão perfeccionismo.

A escala foi validada em dois estudos. No primeiro, apresentava-se composta por 79 itens, respondidos por escalas de respostas tipo Osgood de onze pontos, variando de 0 (Nada Importante) a 10 (Totalmente Importante). Ao todo 961 profissionais de uma instituição bancária participaram como respondentes.

Os resultados do escalonamento multidimensional (MDS) foram satisfatórios (SStress=0,09 e coeficiente de congruência de Tucker igual a 0,98), apontando para seis dimensões: harmonia $(\alpha=0,87)$, domínio $(\alpha=0,81)$, igualitarismo $(\alpha=0,96)$, hierarquia $(\alpha=0,65)$, estabilidade (conservação) $(\alpha=0,86)$ e inovação (autonomia) $(\alpha=0,85)$. Dos 79 itens iniciais, 39 foram retidos; os demais foram excluídos por apresentaram redundância ou por se localizarem em regiões opostas à previsão da teoria. Os resultados confirmaram parcialmente a adequação teórica (Domínio x Harmonia; Igualitarismo x Hierarquia; Inovação x Estabilidade). Entre os problemas, ocorreu um deslocamento dos itens entre igualitarismo e harmonia, bem como o tipo motivacional igualitarismo saturou itens referentes à autonomia.

Os problemas relatados ensejaram a realização de um segundo estudo. Assim, um novo instrumento foi desenvolvido, cujos valores foram descritos com o uso de substantivos, e não mais com o de verbos (estudo1). A amostra foi composta por 207 sujeitos de empresas privadas diversas. A versão reformulada da escala, que aproveitou 39 itens da versão anterior, ficou com 55 valores. com a redação de novos itens, com o objetivo de restarem ao menos 9 itens para cada tipo motivacional (Porto et al., 2012).

Os novos resultados do escalonamento multidimensional (MDS) mostraram-se igualmente aceitáveis ( $\mathrm{S}-\mathrm{Stress}=0,12$ e coeficiente de congruência de Tucker igual a 0,97), apontando para seis dimensões: harmonia $(\alpha=0,87)$, domínio $(\alpha=0,72)$, igualitarismo $(\alpha=0,89)$, hierarquia $(\alpha=0,75)$, estabilidade (conservação) $(\alpha=0,88)$ e inovação (autonomia) $(\alpha=0,91)$. A nova versão da escala reteve 38 dos 55 itens, sendo eliminados os itens que não representavam as dimensões teóricas ou por terem conteúdo já representado em outro item (Porto et al., 2012). Nesse novo estudo, os tipos motivacionais foram previstos conforme à teoria e os índices de confiabilidade adequados, sugerindo sua aplicação para outros contextos. 
A operacionalização da escala de valores organizacionais (Porto et al., 2012), para esta tese, passou por adequações. Diversos itens foram reescritos, ajustando-se ao sugerido pela análise dos 8 juízes e pela análise semântica realizada, igualmente, por 8 policias militares, sem, contudo, perder sua dimensionalidade. Como, por exemplo: "lucros cada vez. maiores" modificado para "obtenção de cada vez mais êxito na sua atuação" e "ambição nos negócios” substituída por “ambição nas ações de segurança pública”. Foi, ainda, acrescentado um novo item à dimensão domínio: "Preocupação com o aumento da prestação dos serviços". A versão utilizada contou com 39 itens. A Tabela 14 apresenta as dimensões e sua definição constitutiva, baseada em Porto et al. (2012) e Sousa (2013) e os respectivos itens da escala de valores organizacionais (EVO), utilizada no presente trabalho.

Tabela 14

Dimensões e itens da escala de valores organizacionais

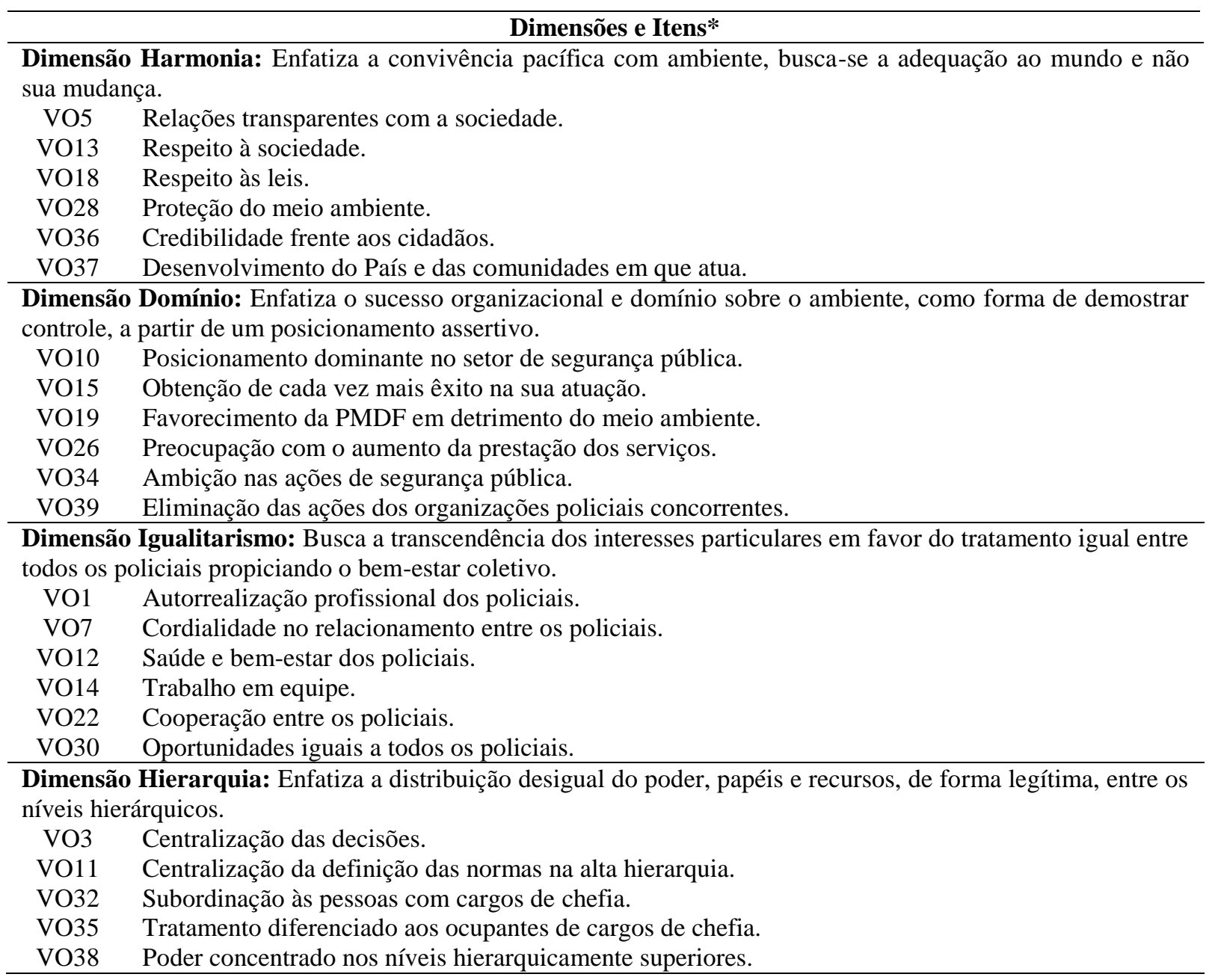




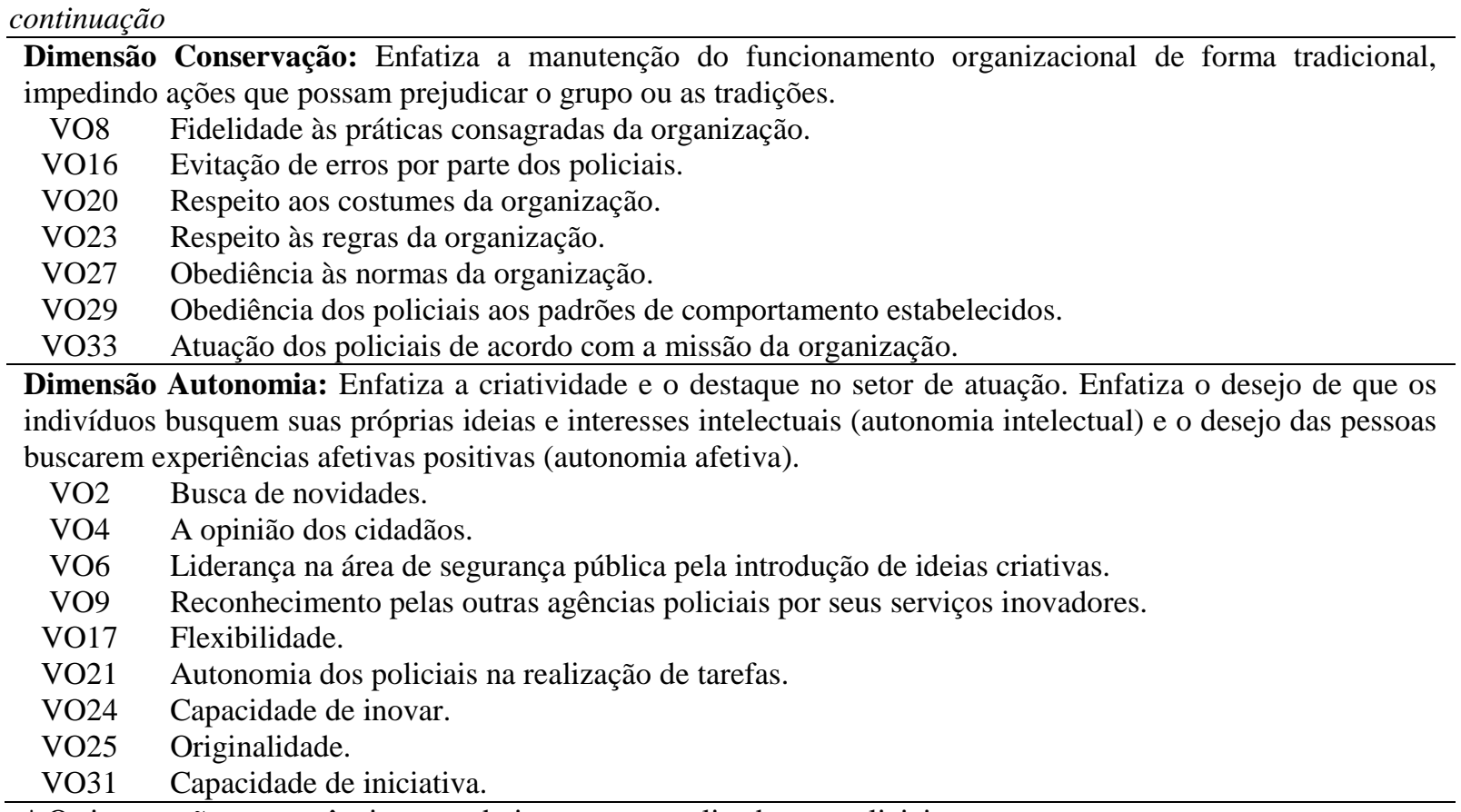

* Os itens estão na sequência exata do instrumento aplicado aos policiais.

\subsubsection{Escala de Práticas Organizacionais}

O estudo das práticas tem recebido maior crédito dos teóricos organizacionais (Verbeke, 2000). Esse fato pode ser explicado pela representatividade que o construto apresenta tanto ao se relacionar com o comportamento dos membros (influenciando desempenho e atitudes) quanto com o desempenho integral da organização. Entretanto, conforme salientam Bedani (2008) e Veiga (2010), são escassos os instrumentos disponibilizados na literatura com a capacidade específica para mapear as práticas organizacionais e que sejam capazes de fazê-lo de modo consistente e sistemático.

Cabe salientar que, em algumas escalas construídas para o estudo da cultura, como os de Hofstede et al. (1990), Calori e Sarnin (1991), Ferreira, Assmar, Estol, Helena e Cisne (2002), encontram-se fatores reservados à avaliação das práticas organizacionais. Tanto no cenário do Brasil, quanto no internacional, encontram-se algumas tentativas de se aferir somente práticas (e.g., Demo \& Rozzett, 2012; Demo, Neiva, Nunes, \& Rozzett, 2012; Fisher et al., 2012). Entretanto, parte desses trabalhos utiliza, de forma restritiva, estudos descritivos de práticas específicas ou mesmo sem uma teoria que embase seu desenvolvimento.

Nesta tese foi validada e adaptada ao contexto da pesquisa a escala de manifestações culturais (EMC), criada por Souza (2014), para aferir as manifestações culturais, por meio de práticas organizacionais, apoiada nos estudos de D’Iribarne (1989). O primeiro momento do processo de construção da escala foi a descrição das categorias apresentadas na Tabela 15, e 
desenvolveu-se em várias etapas, correspondendo a diferentes pesquisas realizadas por Souza e Fenili (2012) e Souza et al. (2013). Nessas pesquisas, foram feitas entrevistas semiestruturadas, individuais e em profundidade que identificaram a percepção de distintos atores organizacionais sobre as categorias em pauta.

Em um segundo momento, após a descrição das categorias, foram criados 50 itens em uma escala likert de 5 pontos, com o objetivo de medir a percepção dos respondentes sobre a implementação das práticas organizacionais, oriundas das categorias de análise, com a finalidade de medir as manifestações culturais da organização em que trabalham. Foram colocadas na construção dos itens situações claras e precisas, frases curtas e simples, validadas semanticamente.

A escala, assim construída, foi submetida a um processo de validação de conteúdo por 14 juízes especialistas no tema. Cada item foi avaliado de acordo com as 7 categorias (senso de dever, relações hierárquicas, qualidade de cooperação, sanções, percepção do controle, regulação) e os quesitos - clareza da linguagem, pertinência prática, relevância teórica - em uma escala variando de 1 a 6, 1 significando não e 6 significando sim. Os itens que obtiveram ao menos $60 \%$ de concordância entre os juízes foram incluídos na versão final, que ficou composta de 45 itens, conforme a Tabela 15.

Com base nessas categorias, foram realizadas 20 entrevistas com policiais militares, pertencentes a todos os níveis hierárquicos. Esses entrevistas subsidiaram a interpretação do instrumento de medida de práticas organizacionais no contexto policial. A adaptação dos itens foi realizada por 14 juízes e, posteriormente, procedeu-se à validação semântica, também. A Tabela 15 apresenta as dimensões e os respectivos itens que compõem a EMC, que passa, no contexto desta tese, a ser chamada de Escala de Práticas Organizacionais (EPO). 
Tabela 15

Dimensões e itens da escala de práticas organizacionais

Dimensões e Itens*

Dimensão Senso de Dever: Refere-se ao exercício de procura de direitos e execução de deveres. Inclui aspectos de motivação na execução do trabalho (obrigação versus compromisso), adesão a valores organizacionais ou prevalência de interesses individuais nas relações de trabalho; sentimentos de orgulho e de pertencimento à organização, compromisso com a obtenção de resultados.

PO2 Os profissionais envolvem-se no trabalho pelo desafio de solucionar problemas e cumprir as metas.

PO3 As equipes trabalham para alcançar resultados.

PO6 Os profissionais sentem prazer nas tarefas que realizam, em seu trabalho.

PO19 Os profissionais envolvem-se no trabalho pelo sentimento de orgulho e pertencimento à organização.

PO27 Os profissionais estão comprometidos com o seu trabalho.

PO32 O ambiente da organização estimula os profissionais a serem mais efetivos no trabalho.

PO35 Os profissionais envolvem-se no trabalho visando o alcance de resultados.

PO43 Os profissionais respeitam-se uns aos outros.

Relações de Hierarquicas: Relação entre os diferentes níveis de gestão e entre profissionais, tomada de decisão na organização, percepção de controle.

PO7 Os profissionais relacionam-se no trabalho por meio de laços de amizade.

PO9 As relações entre os diferentes níveis hierárquicos são flexíveis (desenvolvidas com facilidade, adaptáveis).

PO15 Profissionais comunicam-se livremente sobre suas atividades com distintos níveis de chefia

PO17 A comunicação de assuntos profissionais ocorre de maneira informal entre os diferentes níveis hierárquicos.

PO34 Para realizar as tarefas os profissionais são escolhidos pelas competências necessárias à sua execução.

PO40 As chefias delegam autoridade aos profissionais.

Dimensão Definição de Responsabilidades: Refere-se à forma das funções/tarefas serem atribuídas (segundo critérios normativos, por fidelidade, por amizade, por interesses privados) e avaliadas, ao estabelecimento e à difusão das responsabilidades individuais e dos grupos, aos critérios formais, definidos pelos superiores (responsabilidade objetiva), aos critérios informais de acordo com as relações pessoais ou às crença dos profissionais subordinados (responsabilidade subjetiva), utilização de regras mais formalizadas.

PO1 As práticas de gestão são desempenhadas de acordo com as regras definidas a priori pela organização, independentemente dos interesse individuais.

PO13 Os profissionais priorizam interesses pessoais aos organizacionais.

PO20 O planejamento das tarefas é um processo contínuo.

PO28 A divisão das tarefas é estabelecida mediante critérios claros.

PO33 As regras sobre a operacionalização do trabalho são elaboradas com a participação dos profissionais.

PO38 Os profissionais são valorizados no trabalho.

Dimensão Regulação: Refere-se ações de moderação e de acordos que regem as atividades dos profissionais, o cumprimento de contratos, gestão de interesses organizacionais e individuais.

PO4 Os profissionais resistem à mudanças determinadas pela organização.

PO14 Os profissionais são valorizados no trabalho. A linguagem utilizada pelas chefias estabelece distância com os demais profissionais.

PO22 A chefia interfere diretamente na forma de trabalhar dos profissionais.

PO23 As tarefas e ações são realizadas por meio de acordos e arranjos (maneira informal).

PO29 Os conflitos são resolvidos, formalmente, utilizando-se as regras da organização.

Dimensão Sanções: Refere-se às recompensas e/ou punições aplicadas em função de comportamentos no trabalho; à concessão de benefícios ou punições decorrentes da obtenção de resultados ou objetivos propostos; à existência de políticas organizacionais de sanções, e os critérios para a aplicação de sanções.

PO8 Investe-se continuamente nos profissionais para o desenvolvimento de competências.

PO24 As recompensas concedidas pela organização atendem as expectativas dos profissionais.

PO30 Os profissionais são recompensados pelo bom desempenho no trabalho.

PO42 Os profissionais são punidos pelo baixo desempenho no trabalho. 
continuação

Dimensão Qualidade da Cooperação: Refere-se às características das relações interpessoais entre funcionários no trabalho individual ou em grupo, à disponibilidade dos profissionais para trabalharem em equipe; à forma como são gerenciados os conflito no e pelo grupo; à tendência ao individualismo ou ao coletivismo das relações profissionais; à base em que ocorrem laços de cooperação.

PO11 Os profissionais trabalham de forma mais eficiente individualmente do que em equipe.

PO18 As relações interpessoais nas equipes de trabalho são conflituosas.

PO21 O planejamento das atividades envolve todos os profissionais da seção/unidade/setor.

PO25 A cooperação entre as diferentes áreas de trabalho é encorajada pela organização.

PO31 Os profissionais trabalham sentindo-se membros de uma equipe.

PO37 As tarefas (atividades) são realizadas por meio das equipes.

PO39 Os profissionais criam novas práticas no trabalho.

PO44 As distintas unidades (departamentos) da organização trabalham de forma integrada.

Dimensão Percepção de Controle: Refere-se à percepção que o profissional possui sobre as medidas de controle da organização; aos níveis de consentimento e de conformidade com as normas estabelecidas e com a autoridade; à percepção sobre a liberdade de atuação; à percepção sobre atos arbitrários.

PO5 O ritmo de trabalho das equipes é definido pelos profissionais que as constituem.

PO10 Os horários de trabalho são controlados pela organização.

PO12 Os profissionais são promovidos de acordo com critérios estabelecidos nas normas da organização.

PO16 As escalas de trabalho são respeitadas pelas chefias.

PO26 Os prazos para execução das tarefas são cumpridos.

PO36 Os profissionais concordam com os critérios de controle da execução das tarefas.

PO41 A avaliação dos profissionais é realizada de forma imparcial.

PO45 Os profissionais aceitam o controle de seu desempenho.

* Adaptados de Souza (2014) e Souza et al. (2013). Os itens estão na sequência exata do instrumento aplicado aos policiais.

\subsubsection{Escala de Identidade Profissional}

Medidas de identidade social no trabalho (identidade profissional) são escassas na literatura brasileira (Nascimento, 2010; Nascimento et al., 2013). Entre os estudos que buscaram desenvolver um instrumento para medir identidade profissional está o de Nascimento (2010). As críticas a essa escala referem-se ao seu contexto específico de construção e à falta de uma teoria de suporte.

No contexto internacional, a medida mais utilizada de identificação social foi desenvolvida por Brown, Condor, Mathews, Wade e Williams (1986), cuja tendência é mostrar a identidade social com uma única dimensão, com resultados analíticos do fator denotando direcionalidade do item em vez de dimensionalidade do construto (Brown et al., 1986; Kelly, 1988; Obst \& White, 2005).

A despeito da importância do construto identificação social, desde aspectos teóricos até empíricos em processos de grupo e relações intergrupais, Cameron (2004) observa que a questão da dimensionalidade continua por se resolver. Com o objetivo de testar o modelo trifatorial da identidade social, oriundo da teoria da identidade social (Tajfel, 1978), Cameron (2004) propõe que a identidade social pode ser representada em termos de três fatores, conforme teorizado por Deaux (1996): centralidade (centrality), que se refere ao destaque cognitivo dos membros de um grupo; afetos com o grupo de pertença (ingroup affect), que 
trata da avaliação emocional, englobando a dimensão afetiva; e laços com o grupo de pertença (ingroup ties), que demonstra a percepção de semelhança e vínculos com outros membros do grupo.

A base teórica para a multidimensionalidade da identidade social deriva da definição de Tajfel (1978), muitas vezes citado da construção como "a parte do autoconceito do indivíduo que deriva de seu conhecimento e de sua filiação em certo grupo social (ou grupos), juntamente com o valor emocional e a importância atribuída a esta sociedade" (p. $63)$.

Esta definição levou a tentativas de representar os componentes em medidas de identificação. Como existe suporte teórico (Deaux, 1996; Tajfel, 1978) e empírico (e.g., Jackson, 2002; Ellemers, Kortekaas, Ouwerkerk, 1999; Hinkle, Taylor, Fox-Cardamone, \& Crook, 1989) convincentes para a existência de múltiplas dimensões da identidade social, Cameron (2004) observou que parece incerta a extensão em que as variações das estruturas fatoriais entre os estudos são atribuíveis à variação metodológica. Além disso, nenhum modelo multidimensional da identidade social foi ainda sujeito à análise fatorial confirmatória, dentro e entre diferentes grupos sociais ou sistematicamente validados vis-àvis a medidas comparáveis de identificação. Logo, conclui Cameron (2004) que há como se afirmar quais os componentes de identificação a serem mensurados.

Cinco estudos foram utilizados por Cameron (2004) para confirmar o modelo trifatorial da identidade. Os itens do instrumento foram constituídos com base em estudos de Cameron e Lalonde (2001), que desenvolveram uma escala de 28 itens de identificação social derivados de diferenças de gênero; dos itens de medidas de identidades sociais (Brown et al, 1986; Hinkle et al., 1989) e autoestima coletiva (Luhtanen \& Crocker, 1992), bem como fundamentados em trabalho anterior sobre a identidade social de mulheres (Gurin \& Markus, 1989; Gurin \& Townsend, 1986).

Posteriormente, esta estrutura tripartite foi replicada na medição de identificação étnica em diversas amostras (Boatswain \& Lalonde, 2000; Cameron, Sato, Lalonde, \& Lay, 1997), entre outras como, por exemplo a de Obst, Zinkiewicz, e Smith (2002). Essas evidências preliminares reforçam o aspecto teórico e empírico presente nas três dimensões: centralidade cognitiva, afetos no grupo de pertença e relações no grupo de pertença.

Com o intuito de testar modelos uni, bi e trifatoriais, Cameron (2004) utilizou a escala composta por 18 itens. Os resultados das análises fatoriais confirmatórias asseguram a estrutura trifatorial, sendo que entre os cinco estudos realizados, a escala variou, em 
comprimento, de 11 itens para 15 itens. Os coeficientes de confiabilidades médios nos cinco estudos foram: centralidade $(\alpha=0,73)$, afetos em relação grupo de pertença $(\alpha=0,79)$, e laços com o grupo de pertença $(\alpha=0,79)$, sendo que os índices de adequação mostraram-se muito satisfatórios $\left(\mathrm{CFI}_{\text {Médio }}=0,91 ; \mathrm{GFI}_{\text {Médio }}=0,90\right)$.

Nesta tese, foi utilizada uma adaptação da escala de Cameron (2004), que passa a ser denominada escala de identidade profissional (EIP). Esse instrumento foi submetido à tradução para o português e seguiu a técnica de tradução e retradução de Brislin (1970) e Vallerand (1979) e a validação de conteúdo de Henández-Nieto (2002), com vistas a garantir a equivalência da escala em português., procedimento, esse, que será posteriormente detalhado. A Tabela 16 apresenta as dimensões, com suas respectivas definições constitutivas, e os respectivos itens da escala de identidade profissional (EIP).

Tabela 16

Dimensões e itens da escala de identidade profissional

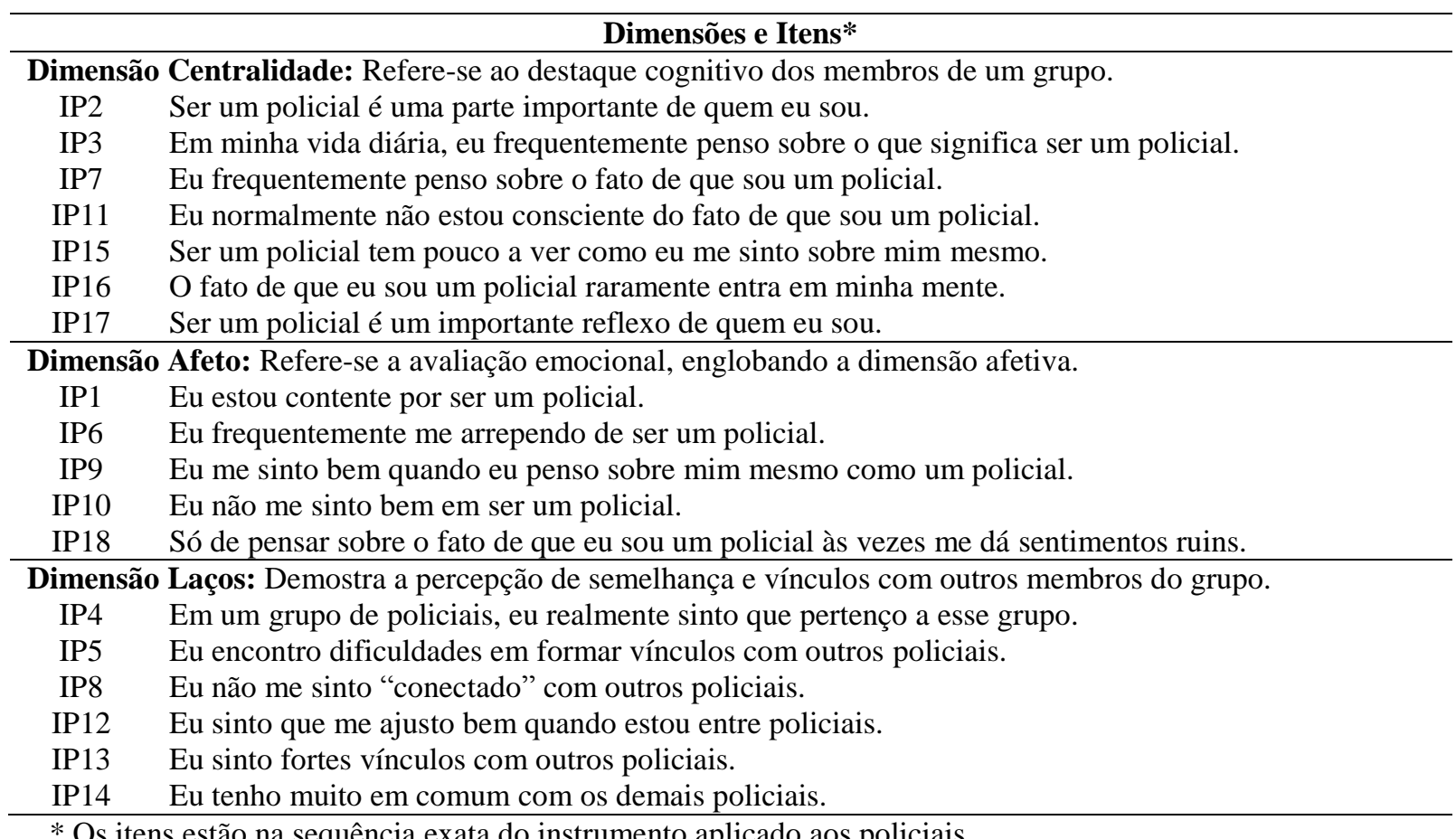

\subsubsection{Escala de Identidade Organizacional}

Para a operacionalização da identidade organizacional foi utilizada a escala de identificação organizacional (EIO), de Mael e Ashforth (1992). Esse instrumento vem sendo muito usado para verificar a identificação organizacional, devido à sua confiabilidade e evidências de validade (Riketta, 2004), em diversos países, inclusive nos de língua 
portuguesa (por exemplo, Cavazotte, Oliveira \& Miranda, 2010; Hildebrand, 2007; Tavares, Caetano \& Silva, 2007).

Desenvolvida por Mael e Ashforth (1992), baseada na escala de identificação organizacional de Mael (1988), que utilizou extensa revisão de literatura para a construção de seus itens. Mael e Ashforth (1992) aplicaram a escala a uma amostra de 297 estudantes de uma faculdade religiosa. Os resultados da análise fatorial confirmatória corroboraram a unidimensionalidade dos 6 itens da escala e boa consistência interna $(\alpha=0,85)$ (Mael \& Ashforth, 1992). Estudos posteriores reportaram maior confiabilidade ( $\alpha=0,92$, Cavazotte et al., 2010). A adaptação dos itens da escala, para utilização nesta tese, foi realizada por 8 juízes e, posteriormente, procedeu-se à avaliação semântica, também, por 8 policiais militares de diversos níveis hierárquicos, conforme a Tabela 17.

Tabela 17

Dimensões e itens da escala de identidade organizacional

\begin{tabular}{ll}
\hline & \multicolumn{1}{c}{ Dimensões e Itens* } \\
\hline \multicolumn{2}{c}{ Dimensão Identificação Organizacional: percepção de unidade ou pertencimento com a organização em que } \\
o indivíduo define a si próprio, pelo menos em parte, em termos de sua filiação organizacional. \\
IO1 Quando alguém critica minha organização é como se estivesse me criticando. \\
IO2 $\quad$ Tenho muito interesse no que os outros pensam sobre minha organização. \\
IO3 $\quad$ Quando me refiro à PMDF, normalmente falo nós, ao invés de eles. \\
IO4 Quando alguém elogia a PMDF é como se estivesse me elogiando. \\
IO5 $\quad$ Quando uma matéria na mídia faz crítica à PMDF, eu me sinto constrangido. \\
IO6 & O sucesso da PMDF é como se fosse o meu sucesso pessoal. \\
\hline * Os itens estão na sequência exata do instrumento aplicado aos policiais.
\end{tabular}

\subsubsection{Escala de Desempenho Profissional por Competências}

A operacionalização da escala de desempenho profissional por competências baseouse no método proposto por Faiad, Coelho Jr., Caetano e Albuquerque (2012) para o mapeamento profissiográfico e de competências, em instituições policiais. Para tanto, foi considerado o mapeamento das competências das policias militares realizado em âmbito nacional brasileiro pela Secretaria Nacional de Segurança Pública (SENASP, 2012), no qual foram consideradas as competências técnicas e comportamentais dos policiais militares, mensuradas em termos de importância e domínio da competência.

Como consequência das análises profissiográficas, foram constituídos grupos focais com policiais militares (oficiais e praças) dos diversos níveis hierárquicos. Cada grupo focal contou com a presença de dez participantes, representativos das diferentes áreas de atuação e da gama de atividades realizadas no cargo. Os participantes foram selecionados segundo o bom desempenho, a experiência, o conhecimento e o domínio das atividades do cargo (SENASP, 2012). Após o mapeamento das competências necessárias para a realização das 
tarefas, tendo como foco as competências técnicas (conhecimentos e habilidades) e as competências comportamentais (atitudes) foi construído o instrumento de mapeamento de competências.

O instrumento de competências foi medido por uma escala tipo Likert, em termos de importância (da competência para a atividade profissional), variando de 1 (nenhuma importância - competência irrelevante) a 5 (extrema importância - competência imprescindível) e domínio (sua própria expertise), variando de 1 (não tenho domínio - não possuo competência) a 5 (tenho domínio completo da competência - excelência na competência).

A escolha dos itens que compuseram a escala de desempenho profissional por competências (EDC) foi realizada por 20 policiais militares (oficiais e praças), tendo como critério a importância técnica e comportamental da tarefa (alta importância para a atividade profissional), sua representatividade em todos os níveis hierárquicos e não ultrapassar quinze itens para cada competência. Esta tese buscará a adequação psicométrica da EDC em duas dimensões. A Tabela 18 apresenta os itens finais utilizados para mensurar o desempenho profissional por competências.

Tabela 18

Dimensões e itens da escala de desempenho profissional por competências

Dimensões e Itens*

Competências Técnicas: baseada nos conhecimentos e habilidades adquiridos na formação profissional e na especialização e capacitação continuada ocorrida durante a carreira. Faz parte do currículo do indivíduo e deve ser adequada à função exercida.

DCT1 Capacidade de utilizar armas e munições, quando necessário.

DCT2 Ser capaz de agir demostrando conhecimentos sobre legislação, normas e regimentos internos.

DCT3 Capacidade de identificar e gerenciar conflitos.

DCT4 Ter capacidade de agir com inovação.

DCT5 Capacidade de visão sistêmica (ter compreensão do todo em uma determinada situação; ser capaz de combinar partes coordenadas entre si e que formam um conjunto).

DCT6 Ser capaz de trabalhar de forma interdisciplinar.

DCT7 Capacidade de resposta imediata à sociedade, de acordo com as necessidades da mesma.

DCT8 Capacidade de persuasão e argumentação (poder de convencimento; capacidade contra-argumentar).

DCT9 Ter capacidade de utilizar a experiência pessoal e profissional ao planejar ações, seguindo normas, doutrina e legislações pertinentes ao âmbito da PMDF.

DCT10 Capacidade de agir com responsabilidade.

DCT11 Agir com eficiência no desempenho das atividades.

DCT12 Capacidade de tomada de decisão.

DCT14 Capacidade de gerar resultados efetivos ao desempenhar as tarefas relativas ao cargo. 
continuação

Competências Comportamentais: Atitudes e habilidades sociais dos profissionais em lidar com pessoas em situações cotidianas. Influenciada pela cultura institucional, seu desenvolvimento é estimulado por características individuais, tais como curiosidade, cautela, ousadia, razão, entre outras.

DCC1 Capacidade de negociação (buscar consenso de ideias; demonstrar firmeza em seus posicionamentos, sem ser intransigente).

DCC2 Capacidade de agir proativamente (buscar soluções de problemas demostrando determinação).

DCC3 Capacidade de reagir a ameaças e enfrentar situações, com prudência e coragem (dominar o medo em uma situação difícil; agir com cautela e precaução, procurando evitar riscos e consequências desagradáveis).

DCC4 Capacidade de agir com dinamismo (ser ativo e ágil, envolvendo-se em diversas atividades ao mesmo tempo).

DCC5 Capacidade de agir com senso crítico (ter postura crítica frente à determinada situação ou evento, após se cientificar das possíveis consequências).

DCC6 Capacidade de agir com empatia (entender e colocar-se no lugar do outro, compreendendo seus sentimentos e percepções / crenças gerais).

DCC7 Capacidade de agir com persistência e determinação, demostrando interesse e comprometimento com o trabalho.

DCC8 Capacidade de agir com flexibilidade (saber aceitar sugestões e críticas, bem como ajustar-se, de forma apropriada, a novos fatos, conceitos ou situações).

DCC9 Capacidade de agir com imparcialidade (agir com neutralidade e impessoalidade).

DCC10 Capacidade de agir com preocupação com a própria segurança.

DCC11 Capacidade de agir com criatividade.

DCC12 Capacidade de agir com postura ética e profissional.

DCC13 Capacidade de trabalhar em equipe.

DCC14 Capacidade de comunicação.

DCC15 Capacidade de agir com deferência (capacidade de acatar normas e agir em conformidade com as mesmas).

DCC16 Capacidade de disciplina.

DCC17 Ter capacidade de manter bom relacionamento com outros servidores.

* Os itens estão na sequência exata do instrumento aplicado aos policiais.

Em resumo, a Tabela 19 apresenta uma síntese da operacionalização das variáveis latentes do modelo de pesquisa.

Tabela 19

Síntese da operacionalização das variáveis

\begin{tabular}{cllc}
\hline & \multicolumn{1}{c}{ Construtos } & \multicolumn{1}{c}{ Operacionalização } & N $^{\circ}$ de Itens \\
\hline & Valores Organizacionais & Adaptado de Porto el. al (2012). & 39 \\
$\begin{array}{c}\text { Variáveis } \\
\text { independentes } \\
\text { ou mediadoras }\end{array}$ & Identidade Profissional Organizacionais & $\begin{array}{l}\text { Construída com base nos estudos de D’Iribarne } \\
(1989) \text { por Souza (2014). }\end{array}$ & 45 \\
& $\begin{array}{l}\text { Identidade } \\
\text { Organizacional }\end{array}$ & Adaptado de Mael e Ashforth (1992). & 18 \\
\hline $\begin{array}{c}\text { Variável } \\
\text { Dependente }\end{array}$ & $\begin{array}{l}\text { Desempenho profissional } \\
\text { por competências }\end{array}$ & $\begin{array}{l}\text { Adaptado de SENASP (2012) como base no } \\
\text { modelo de Faiad et al. (2012). }\end{array}$ & 6 \\
\hline Total & & & 30 \\
\hline
\end{tabular}

Após apresentar a operacionalização dos construtos do modelo, serão expostos os procedimentos de análise dos dados, tanto da validação dos instrumentos de medida quanto dos testes das hipóteses de pesquisa. 


\section{Seção 3. Metodologia de Análise dos Dados}

Nessa seção o interesse recai sobre a metodologia de desenvolvimento e validação dos instrumentos de medida (3.1) e metodologia dos testes de hipóteses da pesquisa (3.2).

\subsection{Metodologia de Desenvolvimento e Validação da Escala de Medida}

A teoria e o modelo de elaboração de instrumentos de medida, utilizada nessa tese, baseia-se em três grandes polos, que são denominados por Pasquali (2010) como procedimentos teóricos, procedimentos empíricos e procedimentos analíticos.

O polo teórico refere-se ao fundamento teórico presente em qualquer iniciativa científica, ou seja, à explicitação da teoria sobre o construto para o qual se quer desenvolver um instrumento de medida, bem como a operacionalização do construto em itens (Pasquali, 2010). Segundo o autor, algumas etapas são verificadas no procedimento teórico: a definição das propriedades do sistema psicológico (componentes psicológicos: variáveis de processo e atributos das práticas organizacionais), a definição da estrutura semântica dos componentes (dimensionalidade do atributo), as definições constitutivas e operacionais das variáveis (construção de itens) e a análise teórica dos itens do instrumento (análise semântica e análise de juízes).

O polo empírico trata do planejamento da pesquisa, ou seja, das etapas e técnicas de aplicação do instrumento para a posterior avaliação psicométrica. E, por fim, o polo analítico é responsável pela validade do instrumento (Pasquali, 2010).

\subsubsection{Validação e Tratamento dos Instrumentos de Medida}

Cinco pontos serão abordados na fase de validação dos instrumentos de medida. $\mathrm{O}$ primeiro ponto trata das condições prévias para a realização das análises multivariadas (3.1.1.1), comuns a todos os instrumentos da tese, a análise fatorial exploratória (3.1.1.2), o escalonamento multidimensional (MDS) (3.1.1.3), a confiabilidade e a validade dos instrumentos (3.1.1.4) e a análise fatorial confirmatória (3.1.1.5), também comum a todos os instrumentos de medida utilizados.

\subsubsection{Condições Prévias para Realização das Análises Multivariadas}

A realização de validação de instrumentos de medida pressupõe o cumprimento de certos pré-requisitos dos métodos de análise multivariada. De acordo com Tabachnick e 
Fidell (2007), Roussel, Durrieu, Campoy e Akremi (2002) e Kline (2010), Marôco (2011) e Pasquali (2012), especial atenção deve ser dada para os seguintes pontos:

\section{$>$ Falta de valores ausentes (missing values) e valores extremos (outliers)}

A existência de valores ausentes pode evidenciar problemas com a amostra. Segundo Tabachnick e Fidell (2007), se os casos faltantes ultrapassarem 5\% da amostra, o pesquisador deve realizar uma verificação pormenorizada do banco. Caso sejam inferiores aos 5\%, devese proceder a algum tipo de tratamento (substituição pela média, regressão, pela remoção da observação, por exemplo). A análise dos outliers deve ser realizada por intermédio dos gráficos dos gráficos de caixas e bigodes e pelos teste da distância de Mahalanobis e distância de Cook.

\section{$>$ Normalidade Multivariada dos dados}

A validade das análises apresenta como pressuposto a existência de uma distribuição normal multivariada dos dados. Para se observar essa condição, podem-se utilizar os histogramas com a curva de Gauss (curva normal) e os testes de Kolmogorov-Smirnov e Shapiro Wilk. Com base nos coeficientes de assimetria (skewness) e achatamento (kurtosis), é possível se avaliar a quasi-normalidade univariada dos dados. Esses dois últimos coeficientes devem estar, respectivamente, entre $|3|$ e $|7|$ (Kline, 2010). Por fim, o teste de Mardia, disponível no software Amos, também será utilizado para verificar a normalidade multivariada.

\section{$>$ Ausência de multicolinearidade entre as variáveis}

A multicolinearidade trata da elevada dependência linear entre duas variáveis (Kline, 2010; Marôco, 2010; Tabachnick \& Fidell, 2007). Sua ocorrência pode causar resultados indesejados, entre os quais: matriz negativamente definida e instabilidade dos parâmetros estimados. Para verificar a ocorrência da multicolinearidade, deve se observar o valor do fator de inflação da variância (VIF - Variances Inflation Factor). Se o valor do VIF exceder a 10, existem motivos para preocupações (Myers, 1990); se a tolerância estiver abaixo de 0,10, este valor é uma indicação de sérios problemas (Menard, 1995; Tabachnick \& Fidell, 2007).

\section{Homogeneidade da Variância da amostra}

Deve ser verificado se a comparação das médias populacionais, baseada em amostras representativas, apresenta variâncias populacionais estimadas pelas amostras, quer sejam homogêneas, quer sejam homocedásticas. A análise da homogeneidade da variância das amostras deve ser realizada com auxílio do teste de Levene, considerado um dos testes mais potentes para este fim (Marôco, 2011). 


\subsubsection{Análise Fatorial Exploratória}

A análise fatorial exploratória (AFE) é uma técnica de análise exploratória de dados que tem por finalidade descobrir e analisar investigar a estrutura de um conjunto de variáveis interrelacionadas de maneira a construir uma escala de medida para fatores (intrínsecos) que, de alguma forma (mais ou menos explícita), controlam as variáveis originais (Marôco, 2011). Existem diversas formas de se extrair as dimensões na AFE. Nesta tese, o método da fatorização do eixo principal (Principal Factor Analysis - PAF) será utilizado. Esse método assume que cada variável é constituída por uma parte comum à estrutura fatorial e por uma parte específica da variável (Marôco, 2011), sendo uma das técnicas mais utilizadas para a extração de fatores (Pasquali, 2012).

Alguns pontos devem ser considerados ao se realizar uma AFE, ou seja, as condições de fatorização, o número de fatores a reter e a interpretação dos fatores.

\section{Condições de fatorização dos dados}

Recomenda-se o exame das correlações entre as variáveis para saber se apresentam o tamanho adequado. Para Kline (2010), Marôco (2011) e Pasquali (2012), 50\% das correlações devem ser maiores do que 0,3. Caso essa condição seja satisfeita, dois testes são realizados:

- Teste de esfericidade de Barlett: testa a hipótese de que a matriz de covariâncias é uma matriz identidade, ou seja, as correlações fora da diagonal principal são todas iguais a 0 e, portanto, nenhuma variável se relaciona com nenhuma outra. Quando se rejeita essa hipótese, a matriz é fatorizável (Pasquali, 2012).

- Teste de adequação da amostra de Kaiser-Meyer-Olkin (KMO): é o teste que verifica se as correlações entre as variáveis originais são suficientemente elevadas para que a análise fatorial seja útil para estimar os fatores comuns (Marôco, 2011). O KMO indica qual a proporção das variáveis retidas que formam um conjunto coerente para se mensurar adequadamente um conceito (Kline, 2010). Valores próximos a 1 indicam que os dados são fatorizáveis, aceitam-se valores acima de 0,7, considerados medianos por Marôco (2011) e Pasquali (2012).

Caso os dados sejam fatorizáveis, parte-se para a extração dos fatores, isto é, a etapa da dimensionalidade da medida. 


\section{Número de fatores a reter}

Serão utilizados critérios de retenção convencionais (teste scree, Kaiser, importância do fator, \% variância explicada, etc.) e o teste estatístico (teste de análise paralela de Horn). Os índices usualmente utilizados são os seguintes:

- Critério do teste scree de Cattel (1966), critério do screeplot: constitui uma representação gráfica dos autovalores.

- Critério Kaiser (1960): os autovalores devem ser superiores a 1 para serem retidos.

- Importância do fator de Harman (1967): um fator deve explicar pelo menos 3\% da variância total das variáveis.

- \% da variância total explicada: nessa pesquisa, a preferência será por um limiar de 50\% (Evrard et al., 2009; Marôco, 2011).

- Teste de análise paralela de Horn (1965): consiste em reter, como número de fatores, o número de autovalores que na matriz empírica forem superiores aos autovalores obtidos de uma matriz de dados aleatória. São retidos os componentes das variáveis que são significativamente superiores aos obtidos aleatoriamente. A sintaxe de Watkins (2000) será utilizada nessa pesquisa.

Em virtude dos diversos critérios de retenção de fatores utilizados, em caso de conflito e após ponderações das implicações teóricas, será utilizado o teste de análise paralela de Horn, como critério final de escolha, considerando, que a análise paralela tem sido considerada uma técnica mais precisa para a decisão sobre o número de fatores (Hayton, Allen \& Scarpello, 2004; Laros, 2005; Zwick \& Velicer, 1986).

\section{$>$ Rotação dos fatores}

Para se obter melhor interpretação dos fatores obtidos, faz-se necessária sua rotação (Pasquali, 2012). Como se pressupõe uma correlação entre os fatores de cada uma das escalas dessa tese, a rotação oblíqua é a mais adequada (Evrard et al., 2009), sendo a Oblimin direta (direct oblimin) a mais frequentemente utilizada (Marôco, 2011).

\section{Interpretação dos fatores}

Dois elementos são essenciais para a interpretação dos fatores: as comunalidades e os coeficientes de correlação entre as variáveis iniciais.

- Comunalidades: responsáveis por avaliar a qualidade da representação das variáveis pelo fator. Mensuram, portanto, a proporção da variância da variável explicada pelos fatores retidos. São candidatas à eliminação as variáveis com baixa comunalidade (inferior a 0,3 ). 
- Coeficientes de correlação: a correlação entre as variáveis iniciais e os fatores permitem observar a contribuição fatorial das variáveis iniciais sobre os fatores retidos. São considerados apenas valores superiores a 0,3 (Marôco, 2011; Pasquali, 2012; Tabachnik \& Fidell, 2007).

\subsubsection{Escalonamento Multidimensional (MDS)}

O escalonamento multidimensional (Multidimensional Scaling - MDS) é uma técnica exploratória multivariada que possibilita a representação de maneira parcimoniosa, em um sistema dimensional, reduzindo as proximidades (semelhanças/dissemelhanças) entre sujeitos e objetos, com base em um conjunto de atributos multivariados medidos (Marôco, 2011). É uma técnica comparada à análise fatorial, que nessa tese será utilizada para identificar as dimensões latentes da escala de valores organizacionais.

Nessa pesquisa será utilizado o MDS clássico, cujos dados consistem em uma matriz de proximidades (semelhanças/dessemelhanças) entre os objetos (Marôco, 2011). De acordo o autor, com esse modelo, o pesquisador deve encontrar as fronteiras que permitam representar as proximidades em diversas variáveis num espaço $r$-dimensional reduzido.

\section{$>$ Algoritmos de MDS}

De acordo com Marôco (2011), no Statistical Package for the Social Sciences - SPPS Statistics encontram-se dois algoritmos de MDS: o alternating least squares scaling (ALSCAL) e o proximity scaling (PROXSCAL). A diferença entre os algoritmos está na maneira como é obtida a solução inicial para o problema de redução da dimensionalidade, e como se dá a avaliação da solução obtida (Marôco, 2011). No algoritmo ALSCAL, a solução inicial de dimensões e coordenadas nessas dimensões inicia-se com o processamento da matriz de proximidades. No PROXSCAL, três são os métodos disponíveis para determinar a solução inicial, segundo Marôco (2011):

- Método Simplex: os objetos são alocados à mesma distância uns dos outros no número de dimensões máximas possíveis (n-1) e, após, ocorre a redução das dimensões, pelo algoritmo, para o número de dimensões solicitado pelo pesquisador.

- Togerson Start: Trata-se da solução de escalonamento clássico para o algoritmo ALSCAL, que será a empregada nesta tese. Neste método, as proximidades de cada fonte são agregadas, elevadas ao quadrado, centradas e multiplicadas por -0,5. Posteriormente, ocorre a decomposição da matriz resultante nos valores próprios para definir as coordenadas dos objetos nas dimensões retidas. 
- Rondom Start: os valores das coordenadas são gerados de forma aleatória para várias soluções; em seguida, é escolhida a solução de menor Raw Stress normalizado.

\section{$>$ Medidas de Qualidade da Solução de MDS}

A avaliação da qualidade da solução inicial é realizada por recurso a uma ou mais funções de discrepância (STRESS). Ao se obter a solução inicial com $r$ dimensões, recorre-se ao algoritmo interativo que se encerra quando a diferença entre as funções STRESS do passo atual e do passo anterior do algoritmo esteja abaixo de um limite afixado pelo pesquisador. No ALSCAL, a função STRESS a minimizar é a SSTRESS, sendo que no PROXSCAL é o Raw Stress; ambos os índices devem ser próximos a 0.

Outras medidas de qualidade de MDS são frequentemente utilizadas (Marôco, 2011). Com o objetivo de evitar o problema da escala do Raw Stress, Kruskal (1964), observando que o STRESS é somente a soma de quadrado dos erros do modelo, sugeriu o Raw Stress Normalizado (NRS). Quanto mais próximo de zero os valores, melhor, sendo que Kruskal (1964) considera a qualidade da solução entre 0,05 e 0,1 boa.

Marôco (2011) observa que o STRESS é uma medida da mediocridade da solução de MDS, ou seja, quanto maior o STRESS-I pior é a qualidade da solução retida. Diante disso, Kruskal (1964) propôs a medida de STRESS-II, em que os valores são aproximadamente duplos dos valores de STRESS-I.

Considera-se, ainda, o cálculo da Dispersão das Proximidades, explicada pela solução retida (Dispersion Accounted For) DAF $=1-N R S$. Quanto mais próximo a 1, melhor será a solução retida ( $\geq 0,7$ são aceitáveis, Marôco, 2011). A interpretação do DAF é semelhante ao $\mathrm{R}^{2}$ da regressão. E, por fim, a raiz quadrada do $D A F$, que define o coeficiente de congruência de Tucker, apresenta a mesma interpretação do $R$ na regressão linear.

\subsubsection{Confiabilidade e Validade dos Instrumentos de Medida}

Confiabilidade e validade, de acordo com Diallo (2011), são dois critérios que qualquer escala deve atender. Entretanto, no que se refere ao processo de validade, segundo Messick (1995), essa não está no instrumento, encontrando-se, sim, na interpretação e aplicabilidade do instrumento de medida em determinado contexto.

\section{$>$ Confiabilidade dos instrumentos de medida}

A confiabilidade (consistência interna) descreve em que medida os itens que compõem uma escala são pertinentes para o construto subjacente. A confiabilidade pode ser influenciada pela técnica utilizada (teste/re-teste, split half, medidas alternativas, por 
exemplo) (Evrard et al., 2009, Pasquali, 2010). Nessa pesquisa, dois indicadores de confiabilidade serão utilizados: o alfa de Cronbach e Rho Jöreskog.

- Alfa de Cronbach: é o coeficiente que reflete o grau de covariância dos itens entre si, ou seja, verifica em qual medida os itens de uma escala medem conjuntamente o mesmo construto. Considera-se superior a 0,7 aceitável (Nunnally, 1978), ou em torno de 0,6 em estudos exploratórios (Hair, Black, Babin, Anderson, \& Tatham, 2009). Como uma medida sensível ao número de itens, um coeficiente alternativo será utilizado, o $\rho$ de Jöreskog.

- Rho $(\rho)$ de de Jöreskog: é a parte da variância dos fatores compostos compartilhada pelos itens que medem esse fator. Representam a consistência interna dos itens reflexivos do fator, indicando o grau em que esses itens são manifestações do fator latente (Jöreskog , 1971; Marôco, 2010).

\section{Validade dos instrumentos de medida}

É a propriedade de o instrumento de medida medir e operacionalizar um construto latente que se busca mensurar (Marôco, 2010), isto é, um instrumento de medida é considerado válido quando ele permite a melhor compreensão do fenômeno que o pesquisador busca medir (Diallo, 2011), em um contexto específico.

- Validade de face e a validade de conteúdo: é o grau em que a operacionalização de um construto representa bem todas as facetas do conceito. Esses dois tipos de validade são avaliadas nessa pesquisa, para a construção da escala de práticas organizacionais, com base na revisão da literatura, nas entrevistas com os policiais militares e na validação dos itens por um grupo de quatorze juízes especialistas no domínio da pesquisa.

- Validade de construto: corresponde ao grau a que os indicadores de um construto são uma boa representação do conceito estudado (Diallo, 2011). Pode-se distinguir a validade convergente da validade discriminante.

- Validade convergente: apresenta-se quando o construto estudado se correlaciona positiva e significativamente com outros construtos paralelos e quando os itens que constituem o construto apresentam elevadas correlações positivas entre si (Marôco, 2010). Para se verificar essa medida, Fornell e Larcker (1981) utilizam o Rho de validade convergente $\left(\rho_{\mathrm{vc}}-\mathrm{Rho}_{\mathrm{vc}}\right)$, calculado por intermédio da variância média extraída (VEM) pelo fator. Valores superiores a 0,5 são indicativos de validade convergente.

- Validade discriminante: Verifica se os indicadores que medem diferentes construtos são pouco correlacionados entre si. Consiste, ainda, em avaliar se os itens que refletem um fator não estão correlacionados com outros fatores, ou seja, os fatores, definidos 
por cada conjunto de itens, são distintos (Marôco, 2010). A validade discriminante verifica-se quando: as VEM dos fatores forem maiores ou iguais ao quadrado das correlações entre esses fatores (Fornell \& Larcker, 1981).

\subsubsection{Análise Fatorial Confirmatória}

A análise fatorial confirmatória (AFC) é uma técnica estatística utilizada para avaliar a qualidade do ajustamento de um modelo de medida teórico à estrutura correlacional observada entre as variáveis manifestas (Marôco, 2011). Pode ser entendida como um prolongamento da análise fatorial exploratória (AFE) (Diallo, 2011), mas que apresenta algumas diferenças, sobretudo a forte dependência da AFE na matriz R, enquanto a AFC impõe aos dados (à matriz R) uma estrutura teórica preliminar, bem como a necessidade de adaptação dos dados empíricos expressos pela mesma matriz R (Pasquali, 2012). A AFC apresenta-se como uma miscelânea entre a análise fatorial e a análise de regressão, que possibilita o teste de estruturas fatoriais dos instrumentos de medida (Pilati \& Laros, 2007; Klem, 2002; Thompson, 2002; Ullman, 2007).

Nessa tese, a AFC será realizada com a utilização do software AMOS 18. Para se confirmar a estrutura latente existente, deve-se especificar as relações entre as variáveis, prioritariamente, levando-se em consideração os índices de ajuste para decidir se os dados se adequam ao modelo (Bollen, 1989). Em caso de índices satisfatórios, conclui-se que o modelo se ajusta aos dados.

O modelo confirmatório é construído com base nas equações estruturais, que necessitam de vários passos para se desenvolver. Diversos autores tratam dos pontos para sua elaboração; por exemplo, Evrard et al. (2009) sugerem quatro etapas: especificação, identificação, avaliação e teste do modelo. De acordo com Diallo (2011), os quatro passos, anteriormente citados, resumem os sete passos de Hair et al. (2009). Para esses últimos autores, as etapas são: desenvolvimento de um modelo teórico, construção de um esquema das relações lineares, transposição do esquema das relações lineares para o modelo estrutural e de medida, estimar o modelo teórico, avaliar a identificação do modelo e avaliar a qualidade do ajuste do modelo aos dados e interpretar os resultados. A Tabela 20 apresenta uma síntese das etapas necessárias para o desenvolvimento de um modelo de equações estruturais. 
Tabela 20

Etapas do modelo de equações estruturais

\begin{tabular}{ll}
\hline \multicolumn{1}{c}{ Etapas } & \multicolumn{1}{c}{ Conteúdo e Comentários } \\
\hline $\begin{array}{l}\text { 1. Desenvolvimento de um } \\
\text { modelo teórico. }\end{array}$ & Quadro teórico adicionando-se as hipóteses de pesquisa. \\
$\begin{array}{l}\text { 2. Construção de um esquema } \\
\text { das relações lineares. }\end{array}$ & $\begin{array}{l}\text { Relações entre as variáveis adicionando-se os sentidos das flechas } \\
\text { (modelo reflexivo nessa tese). }\end{array}$ \\
$\begin{array}{l}\text { 3. Transposição do esquema } \\
\text { das relações lineares para o } \\
\text { modelo estrutural e de } \\
\text { medida. }\end{array}$ & $\begin{array}{l}\text { enquanto que o modelo estrutural conecta as relações entre as a } \\
\text { variánententes ou construtos. }\end{array}$
\end{tabular}

4. Estimar o modelo teórico.

Versa sobre a escolha do tipo de matriz a ser utilizada (covariância ou correlação) do método de estimativa (máxima verossimilhança-ML ou outro) e do tamanho da amostra.

5. Avaliar a identificação do modelo.

A não-recursividade de um modelo se identifica quando existem tantos parâmetros quanto observações e, caso não haja problemas de multicolinearidade.

6. Avaliar a qualidade do Os índices de ajuste utilizados serão os absolutos, os incrementais e ajuste do modelo aos dados. os de parcimônia, em seguida especificados.

7. Interpretar os resultados e No caso de serem satisfeitas as condições acima, o modelo é relatar as possíveis aceitável. Entretanto, os modelos alternativos ou equivalentes devem modificações, desde que haja ser considerados. A introdução de covariáveis também se faz justificativa teórica. necessária para a avaliação dos seus efeitos sobre o modelo validado. Fonte. Adaptado de Hair et al. (2009), Marôco (2010), Kline (2010), Roussel et al. (2002).

O próximo ponto a ser relatado refere-se à estimação dos parâmetros, à identificação do modelo e à interpretação dos resultados.

\subsection{Estimação dos parâmetros do modelo}

Essa etapa consiste na aquisição de estimativas dos parâmetros do modelo que melhor reproduzam os dados observados na amostra em análise (Marôco, 2010). Três pontos são considerados para a estimação dos modelos de equações estruturais:

- A escolha da matriz dos dados: será utilizada a matriz de variâncias-covariâncias, que possibilita a maximização da probabilidade de observar a estrutura correlacional das variáveis percebidas na amostra (Marôco, 2010), além de ser indicada para se testar uma teoria (Roussel et al., 2002).

- O tamanho da amostra: os autores divergem sobre o tamanho da amostra (Marôco, 2010; Kline, 2010; Roussel et al., 2002); entretanto, quando são muito pequenas instabilizam os resultados, grandes demais deterioram os índices de ajuste, notadamente, o qui-quadrado. Para Roussel et al. (2002) entre 200 e 300 respondentes é considerado ideal; entretanto, como 
regra geral, utilizam-se 10 respondentes por item (Kline, 2010; Pasquali, 2012). Neste trabalho, esses critérios são considerados.

- O método de estimação: será utilizado o método da máxima verossimilhança (MV), que permite a obtenção de melhores resultados, mesmo com a violação do pressuposto da normalidade (Marôco, 2010; Kline, 2010).

\subsection{Identificação do modelo}

A identificação do modelo refere-se ao cálculo da estimativa única do seus parâmetros (Roussel et al., 2002). Serão empregados os critérios de Bollen (1989) para a identificação dos modelos de mensuração: (1) número de observações equivalentes ao número de parâmetros livres do modelo e (2) atribuir uma métrica para cada variável latente. Deve-se, ainda, observar a multicolinearidade entre as variáveis, em virtude de uma provável definição não positiva da matriz, impossibilitando a identificação do modelo (Kline, 2010; Marôco, 2010).

\subsection{Identificação dos resultados}

A avaliação da qualidade do modelo tem o objetivo de identificar quanto o modelo teórico é capaz de reproduzir a estrutura correlacional das variáveis manifestas observadas na amostra sob estudo (Marôco, 2010). Segundo esse autor, três são os aspectos referenciados para se avaliar a qualidade do modelo: (1) os testes de ajustamento; (2) os índices empíricos baseados nas funções de verossimilhança ou na matriz de resíduos obtidos durante o ajustamento do modelo; (3) a análise dos resíduos e da significância dos parâmetros. Nessa etapa, pode-se propor a reespecificação dos modelos testados (caso não haja o ajuste adequado), bem como a exploração de modelos equivalentes ou alternativos (Marôco, 2010; Kline, 2010).

\section{Avaliação do modelo}

Distinguem-se o modelo de medida (relações entre os construtos e seus indicadores) e o modelo estrutural (relação entre os construtos). De acordo com Anderson e Gerbing (1988), é preferível a avaliação separada dos dois modelos: primeiro o modelo de medida e, posteriormente, o modelo estrutural, para a melhor compreensão dos problemas em caso de falta de ajuste do modelo. Em todos os casos, é baseado em cinco tipos de índices de ajuste: índices absolutos, índices relativos, índices de parcimônia, índices de discrepância populacional e índices baseados na teoria da informação (Marôco, 2010). 
Ainda que esses índices e seus valores de referência não sejam unanimidades entre os pesquisadores (Barrett, 2007; Bentler, 1990, 2007; Bollen \& Long, 1993; Browne \& Cudeck, 1993; McIntosh, 2007; Mulaik, 2007), eles têm realizado vários estudos de simulação e observação empírica, que sustentam abordagens estratégicas diversas e recomendações para a análise e qualidade do ajustamento. Diante disso, serão apresentados os indicadores de maior consenso nas ciências sociais (Hu \& Bentler, 1999; Kline, 2010; Marôco, 2010; Pilati \& Laros, 2007; Roussel et al., 2002, por exemplo), conformeTabela 21.

Tabela 21

Índices de qualidade dos ajustes e valores de referência

\begin{tabular}{|c|c|c|}
\hline Índices & $\begin{array}{l}\text { Valores de } \\
\text { Referência }\end{array}$ & Comentários \\
\hline Índices Absolutos & \multicolumn{2}{|c|}{$\begin{array}{l}\text { Avaliam a qualidade do modelo por si, sem a comparação com outros } \\
\text { modelos. Permitem avaliar em que medida o modelo teórico proposto } a \\
\text { priori reproduz de forma correta os dados coletados. }\end{array}$} \\
\hline Qui-quadrado $\left(\chi^{2}\right)$ & $p>0,05$ & Mede a falta de ajuste do modelo. \\
\hline$\chi^{2} / g .1$ & $1 \leq \chi^{2} /$ g.l. $\leq 5$ & $\begin{array}{l}\text { Permite detectar modelos "super-ajustados" e "sub- } \\
\text { ajustados" ou medir o grau de parcimônia absoluta } \\
\text { do modelo (Roussel et al., 2002). }\end{array}$ \\
\hline $\begin{array}{l}\text { RMR } \\
\text { (Root Mean Square } \\
\text { Residual) }\end{array}$ & O menor possível & $\begin{array}{l}\text { É a raiz quadrada da matriz dos erros dividida pelos } \\
\text { graus de liberdade admitindo que o modelo } \\
\text { ajustado é o correto (Jöreskog \& Sörbom, 1996). }\end{array}$ \\
\hline $\begin{array}{l}\text { SRMR } \\
\text { (Standardized Root } \\
\text { Mean Square Residual) }\end{array}$ & $<0,10$ & $\begin{array}{l}\text { É a diferença entre a correlação normalizada } \\
\text { observada e a correlação previsível. }\end{array}$ \\
\hline $\begin{array}{l}\text { GFI - AGFI }{ }^{(1)} \\
\text { (Goodness of Fit Index - } \\
\text { Adjusted Goodness of Fit } \\
\text { Index) }\end{array}$ & $>0,90$ & $\begin{array}{l}\text { O GFI explica a proporção da covariância } \\
\text { observada, entre as variáveis manifestas, explicada } \\
\text { pelo modelo ajustado (Marôco, 2010). Mede o grau } \\
\text { de ajuste do modelo. O AGFI é a versão ajustada } \\
\text { pelos graus de liberdade. }\end{array}$ \\
\hline
\end{tabular}

Índices Relativos

Avaliam a qualidade do modelo em estudo comparativamente ao modelo com o pior ajuste possível (restritivo) e/ou ao modelo com melhor ajuste possível (saturado) (Marôco, 2010), ou seja, mede a melhora no ajuste comparando o modelo testado com um modelo base.

\begin{tabular}{lll}
$\begin{array}{l}\text { CFI } \\
\text { (Comparative FIT Index) }\end{array}$ & $>0,90$ & $\begin{array}{l}\text { Mede a diminuição relativa da falta de ajustamento } \\
\text { (Marôco, 2010; Roussel et al., 2002). }\end{array}$ \\
$\begin{array}{l}\text { TLI } \\
\text { (Tucker-Lewis Index) }\end{array}$ & $>0,90$ & $\begin{array}{l}\text { Compara o ajuste do modelo em estudo comparado } \\
\text { com o ajuste do modelo base (Roussel et al., 2002) }\end{array}$ \\
\hline
\end{tabular}


continuação

Índices de Parcimônia Objetivam compensar a melhoria artificial do modelo que se consegue, somente, pela inclusão de mais parâmetros livres aproximando o modelo em estudo do modelo saturado (Marôco, 2010).

\begin{tabular}{|c|c|c|}
\hline $\begin{array}{l}\text { PCFI } \\
\text { (Parsimony Comparative } \\
\text { Fit Index) }\end{array}$ & $>0,60$ & $\begin{array}{l}\text { Penaliza o CFI pela relação de parcimônia. } \\
\text { PCFI=CFI x g.l. / g.l } \text { b. }_{\text {. }} \text { Marôco, 2010). }\end{array}$ \\
\hline $\begin{array}{l}\text { PGFI } \\
\text { (Parsimony Goodness of }\end{array}$ & $>0,60$ & $\begin{array}{l}\text { Penaliza o GFI pelo rácio de parcimônia. } \\
\text { PCFI=GFI x g.l. / g.l l. (Marôco, 2010). }\end{array}$ \\
\hline
\end{tabular}

Índices de Discrepância

Comparam o ajuste do modelo obtido com os momentos amostrais Populacional (médias e variâncias amostrais) relativamente ao ajustamento do modelo que se conseguiria com os momentos populacionais (médias e variâncias populacionais) (Marôco, 2010). Avalia o ajuste do modelo em uma replicação hipotética com amostras do mesmo tamanho e aleatoriamente retiradas da mesma população que a população original do pesquisador (Kline, 2010).

RMSEA

(Root Mean Square Error of Approximation)
Representa a diferença média por graus de liberdade esperado na população total (Roussel et al., 2002). Penalização dos momentos populacionais pelo número de graus de liberdade do modelo de maneira a compensar a melhoria, potencial, do ajuste do modelo pela simples adição de mais parâmetros (Marôco, 2010).

\section{Índices Baseados na Teoria da Informação}

Baseiam-se na estatística do $\chi^{2}$ e penalizam o modelo em razão de sua complexidade (Marôco, 2010). Para esse autor, os índices baseados na teoria da informação não apresentam valores de referência para a classificação do modelo. A partir da comparação entre os modelos alternativos, o de menor valor, para os índices, será o melhor modelo.

\section{AIC}

(Akaike Information O menor possível Penaliza os modelos complexos.

Criterion)

ECVI

(Expected Cross-

Validation Index)
Reflete o ajuste teórico do modelo em outras O menor possível amostras similares àquela em que o modelo foi ajustado, a partir de uma única amostra (Marôco, 2010). Estudos de simulação mostram alta precisão na AFC (Bandalos, 1992).

(1) Esses índices, mesmo sendo pouco confiáveis a partir dos estudos de simulações, foram mantidos pela sua larga utilização nos estudos em ciências sociais. 


\section{Modificação do modelo e interpretação dos resultados}

Caso o modelo ajustado não apresente um ajuste satisfatório para explicar a estrutura correlacional das variáveis observadas na amostra estudada, pode-se realizar a reespecificação do modelo para que o ajuste melhore de forma significativa (Marôco, 2010). Levando-se em conta a teoria de base, três índices são empregados habitualmente:

- Valor $t$ : valores de $|\mathrm{t}|$ inferiores a 1,96 são indicativos da eliminação do parâmetro correspondente, salvo, aqueles com importância teórica para o estudo (Russel et al., 2002).

- Resíduos estandardizados (padronizados): os valores absolutos devem ser inferiores a 2,58, caso contrário, podem indicar problemas no ajustamento. A correção pode-se dar pela eliminação do indicador em questão (MacCallum, 1986).

- Índices de modificação (IM): Estimam a redução (conservadora) da estatística do qui-quadrado do modelo, nos casos em que: o parâmetro fixo ou uma restrição de igualdade entre parâmetros for liberada; os erros de medida forem correlacionados; e novas trajetórias estruturais forem adicionadas, após se considerar a restrição do modelo e a variação dos graus de liberdade associada (Marôco, 2010).

Ao considerar estritamente as questões estatísticas, um determinado modelo pode ser modificado até apresentar um ajuste perfeito (tanto melhor será o ajuste quanto mais próximo estiver do modelo saturado), mais ainda ser teórica e conceitualmente inapropriado (Marôco, 2010). No procedimento de reespecificação, emprega-se, frequentemente, modelos equivalentes (com a configuração das relações estruturais diferentes do modelo do pesquisador, mas que se ajusta bem aos dados) ou modelos concorrentes (que não apresentam o mesmo ajustamento, nem a mesma estrutura que o modelo do pesquisador) (Kline, 2010).

Uma solução possível para a validação do modelo é recorrer a uma estratégia de validação cruzada (Marôco, 2010). Segundo esse autor, quando as amostras são suficientemente grandes ( $>400)$, utiliza-se 3/4 da amostra, selecionada aleatoriamente, para ajustar ao modelo e o 1/4 remanescente é utilizado para avaliar a invariância do modelo. Caso a amostra não seja adequada para a validação cruzada, ou haja mesmo a impossibilidade de uma segunda amostra, Browne e Cudeck (1989) propuseram a utilização do ECVI, juntamente com seu intervalo de confiança, como um indicador da validade de modelos alternativos na população a partir de uma única amostra. $\mathrm{O}$ modelo que apresentar o menor valor do ECVI será o mais estável (invariante) na população, conforme esses autores. 


\subsection{Metodologia dos Testes de Hipóteses da Pesquisa}

Essa seção apresentará o método do teste das hipóteses relativas às relações estruturais diretas (3.2.1), mediadoras (3.2.2), das variáveis sociodemográficas (3.2.3).

\subsubsection{Método do teste dos efeitos diretos nas equações estruturais}

Análise de equações estruturais define-se como uma técnica de modelação generalizada, empregada para testar a validade de modelos teóricos que definem relações (hipotéticas) entre variáveis (Marôco, 2010). Trata-se de uma série de relações que formam um conjunto de equações lineares que relacionam variáveis exógenas (independentes) com variáveis endógenas (dependentes) (Roussel et al., 2002). Além disso, essa análise é uma extensão dos modelos lineares generalizados que analisam, de maneira explícita, os erros de medida associados às variáveis investigadas (Marôco, 2010).

Diversos programas podem ser utilizados para operacionalizar as equações estruturais (LISREL, EQS, AMOS, Mplus, entre outros). Nesta pesquisa, o software Amos 18 (Arbuckle, 2009) será empregado para as análises estruturais. Entre outras razões, destacamse sua interface gráfica amigável e a integração das opções necessárias para as análises dos dados disponíveis.

Para testar as hipóteses de pesquisa (relações entre os construtos), três pontos serão contemplados, conforme as recomendações de Marôco (2010); Kline (2010) e Rousseal et al. (2002):

- Significâncias dos coeficientes de regressão não estandardizados (padronizados): nesse ponto, o valor de teste $t$ de Studentdeve ser analisado, levando-se em consideração cada um dos coeficientes para assegurar que a relação hipotética é estatisticamente diferente de zero. O valor dotdeve ser maior do que 1,96 para um nível de significância de 5\%.

- Coeficientes de regressão estandardizados (padronizados): os coeficientes padronizados permitem estimar a importância relativa dos "caminhos"; situam-se entre 0 e 1. Quanto maior o valor destes coeficientes, maior a força da relação entre as variáveis latentes.

- Correlação múltipla ao quadrado ou porcentagem da variância da variável endógena $\left(R^{2}\right)$ : calcula-se subtraindo 1 do quadrado do coeficiente normalizado (estandardizado) do termo de erro associado à variável latente. Tal percentual é equivalente a $R^{2}$ da regressão. Valores até 0,3 são considerados baixos, entre 0,3 e 0,5 medianos e acima de 0,5 bons. 


\subsubsection{Método do teste dos efeitos mediadores}

A mediação pode ser definida como o grau em que uma dada variável influencia a relação entre a variável independente e a variável dependente (Baron \& Kenny, 1986). Para esses autores, A Figura 16 mostra representações de relações mediadoras; a Figura 16a mostra a representação de uma mediação simples entre X e Y, enquanto a Figura 16b representa uma mediação múltipla entre X e Y (Preacher \& Hayes, 2008). Da mesma forma, destaca-se a mediação múltipla em uma etapa (por exemplo, a relação X-M1-Y) e mediação múltipla em cadeia (isto é, a relação X-M2-M1-Y).

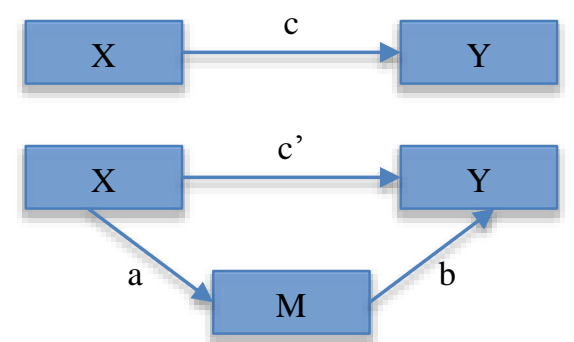

Figura 16a. Mediação simples

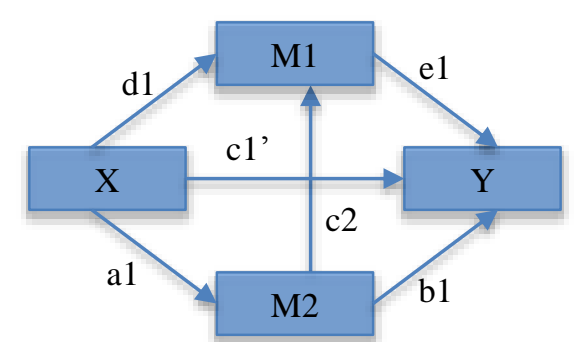

Figura 16b. Mediação múltipla

Figura 16. Relações de mediação adaptado de Preacher e Hayes (2008).

A mediação total se refere ao caso em que a variável $\mathrm{X}$ não afeta $\mathrm{Y}$ após $\mathrm{M}$ ter sido controlada e, assim, o caminho c' é igual a zero. Mediação parcial é o caso em que o percurso de $\mathrm{X}$ para $\mathrm{Y}$ é reduzido em tamanho absoluto, mas ainda é diferente de zero quando o mediador é introduzido (MacKinnon, Fairchild \& Fritz, 2007).

Grande parte das investigações sobre mediação utiliza a abordagem de Kenny e Baron (1986), em conjunto com o teste de significância de Sobel (1982). Entretanto, críticas são dirigidas a esse método de testar a mediação, sobretudo no que se refere à hipótese de normalidade dos dados (Preacher \& Hayes, 2008). Diante disso, vários autores (Cheung \& Lau, 2008; Marôco, 2010; Marôco, 2011; Preacher \& Hayes, 2008; Zhao, Lynch \& Chen, 2010) sugerem a utilização do método alternativo do bootstrap (teste não paramétrico), que será considerado neste trabalho.

O bootstrap é um procedimento que permite explicar a distribuição amostral de um certo parâmetro por reamostragem, de um grande número de amostras, com reposição, da amostra original e com a sua mesma dimensão (Marôco, 2011). Com as várias amostras de bootstrap, segundo o autor, é possível estimar a probabilidade de ocorrência das estatísticas calculadas nas amostras a partir da dedução da distribuição amostral observada, ou seja, o 
teste de hipóteses. O AMOS 18 permite realizar o bootstrap diretamente no caso de variáveis mediadoras latentes.

O bootstrap, portanto, supera as limitações dos métodos estatísticos que se sustentam em premissas como, por exemplo, a necessidade de normalidade (Marôco, 2011; Preacher \& Hayes, 2008), o que ratifica o seu uso, neste trabalho, em virtude da ausência de normalidade dos dados, na maioria das vezes, nas ciências sociais (Pilati \& Laros, 2007) e de gestão (Roussel et al., 2002). Além disso, autores como Cheung e Lau (2008), Marôco (2011) e Taylor, MacKinnon e Tein (2008) recomendam o emprego dos modelos de bootstrap em equações estruturais para testar a mediação, principalmente, quando as variáveis latentes estão envolvidas.

Nesta tese, a simulação de Monte-Carlo será utilizada para estimar os erros-padrão e a significância dos efeitos por reamostragem bootstrap (Marôco, 2011). Para tanto, será considerado o método BC (Bias-corrected confidence intervals), com intervalos de confiança (IC) de 95\%, mais precisos que o padrão (defaut), com pelo menos 1000 reamostragens, pois, acima desse valor, não são encontradas diferenças significativas entre os ICs (Cheung \& Lau, 2008). Além disso, os autores observam a necessidade de a amostra ser superior a 200 respondentes, para se evitar a ocorrência de erro Tipo I.

No caso dos efeitos mediadores múltiplos, o AMOS não fornece o teste de significância dos efeitos indiretos específicos por intermédio do bootstrap, somente o p-valor associado ao total dos efeitos indiretos (Cheung \& Lau, 2008). Para superar essa lacuna, outros testes podem ser utilizados, salientando-se que, esses não são tão robustos como o teste de bootstrap, para testar os efeitos de mediação específicos.

Para testar os efeitos de mediadores específicos em uma única etapa, o método de Monte Carlo para a avaliação de mediação é empregado (MacKinnon, Lockwood \& Williams, 2004). Esse método é uma técnica de reamostragem paramétrica, ao contrário do teste de bootstrap que é não paramétrico (Diallo, 2011). Mesmo que não seja tão Sua aplicação se ocorre baseada nos coeficientes estimados e em seus desvios-padrão, sem a obrigação de dados (Ghantous, 2010). Mesmo sem a força do bootstrap (Mackinnon et al., 2010), o método aqui descrito é mais eficiente do que outros métodos, tais como o teste de Sobel (Diallo, 2011).

Por fim, o teste dos efeitos mediadores específicos em cadeia é executado pelo teste de significância conjunto (joint significance test - MacKinnon, Lockwood, Hoffman, West, \& Sheets, 2002), recomendado por Taylor et al. (2008). Para um modelo de mediação em três 
etapas (cadeia), devem-se observar as condições (rejeição da hipótese H0: o efeito indireto é nulo) seguintes:

|a1 $\mid / \mathrm{s}$ a1 > t.975(n-2); $|\mathrm{c} 2| / \mathrm{s} \mathrm{c} 2>\mathrm{t} .975(\mathrm{n}-3) ;|\mathrm{e} 1| / \mathrm{s}$ e1 > t.975(n-4)

Em que a1|, |c2| e |e1| são os valores absolutos dos efeitos diretos a1, c2 e e1; s - os desvios-padrão, n é o número de graus de liberdade do modelo e t.975(g.1.) é o valor crítico de $t$ de Student de um teste bicaudal, ou seja, em um modelo de mediação de três caminhos, o teste de significância conjunta encontra provas para a mediação de cada uma das três faixas do efeito mediado é significativamente diferente de zero (Taylor et al., 2008). Nesta tesa utiliza-se, ainda, o teste de Preacher e Hayes (2008), que estima os coeficientes da análise de caminhos (path) em um modelo de mediação em cadeia (múltipla) e gera intervalos de confiança por bootstrap para efeitos diretos, indiretos e totais.

\subsubsection{Influência das variáveis individuais antecedentes (sociodemográficas)}

Nessa parte, distinguem-se as variáveis individuais categóricas e as variáveis individuais contínuas.

\section{$>$ Teste de influência das variáveis categóricas}

Como forma de estudar as diferenças nas variáveis do modelo com base em variáveis categóricas (sexo, idade, escolaridade, nível hierárquico, entre outras) será utilizada a análise de variância (ANOVA). De acordo com Evrard et al. (2009) e Marôco (2011), a ANOVA é um teste estatístico utilizado para mensurar uma variável explicativa discreta que influencia a distribuição de uma variável contínua a explicar. Quando se necessita avaliar a influência sobre múltiplas variáveis contínuas dependentes a explicar, consideradas simultaneamente, a análise de variância multivariada (MANOVA) é indispensável. Cabe salientar que ambas as técnicas baseiam-se em pressupostos rigorosos, isto é, na necessidade de independência das amostras, normalidade e homogeneidade da variância (ou covariância) na população. Em caso de violação dos pressupostos da ANOVA, o teste não paramétrico de Kruskal-Wallis será utilizado.

Essas análises serão efetuadas com os escores fatoriais latentes fundamentados nas análises fatoriais confirmatórias (método da regressão). De acordo com DiStefano, Zhu e Mîndrilă (2009), o uso de escores fatoriais por regressão apresenta melhores resultados se comparados a outros métodos (somatório dos escores por fator, soma dos escores por um fator chave, somatório das variáveis estandardizadas, entre outros). Como alguns dos construtos apresentam diversas dimensões, será empregada a média dos escores fatoriais. 


\section{Conclusões do Capítulo V}

Esse capítulo teve por objetivo detalhar a metodologia e a concepção do estudo empírico. A primeira seção apresentou a operacionalização dos construtos do modelo de pesquisa. As escalas de valores organizacionais, identidade profissional e identidade organizacional foram adaptadas de pesquisas anteriores. A escala de desempenho profissional por competências foi criada com base no trabalho sobre o perfil profissiográfico e o mapeamento de competências (técnicas e comportamentais) realizado pela SENASP (2012) e nas observações de Faiad et al. (2012). Foi proposta uma escala para se mensurar as práticas organizacionais, criada por Souza (2014) baseada nos estudos de D'Iribarne (1989) e em trabalhos anteriores (Faria, 2013; Fenili (2012); Souza et al. (2011) e Souza et al., 2013).

A segunda seção tratou das escolhas metodológicas de investigação. Foi apresentada a escolha pela aplicação de um questionário direcionado aos policiais militares, como forma de se responder aos objetivos da pesquisa. A escolha da PMDF como lugar de aplicação foi demonstrada. Por fim, o método de coleta de dados foi abordado.

A terceira seção respondeu pela metodologia de desenvolvimento e de validação das escalas de medida e do teste das hipóteses de pesquisa. No que se refere à fase de validação dos instrumentos, diversos pontos foram considerados, como as condições prévias para a realização das análises multivariadas, a análise fatorial exploratória, o escalonamento multidimensional, a confiabilidade e a validade dos instrumentos e análise fatorial confirmatória. Para os testes de hipóteses de pesquisa, vários métodos foram empregados em função dos tipos de hipóteses. Assim, foram usadas as equações estruturais (para os efeitos diretos), o bootstrap não paramétrico ou paramétrico (para os efeitos mediadores), a ANOVA e o teste t para analisar se existem diferenças entre variáveis individuais e o desempenho profissional por competências. 
PARTE 2

ESTUDO EMPÍRICO E RESULTADO DA PESQUISA
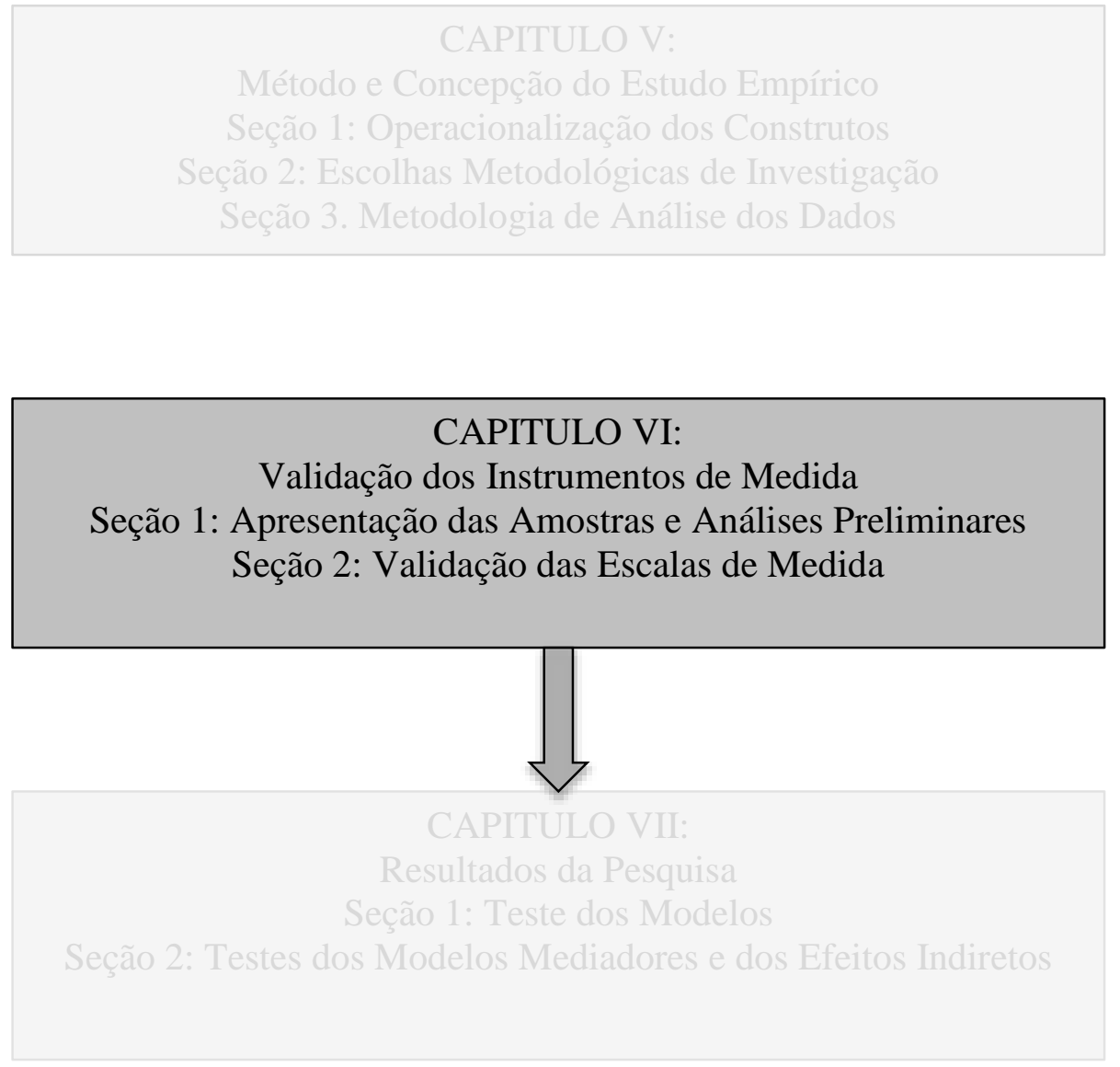

CAPITULO VIII:

Discussão dos Resultados da Pesquisa

Seção 1: Discussão e Interpretacão dos Resultados 


\section{CAPÍTULO VI. EVIDÊNCIAS DE VALIDADE DOS INSTRUMENTOS DE MEDIDA}

\section{Introdução ao Capítulo VI}

O capítulo que se inicia destina-se à busca evidenciar a validação dos instrumentos de medida utilizados no modelo de pesquisa. A validação das variáveis latentes dos instrumentos de medida foi baseada em aspectos estatísticos, bem como na validação por juízes e na validação semântica, conforme estabelecem Churchill (1979) e Pasquali (2012). Para Evrard et al. (2009), essa é uma importante etapa da pesquisa, pois, sem instrumentos confiáveis e válidos, torna-se impossível testar o modelo geral da pesquisa.

Para cada escala de medida será realizada uma análise fatorial exploratória (AFE), exceção feita à escala de práticas organizacionais, que contará com o escalonamento multidimensional (MDS) para determinar a estrutura fatorial dos construtos subjacentes, como, também, no caso das AFE. Em seguida, a confirmação da estrutura exploratória será efetuada por uma análise fatorial confirmatória (AFC), pelo método das equações estruturais. A AFC é importante na medida em que permite avaliar a confiabilidade (consistência interna) e a validade de construto, portanto, discutir os testes de confiabilidade e validade. No que diz respeito à medida das outras variáveis, apresentar-se-á a descrição da distribuição dos participantes da pesquisa, tendo em vista que análises fatoriais não são aplicáveis.

Esse capítulo é composto por três seções. A seção 1 apresenta as amostras utilizadas e as análises preliminares de adequação dos dados para a realização das análises multivariadas. A seção 2 exibe a validação das escalas de medida dos construtos centrais do modelo de pesquisa. Por fim, a seção 3 discute a medida das variáveis individuais no modelo de pesquisa.

\section{Seção 1. Apresentação das Amostras e Análises Preliminares}

O objetivo principal dessa pesquisa é compreender a influência das variáveis antecedentes e mediadoras (valores organizacionais, práticas organizacionais identidade profissional e identidade organizacional) sobre o desempenho profissional por competências do serviço policial, isto é, testar um modelo integrador dos determinantes do desempenho profissional por competências. Para tanto, foram coletados 1.276 questionários, entre os quais vinte e sete questionários foram preenchidos pela metade, sendo que o não preenchimento foi vinculado ao tempo necessário para seu completo término. Decidiu-se desconsiderar estes vinte e sete questionários, em virtude de sua incompletude, além de não trazerem qualquer impacto sobre a amostra analisada, restando ao final 1.249 questionários preenchidos. 
Como não é recomendável que a análise exploratória e confirmatória sejam realizadas com o mesmo conjunto de dados, a amostra foi dividida aleatoriamente em duas subamostras, utilizando o divisor do banco de dados padrão do SPSS (splite file). Foi mantido o preceito de contar com pelo menos 10 respondentes por item, tanto na fase exploratória quanto na confirmatória (Pasquali, 2012; Roussel et al., 2002). Assim, foram selecionados aleatoriamente 50,04\% dos respondentes para a fase exploratória $(n=625)$, e 49,96\% para a confirmatória $(n=624)$, que passarão por adequações para a realização das análises multivariadas.

\subsection{Análises Preliminares de Adequação dos dados às Análises Multivariadas}

Antes de analisar os dados coletados com base em uma amostra de policiais militares, deve-se verificar a adequação desses dados para a análise multivariada. Essa verificação consiste em examinar: os valores extremos (outliers), a normalidade dos dados e a ausência de multicolinearidade (Kline, 2010).

\subsubsection{Valores ausentes}

O tratamento dos valores ausentes (missingvalues) deve ser feito por diferentes métodos, conforme mencionados no Capítulo $\mathrm{V}$, antes que as análises sejam realizadas. $\mathrm{O}$ treinamento oferecido aos aplicadores possibilitou que os respondentes sanassem quaisquer dúvidas antes de completarem o questionário. Assim, grande parte dos formulários coletados não apresentou problemas sérios, sendo, essencialmente, coletados de forma completa, o que não garante, entretanto, que não ocorram problemas com valores extremos (outliers).

Procedeu-se, em conjunto com a análise de frequências, a análise do valor ausente (MVA - missing values analysis), que tem o objetivo de avaliar a quantidade e a distribuição dos dados ausentes, o preenchimento impróprio do questionário, e identificar e eliminar problemas, em casos específicos, com a substituição dos dados ausentes, que podem afetar a normalidade e a homocedasticidade (Neiva, Abbad \& Tróccoli, 2007). A análise das frequências e a MVA demonstraram que a porcentagem dos valores ausentes estava abaixo de 5\% e aleatoriamente distribuídos, o que possibilita sua substituição (Hair et al., 2009; Tabachnick \& Fidell, 2007).

A estimação dos dados ausentes ou sua substituição foi realizada pelo MVA pelo método da regressão, que tem sido considerado superior a outras formas (como por exemplo, substituição pela média), de acordo com Hair et al. (2009). 


\subsubsection{Valores extremos}

Os valores extremos (outliers) sobre as variáveis quantitativas foram investigados, em cada uma das duas amostras, com base nos critérios da distância de Mahalanobis e na distância de Cook, utilizados para a identificação de valores extremos multivariados (Hair et al., 2009; Neiva et al., 2007, Tabachnick \& Fidell, 2007). Para se verificar a distância (Mahalanobis) a partir da qual os outliers serão considerados multivariados, consulta-se a tabela valor do qui-quadrado tendo como parâmetros os graus de liberdade (número de VIs) e $\mathrm{o}$ valor para a probabilidade de $\mathrm{p}<0,001$. Os valores extremos detectados (distância superior aos valor de referência na tabela do qui-quadrado) foram excluídos. Esse resultado foi confirmado pelos valores da distância de Cook (>1).

Diante disso, procedeu-se à exclusão de observações com valores extremos para cada uma das escalas de medida em cada uma das subamostras. No total, 333 observações foram eliminados, podendo-se justificar esse elevado número pela rigorosa análise e pela extensão dos questionários, o que fatiga o respondente em seu trabalho. Ao final, a amostra total foi composta por 916 respondentes, número mais do que suficiente para atender aos critérios empregados sobre o tamanho das amostras.

\subsubsection{Normalidade dos dados e ausência de multicolinearidade}

Para avaliar o pressuposto da normalidade dos dados, três etapas serão seguidas: 1) pela curva de Gauss de normalidade para cada variável estudada, cujos resultados indicam certa normalidade para a maioria das variáveis. Em seguida, 2) foram utilizados os testes de Kolmogorov-Smirnov e Shapiro-Wilk, que são mais poderosos (Diallo, 2011; Marôco, 2011; Neiva et al., 2007, Tabachnick \& Fidell, 2007). Os resultados rejeitam a hipótese de normalidade dos dados (Apêndice 2). Entretanto, estudos de simulação (Harwell, Rubinstein, Hayes \&Olds, 1992; Refinetti, 1996) vêm demonstrando que os métodos paramétricos são robustos à violação do pressuposto de normalidade, desde que as distribuições não sejam muito enviesadas e achatadas e as amostras não sejam extremamente pequenas $(n<100)$.

Como a violação da normalidade é uma situação comum em variáveis do comportamento organizacional, parte-se para a etapa 3, verificando-se os dados, observando se seguem uma distribuição mais próxima da normal (quase-normalidade), inspecionando-se, para isso, os coeficientes de assimetria (skewness) e achatamento (Kurtosis). Os estudos de simulação de Kline (2010) reportam que os modelos paramétricos são robustos para valores absolutos de assimetria $(s k)$ inferiores a 3 e valores absolutos de achatamento $(k u)$ inferiores a 
7-10, sendo esse resultado também descrito por West, Finch e Curran (1995), em que os valores de curtose devem ser menores que 7 e a assimetria menores que 3. Os resultados demonstram uma quase-normalidade univariada de dados satisfatória (Apêndice B). Além disso, o valor de Mardia, dos diferentes construtos indicou uma quase-normalidade multivariada aceitável (Apêndice C).

A multicolinearidade é avaliada com base no fator de inflação da variância (VIF Variance Inflation Factor) e na tolerância. Os resultados não indicam problemas de colinearidade entre as variáveis, uma vez que os valores do VIF são menores do que 10 (Myers, 1990) e os da tolerância são maiores do que 0,1 (Myers, 1990) (Apêndice B).

\subsection{Apresentação do Conjunto dos Dados}

O sorteio aleatório dos dados completos permitiu a separação em dois grupos, o primeiro com 465 respondentes (n1), que serão utilizados na fase exploratória e o segundo, com 451 respondentes (n2), utilizados na fase confirmatória. Será apresentada a divisão dos respondentes por variáveis sociodemográficas.

\subsubsection{Variáveis sociodemográficas}

Em termos de idade, os respondentes têm em média 39,01 anos $(\mathrm{dp}=6,91)$, sendo que na amostra 1 a média foi de 38,78 anos $(\mathrm{dp}=7,08)$ e na amostra 2 foi de 39,25 (dp=6,73). A média de idade da população do estudo é um pouco maior do que a da população brasileira ${ }^{4}$ (IBGE, 2010). Relativamente ao sexo, 88,35\% são do sexo masculino, sendo $88 \%$ da amostra 1 e $88,7 \%$ da amostra 2 . Essa distribuição é perfeitamente explicada pelas características da organização, PMDF, que por restrição legal só pode contar com $10 \%$ do seu efetivo do sexo feminino.

No que se refere ao nível de escolaridade, $62,85 \%$ da amostra total possui graduação ou está cursando. Ademais, 26,4\% está cursando ou já cursou pós-graduação. Na amostra 1, $60,7 \%$ cursa ou já cursou graduação e na amostra $2,65 \%$.

Quando se verificam os níveis hierárquicos, 29,05\% são oficiais e 68,05\% são praças. A Tabela 22 apresenta uma síntese da distribuição dos respondentes nas diferentes categorias.

\footnotetext{
${ }^{4}$ Segundo o Instituto Brasileiro de Geografia e Estatística (IBGE), a população está distribuída da seguinte forma: Idade: abaixo de 20: 34\%; 20-39 anos: 32\%; 40-49 anos: 13\%; 50 anos ou mais: 20\%. Sexo: 51\% mulheres e $49 \%$ homens (IBGE, 2010).
} 
Somam-se a isso a comparação entre as duas amostras $(n 1=465$ e $n 2=451)$ e a população investigada (PMDF), sobretudo, nas categorias sexo e nível hierárquico.

Tabela 22

Distribuição dos dados sociodemográficos

\begin{tabular}{|c|c|c|c|c|c|c|c|}
\hline \multirow{2}{*}{ Variáveis } & \multirow[b]{2}{*}{ Níveis } & \multicolumn{2}{|c|}{$\begin{array}{c}\text { Amostra } 1 \\
(n=465)\end{array}$} & \multicolumn{2}{|c|}{$\begin{array}{c}\text { Amostra } 2 \\
(n=451)\end{array}$} & \multicolumn{2}{|c|}{$\begin{array}{c}\text { População } \\
(\mathrm{N}=15.178)\end{array}$} \\
\hline & & Frequências & $\%$ & Frequências & $\%$ & Frequências & $\%$ \\
\hline \multirow{3}{*}{ Sexo } & Masculino & 409 & 88,0 & 400 & 88,7 & 13.997 & 92,22 \\
\hline & Feminino & 50 & 10,8 & 45 & 10,0 & 1.181 & 7,78 \\
\hline & Omissos & 6 & 1,3 & 6 & 1,3 & 0 & 0 \\
\hline \multirow{15}{*}{$\begin{array}{l}\text { Postos e } \\
\text { Graduações }\end{array}$} & Soldado & 53 & 11,4 & 34 & 7,5 & 2.265 & 14,93 \\
\hline & Cabo & 78 & 16,8 & 108 & 23,9 & 3.277 & 21,59 \\
\hline & $3^{\circ}$ Sargento & 51 & 11,0 & 63 & 14,0 & 2.946 & 19,41 \\
\hline & $2^{\circ}$ Sargento & 40 & 8,6 & 37 & 8,2 & 2.278 & 15,01 \\
\hline & $1^{\circ}$ Sargento & 65 & 14,0 & 58 & 12,9 & 2.350 & 15,48 \\
\hline & Subtenente & 21 & 4,5 & 28 & 6,2 & 656 & 4,32 \\
\hline & Cadete & 43 & 9,2 & 33 & 7,3 & 52 & 0,34 \\
\hline & Aspirante & 27 & 5,8 & 22 & 4,9 & 180 & 1,19 \\
\hline & $2^{\circ}$ Tenente & 15 & 3,2 & 7 & 1,6 & 138 & 0,91 \\
\hline & $1^{\mathrm{o}}$ Tenente & 10 & 2,2 & 9 & 2,0 & 120 & 0,79 \\
\hline & Capitão & 26 & 5,6 & 21 & 4,7 & 396 & 2,61 \\
\hline & Major & 20 & 4,3 & 14 & 3,1 & 327 & 2,15 \\
\hline & Tenente-Coronel & 5 & 1,1 & 6 & 1,3 & 127 & 0,84 \\
\hline & Coronel & 5 & 1,1 & 3 & 0,7 & 66 & 0,43 \\
\hline & Omissos & 6 & 1,2 & 8 & 1,7 & 0 & 0 \\
\hline \multirow{11}{*}{ Escolaridade } & Fundamental I.* & 1 & 0,2 & 2 & 0,4 & & \\
\hline & Fundamental C.** & 3 & 0,6 & 5 & 1,1 & & \\
\hline & Médio I. & 7 & 1,5 & 4 & 0,9 & & \\
\hline & Médio C. & 34 & 7,3 & 38 & 8,4 & & \\
\hline & Graduação I. & 38 & 8,2 & 23 & 5,1 & & \\
\hline & Graduação C. & 244 & 52,5 & 270 & 59,9 & & \\
\hline & Especialização I. & 18 & 3,9 & 13 & 2,9 & & \\
\hline & Especialização C. & 106 & 22,8 & 83 & 18,4 & & \\
\hline & Mestrado I. & 7 & 1,5 & 9 & 2,0 & & \\
\hline & Mestrado C. & 5 & 1,1 & 1 & 0,2 & & \\
\hline & Omissos & 2 & 0,4 & 3 & 0,7 & & \\
\hline \multirow{7}{*}{ Estado Civil } & Casado & 296 & 63,7 & 291 & 64,5 & & \\
\hline & Divorciado & 23 & 4,9 & 31 & 6,9 & & \\
\hline & Separado & 10 & 2,2 & 12 & 2,7 & & \\
\hline & Solteiro & 91 & 19,6 & 80 & 17,7 & & \\
\hline & União Estável & 38 & 8,2 & 27 & 6,0 & & \\
\hline & Viúvo & 0 & 0 & 4 & 0,9 & & \\
\hline & Omissos & 7 & 1,5 & 6 & 1,3 & & \\
\hline \multirow{9}{*}{$\begin{array}{l}\text { Quantidade de } \\
\text { Filhos }\end{array}$} & Nenhum & 115 & 24,7 & 108 & 23,9 & & \\
\hline & Um & 99 & 21,3 & 81 & 18,0 & & \\
\hline & Dois & 137 & 29,5 & 142 & 31,5 & & \\
\hline & Três & 65 & 14,0 & 78 & 17,3 & & \\
\hline & Quatro & 31 & 6,7 & 28 & 6,2 & & \\
\hline & Cinco ou mais & 8 & 1,7 & 6 & 1,3 & & \\
\hline & Omissos & 10 & 2,2 & 8 & 1,8 & & \\
\hline & & Média $=$ & 1,61 & Média $=$ & 1,67 & & \\
\hline & & $\mathrm{DP}=$ & 1,29 & $\mathrm{DP}=$ & 1,27 & & \\
\hline
\end{tabular}




\begin{tabular}{|c|c|c|c|c|c|c|c|}
\hline \multirow[b]{2}{*}{ Variáveis } & \multirow[b]{2}{*}{ Níveis } & \multicolumn{2}{|c|}{$\begin{array}{c}\text { Amostra } 1 \\
(n=465)\end{array}$} & \multicolumn{2}{|c|}{$\begin{array}{c}\text { Amostra } 2 \\
(n=451)\end{array}$} & \multicolumn{2}{|c|}{$\begin{array}{c}\text { População } \\
(\mathrm{N}=15.178)\end{array}$} \\
\hline & & Frequências & $\%$ & Frequências & $\%$ & Frequências & $\%$ \\
\hline \multirow{13}{*}{ Religião } & & Mínimo = & 0 & Mínimo = & 0 & & \\
\hline & & Máximo = & 5 & Máximo = & 5 & & \\
\hline & Católico & 239 & 51,4 & 214 & 47,5 & & \\
\hline & Evangélico & 105 & 22,6 & 136 & 30,2 & & \\
\hline & Protestante & 14 & 3,0 & 22 & 4,9 & & \\
\hline & Espírita & 23 & 4,9 & 21 & 4,7 & & \\
\hline & Afro-brasileiras & 4 & 0,9 & 2 & 0,4 & & \\
\hline & Sem religião & 51 & 11,0 & 32 & 7,1 & & \\
\hline & Outra & 18 & 3,9 & 12 & 2,7 & & \\
\hline & Omissos & 11 & 2,4 & 12 & 2,7 & & \\
\hline & $1-5$ anos & 94 & 20,2 & 82 & 18,2 & & \\
\hline & $6-10$ anos & 22 & 4,7 & 23 & 5,0 & & \\
\hline & $11-15$ anos & 91 & 19,6 & 95 & 21,0 & & \\
\hline Tempo de & $16-20$ anos & 66 & 14,3 & 68 & 15,1 & & \\
\hline \multirow[t]{10}{*}{ Serviço } & $21-25$ anos & 110 & 23,5 & 113 & 25,1 & & \\
\hline & $26-30$ anos & 71 & 15,3 & 60 & 13,4 & & \\
\hline & 31 anos ou mais & 1 & 0,2 & 2 & 0,4 & & \\
\hline & Omissos & 10 & 2,2 & 8 & 1,8 & & \\
\hline & & Média $=$ & 16,12 & Média $=$ & 16,24 & & \\
\hline & & $\mathrm{DP}=$ & 8,63 & $\mathrm{DP}=$ & 8,35 & & \\
\hline & & Mínimo = & 1 & Mínimo = & 1 & & \\
\hline & & Máximo = & 31 & Máximo = & 31 & & \\
\hline & $24-28$ anos & 34 & 7,2 & 24 & 5,3 & & \\
\hline & $29-33$ anos & 95 & 20,5 & 90 & 19,9 & & \\
\hline \multirow[t]{9}{*}{ Idade } & $34-38$ anos & 87 & 18,7 & 91 & 20,2 & & \\
\hline & $39-43$ anos & 95 & 20,5 & 87 & 19,4 & & \\
\hline & $44-48$ anos & 109 & 23,4 & 123 & 27,3 & & \\
\hline & $49-53$ anos & 36 & 7,8 & 27 & 5,9 & & \\
\hline & Omissos & 9 & 1,9 & 9 & 2,0 & & \\
\hline & & Média = & 38,78 & Média $=$ & 39,25 & & \\
\hline & & $\mathrm{DP}=$ & 7,08 & $\mathrm{DP}=$ & 6,73 & & \\
\hline & & Mínimo = & 24 & Mínimo = & 25 & & \\
\hline & & Máximo = & 53 & Máximo = & 53 & & \\
\hline
\end{tabular}

* Incompleto; ** Completo

Cabe, ainda, ressaltar que os dados foram coletados nas diversas unidades da PMDF. A Tabela 23 sintetiza as unidades, divididas em: Unidades de Área; Unidades Especializadas; Unidades de Suporte Administrativo. Maiores detalhes podem ser sanadas na Figura 15. 
Tabela 23

Distribuição dos dados por unidade policial

\begin{tabular}{|c|c|c|}
\hline \multicolumn{3}{|l|}{ Unidades de Área } \\
\hline \multirow[b]{2}{*}{ UPM } & \multicolumn{2}{|c|}{ Número de Questionários Respondidos } \\
\hline & $\begin{array}{c}\text { Amostra } 1 \\
(n=465)\end{array}$ & $\begin{array}{c}\text { Amostra } 2 \\
(\mathrm{n}=451)\end{array}$ \\
\hline $1^{\circ}$ Batalhão de Polícia Militar - $1^{\circ} \mathrm{BPM}$ & 4 & 3 \\
\hline $2^{\circ}$ Batalhão de Polícia Militar - $2^{\circ} \mathrm{BPM}$ & 9 & 11 \\
\hline $3^{\circ}$ Batalhão de Polícia Militar - $3^{\circ} \mathrm{BPM}$ & 10 & 15 \\
\hline $4^{\circ}$ Batalhão de Polícia Militar - $4^{\circ} \mathrm{BPM}$ & 10 & 6 \\
\hline $5^{\circ}$ Batalhão de Polícia Militar - 5 BPM & 7 & 10 \\
\hline $7^{\circ}$ Batalhão de Polícia Militar - $7^{\circ} \mathrm{BPM}$ & 10 & 8 \\
\hline $8^{\circ}$ Batalhão de Polícia Militar - $8^{\circ} \mathrm{BPM}$ & 9 & 11 \\
\hline $9^{\circ}$ Batalhão de Polícia Militar - $9^{\circ} \mathrm{BPM}$ & 8 & 14 \\
\hline $11^{\circ}$ Batalhão de Polícia Militar - $11^{\circ} \mathrm{BPM}$ & 13 & 11 \\
\hline $13^{\circ}$ Batalhão de Polícia Militar - $13^{\circ} \mathrm{BPM}$ & 11 & 12 \\
\hline $14^{\circ}$ Batalhão de Polícia Militar - $14^{\circ} \mathrm{BPM}$ & 7 & 9 \\
\hline $16^{\circ}$ Batalhão de Polícia Militar - $16^{\circ} \mathrm{BPM}$ & 8 & 9 \\
\hline $17^{\circ}$ Batalhão de Polícia Militar - $17^{\circ} \mathrm{BPM}$ & 10 & 12 \\
\hline $20^{\circ}$ Batalhão de Polícia Militar - 20 BPM & 7 & 16 \\
\hline $21^{\circ}$ Batalhão de Polícia Militar - $21^{\circ} \mathrm{BPM}$ & 7 & 16 \\
\hline $24^{\circ}$ Batalhão de Polícia Militar - $24^{\circ} \mathrm{BPM}$ & 9 & 10 \\
\hline $25^{\circ}$ Batalhão de Polícia Militar - $25^{\circ} \mathrm{BPM}$ & 1 & 6 \\
\hline $26^{\circ}$ Batalhão de Polícia Militar - 26º BPM & 8 & 7 \\
\hline $27^{\circ}$ Batalhão de Polícia Militar - $27^{\circ} \mathrm{BPM}$ & 8 & 7 \\
\hline $28^{\circ}$ Batalhão de Polícia Militar - $28^{\circ} \mathrm{BPM}$ & 9 & 10 \\
\hline \multicolumn{3}{|l|}{ Unidades Especializadas } \\
\hline Batalhão de Operações Especiais - BOPE & 19 & 16 \\
\hline Batalhão de Policiamento com Cães - BPCÃES & 9 & 14 \\
\hline Batalhão de Aviação Operacional - BAVOP & 12 & 12 \\
\hline Batalhão de Policiamento Ambiental - BPMA & 11 & 4 \\
\hline Batalhão de Trânsito - BPTRAN & 11 & 9 \\
\hline Batalhão de Policiamento Rodoviário - BPRV & 5 & 6 \\
\hline Batalhão Judiciário - $12^{\circ} \mathrm{BPM}$ & 11 & 11 \\
\hline Batalhão de Patrulhamento Tático Motorizado - ROTAM & 12 & 13 \\
\hline Batalhão de Policiamento Escolar - BPESC & 6 & 8 \\
\hline $19^{\circ}$ Batalhão de Polícia Militar - $19^{\circ} \mathrm{BPM}$ & 7 & 6 \\
\hline Regimento de Polícia Montada - RPMON & 15 & 6 \\
\hline \multicolumn{3}{|c|}{ Unidades de Suporte Administrativo } \\
\hline Academia de Polícia Militar de Brasília - APMB & 76 & 58 \\
\hline Centro de Comunicação Social - CCS & 10 & 4 \\
\hline Centro de Inteligência - CI & 16 & 6 \\
\hline Centro de Polícia Comunitária e Direitos Humanos - CPCDH & 13 & 8 \\
\hline Departamento de Controle e Correição - DCC & 7 & 14 \\
\hline Departamento de Educação e Cultura - DEC & 9 & 17 \\
\hline Departamento de Gestão de Pessoal - DGP & 11 & 9 \\
\hline Departamento de Logística e Finanças - DLF & 13 & 7 \\
\hline Departamento de Saúde e Assistência ao Pessoal - DSAP & 16 & 9 \\
\hline Estado-Maior & 7 & 8 \\
\hline Quartel do Comando-Geral & 4 & 3 \\
\hline
\end{tabular}




\section{Seção 2. Evidências de Validade das Escalas de Medidas dos Construtos do Modelo}

À exceção da escala de valores organizacionais (EVO), que utilizará o escalonamento multidimensional (MDS), para cada uma das escalas será realizada uma análise fatorial exploratória, com o objetivo de se determinar a estrutura dos instrumentos de medida. Em seguida, passa-se à análise fatorial confirmatória, com foco nas evidências de validade convergente e/ou discriminante dos construtos.

\subsection{Evidências de Validade da Escala de Valores Organizacionais}

Foram efetuadas, sucessivamente, as análises exploratórias por MDS e confirmatória (AFC) sobre a escala de valores organizacionais que é composta por seis dimensões (harmonia, domínio, igualitarismo, hierarquia, conservação e autonomia).

\subsubsection{Escalonamento multidimensional com o SPSS Statistics}

Foi utilizada a amostra $1(\mathrm{n}=465)$ para a operacionalização da análise. O MDS revelou a estrutura apresentada na Figura 17. As medidas de ajuste bidimensional foram excelentes: S-Stress igual a 0,057, Raw Stress Normalizado (NRS) igual a 0,037, dispersão das proximidades $(D A F)$ igual a 0,963 e coeficiente de congruência de Tucker igual a 0,982. Os itens que apresentaram redundância e aqueles que se localizaram em região oposta à previsão teórica foram eliminados. Do total de 39 itens, a análise apontou para a adequação de 32 itens. A Tabela 24 apresenta os itens por tipo motivacional e os respectivos Alphas de Cronbach e Lambda 2 de Guttman.

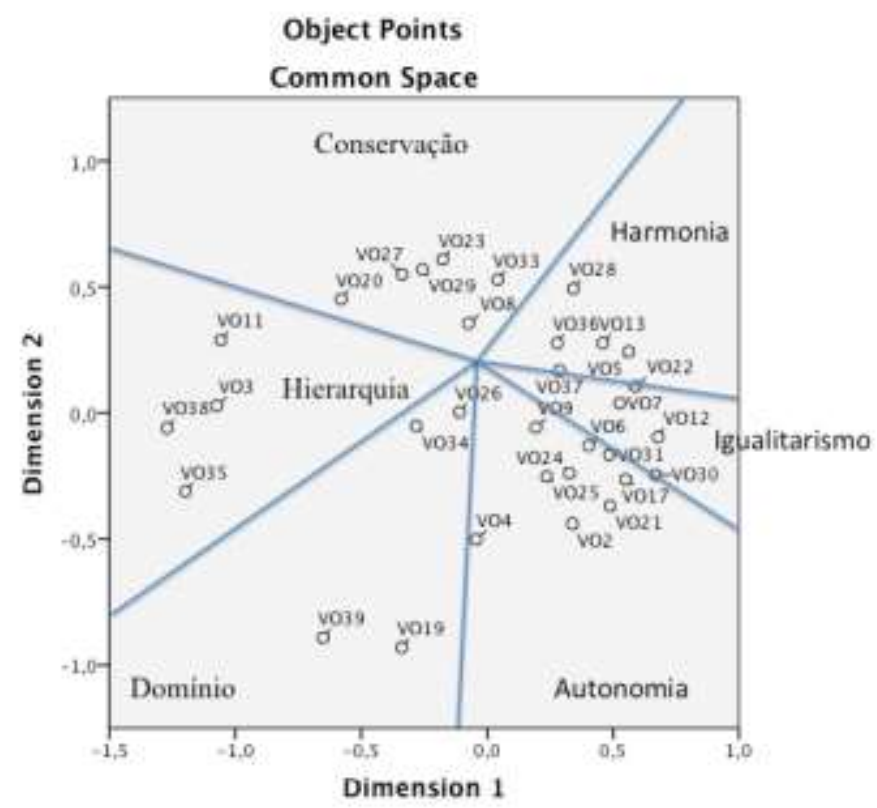

Figura 17. Resultado da análise do MDS da EVO. 
Tabela 24

Itens por tipo motivacional e índices de precisão da EVO

\begin{tabular}{|c|c|c|}
\hline Itens & $\begin{array}{l}\text { Tipo } \\
\text { Motivacional }\end{array}$ & $\begin{array}{l}\text { Alpha de Cronbach / } \\
\text { Lambda } 2 \text { de Guttman }\end{array}$ \\
\hline $\begin{array}{l}\text { VO5 - Relações transparentes com a sociedade. } \\
\text { VO13 - Respeito à sociedade. } \\
\text { VO28 - Proteção do meio ambiente. } \\
\text { VO36 - Credibilidade frente aos cidadãos. } \\
\text { VO37 - Desenvolvimento do País e das comunidades em que atua. }\end{array}$ & Harmonia & $0,89 / 0,89$ \\
\hline $\begin{array}{l}\text { VO19 - Favorecimento da PMDF em detrimento do meio ambiente. } \\
\text { VO26 - Preocupação com o aumento da prestação dos serviços . } \\
\text { VO34 - Ambição nas ações de segurança pública. } \\
\text { VO39 - Eliminação das ações dos organizações policiais concorrentes. }\end{array}$ & Domínio & $0,61 / 0,63$ \\
\hline $\begin{array}{l}\text { VO7 - Cordialidade no relacionamento entre os policiais. } \\
\text { VO12 - Saúde e bem-estar dos policiais. } \\
\text { VO22 - Cooperação entre os policiais. } \\
\text { VO30 - Oportunidades iguais a todos os policiais. }\end{array}$ & Igualitarismo & $0,90 / 0,90$ \\
\hline $\begin{array}{l}\text { VO3 - Centralização das decisões. } \\
\text { VO11 - Centralização da definição das normas na alta hierarquia. } \\
\text { VO35 - Tratamento diferenciado aos ocupantes de cargos de chefia. } \\
\text { VO38 - Poder concentrado nos níveis hierarquicamente superiores. }\end{array}$ & Hierarquia & $0,82 / 0,82$ \\
\hline $\begin{array}{l}\text { VO8 - Fidelidade às práticas consagradas da organização. } \\
\text { VO20 - Respeito aos costumes da organização. } \\
\text { VO23 - Respeito às regras da organização. } \\
\text { VO27 - Obediência às normas da organização. } \\
\text { VO29 - Obediência dos policiais aos padrões de comportamento } \\
\text { estabelecidos. } \\
\text { VO33 - Atuação dos policiais de acordo com a missão da organização. }\end{array}$ & Conservação & $0,91 / 0,91$ \\
\hline $\begin{array}{l}\text { VO2 - Busca de novidades. } \\
\text { VO4 - A opinião dos cidadãos. } \\
\text { VO6 - Liderança na área de segurança pública pela introdução de ideias } \\
\text { criativas. } \\
\text { VO9 - Reconhecimento pelas outras agências policiais por seus serviços } \\
\text { inovadores. } \\
\text { VO17 - Flexibilidade. } \\
\text { VO21 - Autonomia dos policiais na realização de tarefas. } \\
\text { VO24 - Capacidade de inovar. } \\
\text { VO25 - Originalidade. } \\
\text { VO31 - Capacidade de iniciativa. }\end{array}$ & Autonomia & $0,94 / 0,94$ \\
\hline
\end{tabular}

Os resultados encontrados nesta tese para a estrutura circular, teoricamente proposta para compreender os valores culturais, mostraram-se adequados à interpretação dos resultados dos valores organizacionais, como também ocorreu no estudo de Porto et al. (2012).

Em seguida, apresenta-se a análise fatorial confirmatória, como forma de se atestar a estrutura conseguida com a AFE. 


\subsubsection{Análise fatorial confirmatória com Software AMOS}

Para confirmar a estrutura fatorial obtida na AFE, procedeu-se à AFC com o software AMOS 18.

\subsubsection{Ajuste do Modelo de Medida}

Foram testadas as especificações para três modelo de medida dos valores organizacionais. O primeiro consistiu no teste de Harman (modelo de fator único), conforme Malhotra, Sung e Ashutosh (2006). O segundo avaliou as seis dimensões em um mesmo modelo correlacionado de medida. E, por último, foi avaliada a associação entre dimensões bipolares das dimensões propostas.

O Modelo 1 (unidimensional) não se ajustou aos dados, portanto, foi rejeitado. $\mathrm{O}$ modelo2 apresentou índices satisfatórios de ajuste, após a eliminação dos itens que mostraram covariância residual estandardizada superiores ao limite de $|2,58|$, de acordo com MacCallum (1986), e cujos índices de modificação mostravam-se inadequados, ao saturar, com valores elevados (>11, segundo Marôco, 2010), em mais de um item. Além disso, esse modelo apresentou correlações superiores a 0,70 entre os tipos motivacionais, porém, as análises indicaram ser possível a distinção entre eles. Os índices de ajuste dos dois primeiros modelos são mostrados na Tabela 25.

Tabela 25

Índices de ajustamento dos modelos de medida conforme Modelos 1 e 2 da EVO

\begin{tabular}{|c|c|c|c|}
\hline \multicolumn{2}{|l|}{$\begin{array}{l}\text { Amostra } \\
\mathrm{N}=451\end{array}$} & $\begin{array}{c}\text { Modelo } 1 \\
\text { Unidimensional } \\
\end{array}$ & $\begin{array}{c}\text { Modelo } 2 \\
6 \text { Dimensões }\end{array}$ \\
\hline Î́ndices & $\chi /$ g.l. & 7,31 & 3,64 \\
\hline \multirow[t]{4}{*}{ Absolutos } & $\chi^{2} ;$ g.l. & 3173,$73 ; 434$ & 437,$11 ; 120$ \\
\hline & $p$ & 0,000 & 0,000 \\
\hline & GFI (AGFI) & $0,59(0,51)$ & $0,91(0,86)$ \\
\hline & SRMR & 0,111 & 0,054 \\
\hline \multirow[t]{2}{*}{ Índices Relativos } & CFI & 0,74 & 0,95 \\
\hline & TLI & 0,72 & 0,93 \\
\hline Índices de Discrepância & RMSEA & 0,118 & 0,077 \\
\hline Populacional & (Lo90;Hi90) & $(0,115 ; 0,122)$ & $(0,069 ; 0,084)$ \\
\hline \multirow[t]{2}{*}{ Índices de Parcimônia } & PCFI & 0,692 & 0,74 \\
\hline & PGFI & 0,497 & 0,64 \\
\hline Índices Baseados na & AIC & 3297,73 & 539,11 \\
\hline \multirow{2}{*}{ Teoria da Informação } & ECVI & 7,33 & 1,20 \\
\hline & CAIC & 3614,64 & 799,79 \\
\hline
\end{tabular}

O Modelo 3 buscou avaliar a associação entre as dimensões bipolares dos tipos motivacionais. Para tanto, foram considerados os seguintes pares: Autonomia x Conservação; 
Hierarquia x Igualitarismo; Domínio x Harmonia. Adotou-se o procedimento proposto por Cieciuch e Schwartz (2012) de realizar as análises confirmatórias em separado para cada dimensão bipolar.

Nas dimensões foram excluídos os itens que apresentaram covariância residual estandardizada superiores ao limite de $2,58 \mid$ e que saturavam em mais de um fator, conforme os índices de modificação. Ademais, foram considerados a parcimônia, o equilíbrio e a representatividade teórica da dimensão. Esses tipos motivacionais pareados apresentaram índices finais de ajuste extremamente adequados, sendo apresentados na Tabela 26.

Tabela 26

Índices de ajustamento das dimensões bipolares conforme Modelo 3 da EVO

\begin{tabular}{|c|c|c|c|c|}
\hline $\begin{array}{l}\text { Amostra } \\
\mathrm{N}=451\end{array}$ & & $\begin{array}{l}\text { Autonomia } \\
\text { versus } \\
\text { Conservacão }\end{array}$ & $\begin{array}{c}\text { Hierarquia } \\
\text { versus } \\
\text { Igualitarismo }\end{array}$ & $\begin{array}{l}\text { Domínio } \\
\text { versus } \\
\text { Harmonia }\end{array}$ \\
\hline $\begin{array}{l}\text { Índices } \\
\text { Absolutos }\end{array}$ & $\begin{array}{l}\chi / \text { g.l. } \\
\chi^{2} ; \text { g.l. } \\
p \\
\text { GFI (AGFI) } \\
\text { SRMR }\end{array}$ & $\begin{array}{c}3,01 \\
24,10 ; 8 \\
0,002 \\
0,98(0,95) \\
0,021\end{array}$ & $\begin{array}{c}4,56 \\
31,95 ; 7 \\
0,000 \\
0,98(0,93) \\
0,057\end{array}$ & $\begin{array}{c}4,35 \\
34,83 ; 8 \\
0,000 \\
0,97(0,93) \\
0,024\end{array}$ \\
\hline Índices Relativos & $\begin{array}{l}\text { CFI } \\
\text { TLI }\end{array}$ & $\begin{array}{l}0,99 \\
0,98\end{array}$ & $\begin{array}{l}0,98 \\
0,95\end{array}$ & $\begin{array}{l}0,98 \\
0,97\end{array}$ \\
\hline $\begin{array}{l}\text { Índices de Discrepância } \\
\text { Populacional }\end{array}$ & $\begin{array}{l}\text { RMSEA } \\
\text { (Lo90;Hi90) }\end{array}$ & $\begin{array}{c}0,067 \\
(0,037 ; 0,098)\end{array}$ & $\begin{array}{c}0,089 \\
(0,059 ; 0,121)\end{array}$ & $\begin{array}{c}0,086 \\
(0,058 ; 0,117)\end{array}$ \\
\hline Índices de Parcimônia & $\begin{array}{l}\text { PCFI } \\
\text { PGFI }\end{array}$ & $\begin{array}{l}0,53 \\
0,37\end{array}$ & $\begin{array}{l}0,46 \\
0,33\end{array}$ & $\begin{array}{l}0,52 \\
0,37\end{array}$ \\
\hline $\begin{array}{l}\text { Índices Baseados na } \\
\text { Teoria da Informação }\end{array}$ & $\begin{array}{l}\text { AIC } \\
\text { ECVI } \\
\text { CAIC }\end{array}$ & $\begin{array}{c}50,10 \\
0,11 \\
116,55\end{array}$ & $\begin{array}{c}59,95 \\
0,13 \\
131,51\end{array}$ & $\begin{array}{c}60,83 \\
0,14 \\
127,28\end{array}$ \\
\hline
\end{tabular}

2.1.2.2 Confiabilidade e validade da escala de medida de valores organizacionais

Para avaliar a confiabilidade dos tipos motivacionais foi utilizado o Rho de Jöreskog, que é recomendado por ser menos sensível ao número de itens que o alfa de Cronbach. O valor do Rho de Jöreskog (>0,7) indica uma boa consistência interna de cada dimensão, conforme pode ser visto na Tabela 27, relativa ao Modelo 2; e na Tabela 28, referente ao Modelo 3.

Em seguida, foi avaliada a validade convergente, de acordo com o critério de Fornell e Larcker (1981), cujo valor da variância média extraída pelo fator deve ser superior a 0,5. Esse critério foi satisfeito por todas as dimensões da escala estudada nos Modelos 2 e 3 (Tabela 27 e Tabela 28), respectivamente. De forma similar, os pesos fatoriais foram todos 
significativos e fortes $(\lambda \mathrm{i}>0,5 ; p<0,001)$. As correlações múltiplas ao quadrado são, igualmente, superiores à 0,5 (exceção do item VO3), o que fornece uma prova complementar da validade convergente (Bagozzi \& Yi, 1988).

Por último, a validade discriminante foi avaliada pelo método de Fornell e Larcker (1981). De acordo com este método, a validade discriminante entre duas dimensões é estabelecida quando a variância média extraída de cada uma dos pares dimensionais é maior do que o quadrado da correlação entre eles. O Modelo 2 não atendeu a esse critério em sua plenitude. Adotou-se, portanto, a restrição dos modelos fortemente correlacionados $(>0,7)$, fixando essas correlações em 1 e comparando-as com o modelo, cujas correlações encontravam-se livres. Para um $\alpha=0,05$, sendo $\chi^{2}$ dif $>\chi^{2}{ }_{0,95(1)}=3,84$, pode-se asseverar que a correlação entre cada uma das duas dimensões, que apresentaram altas correlações, é diferente de 1 , o que indica a validade discriminante dos fatores.

No Modelo 3, a validade discriminante entre dos dois primeiros pares (Hierarquia $\mathrm{x}$ Igualitarismo e Conservação x Autonomia) está satisfeita (Tabela 27). Para o par Domínio x Harmonia foi adotada uma opção mais restritiva, pois o método de Fornell e Larcker (1981) não foi satisfeito. Assim, comparou-se o modelo livre (com correlações entre fatores livres) e o modelo restrito com correlação entre os fatores fixa em 1 (Marôco, 2010). Para um $\alpha=0,05$, sendo $\chi_{d i f}^{2}=107,29>\chi^{2} 0,95(1)=3,84$, pode-se afirmar que a correlação entre os dois fatores é diferente de 1 , o que indica a validade discriminante dos fatores.

As Tabelas 27 e 28 apresentam os resumos das qualidades psicométricas e as Figuras 18 e 19 mostram as representações gráficas dos Modelos 2 e 3, os pesos fatoriais não estandardizados e as correlações múltiplas ao quadrado. 


\section{Tabela 27}

Confiabilidade e validade das tipologias conforme Modelo 2 da EVO

\begin{tabular}{|c|c|c|c|c|c|c|}
\hline \multicolumn{6}{|c|}{ Confiabilidade e Validade Convergente do Modelo 2} & $\begin{array}{l}\text { Pesos Fatoriais } \\
\text { (t-valor) }\end{array}$ \\
\hline \multicolumn{7}{|c|}{ Dimensão Hierarquia: $\rho=0,84$; Rhovc $=0,65 ; t=51,49>1,96$} \\
\hline \multicolumn{6}{|c|}{ VO3_Centralização das decisões } & $0,52(50,91)$ \\
\hline \multicolumn{6}{|c|}{ VO35_ Tratamento diferenciado aos ocupantes de cargos de chefia } & $0,78(45,61)$ \\
\hline \multicolumn{6}{|c|}{ VO38_Poder concentrado nos níveis hierárquicos superiores } & $0,85(50,60)$ \\
\hline \multicolumn{7}{|c|}{ Dimensão Domínio: $\rho=0,91$; Rhovc $=0,68, t=64,18>1,96$} \\
\hline \multicolumn{6}{|c|}{ VO26_Preocupação com o aumento da prestação dos serviços } & $0,80(50,38)$ \\
\hline \multicolumn{6}{|c|}{ VO34_Ambição nas ações de segurança pública } & $0,67(55,62)$ \\
\hline \multicolumn{7}{|c|}{ Dimensão Conservação: $\rho=0,93 ;$ Rhovc $=0,82, t=73,83>1,96$} \\
\hline \multicolumn{6}{|c|}{ VO23_ Respeito às regras da organização } & $0,83(67,02)$ \\
\hline \multicolumn{6}{|c|}{ VO27_Obediência às normas da organização } & $0,90(66,29)$ \\
\hline \multicolumn{6}{|c|}{ VO29_Obediência dos policiais aos padrões de comportamento estabelecidos } & $0,81(66,38)$ \\
\hline \multicolumn{7}{|c|}{ Dimensão Igualitarismo: $\rho=0,92 ;$ Rhovc $=0,80, t=45,03>1,96$} \\
\hline \multirow{3}{*}{\multicolumn{6}{|c|}{$\begin{array}{l}\text { VO12_ Saúde e bem-estar dos policiais } \\
\text { VO22_Cooperação entre os policiais } \\
\text { VO30_Oportunidades iguais a todos os policiais }\end{array}$}} & $0,83(41,80)$ \\
\hline & & & & & & $0,80(62,50)$ \\
\hline & & & & & & $0,86(32,44)$ \\
\hline \multicolumn{7}{|c|}{ Dimensão Autonomia: $\rho=0,94$; Rhovc $=0,84, t=51,46>1,96$} \\
\hline \multirow{3}{*}{\multicolumn{6}{|c|}{$\begin{array}{l}\text { VO21_ Autonomia dos polic } \\
\text { VO24_Capacidade de inova } \\
\text { VO25_Originalidade }\end{array}$}} & $0,79(45,41)$ \\
\hline & & & & & & $0,93(46,59)$ \\
\hline & & & & & & $0,87(44,88)$ \\
\hline \multicolumn{7}{|c|}{ Dimensão Harmonia: $\rho=0,94$; Rhovc $=0,79, t=62,53>1,96$} \\
\hline \multirow{4}{*}{\multicolumn{6}{|c|}{$\begin{array}{l}\text { VO5_Relações transparentes com a sociedade } \\
\text { VO13_ Respeito à sociedade } \\
\text { VO36_Credibilidade frente aos cidadãos } \\
\text { VO37_ Desenvolvimento do país e das comunidades em que atua }\end{array}$}} & $0,76(49,66)$ \\
\hline & & & & & & $0,80(60,52)$ \\
\hline & & & & & & $0,84(51,73)$ \\
\hline & & & & & & $0,87(50,76)$ \\
\hline \multicolumn{7}{|c|}{ Continua } \\
\hline \multicolumn{7}{|c|}{ Validade Discriminante do Modelo 2} \\
\hline & Hierarquia & Domínio & Conservação & Igualitarismo & Autonomia & Harmonia \\
\hline Hierarquia & 0,65 & & & & & \\
\hline Domínio & 0,01 & $\mathbf{0 , 6 8}$ & & & & \\
\hline Conservação & 0,12 & 0,55 & $\mathbf{0 , 8 2}$ & & & \\
\hline Igualitarismo & 0,09 & 0,69 & 0,29 & $\mathbf{0 , 8 0}$ & & \\
\hline Autonomia & 0,06 & 0,83 & 0,33 & 0,87 & 0,84 & \\
\hline Harmonia & 0,01 & 0,83 & 0,36 & 0,88 & 0,79 & 0,79 \\
\hline
\end{tabular}




\section{Tabela 28}

Confiabilidade e validade das tipologias conforme Modelo 3 da EVO

\begin{tabular}{|c|c|}
\hline Confiabilidade e Validade Convergente do Modelo 3 & Pesos Fatoriais \\
\hline \multicolumn{2}{|c|}{ Dimensão Hierarquia: $\rho=0,84$; Rhovc $=0,64 ; t>1,96$} \\
\hline VO3_Centralização das decisões & 0,51 \\
\hline VO35_Tratamento diferenciado aos ocupantes de cargos de chefia & 0,84 \\
\hline VO38_Poder concentrado nos níveis hierárquicos superiores & 0,78 \\
\hline \multicolumn{2}{|c|}{ Dimensão Igualitarismo: $\rho=0,92 ;$ Rhovc $=0,80, t>1,96$} \\
\hline VO12_Saúde e bem-estar dos policiais & 0,84 \\
\hline VO22_Cooperação entre os policiais & 0,76 \\
\hline VO30_Oportunidades iguais a todos os policiais & 0,89 \\
\hline \multicolumn{2}{|c|}{ Validade Discriminante (Hierarquia x Igualitarismo) } \\
\hline Hierarquia & Igualitarismo \\
\hline Hierarquia & \multirow[b]{2}{*}{$\mathbf{0 , 8 0}$} \\
\hline Igualitarismo & \\
\hline \multicolumn{2}{|c|}{ Dimensão Conservação: $\rho=0,93$; Rhovc $=0,82, t>1,96$} \\
\hline VO23_Respeito às regras da organização & 0,84 \\
\hline VO27_Obediência às normas da organização & 0,90 \\
\hline VO29_Obediência dos policiais aos padrões de comportamento estabel & 0,80 \\
\hline \multicolumn{2}{|c|}{ Dimensão Autonomia: $\rho=0,94$; Rhovc $=0,84, t>1,96$} \\
\hline VO21_Autonomia dos policiais na realização das tarefas & 0,75 \\
\hline VO24_Capacidade de inovar & 0,95 \\
\hline VO25_Originalidade & 0,87 \\
\hline \multicolumn{2}{|c|}{ Validade Discriminante (Conservação x Autonomia) } \\
\hline Conservação & \multirow[t]{2}{*}{ Autonomia } \\
\hline Conservação & \\
\hline Autonomia & $\mathbf{0 , 8 4}$ \\
\hline \multicolumn{2}{|c|}{ Dimensão Domínio: $\rho=0,89$; Rhovc $=0,74, t>1,96$} \\
\hline VO26_Preocupação com o aumento da prestação dos serviços & 0,78 \\
\hline VO34_Ambição nas ações de segurança pública & 0,69 \\
\hline \multicolumn{2}{|c|}{ Dimensão Harmonia: $\rho=0,91$; Rhovc $=0,76, t>1,96$} \\
\hline VO5_Relações transparentes com a sociedade & 0,77 \\
\hline VO13__Respeito à sociedade & 0,76 \\
\hline VO36_Credibilidade frente aos cidadãos & 0,85 \\
\hline VO37_ Desenvolvimento do país e das comunidades em que atua & 0,87 \\
\hline \multicolumn{2}{|l|}{ Validade Discriminante (Domínio x Harmonia) } \\
\hline Domínio & Harmonia \\
\hline Domínio & \\
\hline Harmonia & 0,79 \\
\hline
\end{tabular}




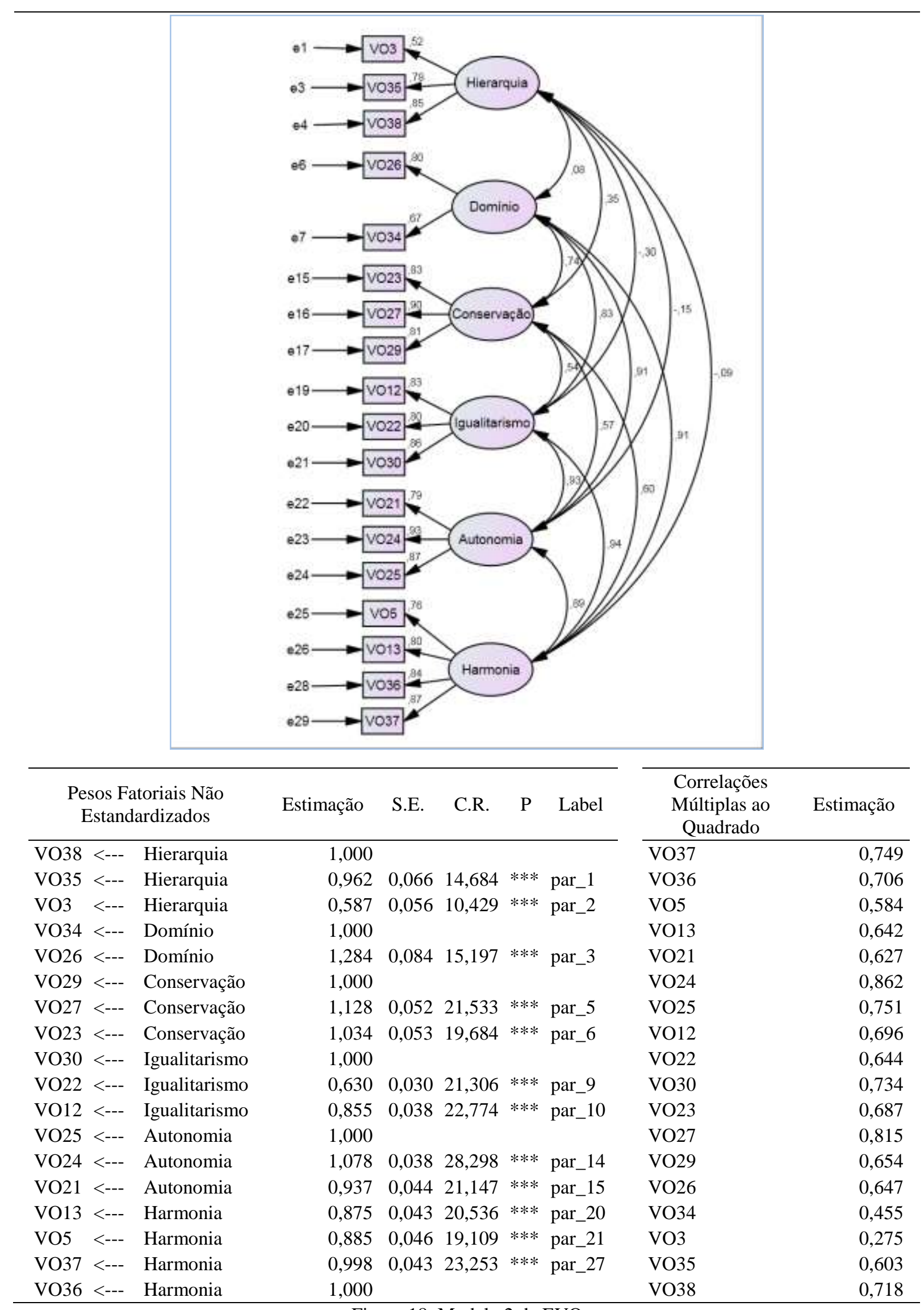

Figura 18. Modelo 2 da EVO. 


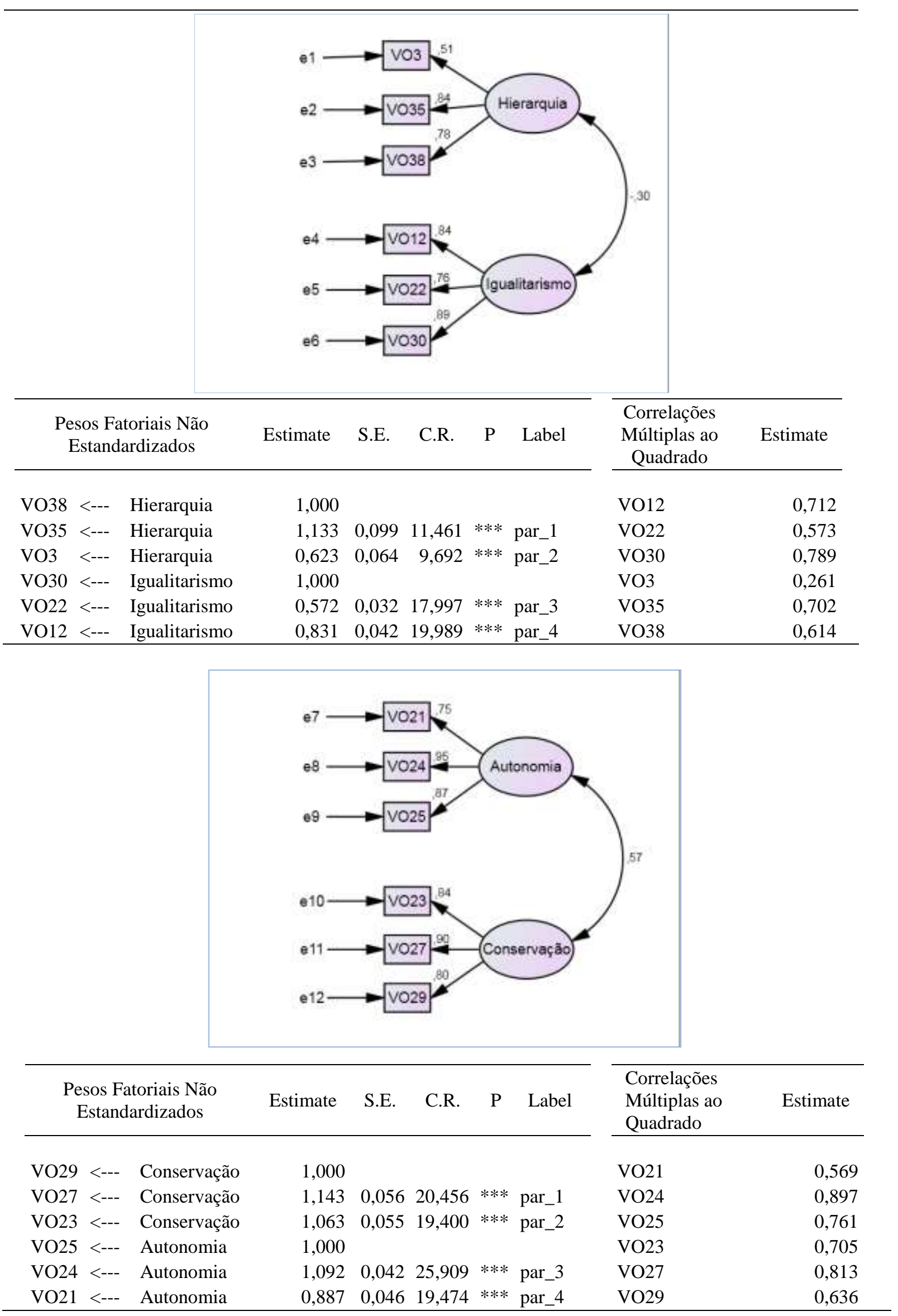




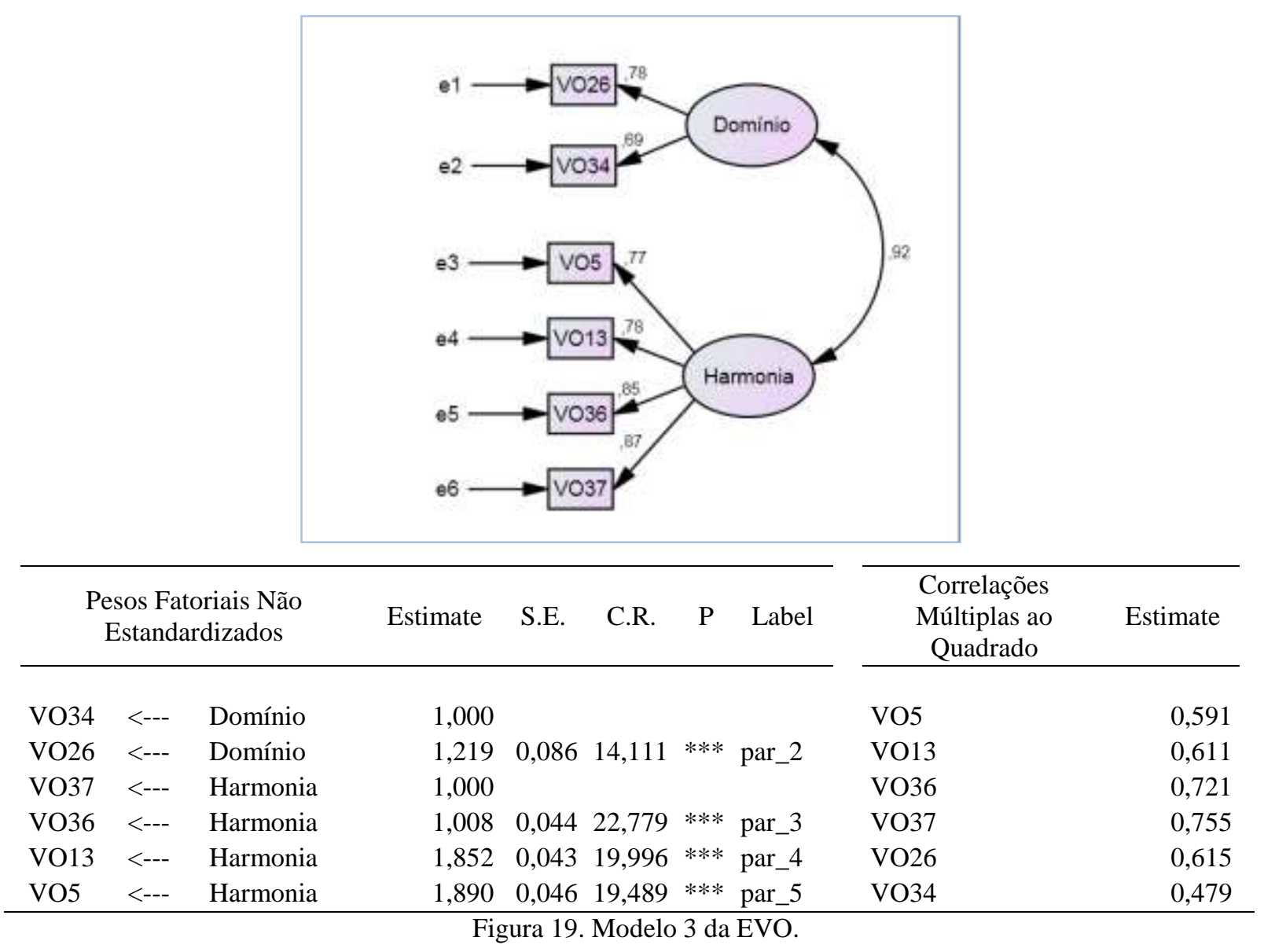

\subsection{Evidências de Validade da Escala de Práticas Organizacionais}

A escala de práticas organizacionais (EPO) foi construída por Souza (2014) com base nos estudos de D’Iribarne (1989). Os procedimentos de elaboração elencados por Pasquali (2010) foram atendidos no que se referem aos procedimentos teóricos e empíricos, restando o polo analítico, responsável pela validação psicométrica da medida, não efetivado pela autora. Diante disso, foi elaborada a análise fatorial exploratória e confirmatória desse instrumento de medida.

\subsubsection{Análise fatorial exploratória com Software SPSS Statistics}

Em análise preliminar dos Componentes Principais (PC), a matriz de intercorrelações mostrou-se fatorizável, isto é, apresentou suficiente covariância que permitisse a procura de fatores. O teste de esfericidade de Bartllet $(\mathrm{p}<0,000)$ e o coeficiente KMO, que indicam tal evento, foi de 0,95 que pode ser considerado maravilhoso (Pasquali, 2010).

Em seguida, foi analisada a dimensionalidade da escala com base em diferentes métodos. O critério de Kaiser identificou até sete fatores que explicam 56,93\% da variância 
total. O primeiro fator é o determinante ( $\Delta$ entre o primeiro e o sétimo fatores é de $21,98 \%$ ). O teste do gráfico de sedimentação (scree plot) indicou que a EPO apresenta até sete componentes. Por fim, foi feita a análise paralela de Horn, que identificou até seis fatores. Esses critérios estão descritos na Figura 20 e Tabela 29.

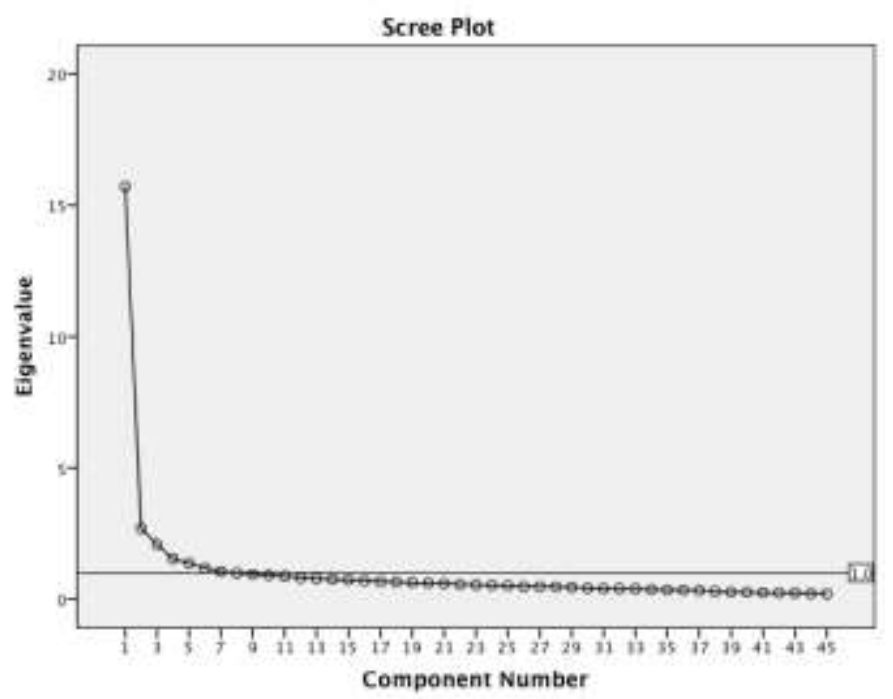

Figura 20. Grafico do Scree EPO.

Tabela 29

Autovalores

empíricos e aleatórios EPO

\begin{tabular}{cccc|c}
\hline \multirow{2}{*}{ Componente } & \multicolumn{2}{|c|}{ Autovalores iniciais } & \multirow{2}{*}{$\begin{array}{c}\text { Autovalores } \\
\text { aleatórios }\end{array}$} \\
\cline { 2 - 3 } & Total & \% de variância & \\
\hline 1 & 15,724 & 34,94 & 1,4513 \\
3 & 2,688 & 5,97 & 1,4063 \\
4 & 2,078 & 4,618 & 1,3714 \\
5 & 1,531 & 3,403 & 1,3421 \\
6 & 1,367 & 3,039 & 1,3147 \\
7 & 1,298 & 2,618 & 1,2904 \\
8 & 1,049 & 2,332 & 1,2667 \\
9 & 0,984 & 2,186 & 1,2448 \\
10 & 1,280 & 2.908 & 1,2239 \\
\hline
\end{tabular}

De posse dessas informações, procedeu-se à análise fatorial pelo método dos eixos principais $(P A F)$, com rotação varimax, para a extração de seis fatores, que se mostrou mais adequada à teoria.Foram excluídos os itens que saturaram em mais de um fator (PO20, PO31, PO39 e PO40), cuja diferença foi inferior a 0,1 (Neiva et al., 2007). Os itens PO5 e PO17 apresentaram baixas comunalidades $(<0,3)$, por isso, também, foram excluídos, além do item PO42 que apresentou carga fatorial abaixo do limite de 0,30. A nova análise melhorou a representatividade dos itens que passaram a explicar $57,73 \%$ da variância total. A análise de 
precisão foi obtida pelos coeficientes alfa de Cronbach e lambda-2 de Guttman, sendo excluídos os itens PO1, PO8, PO16, PO24, PO27, PO28 e PO44 pelo critério da parcimônia (Pasquali, 2012), com vistas a aumentar a confiabilidade do fator. A estrutura final da EPO, portanto, reteve os itens que apresentaram compatibilidades teóricas e parcimônia. A Tabela 30 fornece uma síntese dos resultados finais retidos da análise fatorial exploratória.

Tabela 30

Matriz fatorial da EPO

\begin{tabular}{|c|c|c|c|c|c|c|c|}
\hline Itens & Fator 1 & Fator 2 & Fator 3 & Fator 4 & Fator 5 & Fator 6 & $\begin{array}{c}\text { Comunalidades } \\
\left(\mathrm{R}^{2}\right)\end{array}$ \\
\hline PO38 & 0,79 & & & & & & 0,69 \\
\hline PO30 & 0,74 & & & & & & 0,61 \\
\hline PO33 & 0,71 & & & & & & 0,66 \\
\hline PO34 & 0,68 & & & & & & 0,60 \\
\hline PO32 & 0,66 & & & & & & 0,61 \\
\hline $\mathrm{PO} 25$ & 0,65 & & & & & & 0,54 \\
\hline PO9 & 0,62 & & & & & & 0,55 \\
\hline PO36 & 0,61 & & & & & & 0,65 \\
\hline PO41 & 0,60 & & & & & & 0,54 \\
\hline PO21 & 0,56 & & & & & & 0,48 \\
\hline PO15 & 0,56 & & & & & & 0,42 \\
\hline PO6 & & 0,60 & & & & & 0,56 \\
\hline PO19 & & 0,57 & & & & & 0,51 \\
\hline PO7 & & 0,57 & & & & & 0,40 \\
\hline PO18 & & 0,39 & & & & & 0,34 \\
\hline PO4 & & 0,39 & & & & & 0,30 \\
\hline PO37 & & & 0,60 & & & & 0,55 \\
\hline PO35 & & & 0,51 & & & & 0,65 \\
\hline PO45 & & & 0,46 & & & & 0,49 \\
\hline PO43 & & & 0,46 & & & & 0,43 \\
\hline PO12 & & & & 0,57 & & & 0,37 \\
\hline PO29 & & & & 0,54 & & & 0,44 \\
\hline PO10 & & & & 0,53 & & & 0,38 \\
\hline PO26 & & & & 0,37 & & & 0,43 \\
\hline $\mathrm{PO} 2$ & & & & & 0,60 & & 0,71 \\
\hline PO3 & & & & & 0,55 & & 0,65 \\
\hline $\mathrm{PO} 23$ & & & & & & 0,54 & 0,37 \\
\hline P011 & & & & & & 0,54 & 0,44 \\
\hline PO14 & & & & & & 0,48 & 0,34 \\
\hline PO13 & & & & & & 0,46 & 0,30 \\
\hline $\mathrm{PO} 22$ & & & & & & 0,39 & 0,30 \\
\hline Autovalor & 13,58 & 2,59 & 1,94 & 1,53 & 1,43 & 1,30 & \\
\hline Número de itens & 11 & 5 & 4 & 4 & 2 & 5 & \\
\hline$\%$ Var. Explicada & 35,74 & 6,83 & 5,12 & 3,75 & 3,38 & 2,91 & \\
\hline Alfa & 0,94 & 0,76 & 0,92 & 0,66 & 0,83 & 0,60 & \\
\hline Lambda 2 & 0,93 & 0,77 & 0,92 & 0,67 & 0,83 & 0,60 & \\
\hline Carga mínima & 0,50 & 0,39 & 0,38 & 0,37 & 0,60 & 0,39 & \\
\hline Carga máxima & 0,79 & 0,60 & 0,60 & 0,57 & 0,55 & 0,54 & \\
\hline Carga média & 0,65 & 0,50 & 0,51 & 0,50 & 0,63 & 0,48 & \\
\hline
\end{tabular}

Os seis fatores da EPO estão suficientemente estruturados, com ressalvas para os Fatores 4 e 6, que necessitam maior consistência interna, mesmo que os índices apresentados 
sejam aceitáveis para estudos exploratórios (Hair et al.,2009; Pasquali, 2010). A AFE dos dados redistribuiu os itens em seis fatores, que foram renomeados, buscando-se a adequação com a teoria de base. Os novos fatores, então, renomeados, passaram a ser designados da seguinte forma:

Fator 1: Inicialmente denominado Sanções, passa a ser denominado Recompensas e Punições: Refere-se às recompensas e/ou punições aplicadas em função de comportamentos no trabalho; à concessão de benefícios ou punições decorrentes da obtenção de resultados ou objetivos propostos; à existência de políticas organizacionais de sanções (benefícios ou punições), e à utilização de critérios para a aplicação de sanções.

Por intermédio da análise dos itens, verifica-se que existe a percepção de que na organização há investimento na formação dos profissionais, os quais são valorizados, recompensados pelo bom desempenho e recebem as recompensas que esperam, sendo escolhidos para as missões por competência. Observou-se, também, que os profissionais contam com o apoio da organização no que diz respeito à cooperação, que o ambiente organizacional é estimulador, e que os profissionais concordam com os critérios de controle.

Fator 2: Permanece a dimensão Regulação. Refere-se às ações de moderação e de acordos que regem as atividades dos profissionais, o cumprimento de contratos, a gestão de interesses organizacionais e individuais. A análise dos itens que constituíram esse fator indica a resistência às mudanças, o ritmo definido pelos profissionais nas equipes, o prazer na execução das tarefas, os laços de amizade, a flexibilidade nas relações.

Fator 3: Permanece a dimensão Senso de Dever. Refere-se ao exercício de procura de direitos e à execução de deveres. Inclui aspectos de motivação na execução do trabalho (obrigação versus compromisso), adesão a valores organizacionais ou prevalência de interesses individuais nas relações de trabalho; sentimentos de orgulho e de pertencimento à organização, compromisso com a obtenção de resultados.

Os Itens selecionados para esse fator estão de acordo com os descritores, tendo em conta que representam respeito ao outro, comprometimento, compromisso de trabalho em equipe, cumprimento de prazos, aceitação de trabalho em equipe de forma harmoniosa, aceitação de controle de desempenho, trabalho de forma integrada, sentimento de pertença à organização.

Fator 4: Inicialmente foi denominado Relações Hierárquicas. Ao analisar os dados, observa-se que nesse fator houve a concentração de itens relacionados às regras, às relações dos diferentes níveis hierárquicos, aos critérios definidos, resolução de conflitos. Com base 
nessa análise, propõe-se mudança no nome da categoria, que passará a chamar-se Relações de Autoridade com os seguintes descritores: relação entre os diferentes níveis de gestão e entre profissionais, tomada de decisão na organização, percepção de controle.

Fator 5: Permanece a dimensão Qualidade de Cooperação: Refere-se: às características das relações interpessoais entre funcionários no trabalho individual ou em grupo, à disponibilidade dos profissionais para trabalharem em equipe; à forma como são gerenciados os conflito no e pelo grupo; à tendência ao individualismo ou ao coletivismo das relações profissionais; à base em que ocorrem laços de cooperação (profissionais, sociais, familiares).O estudo dos itens verificou a tendência ao desafio de solucionar problemas, alcançar resultados e planejar rotinas.

Fator 6: Permanece a dimensão Definição de Responsabilidades. Definição de Responsabilidades refere-se à forma como as funções/tarefas são atribuídas (segundo critérios normativos, por fidelidade, por amizade, por interesses privados) e avaliadas, ao estabelecimento e à difusão das responsabilidades individuais e dos grupos, aos critérios formais definidos pelos superiores (responsabilidade objetiva), aos critérios informais de acordo com as relações pessoais ou a crença dos profissionais subordinados (responsabilidade subjetiva), a utilização de regras mais formalizadas.

Observando-se a distribuição dos itens, infere-se que são possíveis relacionamentos e interesses pessoais, com a percepção de maior distância do poder, com acordos e arranjos e trabalhos individuais, a utilização de regras mais formalizadas, deixando de lado ideias e comportamentos alternativos.

Apresenta-se, em seguida, a análise fatorial confirmatória, como forma de se comprovar a estrutura conseguida com a AFE.

\subsubsection{Análise fatorial confirmatória com Software AMOS}

\subsubsection{Ajuste do modelo de medida}

Como forma de verificar a qualidade do ajustamento dos dados, foram apreciadas duas especificações. A primeira, avaliou um modelo unidimensional (teste de Harman, conforme Malhotra et al., 2006), a título exploratório, e a segunda, um modelo com os seis fatores oriundos da AFE.

O Modelo 1 (unidimensional) não mostrou ajustes satisfatórios, o que levou à sua rejeição. O modelo 2 apresentou índices satisfatórios de ajuste, após a eliminação dos itens, que revelaram covariância residual estandardizada, superiores ao limite de $|2,58|$, de acordo 
com MacCallum (1986), e cujos índices de modificação mostravam-se inadequados ao saturar, com valores elevados (>11, segundo Marôco, 2010), em mais de um item. Além disso, esse modelo esclareceu correlações superiores a 0,70 entre os fatores, porém, as análises indicaram ser possível a distinção entre eles. Os índices de ajuste dos dois modelos são mostrados na Tabela 31.

Tabela 31

Índices de ajustamento dos Modelos 1 e 2 da EPO

\begin{tabular}{|c|c|c|c|}
\hline \multicolumn{2}{|l|}{$\begin{array}{l}\text { Amostra } \\
\mathrm{N}=451\end{array}$} & $\begin{array}{c}\text { Modelo } 1 \\
\text { Unidimensional }\end{array}$ & $\begin{array}{c}\text { Modelo } 2 \\
6 \text { Dimensões }\end{array}$ \\
\hline \multirow{5}{*}{$\begin{array}{l}\text { Índices } \\
\text { Absolutos }\end{array}$} & $\chi / \mathrm{g} .1$. & 3,59 & 2,34 \\
\hline & $\chi^{2} ;$ g.l. & 1556,$27 ; 434$ & 660,$76 ; 284$ \\
\hline & & 0,000 & 0,000 \\
\hline & GFI (AGFI) & $0,78(0,75)$ & $0,90(0,87)$ \\
\hline & SRMR & 0,068 & 0,044 \\
\hline \multirow[t]{2}{*}{ Índices Relativos } & CFI & 0,79 & 0,92 \\
\hline & TLI & 0,77 & 0,91 \\
\hline Índices de Discrepância & RMSEA & 0,08 & 0,054 \\
\hline Populacional & (Lo90;Hi90) & $(0,072 ; 0,080)$ & $(0,049 ; 0,060)$ \\
\hline \multirow[t]{2}{*}{ Índices de Parcimônia } & PCFI & 0,734 & 0,81 \\
\hline & PGFI & 0,683 & 0,73 \\
\hline Índices Baseados na & AIC & 1680,27 & 794,76 \\
\hline \multirow[t]{2}{*}{ Teoria da Informação } & ECVI & 3733 & 1,77 \\
\hline & CAIC & 1997,18 & 1137,22 \\
\hline
\end{tabular}

2.2.2.2 Confiabilidade e validade da escala de medida de práticas organizacionais

O valor do Rho de Jöreskog relatou boa consistência interna para a maioria das dimensões, com exceção de duas (Relações de Autoridade e Definição de Responsabilidade). Resolveu-se manter essas duas dimensões (Rho<0,7), por se tratar de um estudo exploratório, que abre uma agenda para estudos futuros que possam aprimorar esses fatores (Hair et al., 2009; Marôco, 2010; Pasquali, 2012).

A validade convergente foi satisfeita para quase todos os fatores; novamente, as dimensões relações de autoridade e definição de responsabilidade apresentaram índices inferiores aos recomendados pela literatura $\left(\mathrm{Rho}_{\mathrm{vc}}>0,5\right)$. Entretanto, as correlações múltiplas ao quadrado são, em sua maioria, superiores a 0,5 , o que fornece nova prova complementar da validade convergente (Bagozzi \& Yi, 1988). Os pesos fatoriais foram todos significativos e fortes $(\lambda \mathrm{i}>0,5 ; p<0,001)$.

E, por último, a validade discriminante entre as dimensões foi avaliada $\left(\mathrm{Rho}_{\mathrm{vc}}>\mathrm{r}^{2}\right)$. Como o Modelo 2 não atendeu a esse critério em sua plenitude, assumiu-se a restrição dos 
modelos fortemente correlacionados $(>0,7)$, fixando essas correlações em 1 e comparando-as com o modelo cujas correlações encontravam-se livres. Para um $\alpha=0,05$, sendo $\chi^{2} d i f>\chi^{2} 0,95(1)=$ 3,84 , pode-se garantir que a correlação entre cada uma das duas dimensões, que apresentaram altas correlações, é diferente de 1, o que indica a validade discriminante dos fatores. A Tabela 32 apresenta o resumo das qualidades psicométricas e a Figuras 22 exibe a representação gráfica do Modelo 2, os pesos fatoriais não estandardizados (padronizados) e as correlações múltiplas ao quadrado.

Tabela 32

Confiabilidade e validade das dimensões conforme Modelo 2 da EPO

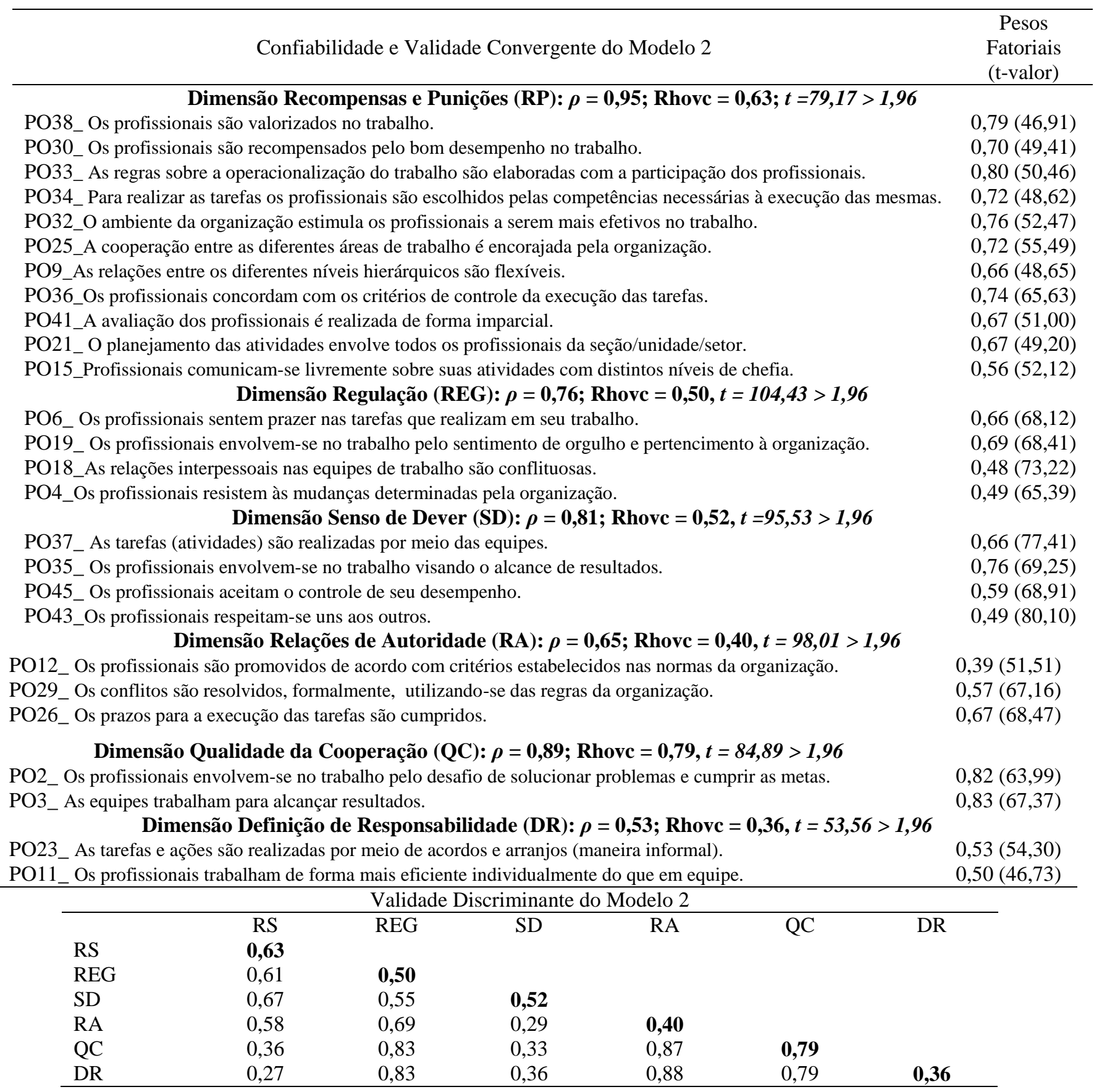




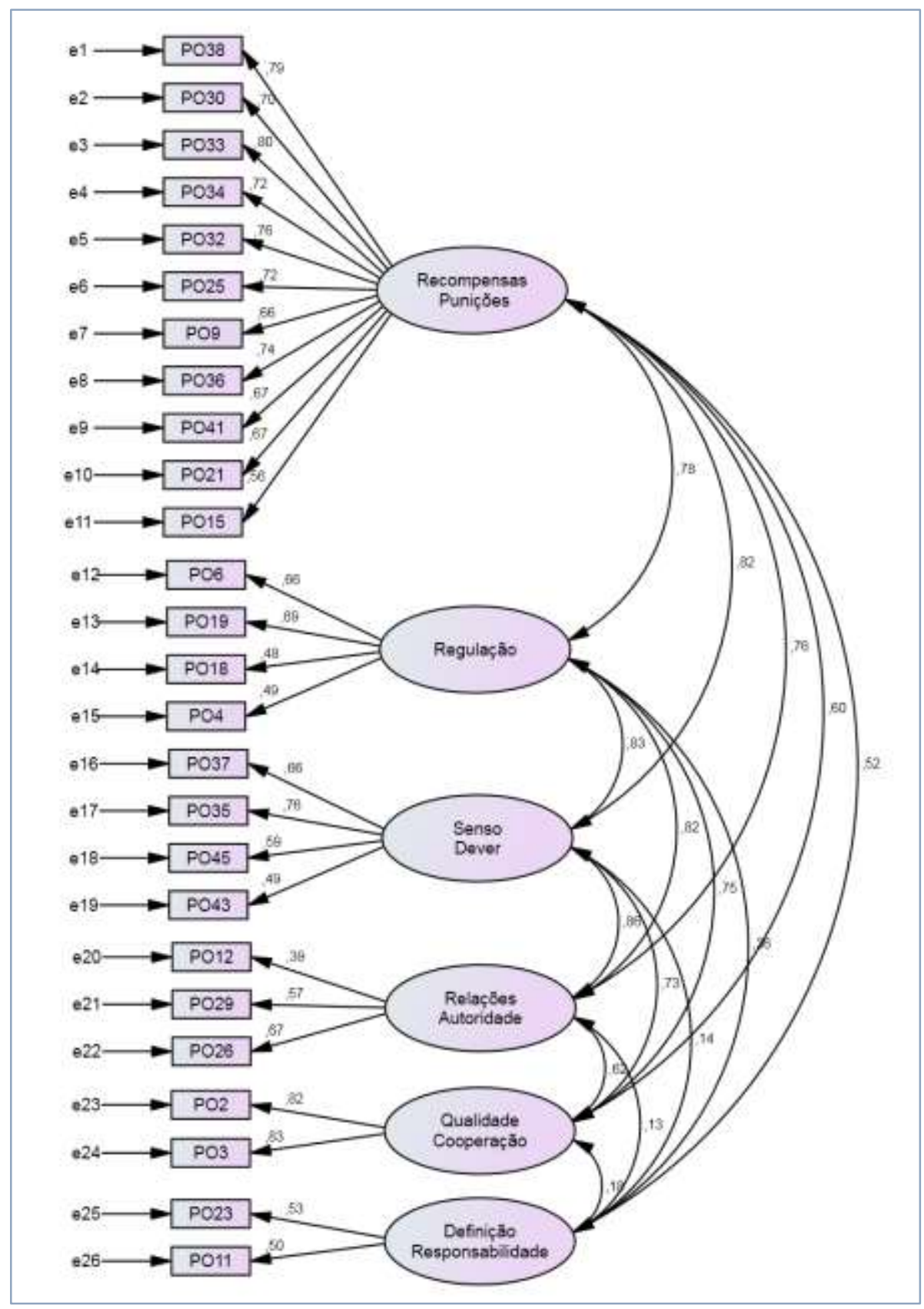




\begin{tabular}{|c|c|c|c|c|c|c|c|c|c|}
\hline \multicolumn{3}{|c|}{$\begin{array}{l}\text { Pesos Fatoriais Não- } \\
\text { Estandardizados }\end{array}$} & \multirow{2}{*}{$\begin{array}{r}\text { Estimate } \\
0,713\end{array}$} & \multirow{2}{*}{$\begin{array}{l}\text { S.E. } \\
0,058\end{array}$} & \multirow{2}{*}{$\begin{array}{c}\text { C.R. } \\
12,229\end{array}$} & \multirow{2}{*}{$\begin{array}{c}\mathrm{P} \\
* * *\end{array}$} & \multirow{2}{*}{$\begin{array}{l}\text { Label } \\
\text { par_1 }\end{array}$} & \multirow{2}{*}{$\begin{array}{c}\text { Correlações } \\
\text { Múltiplas ao } \\
\text { Quadrado } \\
\text { PO6 }\end{array}$} & \multirow{2}{*}{$\begin{array}{r}\text { Estimate } \\
, 429\end{array}$} \\
\hline PO15 & $<---$ & R_P & & & & & & & \\
\hline PO21 & $<---$ & R_P & 0,899 & 0,059 & 15,118 & $* * *$ & par_2 & PO19 & ,476 \\
\hline PO41 & $<---$ & R_P & 0,834 & 0,055 & 15,034 & $* * *$ & par_3 & PO18 & ,230 \\
\hline PO36 & $<---$ & R_P & 0,766 & 0,045 & 16,965 & $* * *$ & par_4 & PO4 & 237 \\
\hline PO9 & $<---$ & R_P & 0,856 & 0,057 & 14,937 & $* * *$ & par_5 & PO12 & , 149 \\
\hline PO25 & $<---$ & R_P & 0,843 & 0,052 & 16,280 & $* * *$ & par_6 & PO29 & ,320 \\
\hline PO32 & $<---$ & R_P & 0,919 & 0,052 & 17,776 & $* * *$ & par_7 & PO26 & ,445 \\
\hline PO34 & $<---$ & R_P & 0,915 & 0,056 & 16,386 & $* * *$ & par_8 & $\mathrm{PO} 23$ & ,285 \\
\hline PO33 & $<---$ & R_P & 0,962 & 0,052 & 18,678 & $* * *$ & par_9 & PO11 & ,251 \\
\hline PO30 & $<---$ & R_P & 0,852 & 0,053 & 16,099 & $* * *$ & par_10 & $\mathrm{PO} 2$ & 669 \\
\hline PO38 & $<---$ & R_P & 1,000 & & & & & PO3 & 689 \\
\hline PO43 & $<---$ & S_D & 0,743 & 0,080 & 9,259 & $* * *$ & par_11 & PO37 & ,436 \\
\hline PO45 & $<---$ & S_D & 0,903 & 0,084 & 10,803 & $* * *$ & par_12 & PO35 & ,582 \\
\hline PO35 & $<---$ & S_D & 1,212 & 0,091 & 13,331 & $* * *$ & par_13 & PO45 & ,352 \\
\hline PO37 & $<---$ & S_D & 1,000 & & & & & $\mathrm{PO} 43$ & 237 \\
\hline PO3 & $<--$ & Q_C & 1,038 & 0,067 & 15,415 & $* * *$ & par_14 & PO38 & 629 \\
\hline $\mathrm{PO} 2$ & $<---$ & Q_C & 1,000 & & & & & PO30 & ,490 \\
\hline PO11 & $<---$ & D_R & 0,967 & 0,183 & 5,271 & $* * *$ & par_15 & PO33 & 634 \\
\hline PO23 & $<---$ & D_R & 1,000 & & & & & PO34 & ,518 \\
\hline PO26 & $<---$ & R_A & 1,286 & 0,188 & 6,842 & $* * *$ & par_16 & PO32 & ,574 \\
\hline PO29 & $<---$ & R_A & 1,109 & 0,164 & 6,768 & $* * *$ & par_17 & $\mathrm{PO} 25$ & ,514 \\
\hline PO12 & $<---$ & R_A & 1,000 & & & & & PO9 & ,440 \\
\hline PO4 & $<---$ & Reg & 0,761 & 0,085 & 8,955 & $* * *$ & par_18 & PO36 & ,550 \\
\hline PO18 & $<---$ & Reg & 0,707 & 0,081 & 8,752 & $* * *$ & par_19 & PO41 & ,445 \\
\hline PO19 & $<---$ & Reg & 1,037 & 0,088 & 11,789 & $* * *$ & par_20 & PO21 & ,455 \\
\hline PO6 & $<---$ & Reg & 1,000 & & & & & PO15 & ,314 \\
\hline
\end{tabular}

Notas: (R_P: Recompensas e punições; S_D: Senso de dever; Q_C: Qualidade da cooperação; D_R: Definição de responsabilidade; R_A: Relações de autoridade; REG: Regulação. Figura 21. Modelo 2 EPO.

\subsection{Evidências de Validade da Escala de Identidade Profissional}

A escala de identidade profissional (EIP) foi construída e validada por Cameron (2004). Esse instrumento foi submetido à adaptação e validação de conteúdo (CasseppBorges, Balbinoti \& Teodoro, 2010). O procedimento de tradução da versão original em inglês para o português seguiu a técnica de tradução e retradução de Brislin (1970) e Vallerand (1979). Com vistas a garantir a equivalência da escala em português, optou-se por tradutores bilíngues. Neste caso, dois psicólogos brasileiros com vivências nos Estados Unidos e Inglaterra efetuaram traduções independentes, segundo as recomendações de Cha, Kim e Erlen (2007). Posteriormente, outros dois psicólogos bilíngues elaboraram a tradução reversa, ou seja, do português para o inglês. Em seguida, um comitê composto por três estudantes de pós-graduação, um dos membros que realizou a primeira tradução e um 
membro externo avaliaram cada um dos itens com o objetivo de aproximar as versões em português e inglês, levando-se em consideração aspectos da cultura brasileira, tendo em conta a versão original em inglês.

Como forma de reduzir os vieses decorrentes do processo de tradução, procedeu-se à validação do conteúdo. Para tanto, utilizou-se o coeficiente da validade de conteúdo (CVC), proposto por Henández-Nieto (2002). Esse coeficiente avalia a concordância entre juízesavaliadores, mediante o uso de uma escala Likert, que variou de 1 (representa pouquíssimo) a 5 (representa muitíssimo), como forma de investigar a clareza da linguagem, a representatividade (pertinência prática), a relevância teórica dos itens, além da dimensão avaliada. Participaram como juízes avaliadores sete professores, doutores em psicologia, sociologia e administração com domínio na temática do construto.

O CVC é obtido, calculando-se, com base na nota dos juízes (1 a 5), a média das notas de cada item; $\mathrm{M}_{\mathrm{x}}=\frac{\sum_{\mathrm{i}=1}^{\mathrm{j}} \mathrm{Xi}}{\mathrm{J}}$, em que $\sum_{\mathrm{i}=1}^{\mathrm{j}} \mathrm{Xi}$ representa a soma das notas dos juízes e $\mathrm{J}$ representa o número de juízes que avaliaram o item. Com base na média, calcula-se o CVC inicial: $\mathrm{CVC}_{\mathrm{i}}=\frac{\mathrm{Mx}}{\mathrm{Vmáx}}$, em que o $\mathrm{V}_{\text {máx }}$ representa o valor máximo que o item pode receber. $\mathrm{O}$ erro associado (possíveis vieses dos juízes) é calculado por: $\mathrm{Pe}_{\mathrm{i}}=\left(\frac{1}{\mathrm{~J}}\right)^{\mathrm{J}}$. O CVC final para cada item é: $\mathrm{CVC}_{\mathrm{c}}=\mathrm{CVC}_{\mathrm{i}}-\mathrm{Pe}_{\mathrm{i}}$, devendo ser esse valor maior do que 0,8 , ou seja, $\mathrm{CVC}_{\mathrm{c}}>0,8$. Por fim, o cálculo do CVC total do questionário, para cada uma das três características (clareza de linguagem, pertinência prática e relevância teórica) é: $\mathrm{CVC}_{\mathrm{t}}=\mathrm{Mcvc}_{\mathrm{i}}=\mathrm{Mcvc}_{\mathrm{i}}-\mathrm{Mpe}_{\mathrm{i}}$, em que $\mathrm{Mcvc}_{\mathrm{i}}$ representa a média dos itens do questionário e $\mathrm{Mpe}_{\mathrm{i}}$ a média dos erros dos itens do questionário (Cassepp-Borges et al., 2010; Henández-Nieto, 2002).

A análise da dimensão teórica é realizada comparando-se a concordância entre os juízes. Por se tratar de uma variável categórica, pode-se utilizar o coeficiente de Kappa médio, calculando-se a média entre os juízes. O critério de Landis e Koch (1977) utilizou, assim, valores entre $40 \%$ e 60\%, que indicam uma concordância moderada (TCJ).

A Tabela 33 mostra a escala final, com os escores de CVC para cada item relacionado às três características avaliadas (clareza de linguagem - CL; pertinência prática - PP; e relevância teórica - RT). Além disso, apresenta em qual dimensão teórica foi categorizado o item avaliado pelos sete juízes e pelo autor da escala (DTC). 
Tabela 33

Cálculo do $\mathrm{CVC}_{c}$ e avaliação da dimensão teórica EIP

\begin{tabular}{|c|c|c|c|c|c|c|c|c|}
\hline \multirow[t]{2}{*}{ Item } & \multicolumn{3}{|c|}{$\mathrm{CVC}_{\mathrm{f}}$} & \multicolumn{4}{|c|}{$\begin{array}{c}\text { Dimensão Teórica } \\
\left(\mathrm{N}^{\circ} \text { de Juízes-avaliadores }\right)\end{array}$} & \multirow[b]{2}{*}{ TCJ } \\
\hline & $\mathrm{CL}$ & PP & RT & $\mathrm{C}$ & A & $\mathrm{L}$ & DTC & \\
\hline Eu estou contente por ser um policial. & 1 & 0,97 & 0,97 & 0 & 7 & 0 & A & $100 \%$ \\
\hline Ser um policial é uma parte importante de quem eu sou. & 0,77 & 0,94 & 0,94 & 6 & 0 & 1 & $\mathrm{C}$ & $86 \%$ \\
\hline Em minha vida diária, eu frequentemente penso sobre o que significa ser um policial. & 0,94 & 0,94 & 0,97 & 7 & 0 & 0 & $\mathrm{C}$ & $100 \%$ \\
\hline Em um grupo de policiais, eu realmente sinto que pertenço a esse grupo. & 0,94 & 0,94 & 0,97 & 0 & 0 & 7 & $\mathrm{~L}$ & $100 \%$ \\
\hline Eu encontro dificuldades em formar vínculos com outros policiais. & 0,89 & 0,91 & 0,97 & 0 & 0 & 7 & $\mathrm{~L}$ & $100 \%$ \\
\hline Eu frequentemente me arrependo de ser um policial. & 0,94 & 0,94 & 0,94 & 1 & 6 & 0 & A & $86 \%$ \\
\hline Eu frequentemente penso sobre o fato de que sou um policial. & 0,94 & 0,89 & 0,94 & 7 & 0 & 0 & $\mathrm{C}$ & $100 \%$ \\
\hline Eu não me sinto "conectado" com outros policiais. & 0,89 & 0,94 & 0,94 & 0 & 0 & 7 & $\mathrm{~L}$ & $100 \%$ \\
\hline Eu não me sinto bem em ser um policial. & 0,97 & 0,94 & 0,94 & 0 & 7 & 0 & A & $100 \%$ \\
\hline Eu normalmente não estou consciente do fato de que sou um policial. & 0,80 & 0,89 & 0,86 & 7 & 0 & 0 & $\mathrm{C}$ & $100 \%$ \\
\hline Eu realmente me ajusto bem quando estou entre policiais. & 0,89 & 0,91 & 0,97 & 0 & 1 & 6 & $\mathrm{~L}$ & $86 \%$ \\
\hline Eu sinto fortes vínculos com outros policiais. & 0,91 & 0,94 & 0,97 & 0 & 0 & 7 & $\mathrm{~L}$ & $100 \%$ \\
\hline Eu tenho muito em comum com os demais policiais. & 0,94 & 0,97 & 0,94 & 1 & 1 & 5 & $\mathrm{~L}$ & $71 \%$ \\
\hline Eu me sinto bem quando eu penso sobre mim mesmo como um policial. & 0,91 & 0,94 & 0,97 & 3 & 4 & 0 & A & $57 \%$ \\
\hline Ser um policial tem pouco a ver como eu me sinto sobre mim mesmo. & 0,86 & 0,86 & 0,89 & 4 & 2 & 1 & $\mathrm{C}$ & $57 \%$ \\
\hline O fato de que eu sou um policial raramente entra em minha mente. & 0,83 & 0,94 & 0,94 & 7 & 0 & 0 & $\mathrm{C}$ & $100 \%$ \\
\hline Ser um policial é um importante reflexo de quem eu sou. & 0,91 & 0,97 & 0,97 & 5 & 0 & 2 & $\mathrm{C}$ & $71 \%$ \\
\hline Às vezes tenho sentimentos ruins só de pensar sobre o fato de que eu sou um policial. & 0,83 & 0,94 & 1 & 0 & 7 & 0 & A & $100 \%$ \\
\hline $\mathrm{CVC}_{\mathrm{t}}$ & 0,90 & 0,93 & 0,95 & & & & & \\
\hline
\end{tabular}

Legenda: $\mathrm{N}^{\circ}$ : Número da questão; $\mathrm{CVC}_{\mathrm{f}}$ coeficiente de validade de conteúdo para cada item; $\mathrm{CVC}$ : Coeficiente Total do Questionário; CL: clareza da linguagem; PP: pertinência prática; RT: relevância teórica; C: centralidade; A: afeto com o grupo de pertença; L: laços com o grupo de pertença; DTC: dimensão teórica proposta por Cameron (2004); TCJ: Taxa de Concordância entre Juízes (\%) sobre a Dimensão Teórica com base na DTC. 


\subsubsection{Análise fatorial exploratória com Software SPSS Statistics}

A análise preliminar dos Componentes Principais (PC) e a matriz de intercorrelações mostrou-se fatorizável, como pode ser observado com o teste de esfericidade de Barltllet $(\mathrm{p}<0,000)$ e KMO, que foi de 0,92, considerado maravilhoso (Pasquali, 2010).

Em seguida, foi analisada a dimensionalidade da escala com base em diferentes métodos. O critério de Kaiser identificou até três fatores que explicam 62,18\% da variância total. O primeiro fator é o determinante ( $\Delta$ entre o primeiro e o terceiro fatores é de $26,21 \%$ ). O teste do gráfico de segmentação (scree plot) indicou que a EIP apresenta até três componentes. Por fim, foi realizada a análise paralela de Horn, que identificou até três fatores. Esses critérios estão descritos na Figura 22 e Tabela 34.

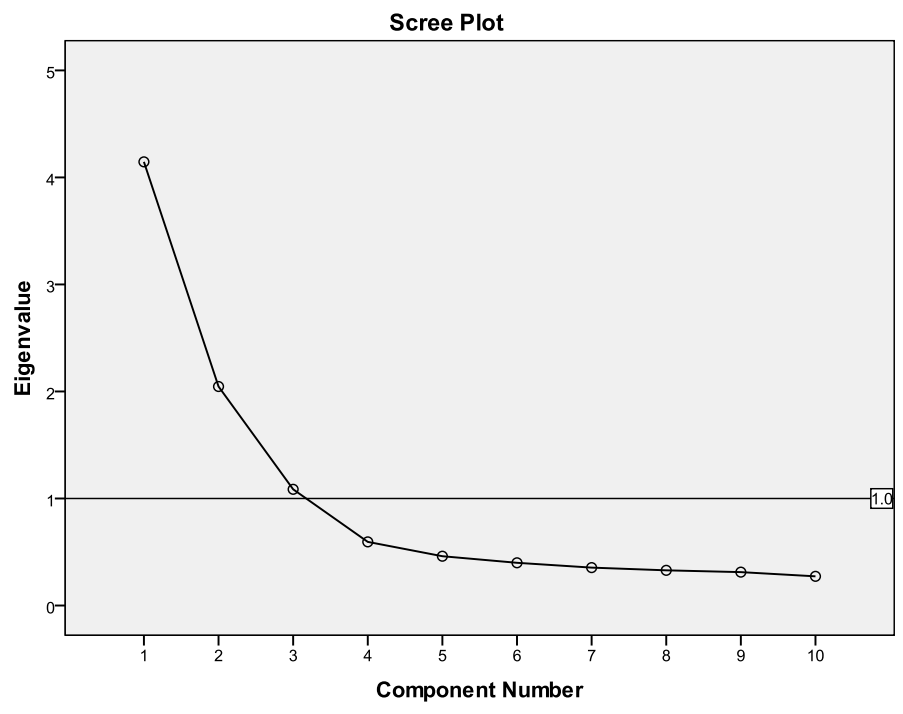

Figura 22. Gráfico do Scree da EIP.

Tabela 34

Autovalores empíricos e aleatórios da EIP

\begin{tabular}{c|ccc|}
\hline \multirow{2}{*}{ Componente } & \multicolumn{2}{|c|}{ Autovalores iniciais } & \multirow{2}{*}{$\begin{array}{c}\text { Autovalores } \\
\text { aleatórios }\end{array}$} \\
\cline { 2 - 3 } & Total & \% de variância & \\
\hline 1 & 6,474 & 35,98 & 1,364 \\
2 & 3,435 & 19,08 & 1,293 \\
3 & 1,283 & 7,20 & 1,239 \\
4 & 0,903 & 5,02 & 1,192 \\
\hline
\end{tabular}

De posse dessas informações, procedeu-se à análise fatorial pelo método dos eixos principais $(P A F)$, com rotação promax, para a extração de três fatores. Foram excluídos os itens que saturaram em mais de um fator (IP5 e IP4), cuja diferença foi inferior a 0,1 (Neiva et al., 2007). Os itens IP1, IP8, IP9, IP11, IP15, IP16 não foram retidos no fator teórico 
correspondente, e, portanto, foram excluídos. A nova análise melhorou a representatividade dos itens que passaram a explicar $72,78 \%$ da variância total.

A análise de precisão foi obtida pelos coeficientes alfa de Cronbach e lambda-2 de Guttman, sendo excluídos o item IP7 (comunalidade=0,3) pelo critério da parcimônia (Pasquali, 2012), com vistas a se aumentar a confiabilidade do fator. A estrutura final da EIP, portanto, reteve nove itens que apresentaram compatibilidades teóricas e parcimônia. A Tabela 35 fornece uma síntese dos resultados finais retidos da análise fatorial exploratória.

Tabela 35

Matriz fatorial da EIP

\begin{tabular}{lcccc}
\hline \multicolumn{1}{c}{ Itens } & Fator 1 & Fator 2 & Fator 3 & $\begin{array}{c}\text { Comunalidades } \\
\left(\mathrm{R}^{2}\right)\end{array}$ \\
\hline IP13 & 0,94 & & & 0,75 \\
IP14 & 0,85 & & & 0,66 \\
IP12 & 0,73 & & & 0,64 \\
IP18 & & 0,83 & & 0,66 \\
1P6 & & 0,81 & & 0,63 \\
IP10 & & 0,75 & & 0,54 \\
IP3 & & & 0,87 & 0,69 \\
IP17 & & & 0,61 & 0,62 \\
IP2 & 4,15 & 2,05 & 0,58 & 0,63 \\
\hline Autovalor & 3 & 3 & 3 & \\
Número de itens & 41,57 & 20,46 & 10,86 & \\
\% Var. Explicada & 0,86 & 0,82 & 0,83 & \\
Alfa & 0,86 & 0,82 & 0,83 & \\
Lambda 2 & 0,73 & 0,75 & 0,58 & \\
Carga mínima & 0,94 & 0,83 & 0,87 & \\
Carga máxima & 0,84 & 0,80 & 0,69 & \\
Carga média & & & & \\
\hline
\end{tabular}

Os três fatores da EIP (laços, afeto e centralidade) estão estruturados de forma bastante satisfatória, representando bem as dimensões teóricas do estudo original (Cameron, 2004). Os procedimentos para a realização da análise fatorial confirmatória, são apresentados a seguir, como maneira de confirmação da estrutura obtida com a AFE.

\subsubsection{Análise fatorial confirmatória com Software AMOS}

\subsubsection{Ajuste do modelo de medida}

Três modelos foram analisados para aferir a qualidade do ajuste dos dados. O primeiro avaliou um modelo unidimensional (teste de Harman, conforme Malhotra et al., 2006), comumente empregado para estudos sobre identidade profissional, como já discutido; o segundo pesquisou um modelo com os três fatores oriundos da AFE, de acordo com o modelo proposto por Cameron (2004); e, por fim, o terceiro investigou um modelo de segunda ordem, contendo a variável latente identidade profissional. 
O Modelo 1 (unidimensional) não apresentou ajustes satisfatórios, o que levou à sua rejeição, reforçando os estudos que evidenciam que a identidade é um construto multidemensional. Diante disso, foi testado o Modelo 2, que apresentou índices muito satisfatórios de ajuste, sem a necessidade de qualquer reespecificação do modelo de medida. O Modelo 3, de segunda ordem, apresentou índices de ajuste excelentes e não houve qualquer reespecificação do modelo. Nesse caso, preferiu-se o modelo 3, que contempla o fator de segunda ordem, conforme observa (Roussel et al., 2002), ou seja, que contém a dimensão dependente que se quer mensurar, ou seja, a identidade profissional.

Os índices de ajuste dos três modelos são mostrados na Tabela 36.

Tabela 36

Índices de ajustamento dos modelos de medida conforme Modelos 1, 2 e 3 da EIP

\begin{tabular}{|c|c|c|c|c|}
\hline \multicolumn{2}{|l|}{$\begin{array}{l}\text { Amostra } \\
\mathrm{N}=451\end{array}$} & $\begin{array}{c}\text { Modelo } 1 \\
\text { Unidimensional }\end{array}$ & $\begin{array}{c}\text { Modelo } 2 \\
\text { 3 Dimensões }\end{array}$ & $\begin{array}{l}\text { Modelo } 3 \\
2^{\mathrm{a} O r d e m}\end{array}$ \\
\hline Índices & $\chi /$ g.l. & 23,82 & 2,67 & 2,08 \\
\hline \multirow{4}{*}{ Absolutos } & $\chi^{2} ;$ g.l. & 643,$26 ; 27$ & 64,$01 ; 24$ & 49,$83 ; 24$ \\
\hline & $p$ & 0,000 & 0,000 & 0,001 \\
\hline & GFI (AGFI) & $0,73(0,55)$ & $0,97(0,94)$ & $0,98(0,96)$ \\
\hline & SRMR & 0,1525 & 0,038 & 0,037 \\
\hline \multirow[t]{2}{*}{ Índices Relativos } & CFI & 0,63 & 0,98 & 0,99 \\
\hline & TLI & 0,51 & 0,96 & 0,98 \\
\hline Índices de Discrepância & RMSEA & 0,225 & 0,061 & 0,049 \\
\hline Populacional & (Lo90;Hi90) & $(0,210 ; 0,240)$ & $(0,043 ; 0,079)$ & $(0,029 ; 0,069)$ \\
\hline \multirow{2}{*}{ Índices de Parcimônia } & PCFI & 0,47 & 0,65 & 0,66 \\
\hline & PGFI & 0,44 & 0,52 & 0,52 \\
\hline Índices baseados na & AIC & 679,26 & 106,01 & 91,83 \\
\hline \multirow{2}{*}{ Teoria da Informação } & ECVI & 1,51 & 0,24 & 0,20 \\
\hline & CAIC & 771,26 & 213,35 & 199,17 \\
\hline
\end{tabular}

2.2.2.2 Confiabilidade e validade da escala de medida de identidade profissional

O valor do Rho, de Jöreskog, mostrou ótima consistência interna para todas as dimensões. Da mesma forma, a validade convergente foi satisfeita para todos os fatores, que apresentaram correlações múltiplas próximas ou superiores a 0,5 , o que fornece nova prova complementar da validade convergente (Bagozzi \& Yi, 1988). Os pesos fatoriais foram todos significativos e fortes $(\lambda \mathrm{i}>0,6 ; p<0,001)$.

Foi testada, por último, a validade discriminante entre as dimensões ( $\left(h_{\mathrm{vc}}>\mathrm{r}^{2}\right)$, sendo confirmada pelos Modelo 2 e 3 em sua totalidade. A Tabela 37 e a Tabela 38 apresentam o resumo das qualidades psicométricas e a Figuras 23 e a Figura 24 exibem as representações 
gráficas do Modelo 2 e do Modelo 3, os pesos fatoriais não estandardizados e as correlações múltiplas ao quadrado, respectivamente.

Tabela 37

Confiabilidade e validade das dimensões conforme Modelo 2 da EIP

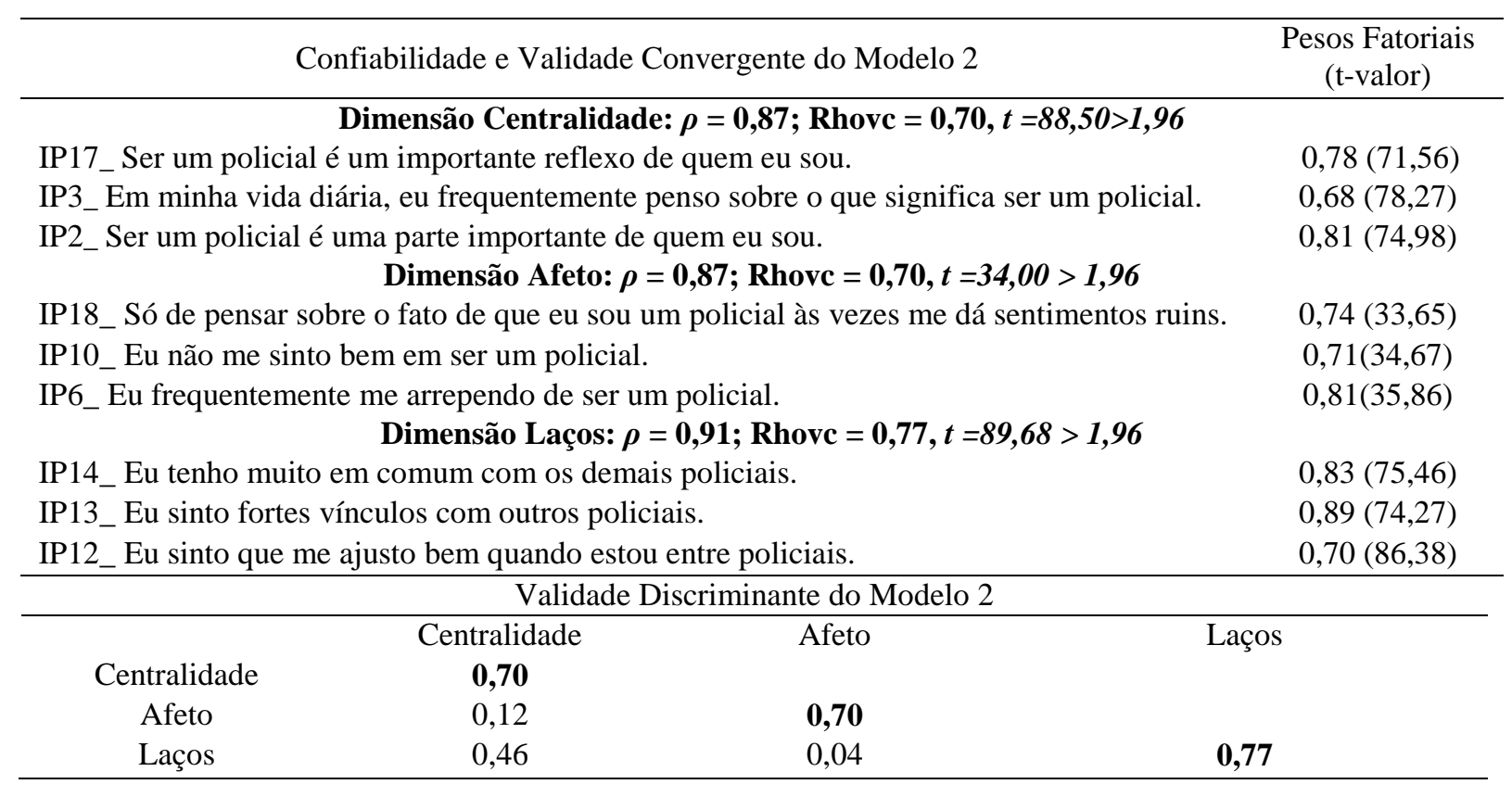

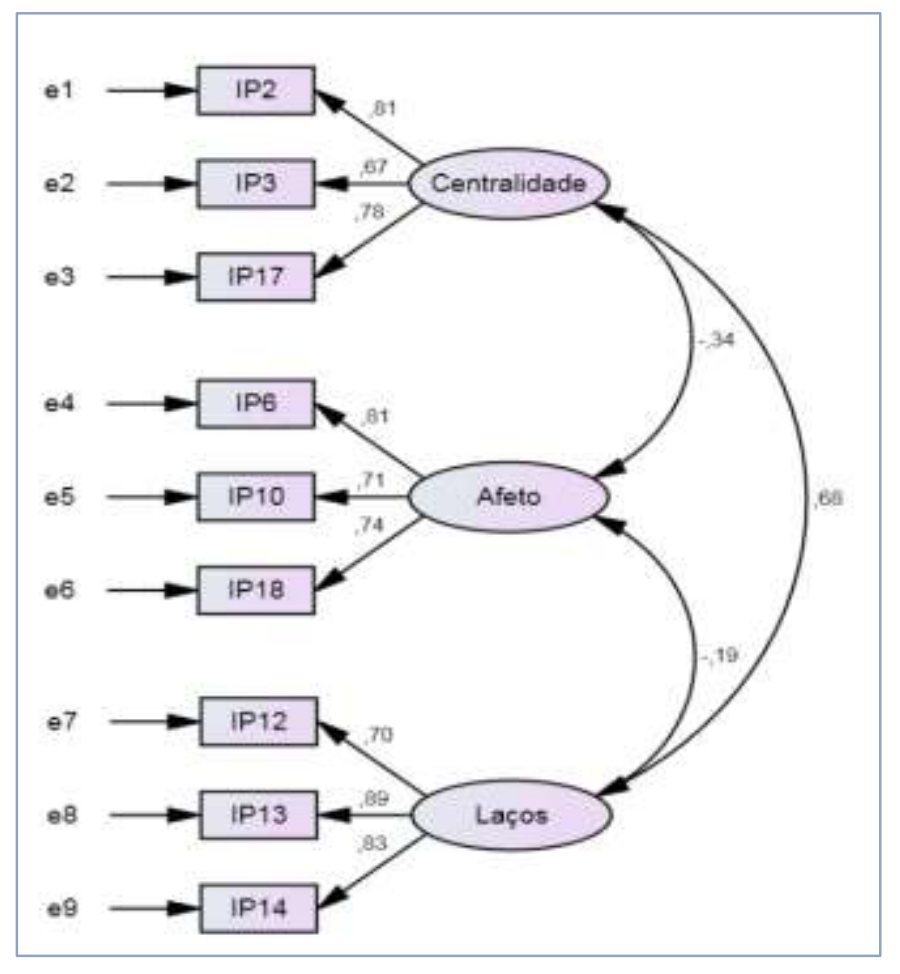




\begin{tabular}{|c|c|c|c|c|c|c|c|c|c|}
\hline \multicolumn{3}{|c|}{$\begin{array}{l}\text { Pesos Fatoriais Não } \\
\text { Estandardizados }\end{array}$} & \multirow{2}{*}{$\begin{array}{r}\text { Estimate } \\
1,000\end{array}$} & \multirow[t]{2}{*}{ S.E. } & \multirow[t]{2}{*}{ C.R. } & \multirow[t]{2}{*}{$\mathrm{P}$} & \multirow[t]{2}{*}{ Label } & \multirow[t]{2}{*}{$\begin{array}{c}\text { Correlações } \\
\text { Múltiplas ao } \\
\text { Quadrado } \\
\end{array}$} & \multirow{2}{*}{$\begin{array}{r}\text { Estimate } \\
0,496\end{array}$} \\
\hline IP17 & $<--$ & Centralidade & & & & & & & \\
\hline IP3 & $<--$ & Centralidade & 0,810 & 0,062 & 13,068 & $* * *$ & par_1 & IP13 & 0,791 \\
\hline IP2 & $<---$ & Centralidade & 1,036 & 0,070 & 14,726 & $* * *$ & par_2 & IP14 & 0,687 \\
\hline IP18 & $<--$ & Afeto & 1,000 & & & & & IP6 & 0,663 \\
\hline IP10 & $<--$ & Afeto & 0,956 & 0,073 & 13,076 & $* * *$ & par_3 & IP10 & 0,508 \\
\hline IP6 & $<---$ & Afeto & 1,027 & 0,078 & 13,089 & $* * *$ & par_4 & IP18 & 0,541 \\
\hline IP14 & $<--$ & Laços & 1,000 & & & & & IP2 & 0,662 \\
\hline IP13 & $<---$ & Laços & 1,096 & 0,055 & 19,789 & $* * *$ & par_5 & IP3 & 0,455 \\
\hline IP12 & $<---$ & Laços & 0,818 & 0,052 & 15,670 & $* * *$ & par_6 & IP17 & 0,603 \\
\hline
\end{tabular}

Figura 23. Modelo 2 da EIP.

\section{Tabela 38}

Confiabilidade e validade das dimensões conforme Modelo 3 da EIP

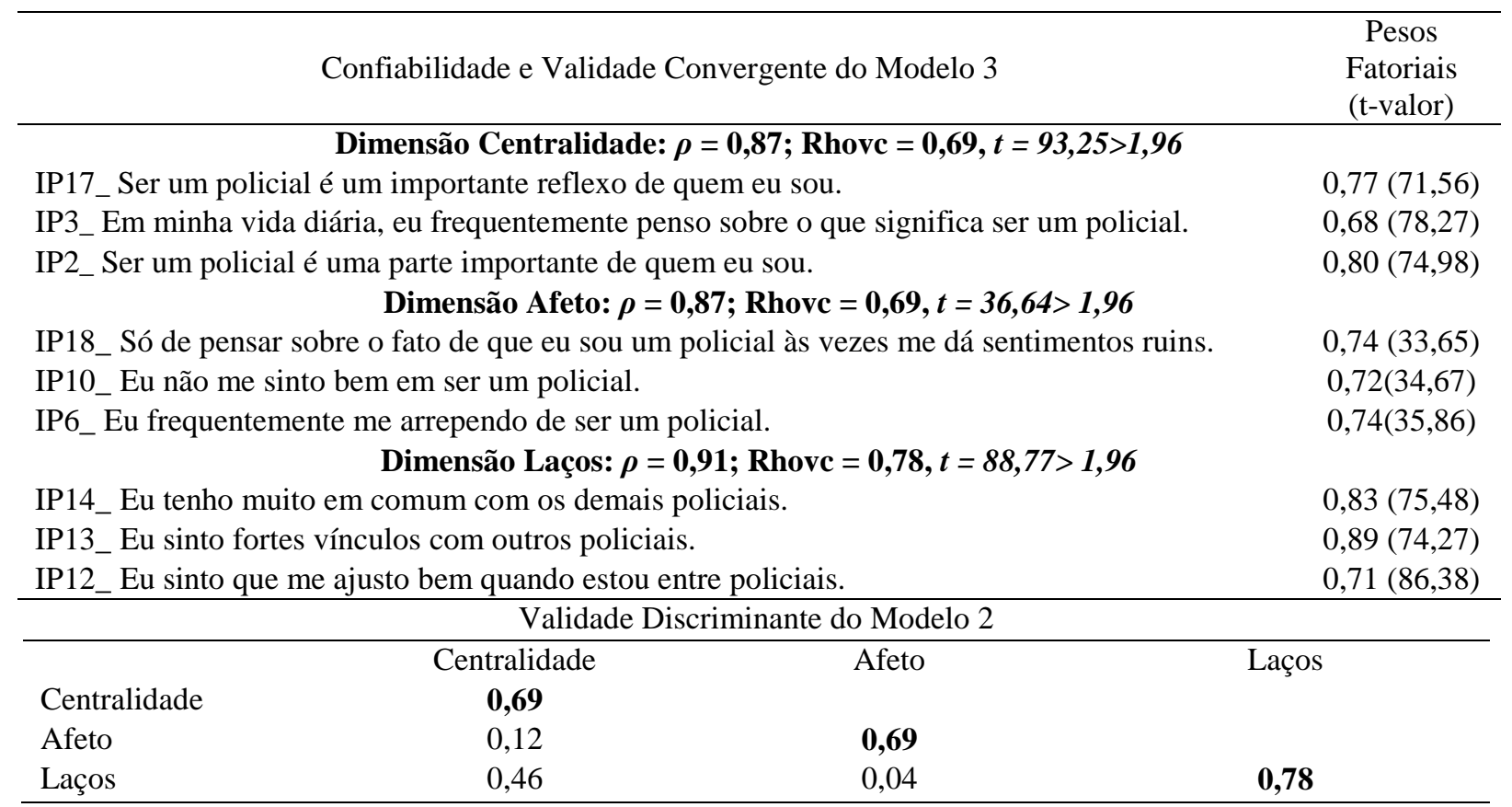




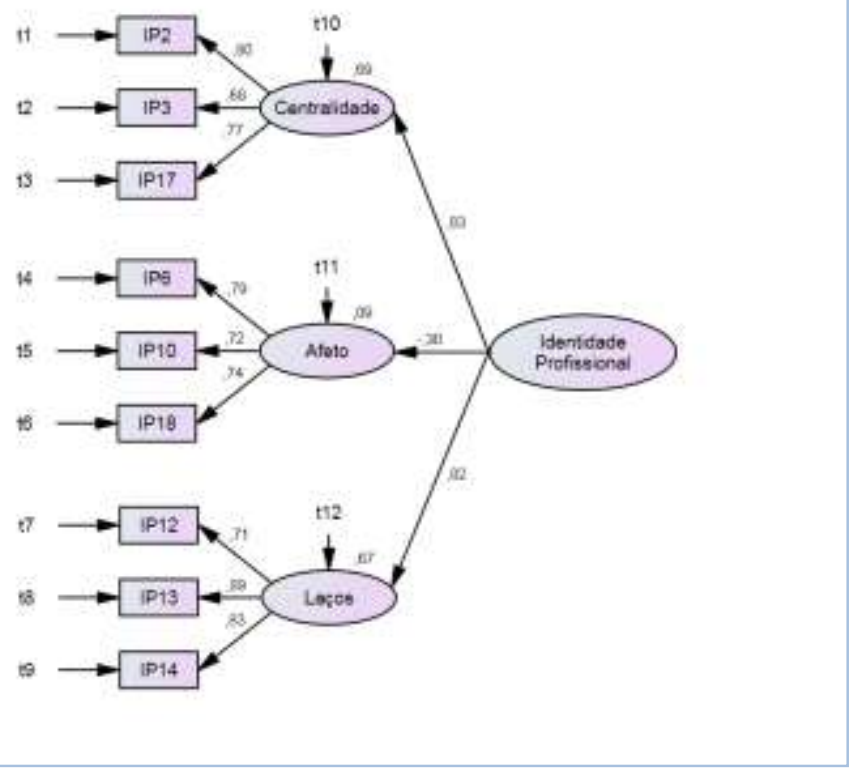

\begin{tabular}{|c|c|c|c|c|c|c|c|c|c|}
\hline \multicolumn{3}{|c|}{$\begin{array}{l}\text { Pesos Fatoriais Não- } \\
\text { Estandardizados }\end{array}$} & \multirow{2}{*}{$\begin{array}{c}\text { Estimate } \\
-0,399\end{array}$} & \multirow{2}{*}{$\begin{array}{l}\text { S.E. } \\
0,086\end{array}$} & \multirow{2}{*}{$\begin{array}{l}\text { C.R. } \\
-4,632\end{array}$} & \multirow{2}{*}{$\begin{array}{c}\mathrm{P} \\
* * *\end{array}$} & \multirow{2}{*}{$\begin{array}{l}\text { Label } \\
\text { par_7 }\end{array}$} & \multirow{2}{*}{$\begin{array}{c}\text { Correlações } \\
\text { Múltiplas ao } \\
\text { Quadrado } \\
\text { Laços }\end{array}$} & \multirow{2}{*}{$\begin{array}{r}\text { Estimate } \\
0,667\end{array}$} \\
\hline Afeto & $<---$ & IP & & & & & & & \\
\hline Centralidade & $<---$ & IP & 1,000 & & & & & Afeto & 0,088 \\
\hline Laços & $<---$ & IP & 1,000 & & & & & Centralidade & 0,689 \\
\hline IP17 & $<---$ & Centralidade & 1,000 & & & & & IP12 & 0,500 \\
\hline IP3 & $<---$ & Centralidade & 0,831 &, 064 & 13,028 & $* * *$ & par_1 & IP13 & 0,793 \\
\hline IP2 & $<---$ & Centralidade & 1,026 &, 072 & 14,298 & $* * *$ & par_2 & IP14 & 0,693 \\
\hline IP18 & $<---$ & Afeto & 1,000 & & & & & IP6 & 0,625 \\
\hline IP10 & $<---$ & Afeto & 0,955 &, 074 & 12,931 & $* * *$ & par_3 & IP10 & 0,515 \\
\hline IP6 & $<---$ & Afeto & 0,976 &, 075 & 12,995 & $* * *$ & par_4 & IP18 & 0,549 \\
\hline IP14 & $<---$ & Laços & 1,000 & & & & & IP2 & 0,639 \\
\hline IP13 & $<---$ & Laços & 1,087 &, 054 & 20,281 & $* * *$ & par_5 & IP3 & 0,464 \\
\hline IP12 & $<---$ & Laços & 0,811 &, 051 & 15,853 & $* * *$ & par_6 & IP17 & 0,596 \\
\hline
\end{tabular}

Figura 24. Modelo 3 da EIP.

\subsection{Evidências de Validade da Escala de Identidade Organizacional}

A escala de identidade organizacional (EIO) foi construída e validada por Mael e Ashforth (1992). Para esta tese, foi considerada a versão em português do instrumento, encontrada em alguns estudos (por exemplo, Cavazotte, Oliveira \& Miranda, 2010; Hildebrand, 2007; Tavares, Caetano \& Silva, 2007). Como não foram encontradas, no cenário brasileiro, evidências de sua validade exploratória e confirmatória, esses procedimentos foram formalizados. 


\subsubsection{Análise fatorial exploratória com Software SPSS Statistics}

A análise preliminar dos Componentes Principais (PC) e a matriz de intercorrelações mostrou-se fatorizável; o teste esfericidade de Barltllet ( $\mathrm{p}<0,000)$ e KMO, que foi de 0,89, que pode ser considerado meritório (Pasquali, 2010), demonstram essa possibilidade.

Posteriormente, analisou-se a dimensionalidade da escala com base em diferentes métodos. $\mathrm{O}$ critério de Kaiser identificou um fator responsável por explicar 64,72\% da variância total. Da mesma maneira, o teste do gráfico de segmentação (scree plot) indicou que a EIP apresenta uma dimensão. Por fim, foi elaborada a análise paralela de Horn, que identificou, novamente, um fator. Esses critérios estão descritos na Figura 25 e na Tabela 39.

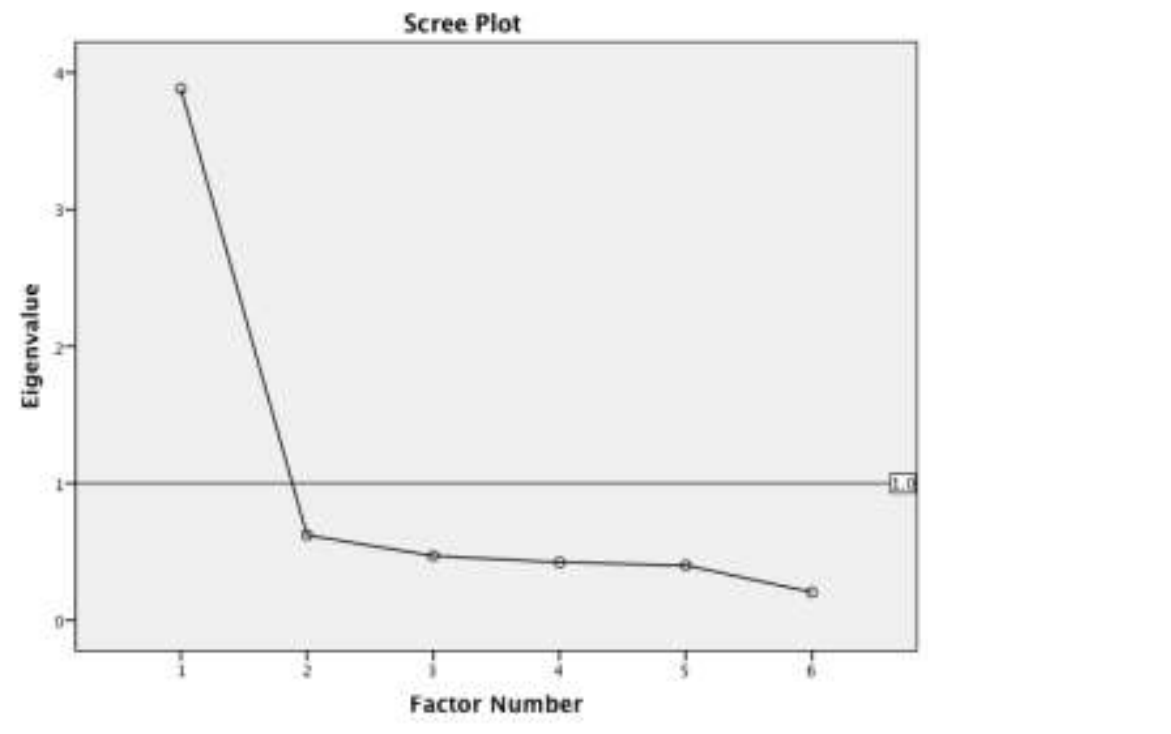

Figura 25. Gráfico do Scree da EIO.

Tabela 39

Autovalores empíricos e aleatórios EIO

\begin{tabular}{c|cc|c}
\hline \multirow{2}{*}{ Componente } & \multicolumn{2}{|c|}{ Autovalores iniciais } & \multirow{2}{*}{$\begin{array}{c}\text { Autovalores } \\
\text { aleatórios }\end{array}$} \\
\cline { 2 - 3 } & Total & $\%$ de variância & \\
\hline 1 & 3,883 & 64,72 & 1,1587 \\
2 & 0,621 & 10,35 & 1,0817 \\
\hline
\end{tabular}

Com base nessas informações, procedeu-se à análise fatorial pelo método dos eixos principais $(P A F)$, para a extração de um fator. A análise de precisão foi obtida pelos coeficientes alfa de Cronbach e lambda-2 de Guttman. A estrutura final da EIO, portanto, reteve os seis itens originais que apresentaram compatibilidades teóricas e parcimônia. A Tabela 40 fornece uma síntese dos resultados finais retidos da análise fatorial exploratória. 
Tabela 40

Matriz fatorial da EIO

\begin{tabular}{lcc}
\hline \multicolumn{1}{c}{ Itens } & Fator 1 & $\begin{array}{c}\text { Comunalidades } \\
\left(\mathrm{R}^{2}\right)\end{array}$ \\
\hline IO1 & 0,72 & 0,51 \\
IO2 & 0,76 & 0,58 \\
IO3 & 0,71 & 0,51 \\
IO4 & 0,88 & 0,78 \\
1O5 & 0,63 & 0,39 \\
IO6 & 0,85 & 0,72 \\
\hline Autovalor & 3,88 & \\
Número de itens & 6 & \\
\% Var. Explicada & 64,72 & \\
Alfa & 0,89 & \\
Lambda 2 & 0,89 & \\
Carga mínima & 0,71 & \\
Carga máxima & 0,88 & \\
Carga média & 0,76 & \\
\hline
\end{tabular}

O uni-fator da EIO (identidade organizacional) está satisfatoriamente estruturado, representando bem a dimensão teórica do estudo original (Mael \& Ashforth (1992). Em seguida, apresentam-se os procedimentos para a realização da análise fatorial confirmatória como modo de comprovação da estrutura obtida com a AFE.

2.4.2 Análise fatorial confirmatória com Software AMOS

2.4.2.1 Ajuste do modelo de medida

Foi analisado o modelo unidimensional da identidade organizacional, como obtido pela AFE e pelos estudos empíricos analisados. O Modelo 1 (unidimensional) apresentou ajustes satisfatórios, sem qualquer necessidade de reespecificação do modelo de medida. Os índices de ajuste do modelo é mostrado na Tabela 41. 
Tabela 41

Índices de ajustamento do Modelo Unidimensional da EIO

\begin{tabular}{|c|c|c|}
\hline \multicolumn{2}{|l|}{$\begin{array}{l}\text { Amostra } \\
\mathrm{N}=451\end{array}$} & $\begin{array}{c}\text { Modelo } 1 \\
\text { Unidimensional } \\
\end{array}$ \\
\hline Índices & $\chi / \mathrm{g} .1$. & 3,08 \\
\hline Absolutos & $\chi^{2} ;$ g.l. & 24,$66 ; 8$ \\
\hline & $p$ & 0,002 \\
\hline & GFI (AGFI) & $0,98(0,96)$ \\
\hline & SRMR & 0,0224 \\
\hline \multirow[t]{2}{*}{ Índices Relativos } & CFI & 0,99 \\
\hline & TLI & 0,98 \\
\hline Índices de Discrepância & RMSEA & 0,068 \\
\hline Populacional & (Lo90;Hi90) & $(0,039 ; 0,099)$ \\
\hline \multirow[t]{2}{*}{ Índices de Parcimônia } & PCFI & 0,53 \\
\hline & PGFI & 0,37 \\
\hline Índices Baseados na & AIC & 50,66 \\
\hline \multirow[t]{2}{*}{ Teoria da Informação } & ECVI & 0,113 \\
\hline & CAIC & 117,10 \\
\hline
\end{tabular}

2.2.2.2 Confiabilidade e validade da escala de medida de identidade organizacional

O valor do Rho de Jöreskog mostrou ótima consistência interna para o fator unidimensional, bem como a validade convergente foi satisfeita. As correlações múltiplas foram próximas ou superiores a 0,5 , o que fornece nova prova complementar da validade convergente (Bagozzi \& Yi, 1988). Os pesos fatoriais foram todos significativos e fortes $(\lambda \mathrm{i}>$ $0,6 ; p<0,001)$.

A Tabela 42 apresenta o resumo das qualidades psicométricas e a Figura 26 exibe a representação gráfica do Modelo unidimensional, os pesos fatoriais não estandardizados e as correlações múltiplas ao quadrado.

Tabela 42

Confiabilidade e validade da dimensão conforme Modelo da EIO

\begin{tabular}{lc}
\hline Confiabilidade e Validade Convergente do Modelo Unidimensional & $\begin{array}{c}\text { Pesos } \\
\text { Fatoriais }\end{array}$ \\
\hline Dimensão Identidade Organizacional: $\boldsymbol{\rho}=\mathbf{0 , 9 3}$; Rhovc $\mathbf{0 , 6 9 , \boldsymbol { t } > \mathbf { 1 , 9 6 }}$ & 0,73 \\
IO1_Quando alguém critica minha organização é como se estivesse me criticando. & 0,65 \\
IO2_Tenho muito interesse no que os outros pensam sobre minha organização. & 0,72 \\
IO3_Quando me refiro à PMDF, normalmente falo nós, ao invés de eles. & 0,84 \\
IO4_Quando alguém elogia a PMDF é como se estivesse me elogiando. & 0,71 \\
IO5_Quando uma matéria na mídia faz crítica à PMDF, eu me sinto constrangido. & 0,82 \\
IO6_O sucesso da PMDF é como se fosse o meu sucesso pessoal. & \\
\hline
\end{tabular}




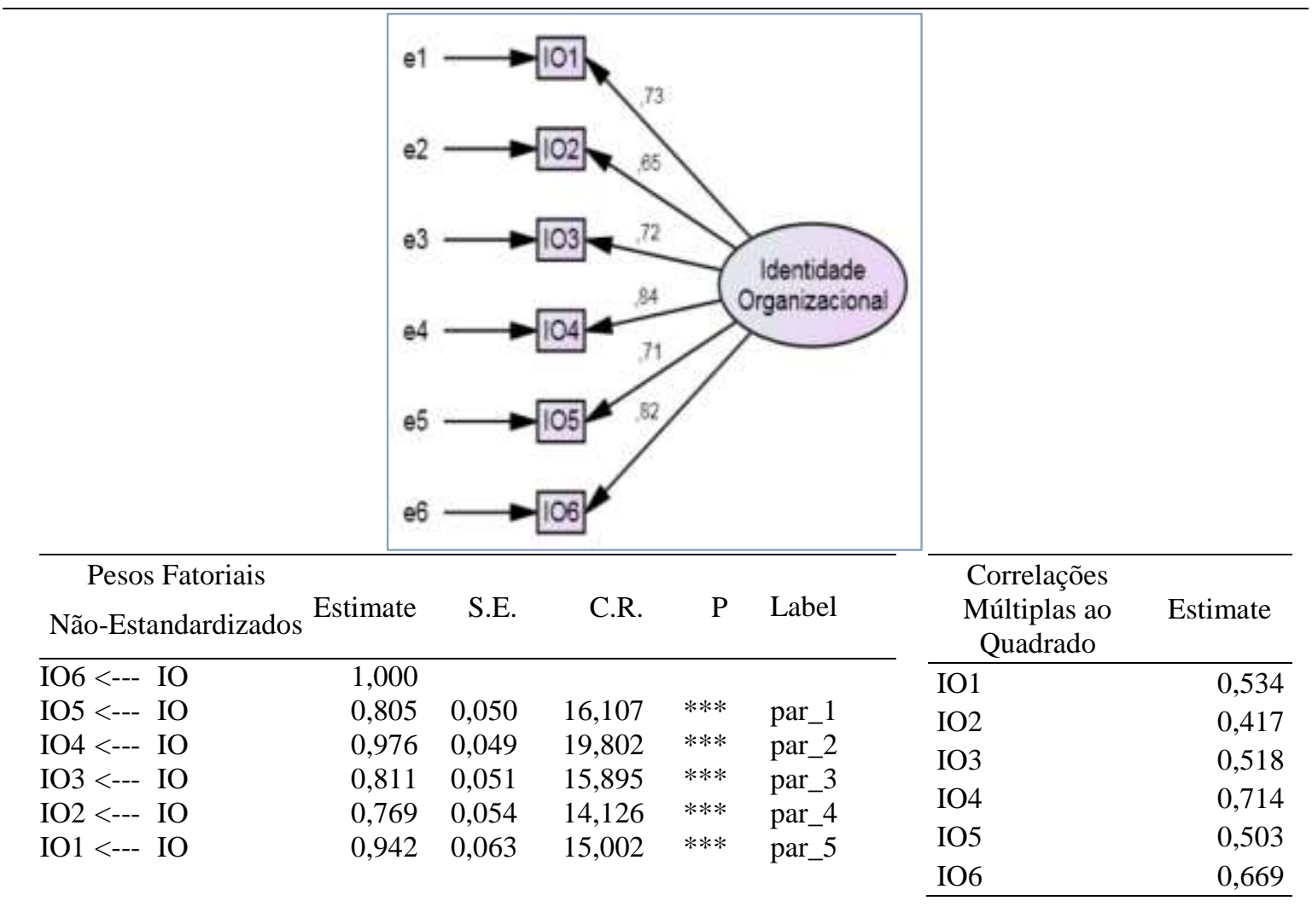

Figura 26. Modelo Unidimensional da EIO.

\subsection{Evidências de Validade da Escala de Desempenho Profissional por Competências}

A escala de desempenho profissional por competências (EDC) foi operacionalizada com base no método proposto por Faiad et al. (2012) para o mapeamento profissiográfico e de competências em instituições policiais, considerando o mapeamento das competências das policiais militares realizado Secretaria Nacional de Segurança Pública (SENASP, 2012), no qual foram consideradas as competências técnicas e comportamentais dos policiais militares, sendo mensuradas em termos domínio da competência, baseadas nas competências consideradas de maior importância.

Antes de se proceder às análises para avaliar as evidências de validade exploratória e confirmatória da EDC, buscou-se verificar se os respondentes consideravam as competências importantes para o desempenho de suas funções, sejam elas técnicas, sejam comportamentais. Mediu-se a importância (da competência para a atividade profissional) por intermédio de uma escala Likert, cujas medidas eram: 1 (nenhuma importância - competência irrelevante); 2 (pouca importância); 3 (média importância); 4 (alta importância - competência necessária) e 5 (extrema importância - competência imprescindível). A média dos 916 respondentes foi acima de 4,0, como pode ser observado na Tabela 43. Esse resultado garante que a EDC, que 
mensura o domínio das competências, representou competências julgadas de alta ou extrema importância para toda a amostra da pesquisa, evidenciando que sua aplicação pode ser realizada para os profissionais de todos os níveis da organização com a mesma importância em média.

Tabela 43

Competências Técnicas e Comportamentais por Importância

\begin{tabular}{|c|c|c|c|c|c|}
\hline & $\mathrm{N}$ & Mínimo & Máximo & Média & Desvio-padrão \\
\hline DCT1IMP & 916 & 1 & 5 & 4,73 & 0,562 \\
\hline DCT2IMP & 916 & 1 & 5 & 4,38 & 0,771 \\
\hline DCT3IMP & 916 & 1 & 5 & 4,44 & 0,713 \\
\hline DCT4IMP & 916 & 1 & 5 & 4,11 & 0,813 \\
\hline DCT5IMP & 916 & 1 & 5 & 4,17 & 0,796 \\
\hline DCT6IMP & 916 & 1 & 5 & 4,21 & 0,782 \\
\hline DCT7IMP & 916 & 1 & 5 & 4,43 & 0,705 \\
\hline DCT8IMP & 916 & 1 & 5 & 4,33 & 0,728 \\
\hline DCT9IMP & 916 & 1 & 5 & 4,34 & 0,757 \\
\hline DCT10IMP & 916 & 1 & 5 & 4,73 & 0,552 \\
\hline DCT11IMP & 916 & 1 & 5 & 4,59 & 0,631 \\
\hline DCT12IMP & 916 & 1 & 5 & 4,56 & 0,627 \\
\hline DCT13IMP & 916 & 1 & 5 & 4,47 & 0,650 \\
\hline DCT14IMP & 916 & 1 & 5 & 4,43 & 0,643 \\
\hline DCC1IMP & 916 & 1 & 5 & 4,35 & 0,710 \\
\hline DCC2IMP & 916 & 1 & 5 & 4,42 & 0,675 \\
\hline DCC3IMP & 916 & 1 & 5 & 4,57 & 0,663 \\
\hline DCC4IMP & 916 & 1 & 5 & 4,21 & 0,798 \\
\hline DCC5IMP & 916 & 1 & 5 & 4,24 & 0,771 \\
\hline DCC6IMP & 916 & 1 & 5 & 4,26 & 0,801 \\
\hline DCC7IMP & 916 & 1 & 5 & 4,48 & 0,673 \\
\hline DCC8IMP & 916 & 1 & 5 & 4,35 & 0,695 \\
\hline DCC9IMP & 916 & 1 & 5 & 4,54 & 0,657 \\
\hline DCC10IMP & 916 & 1 & 5 & 4,70 & 0,571 \\
\hline DCC11IMP & 916 & 1 & 5 & 4,19 & 0,785 \\
\hline DCC12IMP & 916 & 1 & 5 & 4,67 & 0,576 \\
\hline DCC13MP & 916 & 1 & 5 & 4,62 & 0,611 \\
\hline DCC14IMP & 916 & 1 & 5 & 4,45 & 0,687 \\
\hline DCC15IMP & 916 & 1 & 5 & 4,42 & 0,687 \\
\hline DCC16IMP & 916 & 1 & 5 & 4,54 & 0,649 \\
\hline
\end{tabular}




\subsubsection{Análise fatorial exploratória com Software SPSS Statistics}

A análise preliminar dos Componentes Principais (PC) e a matriz de intercorrelações demonstraram ser possível realizar a fatoração. O teste de esfericidade de Barltllet $(\mathrm{p}<0,000)$ e o coeficiente KMO, que indicam esse evento, foi de 0,96 , que pode ser considerado maravilhoso (Pasquali, 2010).

Em seguida, foi analisada a dimensionalidade da escala com base em diferentes métodos. O critério de Kaiser identificou até quatro fatores que explicam 59,02\% da variância total. O primeiro fator é o determinante ( $\Delta$ entre o primeiro e o quarto fatores é de $13,72 \%$ ). O teste do gráfico de segmentação (scree plot) indicou que a EDC apresenta até três componentes. Por fim, foi realizada a análise paralela de Horn, que identificou até dois fatores. Esses critérios estão descritos na Figura 27 e Tabela 44.

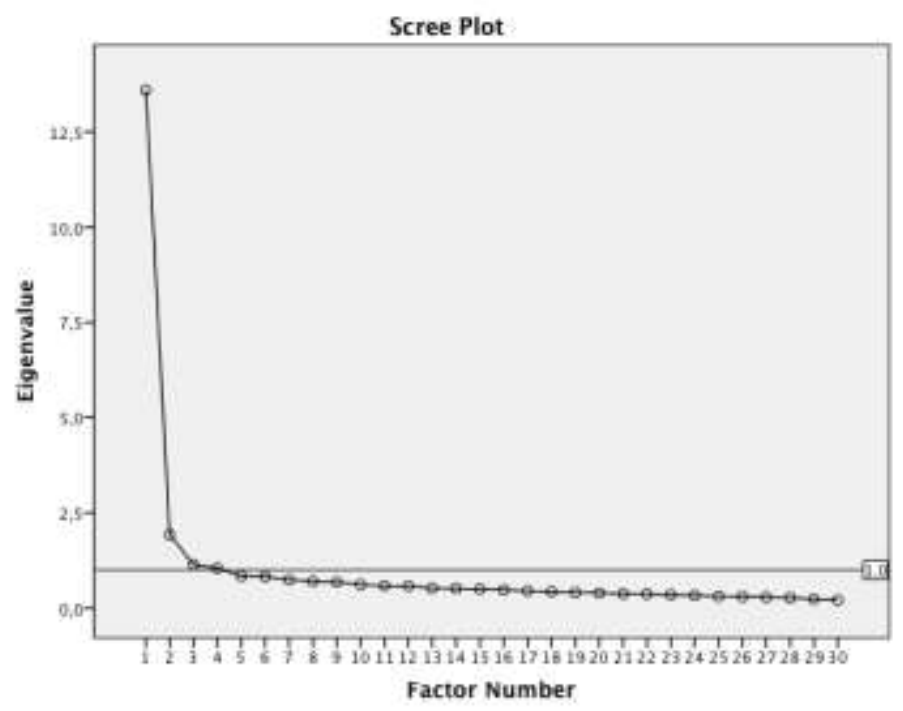

Figura 27. Gráfico do Scree da EDC.

Tabela 44

Autovalores empíricos e aleatórios da EDC

\begin{tabular}{c|ccc|}
\hline \multirow{2}{*}{ Componente } & \multicolumn{2}{|c|}{ Autovalores iniciais } & \multirow{2}{*}{$\begin{array}{c}\text { Autovalores } \\
\text { aleatórios }\end{array}$} \\
\cline { 2 - 3 } & Total & \% de variância & \\
\hline 1 & 13,592 & 45,31 & 1,513 \\
2 & 1,928 & 6,43 & 1,444 \\
3 & 1,142 & 3,81 & 1,389 \\
4 & 1,045 & 3,49 & 1,343 \\
5 & 0,838 & 2,80 & 1,303 \\
\hline
\end{tabular}

Dessas informações, procedeu-se à análise fatorial pelo método dos eixos 
principais $(P A F)$, com rotação oblimin direta, para a extração de dois fatores. Foi excluído o item 16 (DCC2) que saturou em mais de um fator e cuja diferença foi inferior a 0,1 (Neiva et al., 2007). Os itens 10,11, 12, 13, 14 (relativos às competências técnicas - DCT) e os itens1, 3,4 e 5 (relativos às competências comportamentais - DCC) não saturaram no fator teórico correspondente, e, portanto, foram excluídos. A nova análise melhorou a representatividade dos itens que passaram a explicar 53,49\% da variância total.

A estrutura final da EDC, portanto, reteve vinte itens que apresentaram compatibilidades teóricas e parcimônia. A Tabela 45 fornece uma síntese dos resultados finais retidos da análise fatorial exploratória.

Tabela 45

Matriz fatorial da EDC

\begin{tabular}{lccc}
\hline \multicolumn{1}{c}{ Itens } & Fator 1 & Fator 2 & $\begin{array}{c}\text { Comunalidades } \\
\left(\mathrm{R}^{2}\right)\end{array}$ \\
\hline DCC15 & 0,81 & & 0,54 \\
DCC13 & 0,79 & & 0,62 \\
DCC12 & 0,77 & & 0,58 \\
DCC16 & 0,73 & & 0,42 \\
DCC8 & 0,65 & & 0,53 \\
DCC10 & 0,62 & & 0,46 \\
DCC7 & 0,57 & & 0,53 \\
DCC14 & 0,56 & & 0,48 \\
DCC9 & 0,55 & & 0,45 \\
DCC11 & 0,42 & & 044 \\
DCC6 & 0,40 & & 0,31 \\
DCT3 & & 0,79 & 0,54 \\
DCT5 & & 0,72 & 0,52 \\
DCT4 & & 0,70 & 0,49 \\
DCT8 & & 0,66 & 0,56 \\
DCT9 & & 0,65 & 0,52 \\
DCT2 & & 0,64 & 0,41 \\
DCT1 & & 0,64 & 0,37 \\
DCT7 & & 0,63 & 0,53 \\
DCT6 & & 0,56 & 0,46 \\
\hline Número de itens & 11 & 9 & \\
\% Var. Explicada & 44,54 & 8,95 & \\
Alfa & 0,90 & 0,89 & \\
Lambda 2 & 0,91 & 0,89 & \\
Carga mínima & 0,40 & 0,56 & \\
Carga máxima & 0,81 & 0,79 & \\
Carga média & 0,63 & 0,67 & \\
\hline & & & \\
\hline
\end{tabular}

Os dois fatores da EDC (Competências comportamentais e competências técnicas) estão estruturados de forma bastante satisfatória, representando bem as dimensões teóricas propostas. Os procedimentos para a realização da análise fatorial confirmatória são apresentados a seguir, como maneira de ratificação da estrutura obtida com a AFE. 


\subsubsection{Análise fatorial confirmatória com Software AMOS}

\subsubsection{Ajuste do modelo de medida}

Nessa etapa, três modelos foram analisados com o objetivo de avaliar a qualidade do ajuste dos dados ao modelo proposto. A primeira avaliou um modelo unidimensional (teste de Harman, conforme Malhotra et al., 2006). A segunda, um modelo com os dois fatores oriundos da AFE, e, finalmente, um modelo com a presença de um fator de segunda ordem.

O Modelo 1 (unidimensional) não apresentou ajustes satisfatórios, o que levou à sua rejeição, reforçando os estudos que evidenciam que a identidade é um construto multidimensional. O Modelo 2 apresentou índices satisfatórios de ajuste, após a eliminação dos itens que apresentaram covariância residual estandardizada superiores ao limite de |2,58|, de acordo com MacCallum (1986), e cujos índices de modificação mostravam-se inadequados, ao saturar, com valores elevados (>11, segundo Marôco, 2010), em mais de um item. Diante disso foram retirados os itens 14 (DCC14) e 16 (DCC16). Ademais, esse Modelo 2 apresentou correlações superiores a 0,60 entre os fatores, o que possibilitou o teste do Modelo $3 \mathrm{com}$ a presença de um fator de segunda ordem. O Modelo 2 (duas dimensões de ordem um) apresentou os mesmos índices de ajuste que o Modelo 3. Nesse caso, preferiu-se o modelo 3, que contempla o fator de segunda ordem, conforme observam Roussel et al. (2002), ou seja, o fator que contém a dimensão dependente que se quer mensurar, isto é, o desempenho profissional por competências, de forma integrada. O que pode ser observado na Tabela 46.

Tabela 46

Índices de ajustamento dos modelos de medida conforme Modelos 1, 2 e 3 da EDC

\begin{tabular}{|c|c|c|c|c|}
\hline \multicolumn{2}{|l|}{$\begin{array}{l}\text { Amostra } \\
\mathrm{N}=451\end{array}$} & $\begin{array}{c}\text { Modelo } 1 \\
\text { Unidimensional }\end{array}$ & $\begin{array}{c}\text { Modelo } 2 \\
2 \text { Dimensões }\end{array}$ & $\begin{array}{l}\text { Modelo } 3 \\
2^{\text {a }} \text { Ordem } \\
\end{array}$ \\
\hline Índices & $\chi /$ g.l. & 6,61 & 2,23 & 2,23 \\
\hline Absolutos & $\chi^{2} ;$ g.l. & 1381,$15 ; 207$ & 298,$84 ; 134$ & 298,$84 ; 134$ \\
\hline & $p$ & 0,000 & 0,000 & 0,000 \\
\hline & GFI (AGFI) & $0,67(0,55)$ & $0,93(0,91)$ & $0,93(0,91)$ \\
\hline & SRMR & 0,0936 & 0,049 & 0,049 \\
\hline \multirow[t]{2}{*}{ Índices Relativos } & CFI & 0,76 & 0,95 & 0,95 \\
\hline & TLI & 0,73 & 0,95 & 0,95 \\
\hline Índices de Discrepância & RMSEA & 0,112 & 0,052 & 0,052 \\
\hline Populacional & (Lo90;Hi90) & $(0,106 ; 0,117)$ & $(0,044 ; 0,060)$ & $(0,044 ; 0,060)$ \\
\hline \multirow[t]{2}{*}{ Índices de Parcimônia } & PCFI & 0,76 & 0,84 & 0,84 \\
\hline & PGFI & 0,55 & 0,73 & 0,73 \\
\hline Índices Baseados na & AIC & 1469,15 & 372,84 & 372,84 \\
\hline \multirow[t]{2}{*}{ Teoria da Informação } & ECVI & 3,27 & 0,83 & 0,83 \\
\hline & CAIC & 1694,05 & 561,97 & 561,97 \\
\hline
\end{tabular}


2.5.2.2 Confiabilidade e validade da escala de medida do Desempenho

O valor do Rho de Jöreskog dos fatores da EDC apresentou ótima consistência. De maneira similar, a validade convergente foi satisfeita para todos os fatores, que apresentaram correlações múltiplas ao quadrado próximas ou superiores a 0,5 , fornecendo evidências complementares da validade convergente (Bagozzi \& Yi, 1988). Os pesos fatoriais foram todos significativos e fortes $(\lambda \mathrm{i}>0,5 ; p<0,001)$.

A validade discriminante foi testada entre as dimensões $\left(\right.$ Rho $\left._{v c}>r^{2}\right)$, sendo confirmada totalmente. A Tabela 47 apresenta o resumo das qualidades psicométricas e a Figura 28 exibe a representação gráfica do Modelo 3, os pesos fatoriais não estandardizados e as correlações múltiplas ao quadrado.

Tabela 47

Confiabilidade e validade das dimensões conforme Modelo 3 (Segunda Ordem) da EDC

\begin{tabular}{|c|c|}
\hline Confiabilidade e Validade Convergente do Modelo 3 & $\begin{array}{c}\text { Pesos } \\
\text { Fatoriais }\end{array}$ \\
\hline \multicolumn{2}{|l|}{ Dimensão Desempenho por Comepetências: $\rho=0,84$; Rhovc $=0,73, t>1,96$} \\
\hline Dimensão Competências Técnicas: $\rho=0,93$; Rhovc $=0,60, t>1,96$ & $\mathbf{0 , 7 3}$ \\
\hline DCT1_Capacidade de utilizar armas e munições, quando necessário. & 0,62 \\
\hline DCT2__Ser capaz de agir demonstrando conhecimentos sobre legislação, normas [...]. & 0,66 \\
\hline DCT3_Capacidade de identificar e gerenciar conflitos [...]. & 0,74 \\
\hline DCT4_Ter capacidade de agir com inovação[...]. & 0,67 \\
\hline DCT5_Capacidade de visão sistêmica[...]. & 0,73 \\
\hline DCT6_Ser capaz de trabalhar de forma interdisciplinar[...]. & 0,67 \\
\hline DCT7_Capacidade de resposta imediata à sociedade [...]. & 0,71 \\
\hline DCT8_Capacidade de persuasão e argumentação[...]. & 0,70 \\
\hline DCT9__Ter capacidade de utilizar a experiência pessoal e profissional [...]. & 0,69 \\
\hline Dimensão Competências Comportamentais: $\rho=0,98$; Rhovc $=0,62, t>1,96$ & $\mathbf{0 , 8 2}$ \\
\hline DCC6_Capacidade de agir com empatia [...]. & 0,66 \\
\hline DCC7_Capacidade de agir com persistência e determinação [...]. & 0,71 \\
\hline DCC8_Capacidade de agir com flexibilidade[...]. & 0,72 \\
\hline DCC9_Capacidade de agir com imparcialidade[...]. & 0,70 \\
\hline DCC10_Capacidade de agir com preocupação com a própria segurança[...]. & 0,66 \\
\hline DCC11_Capacidade de agir com criatividade. & 0,63 \\
\hline DCC12_Capacidade de agir com postura ética e profissional. & 0,77 \\
\hline DCC13_Capacidade de trabalhar em equipe. & 0,71 \\
\hline DCC15_Capacidade de agir com deferência [...]. & 0,70 \\
\hline \multicolumn{2}{|l|}{ Validade Discriminante do Modelo 3 (Segunda Ordem) } \\
\hline DCC & \\
\hline DCT & \\
\hline DCC & \\
\hline
\end{tabular}




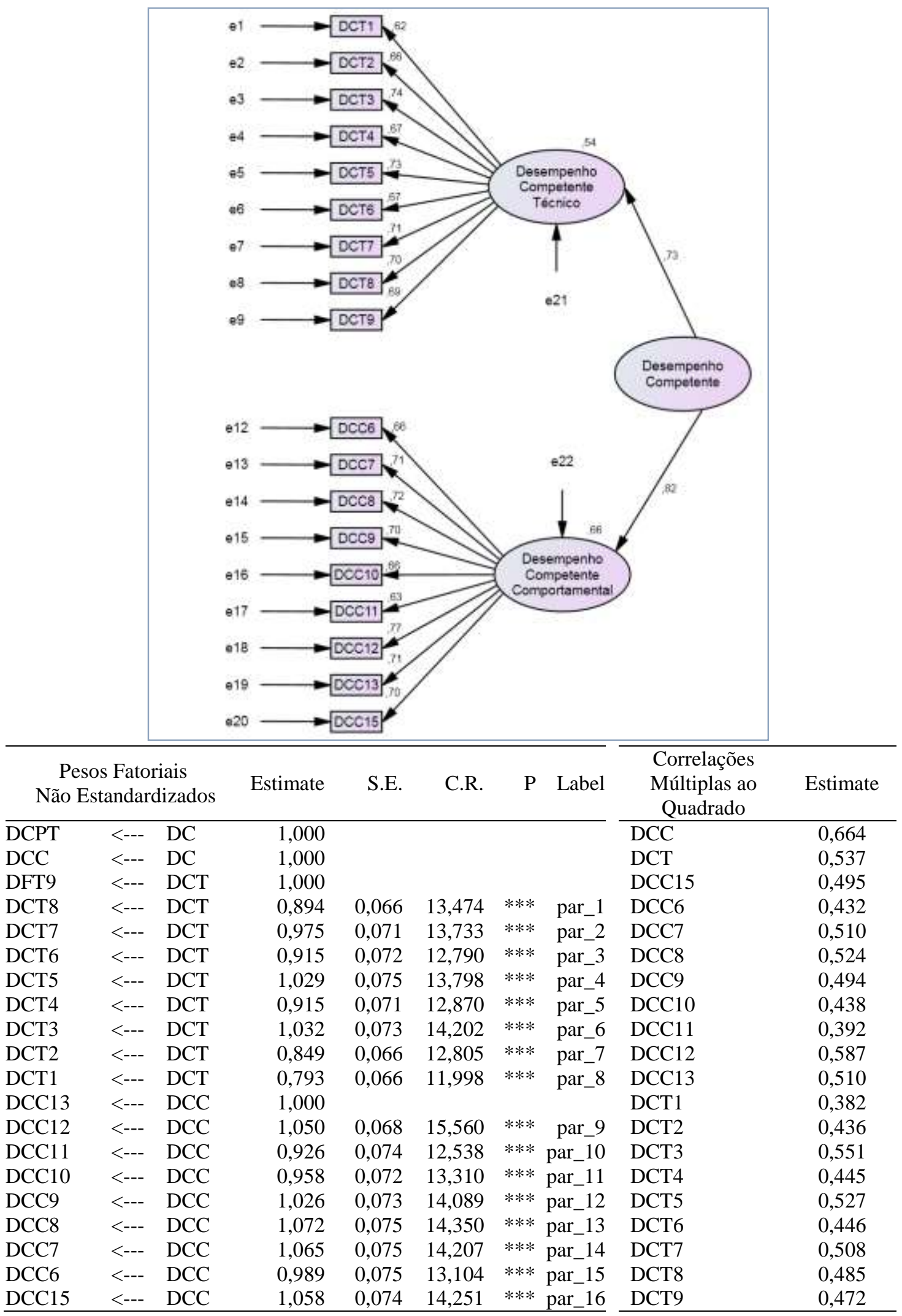

Figura 28. Modelo 3 (segunda ordem) da EDC. 


\section{Conclusão do Capítulo VI}

Esse capítulo tratou dos processos de validação dos diferentes instrumentos de medida utilizados nesta pesquisa. Na primeira seção, foram a amostra estudada e as investigações preliminares de verificação da adequação dos dados às análises multivariadas. Foram coletados 1.276 questionários provenientes de policiais de diversas unidades da PMDF e que contemplaram todos os níveis hierárquicos da organização. Após a retirada de 27 questionários incompletos, foram constituídas duas subamostras aleatórias, a primeira contendo 625 dos respondentes para a fase exploratória, e 624 para a confirmatória, que foram submetidos a adequações para a realização das análises multivariadas.

A segunda seção permitiu encontrar evidências de validade das escalas de medida dos construtos centrais do modelo de pesquisa. Para cada variável latente estudada foi realizada uma análise fatorial exploratória, com exceção da escala de valores organizacionais que foi submetida a um escalonamento multidimensional, e, posteriormente, por uma análise fatorial confirmatória de todas as variáveis. Com isso, foi verificada a confiabilidade e a validade dos instrumentos de medida utilizados para essa pesquisa.

O conjunto desses resultados permite prosseguir com o Capítulo VII, consagrado a analisar as evidências de validade do modelo geral, do teste das hipóteses, da discussão e interpretação dos resultados da pesquisa. 
PARTE 2

ESTUDO EMPÍRICO E RESULTADO DA PESQUISA
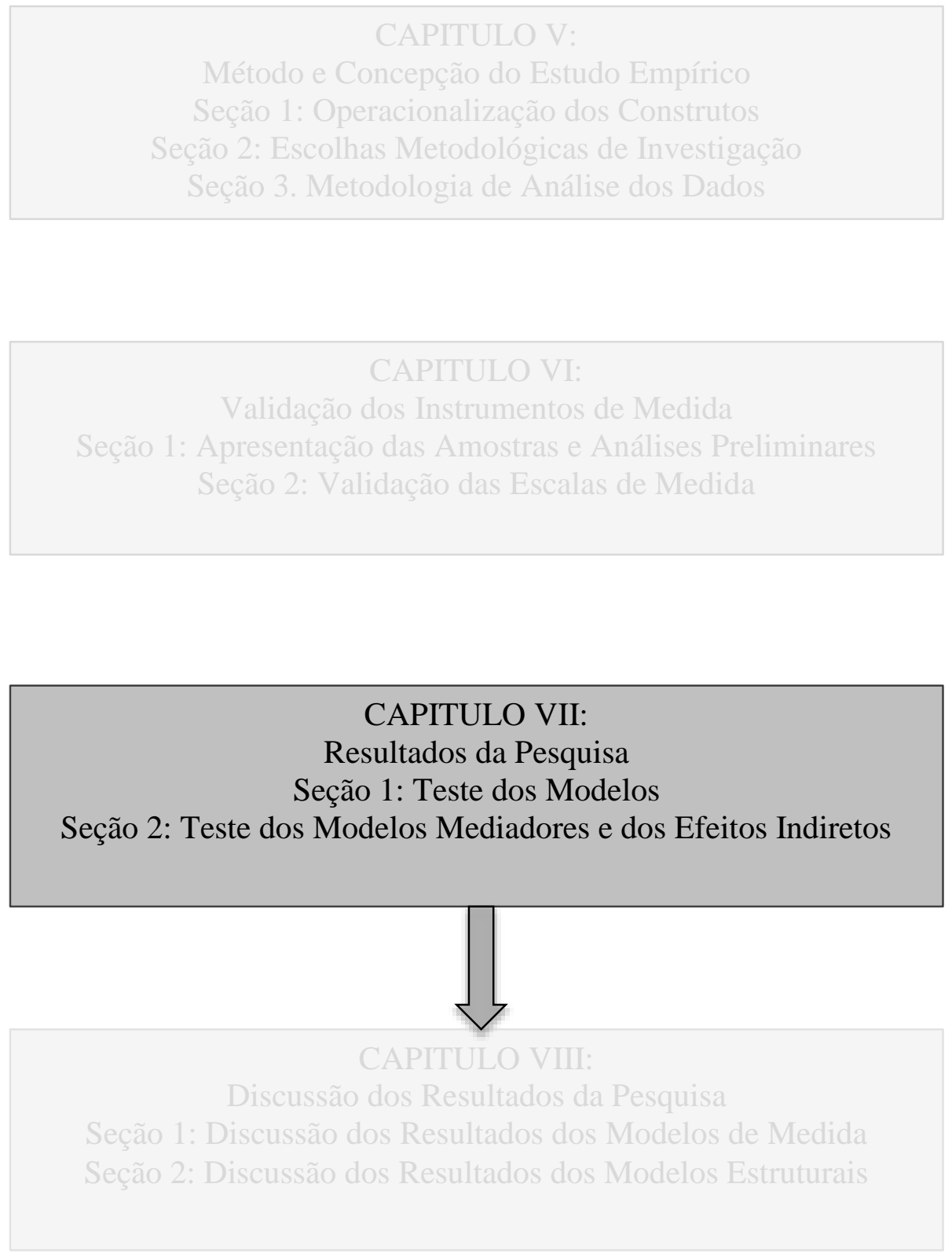


\section{CAPÍTULO VII. RESULTADOS DA PESQUISA}

\section{Introdução ao Capítulo VII}

O capítulo que se inicia consagra-se à apresentação dos resultados da pesquisa. A primeira seção destina-se aos procedimentos relativos aos testes dos modelos preliminares, em que são testadas as relações entre as variáveis, progressivamente. A primeira seção introduz o teste dos modelos parciais e dos efeitos diretos (1.1); em seguida, são apresentados os testes dos modelos parciais e dos efeitos indiretos, ou mediadores (1.2); e, por fim, o teste dos modelos estruturais gerais da pesquisa são exibidos. A segunda seção destina-se à apresentação das hipóteses de pesquisa de forma sistematizada e sumarizada.

\section{Seção 1. Teste dos Modelos}

\subsection{Teste dos Modelos Parciais e dos Efeitos Diretos}

O teste dos modelos parciais é conseguido, primeiramente, avaliando-se seu ajuste aos dados, baseado na validação de modelos mais simples, que contemplam a ligação entre as variáveis estudadas. Os testes foram realizados por etapas para a amostra total válida $(n=916)$ e, posteriormente, foram analisadas as ligações estruturais diretas entre as variáveis.

\subsubsection{Teste dos modelo preliminares e do modelo estrutural geral}

Antes de testar o modelo estrutural geral, testou-se o modelo de medida geral deixando os construtos centrais correlacionados de forma livre. Este teste é importante na medida em que o modelo estrutural é construído com base nos modelos de medida (Hair et al., 2009), além de permitir avaliar a validade discriminante entre os construtos do modelo.

Posteriormente, partiu-se para os teste dos modelos intermediários, ou seja, dos modelos que investigam: a influência dos valores organizacionais sobre a identidade (profissional e organizacional); a influência dos valores organizacionais sobre o desempenho profissional. A influência das práticas organizacionais sobre a identidade (profissional e organizacional); a influência das práticas organizacionais sobre o desempenho profissional. A influência dos valores organizacionais, das práticas organizacionais e da identidade profissional sobre o desempenho profissional; a influência dos valores organizacionais, das práticas organizacionais e da identidade organizacional sobre o desempenho profissional. A influência dos valores organizacionais, das práticas organizacionais, da identidade 
profissional e da identidade organizacional sobre o desempenho profissional (Modelo estrutural geral da pesquisa).

\subsubsection{Ajustamento do modelo correlacional e dos modelos estruturais}

Os modelos preliminares e o modelo geral são avaliados com base nos índices de ajuste anteriormente utilizados para a validação dos modelos de medida. Para essa fase, emprega-se o método de estimação da máxima verossimilhança sobre a matriz de covariância (Kline, 2010). O primeiro teste realizado com o modelo de medida geral, que deixa os construtos centrais correlacionados de forma livre, apontou problemas de não positividade da matriz de covariância. $\mathrm{O}$ exame mais atento dessa matriz mostrou que o tipo motivacional domínio estava interferindo na covariância de todas as outras variáveis latentes. O mesmo ocorre com a matriz dos resíduos padronizados, no que se refere a essa dimensão, que apresentou valores superiores ao limite de |2,58|, indicativo de problemas de ajustes (MacCallum, 1986).

Como o tipo motivacional domínio já apresentava problemas de ajuste da validação confirmatória da EVO, permanecendo somente com dois itens, resolveu-se eliminar essa dimensão, que será mantida quando da necessidade de realizarem-se análises mais parcimoniosas. Com a retirada dessa variável, a matriz tornou-se definida de forma positiva, o que possibilita a realização dos testes de ajuste do modelo.

No ajuste do modelo geral de medida, nota-se que o p-valor do teste do quadrado é inferior ao limite associado de 0,05; no entanto, esse índice é sensível ao tamanho da amostra e a complexidade do modelo. Diante disso, tornou-se consenso a utilização de outros índices para a avaliação da adequação de um modelo (Iacobucci, 2010). Os índices de ajuste (absoluto, relativo, parcimônia, discrepância populacional, e baseados na teoria da informação) mostram que o modelo se ajusta bem aos dados para a amostra total e para as duas subamostras estudadas (Tabela 48).

Somente os valores do GFI e AGFI estão abaixo do limite de 0,90; contudo, sabe-se que estes dois índices são sensíveis ao tamanho da amostra e à complexidade do modelo e, portanto, não comprometem o ajuste global do modelo (Kline, 2010; Roussel et al, 2002). A Figura 29 expõe a representação gráfica do modelo com todas as variáveis correlacionadas, os pesos fatoriais não estandardizados e as correlações múltiplas ao quadrado. 
Tabela 48

Índices de ajustamento dos Modelos Gerais Correlacionais

\begin{tabular}{|c|c|c|c|c|}
\hline \multicolumn{2}{|l|}{ Amostra } & $\begin{array}{c}\text { Modelo Geral } \\
\mathrm{N}=916\end{array}$ & $\begin{array}{l}\text { Modelo Geral } \\
\mathrm{N}=465\end{array}$ & $\begin{array}{c}\text { Modelo Geral } \\
\mathrm{N}=451\end{array}$ \\
\hline Índices & $\chi /$ g.l. & 1,98 & 1,61 & 1,59 \\
\hline \multirow[t]{4}{*}{ Absolutos } & $\chi^{2} ;$ g.l. & 5113,$99 ; 2578$ & 4147,$89 ; 2578$ & 4102,$60 ; 2578$ \\
\hline & $p$ & 0,000 & 0,000 & 0,000 \\
\hline & GFI (AGFI) & $0,87(0,85)$ & $0,81(0,79)$ & $0,81(0,79)$ \\
\hline & SRMR & 0,040 & 0,046 & 0,048 \\
\hline \multirow[t]{2}{*}{ Índices Relativos } & CFI & 0,93 & 0,92 & 0,92 \\
\hline & TLI & 0,93 & 0,92 & 0,91 \\
\hline Índices de Discrepância & RMSEA & 0,033 & 0,036 & 0,036 \\
\hline Populacional & (Lo90;Hi90) & $(0,031 ; 0,034)$ & $(0,034 ; 0,038)$ & $(0,034 ; 0,038)$ \\
\hline \multirow[t]{2}{*}{ Índices de Parcimônia } & PCFI & 0,87 & 0,86 & 0,85 \\
\hline & PGFI & 0,78 & 0,73 & 0,73 \\
\hline Índices Baseados na & AIC & 5657,99 & 4691,89 & 4646,60 \\
\hline \multirow[t]{2}{*}{ Teoria da Informação } & ECVI & 6,18 & 10,12 & 10,37 \\
\hline & CAIC & 7241,03 & 6090,53 & 6036,92 \\
\hline
\end{tabular}

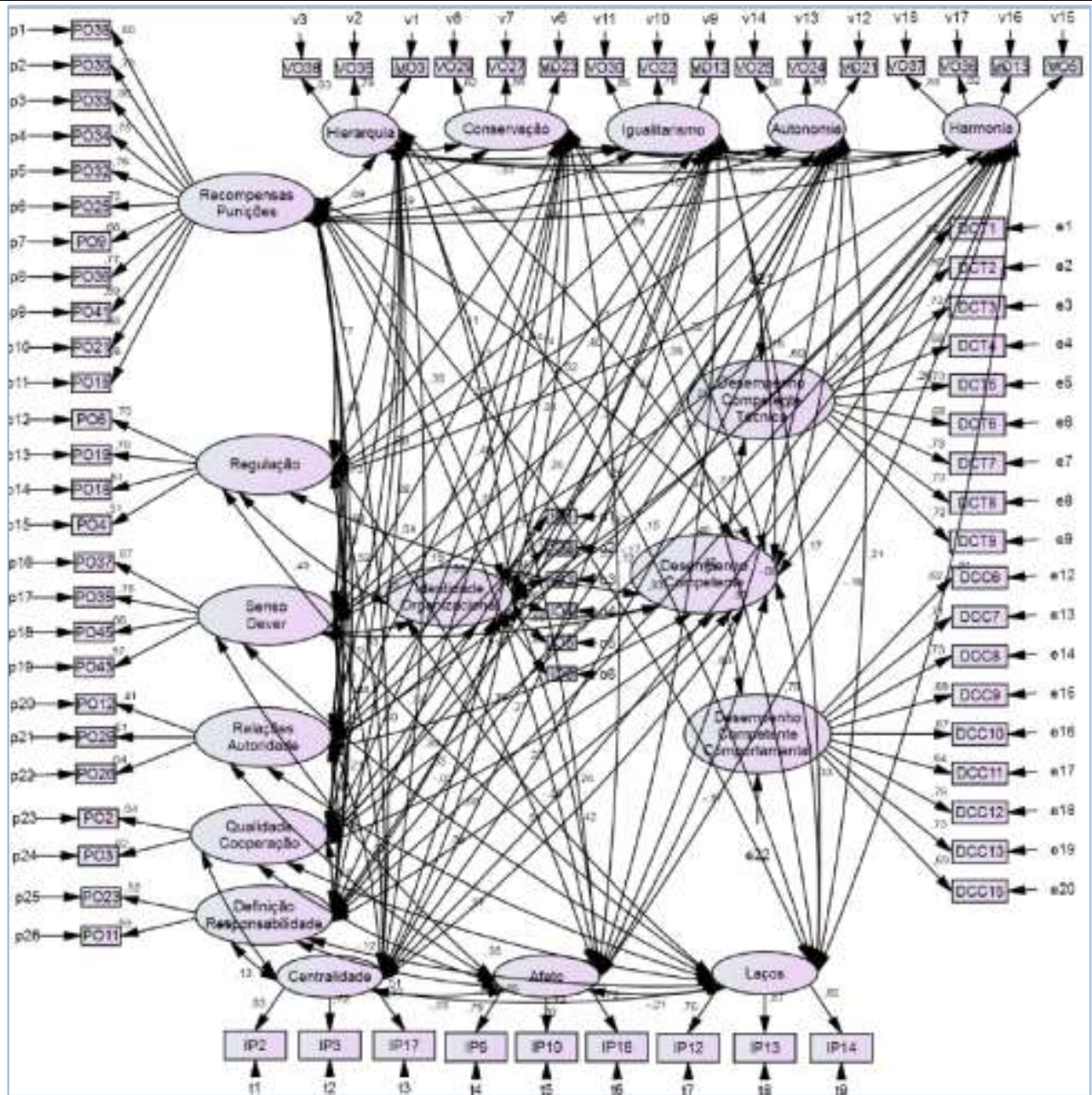




\begin{tabular}{|c|c|c|c|c|c|c|c|c|c|}
\hline \multicolumn{3}{|c|}{$\begin{array}{l}\text { Pesos Fatoriais Não- } \\
\text { Estandardizados }\end{array}$} & \multirow{2}{*}{$\begin{array}{r}\text { Estimate } \\
1,000\end{array}$} & \multirow[t]{2}{*}{ S.E. } & \multirow[t]{2}{*}{ C.R. } & \multirow[t]{2}{*}{$\mathrm{P}$} & \multirow[t]{2}{*}{ Label } & \multirow{2}{*}{$\begin{array}{c}\text { Correlações } \\
\text { Múltiplas ao } \\
\text { Quadrado } \\
\text { DCC }\end{array}$} & \multirow{2}{*}{$\begin{array}{r}\text { Estimate } \\
0,783\end{array}$} \\
\hline DCC & $<---$ & DC & & & & & & & \\
\hline DCT & $<---$ & DC & 1,000 & & & & & DCT & 0,595 \\
\hline DCT9 & $<---$ & DCT & 1,000 & & & & & IP12 & 0,574 \\
\hline DCT8 & $<---$ & DCT & 0,926 & ,043 & 21,767 & $* * *$ & par_1 & IP13 & 0,759 \\
\hline DCT7 & $<---$ & DCT & 0,984 & ,045 & 21,711 & $* * *$ & par_2 & IP14 & 0,665 \\
\hline DCT6 & $<---$ & DCT & 0,886 & ,044 & 20,063 & $* * *$ & par_3 & IP6 & 0,627 \\
\hline DCT5 & $<---$ & DCT & 1,002 & ,047 & 21,537 & $* * *$ & par_4 & IP10 & 0,524 \\
\hline DCT4 & $<---$ & DCT & 0,892 & 044 & 20,117 & $* * *$ & par_5 & IP18 & 0,623 \\
\hline DCT3 & $<---$ & DCT & 0,966 & ,045 & 21,552 & $* * *$ & par_6 & IP2 & 0,691 \\
\hline DCT2 & $<---$ & DCT & 0,818 & ,042 & 19,311 & $* * *$ & par_7 & IP3 & 0,515 \\
\hline DCT1 & $<---$ & DCT & 0,792 & ,044 & 18,073 & $* * *$ & par_8 & IP17 & 0,589 \\
\hline DCC13 & $<---$ & DCC & 1,000 & & & & & IO1 & 0,517 \\
\hline DCC12 & $<---$ & DCC & 1,006 & 043 & 23,181 & $* * *$ & par_9 & IO2 & 0,493 \\
\hline DCC11 & $<---$ & DCC & 0,910 & ,048 & 18,982 & $* * *$ & par_10 & IO3 & 0,519 \\
\hline DCC10 & $<---$ & DCC & 0,907 & ,045 & 20,116 & $* * *$ & par_11 & IO4 & 0,736 \\
\hline DCC9 & $<---$ & DCC & 0,992 & ,048 & 20,520 & $* * *$ & par_12 & IO5 & 0,432 \\
\hline DCC8 & $<---$ & DCC & 1,016 & ,047 & 21,764 & $* * *$ & par_13 & IO6 & 0,730 \\
\hline DCC7 & $<---$ & DCC & 1,017 & ,048 & 21,057 & $* * *$ & par_14 & VO37 & 0,687 \\
\hline DCC6 & $<---$ & DCC & 0,904 & ,050 & 18,238 & $* * *$ & par_15 & VO36 & 0,677 \\
\hline DCC15 & $<---$ & DCC & 1,006 & ,049 & 20,605 & $* * *$ & par_16 & VO5 & 0,593 \\
\hline PO21 & $<---$ & $\mathrm{RP}$ & 0,889 & 040 & 22,079 & $* * *$ & par_17 & VO13 & 0,686 \\
\hline PO41 & $<---$ & $\mathrm{RP}$ & 0,854 & ,038 & 22,470 & $* * *$ & par_18 & VO21 & 0,629 \\
\hline PO36 & $<--$ & $\mathrm{RP}$ & 0,781 & ,030 & 25,628 & $* * *$ & par_19 & VO24 & 0,868 \\
\hline PO9 & $<---$ & $\mathrm{RP}$ & 0,821 & ,039 & 21,193 & $* * *$ & par_20 & VO25 & 0,775 \\
\hline PO25 & $<---$ & $\mathrm{RP}$ & 0,827 & ,035 & 23,494 & $* * *$ & par_21 & VO12 & 0,724 \\
\hline PO32 & $<---$ & $\mathrm{RP}$ & 0,938 & ,036 & 25,913 & $* * *$ & par_22 & VO22 & 0,627 \\
\hline PO34 & $<---$ & $\mathrm{RP}$ & 0,959 & ,038 & 25,062 & $* * *$ & par_23 & VO30 & 0,731 \\
\hline PO33 & $<---$ & $\mathrm{RP}$ & 0,955 & ,035 & 27,142 & $* * *$ & par_24 & VO23 & 0,712 \\
\hline PO30 & $<---$ & $\mathrm{RP}$ & 0,889 & ,037 & 24,282 & $* * *$ & par_25 & VO27 & 0,783 \\
\hline PO15 & $<--$ & $\mathrm{RP}$ & 0,733 & 039 & 18,708 & $* * *$ & par_35 & VO29 & 0,679 \\
\hline PO38 & $<---$ & $\mathrm{RP}$ & 1,000 & & & & & VO3 & 0,288 \\
\hline PO4 & $<--$ & REG & 0,724 & 051 & 14,071 & $* * *$ & par_26 & VO35 & 0,620 \\
\hline PO18 & $<---$ & REG & 0,721 & 051 & 14,075 & $* * *$ & par_27 & VO38 & 0,682 \\
\hline PO19 & $<---$ & REG & 0,989 & ,052 & 18,978 & $* * *$ & par_28 & PO15 & 0,350 \\
\hline PO6 & $<---$ & REG & 1,000 & & & & & $\mathrm{PO} 23$ & 0,269 \\
\hline PO43 & $<---$ & SD & 0,856 & ,056 & 15,346 & $* * *$ & par_29 & PO11 & 0,347 \\
\hline PO45 & $<---$ & SD & 1,062 & ,062 & 17,232 & $* * *$ & par_30 & $\mathrm{PO} 2$ & 0,706 \\
\hline PO35 & $<---$ & SD & 1,247 & 0,063 & 19,727 & $* * *$ & par_31 & PO3 & 0,677 \\
\hline PO37 & $<---$ & SD & 1,000 & & & & & PO12 & 0,164 \\
\hline PO26 & $<---$ & RA & 1,207 & 0,123 & 9,845 & $* * *$ & par_32 & PO29 & 0,368 \\
\hline PO29 & $<---$ & RA & 1,161 & 0,113 & 10,270 & $* * *$ & par_33 & PO26 & 0,412 \\
\hline PO12 & $<---$ & RA & 1,000 & & & & & PO37 & 0,450 \\
\hline $\mathrm{PO} 3$ & $<---$ & $\mathrm{QC}$ & 1,009 & 0,041 & 24,355 & $* * *$ & par_34 & PO35 & 0,605 \\
\hline $\mathrm{PO} 2$ & $<---$ & $\mathrm{QC}$ & 1,000 & & & & & $\mathrm{PO} 45$ & 0,438 \\
\hline PO11 & $<---$ & DR & 1,191 & 0,122 & 9,772 & $* * *$ & par_36 & PO43 & 0,324 \\
\hline $\mathrm{PO} 23$ & $<---$ & $\mathrm{DR}$ & 1,000 & & & & & PO6 & 0,496 \\
\hline VO38 & $<---$ & Hierarquia & 1,000 & & & & & PO19 & 0,495 \\
\hline VO35 & $<---$ & Hierarquia & 0,990 & 0,048 & 20,546 & $* * *$ & par_37 & PO18 & 0,265 \\
\hline VO3 & $<--$ & Hierarquia & 0,616 & 0,041 & 14,858 & $* * *$ & par_38 & $\mathrm{PO} 4$ & 0,258 \\
\hline
\end{tabular}




\begin{tabular}{|c|c|c|c|c|c|c|c|c|c|}
\hline VO29 & $<--$ & Conservação & 1,000 & & & & & PO38 & 0,638 \\
\hline VO27 & $<--$ & Conservação & 1,071 & 0,035 & 30,992 & $* * *$ & par_39 & PO30 & 0,527 \\
\hline VO23 & $<--$ & Conservação & 1,016 & 0,035 & 29,033 & $* * *$ & par_40 & PO33 & 0,638 \\
\hline VO30 & $<--$ & Igualitarismo & 1,000 & & & & & PO34 & 0,566 \\
\hline VO22 & $<--$ & Igualitarismo & 0,637 & 0,022 & 28,955 & $* * *$ & par_41 & PO32 & 0,584 \\
\hline VO12 & $<--$ & Igualitarismo & 0,888 & 0,027 & 33,266 & $* * *$ & par_42 & $\mathrm{PO} 25$ & 0,513 \\
\hline VO25 & $<--$ & Autonomia & 1,000 & & & & & PO9 & 0,430 \\
\hline VO24 & $<--$ & Autonomia & 1,066 & 0,025 & 43,016 & $* * *$ & par_43 & PO36 & 0,589 \\
\hline VO21 & $<---$ & Autonomia & 0,932 & 0,031 & 29,963 & $* * *$ & par_44 & PO41 & 0,474 \\
\hline VO13 & $<---$ & Harmonia & 0,930 & 0,032 & 29,139 & $* * *$ & par_45 & $\mathrm{PO} 21$ & 0,466 \\
\hline VO5 & $<--$ & Harmonia & 0,910 & 0,034 & 26,508 & $* * *$ & par_46 & DCC15 & 0,469 \\
\hline VO37 & $<--$ & Harmonia & 0,992 & 0,033 & 30,010 & $* * *$ & par_47 & DCC6 & 0,380 \\
\hline VO36 & $<---$ & Harmonia & 1,000 & & & & & DCC7 & 0,501 \\
\hline IO6 & $<--$ & IO & 1,000 & & & & & DCC8 & 0,527 \\
\hline IO5 & $<--$ & IO & 0,728 & 0,033 & 21,945 & $* * *$ & par_48 & DCC9 & 0,470 \\
\hline IO4 & $<---$ & IO & 0,961 & 0,030 & 32,038 & $* * *$ & par_49 & DCC10 & 0,447 \\
\hline IO3 & $<---$ & IO & 0,777 & 0,032 & 24,178 & $* * *$ & par_50 & DCC11 & 0,405 \\
\hline $\mathrm{IO} 2$ & $<--$ & IO & 0,780 & 0,033 & 23,517 & $* * *$ & par_51 & DCC12 & 0,576 \\
\hline IO1 & $<---$ & IO & 0,894 & 0,039 & 22,650 & $* * *$ & par_52 & DCC13 & 0,537 \\
\hline IP17 & $<---$ & Centralidade & 1,000 & & & & & DCT1 & 0,378 \\
\hline IP3 & $<---$ & Centralidade & 0,901 & 0,043 & 21,157 & $* * *$ & par_54 & DCT2 & 0,425 \\
\hline IP2 & $<--$ & Centralidade & 1,060 & 0,044 & 24,036 & $* * *$ & par_55 & DCT3 & 0,525 \\
\hline IP18 & $<---$ & Afeto & 1,000 & & & & & DCT4 & 0,465 \\
\hline IP10 & $<---$ & Afeto & 0,912 & 0,046 & 20,031 & $* * *$ & par_56 & DCT5 & 0,528 \\
\hline IP6 & $<---$ & Afeto & 0,924 & 0,044 & 20,942 & $* * *$ & par_57 & DCT6 & 0,464 \\
\hline IP14 & $<---$ & Laços & 1,000 & & & & & DCT7 & 0,530 \\
\hline IP13 & $<---$ & Laços & 1,120 & 0,039 & 28,383 & $* * *$ & par_58 & DCT8 & 0,529 \\
\hline IP12 & $<---$ & Laços & 0,918 & 0,038 & 24,001 & $* * *$ & par_59 & DCT9 & 0,521 \\
\hline
\end{tabular}

Notas: DC: Desempenho por Competências; DCT: Desempenho por Competências Técnicas; DCC: Desempenho por Competências Comportamentais; RP: Recompensas e Punições; REG: Regulação; SD: Senso de Dever; RA: Relações de Autoridade; QC: Qualidade da Cooperação; DR: Definição de Responsabilidades; IO: Identidade Organizacional; IP: Identidade Profissional.

Figura 29. Modelo Total Correlacionado.

Os índices de modificação sugerem correlações entre os termos de erro de algumas variáveis; entretanto, não procedem essas correlações, pela ausência de fundamentos teóricos e pelos riscos de capitalização ao acaso (MacCallum, Roznowski \& Necowitz, 1992). O valor médio das correlações múltiplas ao quadrado $\left(\mathrm{R}^{2}\right)$ de 0,55 também indica que as variáveis independentes explicam a proporção substancial da variância das variáveis endógenas.

Levando-se em consideração todos estes resultados, partiu-se para o teste dos modelos estruturais preliminares, com os efeitos diretos e mediadores, e dos modelos estruturais gerais. 


\section{Influência dos valores organizacionais sobre a identidade profissional}

O primeiro teste buscou verificar a influência dos tipos motivacionais subjacentes aos valores organizacionais (VO), todos correlacionados à identidade profissional (IP), VO $\rightarrow I P$. O segundo teste analisou a associação entre as dimensões bipolares dos tipos motivacionais sobre a identidade profissional. Para tanto, foram considerados os seguintes pares: Autonomia $x$ Conservação $\rightarrow I P$; Hierarquia $x$ Igualitarismo $\rightarrow I P$; Domínio $x$ Harmonia $\rightarrow I P$. Como forma de verificar a qualidade do ajustamento dos dados, foram apreciadas suas especificações.

O Modelo completo correlacionado $V O \rightarrow I P$ apresentou ajustes satisfatórios $(\mathrm{GFI}=0,92 ; \quad \mathrm{CFI}=0,95 ; \quad \mathrm{RMSEA}=0,056), \quad$ sendo significativos $\quad(\mathrm{p}<0,000)$ os tipos motivacionais conservação, igualitarismo e harmonia, responsáveis por explicar $18 \%$ da variância total da identidade profissional $\left(R^{2}=0,76\right.$ para centralidade; $R^{2}=0,10$ para afeto e $\mathrm{R}^{2}=65$ para laços).

No que se refere às dimensões bipolares, a relação Autonomia $x$ Conservação $\rightarrow I P$ foi significativa ( $\mathrm{p}<0,000 ; \mathrm{GFI}=0,97 ; \mathrm{CFI}=0,98 ; \mathrm{RMSEA}=0,044)$, explicando $14 \%$ da variância $\left(\mathrm{R}^{2}=0,76\right.$ para centralidade; $\mathrm{R}^{2}=0,10$ para afeto e $\mathrm{R}^{2}=66$ para laços $)$. A relação Hierarquia $x$ Igualitarismo $\rightarrow I P$ foi significativa $\quad(\mathrm{p}<0,000 ; \quad \mathrm{GFI}=0,97 ; \quad \mathrm{CFI}=0,98 ; \quad \mathrm{RMSEA}=0,044)$, explicando $15 \%$ da variância total $\left(R^{2}=0,74\right.$ para centralidade; $R^{2}=0,09$ para afeto e $R^{2}=67$ para laços), e, por fim, a relação Domínio $x$ Harmonia $\rightarrow I P$ só se mostrou significativa $(\mathrm{p}<0,000 ; \mathrm{GFI}=0,96 ; \mathrm{CFI}=0,97 ; \mathrm{RMSEA}=0,049)$ para o tipo motivacional harmonia; portanto, a trajetória domínio $\rightarrow I P$ foi excluída. Esse modelo explicou $13 \%$ da variância da identidade profissional $\left(R^{2}=0,75\right.$ para centralidade; $R^{2}=0,10$ para afeto e $R^{2}=67$ para laços $)$.

A Tabela 49 sintetiza os índices de ajuste e as Figuras 30, 31, 32 e 33 exibem as representações gráficas de cada um dos modelos, os pesos fatoriais não estandardizados e as correlações múltiplas ao quadrado. 
Tabela 49

Índices de ajustamento da relação entre $V O \rightarrow I P$, completo e por dimensões

\begin{tabular}{|c|c|c|c|c|c|}
\hline \multicolumn{2}{|l|}{$\begin{array}{l}\text { Amostra } \\
\mathrm{N}=916\end{array}$} & \multirow{2}{*}{$\begin{array}{c}\text { Modelo } V O \rightarrow \\
\text { IP } \\
3,75\end{array}$} & \multirow{2}{*}{$\begin{array}{c}\text { Autonomia } x \\
\text { Conservação } \\
\rightarrow I P\end{array}$} & \multirow{2}{*}{$\begin{array}{c}\text { Hierarquia } x \\
\text { Igualitarismo } \\
\rightarrow I P \\
2.81\end{array}$} & \multirow{2}{*}{$\begin{array}{c}\text { Domínio } x \\
\text { Harmonia } \rightarrow \\
\text { IP } \\
3,19\end{array}$} \\
\hline Índices & $\chi /$ g.l. & & & & \\
\hline Absolutos & $\chi^{2} ;$ g.l. & 1135,$84 ; 303$ & 229,$62 ; 84$ & 233,$32 ; 83$ & 270,$91 ; 85$ \\
\hline & $p$ & 0,000 & 0,000 & 0,000 & 0,000 \\
\hline & GFI (AGFI) & $0,92(0,90)$ & $0,97(0,95)$ & $0,97(0,95)$ & $0,96(0,95)$ \\
\hline & SRMR & 0,046 & 0,038 & 0,042 & 0,039 \\
\hline \multirow[t]{2}{*}{ Índices Relativos } & CFI & 0,95 & 0,98 & 0,98 & 0,97 \\
\hline & TLI & 0,94 & 0,98 & 0,97 & 0,97 \\
\hline Índices de & RMSEA & 0,055 & 0,044 & 0,044 & 0,049 \\
\hline $\begin{array}{l}\text { Discrepância } \\
\text { Populacional }\end{array}$ & (Lo90;Hi90) & $(0,051 ; 0,058)$ & $(0,037 ; 0,050)$ & $(0,038 ; 0,051)$ & $(0,042 ; 0,055)$ \\
\hline Índices de & PCFI & 0,82 & 0,78 & 0,77 & 0,79 \\
\hline Parcimônia & PGFI & 0,73 & 0,68 & 0,67 & 0,68 \\
\hline Índices Baseados & $\mathrm{AIC}$ & 1285,84 & 301,62 & 307,32 & 340,91 \\
\hline na Teoria da & ECVI & 1,40 & 0,33 & 0,34 & 0,37 \\
\hline Informação & CAIC & 1722,34 & 511,14 & 522,66 & 544,61 \\
\hline
\end{tabular}

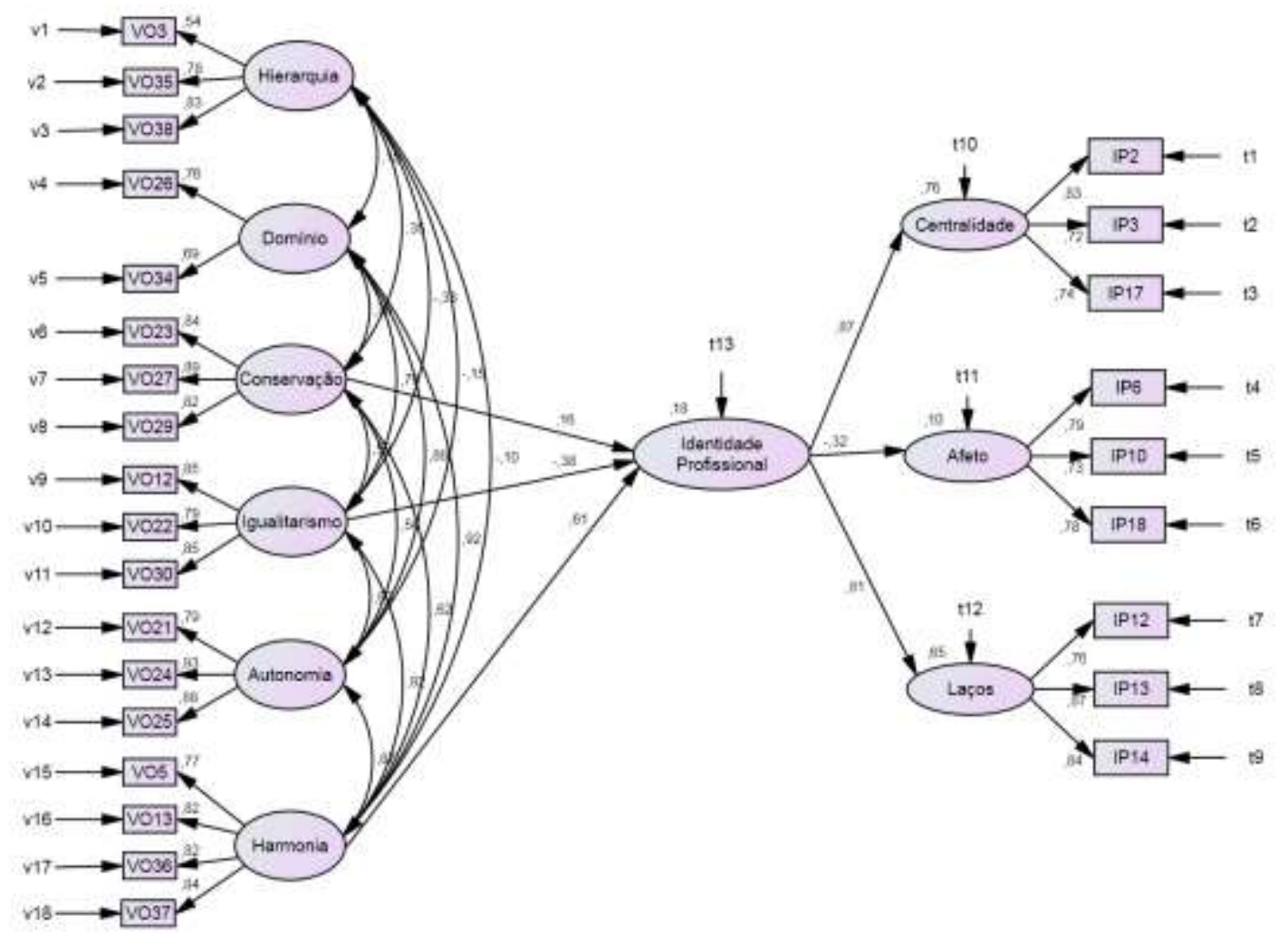




\begin{tabular}{|c|c|c|c|c|c|c|c|c|c|}
\hline \multicolumn{3}{|c|}{$\begin{array}{l}\text { Pesos Fatoriais Não- } \\
\text { Estandardizados }\end{array}$} & \multirow{2}{*}{$\begin{array}{l}\text { Estimate } \\
-0,085\end{array}$} & \multirow{2}{*}{$\begin{array}{l}\text { S.E. } \\
0,032\end{array}$} & \multirow{2}{*}{$\begin{array}{c}\text { C.R. } \\
-2,687\end{array}$} & \multirow{2}{*}{$\begin{array}{r}\mathrm{P} \\
0,007\end{array}$} & \multirow{2}{*}{$\begin{array}{c}\text { Label } \\
\text { par_36 }\end{array}$} & \multirow{2}{*}{$\begin{array}{c}\begin{array}{c}\text { Correlações } \\
\text { Múltiplas ao } \\
\text { Quadrado }\end{array} \\
\text { IP }\end{array}$} & \multirow{2}{*}{$\begin{array}{r}\text { Estimate } \\
0,177\end{array}$} \\
\hline IP & $<---$ & Igualitarismo & & & & & & & \\
\hline IP & $<--$ & Conservação & 0,057 & 0,021 & 2,711 & 0,007 & par_37 & Laços & 0,655 \\
\hline IP & $<---$ & Harmonia & 0,186 & 0,050 & 3,733 & $* * *$ & par_38 & Afeto & 0,104 \\
\hline Afeto & $<---$ & IP & $-0,451$ & 0,060 & $-7,496$ & $* * *$ & par_8 & Centralidade & 0,763 \\
\hline Laços & $<---$ & IP & 1,000 & & & & & VO37 & 0,700 \\
\hline Centralidade & $<---$ & IP & 1,000 & & & & & VO36 & 0,676 \\
\hline IP17 & $<---$ & Centralidade & 1,000 & & & & & VO5 & 0,589 \\
\hline IP3 & $<---$ & Centralidade & 0,953 & 0,047 & 20,268 & $* * *$ & par_1 & VO13 & 0,672 \\
\hline IP2 & $<---$ & Centralidade & 1,112 & 0,052 & 21,369 & $* * *$ & par_2 & VO21 & 0,621 \\
\hline IP18 & $<---$ & Afeto & 1,000 & & & & & VO24 & 0,869 \\
\hline IP10 & $<---$ & Afeto & 0,927 & 0,047 & 19,598 & $* * *$ & par_3 & VO25 & 0,782 \\
\hline IP6 & $<---$ & Afeto & 0,920 & 0,046 & 20,033 & $* * *$ & par_4 & VO12 & 0,725 \\
\hline IP14 & $<---$ & Laços & 1,000 & & & & & VO22 & 0,626 \\
\hline IP13 & $<---$ & Laços & 1,073 & 0,036 & 30,060 & $* * *$ & par_5 & VO30 & 0,731 \\
\hline IP12 & $<---$ & Laços & 0,881 & 0,035 & 24,935 & $* * *$ & par_6 & VO23 & 0,701 \\
\hline VO38 & $<---$ & Hierarquia & 1,000 & & & & & VO27 & 0,792 \\
\hline VO35 & $<---$ & Hierarquia & 0,983 & 0,048 & 20,685 & $* * *$ & par_9 & VO29 & 0,679 \\
\hline VO3 & $<---$ & Hierarquia & 0,614 & 0,041 & 14,849 & $* * *$ & par_10 & VO26 & 0,582 \\
\hline VO34 & $<---$ & Domínio & 1,000 & & & & & VO34 & 0,470 \\
\hline VO26 & $<---$ & Domínio & 1,213 & 0,058 & 20,942 & $* * *$ & par_11 & VO3 & 0,288 \\
\hline VO29 & $<--$ & Conservação & 1,000 & & & & & VO35 & 0,615 \\
\hline VO27 & $<---$ & Conservação & 1,077 & 0,035 & 30,977 & $* * *$ & par_13 & VO38 & 0,687 \\
\hline VO23 & $<---$ & Conservação & 1,008 & 0,035 & 28,872 & $* * *$ & par_14 & IP12 & 0,581 \\
\hline VO30 & $<---$ & Igualitarismo & 1,000 & & & & & IP13 & 0,760 \\
\hline $\mathrm{VO} 22$ & $<---$ & Igualitarismo & 0,637 & 0,022 & 28,991 & $* * *$ & par_17 & IP14 & 0,698 \\
\hline VO12 & $<---$ & Igualitarismo & 0,889 & 0,027 & 33,275 & $* * *$ & par_18 & IP6 & 0,619 \\
\hline VO25 & $<---$ & Autonomia & 1,000 & & & & & IP10 & 0,532 \\
\hline VO24 & $<---$ & Autonomia & 1,062 & 0,024 & 43,524 & $* * *$ & par_22 & IP18 & 0,612 \\
\hline VO21 & $<---$ & Autonomia & 0,923 & 0,031 & 30,059 & $* * *$ & par_23 & IP2 & 0,682 \\
\hline VO13 & $<---$ & Harmonia & 0,921 & 0,032 & 28,945 & $* * *$ & par_28 & IP3 & 0,514 \\
\hline VO5 & $<---$ & Harmonia & 0,907 & 0,034 & 26,518 & $* * *$ & par_29 & IP17 & 0,554 \\
\hline VO37 & $<---$ & Harmonia & 1,002 & 0,033 & 30,481 & $* * *$ & par_35 & & \\
\hline VO36 & $<--$ & Harmonia & 1,000 & & & & & & \\
\hline
\end{tabular}

Figura 30. Modelo com Tipos Motivacionais Correlacionados predizendo a Identidade Profissional (IP). 


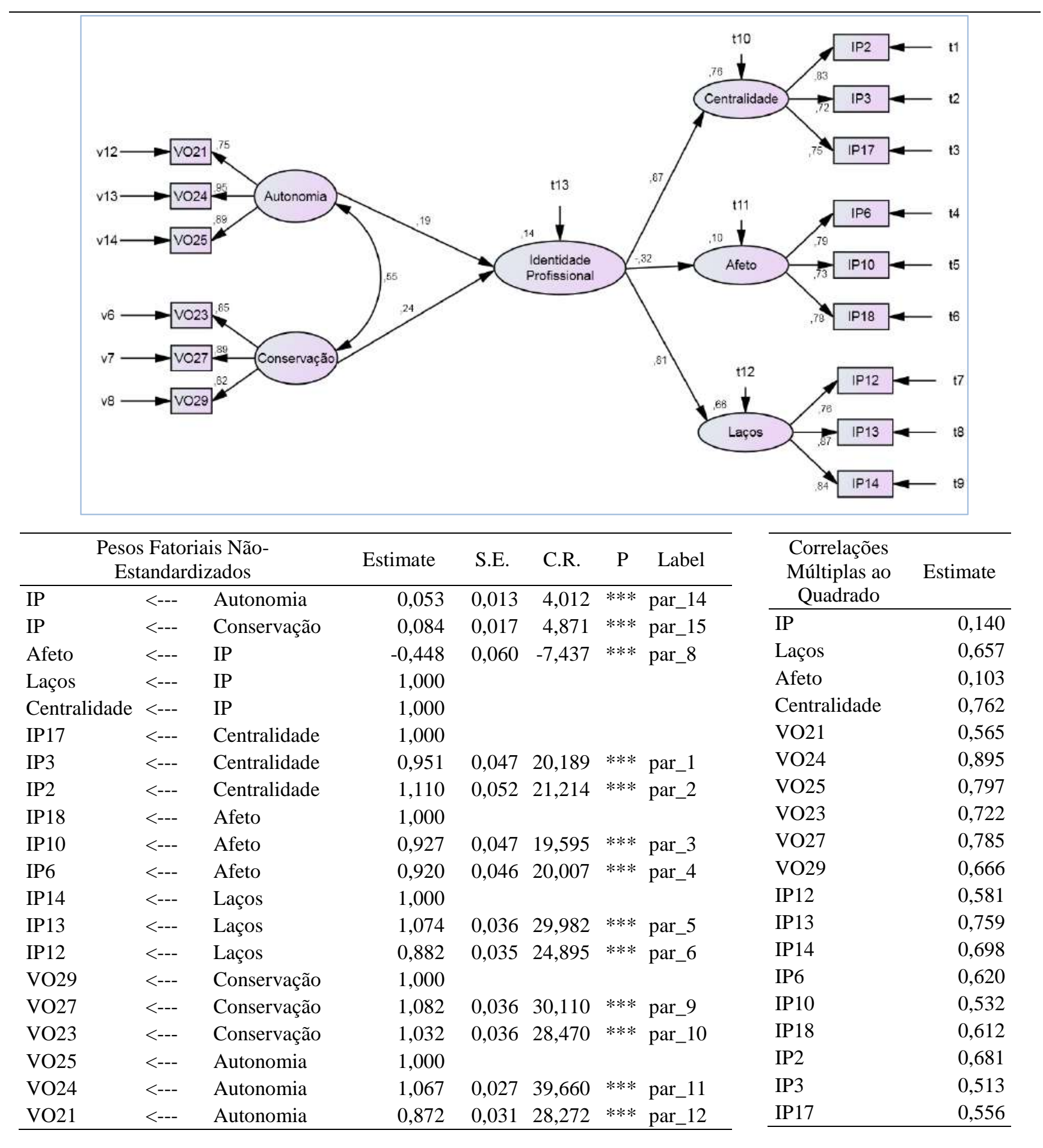

Figura 31. Modelo Autonomia x Conservação $\rightarrow$ IP (Identidade Profissional). 


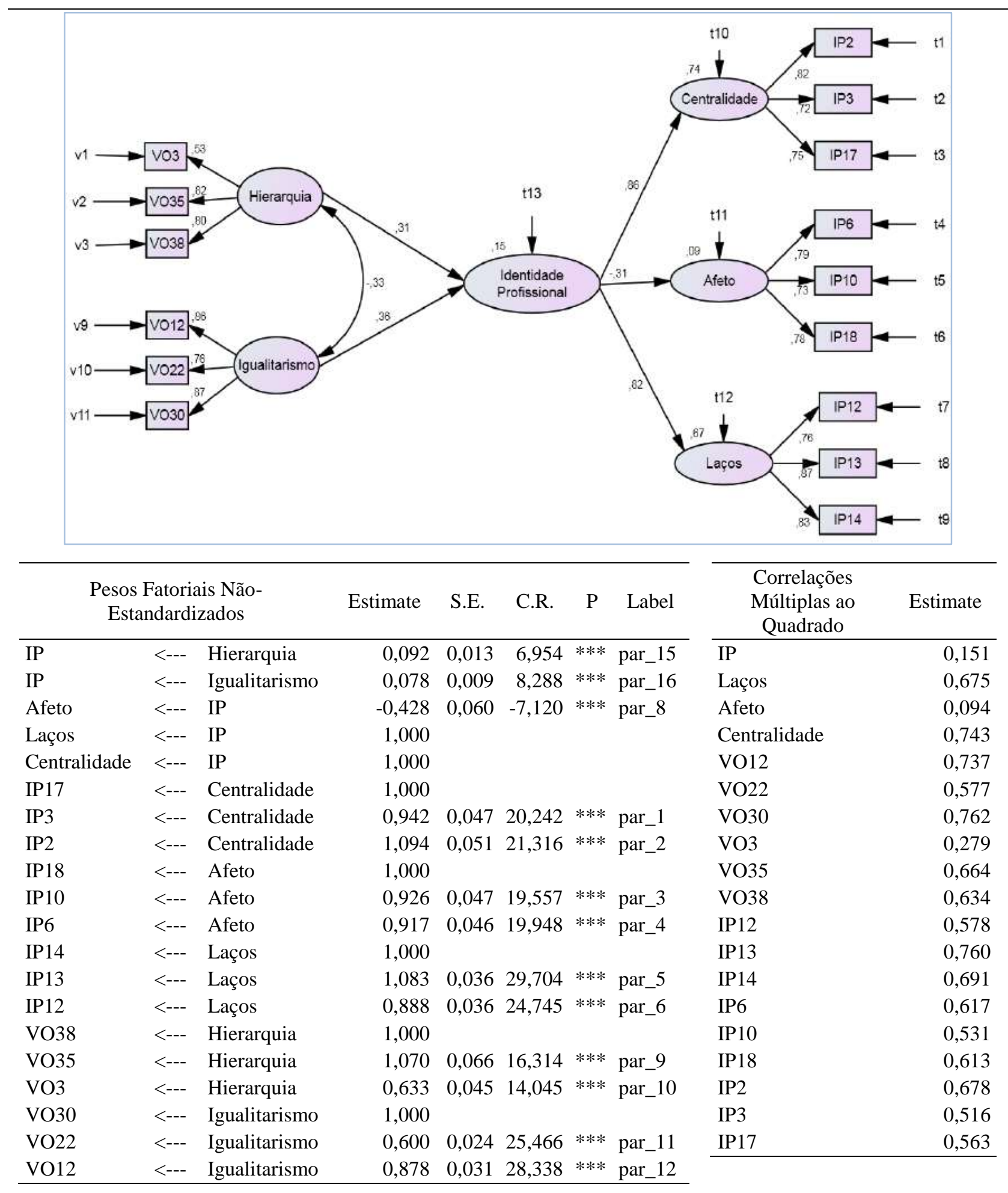

Figura 32. Modelo Hierarquia x Igualitarismo $\rightarrow I P$ (Identidade Profissional). 


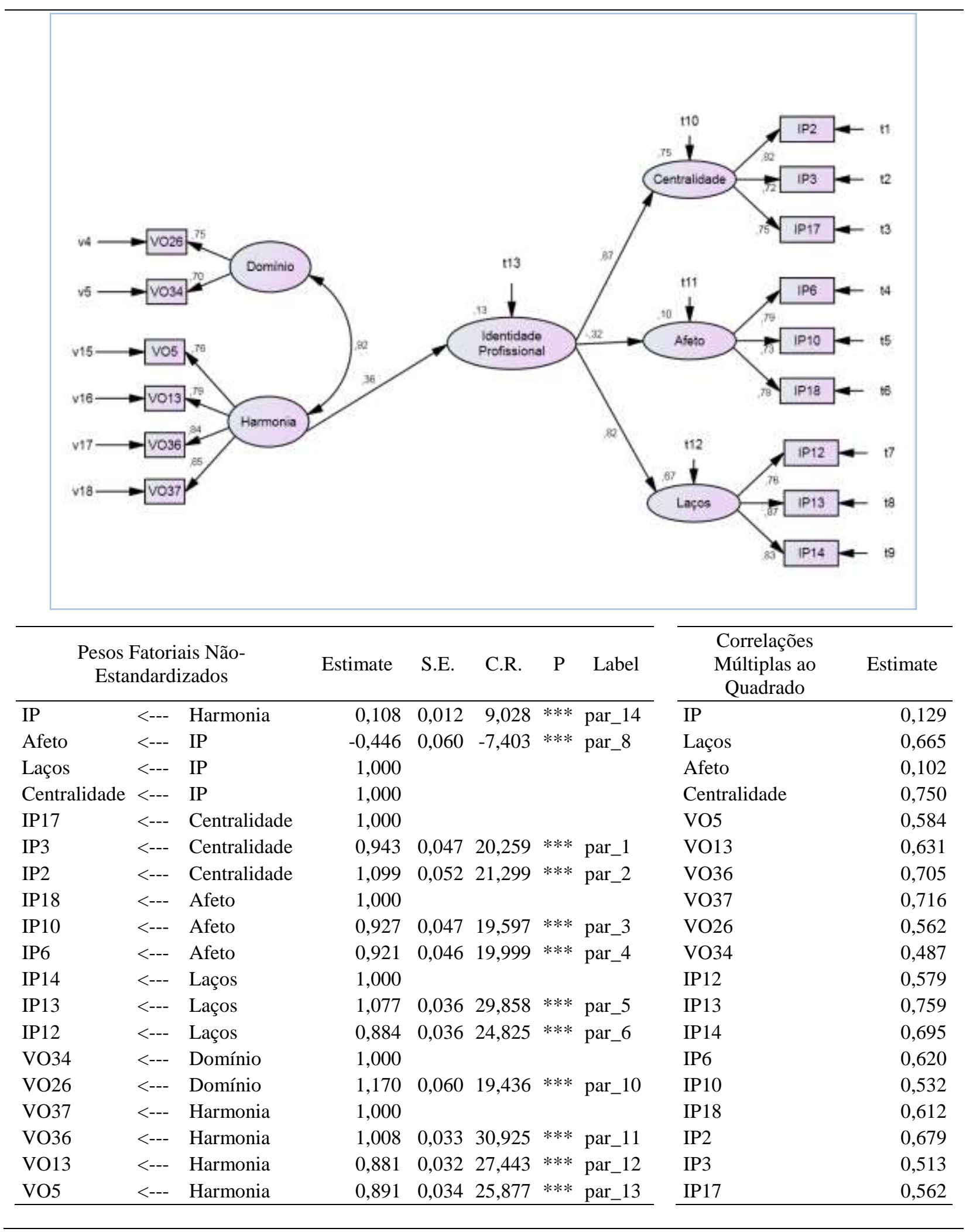

Figura 33. Modelo Domínio $x$ Harmonia $\rightarrow$ IP (Identidade Profissional). 


\section{Influência dos valores organizacionais sobre a identidade organizacional}

Buscou-se, primeiramente, averiguar a influência dos tipos motivacionais subjacentes aos valores organizacionais (VO), todos correlacionados, sobre a identidade organizacional $(\mathrm{IO}), V O \rightarrow I O$. Analisou-se, posteriormente, a associação entre as dimensões bipolares dos tipos motivacionais sobre a identidade organizacional. Foram considerados os seguintes pares: Autonomia x Conservação $\rightarrow I O$; Hierarquia $x$ Igualitarismo $\rightarrow I O$; Domínio $x$ Harmonia $\rightarrow$ IO . Como maneira de verificar a qualidade do ajuste dos dados, foram analisadas as especificações dos modelos.

$\mathrm{O}$ Modelo completo correlacionado $V O \rightarrow I O$ apresentou ajustes satisfatórios $(\mathrm{GFI}=0,92 ; \mathrm{CFI}=0,95 ; \mathrm{RMSEA}=0,059)$, sendo significativos $(\mathrm{p}<0,05)$ os tipos motivacionais conservação, igualitarismo e harmonia, responsáveis por explicar $15 \%$ da variância total da identidade organizacional $\left(\mathrm{R}^{2}=0,15\right)$.

No que se refere às dimensões bipolares, a relação Autonomia $x$ Conservação $\rightarrow I O$ foi significativa ( $\mathrm{p}<0,000 ; \mathrm{GFI}=0,98 ; \mathrm{CFI}=0,99 ; \mathrm{RMSEA}=0,043)$, explicando $12 \%$ da variância $\left(\mathrm{R}^{2}=0,12\right)$, a relação Hierarquia $x$ Igualitarismo $\rightarrow I O$ foi significativa $(\mathrm{p}<0,000$; $\mathrm{GFI}=0,97 ; \mathrm{CFI}=0,98 ; \mathrm{RMSEA}=0,048)$, explicando $10 \%$ da variância $\left(\mathrm{R}^{2}=0,10\right)$, e, por fim, a relação Domínio x Harmonia $\rightarrow I O$ só se mostrou significativa $(\mathrm{p}<0,000 ;$ GFI=0,97; $\mathrm{CFI}=0,97$; RMSEA=0,057) para o tipo motivacional harmonia; portanto, a trajetória harmonia $\rightarrow I O$ foi excluída, explicando $12 \%$ da variância $\left(\mathrm{R}^{2}=0,12\right)$.

A Tabela 50 apresenta um resumo dos índices de ajuste e as Figuras 34, 35, 36 e 37 exibem as representações gráficas de cada um dos modelos, os pesos fatoriais não estandardizados e as correlações múltiplas ao quadrado. 
Tabela 50

Índices de ajustamento da relação entre $V O \rightarrow I O$, completo e por dimensões

\begin{tabular}{|c|c|c|c|c|c|}
\hline \multicolumn{2}{|l|}{$\begin{array}{l}\text { Amostra } \\
\mathrm{N}=916\end{array}$} & $\begin{array}{c}\text { Modelo } V O \rightarrow \\
I O\end{array}$ & $\begin{array}{l}\text { Autonomia x } \\
\text { Conservação } \\
\rightarrow I O\end{array}$ & $\begin{array}{l}\text { Hierarquia } x \\
\text { Igualitarismo } \\
\rightarrow I O\end{array}$ & $\begin{array}{c}\text { Domínio } x \\
\text { Harmonia } \rightarrow \\
I O\end{array}$ \\
\hline Índices & $\chi /$ g.l. & 4,15 & 2,67 & 3,13 & 3,97 \\
\hline \multirow[t]{4}{*}{ Absolutos } & $\chi^{2} ;$ g.l. & 962,$94 ; 232$ & 133,$65 ; 50$ & 153,$29 ; 49$ & 202,$44 ; 51$ \\
\hline & $p$ & 0,000 & 0,000 & 0,000 & 0,000 \\
\hline & GFI (AGFI) & $0,92(0,90)$ & $0,98(0,96)$ & $0,97(0,96)$ & $0,97(0,95)$ \\
\hline & SRMR & 0,045 & 0,029 & 0,039 & 0,036 \\
\hline \multirow[t]{2}{*}{ Índices Relativos } & CFI & 0,95 & 0,99 & 0,98 & 0,97 \\
\hline & TLI & 0,94 & 0,98 & 0,97 & 0,97 \\
\hline Índices de & RMSEA & 0,059 & 0,043 & 0,048 & 0,057 \\
\hline $\begin{array}{l}\text { Discrepância } \\
\text { Populacional }\end{array}$ & (Lo90;Hi90) & $(0,055 ; 0,063)$ & $(0,034 ; 0,052)$ & $(0,040 ; 0,057)$ & $(0,049 ; 0,065)$ \\
\hline Índices de & PCFI & 0,80 & 0,75 & 0,73 & 0,75 \\
\hline Parcimônia & PGFI & 0,71 & 0,63 & 0,61 & 0,63 \\
\hline Índices Baseados & AIC & 1098,94 & 189,65 & 307,32 & 256,44 \\
\hline na Teoria da & ECVI & 1,20 & 0,21 & 0,34 & 0,28 \\
\hline Informação & CAIC & 1494,73 & 352,61 & 522,66 & 413,58 \\
\hline
\end{tabular}

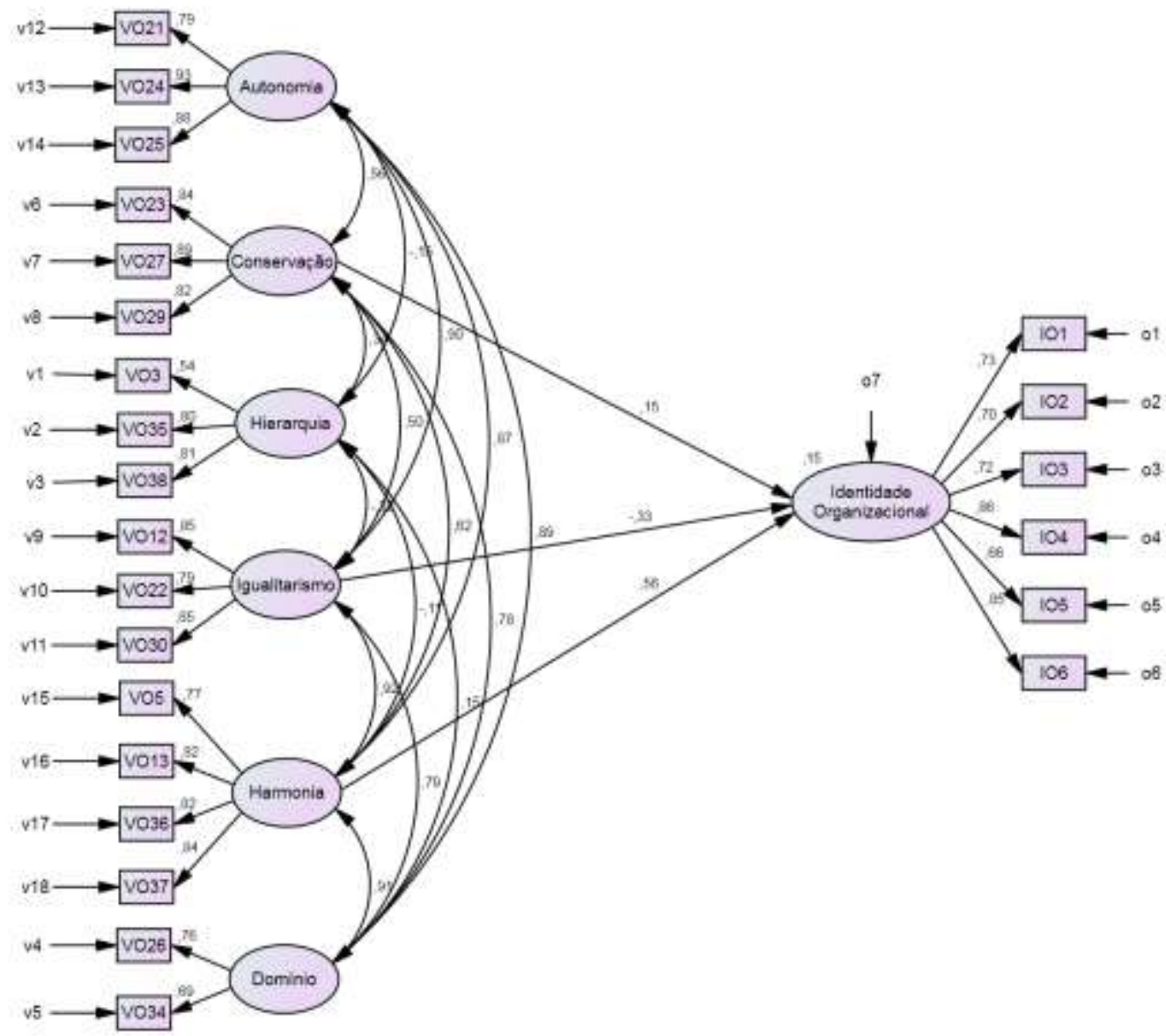




\begin{tabular}{|c|c|c|c|c|c|c|c|c|c|}
\hline \multicolumn{3}{|c|}{$\begin{array}{l}\text { Pesos Fatoriais Não- } \\
\text { Estandardizados }\end{array}$} & \multirow{2}{*}{$\begin{array}{r}\text { Estimate } \\
-0,103\end{array}$} & \multirow{2}{*}{$\begin{array}{l}\text { S.E. } \\
0,039\end{array}$} & \multirow{2}{*}{$\begin{array}{l}\text { C.R. } \\
-2,603\end{array}$} & \multirow{2}{*}{$\begin{array}{r}\mathrm{P} \\
0,009\end{array}$} & \multirow{2}{*}{$\begin{array}{c}\text { Label } \\
\text { par_17 }\end{array}$} & $\begin{array}{c}\text { Correlações } \\
\text { Múltiplas ao } \\
\text { Quadrado }\end{array}$ & \multirow{2}{*}{$\begin{array}{r}\text { Estimate } \\
, 153\end{array}$} \\
\hline $\mathrm{IO}$ & $<---$ & Igualitarismo & & & & & & $\mathrm{IO}$ & \\
\hline IO & $<---$ & Conservação & 0,071 & 0,026 & 2,759 & 0,006 & par_36 & VO26 &, 582 \\
\hline IO & $<---$ & Harmonia & 0,232 & 0,061 & 3,790 & $* * *$ & par_37 & VO34 &, 470 \\
\hline IO6 & $<---$ & IO & 1,000 & & & & & VO21 & ,621 \\
\hline IO5 & $<---$ & $\mathrm{IO}$ & 0,732 & 0,034 & 21,689 & $* * *$ & par_1 & VO24 & ,869 \\
\hline IO4 & $<---$ & $\mathrm{IO}$ & 0,976 & 0,031 & 31,431 & $* * *$ & par_2 & VO25 & ,782 \\
\hline IO3 & $<---$ & $\mathrm{IO}$ & 0,780 & 0,033 & 23,724 & $* * *$ & par_3 & VO5 &, 590 \\
\hline $\mathrm{IO} 2$ & $<---$ & $\mathrm{IO}$ & 0,780 & 0,034 & 23,048 & $* * *$ & par_4 & VO13 & ,675 \\
\hline IO1 & $<---$ & $\mathrm{IO}$ & 0,912 & 0,040 & 22,664 & $* * *$ & par_5 & VO36 & ,677 \\
\hline VO38 & $<---$ & Hierarquia & 1,000 & & & & & VO37 & ,700 \\
\hline VO35 & $<---$ & Hierarquia & 1,028 & 0,052 & 19,731 & $* * *$ & par_7 & VO23 & ,701 \\
\hline VO3 & $<---$ & Hierarquia & 0,639 & 0,043 & 14,722 & $* * *$ & par_8 & VO27 & ,794 \\
\hline VO30 & $<---$ & Igualitarismo & 1,000 & & & & & VO29 & ,678 \\
\hline VO22 & $<---$ & Igualitarismo & 0,642 & 0,022 & 28,859 & $* * *$ & par_9 & VO12 & ,730 \\
\hline VO12 & $<---$ & Igualitarismo & 0,896 & 0,027 & 33,177 & $* * *$ & par_10 & VO22 & ,628 \\
\hline VO29 & $<---$ & Conservação & 1,000 & & & & & VO30 & ,724 \\
\hline VO27 & $<---$ & Conservação & 1,079 & 0,035 & 30,987 & $* * *$ & par_12 & VO3 & ,293 \\
\hline VO23 & $<---$ & Conservação & 1,009 & 0,035 & 28,864 & $* * *$ & par_13 & VO35 & ,632 \\
\hline VO37 & $<---$ & Harmonia & 1,000 & & & & & VO38 & ,655 \\
\hline VO36 & $<---$ & Harmonia & 0,999 & 0,033 & 30,491 & $* * *$ & par_14 & IO1 &, 530 \\
\hline VO13 & $<---$ & Harmonia & 0,921 & 0,031 & 29,551 & $* * *$ & par_15 & IO2 & ,486 \\
\hline VO5 & $<---$ & Harmonia & 0,906 & 0,034 & 26,915 & $* * *$ & par_16 & IO3 &, 515 \\
\hline VO25 & $<---$ & Autonomia & 1,000 & & & & & IO4 & ,747 \\
\hline VO24 & $<---$ & Autonomia & 1,062 & 0,024 & 43,531 & $* * *$ & par_18 & IO5 & ,431 \\
\hline VO21 & $<---$ & Autonomia & 0,922 & 0,031 & 30,054 & $* * *$ & par_19 & IO6 &, 719 \\
\hline VO34 & $<---$ & Domínio & 1,000 & & & & & & \\
\hline VO26 & $<---$ & Domínio & 1,213 & 0,058 & 20,951 & $* * *$ & par_20 & & \\
\hline
\end{tabular}

Figura 34. Modelo com Tipos Motivacionais Correlacionados predizendo a Identidade Organizacional (IO). 


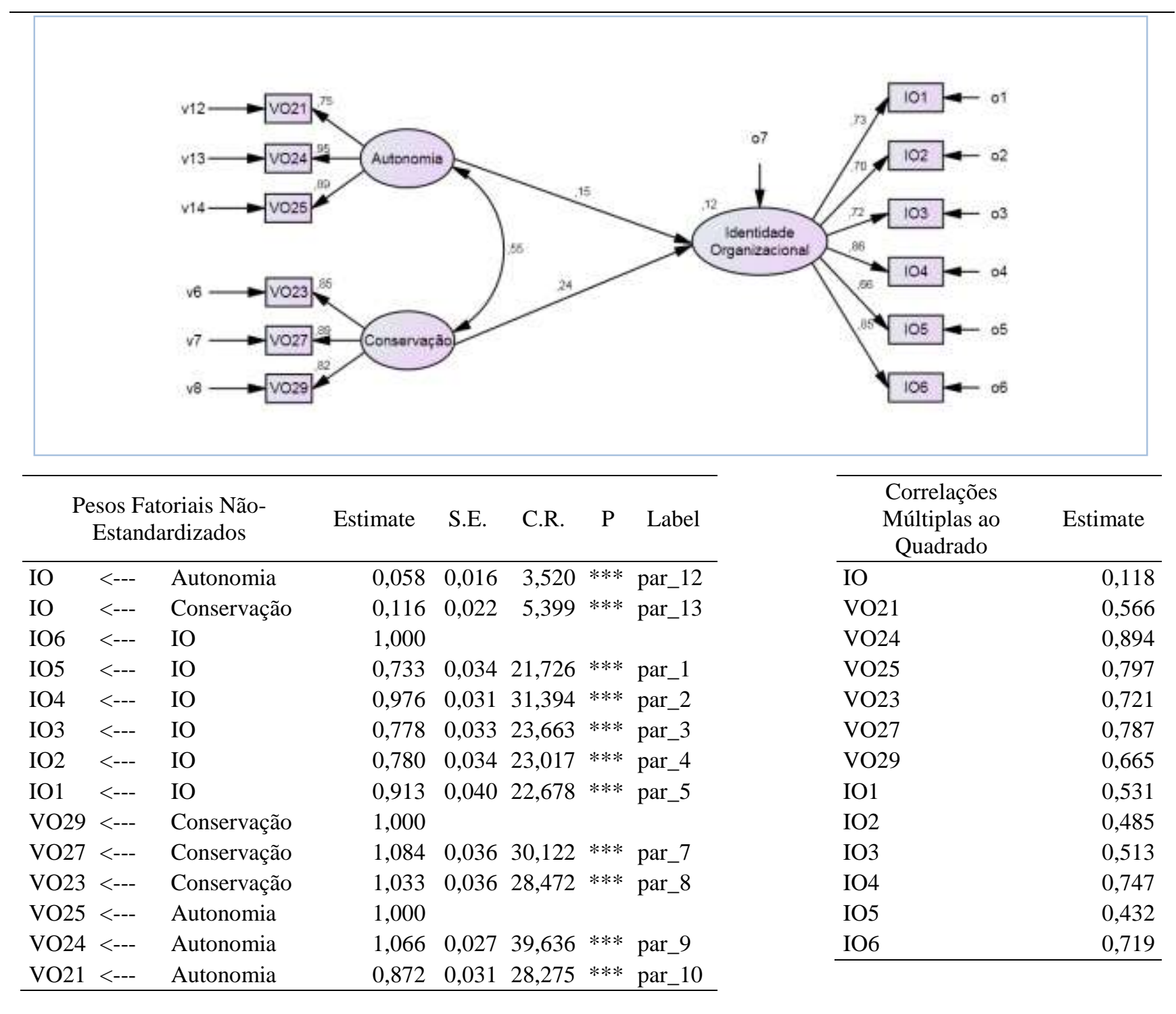

Figura 35. Modelo Autonomia x Conservação $\rightarrow$ IO (Identidade Organizacional). 


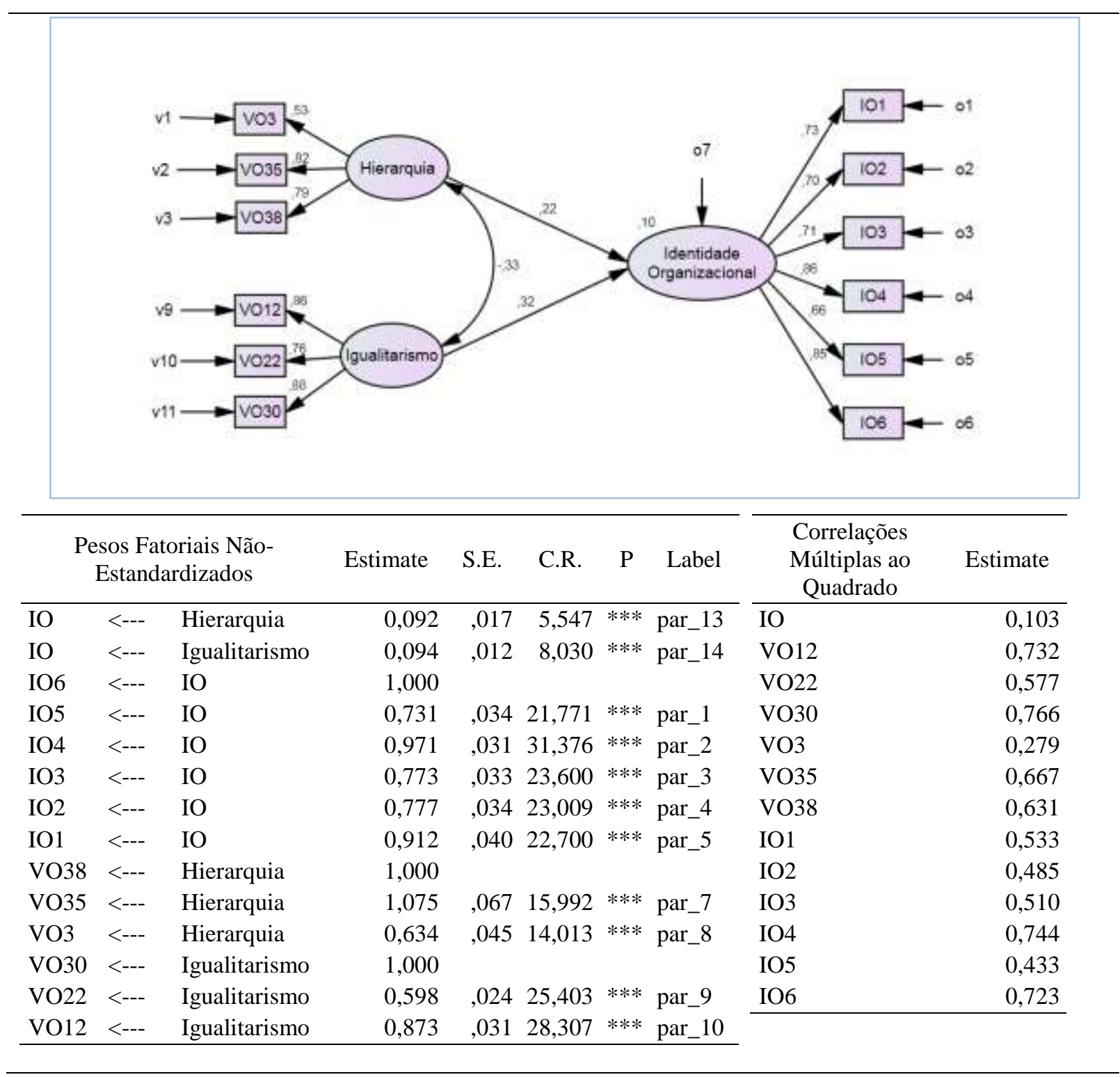

Figura 36. Modelo Hierarquia x Igualitarismo $\rightarrow I O$ (Identidade Organizacional). 


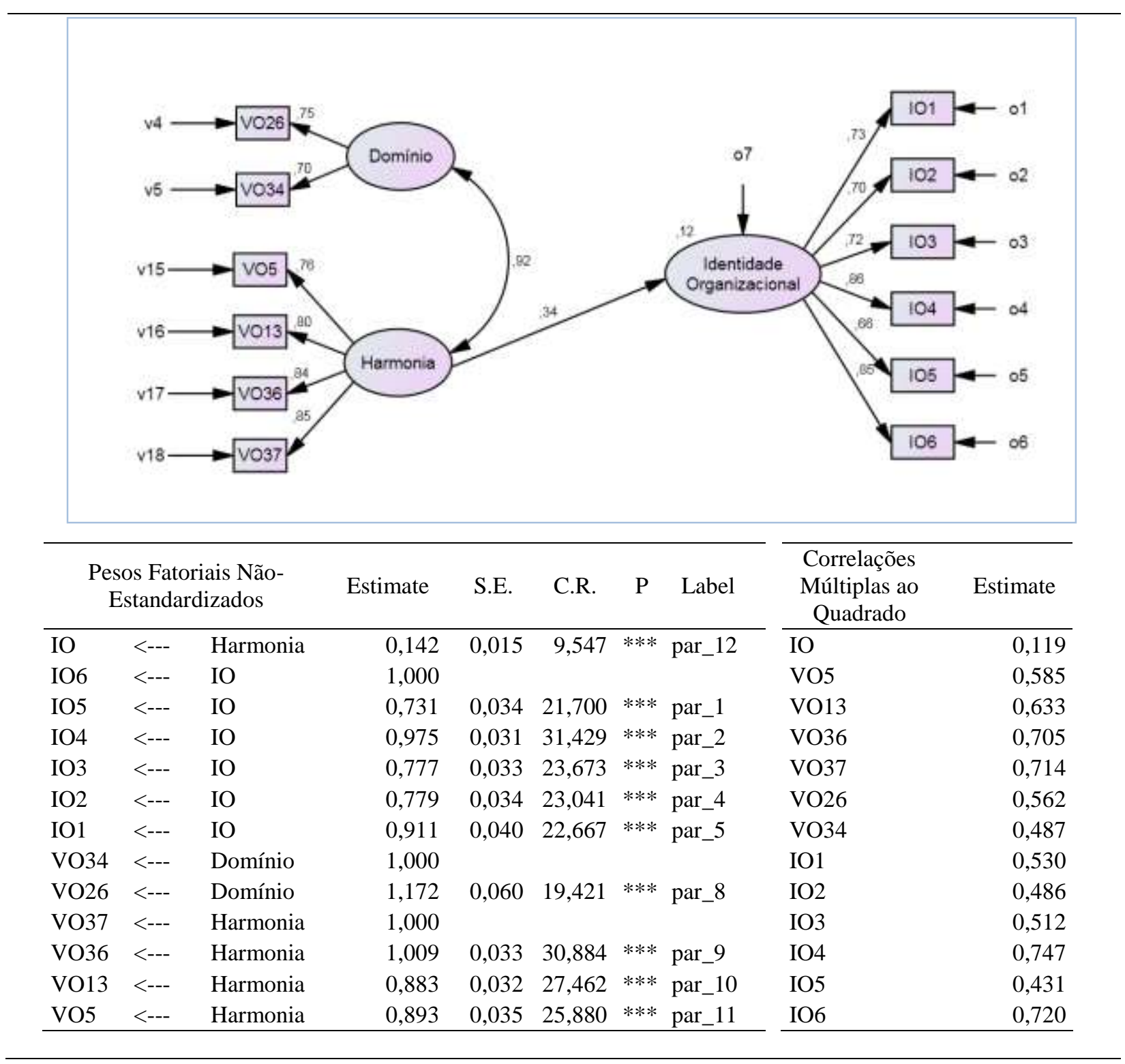

Figura 37. Modelo Domínio x Harmonia $\rightarrow$ IO (Identidade Organizacional). 


\section{Influência dos valores organizacionais sobre o desempenho profissional}

O primeiro teste buscou verificar a influência dos tipos motivacionais subjacentes aos valores organizacionais (VO), todos correlacionados ao desempenho profissional por competências (DC), $V O \rightarrow D C$. O segundo teste analisou a associação entre as dimensões bipolares dos tipos motivacionais sobre a identidade profissional. Para tanto, foram considerados os seguintes pares: Autonomia $x$ Conservação $\rightarrow D C$; Hierarquia $x$ Igualitarismo $\rightarrow D C$; Domínio $x$ Harmonia $\rightarrow D C$. Como forma de verificar a qualidade do ajustamento dos dados, foram apreciadas suas especificações.

O Modelo completo correlacionado $V O \rightarrow D C$ apresentou ajustes satisfatórios $(\mathrm{GFI}=0,91 ; \quad \mathrm{CFI}=0,94 ; \quad \mathrm{RMSEA}=0,046), \quad$ sendo significativos $\quad(\mathrm{p}<0,000)$ os tipos motivacionais conservação, igualitarismo e harmonia, responsáveis por explicar $15 \%$ da variância total do desempenho profissional por competências $\left(\mathrm{R}^{2}=0,62\right.$ para o desempenho por competências técnicas; e $\mathrm{R}^{2}=0,74$ para $\mathrm{o}$ desempenho por competências comportamentais).

No que se refere às dimensões bipolares, a relação Autonomia $x$ Conservação $\rightarrow D C$ foi significativa ( $\mathrm{p}<0,000 ; \mathrm{GFI}=0,94$; $\mathrm{CFI}=0,97$; $\mathrm{RMSEA}=0,041)$ para o tipo motivacional conservação, explicando $10 \%$ da variância do desempenho competente $\left(\mathrm{R}^{2}=0,62\right.$ para o desempenho por competências técnicas; e $\mathrm{R}^{2}=0,75$ para o desempenho por competências comportamentais), a trajetória Autonomia $\rightarrow D C$ foi excluída por não ser significativa. A relação Hierarquia $x$ Igualitarismo $\rightarrow D C$ foi significativa $(\mathrm{p}<0,000 ; \mathrm{GFI}=0,94 ; \mathrm{CFI}=0,96$; RMSEA=0,042), explicando $10 \%$ da variância do desempenho competente $\left(R^{2}=0,65\right.$ para o desempenho por competências técnicas; e $\mathrm{R}^{2}=0,71$ para o desempenho por competências comportamentais), e, por fim, a relação Domínio $x$ Harmonia $\rightarrow D C$ só se mostrou significativa ( $\mathrm{p}<0,000 ; \mathrm{GFI}=0,94 ; \mathrm{CFI}=0,96 ; \mathrm{RMSEA}=0,045)$ para o tipo motivacional harmonia, explicando $8 \%$ da variância $\left(\mathrm{R}^{2}=0,64\right.$ para o desempenho por competências técnicas; e $\mathrm{R}^{2}=0,72$ para o desempenho por competências comportamentais), e a trajetória domínio $\rightarrow D C$ foiexcluída por não ser significativa.

A Tabela 51 resume os índices de ajuste e as Figuras 38, 39, 40 e 41 exibem as representações gráficas de cada um dos modelos, os pesos fatoriais não estandardizados e as correlações múltiplas ao quadrado. 
Tabela 51

Índices de ajustamento da relação entre $V O \rightarrow D C$, completo e por dimensões

\begin{tabular}{|c|c|c|c|c|c|}
\hline $\begin{array}{l}\text { Amostra } \\
\mathrm{N}=916\end{array}$ & & $\begin{array}{c}\text { Modelo } V O \rightarrow \\
D C\end{array}$ & $\begin{array}{l}\text { Autonomia } x \\
\text { Conservação } \\
\rightarrow D C\end{array}$ & $\begin{array}{l}\text { Hierarquia } x \\
\text { Igualitarismo } \\
\rightarrow D C\end{array}$ & $\begin{array}{c}\text { Domínio } x \\
\text { Harmonia } \rightarrow \\
\text { DC }\end{array}$ \\
\hline Índices & $\chi / \mathrm{g} .1$. & 2,92 & 2,54 & 2,63 & 2,82 \\
\hline Absolutos & $\chi^{2} ;$ g.l. & 1680,$21 ; 575$ & 632,$63 ; 249$ & 648,$30 ; 247$ & 701,$74 ; 249$ \\
\hline & $p$ & 0,000 & 0,000 & 0,000 & 0,000 \\
\hline & GFI (AGFI) & $0,91(0,89)$ & $0,94(0,93)$ & $0,94(0,93)$ & $0,94(0,92)$ \\
\hline & SRMR & 0,042 & 0,038 & 0,042 & 0,040 \\
\hline Índices Relativos & $\mathrm{CFI}$ & 0,94 & 0,97 & 0,96 & 0,96 \\
\hline & TLI & 0,94 & 0,96 & 0,95 & 0,95 \\
\hline Índices de & RMSEA & 0,046 & 0,041 & 0,042 & 0,045 \\
\hline $\begin{array}{l}\text { Discrepância } \\
\text { Populacional }\end{array}$ & (Lo90;Hi90) & $(0,043 ; 0,048)$ & $(0,037 ; 0,045)$ & $(0,038 ; 0,046)$ & $(0,041 ; 0,048)$ \\
\hline Índices de & PCFI & 0,86 & 0,87 & 0,86 & 0,86 \\
\hline Parcimônia & PGFI & 0,78 & 0,78 & 0,78 & 0,78 \\
\hline Índices Baseados & AIC & 1233,20 & 734,49 & 754,30 & 803,74 \\
\hline na Teoria da & ECVI & 1,35 & 0,80 & 0,82 & 0,88 \\
\hline Informação & CAIC & 1658,06 & 1031,45 & 1062,76 & 1100,56 \\
\hline
\end{tabular}

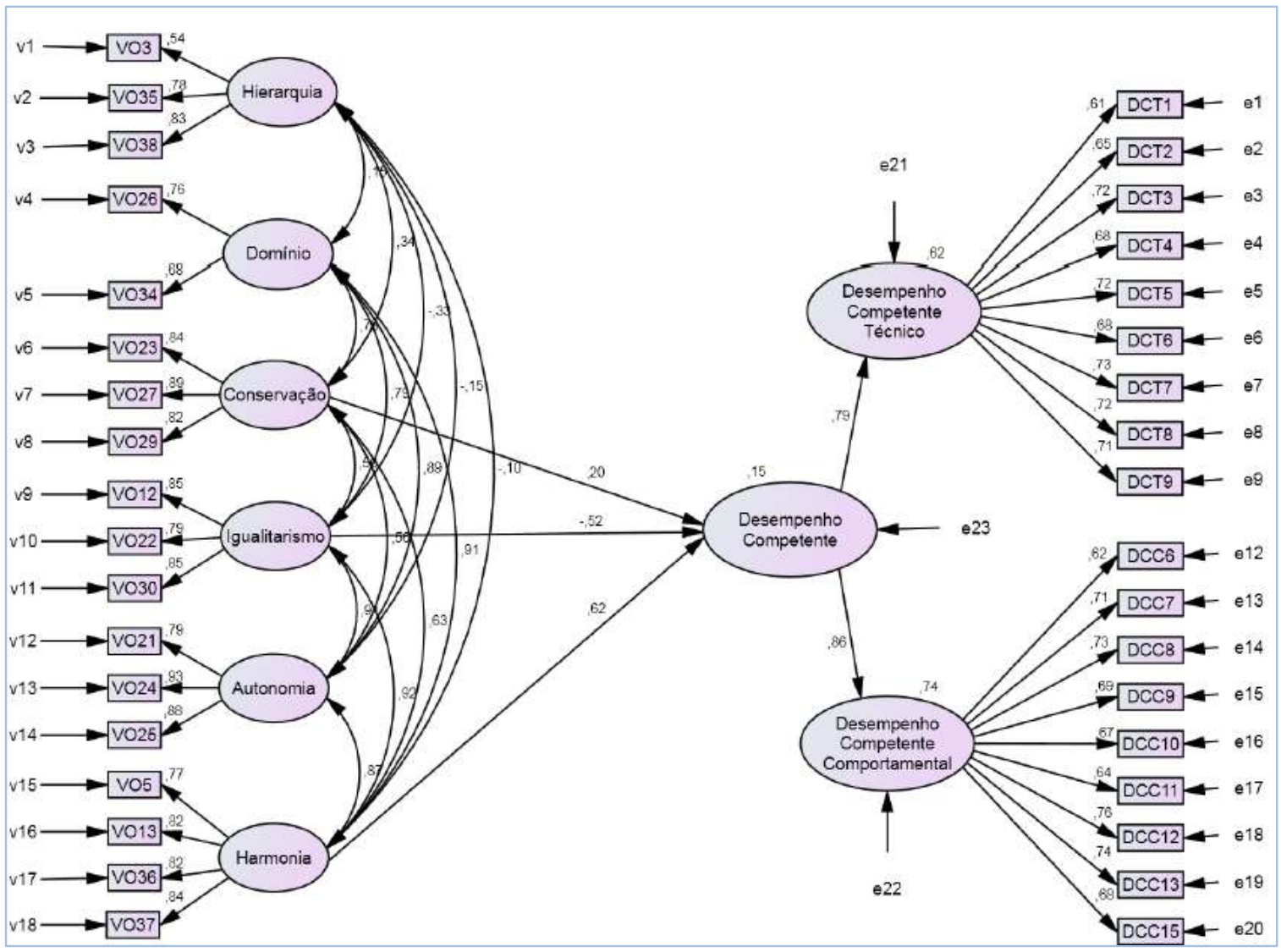




\begin{tabular}{|c|c|c|c|c|c|c|c|c|c|}
\hline \multicolumn{3}{|c|}{$\begin{array}{l}\text { Pesos Fatoriais Não- } \\
\text { Estandardizados }\end{array}$} & \multirow{2}{*}{$\begin{array}{r}\text { Estimate } \\
0,049\end{array}$} & \multirow{2}{*}{$\begin{array}{l}\text { S.E. } \\
0,015\end{array}$} & \multirow{2}{*}{$\begin{array}{l}\text { C.R. } \\
3,352\end{array}$} & \multirow{2}{*}{$\begin{array}{c}\mathrm{P} \\
* * *\end{array}$} & \multirow{2}{*}{$\begin{array}{c}\text { Label } \\
\text { par_44 }\end{array}$} & \multirow{2}{*}{$\begin{array}{c}\text { Correlações } \\
\text { Múltiplas ao } \\
\text { Quadrado }\end{array}$} & \multirow{2}{*}{$\begin{array}{r}\text { Estimate } \\
0,153\end{array}$} \\
\hline $\mathrm{DC}$ & $<--$ & Conservação & & & & & & & \\
\hline DC & $<--$ & Igualitarismo & $-0,080$ & 0,022 & $-3,695$ & $* * *$ & par_45 & DCC & 0,737 \\
\hline DC & $<---$ & Harmonia & 0,131 & 0,034 & 3,839 & $* * *$ & par_46 & DCT & 0,625 \\
\hline DCT & $<---$ & DC & 1,000 & & & & & VO37 & 0,699 \\
\hline DCC & $<--$ & DC & 1,000 & & & & & VO36 & 0,677 \\
\hline DCT9 & $<---$ & DCT & 1,000 & & & & & VO5 & 0,591 \\
\hline DCT8 & $<---$ & DCT & 0,946 & 0,045 & 21,203 & $* * *$ & par_1 & VO13 & 0,674 \\
\hline DCT7 & $<--$ & DCT & 1,006 & 0,048 & 21,153 & $* * *$ & par_2 & VO21 & 0,622 \\
\hline DCT6 & $<---$ & DCT & 0,907 & 0,046 & 19,607 & $* * *$ & par_3 & VO24 & 0,868 \\
\hline DCT5 & $<--$ & DCT & 1,024 & 0,049 & 20,992 & $* * *$ & par_4 & VO25 & 0,782 \\
\hline DCT4 & $<--$ & DCT & 0,913 & 0,046 & 19,671 & $* * *$ & par_5 & VO12 & 0,724 \\
\hline DCT3 & $<---$ & DCT & 0,988 & 0,047 & 21,012 & $* * *$ & par_6 & VO22 & 0,625 \\
\hline DCT2 & $<--$ & DCT & 0,837 & 0,044 & 18,931 & $* * *$ & par_7 & VO30 & 0,731 \\
\hline DCT1 & $<--$ & DCT & 0,809 & 0,046 & 17,758 & $* * *$ & par_8 & VO23 & 0,704 \\
\hline DCC13 & $<--$ & DCC & 1,000 & & & & & VO27 & 0,791 \\
\hline DCC12 & $<--$ & DCC & 0,984 & 0,042 & 23,430 & $* * *$ & par_9 & VO29 & 0,677 \\
\hline DCC11 & $<--$ & DCC & 0,892 & 0,047 & 19,123 & $* * *$ & par_10 & VO26 & 0,585 \\
\hline DCC10 & $<---$ & DCC & 0,891 & 0,044 & 20,309 & $* * *$ & par_11 & VO34 & 0,468 \\
\hline DCC9 & $<--$ & DCC & 0,972 & 0,047 & 20,697 & $* * *$ & par_12 & VO3 & 0,288 \\
\hline DCC8 & $<--$ & DCC & 0,995 & 0,045 & 21,944 & $* * *$ & par_13 & VO35 & 0,616 \\
\hline DCC7 & $<--$ & DCC & 0,993 & 0,047 & 21,220 & $* * *$ & par_14 & VO38 & 0,685 \\
\hline DCC6 & $<---$ & DCC & 0,883 & 0,048 & 18,325 & $* * *$ & par_15 & DCC15 & 0,469 \\
\hline DCC15 & $<--$ & DCC & 0,983 & 0,047 & 20,733 & $* * *$ & par_16 & DCC6 & 0,380 \\
\hline VO38 & $<--$ & Hierarquia & 1,000 & & & & & DCC7 & 0,500 \\
\hline VO35 & $<--$ & Hierarquia & 0,985 & 0,048 & 20,683 & $* * *$ & par_17 & DCC8 & 0,529 \\
\hline VO3 & $<--$ & Hierarquia & 0,615 & 0,041 & 14,862 & $* * *$ & par_18 & DCC9 & 0,472 \\
\hline VO34 & $<--$ & Domínio & 1,000 & & & & & DCC10 & 0,452 \\
\hline VO26 & $<---$ & Domínio & 1,219 & 0,058 & 20,924 & $* * *$ & par_19 & DCC11 & 0,408 \\
\hline VO29 & $<---$ & Conservação & 1,000 & & & & & DCC12 & 0,577 \\
\hline VO27 & $<--$ & Conservação & 1,077 & 0,035 & 30,992 & $* * *$ & par_21 & DCC13 & 0,551 \\
\hline VO23 & $<--$ & Conservação & 1,011 & 0,035 & 28,916 & $* * *$ & par_22 & DCT1 & 0,374 \\
\hline VO30 & $<---$ & Igualitarismo & 1,000 & & & & & DCT2 & 0,422 \\
\hline $\mathrm{VO} 22$ & $<--$ & Igualitarismo & 0,637 & 0,022 & 28,961 & $* * *$ & par_25 & DCT3 & 0,522 \\
\hline VO12 & $<--$ & Igualitarismo & 0,888 & 0,027 & 33,277 & $* * *$ & par_26 & DCT4 & 0,462 \\
\hline VO25 & $<---$ & Autonomia & 1,000 & & & & & DCT5 & 0,525 \\
\hline VO24 & $<--$ & Autonomia & 1,061 & 0,024 & 43,491 & $* * *$ & par_30 & DCT6 & 0,461 \\
\hline VO21 & $<--$ & Autonomia & 0,923 & 0,031 & 30,081 & $* * *$ & par_31 & DCT7 & 0,526 \\
\hline VO13 & $<---$ & Harmonia & 0,922 & 0,032 & 29,000 & $* * *$ & par_36 & DCT8 & 0,525 \\
\hline VO5 & $<--$ & Harmonia & 0,908 & 0,034 & 26,559 & $* * *$ & par_37 & DCT9 & 0,505 \\
\hline VO37 & $<--$ & Harmonia & 1,001 & 0,033 & 30,465 & $* * *$ & par_43 & & \\
\hline VO36 & $<---$ & Harmonia & 1,000 & & & & & & \\
\hline
\end{tabular}

Figura 38. Modelo com Tipos Motivacionais Correlacionados predizendo o desempenho por competências. 


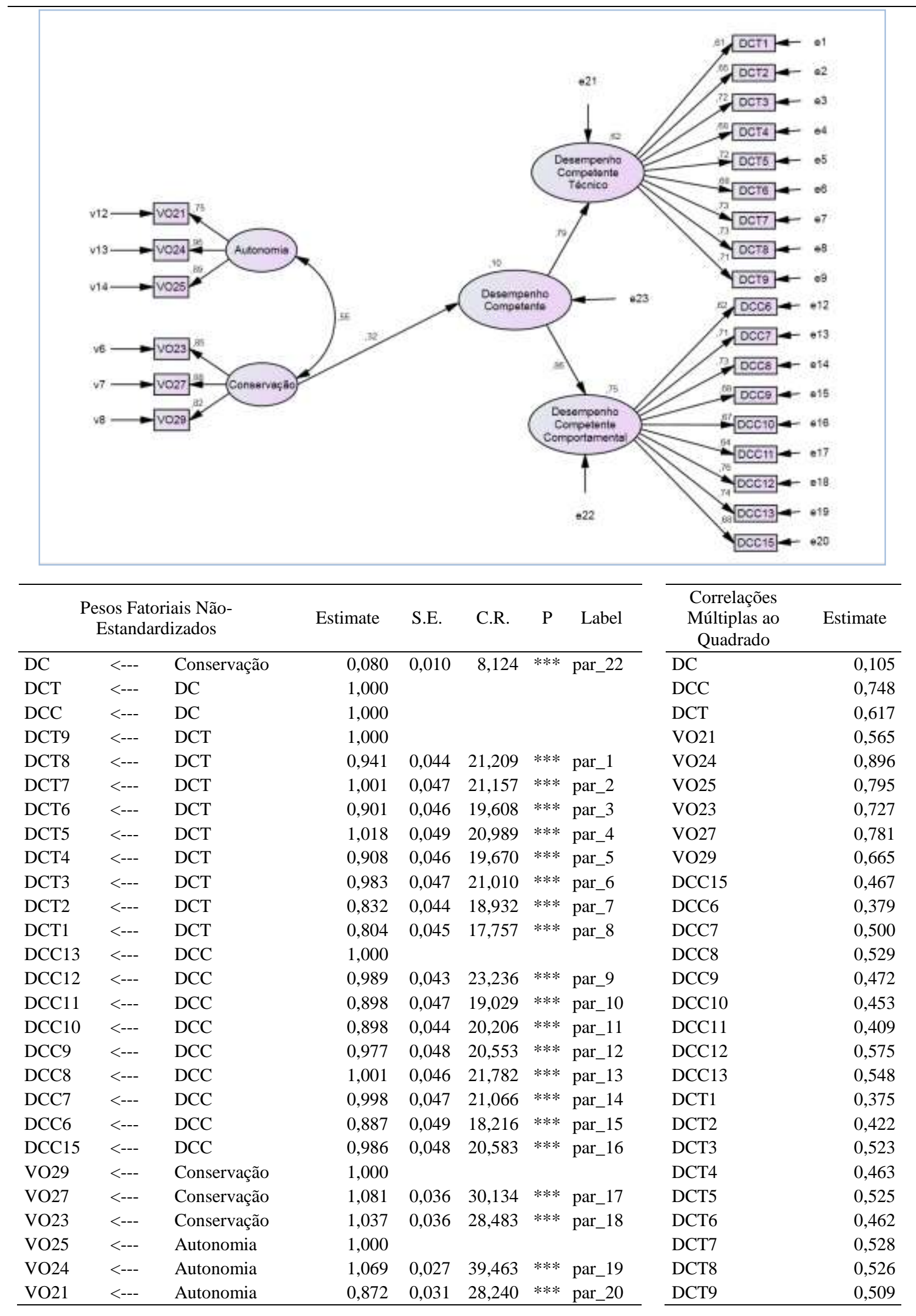

Figura 39. Modelo Autonomia x Conservação $\rightarrow D C$. 


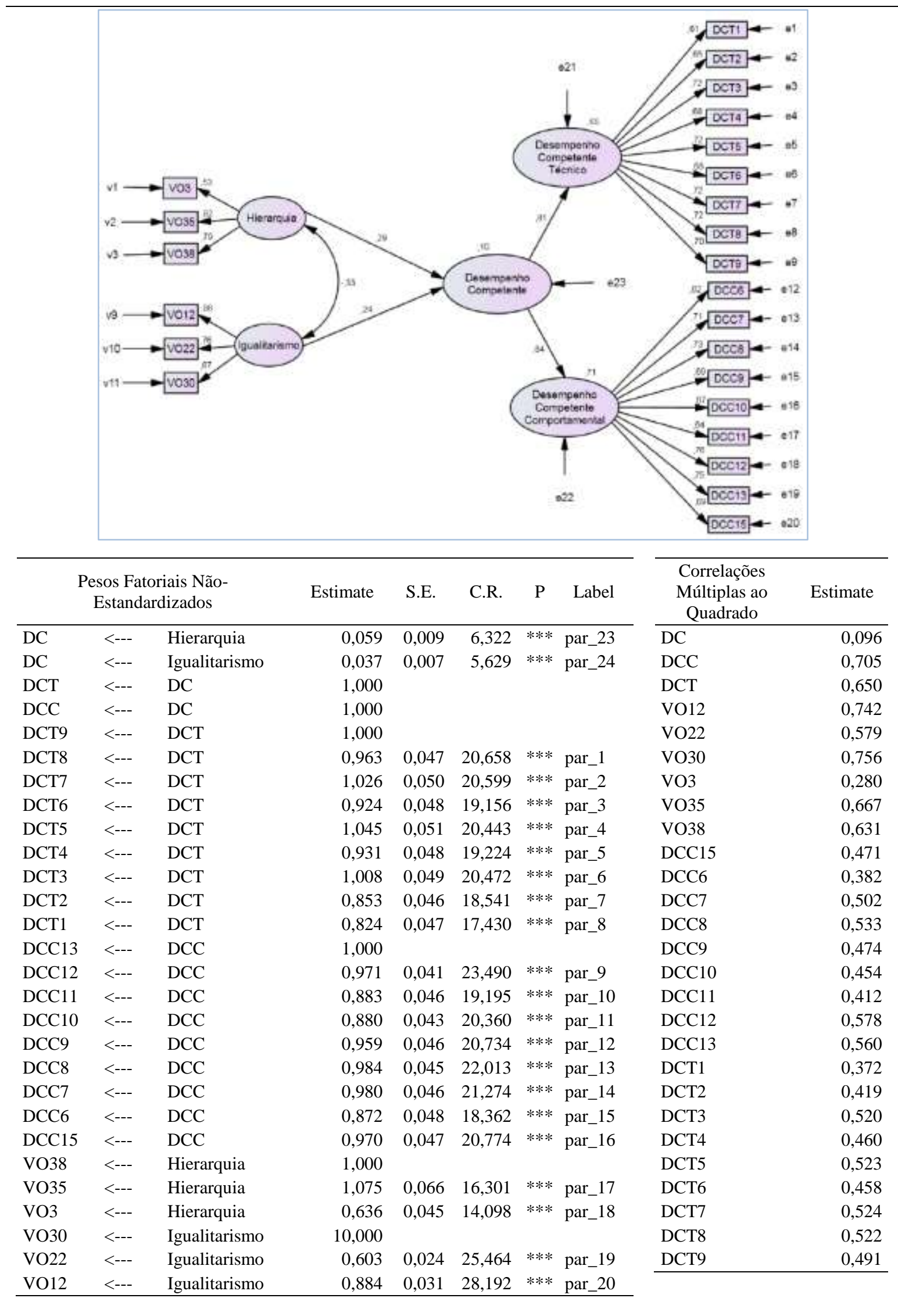

Figura 40. Modelo Autonomia $x$ Conservação $\rightarrow D C$. 


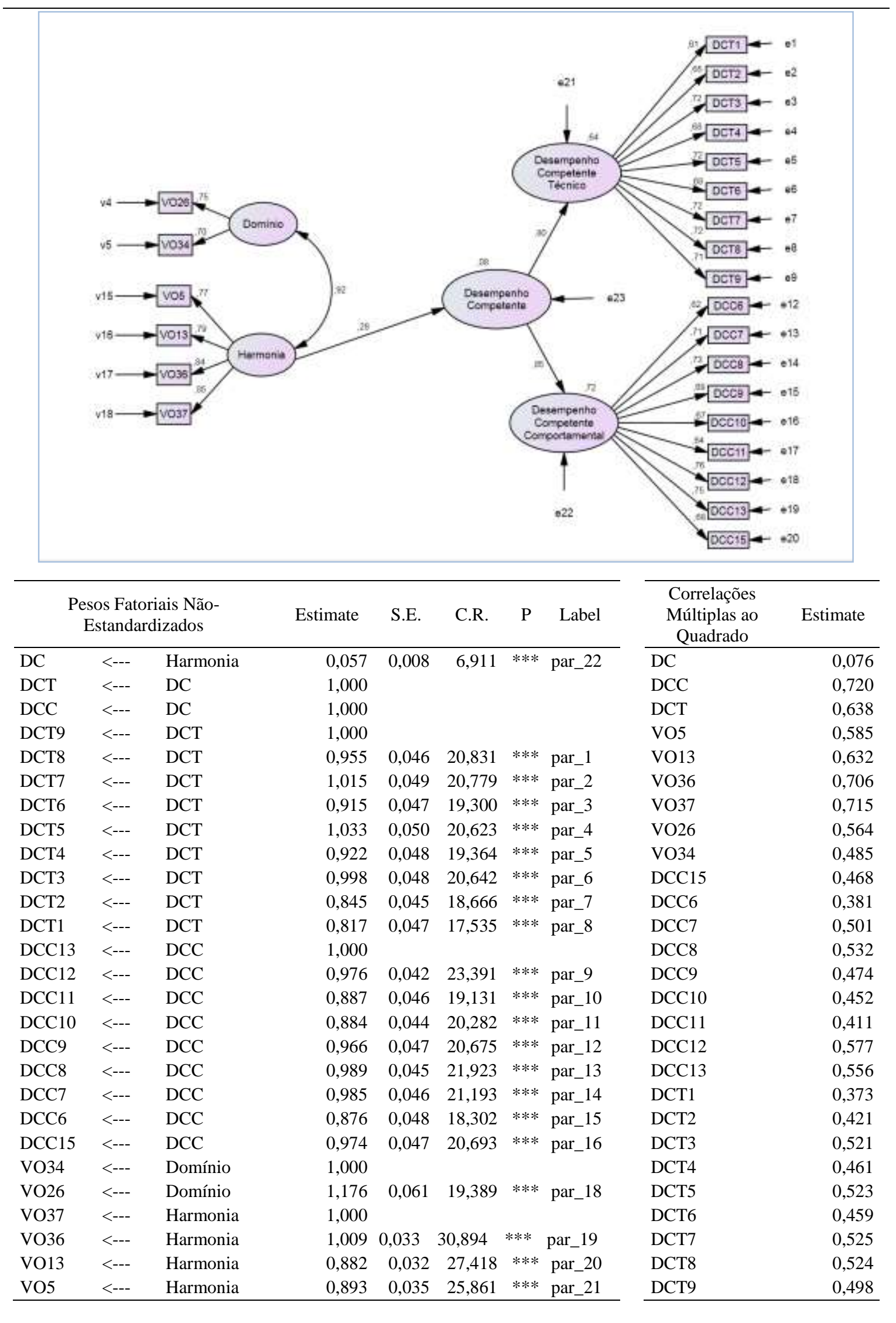

Figura 41. Modelo Domínio $x$ Harmonia $\rightarrow D C$. 


\section{Influência das práticas organizacionais sobre a identidade Profissional}

Nesta etapa, estuda-se a influência das práticas organizacionais (PO) sobre a identidade profissional (IP), $P O \rightarrow I P$. Como forma de verificar a qualidade do ajuste dos dados, foram testados um modelo geral correlacional e, em seguida, cada dimensão específica da prática organizacional, para confirmar seu poder de predição na regressão simples, como forma de se averiguar a parcimônia.

No primeiro teste, o modelo completo correlacionado $P O \rightarrow I P$ apresentou ajustes satisfatórios $(\mathrm{GFI}=0,91 ; \mathrm{CFI}=0,93 ; \mathrm{RMSEA}=0,047)$, sendo significativas $(\mathrm{p}<0,05)$ as práticas regulação e definição de responsabilidades, responsáveis por explicar $42 \%$ da variância total da identidade profissional $\left(\mathrm{R}^{2}=0,75\right.$ para a dimensão centralidade; $\mathrm{R}^{2}=0,08$ para a dimensão afeto; $\mathrm{R}^{2}=0,67$ para a dimensão laços).

O teste da relação prática de Recompensas e Punições $\rightarrow I P$ foi significativo $(\mathrm{p}<0,000$; GFI=0,95; CFI=0,96; RMSEA=0,047), explicando $19 \%$ da variância da identidade profissional $\left(\mathrm{R}^{2}=0,76\right.$ para a dimensão centralidade; $\mathrm{R}^{2}=0,08$ para a dimensão afeto; $\mathrm{R}^{2}=0,68$ para a dimensão laços $). \quad \mathrm{O}$ teste Regulação $\rightarrow I P(\mathrm{p}<0,000 ; \quad \mathrm{GFI}=0,98 ; \quad \mathrm{CFI}=0,98$; RMSEA=0,041) mostrou que a prática de regulação é responsável por uma explicação de $42 \%$ da identidade profissional $\left(\mathrm{R}^{2}=0,87\right.$ para a dimensão centralidade; $\mathrm{R}^{2}=0,09$ para a dimensão afeto; $\mathrm{R}^{2}=0,58$ para a dimensão laços).

A relação Senso de Dever $\rightarrow I P$ apresentou-se significativa $(\mathrm{p}<0,000 ;$ GFI=0,97; $\mathrm{CFI}=0,97$; RMSEA=0,048), explicando $23 \%$ da variância da identidade profissional $\left(\mathrm{R}^{2}=0,95\right.$ para a dimensão centralidade; $\mathrm{R}^{2}=0,09$ para a dimensão afeto; $\mathrm{R}^{2}=0,53$ para a dimensão laços). O teste Relações de Autoridade $\rightarrow I P$ foi significativo ( $\mathrm{p}<0,000 ; \mathrm{GFI}=0,98 ; \mathrm{CFI}=0,98$; RMSEA=0,041), explicando $15 \%$ da variância da identidade profissional $\left(\mathrm{R}^{2}=0,89\right.$ para a dimensão centralidade; $\mathrm{R}^{2}=0,10$ para a dimensão afeto; $\mathrm{R}^{2}=0,57$ para a dimensão laços).

Para Qualidade da Cooperação $\rightarrow I P$ o teste se mostrou significativo $(\mathrm{p}<0,000$; GFI=0,98; CFI=0,99; RMSEA=0,048), responsável por explicar 25\% da variância total da identidade profissional $\left(\mathrm{R}^{2}=0,95\right.$ para a dimensão centralidade; $\mathrm{R}^{2}=0,10$ para a dimensão afeto; $\mathrm{R}^{2}=0,53$ para a dimensão laços). Por fim, o teste Definição de Responsabilidade $\rightarrow I P$ não se mostrou significativo $(\mathrm{p}=0,146)$.

A Tabela 52 apresenta um resumo dos índices de ajuste e as Figuras de 42 a 48 exibem a representação gráfica dos modelos, os pesos fatoriais não estandardizados e as correlações múltiplas ao quadrado. 


\section{Tabela 52}

Índices de ajustamento da relação entre $P O \rightarrow I P$

\begin{tabular}{|c|c|c|c|c|c|c|c|c|}
\hline $\begin{array}{l}\text { Amostra } \\
\mathrm{N}=916\end{array}$ & & $\begin{array}{c}\text { Modelo } P O \rightarrow \\
I P\end{array}$ & $\begin{array}{c}\text { Modelo } R P \rightarrow \\
I P\end{array}$ & $\begin{array}{c}\text { Modelo } R E G \rightarrow \\
I P\end{array}$ & $\begin{array}{c}\text { Modelo } S D \rightarrow \\
I P\end{array}$ & $\begin{array}{c}\text { Modelo } R A \rightarrow \\
I P\end{array}$ & $\begin{array}{c}\text { Modelo } Q C \rightarrow \\
I P\end{array}$ & $\begin{array}{c}\text { Modelo } D R \rightarrow \\
I P\end{array}$ \\
\hline $\begin{array}{l}\text { Índices } \\
\text { Absolutos }\end{array}$ & $\begin{array}{l}\chi / \mathrm{g} .1 . \\
\chi^{2} ; \mathrm{g} .1 . \\
p \\
\text { GFI (AGFI) } \\
\text { SRMR }\end{array}$ & $\begin{array}{c}3,04 \\
1639,88 ; 540 \\
0,000 \\
0,91(0,89) \\
0,055\end{array}$ & $\begin{array}{c}2,90 \\
478,67 ; 165 \\
0,000 \\
0,95(0,94) \\
0,056\end{array}$ & $\begin{array}{c}2,51 \\
150,64 ; 60 \\
0,000 \\
0,98(0,96) \\
0,036\end{array}$ & $\begin{array}{c}3,14 \\
188,24 ; 60 \\
0,000 \\
0,97(0,95) \\
0,047\end{array}$ & $\begin{array}{c}2,53 \\
124,04 ; 49 \\
0,000 \\
0,98(0,97) \\
0,037\end{array}$ & $\begin{array}{c}2,55 \\
99,62 ; 39 \\
0,000 \\
0,98(0,97) \\
0,029\end{array}$ & $\begin{array}{c}5,75 \\
235,59 ; 41 \\
0,000 \\
0,96(0,93) \\
0,077\end{array}$ \\
\hline Índices Relativos & $\begin{array}{l}\text { CFI } \\
\text { TLI }\end{array}$ & $\begin{array}{l}0,93 \\
0,92\end{array}$ & $\begin{array}{l}0,97 \\
0,96\end{array}$ & $\begin{array}{l}0,98 \\
0,98\end{array}$ & $\begin{array}{l}0,97 \\
0,97\end{array}$ & $\begin{array}{l}0,98 \\
0,98\end{array}$ & $\begin{array}{l}0,99 \\
0,98\end{array}$ & $\begin{array}{l}0,95 \\
0,93\end{array}$ \\
\hline $\begin{array}{l}\text { Índices de } \\
\text { Discrepância } \\
\text { Populacional }\end{array}$ & $\begin{array}{l}\text { RMSEA } \\
\text { (Lo90;Hi90) }\end{array}$ & $\begin{array}{c}0,047 \\
(0,045 ; 0,050)\end{array}$ & $\begin{array}{c}0,046 \\
(0,041 ; 0,050)\end{array}$ & $\begin{array}{c}0,041 \\
(0,033 ; 0,049)\end{array}$ & $\begin{array}{c}0,048 \\
(0,041 ; 0,056)\end{array}$ & $\begin{array}{c}0,041 \\
(0,032 ; 0,050)\end{array}$ & $\begin{array}{c}0,041 \\
(0,031 ; 0,051)\end{array}$ & $\begin{array}{c}0,072 \\
(0,063 ; 0,081)\end{array}$ \\
\hline $\begin{array}{l}\text { Índices de } \\
\text { Parcimônia }\end{array}$ & $\begin{array}{l}\text { PCFI } \\
\text { PGFI }\end{array}$ & $\begin{array}{l}0,84 \\
0,78\end{array}$ & $\begin{array}{l}0,84 \\
0,75\end{array}$ & $\begin{array}{l}0,75 \\
0,64\end{array}$ & $\begin{array}{l}0,75 \\
0,64\end{array}$ & $\begin{array}{l}0,73 \\
0,61\end{array}$ & $\begin{array}{l}0,70 \\
0,58\end{array}$ & $\begin{array}{l}0,71 \\
0,60\end{array}$ \\
\hline $\begin{array}{l}\text { Índices Baseados } \\
\text { na Teoria da } \\
\text { Informação }\end{array}$ & $\begin{array}{l}\text { AIC } \\
\text { ECVI } \\
\text { CAIC }\end{array}$ & $\begin{array}{c}1819,88 \\
1,99 \\
845,60\end{array}$ & $\begin{array}{c}568,67 \\
0,62 \\
830,57\end{array}$ & $\begin{array}{c}212,64 \\
0,23 \\
393,06\end{array}$ & $\begin{array}{c}250,24 \\
0,27 \\
430,66\end{array}$ & $\begin{array}{c}182,04 \\
0,20 \\
350,83\end{array}$ & $\begin{array}{c}153,62 \\
0,17 \\
310,76\end{array}$ & $\begin{array}{c}285,59 \\
0,31 \\
431,09\end{array}$ \\
\hline
\end{tabular}

RP: Recompensas e Punições; REG: Regulação; SD: Senso de Dever; RA: Relações de Autoridade; QC: Qualidade da Cooperação; DR: Definição de Rsponsabilidades. 


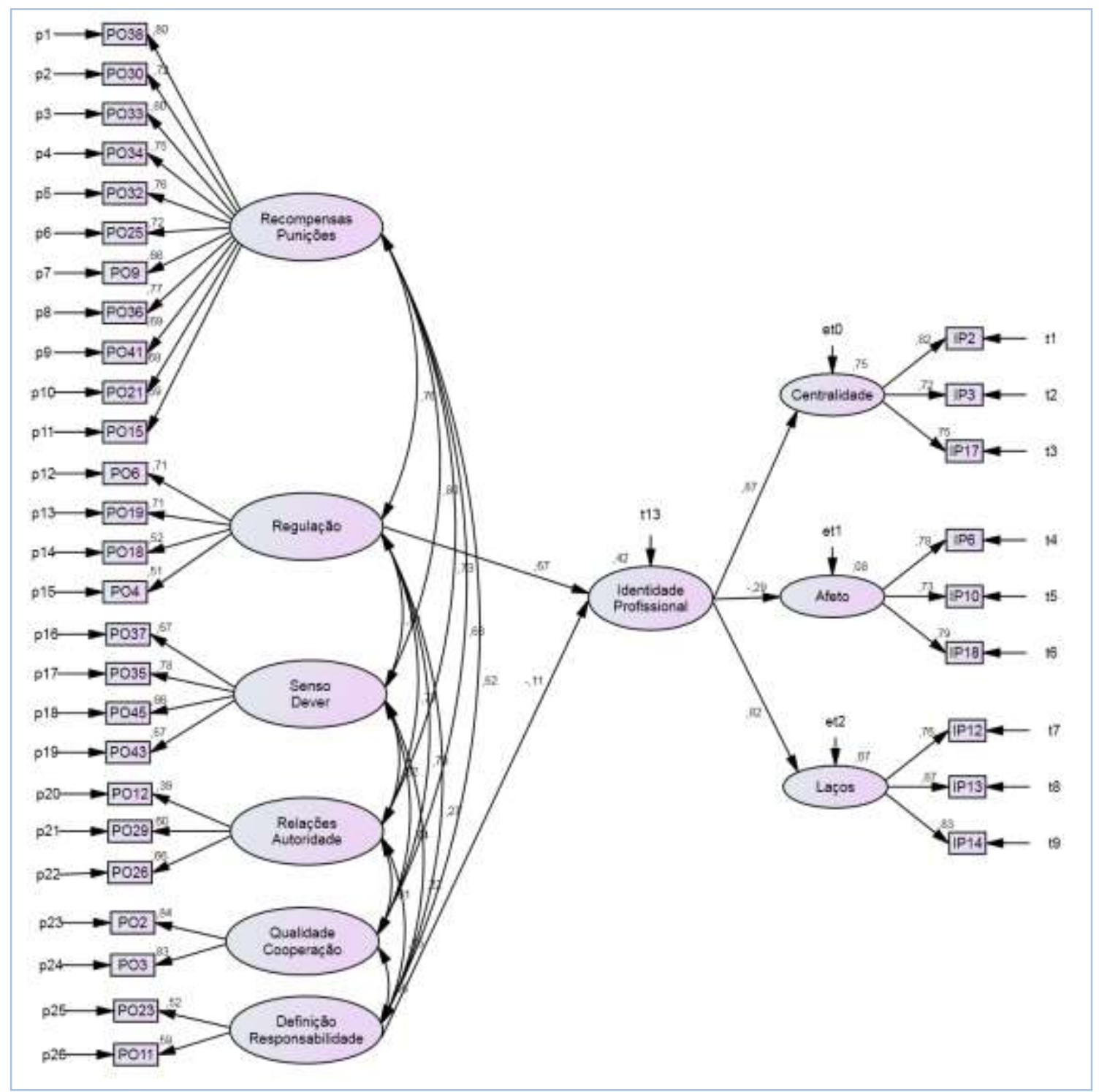




\begin{tabular}{|c|c|c|c|c|c|c|c|c|c|}
\hline \multicolumn{3}{|c|}{$\begin{array}{l}\text { Pesos Fatoriais Não- } \\
\text { Estandardizados }\end{array}$} & \multirow{2}{*}{$\begin{array}{r}\text { Estimate } \\
0,671\end{array}$} & \multirow{2}{*}{$\begin{array}{c}\text { S.E. } \\
0,047\end{array}$} & \multirow{2}{*}{$\begin{array}{c}\text { C.R. } \\
14,268\end{array}$} & \multirow{2}{*}{$\begin{array}{c}\mathrm{P} \\
* * *\end{array}$} & \multirow{2}{*}{$\begin{array}{c}\text { Label } \\
\text { par_44 }\end{array}$} & \multirow{2}{*}{$\begin{array}{c}\begin{array}{c}\text { Correlações } \\
\text { Múltiplas ao } \\
\text { Quadrado }\end{array} \\
\text { IP }\end{array}$} & \multirow{2}{*}{$\begin{array}{r}\text { Estimate } \\
0,422\end{array}$} \\
\hline IP & $<---$ & REG & & & & & & & \\
\hline IP & $<--$ & DR & $-0,135$ & 0,065 & $-2,094$ & 0,036 & par_45 & Laços & 0,674 \\
\hline Afeto & $<--$ & IP & $-0,407$ & 0,059 & $-6,853$ & $* * *$ & par_43 & Afeto & 0,084 \\
\hline Centralidade & $<--$ & IP & 1,000 & & & & & Centralidade & 0,753 \\
\hline Laços & $<--$ & IP & 1,000 & & & & & IP12 & 0,582 \\
\hline PO21 & $<--$ & $\mathrm{RP}$ & 0,887 & 0,040 & 21,950 & $* * *$ & par_1 & IP13 & 0,761 \\
\hline PO41 & $<--$ & $\mathrm{RP}$ & 0,857 & 0,038 & 22,476 & $* * *$ & par_2 & IP14 & 0,689 \\
\hline PO36 & $<---$ & $\mathrm{RP}$ & 0,781 & 0,031 & 25,559 & $* * *$ & par_3 & IP6 & 0,614 \\
\hline PO9 & $<---$ & $\mathrm{RP}$ & 0,822 & 0,039 & 21,163 & $* * *$ & par_4 & IP10 & 0,529 \\
\hline PO25 & $<---$ & $\mathrm{RP}$ & 0,831 & 0,035 & 23,525 & $* * *$ & par_5 & IP18 & 0,617 \\
\hline PO32 & $<---$ & $\mathrm{RP}$ & 0,938 & 0,036 & 25,820 & $* * *$ & par_6 & IP2 & 0,678 \\
\hline PO34 & $<---$ & $\mathrm{RP}$ & 0,962 & 0,038 & 25,065 & $* * *$ & par_7 & IP3 & 0,515 \\
\hline PO33 & $<---$ & $\mathrm{RP}$ & 0,956 & 0,035 & 27,044 & $* * *$ & par_8 & IP17 & 0,560 \\
\hline PO30 & $<---$ & $\mathrm{RP}$ & 0,889 & 0,037 & 24,199 & $* * *$ & par_9 & PO15 & 0,351 \\
\hline PO38 & $<---$ & $\mathrm{RP}$ & 1,000 & & & & & $\mathrm{PO} 23$ & 0,269 \\
\hline PO4 & $<---$ & REG & 0,726 & 0,052 & 14,042 & $* * *$ & par_10 & PO11 & 0,348 \\
\hline PO18 & $<---$ & REG & 0,722 & 0,051 & 14,046 & $* * *$ & par_11 & $\mathrm{PO} 2$ & 0,700 \\
\hline PO19 & $<---$ & REG & 0,996 & 0,053 & 18,948 & $* * *$ & par_12 & PO3 & 0,683 \\
\hline PO6 & $<---$ & REG & 1,000 & & & & & PO12 & 0,150 \\
\hline PO43 & $<---$ & SD & 0,852 & 0,056 & 15,332 & $* * *$ & par_13 & PO29 & 0,355 \\
\hline PO45 & $<---$ & $\mathrm{SD}$ & 1,051 & 0,061 & 17,157 & $* * *$ & par_14 & PO26 & 0,432 \\
\hline PO35 & $<---$ & SD & 1,251 & 0,063 & 19,796 & $* * *$ & par_15 & PO37 & 0,452 \\
\hline PO37 & $<---$ & SD & 1,000 & & & & & PO35 & 0,611 \\
\hline PO26 & $<---$ & RA & 1,295 & 0,137 & 9,441 & $* * *$ & par_16 & PO45 & 0,430 \\
\hline PO29 & $<---$ & RA & 1,194 & 0,123 & 9,741 & $* * *$ & par_17 & PO43 & 0,322 \\
\hline PO12 & $<---$ & RA & 1,000 & & & & & PO6 & 0,501 \\
\hline PO3 & $<---$ & $\mathrm{QC}$ & 1,018 & 0,043 & 23,945 & $* * *$ & par_18 & PO19 & 0,507 \\
\hline $\mathrm{PO} 2$ & $<---$ & QC & 1,000 & & & & & PO18 & 0,268 \\
\hline PO15 & $<---$ & $\mathrm{RP}$ & 0,735 & 0,039 & 18,714 & $* * *$ & par_34 & PO4 & 0,263 \\
\hline PO11 & $<---$ & DR & 1,192 & 0,154 & 7,718 & $* * *$ & par_35 & PO38 & 0,636 \\
\hline $\mathrm{PO} 23$ & $<---$ & DR & 1,000 & & & & & PO30 & 0,525 \\
\hline IP17 & $<---$ & Centralidade & 1,000 & & & & & PO33 & 0,638 \\
\hline IP3 & $<---$ & Centralidade & 0,946 & 0,045 & 20,999 & $* * *$ & par_36 & PO34 & 0,568 \\
\hline IP2 & $<---$ & Centralidade & 1,099 & 0,048 & 22,750 & $* * *$ & par_37 & PO32 & 0,583 \\
\hline IP18 & $<---$ & Afeto & 1,000 & & & & & $\mathrm{PO} 25$ & 0,516 \\
\hline IP10 & $<---$ & Afeto & 0,921 & 0,047 & 19,503 & $* * *$ & par_38 & PO9 & 0,430 \\
\hline IP6 & $<---$ & Afeto & 0,911 & 0,046 & 19,874 & $* * *$ & par_39 & PO36 & 0,588 \\
\hline IP14 & $<---$ & Laços & 1,000 & & & & & PO41 & 0,476 \\
\hline IP13 & $<---$ & Laços & 1,084 & 0,036 & 30,396 & $* * *$ & par_40 & $\mathrm{PO} 21$ & 0,463 \\
\hline IP12 & $<---$ & Laços & 0,890 & 0,035 & 25,080 & $* * *$ & par_41 & & \\
\hline
\end{tabular}

Figura 42. Modelo $P O \rightarrow I P$ (Centralidade, Afeto, Laços). 


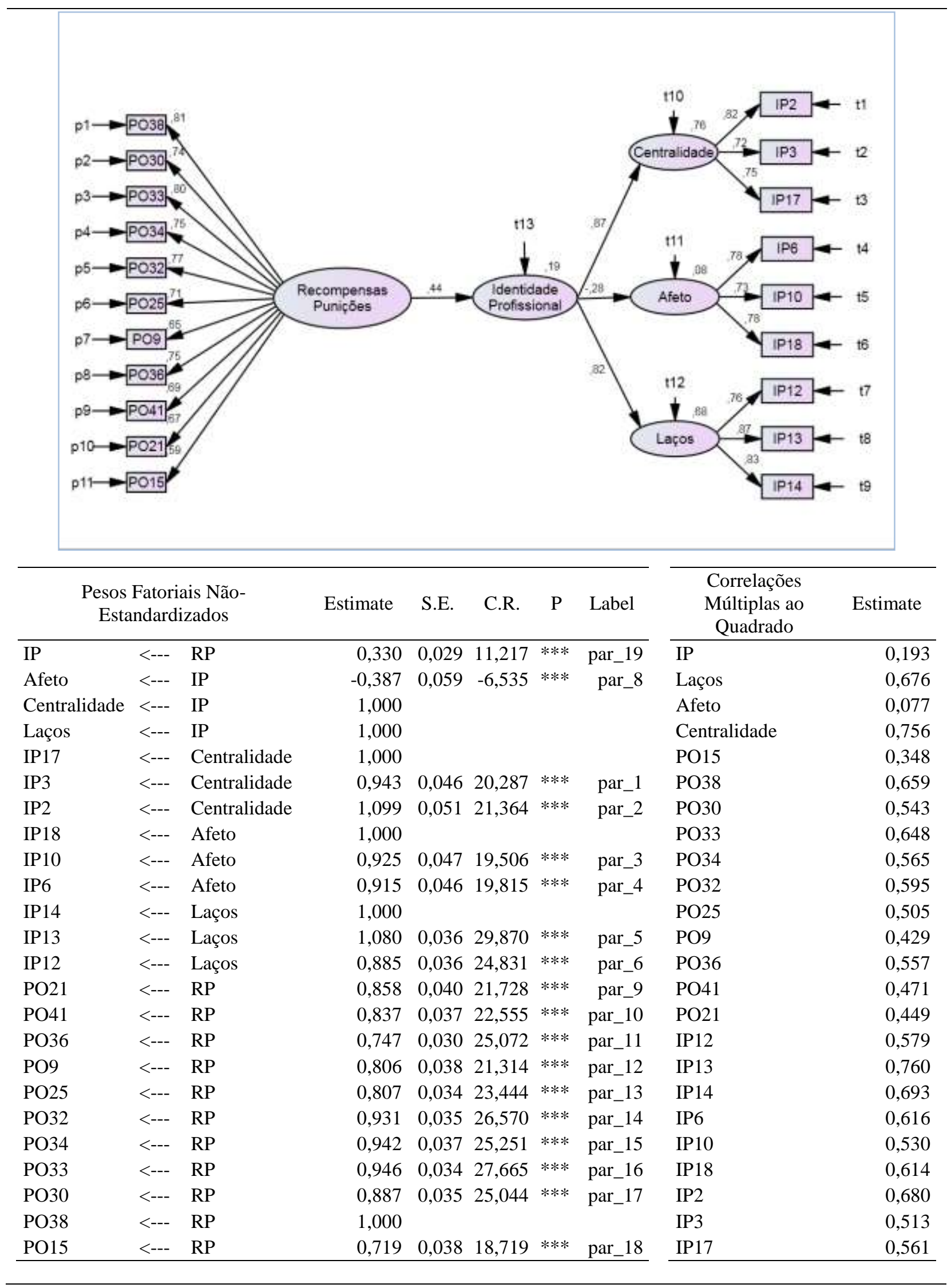

Figura 43. Modelo Recompensas e Punições $\rightarrow$ IP (Centralidade, Afeto, Laços). 


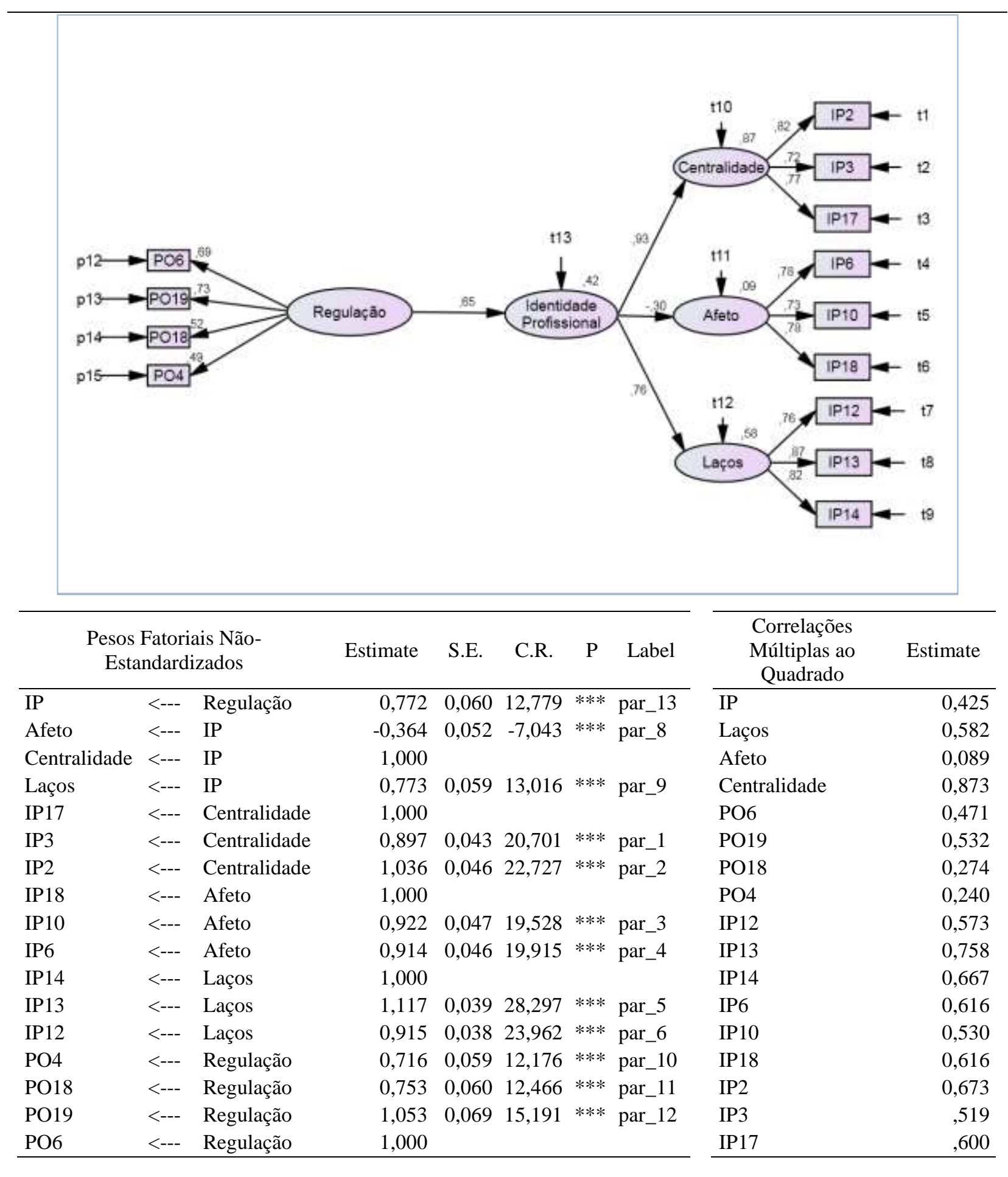

Figura 44. Modelo Regulação $\rightarrow I P$ (Centralidade, Afeto, Laços). 


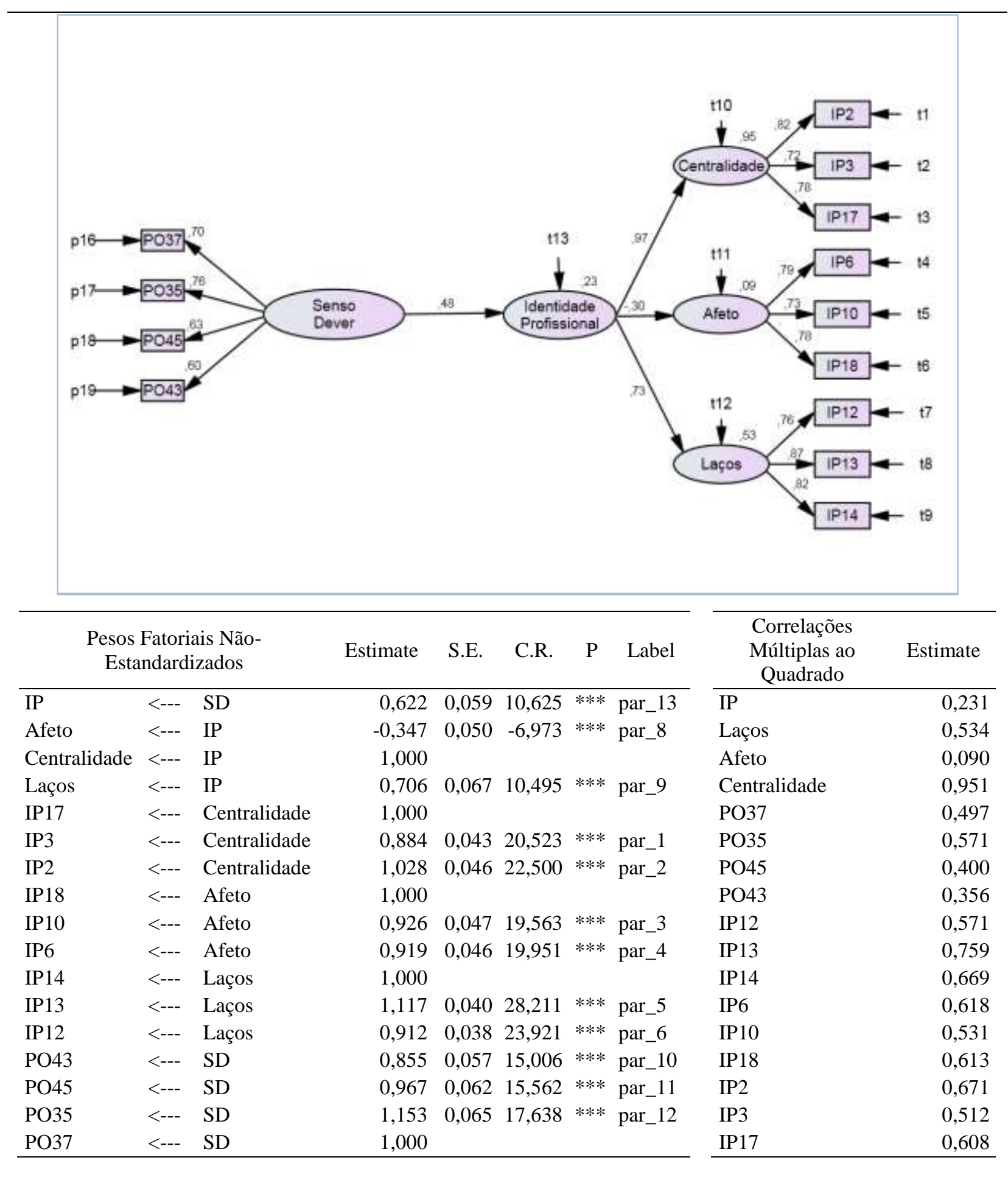

Figura 45. Modelo Senso de Dever $\rightarrow$ IP (Centralidade, Afeto, Laços). 


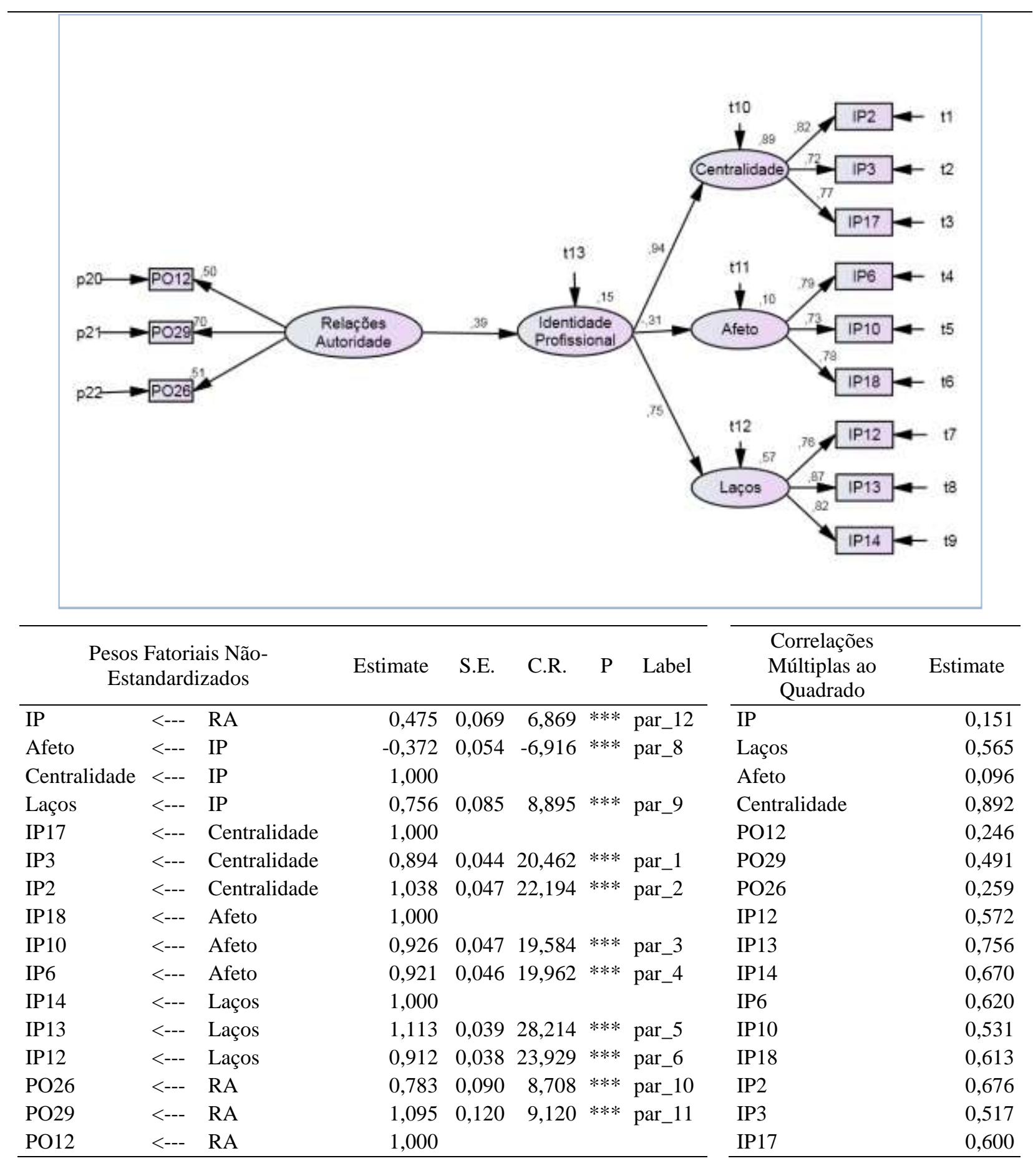

Figura 46. Modelo Relações de Autoridade $\rightarrow I P$ (Centralidade, Afeto, Laços). 


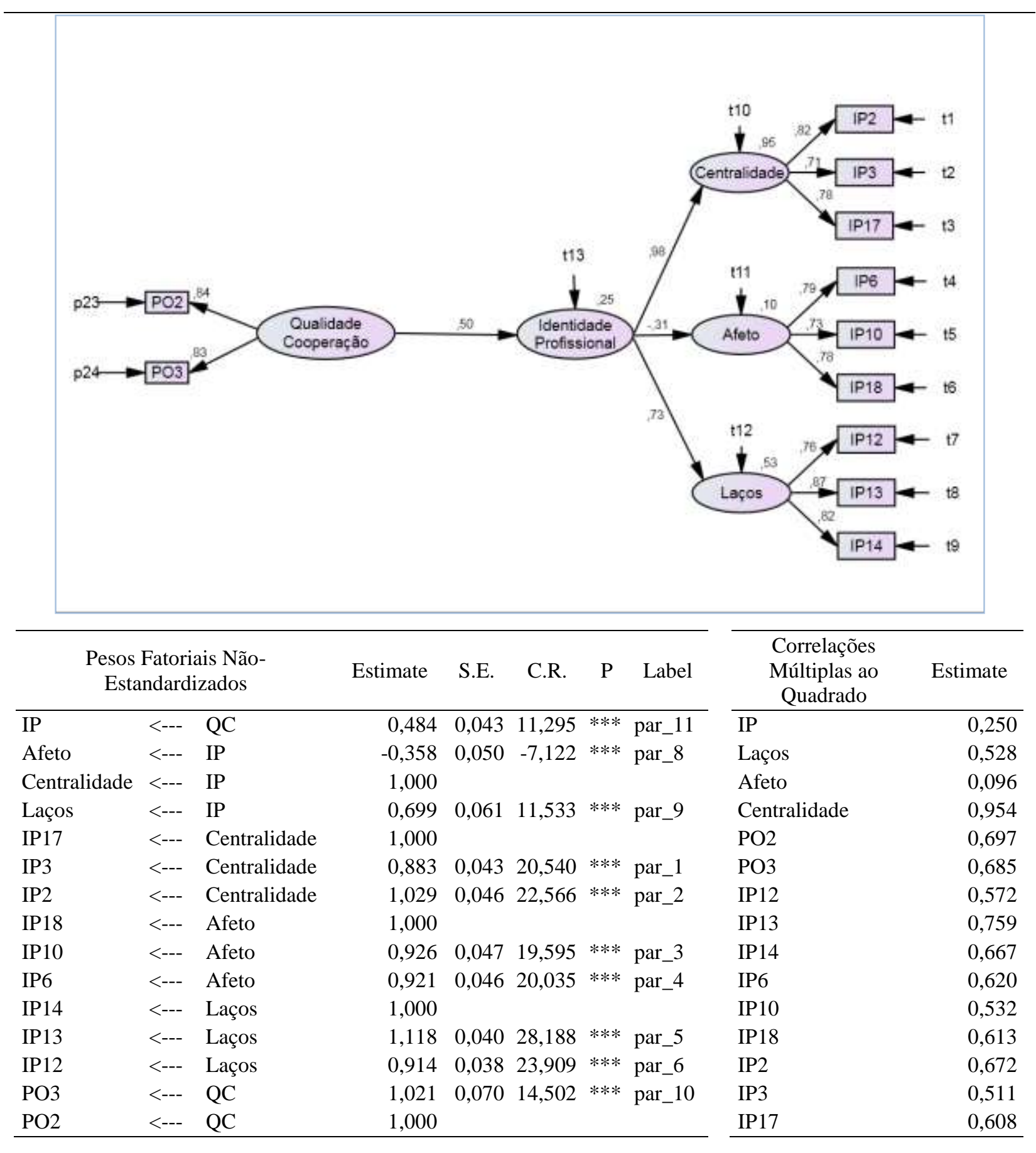

Figura 47. Modelo Qualidade da Cooperação $\rightarrow I P$ (Centralidade, Afeto, Laços). 


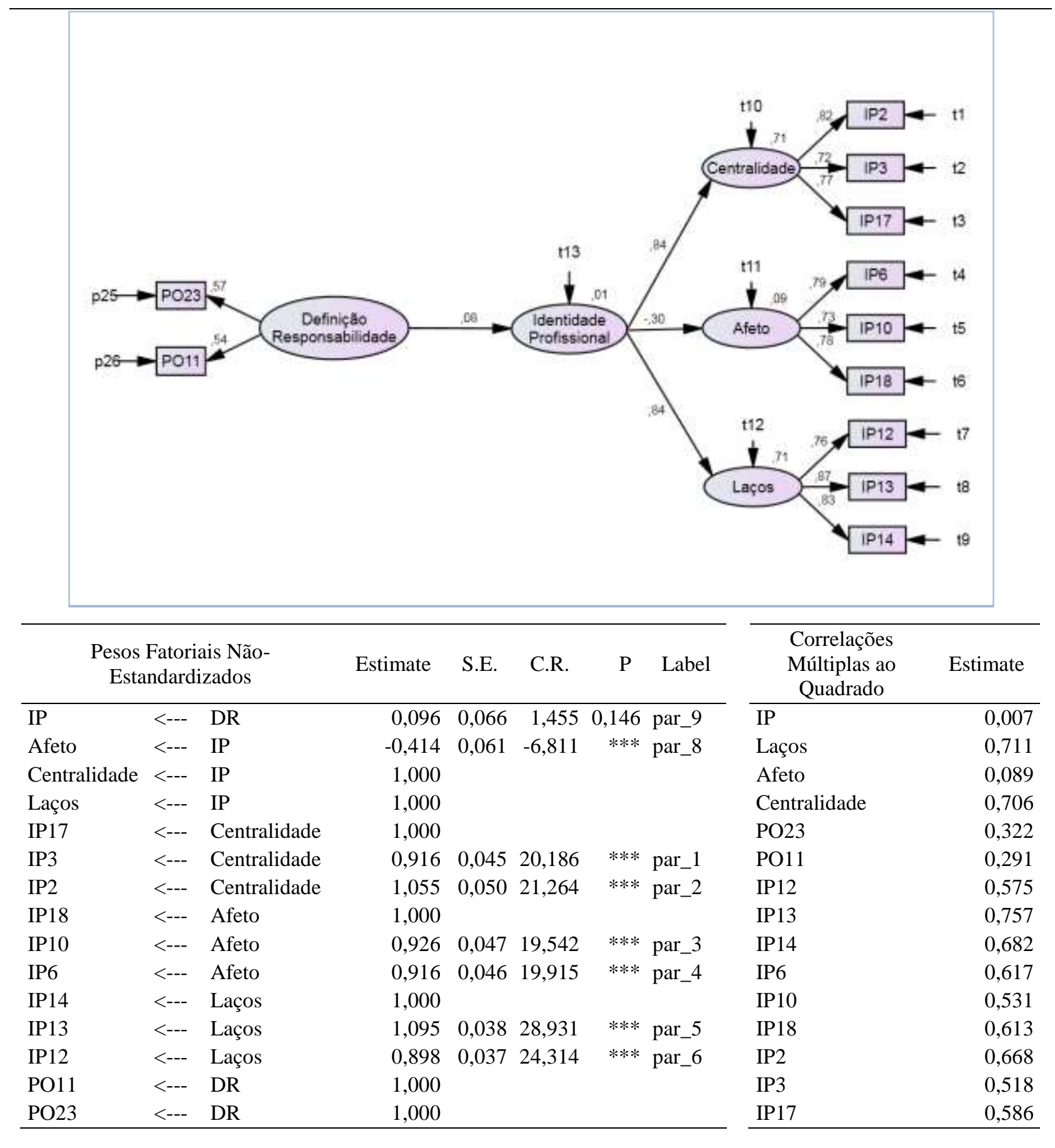

Figura 48. Modelo Definição de Responsabilidade $\rightarrow$ IP (Centralidade, Afeto, Laços). 


\section{Influência das práticas organizacionais sobre a identidade Organizacional}

Estuda-se, neste ponto, a influência das práticas organizacionais (PO) sobre a identidade organizacional $(\mathrm{IO}), P O \rightarrow I O$. Como forma de verificar a qualidade do ajuste dos dados, foi testado um modelo geral correlacional e, em seguida, cada dimensão específica da prática organizacional, para verificar seu poder de predição na regressão simples como forma de averiguar a parcimônia.

No primeiro teste, o modelo completo correlacionado $P O \rightarrow I P$ apresentou ajustes satisfatórios $(\mathrm{GFI}=0,92 ; \mathrm{CFI}=0,93 ; \mathrm{RMSEA}=0,047)$, sendo significativas $(\mathrm{p}<0,05)$ as práticas regulação e definição de responsabilidades, responsáveis por explicar $22 \%$ da variância total da identidade organizacional.

O teste da relação prática Recompensas e Punições $\rightarrow I O$ foi significativo ( $<<0,000$; $\mathrm{GFI}=0,96 ; \mathrm{CFI}=0,97 ; \quad \mathrm{RMSEA}=0,046$ ), explicando $9 \%$ da variância da identidade organizacional. O teste Regulação $\rightarrow I O(\mathrm{p}<0,000 ; \mathrm{GFI}=0,98 ; \mathrm{CFI}=0,98 ; \mathrm{RMSEA}=0,045)$ mostrou que a prática de regulação é responsável por uma explicação de $20 \%$ da identidade organizacional.

A relação Senso de Dever $\rightarrow I O$ apresentou-se significativa $(\mathrm{p}<0,000$; GFI=0,98; $\mathrm{CFI}=0,98 ; \mathrm{RMSEA}=0,046$ ), explicando $11 \%$ da variância da identidade organizacional. O teste Relações de Autoridade $\rightarrow I P$ foi significativo ( $\mathrm{p}<0,000 ; \mathrm{GFI}=0,98 ; \mathrm{CFI}=0,99$; RMSEA=0,043), explicando 10\% da variância da identidade organizacional.

Para Qualidade da Cooperação $\rightarrow I O$ o teste mostrou-se significativo ( $<<0,000$; $\mathrm{GFI}=0,99 ; \mathrm{CFI}=0,99 ; \mathrm{RMSEA}=0,045)$, responsável por explicar $15 \%$ da variância total da identidade organizacional. Por fim, o teste Definição de Responsabilidade $\rightarrow I O$ não se mostrou significativo $(\mathrm{p}=0,286)$.

A Tabela 53 apresenta um resumo dos índices de ajuste e as Figuras de 49 a 55 exibem a representação gráfica dos modelos, os pesos fatoriais não estandardizados e as correlações múltiplas ao quadrado. 


\section{Tabela 53}

Índices de ajustamento da relação entre $\mathrm{PO} \rightarrow \mathrm{IO}$

\begin{tabular}{|c|c|c|c|c|c|c|c|c|}
\hline $\begin{array}{l}\text { Amostra } \\
\mathrm{N}=916\end{array}$ & & $\begin{array}{c}\text { Modelo } P O \rightarrow \\
I O\end{array}$ & $\begin{array}{c}\text { Modelo } R P \rightarrow \\
I O\end{array}$ & $\begin{array}{c}\text { Modelo } R E G \rightarrow \\
I O\end{array}$ & $\begin{array}{c}\text { Modelo } S D \rightarrow \\
I O\end{array}$ & $\begin{array}{c}\text { Modelo } R A \rightarrow \\
I O\end{array}$ & $\begin{array}{c}\text { Modelo } Q C \rightarrow \\
I O\end{array}$ & $\begin{array}{c}\text { Modelo } D R \rightarrow \\
I O\end{array}$ \\
\hline $\begin{array}{l}\text { Índices } \\
\text { Absolutos }\end{array}$ & $\begin{array}{l}\chi / \text { g.l. } \\
\chi^{2} ; \text { g.l. } \\
p \\
\text { GFI (AGFI) } \\
\text { SRMR }\end{array}$ & $\begin{array}{c}3,02 \\
1345,68 ; 446 \\
0,000 \\
0,92(0,90) \\
0,038\end{array}$ & $\begin{array}{c}2,94 \\
343,39 ; 117 \\
0,000 \\
0,96(0,94) \\
0,029\end{array}$ & $\begin{array}{c}2,86 \\
94,51 ; 33 \\
0,000 \\
0,98(0,98) \\
0,026\end{array}$ & $\begin{array}{c}2,90 \\
95,66 ; 33 \\
0,000 \\
0,98(0,97) \\
0,033\end{array}$ & $\begin{array}{c}2,73 \\
68,22 ; 25 \\
0,000 \\
0,98(0,97) \\
0,025\end{array}$ & $\begin{array}{c}2,85 \\
51,32 ; 39 \\
0,000 \\
0,99(0,97) \\
0,021\end{array}$ & $\begin{array}{c}2,67 \\
50,73 ; 19 \\
0,000 \\
0,99(0,97) \\
0,024\end{array}$ \\
\hline Índices Relativos & $\begin{array}{l}\text { CFI } \\
\text { TLI }\end{array}$ & $\begin{array}{l}0,93 \\
0,93\end{array}$ & $\begin{array}{l}0,97 \\
0,97\end{array}$ & $\begin{array}{l}0,98 \\
0,98\end{array}$ & $\begin{array}{l}0,98 \\
0,98\end{array}$ & $\begin{array}{l}0,99 \\
0,98\end{array}$ & $\begin{array}{l}0,99 \\
0,99\end{array}$ & $\begin{array}{l}0,99 \\
0,98\end{array}$ \\
\hline $\begin{array}{l}\text { Índices de } \\
\text { Discrepância } \\
\text { Populacional }\end{array}$ & $\begin{array}{l}\text { RMSEA } \\
\text { (Lo90;Hi90) }\end{array}$ & $\begin{array}{c}0,047 \\
(0,044 ; 0,050)\end{array}$ & $\begin{array}{c}0,046 \\
(0,040 ; 0,052)\end{array}$ & $\begin{array}{c}0,045 \\
(0,035 ; 0,056)\end{array}$ & $\begin{array}{c}0,048 \\
(0,035 ; 0,056)\end{array}$ & $\begin{array}{c}0,043 \\
(0,031 ; 0,056)\end{array}$ & $\begin{array}{c}0,045 \\
(0,031 ; 0,060)\end{array}$ & $\begin{array}{c}0,043 \\
(0,029 ; 0,057)\end{array}$ \\
\hline $\begin{array}{l}\text { Índices de } \\
\text { Parcimônia }\end{array}$ & $\begin{array}{l}\text { PCFI } \\
\text { PGFI }\end{array}$ & $\begin{array}{l}0,84 \\
0,77\end{array}$ & $\begin{array}{l}0,84 \\
0,73\end{array}$ & $\begin{array}{l}0,72 \\
0,59\end{array}$ & $\begin{array}{l}0,72 \\
0,59\end{array}$ & $\begin{array}{l}0,70 \\
0,55\end{array}$ & $\begin{array}{l}0,64 \\
0,49\end{array}$ & $\begin{array}{l}0,67 \\
0,52\end{array}$ \\
\hline $\begin{array}{l}\text { Índices Baseados } \\
\text { na Teoria da } \\
\text { Informação }\end{array}$ & $\begin{array}{l}\text { AIC } \\
\text { ECVI } \\
\text { CAIC }\end{array}$ & $\begin{array}{c}1819,88 \\
1,99 \\
2343,68\end{array}$ & $\begin{array}{c}415,39 \\
0,45 \\
624,91\end{array}$ & $\begin{array}{c}138,51 \\
0,15 \\
266,55\end{array}$ & $\begin{array}{c}139,66 \\
0,15 \\
267,70\end{array}$ & $\begin{array}{c}108,22 \\
0,12 \\
224,62\end{array}$ & $\begin{array}{c}87,32 \\
0,10 \\
192,08\end{array}$ & $\begin{array}{c}84,73 \\
0,09 \\
183,67\end{array}$ \\
\hline
\end{tabular}

RP: Recompensas e Punições; REG: Regulação; SD: Senso de Dever; RA: Relações de Autoridade; QC: Qualidade da Cooperação; DR: Definição de Responsabilidades. 


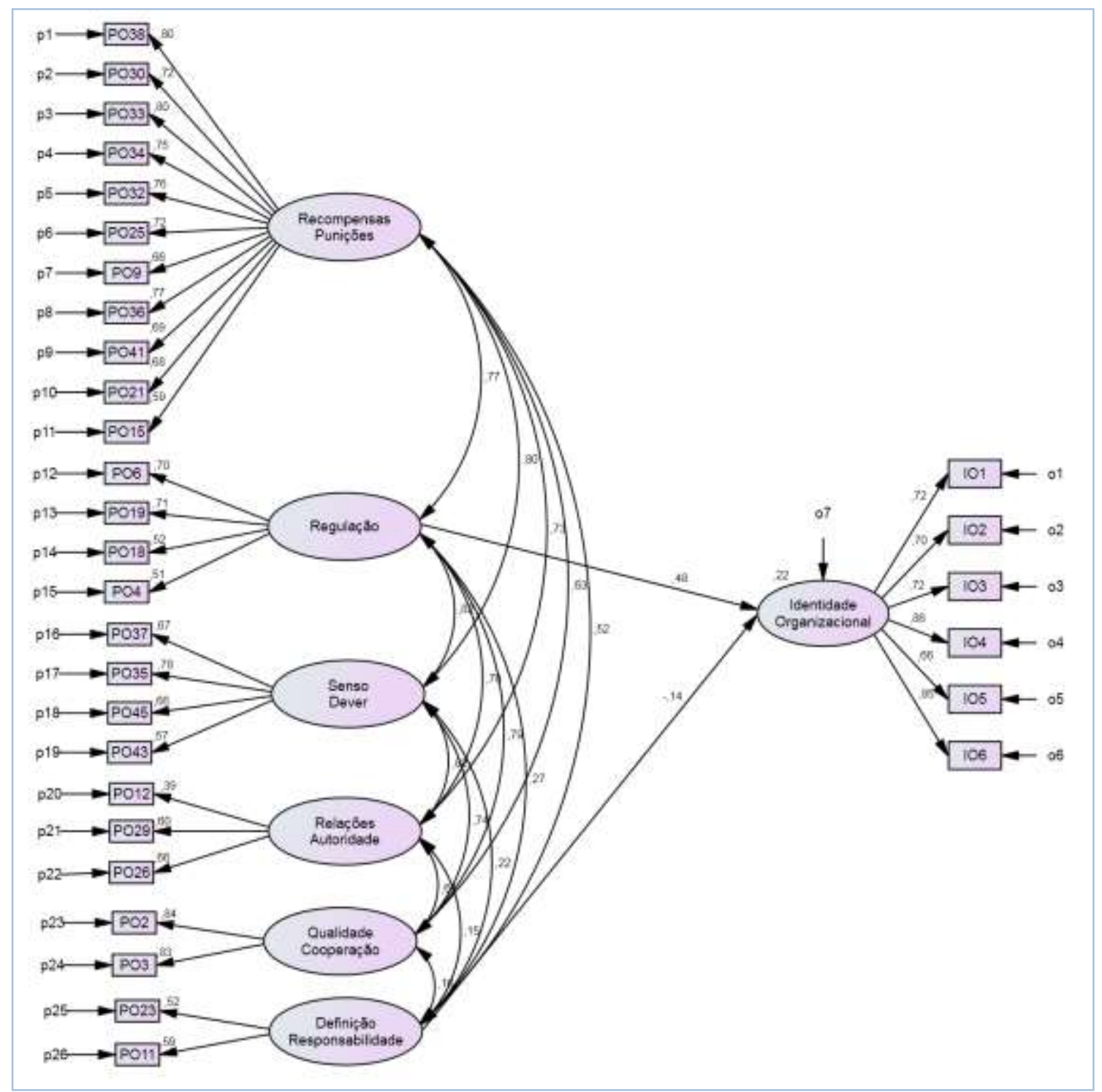




\begin{tabular}{|c|c|c|c|c|c|c|c|c|c|}
\hline \multicolumn{3}{|c|}{$\begin{array}{l}\text { Pesos Fatoriais Não- } \\
\text { Estandardizados }\end{array}$} & \multirow{2}{*}{$\begin{array}{r}\text { Estimate } \\
0,673\end{array}$} & \multirow{2}{*}{$\begin{array}{l}\text { S.E. } \\
0,060\end{array}$} & \multirow{2}{*}{$\begin{array}{c}\text { C.R. } \\
11,193\end{array}$} & \multirow{2}{*}{$\begin{array}{c}\mathrm{P} \\
* * *\end{array}$} & \multirow{2}{*}{$\begin{array}{l}\text { Label } \\
\text { par_42 }\end{array}$} & $\begin{array}{c}\text { Correlações } \\
\text { Múltiplas ao } \\
\text { Quadrado }\end{array}$ & \multirow{2}{*}{$\begin{array}{r}\text { Estimate } \\
0,216\end{array}$} \\
\hline IO & $<---$ & REG & & & & & & $\mathrm{IO}$ & \\
\hline IO & $<---$ & DR & $-0,235$ & 0,084 & $-2,807$ & 0,005 & par_43 & IO1 & 0,526 \\
\hline PO21 & $<---$ & $\mathrm{RP}$ & 0,888 & 0,040 & 21,945 & $* * *$ & par_1 & $\mathrm{IO} 2$ & 0,488 \\
\hline PO41 & $<---$ & $\mathrm{RP}$ & 0,857 & 0,038 & 22,469 & $* * *$ & par_2 & IO3 & 0,515 \\
\hline PO36 & $<---$ & $\mathrm{RP}$ & 0,782 & 0,031 & 25,556 & $* * *$ & par_3 & IO4 & 0,745 \\
\hline PO9 & $<---$ & $\mathrm{RP}$ & 0,822 & 0,039 & 21,154 & $* * *$ & par_4 & IO5 & 0,433 \\
\hline $\mathrm{PO} 25$ & $<---$ & $\mathrm{RP}$ & 0,830 & 0,035 & 23,515 & $* * *$ & par_5 & IO6 & 0,721 \\
\hline PO32 & $<---$ & $\mathrm{RP}$ & 0,938 & 0,036 & 25,815 & $* * *$ & par_6 & PO15 & 0,351 \\
\hline PO34 & $<---$ & $\mathrm{RP}$ & 0,962 & 0,038 & 25,064 & $* * *$ & par_7 & PO23 & 0,275 \\
\hline PO33 & $<---$ & $\mathrm{RP}$ & 0,956 & 0,035 & 27,046 & $* * *$ & par_8 & PO11 & 0,346 \\
\hline PO30 & $<---$ & $\mathrm{RP}$ & 0,889 & 0,037 & 24,196 & $* * *$ & par_9 & PO2 & 0,700 \\
\hline PO38 & $<---$ & $\mathrm{RP}$ & 1,000 & & & & & PO3 & 0,683 \\
\hline PO4 & $<---$ & REG & 0,736 & 0,053 & 13,901 & $* * *$ & par_10 & PO12 & 0,150 \\
\hline PO18 & $<---$ & REG & 0,736 & 0,053 & 13,985 & $* * *$ & par_11 & PO29 & 0,360 \\
\hline PO19 & $<---$ & REG & 1,006 & 0,054 & 18,625 & $* * *$ & par_12 & PO26 & 0,429 \\
\hline PO6 & $<---$ & REG & 1,000 & & & & & PO37 & 0,451 \\
\hline PO43 & $<---$ & SD & 0,852 & 0,056 & 15,305 & $* * *$ & par_13 & PO35 & 0,611 \\
\hline PO45 & $<---$ & SD & 1,054 & 0,061 & 17,167 & $* * *$ & par_14 & PO45 & 0,432 \\
\hline PO35 & $<---$ & SD & 1,252 & 0,063 & 19,759 & $* * *$ & par_15 & PO43 & 0,322 \\
\hline PO37 & $<---$ & SD & 1,000 & & & & & PO6 & 0,486 \\
\hline PO26 & $<---$ & RA & 1,292 & 0,137 & 9,438 & $* * *$ & par_16 & PO19 & 0,501 \\
\hline PO29 & $<---$ & RA & 1,202 & 0,123 & 9,759 & $* * *$ & par_17 & PO18 & 0,270 \\
\hline PO12 & $<---$ & RA & 1,000 & & & & & PO4 & 0,261 \\
\hline PO3 & $<---$ & $\mathrm{QC}$ & 1,018 & 0,042 & 23,950 & $* * *$ & par_18 & PO38 & 0,636 \\
\hline $\mathrm{PO} 2$ & $<---$ & $\mathrm{QC}$ & 1,000 & & & & & PO30 & 0,526 \\
\hline PO15 & $<---$ & $\mathrm{RP}$ & 0,736 & 0,039 & 18,723 & $* * *$ & par_34 & PO33 & 0,638 \\
\hline PO11 & $<---$ & DR & 1,176 & 0,151 & 7,809 & $* * *$ & par_35 & PO34 & 0,568 \\
\hline $\mathrm{PO} 23$ & $<---$ & DR & 1,000 & & & & & PO32 & 0,583 \\
\hline IO6 & $<---$ & IO & 1,000 & & & & & PO25 & 0,516 \\
\hline IO5 & $<---$ & $\mathrm{IO}$ & 0,733 & 0,034 & 21,789 & $* * *$ & par_36 & PO9 & 0,430 \\
\hline IO4 & $<---$ & $\mathrm{IO}$ & 0,973 & 0,031 & 31,532 & $* * *$ & par_37 & PO36 & 0,588 \\
\hline IO3 & $<---$ & IO & 0,778 & 0,033 & 23,780 & $* * *$ & par_38 & PO41 & 0,475 \\
\hline $\mathrm{IO} 2$ & $<---$ & $\mathrm{IO}$ & 0,781 & 0,034 & 23,133 & $* * *$ & par_39 & PO21 & 0,463 \\
\hline IO1 & $<---$ & $\mathrm{IO}$ & 0,907 & 0,040 & 22,626 & $* * *$ & par_40 & & \\
\hline
\end{tabular}

Figura 49. Modelo $P O \rightarrow I O$. 


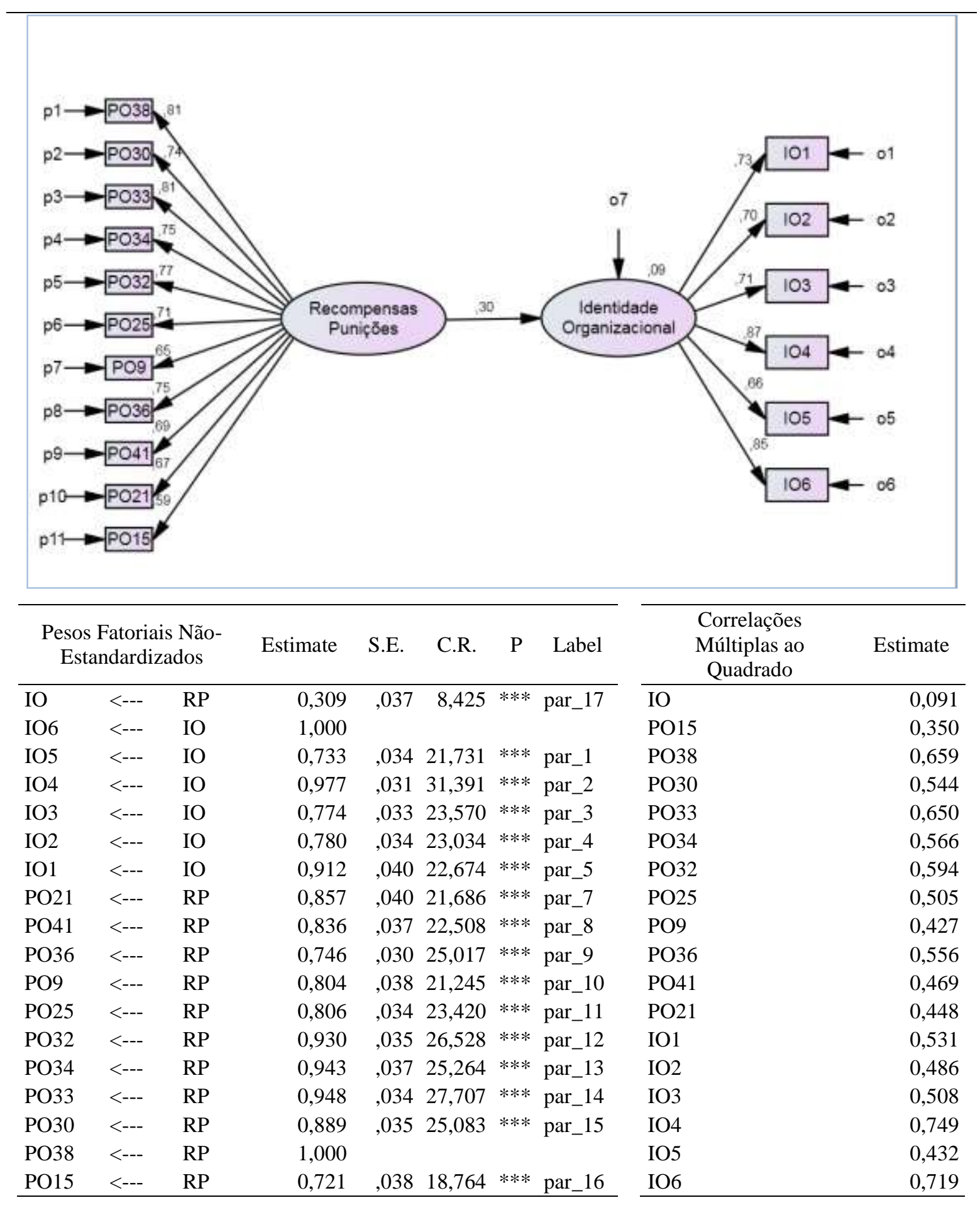

Figura 50. Modelo Recompensas e Punições $\rightarrow I O$ 


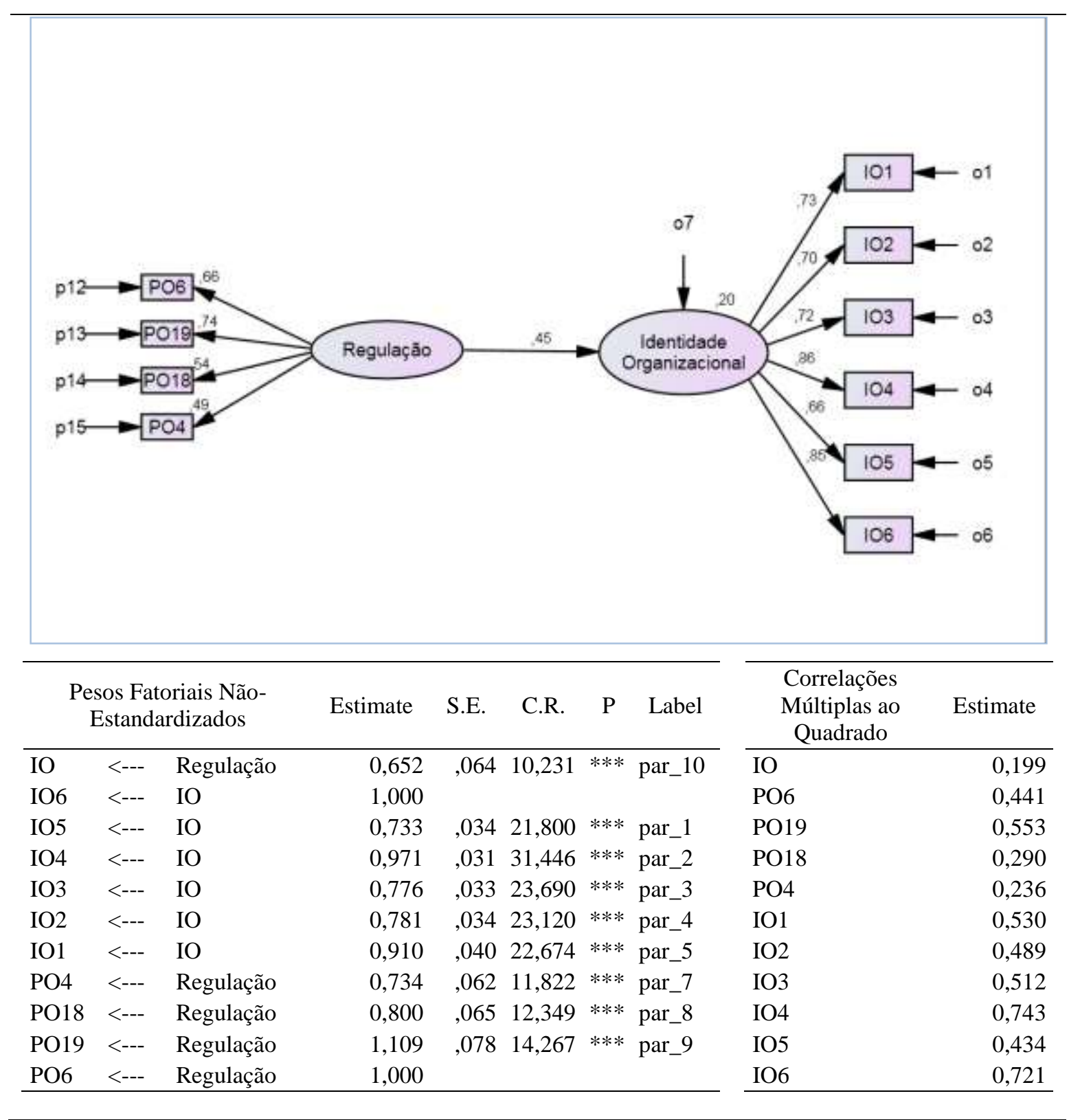

Figura 51. Modelo Regulação $\rightarrow I O$. 


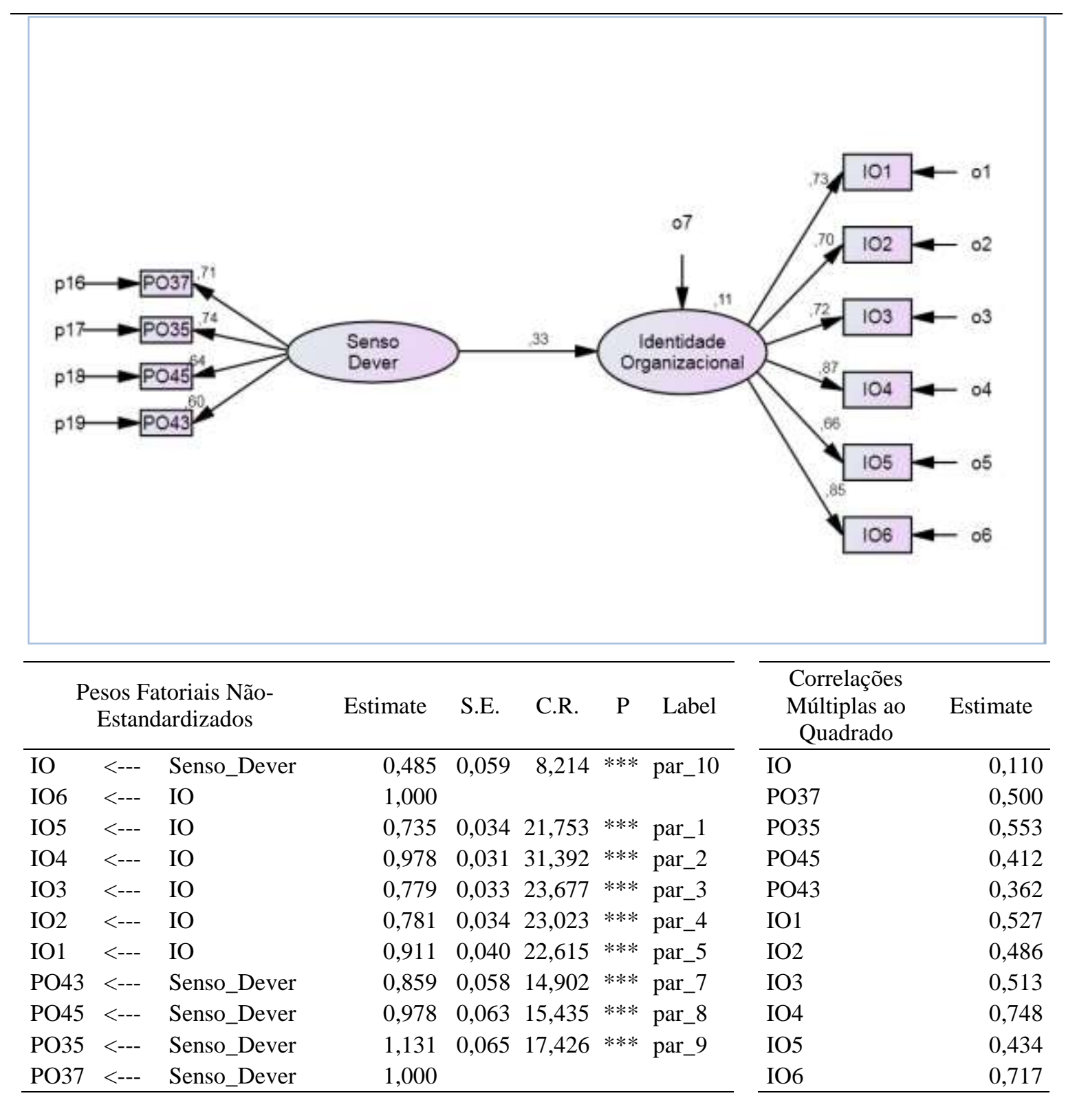

Figura 52. Modelo Senso de Dever $\rightarrow I O$. 


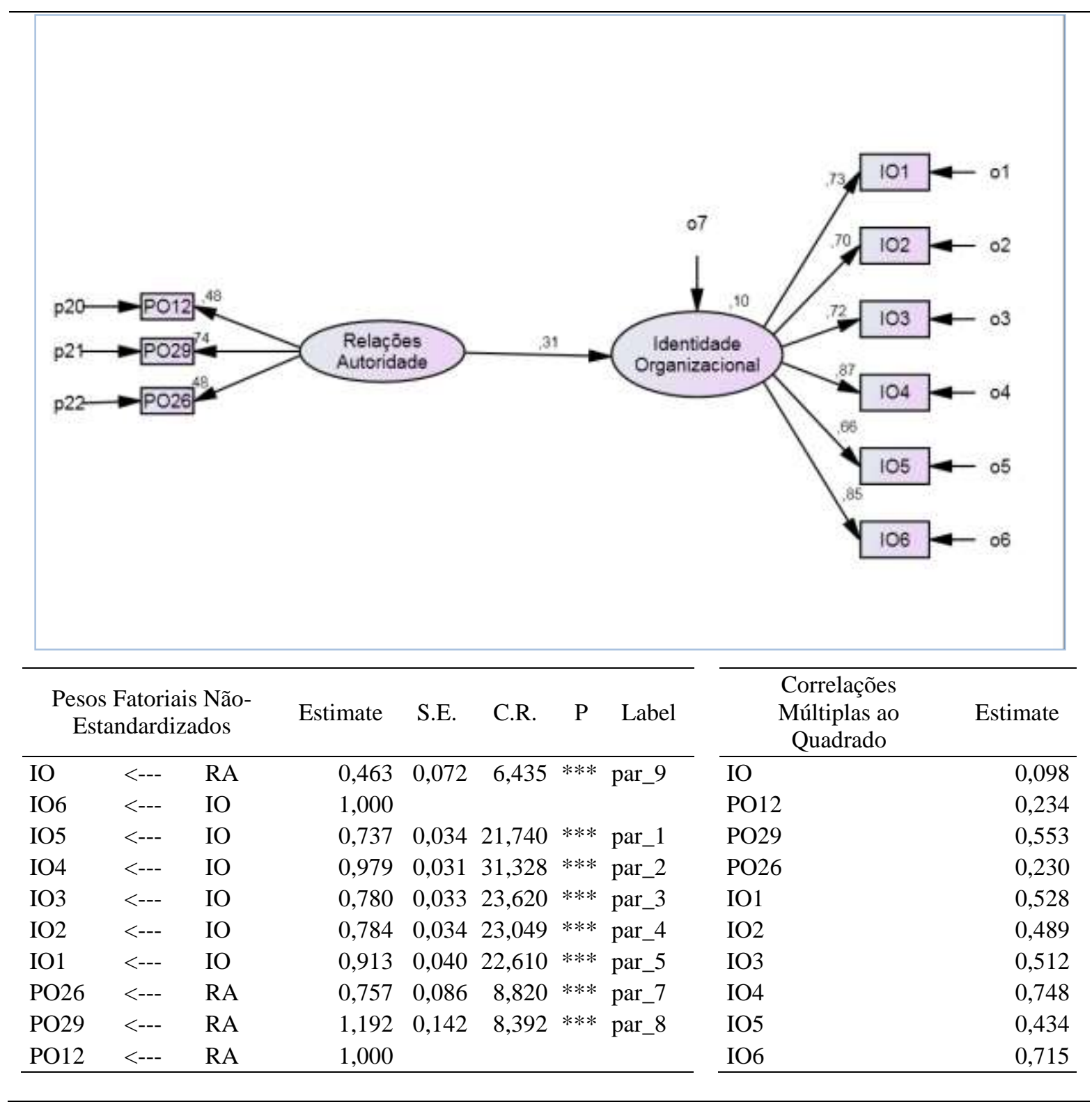

Figura 53. Modelo Relações de Autoridade $\rightarrow I O$. 




Figura 54. Modelo Qualidade da Cooperação $\rightarrow I O$. 


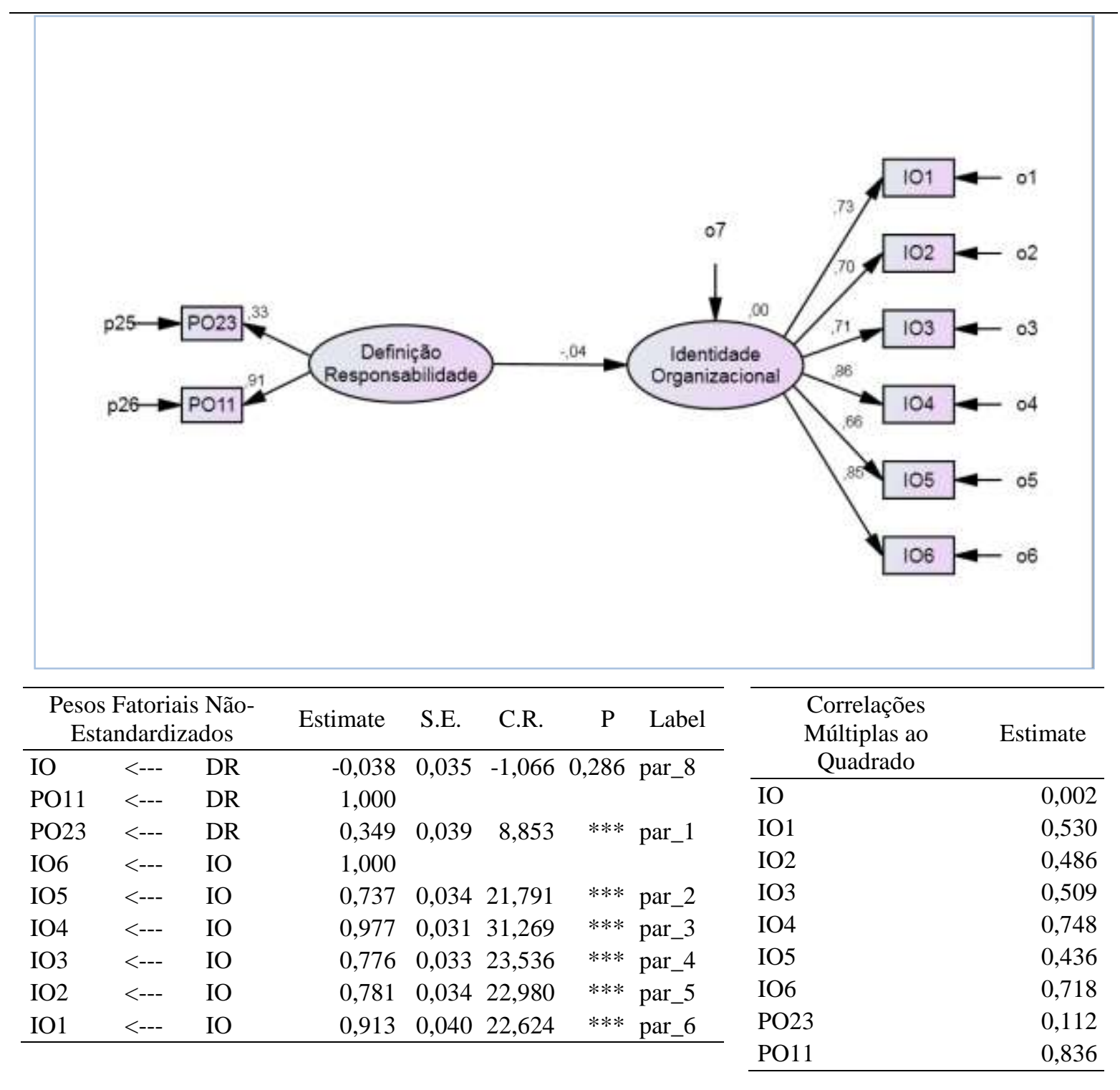

Figura 55. Modelo Definição de Responsabilidade $\rightarrow I O$. 


\section{Influência das práticas organizacionais sobre o desempenho profissional}

Investiga-se a influência das práticas organizacionais (PO) sobre o desempenho profissional por competências (DC), $P O \rightarrow D C$. Como forma de verificar a qualidade do ajuste dos dados, foi testado um modelo geral correlacional e, em seguida, cada dimensão específica da prática organizacional, para avaliar seu poder de predição na regressão simples, como forma de averiguar a parcimônia.

O Modelo completo correlacionado $P O \rightarrow D C$ apresentou ajustes satisfatórios $(\mathrm{GFI}=0,86 ; \mathrm{CFI}=0,91 ; \mathrm{RMSEA}=0,045)$, sendo significativas $(\mathrm{p}<0,05)$ as práticas regulação e definição de responsabilidades, responsáveis por explicar $17 \%$ da variância total do desempenho profissional $\left(\mathrm{R}^{2}=0,55\right.$ para o desempenho por competências técnicas; e $\mathrm{R}^{2}=0,67$ para o desempenho por competências comportamentais). Somente os valores do GFI e AGFI estão abaixo do limite de 0,90; entretanto, como esses índices são sensíveis ao tamanho da amostra e à complexidade do modelo, não comprometem seu ajuste global (Kline, 2010; Roussel et al., 2002).

O teste da relação prática de Recompensas e Punições $\rightarrow D C$ foi significativo ( $\mathrm{p}<0,000 ; \quad$ GFI=0,95; $\mathrm{CFI}=0,97 ; \quad \mathrm{RMSEA}=0,045)$, explicando $4 \%$ da variância do desempenho profissional $\left(\mathrm{R}^{2}=0,57\right.$ para o desempenho por competências técnicas; e $\mathrm{R}^{2}=0,62$ para o desempenho por competências comportamentais). O teste Regulação $\rightarrow D C$ ( $<<0,000$; GFI=0,93; CFI=0,95; RMSEA=0,046) mostrou que a prática de regulação é responsável por uma explicação de $11 \%$ do desempenho profissional $\left(\mathrm{R}^{2}=0,54\right.$ para o desempenho por competências técnicas; e $\mathrm{R}^{2}=0,66$ para o desempenho por competências comportamentais).

A relação entre Senso de Dever $\rightarrow D C$ apresentou-se significativa $(\mathrm{p}<0,000$; $\mathrm{GFI}=0,92 ; \mathrm{CFI}=0,95 ; \mathrm{RMSEA}=0,046$ ), explicando $6 \%$ da variância do desempenho profissional $\left(\mathrm{R}^{2}=0,55\right.$ para o desempenho por competências técnicas; e $\mathrm{R}^{2}=0,64$ para o desempenho por competências comportamentais). O teste Relações de Autoridade $\rightarrow D C$ foi significativo ( $\mathrm{p}<0,000$; GFI=0,93; $\mathrm{CFI}=0,95 ; \mathrm{RMSEA}=0,048)$, explicando $7 \%$ da variância do desempenho profissional $\left(\mathrm{R}^{2}=0,54\right.$ para o desempenho por competências técnicas; e $\mathrm{R}^{2}=0,66$ para o desempenho por competências comportamentais).

Para Qualidade da Cooperação $\rightarrow D C$ o teste mostrou-se significativo $(\mathrm{p}<0,000$; GFI=0,93; CFI=0,95; RMSEA=0,049), responsável por explicar 6\% da variância total do desempenho profissional $\left(\mathrm{R}^{2}=0,54\right.$ para o desempenho por competências técnicas; e $\mathrm{R}^{2}=0,66$ para o desempenho por competências comportamentais). Por fim, o teste Definição de Responsabilidade $\rightarrow D C$ não se mostrou significativo $(\mathrm{p}=0,930)$. 
A Tabela 54 apresenta um resumo dos índices de ajuste e as Figuras de 51 a 62 exibem a representação gráfica dos modelos, os pesos fatoriais não estandardizados e as correlações múltiplas ao quadrado. 
Tabela 54

Índices de ajustamento da relação entre $P O \rightarrow D C$.

\begin{tabular}{|c|c|c|c|c|c|c|c|c|}
\hline \multicolumn{2}{|l|}{$\begin{array}{l}\text { Amostra } \\
\mathrm{N}=916\end{array}$} & $\begin{array}{c}\text { Modelo } P O \rightarrow \\
D C\end{array}$ & $\begin{array}{c}\text { Modelo } R P \rightarrow \\
D C\end{array}$ & $\begin{array}{c}\text { Modelo } R E G \rightarrow \\
D C\end{array}$ & $\begin{array}{c}\text { Modelo } S D \rightarrow \\
D C\end{array}$ & $\begin{array}{c}\text { Modelo } R A \rightarrow \\
D C\end{array}$ & $\begin{array}{c}\text { Modelo } Q C \rightarrow \\
D C\end{array}$ & $\begin{array}{c}\text { Modelo } D R \rightarrow \\
D C\end{array}$ \\
\hline $\begin{array}{l}\text { Índices } \\
\text { Absolutos }\end{array}$ & $\begin{array}{l}\chi / \text { g.l. } \\
\chi^{2} ; \text { g.1. } \\
p \\
\text { GFI (AGFI) } \\
\text { SRMR }\end{array}$ & $\begin{array}{c}1,93 \\
1345,68 ; 446 \\
0,000 \\
0,86(0,84) \\
0,080\end{array}$ & $\begin{array}{c}1,90 \\
711,54 ; 375 \\
0,000 \\
0,90(0,89) \\
0,056\end{array}$ & $\begin{array}{c}1,94 \\
402,43 ; 207 \\
0,000 \\
0,93(0,91) \\
0,047\end{array}$ & $\begin{array}{c}1,97 \\
407,80 ; 207 \\
0,000 \\
0,92(0,91) \\
0,049\end{array}$ & $\begin{array}{c}2,03 \\
380,35 ; 187 \\
0,000 \\
0,93(0,91) \\
0,047\end{array}$ & $\begin{array}{c}2,07 \\
348,36 ; 168 \\
0,000 \\
0,93(0,91) \\
0,047\end{array}$ & $\begin{array}{c}2,01 \\
336,83 ; 168 \\
0,000 \\
0,93(0,91) \\
0,047\end{array}$ \\
\hline Índices Relativos & $\begin{array}{l}\text { CFI } \\
\text { TLI }\end{array}$ & $\begin{array}{l}0,91 \\
0,90\end{array}$ & $\begin{array}{l}0,95 \\
0,94\end{array}$ & $\begin{array}{l}0,95 \\
0,94\end{array}$ & $\begin{array}{l}0,95 \\
0,94\end{array}$ & $\begin{array}{l}0,95 \\
0,94\end{array}$ & $\begin{array}{l}0,95 \\
0,95\end{array}$ & $\begin{array}{l}0,95 \\
0,95\end{array}$ \\
\hline $\begin{array}{l}\text { Índices de } \\
\text { Discrepância } \\
\text { Populacional }\end{array}$ & $\begin{array}{l}\text { RMSEA } \\
\text { (Lo90;Hi90) }\end{array}$ & $\begin{array}{c}0,045 \\
(0,042 ; 0,049)\end{array}$ & $\begin{array}{c}0,045 \\
(0,040 ; 0,050)\end{array}$ & $\begin{array}{c}0,046 \\
(0,039 ; 0,052)\end{array}$ & $\begin{array}{c}0,046 \\
(0,040 ; 0,053)\end{array}$ & $\begin{array}{c}0,048 \\
(0,041 ; 0,055)\end{array}$ & $\begin{array}{c}0,049 \\
(0,042 ; 0,056)\end{array}$ & $\begin{array}{c}0,047 \\
(0,040 ; 0,055)\end{array}$ \\
\hline $\begin{array}{l}\text { Índices de } \\
\text { Parcimônia }\end{array}$ & $\begin{array}{l}\text { PCFI } \\
\text { PGFI }\end{array}$ & $\begin{array}{l}0,85 \\
0,77\end{array}$ & $\begin{array}{l}0,87 \\
0,78\end{array}$ & $\begin{array}{l}0,85 \\
0,76\end{array}$ & $\begin{array}{l}0,85 \\
0,76\end{array}$ & $\begin{array}{l}0,85 \\
0,75\end{array}$ & $\begin{array}{l}0,83 \\
0,74\end{array}$ & $\begin{array}{l}0,84 \\
0,74\end{array}$ \\
\hline $\begin{array}{l}\text { Índices Baseados } \\
\text { na Teoria da } \\
\text { Informação }\end{array}$ & $\begin{array}{l}\text { AIC } \\
\text { ECVI } \\
\text { CAIC }\end{array}$ & $\begin{array}{c}1918,39 \\
4,26 \\
2445,10\end{array}$ & $\begin{array}{c}831,54 \\
1,85 \\
1138,23\end{array}$ & $\begin{array}{c}494,43 \\
1,10 \\
729,56\end{array}$ & $\begin{array}{c}499,80 \\
1,11 \\
734,93\end{array}$ & $\begin{array}{c}468,35 \\
1,04 \\
693,26\end{array}$ & $\begin{array}{c}432,36 \\
0,96 \\
647,05\end{array}$ & $\begin{array}{c}420,83 \\
0,94 \\
635,51\end{array}$ \\
\hline
\end{tabular}

Responsabilidades. 


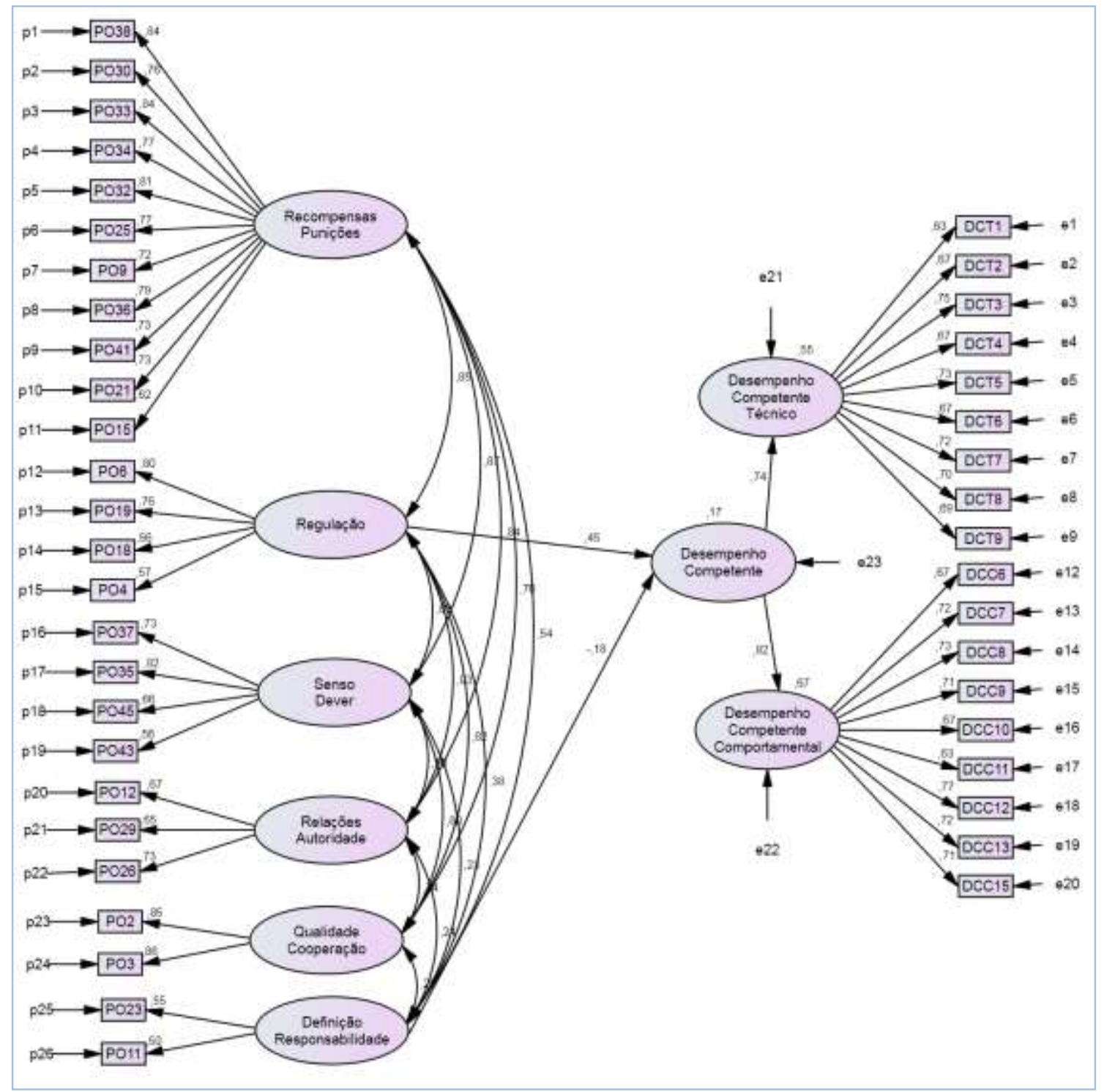




\begin{tabular}{|c|c|c|c|c|c|c|c|c|c|}
\hline \multicolumn{3}{|c|}{$\begin{array}{l}\text { Pesos Fatoriais Não- } \\
\text { Estandardizados }\end{array}$} & \multirow{2}{*}{$\begin{array}{r}\text { Estimate } \\
0,208\end{array}$} & \multirow{2}{*}{$\begin{array}{l}\text { S.E. } \\
0,039\end{array}$} & \multirow{2}{*}{$\begin{array}{l}\text { C.R. } \\
5,286\end{array}$} & \multirow{2}{*}{$\begin{array}{c}\mathrm{P} \\
* * *\end{array}$} & \multirow{2}{*}{$\begin{array}{c}\text { Label } \\
\text { par_51 }\end{array}$} & $\begin{array}{c}\text { Correlações } \\
\text { Múltiplas ao } \\
\text { Quadrado }\end{array}$ & Estimate \\
\hline $\mathrm{DC}$ & $\begin{array}{l}<-- \\
\end{array}$ & REG & & & & & & $\mathrm{DC}$ & 0,173 \\
\hline DC & $<--$ & DR & $-0,133$ & 0,064 & $-2,081$ & 0,037 & par_52 & DCC & 0,675 \\
\hline DCC & $<---$ & $\mathrm{DC}$ & 1,000 & & & & & DCT & 0,553 \\
\hline DCT & $<---$ & $\mathrm{DC}$ & 1,000 & & & & & PO15 & 0,389 \\
\hline DCT9 & $<---$ & DCT & 1,000 & & & & & $\mathrm{PO} 23$ & 0,307 \\
\hline DCT8 & $<---$ & DCT & 0,894 & 0,066 & 13,585 & $* * *$ & par_1 & PO11 & 0,253 \\
\hline DCT7 & $<--$ & DCT & 0,977 & 0,071 & 13,840 & $* * *$ & par_2 & $\mathrm{PO} 2$ & 0,726 \\
\hline DCT6 & $<---$ & DCT & 0,917 & 0,071 & 12,886 & $* * *$ & par_3 & PO3 & 0,745 \\
\hline DCT5 & $<---$ & DCT & 1,034 & 0,074 & 13,920 & $* * *$ & par_4 & PO12 & 0,450 \\
\hline DCT4 & $<--$ & DCT & 0,916 & 0,071 & 12,972 & $* * *$ & par_5 & PO29 & 0,423 \\
\hline DCT3 & $<---$ & DCT & 1,034 & 0,072 & 14,340 & $* * *$ & par_6 & PO26 & 0,528 \\
\hline DCT2 & $<---$ & DCT & 0,851 & 0,066 & 12,900 & $* * *$ & par_7 & PO37 & 0,528 \\
\hline DCT1 & $<---$ & DCT & 0,797 & 0,066 & 12,075 & $* * *$ & par_8 & PO35 & 0,675 \\
\hline DCC13 & $<---$ & DCC & 1,000 & & & & & PO45 & 0,438 \\
\hline DCC12 & $<---$ & $\mathrm{DCC}$ & 1,049 & 0,067 & 15,715 & $* * *$ & par_9 & PO43 & 0,309 \\
\hline DCC11 & $<---$ & DCC & 0,925 & 0,073 & 12,623 & $* * *$ & par_10 & PO6 & 0,646 \\
\hline DCC10 & $<---$ & $\mathrm{DCC}$ & 0,957 & 0,071 & 13,401 & $* * *$ & par_11 & PO19 & 0,578 \\
\hline DCC9 & $<---$ & $\mathrm{DCC}$ & 1,026 & 0,072 & 14,214 & $* * *$ & par_12 & PO18 & 0,312 \\
\hline DCC8 & $<---$ & DCC & 1,072 & 0,074 & 14,487 & $* * *$ & par_13 & PO4 & 0,329 \\
\hline DCC7 & $<---$ & DCC & 1,063 & 0,074 & 14,329 & $* * *$ & par_14 & PO38 & 0,702 \\
\hline DCC6 & $<---$ & DCC & 0,990 & 0,075 & 13,214 & $* * *$ & par_15 & PO30 & 0,572 \\
\hline DCC15 & $<---$ & $\mathrm{DCC}$ & 1,058 & 0,074 & 14,386 & $* * *$ & par_16 & PO33 & 0,706 \\
\hline PO21 & $<---$ & $\mathrm{RP}$ & 0,898 & 0,059 & 15,108 & $* * *$ & par_17 & PO34 & 0,598 \\
\hline PO41 & $<---$ & $\mathrm{RP}$ & 0,834 & 0,055 & 15,039 & $* * *$ & par_18 & PO32 & 0,652 \\
\hline PO36 & $<---$ & $\mathrm{RP}$ & 0,766 & 0,045 & 16,969 & $* * *$ & par_19 & $\mathrm{PO} 25$ & 0,594 \\
\hline PO9 & $<---$ & $\mathrm{RP}$ & 0,856 & 0,057 & 14,951 & $* * *$ & par_20 & PO9 & 0,522 \\
\hline PO25 & $<---$ & $\mathrm{RP}$ & 0,842 & 0,052 & 16,272 & $* * *$ & par_21 & PO36 & 0,629 \\
\hline PO32 & $<---$ & $\mathrm{RP}$ & 0,919 & 0,052 & 17,788 & $* * *$ & par_22 & PO41 & 0,526 \\
\hline PO34 & $<---$ & $\mathrm{RP}$ & 0,915 & 0,056 & 16,392 & $* * *$ & par_23 & PO21 & 0,536 \\
\hline PO33 & $<---$ & $\mathrm{RP}$ & 0,962 & 0,051 & 18,688 & $* * *$ & par_24 & DCC15 & 0,506 \\
\hline PO30 & $<---$ & $\mathrm{RP}$ & 0,852 & 0,053 & 16,105 & $* * *$ & par_25 & DCC6 & 0,443 \\
\hline PO38 & $<---$ & $\mathrm{RP}$ & 1,000 & & & & & DCC7 & 0,519 \\
\hline PO4 & $<---$ & REG & 0,620 & 0,063 & 9,882 & $* * *$ & par_26 & DCC8 & 0,535 \\
\hline PO18 & $<---$ & REG & 0,567 & 0,060 & 9,524 & $* * *$ & par_27 & DCC9 & 0,504 \\
\hline PO19 & $<---$ & REG & 0,835 & 0,059 & 14,241 & $* * *$ & par_28 & DCC10 & 0,447 \\
\hline PO6 & $<---$ & REG & 1,000 & & & & & DCC11 & 0,401 \\
\hline PO43 & $<---$ & SD & 0,740 & 0,080 & 9,207 & $* * *$ & par_29 & DCC12 & 0,596 \\
\hline PO45 & $<---$ & SD & 0,899 & 0,084 & 10,731 & $* * *$ & par_30 & DCC13 & 0,520 \\
\hline PO35 & $<---$ & SD & 1,219 & 0,092 & 13,323 & $* * *$ & par_31 & DCT1 & 0,392 \\
\hline PO37 & $<---$ & SD & 1,000 & & & & & DCT2 & 0,445 \\
\hline PO26 & $<---$ & RA & 0,714 & 0,060 & 11,950 & $* * *$ & par_32 & DCT3 & 0,558 \\
\hline PO29 & $<---$ & RA & 0,634 & 0,060 & 10,652 & $* * *$ & par_33 & DCT4 & 0,452 \\
\hline PO12 & $<---$ & RA & 1,000 & & & & & DCT5 & 0,537 \\
\hline PO3 & $<---$ & $\mathrm{QC}$ & 1,039 & 0,067 & 15,498 & $* * *$ & par_34 & DCT6 & 0,454 \\
\hline $\mathrm{PO} 2$ & $<---$ & QC & 1,000 & & & & & DCT7 & 0,515 \\
\hline PO15 & $<---$ & $\mathrm{RP}$ & 0,713 & 0,058 & 12,237 & $* * *$ & par_49 & DCT8 & 0,490 \\
\hline PO11 & $<---$ & DR & 0,935 & 0,180 & 5,188 & $* * *$ & par_50 & DCT9 & 0,478 \\
\hline $\mathrm{PO} 23$ & $<---$ & DR & 1,000 & & & & & & \\
\hline
\end{tabular}

Figura 56. Modelo $P O \rightarrow D C$. 


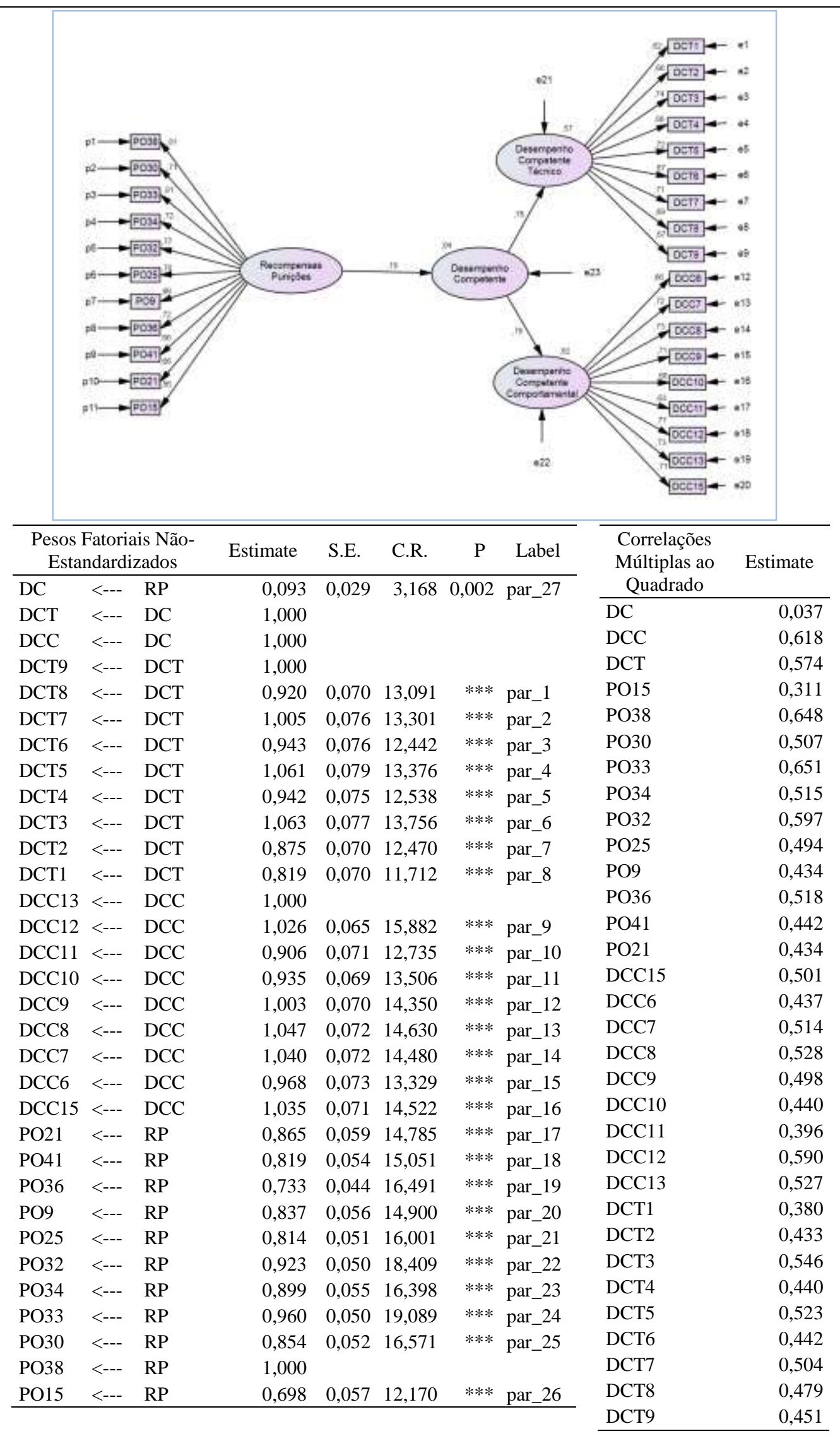

Figura 57. Modelo Recompensas e Punições $\rightarrow D C$. 


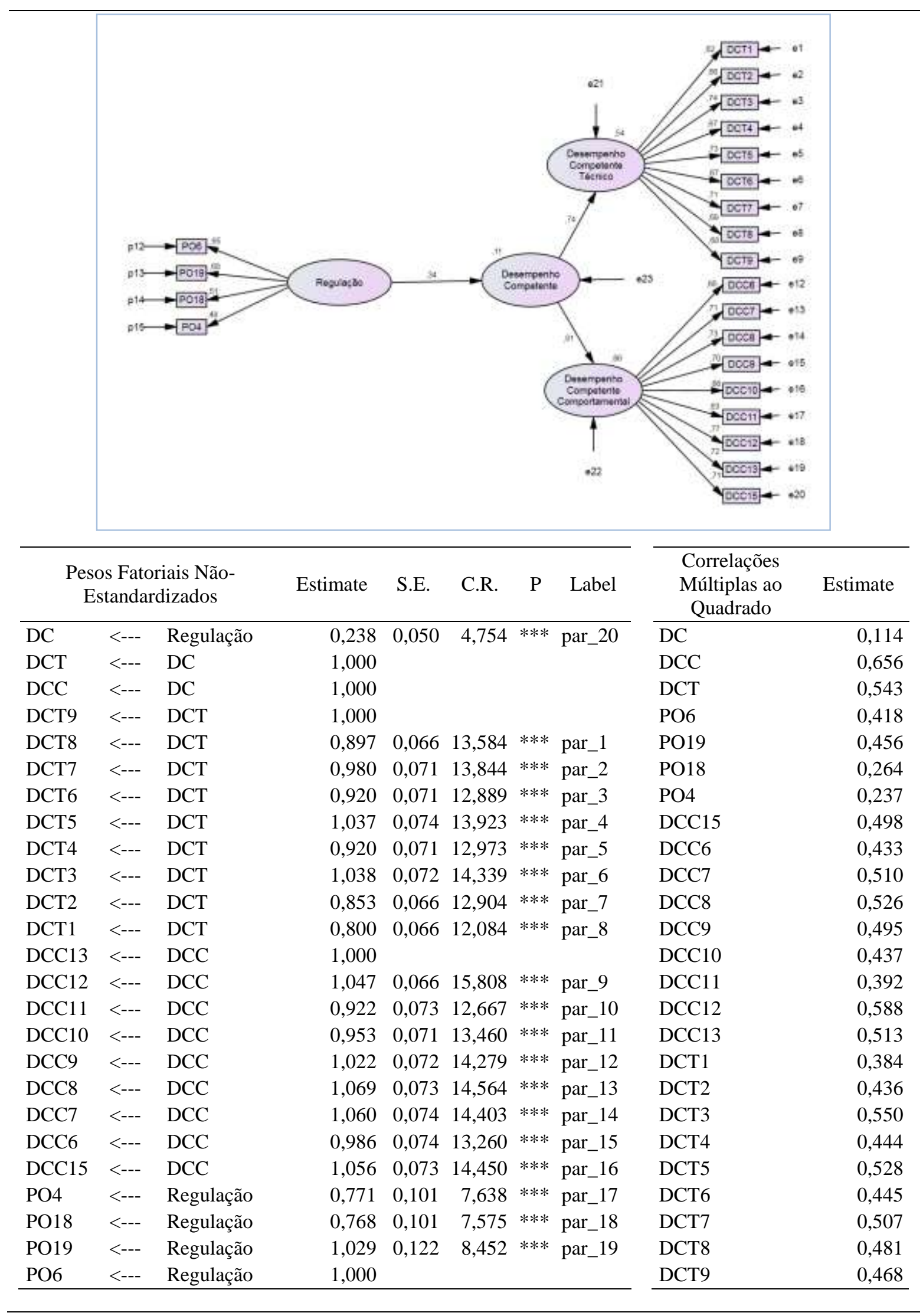

Figura 58. Modelo Regulação $\rightarrow D C$. 


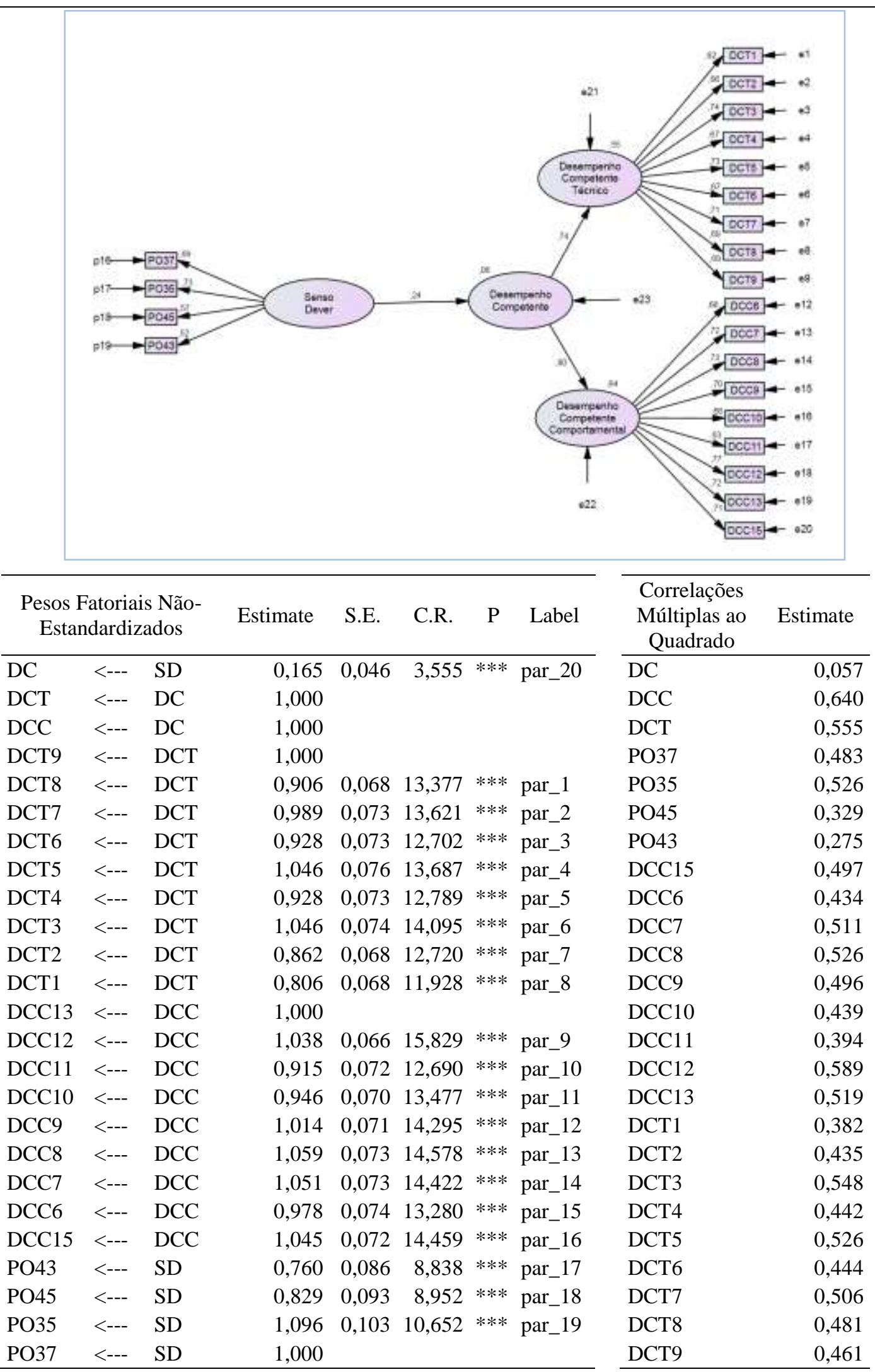

Figura 59. Modelo Senso de Dever $\rightarrow D C$. 


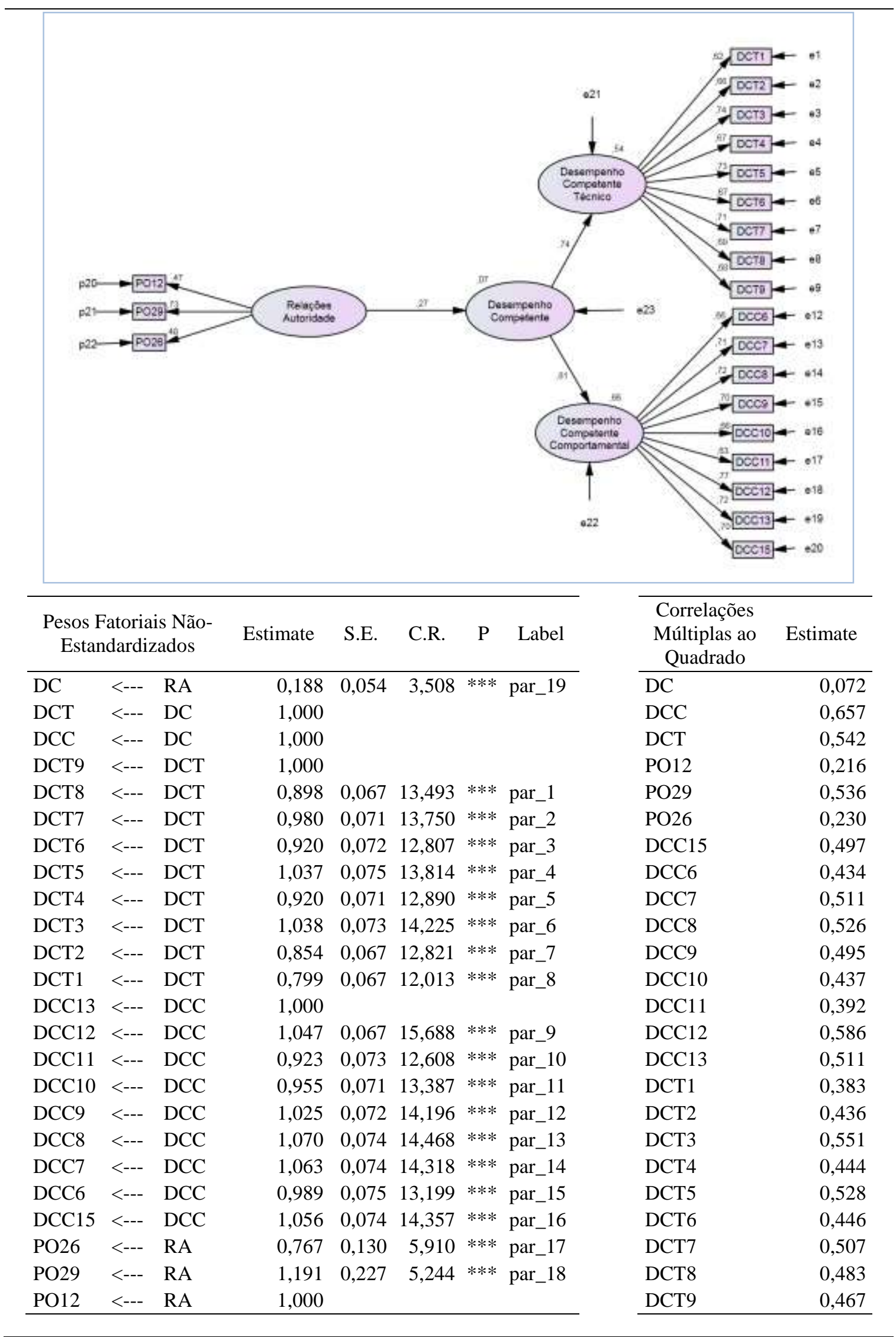

Figura 60. Modelo Relações de Autoridade $\rightarrow D C$. 


\begin{tabular}{|c|c|c|c|c|c|c|c|c|}
\hline & & & & & & $=2$ & 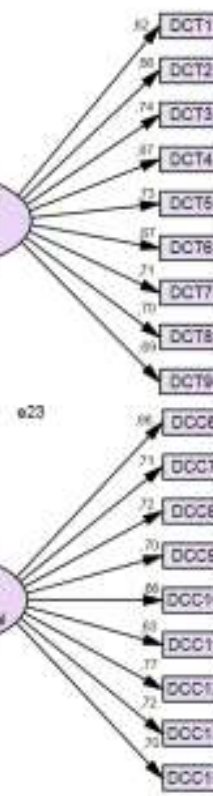 & 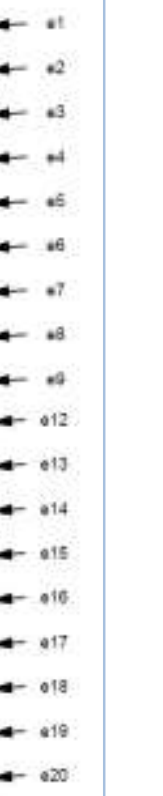 \\
\hline $\begin{array}{r}\text { Pesos F } \\
\text { Estan }\end{array}$ & $\begin{array}{l}\text { Fatoria } \\
\text { ndardi }\end{array}$ & $\begin{array}{l}\text { is Não- } \\
\text { ados }\end{array}$ & Estimate & S.E. & C.R. & P Label & $\begin{array}{c}\text { Correlações } \\
\text { Múltiplas ao } \\
\text { Quadrado }\end{array}$ & Estimate \\
\hline$\overline{\mathrm{DC}}$ & $\begin{array}{l}<-- \\
\end{array}$ & QC & 0,124 & 0,036 & 3,476 & **** par_18 & $\overline{\mathrm{DC}}$ & 0,056 \\
\hline DCT & $<--$ & $\mathrm{DC}$ & 1,000 & & & & DCC & 0,657 \\
\hline DCC & $<--$ & $\mathrm{DC}$ & 1,000 & & & & DCT & 0,542 \\
\hline DCT9 & $<---$ & DCT & 1,000 & & & & $\mathrm{PO} 2$ & 0,680 \\
\hline DCT8 & $<---$ & DCT & 0,896 & 0,066 & 13,549 & *** par_1 & PO3 & 0,677 \\
\hline DCT7 & $<--$ & DCT & 0,978 & 0,071 & 13,809 & $* * *$ par_2 & DCC15 & 0,497 \\
\hline DCT6 & $<--$ & DCT & 0,918 & 0,071 & 12,859 & $* * *$ par_3 & DCC6 & 0,433 \\
\hline DCT5 & $<---$ & DCT & 1,033 & 0,074 & 13,887 & *** par_4 & DCC7 & 0,509 \\
\hline DCT4 & $<---$ & DCT & 0,917 & 0,071 & 12,943 & $* * *$ par_5 & DCC8 & 0,525 \\
\hline DCT3 & $<--$ & DCT & 1,035 & 0,072 & 14,299 & *** par_6 & DCC9 & 0,495 \\
\hline DCT2 & $<---$ & DCT & 0,852 & 0,066 & 12,872 & *** par_7 & DCC10 & 0,438 \\
\hline DCT1 & $<--$ & DCT & 0,797 & 0,066 & 12,055 & $* * *$ par_8 & DCC11 & 0,392 \\
\hline DCC13 & $<---$ & DCC & 1,000 & & & & DCC12 & 0,588 \\
\hline $\mathrm{DCC} 12$ & $<---$ & DCC & 1,046 & 0,067 & 15,726 & *** par_9 & DCC13 & 0,513 \\
\hline DCC11 & $<---$ & DCC & 0,923 & 0,073 & 12,629 & *** par_10 & DCT1 & 0,383 \\
\hline DCC10 & $<---$ & DCC & 0,954 & 0,071 & 13,418 & *** par_11 & DCT2 & 0,436 \\
\hline DCC9 & $<---$ & DCC & 1,023 & 0,072 & 14,220 & **** par_12 & DCT3 & 0,550 \\
\hline DCC8 & $<---$ & DCC & 1,068 & 0,074 & 14,489 & *** par_13 & DCT4 & 0,444 \\
\hline DCC7 & $<--$ & DCC & 1,059 & 0,074 & 14,336 & *** par_14 & DCT5 & 0,527 \\
\hline DCC6 & $<--$ & DCC & 0,986 & 0,075 & 13,212 & *** par_15 & DCT6 & 0,445 \\
\hline DCC15 & $<---$ & DCC & 1,055 & 0,073 & 14,386 & *** par_16 & DCT7 & 0,507 \\
\hline PO3 & $<--$ & QC & 1,021 & 0,236 & 4,331 & *** par_17 & DCT8 & 0,483 \\
\hline $\mathrm{PO} 2$ & $<--$ & $\mathrm{QC}$ & 1,000 & & & & DCT9 & 0,469 \\
\hline
\end{tabular}

Figura 61. Modelo Qualidade da Cooperação $\rightarrow D C$. 


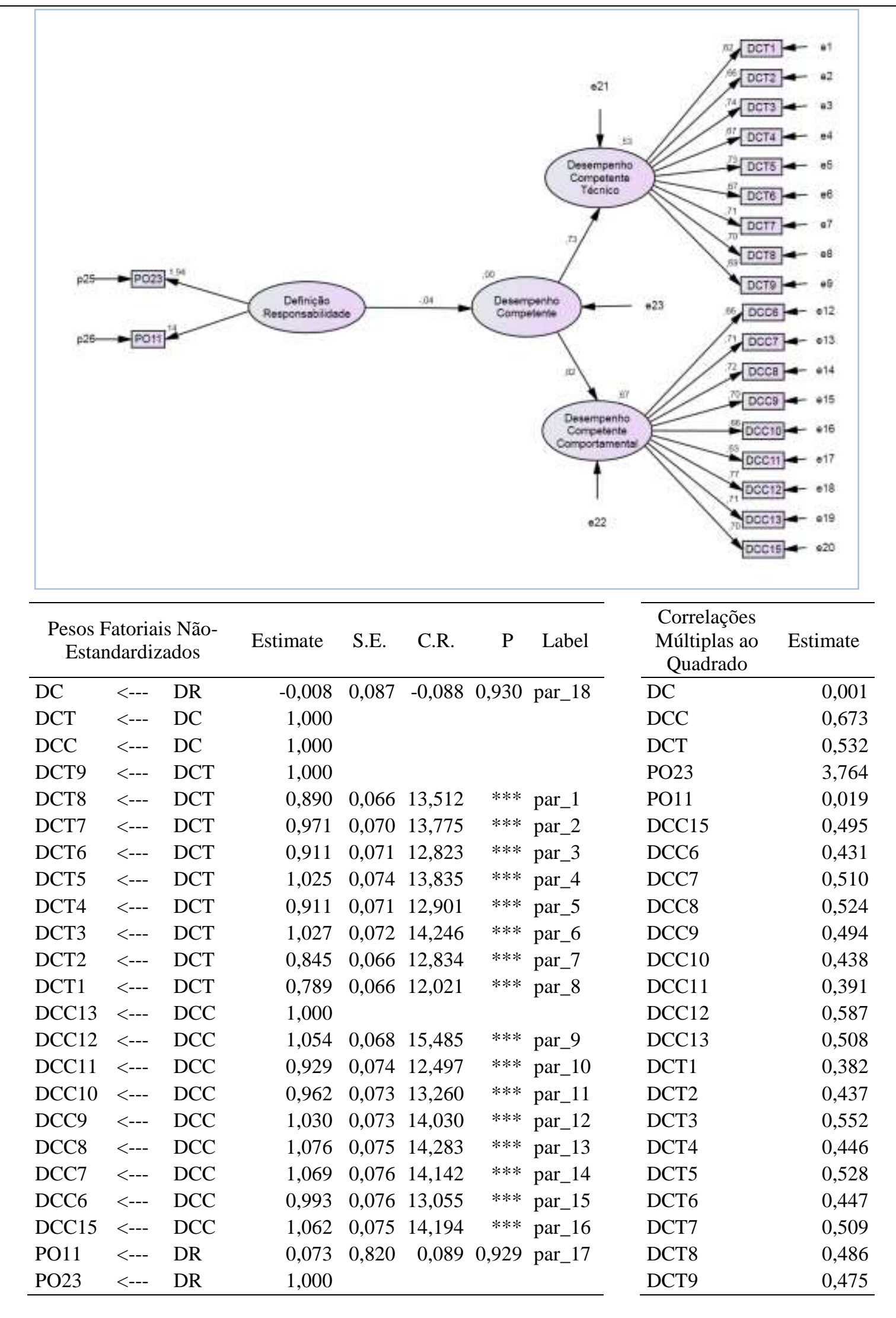

Figura 62. Modelo Definição de Responsabilidade $\rightarrow D C$. 


\section{Influência da identidade profissional sobre o desempenho profissional}

Trata-se da análise da influência da identidade profissional (IP) sobre o desempenho profissional por competências (DC), IP $\rightarrow D C$. Como forma de verificar a qualidade do ajuste dos dados, foram aferidas suas especificações.

O Modelo de Segunda Ordem da Identidade Profissional $I P \rightarrow D C$ apresentou ajustes satisfatórios $\quad(\mathrm{GFI}=0,94 ; \quad \mathrm{CFI}=0,96 ; \quad \mathrm{RMSEA}=0,038)$, sendo significativo $\quad(\mathrm{p}<0,000)$, responsável por explicar $19 \%$ da variância total do desempenho profissional $\left(R^{2}=0,62\right.$ para o desempenho por competências técnicas; e $\mathrm{R}^{2}=0,75$ para o desempenho por competências comportamentais). A Tabela 55 apresenta um resumo dos índices de ajuste e a Figura 63 exibe a representação gráfica do modelo, os pesos fatoriais não estandardizados e as correlações múltiplas ao quadrado.

Tabela 55

Índices de ajustamento da relação entre IP $\rightarrow D C$

\begin{tabular}{|c|c|c|}
\hline \multicolumn{2}{|l|}{$\begin{array}{l}\text { Amostra } \\
\mathrm{N}=916\end{array}$} & $\begin{array}{c}\text { Modelo } I P \rightarrow \\
D C\end{array}$ \\
\hline \multirow{4}{*}{$\begin{array}{l}\text { Índices } \\
\text { Absolutos }\end{array}$} & $\chi / g .1$. & 2,35 \\
\hline & $\chi^{2} ;$ g.l. & 748,$02 ; 319$ \\
\hline & $p$ & $\begin{array}{c}0,000 \\
0.0403)\end{array}$ \\
\hline & $\begin{array}{l}\text { GFI (AGFI) } \\
\text { SRMR }\end{array}$ & 0,040 \\
\hline \multirow[t]{2}{*}{ Índices Relativos } & CFI & 0,96 \\
\hline & TLI & 0,96 \\
\hline Índices de Discrepância & RMSEA & 0,038 \\
\hline Populacional & (Lo90;Hi90) & $(0,035 ; 0,042)$ \\
\hline \multirow[t]{2}{*}{ Índices de Parcimônia } & PCFI & 0,87 \\
\hline & PGFI & 0,79 \\
\hline Índices Baseados na & AIC & 866,02 \\
\hline \multirow[t]{2}{*}{ Teoria da Informação } & ECVI & 0,95 \\
\hline & CAIC & 1209,41 \\
\hline
\end{tabular}




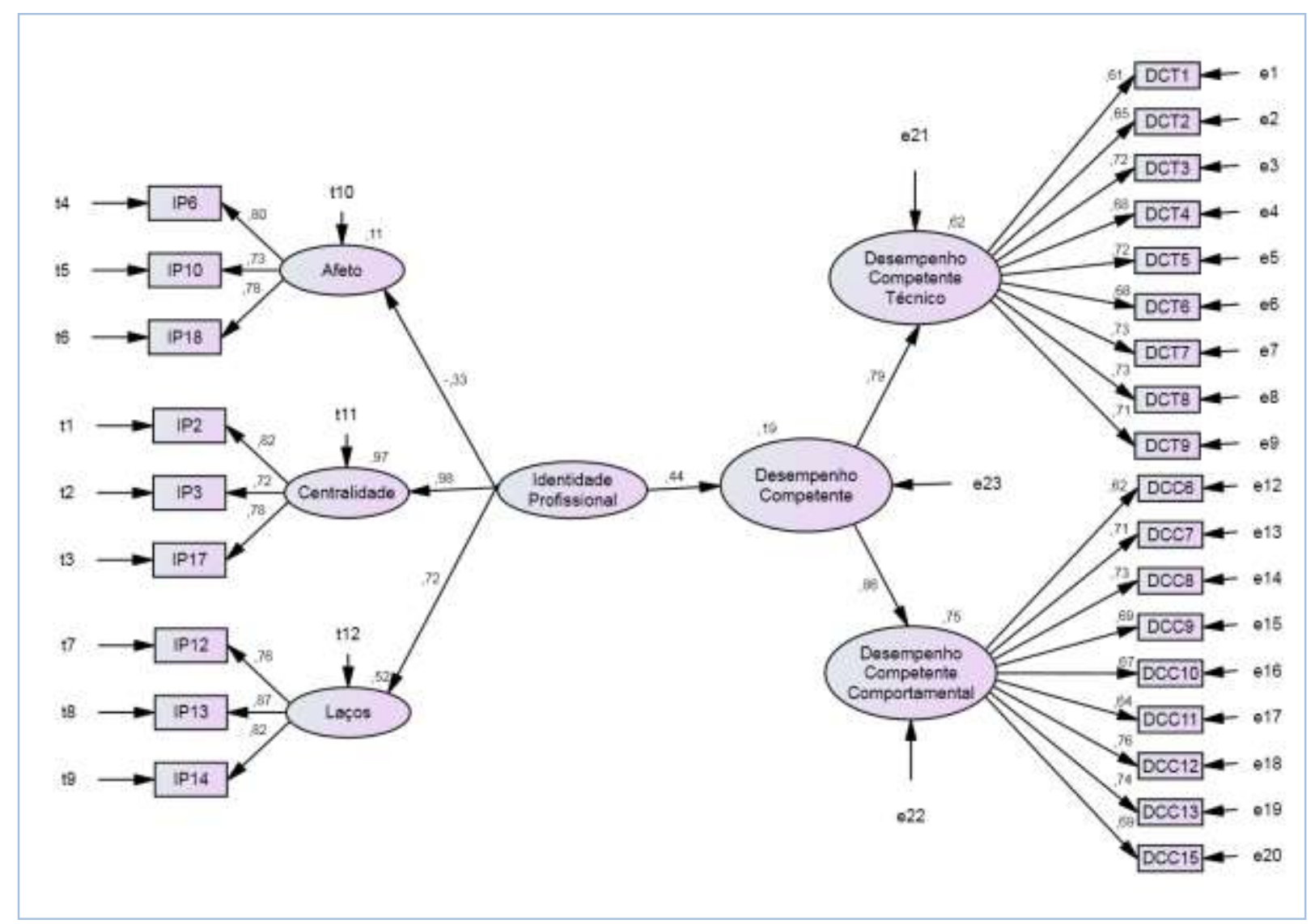




\begin{tabular}{|c|c|c|c|c|c|c|c|c|c|}
\hline \multicolumn{3}{|c|}{$\begin{array}{l}\text { Pesos Fatoriais Não- } \\
\text { Estandardizados }\end{array}$} & \multirow{2}{*}{$\begin{array}{r}\text { Estimate } \\
0,251\end{array}$} & \multirow{2}{*}{$\begin{array}{l}\text { S.E. } \\
0,030\end{array}$} & \multirow{2}{*}{$\begin{array}{l}\text { C.R. } \\
8,440\end{array}$} & \multirow{2}{*}{$\begin{array}{c}\mathrm{P} \\
* * *\end{array}$} & \multirow{2}{*}{$\begin{array}{c}\text { Label } \\
\text { par_23 }\end{array}$} & $\begin{array}{c}\text { Correlações } \\
\text { Múltiplas ao } \\
\text { Quadrado }\end{array}$ & \multirow{2}{*}{$\begin{array}{r}\text { Estimate } \\
0,194\end{array}$} \\
\hline $\mathrm{DC}$ & $<---$ & IP & & & & & & $\overline{\mathrm{DC}}$ & \\
\hline DCT & $<---$ & DC & 1,000 & & & & & Laços & 0,516 \\
\hline DCC & $<---$ & DC & 1,000 & & & & & Afeto & 0,106 \\
\hline Afeto & $<---$ & IP & $-0,374$ & 0,052 & $-7,231$ & $* * *$ & par_24 & Centralidade & 0,967 \\
\hline Centralidade & $<---$ & IP & 1,000 & & & & & $\mathrm{DCC}$ & 0,748 \\
\hline Laços & $<---$ & IP & 0,690 & 0,064 & 10,812 & $* * *$ & par_25 & DCT & 0,617 \\
\hline DCT9 & $<---$ & DCT & 1,000 & & & & & IP12 & 0,571 \\
\hline DCT8 & $<---$ & DCT & 0,941 & 0,044 & 21,459 & $* * *$ & par_1 & IP13 & 0,758 \\
\hline DCT7 & $<---$ & DCT & 1,001 & 0,047 & 21,410 & $* * *$ & par_2 & IP14 & 0,670 \\
\hline DCT6 & $<---$ & DCT & 0,900 & 0,045 & 19,815 & $* * *$ & par_3 & IP6 & 0,635 \\
\hline DCT5 & $<---$ & DCT & 1,017 & 0,048 & 21,251 & $* * *$ & par_4 & IP10 & 0,530 \\
\hline DCT4 & $<---$ & DCT & 0,908 & 0,046 & 19,883 & $* * *$ & par_5 & IP18 & 0,609 \\
\hline DCT3 & $<---$ & DCT & 0,982 & 0,046 & 21,266 & $* * *$ & par_6 & IP2 & 0,678 \\
\hline DCT2 & $<---$ & DCT & 0,832 & 0,044 & 19,116 & $* * *$ & par_7 & IP3 & 0,512 \\
\hline DCT1 & $<---$ & DCT & 0,805 & 0,045 & 17,913 & $* * *$ & par_8 & IP17 & 0,604 \\
\hline DCC13 & $<---$ & DCC & 1,000 & & & & & DCC15 & 0,469 \\
\hline DCC12 & $<---$ & $\mathrm{DCC}$ & 0,989 & 0,042 & 23,417 & $* * *$ & par_9 & DCC6 & 0,380 \\
\hline DCC11 & $<---$ & $\mathrm{DCC}$ & 0,899 & 0,047 & 19,138 & $* * *$ & par_10 & DCC7 & 0,501 \\
\hline DCC10 & $<---$ & DCC & 0,895 & 0,044 & 20,293 & $* * *$ & par_11 & DCC8 & 0,530 \\
\hline DCC9 & $<---$ & DCC & 0,976 & 0,047 & 20,672 & $* * *$ & par_12 & DCC9 & 0,470 \\
\hline DCC8 & $<---$ & DCC & 1,002 & 0,046 & 21,953 & $* * *$ & par_13 & DCC10 & 0,450 \\
\hline DCC7 & $<---$ & $\mathrm{DCC}$ & 1,000 & 0,047 & 21,226 & $* * *$ & par_14 & DCC11 & 0,410 \\
\hline DCC6 & $<---$ & DCC & 0,889 & 0,049 & 18,330 & $* * *$ & par_15 & DCC12 & 0,575 \\
\hline DCC15 & $<---$ & $\mathrm{DCC}$ & 0,989 & 0,048 & 20,740 & $* * *$ & par_16 & DCC13 & 0,547 \\
\hline IP17 & $<---$ & Centralidade & 1,000 & & & & & DCT1 & 0,375 \\
\hline IP3 & $<---$ & Centralidade & 0,887 & 0,043 & 20,547 & $* * *$ & par_17 & DCT2 & 0,422 \\
\hline IP2 & $<---$ & Centralidade & 1,038 & 0,046 & 22,496 & $* * *$ & par_18 & DCT3 & 0,523 \\
\hline IP18 & $<---$ & Afeto & 1,000 & & & & & DCT4 & 0,463 \\
\hline IP10 & $<---$ & Afeto & 0,928 & 0,047 & 19,789 & $* * *$ & par_19 & DCT5 & 0,524 \\
\hline IP6 & $<---$ & Afeto & 0,940 & 0,046 & 20,324 & $* * *$ & par_20 & DCT6 & 0,461 \\
\hline IP14 & $<---$ & Laços & 1,000 & & & & & DCT7 & 0,528 \\
\hline IP13 & $<---$ & Laços & 1,115 & 0,040 & 28,176 & $* * *$ & par_21 & DCT8 & 0,526 \\
\hline IP12 & $<---$ & Laços & 0,911 & 0,038 & 23,909 & $* * *$ & par_22 & DCT9 & 0,509 \\
\hline
\end{tabular}

Figura 63. Modelo $I P \rightarrow D C$. 


\section{Influência da identidade organizacional sobre o desempenho profissional}

Busca-se analisar a influência da identidade organizacional (IO) sobre o desempenho profissional por competências (DC), IO $\rightarrow D C$. Como forma de verificar a qualidade do ajuste dos dados, foram aferidas suas especificações.

O Modelo da Identidade organizacional $I O \rightarrow D C$ apresentou ajustes satisfatórios (GFI=0,94; CFI=0,96; RMSEA=0,043), sendo significativo $(\mathrm{p}<0,000)$, responsável por explicar $13 \%$ da variância total do desempenho profissional $\left(\mathrm{R}^{2}=0,59\right.$ para o desempenho por competências técnicas; e $\mathrm{R}^{2}=0,79$ para o desempenho por competências comportamentais). A Tabela 56 apresenta um resumo dos índices de ajuste e a Figura 64 exibe a representação gráfica do modelo, os pesos fatoriais não estandardizados e as correlações múltiplas ao quadrado.

Tabela 56

Índices de ajustamento da relação entre $I O \rightarrow D C$

\begin{tabular}{|c|c|c|}
\hline \multicolumn{2}{|l|}{$\begin{array}{l}\text { Amostra } \\
\mathrm{N}=916\end{array}$} & $\begin{array}{l}\text { Modelo } I P \rightarrow \\
D C\end{array}$ \\
\hline $\begin{array}{l}\text { Índices } \\
\text { Absolutos }\end{array}$ & $\begin{array}{l}\chi / \mathrm{g} .1 . \\
\chi^{2} ; \mathrm{g} .1 . \\
p \\
\text { GFI (AGFI) } \\
\text { SRMR }\end{array}$ & $\begin{array}{c}2,72 \\
678,08 ; 249 \\
0,000 \\
0,94(0,93) \\
0,041\end{array}$ \\
\hline Índices Relativos & $\begin{array}{l}\text { CFI } \\
\text { TLI }\end{array}$ & $\begin{array}{l}0,96 \\
0,95\end{array}$ \\
\hline $\begin{array}{l}\text { Índices de Discrepância } \\
\text { Populacional }\end{array}$ & $\begin{array}{l}\text { RMSEA } \\
\text { (Lo90;Hi90) }\end{array}$ & $\begin{array}{c}0,043 \\
(0,039 ; 0,047)\end{array}$ \\
\hline Índices de Parcimônia & $\begin{array}{l}\text { PCFI } \\
\text { PGFI }\end{array}$ & $\begin{array}{l}0,87 \\
0,78\end{array}$ \\
\hline $\begin{array}{l}\text { Índices Baseados na } \\
\text { Teoria da Informação }\end{array}$ & $\begin{array}{l}\text { AIC } \\
\text { ECVI } \\
\text { CAIC }\end{array}$ & $\begin{array}{c}780,08 \\
0,85 \\
1076,90\end{array}$ \\
\hline
\end{tabular}




\begin{tabular}{|c|c|c|c|c|c|c|c|c|}
\hline & & & & & $y$ & & DOC & \\
\hline \multicolumn{3}{|c|}{$\begin{array}{l}\text { Pesos Fatoriais } \\
\text { Não- } \\
\text { Estandardizados }\end{array}$} & Estimate & S.E. & C.R. & P Label & $\begin{array}{c}\text { Correlações } \\
\text { Múltiplas ao } \\
\text { Quadrado } \\
\end{array}$ & Estimate \\
\hline $\mathrm{DC}$ & $<--$ & IO & 0,186 & 0,020 & 9,349 & *** par_23 & $\mathrm{DC}$ & 0,134 \\
\hline DCT & $<---$ & $\mathrm{DC}$ & 1,000 & & & & $\mathrm{DCC}$ & 0,787 \\
\hline $\mathrm{DCC}$ & $<---$ & $\mathrm{DC}$ & 1,000 & & & & DCT & 0,593 \\
\hline DCT9 & $<---$ & DCT & 1,000 & & & & IO1 & 0,525 \\
\hline DCT8 & $<---$ & DCT & 0,925 & 0,043 & 21,628 & *** par_1 & $\mathrm{IO} 2$ & 0,489 \\
\hline DCT7 & $<---$ & DCT & 0,983 & 0,046 & 21,581 & *** par_2 & IO3 & 0,512 \\
\hline DCT6 & $<---$ & DCT & 0,884 & 0,044 & 19,951 & *** par_3 & $\mathrm{IO} 4$ & 0,747 \\
\hline DCT5 & $<---$ & DCT & 0,999 & 0,047 & 21,403 & *** par_4 & IO5 & 0,438 \\
\hline DCT4 & $<---$ & DCT & 0,891 & 0,045 & 20,007 & *** par_5 & IO6 & 0,717 \\
\hline DCT3 & $<---$ & DCT & 0,965 & 0,045 & 21,418 & *** par_6 & DCC 15 & 0,466 \\
\hline DCT2 & $<--$ & DCT & 0,817 & 0,042 & 19,224 & *** par_7 & DCC6 & 0,379 \\
\hline DCT1 & $<---$ & DCT & 0,790 & 0,044 & 17,999 & *** par_8 & DCC7 & 0,501 \\
\hline DCC13 & $<---$ & $\mathrm{DCC}$ & 1,000 & & & & DCC8 & 0,528 \\
\hline DCC12 & $<---$ & $\mathrm{DCC}$ & 1,008 & 0,044 & 22,945 & *** par_9 & DCC9 & 0,470 \\
\hline DCC11 & $<---$ & $\mathrm{DCC}$ & 0,914 & 0,048 & 18,842 & *** par_10 & DCC10 & 0,447 \\
\hline DCC10 & $<---$ & $\mathrm{DCC}$ & 0,910 & 0,046 & 19,970 & *** par_11 & DCC11 & 0,407 \\
\hline DCC9 & $<--$ & DCC & 0,995 & 0,049 & 20,337 & *** par_12 & DCC12 & 0,576 \\
\hline DCC8 & $<---$ & $\mathrm{DCC}$ & 1,019 & 0,047 & 21,525 & *** par_13 & DCC13 & 0,535 \\
\hline DCC7 & $<---$ & $\mathrm{DCC}$ & 1,019 & 0,049 & 20,841 & *** par_14 & DCT1 & 0,378 \\
\hline DCC6 & $<---$ & $\mathrm{DCC}$ & 0,905 & 0,050 & 18,077 & *** par_15 & DCT2 & 0,426 \\
\hline DCC15 & $<---$ & $\mathrm{DCC}$ & 1,005 & 0,049 & 20,378 & *** par_16 & DCT3 & 0,526 \\
\hline IO6 & $<---$ & $\mathrm{IO}$ & 1,000 & & & & DCT4 & 0,466 \\
\hline IO5 & $<---$ & $\mathrm{IO}$ & 0,739 & 0,034 & 21,860 & *** par_17 & DCT5 & 0,528 \\
\hline IO4 & $<---$ & $\mathrm{IO}$ & 0,977 & 0,031 & 31,411 & *** par_18 & DCT6 & 0,464 \\
\hline IO3 & $<---$ & $\mathrm{IO}$ & 0,778 & 0,033 & 23,655 & *** par_19 & DCT7 & 0,531 \\
\hline IO2 & $<---$ & $\mathrm{IO}$ & 0,784 & 0,034 & 23,090 & *** par_20 & DCT8 & 0,531 \\
\hline IO1 & $<---$ & $\mathrm{IO}$ & 0,909 & 0,040 & 22,589 & *** par_21 & DCT9 & 0,522 \\
\hline
\end{tabular}




\subsection{Teste dos Modelos Mediadores e dos Efeitos Indiretos}

Após o teste dos efeitos diretos, são apresentados os testes sobre relacionamentos indiretos (efeitos mediadores). Nesta tese, dois tipos de efeitos de mediação foram testados: o primeiro refere-se aos efeitos de mediação simples, e o segundo aos efeitos de mediação múltiplos, em uma etapa ou em cadeia. Para o teste das hipóteses da pesquisa, apenas o total dos efeitos indiretos foram considerados. No entanto, no caso de efeitos de mediação múltiplos, pode ser útil distinguir os efeitos indiretos específicos de efeitos indiretos totais. Os coeficientes de bootstrap não paramétricos são utilizados para testar os efeitos de mediadores totais (Cheung \& Lau, 2008). O método de Monte Carlo para avaliação de mediação (bootstrap paramétrico) é utilizado para testar os efeitos de mediadores específicos num só passo (MacKinnon, Lockwood \& Williams, 2004) e o método do teste de significância conjunto é empregado para o teste de mediação em cadeia de efeitos específicos (Taylor, MacKinnon \& Tein, 2008). Nesta tese utiliza-se o teste de Preacher e Hayes (2008), que estima os coeficientes em um modelo de mediação em cadeia e gera intervalos de confiança por bootstrap para efeitos diretos, indiretos e totais. Além disso, as recomendações de Zhao, Lynch e Chen (2010) foram observadas com o objetivo de testar os efeitos de mediação, examinando-se, para tanto, a matriz de efeitos indiretos (fornecida pelo Amos) de maneira simultânea.

Mediação simples da identidade profissional na relação entre os valores organizacionais e o desempenho profissional

O O primeiro teste buscou verificar a relação de mediação que a identidade profissional (IP) estabelece entre os tipos motivacionais subjacentes aos valores organizacionais (VO), todos correlacionados, e o desempenho profissional (DC) $V O \rightarrow I P \rightarrow$ $D C$. O segundo teste analisou a associação entre as dimensões bipolares dos tipos motivacionais sobre o desempenho profissional por competências, relação essa mediada pela identidade profissional. Para tanto, foram considerados os seguintes pares: Autonomia $x$ Conservação $\rightarrow I P \rightarrow D C$; Hierarquia x Igualitarismo $\rightarrow I P \rightarrow D C$; Domínio x Harmonia $\rightarrow$ $I P \rightarrow D C$. Como forma de verificar a qualidade do ajustamento dos dados, foram apreciadas suas especificações.

O primeiro teste apresentou ajustes satisfatórios (GFI=090; CFI=0,94; RMSEA=0,040), sendo significativos $(\mathrm{p}<0,05)$ os tipos motivacionais conservação, igualitarismo e harmonia, responsáveis por explicar $18 \%$ da identidade profissional $\left(\mathrm{R}^{2}=0,79\right.$ 
para centralidade; $\mathrm{R}^{2}=0,11$ para afeto; e $\mathrm{R}^{2}=0,64$ para laços), além de explicar, em conjunto com a identidade profissional, $26 \%$ da variância total do desempenho profissional $\left(\mathrm{R}^{2}=0,62\right.$ do desempenho por competências técnicas; e $\mathrm{R}^{2}=0,74$ do desempenho por competências comportamentais). Ademais, em relação ao modelo geral correlacional dos tipos motivacionais, a identidade profissional mediou de forma parcial a relação entre os tipos motivacionais e o desempenho profissional (Figura 65) de forma significativa, respectivamente $(\mathrm{p}=0,008 ; \mathrm{p}=0,007 ; \mathrm{p}=0,009)$.

$$
\begin{aligned}
& V O(\text { conservação }) \stackrel{0,16}{\longrightarrow} I P \stackrel{0,36}{\longrightarrow} D C \quad \text { VO(igualitarismo }) \stackrel{-0,38}{\longrightarrow} I P \stackrel{0,36}{\longrightarrow} D C \\
& V O(\text { conservação }) \stackrel{0,14}{\longrightarrow} D C \\
& \text { Efeito Indireto: } 0,058, p=0,003
\end{aligned}
$$

$$
\begin{gathered}
V O(\text { harmonia }) \stackrel{0,61}{\longrightarrow} I P \stackrel{0,36}{\longrightarrow} D C \\
\quad V O(\text { harmonia }) \stackrel{0,41}{\longrightarrow} D C \\
\text { Efeito Indireto: } 0,223, \mathrm{p}=0,007
\end{gathered}
$$

O segundo teste verificou a mediação da identidade profissional na relação entre os tipos motivacionais bipolares, analisados de forma independentes, e o desempenho profissional. Relativamente aos tipos conservação x autonomia e o desempenho profissional, a identidade profissional mediou parcialmente a relação entre conservação e desempenho profissional e totalmente a relação entre autonomia e desempenho profissional, de forma significativa ( $\mathrm{p}=0,001$ e $n . s .=$ não significativo) conforme Figura 66, com ajustes adequados (GFI=0,93; CFI=0,96; RMSEA=0,036).

$$
\begin{gathered}
\text { Conservação } \stackrel{0,24}{\longrightarrow} I P \stackrel{0,29}{\longrightarrow} D C \\
\text { Conservaçãa } o \stackrel{0,23}{\longrightarrow} D C
\end{gathered}
$$

Efeito Indireto: 0,094, p=0,001

$$
\begin{gathered}
\text { Autonomia } \stackrel{0,15}{\longrightarrow} I P \stackrel{0,29}{\longrightarrow} D C \\
\text { Autonomia } \stackrel{\text { n.s. }}{\longrightarrow} D C
\end{gathered}
$$

Efeito Indireto: $0,073, p=0,001$

Os tipos motivacionais Autonomia x Conservação foram responsáveis por explicar $14 \%$ da identidade profissional $\left(\mathrm{R}^{2}=0,78\right.$ para centralidade; $\mathrm{R}^{2}=0,11$ para afeto; e $\mathrm{R}^{2}=0,64$ para laços), além de explicar, em conjunto com a identidade profissional, $24 \%$ da variância total do desempenho profissional $\left(\mathrm{R}^{2}=0,62\right.$ do desempenho por competências técnicas; e $\mathrm{R}^{2}=0,75$ do desempenho por competências comportamentais).

Para os tipos motivacionais hierarquia x igualitarismo e o desempenho profissional, a identidade profissional mediou parcialmente essa relação (ver Figura 67), com ajustes adequados $(\mathrm{GFI}=0,93 ; \mathrm{CFI}=0,98 ; \mathrm{RMSEA}=0,036)$, e significativos $(\mathrm{p}=0,001 ; \mathrm{p}=0,024)$.

$$
\begin{aligned}
& \text { Hierarquia } \stackrel{0,31}{\longrightarrow} I P \stackrel{0,40}{\longrightarrow} D C \quad \text { Igualitarismo } \stackrel{0,36}{\longrightarrow} I P \stackrel{0,40}{\longrightarrow} D C \\
& \text { Hierarquia } \stackrel{0,16}{\longrightarrow} D C \quad \text { Igualitarismo } \stackrel{0,10}{\longrightarrow} D C \\
& \text { Efeito Indireto: 0,125, } \mathrm{p}=0,001 \quad \text { Efeito Indireto: } 0,145, \mathrm{p}=0,001
\end{aligned}
$$

As dimensões Hierarquia x igualitarismo foram responsáveis por explicar $15 \%$ da identidade profissional $\left(\mathrm{R}^{2}=0,88\right.$ para centralidade; $\mathrm{R}^{2}=0,10$ para afeto; e $\mathrm{R}^{2}=0,65$ para laços), além de explicar, em conjunto com a identidade profissional, $23 \%$ da variância total 
do desempenho profissional $\left(\mathrm{R}^{2}=0,63\right.$ do desempenho por competências técnicas; e $\mathrm{R}^{2}=0,72$ do desempenho por competências comportamentais).

Por fim, para os tipos motivacionais domínio $x$ harmonia e o desempenho profissional, a identidade profissional mediou parcialmente a essa relação para o tipo harmonia ( $\mathrm{p}=0,01)$ (ver Figura 68), com ajustes adequados (GFI=0,93; CFI=0,96; RMSEA=0,038).

$$
\begin{gathered}
\text { Domínio } \stackrel{\text { n.s. }}{\rightarrow} I P \stackrel{0,41}{\longrightarrow} D C \\
\text { Domínio } \stackrel{\text { n.s. }}{\rightarrow} D C
\end{gathered}
$$

Efeito Indireto: n.s.

$$
\begin{gathered}
\text { Harmonia } \stackrel{0,36}{\longrightarrow} I P \stackrel{0,41}{\longrightarrow} D C \\
\text { Harmonia } \stackrel{0,14}{\longrightarrow} D C
\end{gathered}
$$

Efeito Indireto: $0,150, \mathrm{p}=0,001$

A dimensão Harmonia foi responsável por explicar $13 \%$ da identidade profissional $\left(\mathrm{R}^{2}=0,77\right.$ para centralidade; $\mathrm{R}^{2}=0,11$ para afeto; e $\mathrm{R}^{2}=0,65$ para laços), além de explicar, em conjunto com a identidade profissional, $22 \%$ da variância total do desempenho profissional $\left(\mathrm{R}^{2}=0,63\right.$ do desempenho por competências técnicas; e $\mathrm{R}^{2}=0,73$ do desempenho por competências comportamentais).

A Tabela 57 sintetiza os índices de ajuste e as Figuras 65, 66, 67 e 68 exibem as representações gráficas de cada um dos modelos, os pesos fatoriais não estandardizados e as

\begin{tabular}{|c|c|c|c|c|c|}
\hline $\begin{array}{l}\text { Amostra } \\
\mathrm{N}=916\end{array}$ & & $\begin{array}{c}\text { Modelo } V O \rightarrow \\
I P \\
\rightarrow D C\end{array}$ & $\begin{array}{l}\text { Autonomia x } \\
\text { Conservação } \\
\rightarrow I P \rightarrow D C\end{array}$ & $\begin{array}{l}\text { Hierarquia } x \\
\text { Igualitarismo } \\
\rightarrow I P \rightarrow D C\end{array}$ & $\begin{array}{c}\text { Domínio } x \\
\text { Harmonia } \rightarrow \\
I P \rightarrow D C\end{array}$ \\
\hline $\begin{array}{l}\text { Índices } \\
\text { Absolutos }\end{array}$ & $\begin{array}{l}\chi / \text { g.l. } \\
\chi^{2} ; \text { g.l. } \\
p \\
\text { GFI (AGFI) } \\
\text { SRMR }\end{array}$ & $\begin{array}{c}2,46 \\
2261,76 ; 920 \\
0,000 \\
0,90(0,89) \\
0,042\end{array}$ & $\begin{array}{c}2,17 \\
1058,04 ; 487 \\
0,000 \\
0,93(0,92) \\
0,040\end{array}$ & $\begin{array}{c}2,17 \\
1054,30 ; 485 \\
0,000 \\
0,93(0,92) \\
0,042\end{array}$ & $\begin{array}{c}2,29 \\
1118,04 ; 488 \\
0,000 \\
0,93(0,92) \\
0,041\end{array}$ \\
\hline Índices Relativos & $\begin{array}{l}\text { CFI } \\
\text { TLI }\end{array}$ & $\begin{array}{l}0,94 \\
0,94\end{array}$ & $\begin{array}{l}0,96 \\
0,96\end{array}$ & $\begin{array}{l}0,98 \\
0,97\end{array}$ & $\begin{array}{l}0,96 \\
0,95\end{array}$ \\
\hline $\begin{array}{l}\text { Índices de } \\
\text { Discrepância } \\
\text { Populacional }\end{array}$ & $\begin{array}{l}\text { RMSEA } \\
\text { (Lo90;Hi90) }\end{array}$ & $\begin{array}{c}0,040 \\
(0,038 ; 0,042)\end{array}$ & $\begin{array}{c}0,036 \\
(0,033 ; 0,039)\end{array}$ & $\begin{array}{c}0,036 \\
(0,033 ; 0,039)\end{array}$ & $\begin{array}{c}0,038 \\
(0,035 ; 0,040)\end{array}$ \\
\hline $\begin{array}{l}\text { Índices de } \\
\text { Parcimônia }\end{array}$ & $\begin{array}{l}\text { PCFI } \\
\text { PGFI }\end{array}$ & $\begin{array}{l}0,88 \\
0,80\end{array}$ & $\begin{array}{l}0,89 \\
0,81\end{array}$ & $\begin{array}{l}0,88 \\
0,81\end{array}$ & $\begin{array}{l}0,88 \\
0,81\end{array}$ \\
\hline $\begin{array}{l}\text { Índices Baseados } \\
\text { na Teoria da } \\
\text { Informação }\end{array}$ & $\begin{array}{l}\text { AIC } \\
\text { ECVI } \\
\text { CAIC }\end{array}$ & $\begin{array}{c}2491,76 \\
2,72 \\
3161,06\end{array}$ & $\begin{array}{c}1206,04 \\
1,32 \\
1636,72\end{array}$ & $\begin{array}{c}1206,30 \\
1,32 \\
1648,62\end{array}$ & $\begin{array}{c}1264,05 \\
1,38 \\
1688,91\end{array}$ \\
\hline
\end{tabular}
correlações múltiplas ao quadrado

Tabela 57

Índices de ajustamento da relação entre $V O \rightarrow I P \rightarrow D C$, completo e por dimensões 


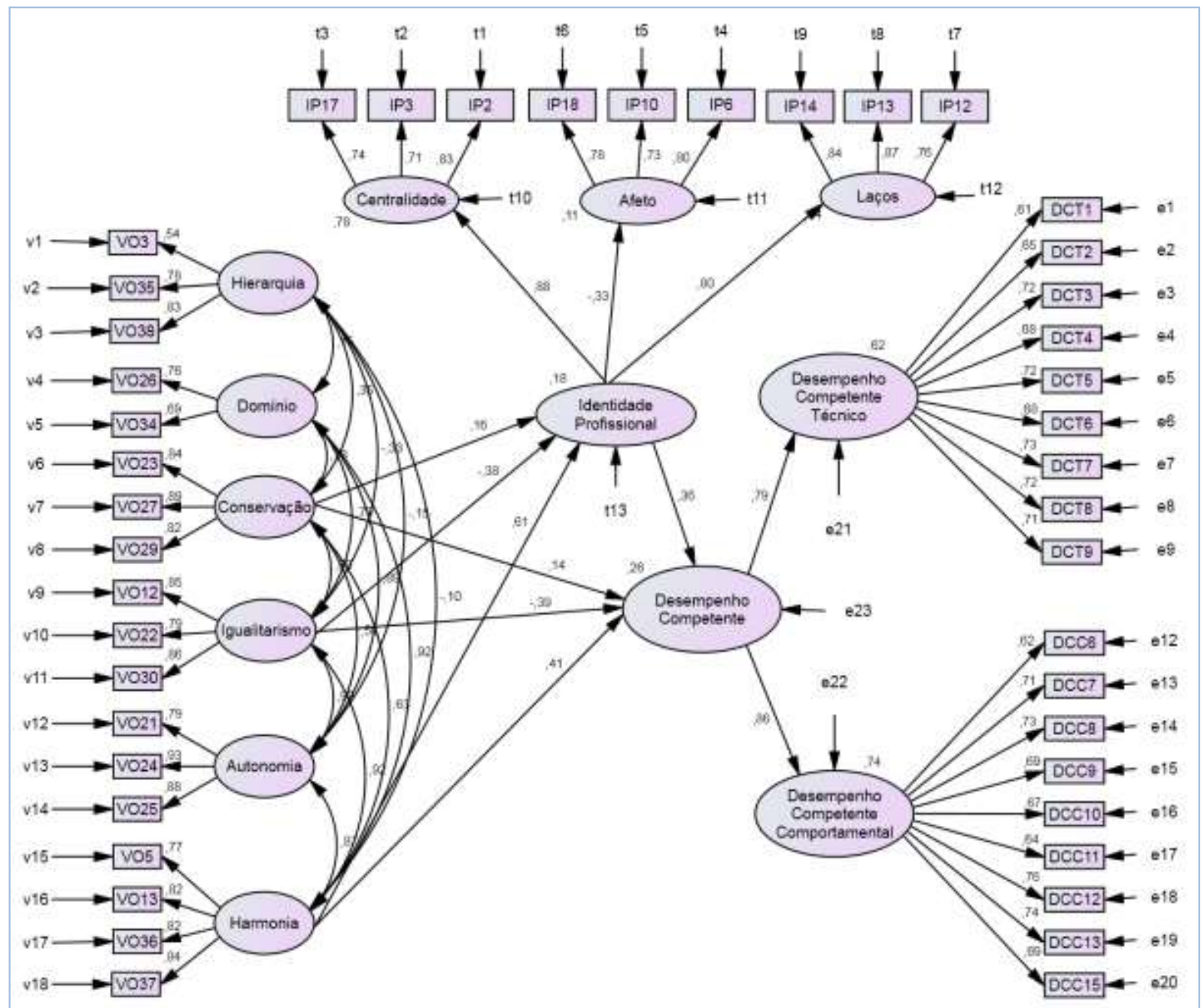

\begin{tabular}{|c|c|c|c|c|c|c|c|c|c|}
\hline \multicolumn{3}{|c|}{$\begin{array}{l}\text { Pesos Fatoriais Não- } \\
\text { Estandardizados }\end{array}$} & \multirow{2}{*}{$\begin{array}{r}\text { Estimate } \\
0,056\end{array}$} & \multirow{2}{*}{$\begin{array}{l}\text { S.E. } \\
0,021\end{array}$} & \multirow{2}{*}{$\begin{array}{l}\text { C.R. } \\
2,708\end{array}$} & \multirow{2}{*}{$\begin{array}{r}\mathrm{P} \\
0,007\end{array}$} & \multirow{2}{*}{$\begin{array}{c}\text { Label } \\
\text { par_54 }\end{array}$} & \multirow{2}{*}{$\begin{array}{c}\text { Correlações } \\
\text { Múltiplas ao } \\
\text { Quadrado }\end{array}$} & \multirow{2}{*}{$\begin{array}{r}\text { Estimate } \\
0,178\end{array}$} \\
\hline$\overline{\text { IP }}$ & <--- & Conservação & & & & & & & \\
\hline IP & $<--$ & Igualitarismo & $-0,085$ & 0,032 & $-2,681$ & 0,007 & par_55 & $\mathrm{DC}$ & 0,262 \\
\hline IP & $<--$ & Harmonia & 0,186 & 0,050 & 3,755 & $* * *$ & par_56 & Laços & 0,642 \\
\hline DC & $<--$ & Harmonia & 0,085 & 0,033 & 2,572 & 0,010 & par_51 & Afeto & 0,110 \\
\hline DC & $<--$ & Igualitarismo & $-0,060$ & 0,021 & $-2,868$ & 0,004 & par_52 & Centralidade & 0,778 \\
\hline DC & $<--$ & Conservação & 0,034 & 0,014 & 2,490 & 0,013 & par_53 & DCC & 0,743 \\
\hline DC & $<--$ & IP & 0,252 & 0,033 & 7,539 & $* * *$ & par_57 & DCT & 0,620 \\
\hline DCT & $<--$ & DC & 1,000 & & & & & IP12 & 0,582 \\
\hline DCC & $<--$ & DC & 1,000 & & & & & IP13 & 0,762 \\
\hline Centralidade & $<--$ & IP & 1,000 & & & & & IP14 & 0,701 \\
\hline Afeto & $<--$ & IP & $-0,465$ & 0,060 & $-7,765$ & $* * *$ & par_50 & IP6 & 0,633 \\
\hline Laços & $<--$ & IP & 1,000 & & & & & IP10 & 0,530 \\
\hline DCT9 & $<--$ & DCT & 1,000 & & & & & IP18 & 0,611 \\
\hline DCT8 & $<--$ & DCT & 0,942 & 0,044 & 21,572 & $* * *$ & par_1 & IP2 & 0,689 \\
\hline
\end{tabular}




\begin{tabular}{|c|c|c|c|c|c|c|c|c|c|}
\hline DCT7 & $<--$ & DCT & 1,002 & 0,047 & 21,523 & $* * *$ & par_2 & IP3 & 0,510 \\
\hline DCT6 & $<---$ & DCT & 0,903 & 0,045 & 19,912 & $* * *$ & par_3 & IP17 & 0,547 \\
\hline DCT5 & $<---$ & DCT & 1,020 & 0,048 & 21,374 & $* * *$ & par_4 & VO37 & 0,699 \\
\hline DCT4 & $<--$ & DCT & 0,910 & 0,046 & 19,981 & $* * *$ & par_5 & VO36 & 0,675 \\
\hline DCT3 & $<--$ & DCT & 0,984 & 0,046 & 21,386 & $* * *$ & par_6 & VO5 & 0,590 \\
\hline DCT2 & $<---$ & DCT & 0,834 & 0,043 & 19,203 & $* * *$ & par_7 & VO13 & 0,673 \\
\hline DCT1 & $<---$ & DCT & 0,807 & 0,045 & 17,992 & $* * *$ & par_8 & VO21 & 0,622 \\
\hline DCC13 & $<--$ & DCC & 1,000 & & & & & VO24 & 0,868 \\
\hline DCC12 & $<--$ & DCC & 0,987 & 0,042 & 23,640 & $* * *$ & par_9 & VO25 & 0,782 \\
\hline DCC11 & $<---$ & DCC & 0,895 & 0,047 & 19,234 & $* * *$ & par_10 & VO12 & 0,725 \\
\hline DCC10 & $<--$ & DCC & 0,892 & 0,044 & 20,420 & $* * *$ & par_11 & VO22 & 0,625 \\
\hline DCC9 & $<---$ & DCC & 0,974 & 0,047 & 20,835 & $* * *$ & par_12 & VO30 & 0,731 \\
\hline DCC8 & $<--$ & DCC & 0,998 & 0,045 & 22,130 & $* * *$ & par_13 & VO23 & 0,703 \\
\hline DCC7 & $<---$ & DCC & 0,997 & 0,047 & 21,402 & $* * *$ & par_14 & VO27 & 0,790 \\
\hline DCC6 & $<--$ & DCC & 0,888 & 0,048 & 18,450 & $* * *$ & par_15 & VO29 & 0,679 \\
\hline DCC15 & $<--$ & DCC & 0,988 & 0,047 & 20,915 & $* * *$ & par_16 & VO26 & 0,583 \\
\hline VO38 & $<---$ & Hierarquia & 1,000 & & & & & VO34 & 0,469 \\
\hline VO35 & $<--$ & Hierarquia & 0,982 & 0,047 & 20,726 & $* * *$ & par_17 & $\mathrm{VO} 3$ & 0,288 \\
\hline VO3 & $<--$ & Hierarquia & 0,613 & 0,041 & 14,854 & $* * *$ & par_18 & VO35 & 0,614 \\
\hline VO34 & $<---$ & Domínio & 1,000 & & & & & VO38 & 0,688 \\
\hline VO26 & $<---$ & Domínio & 1,215 & 0,058 & 20,940 & $* * *$ & par_19 & DCC15 & 0,471 \\
\hline VO29 & $<--$ & Conservação & 1,000 & & & & & DCC6 & 0,381 \\
\hline VO27 & $<---$ & Conservação & 1,075 & 0,035 & 30,993 & $* * *$ & par_21 & DCC7 & 0,501 \\
\hline VO23 & $<---$ & Conservação & 1,009 & ,035 & 28,913 & $* * *$ & par_22 & DCC8 & 0,529 \\
\hline VO30 & $<--$ & Igualitarismo & 1,000 & & & & & DCC9 & 0,471 \\
\hline VO22 & $<--$ & Igualitarismo & ,636 & ,022 & 28,961 & $* * *$ & par_25 & DCC10 & 0,450 \\
\hline VO12 & $<---$ & Igualitarismo & ,888 & 027 & 33,295 & $* * *$ & par_26 & DCC11 & 0,408 \\
\hline VO25 & $<--$ & Autonomia & 1,000 & & & & & DCC12 & 0,576 \\
\hline $\mathrm{VO} 24$ & $<---$ & Autonomia & 1,061 & ,024 & 43,511 & $* * *$ & par_30 & DCC13 & 0,549 \\
\hline VO21 & $<---$ & Autonomia & ,923 & 031 & 30,073 & $* * *$ & par_31 & DCT1 & 0,376 \\
\hline VO13 & $<--$ & Harmonia & ,923 & ,032 & 28,961 & $* * *$ & par_36 & DCT2 & 0,422 \\
\hline VO5 & $<--$ & Harmonia & ,908 & ,034 & 26,520 & $* * *$ & par_37 & DCT3 & 0,522 \\
\hline VO37 & $<---$ & Harmonia & 1,002 & ,033 & 30,422 & $* * *$ & par_43 & DCT4 & 0,462 \\
\hline VO36 & $<---$ & Harmonia & 1,000 & & & & & DCT5 & 0,525 \\
\hline IP17 & $<--$ & Centralidade & 1,000 & & & & & DCT6 & 0,461 \\
\hline IP3 & $<--$ & Centralidade & 960 & ,047 & 20,440 & $* * *$ & par_44 & DCT7 & 0,526 \\
\hline IP2 & $<---$ & Centralidade & 1,130 & 052 & 21,804 & $* * *$ & par_45 & DCT8 & 0,525 \\
\hline IP18 & $<--$ & Afeto & 1,000 & & & & & DCT9 & 0,508 \\
\hline IP10 & $<---$ & Afeto & ,927 & ,047 & 19,770 & $* * *$ & par_46 & & \\
\hline IP6 & $<---$ & Afeto & ,938 & ,046 & 20,331 & $* * *$ & par_47 & & \\
\hline IP14 & $<--$ & Laços & 1,000 & & & & & & \\
\hline IP13 & $<--$ & Laços & 1,070 & ,035 & 30,410 & $* * *$ & par_48 & & \\
\hline IP12 & $<---$ & Laços & 877 & ,035 & 25,127 & $* * *$ & par_49 & & \\
\hline
\end{tabular}

Figura 65. Modelo $V O \rightarrow I P \rightarrow D C$. 







\begin{tabular}{|c|c|c|c|c|c|c|c|c|c|}
\hline \multicolumn{3}{|c|}{$\begin{array}{c}\text { Pesos Fatoriais } \\
\text { Não-Estandardizados }\end{array}$} & \multirow{2}{*}{$\begin{array}{l}\text { Estimate } \\
0,052\end{array}$} & \multirow{2}{*}{$\begin{array}{l}\text { S.E. } \\
0,013\end{array}$} & \multirow{2}{*}{$\begin{array}{l}\text { C.R. } \\
3,994\end{array}$} & \multirow{2}{*}{$\begin{array}{c}\mathrm{P} \\
* * *\end{array}$} & \multirow{2}{*}{$\begin{array}{c}\text { Label } \\
\text { par_30 }\end{array}$} & $\begin{array}{c}\text { Correlações } \\
\text { Múltiplas ao } \\
\text { Quadrado }\end{array}$ & \multirow{2}{*}{$\begin{array}{r}\text { Estimate } \\
0,141\end{array}$} \\
\hline IP & $<--$ & Autonomia & & & & & & IP & \\
\hline IP & $<--$ & Conservação & 0,085 & 0,017 & 4,983 & $* * *$ & par_31 & DC & 0,237 \\
\hline DC & $<--$ & IP & 0,271 & 0,032 & 8,483 & $* * *$ & par_28 & Laços & 0,643 \\
\hline DC & $<--$ & Conservação & 0,046 & 0,010 & 4,531 & $* * *$ & par_29 & Afeto & 0,109 \\
\hline DCT & & DC & 1,000 & & & & & Centralidade & 0,781 \\
\hline DCC & $<--$ & DC & 1,000 & & & & & DCC & 0,747 \\
\hline Afeto & $<--$ & IP & $-0,462$ & 0,060 & $-7,723$ & $* * *$ & par_32 & DCT & 0,618 \\
\hline Laços & $<--$ & IP & 1,000 & & & & & IP12 & 0,582 \\
\hline Centralidade & $<--$ & IP & 1,000 & & & & & IP13 & 0,762 \\
\hline DCT9 & $<--$ & DCT & 1,000 & & & & & IP14 & 0,702 \\
\hline DCT8 & $<--$ & DCT & 0,941 & 0,044 & 21,558 & $* * *$ & par_1 & IP6 & 0,633 \\
\hline DCT7 & $<--$ & DCT & 1,001 & 0,047 & 21,509 & $* * *$ & par_2 & IP10 & 0,530 \\
\hline DCT6 & $<--$ & DCT & 0,901 & 0,045 & 19,898 & $* * *$ & par_3 & IP18 & 0,611 \\
\hline DCT5 & & DCT & 1,018 & 0,048 & 21,355 & $* * *$ & par_4 & IP2 & 0,689 \\
\hline DCT4 & & DCT & 0,908 & 0,045 & 19,967 & $* * *$ & par_5 & IP3 & 0,510 \\
\hline DCT3 & & DCT & 0,983 & 0,046 & 21,370 & $* * *$ & par_6 & IP17 & 0,547 \\
\hline DCT2 & $<--$ & DCT & 0,832 & 0,043 & 19,192 & $* * *$ & par_7 & VO21 & 0,565 \\
\hline DCT1 & & DCT & 0,806 & 0,045 & 17,984 & $* * *$ & par_8 & VO24 & 0,895 \\
\hline DCC13 & $<--$ & DCC & 1,000 & & & & & VO25 & 0,796 \\
\hline DCC12 & $<---$ & DCC & 0,988 & 0,042 & 23,563 & $* * *$ & par_9 & VO23 & 0,724 \\
\hline DCC11 & $<--$ & DCC & 0,898 & 0,047 & 19,212 & $* * *$ & par_10 & VO27 & 0,782 \\
\hline DCC10 & $<--$ & DCC & 0,894 & 0,044 & 20,388 & $* * *$ & par_11 & VO29 & 0,667 \\
\hline DCC9 & $<--$ & DCC & 0,975 & 0,047 & 20,779 & $* * *$ & par_12 & DCC15 & 0,470 \\
\hline DCC8 & & DCC & 1,001 & 0,045 & 22,075 & $* * *$ & par_13 & DCC6 & 0,380 \\
\hline DCC7 & $<--$ & DCC & 0,999 & 0,047 & 21,345 & $* * *$ & par_14 & DCC7 & 0,501 \\
\hline DCC6 & $<--$ & DCC & 0,889 & 0,048 & 18,404 & $* * *$ & par_15 & DCC8 & 0,529 \\
\hline DCC15 & $<--$ & DCC & 0,989 & 0,047 & 20,850 & $* * *$ & par_16 & DCC9 & 0,470 \\
\hline VO29 & $<--$ & Conservação & 1,000 & & & & & DCC10 & 0,450 \\
\hline VO27 & $<--$ & Conservação & 1,080 & 0,036 & 30,160 & $* * *$ & par_17 & DCC11 & 0,409 \\
\hline VO23 & & Conservação & 1,033 & 0,036 & 28,514 & $* * *$ & par_18 & DCC12 & 0,575 \\
\hline VO25 & $<--$ & Autonomia & 1,000 & & & & & DCC13 & 0,548 \\
\hline VO24 & $<--$ & Autonomia & 1,068 & 0,027 & 39,638 & $* * *$ & par_19 & DCT1 & 0,376 \\
\hline VO21 & $<---$ & Autonomia & 0,872 & 0,031 & 28,262 & $* * *$ & par_20 & DCT2 & 0,423 \\
\hline IP17 & $<--$ & Centralidade & 1,000 & & & & & DCT3 & 0,523 \\
\hline IP3 & $<--$ & Centralidade & 0,960 & 0,047 & 20,362 & $* * *$ & par_22 & DCT4 & 0,463 \\
\hline IP2 & $<--$ & Centralidade & 1,131 & 0,052 & 21,658 & $* * *$ & par_23 & DCT5 & 0,524 \\
\hline IP18 & $<---$ & Afeto & 1,000 & & & & & DCT6 & 0,461 \\
\hline IP10 & $<--$ & Afeto & 0,926 & 0,047 & 19,768 & $* * *$ & par_24 & DCT7 & 0,527 \\
\hline IP6 & $<---$ & Afeto & 0,938 & 0,046 & 20,316 & $* * *$ & par_25 & DCT8 & 0,526 \\
\hline IP14 & $<---$ & Laços & 1,000 & & & & & DCT9 & 0,509 \\
\hline IP13 & $<--$ & Laços & 1,069 & 0,035 & 30,375 & $* * *$ & par_26 & & \\
\hline IP12 & $<--$ & Laços & 0,877 & 0,035 & 25,113 & $* * *$ & par_27 & & \\
\hline
\end{tabular}

Figura 66. Modelo Autonomia $x$ Conservação $\rightarrow I P \rightarrow D C$. 


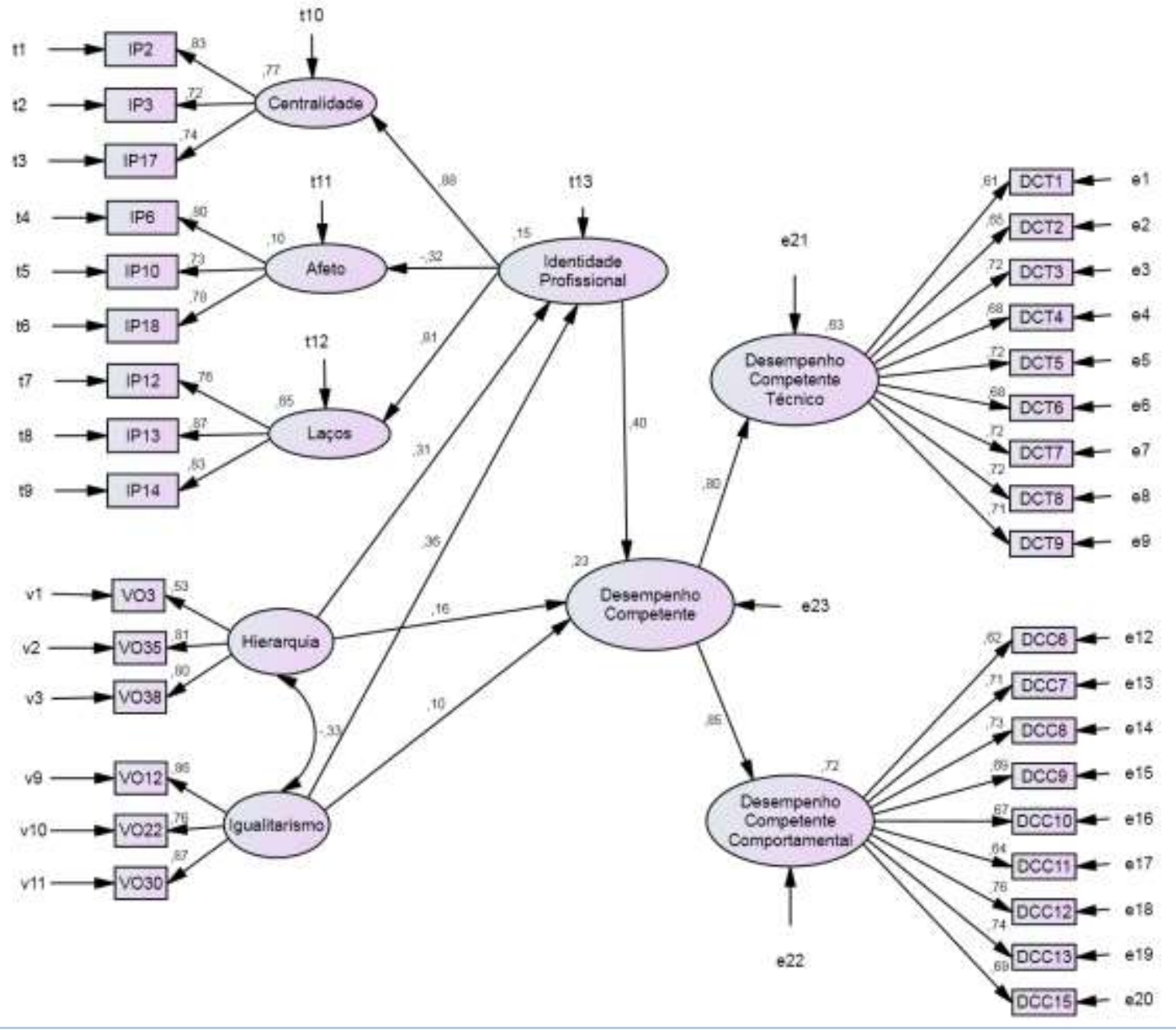




\begin{tabular}{|c|c|c|c|c|c|c|c|c|c|}
\hline \multicolumn{3}{|c|}{$\begin{array}{l}\text { Pesos Fatoriais Não- } \\
\text { Estandardizados }\end{array}$} & \multirow{2}{*}{$\begin{array}{c}\text { Estimate } \\
0,091\end{array}$} & \multirow{2}{*}{$\begin{array}{c}\text { S.E. } \\
0,013\end{array}$} & \multirow{2}{*}{$\begin{array}{l}\text { C.R. } \\
6,963\end{array}$} & \multirow{2}{*}{$\begin{array}{c}\mathrm{P} \\
* * *\end{array}$} & \multirow{2}{*}{$\begin{array}{l}\text { Label } \\
\text { par_33 }\end{array}$} & \multirow{2}{*}{$\begin{array}{c}\text { Correlações } \\
\text { Múltiplas ao } \\
\text { Quadrado } \\
\text { IP }\end{array}$} & \multirow{2}{*}{$\begin{array}{c}\text { Estimate } \\
0,153\end{array}$} \\
\hline IP & <--- & Hierarquia & & & & & & & \\
\hline IP & $<---$ & Igualitarismo & 0,078 & 0,009 & 8,397 & $* * *$ & par_34 & $\mathrm{DC}$ & 0,232 \\
\hline $\mathrm{DC}$ & $<---$ & IP & 0,278 & 0,033 & 8,290 & $* * *$ & par_23 & Laços & 0,654 \\
\hline $\mathrm{DC}$ & $<---$ & Hierarquia & 0,033 & 0,009 & 3,486 & $* * *$ & par_31 & Afeto & 0,102 \\
\hline $\mathrm{DC}$ & $<---$ & Igualitarismo & 0,015 & 0,007 & 2,153 & 0,031 & par_32 & Centralidade & 0,766 \\
\hline DCT & $<---$ & DC & 1,000 & & & & & DCC & 0,724 \\
\hline $\mathrm{DCC}$ & $<---$ & $\mathrm{DC}$ & 1,000 & & & & & DCT & 0,635 \\
\hline Afeto & $<---$ & IP & $-0,448$ & 0,060 & $-7,487$ & $* * *$ & par_24 & VO12 & 0,739 \\
\hline Laços & $<---$ & IP & 1,000 & & & & & VO22 & 0,580 \\
\hline Centralidade & $<---$ & IP & 1,000 & & & & & VO30 & 0,758 \\
\hline DCT9 & $<---$ & DCT & 1,000 & & & & & VO3 & 0,279 \\
\hline DCT8 & $<---$ & DCT & 0,953 & 0,045 & 21,286 & $* * *$ & par_1 & VO35 & 0,658 \\
\hline DCT7 & $<---$ & DCT & 1,014 & 0,048 & 21,232 & $* * *$ & par_2 & VO38 & 0,641 \\
\hline DCT6 & $<---$ & DCT & 0,913 & 0,046 & 19,674 & $* * *$ & par_3 & IP12 & 0,580 \\
\hline DCT5 & $<---$ & DCT & 1,032 & 0,049 & 21,083 & $* * *$ & par_4 & IP13 & 0,762 \\
\hline DCT4 & $<---$ & DCT & 0,921 & 0,047 & 19,750 & $* * *$ & par_5 & IP14 & 0,697 \\
\hline DCT3 & $<---$ & DCT & 0,996 & 0,047 & 21,104 & $* * *$ & par_6 & IP6 & 0,632 \\
\hline DCT2 & $<---$ & DCT & 0,843 & 0,044 & 19,000 & $* * *$ & par_7 & IP10 & 0,530 \\
\hline DCT1 & $<---$ & DCT & 0,816 & 0,046 & 17,823 & $* * *$ & par_8 & IP18 & 0,612 \\
\hline DCC13 & $<---$ & DCC & 1,000 & & & & & IP2 & 0,686 \\
\hline DCC12 & $<---$ & DCC & 0,979 & 0,041 & 23,671 & $* * *$ & par_9 & IP3 & 0,512 \\
\hline DCC11 & $<---$ & DCC & 0,890 & 0,046 & 19,283 & $* * *$ & par_10 & IP17 & 0,553 \\
\hline DCC10 & $<---$ & DCC & 0,885 & 0,043 & 20,452 & $* * *$ & par_11 & DCC15 & 0,472 \\
\hline DCC9 & $<---$ & DCC & 0,966 & 0,046 & 20,851 & $* * *$ & par_12 & DCC6 & 0,382 \\
\hline DCC8 & $<---$ & DCC & 0,992 & 0,045 & 22,174 & $* * *$ & par_13 & DCC7 & 0,502 \\
\hline DCC7 & $<---$ & DCC & 0,989 & 0,046 & 21,428 & $* * *$ & par_14 & DCC8 & 0,531 \\
\hline DCC6 & $<---$ & DCC & 0,881 & 0,048 & 18,468 & $* * *$ & par_15 & DCC9 & 0,471 \\
\hline DCC15 & $<---$ & DCC & 0,980 & 0,047 & 20,933 & $* * *$ & par_16 & DCC10 & 0,451 \\
\hline IP17 & $<---$ & Centralidade & 1,000 & & & & & DCC11 & 0,411 \\
\hline IP3 & $<---$ & Centralidade & 0,954 & 0,047 & 20,442 & $* * *$ & par_17 & DCC12 & 0,577 \\
\hline IP2 & $<---$ & Centralidade & 1,119 & 0,051 & 21,794 & $* * *$ & par_18 & DCC13 & 0,554 \\
\hline IP18 & $<---$ & Afeto & 1,000 & & & & & DCT1 & 0,374 \\
\hline IP10 & $<---$ & Afeto & 0,926 & 0,047 & 19,749 & $* * *$ & par_19 & DCT2 & 0,421 \\
\hline IP6 & $<---$ & Afeto & 0,937 & 0,046 & 20,297 & $* * *$ & par_20 & DCT3 & 0,521 \\
\hline IP14 & $<---$ & Laços & 1,000 & & & & & DCT4 & 0,461 \\
\hline IP13 & $<---$ & Laços & 1,076 & 0,036 & 30,233 & $* * *$ & par_21 & DCT5 & 0,523 \\
\hline IP12 & $<---$ & Laços & 0,881 & 0,035 & 25,034 & $* * *$ & par_22 & DCT6 & 0,459 \\
\hline VO38 & $<---$ & Hierarquia & 1,000 & & & & & DCT7 & 0,525 \\
\hline VO35 & $<---$ & Hierarquia & 1,059 & ,064 & 16,646 & $* * *$ & par_25 & DCT8 & 0,523 \\
\hline VO3 & $<---$ & Hierarquia & 630 & 045 & 14,055 & $* * *$ & par_26 & DCT9 & 0,499 \\
\hline VO30 & $<---$ & Igualitarismo & 1,000 & & & & & & \\
\hline VO22 & $<---$ & Igualitarismo & ,602 &, 024 & 25,547 & $* * *$ & par_27 & & \\
\hline VO12 & $<---$ & Igualitarismo & ,882 &, 031 & 28,494 & $* * *$ & par_28 & & \\
\hline
\end{tabular}




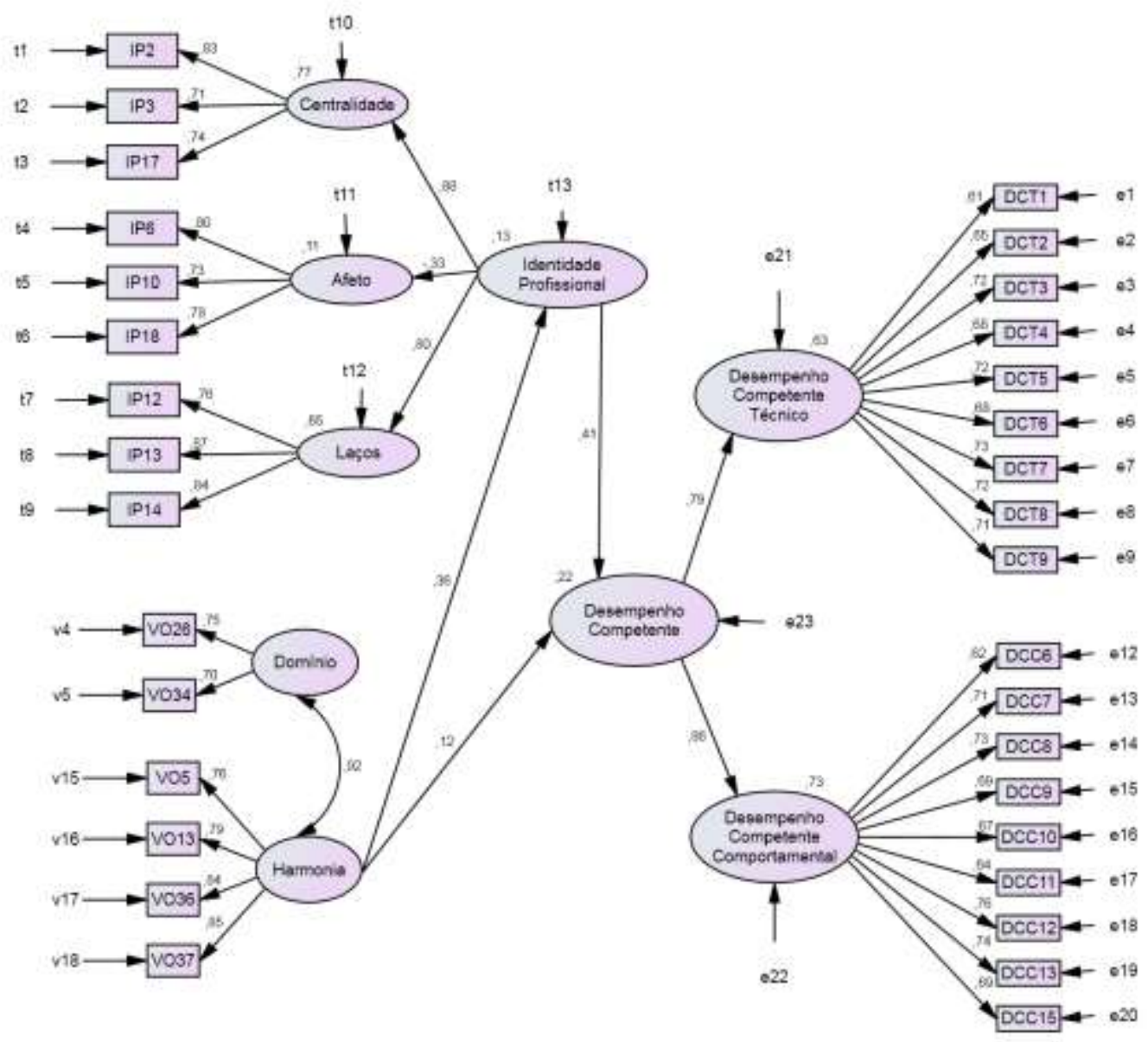




\begin{tabular}{|c|c|c|c|c|c|c|c|c|c|}
\hline \multicolumn{3}{|c|}{$\begin{array}{l}\text { Pesos Fatoriais Não- } \\
\text { Estandardizados }\end{array}$} & \multirow{2}{*}{$\begin{array}{r}\text { Estimate } \\
0,109\end{array}$} & \multirow{2}{*}{$\begin{array}{l}\text { S.E. } \\
0,012\end{array}$} & \multirow{2}{*}{$\begin{array}{l}\text { C.R. } \\
9,177\end{array}$} & \multirow{2}{*}{$\begin{array}{c}\mathrm{P} \\
* * *\end{array}$} & \multirow{2}{*}{$\begin{array}{c}\text { Label } \\
\text { par_31 }\end{array}$} & $\begin{array}{c}\text { Correlações } \\
\text { Múltiplas ao } \\
\text { Quadrado }\end{array}$ & Estimate \\
\hline IP & $<--$ & Harmonia & & & & & & IP & 0,132 \\
\hline DC & $<---$ & IP & 0,286 & 0,033 & 8,695 & $* * *$ & par_28 & $\mathrm{DC}$ & 0,223 \\
\hline $\mathrm{DC}$ & $<---$ & Harmonia & 0,026 & 0,009 & 2,995 & 0,003 & par_30 & Laços & 0,647 \\
\hline DCT & $<---$ & $\mathrm{DC}$ & 1,000 & & & & & Afeto & 0,109 \\
\hline DCC & $<---$ & $\mathrm{DC}$ & 1,000 & & & & & Centralidade & 0,771 \\
\hline Laços & $<--$ & IP & 1,000 & & & & & DCC & 0,733 \\
\hline Centralidade & $<---$ & IP & 1,000 & & & & & DCT & 0,628 \\
\hline Afeto & $<--$ & IP & $-0,462$ & 0,060 & $-7,711$ & $* * *$ & par_27 & VO5 & 0,585 \\
\hline DCT9 & $<--$ & DCT & 1,000 & & & & & V013 & 0,632 \\
\hline DCT8 & $<---$ & DCT & 0,948 & 0,044 & 21,380 & $* * *$ & par_1 & VO36 & 0,704 \\
\hline DCT7 & $<---$ & DCT & 1,008 & 0,047 & 21,330 & $* * *$ & par_2 & VO37 & 0,715 \\
\hline DCT6 & $<---$ & DCT & 0,907 & 0,046 & 19,752 & $* * *$ & par_3 & VO26 & 0,562 \\
\hline DCT5 & $<---$ & DCT & 1,025 & 0,048 & 21,180 & $* * *$ & par_4 & VO34 & 0,487 \\
\hline DCT4 & $<--$ & DCT & 0,915 & 0,046 & 19,825 & $* * *$ & par_5 & IP12 & 0,581 \\
\hline DCT3 & $<--$ & DCT & 0,990 & 0,047 & 21,196 & $* * *$ & par_6 & IP13 & 0,761 \\
\hline DCT2 & $<---$ & DCT & 0,839 & 0,044 & 19,069 & $* * *$ & par_7 & IP14 & 0,700 \\
\hline DCT1 & $<---$ & DCT & 0,812 & 0,045 & 17,880 & $* * *$ & par_8 & IP6 & 0,633 \\
\hline DCC13 & $<---$ & $\mathrm{DCC}$ & 1,000 & & & & & IP10 & 0,530 \\
\hline DCC12 & $<---$ & $\mathrm{DCC}$ & 0,982 & 0,042 & 23,624 & $* * *$ & par_9 & IP18 & 0,611 \\
\hline DCC11 & $<--$ & DCC & 0,892 & 0,046 & 19,251 & $* * *$ & par_10 & IP2 & 0,687 \\
\hline DCC10 & $<---$ & DCC & 0,887 & 0,043 & 20,407 & $* * *$ & par_11 & IP3 & 0,510 \\
\hline DCC9 & $<---$ & DCC & 0,970 & 0,047 & 20,832 & $* * *$ & par_12 & IP17 & 0,551 \\
\hline DCC8 & $<---$ & $\mathrm{DCC}$ & 0,995 & 0,045 & 22,133 & $* * *$ & par_13 & DCC15 & 0,470 \\
\hline DCC7 & $<---$ & $\mathrm{DCC}$ & 0,992 & 0,046 & 21,392 & $* * *$ & par_14 & DCC6 & 0,381 \\
\hline DCC6 & $<---$ & $\mathrm{DCC}$ & 0,883 & 0,048 & 18,437 & $* * *$ & par_15 & DCC7 & 0,502 \\
\hline DCC15 & $<---$ & DCC & 0,982 & 0,047 & 20,889 & $* * *$ & par_16 & DCC8 & 0,531 \\
\hline IP17 & $<--$ & Centralidade & 1,000 & & & & & DCC9 & 0,472 \\
\hline IP3 & $<--$ & Centralidade & 0,955 & 0,047 & 20,438 & $* * *$ & par_17 & DCC10 & 0,449 \\
\hline IP2 & $<---$ & Centralidade & 1,123 & 0,052 & 21,766 & $* * *$ & par_18 & DCC11 & 0,410 \\
\hline IP18 & $<---$ & Afeto & 1,000 & & & & & DCC12 & 0,576 \\
\hline IP10 & $<---$ & Afeto & 0,926 & 0,047 & 19,769 & $* * *$ & par_19 & DCC13 & 0,552 \\
\hline IP6 & $<---$ & Afeto & 0,938 & 0,046 & 20,316 & $* * *$ & par_20 & DCT1 & 0,375 \\
\hline IP14 & $<---$ & Laços & 1,000 & & & & & DCT2 & 0,422 \\
\hline IP13 & $<---$ & Laços & 1,071 & 0,035 & 30,328 & $* * *$ & par_21 & DCT3 & 0,522 \\
\hline IP12 & $<---$ & Laços & 0,878 & 0,035 & 25,083 & $* * *$ & par_22 & DCT4 & 0,462 \\
\hline VO34 & $<---$ & Domínio & 1,000 & & & & & DCT5 & 0,523 \\
\hline VO26 & $<---$ & Domínio & 1,171 & 0,060 & 19,456 & $* * *$ & par_23 & DCT6 & 0,460 \\
\hline VO37 & $<--$ & Harmonia & 1,000 & & & & & DCT7 & 0,526 \\
\hline VO36 & $<--$ & Harmonia & 1,008 & 0,033 & 30,876 & $* * *$ & par_24 & DCT8 & 0,525 \\
\hline VO13 & $<--$ & Harmonia & 0,882 & 0,032 & 27,455 & $* * *$ & par_25 & DCT9 & 0,503 \\
\hline VO5 & $<--$ & Harmonia & 0,892 & 0,034 & 25,885 & $* * *$ & par_26 & & \\
\hline
\end{tabular}


Mediação simples da identidade organizacional na relação entre os valores organizacionais e o desempenho profissional

Testou-se, em primeiro lugar, a relação de mediação que a identidade organizacional (IO) estabelece entre os tipos motivacionais subjacentes aos valores organizacionais (VO), todos correlacionados, e o desempenho profissional por competências (DC) $V O \rightarrow I O \rightarrow D C$. Em seguida, em segundo plano, analisou-se a associação entre as dimensões bipolares dos tipos motivacionais sobre o desempenho profissional, sendo essa relação mediada pela identidade organizacional. Para tanto, foram considerados os seguintes pares: Autonomia $x$ Conservação $\rightarrow I O \rightarrow D C$; Hierarquia x Igualitarismo $\rightarrow I O \rightarrow D C ;$ Domínio x Harmonia $\rightarrow$ $I O \rightarrow D C$. Como forma de se avaliar a qualidade do ajustamento dos dados, foram apreciadas suas especificações.

O primeiro teste apresentou ajustes satisfatórios (GFI=090; CFI=0,94; RMSEA=0,042), sendo significativos $(p<0,05)$ os tipos motivacionais conservação, igualitarismo e harmonia, responsáveis por explicar 15\% da identidade organizacional, além de explicar, em conjunto com a identidade organizacional, $21 \%$ da variância total do desempenho profissional $\left(\mathrm{R}^{2}=0,60\right.$ do desempenho por competências técnicas; e $\mathrm{R}^{2}=0,78$ do desempenho por competências comportamentais). No que se refere ao modelo geral correlacional dos tipos motivacionais, a identidade organizacional mediou parcialmente as relações entre os tipos motivacionaisl e o desempenho profissional (Figura 69) de forma significativa, para conservação $(p=0,008)$, Igualitarismo $(p=0,003)$ e haronia $(p=0,005)$.

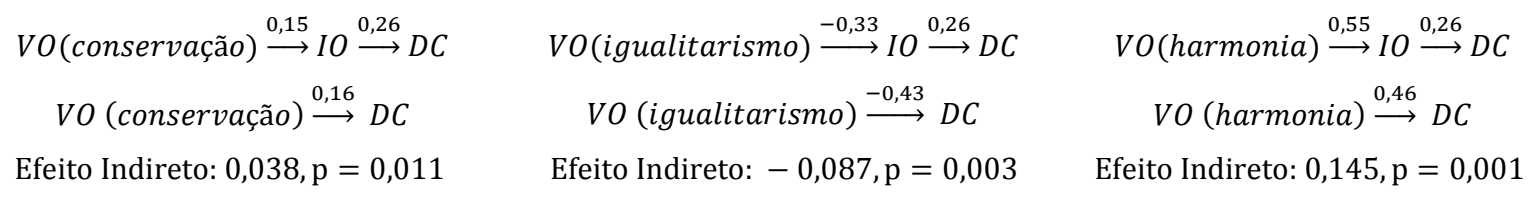

O segundo teste verificou a mediação da identidade organizacional na relação entre os tipos motivacionais bipolares, analisados de forma independentes, e o desempenho profissional. Relativamente aos tipos conservação $x$ autonomia e o desempenho profissional, a identidade profissional mediou parcialmente a relação entre conservação e desempenho profissional e totalmente a relação entre autonomia e desempenho profissional, de forma significativa ( $\mathrm{p}=0,001$ e $n . s .=$ não significativo) conforme Figura 70, com ajustes adequados (GFI=0,94; CFI=0,96; RMSEA=0,038).

$$
\begin{array}{cc}
\text { Conservação } o \stackrel{0,24}{\longrightarrow} I P \stackrel{0,29}{\longrightarrow} D C & \text { Autonomia } \stackrel{0,15}{\longrightarrow} I P \stackrel{0,29}{\longrightarrow} D C \\
\text { Conservação } \stackrel{0,23}{\longrightarrow} D C & \text { Autonomia } \stackrel{\text { n.s. }}{\rightarrow} D C
\end{array}
$$

Efeito Indireto: $0,018, p=0,001$

Efeito Indireto: $0,043, p=0,001$ 
Os tipos motivacionais Autonomia x Conservação foram responsáveis por explicar $12 \%$ da identidade organizacional, além de explicar, em conjunto com a identidade organizacional, $18 \%$ da variância total do desempenho profissional $\left(\mathrm{R}^{2}=0,59\right.$ do desempenho por competências técnicas; e $\mathrm{R}^{2}=0,79$ do desempenho por competências comportamentais).

Para os tipos motivacionais hierarquia x igualitarismo e o desempenho profissional, a identidade organizacional mediou parcialmente essa relação com ajustes adequados (GFI=0,93; CFI=0,96; RMSEA=0,039), de forma significativa ( $p=0,001$ e $p=0,03$ ).

$$
\begin{aligned}
& \text { Hierarquia } \stackrel{0,23}{\longrightarrow} I O \stackrel{0,31}{\longrightarrow} D C \quad \text { Igualitarismo } \stackrel{0,32}{\longrightarrow} I O \stackrel{0,31}{\longrightarrow} D C \\
& \text { Hierarquia } \stackrel{0,21}{\longrightarrow} D C \quad \text { Igualitarismo } \stackrel{0,14}{\longrightarrow} D C \\
& \text { Efeito Indireto: } 0,069, p=0,001 \quad \text { Efeito Indireto: } 0,096, p=0,001
\end{aligned}
$$

As dimensões Hierarquia x Igualitarismo foram responsáveis por explicar $10 \%$ da identidade organizacional, além de explicar, em conjunto com a identidade organizacional, $18 \%$ da variância total do desempenho profissional $\left(\mathrm{R}^{2}=0,61\right.$ do desempenho por competências técnicas; e $\mathrm{R}^{2}=0,76$ do desempenho por competências comportamentais), conforme Figura 71.

Por fim, a identidade organizacional mediou parcialmente a relação entre os tipos motivacionais harmonia e o desempenho profissional, de forma significativa $(\mathrm{p}=0,001)$, com ajustes adequados (GFI=0,93; CFI=0,96; RMSEA=0,041), conforme Figura 72.

$$
\begin{aligned}
& \text { Domínio } \stackrel{\text { n.s. }}{\longrightarrow} I O \stackrel{0,31}{\longrightarrow} D C \\
& \text { Harmonia } \stackrel{0,35}{\longrightarrow} I O \stackrel{0,31}{\longrightarrow} D C \\
& \text { Domínio } \stackrel{\text { n.s. }}{\rightarrow} D C \\
& \text { Harmonia } \stackrel{0,16}{\longrightarrow} D C
\end{aligned}
$$

O tipo motivacional Harmonia foi responsável por explicar $12 \%$ da identidade organizacional, além de Domínio x Harmonia explicarem em conjunto com a identidade organizacional, $16 \%$ da variância total do desempenho profissional $\left(\mathrm{R}^{2}=0,60\right.$ do desempenho por competências técnicas; e $\mathrm{R}^{2}=0,77$ do desempenho por competências comportamentais).

A Tabela 58 sintetiza os índices de ajuste e as Figuras 69, 70, 71 e 72 exibem as representações gráficas de cada um dos modelos, os pesos fatoriais não estandardizados e as correlações múltiplas ao quadrado. 
Tabela 58

Índices de ajustamento da relação entre $V O \rightarrow I O \rightarrow D C$, completo e por dimensões

\begin{tabular}{|c|c|c|c|c|c|}
\hline \multicolumn{2}{|l|}{$\begin{array}{l}\text { Amostra } \\
\mathrm{N}=916\end{array}$} & $\begin{array}{c}\text { Modelo } V O \rightarrow \\
I O \\
\rightarrow D C\end{array}$ & $\begin{array}{l}\text { Autonomia } x \\
\text { Conservação } \\
\rightarrow I O \rightarrow D C\end{array}$ & $\begin{array}{l}\text { Hierarquia } x \\
\text { Igualitarismo } \\
\rightarrow I O \rightarrow D C\end{array}$ & $\begin{array}{c}\text { Dominio } x \\
\text { Harmonia } \rightarrow \\
I O \rightarrow D C\end{array}$ \\
\hline $\begin{array}{l}\text { Índices } \\
\text { Absolutos }\end{array}$ & $\begin{array}{l}\chi \text { g.l. } \\
\chi^{2} ; \text { g.l. } \\
p \\
\text { GFI (AGFI) } \\
\text { SRMR }\end{array}$ & $\begin{array}{c}2,61 \\
2071,27 ; 795 \\
0,000 \\
0,90(0,89) \\
0,042\end{array}$ & $\begin{array}{c}2,35 \\
933,34 ; 398 \\
0,000 \\
0,94(0,92) \\
0,039\end{array}$ & $\begin{array}{c}2,38 \\
994,14 ; 396 \\
0,000 \\
0,93(0,92) \\
0,042\end{array}$ & $\begin{array}{c}2,54 \\
1009,65 ; 398 \\
0,000 \\
0,93(0,92) \\
0,040\end{array}$ \\
\hline Índices Relativos & $\begin{array}{l}\text { CFI } \\
\text { TLI }\end{array}$ & $\begin{array}{l}0,94 \\
0,94\end{array}$ & $\begin{array}{l}0,96 \\
0,96\end{array}$ & $\begin{array}{l}0,96 \\
0,95\end{array}$ & $\begin{array}{l}0,96 \\
0,95\end{array}$ \\
\hline $\begin{array}{l}\text { Índices de } \\
\text { Discrepância } \\
\text { Populacional }\end{array}$ & $\begin{array}{l}\text { RMSEA } \\
\text { (Lo90;Hi90) }\end{array}$ & $\begin{array}{c}0,042 \\
(0,040 ; 0,044)\end{array}$ & $\begin{array}{c}0,038 \\
(0,035 ; 0,042)\end{array}$ & $\begin{array}{c}0,039 \\
(0,036 ; 0,042)\end{array}$ & $\begin{array}{c}0,041 \\
(0,038 ; 0,044)\end{array}$ \\
\hline $\begin{array}{l}\text { Índices de } \\
\text { Parcimônia }\end{array}$ & $\begin{array}{l}\text { PCFI } \\
\text { PGFI }\end{array}$ & $\begin{array}{l}0,87 \\
0,79\end{array}$ & $\begin{array}{l}0,88 \\
0,80\end{array}$ & $\begin{array}{l}0,87 \\
0,80\end{array}$ & $\begin{array}{l}0,87 \\
0,80\end{array}$ \\
\hline $\begin{array}{l}\text { Índices Baseados } \\
\text { na Teoria da } \\
\text { Informação }\end{array}$ & $\begin{array}{l}\text { AIC } \\
\text { ECVI } \\
\text { CAIC }\end{array}$ & $\begin{array}{c}2287,27 \\
2,50 \\
2915,83\end{array}$ & $\begin{array}{c}1067,34 \\
1,16 \\
1457,28\end{array}$ & $\begin{array}{c}1082,14 \\
1,18 \\
1483,73\end{array}$ & $\begin{array}{c}1143,65 \\
1,25 \\
1533,59\end{array}$ \\
\hline
\end{tabular}

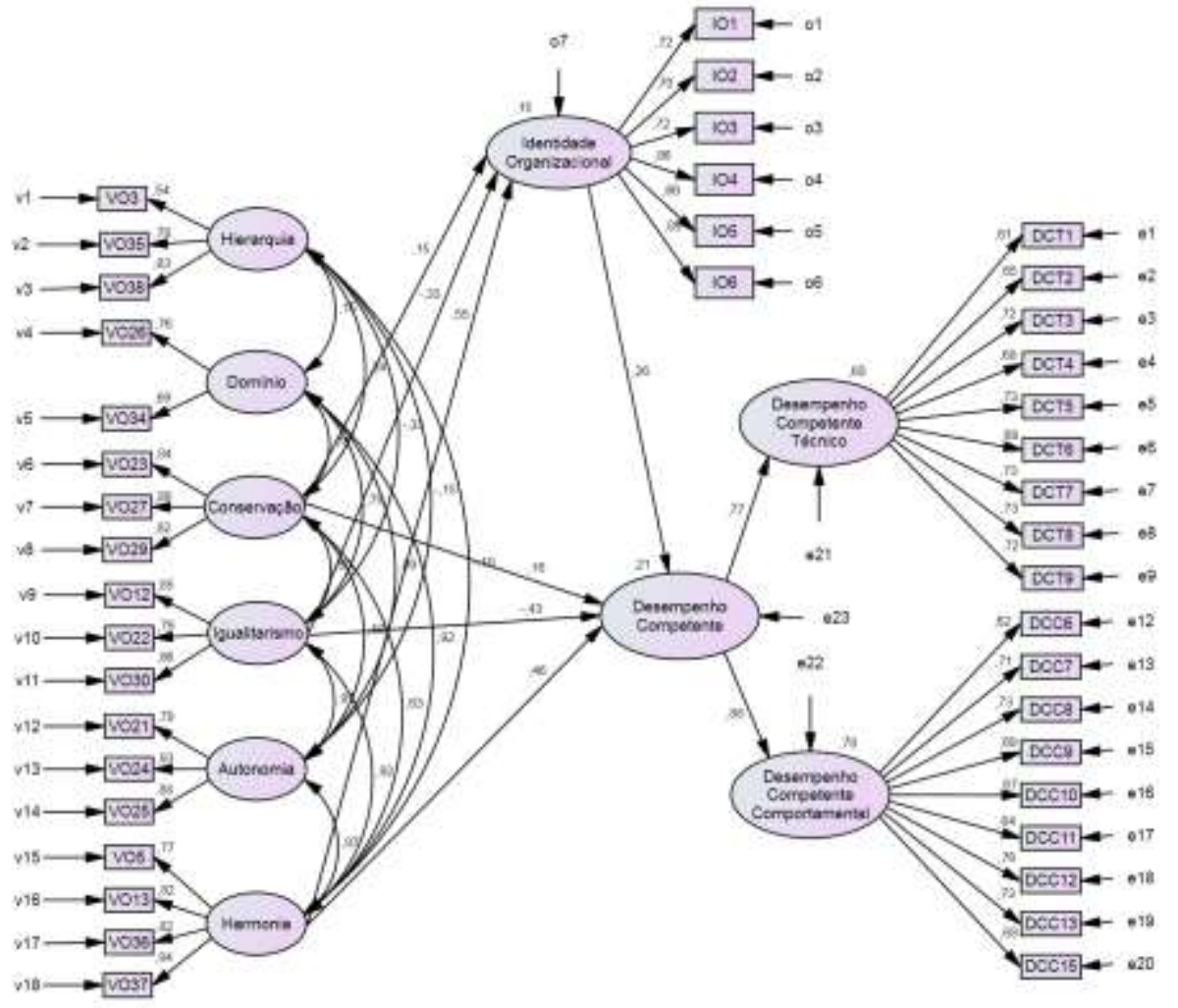




\begin{tabular}{|c|c|c|c|c|c|c|c|c|c|}
\hline \multicolumn{3}{|c|}{$\begin{array}{c}\text { Pesos Fatoriais Não- } \\
\text { Estandardizados }\end{array}$} & \multirow{2}{*}{$\begin{array}{r}\text { Estimate } \\
0,071\end{array}$} & \multirow{2}{*}{$\begin{array}{l}\text { S.E. } \\
0,026\end{array}$} & \multirow{2}{*}{$\begin{array}{l}\text { C.R. } \\
2,757\end{array}$} & \multirow{2}{*}{$\begin{array}{c}\mathrm{P} \\
0,006\end{array}$} & \multirow{2}{*}{$\begin{array}{c}\text { Label } \\
\text { par_51 }\end{array}$} & \multirow{2}{*}{$\begin{array}{c}\text { Correlações } \\
\text { Múltiplas ao } \\
\text { Quadrado }\end{array}$} & \multirow{2}{*}{$\begin{array}{r}\text { Estimate } \\
0,153\end{array}$} \\
\hline IO & $<--$ & Conservação & & & & & & & \\
\hline IO & $<---$ & Harmonia & 0,231 & 0,060 & 3,865 & $* * *$ & par_53 & $\mathrm{DC}$ & 0,209 \\
\hline IO & $<---$ & Igualitarismo & $-0,101$ & 0,038 & $-2,664$ & 0,008 & par_54 & DCC & 0,777 \\
\hline DC & $<--$ & IO & 0,133 & 0,021 & 6,228 & $* * *$ & par_23 & DCT & 0,599 \\
\hline DC & $<---$ & Igualitarismo & $-0,066$ & 0,021 & $-3,138$ & 0,002 & par_52 & VO37 & 0,698 \\
\hline DC & $<---$ & Conservação & 0,041 & 0,014 & 2,914 & 0,004 & par_55 & VO36 & 0,676 \\
\hline DC & $<---$ & Harmonia & 0,098 & 0,033 & 2,937 & 0,003 & par_56 & VO5 & 0,591 \\
\hline DCT & $<---$ & $\mathrm{DC}$ & 1,000 & & & & & VO13 & 0,675 \\
\hline DCC & $<---$ & DC & 1,000 & & & & & VO21 & 0,622 \\
\hline DCT9 & $<---$ & DCT & 1,000 & & & & & VO24 & 0,868 \\
\hline DCT8 & $<--$ & DCT & 0,928 & 0,043 & 21,723 & $* * *$ & par_1 & VO25 & 0,782 \\
\hline DCT7 & $<---$ & DCT & 0,987 & 0,046 & 21,674 & $* * *$ & par_2 & VO12 & 0,725 \\
\hline DCT6 & $<---$ & DCT & 0,888 & 0,044 & 20,025 & $* * *$ & par_3 & VO22 & 0,625 \\
\hline DCT5 & $<---$ & DCT & 1,004 & 0,047 & 21,505 & $* * *$ & par_4 & VO30 & 0,732 \\
\hline DCT4 & $<---$ & DCT & 0,894 & 0,045 & 20,088 & $* * *$ & par_5 & VO23 & 0,703 \\
\hline DCT3 & $<---$ & DCT & 0,968 & 0,045 & 21,520 & $* * *$ & par_6 & VO27 & 0,791 \\
\hline DCT2 & $<---$ & DCT & 0,821 & 0,043 & 19,295 & $* * *$ & par_7 & VO29 & 0,679 \\
\hline DCT1 & $<---$ & DCT & 0,794 & 0,044 & 18,062 & $* * *$ & par_8 & VO26 & 0,584 \\
\hline DCC13 & $<---$ & DCC & 1,000 & & & & & VO34 & 0,469 \\
\hline DCC12 & $<---$ & $\mathrm{DCC}$ & 1,003 & 0,043 & 23,258 & $* * *$ & par_9 & VO3 & 0,288 \\
\hline DCC11 & $<---$ & DCC & 0,907 & 0,048 & 18,995 & $* * *$ & par_10 & VO35 & 0,615 \\
\hline DCC10 & $<---$ & DCC & 0,905 & 0,045 & 20,161 & $* * *$ & par_11 & VO38 & 0,687 \\
\hline DCC9 & $<---$ & DCC & 0,990 & 0,048 & 20,567 & $* * *$ & par_12 & IO1 & 0,526 \\
\hline DCC8 & $<---$ & DCC & 1,012 & 0,046 & 21,779 & $* * *$ & par_13 & $\mathrm{IO} 2$ & 0,488 \\
\hline DCC7 & $<---$ & DCC & 1,013 & 0,048 & 21,091 & $* * *$ & par_14 & IO3 & 0,516 \\
\hline DCC6 & $<---$ & DCC & 0,901 & 0,049 & 18,246 & $* * *$ & par_15 & IO4 & 0,746 \\
\hline DCC15 & $<---$ & DCC & 1,002 & 0,049 & 20,622 & $* * *$ & par_16 & IO5 & 0,433 \\
\hline IO6 & $<---$ & $\mathrm{IO}$ & 1,000 & & & & & IO6 & 0,719 \\
\hline IO5 & $<---$ & IO & 0,734 & 0,034 & 21,757 & $* * *$ & par_17 & DCC15 & 0,468 \\
\hline IO4 & $<---$ & $\mathrm{IO}$ & 0,975 & 0,031 & 31,522 & $* * *$ & par_18 & DCC6 & 0,380 \\
\hline IO3 & $<---$ & $\mathrm{IO}$ & 0,780 & 0,033 & 23,795 & $* * *$ & par_19 & DCC7 & 0,501 \\
\hline $\mathrm{IO} 2$ & $<---$ & $\mathrm{IO}$ & 0,782 & 0,034 & 23,126 & $* * *$ & par_20 & CDCC8 & 0,526 \\
\hline IO1 & $<---$ & IO & 0,908 & 0,040 & 22,628 & $* * *$ & par_21 & DCC9 & 0,471 \\
\hline VO38 & $<---$ & Hierarquia & 1,000 & & & & & DCC10 & 0,448 \\
\hline VO35 & $<---$ & Hierarquia & 0,983 & 0,048 & 20,682 & $* * *$ & par_24 & DCC11 & 0,406 \\
\hline VO3 & $<---$ & Hierarquia & 0,614 & 0,041 & 14,849 & $* * *$ & par_25 & DCC12 & 0,576 \\
\hline VO34 & $<---$ & Domínio & 1,000 & & & & & DCC13 & 0,539 \\
\hline VO26 & $<---$ & Domínio & 1,216 & 0,058 & 20,942 & $* * *$ & par_26 & DCT1 & 0,378 \\
\hline VO29 & $<--$ & Conservação & 1,000 & & & & & DCT2 & 0,425 \\
\hline VO27 & $<---$ & Conservação & 1,076 & 0,035 & 31,013 & $* * *$ & par_28 & DCT3 & 0,525 \\
\hline $\mathrm{VO} 23$ & $<---$ & Conservação & 1,010 & 0,035 & 28,919 & $* * *$ & par_29 & DCT4 & 0,464 \\
\hline VO30 & $<---$ & Igualitarismo & 1,000 & & & & & DCT5 & 0,528 \\
\hline $\mathrm{VO} 22$ & $<---$ & Igualitarismo & 0,636 & 0,022 & 28,972 & $* * *$ & par_32 & DCT6 & 0,464 \\
\hline VO12 & $<---$ & Igualitarismo & 0,888 & 0,027 & 33,317 & $* * *$ & par_33 & DCT7 & 0,530 \\
\hline $\mathrm{VO} 25$ & $<---$ & Autonomia & 1,000 & & & & & DCT8 & 0,529 \\
\hline $\mathrm{VO} 24$ & $<---$ & Autonomia & 1,061 & 0,024 & 43,503 & $* * *$ & par_37 & DCT9 & 0,519 \\
\hline VO21 & $<---$ & Autonomia & 0,923 & 0,031 & 30,075 & $* * *$ & par_38 & & \\
\hline VO13 & $<---$ & Harmonia & 0,923 & 0,032 & 29,023 & $* * *$ & par_43 & & \\
\hline VO5 & $<---$ & Harmonia & 0,908 & 0,034 & 26,558 & $* * *$ & par_44 & & \\
\hline VO37 & $<---$ & Harmonia & 1,001 & 0,033 & 30,424 & $* * *$ & par_50 & & \\
\hline VO36 & $<---$ & Harmonia & 1,000 & & & & & & \\
\hline
\end{tabular}

Figura 69. Modelo $V O \rightarrow I O \rightarrow D C$. 


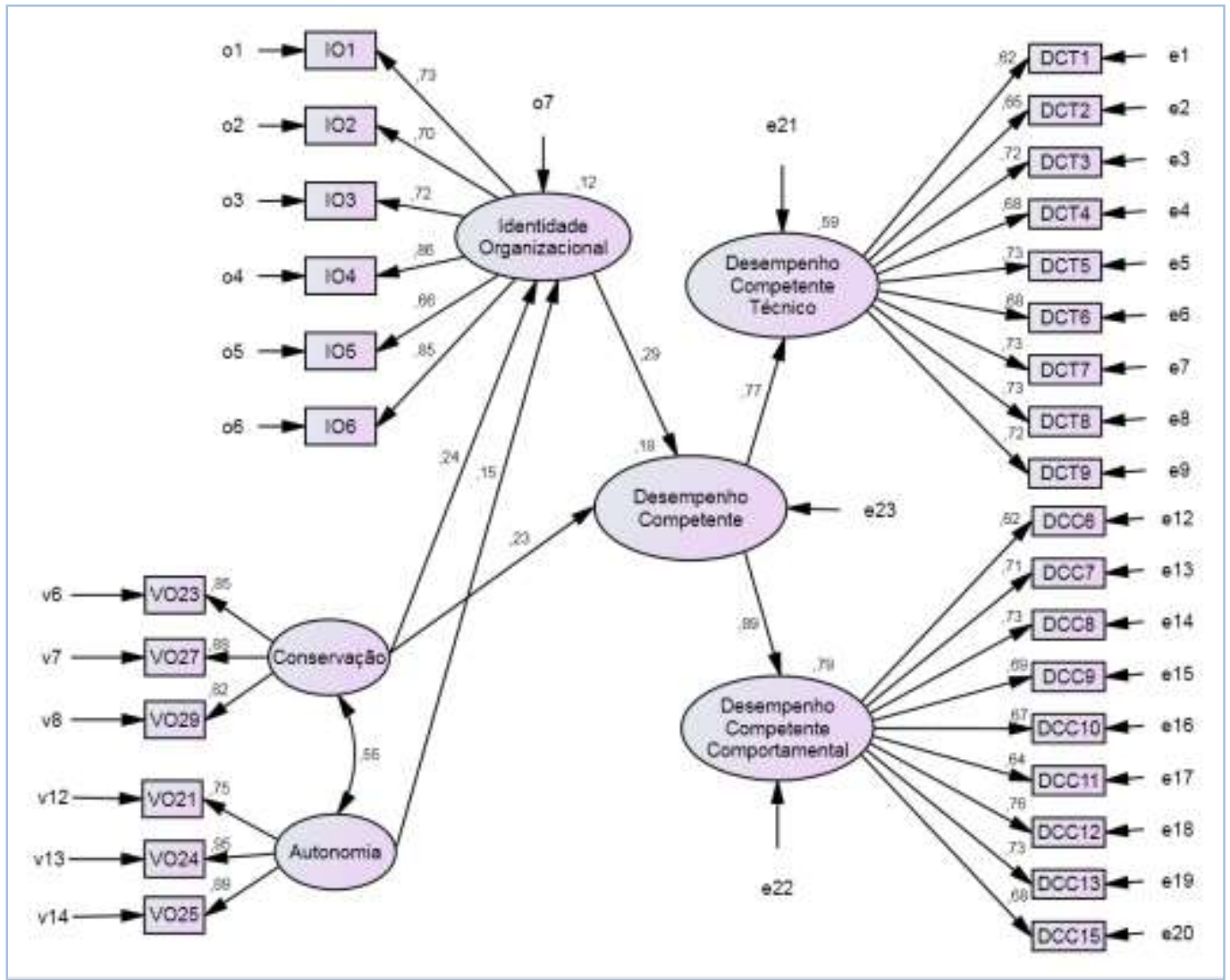




\begin{tabular}{|c|c|c|c|c|c|c|c|c|c|}
\hline \multicolumn{3}{|c|}{$\begin{array}{l}\text { Pesos Fatoriais Não- } \\
\text { Estandardizados }\end{array}$} & \multirow{2}{*}{$\begin{array}{r}\text { Estimate } \\
0,117\end{array}$} & \multirow{2}{*}{$\begin{array}{l}\text { S.E. } \\
0,022\end{array}$} & \multirow{2}{*}{$\begin{array}{l}\text { C.R. } \\
5,419\end{array}$} & \multirow{2}{*}{$\begin{array}{c}\mathrm{P} \\
* * *\end{array}$} & \multirow{2}{*}{$\begin{array}{c}\text { Label } \\
\text { par_28 }\end{array}$} & \multirow{2}{*}{$\begin{array}{l}\text { Correlações } \\
\text { Múltiplas ao } \\
\text { Quadrado } \\
\text { IO }\end{array}$} & \multirow{2}{*}{$\begin{array}{r}\text { Estimate } \\
0,118\end{array}$} \\
\hline $\begin{array}{l}\mathrm{IO} \\
\end{array}$ & <--- & Conservação & & & & & & & \\
\hline IO & $<--$ & Autonomia & 0,057 & 0,016 & 3,492 & $* * *$ & par_31 & DC & 0,180 \\
\hline DC & $<--$ & Conservação & 0,056 & 0,010 & 5,614 & $* * *$ & par_29 & DCC & 0,786 \\
\hline DC & $<--$ & IO & 0,149 & 0,020 & 7,274 & $* * *$ & par_30 & DCT & 0,594 \\
\hline DCT & $<--$ & DC & 1,000 & & & & & IO1 & 0,527 \\
\hline DCC & $<--$ & DCT & 1,000 & & & & & IO2 & 0,488 \\
\hline DCT9 & $<--$ & DCT & 1,000 & & & & & IO3 & 0,514 \\
\hline DCT8 & $<--$ & DCT & 0,925 & 0,043 & 21,754 & $* * *$ & par_1 & IO4 & 0,746 \\
\hline DCT7 & $<--$ & DCT & 0,984 & 0,045 & 21,704 & $* * *$ & par_2 & IO5 & 0,434 \\
\hline DCT6 & $<--$ & DCT & 0,885 & 0,044 & 20,050 & $* * *$ & par_3 & IO6 & 0,718 \\
\hline DCT5 & $<--$ & DCT & 1,000 & 0,046 & 21,531 & $* * *$ & par_4 & VO21 & 0,565 \\
\hline DCT4 & $<--$ & DCT & 0,891 & 0,044 & 20,112 & $* * *$ & par_5 & VO24 & 0,894 \\
\hline DCT3 & $<--$ & DCT & 0,965 & 0,045 & 21,546 & $* * *$ & par_6 & VO25 & 0,797 \\
\hline DCT2 & $<--$ & DCT & 0,818 & 0,042 & 19,316 & $* * *$ & par_7 & VO23 & 0,724 \\
\hline DCT1 & $<--$ & DCT & 0,791 & 0,044 & 18,078 & $* * *$ & par_8 & VO27 & 0,783 \\
\hline DCC13 & $<--$ & DCC & 1,000 & & & & & VO29 & 0,667 \\
\hline DCC12 & $<--$ & DCC & 1,007 & 0,043 & 23,149 & $* * *$ & par_9 & DCC15 & 0,467 \\
\hline DCC11 & $<--$ & DCC & 0,912 & 0,048 & 18,949 & $* * *$ & par_10 & DCC6 & 0,379 \\
\hline DCC10 & $<--$ & DCC & 0,909 & 0,045 & 20,108 & $* * *$ & par_11 & DCC7 & 0,501 \\
\hline DCC9 & $<--$ & DCC & 0,993 & 0,048 & 20,484 & $* * *$ & par_12 & DCC8 & 0,527 \\
\hline DCC8 & $<--$ & DCC & 1,017 & 0,047 & 21,692 & $* * *$ & par_13 & DCC9 & 0,470 \\
\hline DCC7 & $<--$ & DCC & 1,017 & 0,048 & 21,006 & $* * *$ & par_14 & DCC10 & 0,448 \\
\hline DCC6 & $<--$ & DCC & 0,904 & 0,050 & 18,181 & $* * *$ & par_15 & DCC11 & 0,406 \\
\hline DCC15 & $<--$ & DCC & 1,004 & 0,049 & 20,530 & $* * *$ & par_16 & DCC12 & 0,576 \\
\hline VO29 & $<--$ & Conservação & 1,000 & & & & & DCC13 & 0,536 \\
\hline VO27 & $<--$ & Conservação & 1,081 & 0,036 & 30,182 & $* * *$ & par_17 & DCT1 & 0,379 \\
\hline VO23 & $<--$ & Conservação & 1,034 & 0,036 & 28,525 & $* * *$ & par_18 & DCT2 & 0,426 \\
\hline VO25 & $<--$ & Autonomia & 1,000 & & & & & DCT3 & 0,526 \\
\hline $\mathrm{VO} 24$ & $<--$ & Autonomia & 1,067 & 0,027 & 39,624 & $* * *$ & par_19 & DCT4 & 0,465 \\
\hline VO21 & $<--$ & Autonomia & 0,872 & 0,031 & 28,269 & $* * *$ & par_20 & DCT5 & 0,528 \\
\hline IO6 & $<--$ & IO & 1,000 & & & & & DCT6 & 0,464 \\
\hline IO5 & $<--$ & IO & 0,735 & 0,034 & 21,793 & $* * *$ & par_21 & DCT7 & 0,531 \\
\hline IO4 & $<--$ & IO & 0,975 & 0,031 & 31,498 & $* * *$ & par_22 & DCT8 & 0,530 \\
\hline IO3 & $<--$ & IO & 0,779 & 0,033 & 23,748 & $* * *$ & par_23 & DCT9 & 0,522 \\
\hline IO2 & $<--$ & IO & 0,782 & 0,034 & 23,107 & $* * *$ & par_24 & & \\
\hline IO1 & $<--$ & IO & 0,909 & 0,040 & 22,637 & $* * *$ & par_25 & & \\
\hline
\end{tabular}

Figura 70. Modelo Autonomia $x$ Conservação $\rightarrow I O \rightarrow D C$. 


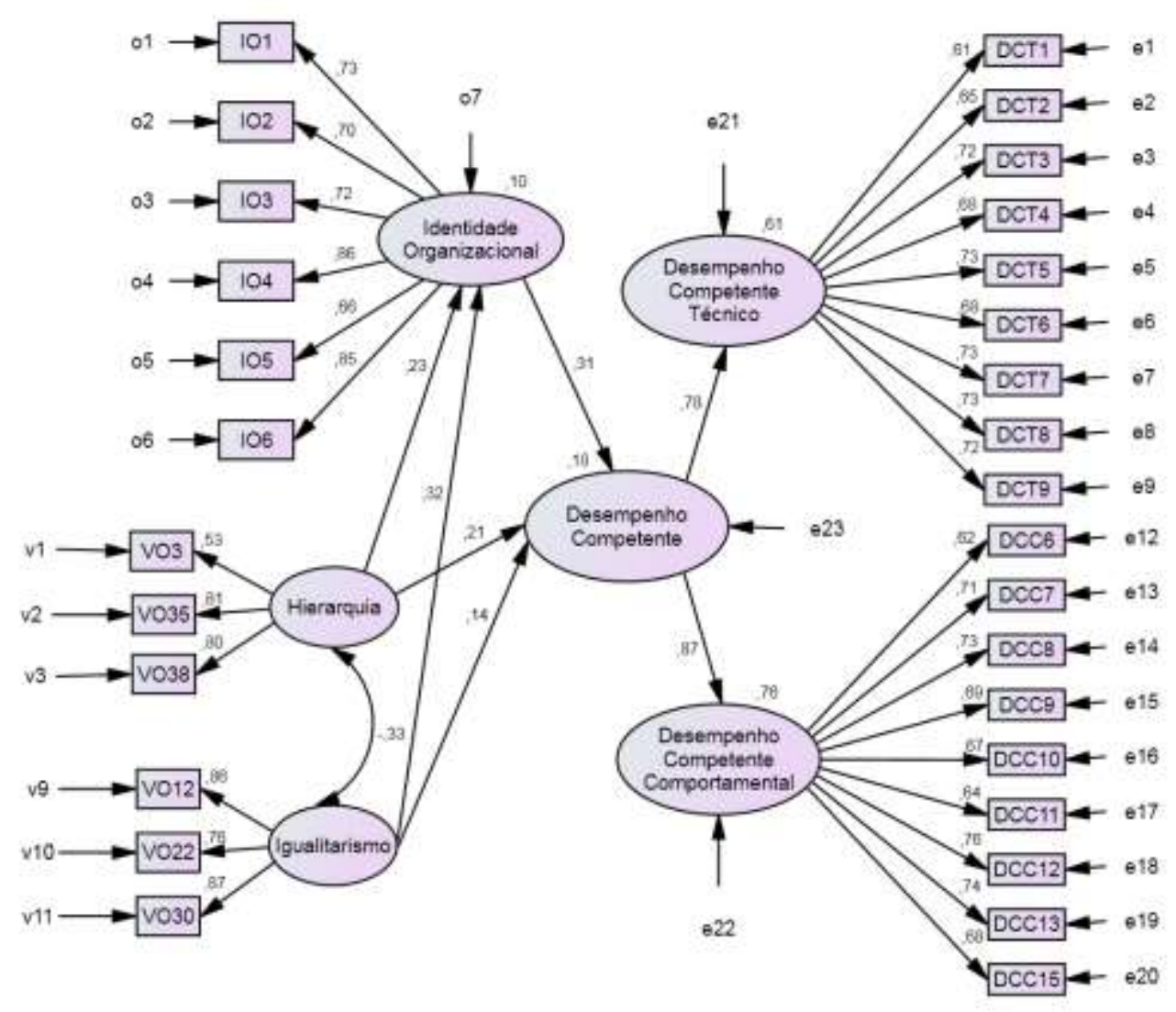




\begin{tabular}{|c|c|c|c|c|c|c|c|c|c|}
\hline & $\begin{array}{l}\text { sos Fat } \\
\text { Estand }\end{array}$ & $\begin{array}{l}\text { oriais Não- } \\
\text { rdizados }\end{array}$ & Estimate & S.E. & C.R. & $\mathrm{P}$ & Label & $\begin{array}{l}\text { Correlações } \\
\text { Múltiplas ao } \\
\text { Quadrado }\end{array}$ & Estimate \\
\hline $\mathrm{IO}$ & <--- & Hierarquia & 0,091 & 0,016 & 5,560 & $* * *$ & par_31 & $\mathrm{IO}$ & 0,103 \\
\hline IO & $<--$ & Igualitarismo & 0,094 & 0,012 & 8,023 & $* * *$ & par_32 & $\mathrm{DC}$ & 0,175 \\
\hline $\mathrm{DC}$ & $<--$ & IO & 0,154 & 0,021 & 7,365 & $* * *$ & par_23 & DCC & 0,759 \\
\hline DC & $<--$ & Hierarquia & 0,043 & 0,009 & 4,721 & $* * *$ & par_29 & DCT & 0,609 \\
\hline DC & $<--$ & Igualitarismo & 0,021 & 0,007 & 3,199 & 0,001 & par_30 & VO12 & 0,735 \\
\hline DCT & $<---$ & DC & 1,000 & & & & & VO22 & 0,580 \\
\hline DCC & $<---$ & DC & 1,000 & & & & & VO30 & 0,761 \\
\hline DCT9 & $<---$ & DCT & 1,000 & & & & & VO3 & 0,279 \\
\hline DCT8 & $<---$ & DCT & 0,936 & 0,044 & 21,468 & $* * *$ & par_1 & VO35 & 0,659 \\
\hline DCT7 & $<---$ & DCT & 0,996 & 0,047 & 21,412 & $* * *$ & par_2 & VO38 & 0,639 \\
\hline DCT6 & $<---$ & DCT & 0,895 & 0,045 & 19,815 & $* * *$ & par_3 & IO1 & 0,528 \\
\hline DCT5 & $<---$ & DCT & 1,013 & 0,048 & 21,244 & $* * *$ & par_4 & $\mathrm{IO} 2$ & 0,487 \\
\hline DCT4 & $<---$ & DCT & 0,903 & 0,045 & 19,881 & $* * *$ & par_5 & IO3 & 0,512 \\
\hline DCT3 & $<---$ & DCT & 0,977 & 0,046 & 21,265 & $* * *$ & par_6 & IO4 & 0,744 \\
\hline DCT2 & $<---$ & DCT & 0,828 & 0,043 & 19,115 & $* * *$ & par_7 & IO5 & 0,434 \\
\hline DCT1 & $<---$ & DCT & 0,801 & 0,045 & 17,911 & $* * *$ & par_8 & IO6 & 0,722 \\
\hline DCC13 & $<---$ & DCC & 1,000 & & & & & DCC15 & 0,469 \\
\hline DCC12 & $<---$ & DCC & 0,997 & 0,043 & 23,244 & $* * *$ & par_9 & DCC6 & 0,380 \\
\hline DCC11 & $<---$ & DCC & 0,903 & 0,047 & 19,020 & $* * *$ & par_10 & DCC7 & 0,502 \\
\hline DCC 10 & $<---$ & DCC & 0,899 & 0,045 & 20,163 & $* * *$ & par_11 & DCC8 & 0,528 \\
\hline DCC9 & $<---$ & DCC & 0,982 & 0,048 & 20,548 & $* * *$ & par_12 & DCC9 & 0,470 \\
\hline DCC8 & $<---$ & DCC & 1,007 & 0,046 & 21,787 & $* * *$ & par_13 & DCC10 & 0,448 \\
\hline DCC7 & $<--$ & DCC & 1,006 & 0,048 & 21,082 & $* * *$ & par_14 & DCC11 & 0,408 \\
\hline DCC6 & $<---$ & DCC & 0,895 & 0,049 & 18,245 & $* * *$ & par_15 & DCC12 & 0,577 \\
\hline DCC15 & $<---$ & DCC & 0,995 & 0,048 & 20,614 & $* * *$ & par_16 & DCC13 & 0,543 \\
\hline IO6 & $<---$ & IO & 1,000 & & & & & DCT1 & 0,376 \\
\hline IO5 & $<---$ & IO & 0,734 & 0,034 & 21,827 & $* * *$ & par_17 & DCT2 & 0,424 \\
\hline IO4 & $<---$ & IO & 0,972 & 0,031 & 31,497 & $* * *$ & par_18 & DCT3 & 0,524 \\
\hline IO3 & $<---$ & IO & 0,776 & 0,033 & 23,711 & $* * *$ & par_19 & DCT4 & 0,463 \\
\hline IO2 & $<--$ & IO & 0,780 & 0,034 & 23,105 & $* * *$ & par_20 & DCT5 & 0,526 \\
\hline IO1 & $<---$ & IO & 0,908 & 0,040 & 22,650 & $* * *$ & par_21 & DCT6 & 0,461 \\
\hline VO38 & $<---$ & Hierarquia & 1,000 & & & & & DCT7 & 0,529 \\
\hline VO35 & $<---$ & Hierarquia & 1,062 & 0,065 & 16,428 & $* * *$ & par_24 & DCT8 & 0,527 \\
\hline VO3 & $<---$ & Hierarquia & 0,631 & 0,045 & 14,030 & $* * *$ & par_25 & DCT9 & 0,513 \\
\hline VO30 & $<---$ & Igualitarismo & 1,000 & & & & & & \\
\hline $\mathrm{VO} 22$ & $<---$ & Igualitarismo & 0,601 & 0,024 & 25,503 & $* * *$ & par_26 & & \\
\hline VO12 & $<---$ & Igualitarismo & 0,877 & 0,031 & 28,480 & $* * *$ & par_27 & & \\
\hline
\end{tabular}

Figura 71. Modelo Hierarquia $x$ Igualitarismo $\rightarrow I O \rightarrow D C$. 







\begin{tabular}{|c|c|c|c|c|c|c|c|c|c|}
\hline \multicolumn{3}{|c|}{$\begin{array}{c}\text { Pesos Fatoriais } \\
\text { Não-Estandardizados }\end{array}$} & \multirow{2}{*}{$\begin{array}{r}\text { Estimate } \\
0,142\end{array}$} & \multirow{2}{*}{$\begin{array}{l}\text { S.E. } \\
0,015\end{array}$} & \multirow{2}{*}{$\begin{array}{l}\text { C.R. } \\
9,548\end{array}$} & \multirow{2}{*}{$\begin{array}{l}\mathrm{P} \\
* * *\end{array}$} & \multirow{2}{*}{$\begin{array}{c}\text { Label } \\
\text { par_30 }\end{array}$} & \multirow{2}{*}{$\begin{array}{c}\text { Correlações } \\
\text { Múltiplas ao } \\
\text { Quadrado }\end{array}$} & \multirow{2}{*}{$\begin{array}{r}\text { Estimate } \\
0,119\end{array}$} \\
\hline $\mathrm{IO}$ & $<---$ & Harmonia & & & & & & & \\
\hline $\mathrm{DC}$ & $<---$ & IO & 0,157 & 0,021 & 7,442 & $* * *$ & par_23 & DC & 0,158 \\
\hline DC & $<--$ & Harmonia & 0,034 & 0,009 & 4,022 & $* * *$ & par_29 & DCC & 0,770 \\
\hline DCT & $<---$ & DC & 1,000 & & & & & DCT & 0,603 \\
\hline DCC & $<---$ & DC & 1,000 & & & & & VO5 & 0,586 \\
\hline DCT9 & $<---$ & DCT & 1,000 & & & & & VO13 & 0,634 \\
\hline DCT8 & $<---$ & DCT & 0,931 & 0,043 & 21,555 & $* * *$ & par_1 & VO36 & 0,704 \\
\hline DCT7 & $<--$ & DCT & 0,990 & 0,046 & 21,505 & $* * *$ & par_2 & VO37 & 0,713 \\
\hline DCT6 & $<---$ & DCT & 0,891 & 0,045 & 19,888 & $* * *$ & par_3 & VO26 & 0,563 \\
\hline DCT5 & $<--$ & DCT & 1,007 & 0,047 & 21,337 & $* * *$ & par_4 & VO34 & 0,487 \\
\hline DCT4 & $<--$ & DCT & 0,898 & ,045 & 19,951 & $* * *$ & par_5 & IO1 & 0,525 \\
\hline DCT3 & $<--$ & DCT & 0,972 & 0,046 & 21,351 & $* * *$ & par_6 & $\mathrm{IO} 2$ & 0,488 \\
\hline DCT2 & $<--$ & DCT & 0,824 & 0,043 & 19,176 & $* * *$ & par_7 & IO3 & 0,514 \\
\hline DCT1 & $<--$ & DCT & 0,797 & 0,044 & 17,962 & $* * *$ & par_8 & IO4 & 0,746 \\
\hline DCC13 & $<--$ & DCC & 1,000 & & & & & IO5 & 0,433 \\
\hline DCC12 & $<--$ & DCC & 1,000 & 0,043 & 23,177 & $* * *$ & par_9 & IO6 & 0,720 \\
\hline DCC11 & $<--$ & DCC & 0,906 & 0,048 & 18,976 & $* * *$ & par_10 & DCC15 & 0,467 \\
\hline DCC10 & $<---$ & DCC & 0,901 & 0,045 & 20,104 & $* * *$ & par_11 & DCC6 & 0,379 \\
\hline DCC9 & $<--$ & DCC & 0,987 & 0,048 & 20,517 & $* * *$ & par_12 & DCC7 & 0,501 \\
\hline DCC8 & $<--$ & DCC & 1,010 & 0,047 & 21,728 & $* * *$ & par_13 & DCC8 & 0,528 \\
\hline DCC7 & $<--$ & DCC & 1,010 & 0,048 & 21,029 & $* * *$ & par_14 & DCC9 & 0,471 \\
\hline DCC6 & $<---$ & DCC & 0,898 & 0,049 & 18,201 & $* * *$ & par_15 & DCC10 & 0,447 \\
\hline DCC15 & $<--$ & DCC & 0,997 & 0,049 & 20,551 & $* * *$ & par_16 & DCC11 & 0,407 \\
\hline IO6 & $<---$ & IO & 1,000 & & & & & DCC12 & 0,576 \\
\hline IO5 & $<--$ & IO & 0,733 & 0,034 & 21,767 & $* * *$ & par_17 & DCC13 & 0,541 \\
\hline IO4 & $<---$ & IO & 0,975 & 0,031 & 31,534 & $* * *$ & par_18 & DCT1 & 0,377 \\
\hline IO3 & $<--$ & IO & 0,779 & 0,033 & 23,769 & $* * *$ & par_19 & DCT2 & 0,425 \\
\hline IO2 & $<---$ & IO & 0,782 & 0,034 & 23,130 & $* * *$ & par_20 & DCT3 & 0,524 \\
\hline IO1 & $<--$ & IO & 0,907 & 0,040 & 22,624 & $* * *$ & par_21 & DCT4 & 0,464 \\
\hline VO34 & $<--$ & Domínio & 1,000 & & & & & DCT5 & 0,526 \\
\hline VO26 & $<---$ & Domínio & 1,172 & 0,060 & 19,446 & $* * *$ & par_24 & DCT6 & 0,462 \\
\hline VO37 & $<--$ & Harmonia & 1,000 & & & & & DCT7 & 0,529 \\
\hline VO36 & $<--$ & Harmonia & 1,009 & 0,033 & 30,832 & $* * *$ & par_25 & DCT8 & 0,529 \\
\hline VO13 & $<--$ & Harmonia & 0,884 & 0,032 & 27,471 & $* * *$ & par_26 & DCT9 & 0,517 \\
\hline VO5 & $<---$ & Harmonia & 0,894 & 0,035 & 25,885 & $* * *$ & par_27 & & \\
\hline
\end{tabular}

Figura 72. Modelo Domínio $x$ Harmonia $\rightarrow I O \rightarrow D C$. 
Mediação simples da identidade profissional na relação entre as práticas organizacionais e o desempenho profissional

P Para esse modelo, testou-se a relação de mediação que a identidade profissional (IP) estabelece entre as práticas organizacionais (PO), com os fatores correlacionados, e o desempenho profissional por competências (DC) $P O \rightarrow I P \rightarrow D C$.

Os índices de ajuste do modelo foram satisfatórios (GFI=0,88; CFI=0,92; RMSEA=0,040); entretanto, os valores do GFI e AGFI ficaram abaixo do limite de 0,90, em virtude do tamanho da amostra e da complexidade do modelo, não comprometendo, contudo, seu ajuste global (Kline, 2010; Roussel et al, 2002). A prática de regulação ( $p<0,000)$ explicou $49 \%$ da variância total da identidade profissional $\left(\mathrm{R}^{2}=0,92\right.$ para a dimensão centralidade; $\mathrm{R}^{2}=0,10$ para afeto; e $\mathrm{R}^{2}=0,61$ para laços). Foram significativas $(\mathrm{p}<0,005)$, ainda, as práticas de regulação e de definição de responsabilidades, responsáveis por explicar em conjunto com a identidade profissional $27 \%$ da variância total do desempenho profissional $\left(\mathrm{R}^{2}=0,62\right.$ para o $\mathrm{DCT}$; e $\mathrm{R}^{2}=0,77$ para o $\left.\mathrm{DCC}\right)$.

A identidade profissional mediou parcialmente a relação entre a prática organizacional de regulação e o desempenho profissional de forma significativa $(p=0,05)$ (para mais detalhes ver Tabela 59 e Figura 73).

$$
\begin{array}{cc}
P O(\text { regulação }) \stackrel{0,70}{\longrightarrow} I P \stackrel{0,44}{\longrightarrow} D C & P O(\text { definição de responsabilidade }) \stackrel{n . s .}{\rightarrow} I P \stackrel{0,44}{\longrightarrow} D C \\
P O(\text { regulação }) \stackrel{0,13}{\longrightarrow} D C & P O(\text { definição de responsabilidade }) \stackrel{-0,18}{\longrightarrow} D C \\
\text { Efeito Indireto: } 0,305, \mathrm{p}=0,001 & \text { Efeito Indireto: } n . s .
\end{array}
$$

Tabela 59

Índices de ajustamento da relação entre $P O \rightarrow I P \rightarrow D C$.

\begin{tabular}{l|lc}
\hline \multicolumn{3}{l}{ Amostra } \\
N=916 & $\chi /$ g.l. & Modelo $P O \rightarrow I P \rightarrow D C$ \\
\hline Índices & $\chi^{2} ;$ g.l. & 2,43 \\
& $p$ & 3167,$94 ; 1303$ \\
& GFI (AGFI) & 0,000 \\
& SRMR & $0,88(0,87)$ \\
& & 0,087 \\
Índices Relativos & CFI & 0,92 \\
& TLI & 0,91 \\
Índices de Discrepância & RMSEA & 0,041 \\
Populacional & (Lo90;Hi90) & $(0,038 ; 0,041)$ \\
Índices de Parcimônia & PCFI & 0,87 \\
& PGFI & 0,80 \\
Índices Baseados na & AIC & 3425,94 \\
Teoria da Informação & ECVI & 3,74 \\
& CAIC & 4176,73 \\
\hline
\end{tabular}




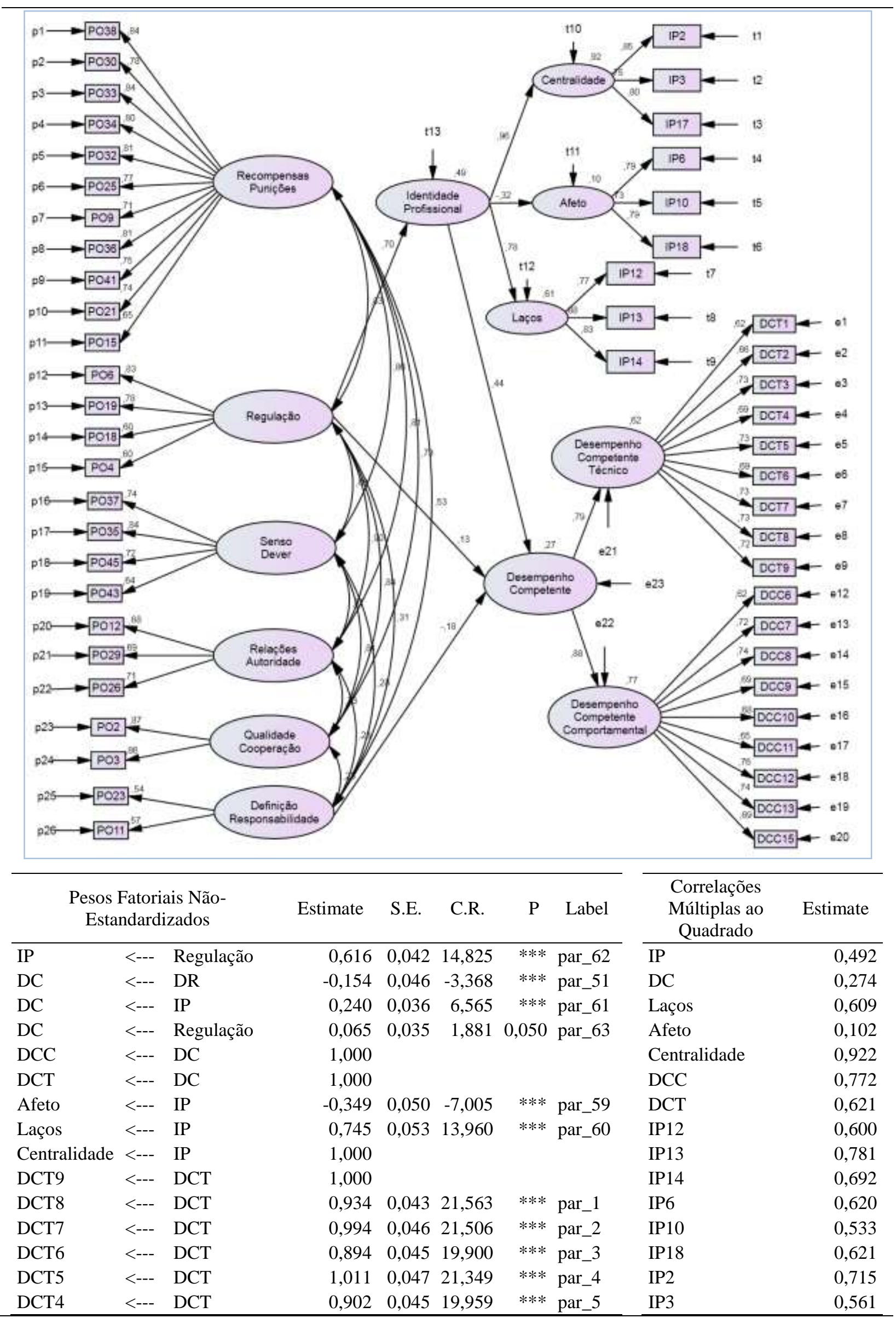




\begin{tabular}{|c|c|c|c|c|c|c|c|c|c|}
\hline$\overline{\text { DCT3 }}$ & <--- & DCT & 0,975 & 0,046 & 21,360 & **** & par_6 & IP17 & 0,642 \\
\hline DCT2 & $<---$ & DCT & 0,826 & 0,043 & 19,175 & $* * *$ & par_7 & PO15 & 0,428 \\
\hline DCT1 & $<---$ & DCT & 0,799 & 0,045 & 17,961 & $* * *$ & par_8 & $\mathrm{PO} 23$ & 0,291 \\
\hline DCC13 & $<---$ & DCC & 1,000 & & & & & PO11 & 0,324 \\
\hline DCC12 & $<--$ & DCC & 0,995 & 0,043 & 23,288 & $* * *$ & par_9 & $\mathrm{PO} 2$ & 0,756 \\
\hline DCC11 & $<---$ & DCC & 0,904 & 0,047 & 19,070 & $* * *$ & par_10 & $\mathrm{PO} 3$ & 0,744 \\
\hline DCC10 & $<---$ & DCC & 0,900 & 0,045 & 20,206 & $* * *$ & par_11 & PO12 & 0,459 \\
\hline DCC9 & $<---$ & DCC & 0,983 & 0,048 & 20,599 & $* * *$ & par_12 & PO29 & 0,474 \\
\hline DCC8 & $<---$ & DCC & 1,009 & 0,046 & 21,868 & $* * *$ & par_13 & PO26 & 0,508 \\
\hline DCC7 & $<---$ & DCC & 1,006 & 0,048 & 21,140 & $* * *$ & par_14 & PO37 & 0,542 \\
\hline DCC6 & $<---$ & DCC & 0,895 & 0,049 & 18,276 & $* * *$ & par_15 & PO35 & 0,699 \\
\hline DCC15 & $<---$ & DCC & 0,995 & 0,048 & 20,661 & $* * *$ & par_16 & PO45 & 0,520 \\
\hline $\mathrm{PO} 21$ & $<---$ & $\mathrm{RP}$ & 0,887 & 0,040 & 21,946 & $* * *$ & par_17 & PO43 & 0,406 \\
\hline $\mathrm{PO} 41$ & $<---$ & RP & 0,857 & 0,038 & 22,490 & $* * *$ & par_18 & PO6 & 0,689 \\
\hline PO36 & $<---$ & $\mathrm{RP}$ & 0,781 & 0,031 & 25,573 & $* * *$ & par_19 & PO19 & 0,609 \\
\hline PO9 & $<---$ & $\mathrm{RP}$ & 0,822 & 0,039 & 21,182 & $* * *$ & par_20 & PO18 & 0,362 \\
\hline $\mathrm{PO} 25$ & $<---$ & $\mathrm{RP}$ & 0,830 & 0,035 & 23,525 & $* * *$ & par_21 & PO4 & 0,356 \\
\hline PO32 & $<---$ & $\mathrm{RP}$ & 0,938 & 0,036 & 25,829 & $* * *$ & par_22 & PO38 & 0,708 \\
\hline PO34 & $<---$ & $\mathrm{RP}$ & 0,961 & 0,038 & 25,082 & $* * *$ & par_23 & PO30 & 0,605 \\
\hline $\mathrm{PO} 33$ & $<---$ & RP & 0,955 & 0,035 & 27,049 & $* * *$ & par_24 & PO33 & 0,708 \\
\hline $\mathrm{PO} 30$ & $<---$ & $\mathrm{RP}$ & 0,889 & 0,037 & 24,215 & $* * *$ & par_25 & PO34 & 0,646 \\
\hline PO38 & $<---$ & $\mathrm{RP}$ & 1,000 & & & & & PO32 & 0,659 \\
\hline $\mathrm{PO} 4$ & $<---$ & REG & 0,616 & 0,041 & 15,101 & $* * *$ & par_26 & PO25 & 0,596 \\
\hline PO18 & $<---$ & REG & 0,612 & 0,040 & 15,177 & $* * *$ & par_27 & PO9 & 0,511 \\
\hline PO19 & $<---$ & REG & 0,841 & 0,038 & 21,938 & $* * *$ & par_28 & PO36 & 0,664 \\
\hline PO6 & $<---$ & REG & 1,000 & & & & & $\mathrm{PO} 41$ & 0,556 \\
\hline $\mathrm{PO} 43$ & $<---$ & SD & 0,852 & 0,056 & 15,255 & $* * *$ & par_29 & $\mathrm{PO} 21$ & 0,543 \\
\hline $\mathrm{PO} 45$ & $<--$ & SD & 1,051 & 0,062 & 17,081 & $* * *$ & par_30 & DCC15 & 0,479 \\
\hline $\mathrm{PO} 35$ & $<---$ & SD & 1,259 & 0,064 & 19,756 & $* * *$ & par_31 & DCC6 & 0,390 \\
\hline PO37 & $<--$ & SD & 1,000 & & & & & DCC7 & 0,511 \\
\hline $\mathrm{PO} 26$ & $<---$ & RA & 0,708 & 0,043 & 16,317 & $* * *$ & par_32 & DCC8 & 0,540 \\
\hline $\mathrm{PO} 29$ & $<---$ & RA & 0,690 & 0,043 & 16,097 & $* * *$ & par_33 & DCC9 & 0,481 \\
\hline $\mathrm{PO} 12$ & $<---$ & RA & 1,000 & & & & & DCC10 & 0,459 \\
\hline $\mathrm{PO} 3$ & $<--$ & $\mathrm{QC}$ & 1,020 & 0,042 & 24,014 & $* * *$ & par_34 & DCC11 & 0,418 \\
\hline $\mathrm{PO} 2$ & $<--$ & $\mathrm{QC}$ & 1,000 & & & & & DCC12 & 0,584 \\
\hline PO15 & $<---$ & $\mathrm{RP}$ & 0,735 & 0,039 & 18,719 & $* * *$ & par_49 & DCC13 & 0,553 \\
\hline PO11 & $<--$ & DR & 1,107 & 0,138 & 8,041 & $* * *$ & par_50 & DCT1 & 0,384 \\
\hline $\mathrm{PO} 23$ & $<---$ & DR & 1,000 & & & & & DCT2 & 0,431 \\
\hline IP17 & $<--$ & Centralidade & 1,000 & & & & & DCT3 & 0,532 \\
\hline IP3 & $<--$ & Centralidade & 0,894 & 0,043 & 20,795 & $* * *$ & par_52 & DCT4 & 0,472 \\
\hline IP2 & $<---$ & Centralidade & 1,040 & 0,045 & 23,055 & $* * *$ & par_53 & DCT5 & 0,534 \\
\hline IP18 & $<--$ & Afeto & 1,000 & & & & & DCT6 & 0,470 \\
\hline IP10 & $<--$ & Afeto & 0,921 & 0,047 & 19,511 & $* * *$ & par_54 & DCT7 & 0,537 \\
\hline IP6 & $<---$ & Afeto & 0,913 & 0,046 & 19,873 & $* * *$ & par_55 & DCT8 & 0,536 \\
\hline IP14 & $<---$ & Laços & 1,000 & & & & & DCT9 & 0,523 \\
\hline IP13 & $<---$ & Laços & 1,120 & 0,040 & 28,295 & $* * *$ & par_56 & & \\
\hline IP12 & $<--$ & Laços & 0,915 & 0,038 & 23,953 & $* * *$ & par_57 & & \\
\hline
\end{tabular}

Figura 73. Modelo $P O \rightarrow I P \rightarrow D C$. 
Mediação simples da identidade organizacional na relação entre as práticas organizacionais e o desempenho profissional

Testou-se a relação de mediação que a identidade organizacional (IO) estabelece entre as práticas organizacionais (PO), com os fatores correlacionados, e o desempenho profissional por competências (DC) $P O \rightarrow I O \rightarrow D C$.

Os índices de ajuste do modelo foram satisfatórios (GFI=0,89; CFI=0,92; RMSEA=0,040); entretanto, os valores do GFI e AGFI ficaram abaixo do limite de 0,90, em virtude do tamanho da amostra e da complexidade do modelo, não comprometendo, apesar disso, seu ajuste global (Kline, 2010; Roussel et al, 2002). As práticas de regulação e definição de responsabilidade $(\mathrm{p}<0,005)$ explicaram $29 \%$ da variância total da identidade organizacional. Foram significativas $(\mathrm{p}<0,002)$, ainda, as práticas de regulação e de definição de responsabilidades, responsáveis por explicar em conjunto com a identidade profissional $23 \%$ da variância total do desempenho profissional $\left(\mathrm{R}^{2}=0,61\right.$ para o desempenho por competências técnicas; e $\mathrm{R}^{2}=0,80$ para o desempenho por competências comportamentais).

A identidade organizacional mediou parcialmente a relação entre as práticas de regulação e definição de responsabilidade e o desempenho profissional $(p=0,01$ e p=0,05), conforme Tabela 60 e Figura 74.

$$
\begin{array}{cc}
P O(\text { regulação }) \stackrel{0,57}{\longrightarrow} I O \stackrel{0,27}{\longrightarrow} D C & P O(\text { definição de responsabilidade }) \stackrel{-0,13}{\longrightarrow} I O \stackrel{0,27}{\longrightarrow} D C \\
P O \text { (regulação) } \stackrel{0,29}{\longrightarrow} D C & P O(\text { definição de responsabilidade }) \stackrel{-0,17}{\longrightarrow} D C \\
\text { Efeito Indireto: } 0,152, \mathrm{p}=0,005 & \text { Efeito Indireto: }-0,034, \mathrm{p}=0,001
\end{array}
$$

Tabela 60

Índices de ajustamento da relação entre $P O \rightarrow I O \rightarrow D C$

\begin{tabular}{l|lc}
\hline \multicolumn{3}{l}{ Amostra } \\
$\mathrm{N}=916$ & $\chi /$ g.l. & \\
\hline Índices & $\chi^{2} ;$ g.l. & 2,48 \\
Absolutos & $p$ & 2867,$01 ; 1154$ \\
& GFI (AGFI) & 0,000 \\
& SRMR & $0,89(0,88)$ \\
& & 0,082 \\
Índices Relativos & CFI & \\
& TLI & 0,92 \\
Índices de Discrepância & RMSEA & 0,92 \\
Populacional & Lo90;Hi90) & 0,040 \\
Índices de Parcimônia & PCFI & $(0,038 ; 0,042)$ \\
& PGFI & 0,87 \\
Índices Baseados na & AIC & 0,80 \\
Teoria da Informação & ECVI & 3109,01 \\
& CAIC & 3,40 \\
\hline
\end{tabular}




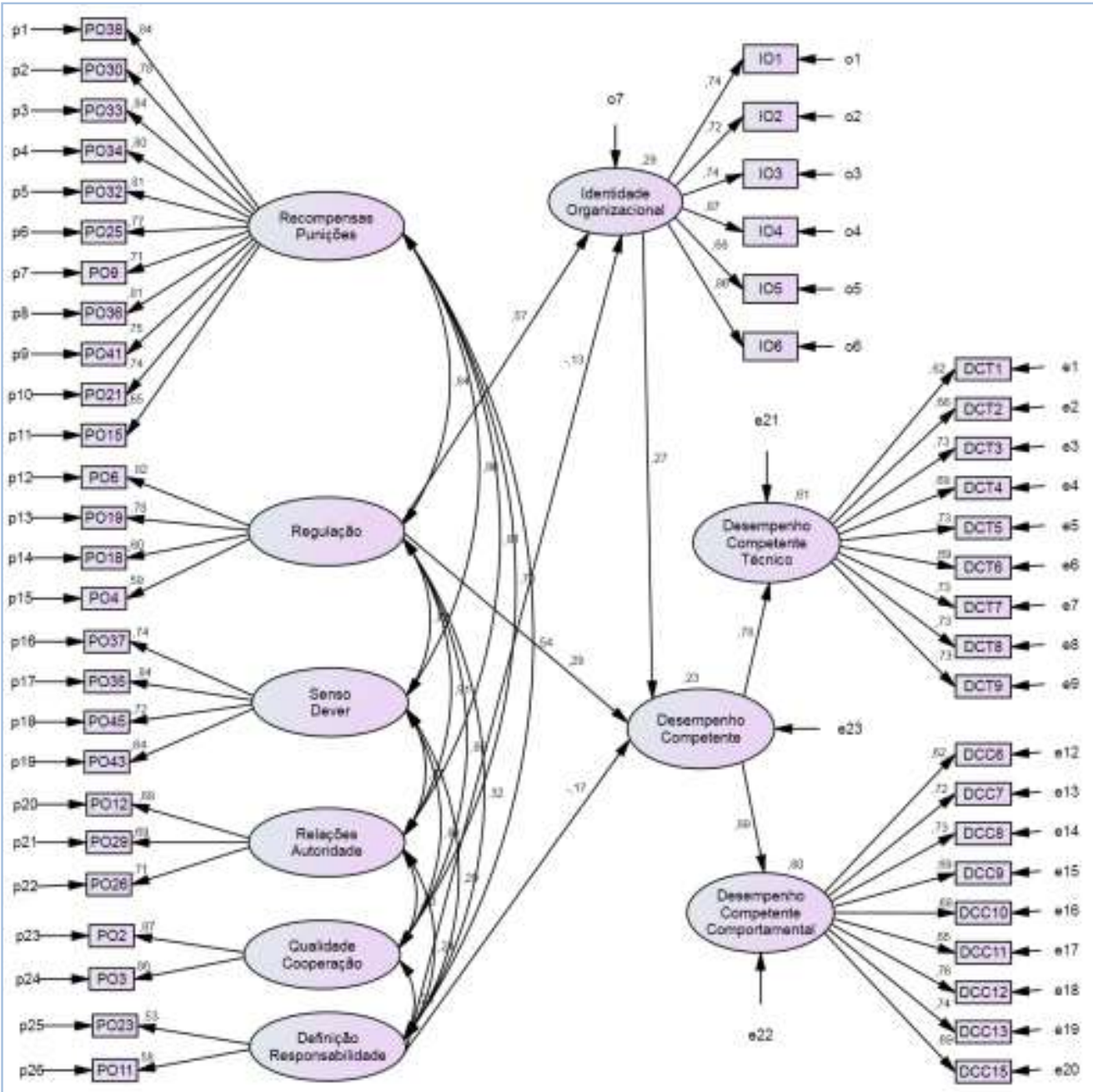

\begin{tabular}{|c|c|c|c|c|c|c|c|c|c|}
\hline \multicolumn{3}{|c|}{$\begin{array}{l}\text { Pesos Fatoriais } \\
\text { Não- } \\
\text { Estandardizados }\end{array}$} & \multirow{2}{*}{$\begin{array}{l}\text { Estimate } \\
-0,222\end{array}$} & \multirow{2}{*}{$\begin{array}{l}\text { S.E. } \\
0,083\end{array}$} & \multirow{2}{*}{$\begin{array}{c}\text { C.R. } \\
-2,689\end{array}$} & \multirow{2}{*}{$\begin{array}{r}P \\
0,007\end{array}$} & \multirow{2}{*}{$\begin{array}{c}\text { Label } \\
\text { par_59 }\end{array}$} & $\begin{array}{l}\text { Correlações } \\
\text { Múltiplas ao } \\
\text { Quadrado }\end{array}$ & \multirow{2}{*}{$\begin{array}{r}\text { Estimate } \\
0,293\end{array}$} \\
\hline IO & $<---$ & DR & & & & & & IO & \\
\hline IO & $<---$ & REG & 0,562 & 0,048 & 11,736 & $* * *$ & par_60 & $\mathrm{DC}$ & 0,231 \\
\hline $\mathrm{DC}$ & $<---$ & REG & 0,142 & 0,030 & 4,786 & $* * *$ & par 51 & $\mathrm{DCC}$ & 0,796 \\
\hline DC & $<---$ & DR & $-0,150$ & 0,047 & $-3,173$ & 0,002 & par_52 & DCT & 0,606 \\
\hline DC & $<--$ & IO & 0,133 & 0,023 & 5,851 & $* * *$ & par_61 & IO1 & 0,549 \\
\hline DCC & $<--$ & DC & 1,000 & & & & & $\mathrm{IO} 2$ & 0,518 \\
\hline DCT & $<--$ & DC & 1,000 & & & & & IO3 & 0,543 \\
\hline DCT9 & $<---$ & DCT & 1,000 & & & & & IO4 & 0,764 \\
\hline DCT8 & $<---$ & DCT & 0,924 & 0,043 & 21,652 & $* * *$ & par_1 & IO5 & 0,462 \\
\hline DCT7 & $<---$ & DCT & 0,984 & 0,046 & 21,592 & $* * *$ & par_2 & IO6 & 0,741 \\
\hline DCT6 & $<---$ & DCT & 0,884 & 0,044 & 19,968 & $* * *$ & par_3 & PO15 & 0,428 \\
\hline DCT5 & $<---$ & DCT & 1,000 & 0,047 & 21,422 & $* * *$ & par_4 & PO23 & 0,285 \\
\hline DCT4 & $<---$ & DCT & 0,891 & 0,044 & 20,021 & $* * *$ & par_5 & PO11 & 0,337 \\
\hline DCT3 & $<---$ & DCT & 0,964 & 0,045 & 21,437 & $* * *$ & par_6 & $\mathrm{PO} 2$ & 0,756 \\
\hline DCT2 & $<--$ & DCT & 0,817 & 0,042 & 19,231 & $* * *$ & par_7 & PO3 & 0,743 \\
\hline
\end{tabular}




\begin{tabular}{|c|c|c|c|c|c|c|c|c|c|}
\hline DCT1 & $<--$ & DCT & 0,791 & 0,044 & 18,003 & $* * *$ & par_8 & PO12 & 0,458 \\
\hline DCC13 & $<--$ & DCC & 1,000 & & & & & PO29 & 0,478 \\
\hline DCC12 & $<--$ & DCC & 1,007 & 0,044 & 22,954 & $* * *$ & par_9 & PO26 & 0,505 \\
\hline DCC11 & $<--$ & DCC & 0,913 & 0,048 & 18,869 & $* * *$ & par_10 & PO37 & 0,541 \\
\hline DCC10 & $<--$ & DCC & 0,909 & 0,046 & 19,978 & $* * *$ & par_11 & PO35 & 0,697 \\
\hline DCC9 & $<---$ & DCC & 0,996 & 0,049 & 20,372 & $* * *$ & par_12 & PO45 & 0,520 \\
\hline DCC8 & $<--$ & DCC & 1,020 & 0,047 & 21,578 & $* * *$ & par_13 & $\mathrm{PO} 43$ & 0,405 \\
\hline DCC7 & $<--$ & DCC & 1,019 & 0,049 & 20,875 & $* * *$ & par_14 & PO6 & 0,680 \\
\hline DCC6 & $<---$ & DCC & 0,905 & 0,050 & 18,103 & $* * *$ & par_15 & PO19 & 0,602 \\
\hline DCC15 & $<--$ & DCC & 1,005 & 0,049 & 20,411 & $* * *$ & par_16 & PO18 & 0,364 \\
\hline PO21 & $<---$ & $\mathrm{RP}$ & 0,887 & 0,040 & 21,933 & $* * *$ & par_17 & $\mathrm{PO} 4$ & 0,354 \\
\hline PO41 & $<--$ & $\mathrm{RP}$ & 0,857 & 0,038 & 22,472 & $* * *$ & par_18 & PO38 & 0,707 \\
\hline PO36 & $<--$ & $\mathrm{RP}$ & 0,781 & 0,031 & 25,566 & $* * *$ & par_19 & PO30 & 0,604 \\
\hline PO9 & $<---$ & $\mathrm{RP}$ & 0,822 & 0,039 & 21,169 & $* * *$ & par_20 & PO33 & 0,708 \\
\hline $\mathrm{PO} 25$ & $<--$ & $\mathrm{RP}$ & 0,830 & 0,035 & 23,510 & $* * *$ & par_21 & PO34 & 0,645 \\
\hline PO32 & $<--$ & RP & 0,938 & 0,036 & 25,826 & $* * *$ & par_22 & PO32 & 0,658 \\
\hline PO34 & $<--$ & $\mathrm{RP}$ & 0,962 & 0,038 & 25,076 & $* * *$ & par_23 & $\mathrm{PO} 25$ & 0,595 \\
\hline PO33 & $<--$ & $\mathrm{RP}$ & 0,956 & 0,035 & 27,053 & $* * *$ & par_24 & PO9 & 0,510 \\
\hline PO30 & $<---$ & $\mathrm{RP}$ & 0,889 & 0,037 & 24,203 & $* * *$ & par_25 & PO36 & 0,664 \\
\hline PO38 & $<---$ & $\mathrm{RP}$ & 1,000 & & & & & PO41 & 0,555 \\
\hline $\mathrm{PO} 4$ & $<---$ & REG & 0,618 & 0,041 & 15,022 & $* * *$ & par_26 & PO21 & 0,542 \\
\hline PO18 & $<---$ & REG & 0,618 & 0,041 & 15,202 & $* * *$ & par_27 & DCC15 & 0,477 \\
\hline PO19 & $<--$ & REG & 0,840 & 0,039 & 21,688 & $* * *$ & par_28 & DCC6 & 0,389 \\
\hline PO6 & $<--$ & REG & 1,000 & & & & & DCC7 & 0,512 \\
\hline PO43 & $<--$ & SD & 0,852 & 0,056 & 15,246 & $* * *$ & par_29 & DCC8 & 0,540 \\
\hline PO45 & $<---$ & SD & 1,053 & 0,062 & 17,077 & $* * *$ & par_30 & DCC9 & 0,482 \\
\hline PO35 & $<--$ & SD & 1,258 & 0,064 & 19,730 & $* * *$ & par_31 & DCC10 & 0,458 \\
\hline PO37 & $<---$ & SD & 1,000 & & & & & DCC11 & 0,417 \\
\hline PO26 & $<---$ & RA & 0,706 & 0,043 & 16,269 & $* * *$ & par_32 & DCC12 & 0,585 \\
\hline PO29 & $<--$ & RA & 0,695 & 0,043 & 16,195 & $* * *$ & par_33 & DCC13 & 0,546 \\
\hline PO12 & $<--$ & RA & 1,000 & & & & & DCT1 & 0,386 \\
\hline $\mathrm{PO} 3$ & $<---$ & $\mathrm{QC}$ & 1,020 & 0,042 & 24,006 & $* * *$ & par_34 & DCT2 & 0,433 \\
\hline $\mathrm{PO} 2$ & $<---$ & QC & 1,000 & & & & & DCT3 & 0,534 \\
\hline PO15 & $<--$ & $\mathrm{RP}$ & 0,736 & 0,039 & 18,731 & $* * *$ & par_49 & DCT4 & 0,474 \\
\hline PO11 & $<--$ & DR & 1,142 & 0,141 & 8,085 & $* * *$ & par_50 & DCT5 & 0,536 \\
\hline $\mathrm{PO} 23$ & $<---$ & DR & 1,000 & & & & & DCT6 & 0,472 \\
\hline IO6 & $<--$ & IO & 1,000 & & & & & DCT7 & 0,540 \\
\hline IO5 & $<---$ & IO & 0,735 & 0,034 & 21,840 & $* * *$ & par_53 & DCT8 & 0,538 \\
\hline IO4 & $<--$ & IO & 0,973 & 0,031 & 31,600 & $* * *$ & par_54 & DCT9 & 0,531 \\
\hline IO3 & $<--$ & IO & 0,780 & 0,033 & 23,854 & $* * *$ & par_55 & & \\
\hline IO2 & $<---$ & IO & 0,783 & 0,034 & 23,210 & $* * *$ & par_56 & & \\
\hline IO1 & $<--$ & IO & 0,904 & 0,040 & 22,589 & $* * *$ & par_57 & & \\
\hline
\end{tabular}

Figura 74. Modelo $P O \rightarrow I O \rightarrow D C$. 
Mediação em cadeia da identidade profissional e da identidade organizacional na relação entre os valores organizacionais e o desempenho competente

Nessa primeira análise de mediação em cadeia, busca-se testar a relação de mediação que a identidade profissional (IP) e a identidade organizacional (IO) estabelecem entre os tipos motivacionais subjacentes aos valores organizacionais (VO), todos correlacionados, e o desempenho profissional por competências (DC) $V O \rightarrow I P \rightarrow I O \rightarrow D C$. Em seguida, o segundo teste analisou a associação entre as dimensões bipolares dos tipos motivacionais sobre o desempenho profissional, sendo essa relação mediada pela identidade profissional e pela identidade organizacional. Para tanto, foram considerados os seguintes pares: Autonomia $x$ Conservação $\rightarrow I P \rightarrow I O \rightarrow D C ;$ Hierarquia $x$ Igualitarismo $\rightarrow I P \rightarrow I O \rightarrow D C ;$ Domínio $x$ Harmonia $\rightarrow I P \rightarrow I O \rightarrow D C$. Como forma de verificar a qualidade do ajustamento dos dados, foram apreciadas suas especificações.

$\mathrm{O}$ primeiro teste apresentou ajustes satisfatórios (GFI=089; $\mathrm{CFI}=0,94$; RMSEA=0,037), entretanto os valores do GFI e AGFI ficaram abaixo do limite de 0,90, em virtude do tamanho da amostra e da complexidade do modelo, não comprometendo, apesar disso, seu ajuste global (Kline, 2010; Roussel et al, 2002). Foram significativos ( $<<0,005$ ) os tipos motivacionais conservação, igualitarismo e harmonia, responsáveis por explicar $21 \%$ da identidade profissional $\left(\mathrm{R}^{2}=0,92\right.$ para centralidade; $\mathrm{R}^{2}=0,11$ para afeto; e $\mathrm{R}^{2}=0,52$ para laços), a identidade profissional, sofrendo efeitos diretos dos tipos motivacionais conservação, igualitarismo e harmonia, explicou $52 \%$ da variância da identidade organizacional. No que se refere à mediação em cadeia, a identidade profissional e a identidade organizacional mediaram parcialmente a relação entre os tipos motivacionais conservação, igualitarismo e harmonia e o desempenho profissional, de forma significativa, $p=0,026 ; p=0,003$ e $p=0,002$, respectivamente. $O$ modelo foi responsável por explicar $22 \%$ da variância do desempenho profissional $\left(\mathrm{R}^{2}=0,80\right.$ de explicação para o desempenho por competências técnicas; $\mathrm{R}^{2}=0,77$ de explicação para o desempenho por competências comportamentais), conforme Figura 75.

$$
\begin{array}{cc}
V O(\text { conservação) }) & \stackrel{0,16}{\longrightarrow} I P \stackrel{0,72}{\longrightarrow} I O \stackrel{0,27}{\longrightarrow} \mathrm{DC} \quad \text { VO (igualitarismo }) \stackrel{-0,45}{\longrightarrow} I P \stackrel{0,72}{\longrightarrow} I O \stackrel{0,27}{\longrightarrow} \mathrm{DC} \\
V O(\text { conservação }) & \stackrel{0,15}{\longrightarrow} D C \\
\text { Efeito Indireto: } 0,032, \mathrm{p}=0,015 & \text { VO (igualitarismo }) \stackrel{-0,50}{\longrightarrow} D C \\
\text { Efeito Indireto: }-0,088, \mathrm{p}=0,001
\end{array}
$$

$$
\begin{gathered}
V O(\text { harmonia }) \stackrel{0,70}{\longrightarrow} I P \stackrel{0,72}{\longrightarrow} I O \stackrel{0,27}{\longrightarrow} \mathrm{DC} \\
\text { VO (harmonia) } \stackrel{0,55}{\longrightarrow} D C \\
\text { Efeito Indireto: } 0,138, \mathrm{p}=0,001
\end{gathered}
$$


O segundo teste verificou a mediação em cadeia da identidade profissional e da identidade organizacional na relação entre os tipos motivacionais bipolares, analisados de forma independente, e o desempenho profissional. Relativamente aos tipos conservação $x$ autonomia e o desempenho profissional, a identidade profissional e a identidade organizacional mediaram parcialmente a relação entre conservação e o desempenho profissional $(\mathrm{p}=0,001)$ e, totalmente, a relação entre autonomia e o desempenho profissional $(\mathrm{p}=0,872)$, conforme Figura 76, com ajustes adequados $(\mathrm{GFI}=0,92 ; \quad \mathrm{CFI}=0,96$; RMSEA=0,036).

$$
\begin{array}{cc}
\text { Conservação } \stackrel{0,26 *}{\longrightarrow} I P \stackrel{0,72 *}{\longrightarrow} I O \stackrel{0,31 *}{\longrightarrow} D C & \text { Autonomia } \stackrel{0,19 *}{\longrightarrow} I P \stackrel{0,72 *}{\longrightarrow} I O \stackrel{0,31 *}{\longrightarrow} D C \\
\text { Conservação } \stackrel{0,25 *}{\longrightarrow} D C & \text { Autonomia } \stackrel{\text { n.s. }}{\rightarrow} D C \\
\text { Efeito Indireto: } 0,059, \mathrm{p}=0,001 & \text { Efeito Indireto: } 0,044, \mathrm{p}=0,001
\end{array}
$$

Os tipos motivacionais Autonomia x Conservação foram responsáveis por explicar $16 \%$ da identidade profissional $\left(\mathrm{R}^{2}=0,93\right.$ para centralidade; $\mathrm{R}^{2}=0,11$ para afeto; e $\mathrm{R}^{2}=0,52$ para laços). A identidade profissional, que sofre efeitos diretos dos tipos motivacionais conservação e autonomia, explicou $51 \%$ da variância da identidade organizacional. O modelo foi responsável por explicar $19 \%$ da variância do desempenho profissional $\left(\mathrm{R}^{2}=0,59\right.$ de explicação para o desempenho por competências técnicas; $R^{2}=0,79$ de explicação para $\mathrm{o}$ desempenho por competências comportamentais).

Para os tipos motivacionais hierarquia x igualitarismo e o desempenho profissional, a identidade profissional e a identidade organizacional mediaram parcialmente essa relação $(\mathrm{p}=0,001$ e $\mathrm{p}=0,001)$, com ajustes adequados (GFI=0,92; CFI=0,96; RMSEA=0,034), , conforme Figura 77.

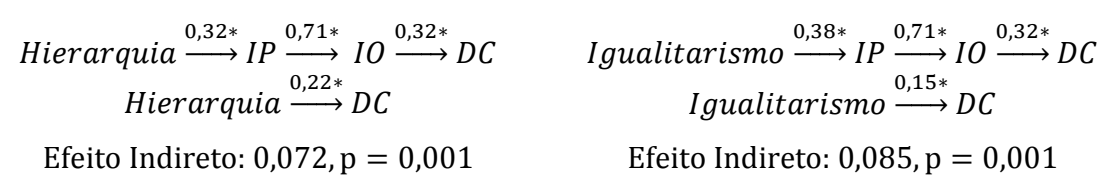

As dimensões Hierarquia $x$ igualitarismo foram responsáveis por explicar $16 \%$ da identidade profissional $\left(\mathrm{R}^{2}=0,93\right.$ para centralidade; $\mathrm{R}^{2}=0,10$ para afeto; e $\mathrm{R}^{2}=0,53$ para laços). A identidade profissional, que recebe efeitos diretos dos tipos motivacionais hierarquia e igualitarismo, explicou $51 \%$ da variância da identidade organizacional. O modelo foi responsável por explicar $19 \%$ da variância do desempenho profissional $\left(\mathrm{R}^{2}=0,61\right.$ de explicação para o desempenho por competências técnicas; $\mathrm{R}^{2}=0,76$ de explicação para $\mathrm{o}$ desempenho por competências comportamentais). 
Por fim, a relação entre os tipos motivacionais domínio x harmonia e o desempenho profissional foi mediada parcialmente (mediação em cadeia) pela identidade profissional e identidade organizacional ( $\mathrm{p}=0,001)$, com ajustes adequados $(\mathrm{p}<0,000 ; \mathrm{GFI}=0,92 ; \mathrm{CFI}=0,96$; RMSEA=0,036), somente para a dimensão harmonia, conforme Figura 78.

$$
\begin{gathered}
\text { Domínio } \stackrel{\text { n.s. }}{\longrightarrow} I P \stackrel{0,72}{\longrightarrow} I O \stackrel{0,31}{\longrightarrow} D C \\
\text { Domínio } \stackrel{\text { n.s. }}{\longrightarrow} D C
\end{gathered}
$$

Efeito Indireto: $n . s$.

$$
\begin{gathered}
\text { Harmonia } \stackrel{0,39}{\longrightarrow} I P \stackrel{0,72}{\longrightarrow} I O \stackrel{0,33}{\longrightarrow} D C \\
\text { Harmonia } \stackrel{0,17}{\longrightarrow} D C
\end{gathered}
$$

Efeito Indireto: $0,091, p=0,001$

A dimensão harmonia foi responsável por explicar $15 \%$ da identidade profissional $\left(\mathrm{R}^{2}=0,91\right.$ para centralidade; $\mathrm{R}^{2}=0,11$ para afeto; e $\mathrm{R}^{2}=0,53$ para laços). A identidade profissional, que recebe efeito direto do tipo motivacional harmonia, explicou $52 \%$ da variância da identidade organizacional. O modelo foi responsável por explicar $17 \%$ da variância do desempenho profissional $\left(\mathrm{R}^{2}=0,60\right.$ de explicação para o desempenho por competências técnicas; $\mathrm{R}^{2}=0,77$ de explicação para o desempenho por competências comportamentais).

A Tabela 61 sintetiza os índices de ajuste e as Figuras 75, 76, 77 e 78 exibem as representações gráficas de cada um dos modelos, os pesos fatoriais não estandardizados e as

\begin{tabular}{|c|c|c|c|c|c|}
\hline \multicolumn{2}{|l|}{$\begin{array}{l}\text { Amostra } \\
\mathrm{N}=916\end{array}$} & $\begin{array}{c}\text { Modelo } V O \rightarrow \\
I P \rightarrow I O \rightarrow \\
D C \\
2,27\end{array}$ & $\begin{array}{c}\text { Autonomia } x \\
\text { Conservação } \\
\rightarrow I P \rightarrow \\
I O \rightarrow D C \\
2,06\end{array}$ & $\begin{array}{c}\text { Hierarquia } x \\
\text { Igualitarismo } \\
\rightarrow I P \rightarrow \\
I O \rightarrow D C \\
2,05\end{array}$ & $\begin{array}{c}\text { Domínio } x \\
\text { Harmonia } \rightarrow \\
I P \rightarrow I O \rightarrow \\
D C \\
2,17\end{array}$ \\
\hline $\begin{array}{l}\text { Índices } \\
\text { Absolutos }\end{array}$ & $\begin{array}{l}\chi \text { g.l. } \\
\chi^{2} ; \text { g.l. } \\
p \\
\text { GFI (AGFI) } \\
\text { SRMR }\end{array}$ & $\begin{array}{c}2,27 \\
2711,97 ; 1195 \\
0,000 \\
0,89(0,88) \\
0,044\end{array}$ & $\begin{array}{c}2,06 \\
1421,66 ; 689 \\
0,000 \\
0,92(0,91) \\
0,045\end{array}$ & $\begin{array}{c}2,05 \\
1412,47 ; 688 \\
0,000 \\
0,92(0,91) \\
0,046\end{array}$ & $\begin{array}{c}2,17 \\
1501,09 ; 691 \\
0,000 \\
0,92(0,91) \\
0,047\end{array}$ \\
\hline Índices Relativos & $\begin{array}{l}\text { CFI } \\
\text { TLI }\end{array}$ & $\begin{array}{l}0,94 \\
0,94\end{array}$ & $\begin{array}{l}0,96 \\
0,96\end{array}$ & $\begin{array}{l}0,96 \\
0,95\end{array}$ & $\begin{array}{l}0,96 \\
0,95\end{array}$ \\
\hline $\begin{array}{l}\text { Índices de } \\
\text { Discrepância } \\
\text { Populacional }\end{array}$ & $\begin{array}{l}\text { RMSEA } \\
\text { (Lo90;Hi90) }\end{array}$ & $\begin{array}{c}0,037 \\
(0,035 ; 0,039)\end{array}$ & $\begin{array}{c}0,034 \\
(0,032 ; 0,037)\end{array}$ & $\begin{array}{c}0,034 \\
(0,031 ; 0,036)\end{array}$ & $\begin{array}{c}0,036 \\
(0,033 ; 0,038)\end{array}$ \\
\hline $\begin{array}{l}\text { Índices de } \\
\text { Parcimônia }\end{array}$ & $\begin{array}{l}\text { PCFI } \\
\text { PGFI }\end{array}$ & $\begin{array}{l}0,89 \\
0,81\end{array}$ & $\begin{array}{l}0,89 \\
0,82\end{array}$ & $\begin{array}{l}0,89 \\
0,82\end{array}$ & $\begin{array}{l}0,89 \\
0,81\end{array}$ \\
\hline $\begin{array}{l}\text { Índices Baseados } \\
\text { na Teoria da } \\
\text { Informação }\end{array}$ & $\begin{array}{l}\text { AIC } \\
\text { ECVI } \\
\text { CAIC }\end{array}$ & $\begin{array}{c}2973,97 \\
3,25 \\
3736,39 \\
\end{array}$ & $\begin{array}{c}1603,66 \\
1,75 \\
2133,29\end{array}$ & $\begin{array}{c}1596,47 \\
1,75 \\
2131,91\end{array}$ & $\begin{array}{c}1679,09 \\
1,83 \\
2197,07\end{array}$ \\
\hline
\end{tabular}
correlações múltiplas ao quadrado.

Tabela 61

Índices de ajustamento da relação entre $V O \rightarrow I P \rightarrow I O \rightarrow D C$, completo e por dimensões 


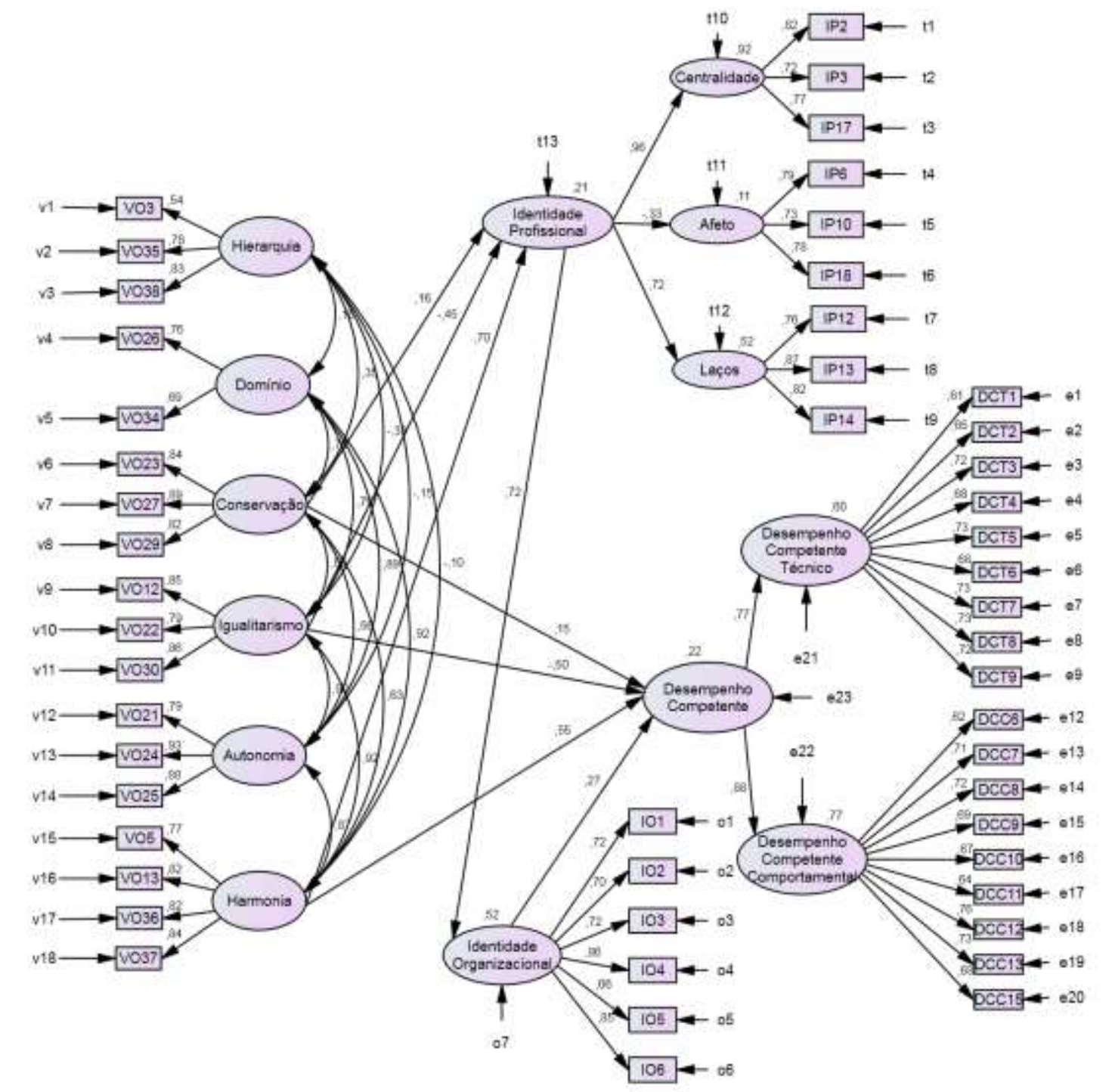

\begin{tabular}{|c|c|c|c|c|c|c|c|c|c|}
\hline \multicolumn{3}{|c|}{$\begin{array}{l}\text { Pesos Fatoriais Não- } \\
\text { Estandardizados }\end{array}$} & \multirow{2}{*}{$\begin{array}{r}\text { Estimate } \\
0,067\end{array}$} & \multirow{2}{*}{$\begin{array}{l}\text { S.E. } \\
0,024\end{array}$} & \multirow{2}{*}{$\begin{array}{l}\text { C.R. } \\
2,857\end{array}$} & \multirow{2}{*}{$\begin{array}{r}P \\
0,004\end{array}$} & \multirow{2}{*}{$\begin{array}{l}\text { Label } \\
\text { par_61 }\end{array}$} & \multirow{2}{*}{$\begin{array}{c}\text { Correlações } \\
\text { Múltiplas ao } \\
\text { Quadrado }\end{array}$} & \multirow{2}{*}{$\begin{array}{r}\text { Estimate } \\
0,209\end{array}$} \\
\hline IP & $<--$ & Conservação & & & & & & & \\
\hline IP & $<--$ & Igualitarismo & $-0,117$ & 0,036 & $-3,231$ & 0,001 & par_63 & IO & 0,518 \\
\hline IP & $<--$ & Harmonia & 0,250 & 0,057 & 4,369 & $* * *$ & par_65 & DC & 0,222 \\
\hline IO & $<--$ & IP & 0,848 & 0,055 & 15,402 & *** & par_33 & Laços & 0,524 \\
\hline DC & $<--$ & IO & 0,137 & 0,021 & 6,538 & $* * *$ & par_32 & Afeto & 0,110 \\
\hline DC & $<--$ & Conservação & 0,037 & 0,014 & 2,612 & 0,009 & par_62 & Centralidade & 0,916 \\
\hline DC & $<--$ & Igualitarismo & $-0,077$ & 0,022 & $-3,519$ & $* * *$ & par_64 & DCC & 0,773 \\
\hline $\mathrm{DC}$ & $<--$ & Harmonia & 0,115 & 0,035 & 3,314 & $* * *$ & par_66 & DCT & 0,599 \\
\hline DCC & $<--$ & DC & 1,000 & & & & & VO37 & 0,698 \\
\hline DCT & $<--$ & DC & 1,000 & & & & & VO36 & 0,674 \\
\hline Laços & $<--$ & IP & 0,720 & 0,045 & 15,896 & $* * *$ & par_24 & VO5 & 0,590 \\
\hline Centralidade & $<--$ & IP & 1,000 & & & & & VO13 & 0,673 \\
\hline Afeto & $<--$ & IP & $-0,394$ & 0,050 & $-7,876$ & $* * *$ & par_31 & VO21 & 0,621 \\
\hline DCT9 & $<--$ & DCT & 1,000 & & & & & VO24 & 0,868 \\
\hline DCT8 & $<--$ & DCT & 0,929 & 0,043 & 21,746 & $* * *$ & par_1 & VO25 & 0,782 \\
\hline DCT7 & $<--$ & DCT & 0,988 & 0,046 & 21,697 & $* * *$ & par 2 & VO12 & 0,725 \\
\hline
\end{tabular}




\begin{tabular}{|c|c|c|c|c|c|c|c|c|c|}
\hline DCT6 & <-- & DCT & 0,889 & 0,044 & 20,044 & $* * *$ & par_3 & $\overline{\mathrm{VO} 22}$ & 0,625 \\
\hline DCT5 & $<--$ & DCT & 1,005 & 0,047 & 21,530 & $* * *$ & par_4 & VO30 & 0,732 \\
\hline DCT4 & $<--$ & DCT & 0,895 & 0,045 & 20,108 & $* * *$ & par_5 & VO23 & 0,703 \\
\hline DCT3 & $<--$ & DCT & 0,969 & 0,045 & 21,544 & $* * *$ & par_6 & VO27 & 0,789 \\
\hline DCT2 & $<--$ & DCT & 0,822 & 0,043 & 19,313 & $* * *$ & par_7 & VO29 & 0,680 \\
\hline DCT1 & $<--$ & DCT & 0,795 & 0,044 & 18,078 & $* * *$ & par_8 & VO26 & 0,583 \\
\hline DCC13 & $<--$ & DCC & 1,000 & & & & & VO34 & 0,470 \\
\hline DCC11 & $<--$ & DCC & 1,002 & 0,043 & 23,318 & $* * *$ & par_9 & VO3 & 0,287 \\
\hline DCC10 & $<---$ & DCC & 0,906 & 0,048 & 19,028 & $* * *$ & par_10 & VO35 & 0,614 \\
\hline DCC9 & $<--$ & DCC & 0,903 & 0,045 & 20,194 & $* * *$ & par_11 & VO38 & 0,688 \\
\hline DCC8 & $<--$ & DCC & 0,988 & 0,048 & 20,608 & $* * *$ & par_12 & IO1 & 0,516 \\
\hline DCC7 & $<--$ & DCC & 1,011 & 0,046 & 21,830 & $* * *$ & par_13 & $\mathrm{IO} 2$ & 0,494 \\
\hline DCC6 & $<---$ & DCC & 1,012 & 0,048 & 21,140 & $* * *$ & par_14 & IO3 & 0,516 \\
\hline DCC5 & $<--$ & DCC & 0,900 & 0,049 & 18,281 & $* * *$ & par_15 & IO4 & 0,734 \\
\hline DCC15 & $<---$ & DCC & 1,001 & 0,048 & 20,670 & $* * *$ & par_16 & IO5 & 0,435 \\
\hline IP17 & $<--$ & Centralidade & 1,000 & & & & & IO6 & 0,729 \\
\hline IP3 & $<--$ & Centralidade & 0,903 & 0,043 & 21,066 & $* * *$ & par_17 & IP12 & 0,572 \\
\hline IP2 & $<--$ & Centralidade & 1,047 & 0,044 & 23,559 & $* * *$ & par_18 & IP13 & 0,758 \\
\hline IP18 & $<---$ & Afeto & 1,000 & & & & & IP14 & 0,668 \\
\hline IP10 & $<--$ & Afeto & 0,928 & 0,047 & 19,677 & $* * *$ & par_19 & IP6 & 0,624 \\
\hline IP6 & $<--$ & Afeto & 0,927 & 0,046 & 20,161 & $* * *$ & par_20 & IP10 & 0,532 \\
\hline IP14 & $<---$ & Laços & 1,000 & & & & & IP18 & 0,610 \\
\hline IP13 & $<--$ & Laços & 1,116 & 0,040 & 28,226 & $* * *$ & par_21 & IP2 & 0,680 \\
\hline IP12 & $<--$ & Laços & 0,914 & 0,038 & 23,933 & $* * *$ & par_22 & IP3 & 0,521 \\
\hline IO6 & $<--$ & IO & 1,000 & & & & & IP17 & 0,594 \\
\hline IO5 & $<--$ & IO & 0,731 & 0,033 & 22,021 & $* * *$ & par_25 & DCC15 & 0,468 \\
\hline IO4 & $<--$ & IO & 0,961 & 0,030 & 32,029 & $* * *$ & par_26 & DCC6 & 0,379 \\
\hline IO3 & $<---$ & IO & 0,775 & 0,032 & 24,143 & $* * *$ & par_27 & DCC7 & 0,500 \\
\hline $\mathrm{IO} 2$ & $<--$ & IO & 0,781 & 0,033 & 23,546 & $* * *$ & par_28 & DCC8 & 0,525 \\
\hline IO1 & $<--$ & IO & 0,894 & 0,039 & 22,641 & $* * *$ & par_29 & DCC9 & 0,469 \\
\hline VO38 & $<--$ & Hierarquia & 1,000 & & & & & DCC10 & 0,446 \\
\hline VO35 & $<---$ & Hierarquia & 0,981 & 0,047 & 20,749 & $* * *$ & par_34 & DCC11 & 0,405 \\
\hline VO3 & $<--$ & Hierarquia & 0,613 & 0,041 & 14,857 & $* * *$ & par_35 & DCC12 & 0,575 \\
\hline VO34 & $<--$ & Domínio & 1,000 & & & & & DCC13 & 0,538 \\
\hline VO26 & $<--$ & Domínio & 1,215 & 0,058 & 20,935 & $* * *$ & par_36 & DCT1 & 0,377 \\
\hline VO29 & $<--$ & Conservação & 1,000 & & & & & DCT2 & 0,424 \\
\hline VO27 & $<--$ & Conservação & 1,075 & 0,035 & 30,994 & $* * *$ & par_38 & DCT3 & 0,524 \\
\hline VO23 & $<--$ & Conservação & 1,009 & 0,035 & 28,917 & $* * *$ & par_39 & DCT4 & 0,463 \\
\hline VO30 & $<--$ & Igualitarismo & 1,000 & & & & & DCT5 & 0,526 \\
\hline $\mathrm{VO} 22$ & $<--$ & Igualitarismo & 0,636 & 0,022 & 28,971 & $* * *$ & par_42 & DCT6 & 0,462 \\
\hline VO12 & $<--$ & Igualitarismo & 0,888 & 0,027 & 33,322 & $* * *$ & par_43 & DCT7 & 0,529 \\
\hline VO25 & $<---$ & Autonomia & 1,000 & & & & & DCT8 & 0,528 \\
\hline VO24 & $<--$ & Autonomia & 1,061 & 0,024 & 43,526 & $* * *$ & par_47 & DCT9 & 0,518 \\
\hline $\mathrm{VO} 21$ & $<---$ & Autonomia & 0,922 & 0,031 & 30,069 & $* * *$ & par_48 & & \\
\hline VO13 & $<--$ & Harmonia & 0,923 & 0,032 & 28,945 & $* * *$ & par_53 & & \\
\hline VO5 & $<--$ & Harmonia & 0,909 & 0,034 & 26,512 & $* * *$ & par_54 & & \\
\hline VO37 & $<--$ & Harmonia & 1,002 & 0,033 & 30,364 & $* * *$ & par_60 & & \\
\hline VO36 & $<--$ & Harmonia & 1,000 & & & & & & \\
\hline
\end{tabular}

Figura 75. Modelo $V O \rightarrow I P \rightarrow I O \rightarrow D C$. 


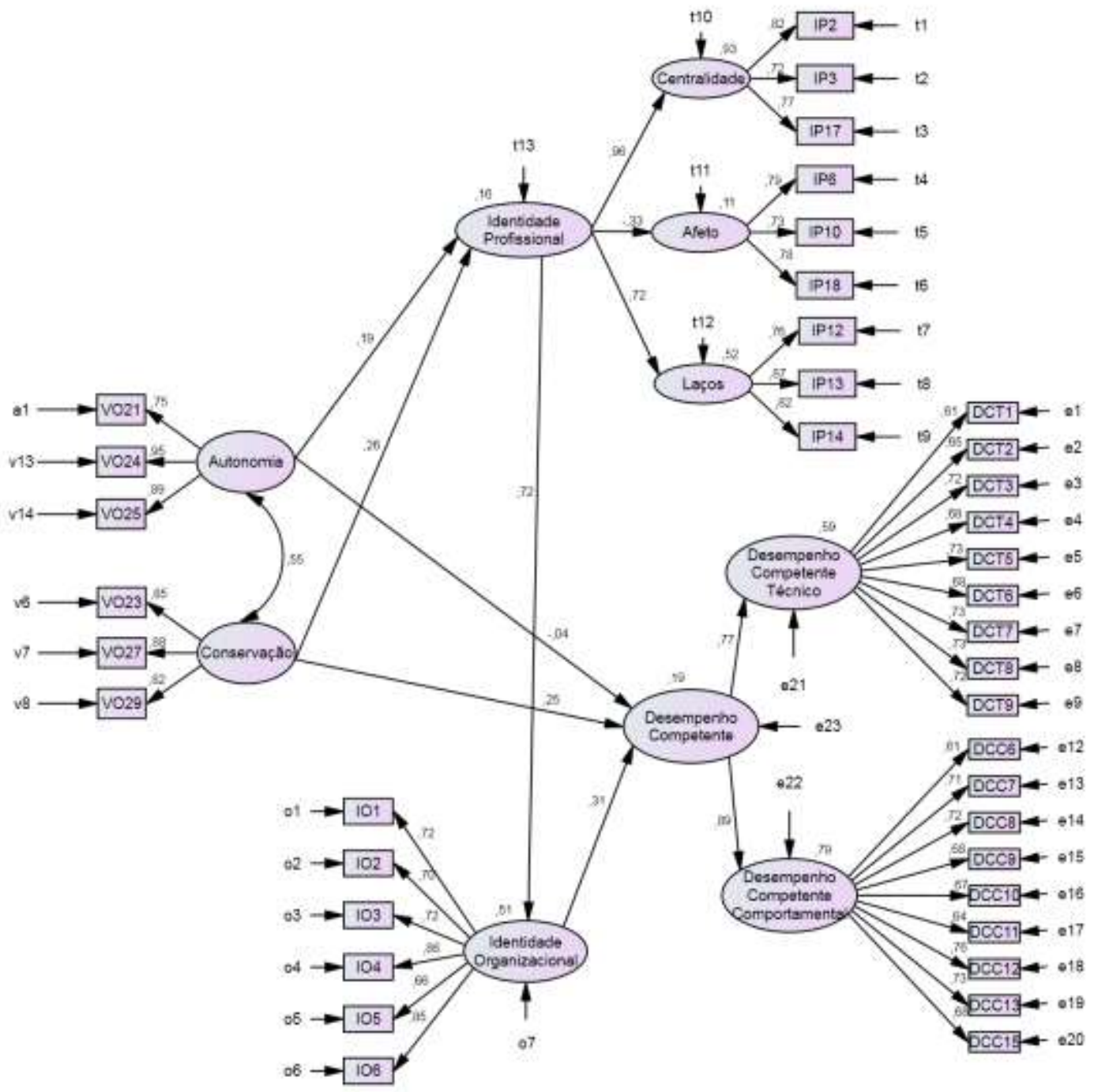




\begin{tabular}{|c|c|c|c|c|c|c|c|c|c|}
\hline Pesos Fatoria & s Não & Estandardizados & Estimate & S.E. & C.R. & $\mathrm{P}$ & Label & $\begin{array}{c}\text { Correlações } \\
\text { Múltiplas ao } \\
\text { Quadrado }\end{array}$ & Estimate \\
\hline IP & <--- & Autonomia & 0,064 & 0,015 & 4,349 & $* * *$ & par_38 & IP & 0,161 \\
\hline IP & $<---$ & Conservação & 0,110 & 0,019 & 5,691 & $* * *$ & par_39 & IO & 0,512 \\
\hline IO & $<---$ & IP & 0,835 & 0,055 & 15,265 & $* * *$ & par_33 & DC & 0,188 \\
\hline $\mathrm{DC}$ & $<---$ & IO & 0,158 & 0,020 & 7,774 & $* * *$ & par_32 & Laços & 0,521 \\
\hline $\mathrm{DC}$ & $<---$ & Autonomia & $-0,007$ & 0,009 & $-0,803$ & 0,422 & par_40 & Afeto & 0,108 \\
\hline DC & $<---$ & Conservação & 0,062 & 0,012 & 5,188 & $* * *$ & par_41 & Centralidade & 0,929 \\
\hline DCC & $<---$ & $\mathrm{DC}$ & 1,000 & & & & & DCC & 0,789 \\
\hline DCT & $<---$ & DC & 1,000 & & & & & DCT & 0,590 \\
\hline Laços & $<---$ & IP & 0,712 & 0,045 & 15,750 & $* * *$ & par_24 & VO21 & 0,565 \\
\hline Centralidade & $<---$ & IP & 1,000 & & & & & VO24 & 0,894 \\
\hline Afeto & $<---$ & IP & $-0,388$ & 0,050 & $-7,836$ & $* * *$ & par_31 & VO25 & 0,797 \\
\hline DCT9 & $<---$ & DCT & 1,000 & & & & & VO23 & 0,724 \\
\hline DCT8 & $<---$ & DCT & 0,923 & 0,042 & 21,801 & $* * *$ & par_1 & VO27 & 0,780 \\
\hline DCT7 & $<---$ & DCT & 0,982 & 0,045 & 21,747 & $* * *$ & par_2 & VO29 & 0,669 \\
\hline DCT6 & $<---$ & DCT & 0,883 & 0,044 & 20,087 & $* * *$ & par_3 & IO1 & 0,515 \\
\hline DCT5 & $<---$ & DCT & 0,998 & 0,046 & 21,578 & $* * *$ & par_4 & IO2 & 0,494 \\
\hline DCT4 & $<---$ & DCT & 0,889 & 0,044 & 20,145 & $* * *$ & par_5 & IO3 & 0,516 \\
\hline DCT3 & $<---$ & DCT & 0,963 & 0,045 & 21,589 & $* * *$ & par_6 & IO4 & 0,734 \\
\hline DCT2 & $<---$ & DCT & 0,816 & 0,042 & 19,343 & $* * *$ & par_7 & IO5 & 0,435 \\
\hline DCT1 & $<---$ & DCT & 0,789 & 0,044 & 18,100 & $* * *$ & par_8 & IO6 & 0,729 \\
\hline DCC13 & $<---$ & DCC & 1,000 & & & & & IP12 & 0,573 \\
\hline DCC12 & $<---$ & DCC & 1,009 & 0,044 & 23,118 & $* * *$ & par_9 & IP13 & 0,758 \\
\hline DCC11 & $<---$ & DCC & 0,913 & 0,048 & 18,935 & $* * *$ & par_10 & IP14 & 0,668 \\
\hline DCC10 & $<--$ & DCC & 0,911 & 0,045 & 20,081 & $* * *$ & par_11 & IP6 & 0,625 \\
\hline DCC9 & $<---$ & DCC & 0,995 & 0,049 & 20,465 & $* * *$ & par_12 & IP10 & 0,532 \\
\hline DCC8 & $<---$ & DCC & 1,018 & 0,047 & 21,672 & $* * *$ & par_13 & IP18 & 0,610 \\
\hline DCC7 & $<---$ & DCC & 1,019 & 0,049 & 20,988 & $* * *$ & par_14 & IP2 & 0,679 \\
\hline DCC6 & $<---$ & $\mathrm{DCC}$ & 0,906 & 0,050 & 18,171 & $* * *$ & par_15 & IP3 & 0,520 \\
\hline DCC15 & $<---$ & DCC & 1,007 & 0,049 & 20,513 & $* * *$ & par_16 & IP17 & 0,595 \\
\hline IP17 & $<---$ & Centralidade & 1,000 & & & & & DCC15 & 0,466 \\
\hline IP3 & $<--$ & Centralidade & 0,900 & 0,043 & 21,068 & $* * *$ & par_17 & DCC6 & 0,378 \\
\hline IP2 & $<---$ & Centralidade & 1,045 & 0,044 & 23,580 & $* * *$ & par_18 & DCC7 & 0,500 \\
\hline IP18 & $<---$ & Afeto & 1,000 & & & & & DCC8 & 0,525 \\
\hline IP10 & $<---$ & Afeto & 0,928 & 0,047 & 19,678 & $* * *$ & par_19 & DCC9 & 0,469 \\
\hline IP6 & $<---$ & Afeto & 0,928 & 0,046 & 20,145 & $* * *$ & par_20 & DCC10 & 0,447 \\
\hline IP14 & $<---$ & Laços & 1,000 & & & & & DCC11 & 0,405 \\
\hline IP13 & $<---$ & Laços & 1,116 & 0,040 & 28,227 & $* * *$ & par_21 & DCC12 & 0,575 \\
\hline IP12 & $<--$ & Laços & 0,914 & 0,038 & 23,935 & $* * *$ & par_22 & DCC13 & 0,534 \\
\hline IO6 & $<---$ & IO & 1,000 & & & & & DCT1 & 0,378 \\
\hline IO5 & $<--$ & IO & 0,731 & 0,033 & 22,031 & $* * *$ & par_25 & DCT2 & 0,425 \\
\hline IO4 & $<---$ & IO & 0,961 & 0,030 & 32,022 & $* * *$ & par_26 & DCT3 & 0,525 \\
\hline IO3 & $<---$ & IO & 0,775 & 0,032 & 24,135 & $* * *$ & par_27 & DCT4 & 0,465 \\
\hline IO2 & $<---$ & IO & 0,782 & 0,033 & 23,552 & $* * *$ & par_28 & DCT5 & 0,527 \\
\hline IO1 & $<--$ & IO & 0,893 & 0,039 & 22,637 & $* * *$ & par_29 & DCT6 & 0,464 \\
\hline VO29 & $<---$ & Conservação & 1,000 & & & & & DCT7 & 0,531 \\
\hline $\mathrm{VO} 27$ & $<--$ & Conservação & 1,077 & 0,036 & 30,181 & $* * *$ & par_34 & DCT8 & 0,530 \\
\hline VO23 & $<---$ & Conservação & 1,032 & 0,036 & 28,534 & $* * *$ & par_35 & DCT9 & 0,523 \\
\hline $\mathrm{VO} 25$ & $<---$ & Autonomia & 1,000 & & & & & & \\
\hline VO24 & $<---$ & Autonomia & 1,067 & 0,027 & 39,681 & $* * *$ & par_36 & & \\
\hline VO21 & $<---$ & Autonomia & 0,872 & 0,031 & 28,276 & $* * *$ & par_37 & & \\
\hline
\end{tabular}

Figura 76. Modelo Autonomia $x$ Conservação $\rightarrow I P \rightarrow I O \rightarrow D C$. 


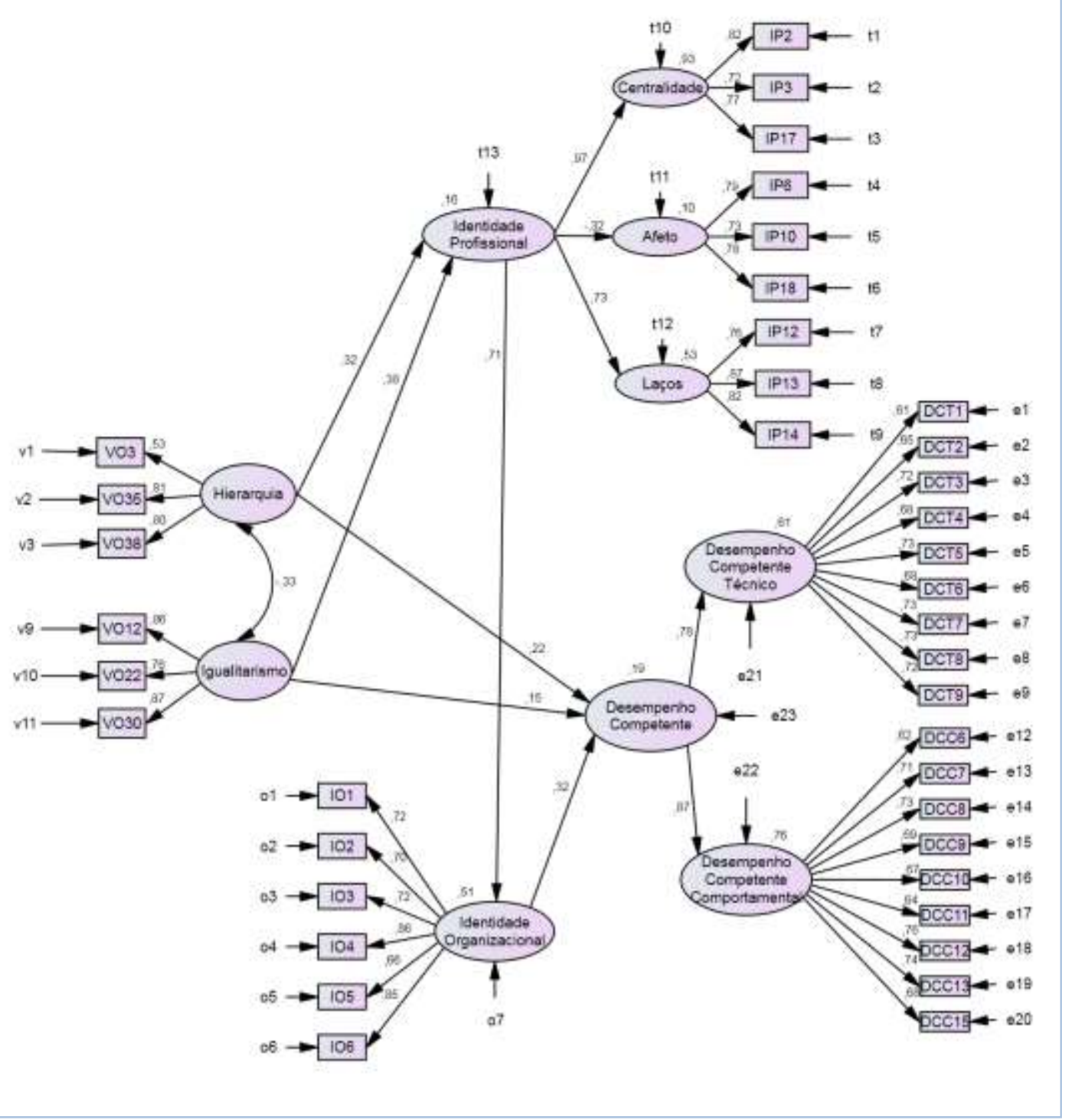




\begin{tabular}{|c|c|c|c|c|c|c|c|c|c|}
\hline \multicolumn{3}{|c|}{$\begin{array}{l}\text { Pesos Fatoriais Não- } \\
\text { Estandardizados }\end{array}$} & \multirow{2}{*}{$\begin{array}{r}\text { Estimate } \\
0,110\end{array}$} & \multirow{2}{*}{$\begin{array}{l}\text { S.E. } \\
, 015\end{array}$} & \multirow{2}{*}{$\begin{array}{l}\text { C.R. } \\
7,386\end{array}$} & \multirow{2}{*}{$\begin{array}{c}\mathrm{P} \\
* * *\end{array}$} & \multirow{2}{*}{$\begin{array}{c}\text { Label } \\
\text { par_39 }\end{array}$} & $\begin{array}{c}\text { Correlações } \\
\text { Múltiplas ao } \\
\text { Quadrado } \\
\end{array}$ & \multirow{2}{*}{$\begin{array}{r}\text { Estimate } \\
0,165\end{array}$} \\
\hline IP & $\begin{array}{ll}<-- \\
\end{array}$ & Hierarquia & & & & & & $\overline{\text { IP }}$ & \\
\hline IP & $<--$ & Igualitarismo & 0,098 & ,011 & 9,077 & $* * *$ & par_40 & IO & 0,505 \\
\hline IO & $<--$ & IP & 0,831 &, 054 & 15,268 & $* * *$ & par_33 & DC & 0,188 \\
\hline $\mathrm{DC}$ & $<---$ & IO & 0,159 &, 021 & 7,709 & $* * *$ & par_32 & Laços & 0,528 \\
\hline DC & $<--$ & Hierarquia & 0,045 & ,009 & 4,933 & $* * *$ & par_41 & Afeto & 0,104 \\
\hline DC & $<---$ & Igualitarismo & 0,023 & ,007 & 3,412 & $* * *$ & par_42 & Centralidade & 0,932 \\
\hline DCC & $<--$ & $\mathrm{DC}$ & 1,000 & & & & & DCC & 0,758 \\
\hline DCT & $<--$ & DC & 1,000 & & & & & $\mathrm{DCT}$ & 0,609 \\
\hline Laços & $<---$ & IP & 0,717 & ,046 & 15,614 & $* * *$ & par_24 & VO12 & 0,739 \\
\hline Centralidade & $<--$ & IP & 1,000 & & & & & VO22 & 0,580 \\
\hline Afeto & $<---$ & IP & $-0,381$ & ,049 & $-7,711$ & $* * *$ & par_31 & VO30 & 0,757 \\
\hline DCT9 & $<--$ & DCT & 1,000 & & & & & VO3 & 0,279 \\
\hline DCT8 & $<---$ & DCT & 0,936 & 044 & 21,511 & $* * *$ & par_1 & VO35 & 0,653 \\
\hline DCT7 & $<---$ & DCT & 0,996 & ,046 & 21,455 & $* * *$ & par_2 & VO38 & 0,644 \\
\hline DCT6 & $<---$ & DCT & 0,896 &, 045 & 19,850 & $* * *$ & par_3 & IO1 & 0,516 \\
\hline DCT5 & $<---$ & DCT & 1,014 & ,048 & 21,289 & $* * *$ & par_4 & $\mathrm{IO} 2$ & 0,494 \\
\hline DCT4 & $<---$ & DCT & 0,903 & ,045 & 19,917 & $* * *$ & par_5 & IO3 & 0,516 \\
\hline DCT3 & $<---$ & DCT & 0,978 & ,046 & 21,309 & $* * *$ & par_6 & IO4 & 0,734 \\
\hline DCT2 & $<---$ & DCT & 0,828 & ,043 & 19,147 & $* * *$ & par_7 & IO5 & 0,435 \\
\hline DCT1 & $<---$ & DCT & 0,801 & ,045 & 17,939 & $* * *$ & par_8 & IO6 & 0,729 \\
\hline DCC13 & $<---$ & DCC & 1,000 & & & & & IP12 & 0,573 \\
\hline DCC12 & $<---$ & $\mathrm{DCC}$ & 0,996 & ,043 & 23,297 & $* * *$ & par_9 & IP13 & 0,758 \\
\hline DCC11 & $<--$ & DCC & 0,903 & ,047 & 19,049 & $* * *$ & par_10 & IP14 & 0,668 \\
\hline DCC10 & $<---$ & DCC & 0,898 & ,044 & 20,193 & $* * *$ & par_11 & IP6 & 0,623 \\
\hline DCC9 & $<--$ & DCC & 0,982 & ,048 & 20,584 & $* * *$ & par_12 & IP10 & 0,531 \\
\hline DCC8 & $<--$ & DCC & 1,006 & ,046 & 21,832 & $* * *$ & par_13 & IP18 & 0,611 \\
\hline DCC7 & $<---$ & $\mathrm{DCC}$ & 1,006 & ,048 & 21,126 & $* * *$ & par_14 & IP2 & 0,680 \\
\hline DCC6 & $<--$ & DCC & 0,895 & ,049 & 18,274 & $* * *$ & par_15 & IP3 & 0,522 \\
\hline DCC15 & $<---$ & DCC & 0,995 & ,048 & 20,656 & $* * *$ & par_16 & IP17 & 0,593 \\
\hline IP17 & $<--$ & Centralidade & 1,000 & & & & & DCC15 & 0,469 \\
\hline IP3 & $<--$ & Centralidade & 0,905 & 043 & 21,082 & $* * *$ & par_17 & DCC6 & 0,380 \\
\hline IP2 & $<---$ & Centralidade & 1,048 & 044 & 23,551 & $* * *$ & par_18 & DCC7 & 0,501 \\
\hline IP18 & $<---$ & Afeto & 1,000 & & & & & DCC8 & 0,528 \\
\hline IP10 & $<---$ & Afeto & 0,927 & ,047 & 19,653 & $* * *$ & par_19 & DCC9 & 0,470 \\
\hline IP6 & $<---$ & Afeto & 0,925 & ,046 & 20,109 & $* * *$ & par_20 & DCC 10 & 0,448 \\
\hline IP14 & $<---$ & Laços & 1,000 & & & & & DCC11 & 0,408 \\
\hline IP13 & $<--$ & Laços & 1,116 & ,039 & 28,255 & $* * *$ & par_21 & DCC12 & 0,577 \\
\hline IP12 & $<--$ & Laços & 0,914 & ,038 & 23,946 & $* * *$ & par_22 & DCC13 & 0,542 \\
\hline IO6 & $<---$ & IO & 1,000 & & & & & DCT1 & 0,376 \\
\hline IO5 & $<--$ & IO & 0,731 & ,033 & 22,032 & $* * *$ & par_25 & DCT2 & 0,423 \\
\hline IO4 & $<--$ & IO & 0,961 &, 030 & 32,018 & $* * *$ & par_26 & DCT3 & 0,523 \\
\hline IO3 & $<---$ & IO & 0,775 & ,032 & 24,134 & $* * *$ & par_27 & DCT4 & 0,463 \\
\hline $\mathrm{IO} 2$ & $<---$ & IO & 0,781 & ,033 & 23,546 & $* * *$ & par_28 & DCT5 & 0,526 \\
\hline IO1 & $<--$ & IO & 0,893 & ,039 & 22,636 & $* * *$ & par_29 & DCT6 & 0,461 \\
\hline VO38 & $<---$ & Hierarquia & 1,000 & & & & & DCT7 & 0,528 \\
\hline VO35 & $<---$ & Hierarquia & 1,054 &, 062 & 16,983 & $* * *$ & par_34 & DCT8 & 0,527 \\
\hline VO3 & $<--$ & Hierarquia & 0,629 &, 045 & 14,076 & $* * *$ & par_35 & DCT9 & 0,512 \\
\hline VO30 & $<---$ & Igualitarismo & 1,000 & & & & & & \\
\hline VO22 & $<---$ & Igualitarismo & 0,603 & 024 & 25,582 & $* * *$ & par_36 & & \\
\hline VO12 & $<---$ & Igualitarismo & 0,882 & ,031 & 28,599 & $* * *$ & par_37 & & \\
\hline
\end{tabular}

Figura 77. Modelo Hierarquia $x$ Igualitarismo $\rightarrow I P \rightarrow I O \rightarrow D C$. 


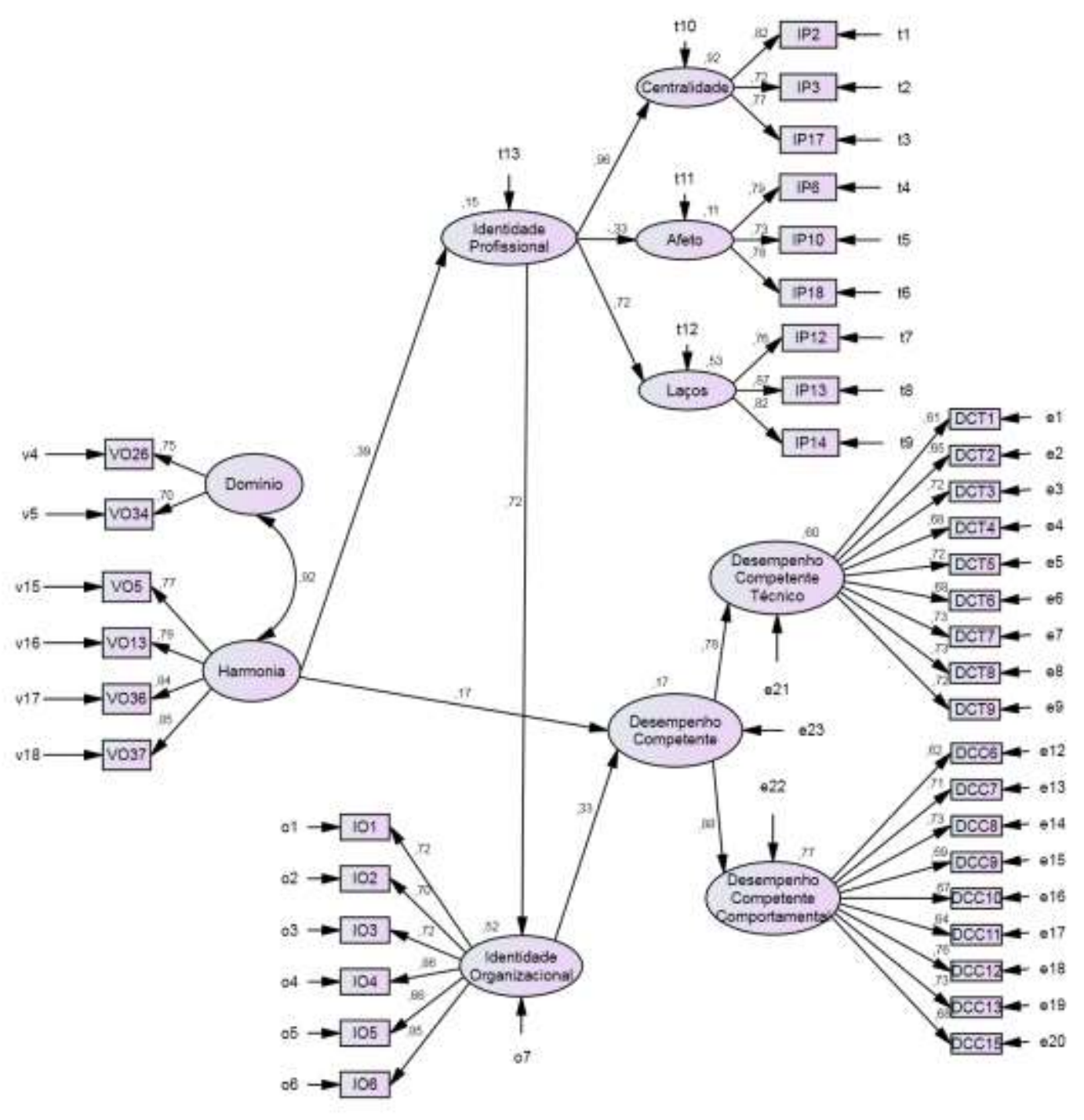




\begin{tabular}{|c|c|c|c|c|c|c|c|c|c|}
\hline \multicolumn{3}{|c|}{$\begin{array}{c}\text { Pesos Fatoriais } \\
\text { Não-Estandardizados }\end{array}$} & \multirow{2}{*}{$\begin{array}{r}\text { Estimate } \\
0,138\end{array}$} & \multirow{2}{*}{$\begin{array}{l}\text { S.E. } \\
, 014\end{array}$} & \multirow{2}{*}{$\begin{array}{l}\text { C.R. } \\
1,047\end{array}$} & \multirow{2}{*}{$\begin{array}{c}\mathrm{P} \\
* * *\end{array}$} & \multirow{2}{*}{$\begin{array}{c}\text { Label } \\
\text { par_39 }\end{array}$} & $\begin{array}{c}\text { Correlações } \\
\text { Múltiplas ao } \\
\text { Quadrado }\end{array}$ & \multirow{2}{*}{$\begin{array}{r}\text { Estimate } \\
0,152\end{array}$} \\
\hline IP & <--- & Domínio & & & & & & IP & \\
\hline IO & $<---$ & IP & 0,844 &, 055 & 15,269 & $* * *$ & par_33 & $\mathrm{IO}$ & 0,517 \\
\hline $\mathrm{DC}$ & $<---$ & IO & 0,164 & ,021 & 7,907 & $* * *$ & par_32 & DC & 0,165 \\
\hline $\mathrm{DC}$ & $<---$ & Domínio & 0,035 & ,008 & 4,136 & $* * *$ & par_40 & Laços & 0,525 \\
\hline DCC & $<---$ & DC & 1,000 & & & & & Afeto & 0,109 \\
\hline DCT & $<---$ & DC & 1,000 & & & & & Centralidade & 0,919 \\
\hline Laços & $<---$ & IP & 0,719 & ,046 & 15,761 & $* * *$ & par_24 & DCC & 0,769 \\
\hline Centralidade & $<---$ & IP & 1,000 & & & & & DCT & 0,601 \\
\hline Afeto & $<---$ & IP & $-0,392$ &, 050 & $-7,850$ & $* * *$ & par_31 & VO5 & 0,585 \\
\hline DCT9 & $<---$ & DCT & 1,000 & & & & & VO13 & 0,632 \\
\hline DCT8 & $<---$ & DCT & 0,931 &, 043 & 21,599 & $* * *$ & par_1 & VO36 & 0,704 \\
\hline DCT7 & $<---$ & DCT & 0,990 & ,046 & 21,549 & $* * *$ & par_2 & VO37 & 0,714 \\
\hline DCT6 & $<---$ & DCT & 0,890 &, 045 & 19,924 & $* * *$ & par_3 & VO26 & 0,562 \\
\hline DCT5 & $<---$ & DCT & 1,006 & ,047 & 21,383 & $* * *$ & par_4 & VO34 & 0,487 \\
\hline DCT4 & $<---$ & DCT & 0,898 & ,045 & 19,988 & $* * *$ & par_5 & IO1 & 0,515 \\
\hline DCT3 & $<---$ & DCT & 0,972 & ,045 & 21,396 & $* * *$ & par_6 & IO2 & 0,495 \\
\hline DCT2 & $<---$ & DCT & 0,824 & ,043 & 19,208 & $* * *$ & par_7 & IO3 & 0,517 \\
\hline DCT1 & $<---$ & DCT & 0,797 & ,044 & 17,990 & $* * *$ & par_8 & IO4 & 0,734 \\
\hline DCC13 & $<---$ & $\mathrm{DCC}$ & 1,000 & & & & & IO5 & 0,435 \\
\hline DCC12 & $<---$ & $\mathrm{DCC}$ & 1,000 & ,043 & 23,214 & $* * *$ & par_9 & IO6 & 0,728 \\
\hline DCC12 & $<---$ & $\mathrm{DCC}$ & 0,906 & ,048 & 18,996 & $* * *$ & par_10 & IP12 & 0,573 \\
\hline DCC10 & $<---$ & $\mathrm{DCC}$ & 0,901 & ,045 & 20,123 & $* * *$ & par_11 & IP13 & 0,757 \\
\hline DCC9 & $<---$ & $\mathrm{DCC}$ & 0,987 & ,048 & 20,543 & $* * *$ & par_12 & IP14 & 0,669 \\
\hline DCC8 & $<---$ & $\mathrm{DCC}$ & 1,011 & ,046 & 21,759 & $* * *$ & par_13 & IP6 & 0,625 \\
\hline DCC7 & $<---$ & $\mathrm{DCC}$ & 1,011 & ,048 & 21,061 & $* * *$ & par_14 & IP10 & 0,532 \\
\hline DCC6 & $<---$ & DCC & 0,898 & ,049 & 18,221 & $* * *$ & par_15 & IP18 & 0,610 \\
\hline DCC15 & $<---$ & $\mathrm{DCC}$ & 0,998 & ,048 & 20,580 & $* * *$ & par_16 & IP2 & 0,679 \\
\hline IP17 & $<---$ & Centralidade & 1,000 & & & & & IP3 & 0,520 \\
\hline IP3 & $<---$ & Centralidade & 0,900 & ,043 & 21,042 & $* * *$ & par_17 & IP17 & 0,596 \\
\hline IP2 & $<---$ & Centralidade & 1,045 & ,044 & 23,526 & $* * *$ & par_18 & DCC15 & 0,467 \\
\hline IP18 & $<---$ & Afeto & 1,000 & & & & & DCC6 & 0,379 \\
\hline IP10 & $<---$ & Afeto & 0,928 & ,047 & 19,681 & $* * *$ & par_19 & DCC7 & 0,500 \\
\hline IP6 & $<---$ & Afeto & 0,928 & ,046 & 20,142 & $* * *$ & par_20 & DCC8 & 0,527 \\
\hline IP14 & $<---$ & Laços & 1,000 & & & & & DCC9 & 0,470 \\
\hline IP13 & $<---$ & Laços & 1,115 &, 040 & 28,231 & $* * *$ & par_21 & DCC10 & 0,445 \\
\hline IP12 & $<---$ & Laços & 0,914 & ,038 & 23,937 & $* * *$ & par_22 & DCC11 & 0,406 \\
\hline IO6 & $<---$ & IO & 1,000 & & & & & DCC12 & 0,575 \\
\hline IO5 & $<---$ & IO & 0,731 & ,033 & 22,021 & $* * *$ & par_25 & DCC13 & 0,539 \\
\hline IO4 & $<---$ & IO & 0,961 & ,030 & 32,021 & $* * *$ & par_26 & DCT1 & 0,377 \\
\hline IO3 & $<---$ & IO & 0,776 &, 032 & 24,152 & $* * *$ & par_27 & DCT2 & 0,424 \\
\hline $\mathrm{IO} 2$ & $<---$ & IO & 0,782 &, 033 & 23,556 & $* * *$ & par_28 & DCT3 & 0,524 \\
\hline IO1 & $<---$ & IO & 0,893 & ,039 & 22,627 & $* * *$ & par_29 & DCT4 & 0,463 \\
\hline VO34 & $<---$ & Domínio & 1,000 & & & & & DCT5 & 0,525 \\
\hline VO26 & $<---$ & Domínio & 1,171 & 0,060 & 19,467 & $* * *$ & par_34 & DCT6 & 0,462 \\
\hline VO37 & $<---$ & Harmonia & 1,000 & & & & & DCT7 & 0,529 \\
\hline VO36 & $<---$ & Harmonia & 1,008 & 0,033 & 30,850 & $* * *$ & par_35 & DCT8 & 0,528 \\
\hline VO13 & $<---$ & Harmonia & 0,883 & 0,032 & 27,460 & $* * *$ & par_36 & DCT9 & 0,516 \\
\hline VO5 & $<---$ & Harmonia & 0,893 & 0,034 & 25,900 & $* * *$ & par_37 & & \\
\hline
\end{tabular}

Figura 78. Modelo Domínio $x$ Harmonia $\rightarrow I P \rightarrow I O \rightarrow D C$. 
Mediação em cadeia da identidade organizacional e da identidade profissional na relação entre os valores organizacionais e o desempenho profissional

Nessa primeira análise de mediação em cadeia, busca-se testar a relação de mediação que a identidade organizacional (IO) e a identidade profissional (IP) estabelecem entre os tipos motivacionais subjacentes aos valores organizacionais (VO), todos correlacionados, e o desempenho profissional por competências (DC) $V O \rightarrow I O \rightarrow I P \rightarrow D C$. Em seguida, o segundo teste analisou a associação entre as dimensões bipolares dos tipos motivacionais sobre o desempenho profissional, relação essa mediada pela identidade profissional e pela identidade organizacional. Para tanto, foram considerados os seguintes pares: Autonomia $x$ Conservação $\rightarrow I O \rightarrow I P \rightarrow D C ;$ Hierarquia $x$ Igualitarismo $\rightarrow I O \rightarrow I P \rightarrow D C ;$ Domínio $x$ Harmonia $\rightarrow I O \rightarrow I P \rightarrow D C$. Como forma de verificar a qualidade do ajustamento dos dados, foram apreciadas suas especificações.

$\mathrm{O}$ primeiro teste apresentou ajustes satisfatórios $(\mathrm{GFI}=0,89 ; \quad \mathrm{CFI}=0,94$; RMSEA=0,037); entretanto, os valores do GFI e AGFI ficaram abaixo do limite de 0,90, em virtude do tamanho da amostra e da complexidade do modelo, não comprometendo, apesar disso, seu ajuste global (Kline, 2010; Roussel et al, 2002). Foram significativos ( $\mathrm{p}<0,005)$ os tipos motivacionais conservação, igualitarismo e harmonia, responsáveis por explicar $16 \%$ da identidade organizacional; a identidade profissional, que sofre efeitos diretos dos tipos motivacionais conservação, igualitarismo e harmonia, explicou $51 \%$ da variância da identidade profissional $\left(R^{2}=0,92\right.$ para centralidade; $R^{2}=0,11$ para afeto; e $R^{2}=0,53$ para laços). No que se refere à mediação em cadeia, a identidade organizacional e a identidade profissional mediaram parcialmente mediaram parcialmente a relação entre os tipos motivacionais conservação, igualitarismo e harmonia e o desempenho profissional, de forma significativa, $\mathrm{p}=0,019 ; \mathrm{p}=0,005$ e $\mathrm{p}=0,006$, respectivamente. $\mathrm{O}$ modelo foi responsável por explicar $25 \%$ da variância do desempenho profissional $\left(\mathrm{R}^{2}=0,61\right.$ de explicação para $\mathrm{o}$ desempenho por competências técnicas; $\mathrm{R}^{2}=0,76$ de explicação para o desempenho por competências comportamentais), conforme Figura 79.

$$
\begin{aligned}
& V O(\text { conservação }) \stackrel{0,15}{\longrightarrow} I O \stackrel{0,71}{\longrightarrow} I P \stackrel{0,36}{\longrightarrow} \mathrm{DC} \quad V O(\text { igualitarismo }) \stackrel{-0,35}{\longrightarrow} I O \stackrel{0,71}{\longrightarrow} I P \stackrel{0,36}{\longrightarrow} \mathrm{DC} \\
& V O(\text { conservação }) \stackrel{0,15}{\longrightarrow} D C \\
& \text { VO (igualitarismo) } \stackrel{-0,41}{\longrightarrow} D C \\
& \text { Efeito Indireto: } 0,038, p=0,009 \\
& \text { Efeito Indireto: }-0,090, p=0,005 \\
& \text { VO (harmonia }) \stackrel{0,58}{\longrightarrow} I O \stackrel{0,71}{\longrightarrow} I P \stackrel{0,36}{\longrightarrow} \mathrm{DC} \\
& \text { VO (harmonia) } \stackrel{0,44}{\longrightarrow} D C \\
& \text { Efeito Indireto: } 0,149, p=0,001
\end{aligned}
$$


O segundo teste verificou a mediação em cadeia da identidade profissional e da identidade organizacional na relação entre os tipos motivacionais bipolares, analisados de forma independente, e o desempenho profissional. Relativamente aos tipos conservação $x$ autonomia e o desempenho profissional, a identidade organizacional e a identidade profissional mediaram parcialmente a relação entre conservação $(\mathrm{p}=0,001)$ e o desempenho profissional e totalmente a relação entre autonomia e o desempenho profissional $(p=0,267)$, conforme Figura 80, com ajustes adequados (GFI=0,92; $\mathrm{CFI}=0,96$; RMSEA=0,036).

$$
\begin{array}{cc}
\text { Conservação } \stackrel{0,26}{\longrightarrow} I O \stackrel{0,72}{\longrightarrow} I P \stackrel{0,31}{\longrightarrow} D C & \text { Autonomia } \stackrel{0,19}{\longrightarrow} I O \stackrel{0,72}{\longrightarrow} I P \stackrel{0,31}{\longrightarrow} D C \\
\text { Conservação } \stackrel{0,25}{\longrightarrow} D C & \text { Autonomia } \stackrel{\text { n.s. }}{\longrightarrow} D C \\
\text { Efeito Indireto: } 0,069, \mathrm{p}=0,001 & \text { Efeito Indireto: } 0,0,045, \mathrm{p}=0,001
\end{array}
$$

Os tipos motivacionais Autonomia x Conservação foram responsáveis por explicar $13 \%$ da identidade organizacional. A identidade organizacional, que sofre influência direta dos tipos motivacionais conservação e autonomia, explicou $51 \%$ da variância da identidade profissional $\left(\mathrm{R}^{2}=0,92\right.$ para centralidade; $\mathrm{R}^{2}=0,11$ para afeto; e $\mathrm{R}^{2}=0,53$ para laços $)$. $\mathrm{O}$ modelo foi responsável por explicar $23 \%$ da variância do desempenho profissional $\left(\mathrm{R}^{2}=0,60\right.$ de explicação para o desempenho por competências técnicas; $\mathrm{R}^{2}=0,77$ de explicação para $\mathrm{o}$ desempenho por competências comportamentais).

Para os tipos motivacionais hierarquia x igualitarismo e o desempenho profissional, a identidade organizacional e a identidade profissional mediaram parcialmente essa relação ( $\mathrm{p}=0,001$ e $\mathrm{p}=0,009)$, com ajustes adequados $(\mathrm{GFI}=0,92 ; \mathrm{CFI}=0,96 ; \mathrm{RMSEA}=0,034)$.

$$
\begin{array}{rr}
\text { Hierarquia } \stackrel{0,24}{\longrightarrow} I O \stackrel{0,71}{\longrightarrow} I P \stackrel{0,40}{\longrightarrow} D C & \text { Igualitarismo } \stackrel{0,33}{\longrightarrow} I O \stackrel{0,71}{\longrightarrow} I P \stackrel{0,40}{\longrightarrow} D C \\
\text { Hierarquia } \stackrel{0,18}{\longrightarrow} D C & \text { Igualitarismo } \stackrel{0,11}{\longrightarrow} D C \\
\text { Efeito Indireto: } 0,069, \mathrm{p}=0,001 & \text { Efeito Indireto: } 0,095, \mathrm{p}=0,001
\end{array}
$$

As dimensões Hierarquia x igualitarismo foram responsáveis por explicar $11 \%$ da identidade Organizacional. A identidade organizacional, que recebe efeitos diretos dos tipos motivacionais hierarquia e igualitarismo, explicou $51 \%$ da variância da identidade profissional $\left(\mathrm{R}^{2}=0,92\right.$ para centralidade; $\mathrm{R}^{2}=0,11$ para afeto; e $\mathrm{R}^{2}=0,53$ para laços $)$. $\mathrm{O}$ modelo foi responsável por explicar $22 \%$ da variância do desempenho profissional $\left(\mathrm{R}^{2}=0,62\right.$ de explicação para o desempenho por competências técnicas; $\mathrm{R}^{2}=0,74$ de explicação para $\mathrm{O}$ desempenho por competências comportamentais), conforme Figura 81. 
Por fim, a relação entre os tipos motivacionais domínio $x$ harmonia e o desempenho profissional foi mediada parcialmente (mediação em cadeia) pela identidade organizacional e identidade profissional (ver Figura 82), com ajustes adequados (GFI=0,92; CFI=0,96; RMSEA=0,035), somente para a dimensão harmonia ( $\mathrm{p}=0,001)$.

$$
\begin{gathered}
\text { Domínio } \stackrel{\text { n.s. }}{\longrightarrow} I O \stackrel{0,71}{\longrightarrow} I P \stackrel{0,41}{\longrightarrow} D C \\
\text { Domínio } \stackrel{\text { n.s. }}{\longrightarrow} D C
\end{gathered}
$$

Efeito Indireto: $n . s$.

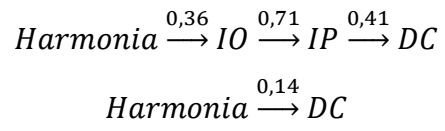

Efeito Indireto: $0,104, p=0,001$

A dimensão harmonia foi responsável por explicar 13\% da identidade organizacional. A identidade organizacional, que recebe efeito direto do tipo motivacional harmonia, explicou $51 \%$ da variância da identidade profissional $\left(\mathrm{R}^{2}=0,92\right.$ para centralidade; $\mathrm{R}^{2}=0,11$ para afeto; e $\mathrm{R}^{2}=0,53$ para laços). O modelo foi responsável por explicar $22 \%$ da variância do desempenho profissional $\left(\mathrm{R}^{2}=0,61\right.$ de explicação para o desempenho por competências técnicas; $\mathrm{R}^{2}=0,75$ de explicação para o desempenho por competências comportamentais).

A Tabela 62 sintetiza os índices de ajuste e as Figuras 79, 80, 81 e 82 exibem as representações gráficas de cada um dos modelos, os pesos fatoriais não estandardizados e as correlações múltiplas ao quadrado.

Tabela 62

\begin{tabular}{|c|c|c|c|c|c|}
\hline \multicolumn{2}{|l|}{$\begin{array}{l}\text { Amostra } \\
\mathrm{N}=916\end{array}$} & \multirow[t]{2}{*}{$\begin{array}{c}\text { Modelo } V O \rightarrow \\
I O \rightarrow \\
I P \rightarrow D C \\
2,26\end{array}$} & \multirow[t]{2}{*}{$\begin{array}{c}\text { Autonomia } x \\
\text { Conservação } \\
\rightarrow I O \rightarrow \\
I P \rightarrow D C \\
2,05\end{array}$} & \multirow[t]{2}{*}{$\begin{array}{c}\text { Hierarquia } x \\
\text { Igualitarismo } \\
\rightarrow I O \rightarrow \\
I P \rightarrow D C \\
2,05\end{array}$} & \multirow[t]{2}{*}{$\begin{array}{c}\text { Domínio } x \\
\text { Harmonia } \rightarrow \\
I O \rightarrow I P \rightarrow \\
D C \\
2,14\end{array}$} \\
\hline Índices & $\chi / \mathrm{g} .1$. & & & & \\
\hline Absolutos & $\begin{array}{l}\chi^{2} ; \text { g.l. } \\
p\end{array}$ & $\begin{array}{c}2704,17 ; 1195 \\
0,000\end{array}$ & $\begin{array}{c}1411,90 ; 689 \\
0,000\end{array}$ & $\begin{array}{c}1412,57 ; 688 \\
0,000\end{array}$ & $\begin{array}{c}1480,90 ; 691 \\
0,000\end{array}$ \\
\hline & GFI (AGFI) & $0,89(0,88)$ & $0,92(0,91)$ & $0,92(0,91)$ & $0,92(0,91)$ \\
\hline & SRMR & 0,045 & 0,042 & 0,043 & 0,043 \\
\hline \multirow[t]{2}{*}{ Índices Relativos } & CFI & 0,94 & 0,96 & 0,96 & 0,96 \\
\hline & TLI & 0,94 & 0,96 & 0,95 & 0,95 \\
\hline Índices de & RMSEA & 0,037 & 0,034 & 0,034 & 0,035 \\
\hline $\begin{array}{l}\text { Discrepância } \\
\text { Populacional }\end{array}$ & (Lo90;Hi90) & $(0,035 ; 0,039)$ & $(0,031 ; 0,036)$ & $(0,0361 ; 0,036)$ & $(0,033 ; 0,038)$ \\
\hline Índices de & PCFI & 0,89 & 0,89 & 0,89 & 0,89 \\
\hline Parcimônia & PGFI & 0,81 & 0,82 & 0,82 & 0,82 \\
\hline Índices Baseados & AIC & 2966,17 & 1593,90 & 1596,57 & 1658,90 \\
\hline na Teoria da & ECVI & 3,24 & 1,74 & 1,74 & 1,81 \\
\hline Informação & CAIC & 3728,59 & 2123,52 & 2132,01 & 2176,88 \\
\hline
\end{tabular}

Índices de ajustamento da relação entre $V O \rightarrow I O \rightarrow I P \rightarrow D C$, completo e por dimensões 


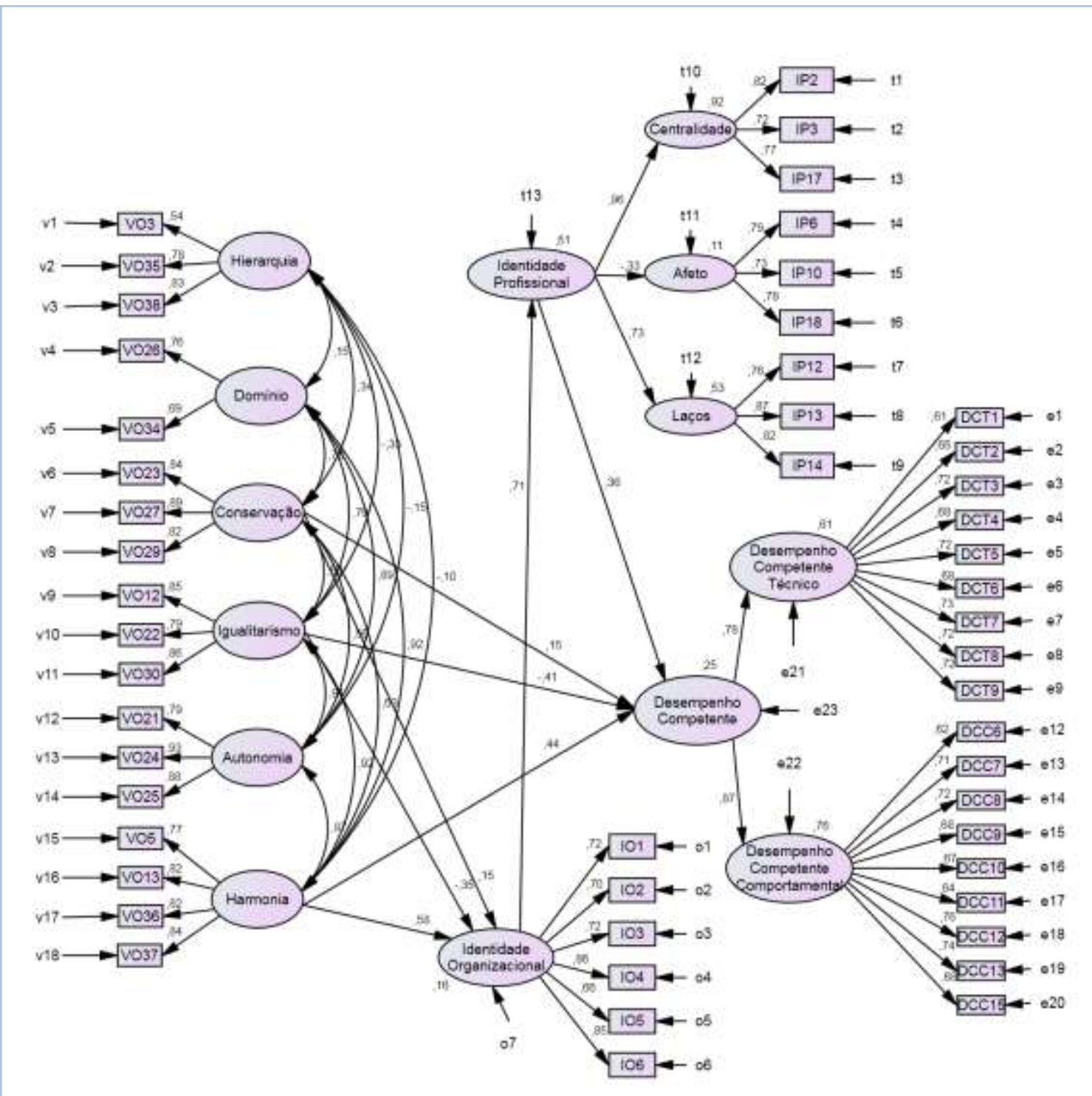

Pesos Fatoriais Não-Estandardizados $\quad$ Estimate $\quad$ S.E. $\quad$ C.R. $\quad P \quad$ Label

\begin{tabular}{|c|c|c|c|c|c|c|c|c|c|}
\hline Pesos Fatoriai & is Não & Estandardizados & Estimate & S.E. & C.R. & $\mathrm{P}$ & Label & $\begin{array}{c}\text { Correlações } \\
\text { Múltiplas ao } \\
\text { Quadrado }\end{array}$ & Estimate \\
\hline IO & $<---$ & Conservação & 0,073 & 0,026 & 2,857 & 0,004 & par_61 & $\mathrm{IO}$ & 0,164 \\
\hline IO & $<---$ & Igualitarismo & $-0,108$ & 0,038 & $-2,815$ & 0,005 & par_62 & IP & 0,508 \\
\hline IO & $<--$ & Harmonia & 0,244 & 0,060 & 4,053 & $* * *$ & par_63 & $\mathrm{DC}$ & 0,252 \\
\hline IP & $<---$ & $\mathrm{IO}$ & 0,609 & 0,034 & 18,021 & $* * *$ & par_33 & Laços & 0,533 \\
\hline $\mathrm{DC}$ & $<---$ & IP & 0,211 & 0,027 & 7,801 & $* * *$ & par_32 & Afeto & 0,107 \\
\hline $\mathrm{DC}$ & $<---$ & Igualitarismo & $-0,064$ & 0,020 & $-3,099$ & 0,002 & par_64 & Centralidade & 0,924 \\
\hline DC & $<---$ & Conservação & 0,036 & 0,014 & 2,626 & 0,009 & par_65 & $\mathrm{DCC}$ & 0,757 \\
\hline $\mathrm{DC}$ & $<--$ & Harmonia & 0,092 & 0,032 & 2,841 & 0,004 & par_66 & DCT & 0,606 \\
\hline DCC & $<---$ & $\mathrm{DC}$ & 1,000 & & & & & VO37 & 0,698 \\
\hline DCT & $<---$ & $\mathrm{DC}$ & 1,000 & & & & & VO36 & 0,676 \\
\hline Afeto & $<--$ & IP & $-0,388$ & 0,050 & $-7,786$ & $* * *$ & par_24 & VO5 & 0,591 \\
\hline Laços & $<---$ & IP & 0,723 & 0,046 & 15,597 & $* * *$ & par_25 & VO13 & 0,675 \\
\hline Centralidade & $<---$ & IP & 1,000 & & & & & VO21 & 0,622 \\
\hline DCT9 & $<---$ & DCT & 1,000 & & & & & VO24 & 0,868 \\
\hline
\end{tabular}




\begin{tabular}{|c|c|c|c|c|c|c|c|c|c|}
\hline DCT8 & $<---$ & DCT & 0,935 & 0,043 & 21,739 & $* * *$ & par_1 & VO25 & 0,782 \\
\hline DCT7 & $<---$ & DCT & 0,994 & 0,046 & 21,689 & $* * *$ & par_2 & VO12 & 0,726 \\
\hline DCT6 & $<---$ & DCT & 0,895 & 0,045 & 20,043 & $* * *$ & par_3 & VO22 & 0,625 \\
\hline DCT5 & $<--$ & DCT & 1,012 & 0,047 & 21,535 & $* * *$ & par_4 & VO30 & 0,731 \\
\hline DCT4 & $<---$ & DCT & 0,902 & 0,045 & 20,111 & $* * *$ & par_5 & VO23 & 0,703 \\
\hline DCT3 & $<---$ & DCT & 0,976 & 0,045 & 21,546 & $* * *$ & par_6 & VO27 & 0,791 \\
\hline DCT2 & $<---$ & DCT & 0,827 & 0,043 & 19,316 & $* * *$ & par_7 & VO29 & 0,678 \\
\hline DCT1 & $<---$ & DCT & 0,800 & 0,044 & 18,084 & $* * *$ & par_8 & VO26 & 0,584 \\
\hline DCC13 & $<--$ & DCC & 1,000 & & & & & VO34 & 0,469 \\
\hline DCC12 & $<---$ & DCC & 0,995 & 0,042 & 23,538 & $* * *$ & par_9 & VO3 & 0,288 \\
\hline DCC11 & $<--$ & DCC & 0,901 & 0,047 & 19,165 & $* * *$ & par_10 & VO35 & 0,615 \\
\hline DCC10 & $<--$ & DCC & 0,898 & 0,044 & 20,340 & $* * *$ & par_11 & VO38 & 0,686 \\
\hline DCC9 & $<---$ & DCC & 0,981 & 0,047 & 20,758 & $* * *$ & par_12 & IO1 & 0,517 \\
\hline DCC8 & $<---$ & DCC & 1,005 & 0,046 & 22,029 & $* * *$ & par_13 & IO2 & 0,493 \\
\hline DCC7 & $<--$ & DCC & 1,005 & 0,047 & 21,322 & $* * *$ & par_14 & IO3 & 0,520 \\
\hline DCC6 & $<---$ & DCC & 0,894 & 0,049 & 18,399 & $* * *$ & par_15 & IO4 & 0,734 \\
\hline DCC15 & $<---$ & DCC & 0,996 & 0,048 & 20,841 & $* * *$ & par_16 & IO5 & 0,430 \\
\hline IP17 & $<---$ & Centralidade & 1,000 & & & & & IO6 & 0,729 \\
\hline IP3 & $<--$ & Centralidade & 0,903 & 0,043 & 21,085 & $* * *$ & par_17 & IP12 & 0,573 \\
\hline IP2 & $<---$ & Centralidade & 1,044 & 0,044 & 23,509 & $* * *$ & par_18 & IP13 & 0,758 \\
\hline IP18 & $<---$ & Afeto & 1,000 & & & & & IP14 & 0,668 \\
\hline IP10 & $<--$ & Afeto & 0,926 & 0,047 & 19,657 & $* * *$ & par_19 & IP6 & 0,623 \\
\hline IP6 & $<---$ & Afeto & 0,925 & 0,046 & 20,117 & $* * *$ & par_20 & IP10 & 0,530 \\
\hline IP14 & $<---$ & Laços & 1,000 & & & & & IP18 & 0,612 \\
\hline IP13 & $<--$ & Laços & 1,116 & 0,039 & 28,265 & $* * *$ & par_21 & IP2 & 0,677 \\
\hline IP12 & $<---$ & Laços & 0,914 & 0,038 & 23,951 & $* * *$ & par_22 & IP3 & 0,523 \\
\hline IO6 & $<---$ & IO & 1,000 & & & & & IP17 & 0,595 \\
\hline IO5 & $<--$ & IO & 0,726 & 0,033 & 21,882 & $* * *$ & par_26 & DCC15 & 0,468 \\
\hline IO4 & $<---$ & IO & 0,961 & 0,030 & 32,047 & $* * *$ & par_27 & DCC6 & 0,378 \\
\hline IO3 & $<---$ & IO & 0,778 & 0,032 & 24,237 & $* * *$ & par_28 & DCC7 & 0,499 \\
\hline $\mathrm{IO} 2$ & $<---$ & IO & 0,781 & 0,033 & 23,534 & $* * *$ & par_29 & DCC8 & 0,525 \\
\hline IO1 & $<--$ & IO & 0,895 & 0,039 & 22,670 & $* * *$ & par_30 & DCC9 & 0,468 \\
\hline VO38 & $<---$ & Hierarquia & 1,000 & & & & & DCC10 & 0,446 \\
\hline VO35 & $<---$ & Hierarquia & 0,984 & 0,048 & 20,670 & $* * *$ & par_34 & DCC11 & 0,405 \\
\hline VO3 & $<--$ & Hierarquia & 0,614 & 0,041 & 14,848 & $* * *$ & par_35 & DCC12 & 0,574 \\
\hline VO34 & $<---$ & Domínio & 1,000 & & & & & DCC13 & 0,541 \\
\hline VO26 & $<---$ & Domínio & 1,216 & 0,058 & 20,942 & $* * *$ & par_36 & DCT1 & 0,375 \\
\hline VO29 & $<--$ & Conservação & 1,000 & & & & & DCT2 & 0,422 \\
\hline VO27 & $<---$ & Conservação & 1,077 & 0,035 & 31,012 & $* * *$ & par_38 & DCT3 & 0,521 \\
\hline VO23 & $<---$ & Conservação & 1,010 & 0,035 & 28,910 & $* * *$ & par_39 & DCT4 & 0,461 \\
\hline VO30 & $<---$ & Igualitarismo & 1,000 & & & & & DCT5 & 0,524 \\
\hline VO22 & $<---$ & Igualitarismo & 0,636 & 0,022 & 28,971 & $* * *$ & par_42 & DCT6 & 0,460 \\
\hline VO12 & $<---$ & Igualitarismo & 0,889 & 0,027 & 33,321 & $* * *$ & par_43 & DCT7 & 0,526 \\
\hline VO25 & $<--$ & Autonomia & 1,000 & & & & & DCT8 & 0,525 \\
\hline VO24 & $<---$ & Autonomia & 1,062 & 0,024 & 43,503 & $* * *$ & par_47 & DCT9 & 0,512 \\
\hline VO21 & $<---$ & Autonomia & 0,923 & 0,031 & 30,075 & $* * *$ & par_48 & & \\
\hline VO13 & $<---$ & Harmonia & 0,923 & 0,032 & 29,024 & $* * *$ & par_53 & & \\
\hline VO5 & $<--$ & Harmonia & 0,908 & 0,034 & 26,556 & $* * *$ & par_54 & & \\
\hline VO37 & $<---$ & Harmonia & 1,001 & 0,033 & 30,421 & $* * *$ & par_60 & & \\
\hline VO36 & $<--$ & Harmonia & 1,000 & & & & & & \\
\hline
\end{tabular}

Figura 79. Modelo $V O \rightarrow I O \rightarrow I P \rightarrow D C$. 


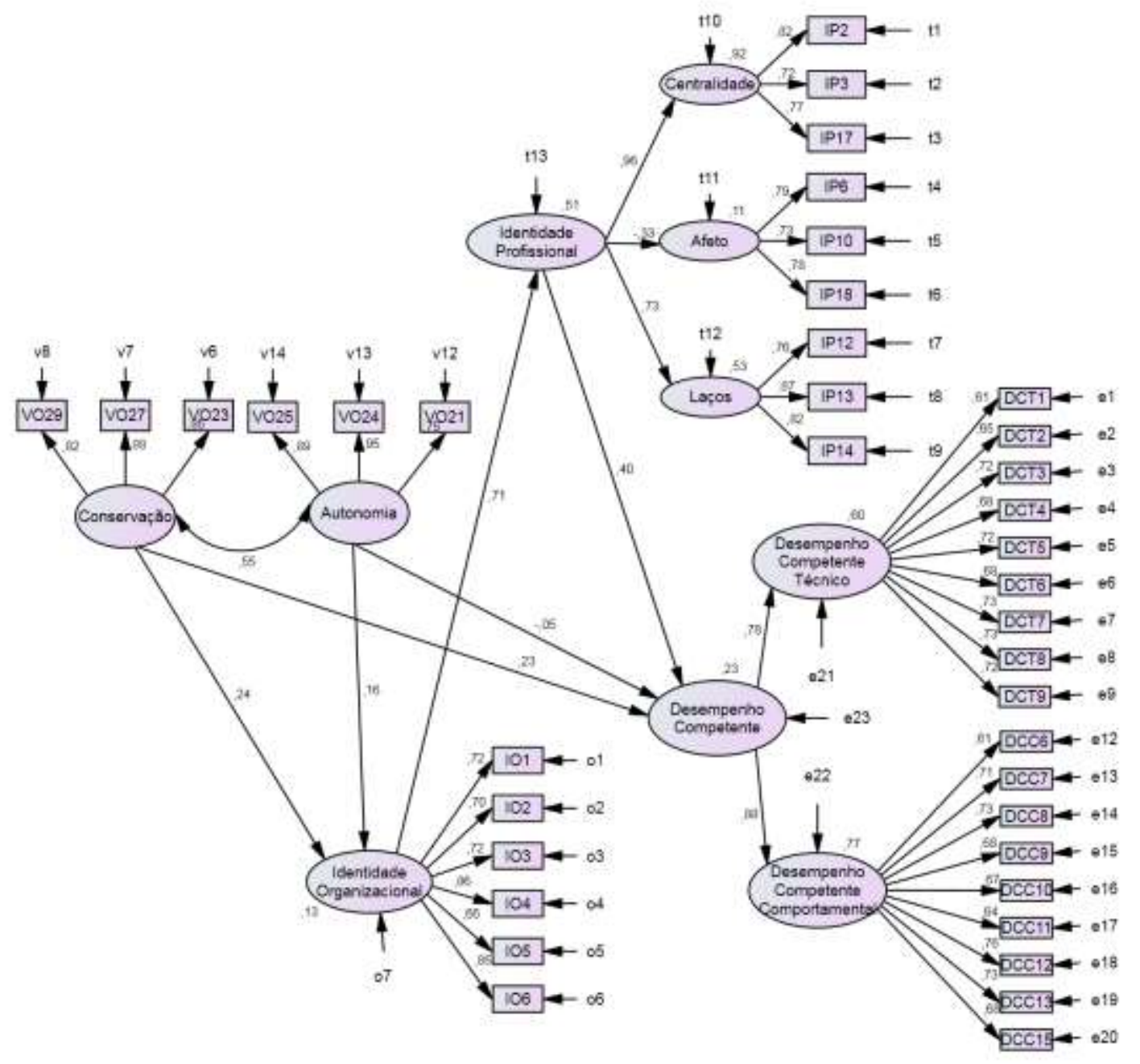




\begin{tabular}{|c|c|c|c|c|c|c|c|c|c|}
\hline \multicolumn{3}{|c|}{$\begin{array}{l}\text { Pesos Fatoriais Não- } \\
\text { Estandardizados }\end{array}$} & \multirow{2}{*}{$\begin{array}{r}\text { Estimate } \\
0,121\end{array}$} & \multirow{2}{*}{$\begin{array}{l}\text { S.E. } \\
0,022\end{array}$} & \multirow{2}{*}{$\begin{array}{l}\text { C.R. } \\
5,609\end{array}$} & \multirow{2}{*}{$\begin{array}{c}\mathrm{P} \\
* * *\end{array}$} & \multirow{2}{*}{$\begin{array}{c}\text { Label } \\
\text { par_38 }\end{array}$} & $\begin{array}{c}\text { Correlações } \\
\text { Múltiplas ao } \\
\text { Quadrado }\end{array}$ & \multirow{2}{*}{$\begin{array}{r}\text { Estimate } \\
0,128\end{array}$} \\
\hline IO & $<--$ & Conservação & & & & & & $\mathrm{IO}$ & \\
\hline IO & $<--$ & Autonomia & 0,061 & 0,016 & 3,710 & $* * *$ & par_39 & IP & 0,509 \\
\hline IP & $<--$ & $\mathrm{IO}$ & 0,608 & 0,034 & 18,015 & $* * *$ & par_33 & DC & 0,234 \\
\hline DC & $<--$ & IP & 0,233 & 0,027 & 8,658 & $* * *$ & par_32 & Laços & 0,534 \\
\hline DC & $<--$ & Conservação & 0,057 & 0,012 & 4,850 & $* * *$ & par_40 & Afeto & 0,107 \\
\hline DC & $<--$ & Autonomia & $-0,010$ & 0,009 & $-1,149$ & 0,251 & par_41 & Centralidade & 0,920 \\
\hline DCC & $<---$ & DC & 1,000 & & & & & DCC & 0,767 \\
\hline DCT & $<---$ & DC & 1,000 & & & & & DCT & 0,601 \\
\hline Afeto & $<--$ & IP &,- 389 & 0,050 & $-7,792$ & $* * *$ & par_24 & VO21 & 0,566 \\
\hline Laços & $<---$ & IP & 0,725 & 0,046 & 15,691 & $* * *$ & par_25 & VO24 & 0,893 \\
\hline Centralidade & $<--$ & IP & 1,000 & & & & & VO25 & 0,798 \\
\hline DCT9 & $<---$ & DCT & 1,000 & & & & & VO23 & 0,724 \\
\hline DCT8 & $<--$ & DCT & 0,931 & 0,043 & 21,759 & $* * *$ & par_1 & VO27 & 0,783 \\
\hline DCT7 & $<---$ & DCT & 0,991 & 0,046 & 21,704 & $* * *$ & par_2 & VO29 & 0,666 \\
\hline DCT6 & $<---$ & DCT & 0,891 & 0,044 & 20,057 & $* * *$ & par_3 & IO1 & 0,518 \\
\hline DCT5 & $<--$ & DCT & 1,007 & 0,047 & 21,548 & $* * *$ & par_4 & IO2 & 0,492 \\
\hline DCT4 & $<---$ & DCT & 0,898 & 0,045 & 20,120 & $* * *$ & par_5 & IO3 & 0,518 \\
\hline DCT3 & $<---$ & DCT & 0,972 & 0,045 & 21,559 & $* * *$ & par_6 & IO4 & 0,734 \\
\hline DCT2 & $<---$ & DCT & 0,823 & 0,043 & 19,323 & $* * *$ & par_7 & IO5 & 0,431 \\
\hline DCT1 & $<---$ & DCT & 0,797 & 0,044 & 18,088 & $* * *$ & par_8 & IO6 & 0,729 \\
\hline DCC13 & $<---$ & $\mathrm{DCC}$ & 1,000 & & & & & IP12 & 0,573 \\
\hline DCC12 & $<---$ & DCC & 0,999 & 0,043 & 23,407 & $* * *$ & par_9 & IP13 & 0,758 \\
\hline DCC11 & $<---$ & $\mathrm{DCC}$ & 0,906 & 0,047 & 19,110 & $* * *$ & par_10 & IP14 & 0,668 \\
\hline DCC10 & $<---$ & DCC & 0,903 & 0,045 & 20,273 & $* * *$ & par_11 & IP6 & 0,623 \\
\hline DCC9 & $<---$ & DCC & 0,985 & 0,048 & 20,664 & $* * *$ & par_12 & IP10 & 0,530 \\
\hline DCC8 & $<--$ & DCC & 1,010 & 0,046 & 21,931 & $* * *$ & par_13 & IP18 & 0,613 \\
\hline DCC7 & $<--$ & DCC & 1,009 & 0,048 & 21,223 & $* * *$ & par_14 & IP2 & 0,677 \\
\hline DCC6 & $<--$ & DCC & 0,898 & 0,049 & 18,327 & $* * *$ & par_15 & IP3 & 0,523 \\
\hline DCC15 & $<--$ & DCC & 0,999 & 0,048 & 20,738 & $* * *$ & par_16 & IP17 & 0,594 \\
\hline IP17 & $<--$ & Centralidade & 1,000 & & & & & DCC15 & 0,467 \\
\hline IP3 & $<--$ & Centralidade & 0,904 & 0,043 & 21,093 & $* * *$ & par_17 & DCC6 & 0,378 \\
\hline IP2 & $<--$ & Centralidade & 1,045 & 0,044 & 23,513 & $* * *$ & par_18 & DCC7 & 0,499 \\
\hline IP18 & $<--$ & Afeto & 1,000 & & & & & DCC8 & 0,526 \\
\hline IP10 & $<--$ & Afeto & 0,925 & 0,047 & 19,655 & $* * *$ & par_19 & DCC9 & 0,468 \\
\hline IP6 & $<---$ & Afeto & 0,925 & 0,046 & 20,114 & $* * *$ & par_20 & DCC10 & 0,447 \\
\hline IP14 & $<--$ & Laços & 1,000 & & & & & DCC11 & 0,406 \\
\hline IP13 & $<---$ & Laços & 1,116 & 0,039 & 28,264 & $* * *$ & par_21 & DCC12 & 0,574 \\
\hline IP12 & $<---$ & Laços & 0,914 & 0,038 & 23,949 & $* * *$ & par_22 & DCC13 & 0,539 \\
\hline IO6 & $<---$ & IO & 1,000 & & & & & DCT1 & 0,376 \\
\hline IO5 & $<--$ & IO & 0,727 & 0,033 & 21,923 & $* * *$ & par_26 & DCT2 & 0,423 \\
\hline IO4 & $<---$ & IO & 0,961 & 0,030 & 32,042 & $* * *$ & par_27 & DCT3 & 0,523 \\
\hline IO3 & $<---$ & $\mathrm{IO}$ & 0,776 & 0,032 & 24,184 & $* * *$ & par_28 & DCT4 & 0,463 \\
\hline $\mathrm{IO} 2$ & $<---$ & IO & 0,780 & 0,033 & 23,510 & $* * *$ & par_29 & DCT5 & 0,525 \\
\hline IO1 & $<--$ & $\mathrm{IO}$ & 0,896 & 0,039 & 22,688 & $* * *$ & par_30 & DCT6 & 0,461 \\
\hline VO29 & $<---$ & Conservação & 1,000 & & & & & DCT7 & 0,528 \\
\hline $\mathrm{VO} 27$ & $<--$ & Conservação & 1,081 & 0,036 & 30,174 & $* * *$ & par_34 & DCT8 & 0,527 \\
\hline VO23 & $<--$ & Conservação & 1,034 & 0,036 & 28,518 & $* * *$ & par_35 & DCT9 & 0,515 \\
\hline $\mathrm{VO} 25$ & $<---$ & Autonomia & 1,000 & & & & & & \\
\hline $\mathrm{VO} 24$ & $<---$ & Autonomia & 1,066 & 0,027 & 39,659 & $* * *$ & par_36 & & \\
\hline VO21 & $<---$ & Autonomia & 0,872 & 0,031 & 28,284 & $* * *$ & par_37 & & \\
\hline
\end{tabular}

Figura 80. Modelo Conservação $x$ Autonomia $\rightarrow I O \rightarrow I P \rightarrow D C$. 


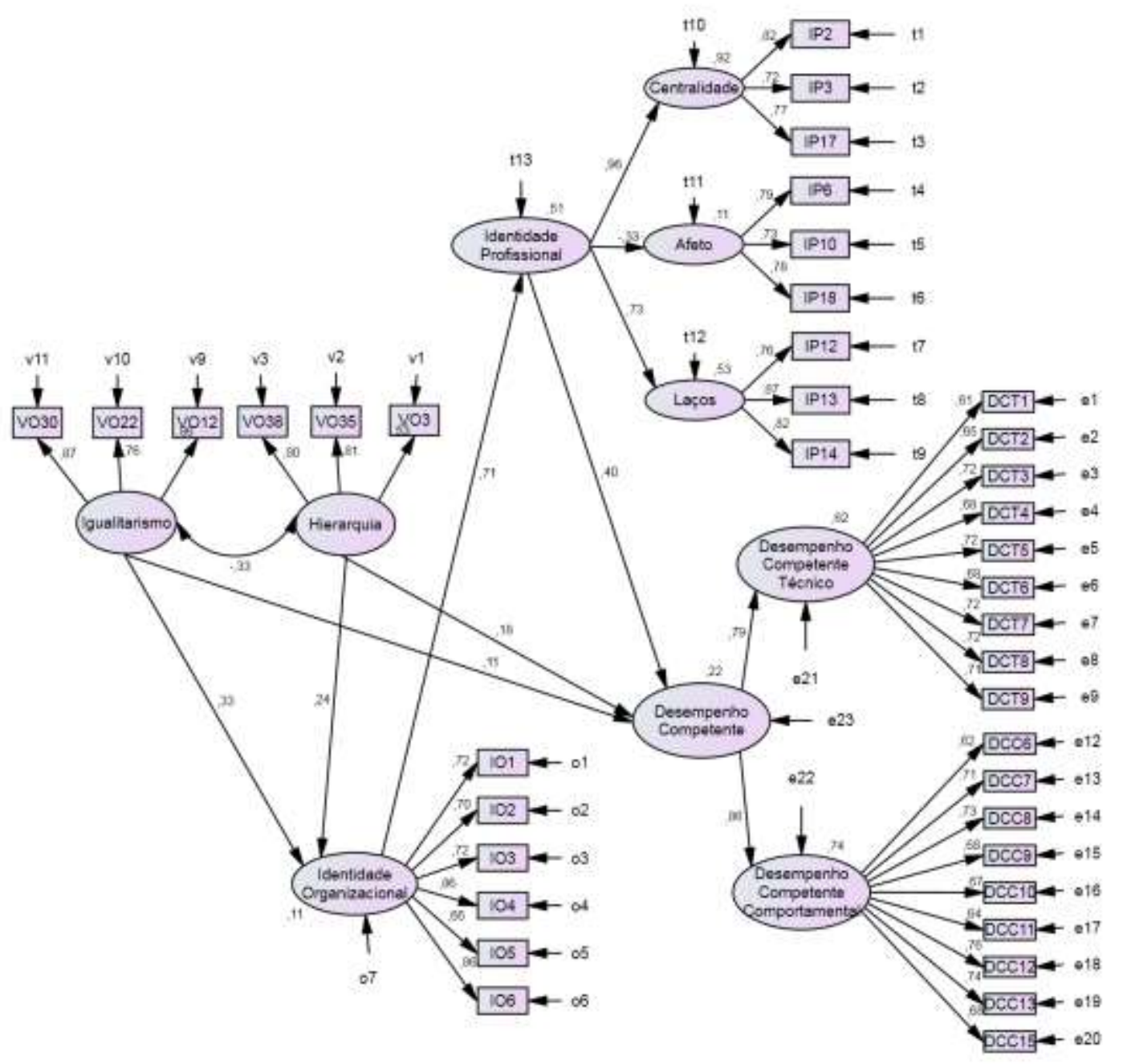




\begin{tabular}{|c|c|c|c|c|c|c|c|c|c|}
\hline \multicolumn{3}{|c|}{$\begin{array}{c}\text { Pesos Fatoriais } \\
\text { Não-Estandardizados }\end{array}$} & \multirow{2}{*}{$\begin{array}{r}\text { Estimate } \\
0,099\end{array}$} & \multirow{2}{*}{$\begin{array}{l}\text { S.E. } \\
0,012\end{array}$} & \multirow{2}{*}{$\begin{array}{l}\text { C.R. } \\
8,431\end{array}$} & \multirow{2}{*}{$\begin{array}{c}\mathrm{P} \\
* * *\end{array}$} & \multirow{2}{*}{$\begin{array}{c}\text { Label } \\
\text { par_40 }\end{array}$} & $\begin{array}{c}\text { Correlações } \\
\text { Múltiplas ao } \\
\text { Quadrado }\end{array}$ & \multirow{2}{*}{$\begin{array}{r}\text { Estimate } \\
0,114\end{array}$} \\
\hline IO & $\begin{array}{l}<-- \\
\end{array}$ & Igualitarismo & & & & & & IO & \\
\hline IO & $<---$ & Hierarquia & 0,098 & 0,016 & 5,967 & $* * *$ & par_41 & IP & 0,509 \\
\hline IP & $<---$ & IO & 0,606 & 0,034 & 18,039 & $* * *$ & par_33 & DC & 0,225 \\
\hline DC & $<---$ & IP & 0,236 & 0,027 & 8,634 & $* * *$ & par_32 & Laços & 0,534 \\
\hline DC & $<---$ & Hierarquia & 0,037 & 0,009 & 4,059 & $* * *$ & par_42 & Afeto & 0,108 \\
\hline DC & $<---$ & Igualitarismo & 0,017 & 0,007 & 2,626 & 0,009 & par_43 & Centralidade & 0,919 \\
\hline DCC & $<---$ & $\mathrm{DC}$ & 1,000 & & & & & DCC & 0,741 \\
\hline DCT & $<---$ & DC & 1,000 & & & & & DCT & 0,618 \\
\hline Afeto & $<---$ & IP & $-0,390$ & 0,050 & $-7,805$ & $* * *$ & par_24 & VO12 & 0,734 \\
\hline Laços & $<---$ & IP & 0,725 & 0,046 & 15,702 & $* * *$ & par_25 & VO22 & 0,580 \\
\hline Centralidade & $<---$ & IP & 1,000 & & & & & VO30 & 0,762 \\
\hline DCT9 & $<---$ & DCT & 1,000 & & & & & VO3 & 0,279 \\
\hline DCT8 & $<---$ & DCT & 0,943 & 0,044 & 21,508 & $* * *$ & par_1 & VO35 & 0,660 \\
\hline DCT7 & $<---$ & DCT & 1,004 & 0,047 & 21,454 & $* * *$ & par_2 & VO38 & 0,639 \\
\hline DCT6 & $<---$ & DCT & 0,903 & 0,045 & 19,852 & $* * *$ & par_3 & IO1 & 0,520 \\
\hline DCT5 & $<---$ & DCT & 1,021 & 0,048 & 21,300 & $* * *$ & par_4 & $\mathrm{IO} 2$ & 0,492 \\
\hline DCT4 & $<---$ & DCT & 0,911 & 0,046 & 19,927 & $* * *$ & par_5 & IO3 & 0,515 \\
\hline DCT3 & $<---$ & DCT & 0,985 & 0,046 & 21,319 & $* * *$ & par_6 & IO4 & 0,732 \\
\hline DCT2 & $<---$ & DCT & 0,835 & 0,044 & 19,154 & $* * *$ & par_7 & IO5 & 0,432 \\
\hline DCT1 & $<---$ & DCT & 0,808 & 0,045 & 17,949 & $* * *$ & par_8 & IO6 & 0,733 \\
\hline DCC13 & $<---$ & DCT & 1,000 & & & & & IP12 & 0,573 \\
\hline DCC12 & $<---$ & DCT & 0,988 & 0,042 & 23,553 & $* * *$ & par_9 & IP13 & 0,758 \\
\hline DCC11 & $<---$ & DCT & 0,897 & 0,047 & 19,204 & $* * *$ & par_10 & IP14 & 0,668 \\
\hline DCC10 & $<---$ & DCT & 0,892 & 0,044 & 20,361 & $* * *$ & par_11 & IP6 & 0,623 \\
\hline DCC9 & $<---$ & DCT & 0,974 & 0,047 & 20,761 & $* * *$ & par_12 & IP10 & 0,530 \\
\hline DCC8 & $<---$ & DCT & 1,000 & 0,045 & 22,060 & $* * *$ & par_13 & IP18 & 0,612 \\
\hline DCC7 & $<---$ & DCT & 0,998 & 0,047 & 21,335 & $* * *$ & par_14 & IP2 & 0,677 \\
\hline DCC6 & $<---$ & DCT & 0,889 & 0,048 & 18,410 & $* * *$ & par_15 & IP3 & 0,523 \\
\hline DCC15 & $<---$ & DCT & 0,989 & 0,047 & 20,850 & $* * *$ & par_16 & IP17 & 0,595 \\
\hline IP17 & $<---$ & Centralidade & 1,000 & & & & & DCC15 & 0,469 \\
\hline IP3 & $<---$ & Centralidade & 0,903 & 0,043 & 21,087 & $* * *$ & par_17 & DCC6 & 0,380 \\
\hline IP2 & $<---$ & Centralidade & 1,044 & 0,044 & 23,509 & $* * *$ & par_18 & DCC7 & 0,500 \\
\hline IP18 & $<---$ & Afeto & 1,000 & & & & & DCC8 & 0,528 \\
\hline IP10 & $<---$ & Afeto & 0,925 & 0,047 & 19,657 & $* * *$ & par_19 & DCC9 & 0,468 \\
\hline IP6 & $<---$ & Afeto & 0,925 & 0,046 & 20,119 & $* * *$ & par_20 & DCC10 & 0,447 \\
\hline IP14 & $<---$ & Laços & 1,000 & & & & & DCC11 & 0,407 \\
\hline IP13 & $<---$ & Laços & 1,116 & 0,039 & 28,263 & $* * *$ & par_21 & DCC12 & 0,574 \\
\hline IP12 & $<---$ & Laços & 0,914 & 0,038 & 23,949 & $* * *$ & par_22 & DCC13 & 0,546 \\
\hline IO6 & $<---$ & $\mathrm{IO}$ & 1,000 & & & & & DCT1 & 0,374 \\
\hline IO5 & $<---$ & IO & 0,726 & 0,033 & 21,965 & $* * *$ & par_26 & DCT2 & 0,421 \\
\hline IO4 & $<---$ & $\mathrm{IO}$ & 0,957 & 0,030 & 32,066 & $* * *$ & par_27 & DCT3 & 0,520 \\
\hline IO3 & $<---$ & $\mathrm{IO}$ & 0,773 & 0,032 & 24,142 & $* * *$ & par_28 & DCT4 & 0,461 \\
\hline $\mathrm{IO} 2$ & $<---$ & $\mathrm{IO}$ & 0,777 & 0,033 & 23,511 & $* * *$ & par_29 & DCT5 & 0,523 \\
\hline IO1 & $<---$ & IO & 0,894 & 0,039 & 22,706 & $* * *$ & par_30 & DCT6 & 0,458 \\
\hline VO38 & $<---$ & Hierarquia & 1,000 & & & & & DCT7 & 0,525 \\
\hline VO35 & $<---$ & Hierarquia & 1,063 & 0,065 & 16,403 & $* * *$ & par_34 & DCT8 & 0,524 \\
\hline VO3 & $<---$ & Hierarquia & 0,631 & 0,045 & 14,026 & $* * *$ & par_35 & DCT9 & 0,505 \\
\hline VO30 & $<---$ & Igualitarismo & 1,000 & & & & & & \\
\hline VO22 & $<---$ & Igualitarismo & 0,601 & 0,024 & 25,488 & $* * *$ & par_36 & & \\
\hline VO12 & $<--$ & Igualitarismo & 0,876 & 0,031 & 28,476 & $* * *$ & par_37 & & \\
\hline
\end{tabular}

Figura 81. Modelo Hierarquia x Igualitarismo $\rightarrow I O \rightarrow I P \rightarrow D C$. 


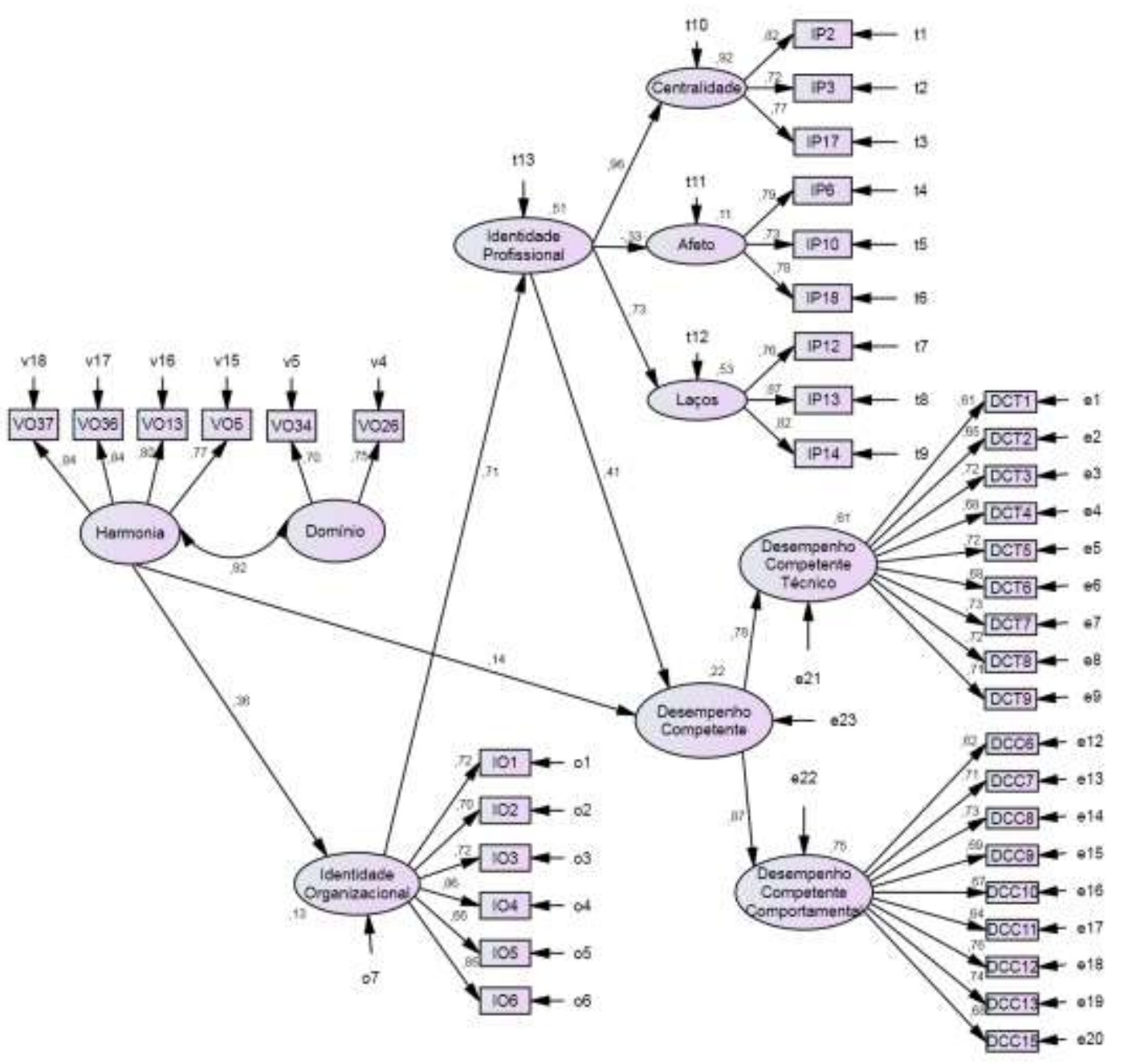




\begin{tabular}{|c|c|c|c|c|c|c|c|c|c|}
\hline \multicolumn{3}{|c|}{$\begin{array}{c}\text { Pesos Fatoriais } \\
\text { Não-Estandardizados }\end{array}$} & \multirow{2}{*}{$\begin{array}{r}\text { Estimate } \\
0,148\end{array}$} & \multirow{2}{*}{$\begin{array}{l}\text { S.E. } \\
0,015\end{array}$} & \multirow{2}{*}{$\begin{array}{l}\text { C.R. } \\
9,930\end{array}$} & \multirow{2}{*}{$\begin{array}{c}\mathrm{P} \\
* * *\end{array}$} & \multirow{2}{*}{$\begin{array}{c}\text { Label } \\
\text { par_39 }\end{array}$} & $\begin{array}{c}\text { Correlações } \\
\text { Múltiplas ao } \\
\text { Quadrado }\end{array}$ & \multirow{2}{*}{$\begin{array}{r}\text { Estimate } \\
0,127\end{array}$} \\
\hline IO & $\begin{array}{l}<-- \\
\end{array}$ & Harmonia & & & & & & IO & \\
\hline IP & $<---$ & IO & 0,606 & 0,034 & 18,012 & $* * *$ & par_33 & IP & 0,509 \\
\hline DC & $<---$ & IP & 0,240 & 0,027 & 8,819 & $* * *$ & par_32 & DC & 0,216 \\
\hline DC & $<---$ & Harmonia & 0,029 & 0,008 & 3,520 & $* * *$ & par_40 & Laços & 0,534 \\
\hline DCC & $<---$ & $\mathrm{DC}$ & 1,000 & & & & & Afeto & 0,107 \\
\hline DCT & $<---$ & DC & 1,000 & & & & & Centralidade & 0,919 \\
\hline Afeto & $<---$ & IP & $-0,390$ & 0,050 & $-7,797$ & $* * *$ & par_24 & DCC & 0,749 \\
\hline Laços & $<--$ & IP & 0,725 & 0,046 & 15,704 & $* * *$ & par_25 & DCT & 0,614 \\
\hline Centralidade & $<---$ & IP & 1,000 & & & & & VO5 & 0,586 \\
\hline DCT9 & $<---$ & DCT & 1,000 & & & & & VO13 & 0,634 \\
\hline DCT8 & $<---$ & DCT & 0,940 & 0,044 & 21,576 & $* * *$ & par_1 & VO36 & 0,704 \\
\hline DCT7 & $<---$ & DCT & 0,999 & 0,046 & 21,525 & $* * *$ & par_2 & VO37 & 0,713 \\
\hline DCT6 & $<---$ & DCT & 0,899 & 0,045 & 19,908 & $* * *$ & par_3 & VO26 & 0,563 \\
\hline DCT5 & $<---$ & DCT & 1,016 & 0,048 & 21,370 & $* * *$ & par_4 & VO34 & 0,487 \\
\hline DCT4 & $<---$ & DCT & 0,907 & 0,045 & 19,980 & $* * *$ & par_5 & IO1 & 0,517 \\
\hline DCT3 & $<---$ & DCT & 0,981 & 0,046 & 21,385 & $* * *$ & par_6 & $\mathrm{IO} 2$ & 0,493 \\
\hline DCT2 & $<---$ & DCT & 0,831 & 0,043 & 19,203 & $* * *$ & par_7 & IO3 & 0,518 \\
\hline DCT1 & $<---$ & DCT & 0,805 & 0,045 & 17,990 & $* * *$ & par_8 & IO4 & 0,734 \\
\hline DCC13 & $<---$ & DCC & 1,000 & & & & & IO5 & 0,430 \\
\hline DCC12 & $<---$ & DCC & 0,990 & 0,042 & 23,512 & $* * *$ & par_9 & IO6 & 0,731 \\
\hline DCC12 & $<---$ & DCC & 0,899 & 0,047 & 19,178 & $* * *$ & par_10 & IP12 & 0,573 \\
\hline DCC10 & $<---$ & DCC & 0,893 & 0,044 & 20,321 & $* * *$ & par_11 & IP13 & 0,758 \\
\hline DCC9 & $<---$ & DCC & 0,977 & 0,047 & 20,748 & $* * *$ & par_12 & IP14 & 0,668 \\
\hline DCC8 & $<---$ & DCC & 1,002 & 0,046 & 22,025 & $* * *$ & par_13 & IP6 & 0,623 \\
\hline DCC7 & $<---$ & DCC & 1,001 & 0,047 & 21,304 & $* * *$ & par_14 & IP10 & 0,530 \\
\hline DCC6 & $<---$ & DCC & 0,890 & 0,048 & 18,382 & $* * *$ & par_15 & IP18 & 0,613 \\
\hline DCC15 & $<---$ & DCC & 0,990 & 0,048 & 20,809 & $* * *$ & par_16 & IP2 & 0,677 \\
\hline IP17 & $<---$ & Centralidade & 1,000 & & & & & IP3 & 0,523 \\
\hline IP3 & $<---$ & Centralidade & 0,904 & 0,043 & 21,094 & $* * *$ & par_17 & IP17 & 0,594 \\
\hline IP2 & $<---$ & Centralidade & 1,044 & 0,044 & 23,513 & $* * *$ & par_18 & DCC15 & 0,468 \\
\hline IP18 & $<---$ & Afeto & 1,000 & & & & & DCC6 & 0,379 \\
\hline IP10 & $<---$ & Afeto & 0,925 & 0,047 & 19,654 & $* * *$ & par_19 & DCC7 & 0,500 \\
\hline IP6 & $<---$ & Afeto & 0,924 & 0,046 & 20,118 & $* * *$ & par_20 & DCC8 & 0,528 \\
\hline IP14 & $<---$ & Laços & 1,000 & & & & & DCC9 & 0,469 \\
\hline IP13 & $<---$ & Laços & 1,116 & 0,039 & 28,264 & $* * *$ & par_21 & DCC10 & 0,446 \\
\hline IP12 & $<---$ & Laços & 0,914 & 0,038 & 23,949 & $* * *$ & par_22 & DCC11 & 0,407 \\
\hline IO6 & $<--$ & IO & 1,000 & & & & & DCC12 & 0,574 \\
\hline IO5 & $<---$ & IO & 0,725 & 0,033 & 21,901 & $* * *$ & par_26 & DCC13 & 0,545 \\
\hline $\mathrm{IO} 4$ & $<---$ & IO & 0,960 & 0,030 & 32,090 & $* * *$ & par_27 & DCT1 & 0,375 \\
\hline IO3 & $<---$ & IO & 0,775 & 0,032 & 24,198 & $* * *$ & par_28 & DCT2 & 0,422 \\
\hline $\mathrm{IO} 2$ & $<---$ & IO & 0,779 & 0,033 & 23,535 & $* * *$ & par_29 & DCT3 & 0,522 \\
\hline IO1 & $<---$ & IO & 0,894 & 0,039 & 22,680 & $* * *$ & par_30 & DCT4 & 0,462 \\
\hline VO34 & $<---$ & Domínio & 1,000 & & & & & DCT5 & 0,523 \\
\hline VO26 & $<---$ & Domínio & 1,172 & 0,060 & 19,446 & $* * *$ & par_34 & DCT6 & 0,460 \\
\hline VO37 & $<---$ & Harmonia & 1,000 & & & & & DCT7 & 0,526 \\
\hline VO36 & $<---$ & Harmonia & 1,009 & 0,033 & 30,834 & $* * *$ & par_35 & DCT8 & 0,525 \\
\hline VO13 & $<---$ & Harmonia & 0,884 & 0,032 & 27,472 & $* * *$ & par_36 & DCT9 & 0,509 \\
\hline VO5 & $<---$ & Harmonia & 0,894 & 0,035 & 25,885 & $* * *$ & par_37 & & \\
\hline
\end{tabular}

Figura 82. Modelo Domínio x Harmonia $\rightarrow I O \rightarrow I P \rightarrow D C$. 
Mediação em cadeia da identidade profissional e da identidade organizacional na relação entre as práticas organizacionais e o desempenho profissional

Testou-se a relação de mediação que a identidade profissional (IP) e a identidade organizacional (IO) estabelecem entre as práticas organizacionais (PO), com os fatores correlacionados, e o desempenho profissional por competências (DC) $P O \rightarrow I P \rightarrow I O \rightarrow D C$.

Os índices de ajuste do modelo foram satisfatórios (GFI=0,88; CFI=0,92; RMSEA=0,037), contudo os valores do GFI e AGFI foram inferiores ao limite de 0,90, em virtude do tamanho da amostra e da complexidade do modelo, não comprometendo, apesar disso, seu ajuste global (Kline, 2010; Roussel et al, 2002). As práticas de regulação e definição de responsabilidade $(\mathrm{p}<0,005)$ explicaram $29 \%$ da variância total da identidade profissional $\left(\mathrm{R}^{2}=0,92\right.$ para centralidade; $\mathrm{R}^{2}=0,11$ para afeto; e $\mathrm{R}^{2}=0,60$ para laços). $\mathrm{A}$ identidade profissional, que sofre efeitos diretos das práticas de regulação e definição de responsabilidade (DR), explicou 56\% da variância da identidade organizacional. O modelo foi responsável por explicar $25 \%$ da variância do desempenho profissional $\left(\mathrm{R}^{2}=0,61\right.$ de explicação para o desempenho por competências técnicas; $\mathrm{R}^{2}=0,80$ de explicação para $\mathrm{O}$ desempenho por competências comportamentais).

A identidade profissional e a identidade organizacional mediaram parcialmente (mediacão em cadeia) a relação entre a prática de regulação e de definição de responsabilidade $(\mathrm{p}=0,001$ e $\mathrm{p}=0,001$, respectivamente) e o desempenho profissional, conforme Figura 83.

$$
\begin{gathered}
P O(\text { Regulação }) \stackrel{0,74}{\longrightarrow} I P \stackrel{0,75}{\longrightarrow} I O \stackrel{0,27}{\longrightarrow} D C \\
P O(\text { Regulação }) \stackrel{0,31}{\longrightarrow} D C \\
\text { Efeito Indireto: } 0,152, \mathrm{p}=0,001
\end{gathered}
$$

$$
\begin{gathered}
P O(D R) \stackrel{-0,10}{\longrightarrow} I O \stackrel{0,51}{\longrightarrow} I P \stackrel{0,27}{\longrightarrow} D C \\
P O(D R) \stackrel{-0,19}{\longrightarrow} D C \\
\text { Efeito Indireto: }-0,021, \mathrm{p}=0,032
\end{gathered}
$$

A Tabela 63 exibe um resumo dos índices de ajuste e a Figura 83 apresenta a representação gráfica do modelo, os pesos fatoriais não estandardizados e as correlações múltiplas ao quadrado. 
Tabela 63

Índices de ajustamento da relação entre $P O \rightarrow I P \rightarrow I O \rightarrow D C$

\begin{tabular}{|c|c|c|}
\hline \multicolumn{2}{|l|}{$\begin{array}{l}\text { Amostra } \\
\mathrm{N}=916\end{array}$} & Modelo $P O \rightarrow I P \rightarrow I O \rightarrow D C$ \\
\hline Índices & $\chi /$ g.l. & 2,28 \\
\hline Absolutos & $\chi^{2} ;$ g.l. & 3711,$76 ; 1626$ \\
\hline & & 0,000 \\
\hline & GFI (AGFI) & $0,88(0,87)$ \\
\hline & SRMR & 0,086 \\
\hline \multirow[t]{2}{*}{ Índices Relativos } & CFI & 0,92 \\
\hline & TLI & 0,92 \\
\hline Índices de Discrepância & RMSEA & 0,037 \\
\hline Populacional & (Lo90;Hi90) & $(0,036 ; 0,039)$ \\
\hline \multirow[t]{2}{*}{ Índices de Parcimônia } & PCFI & 0,87 \\
\hline & PGFI & 0,81 \\
\hline Índices Baseados na & AIC & 3999,76 \\
\hline \multirow[t]{2}{*}{ Teoria da Informação } & ECVI & 4,37 \\
\hline & CAIC & 4837,85 \\
\hline
\end{tabular}




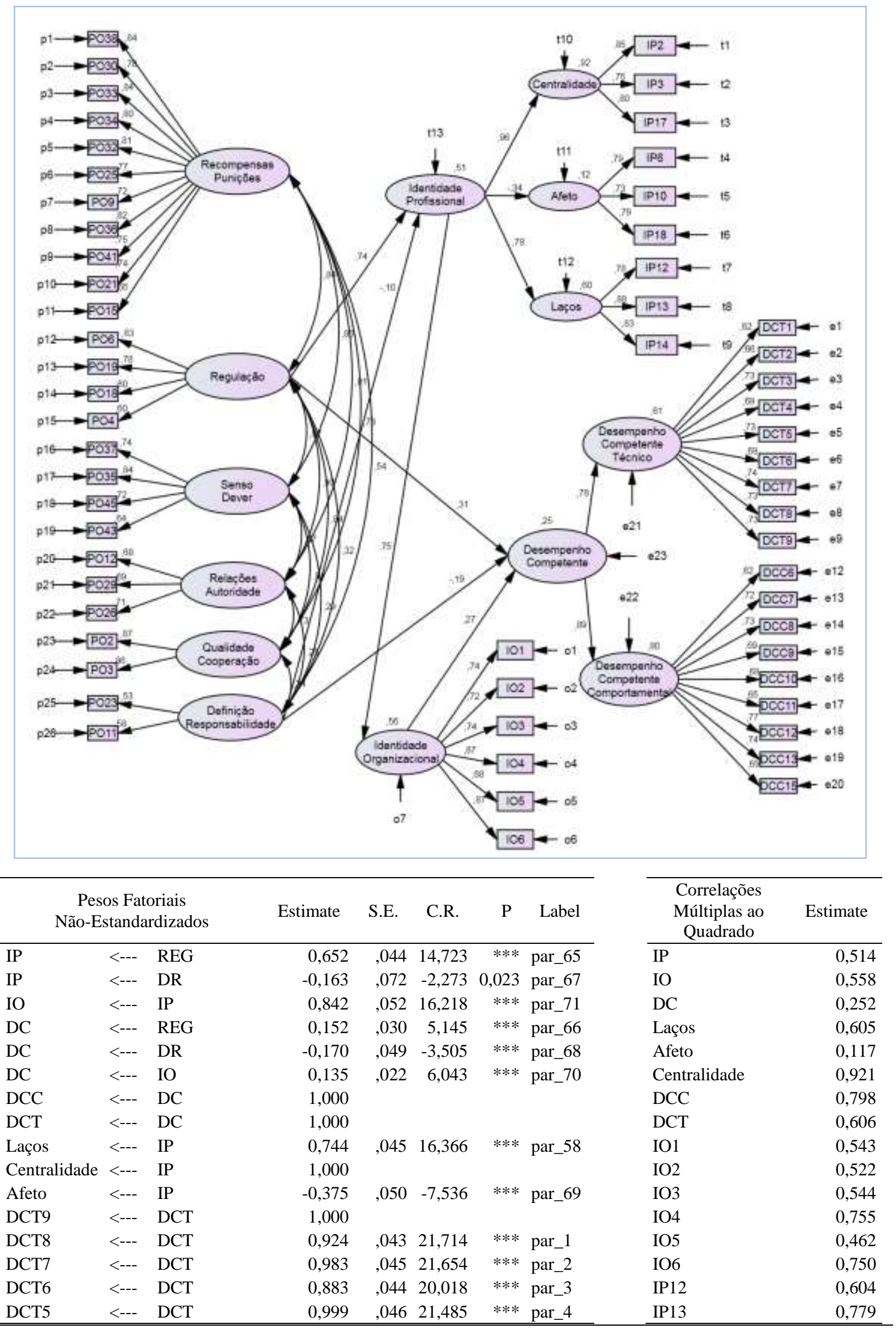




\begin{tabular}{|c|c|c|c|c|c|c|c|c|c|}
\hline DCT4 & <--- & DCT & 0,890 & ,044 & 20,072 & **** & par_5 & IP14 & 0,692 \\
\hline DCT3 & $<---$ & DCT & 0,964 & 045 & 21,500 & $* * *$ & par_6 & IP6 & 0,625 \\
\hline DCT2 & $<---$ & DCT & 0,816 & 042 & 19,275 & $* * *$ & par_7 & IP10 & 0,535 \\
\hline DCT1 & $<---$ & DCT & 0,790 & 044 & 18,041 & $* * *$ & par_8 & IP18 & 0,620 \\
\hline DCC13 & $<---$ & $\mathrm{DCC}$ & 1,000 & & & & & IP2 & 0,718 \\
\hline DCC12 & $<---$ & $\mathrm{DCC}$ & 1,008 & 044 & 23,002 & $* * *$ & par_9 & IP3 & 0,567 \\
\hline DCC11 & $<---$ & DCC & 0,913 & 048 & 18,894 & $* * *$ & par_10 & IP17 & 0,639 \\
\hline DCC10 & $<---$ & DCC & 0,909 & 045 & 20,007 & $* * *$ & par_11 & PO15 & 0,429 \\
\hline DCC9 & $<---$ & DCC & 0,996 & 049 & 20,407 & $* * *$ & par_12 & $\mathrm{PO} 23$ & 0,279 \\
\hline DCC8 & $<--$ & DCC & 1,020 & 047 & 21,620 & $* * *$ & par_13 & PO11 & 0,334 \\
\hline DCC7 & $<---$ & DCC & 1,019 & 049 & 20,916 & $* * *$ & par_14 & $\mathrm{PO} 2$ & 0,756 \\
\hline DCC6 & $<---$ & DCC & 0,906 & 050 & 18,129 & $* * *$ & par_15 & PO3 & 0,744 \\
\hline DCC15 & $<---$ & DCC & 1,006 & 049 & 20,449 & $* * *$ & par_16 & PO12 & 0,460 \\
\hline $\mathrm{PO} 21$ & $<--$ & $\mathrm{RP}$ & 0,887 & 040 & 21,940 & $* * *$ & par_17 & PO29 & 0,475 \\
\hline PO41 & $<---$ & $\mathrm{RP}$ & 0,857 & 038 & 22,479 & $* * *$ & par_18 & PO26 & 0,506 \\
\hline PO36 & $<---$ & $\mathrm{RP}$ & 0,781 & 031 & 25,569 & $* * *$ & par_19 & PO37 & 0,543 \\
\hline PO9 & $<---$ & $\mathrm{RP}$ & 0,822 & 039 & 21,178 & $* * *$ & par_20 & PO35 & 0,700 \\
\hline $\mathrm{PO} 25$ & $<---$ & $\mathrm{RP}$ & 0,830 & 035 & 23,517 & $* * *$ & par_21 & PO45 & 0,519 \\
\hline PO32 & $<---$ & $\mathrm{RP}$ & 0,938 & 036 & 25,829 & $* * *$ & par_22 & PO43 & 0,406 \\
\hline PO34 & $<---$ & $\mathrm{RP}$ & 0,962 & 038 & 25,079 & $* * *$ & par_23 & PO6 & 0,688 \\
\hline PO33 & $<---$ & $\mathrm{RP}$ & 0,955 & 035 & 27,051 & $* * *$ & par_24 & PO19 & 0,608 \\
\hline PO30 & $<---$ & $\mathrm{RP}$ & 0,889 & 037 & 24,210 & $* * *$ & par_25 & PO18 & 0,363 \\
\hline PO38 & $<---$ & $\mathrm{RP}$ & 1,000 & & & & & PO4 & 0,355 \\
\hline PO4 & $<--$ & REG & 0,615 & 041 & 15,096 & $* * *$ & par_26 & PO38 & 0,708 \\
\hline PO18 & $<--$ & REG & 0,612 & 040 & 15,211 & $* * *$ & par_27 & PO30 & 0,606 \\
\hline PO19 & $<--$ & REG & 0,840 & 038 & 21,951 & $* * *$ & par_28 & PO33 & 0,709 \\
\hline PO6 & $<---$ & REG & 1,000 & & & & & PO34 & 0,646 \\
\hline PO43 & $<--$ & SD & 0,851 & 056 & 15,258 & $* * *$ & par_29 & PO32 & 0,660 \\
\hline PO45 & $<--$ & SD & 1,049 &, 062 & 17,057 & $* * *$ & par_30 & $\mathrm{PO} 25$ & 0,596 \\
\hline PO35 & $<--$ & SD & 1,259 & ,064 & 19,763 & $* * *$ & par_31 & PO9 & 0,512 \\
\hline PO37 & $<--$ & SD & 1,000 & & & & & PO36 & 0,665 \\
\hline PO26 & $<---$ & RA & 0,705 & 043 & 16,263 & $* * *$ & par_32 & PO41 & 0,557 \\
\hline PO29 & $<--$ & RA & 0,690 & 043 & 16,108 & $* * *$ & par_33 & PO21 & 0,544 \\
\hline PO12 & $<--$ & RA & 1,000 & & & & & DCC 15 & 0,478 \\
\hline PO3 & $<--$ & $\mathrm{QC}$ & 1,020 & ,042 & 24,047 & $* * *$ & par_34 & DCC6 & 0,390 \\
\hline $\mathrm{PO} 2$ & $<--$ & QC & 1,000 & & & & & DCC7 & 0,513 \\
\hline PO15 & $<--$ & $\mathrm{RP}$ & 0,735 & ,039 & 18,727 & $* * *$ & par_49 & DCC8 & 0,540 \\
\hline PO11 & $<---$ & DR & 1,149 &, 142 & 8,107 & $* * *$ & par_50 & DCC9 & 0,483 \\
\hline PO23 & $<--$ & DR & 1,000 & & & & & DCC 10 & 0,458 \\
\hline $\begin{array}{l}\text { IP17 } \\
\text { IP3 }\end{array}$ & $\begin{array}{l}<-- \\
<--\end{array}$ & $\begin{array}{l}\text { Centralidade } \\
\text { Centralidade }\end{array}$ & $\begin{array}{l}1,000 \\
0,902\end{array}$ & 043 & 21.173 & $* * *$ & par 51 & DCC 11 & 0,418 \\
\hline IP2 & $<--$ & Centralidade & 1,045 & 044 & 23,763 & $* * *$ & par_52 & DCC 12 & 0,586 \\
\hline IP18 & $<--$ & Afeto & 1,000 & & & & & DCC13 & 0,546 \\
\hline IP10 & $<--$ & Afeto & 0,923 & 047 & 19,601 & $* * *$ & par_53 & DCT1 & 0,387 \\
\hline IP6 & $<--$ & Afeto & 0,919 & ,046 & 20,034 & $* * *$ & par_54 & DCT2 & 0,434 \\
\hline IP14 & $<---$ & Laços & 1,000 & & & & & DCT3 & 0,534 \\
\hline IP13 & $<--$ & Laços & 1,118 & ,039 & 28,362 & $* * *$ & par_55 & DCT4 & 0,474 \\
\hline IP12 & $<---$ & Laços & 0,917 & ,038 & 23,993 & $* * *$ & par_56 & DCT5 & 0,537 \\
\hline IO6 & $<--$ & IO & 1,000 & & & & & DCT6 & 0,473 \\
\hline IO5 & $<---$ & IO & 0,731 & ,033 & 22,016 & $* * *$ & par_59 & DCT7 & 0,541 \\
\hline $\begin{array}{l}\mathrm{IO} 4 \\
\mathrm{IO} 3\end{array}$ & $\begin{array}{l}<-- \\
<--\end{array}$ & $\begin{array}{l}\text { IO } \\
\text { IO }\end{array}$ & $\begin{array}{l}0,961 \\
0,776\end{array}$ & $\begin{array}{r}, 030 \\
.032\end{array}$ & $\begin{array}{l}32,014 \\
24,142\end{array}$ & $\begin{array}{l}* * * \\
* * *\end{array}$ & $\begin{array}{l}\text { par_60 } \\
\text { par } 61\end{array}$ & DCT8 & 0,539 \\
\hline $\mathrm{IO} 2$ & $<--$ & IO & 0,782 & ,033 & 23,543 & $* * *$ & par_62 & DCT9 & 0,532 \\
\hline IO1 & $<---$ & IO & 0,894 & 039 & 22,638 & $* * *$ & par_63 & & \\
\hline
\end{tabular}

Figura 83. Modelo $P O \rightarrow I P \rightarrow I O \rightarrow D C$. 
Mediação em cadeia da identidade organizacional e da identidade profissional na relação entre as práticas organizacionais e o desempenho profissional

Testou-se a relação de mediação que a identidade organizacional (IO) e a identidade profissional (IP) estabelecem entre as práticas organizacionais (PO), com os fatores correlacionados, e o desempenho profissional por competências (DC) $P O \rightarrow I O \rightarrow I P \rightarrow D C$.

Os índices de ajuste do modelo foram satisfatórios (GFI=0,88; CFI=0,92; RMSEA=0,040); contudo, os valores do GFI e AGFI foram inferiores ao limite de 0,90, em virtude do tamanho da amostra e da complexidade do modelo, não comprometendo, apesar disso, seu ajuste global (Kline, 2010; Roussel et al, 2002). As práticas de regulação e definição de responsabilidade $(\mathrm{p}<0,005)$ explicaram $33 \%$ da variância total da identidade Organizacional. A identidade organizacional, que sofre efeitos diretos das práticas de regulação e definição de responsabilidade, explicou $55 \%$ da variância da identidade profissional $\left(\mathrm{R}^{2}=0,93\right.$ para centralidade; $\mathrm{R}^{2}=0,11$ para afeto; e $\mathrm{R}^{2}=0,55$ para laços $)$. $\mathrm{O}$ modelo foi responsável por explicar $26 \%$ da variância do desempenho profissional $\left(R^{2}=0,60\right.$ de explicação para o desempenho por competências técnicas; $\mathrm{R}^{2}=0,78$ de explicação para $\mathrm{O}$ desempenho por competências comportamentais).

A identidade organizacional e a identidade profissional mediaram parcialmente a relação entre as práticas organizacionais de regulação e de definição de responsabilidade e o desempenho profissional ( $\mathrm{p}=0,002$ e $\mathrm{p}=0,001$, respectivamente), conforme Figura 84.

$$
\begin{array}{cc}
P O(\text { Regulação }) \stackrel{0,60 *}{\longrightarrow} I O \stackrel{0,74 *}{\longrightarrow} I P \stackrel{0,39 *}{\longrightarrow} D C & P O(D R) \stackrel{-0,13 *}{\longrightarrow} I P \stackrel{0,74 *}{\longrightarrow} I O \stackrel{0,39 *}{\longrightarrow} D C \\
P O \text { (Regulação) } \stackrel{0,20 *}{\longrightarrow} D C & P O(D R) \stackrel{-0,18 *}{\longrightarrow} D C \\
\text { Efeito Indireto: } 0,173, \mathrm{p}=0,001 & \text { Efeito Indireto: }-0,037, \mathrm{p}=0,008
\end{array}
$$

A Tabela 64 exibe um resumo dos índices de ajuste e a Figura 84 apresenta a representação gráfica do modelo, os pesos fatoriais não estandardizados e as correlações múltiplas ao quadrado. 
Tabela 64

Índices de ajustamento da relação entre $P O \rightarrow I O \rightarrow I P \rightarrow D C$

\begin{tabular}{|c|c|c|}
\hline \multicolumn{2}{|l|}{$\begin{array}{l}\text { Amostra } \\
\mathrm{N}=916\end{array}$} & Modelo $P O \rightarrow I O \rightarrow I P \rightarrow D C$ \\
\hline Índices & $\chi /$ g.l. & 2,34 \\
\hline Absolutos & $\chi^{2} ;$ g.l. & 3083,$99 ; 1626$ \\
\hline & $p$ & 0,000 \\
\hline & GFI (AGFI) & $0,88(0,87)$ \\
\hline & SRMR & 0,076 \\
\hline \multirow[t]{2}{*}{ Índices Relativos } & CFI & 0,92 \\
\hline & TLI & 0,91 \\
\hline Índices de Discrepância & RMSEA & 0,040 \\
\hline Populacional & (Lo90;Hi90) & $(0,038 ; 0,042)$ \\
\hline \multirow[t]{2}{*}{ Índices de Parcimônia } & PCFI & 0,87 \\
\hline & PGFI & 0,80 \\
\hline Índices Baseados na & AIC & 4091,99 \\
\hline \multirow[t]{2}{*}{ Teoria da Informação } & ECVI & 4,47 \\
\hline & CAIC & 4930,08 \\
\hline
\end{tabular}




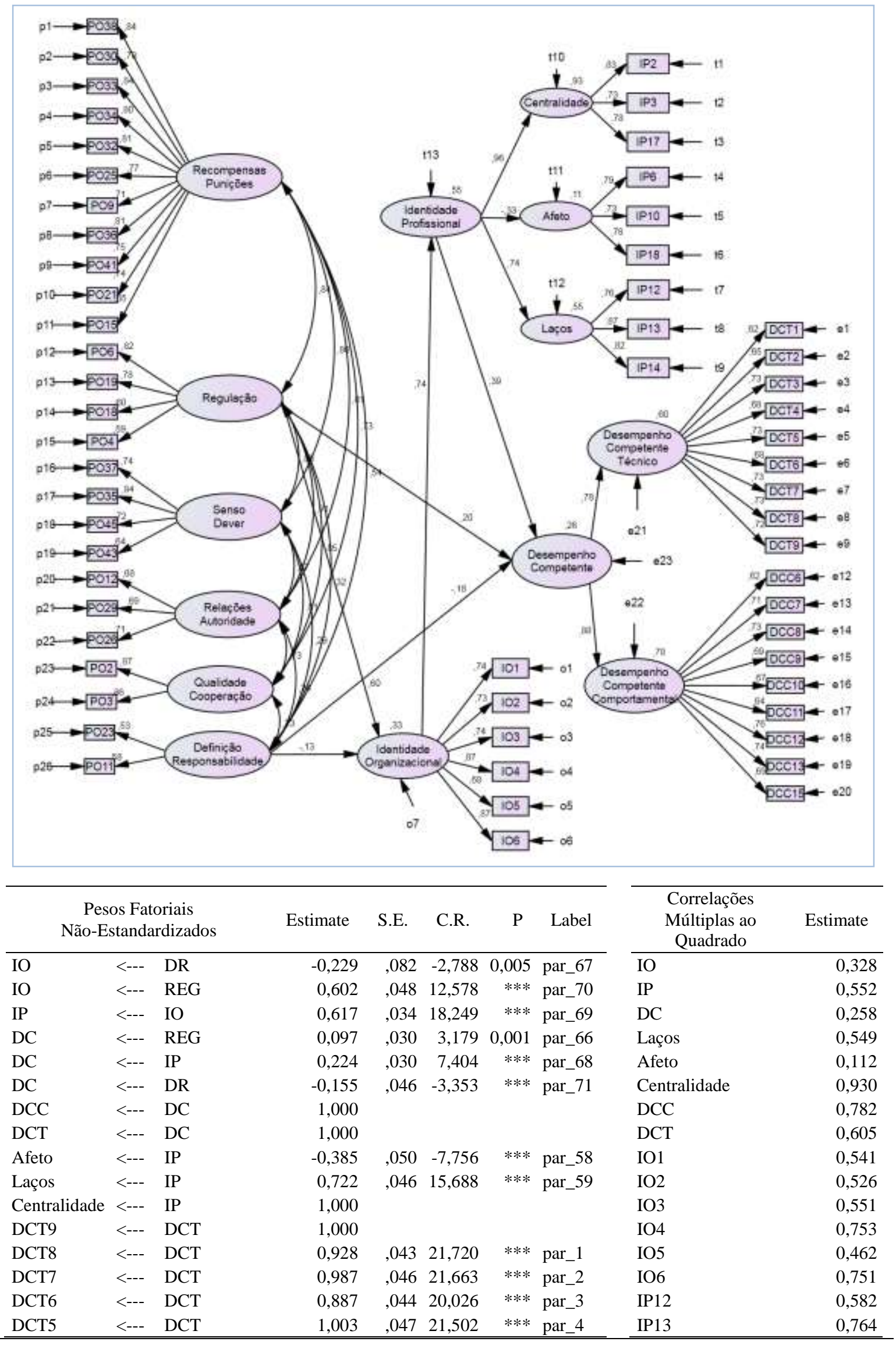




\begin{tabular}{|c|c|c|c|c|c|c|c|c|c|}
\hline DCT4 & <--- & DCT & 0,895 & ,045 & 20,084 & "*** & par_5 & IP14 & 0,676 \\
\hline DCT3 & $<---$ & DCT & 0,968 & 045 & 21,513 & $* * *$ & par_6 & IP6 & 0,625 \\
\hline DCT2 & $<---$ & DCT & 0,820 & ,043 & 19,284 & $* * *$ & par_7 & IP10 & 0,532 \\
\hline DCT1 & $<---$ & DCT & 0,794 & ,044 & 18,051 & $* * *$ & par_8 & IP18 & 0,614 \\
\hline DCC13 & $<---$ & DCC & 1,000 & & & & & IP2 & 0,690 \\
\hline DCC12 & $<---$ & DCC & 1,002 & ,043 & 23,202 & $* * *$ & par_9 & IP3 & 0,539 \\
\hline DCC11 & $<---$ & DCC & 0,909 & ,048 & 19,009 & $* * *$ & par_10 & IP17 & 0,609 \\
\hline DCC10 & $<---$ & DCC & 0,905 & ,045 & 20,136 & $* * *$ & par_11 & PO15 & 0,428 \\
\hline DCC9 & $<---$ & DCC & 0,990 & ,048 & 20,536 & $* * *$ & par_12 & PO23 & 0,286 \\
\hline DCC8 & $<---$ & DCC & 1,015 & ,047 & 21,786 & $* * *$ & par_13 & PO11 & 0,334 \\
\hline DCC7 & $<---$ & DCC & 1,014 & ,048 & 21,074 & $* * *$ & par_14 & PO2 & 0,756 \\
\hline DCC6 & $<---$ & DCC & 0,901 & ,049 & 18,234 & $* * *$ & par_15 & PO3 & 0,743 \\
\hline DCC15 & $<---$ & DCC & 1,002 & ,049 & 20,600 & $* * *$ & par_16 & PO12 & 0,458 \\
\hline PO21 & $<---$ & $\mathrm{RP}$ & 0,887 & ,040 & 21,936 & $* * *$ & par_17 & PO29 & 0,478 \\
\hline PO41 & $<---$ & $\mathrm{RP}$ & 0,857 & ,038 & 22,475 & $* * *$ & par_18 & PO26 & 0,505 \\
\hline PO36 & $<---$ & $\mathrm{RP}$ & 0,781 & ,031 & 25,567 & $* * *$ & par_19 & PO37 & 0,541 \\
\hline PO9 & $<---$ & $\mathrm{RP}$ & 0,822 & ,039 & 21,169 & $* * *$ & par_20 & PO35 & 0,698 \\
\hline $\mathrm{PO} 25$ & $<---$ & $\mathrm{RP}$ & 0,830 & ,035 & 23,511 & $* * *$ & par_21 & PO45 & 0,520 \\
\hline PO32 & $<---$ & $\mathrm{RP}$ & 0,938 & ,036 & 25,827 & $* * *$ & par_22 & PO43 & 0,405 \\
\hline PO34 & $<---$ & $\mathrm{RP}$ & 0,962 & ,038 & 25,078 & $* * *$ & par_23 & PO6 & 0,680 \\
\hline PO33 & $<---$ & $\mathrm{RP}$ & 0,956 & ,035 & 27,053 & $* * *$ & par_24 & PO19 & 0,602 \\
\hline PO30 & $<---$ & $\mathrm{RP}$ & 0,889 & ,037 & 24,204 & $* * *$ & par_25 & PO18 & 0,364 \\
\hline PO38 & $<---$ & $\mathrm{RP}$ & 1,000 & & & & & PO4 & 0,353 \\
\hline PO4 & $<---$ & REG & 0,617 & ,041 & 15,006 & $* * *$ & par_26 & PO38 & 0,707 \\
\hline PO18 & $<---$ & REG & 0,618 & 041 & 15,196 & $* * *$ & par_27 & PO30 & 0,605 \\
\hline PO19 & $<---$ & REG & 0,841 & ,039 & 21,703 & $* * *$ & par_28 & PO33 & 0,708 \\
\hline PO6 & $<---$ & REG & 1,000 & & & & & PO34 & 0,646 \\
\hline PO43 & $<---$ & SD & 0,852 & ,056 & 15,242 & $* * *$ & par_29 & PO32 & 0,659 \\
\hline PO45 & $<---$ & SD & 1,053 &, 062 & 17,076 & $* * *$ & par_30 & $\mathrm{PO} 25$ & 0,595 \\
\hline PO35 & $<---$ & SD & 1,259 & ,064 & 19,728 & $* * *$ & par_31 & PO9 & 0,510 \\
\hline PO37 & $<---$ & SD & 1,000 & & & & & PO36 & 0,664 \\
\hline PO26 & $<---$ & RA & 0,706 & ,043 & 16,273 & $* * *$ & par_32 & PO41 & 0,556 \\
\hline PO29 & $<---$ & RA & 0,694 & 043 & 16,185 & $* * *$ & par_33 & $\mathrm{PO} 21$ & 0,543 \\
\hline PO12 & $<---$ & RA & 1,000 & & & & & DCC15 & 0,473 \\
\hline PO3 & $<---$ & QC & 1,020 &, 042 & 24,022 & $* * *$ & par_34 & DCC6 & 0,384 \\
\hline PO2 & $<---$ & QC & 1,000 & & & & & DCC7 & 0,506 \\
\hline PO15 & $<---$ & $\mathrm{RP}$ & 0,736 & ,039 & 18,731 & $* * *$ & par_49 & DCC8 & 0,534 \\
\hline PO11 & $<---$ & DR & 1,135 & , 140 & 8,094 & $* * *$ & par_50 & DCC9 & 0,475 \\
\hline PO23 & $<--$ & DR & 1,000 & & & & & DCC10 & 0,453 \\
\hline $\begin{array}{l}\text { IP17 } \\
\text { IP3 }\end{array}$ & $\begin{array}{l}<--- \\
<---\end{array}$ & $\begin{array}{l}\text { Centralidade } \\
\text { Centralidade }\end{array}$ & $\begin{array}{l}1,000 \\
0,904\end{array}$ & 043 & 21,116 & $* * *$ & par 51 & DCC11 & 0,412 \\
\hline IP2 & $<--$ & Centralidade & 1,045 &, 044 & 23,565 & $* * *$ & par_52 & DCC12 & 0,580 \\
\hline IP18 & $<---$ & Afeto & 1,000 & & & & & DCC13 & 0,543 \\
\hline IP10 & $<---$ & Afeto & 0,926 & ,047 & 19,650 & $* * *$ & par_53 & DCT1 & 0,382 \\
\hline IP6 & $<---$ & Afeto & 0,924 & ,046 & 20,108 & $* * *$ & par_54 & DCT2 & 0,428 \\
\hline IP14 & $<---$ & Laços & 1,000 & & & & & DCT3 & 0,529 \\
\hline IP13 & $<---$ & Laços & 1,116 & ,039 & 28,268 & $* * *$ & par_55 & DCT4 & 0,469 \\
\hline IP12 & $<---$ & Laços & 0,914 & ,038 & 23,952 & $* * *$ & par_56 & DCT5 & 0,531 \\
\hline IO6 & $<---$ & IO & 1,000 & & & & & DCT6 & 0,467 \\
\hline IO5 & $<---$ & IO & 0,728 & 033 & 21,912 & $* * *$ & par_60 & DCT7 & 0,534 \\
\hline IO4 & $<---$ & IO & 0,959 & ,030 & 31,994 & *** & par_61 & DCT8 & 0,533 \\
\hline IO3 & $<---$ & IO & 0,779 & ,032 & 24,277 & $* * *$ & par_62 & DCT9 & 0,523 \\
\hline $\begin{array}{l}\mathrm{IO} 2 \\
\mathrm{IO} 1\end{array}$ & $\begin{array}{l}<-- \\
<---\end{array}$ & $\begin{array}{l}\text { IO } \\
\text { IO }\end{array}$ & $\begin{array}{l}0,783 \\
0,889\end{array}$ & $\begin{array}{l}, 033 \\
, 039\end{array}$ & $\begin{array}{l}23,595 \\
22,571\end{array}$ & $\begin{array}{l}* * * \\
* * *\end{array}$ & $\begin{array}{l}\text { par_63 } \\
\text { par_64 }\end{array}$ & & \\
\hline
\end{tabular}

Figura 84. Modelo $P O \rightarrow I O \rightarrow I P \rightarrow D C$. 


\subsection{Teste dos Modelos Gerais}

Realizados os testes dos efeitos diretos e indiretos, são apresentados os testes dos modelos estruturais gerais e dos modelos estruturais gerais parcimoniosos.

Os modelos estruturais gerais (MEG1 e MEG2) foram construídos a partir das análises dos modelos preliminares e dos modelos de mediação (simples ou em cadeia), sendo que, os valores e as práticas organizacionais foram examinados com seus fatores correlacionados, para se investigar quais tipos motivacionais e quais práticas mais contribuiriam com a predição do desempenho.

Os modelos chamados parcimoniosos são derivados dos modelos gerais (MEGP1 e MEGP2), representando relações das variáveis independentes sobre a variável dependente. Para estes modelos foram considerados os tipos motivacionais subjacentes aos valores organizacionais por pares bipolares, bem como as práticas de regulação e definição de responsabilidade, por serem estas últimas as únicas que apresentaram significância na relação com a identidade (profissional e organizacional) e com o desempenho profissional por competências nos modelos gerais.

\section{> Modelo Estrutural Geral 1 (MEG1) e Modelo Estrutural Geral 2 (MEG2)}

O primeiro modelo estrutural (Modelo Estrutural Geral 1) testou a influência dos valores organizacionais, práticas organizacionais, identidade profissional e identidade organizacional sobre o desempenho profissional. Neste primeiro modelo, a identidade profissional é considerada como antecedente da identidade organizacional, isto é, o modelo descreve uma mediação em cadeia (VO e $\mathrm{PO} \rightarrow I P \rightarrow I O \rightarrow D C ; V O$ e $P O \rightarrow D C$ ) em que os valores e as práticas organizacionais influenciam a identidade profissional e o desempenho profissional de forma direta. No ajuste do MEG1, nota-se que o teste do qui-quadrado mostra um valor de p menor que o limite associado de 0,05. No entanto, este índice é sensível ao tamanho da amostra e a complexidade do modelo. Diante disso, tornou-se consenso referir-se a outros índices para avaliar o ajuste de um modelo (Iacobucci, 2010). Os índices de ajuste (absoluto, relativo, parcimônia, discrepância populacional, e baseados na teoria da informação) indicam que o modelo se ajusta bem aos dados para a amostra total (conforme Tabela 65). Somente os valores de GFI e AGFI estão abaixo do limite de 0,90, mas sabe-se que estes dois índices são sensíveis ao tamanho da amostra e a complexidade do modelo e, portanto, não põem em dúvida o ajuste do modelo global (Kline, 2010; Roussel et al, 2002). 
No que se refere aos valores e às práticas organizacionais, mostraram-se significativos $(\mathrm{p}<0,05)$ os tipos motivacionais igualitarismo e harmonia, responsáveis por explicar em conjunto com as práticas de regulação e definição de responsabilidades $40 \%$ da identidade profissional $\left(\mathrm{R}^{2}=0,90\right.$ para centralidade; $\mathrm{R}^{2}=0,09$ para afeto; e $\mathrm{R}^{2}=0,53$ para laços). A identidade profissional, que sofre efeitos diretos dos tipos motivacionais igualitarismo e harmonia, e das práticas organizacionais de regulação e definição de responsabilidade, explicou $49 \%$ da variância da identidade organizacional. Relativo à mediação em cadeia do MEG1, a identidade profissional e a identidade organizacional mediaram parcialmente a relação entre os tipos motivacionais igualitarismo e harmonia e o desempenho profissional ( $p=0,000$ e p=0,000, respectivamente). Já em relação às práticas organizacionais, a identidade profissional e a identidade organizacional mediaram parcialmente a relação entre as práticas de regulação e definição de responsabilidade e o desempenho profissional ( $p=0,001$ e p=0,05, respectivamente). O modelo foi responsável por explicar $22 \%$ da variância do desempenho profissional $\left(\mathrm{R}^{2}=0,59\right.$ de explicação para o desempenho por competências técnicas; $\mathrm{R}^{2}=0,77$ de explicação para o desempenho por competências comportamentais), conforme Figura 85.

O segundo modelo (MEG2) testou a influência dos valores organizacionais, práticas organizacionais, identidade organizacional e identidade profissional sobre o desempenho profissional. Neste segundo modelo, inverte-se a lógica utilizada no modelo 1; assim, a identidade organizacional passa a ser considerada como antecedente da identidade profissional, isto é, o modelo descreve uma mediação em cadeia (VO e PO $\rightarrow I O \rightarrow I P \rightarrow$ $D C$; $V O$ e $P O \rightarrow D C$ ) em que os valores e as práticas organizacionais influenciam a identidade organizacional e o desempenho profissional de forma direta. De forma semelhante ao ocorrido no MEG1, no ajuste do segundo modelo estrutural, o teste do qui-quadrado apresentou um p-valor abaixo do limite de 0,05. Consideraram-se, portanto, outros índices para avaliar o ajuste de um modelo (Iacobucci, 2010). Os demais índices de ajuste mostramse adequados, comprovando o ajuste do modelo aos dados para a amostra total (conforme Tabela 65). Somente os valores de GFI e AGFI, que tangenciaram o valor limite de 0,90, sem maiores influências no ajuste do modelo global (Kline, 2010; Roussel et al, 2002).

Referindo-se aos valores e às práticas organizacionais, mostraram-se significativos $(\mathrm{p}<0,05)$ os tipos motivacionais igualitarismo e harmonia, responsáveis por explicar em conjunto com as práticas de regulação e definição de responsabilidades $29 \%$ da identidade organizacional. A identidade organizacional, que recebe efeitos diretos dos tipos motivacionais igualitarismo e harmonia, e das práticas organizacionais de regulação e 
definição de responsabilidade, explicou $52 \%$ da variância da identidade profissional $\left(\mathrm{R}^{2}=0,93\right.$ para centralidade; $\mathrm{R}^{2}=0,11$ para afeto; e $\mathrm{R}^{2}=0,53$ para laços). No que se refere à mediação em cadeia do MEG2, a identidade organizacional e a identidade profissional mediaram parcialmente a relação entre os tipos motivacionais igualitarismo e harmonia e o desempenho profissional ( $\mathrm{p}=0,001 \mathrm{e} \mathrm{p}=0,001$, respectivamente). Já em relação às práticas organizacionais, a identidade profissional e a identidade organizacional mediaram parcialmente a relação entre as práticas de regulação e definição de responsabilidade e o desempenho profissional ( $\mathrm{p}=0,001$ e $\mathrm{p}=0,001$, respectivamente). O modelo foi responsável por explicar $24 \%$ da variância do desempenho profissional $\left(\mathrm{R}^{2}=0,59\right.$ de explicação para o desempenho por competências técnicas; $\mathrm{R}^{2}=0,77$ de explicação para o desempenho por competências comportamentais), conforme Figura 86.

Tabela 65

Índices de ajustamento do MEG1 e MEG2

\begin{tabular}{l|lcc}
\hline \multicolumn{3}{l}{ Amostra } \\
$\mathrm{N}=916$
\end{tabular}




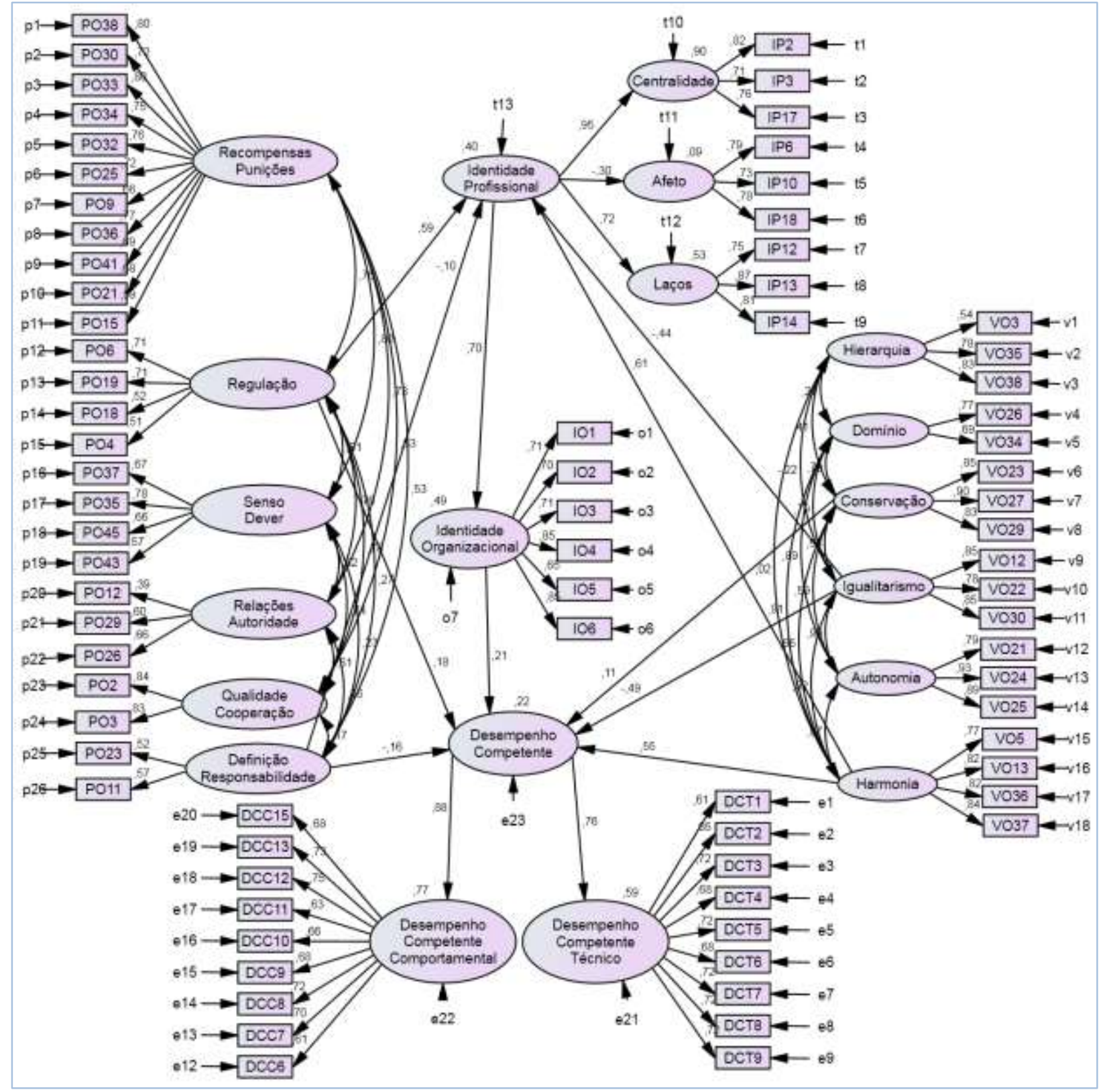




\begin{tabular}{|c|c|c|c|c|c|c|c|c|c|}
\hline \multicolumn{3}{|c|}{$\begin{array}{c}\text { Pesos Fatoriais } \\
\text { Não-Estandardizados }\end{array}$} & \multirow{2}{*}{$\begin{array}{r}\text { Estimate } \\
0,663\end{array}$} & \multirow{2}{*}{$\begin{array}{l}\text { S.E. } \\
0,055\end{array}$} & \multirow{2}{*}{$\begin{array}{c}\text { C.R. } \\
11,994\end{array}$} & \multirow[t]{2}{*}{$\mathrm{P}$} & \multirow{2}{*}{$\begin{array}{c}\text { Label } \\
\text { par_66 }\end{array}$} & $\begin{array}{c}\text { Correlações } \\
\text { Múltiplas ao } \\
\text { Quadrado }\end{array}$ & \multirow{2}{*}{$\begin{array}{r}\text { Estimate } \\
0,404\end{array}$} \\
\hline IP & $\begin{array}{l}<-- \\
\end{array}$ & REG & & & & & & IP & \\
\hline IP & $<--$ & DR & $-0,139$ & 0,070 & $-1,986$ & 0,047 & par_68 & IO & 0,494 \\
\hline IP & $<---$ & Igualitarismo & $-0,112$ & 0,029 & $-3,935$ & $* * *$ & par_99 & DC & 0,220 \\
\hline IP & $<---$ & Harmonia & 0,208 & 0,040 & 5,136 & $* * *$ & par_100 & Laços & 0,525 \\
\hline IO & $<---$ & IP & 0,851 & 0,052 & 16,289 & $* * *$ & par_98 & Afeto & 0,092 \\
\hline $\mathrm{DC}$ & $<---$ & REG & 0,124 & 0,035 & 3,485 & $* * *$ & par_67 & Centralidade & 0,896 \\
\hline DC & $<---$ & DR & $-0,137$ & 0,047 & $-2,889$ & 0,004 & par_69 & DCC & 0,774 \\
\hline DC & $<--$ & Harmonia & 0,113 & 0,034 & 3,327 & $* * *$ & par_97 & DCT & 0,585 \\
\hline $\mathrm{DC}$ & $<---$ & IO & 0,108 & 0,023 & 4,747 & $* * *$ & par_101 & VO37 & 0,700 \\
\hline $\mathrm{DC}$ & $<--$ & Conservação & 0,026 & 0,014 & 1,836 & 0,046 & par_102 & VO36 & 0,677 \\
\hline $\mathrm{DC}$ & $<---$ & Igualitarismo & $-0,076$ & 0,021 & $-3,520$ & $* * *$ & par_103 & VO5 & 0,590 \\
\hline DCC & $<---$ & $\mathrm{DC}$ & 1,000 & & & & & VO13 & 0,675 \\
\hline DCT & $<---$ & $\mathrm{DC}$ & 1,000 & & & & & VO21 & 0,621 \\
\hline Laços & $<---$ & IP & 0,739 & 0,045 & 16,514 & $* * *$ & par_59 & $\mathrm{VO} 24$ & 0,867 \\
\hline Centralidade & $<---$ & I[ & 1,000 & & & & & VO25 & 0,784 \\
\hline Afeto & $<---$ & IP & $-0,379$ & 0,050 & $-7,609$ & $* * *$ & par_70 & VO12 & 0,716 \\
\hline DCT9 & $<---$ & DCT & 1,000 & & & & & $\mathrm{VO} 22$ & 0,615 \\
\hline DCT8 & $<---$ & DCT & 0,926 & 0,042 & 21,782 & $* * *$ & par_1 & VO30 & 0,723 \\
\hline DCT7 & $<---$ & DCT & 0,985 & 0,045 & 21,726 & $* * *$ & par_2 & VO23 & 0,715 \\
\hline DCT6 & $<---$ & DCT & 0,886 & 0,044 & 20,073 & $* * *$ & par_3 & VO27 & 0,801 \\
\hline DCT5 & $<--$ & DCT & 1,002 & 0,046 & 21,560 & $* * *$ & par_4 & VO29 & 0,689 \\
\hline DCT4 & $<---$ & DCT & 0,892 & 0,044 & 20,131 & $* * *$ & par_5 & VO26 & 0,598 \\
\hline DCT3 & $<---$ & DCT & 0,966 & 0,045 & 21,573 & $* * *$ & par_6 & VO34 & 0,481 \\
\hline DCT2 & $<---$ & DCT & 0,818 & 0,042 & 19,327 & $* * *$ & par_7 & VO3 & 0,292 \\
\hline DCT1 & $<---$ & DCT & 0,792 & 0,044 & 18,088 & $* * *$ & par_8 & VO35 & 0,613 \\
\hline DCC13 & $<---$ & DCC & 1,000 & & & & & VO38 & 0,685 \\
\hline DCC12 & $<---$ & DCC & 1,005 & 0,043 & 23,221 & $* * *$ & par_9 & IO1 & 0,507 \\
\hline DCC11 & $<---$ & DCC & 0,908 & 0,048 & 18,988 & $* * *$ & par_10 & $\mathrm{IO} 2$ & 0,484 \\
\hline DCC10 & $<---$ & DCC & 0,906 & 0,045 & 20,137 & $* * *$ & par_11 & IO3 & 0,507 \\
\hline DCC9 & $<---$ & DCC & 0,992 & 0,048 & 20,560 & $* * *$ & par_12 & IO4 & 0,727 \\
\hline DCC8 & $<---$ & DCC & 1,014 & 0,047 & 21,782 & $* * *$ & par_13 & IO5 & 0,425 \\
\hline DCC7 & $<---$ & DCC & 1,015 & 0,048 & 21,083 & $* * *$ & par_14 & IO6 & 0,721 \\
\hline DCC6 & $<---$ & DCC & 0,903 & 0,049 & 18,245 & $* * *$ & par_15 & IP12 & 0,563 \\
\hline DCC15 & $<---$ & DCC & 1,004 & 0,049 & 20,620 & $* * *$ & par_16 & IP13 & 0,751 \\
\hline PO21 & $<---$ & $\mathrm{RP}$ & 0,888 & 0,040 & 21,951 & $* * *$ & par_17 & IP14 & 0,656 \\
\hline PO41 & $<---$ & $\mathrm{RP}$ & 0,857 & 0,038 & 22,475 & $* * *$ & par_18 & IP6 & 0,618 \\
\hline PO36 & $<---$ & $\mathrm{RP}$ & 0,782 & 0,031 & 25,558 & $* * *$ & par_19 & IP10 & 0,528 \\
\hline PO9 & $<---$ & $\mathrm{RP}$ & 0,822 & 0,039 & 21,150 & $* * *$ & par_20 & IP18 & 0,612 \\
\hline PO25 & $<---$ & $\mathrm{RP}$ & 0,831 & 0,035 & 23,524 & $* * *$ & par_21 & IP2 & 0,664 \\
\hline PO32 & $<---$ & $\mathrm{RP}$ & 0,938 & 0,036 & 25,807 & $* * *$ & par_22 & IP3 & 0,503 \\
\hline PO34 & $<---$ & $\mathrm{RP}$ & 0,962 & 0,038 & 25,070 & $* * *$ & par_23 & IP17 & 0,575 \\
\hline PO33 & $<---$ & $\mathrm{RP}$ & 0,956 & 0,035 & 27,043 & $* * *$ & par_24 & PO15 & 0,351 \\
\hline PO30 & $<---$ & $\mathrm{RP}$ & 0,889 & 0,037 & 24,194 & $* * *$ & par_25 & $\mathrm{PO} 23$ & 0,271 \\
\hline PO38 & $<---$ & $\mathrm{RP}$ & 1,000 & & & & & PO11 & 0,330 \\
\hline $\mathrm{PO} 4$ & $<---$ & REG & 0,728 & 0,052 & 14,060 & $* * *$ & par_26 & $\mathrm{PO} 2$ & 0,699 \\
\hline PO18 & $<---$ & REG & 0,722 & 0,051 & 14,049 & $* * *$ & par_27 & PO3 & 0,684 \\
\hline PO19 & $<---$ & REG & 0,994 & 0,053 & 18,884 & $* * *$ & par_28 & $\mathrm{PO} 12$ & 0,150 \\
\hline PO6 & $<---$ & REG & 1,000 & & & & & PO29 & 0,358 \\
\hline PO43 & $<---$ & SD & 0,852 & 0,056 & 15,334 & $* * *$ & par_29 & PO26 & 0,430 \\
\hline
\end{tabular}




\begin{tabular}{|c|c|c|c|c|c|c|c|c|c|}
\hline PO45 & $<--$ & SD & 1,051 & 0,061 & 17,151 & $* * *$ & par_30 & $\overline{\text { PO37 }}$ & 0,452 \\
\hline PO35 & $<--$ & SD & 1,251 & 0,063 & 19,786 & $* * *$ & par_31 & PO35 & 0,611 \\
\hline PO37 & $<--$ & SD & 1,000 & & & & & PO45 & 0,430 \\
\hline PO26 & $<---$ & RA & 1,291 & 0,137 & 9,422 & $* * *$ & par_32 & $\mathrm{PO} 43$ & 0,322 \\
\hline PO29 & $<--$ & RA & 1,199 & 0,123 & 9,750 & $* * *$ & par_33 & PO6 & 0,502 \\
\hline PO12 & $<--$ & RA & 1,000 & & & & & PO19 & 0,505 \\
\hline PO3 & $<---$ & QC & 1,020 & 0,043 & 23,938 & $* * *$ & par_34 & PO18 & 0,269 \\
\hline $\mathrm{PO} 2$ & $<--$ & QC & 1,000 & & & & & $\mathrm{PO} 4$ & 0,264 \\
\hline PO15 & $<---$ & $\mathrm{RP}$ & 0,736 & 0,039 & 18,721 & $* * *$ & par_50 & PO38 & 0,636 \\
\hline PO11 & $<--$ & DR & 1,157 & 0,144 & 8,053 & $* * *$ & par_51 & $\mathrm{PO} 30$ & 0,525 \\
\hline $\mathrm{PO} 23$ & $<--$ & DR & 1,000 & & & & & PO33 & 0,638 \\
\hline IP17 & $<--$ & Centralidade & 1,000 & & & & & PO34 & 0,569 \\
\hline IP3 & $<--$ & Centralidade & 0,903 & 0,043 & 21,185 & $* * *$ & par_52 & PO32 & 0,583 \\
\hline IP2 & $<--$ & Centralidade & 1,048 & 0,044 & 23,819 & $* * *$ & par_53 & PO25 & 0,516 \\
\hline IP18 & $<---$ & Afeto & 1,000 & & & & & PO9 & 0,430 \\
\hline IP10 & $<--$ & Afeto & 0,924 & 0,047 & 19,614 & $* * *$ & par_54 & PO36 & 0,588 \\
\hline IP6 & $<---$ & Afeto & 0,920 & 0,046 & 20,061 & $* * *$ & par_55 & PO41 & 0,476 \\
\hline IP14 & $<--$ & Laços & 1,000 & & & & & PO21 & 0,463 \\
\hline IP13 & $<--$ & Laços & 1,119 & 0,039 & 28,332 & $* * *$ & par_56 & DCC15 & 0,460 \\
\hline IP12 & $<--$ & Laços & 0,917 & 0,038 & 23,975 & $* * *$ & par_57 & DCC6 & 0,372 \\
\hline IO6 & $<---$ & IO & 1,000 & & & & & DCC7 & 0,493 \\
\hline IO5 & $<--$ & IO & 0,730 & 0,033 & 22,005 & $* * *$ & par_60 & DCC8 & 0,518 \\
\hline IO4 & $<--$ & IO & 0,961 & 0,030 & 32,033 & $* * *$ & par_61 & DCC9 & 0,463 \\
\hline $\mathrm{IO} 3$ & $<--$ & IO & 0,776 & 0,032 & 24,148 & $* * *$ & par_62 & DCC10 & 0,439 \\
\hline $\mathrm{IO} 2$ & $<--$ & IO & 0,781 & 0,033 & 23,542 & $* * *$ & par_63 & DCC11 & 0,397 \\
\hline IO1 & $<--$ & IO & 0,894 & 0,039 & 22,650 & $* * *$ & par_64 & DCC12 & 0,567 \\
\hline VO38 & $<--$ & Hierarquia & 1,000 & & & & & DCC13 & 0,529 \\
\hline VO35 & $<---$ & Hierarquia & 0,983 & 0,048 & 20,677 & $* * *$ & par_71 & DCT1 & 0,372 \\
\hline VO3 & $<--$ & Hierarquia & 0,619 & 0,042 & 14,914 & $* * *$ & par_72 & DCT2 & 0,419 \\
\hline VO34 & $<--$ & Domínio & 1,000 & & & & & DCT3 & 0,518 \\
\hline VO26 & $<--$ & Domínio & 1,218 & 0,058 & 20,899 & $* * *$ & par_73 & DCT4 & 0,458 \\
\hline VO29 & $<--$ & Conservação & 0,989 & 0,034 & 28,888 & $* * *$ & par_74 & DCT5 & 0,522 \\
\hline VO27 & $<--$ & Conservação & 1,067 & 0,033 & 32,476 & $* * *$ & par_75 & DCT6 & 0,458 \\
\hline $\mathrm{VO} 23$ & $<--$ & Conservação & 1,000 & & & & & DCT7 & 0,524 \\
\hline VO30 & $<--$ & Igualitarismo & 1,000 & & & & & DCT8 & 0,523 \\
\hline $\mathrm{VO} 22$ & $<--$ & Igualitarismo & 0,637 & 0,022 & 29,003 & $* * *$ & par_76 & DCT9 & 0,515 \\
\hline VO12 & $<--$ & Igualitarismo & 0,888 & 0,027 & 33,279 & $* * *$ & par_77 & & \\
\hline VO25 & $<--$ & Autonomia & 1,000 & & & & & & \\
\hline VO24 & $<--$ & Autonomia & 1,059 & 0,024 & 43,576 & $* * *$ & par_78 & & \\
\hline $\mathrm{VO} 21$ & $<--$ & Autonomia & 0,921 & 0,031 & 30,091 & $* * *$ & par_79 & & \\
\hline VO13 & $<--$ & Harmonia & 0,923 & 0,032 & 28,999 & $* * *$ & par_80 & & \\
\hline VO5 & $<---$ & Harmonia & 0,907 & 0,034 & 26,516 & $* * *$ & par_81 & & \\
\hline VO37 & $<--$ & Harmonia & 1,002 & 0,033 & 30,439 & $* * *$ & par_82 & & \\
\hline VO36 & $<--$ & Harmonia & 1,000 & & & & & & \\
\hline
\end{tabular}

Figura 85. Modelo $V O, P O \rightarrow I P \rightarrow I O \rightarrow D C-M E G 1$. 


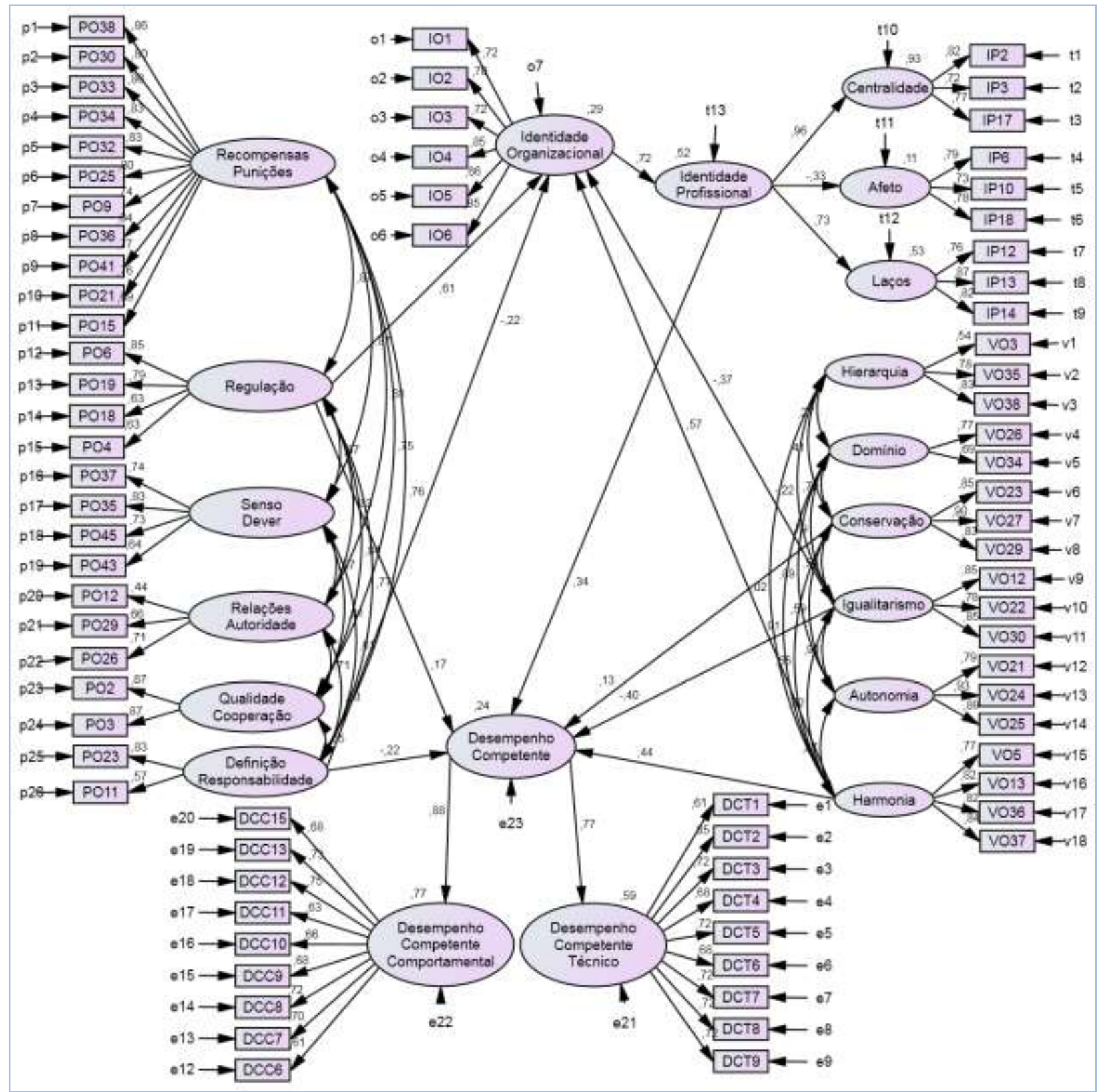




\begin{tabular}{|c|c|c|c|c|c|c|c|c|}
\hline \multicolumn{2}{|c|}{$\begin{array}{c}\text { Pesos Fatoriais } \\
\text { Não-Estandardizados }\end{array}$} & \multirow{2}{*}{$\begin{array}{l}\text { Estimate } \\
-0,178\end{array}$} & \multirow{2}{*}{$\begin{array}{l}\text { S.E. } \\
0,059\end{array}$} & \multirow{2}{*}{$\begin{array}{c}\text { C.R. } \\
-3,034\end{array}$} & \multirow{2}{*}{$\begin{array}{r}\mathrm{P} \\
0,002\end{array}$} & \multirow{2}{*}{$\begin{array}{c}\text { Label } \\
\text { par_98 }\end{array}$} & $\begin{array}{c}\text { Correlações } \\
\text { Múltiplas ao } \\
\text { Quadrado }\end{array}$ & \multirow{2}{*}{$\begin{array}{r}\text { Estimate } \\
0,290\end{array}$} \\
\hline IO & $<---\quad$ DR & & & & & & $\overline{\mathrm{IO}}$ & \\
\hline IO & $<---\quad$ REG & 0,521 & 0,058 & 8,931 & $* * *$ & par_99 & IP & 0,522 \\
\hline IO & $<---\quad$ Igualitarismo & $-0,117$ & 0,033 & $-3,546$ & $* * *$ & par_100 & DC & 0,242 \\
\hline IO & $<---\quad$ Harmonia & 0,238 & 0,047 & 5,094 & $* * *$ & par_101 & Laços & 0,534 \\
\hline IP & $<---\quad$ IO & 0,618 & 0,034 & 18,241 & $* * *$ & par_97 & Afeto & 0,106 \\
\hline $\mathrm{DC}$ & <--- REG & 0,072 & 0,036 & 2,020 & 0,043 & par_65 & Centralidade & 0,929 \\
\hline DC & $<---\quad D R$ & $-0,087$ & 0,033 & $-2,640$ & 0,008 & par_66 & DCC & 0,767 \\
\hline DC & $<---\quad$ Harmonia & 0,091 & 0,033 & 2,800 & 0,005 & par_94 & DCT & 0,590 \\
\hline DC & <--- Conservação & 0,030 & 0,014 & 2,114 & 0,035 & par_95 & VO37 & 0,699 \\
\hline DC & $<---\quad$ Igualitarismo & $-0,062$ & 0,021 & $-3,012$ & 0,003 & par_96 & VO36 & 0,677 \\
\hline DC & $<---\quad$ IP & 0,195 & 0,030 & 6,502 & $* * *$ & par_102 & VO5 & 0,591 \\
\hline DCC & $<---\quad \mathrm{DC}$ & 1,000 & & & & & VO13 & 0,676 \\
\hline DCT & $<---\quad \mathrm{DC}$ & 1,000 & & & & & VO21 & 0,621 \\
\hline Laços & $<---\quad$ IP & 0,721 & 0,046 & 15,602 & $* * *$ & par_58 & VO24 & 0,867 \\
\hline Centralidade & $<---\quad$ IP & 1,000 & & & & & VO25 & 0,784 \\
\hline Afeto & $<---\quad$ IP & $-0,384$ & 0,050 & $-7,752$ & $* * *$ & par_67 & VO12 & 0,717 \\
\hline DCT9 & $<---\quad$ DCT & 1,000 & & & & & $\mathrm{VO} 22$ & 0,615 \\
\hline DCT8 & $<---\quad \mathrm{DCT}$ & 0,929 & 0,043 & 21,812 & $* * *$ & par_1 & VO30 & 0,723 \\
\hline DCT7 & $<---\quad$ DCT & 0,988 & 0,045 & 21,757 & $* * *$ & par_2 & VO23 & 0,715 \\
\hline DCT6 & $<---\quad$ DCT & 0,889 & 0,044 & 20,101 & $* * *$ & par_3 & VO27 & 0,801 \\
\hline DCT5 & $<---\quad$ DCT & 1,005 & 0,047 & 21,600 & $* * *$ & par_4 & VO29 & 0,689 \\
\hline DCT4 & $<---\quad$ DCT & 0,895 & 0,044 & 20,161 & $* * *$ & par_5 & VO26 & 0,597 \\
\hline DCT3 & $<---\quad$ DCT & 0,969 & 0,045 & 21,610 & $* * *$ & par_6 & VO34 & 0,482 \\
\hline DCT2 & $<---\quad$ DCT & 0,821 & 0,042 & 19,355 & $* * *$ & par_7 & VO3 & 0,293 \\
\hline DCT1 & $<---\quad$ DCT & 0,795 & 0,044 & 18,112 & $* * *$ & par_8 & VO35 & 0,615 \\
\hline DCC13 & $<---\quad$ DCC & 1,000 & & & & & VO38 & 0,683 \\
\hline DCC12 & $<---\quad$ DCC & 1,001 & 0,043 & 23,377 & $* * *$ & par_9 & IO1 & 0,512 \\
\hline DCC11 & $<---\quad D C C$ & 0,906 & 0,047 & 19,077 & $* * *$ & par_10 & $\mathrm{IO} 2$ & 0,497 \\
\hline DCC10 & $<---\quad$ DCC & 0,904 & 0,045 & 20,236 & $* * *$ & par_11 & IO3 & 0,524 \\
\hline DCC9 & $<---\quad$ DCC & 0,988 & 0,048 & 20,655 & $* * *$ & par_12 & IO4 & 0,731 \\
\hline DCC8 & $<---$ DCC & 1,011 & 0,046 & 21,908 & $* * *$ & par_13 & IO5 & 0,430 \\
\hline DCC7 & $<---\quad$ DCC & 1,012 & 0,048 & 21,206 & $* * *$ & par_14 & IO6 & 0,729 \\
\hline DCC6 & $<---\quad$ DCC & 0,900 & 0,049 & 18,324 & $* * *$ & par_15 & IP12 & 0,573 \\
\hline DCC15 & $<---\quad$ DCC & 1,002 & 0,048 & 20,735 & $* * *$ & par_16 & IP13 & 0,758 \\
\hline PO21 & $<---\quad R P$ & 0,887 & 0,040 & 21,936 & $* * *$ & par_17 & IP14 & 0,669 \\
\hline PO41 & $<---\quad R P$ & 0,858 & 0,038 & 22,512 & $* * *$ & par_18 & IP6 & 0,623 \\
\hline PO36 & $<---\quad R P$ & 0,781 & 0,031 & 25,568 & $* * *$ & par_19 & IP10 & 0,531 \\
\hline PO9 & $<--\quad R P$ & 0,820 & 0,039 & 21,130 & $* * *$ & par_20 & IP18 & 0,613 \\
\hline $\mathrm{PO} 25$ & $<--\quad R P$ & 0,830 & 0,035 & 23,512 & $* * *$ & par_21 & IP2 & 0,678 \\
\hline PO32 & $<---\quad R P$ & 0,937 & 0,036 & 25,809 & $* * *$ & par_22 & IP3 & 0,524 \\
\hline PO34 & $<--\quad R P$ & 0,962 & 0,038 & 25,081 & $* * *$ & par_23 & IP17 & 0,596 \\
\hline PO33 & $<---\quad R P$ & 0,955 & 0,035 & 27,045 & $* * *$ & par_24 & PO15 & 0,470 \\
\hline PO30 & $<---\quad R P$ & 0,889 & 0,037 & 24,221 & $* * *$ & par_25 & $\mathrm{PO} 23$ & 0,682 \\
\hline PO38 & $<--\quad R P$ & 1,000 & & & & & PO11 & 0,329 \\
\hline PO4 & $<---\quad$ REG & 0,602 & 0,040 & 15,149 & $* * *$ & par_26 & $\mathrm{PO} 2$ & 0,761 \\
\hline PO18 & $<---\quad$ REG & 0,601 & 0,039 & 15,290 & $* * *$ & par_27 & PO3 & 0,750 \\
\hline PO19 & $<---\quad$ REG & 0,805 & 0,037 & 21,522 & $* * *$ & par_28 & PO12 & 0,193 \\
\hline PO6 & $<---\quad$ REG & 1,000 & & & & & PO29 & 0,434 \\
\hline $\mathrm{PO} 43$ & $<---$ SD & 0,855 & 0,056 & 15,275 & $* * *$ & par_29 & $\mathrm{PO} 26$ & 0,501 \\
\hline
\end{tabular}




\begin{tabular}{|c|c|c|c|c|c|c|c|c|}
\hline & & & & & & & PO37 & 0,541 \\
\hline PO45 & $<---$ & SD & 1,060 & 0,062 & 17,167 & *** par_30 & PO35 & 0,696 \\
\hline PO35 & $<---$ & SD & 1,256 & 0,064 & 19,713 & *** par_31 & PO45 & 0,527 \\
\hline PO37 & $<---$ & SD & 1,000 & & & & $\mathrm{PO} 43$ & 0,408 \\
\hline PO26 & $<---$ & RA & 1,282 & 0,136 & 9,450 & *** par_32 & PO6 & 0,726 \\
\hline PO29 & $<---$ & RA & 1,201 & 0,123 & 9,800 & *** par_33 & PO19 & 0,628 \\
\hline PO12 & $<--$ & RA & 1,000 & & & & PO18 & 0,403 \\
\hline $\mathrm{PO} 3$ & $<--$ & QC & 1,021 & 0,043 & 23,988 & *** par_34 & $\mathrm{PO} 4$ & 0,394 \\
\hline $\mathrm{PO} 2$ & $<---$ & QC & 1,000 & & & & PO38 & 0,742 \\
\hline PO15 & $<---$ & $\mathrm{RP}$ & 0,735 & 0,039 & 18,721 & *** par_49 & $\mathrm{PO} 30$ & 0,645 \\
\hline PO11 & $<---$ & DR & 0,583 & 0,055 & 10,579 & *** par_50 & $\mathrm{PO} 33$ & 0,742 \\
\hline $\mathrm{PO} 23$ & $<---$ & DR & 1,000 & & & & $\mathrm{PO} 34$ & 0,684 \\
\hline IP17 & $<---$ & Centralidade & 1,000 & & & & $\mathrm{PO} 32$ & 0,696 \\
\hline IP3 & $<--$ & Centralidade & 0,903 & 0,043 & 21,110 & *** par_51 & $\mathrm{PO} 25$ & 0,636 \\
\hline IP2 & $<---$ & Centralidade & 1,044 & 0,044 & 23,558 & *** par_52 & PO9 & 0,552 \\
\hline IP18 & $<---$ & Afeto & 1,000 & & & & PO36 & 0,701 \\
\hline IP10 & $<--$ & Afeto & 0,926 & 0,047 & 19,651 & *** par_53 & $\mathrm{PO} 41$ & 0,599 \\
\hline IP6 & $<---$ & Afeto & 0,924 & 0,046 & 20,108 & *** par_54 & $\mathrm{PO} 21$ & 0,585 \\
\hline IP14 & $<---$ & Laços & 1,000 & & & & DCC15 & 0,461 \\
\hline IP13 & $<---$ & Laços & 1,116 & 0,039 & 28,273 & *** par_55 & DCC6 & 0,372 \\
\hline IP12 & $<--$ & Laços & 0,914 & 0,038 & 23,954 & *** par_56 & DCC7 & 0,493 \\
\hline IO6 & $<--$ & IO & 1,000 & & & & DCC 8 & 0,519 \\
\hline IO5 & $<---$ & IO & 0,726 & 0,033 & 21,834 & *** par_59 & DCC9 & 0,462 \\
\hline $\mathrm{IO} 4$ & $<---$ & IO & 0,959 & 0,030 & 32,015 & *** par_60 & DCC10 & 0,440 \\
\hline $\mathrm{IO} 3$ & $<---$ & IO & 0,781 & 0,032 & 24,338 & *** par_61 & DCC11 & 0,398 \\
\hline $\mathrm{IO} 2$ & $<---$ & $\mathrm{IO}$ & 0,783 & 0,033 & 23,599 & *** par_62 & DCC12 & 0,568 \\
\hline IO1 & $<---$ & IO & 0,890 & 0,039 & 22,586 & *** par_63 & DCC13 & 0,532 \\
\hline VO38 & $<---$ & Hierarquia & 1,000 & & & & DCT1 & 0,372 \\
\hline VO35 & $<---$ & Hierarquia & 0,986 & 0,048 & 20,632 & *** par_68 & DCT2 & 0,419 \\
\hline VO3 & $<---$ & Hierarquia & 0,621 & 0,042 & 14,916 & *** par_69 & DCT3 & 0,518 \\
\hline VO34 & $<---$ & Domínio & 1,000 & & & & DCT4 & 0,458 \\
\hline VO26 & $<---$ & Domínio & 1,218 & 0,058 & 20,918 & *** par_70 & DCT5 & 0,521 \\
\hline VO29 & $<---$ & Conservação & 1,000 & & & & DCT6 & 0,457 \\
\hline VO27 & $<--$ & Conservação & 1,079 & 0,035 & 30,979 & *** par_71 & DCT7 & 0,524 \\
\hline VO23 & $<--$ & Conservação & 1,011 & 0,035 & 28,890 & *** par_72 & DCT8 & 0,522 \\
\hline VO30 & $<--$ & Igualitarismo & 1,000 & & & & DCT9 & 0,513 \\
\hline $\mathrm{VO} 22$ & $<---$ & Igualitarismo & 0,636 & 0,022 & 28,977 & *** par_73 & & \\
\hline VO12 & $<--$ & Igualitarismo & 0,889 & 0,027 & 33,313 & *** par_74 & & \\
\hline VO25 & $<--$ & Autonomia & 1,000 & & & & & \\
\hline $\mathrm{VO} 24$ & $<---$ & Autonomia & 1,059 & 0,024 & 43,575 & *** par_75 & & \\
\hline $\mathrm{VO} 21$ & $<---$ & Autonomia & 0,921 & 0,031 & 30,091 & *** par_76 & & \\
\hline VO13 & $<--$ & Harmonia & 0,923 & 0,032 & 29,044 & *** par_77 & & \\
\hline VO5 & $<---$ & Harmonia & 0,907 & 0,034 & 26,541 & *** par_78 & & \\
\hline VO37 & $<---$ & Harmonia & 1,001 & 0,033 & 30,439 & *** par_79 & & \\
\hline VO36 & $<---$ & Harmonia & 1,000 & & & & & \\
\hline
\end{tabular}

Figura 86. Modelo $V O, P O \rightarrow I O \rightarrow I P \rightarrow D C-M E G 2$. 


\section{Modelos Estruturais Gerais Parcimoniosos 1 (MEGPl $a, b$ e c)}

O modelo estrutural parcimonioso (MEGP1a) testou a influência dos tipos motivacionais conservação $x$ autonomia, práticas organizacionais de regulação e definição de responsabilidade, identidade profissional e identidade organizacional sobre o desempenho profissional por competências. Neste modelo, a identidade profissional é considerada como antecedente da identidade organizacional, isto é, o modelo descreve a relação (VO Conservação $x$ Autonomia e PO Regulação e Definição de Responsabilidade $\rightarrow I P \rightarrow I O \rightarrow D C ;$ VO e PO $\rightarrow D C ; I O \rightarrow D C$ ) em que os valores e as práticas organizacionais influenciam a identidade profissional e o desempenho profissional de forma direta. No ajuste do MEGP1a, verifica-se que o teste do qui-quadrado mostrou que o valor de $\mathrm{p}$ foi menor que o limite de 0,05. Diante disso, outros índices de ajuste (absoluto, relativo, parcimônia, discrepância populacional, e baseados na teoria da informação) indicaram que o modelo MEGP1a ajusta-se bem aos dados para a amostra total (conforme Tabela 66).

No que se referem aos valores e às práticas organizacionais, mostraram-se significativos o tipo motivacional conservação $(\mathrm{p}<0,000)$, responsáveis por explicar em conjunto com a prática de regulação $(\mathrm{p}<0,000) 39 \%$ da identidade profissional $\left(\mathrm{R}^{2}=0,91\right.$ para centralidade; $\mathrm{R}^{2}=0,09$ para afeto; $\mathrm{R}^{2}=0,53$ para laços). A identidade profissional, sofrendo efeitos diretos do tipo motivacional conservação e da prática organizacional de regulação, explicou $49 \%$ da variância da identidade organizacional. Relativo à mediação em cadeia do MEGP1a, a identidade profissional e a identidade organizacional mediaram parcialmente a relação entre o tipo motivacional conservação e o desempenho profissional $(\mathrm{p}<0,001)$. A identidade profissional e a identidade organizacional mediaram parcialmente a relação entre a prática de regulação e o desempenho profissional $(\mathrm{p}<0,001)$. O modelo foi responsável por explicar $19 \%$ da variância do desempenho profissional $\left(\mathrm{R}^{2}=0,58\right.$ de explicação para o desempenho por competências técnicas; $\mathrm{R}^{2}=0,78$ de explicação para o desempenho por competências comportamentais), conforme Figura 87.

O modelo estrutural Parcimonioso (MEGP1b) testou a influência dos tipos motivacionais hierarquia $x$ igualitarismo, práticas organizacionais de regulação e definição de responsabilidade, identidade profissional e identidade organizacional sobre o desempenho profissional por competências. Neste MEGP1b, descreve-se a relação (VO Hierarquia $x$ Igualitarismo e PO Regulação e Definição de Responsabilidade $\rightarrow I P \rightarrow I O \rightarrow D C ;$; VO e PO $\rightarrow D C ; I O \rightarrow D C$ ) em que os valores e as práticas organizacionais diretamente influenciam a identidade profissional e o desempenho profissional. O teste do qui-quadrado apresentou um p-valor abaixo do limite 
de 0,05. Procedeu-se, assim, a análise de outros indicadores de adequação do modelo (absoluto, relativo, parcimônia, discrepância populacional, e baseados na teoria da informação). Esses índices mostraram-se ajustados, corroborando o ajuste do modelo aos dados para a amostra total (conforme Tabela 66).

Apresentaram-se significativos os tipos motivacionais hierarquia e igualitarismo $(\mathrm{p}<0,000)$, responsáveis por explicar em conjunto com a prática de regulação $(\mathrm{p}<0,000) 40 \%$ da variância da identidade profissional $\left(\mathrm{R}^{2}=0,91\right.$ para centralidade; $\mathrm{R}^{2}=0,09$ para afeto; e $\mathrm{R}^{2}=0,53$ para laços). A identidade profissional, recebendo efeitos diretos dos tipos motivacionais hierarquia e igualitarismo, e da prática de regulação, explicou $48 \%$ da variância da identidade organizacional. No que se refere à mediação em cadeia do MEGP1b, a identidade profissional e a identidade organizacional mediaram parcialmente a relação entre os tipos motivacionais hierarquia e igualitarismo e o desempenho profissional $(p=0,001$ e $\mathrm{p}=0,001$, respectivamente). Em relação às práticas organizacionais, a identidade profisssional e a identidade organizacional mediaram parcialmente a relação entre a práticas de regulação e definição de resposabilidade e o desempenho profissional $(p=0,001$ e $p=0,001$, respectivamente). O modelo foi responsável por explicar $20 \%$ da variância do desempenho profissional $\left(\mathrm{R}^{2}=0,60\right.$ de explicação para o desempenho por competências técnicas; $\mathrm{R}^{2}=0,76$ de explicação para o desempenho por competências comportamentais), conforme Figura 88.

O modelo estrutural Parcimonioso (MEGP1c) testou a influência dos tipos motivacionais domínio $x$ harmonia, práticas organizacionais de regulação e definição de responsabilidade, identidade profissional e identidade organizacional sobre o desempenho profissional por competências. Neste MEGP1c, registra-se a relação (VO Domínio $x$ Harmonia e PO Regulação e Definição de Responsabilidade $\rightarrow I P \rightarrow I O \rightarrow D C ; V O$ e $P O \rightarrow D C ; I O \rightarrow D C)$ em que os valores e as práticas organizacionais influenciam de forma direta a identidade profissional e o desempenho profissional. Como o teste do qui-quadrado mostrou um p-valor inferior ao limite de 0,05. Procedeu-se, a análise de outros indicadores de adequação do modelo, que mostraram-se ajustados aos dados para a amostra total (conforme Tabela 66).

Apresentaram-se significativos os tipos motivacionais Harmonia $(p<0,000)$, responsáveis por explicar em conjunto com a práticas de regulação $(p<0,000) 39 \%$ da variância da identidade profissional $\left(\mathrm{R}^{2}=0,91\right.$ para centralidade; $\mathrm{R}^{2}=0,09$ para afeto; e $\mathrm{R}^{2}=0,53$ para laços). A identidade profissional, recebendo efeitos direto do tipo motivacional domínio e da prática de regulação, explicou 49\% da variância da identidade organizacional. Para a mediação em cadeia do MEGP1c, a identidade profissional e a identidade 
organizacional mediaram parcialmente a relação entre o tipo motivacional harmonia e o desempenho profissional $(\mathrm{p}=0,001)$. Em relação às práticas organizacionais, a identidade profissional e a identidade organizacional mediaram parcialmente a relação entre a prática de regulação e o desempenho profissional $(\mathrm{p}=0,001)$. O modelo foi responsável por explicar $19 \%$ da variância do desempenho profissional $\left(\mathrm{R}^{2}=0,59\right.$ de explicação para o desempenho por competências técnicas; $\mathrm{R}^{2}=0,77$ de explicação para o desempenho por competências comportamentais), conforme Figura 89.

Tabela 66

Índices de ajustamento do MEGPI a b e c

\begin{tabular}{|c|c|c|c|c|}
\hline \multicolumn{2}{|l|}{$\begin{array}{l}\text { Amostra } \\
\mathrm{N}=916\end{array}$} & MEGP1a & MEGP1b & MEGP1c \\
\hline Índices & $\chi / \mathrm{g} .1$. & 2,21 & 2,18 & 2,28 \\
\hline \multirow[t]{4}{*}{ Absolutos } & $\chi^{2} ;$ g.l. & 2051,17; 930 & 2026,13; 928 & 2116,$35 ; 930$ \\
\hline & $p$ & 0,000 & 0,000 & 0,000 \\
\hline & GFI (AGFI) & $0,91(0,90)$ & $0,91(0,90)$ & $0,90(0,89)$ \\
\hline & SRMR & 0,067 & 0,056 & 0,065 \\
\hline \multirow[t]{2}{*}{ Índices Relativos } & CFI & 0,94 & 0,94 & 0,94 \\
\hline & TLI & 0,94 & 0,94 & 0,93 \\
\hline Índices de & RMSEA & 0,036 & 0,036 & 0,037 \\
\hline Discrepância & (Lo90;Hi90) & $(0,034 ; 0,038)$ & $(0,034 ; 0,038)$ & $(0,035 ; 0,039)$ \\
\hline Populacional & & & & \\
\hline Índices de & PCFI & 0,89 & 0,88 & 0,88 \\
\hline Parcimônia & PGFI & 0,81 & 0,81 & 0,81 \\
\hline Índices Baseados na & AIC & 2261,17 & 2240,13 & 2326,35 \\
\hline Teoria da & ECVI & 2,47 & 2,45 & 2,54 \\
\hline Informação & CAIC & 2872,27 & 2862,87 & 2937,45 \\
\hline
\end{tabular}




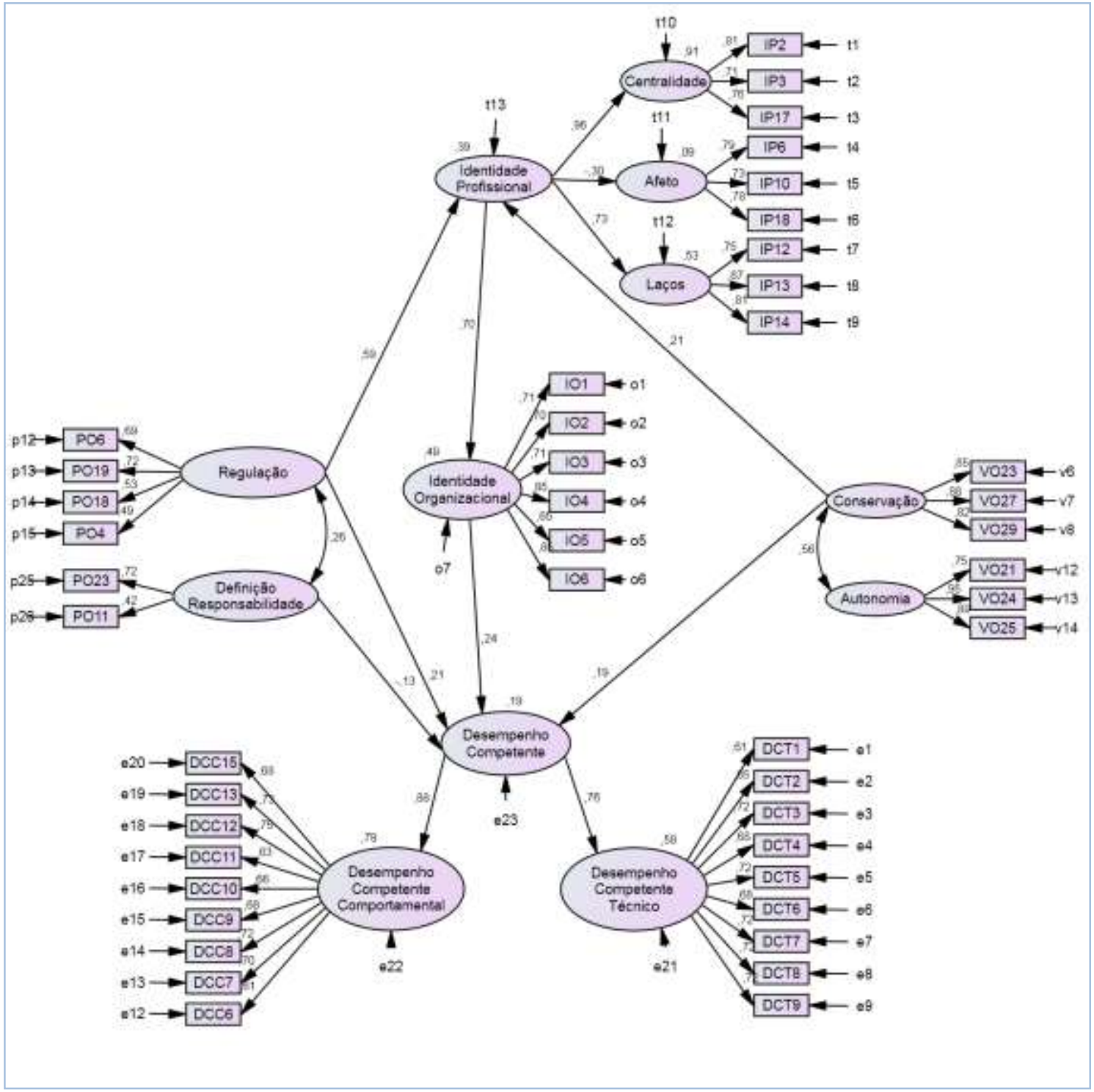

\begin{tabular}{|c|c|c|c|c|c|c|}
\hline \multicolumn{2}{|c|}{$\begin{array}{c}\text { Pesos Fatoriais } \\
\text { Não-Estandardizados }\end{array}$} & Estimate & S.E. & C.R. & $\mathrm{P}$ & Label \\
\hline IP & <--- $\quad$ Conservação & 0,084 & 0,014 & 5,822 & $* * *$ & par_45 \\
\hline IP & <--- Regulação & 0,684 & 0,058 & 11,855 & **** & par_47 \\
\hline IO & $<---\quad$ IP & 0,836 & 0,052 & 16,197 & **** & par_42 \\
\hline $\mathrm{DC}$ & $<---\quad$ IO & 0,119 & 0,022 & 5,306 & $* * *$ & par_43 \\
\hline DC & <--- Conservação & 0,045 & 0,010 & 4,718 & $* * *$ & par_44 \\
\hline DC & <--- Regulação & 0,148 & 0,038 & 3,907 & $* * *$ & par_46 \\
\hline DC & $<---\quad$ DR & $-0,081$ & 0,039 & $-2,092$ & 0,036 & par_48 \\
\hline DCC & $<---\quad D C$ & 1,000 & & & & \\
\hline DCT & $<---\quad D C$ & 1,000 & & & & \\
\hline Laços & $<---\quad$ IP & 0,732 & 0,045 & 16,382 & *** & par_29 \\
\hline Centralidade & $<---\quad$ IP & 1,000 & & & & \\
\hline Afeto & $<---\quad$ IP & $-0,373$ & 0,049 & $-7,593$ & $* * *$ & par_36 \\
\hline DCT9 & $<---\quad$ DCT & 1,000 & & & & \\
\hline
\end{tabular}

\begin{tabular}{lr}
$\begin{array}{c}\text { Correlações } \\
\text { Múltiplas ao } \\
\text { Quadrado }\end{array}$ & Estimate \\
\hline IP & 0,390 \\
IO & 0,488 \\
DC & 0,189 \\
Laços & 0,527 \\
Afeto & 0,092 \\
Centralidade & 0,912 \\
DCC & 0,776 \\
DCT & 0,585 \\
VO21 & 0,565 \\
VO24 & 0,896 \\
VO25 & 0,796 \\
VO23 & 0,725 \\
VO27 & 0,781 \\
\hline
\end{tabular}




\begin{tabular}{|c|c|c|c|c|c|c|c|c|c|}
\hline$\overline{\mathrm{DCT} 8}$ & $<---$ & DCT & 0,926 & 0,042 & 21,784 & $* * *$ & par_1 & VO29 & 0,666 \\
\hline DCT7 & $<---$ & DCT & 0,985 & 0,045 & 21,728 & $* * *$ & par_2 & IO1 & 0,509 \\
\hline DCT6 & $<---$ & DCT & 0,885 & 0,044 & 20,073 & $* * *$ & par_3 & IO2 & 0,486 \\
\hline DCT5 & $<---$ & DCT & 1,001 & 0,046 & 21,562 & $* * *$ & par_4 & IO3 & 0,508 \\
\hline DCT4 & $<---$ & DCT & 0,892 & 0,044 & 20,133 & $* * *$ & par_5 & IO4 & 0,728 \\
\hline DCT3 & $<---$ & DCT & 0,966 & 0,045 & 21,577 & $* * *$ & par_6 & IO5 & 0,427 \\
\hline DCT2 & $<---$ & DCT & 0,818 & 0,042 & 19,334 & $* * *$ & par_7 & IO6 & 0,722 \\
\hline DCT1 & $<---$ & DCT & 0,792 & 0,044 & 18,095 & $* * *$ & par_8 & IP12 & 0,566 \\
\hline DCC13 & $<---$ & DCC & 1,000 & & & & & IP13 & 0,751 \\
\hline DCC12 & $<---$ & DCC & 1,005 & 0,043 & 23,196 & $* * *$ & par_9 & IP14 & 0,659 \\
\hline DCC11 & $<---$ & DCC & 0,911 & 0,048 & 18,988 & $* * *$ & par_10 & IP6 & 0,618 \\
\hline DCC10 & $<---$ & DCC & 0,908 & 0,045 & 20,137 & $* * *$ & par_11 & IP10 & 0,529 \\
\hline DCC 9 & $<---$ & DCC & 0,993 & 0,048 & 20,535 & $* * *$ & par_12 & IP18 & 0,613 \\
\hline DCC8 & $<---$ & DCC & 1,017 & 0,047 & 21,769 & $* * *$ & par_13 & IP2 & 0,664 \\
\hline DCC7 & $<---$ & DCC & 1,017 & 0,048 & 21,064 & $* * *$ & par_14 & IP3 & 0,508 \\
\hline DCC6 & $<---$ & DCC & 0,903 & 0,050 & 18,223 & $* * *$ & par_15 & IP17 & 0,579 \\
\hline DCC15 & $<---$ & DCC & 1,004 & 0,049 & 20,586 & $* * *$ & par_16 & $\mathrm{PO} 23$ & 0,521 \\
\hline $\mathrm{PO} 4$ & $<---$ & Regulação & 0,719 & 0,059 & 12,211 & $* * *$ & par_17 & PO11 & 0,179 \\
\hline PO18 & $<---$ & Regulação & 0,755 & 0,061 & 12,479 & $* * *$ & par_18 & PO6 & 0,475 \\
\hline PO19 & $<---$ & Regulação & 1,033 & 0,068 & 15,181 & $* * *$ & par_19 & PO19 & 0,516 \\
\hline PO6 & $<---$ & Regulação & 1,000 & & & & & PO18 & 0,278 \\
\hline PO11 & $<---$ & DR & 0,615 & 0,193 & 3,183 & ,001 & par_21 & PO4 & 0,244 \\
\hline $\mathrm{PO} 23$ & $<---$ & DR & 1,000 & & & & & DCC15 & 0,459 \\
\hline IP17 & $<---$ & Centralidade & 1,000 & & & & & DCC6 & 0,371 \\
\hline IP3 & $<---$ & Centralidade & 0,905 & 0,043 & 21,237 & $* * *$ & par_22 & DCC7 & 0,493 \\
\hline IP2 & $<---$ & Centralidade & 1,045 & 0,044 & 23,817 & $* * *$ & par_23 & DCC8 & 0,520 \\
\hline IP18 & $<---$ & Afeto & 1,000 & & & & & DCC9 & 0,463 \\
\hline IP10 & $<---$ & Afeto & 0,924 & 0,047 & 19,606 & $* * *$ & par_24 & DCC10 & 0,439 \\
\hline IP6 & $<---$ & Afeto & 0,920 & 0,046 & 20,053 & $* * *$ & par_25 & DCC11 & 0,398 \\
\hline IP14 & $<---$ & Laços & 1,000 & & & & & DCC12 & 0,567 \\
\hline IP13 & $<---$ & Laços & 1,117 & 0,039 & 28,332 & $* * *$ & par_26 & DCC13 & 0,528 \\
\hline IP12 & $<---$ & Laços & 0,916 & 0,038 & 23,981 & $* * *$ & par_27 & DCT1 & 0,373 \\
\hline IO6 & $<---$ & IO & 1,000 & & & & & DCT2 & 0,419 \\
\hline IO5 & $<---$ & IO & 0,731 & 0,033 & 22,022 & $* * *$ & par_30 & DCT3 & 0,519 \\
\hline IO4 & $<---$ & IO & 0,961 & 0,030 & 32,004 & $* * *$ & par_31 & DCT4 & 0,459 \\
\hline IO3 & $<--$ & IO & 0,775 & 0,032 & 24,124 & $* * *$ & par_32 & DCT5 & 0,521 \\
\hline $\mathrm{IO} 2$ & $<---$ & IO & 0,781 & 0,033 & 23,538 & $* * *$ & par_33 & DCT6 & 0,457 \\
\hline IO1 & $<---$ & IO & 0,895 & 0,039 & 22,658 & $* * *$ & par_34 & DCT7 & 0,525 \\
\hline VO29 & $<---$ & Conservação & 0,967 & 0,034 & 28,478 & $* * *$ & par_37 & DCT8 & 0,523 \\
\hline VO27 & $<---$ & Conservação & 1,044 & 0,033 & 31,715 & $* * *$ & par_38 & DCT9 & 0,515 \\
\hline $\mathrm{VO} 23$ & $<---$ & Conservação & 1,000 & & & & & & \\
\hline VO25 & $<---$ & Autonomia & 1,000 & & & & & & \\
\hline VO24 & $<---$ & Autonomia & 1,069 & 0,027 & 39,463 & $* * *$ & par_39 & & \\
\hline $\mathrm{VO} 21$ & $<---$ & Autonomia & 0,872 & 0,031 & 28,238 & $* * *$ & par_40 & & \\
\hline
\end{tabular}

Figura 87. Modelo Estrutural Geral Parcimonioso 1a - MEGP1a. 


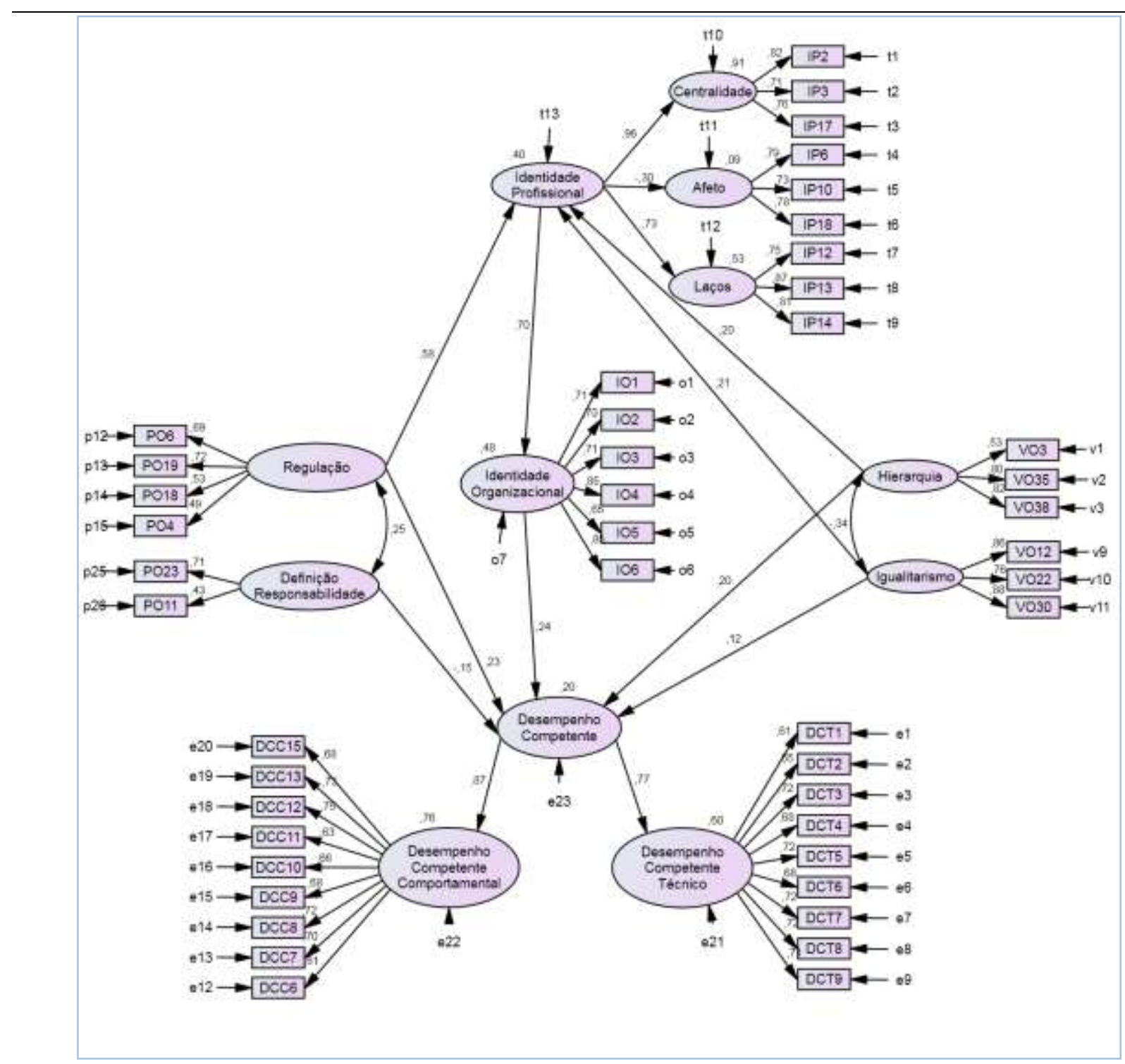

\begin{tabular}{|c|c|c|c|c|c|c|c|c|c|}
\hline \multicolumn{3}{|c|}{$\begin{array}{c}\text { Pesos Fatoriais } \\
\text { Não-Estandardizados }\end{array}$} & \multirow{2}{*}{$\begin{array}{l}\text { Estimate } \\
0,682\end{array}$} & \multirow{2}{*}{$\begin{array}{l}\text { S.E. } \\
0,058\end{array}$} & \multirow{2}{*}{$\begin{array}{c}\text { C.R. } \\
11,798\end{array}$} & \multirow{2}{*}{$\begin{array}{c}\mathrm{P} \\
* * *\end{array}$} & \multirow{2}{*}{$\begin{array}{c}\text { Label } \\
\text { par_40 }\end{array}$} & $\begin{array}{c}\text { Correlações } \\
\text { Múltiplas ao } \\
\text { Quadrado }\end{array}$ & \multirow{2}{*}{$\begin{array}{r}\text { Estimate } \\
0,396\end{array}$} \\
\hline IP & $<--$ & Regulação & & & & & & IP & \\
\hline IP & $<---$ & Hierarquia & 0,064 & 0,013 & 4,958 & $* * *$ & par_47 & IO & 0,484 \\
\hline IP & $<---$ & Igualitarismo & 0,051 & 0,010 & 5,164 & $* * *$ & par_48 & $\mathrm{DC}$ & 0,204 \\
\hline IO & $<---$ & IP & 0,834 & 0,051 & 16,202 & $* * *$ & par_37 & Laços & 0,530 \\
\hline DC & $<--$ & IO & 0,120 & 0,023 & 5,310 & $* * *$ & par_38 & Afeto & 0,088 \\
\hline DC & $<---$ & Regulação & 0,163 & 0,038 & 4,285 & $* * *$ & par_39 & Centralidade & 0,915 \\
\hline DC & $<---$ & DR & $-0,093$ & 0,041 & $-2,266$ & 0,023 & par_41 & DCC & 0,757 \\
\hline DC & $<--$ & Hierarquia & 0,039 & 0,009 & 4,417 & $* * *$ & par_49 & DCT & 0,599 \\
\hline DC & $<---$ & Igualitarismo & 0,017 & 0,007 & 2,578 & 0,010 & par_50 & VO12 & 0,737 \\
\hline DCC & $<---$ & DC & 1,000 & & & & & VO22 & 0,573 \\
\hline DCT & $<---$ & DC & 1,000 & & & & & VO30 & 0,766 \\
\hline Laços & $<--$ & IP & 0,735 & 0,045 & 16,346 & $* * *$ & par_29 & VO3 & 0,277 \\
\hline Centralidade & $<---$ & IP & 1,000 & & & & & VO35 & 0,636 \\
\hline Afeto & $<--$ & IP & $-0,366$ & 0,049 & $-7,475$ & $* * *$ & par_36 & VO38 & 0,674 \\
\hline DCT9 & $<---$ & DCT & 1,000 & & & & & IO1 & 0,509 \\
\hline
\end{tabular}




\begin{tabular}{|c|c|c|c|c|c|c|c|c|c|}
\hline DCT8 & $<---$ & DCT & 0,934 & 0,043 & 21,598 & $* * *$ & par_1 & IO2 & 0,486 \\
\hline DCT7 & $<--$ & DCT & 0,994 & 0,046 & 21,539 & $* * *$ & par_2 & IO3 & 0,508 \\
\hline DCT6 & $<--$ & DCT & 0,894 & 0,045 & 19,920 & $* * *$ & par_3 & IO4 & 0,728 \\
\hline DCT5 & $<--$ & DCT & 1,011 & 0,047 & 21,376 & $* * *$ & par_4 & IO5 & 0,427 \\
\hline DCT4 & $<--$ & DCT & 0,901 & 0,045 & 19,984 & $* * *$ & par_5 & IO6 & 0,723 \\
\hline DCT3 & $<--$ & DCT & 0,975 & 0,046 & 21,396 & $* * *$ & par_6 & IP12 & 0,565 \\
\hline DCT2 & $<--$ & DCT & 0,826 & 0,043 & 19,204 & $* * *$ & par_7 & IP13 & 0,751 \\
\hline DCT1 & $<--$ & DCT & 0,800 & 0,044 & 17,988 & $* * *$ & par_8 & IP14 & 0,659 \\
\hline DCC13 & $<--$ & DCC & 1,000 & & & & & IP6 & 0,618 \\
\hline DCC12 & $<--$ & DCC & 0,997 & 0,043 & 23,291 & $* * *$ & par_9 & IP10 & 0,528 \\
\hline DCC11 & $<--$ & DCC & 0,904 & 0,047 & 19,051 & $* * *$ & par_10 & IP18 & 0,613 \\
\hline DCC10 & $<--$ & DCC & 0,900 & 0,045 & 20,193 & $* * *$ & par_11 & IP2 & 0,665 \\
\hline DCC9 & $<---$ & DCC & 0,985 & 0,048 & 20,595 & $* * *$ & par_12 & IP3 & 0,510 \\
\hline DCC8 & $<---$ & DCC & 1,009 & 0,046 & 21,855 & $* * *$ & par_13 & IP17 & 0,576 \\
\hline DCC7 & $<--$ & DCC & 1,008 & 0,048 & 21,138 & $* * *$ & par_14 & $\mathrm{PO} 23$ & 0,510 \\
\hline DCC6 & $<--$ & DCC & 0,897 & 0,049 & 18,282 & $* * *$ & par_15 & PO11 & 0,183 \\
\hline DCC15 & $<---$ & DCC & 0,997 & 0,048 & 20,667 & $* * *$ & par_16 & PO6 & 0,472 \\
\hline $\mathrm{PO} 4$ & $<--$ & Regulação & 0,721 & 0,059 & 12,210 & $* * *$ & par_17 & PO19 & 0,516 \\
\hline PO18 & $<--$ & Regulação & 0,763 & 0,061 & 12,542 & **** & par_18 & PO18 & 0,282 \\
\hline PO19 & $<--$ & Regulação & 1,036 & 0,068 & 15,213 & $* * *$ & par_19 & PO4 & 0,244 \\
\hline PO6 & $<--$ & Regulação & 1,000 & & & & & DCC15 & 0,463 \\
\hline PO11 & $<--$ & DR & 0,629 & 0,193 & 3,256 & 0,001 & par_21 & DCC6 & 0,375 \\
\hline $\mathrm{PO} 23$ & $<---$ & DR & 1,000 & & & & & DCC7 & 0,496 \\
\hline IP17 & $<--$ & Centralidade & 1,000 & & & & & DCC8 & 0,523 \\
\hline IP3 & $<--$ & Centralidade & 0,908 & 0,043 & 21,244 & $* * *$ & par_22 & DCC9 & 0,465 \\
\hline IP2 & $<---$ & Centralidade & 1,049 & 0,044 & 23,812 & $* * *$ & par_23 & DCC10 & 0,442 \\
\hline IP18 & $<--$ & Afeto & 1,000 & & & & & DCC11 & 0,401 \\
\hline IP10 & $<--$ & Afeto & 0,924 & 0,047 & 19,589 & $* * *$ & par_24 & DCC12 & 0,570 \\
\hline IP6 & $<--$ & Afeto & 0,918 & 0,046 & 20,013 & $* * *$ & par_25 & DCC13 & 0,535 \\
\hline IP14 & $<---$ & Laços & 1,000 & & & & & DCT1 & 0,372 \\
\hline IP13 & $<---$ & Laços & 1,117 & 0,039 & 28,349 & $* * *$ & par_26 & DCT2 & 0,419 \\
\hline IP12 & $<--$ & Laços & 0,916 & 0,038 & 23,987 & $* * *$ & par_27 & DCT3 & 0,519 \\
\hline IO6 & $<--$ & IO & 1,000 & & & & & DCT4 & 0,458 \\
\hline IO5 & $<---$ & IO & 0,730 & 0,033 & 22,022 & $* * *$ & par_30 & DCT5 & 0,522 \\
\hline IO4 & $<--$ & IO & 0,960 & 0,030 & 32,010 & $* * *$ & par_31 & DCT6 & 0,457 \\
\hline IO3 & $<---$ & IO & 0,775 & 0,032 & 24,118 & $* * *$ & par_32 & DCT7 & 0,525 \\
\hline $\mathrm{IO} 2$ & $<---$ & IO & 0,781 & 0,033 & 23,535 & $* * *$ & par_33 & DCT8 & 0,522 \\
\hline IO1 & $<--$ & IO & 0,895 & 0,039 & 22,663 & $* * *$ & par_34 & DCT9 & 0,509 \\
\hline VO38 & $<--$ & Hierarquia & 1,000 & & & & & & \\
\hline VO35 & $<---$ & Hierarquia & 1,010 & 0,060 & 16,693 & $* * *$ & par_42 & & \\
\hline VO3 & $<--$ & Hierarquia & 0,608 & 0,044 & 13,864 & $* * *$ & par_43 & & \\
\hline VO30 & $<--$ & Igualitarismo & 1,000 & & & & & & \\
\hline $\mathrm{VO} 22$ & $<--$ & Igualitarismo & 0,595 & 0,024 & 25,258 & $* * *$ & par_44 & & \\
\hline VO12 & $<--$ & Igualitarismo & 0,875 & 0,031 & 27,942 & $* * *$ & par_45 & & \\
\hline
\end{tabular}

Figura 88. Modelo Estrutural Geral Parcimonioso 1b - MEGP1b. 


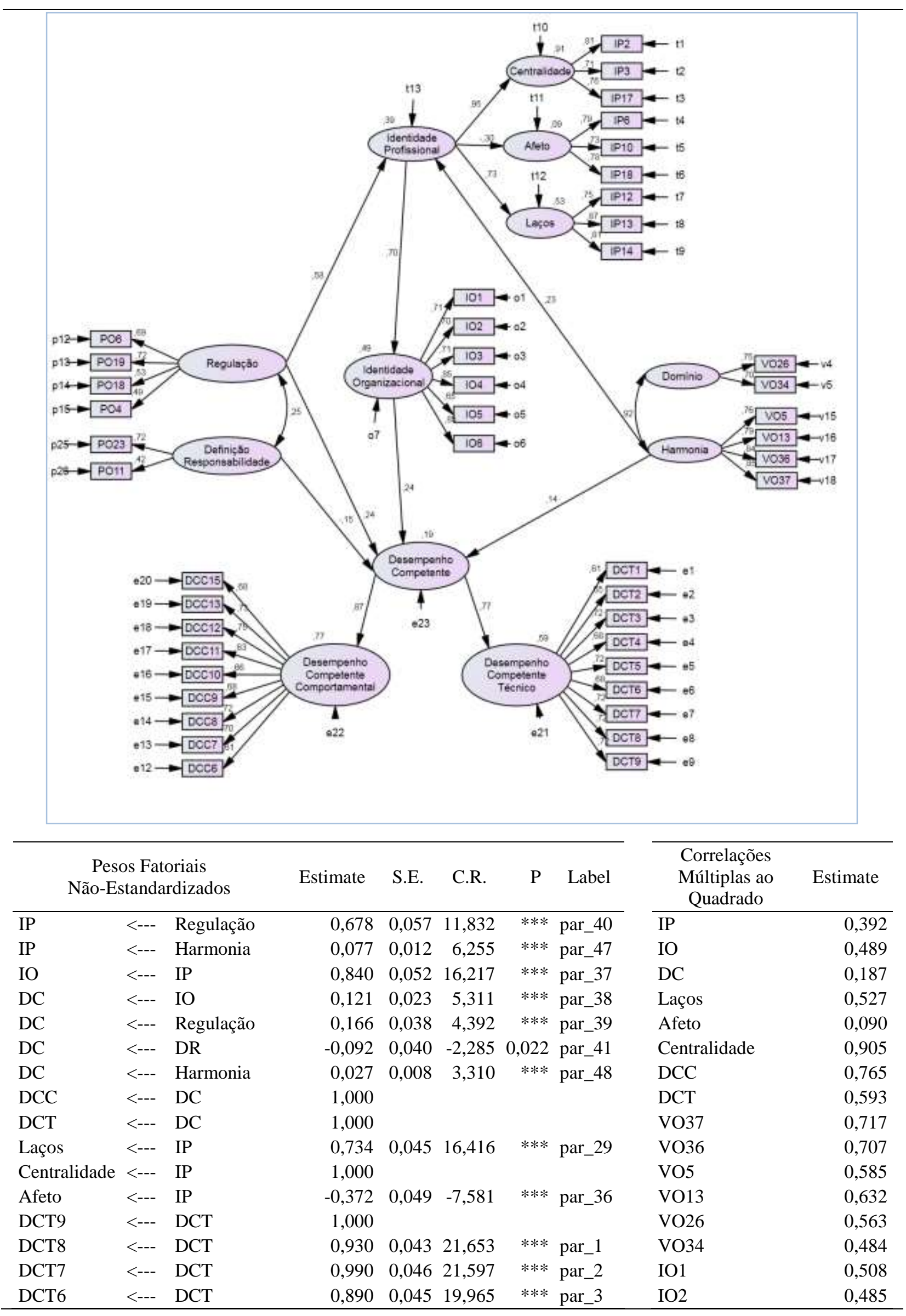




\begin{tabular}{|c|c|c|c|c|c|c|c|c|c|}
\hline DCT5 & <--- & DCT & 1,006 & 0,047 & 21,434 & $* * *$ & par_4 & IO3 & 0,507 \\
\hline DCT4 & $<--$ & DCT & 0,897 & 0,045 & 20,028 & $* * *$ & par_5 & IO4 & 0,727 \\
\hline DCT3 & $<---$ & DCT & 0,971 & 0,045 & 21,449 & $* * *$ & par_6 & IO5 & 0,426 \\
\hline DCT2 & $<---$ & DCT & 0,823 & 0,043 & 19,242 & $* * *$ & par_7 & IO6 & 0,722 \\
\hline DCT1 & $<---$ & DCT & 0,797 & 0,044 & 18,019 & $* * *$ & par_8 & IP12 & 0,564 \\
\hline DCC13 & $<---$ & DCC & 1,000 & & & & & IP13 & 0,750 \\
\hline DCC12 & $<---$ & DCC & 1,000 & 0,043 & 23,223 & $* * *$ & par_9 & IP14 & 0,658 \\
\hline DCC11 & $<--$ & DCC & 0,906 & 0,048 & 19,011 & $* * *$ & par_10 & IP6 & 0,619 \\
\hline DCC10 & $<--$ & DCC & 0,902 & 0,045 & 20,136 & $* * *$ & par_11 & IP10 & 0,528 \\
\hline DCC9 & $<---$ & DCC & 0,989 & 0,048 & 20,564 & $* * *$ & par_12 & IP18 & 0,612 \\
\hline DCC8 & $<--$ & DCC & 1,012 & 0,046 & 21,799 & $* * *$ & par_13 & IP2 & 0,662 \\
\hline DCC7 & $<---$ & DCC & 1,011 & 0,048 & 21,086 & $* * *$ & par_14 & IP3 & 0,507 \\
\hline DCC6 & $<--$ & DCC & 0,899 & 0,049 & 18,239 & $* * *$ & par_15 & IP17 & 0,576 \\
\hline DCC15 & $<---$ & DCC & 0,999 & 0,048 & 20,605 & $* * *$ & par_16 & $\mathrm{PO} 23$ & 0,519 \\
\hline PO4 & $<--$ & Regulação & 0,719 & 0,059 & 12,220 & $* * *$ & par_17 & PO11 & 0,180 \\
\hline PO18 & $<---$ & Regulação & 0,757 & 0,061 & 12,515 & $* * *$ & par_18 & PO6 & 0,475 \\
\hline PO19 & $<---$ & Regulação & 1,029 & 0,068 & 15,212 & $* * *$ & par_19 & PO19 & 0,514 \\
\hline PO6 & $<--$ & Regulação & 1,000 & & & & & PO18 & 0,280 \\
\hline PO11 & $<--$ & DR & 0,617 & 0,191 & 3,228 & ,001 & par_21 & PO4 & 0,244 \\
\hline $\mathrm{PO} 23$ & $<---$ & DR & 1,000 & & & & & DCC15 & 0,461 \\
\hline IP17 & $<--$ & Centralidade & 1,000 & & & & & DCC6 & 0,373 \\
\hline IP3 & $<--$ & Centralidade & 0,904 & 0,043 & 21,227 & $* * *$ & par_22 & DCC7 & 0,494 \\
\hline IP2 & $<---$ & Centralidade & 1,046 & 0,044 & 23,820 & $* * *$ & par_23 & DCC8 & 0,522 \\
\hline IP18 & $<---$ & Afeto & 1,000 & & & & & DCC9 & 0,465 \\
\hline IP10 & $<--$ & Afeto & 0,924 & 0,047 & 19,610 & $* * *$ & par_24 & DCC10 & 0,439 \\
\hline IP6 & $<---$ & Afeto & 0,921 & 0,046 & 20,038 & $* * *$ & par_25 & DCC11 & 0,400 \\
\hline IP14 & $<---$ & Laços & 1,000 & & & & & DCC12 & 0,568 \\
\hline IP13 & $<--$ & Laços & 1,117 & 0,039 & 28,335 & $* * *$ & par_26 & DCC13 & 0,533 \\
\hline IP12 & $<---$ & Laços & 0,916 & 0,038 & 23,982 & $* * *$ & par_27 & DCT1 & 0,373 \\
\hline IO6 & $<---$ & IO & 1,000 & & & & & DCT2 & 0,419 \\
\hline IO5 & $<---$ & IO & 0,730 & 0,033 & 22,014 & $* * *$ & par_30 & DCT3 & 0,519 \\
\hline IO4 & $<--$ & IO & 0,961 & 0,030 & 32,016 & $* * *$ & par_31 & DCT4 & 0,458 \\
\hline IO3 & $<---$ & IO & 0,775 & 0,032 & 24,131 & $* * *$ & par_32 & DCT5 & 0,521 \\
\hline IO2 & $<---$ & IO & 0,781 & 0,033 & 23,542 & $* * *$ & par_33 & DCT6 & 0,457 \\
\hline IO1 & $<--$ & IO & 0,895 & 0,039 & 22,659 & $* * *$ & par_34 & DCT7 & 0,525 \\
\hline VO34 & $<---$ & Domínio & 1,000 & & & & & DCT8 & 0,523 \\
\hline VO26 & $<---$ & Domínio & 1,175 & 0,061 & 19,367 & $* * *$ & par_42 & DCT9 & 0,512 \\
\hline VO13 & $<--$ & Harmonia & 0,874 & 0,032 & 27,490 & $* * *$ & par_43 & & \\
\hline VO5 & $<---$ & Harmonia & 0,884 & 0,034 & 25,980 & $* * *$ & par_44 & & \\
\hline VO37 & $<---$ & Harmonia & 0,992 & 0,032 & 30,943 & $* * *$ & par_45 & & \\
\hline VO36 & $<--$ & Harmonia & 1,000 & & & & & & \\
\hline
\end{tabular}

Figura 89. Modelo Estrutural Geral Parcimonioso 1c - MEGP1c. 


\section{Modelos Estruturais Gerais Parcimoniosos 2 (MEGP2 a,b e c)}

No segundo modelo estrutural parcimonioso (MEGP2a) ocorre a inversão na ordem da identidade no modelo, passando a identidade organizacional ser antecedente à identidade profissional. Desse modo, testou-se a influência dos tipos motivacionais conservação $x$ autonomia, das práticas organizacionais de regulação e definição de responsabilidade, da identidade organizacional e da identidade profissional sobre o desempenho profissional por competências. O modelo descreve a relação (VO Conservação $x$ Autonomia e PO Regulação e Definição de Responsabilidade $\rightarrow I O \rightarrow I P \rightarrow D C ; V O$ e $P O \rightarrow D C ; I P \rightarrow D C$ ) em que os valores e as práticas organizacionais influenciam a identidade organizacional e o desempenho profissional de forma direta. No ajuste do MEGP2a, o teste do qui-quadrado mostrou que o valor de $\mathrm{p}$ foi menor que o limite de 0,05 , portanto, outros índices foram considerados (absoluto, relativo, parcimônia, discrepância populacional, e baseados na teoria da informação). Os resultados dos novos índices apontam para um ajuste adequado do modelo MEGP2a aos dados da amostra total (conforme Tabela 67).

$\mathrm{Na}$ análise do modelo MEGP2a, os tipos motivacionais conservação $(p<0,000)$ e Autonomia $(\mathrm{p}<0,05)$, em conjunto com as práticas de regulação $(\mathrm{p}<0,000)$ e definição de responsabilidades $(\mathrm{p}<0,05)$ foram responsáveis por explicar $21 \%$ da identidade organizacional. A identidade organizacional, sofrendo efeitos diretos do tipo motivacional conservação e das práticas organizacionais de regulação e definição de responsabilidade, explicou $51 \%$ da variância da identidade profissional $\left(R^{2}=0,92\right.$ para centralidade; $R^{2}=0,10$ para afeto; e $\mathrm{R}^{2}=0,53$ para laços). No que se refere a mediação em cadeia do MEGP2a, a identidade organizacional e a identidade profissional mediaram parcialmente a relação entre o tipo motivacional conservação e o desempenho profissional $(p=0,001)$ e totalmente entre o tipo autonomia e o desempenho profissional $(\mathrm{p}=0,280)$. Em relação às práticas organizacionais, a identidade profissional e a identidade organizacional mediaram parcialmente a relação entre as práticas de regulação e definição de responsabilidade e o desempenho profissional $(\mathrm{p}=0,001 \mathrm{e} \mathrm{p}=0,001)$. O modelo foi responsável por explicar $22 \%$ da variância do desempenho profissional $\left(\mathrm{R}^{2}=0,59\right.$ de explicação para o desempenho por competências técnicas; $\mathrm{R}^{2}=0,77$ de explicação para o desempenho por competências comportamentais), conforme Figura 90.

O modelo estrutural Parcimonioso (MEGP2b) testou a influência dos tipos motivacionais hierarquia $x$ igualitarismo, práticas organizacionais de regulação e definição de responsabilidade, identidade organizacional e identidade profissional sobre o desempenho 
profissional por competências. Neste MEGP2b, descreve-se a relação (VO Hierarquia $x$ Igualitarismo e PO Regulação e Definição de Responsabilidade $\rightarrow I O \rightarrow I P \rightarrow D C$; VO e PO $\rightarrow D C ; I P \rightarrow D C$ ) em que os valores e as práticas organizacionais diretamente influenciam a identidade organizacional e o desempenho profissional. O teste do qui-quadrado apresentou um p-valor abaixo do limite de 0,05. Os índices de ajustamento mostraram-se satisfatórios, conforme Tabela 67.

Apresentaram-se significativos os tipos motivacionais hierarquia e igualitarismo $(\mathrm{p}<0,000)$, que em conjunto com a prática de regulação $(\mathrm{p}<0,000)$ foram responsáveis por explicar $21 \%$ da variância da identidade organizacional. A identidade organizacional, recebendo efeitos diretos dos tipos motivacionais hierarquia e igualitarismo, e da prática organizacional de regulação, explicou $51 \%$ da variância da identidade profissional $\left(\mathrm{R}^{2}=0,92\right.$ para centralidade; $\mathrm{R}^{2}=0,10$ para afeto; e $\mathrm{R}^{2}=0,53$ para laços). No que se refere a mediação em cadeia do MEGP2b, a identidade organizacional e a identidade profissional mediaram parcialmente a relação entre os tipos motivacionais hierarquia e igualitarismo e o desempenho profissional $(\mathrm{p}=0,001 \mathrm{e} \mathrm{p}=0,001$, respectivamente). Em relação às práticas organizacionais, a identidade organizacional e a identidade profissional mediaram parcialmente a relação entre a prática de regulação e o desempenho profissional $(p=0,001)$. $O$ modelo foi responsável por explicar $22 \%$ da variância do desempenho profissional $\left(\mathrm{R}^{2}=0,60\right.$ de explicação para o desempenho por competências técnicas; $\mathrm{R}^{2}=0,75$ de explicação para $\mathrm{O}$ desempenho por competências comportamentais), conforme Figura 91.

O modelo estrutural Parcimonioso (MEGP2c) testou a influência dos tipos motivacionais domínio $x$ harmonia, práticas organizacionais de regulação e definição de responsabilidade, identidade organizacional e identidade profissional sobre o desempenho profissional por competências. Neste MEGP2c, registra-se a relação (VO Domínio $x$ Harmonia e PO Regulação e Definição de Responsabilidade $\rightarrow I O \rightarrow I P \rightarrow D C ; V O$ e $P O \rightarrow D C ; I P \rightarrow D C$ ) em que os valores e as práticas organizacionais influenciam de forma direta a identidade organizacional e o desempenho profissional. Como o teste do qui-quadrado mostrou um p-valor inferior ao limite de 0,05. Procedeu-se, a análise de outros indicadores de adequação do modelo, que mostraram-se ajustados aos dados para a amostra total (conforme Tabela 67).

Apresentaram-se significativos os tipos motivacionais harmonia $(\mathrm{p}<0,000)$, que em conjunto com a prática de regulação $(\mathrm{p}<0,000)$ explicaram $22 \%$ da variância da identidade organizacional. A identidade organizacional, recebendo efeitos diretos do tipo motivacional domínio e da prática organizacional de regulação, explicou $51 \%$ da variância da identidade profissional $\left(\mathrm{R}^{2}=0,92\right.$ para centralidade; $\mathrm{R}^{2}=0,10$ para afeto; e $\mathrm{R}^{2}=0,53$ para laços $)$. No que 
se refere a mediação em cadeia do MEGP2c, a identidade organizacional e a identidade profissional mediaram parcialmente a relação entre o tipo motivacional harmonia e o desempenho profissional $(\mathrm{p}=0,001)$. Em relação às práticas organizacionais, a identidade organizacional e a identidade profissional mediaram parcialmente a relação entre a prática de regulação e o desempenho profissional $(p=0,001)$. O modelo foi responsável por explicar $22 \%$ da variância do desempenho profissional $\left(\mathrm{R}^{2}=0,60\right.$ de explicação para o desempenho por competências técnicas; $\mathrm{R}^{2}=0,76$ de explicação para o desempenho por competências comportamentais), conforme Figura 92.

Tabela 67

Índices de ajustamento do MEGP2 $a, b$ e $c$

\begin{tabular}{|c|c|c|c|c|}
\hline \multicolumn{2}{|l|}{$\begin{array}{l}\text { Amostra } \\
\mathrm{N}=916\end{array}$} & \multirow{2}{*}{$\begin{array}{c}\text { MEGP2a } \\
2,30\end{array}$} & MEGP2b & MEGP2c \\
\hline Índices & $\chi /$ g.l. & & 2,29 & 2,40 \\
\hline Absolutos & $\chi^{2} ;$ g.l. & 2135,$81 ; 929$ & 2127,$68 ; 928$ & 2203,$31 ; 930$ \\
\hline & $p$ & 0,000 & 0,000 & 0,000 \\
\hline & GFI (AGFI) & $0,90(0,89)$ & $0,90(0,89)$ & $0,90(0,89)$ \\
\hline & SRMR & 0,067 & 0,059 & 0,066 \\
\hline Índices Relativos & CFI & 0,94 & 0,94 & 0,93 \\
\hline & TLI & 0,94 & 0,93 & 0,93 \\
\hline Índices de & RMSEA & 0,038 & 0,038 & 0,039 \\
\hline $\begin{array}{l}\text { Discrepância } \\
\text { Populacional }\end{array}$ & (Lo90;Hi90) & $(0,036 ; 0,040)$ & $(0,035 ; 0,040)$ & $(0,037 ; 0,041)$ \\
\hline Índices de & PCFI & 0,88 & 0,88 & 0,88 \\
\hline Parcimônia & PGFI & 0,81 & 0,81 & 0,81 \\
\hline Índices Baseados na & AIC & 2347,81 & 2341,68 & 2413,31 \\
\hline Teoria da & ECVI & 2,57 & 2,56 & 2,63 \\
\hline Informação & CAIC & 2964,73 & 2964,42 & 3024,42 \\
\hline
\end{tabular}




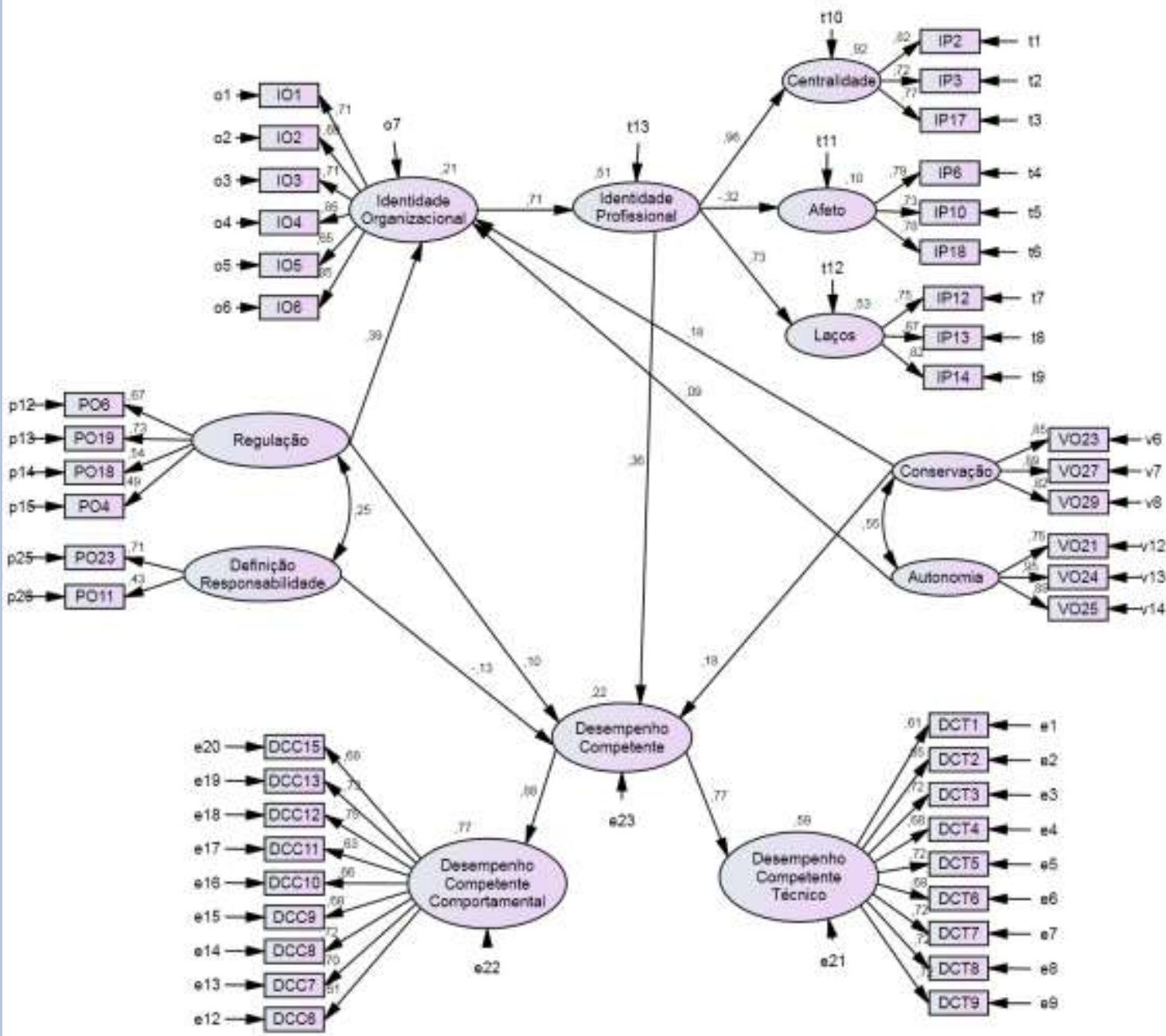

\begin{tabular}{|c|c|c|c|c|c|c|c|c|c|}
\hline \multicolumn{3}{|c|}{$\begin{array}{c}\text { Pesos Fatoriais } \\
\text { Não-Estandardizados }\end{array}$} & \multirow{2}{*}{$\begin{array}{r}\text { Estimate } \\
0,083\end{array}$} & \multirow{2}{*}{$\begin{array}{l}\text { S.E. } \\
0,020\end{array}$} & \multirow{2}{*}{$\begin{array}{l}\text { C.R. } \\
4,136\end{array}$} & \multirow{2}{*}{$\begin{array}{c}\mathrm{P} \\
* * *\end{array}$} & \multirow{2}{*}{$\begin{array}{c}\text { Label } \\
\text { par_46 }\end{array}$} & \multirow[t]{2}{*}{$\begin{array}{c}\text { Correlações } \\
\text { Múltiplas ao } \\
\text { Quadrado } \\
\end{array}$} & \multirow{2}{*}{$\begin{array}{r}\text { Estimate } \\
0,208\end{array}$} \\
\hline $\mathrm{IO}$ & $<--$ & Conservação & & & & & & & \\
\hline IO & $<--$ & Autonomia & 0,035 & 0,016 & 2,184 & 0,029 & par_47 & IP & 0,507 \\
\hline IO & $<--$ & Regulação & 0,547 & 0,063 & 8,735 & $* * *$ & par_49 & DC & 0,218 \\
\hline IP & $<--$ & IO & 0,617 & 0,034 & 18,222 & $* * *$ & par_48 & Laços & 0,526 \\
\hline DC & $<--$ & Conservação & 0,043 & 0,010 & 4,522 & $* * *$ & par_42 & Afeto & 0,103 \\
\hline DC & $<--$ & Regulação & 0,075 & 0,039 & 1,911 & 0,050 & par_43 & Centralidade & 0,923 \\
\hline DC & $<--$ & DR & $-0,080$ & 0,038 & $-2,109$ & 0,035 & par_44 & DCC & 0,766 \\
\hline DC & $<--$ & IP & 0,209 & 0,030 & 6,997 & $* * *$ & par_45 & DCT & 0,590 \\
\hline DCC & $<--$ & DC & 1,000 & & & & & VO21 & 0,565 \\
\hline DCT & $<--$ & DC & 1,000 & & & & & VO24 & 0,895 \\
\hline Laços & $<--$ & IP & 0,723 & 0,046 & 15,657 & $* * *$ & par_29 & VO25 & 0,796 \\
\hline Centralidade & $<--$ & IP & 1,000 & & & & & VO23 & 0,724 \\
\hline Afeto & $<--$ & IP & $-0,385$ & 0,050 & $-7,749$ & $* * *$ & par_36 & VO27 & 0,784 \\
\hline DCT9 & $<--$ & DCT & 1,000 & & & & & VO29 & 0,664 \\
\hline DCT8 & $<--$ & DCT & 0,929 & 0,043 & 21,799 & $* * *$ & par_1 & IO1 & 0,501 \\
\hline
\end{tabular}




\begin{tabular}{|c|c|c|c|c|c|c|c|c|c|}
\hline DCT7 & $<---$ & DCT & 0,989 & 0,045 & 21,747 & $* * *$ & $\overline{\text { par_2 }}$ & $\mathrm{IO} 2$ & 0,481 \\
\hline DCT6 & $<---$ & DCT & 0,889 & 0,044 & 20,089 & $* * *$ & par_3 & IO3 & 0,506 \\
\hline DCT5 & $<---$ & DCT & 1,005 & 0,047 & 21,586 & **** & par_4 & IO4 & 0,717 \\
\hline DCT4 & $<---$ & DCT & 0,896 & 0,044 & 20,152 & $* * *$ & par_5 & IO5 & 0,416 \\
\hline DCT3 & $<---$ & DCT & 0,970 & 0,045 & 21,599 & $* * *$ & par_6 & IO6 & 0,717 \\
\hline DCT2 & $<---$ & DCT & 0,821 & 0,042 & 19,350 & $* * *$ & par_7 & IP12 & 0,569 \\
\hline DCT1 & $<---$ & DCT & 0,795 & 0,044 & 18,111 & $* * *$ & par_8 & IP13 & 0,755 \\
\hline $\mathrm{DCC} 13$ & $<---$ & DCC & 1,000 & & & & & IP14 & 0,665 \\
\hline DCC12 & $<---$ & DCC & 1,001 & 0,043 & 23,371 & $* * *$ & par_9 & IP6 & 0,622 \\
\hline DCC11 & $<---$ & DCC & 0,907 & 0,048 & 19,088 & $* * *$ & par_10 & IP10 & 0,530 \\
\hline DCC10 & $<---$ & DCC & 0,904 & 0,045 & 20,250 & $* * *$ & par_11 & IP18 & 0,612 \\
\hline DCC9 & $<--$ & DCC & 0,988 & 0,048 & 20,647 & $* * *$ & par_12 & IP2 & 0,671 \\
\hline DCC8 & $<---$ & DCC & 1,012 & 0,046 & 21,911 & $* * *$ & par_13 & IP3 & 0,517 \\
\hline DCC7 & $<---$ & DCC & 1,012 & 0,048 & 21,202 & $* * *$ & par_14 & IP17 & 0,588 \\
\hline DCC6 & $<---$ & DCC & 0,899 & 0,049 & 18,312 & $* * *$ & par_15 & $\mathrm{PO} 23$ & 0,511 \\
\hline DCC15 & $<---$ & DCC & 1,001 & 0,048 & 20,719 & $* * *$ & par_16 & PO11 & 0,183 \\
\hline PO4 & $<---$ & Regulação & 0,736 & 0,062 & 11,902 & $* * *$ & par_17 & PO6 & 0,450 \\
\hline PO18 & $<---$ & Regulação & 0,797 & 0,065 & 12,332 & $* * *$ & par_18 & PO19 & 0,537 \\
\hline PO19 & $<---$ & Regulação & 1,082 & 0,076 & 14,263 & $* * *$ & par_19 & PO18 & 0,294 \\
\hline PO6 & $<---$ & Regulação & 1,000 & & & & & $\mathrm{PO} 4$ & 0,242 \\
\hline PO11 & $<---$ & DR & 0,627 & 0,198 & 3,169 & 0,002 & par_21 & DCC15 & 0,461 \\
\hline $\mathrm{PO} 23$ & $<---$ & DR & 1,000 & & & & & DCC6 & 0,372 \\
\hline IP17 & $<---$ & Centralidade & 1,000 & & & & & DCC7 & 0,493 \\
\hline IP3 & $<---$ & Centralidade & 0,905 & 0,043 & 21,117 & $* * *$ & par_22 & DCC8 & 0,520 \\
\hline IP2 & $<---$ & Centralidade & 1,044 & 0,044 & 23,550 & $* * *$ & par_23 & DCC9 & 0,462 \\
\hline IP18 & $<---$ & Afeto & 1,000 & & & & & DCC10 & 0,440 \\
\hline IP10 & $<---$ & Afeto & 0,926 & 0,047 & 19,649 & $* * *$ & par_24 & DCC11 & 0,399 \\
\hline IP6 & $<---$ & Afeto & 0,924 & 0,046 & 20,106 & $* * *$ & par_25 & DCC12 & 0,567 \\
\hline IP14 & $<---$ & Laços & 1,000 & & & & & DCC13 & 0,531 \\
\hline IP13 & $<---$ & Laços & 1,116 & 0,039 & 28,270 & $* * *$ & par_26 & DCT1 & 0,372 \\
\hline IP12 & $<---$ & Laços & 0,914 & 0,038 & 23,953 & $* * *$ & par_27 & DCT2 & 0,418 \\
\hline IO6 & $<---$ & IO & 1,000 & & & & & DCT3 & 0,518 \\
\hline IO5 & $<---$ & IO & 0,727 & 0,033 & 21,873 & $* * *$ & par_30 & DCT4 & 0,458 \\
\hline IO4 & $<---$ & IO & 0,958 & 0,030 & 31,979 & $* * *$ & par_31 & DCT5 & 0,520 \\
\hline IO3 & $<--$ & IO & 0,778 & 0,032 & 24,249 & $* * *$ & par_32 & DCT6 & 0,457 \\
\hline $\mathrm{IO} 2$ & $<--$ & IO & 0,782 & 0,033 & 23,580 & $* * *$ & par_33 & DCT7 & 0,524 \\
\hline IO1 & $<---$ & IO & 0,893 & 0,039 & 22,649 & $* * *$ & par_34 & DCT8 & 0,522 \\
\hline VO29 & $<--$ & Conservação & 0,966 & 0,034 & 28,471 & $* * *$ & par_37 & DCT9 & 0,512 \\
\hline VO27 & $<---$ & Conservação & 1,046 & 0,033 & 31,685 & $* * *$ & par_38 & & \\
\hline VO23 & $<---$ & Conservação & 1,000 & & & & & & \\
\hline VO25 & $<---$ & Autonomia & 1,000 & & & & & & \\
\hline VO24 & $<--$ & Autonomia & 1,068 & 0,027 & 39,501 & $* * *$ & par_39 & & \\
\hline VO21 & $<---$ & Autonomia & 0,872 & 0,031 & 28,243 & $* * *$ & par_40 & & \\
\hline
\end{tabular}

Figura 90. Modelo Estrutural Geral Parcimonioso 2a - MEGP2a. 


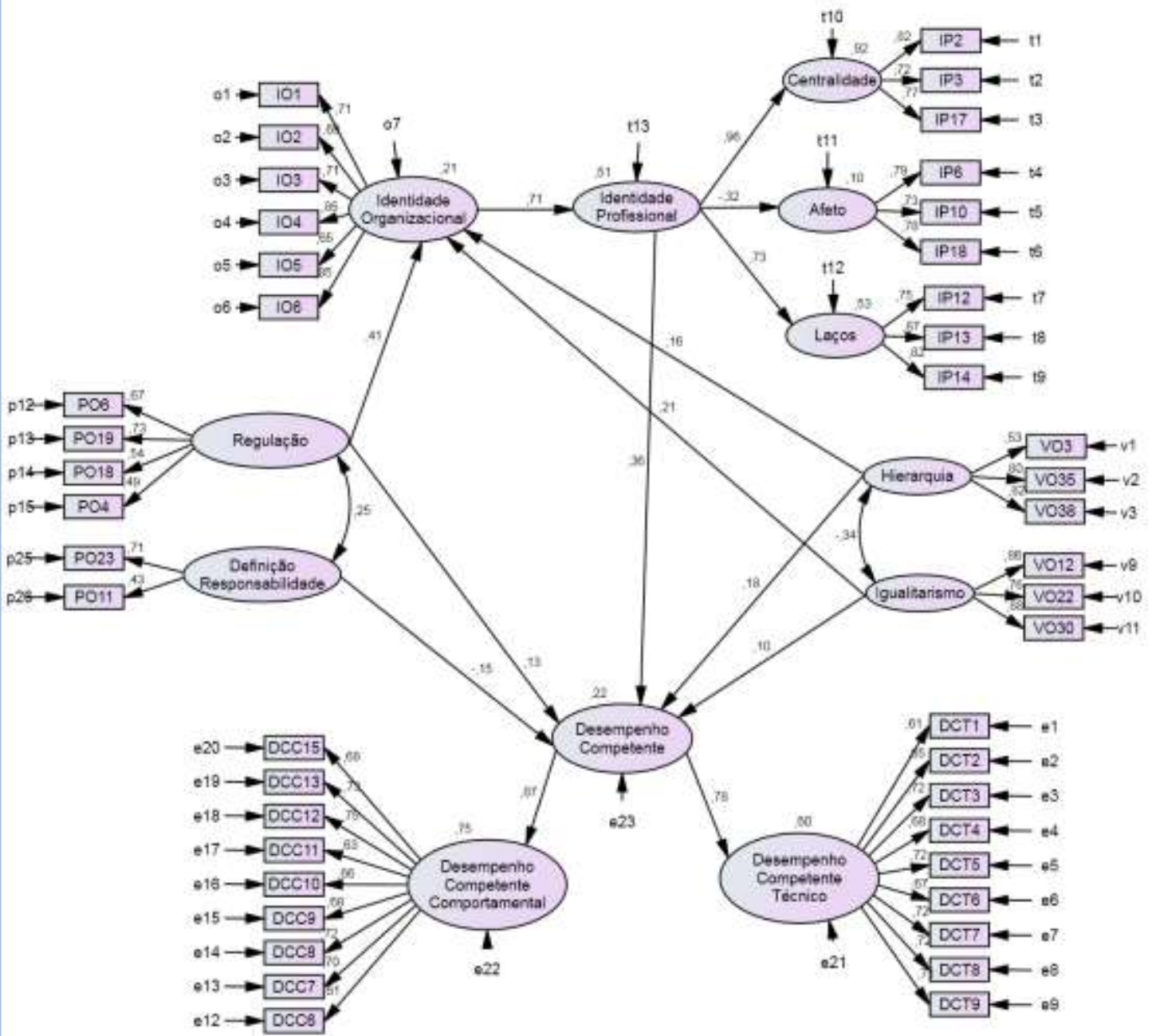

Pesos Fatoriais

Não-Estandardizados
Estimate S.E. $\quad$ C.R. $\quad$ P Label

\begin{tabular}{|c|c|c|c|c|c|c|c|}
\hline IO & $<---$ & Regulação & 0,580 & 0,063 & 9,187 & $* * *$ & par_41 \\
\hline IO & $<---$ & Hierarquia & 0,061 & 0,016 & 3,935 & $* * *$ & par_47 \\
\hline IO & $<---$ & Igualitarismo & 0,061 & 0,012 & 5,241 & $* * *$ & par_48 \\
\hline IP & $<---$ & IO & 0,616 & 0,034 & 18,254 & $* * *$ & par_40 \\
\hline $\mathrm{DC}$ & $<---$ & Regulação & 0,094 & 0,040 & 2,387 & 0,017 & par_37 \\
\hline $\mathrm{DC}$ & $<--$ & DR & $-0,094$ & 0,041 & $-2,305$ & 0,021 & par_38 \\
\hline DC & $<---$ & IP & 0,209 & 0,030 & 6,884 & $* * *$ & par_39 \\
\hline DC & $<---$ & Hierarquia & 0,035 & 0,009 & 3,934 & $* * *$ & par_49 \\
\hline DC & $<---$ & Igualitarismo & 0,015 & 0,007 & 2,323 & 0,020 & par_50 \\
\hline DCC & $<---$ & DC & 1,000 & & & & \\
\hline DCT & $<---$ & DC & 1,000 & & & & \\
\hline Laços & $<---$ & IP & 0,722 & 0,046 & 15,656 & $* * *$ & par_29 \\
\hline Centralidade & $<---$ & IP & 1,000 & & & & \\
\hline Afeto & $<---$ & IP & $-0,385$ & 0,050 & $-7,755$ & $* * *$ & par_36 \\
\hline DCT9 & $<---$ & DCT & 1,000 & & & & \\
\hline
\end{tabular}

\begin{tabular}{lr}
\hline $\begin{array}{c}\text { Correlações } \\
\text { Múltiplas ao } \\
\text { Quadrado }\end{array}$ & Estimate \\
\hline IO & 0,212 \\
IP & 0,510 \\
DC & 0,223 \\
Laços & 0,527 \\
Afeto & 0,103 \\
Centralidade & 0,924 \\
DCC & 0,749 \\
DCT & 0,602 \\
VO12 & 0,733 \\
VO22 & 0,574 \\
VO30 & 0,769 \\
VO3 & 0,277 \\
VO35 & 0,645 \\
VO38 & 0,665 \\
IO1 & 0,504 \\
\hline
\end{tabular}




\begin{tabular}{|c|c|c|c|c|c|c|c|c|c|}
\hline DCT8 & $<---$ & DCT & 0,937 & 0,043 & 21,624 & $* * *$ & par_1 & $\mathrm{IO} 2$ & 0,483 \\
\hline DCT7 & $<---$ & DCT & 0,997 & 0,046 & 21,569 & $* * *$ & par_2 & IO3 & 0,506 \\
\hline DCT6 & $<---$ & DCT & 0,897 & 0,045 & 19,945 & $* * *$ & par_3 & IO4 & 0,718 \\
\hline DCT5 & $<---$ & DCT & 1,014 & 0,047 & 21,412 & $* * *$ & par_4 & IO5 & 0,419 \\
\hline DCT4 & $<---$ & DCT & 0,904 & 0,045 & 20,013 & $* * *$ & par_5 & IO6 & 0,721 \\
\hline DCT3 & $<---$ & DCT & 0,979 & 0,046 & 21,429 & $* * *$ & par_6 & IP12 & 0,570 \\
\hline DCT2 & $<---$ & DCT & 0,829 & 0,043 & 19,228 & $* * *$ & par_7 & IP13 & 0,755 \\
\hline DCT1 & $<---$ & DCT & 0,802 & 0,045 & 18,010 & $* * *$ & par_8 & IP14 & 0,666 \\
\hline DCC13 & $<---$ & DCC & 1,000 & & & & & IP6 & 0,622 \\
\hline DCC12 & $<---$ & DCC & 0,994 & 0,042 & 23,451 & $* * *$ & par_9 & IP10 & 0,530 \\
\hline DCC11 & $<--$ & DCC & 0,901 & 0,047 & 19,142 & $* * *$ & par_10 & IP18 & 0,612 \\
\hline DCC10 & $<---$ & DCC & 0,897 & 0,044 & 20,295 & $* * *$ & par_11 & IP2 & 0,672 \\
\hline DCC9 & $<---$ & DCC & 0,980 & 0,047 & 20,698 & $* * *$ & par_12 & IP3 & 0,518 \\
\hline DCC8 & $<---$ & DCC & 1,005 & 0,046 & 21,984 & $* * *$ & par_13 & IP17 & 0,590 \\
\hline DCC7 & $<---$ & DCC & 1,004 & 0,047 & 21,263 & $* * *$ & par_14 & $\mathrm{PO} 23$ & 0,501 \\
\hline DCC6 & $<---$ & DCC & 0,894 & 0,049 & 18,363 & $* * *$ & par_15 & PO11 & 0,187 \\
\hline DCC15 & $<---$ & DCC & 0,994 & 0,048 & 20,785 & $* * *$ & par_16 & PO6 & 0,450 \\
\hline PO4 & $<---$ & Regulação & 0,736 & 0,062 & 11,930 & $* * *$ & par_17 & PO19 & 0,536 \\
\hline PO18 & $<---$ & Regulação & 0,800 & 0,065 & 12,392 & $* * *$ & par_18 & PO18 & 0,295 \\
\hline PO19 & $<---$ & Regulação & 1,081 & 0,075 & 14,381 & $* * *$ & par_19 & PO4 & 0,243 \\
\hline PO6 & $<---$ & Regulação & 1,000 & & & & & DCC15 & 0,463 \\
\hline PO11 & $<---$ & DR & 0,640 & 0,196 & 3,270 & 0,001 & par_21 & DCC6 & 0,374 \\
\hline $\mathrm{PO} 23$ & $<---$ & DR & 1,000 & & & & & DCC7 & 0,494 \\
\hline IP17 & $<---$ & Centralidade & 1,000 & & & & & DCC8 & 0,522 \\
\hline IP3 & $<---$ & Centralidade & 0,904 & 0,043 & 21,113 & $* * *$ & par_22 & DCC9 & 0,463 \\
\hline IP2 & $<--$ & Centralidade & 1,044 & 0,044 & 23,551 & $* * *$ & par_23 & DCC10 & 0,441 \\
\hline IP18 & $<---$ & Afeto & 1,000 & & & & & DCC11 & 0,401 \\
\hline IP10 & $<---$ & Afeto & 0,926 & 0,047 & 19,651 & $* * *$ & par_24 & DCC12 & 0,568 \\
\hline IP6 & $<---$ & Afeto & 0,924 & 0,046 & 20,109 & $* * *$ & par_25 & DCC13 & 0,537 \\
\hline IP14 & $<---$ & Laços & 1,000 & & & & & DCT1 & 0,371 \\
\hline IP13 & $<---$ & Laços & 1,116 & 0,039 & 28,269 & $* * *$ & par_26 & DCT2 & 0,417 \\
\hline IP12 & $<---$ & Laços & 0,914 & 0,038 & 23,952 & $* * *$ & par_27 & DCT3 & 0,517 \\
\hline IO6 & $<---$ & IO & 1,000 & & & & & DCT4 & 0,457 \\
\hline IO5 & $<---$ & IO & 0,726 & 0,033 & 21,902 & $* * *$ & par_30 & DCT5 & 0,520 \\
\hline IO4 & $<---$ & IO & 0,955 & 0,030 & 32,001 & $* * *$ & par_31 & DCT6 & 0,455 \\
\hline IO3 & $<---$ & IO & 0,776 & 0,032 & 24,222 & $* * *$ & par_32 & DCT7 & 0,523 \\
\hline $\mathrm{IO} 2$ & $<---$ & IO & 0,781 & 0,033 & 23,585 & $* * *$ & par_33 & DCT8 & 0,521 \\
\hline IO1 & $<--$ & IO & 0,892 & 0,039 & 22,659 & $* * *$ & par_34 & DCT9 & 0,506 \\
\hline VO38 & $<---$ & Hierarquia & 1,000 & & & & & & \\
\hline VO35 & $<---$ & Hierarquia & 1,023 & 0,062 & 16,436 & $* * *$ & par_42 & & \\
\hline VO3 & $<---$ & Hierarquia & 0,612 & 0,044 & 13,902 & $* * *$ & par_43 & & \\
\hline VO30 & $<---$ & Igualitarismo & 1,000 & & & & & & \\
\hline VO22 & $<---$ & Igualitarismo & 0,595 & 0,024 & 25,229 & $* * *$ & par_44 & & \\
\hline VO12 & $<--$ & Igualitarismo & 0,871 & 0,031 & 27,983 & $* * *$ & par_45 & & \\
\hline
\end{tabular}

Figura 91. Modelo Estrutural Geral Parcimonioso 2b - MEGP2b. 


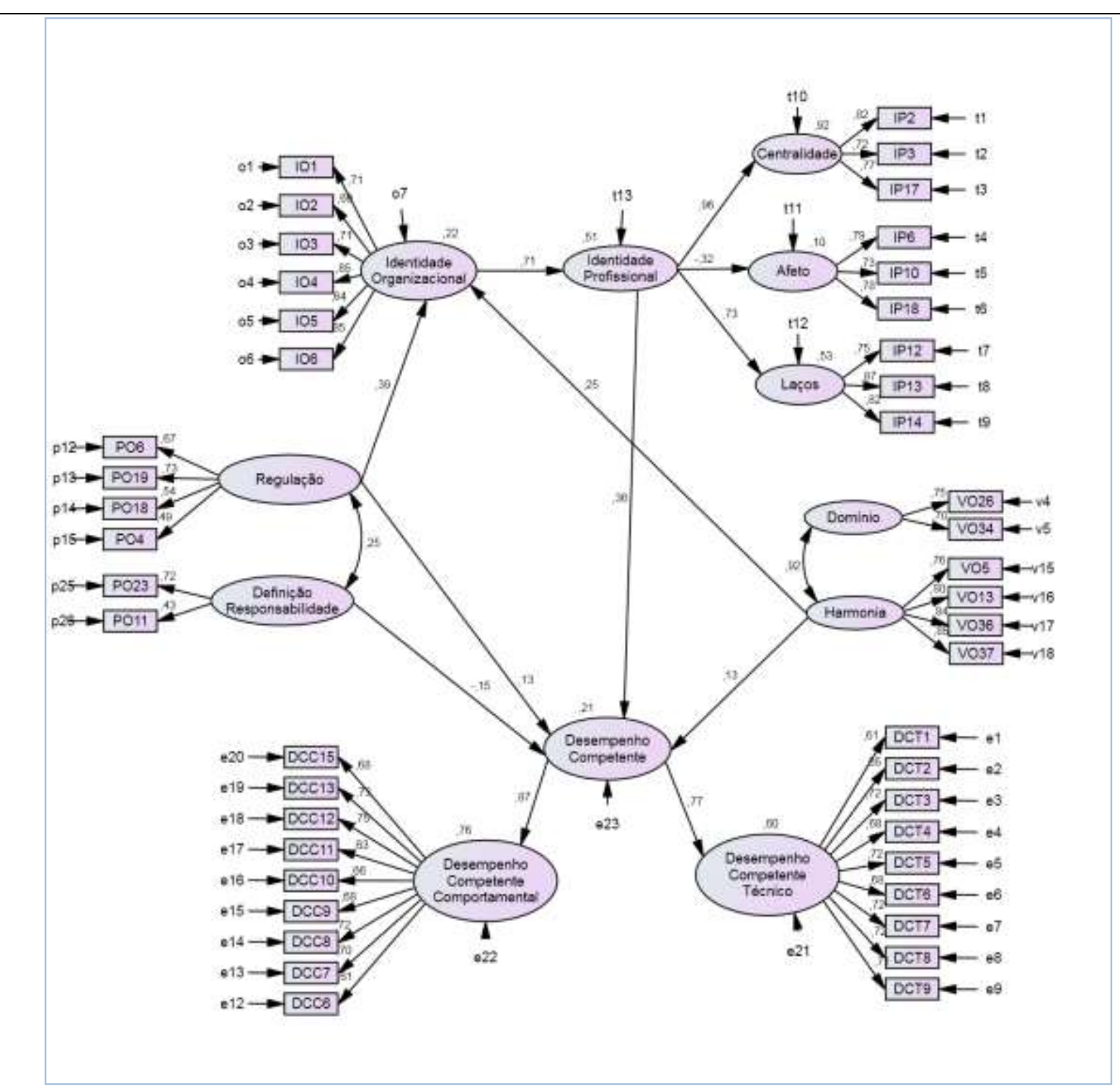

\begin{tabular}{|c|c|c|c|c|c|c|c|c|c|}
\hline \multicolumn{3}{|c|}{$\begin{array}{c}\text { Pesos Fatoriais } \\
\text { Não-Estandardizados }\end{array}$} & \multirow{2}{*}{$\begin{array}{r}\text { Estimate } \\
0,559\end{array}$} & \multirow{2}{*}{$\begin{array}{l}\text { S.E. } \\
0,062\end{array}$} & \multirow{2}{*}{$\begin{array}{l}\text { C.R. } \\
9,047\end{array}$} & \multirow{2}{*}{$\begin{array}{c}\mathrm{P} \\
* * *\end{array}$} & \multirow{2}{*}{$\begin{array}{c}\text { Label } \\
\text { par_41 }\end{array}$} & $\begin{array}{c}\text { Correlações } \\
\text { Múltiplas ao } \\
\text { Quadrado }\end{array}$ & \multirow{2}{*}{$\begin{array}{r}\text { Estimate } \\
0,218\end{array}$} \\
\hline IO & <--- & Regulação & & & & & & $\overline{\mathrm{IO}}$ & \\
\hline IO & $<---$ & Harmonia & 0,100 & 0,015 & 6,883 & $* * *$ & par_47 & IP & 0,508 \\
\hline IP & $<--$ & IO & 0,616 & 0,034 & 18,238 & $* * *$ & par_40 & DC & 0,213 \\
\hline DC & $<--$ & Regulação & 0,092 & 0,039 & 2,345 & 0,019 & par_37 & Laços & 0,526 \\
\hline DC & $<--$ & DR & $-0,091$ & 0,040 & $-2,306$ & 0,021 & par_38 & Afeto & 0,103 \\
\hline DC & $<--$ & IP & 0,213 & 0,030 & 7,020 & $* * *$ & par_39 & Centralidade & 0,924 \\
\hline DC & $<--$ & Harmonia & 0,026 & 0,008 & 3,121 & 0,002 & par_48 & DCC & 0,756 \\
\hline DCC & $<--$ & $\mathrm{DC}$ & 1,000 & & & & & DCT & 0,599 \\
\hline DCT & $<--$ & DC & 1,000 & & & & & VO37 & 0,715 \\
\hline Laços & $<---$ & IP & 0,722 & 0,046 & 15,660 & $* * *$ & par_29 & VO36 & 0,706 \\
\hline Centralidade & $<--$ & IP & 1,000 & & & & & VO5 & 0,585 \\
\hline Afeto & $<---$ & IP & $-0,385$ & 0,050 & $-7,749$ & $* * *$ & par_36 & VO13 & 0,633 \\
\hline DCT9 & $<---$ & DCT & 1,000 & & & & & VO26 & 0,564 \\
\hline DCT8 & $<--$ & DCT & 0,934 & 0,043 & 21,679 & $* * *$ & par_1 & VO34 & 0,485 \\
\hline DCT7 & $<---$ & DCT & 0,993 & 0,046 & 21,626 & $* * *$ & par_2 & IO1 & 0,501 \\
\hline
\end{tabular}




\begin{tabular}{|c|c|c|c|c|c|c|c|c|c|}
\hline DCT6 & <--- & DCT & 0,893 & 0,045 & 19,990 & $* * *$ & par_3 & IO2 & 0,482 \\
\hline DCT5 & $<--$ & DCT & 1,009 & 0,047 & 21,469 & $* * *$ & par_4 & IO3 & 0,506 \\
\hline DCT4 & $<---$ & DCT & 0,901 & 0,045 & 20,056 & $* * *$ & par_5 & IO4 & 0,718 \\
\hline DCT3 & $<---$ & DCT & 0,975 & 0,045 & 21,482 & $* * *$ & par_6 & IO5 & 0,416 \\
\hline DCT2 & $<---$ & DCT & 0,826 & 0,043 & 19,267 & $* * *$ & par_7 & IO6 & 0,719 \\
\hline DCT1 & $<---$ & DCT & 0,800 & 0,044 & 18,042 & $* * *$ & par_8 & IP12 & 0,569 \\
\hline DCC13 & $<---$ & DCC & 1,000 & & & & & IP13 & 0,755 \\
\hline DCC12 & $<--$ & DCC & 0,996 & 0,043 & 23,404 & $* * *$ & par_9 & IP14 & 0,665 \\
\hline DCC11 & $<--$ & DCC & 0,903 & 0,047 & 19,113 & $* * *$ & par_10 & IP6 & 0,622 \\
\hline DCC10 & $<---$ & DCC & 0,898 & 0,044 & 20,251 & $* * *$ & par_11 & IP10 & 0,530 \\
\hline DCC9 & $<---$ & DCC & 0,984 & 0,048 & 20,680 & $* * *$ & par_12 & IP18 & 0,612 \\
\hline DCC8 & $<---$ & DCC & 1,008 & 0,046 & 21,946 & $* * *$ & par_13 & IP2 & 0,671 \\
\hline DCC7 & $<--$ & DCC & 1,007 & 0,047 & 21,228 & $* * *$ & par_14 & IP3 & 0,518 \\
\hline DCC6 & $<--$ & DCC & 0,895 & 0,049 & 18,331 & $* * *$ & par_15 & IP17 & 0,588 \\
\hline DCC15 & $<--$ & DCC & 0,996 & 0,048 & 20,740 & $* * *$ & par_16 & $\mathrm{PO} 23$ & 0,513 \\
\hline PO4 & $<---$ & Regulação & 0,735 & 0,062 & 11,929 & $* * *$ & par_17 & PO11 & 0,182 \\
\hline PO18 & $<---$ & Regulação & 0,797 & 0,064 & 12,356 & $* * *$ & par_18 & PO6 & 0,452 \\
\hline PO19 & $<--$ & Regulação & 1,076 & 0,075 & 14,334 & $* * *$ & par_19 & PO19 & 0,533 \\
\hline PO6 & $<--$ & Regulação & 1,000 & & & & & PO18 & 0,294 \\
\hline PO11 & $<---$ & DR & 0,625 & 0,194 & 3,229 & ,001 & par_21 & $\mathrm{PO} 4$ & 0,243 \\
\hline $\mathrm{PO} 23$ & $<--$ & DR & 1,000 & & & & & DCC15 & 0,462 \\
\hline IP17 & $<--$ & Centralidade & 1,000 & & & & & DCC6 & 0,373 \\
\hline IP3 & $<---$ & Centralidade & 0,905 & 0,043 & 21,119 & $* * *$ & par_22 & DCC7 & 0,495 \\
\hline IP2 & $<---$ & Centralidade & 1,044 & 0,044 & 23,556 & $* * *$ & par_23 & DCC8 & 0,522 \\
\hline IP18 & $<--$ & Afeto & 1,000 & & & & & DCC9 & 0,464 \\
\hline IP10 & $<--$ & Afeto & 0,926 & 0,047 & 19,649 & $* * *$ & par_24 & DCC10 & 0,440 \\
\hline IP6 & $<---$ & Afeto & 0,924 & 0,046 & 20,108 & $* * *$ & par_25 & DCC11 & 0,401 \\
\hline IP14 & $<--$ & Laços & 1,000 & & & & & DCC12 & 0,568 \\
\hline IP13 & $<---$ & Laços & 1,116 & 0,039 & 28,270 & $* * *$ & par_26 & DCC13 & 0,536 \\
\hline IP12 & $<---$ & Laços & 0,914 & 0,038 & 23,953 & $* * *$ & par_27 & DCT1 & 0,372 \\
\hline IO6 & $<---$ & IO & 1,000 & & & & & DCT2 & 0,419 \\
\hline IO5 & $<--$ & IO & 0,725 & 0,033 & 21,851 & $* * *$ & par_30 & DCT3 & 0,518 \\
\hline IO4 & $<---$ & IO & 0,957 & 0,030 & 32,023 & $* * *$ & par_31 & DCT4 & 0,458 \\
\hline IO3 & $<--$ & IO & 0,777 & 0,032 & 24,265 & $* * *$ & par_32 & DCT5 & 0,520 \\
\hline $\mathrm{IO} 2$ & $<--$ & IO & 0,782 & 0,033 & 23,603 & $* * *$ & par_33 & DCT6 & 0,456 \\
\hline IO1 & $<--$ & IO & 0,892 & 0,039 & 22,643 & $* * *$ & par_34 & DCT7 & 0,524 \\
\hline VO34 & $<---$ & Domínio & 1,000 & & & & & DCT8 & 0,522 \\
\hline VO26 & $<--$ & Domínio & 1,175 & 0,061 & 19,377 & $* * *$ & par_42 & DCT9 & 0,509 \\
\hline VO13 & $<--$ & Harmonia & 0,875 & 0,032 & 27,513 & $* * *$ & par_43 & & \\
\hline VO5 & $<---$ & Harmonia & 0,885 & 0,034 & 25,984 & $* * *$ & par_44 & & \\
\hline VO37 & $<--$ & Harmonia & 0,991 & 0,032 & 30,904 & $* * *$ & par_45 & & \\
\hline VO36 & $<--$ & Harmonia & 1,000 & & & & & & \\
\hline
\end{tabular}

Figura 92. Modelo Estrutural Geral Parcimonioso 2c - MEGP2c. 


\section{Seção 2. Teste das Hipóteses de Pesquisa}

Esta seção, destina-se à apresentação das hipóteses de pesquisa. Primeiramente, serão apresentados os resultados das hipóteses relativas aos testes das relações estruturais diretas, que tratam das variáveis principais do estudo, ou seja, valores, práticas organizacionais, identidade profissional, identidade organizacional e desempenho profissional (2.1). No segundo momento, exibem-se as implicações das hipóteses das relações indiretas (mediadoras) (2.2). E, por fim, as hipóteses que contemplam as variáveis individuais (sexo, idade, tempo de serviço, escolaridade, níveis hierárquicos e tipo de atividade) são expostas (2.3).

\subsection{Teste das Hipóteses dos Relações Estruturais Diretas}

Para testar as hipóteses sobre a relação direta entre os construtos, os modelos estruturais propostos e validados são confrontados com os dados empíricos. As relações estruturais diretas foram avaliadas pelo teste $t$ de Student, que deve apresentar um valor mínimo absoluto superior a 1,96 (p-valor $<0,05)$.

2.1.1 Testes das hipóteses das relações entre os valores organizacionais (H1; H4: H4a e H4b)

As hipóteses $\mathrm{H} 1, \mathrm{H} 4 \mathrm{a}$ e $\mathrm{H} 4 \mathrm{~b}$ tratam das relações entre os valores organizacionais sobre o desempenho profissional, sobre a identidade profissional e sobre a identidade organizacional, respectivamente.

H1: Os valores organizacionais influenciam de forma direta e positiva o desempenho profissional por competências.

\section{H4: Os valores organizacionais influenciam de forma direta e positiva a identidade profissional (H4a) e a identidade organizacional (H4b).}

Os resultados demostraram que:

- Relativos aos valores organizacionais, os tipos motivacionais têm influência direta sobre o desempenho profissional por competências. Sendo a relação positiva para os tipos motivacionais analisados por dimensões bipolares separadas (domínio $x$ harmonia; hierarquia $x$ igualitarismo; autonomia $x$ conservação) e positiva para os tipos motivacionais conservação e harmonia e negativa para igualitarismo quando os tipos motivacionais encontram-se correlacionados, esses resultados permitem corroborar parcialmente a hipótese H1. 
- No que se refere aos valores organizacionais, os tipos motivacionais têm influência direta sobre a identidade profissional. Sendo a relação positiva para os tipos motivacionais analisados por dimensões bipolares separadas (domínio $x$ harmonia; hierarquia x igualitarismo; autonomia x conservação) e positiva para conservação e harmonia e negativa para igualitarismo, quando os tipos motivacionais encontram-se correlacionados, esses resultados corroboram em parte a hipótese $\mathrm{H} 4 \mathrm{a}$.

- Tendo em vista os valores organizacionais, os tipos motivacionais apresentam influência direta sobre a identidade organizacional. Sendo a relação positiva para os tipos motivacionais analisados por dimensões bipolares separadas (domínio x harmonia; hierarquia x igualitarismo; autonomia x conservação) $e$ positiva para conservação e harmonia e negativa para igualitarismo, quando os tipos motivacionais encontram-se correlacionados, esse resultado confirma parcialmente a hipótese $H 4 b$.

A Tabela 68 apresenta os resultados sistematizados das relações diretas entre os tipos motivacionais e o desempenho profissional, a identidade profissional e a identidade organizacional, de forma respectiva.

\section{Tabela 68}

Teste dos efeitos dos valores organizacionais (tipos motivacionais)

\begin{tabular}{|c|c|c|c|}
\hline Hipóteses & Relações Estruturais & $\begin{array}{l}\text { Parâmetros Estruturais } \\
\text { Estandardizados. } \beta(t) \\
\end{array}$ & $\begin{array}{c}\text { Resultado do teste } \\
(\text { sig. do } t)\end{array}$ \\
\hline \multirow[t]{2}{*}{ H1 } & $\begin{array}{c}\text { VO }(\text { Correlacionados }) \rightarrow \text { Desempenho Competente } \\
\text { VO }(\text { Conservação }) x \text { VO (Igualitarismo }) \times \text { VO (Harmonia }) \\
\rightarrow \text { Desempenho Competente }\end{array}$ & $\begin{array}{c}0,20(3,53) x \\
-0,52(-3,87) x \\
0,62(4,06)\end{array}$ & $\begin{array}{l}(\mathrm{p}<0,000) x \\
(\mathrm{p}<0,000) x \\
(\mathrm{p}<0,000)\end{array}$ \\
\hline & $\begin{array}{l}\text { VO }(\text { Autonomia x Conservação }) \rightarrow \text { Desempenho Competente } \\
\text { VO }(\text { Hierarquia x Igualitarismo }) \rightarrow \text { Desempenho Competente } \\
\text { VO }(\text { Domínio x Harmonia }) \rightarrow \text { Desempenho Competente }\end{array}$ & $\begin{array}{c}\text { n.s. } \times 0,32(0,26 \times 6,85) \\
0,29 \times 0,24(7,70 \times 7,04) \\
n . s \times 0,36(5,40 \times 6,72) \\
\end{array}$ & $\begin{array}{l}(p=0,791 ; p<0,000) \\
(p<0,000 ; p<0,000) \\
(p<0,000 ; p<0,000)\end{array}$ \\
\hline \multirow[t]{2}{*}{$\mathrm{H} 4 \mathrm{a}$} & $\begin{array}{c}\text { VO }(\text { Correlacionados }) \rightarrow \text { Identidade Profissional } \\
\text { VO }(\text { Conservação }) x \text { VO }(\text { Igualitarismo }) x \text { VO (Harmonia }) \\
\rightarrow \text { Identidade Profissional }\end{array}$ & $\begin{array}{c}0,12(67,64) x \\
-0,43(42,65) x \\
0,68(55,62) \\
\end{array}$ & $\begin{array}{l}(\mathrm{p}<0,000) x \\
(\mathrm{p}<0,000) x \\
(\mathrm{p}<0,000)\end{array}$ \\
\hline & $\begin{array}{l}\text { VO }(\text { Autonomia } x \text { Conservação }) \rightarrow \text { Identidade Profissional } \\
V O(\text { Hierarquia x Igualitarismo } \rightarrow \text { Identidade Profissional } \\
\text { VO }(\text { Domínio x Harmonia }) \rightarrow \text { Identidade Profissional }\end{array}$ & $\begin{aligned} & 0,19 \times 0,24(4,19 \times 5,67) \\
& 0,31 \times 0,38(8,39 \times 10,64) \\
& \text { n.s. } \times 0,36(6,14 \times 9,92) \\
&\end{aligned}$ & $\begin{array}{l}(p<0,000 ; p=0,000) \\
(p<0,000 ; p=0,000) \\
(p<0,000 ; p=0,000)\end{array}$ \\
\hline \multirow[t]{2}{*}{$\mathrm{H} 4 \mathrm{~b}$} & $\begin{array}{c}\text { VO }(\text { Correlacionados }) \rightarrow \text { Identidade Organizacional } \\
\text { VO }(\text { Conservação }) x \text { VO }(\text { Igualitarismo }) \times \text { VO (Harmonia }) \\
\rightarrow \text { Identidade Organizacional }\end{array}$ & $\begin{array}{c}0,15(2,88) x \\
-0,33(-2,69) x \\
0,55(3,99)\end{array}$ & $\begin{array}{l}(\mathrm{p}<0,004) x \\
(\mathrm{p}<0,007) x \\
(\mathrm{p}<0,000)\end{array}$ \\
\hline & $\begin{array}{l}\text { VO }(\text { Autonomia } x \text { Conservação }) \rightarrow \text { Identidade Organizacional } \\
V O(\text { Hierarquia x Igualitarismo }) \rightarrow \text { Identidade Organizacional } \\
\text { VO }(\text { Domínio x Harmonia }) \rightarrow \text { Identidade Organizacional }\end{array}$ & $\begin{array}{l}0,15 \times 0,24(3,57 \times 5,74) \\
0,22 \times 0,32(6,85 \times 9,87) \\
\text { n.s. } \times 0,34(4,80 \times 9,74)\end{array}$ & $\begin{array}{l}(\mathrm{p}<0,000 ; \mathrm{p}<0,000) \\
(\mathrm{p}<0,000 ; \mathrm{p}<0,000) \\
(\mathrm{p}<0,000 ; \mathrm{p}=0,000)\end{array}$ \\
\hline
\end{tabular}


2.1.2 Testes das hipóteses das relações entre as práticas organizacionais (H2; H5: H5a; H5b)

As hipóteses H2, H5a e H5b tratam das relações entre as práticas organizacionais sobre o desempenho profissional por competências, sobre a identidade profissional e sobre a identidade organizacional, respectivamente.

H2: As práticas organizacionais influenciam de forma direta e positiva o desempenho profissional por competências.

H5: As práticas organizacionais influenciam de forma direta e positiva a identidade profissional (H5a) e a identidade organizacional (H5b).

Os resultados demonstram que:

- As práticas organizacionais têm influência direta sobre o desempenho profissional. Essa relação é positiva para cada uma das práticas analisadas de forma separada, exceto definição de responsabilidade $(p>0,05)$, e quando as práticas organizacionais encontram-se correlacionados, a relação é positiva para a prática de regulação e negativa para a de definição de responsabilidade. Tal resultado corrobora, em parte, a hipótese $\mathrm{H} 2$.

- As práticas organizacionais têm influência direta sobre a identidade profissional. Essa relação é positiva para cada uma das práticas analisadas de forma separada, exceto definição de responsabilidade ( $p>0,05)$, e, quando as práticas organizacionais encontram-se correlacionados, a relação é positiva para a prática de regulação e negativa para a de definição de responsabilidade. Esse resultado confirma, parcialmente, a hipótese $\mathrm{H5a}$.

- As práticas organizacionais têm influência direta sobre a identidade organizacional. Essa relação é positiva para cada uma das práticas analisadas de forma separada, exceto definição de responsabilidade ( $p>0,05)$, e, quando as práticas organizacionais encontram-se correlacionados, a relação é positiva para a prática de regulação e negativa para a de definição de responsabilidade. Esse resultado ratifica, parcialmente, a hipótese $H 5 b$.

Conforme Tabela 69, são expostos os resultados sistematizados das relações diretas entre as práticas organizacionais e o desempenho profissional, a identidade profissional e a identidade organizacional, respectivamente. 
Tabela 69

Teste dos efeitos das práticas organizacionais

\begin{tabular}{|c|c|c|c|}
\hline Hipóteses & Relações Estruturais & $\begin{array}{l}\text { Parâmetros Estruturais } \\
\text { Estandardizados. } \beta(t)\end{array}$ & $\begin{array}{c}\text { Resultado do } \\
\text { teste (sig. } t \text { ) }\end{array}$ \\
\hline \multirow{10}{*}{$\mathrm{H} 2$} & $P O($ Corralacionadas $) \rightarrow$ Desempenho Competente & - & \multirow{3}{*}{$\begin{array}{c}(\mathrm{p}<0,000) x \\
(\mathrm{p}<0,000)\end{array}$} \\
\hline & PO (Regulação) x PO (Def.Responsabilidade) & $0,45(8,39) x$ & \\
\hline & $\rightarrow$ Desempenho Competente & $-0,18(-3,70)$ & \\
\hline & $P O($ Independentes $) \rightarrow$ Desempenho Competente & & \\
\hline & PO (Recompensas e Punições) $\rightarrow$ Desempenho Competente & $0,19(4,38)$ & $(\mathrm{p}<0,000)$ \\
\hline & $P O($ Regulação $) \rightarrow$ Desempenho Competente & $0,34(7,49)$ & $(\mathrm{p}<0,000)$ \\
\hline & PO (Senso de Dever) $\rightarrow$ Desempenho Competente & $0,24(6,25)$ & $(\mathrm{p}<0,000)$ \\
\hline & PO (Relações de Autoridade) $\rightarrow$ Desempenho Competente & $0,27(6,87)$ & $(\mathrm{p}<0,000)$ \\
\hline & PO (Qualidade da Cooperação) $\rightarrow$ Desempenho Competente & $0,24(6,54)$ & $(\mathrm{p}<0,000)$ \\
\hline & PO (Def.Responsabilidade) $\rightarrow$ Desempenho Competente & n.s. $(-0,39)$ & $(\mathrm{p}=0,700)$ \\
\hline \multirow{10}{*}{ H5a } & $P O($ Corralacionadas $) \rightarrow$ Identidade Profissional & - & $(\mathrm{p}<0,000)$ \\
\hline & PO (Regulação) x PO (Def.Responsabilidade) & $0,67(16,68) x$ & $(\mathrm{p}<0,000)$ \\
\hline & $\rightarrow$ Identidade Profissional & $-0,11(-1,53)$ & $(\mathrm{p}=0,127)$ \\
\hline & $P O($ Independentes $) \rightarrow$ Identidade Profissional & & \\
\hline & PO (Recompensas e Punições) $\rightarrow$ Identidade Profissional & $0,42(13,14)$ & $(\mathrm{p}<0,000)$ \\
\hline & PO (Regulação) $\rightarrow$ Identidade Profissional & $0,65(17,50)$ & $(\mathrm{p}<0,000)$ \\
\hline & PO $($ Senso de Dever $) \rightarrow$ Identidade Profissional & $0,48(15,08)$ & $(\mathrm{p}<0,000)$ \\
\hline & PO (Relações de Autoridade $) \rightarrow$ Identidade Profissional & $0,39(14,17)$ & $(\mathrm{p}<0,000)$ \\
\hline & PO (Qualidade da Cooperação) $\rightarrow$ Identidade Profissional & $0,50(15,49)$ & $(\mathrm{p}<0,000)$ \\
\hline & PO (Def.Responsabilidade) $\rightarrow$ Identidade Profissional & n.s. $(4,86)$ & $(\mathrm{p}<0,000)$ \\
\hline \multirow{10}{*}{$\mathrm{H} 5 \mathrm{~b}$} & $P O($ Corralacionadas $) \rightarrow$ Identidade Organizacional & - & $(\mathrm{p}<0,000)$ \\
\hline & PO (Regulação) x PO (Def.Responsabilidade) & $0,48(12,74)$ & $(\mathrm{p}<0,000)$ \\
\hline & $\rightarrow$ Identidade Organizacional & $-0,14(-2,95)$ & $(\mathrm{p}=0,003)$ \\
\hline & $P O($ Independentes $) \rightarrow$ Identidade Organizacional & & \\
\hline & PO (Recompensas e Punições $) \rightarrow$ Identidade Organizacional & $0,30(9,26)$ & $(\mathrm{p}<0,000)$ \\
\hline & PO $($ Regulação $) \rightarrow$ Identidade Organizacional & $0,45(12,55)$ & $(\mathrm{p}<0,000)$ \\
\hline & $P O($ Senso de Dever $) \rightarrow$ Identidade Organizacional & $0,33(10,92)$ & $(\mathrm{p}<0,000)$ \\
\hline & PO (Relações de Autoridade) $\rightarrow$ Identidade Organizacional & $0,31(10,78)$ & $(\mathrm{p}<0,000)$ \\
\hline & PO (Qualidade da Cooperação) $\rightarrow$ Identidade Organizacional & $0,39(11,85)$ & $(\mathrm{p}<0,000)$ \\
\hline & PO (Def. Responsabilidade) $\rightarrow$ Identidade Organizacional & n.s. $(2,11)$ & $(\mathrm{p}=0,035)$ \\
\hline
\end{tabular}

2.1.3 Testes das hipóteses das relações entre valores e práticas organizacionais (H3; H6: H6a; H6b)

As hipóteses H3, H6a e H6b tratam da força das relações de predição dos valores (tipos motivacionais) e das práticas organizacionais sobre o desempenho profissional por competências, sobre a identidade profissional e sobre a identidade organizacional, respectivamente.

H3: As práticas organizacionais têm maior poder de predição sobre o desempenho em comparação com os valores organizacionais.

H6: As práticas organizacionais têm maior poder de predição sobre a identidade profissional (H6a) e identidade organizacional (H6b) em comparação com os valores organizacionais. 
Os resultados demonstram que:

- As práticas organizacionais apresentam maior poder de predição sobre o desempenho profissional se comparado aos tipos motivacionais subjacentes aos valores organizacionais. Esses resultados corroboram a hipótese H3.

- As práticas organizacionais apresentam maior poder de explicação sobre a identidade profissional se comparado aos tipos motivacionais subjacentes aos valores organizacionais. Os resultados confirmam a hipótese H6a.

- As práticas organizacionais apresentam maior poder de predição sobre a identidade organizacional se comparado aos tipos motivacionais subjacentes aos valores organizacionais. Esses resultados corroboram a hipótese H6b.

2.1.3 Testes das hipóteses das relações da identidade profissional e da identidade organizacional (H9: H9a; H9b)

As hipóteses $\mathrm{H} 9 \mathrm{a}$ e $\mathrm{H} 9 \mathrm{~b}$ tratam das relações entre a identidade profissional e a identidade organizacional sobre o desempenho profissional, respectivamente.

H9: A identidade profissional (H9a) e a identidade organizacional (H9b) influenciam de forma direta e positiva o desempenho profissional por competências.

Os resultados demonstram que:

- A identidade profissional apresenta a influência direta e positiva sobre o desempenho profissional. Esse resultado corrobora a hipótese H9a.

- A identidade organizacional apresenta a influência direta e positiva sobre o desempenho profissional. Esse resultado corrobora a hipótese H9b.

A Tabela 70 apresenta os resultados dos testes destas hipóteses.

Tabela 70

Teste dos efeitos das identidades profissional e organizacional sobre o desempenho profissional

\begin{tabular}{|c|c|c|c|}
\hline $\begin{array}{l}\text { Hipóteses } \\
\text { H9 }\end{array}$ & Relações Estruturais & $\begin{array}{l}\text { Parâmetros Estruturais } \\
\text { Estandardizados. } \beta(t)\end{array}$ & $\begin{array}{l}\text { Resultado do } \\
\text { teste }(\text { sig. } t)\end{array}$ \\
\hline $\mathrm{H} 9 \mathrm{a}$ & Identidade Profissional $\rightarrow$ Desempenho Competente & $0,44(11,26)$ & $(\mathrm{p}<0,000)$ \\
\hline $\mathrm{H} 9 \mathrm{~b}$ & Identidade Organizacional $\rightarrow$ Desempenho Competente & $0,37(9,58)$ & $(\mathrm{p}<0,000)$ \\
\hline
\end{tabular}




\subsection{Teste das Hipóteses Relativas às Relações Indiretas (Efeitos Mediadores)}

Para testar as hipóteses sobre os relacionamentos indiretos, foram realizados estudos de mediação simples e de mediação em cadeia.

2.1.1 Testes das hipóteses das relações de mediação simples da identidade profissional e da identidade organizacional entre os valores organizacionais e o desempenho profissional por competências (H7: H7a; H7b)

As hipóteses (H7a e H7b) tratam das relações de mediação simples, que a identidade profissional e a identidade organizacional, respectivamente, estabelecem entre os valores organizacionais (tipos motivacionais) e o desempenho profissional.

H7: A identidade profissional (H7a) e a identidade organizacional (H7b) mediam a relação entre os valores organizacionais e o desempenho profissional por competências.

Os resultados mostraram que:

- Ao se observarem os tipos motivacionais correlacionados, verifica-se a existência da mediação parcial da identidade profissional entre os tipos motivacionais conservação, igualitarismo e harmonia e o desempenho profissional. Com relação aos pares bipolares, na relação entre o par autonomia $x$ conservação e o desempenho profissional, o tipo autonomia é mediado totalmente pela identidade profissional e o tipo conservação parcialmente. $\mathrm{Na}$ relação entre o par hierarquia x Igualitarismo e o desempenho profissional, a identidade profissional é mediadora parcial dessa relação. $O$ par domínio $x$ harmonia só mostra a mediação da identidade na relação entre o tipo harmonia e o desempenho profissional. Esses resultados confirmam em parte a hipótese H7a.

- Ao se observarem os tipos motivacionais correlacionados, verifica-se a existência da mediação parcial da identidade organizacional entre os tipos motivacionais conservação, igualitarismo e harmonia e o desempenho profissional. Com relação aos pares bipolares, a relação entre o par autonomia $x$ conservação, a identidade organizacional medeia totalmente a relação entre o tipo autonomia e parcialmente o tipo conservação na relação com o desempenho. Para os tipos hierarquia $x$ Igualitarismo e o desempenho profissional, a identidade organizacional é mediadora parcial dessa relação. $O$ par domínio $x$ 
harmonia só mostra a mediação parcial da identidade na relação entre o tipo harmonia $e$ o desempenho profissional. Esses resultados corroboram parcialmente a hipótese $H 7 b$.

A Tabela 71 apresenta os resultados dos testes destas hipóteses H7a e H7b.

Tabela 71

Teste de mediação simples das identidades profissional e organizacional na relação entre os tipos motivacionais e o desempenho profissional

\begin{tabular}{|c|c|c|c|c|}
\hline $\begin{array}{l}\text { Hipóteses } \\
\text { H7 }\end{array}$ & $\begin{array}{l}\text { Relações Estruturais } \\
\text { Efeitos Indiretos }\end{array}$ & $\begin{array}{l}\text { Parâmetros bootstrap Não- } \\
\text { estandardizado (Stand.) } \\
\text { [Inter. Conf. } 95 \% \text { ] }\end{array}$ & $\begin{array}{l}\text { Resultado } \\
\text { do Teste }\end{array}$ & Mediação \\
\hline \multirow{4}{*}{$\mathrm{H} 7 \mathrm{a}$} & $\begin{array}{c}\text { VO Correlacionados } \\
\text { Conservação, Igualitarismo e Harmonia } \\
\rightarrow I P \rightarrow D C\end{array}$ & $\begin{array}{c}0,014(0,058)[0,009 ; 0,109] \\
-0,021(-0,139)[-0,259 ;-0,028] \\
0,047(0,223)[0,103 ; 0,365]\end{array}$ & $\begin{array}{l}\text { Sig. }(p=0,030) \\
\text { Sig. }(p=0,009) \\
\text { Sig. }(p=0,007)\end{array}$ & $\begin{array}{l}\text { Parcial } \\
\text { Parcial } \\
\text { Parcial }\end{array}$ \\
\hline & $\begin{array}{c}V O_{\text {Bipolares }} \\
(\text { Conservação } x \text { Autonomia }) \rightarrow I P \rightarrow D C\end{array}$ & $\begin{array}{l}0,023(0,073)[0,056 ; 0,142] \\
0,014(0,094)[0,037 ; 0,112]\end{array}$ & $\begin{array}{l}\text { Sig. }(p=0,001) \\
\text { Sig. }(p=0,001)\end{array}$ & $\begin{array}{c}\text { Parcial } \\
\text { Total }\end{array}$ \\
\hline & $\begin{array}{c}V O_{\text {Bipolares }} \\
(\text { Hierarquia } x \text { Igualitarismo }) \rightarrow I P \rightarrow D C\end{array}$ & $\begin{array}{l}0,025(0,125)[0,083 ; 0,169] \\
0,022(0,145)[0,102 ; 0,194]\end{array}$ & $\begin{array}{l}\text { Sig. }(p=0,001) \\
\text { Sig. }(p=0,001)\end{array}$ & $\begin{array}{l}\text { Parcial } \\
\text { Parcial }\end{array}$ \\
\hline & $\begin{array}{c}V O \text { Bipolares } \\
(\text { Domínio } x \text { Harmonia }) \rightarrow I P \rightarrow D C\end{array}$ & $\begin{array}{l}0,000(0,000)[0,000 ; 0,000] \\
0,031(0,150)[0,104 ; 0,210]\end{array}$ & $\begin{array}{l}\text { Sig. }(\mathrm{p}=\text { n.s. }) \\
\text { Sig. }(\mathrm{p}=0,001)\end{array}$ & $\begin{array}{c}-x \\
\text { Parcial } \\
\end{array}$ \\
\hline \multirow{4}{*}{$\mathrm{H} 7 \mathrm{~b}$} & $\begin{array}{c}\text { VO Correlacionados } \\
\text { Conservação, Igualitarismo e Harmonia } \\
\rightarrow I O \rightarrow D C\end{array}$ & $\begin{array}{c}0,009(0,038)[0,009 ; 0,072] \\
-0,013(-0,087)[-0,180 ;-0,030] \\
0,031(0,145)[0,074 ; 0,252]\end{array}$ & $\begin{array}{l}\text { Sig. }(p=0,011) \\
\text { Sig. }(p=0,003) \\
\text { Sig. }(p=0,001)\end{array}$ & $\begin{array}{l}\text { Parcial } \\
\text { Parcial } \\
\text { Parcial }\end{array}$ \\
\hline & $\begin{array}{c}V O_{\text {Bipolares }} \\
(\text { Conservação } x \text { Autonomia }) \rightarrow I O \rightarrow D C\end{array}$ & $\begin{array}{l}0,017(0,070)[0,043 ; 0,103] \\
0,009(0,044)[0,018 ; 0,073]\end{array}$ & $\begin{array}{l}\text { Sig. }(p=0,001) \\
\text { Sig. }(p=0,001)\end{array}$ & $\begin{array}{c}\text { Parcial } \\
\text { Total }\end{array}$ \\
\hline & $\begin{array}{c}V O \text { Bipolares } \\
(\text { Hierarquia } x \text { Igualitarismo }) \rightarrow I O \rightarrow D C\end{array}$ & $\begin{array}{l}0,014(0,069)[0,042 ; 0,102] \\
0,015(0,096)[0,066 ; 0,132]\end{array}$ & $\begin{array}{l}\text { Sig. }(p=0,001) \\
\text { Sig. }(p=0,001)\end{array}$ & $\begin{array}{l}\text { Parcial } \\
\text { Parcial }\end{array}$ \\
\hline & $\begin{array}{c}\text { VO Bipolares } \\
(\text { Domínio x Harmonia }) \rightarrow I O \rightarrow D C\end{array}$ & $\begin{array}{l}0,000(0,000)[0,000 ; 0,000] \\
0,022(0,107)[0,075 ; 0,144]\end{array}$ & $\begin{array}{l}\text { Sig. }(\mathrm{p}=\text { n.s. }) \\
\text { Sig. }(\mathrm{p}=0,001)\end{array}$ & $\begin{array}{c}-x \\
\text { Parcial } \\
\end{array}$ \\
\hline
\end{tabular}

2.1.2 Testes das hipóteses das relações de mediação simples da identidade profissional e da identidade organizacional entre as práticas organizacionais e o desempenho profissional (H8: $\mathrm{H} 8 \mathrm{a} ; \mathrm{H} 8 \mathrm{~b})$

As hipóteses (H8a e H8b) tratam das relações de mediação simples, que a identidade profissional e a identidade organizacional, respectivamente, estabelecem entre as práticas organizacionais e o desempenho profissional.

H8: A identidade profissional (H8a) e a identidade organizacional (H8b) mediam a relação entre as práticas organizacionais e o desempenho profissional por competências.

Os resultados mostraram que: 
- Ao se observarem as práticas organizacionais, nota-se a mediação parcial da identidade profissional entre a prática de regulação e o desempenho profissional. Esse resultado corrobora parcialmente a hipótese $H 8$.

- Ao se verificarem as práticas organizacionais, observa-se a mediação parcial da identidade organizacional entre a prática de regulação e de definição de responsabilidade e o desempenho profissional. Esse resultado corrobora parcialmente a hipótese $H 8 b$.

A Tabela 72 apresenta os resultados dos testes destas hipóteses H8a e H8b.

Tabela 72

Teste de mediação simples das identidades profissional e organizacional na relação práticas organizacionais e o desempenho profissional

\begin{tabular}{|c|c|c|c|c|}
\hline $\begin{array}{l}\text { Hipóteses } \\
\text { H8 }\end{array}$ & $\begin{array}{l}\text { Relações Estruturais } \\
\text { Efeitos Indiretos }\end{array}$ & $\begin{array}{l}\text { Parâmetros bootstrap Não- } \\
\text { estandardizado (Stand.) } \\
\text { [Inter. Conf. 95\%] } \\
\end{array}$ & $\begin{array}{c}\text { Resultado } \\
\text { do Teste }\end{array}$ & Mediação \\
\hline H8a & $\begin{array}{c}P O \text { Correlacionadas } \\
\text { Regulação e Def.de Responsabilidade } \\
\rightarrow I P \rightarrow D C\end{array}$ & $\begin{array}{c}0,06(0,70)[0,25 ; 0,37] \\
0,000(0,000)[0,000 ; 0,000]\end{array}$ & $\begin{array}{c}\text { Sig. }(\mathrm{p}=0,001) \\
\text { Sig. }(\mathrm{p}=\text { n.s. })\end{array}$ & $\begin{array}{l}\text { Parcial } \\
-x\end{array}$ \\
\hline $\mathrm{H} 8 \mathrm{~b}$ & $\begin{array}{c}P O \text { Correlacionadas } \\
\text { Regulação e Def.de Responsabilidade } \\
\rightarrow I O \rightarrow D C\end{array}$ & $\begin{array}{c}0,074(0,152)[0,101 ; 0,210] \\
-0,029(-0,034)[-0,065 ;-0,010]\end{array}$ & $\begin{array}{l}\text { Sig. }(p=0,001) \\
\text { Sig. }(p=0,005)\end{array}$ & $\begin{array}{l}\text { Parcial } \\
\text { Parcial }\end{array}$ \\
\hline
\end{tabular}

2.1.3 Testes das hipóteses das relações de mediação em cadeia da identidade profissional e da identidade organizacional ( $\mathrm{H} 7: \mathrm{H} 7 \mathrm{c}$ e $\mathrm{H} 7 \mathrm{~d}$ ) entre os tipos motivacionais (valores organizacionais) e o desempenho profissional.

As hipóteses tratam das relações de mediação em cadeia da identidade profissional e da identidade organizacional na relação entre os tipos motivacionais e o desempenho profissional $(\mathrm{H} 7 \mathrm{c})$; e da mediação em cadeia da identidade organizacional e da identidade profissional na relação entre os tipos motivacionais e o desempenho profissional (H7d).

H7: A identidade organizacional antecede a identidade profissional (H7c) na mediação da relação entre os valores organizacionais e o desempenho profissional. A identidade profissional antecede a identidade organizacional (H7d) na mediação da relação entre os valores organizacionais e o desempenho profissional por competências.

Os resultados demonstram que:

- Ao se observarem os tipos motivacionais correlacionados, verifica-se a existência da mediação parcial em cadeia das identidades organizacional e profissional entre os tipos motivacionais conservação, igualitarismo e harmonia e o desempenho profissional. Com relação aos pares bipolares, a relação entre o par (autonomia x conservação), as identidades organizacional e profissional 
medeiam totalmente a relação entre o tipo autonomia e parcialmente o tipo conservação na relação com o desempenho. Para os tipos hierarquia $x$ Igualitarismo e o desempenho profissional, as identidades organizacional $e$ profissional são mediadoras parciais dessa relação. O par domínio x harmonia só mostra a mediação parcial das identidades organizacional e profissional na relação entre o tipo harmonia e o desempenho profissional. Esses resultados corroboram parcialmente a hipótese $\mathrm{H7c}$.

- Ao se observarem os tipos motivacionais correlacionados, verifica-se a existência da mediação parcial em cadeia das identidades profissional e organizacional entre os tipos motivacionais conservação, igualitarismo $e$ harmonia e o desempenho profissional. Com relação aos pares bipolares, a relação entre o par (autonomia x conservação), as identidades profissional $e$ organizacional medeiam totalmente a relação entre o tipo autonomia $e$ parcialmente o tipo conservação na relação com o desempenho. Para os tipos hierarquia $x$ Igualitarismo e o desempenho profissional, as identidades profissional e organizacional são mediadoras parciais dessa relação. O par domínio x harmonia só mostra a mediação parcial das identidades profissional e organizacional na relação entre o tipo harmonia e o desempenho profissional. Esses resultados corroboram parcialmente a hipótese $H 7 d$.

A Tabela 73 e 74 apresentam os resultados dos testes destas hipóteses H7c e H7d, respectivamente.

Tabela 73

Teste de mediação em cadeia da identidade organizacional e da identidade profissional na relação entre os tipos motivacionais e o desempenho profissional

\begin{tabular}{|c|c|c|c|c|}
\hline $\begin{array}{l}\text { Hipóteses } \\
\text { H7 }\end{array}$ & $\begin{array}{l}\text { Relações Estruturais } \\
\text { Efeitos Indiretos }\end{array}$ & $\begin{array}{l}\text { Parâmetros bootstrap Não- } \\
\text { estandardizado (Stand.) } \\
\text { [Inter. Conf. 95\%] }\end{array}$ & $\begin{array}{l}\text { Resultado } \\
\text { do Teste }\end{array}$ & Mediação \\
\hline \multirow{9}{*}{$\mathrm{H} 7 \mathrm{c}$} & VO Correlacionados & $0,009(0,038)[0,003 ; 0,018]$ & Sig. $(\mathrm{p}=0,009)$ & Parcial \\
\hline & Conservação, Igualitarismo e Harmonia & $-0,014(-0,090)[-0,027 ;-0,005]$ & Sig. $(p=0,005)$ & Parcial \\
\hline & $\rightarrow I O \rightarrow I P \rightarrow D C$ & $0,031(0,149)[0,017 ; 0,053]$ & Sig. $(p=0,001)$ & Parcial \\
\hline & $V O_{\text {Bipolares }}$ & $0,017(0,069)[0,011 ; 0,025]$ & Sig. $(p=0,001)$ & Parcial \\
\hline & (Conservação $x$ Autonomia) $\rightarrow I O \rightarrow I P \rightarrow D C$ & $0,009(0,045)[0,004 ; 0,014]$ & Sig. $(p=0,001)$ & Total \\
\hline & $V O_{\text {Bipolares }}$ & $0,014(0,069)[0,044 ; 0,100]$ & Sig. $(p=0,001)$ & Parcial \\
\hline & (Hierarquia $x$ Igualitarismo) $\rightarrow I O \rightarrow I P \rightarrow D C$ & $0,014(0,095)[0,066 ; 0,126]$ & Sig. $(p=0,001)$ & Parcial \\
\hline & $V O_{\text {Bipolares }}$ & $0,000(0,000)[0,000 ; 0,000]$ & Sig. (p=n.s.) & $-x$ \\
\hline & $($ Domínio $x$ Harmonia $) \rightarrow I O \rightarrow I P \rightarrow D C$ & $0,022(0,104)[0,075 ; 0,134]$ & Sig. $(p=0,001)$ & Parcial \\
\hline
\end{tabular}


Tabela 74

Teste de mediação em cadeia da identidade profissional e da identidade organizacional na relação entre os tipos motivacionais e o desempenho profissional

\begin{tabular}{|c|c|c|c|c|}
\hline $\begin{array}{c}\text { Hipóteses } \\
\text { H7 }\end{array}$ & $\begin{array}{l}\text { Relações Estruturais } \\
\text { Efeitos Indiretos }\end{array}$ & $\begin{array}{c}\text { Parâmetros bootstrap Não- } \\
\text { estandardizado (Stand.) } \\
\text { [Inter. Conf. 95\%] }\end{array}$ & $\begin{array}{l}\text { Resultado } \\
\text { do Teste }\end{array}$ & Mediação \\
\hline \multirow{9}{*}{$\mathrm{H} 7 \mathrm{~d}$} & VO Correlacionados & $0,008(0,032)[0,007 ; 0,062]$ & Sig. $(p=0,015)$ & Parcial \\
\hline & Conservação, Igualitarismo e Harmonia & $-0,014(-0,088)[-0,166 ;-0,036]$ & Sig. $(p=0,001)$ & Parcial \\
\hline & $\rightarrow I P \rightarrow I O \rightarrow D C$ & $0,029(0,138)[0,074 ; 0,231]$ & Sig. $(p=0,001)$ & Parcial \\
\hline & $V O_{\text {Bipolares }}$ & $0,015(0,059)[0,036 ; 0,086]$ & Sig. $(p=0,001)$ & Parcial \\
\hline & (Conservação $x$ Autonomia) $\rightarrow I P \rightarrow I O \rightarrow D C$ & $0,008(0,044)[0,022 ; 0,067]$ & Sig. $(p=0,001)$ & Total \\
\hline & $V O_{\text {Bipolares }}$ & $0,015(0,072)[0,049 ; 0,101]$ & Sig. $(p=0,001)$ & Parcial \\
\hline & (Hierarquia $x$ Igualitarismo) $\rightarrow I P \rightarrow I O \rightarrow D C$ & $0,013(0,085)[0,059 ; 0,116]$ & Sig. $(\mathrm{p}=0,001)$ & Parcial \\
\hline & $V O_{\text {Bipolares }}$ & $0,000(0,000)[0,000 ; 0,000]$ & Sig. $(\mathrm{p}=$ n.s. $)$ & $-x$ \\
\hline & (Domínio $x$ Harmonia) $\rightarrow I P \rightarrow I O \rightarrow D C$ & $0,019(0,091)[0,064 ; 0,123]$ & Sig. $(p=0,001)$ & Parcial \\
\hline
\end{tabular}

2.1.3 Testes das hipóteses das relações de mediação em cadeia da identidade profissional e da identidade organizacional (H8: H8c e H8d) entre as práticas organizacionais e o desempenho profissional.

As hipóteses tratam das relações de mediação em cadeia da identidade profissional e da identidade organizacional na relação entre as práticas organizacionais e o desempenho profissional (H8c); e da mediação em cadeia da identidade organizacional e da identidade profissional na relação entre as práticas organizacionais e o desempenho profissional (H8d).

H8: A identidade organizacional antecede a identidade profissional (H8c) na mediação da relação entre as práticas organizacionais e o desempenho profissional. A identidade profissional antecede a identidade organizacional (H8d) na mediação da relação entre as práticas organizacionais e o desempenho profissional por competências.

Os resultados demonstram que:

- Ao se observarem as práticas organizacionais, nota-se a mediação parcial das identidades organizacional e profissional entre a prática de regulação e de definição de responsabilidade e o desempenho profissional. Esse resultado corrobora parcialmente a hipótese $H 8 c$.

- Ao se verificarem as práticas organizacionais, observa-se a mediação parcial das identidades profissional e organizacional entre as práticas de regulação e de definição de responsabilidade e o desempenho profissional. Esse resultado corrobora parcialmente a hipótese H8d.

A Tabela 75 apresenta os resultados dos testes destas hipóteses H8c e H8d. 
Tabela 75

Teste de mediação simples das identidades organizacional e profissional na relação práticas organizacionais e o desempenho profissional

\begin{tabular}{ccccc}
\hline $\begin{array}{c}\text { Hipóteses } \\
\text { H8 }\end{array}$ & $\begin{array}{c}\text { Relações Estruturais } \\
\text { Efeitos Indiretos }\end{array}$ & $\begin{array}{c}\text { Parâmetros bootstrap Não- } \\
\text { estandardizado (Stand.) } \\
\text { [Inter. Conf. } 95 \%]\end{array}$ & $\begin{array}{c}\text { Resultado } \\
\text { do Teste }\end{array}$ & Mediação \\
\hline H8c & $\begin{array}{c}P O \text { Correlacionadas } \\
\text { Regulação } \begin{array}{c}\text { Def.de Responsabilidade } \\
\rightarrow I O \rightarrow I P \rightarrow D C\end{array}\end{array}$ & $\begin{array}{c}0,083(0,173)[0,125 ; 232] \\
-0,032(-0,037)[-0,065 ;-0,010]\end{array}$ & $\begin{array}{c}\text { Sig. (p=0,001) } \\
\text { Sig. (p=0,008) }\end{array}$ & $\begin{array}{c}\text { Parcial } \\
\text { Parcial }\end{array}$ \\
\hline H8d & $\begin{array}{c}P O \text { Correlacionadas } \\
\text { Regulação e Def.de Responsabilidade } \\
\rightarrow I P \rightarrow I O \rightarrow D C\end{array}$ & $\begin{array}{c}0,074(0,152)[0,100 ; 0,205] \\
-0,019(-0,021)[-0,042 ;-0,002]\end{array}$ & $\begin{array}{l}\text { Sig. (p=0,001) } \\
\text { Sig. (p=0,032) }\end{array}$ & $\begin{array}{l}\text { Parcial } \\
\text { Parcial }\end{array}$ \\
\hline
\end{tabular}

2.1.4 Testes das hipóteses relativas à influência das variáveis sociodemográficas na predição do desempenho (H10; H11; H12; H13 e H14).

Nesta parte, concentram-se as hipóteses relativas à influência das cinco variáveis sociodemográficas sobre o desempenho profissional. Busca-se determinar se o desempenho profissional é diferente em função da idade (H10), do tempo de serviço (H11), do nível de escolaridade (H12), da atividade (área-fim ou área-meio - H13) e do nível hierárquico (oficiais e praças - H14) dos respondentes. Foram utilizadas diferença de médias (teste $t e$ ANOVA) para testar as hipóteses. Além disso, o teste de Kruskal-Wallis (não paramétrico) foi utilizado de forma complementar, quando o teste de Levene rejeita a hipótese homogeneidade de variância.

H10: Existe uma diferença no desempenho profissional por competências em função da idade do policial.

Foi realizada uma divisão da idade por quartil (até 33 anos; de 33 a 39 anos; de 40 a 45 anos; e mais de 46 anos); os resultados da ANOVA demonstram que não há diferença no desempenho profissional em função da idade do policial. Esse resultado refuta a hipótese H10, conforme observado na Tabela 76. 
Tabela 76

Teste referente à idade do policial

\begin{tabular}{|c|c|c|c|c|c|c|}
\hline \multirow{2}{*}{\multicolumn{2}{|c|}{ Desempenho profissional (DC) }} & & Teste de Levene & g.1.1 & g.1.2 & Sig. \\
\hline & & & 2,516 & 3 & 894 & 0,057 \\
\hline \multicolumn{3}{|c|}{ Desempenho por competências comportamentais (DCC) } & 0,636 & 3 & 894 & 0,592 \\
\hline \multicolumn{3}{|c|}{ Desempenho por competências técnicas (DCT) } & 5,228 & 3 & 894 & 0,001 \\
\hline \multirow{5}{*}{ DC } & \multicolumn{2}{|r|}{ Quadrados } & $\begin{array}{l}\text { Grau de } \\
\text { Liberdade }\end{array}$ & $\begin{array}{l}\text { Média dos } \\
\text { Quadrados }\end{array}$ & $\mathrm{F}$ & Sig. \\
\hline & Entre Grupos & 0,804 & 3 & 0,268 & \multirow[t]{3}{*}{1,594} & \multirow[t]{3}{*}{0,189} \\
\hline & Intra Grupos & 150,245 & 894 & 0,168 & & \\
\hline & Total & 151,049 & 897 & & & \\
\hline & \multicolumn{4}{|c|}{ Teste de Kruskal-Wallis: Qui-quadrado (g.l.) = 6,501 (3) } & & 0,090 \\
\hline \multirow{4}{*}{ DCC } & Entre Grupos & 0,881 & 3 & 0,294 & \multirow[t]{4}{*}{1,073} & 0,359 \\
\hline & Intra Grupos & 244,663 & 894 & 0,274 & & \\
\hline & Total & 245,544 & 897 & & & \\
\hline & \multicolumn{4}{|c|}{ Teste de Kruskal-Wallis: Qui-quadrado (g.l.) = 4,225 (3) } & & 0,238 \\
\hline \multirow{4}{*}{ DCT } & Entre Grupos & 1,927 & 3 & 0,642 & \multirow[t]{4}{*}{2,037} & 0,107 \\
\hline & Intra Grupos & 281,853 & 894 & 0,315 & & \\
\hline & Total & 283,78 & 897 & & & \\
\hline & \multicolumn{4}{|c|}{ Teste de Kruskal-Wallis: Qui-quadrado (g.l.) = 8,498 (3) } & & 0,037 \\
\hline
\end{tabular}

H11: Existe uma diferença no desempenho profissional por competências em função do tempo de serviço do policial.

Foi realizada uma divisão do tempo de serviço (até 11 anos; de 12 a 22 anos; e 23 anos ou mais); os resultados da ANOVA apontam que não existe diferença no desempenho profissional em função do tempo de serviço policial. Esse resultado refuta a hipótese H11, conforme observado na Tabela 77.

Tabela 77

Teste referente ao tempo de serviço do policial

\begin{tabular}{|c|c|c|c|c|c|c|}
\hline \multirow{4}{*}{\multicolumn{3}{|c|}{$\begin{array}{l}\text { Desempenho profissional (DC) } \\
\text { Desempenho por competências comportamentais (DCC) } \\
\text { Desempenho por competências técnicas (DCT) }\end{array}$}} & Teste de Levene & g.1.1 & g.1.2 & Sig. \\
\hline & & & 3,358 & 2 & 895 & 0,035 \\
\hline & & & 1,501 & 2 & 895 & 0,224 \\
\hline & & & 6,672 & 2 & 895 & 0,001 \\
\hline \multirow{5}{*}{ DC } & & $\begin{array}{l}\text { Soma dos } \\
\text { Quadrados }\end{array}$ & $\begin{array}{c}\text { Grau de } \\
\text { Liberdade }\end{array}$ & $\begin{array}{l}\text { Média dos } \\
\text { Quadrados }\end{array}$ & $\mathrm{F}$ & Sig. \\
\hline & Entre Grupos & 0,322 & 2 & 0,161 & \multirow[t]{3}{*}{0,962} & \multirow[t]{3}{*}{0,383} \\
\hline & Intra Grupos & 149,776 & 895 & 0,167 & & \\
\hline & Total & 150,098 & 897 & & & \\
\hline & \multicolumn{4}{|c|}{ Teste de Kruskal-Wallis: Qui-quadrado (g.1.) = 3,015 (2) } & & 0,221 \\
\hline \multirow{4}{*}{$\mathrm{DCC}$} & Entre Grupos & 0,470 & 2 & 0,235 & \multirow[t]{4}{*}{0,862} & 0,423 \\
\hline & Intra Grupos & 243,693 & 895 & 0,272 & & \\
\hline & Total & 244,163 & 897 & & & \\
\hline & \multicolumn{4}{|c|}{ Teste de Kruskal-Wallis: Qui-quadrado (g.1.) = 2,251 (2) } & & 0,324 \\
\hline \multirow{4}{*}{ DCT } & Entre Grupos & 0,514 & 2 & 0,257 & \multirow[t]{4}{*}{0,815} & 0,443 \\
\hline & Intra Grupos & 282,285 & 895 & 0,315 & & \\
\hline & Total & 282,799 & 897 & & & \\
\hline & \multicolumn{4}{|c|}{ Teste de Kruskal-Wallis: Qui-quadrado (g.l.) = 2,685 (2) } & & 0,261 \\
\hline
\end{tabular}




\section{H12: Existe uma diferença no desempenho profissional por competências em}

\section{função da escolaridade do policial.}

Foi realizada uma divisão da escolaridade (1 - policiais de menor formação até a graduação completa; e 2- policiais pós-graduados); os resultados do teste $t$ apontam que há diferença no desempenho profissional em função da escolaridade. Esse resultado corrobora a hipótese H12, conforme observado na Tabela 78.

Tabela 78

Teste referente à escolaridade do policial

\begin{tabular}{|c|c|c|c|c|c|c|c|c|c|}
\hline $\begin{array}{l}\text { De } \\
\text { De } \\
\text { De }\end{array}$ & $\begin{array}{l}\text { penho profissic } \\
\text { penho por com } \\
\text { penho por com }\end{array}$ & $\begin{array}{l}\text { al (DC } \\
\text { tência } \\
\text { tência }\end{array}$ & $\begin{array}{l}\text { mportam } \\
\text { nicas (D }\end{array}$ & (DCC) & & $\begin{array}{r}\text { Teste de L } \\
8,238 \\
1,501 \\
6,672\end{array}$ & ene & & $\begin{array}{l}\text { ig. } \\
004 \\
011 \\
100\end{array}$ \\
\hline & & & & & \multirow[b]{2}{*}{$\mathrm{t}$} & \multirow[b]{2}{*}{ g.1. } & \multirow[b]{2}{*}{ Sig. } & $\begin{array}{r}\text { Inter } \\
\text { confiar }\end{array}$ & $\begin{array}{l}\text { lo de } \\
95 \%\end{array}$ \\
\hline & Escolaridade & $\mathrm{N}$ & Média & $\begin{array}{l}\text { Desvio- } \\
\text { Padrão }\end{array}$ & & & & Inferior & Superior \\
\hline \multirow{3}{*}{$\mathrm{DC}$} & 1 & 669 & 3,1105 & 0,42038 & $-3,416$ & 909 & 0,001 & $-0,16389$ & $-0,0443$ \\
\hline & 2 & 242 & 3,2145 & 0,36388 & $-3,654$ & 488,768 & 0,000 & $-0,16006$ & $-0,04813$ \\
\hline & \multicolumn{9}{|c|}{ Teste de Kruskal-Wallis: Qui-quadrado (g.l.) = 12,039 (1); Sig. $=0,001$} \\
\hline \multirow[t]{3}{*}{ DCC } & 1 & 669 & 3,9237 & 0,53562 & $-2,765$ & 909 & 0,006 & $-0,18374$ & $-0,03119$ \\
\hline & 2 & 242 & 4,0311 & 0,46613 & $-2,950$ & 486,185 & 0,003 & $-0,17903$ & $-0,0359$ \\
\hline & \multicolumn{9}{|c|}{ Teste de Kruskal-Wallis: Qui-quadrado (g.1.) $=6,933$ (1); Sig. $=0,008$} \\
\hline \multirow[t]{3}{*}{ DCT } & 1 & 669 & 3,6396 & 0,57192 & $-3,826$ & 909 & 0,000 & $-0,24217$ & $-0,07797$ \\
\hline & 2 & 242 & 3,7997 & 0,51608 & $-4,015$ & 469,274 & 0,000 & $-0,23841$ & $-0,08173$ \\
\hline & \multicolumn{9}{|c|}{ Teste de Kruskal-Wallis: Qui-quadrado (g.1.) = 15,323 (1); Sig. $=0,000$} \\
\hline
\end{tabular}

1 - policiais de menor formação até a graduação completa; 2- policiais pós-graduados. 


\section{H13: Existe uma diferença no desempenho profissional por competências em} função da área de lotação (atividade fim versus atividade meio) do policial.

Realizou-se a divisão da lotação do policial em função da unidade em que trabalha (1 - unidades administrativas/atividade meio ou 2 - unidades operacionais/atividade fim), os resultados do teste $t$ apontam que não há uma diferença no desempenho profissional em função da área de lotação. Esse resultado refuta a hipótese H13, conforme observado na Tabela 79.

Tabela 79

Teste referente à área de lotação do policial por atividade

\begin{tabular}{|c|c|c|c|c|c|c|c|c|c|}
\hline \multirow{2}{*}{\multicolumn{5}{|c|}{ 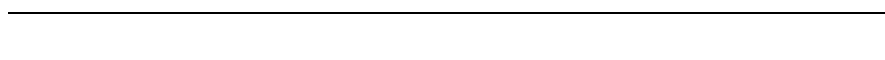 }} & \multirow{2}{*}{\multicolumn{3}{|c|}{ Teste de Levene }} & \multicolumn{2}{|c|}{ Sig. } \\
\hline & & & & & & & & \multicolumn{2}{|c|}{0,031} \\
\hline \multirow{2}{*}{\multicolumn{5}{|c|}{$\begin{array}{l}\text { Desempenho por competências comportamentais (DCC) } \\
\text { Desempenho por competências técnicas (DCT) }\end{array}$}} & \multicolumn{3}{|c|}{4,109} & \multicolumn{2}{|c|}{0,043} \\
\hline & & & & & & 1,539 & & & \\
\hline & \multirow[b]{2}{*}{ Atividade } & \multirow[b]{2}{*}{$\mathrm{N}$} & \multirow[b]{2}{*}{ Média } & \multirow[b]{2}{*}{$\begin{array}{l}\text { Desvio- } \\
\text { Padrão }\end{array}$} & \multirow[b]{2}{*}{$\mathrm{t}$} & \multirow[b]{2}{*}{ g.l. } & \multirow[b]{2}{*}{ Sig. } & \multicolumn{2}{|c|}{$\begin{array}{c}\text { Intervalo de } \\
\text { confiança 95\% }\end{array}$} \\
\hline & & & & & & & & Inferior & Superior \\
\hline \multirow[t]{3}{*}{ DC } & 1 & 320 & 3,1302 & 0,38271 & $-0,341$ & 910 & 0,733 & $-0,06571$ & 0,04627 \\
\hline & 2 & 592 & 3,1399 & 0,42576 & $-0,352$ & 715,697 & 0,725 & $-0,06399$ & 0,04454 \\
\hline & \multicolumn{9}{|c|}{ Teste de Kruskal-Wallis: Qui-quadrado (g.l.) $=0,197$ (1); Sig. $=0,657$} \\
\hline \multirow[t]{3}{*}{ DCC } & 1 & 320 & 3,9527 & 0,49755 & 0,142 & 910 & 0,887 & $-0,06614$ & 0,07647 \\
\hline & 2 & 592 & 3,9475 & 0,53719 & 0,145 & 698,061 & 0,884 & $-0,06456$ & 0,07489 \\
\hline & \multicolumn{9}{|c|}{ Teste de Kruskal-Wallis: Qui-quadrado (g.1.) $=0,000$ (1); Sig. $=0,985$} \\
\hline \multirow[t]{3}{*}{ DCT } & 1 & 320 & 3,6560 & 0,53499 & $-1,005$ & 910 & 0,315 & $-0,11618$ & 0,03748 \\
\hline & 2 & 592 & 3,6954 & 0,57938 & $-1,029$ & 699,855 & 0,304 & $-0,11441$ & 0,0357 \\
\hline & \multicolumn{9}{|c|}{ Teste de Kruskal-Wallis: Qui-quadrado (g.l.) $=0,950$ (1); Sig. $=0,330$} \\
\hline
\end{tabular}

1 - Atividade meio; 2- Atividade fim. 


\section{H14: Existe uma diferença no desempenho profissional por competências em} função do nível hierárquico (oficiais e praças) do policial.

Por fim, efetuou-se a divisão da amostra em dois grupos de policiais (oficiais e praças), os resultados do teste $t$ apontam que existe uma diferença no desempenho profissional em função do nível hierárquico. Esse resultado corrobora a hipótese H14, conforme observado na Tabela 80.

Tabela 80

Teste referente ao nível hierárquico do policial

\begin{tabular}{|c|c|c|c|c|c|c|c|c|c|}
\hline \multicolumn{5}{|c|}{$\begin{array}{l}\text { Desempenho profissional (DC) } \\
\text { Desempenho por competências comportamentais (DCC) } \\
\text { Desempenho por competências técnicas (DCT) }\end{array}$} & \multicolumn{2}{|c|}{$\begin{array}{c}\text { Teste de Levene } \\
6,069 \\
4,079 \\
2,362\end{array}$} & \multicolumn{3}{|c|}{$\begin{array}{c}\text { Sig. } \\
0,014 \\
0,044 \\
0,125\end{array}$} \\
\hline & \multirow[b]{2}{*}{ Hierarquia } & \multirow[b]{2}{*}{$\mathrm{N}$} & \multirow[b]{2}{*}{ Média } & \multirow[b]{2}{*}{ Desvio-Padrão } & \multirow[b]{2}{*}{$\mathrm{t}$} & \multirow[b]{2}{*}{ g.l. } & \multirow[b]{2}{*}{ Sig. } & \multicolumn{2}{|c|}{$\begin{array}{c}\text { Intervalo de } \\
\text { confiança } 95 \%\end{array}$} \\
\hline & & & & & & & & Inferior & Superior \\
\hline \multirow[t]{3}{*}{ DC } & Oficiais & 266 & 3,2043 & 0,37187 & 3,175 & 900 & 0,002 & 0,03616 & 0,15318 \\
\hline & Praças & 636 & 3,1097 & 0,42256 & 3,346 & 560,3 & 0,001 & 0,03909 & 0,15025 \\
\hline & \multicolumn{9}{|c|}{ Teste de Kruskal-Wallis: Qui-quadrado (g.1.) $=9,856$ (1); Sig. $=0,002$} \\
\hline \multirow[t]{3}{*}{ DCC } & Oficiais & 266 & 4,0122 & 0,47632 & 2,278 & 900 & 0,023 & 0,01202 & 0,16163 \\
\hline & Praças & 636 & 3,9254 & 0,53991 & 2,398 & 558,968 & 0,017 & 0,0157 & 0,15795 \\
\hline & \multicolumn{9}{|c|}{ Teste de Kruskal-Wallis: Qui-quadrado (g.l.) $=4,577$ (1); Sig. $=0,0032$} \\
\hline \multirow[t]{3}{*}{ DCT } & Oficiais & 266 & 3,7975 & 0,5165 & 4,005 & 900 & 0,000 & 0,08317 & 0,24302 \\
\hline & Praças & 636 & 3,6344 & 0,57403 & 4,182 & 548,436 & 0,000 & 0,08649 & 0,2397 \\
\hline & \multicolumn{9}{|c|}{ Teste de Kruskal-Wallis: Qui-quadrado (g.l.) $=17,384$ (1); Sig. $=0,000$} \\
\hline
\end{tabular}


A Tabela 81 apresenta uma síntese dos resultados do teste das hipóteses de pesquisa.

Tabela 81

Sumário dos testes das hipóteses de pesquisa

\begin{tabular}{|c|c|c|c|}
\hline & \multicolumn{2}{|r|}{ Valores, Práticas Organizacionais e Identidade no trabalho e Organizacional } & Confirmação \\
\hline & H1 & Os valores organizacionais influenciam de forma direta e positiva o desempenho profissional. & Parcial \\
\hline \multirow{8}{*}{ 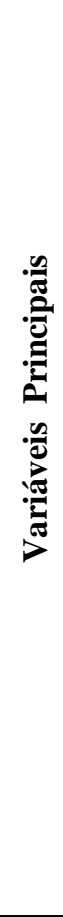 } & $\mathrm{H} 2$ & As práticas organizacionais influenciam de forma direta e positiva o desempenho profissional. & Parcial \\
\hline & H3 & $\begin{array}{l}\text { As práticas organizacionais têm maior poder de predição sobre o desempenho em comparação } \\
\text { com os valores organizacionais. }\end{array}$ & Total \\
\hline & $\mathrm{H} 4$ & $\begin{array}{l}\text { Os valores organizacionais influenciam de forma direta e positiva a identidade profissional } \\
\text { (H4a) e a identidade organizacional }(\mathrm{H} 4 \mathrm{~b}) \text {. }\end{array}$ & Parcial/Parcial \\
\hline & H5 & $\begin{array}{l}\text { As práticas organizacionais influenciam de forma direta e positiva influenciam de forma direta } \\
\text { e positiva a identidade profissional (H5a) e a identidade organizacional }(\mathrm{H} 5 \mathrm{~b}) \text {. }\end{array}$ & Parcial/Parcial \\
\hline & H6 & $\begin{array}{l}\text { As práticas organizacionais têm maior poder de predição sobre a identidade profissional (H6a) } \\
\text { e identidade organizacional (H6b) em comparação com os valores organizacionais. }\end{array}$ & Total/Total \\
\hline & H7 & $\begin{array}{l}\text { A identidade profissional (H7a) e a identidade organizacional (H7b) mediam a relação entre } \\
\text { os valores organizacionais e o desempenho profissional. A identidade organizacional antecede } \\
\text { a identidade profissional }(\mathrm{H} 7 \mathrm{c}) \text { na mediação da relação entre os valores organizacionais e o } \\
\text { desempenho profissional. A identidade profissional antecede a identidade organizacional } \\
\text { (H7d) na mediação da relação entre os valores organizacionais e o desempenho profissional. }\end{array}$ & $\begin{array}{l}\text { Parcial/Parcial } \\
\text { Parcial/Parcial }\end{array}$ \\
\hline & H8 & $\begin{array}{l}\text { A identidade profissional (H8a) e a identidade organizacional (H8b) mediam a relação entre } \\
\text { as práticas organizacionais e o desempenho profissional. A identidade organizacional } \\
\text { antecede a identidade profissional (H8c) na mediação da relação entre as práticas } \\
\text { organizacionais e o desempenho profissional. A identidade profissional antecede a identidade } \\
\text { organizacional (H8d) na mediação da relação entre as práticas organizacionais e o } \\
\text { desempenho profissional. }\end{array}$ & $\begin{array}{l}\text { Parcial/Parcial } \\
\text { Parcial/Parcial }\end{array}$ \\
\hline & H9 & $\begin{array}{l}\text { A identidade profissional }(\mathrm{H} 9 \mathrm{a}) \text { e a identidade organizacional }(\mathrm{H} 9 \mathrm{~b}) \text { influenciam de forma } \\
\text { direta e positiva o desempenho profissional. }\end{array}$ & Total/Total \\
\hline \multirow{6}{*}{ 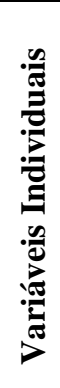 } & \multicolumn{2}{|r|}{$\begin{array}{l}\text { Variáveis Sociodemográficas } \\
\text { (idade, sexo, escolaridade, tempo de serviço, nível hierárquico, lotação) }\end{array}$} & \\
\hline & H10 & Existe uma diferença no desempenho profissional em função da idade do policial. & Refutada \\
\hline & H11 & Existe uma diferença no desempenho profissional em função do tempo de serviço do policial. & Refutada \\
\hline & $\mathrm{H} 12$ & Existe uma diferença no desempenho profissional em função da escolaridade do policial. & Confirmada \\
\hline & H13 & $\begin{array}{l}\text { Existe uma diferença no desempenho profissional em função da área de lotação (atividade fim } \\
\text { versus atividade meio) do policial. }\end{array}$ & Refutada \\
\hline & $\mathrm{H} 14$ & Existe uma diferença no desempenho profissional em função do nível hierárquico do policial. & Confirmada \\
\hline
\end{tabular}




\section{Conclusão ao Capítulo VII}

Este capítulo permitiu apresentar os resultados dos testes das hipóteses de pesquisa. No primeiro momento foram testados modelos preliminares, em que são testadas as relações entre as variáveis, progressivamente. Em seguida, testaram-se os efeitos diretos, os efeitos indiretos, ou mediadores e, por fim, o teste dos modelos estruturais gerais com seus índices de ajustamento satisfeitos para a amostra total. As variáveis latentes preditoras explicaram variância significativa das variáveis latentes preditas.

Em um segundo momento, os testes das hipóteses de pesquisa sobre os efeitos diretos, indiretos (mediadores) e sobre as variáveis sociodemográficas permitiram corroborar, mesmo que de forma parcial, a grande maioria das hipóteses propostas, o que demonstra que os valores organizacionais, as práticas organizacionais, a identidade organizacional e a identidade profissional influenciam o desempenho profissional de forma direta ou indireta. As variáveis sociodemográfica que dizem respeito à escolaridade e ao nível hierárquico dos policiais apresentam, igualmente, um efeito global significativo no desempenho profissional.

O próximo capítulo apresentará a discussão e interpretação dos resultados obtidos, primeiramente referindo-se às qualidades psicométricas dos instrumentos utilizados, e posteriormente, às hipóteses de pesquisa. 
PARTE 2

ESTUDO EMPÍRICO E RESULTADO DA PESQUISA
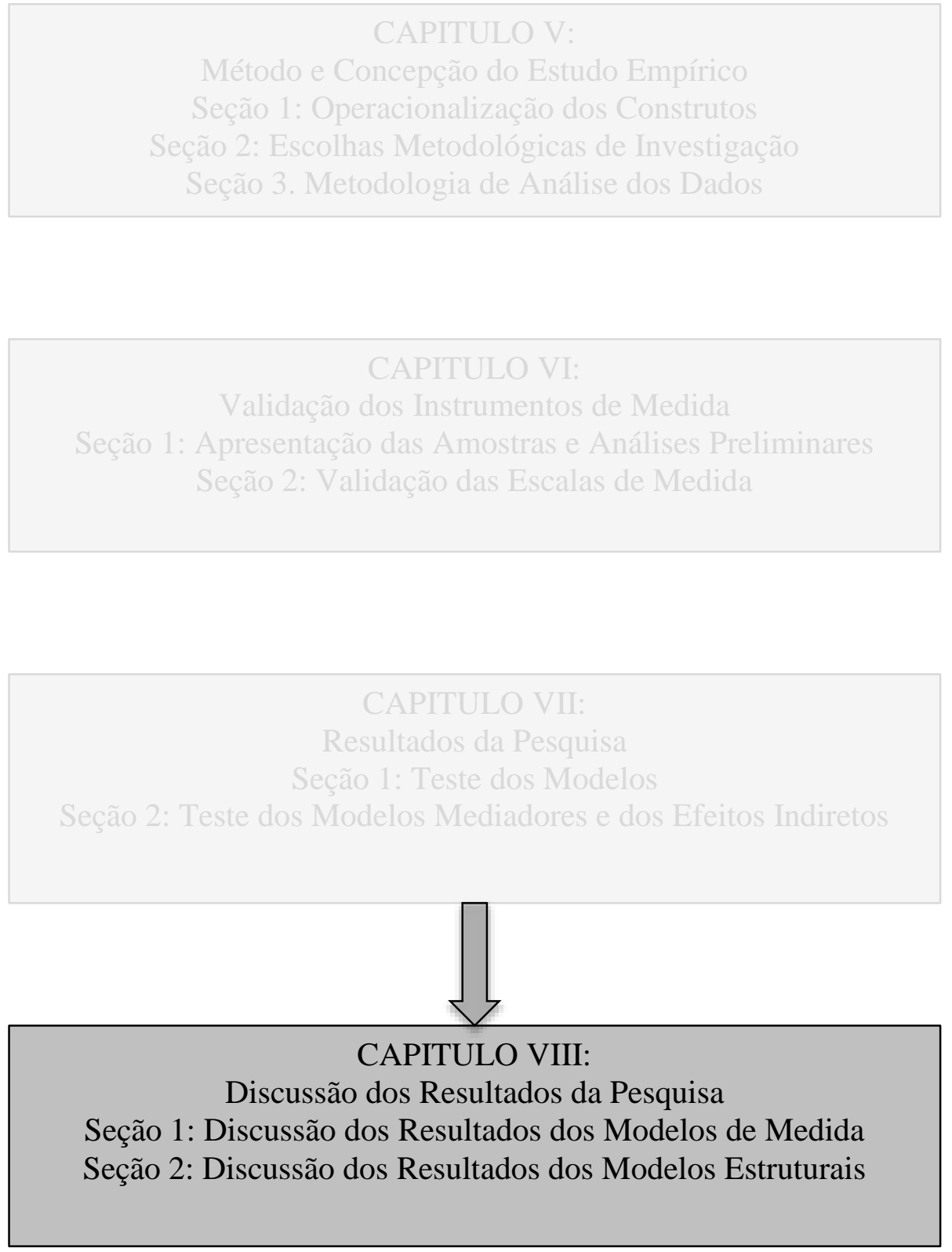


\section{CAPÍTULO VIII. DISCUSSÃO DOS RESULTADOS DA PESQUISA}

\section{Introdução ao Capítulo VIII}

Este capítulo discute os resultados concernentes as escalas de medidas utilizadas para a operacionalização dos construtos (Seção 1) e os resultados obtidos das relações dos modelos estruturais, e dos efeitos das variáveis sociodemográficas (Seção 2), que contemplam as hipóteses de pesquisa.

\section{Seção 1. Discussão dos Resultados dos Modelos de Medida}

Esta seção discute tanto os resultados dos modelos de medida das variáveis latentes (valores organizacionais - 1.1; práticas organizacionais - 1.2; identidade profissional - 1.3; identidade organizacional - 1.4), tratadas como variáveis antecedentes ou mediadoras, como, o modelo de medida da variável dependente, desempenho profissional (1.5).

\subsection{Discussão da Escala Valores Organizacionais (EVO)}

Os valores organizacionais foram operacionalizados nesta pesquisa pela EVO, desenvolvida por Porto et al. (2012). Conforme visto, apesar de a literatura brasileira e a internacional contarem com diversas escalas de valores organizacionais (Cameron \& Quinn, 2011; Hofstede et al., 1990; Oliveira \& Tamayo, 2004; O’Reilly et al., 1991; Tamayo, 2000), optou-se pela EVO em virtude de seu processo de construção ter advindo da sistematização das dimensões, realizada por Porto et al. (2012), encontradas nas diversas escalas anteriormente relatadas. Além disso, a EVO mostrou-se adequada ao modelo teórico de Schwartz (1999), bem como foi adaptada e aplicada na PMDF por Sousa (2013), demonstrando boa adequação ao contexto organizacional e índices psicométricos satisfatórios, servindo, assim, como um teste piloto.

A aplicação da EVO nesta tese, reteve 32 dos 39 itens do instrumento utilizado, mantendo a mesma estrutura empírica encontrada no estudo de Porto et al. (2012) e que corrobora a estrutura conceitual do modelo dos valores de Schwartz (1999). Os indicadores do estudo exploratório (MDS) demonstraram adequações psicométricas satisfatórias, com índices de confiabilidades aceitáveis (Harmonia $\alpha=0,89$; Igualitarismo $\alpha=0,90$; Domínio $\alpha=0,61$; Autonomia $\alpha=0,94$; Hierarquia $\alpha=0,82$; Conservação $\alpha=0,91$ ). Esses índices mostraram-se superiores ou similares aos encontrados por Porto et al. (2012), que relataram os valores médios de: Harmonia $\alpha=0,87$; Igualitarismo $\alpha=0,92$; Domínio $\alpha=0,76$; Autonomia $\alpha=0,88$; Hierarquia $\alpha=0,70$; Conservação $\alpha=0,87$; e aos constatados por Sousa (2013), que 
encontrou os seguintes resultados: Harmonia $\alpha=0,88$; Igualitarismo $\alpha=0,93$; Domínio $\alpha=0,79$; Autonomia $\alpha=0,92$; Hierarquia/Conservação $\alpha=0,88$. O estudo confirmatório (AFC), que até então não havia sido realizado com o instrumento, corroborou a estrutura encontrada no estudo exploratório, com índices de precisão adequados, medidos pelo Rho de Jöreskog. Por fim, a EVO mostrou validade convergente e discriminante para a amostra utilizada, o que configura evidências de sua generalidade e confiabilidade para ser utilizada em outras investigações.

Pode-se observar nos resultados que os tipos motivacionais Harmonia x Domínio contrapõem-se em sua plenitude (posicionamento assertivo versus ajustamento harmonioso, conforme Porto et al., 2012), o que demonstra a compatibilidade desse resultado com a teoria de Schwartz e Ros (1995), Schwartz (1994, 1999) e Tamayo (1996). De acordo com a teoria, o eixo Igualitarismo x Hierarquia contrapõe a autotranscedência dos interesses pessoais à distribuição desigual do poder, papéis e recursos (Porto et al., 2012). Novamente os resultados mostraram a aderência dos tipos motivacionais ao modelo de Schwartz (1994, 1999). Os resultados para o eixo Autonomia x Conservação apresentam a oposição entre a ênfase pela criatividade, a inovação, as novas práticas de gestão, ou seja, a busca por mudanças e a manutenção do status quo, isto é, a manutenção das práticas tradicionais da organização, confirmando a teoria (Schwartz, 1999).

Em síntese, os resultados apontaram que as motivações subjacentes aos valores organizacionais são compatíveis com aquelas estipuladas por Schwartz (1999) e Tamayo et al. (2000). Os resultados demonstraram que as oposições teóricas foram todas encontradas, garantindo, assim, a aderência teórica, além de confirmar a dinâmica de compatibilidades e conflitos entre os tipos motivacionais. Resultados similares foram encontrados por Porto et al. (2012) e Sousa (2013); entretanto, esses estudos apresentaram adequações parciais com a teoria, seja em virtude da amostra estudada, seja na forma de redação dos itens.

Os resultados desta tese confirmam a adequação da nova escala proposta por Porto et al. (2012) ao modelo teórico de Schwartz (1999) e Tamayo et al. (2000), diferindo, nesse sentido, de outros instrumentos de medida de valores organizacionais, que não apresentam uma teoria de base, sendo construídos, somente, de forma empírica (Porto et al., 2012). Diante disso, a EVO, utilizada nesta tese, demonstra novas evidências de validade e confiabilidade, em contexto diverso dos estudos originais (Porto et al., 2012), garantindo sua generalidade, possibilitando seu emprego em diversos contextos. 


\subsection{Discussão da Escala de Práticas Organizacionais (EPO)}

O Instrumento de Medida de Manifestações Culturais, por meio das práticas organizacionais, EMC, construído por Souza (2014) e validada nesta Tese, com a aplicação da EPO, reteve 31 dos 45 itens que compunham, inicialmente, o instrumento. A estrutura empírica esperada, de acordo com o que preconiza a teoria, de sete dimensões, não se confirmou. A AFE apresentou seis dimensões, que não inviabilizam a utilização do instrumento. Ainda mais que os estudos de D’Iribarne (1989) são de cunho etnográfico, propiciando que determinadas categorias apresentassem definições contíguas, dificultando a separação das sete categorias elencadas por Souza (2009), como nos estudos de Souza e Fenili (2012), Neumann et al. (2012), Souza et al. (2012) e Souza, et al. (2013).

Os indicadores do estudo exploratório (AFE) e do estudo confirmatório (AFC) demonstraram adequações psicométricas satisfatórias, com índices de confiabilidades aceitáveis, medidos pelos indicadores: Alpha de Cronbach, Lambda 2 de Guttman e Rho de Jöreskog. Dessa forma, a EMC - denominada nesta tese de EPO - mostrou validade convergente e discriminante para a amostra utilizada. $\mathrm{O}$ estudo exploratório possibilitou a avaliação das categorias (fatores), comparando a descrição com os itens que as compõem após a análise; dessa forma, os resultados possibilitaram uma nova interpretação da EPO, expostas da seguinte forma:

O Fator 1, inicialmente denominado Sanções, passa a ser denominado Recompensas e Punições, abarcando as recompensas e/ou punições aplicadas em função de comportamentos no trabalho; da obtenção de resultados ou objetivos propostos; da existência de políticas organizacionais e da percepção de utilização de critérios para a aplicação de sanções.

Por intermédio da análise dos itens, verifica-se que existe a percepção de que na organização há investimento na formação dos profissionais, os quais são valorizados, recompensados pelo bom desempenho e recebem as recompensas que esperam, sendo escolhidos para as missões por competência, que correspondem aos resultados encontrados nos estudos de Farias (2013), Fenili (2012), Neumann et al. (2012) e Souza et al. (2013). Observou-se, também, que os profissionais contam com o apoio da organização no que diz respeito à cooperação, que o ambiente organizacional é estimulador, e que os profissionais concordam com os critérios de controle. Novamente, os resultados de Farias (2013), Fenili (2012) e Neumann et al. (2012) foram similares. 
O Fator 2, dimensão Regulação, refere-se às ações de moderação e de acordos que regem as atividades dos profissionais, o cumprimento de contratos, a gestão de interesses organizacionais e individuais. A análise dos itens que constituíram esse fator indica a resistência às mudanças, o ritmo definido pelos profissionais nas equipes, o prazer na execução das tarefas, os laços de amizade, a flexibilidade nas relações.

Os resultados encontrados são similares aos descritos por Fenili (2012), ao declarar que a percepção de regulação refere-se a aspectos de moderação que permeiam as regras da organização, o que foi tratado por Souza et al. (2012) como moderação com ajustes informais no contexto brasileiro e por D'Iribarne et al. (1998) no contexto francês . Além disso, conforme observa Dupuis (1996), os indivíduos incorporam suas experiências em suas práticas. A esse respeito, Neumann et al. (2012) colocam, com base nos resultados de sua investigação, que os indivíduos se guiam na direção do apego às normas e aos protocolos como resguardo tanto do lado profissional quanto do prisma da organização.

No Fator 3, dimensão Senso de Dever, é tratado não apenas o exercício de procura de direitos, mas também a execução de deveres. Essa dimensão inclui aspectos de obrigação e compromisso na execução do trabalho; adesão a valores organizacionais ou prevalência de interesses individuais nas relações de trabalho; sentimentos de orgulho e de pertencimento à organização e compromisso com a obtenção de resultados.

Os Itens selecionados para esse fator estão de acordo com os descritores, tendo em conta que representam respeito ao outro, compromisso de trabalho em equipe, cumprimento de prazos, aceitação de trabalho em equipe de forma harmoniosa, aceitação de controle de desempenho, trabalho de forma integrada, sentimento de pertença à organização. De forma análoga, Fenili (2012), em seu estudo qualitativo, apresentou a percepção do senso de dever descrito pelos funcionários como comprometimento, dedicação e motivação para com a organização. No Brasil, esse pensamento está vinculado à realização de acordos e relações de interesse (Souza et al., 2012), o que resume os resultados da pesquisa de Farias (2013), para quem senso de dever se resume a fazer as obrigações.

O Fator 4, inicialmente denominado Relações Hierárquicas, passou a chamar-se Relações de Autoridade ao concentrar itens vinculados à relação entre os diferentes níveis de gestão e entre profissionais, à tomada de decisão na organização e à percepção de controle.

Os resultados tratam essa dimensão como vinculada aos processos de comunicação e a percepção de controle, cujos resultados demostram o monitoramento da organização sobre 
as atividades dos indivíduos no trabalho, corroborando o encontrado em outras pesquisas, como as de Farias (2013) e Fenili (2012) .

O Fator 5, dimensão Qualidade de Cooperação, diz respeito às características das relações interpessoais entre funcionários no trabalho individual ou em grupo; à disponibilidade dos profissionais para trabalharem em equipe; à forma como são gerenciados os conflito no grupo e pelo grupo; à tendência ao individualismo ou ao coletivismo das relações profissionais; à base em que ocorrem laços de cooperação (profissionais, sociais, familiares).

O estudo dos itens verificou a tendência ao desafio de solucionar problemas, alcançar resultados e planejar rotinas, estando associado, ainda, aos atributos das relações entre as pessoas, vinculados à colaboração, à amizade e à competitividade (Farias, 2013; Fenili, 2012), ou seja, dependente das relações pessoais (D'Iribarne et al., 1998; Souza et al., 2012).

O último Fator 6, dimensão Definição de Responsabilidades, refere-se à forma como as funções/tarefas são atribuídas (segundo critérios normativos, por fidelidade, por amizade, por interesses privados) e avaliadas, ao estabelecimento e à difusão das responsabilidades individuais e dos grupos, aos critérios formais definidos pelos superiores (responsabilidade objetiva), aos critérios informais de acordo com as relações pessoais ou a crença dos profissionais subordinados (responsabilidade subjetiva), a utilização de regras mais formalizadas.

Observando-se a distribuição dos itens, infere-se que são possíveis relacionamentos e interesses pessoais, com a percepção de maior distância do poder, com acordos e arranjos e trabalhos individuais, a utilização de regras mais formalizadas, deixando de lado ideias e comportamentos alternativos, o que também foi descrito por Farias (2013), Fenili (2012), Neumann et al. (2012), que ainda ressaltaram aspectos de informalidade na definição de responsabilidades aos indivíduos na organização.

Em síntese, a escala mostrou-se fidedigna no que se refere ao seu objetivo de mensurar práticas organizacionais, configurando-se como um instrumento importante para a gestão na esfera organizacional. Com vistas a buscar novas evidências de validade e de se testar a generalidade e confiabilidade, recomenda-se sua replicação em outras organizações, que apresentem características culturais e estrutura organizacional diversificada em relação àquela utilizada na validação deste estudo. 


\subsection{Discussão da Escala de Identidade Profissional (EIP)}

A medida da identidade profissional, nesta tese, operacionalizou-se pela medida trifatorial construída e validada por Cameron (2004) e construída com base na teoria da identidade social (Tajfel, 1978). Cameron (2004) buscou resolver a questão da dimensionalidade do construto, entre outras razões, devido à unidimensionalidade da escala de Brown et al. (1986), comumente a medida mais utilizada em pesquisas, que apontava para resultados analíticos do fator, denotando direcionalidade do item em vez de dimensionalidade do construto (Kelly, 1988; Obst \& White, 2005). Como existe suporte teórico (Deaux, 1996; Tajfel, 1978) e empírico (Jackson, 2002; Ellemers et al., 1999; Hinkle, Taylor et al., 1989) convincentes para a existência de múltiplas dimensões da identidade social, Cameron (2004) testou e confirmou a multidimensionalidade (tri-fatorial) em cinco estudos.

A aplicação da EIP, utilizada nesta tese, reteve 9 dos 18 itens do instrumento original. A perda de metade dos itens não ocasionou problemas vinculados ao objetivo do construto, mantendo uma de variância explicada de 72,78\%, com índices de confiabilidade (Laços $\alpha=0,86$; Afeto $\alpha=0,82$; Centralidade $\alpha=0,83$ ), superiores à média do estudo original de Cameron (2004) para as três dimensões (Laços $\alpha=0,79$; Afeto $\alpha=0,79$; Centralidade $\alpha=0,73$ ), bem como superior à média encontrada no estudo de Obst e White (2005) (Laços $\alpha=0,84$; Afeto $\alpha=0,81$; Centralidade $\alpha=0,74$ ). Além disso, o próprio Cameron (2004) sugere a utilização do instrumento em versões reduzidas, aumentando sua parcimônia e equilibrando o número de itens para cada dimensão.

Os indicadores do estudo exploratório (AFE) e do estudo confirmatório (AFC) demonstraram adequações psicométricas satisfatórias, com índices de confiabilidades aceitáveis, medidos pelos indicadores: Alpha de Cronbach, Lambda 2 de Guttman e Rho de Jöreskog. Por fim, a EPI mostrou validade convergente e discriminante para a amostra utilizada, como aconteceu com Cameron (2004).

A escala mostrou-se fidedigna no que se refere a seu objetivo de mensurar identidade social, no caso específico, adaptada para medir a identidade profissional, apresentando-se como um novo e importante instrumento de medida no contexto brasileiro, sobretudo para a gestão de organizações. Recomenda-se, ainda, que novos estudos sejam realizados com este instrumento, com o objetivo de encontrar novas evidência de validade, generalidade e confiabilidade, em organizações e profissionais de do setores público e privado, que apresentem diversidade em relação à amostra estudada nesta tese. 


\subsection{Discussão da Escala de Identidade Organizacional (EIO)}

A operacionalização da medida de identidade organizacional utilizada nesta pesquisa foi adaptada de Mael e Ashforth (1992), considerada a versão em português do instrumento, encontrada em alguns estudos (por exemplo, Cavazotte et al., 2010; Hildebrand, 2007; Tavares et al., 2007). A escolha pelo instrumento de Mael e Ashforth (1992) justificou-se por ser um dos mais utilizados no contexto de pesquisas de identidade organizacional (Cavazotte et al., 2010; Hildebrand, 2007; Riketta, 2004; Tavares et al., 2007).

Os resultados da AFE e da AFC aqui encontrados corroboraram a unidimensionalidade dos 6 itens da escala, e uma boa consistência interna $(\alpha=0,89)$, superior à do estudo original de Mael \&Ashforth (1992), que reportou um alfa de 0,85 e próximo ao índice de confiabilidade relatado por Cavazotte et al.(2010) de 0,92. Como não foram encontrados na literatura indicadores da AFC da EIO, esta tese fornece, por intermédio de análise confirmatória, provas complementares de validade e de confiabilidade do construto (medido pelo Rho de Jöreskog). A EIO mostrou validade convergente e discriminante para a amostra utilizada, demonstrando sua generalidade e adequação para ser empregada em futuras investigações.

\subsection{Discussão da Escala de Desempenho Profissional por Competências (EDC)}

A operacionalização da medida do desempenho profissional baseou-se no método proposto por Faiad et al. (2012) para o mapeamento profissiográfico e de competências em instituições policiais, com o emprego do mapeamento das competências (técnicas e comportamentais), realizado pela Secretaria Nacional de Segurança Pública (SENASP, 2012), sendo mensuradas em termos de domínio da competência, apoiadas nas competências consideradas de maior importância.

Diversos estudos têm mostrado a utilização das competências para se mensurar o desempenho no trabalho (Carbone et al., 2005; Brandão, 2009; Brandão et al., 2012; Laverson et al., 2006; Santos, 2012). Diante disso, foi proposta a presente medida, baseada em competências técnicas e comportamentais, conforme proposto por Faiad et al. (2012) e SENASP (2012).

Os resultados da AFE confirmaram a bi-dimensionalidade do construto, formada por um fator correspondente às competências técnicas (DCT) e outro fator cobrindo as competências comportamentais (DCC). A EDC reteve 20 dos 30 itens do instrumento aplicado. A perda de dez itens não ocasionou problemas vinculados ao objetivo do construto, 
mantendo uma variância explicada de 53,49\%, com índices de confiabilidade (DCT $\alpha=0,89$ e DCC $\alpha=0,90)$. Além disso, os resultados da AFC confirmaram a estrutura composta por dois fatores (desempenho por competências técnicas e desempenho por competências comportamentais). Como a correlação entre os fatores foi superior a 0,60 , possibilitou-se o teste de um modelo com fator de segunda ordem (Roussel et al., 2002), que contém a dimensão dependente que se quer mensurar, isto é, o desempenho profissional, de forma integrada.

Os índices da AFC, do modelo de segunda ordem, mostraram-se satisfatórios, garantindo a adequabilidade e a confiabilidade do instrumento (medido pelo Rho de Jöreskog). A EDC mostrou validade convergente e discriminante para a amostra utilizada.

Conforme se pode observar com os resultados, a escala mostrou-se fidedigna ao seu objetivo. Esse instrumento pode ser utilizado por outras instituições policiais como forma de avaliar o desempenho no trabalho, apresentando-se, assim, como uma importante ferramenta de gestão. Assim, recomenda-se, que novos estudos sejam realizados para verificar novas evidência de validade, generalidade e confiabilidade, em organizações policiais brasileiras e estrangeiras. 


\section{Seção 2. Discussão dos Resultados dos Modelos Estruturais}

Os resultados desta pesquisa mostram que as relações estruturais postuladas entre as variáveis são geralmente corroboradas pelas análises da amostra global. No entanto, a força do relacionamento é diferente, quando se testam modelos preliminares, com relações mais simples e parcimoniosas, comparados aos modelos mais complexos, que refletem os testes dos modelos estruturais globais finais.

Propõe-se a discussão dos resultados partindo das relações entre as variáveis antecedentes e mediadoras (valores organizacionais, práticas organizacionais, identidade profissional e identidade organizacional), e destas sobre a variável dependente, ou seja, o desempenho profissional. Discutem-se, portanto, os efeitos dos valores organizacionais (2.1), das práticas organizacionais (2.2), da identidade profissional e da identidade organizacional (2.3), entre si, e destas e das variáveis sociodemográficas (2.4) sobre o desempenho profissional.

\subsection{Discussão dos Valores Organizacionais}

Nesta parte, serão discutidos os resultados referentes aos valores organizacionais e sua relação com as variáveis independentes (identidade profissional e identidade organizacional), que compõem os modelos gerais e com a variável critério (desempenho profissional).

Discussão da Influência dos valores organizacionais sobre a identidade profissional e sobre a identidade organizacional

A literatura revisada apontou que cultura organizacional e identidade são construtos relacionados (Dutton \& Dukerich, 1991; Hatch, 1993; Fiol et al., 1998; Schein, 1985), de tal maneira que a identidade advém da cultura (Cheung et al., 2011). As investigações mais recentes dessa relação, ou melhor, do impacto da cultura organizacional na identidade (seja profissional ou organizacional) têm sido feitas por Bingöl et al. (2013), Chen (2011), Hatch e Schultz (2002), Kira e Balkin (2014), Millward e Haslam (2012) Prati et al. (2009), Ravasi e Schultz (2006), Ruiz Castro (2012), e Schultz e Hernes (2014), entre outros.

Os trabalhos anteriores mostraram que a cultura organizacional e seus componentes constituintes (valores e práticas organizacionais) são um antecedente maior da identidade (profissional ou organizacional). Os resultados desta pesquisa, referentes à relação entre os 
valores organizacionais, componente da cultura organizacional, e a identidade profissional e a identidade organizacional, vão nessa mesma direção.

Efetivamente, eles mostram que os tipos motivacionais subjacentes aos valores organizacionais, quando correlacionados, apresentam influência direta sobre a identidade profissional, com estes dois construtos examinados isoladamente, sendo essa relação positiva para os tipos conservação e harmonia, e negativa para igualitarismo $(\gamma=0,16, p<0,005$; $\gamma=0,61, \mathrm{p}<0,005 ; \gamma=-0,38, \mathrm{p}<0,000$, respectivamente - Figura 30).

Ao se verificarem os tipos motivacionais por dimensões bipolares separadas e de forma isolada (Sagiv et al., 2011; Schwartz et al., 2012; Tamayo, 1999; Torres et al., 2014) sobre a identidade profissional, o par Autonomia $x$ Conservação apresentou uma influência direta e positiva sobre a identidade profissional (Figura 31, $\gamma=0,19, p<0,000$ e $\gamma=0,24$, $\mathrm{p}<0,000)$. Para o par Hierarquia $x$ Igualitarismo, a relação é direta e positiva para os dois tipos (Figura 32, $\gamma=0,31, \mathrm{p}<0,000$ e $\gamma=0,38, \mathrm{p}<0,000$, respectivamente). Por fim, para Domínio $x$ Harmonia, a relação foi direta e positiva somente para o tipo harmonia sobre o desempenho competente (Figura 33, $\gamma=0,36, \mathrm{p}<0,000$ ).

A análise do modelo geral (MEG1, Figura 85) permitiu afirmar que os tipos motivacionais, Harmonia (MEG1: $\gamma=0,61, \mathrm{p}<0,000$ ) e Igualitarismo (MEG 1: $\gamma=-0,49$, $\mathrm{p}<0,000)$, apresentam relação direta e positiva e direta e negativa sobre a identidade profissional, respectivamente. Para os modelos estruturais gerais parcimoniosos - MEGP (1a, $1 \mathrm{~b}$ e 1c) - que refletem, entre outros aspectos, os tipos motivacionais bipolares, os resultados demonstraram que o tipo conservação, do par Autonomia $x$ Conservação, apresentou uma influência direta e positiva sobre a identidade profissional (MEGP1a: $\gamma=0,21, p<0,000$, Figura 87). O par Hierarquia $x$ Igualitarismo apresentou uma relação direta e positiva para os dois tipos (MEGP1b: $\gamma=0,20, \mathrm{p}<0,000$ e $\gamma=0,21, \mathrm{p}<0,000$, conforme a Figura 88). E, por último, para Domínio $x$ Harmonia, a relação foi direta e positiva somente para o tipo harmonia sobre a identidade profissional (MEGP1c: $\gamma=0,14, p<0,000$, conforme Figura 89).

A hipótese elaborada nesta tese previa que:

\section{H4a: Os valores organizacionais influenciam de forma direta e positiva a} identidade profissional.

Estes resultados indicam que a hipótese $\mathrm{H} 4 \mathrm{a}$ foi confirmada parcialmente, pois esperava-se que outras relações fossem contempladas, como, com os outros tipos motivacionais, que não se mostraram significativos. 
No que se refere à relação entre os valores organizacionais e a identidade organizacional, os achados da tese demonstram que os tipos motivacionais subjacentes aos valores organizacionais, quando correlacionados e isoladamente analisados, apresentam uma relação positiva para os tipos conservação $(\gamma=0,15, \mathrm{p}<0,005)$ e harmonia $(\gamma=0,56, p<0,000)$, e negativa para igualitarismo $(\gamma=-0,33, \mathrm{p}<0,005)$, conforme a Figura 34. Esse resultado, no que diz respeito aos tipos motivacionais, foi o mesmo da relação entre valores organizacionais e identidade profissional. $\mathrm{O}$ que demonstra que as prioridades axiológicas da organização são compatíveis ao influenciarem a identidade profissional ou organizacional.

Da mesma forma como ocorreu na relação entre os tipos motivacionais e a identidade profissional, quando se verificam os tipos motivacionais por dimensões bipolares separadas e de forma isolada sobre a identidade organizacional, o par Autonomia $x$ Conservação apresentou uma influência direta e positiva sobre a identidade organizacional (Figura 35, $\gamma=0,15, \mathrm{p}<0,000$ e $\gamma=0,24, \mathrm{p}<0,000)$. Para o par Hierarquia $x$ Igualitarismo, a relação é direta e positiva para os dois tipos (Figura 36, $\gamma=0,22, \quad \mathrm{p}<0,000$ e $\gamma=0,32, \quad \mathrm{p}<0,000$, respectivamente). Por fim, para Domínio $x$ Harmonia, a relação foi direta e positiva somente para o tipo harmonia sobre o desempenho profissional (Figura 37, $\gamma=0,34, p<0,000$ ).

A análise do modelo geral (MEG2, Figura 86) permitiu afirmar que os tipos motivacionais, Harmonia (MEG1: $\gamma=0,57, \mathrm{p}<0,000$ ) e Igualitarismo (MEG2: $\gamma=-0,37$, $\mathrm{p}<0,000)$, apresentam uma relação direta e positiva e direta e negativa sobre a identidade organizacional, respectivamente. Para os modelos estruturais gerais parcimoniosos - MEGP $(2 \mathrm{a}, 2 \mathrm{~b}$ e $2 \mathrm{c})$ - que refletem os tipos motivacionais bipolares, os resultados demonstraram uma influência direta e positiva do par Autonomia $x$ Conservação sobre a identidade organizacional (MEGP2a: $\gamma=0,09, \mathrm{p}<0,05$ e $\gamma=0,16, \mathrm{p}<0,000$, conforme Figura 90). Para o par Hierarquia $x$ Igualitarismo, a relação é direta e positiva para os dois tipos (MEGP2b: $\gamma=0,16, \mathrm{p}<0,000$ e $\gamma=0,21, \mathrm{p}<0,000$, respectivamente, como mostra a Figura 91) sobre a identidade organizacional. Por último, para o par Domínio $x$ Harmonia, a relação foi direta e positiva somente para o tipo harmonia sobre a identidade organizacional (MEGP1c: $\gamma=0,13$, $\mathrm{p}<0,005$, Figura 92).

Estes resultados demonstram algumas modificações nas relações entre os valores organizacionais e a identidade profissional, comparando-se com a relação daqueles com a identidade organizacional, notadamente, no poder de predição dos tipos motivacionais, que foram superiores na explicação da identidade profissional. Disso resulta que a forma como o indivíduo se identifica na organização, principalmente em termos de sua centralidade, ou 
seja, do seu destaque cognitivo, que reflete sua vinculação à profissão (Dubar, 1994, 2005; Machado, 2003), de sua avaliação emocional (afetiva) e dos vínculos que forma com os membros da organização (Dubar, 2005; Sainsanlieu, 1995), é superiormente afetada pelos valores organizacionais se comparada com a identidade organizacional.

Parte desses resultados podem ser encontrados nos estudos de Nascimento (2010) e Sousa (2009). Estes autores mostram como os valores afetam a identidade profissional, principalmente, quando, no ambiente organizacional, os indivíduos têm seus espaços de autonomia restringidos (Machado, 2003; Dubar, 2005), fazendo com o que os interesses pessoais e coletivos ganhem relevo no ambiente organizacional.

A hipótese elaborada nesta tese, para esta relação, previa que:

H4b: Os valores organizacionais influenciam de forma direta e positiva a identidade organizacional.

Os resultados da presente pesquisa indicam que a hipótese $\mathrm{H} 4 \mathrm{~b}$ foi confirmada parcialmente.

Além disso, tais resultados evidenciam que os tipos motivacionais podem ser investigados em conjunto (covariantes) ou separados por dimensão bipolar, o que se repetiu para as outras análises com a dimensão valores organizacionais. No primeiro caso, a covariância entre os tipos motivacionais faz com que a variância seja concentrada nos tipos motivacionais de maior representatividade (significância estatística), o que representa a definição da percepção da prioridade axiológica da organização, como aconteceu nos estudos de Veiga (2010) e Sousa (2013). Ao se examinarem os pares bipolares, a parcimônia do modelo permite verificar a influência direta dos tipos motivacionais opostos separadamente, o que possibilita um teste mais aprimorado da influência na variável dependente (Torres et al., 2014).

Quando os valores organizacionais encontram-se todos relacionados e influenciam de forma direta a identidade profissional e a identidade organizacional, as prioridades axiológicas da organização estudada são conservação e harmonia (influência positiva) e igualitarismo (influência negativa). Nos modelos gerais (MEG1 e 2, e MEGP 1a e 2a), conservação deixou de influenciar a identidade, permanecendo a influência direta e positiva do tipo harmonia e negativa de igualitarismo.

A presença do tipo conservação reflete o tradicionalismo da função exercida pelos policiais e como isso afeta sua identidade (Nascimento, 2010; Sousa, 2009). Para o tipo harmonia, busca-se uma convivência pacífica, adequando-se a organização e não sua 
mudança, como forma de se manter a coesão organizacional e a identidade profissional dos policiais (Sousa, 2009) bem como sua identificação com a organização (Prati et al., 2009), além de manter uma relação de transparência e respeito com a sociedade, buscando a credibilidade frente aos cidadãos. Já o igualitarismo, que se apresenta de forma negativa no modelo, reflete uma comprovação de que na PMDF os interesses pessoais se sobrepõem aos interesses organizacionais, como relatado por Nascimento (2010) e Pinto (2000), sendo novamente encontrados e melhor evidenciados pelos relatos das entrevistas conduzidas por Nascimento (2014) e analisadas por Vasques-Menezes et al. (2014). Segundo Machado (2003), os interesses pessoais e coletivos estão vinculados ao processo de construção das identidades, que passam por constantes articulações no ambiente organizacional.

Assim sendo, os arranjos sociais constituídos no seio da organização passam a compor a memória de seus sujeitos, os quais elegem os relacionamentos que comporão o universo de relacional, com o intuito de construir as experiências e os relacionamentos que irão fazer frente às pressões que objetivam aumentar os espaços de poder organizacional (Fernandes \& Zanelli, 2006; Machado, 2003).

Esses tipos motivacionais exprimem características da organização policial militar em manter o respeito a suas tradições e a conformidade com as regras organizacionais, principalmente relativos aos pilares que a sustentam, hierarquia e disciplina. Soma-se a isto, o fato de o tipo motivacional harmonia ser considerado uma prioridade axiológica, representando um importante pilar da função policial, dirigida à sociedade, buscando relações cristalinas, com respeito às leis, com o intuito de salvaguardar a sociedade.

Estabelece-se, portanto, a necessidade de uma concordância, mesmo que relativa, entre os policiais e a organização, na tentativa de se preservar a ordem social, o que possibilita o atendimento de interesses particulares em detrimento aos organizacionais. Tudo isso, para evitar-se um rompimento com a tradição, com a harmonia e com os pilares de hierarquia e disciplina, mesmo que se impacte a identidade profissional e a identidade organizacional dos policiais (Nascimento, 2010; Millward \& Haslam, 2012; Rodrigues et al., no prelo; Souza, 2010; Wieseke et al., 2009).

\section{Discussão da Influência dos valores organizacionais sobre o desempenho profissional}

Conforme as antecipações teóricas encontradas na revisão de literatura (Gregory et al., 2008; Hartnell et al., 2011; Tomczyk et al., 2013), os valores organizacionais, mensurados 
nesta tese pelos seus tipos motivacionais subjacentes, apresentam um efeito direto sobre o desempenho profissional, sendo essa relação positiva para a maioria dos tipos motivacionais.

Quando os tipos motivacionais encontram-se correlacionados e se testou a influência sobre o desempenho profissional, com estes dois construtos examinados isoladamente, a relação foi positiva para os tipos motivacionais conservação $(\gamma=0,20, p<0,000)$ e harmonia $(\gamma=0,62, p<0,000)$ e negativa para igualitarismo $(\gamma=-0,52, \mathrm{p}<0,000)$, conforme Figura 38.

Ao se analisarem os tipos motivacionais por dimensões bipolares separadas e de forma isolada sobre o desempenho, o tipo conservação, do par Autonomia $x$ Conservação, apresentou uma influência direta e positiva sobre o desempenho profissional $(\gamma=0,32$, p<0,000, Figura 39). Para o par Hierarquia $x$ Igualitarismo, a relação é direta e positiva para os dois tipos $(\gamma=0,29, p<0,000$ e $\gamma=0,24, p<0,000$, respectivamente, Figura 40). Por fim, para Domínio $x$ Harmonia, a relação foi direta e positiva somente para o tipo harmonia sobre o desempenho profissional $(\gamma=0,28, p<0,000$, Figura 41$)$. Estes resultados indicam que os tipos motivacionais subjacentes aos valores organizacionais, apresentam uma influência direta sobre o desempenho profissional, sendo positiva quando se analisam os tipos separadamente pelos pares bipolares.

As análises dos modelos estruturais gerais (MEG) permitem afirmar que os tipos motivacionais, subjacentes aos valores organizacionais, apresentam uma relação direta e positiva sobre o desempenho profissional para Conservação (MEG 1: $\gamma=0,11, p<0,05$; MEG 2: $\gamma=0,13, p<0,05$ ) e Harmonia (MEG 1: $\gamma=0,55, p<0,000$; MEG 2: $\gamma=0,44 p<0,005$ ), sendo a relação direta e negativa para Igualitarismo (MEG 1: $\gamma=-0,49, p<0,000$; MEG 2: $\gamma=-0,40$, $\mathrm{p}<0,005)$, conforme Figuras 85 e 86.

Para os modelos estruturais gerais parcimoniosos - MEGP (1a, 1b e 1c) - que refletem, entre outros aspectos, os tipos motivacionais bipolares, os resultados demonstraram que o tipo conservação, do par Autonomia $x$ Conservação, apresentou uma influência direta e positiva sobre o desempenho profissional (MEGP1a: $\gamma=0,19, \mathrm{p}<0,000$, Figura 87). Para o par Hierarquia $x$ Igualitarismo, a relação é direta e positiva para os dois tipos (MEGP1b: $\gamma=0,20$, $\mathrm{p}<0,000$ e $\gamma=0,12, \mathrm{p}<0,000$, respectivamente, Figura 88). Por último, para Domínio $x$ Harmonia, a relação foi direta e positiva somente para o tipo harmonia sobre o desempenho profissional (MEGP1c: $\gamma=0,14, \mathrm{p}<0,000$, Figura 89).

No mesmo sentido das relações acima apresentadas, os resultados dos modelos estruturais gerais parcimoniosos - MEGP (2a, 2b e 2c) - expuseram que, referente aos tipos Autonomia $x$ Conservação, o tipo conservação demonstrou influência direta e positiva sobre 
o desempenho profissional (MEGP2a: $\gamma=0,19, \mathrm{p}<0,000$, Figura 90). No que se refere ao par Hierarquia $x$ Igualitarismo, a relação é direta e positiva para os dois tipos (MEGP2b: $\gamma=0,18$, $\mathrm{p}<0,000$ e $\gamma=0,10, \mathrm{p}<0,000$, respectivamente, Figura 91). Por último, Domínio $x$ Harmonia, a relação foi direta e positiva somente para o tipo harmonia sobre o desempenho profissional (MEGP2c: $\gamma=0,13, p<0,000$, Figura 92).

A hipótese da tese previa que:

\section{H1: Os valores organizacionais influenciam de forma direta e positiva o} desempenho profissional por competências.

Os resultados indicam que os tipos motivacionais subjacentes aos valores organizacionais apresentam uma influência direta sobre o desempenho profissional, sendo positiva quando se analisam os tipos separadamente pelos pares bipolares, confirmando parcialmente a hipótese H1. Esperava-se que todas as relações fossem confirmadas, o que não ocorreu para o tipo domínio.

A análise da literatura permite ratificar parte dos efeitos encontrados neste estudo. A ausência de influência do tipo motivacional autonomia encontra respaldo nos estudos de Veiga (2010), que estabelece ser a autonomia uma prioridade axiológica da organização, predizendo, portanto, comportamentos proativos (Veiga, 2010) e de cidadania organizacional (Porto \& Tamayo, 2005), por exemplo. Entretanto, como a PMDF é uma organização militarmente organizada, baseada em hierarquia e disciplina, o tipo motivacional autonomia, que reflete a criatividade, a autonomia intelectual e afetiva, tende a ser tolhido. Resultados semelhantes a estes podem ser encontrados em Nascimento (2010), Pinto (2000), Rodrigues et al. (no prelo) e Sousa (2009).

Prefere-se, diante disso, a manutenção de um status quo vinculado à manutenção de suas tradições, não sendo considerados aspectos ligados à inovação ou autonomia (Nascimento, 2010; Nascimento et al., 2013; Sousa, 2009), justificando-se a prevalência do tipo motivacional conservação, que ressalta a manutenção do funcionamento da organização de maneira tradicional, impedindo ações que possam prejudicar o grupo ou as tradições.

Os valores organizacionais, conforme explicam Tamayo et al. (2000), são sociocêntricos, isto é, os interesses dos indivíduos não são vistos como diferentes dos interesses da organização. Entretanto, pode-se observar que a percepção do tipo motivacional relacionado ao igualitarismo, que expressa o desejo de redução do interesse particular em prol do bem-estar coletivo, quando em conjunto com os tipos conservação e harmonia, apresentou-se impactando negativamente o desempenho, o que demonstra que o interesse do 
indivíduo supera o interesse da coletividade. Esses resultados foram similarmente encontrados por Nascimento (2010), Nascimento et al. (2013) e Rodrigues et al. (no prelo), mesmo que a literatura apresente resultados diferentes, por exemplo no trabalho de Hartnell et al. (2011) que encontraram um efeito mais forte entre a cultura tipo Clã, similar ao tipo Igualitarismo, e o desempenho no trabalho.

Relativamente à harmonia, sua influência positiva sobre o desempenho, relacionandose com os demais tipos motivacionais, pode ser justificada pela necessidade de os indivíduos da organização buscarem uma forma de convivência pacífica, sem a mudança no ambiente organizacional, pois, conforme observa Monjardet (2002), a organização policial apresenta um modelo rígido de autoridade, que se baseia em ordens, comandos e disciplina, para o alcance do sucesso organizacional. Junta-se a isso, o fato de o tipo harmonia estar atrelado à missão da organização, que obriga a PMDF a atuar com transparência e respeito frente à sociedade, buscando a credibilidade da população.

Os resultados demonstram que, ao se analisarem as prioridades axiológicas da polícia, os tipos motivacionais de conservação e harmonia refletem uma busca pela manutenção do status social da organização, com foco em sua missão de servir e proteger a sociedade. O tipo motivacional igualitarismo encontrado nesta tese nos modelos gerais reforça o que Monjardet (2002) observou sobre a eficácia das organizações policiais. Para o autor, o funcionamento eficaz das instituições policiais passa pelo estabelecimento de uma organização informal, com a finalidade de se implementar mecanismos de cooperação no reconhecimento mútuo de uma interdependência funcional muito estreita. Pode-se considerar, portanto, os valores organizacionais como respostas para um problema concreto, fundamental, da organização, ou seja, soluções que a levam ao sucesso (Tamayo \& Borges, 2006).

\subsection{Discussão das Práticas Organizacionais}

Nesta parte, serão discutidos os resultados referentes às práticas organizacionais e sua relação com a identidade profissional e a identidade organizacional e com o desempenho profissional.

Discussão da Influência das práticas organizacionais sobre a identidade profissional e sobre a identidade organizacional

As práticas organizacionais estabelecem-se como a manifestação da cultura da organização (D’Iribarne, 1983), sendo um de seus principais componentes (Hofstede, 2001). 
Da mesma forma que os valores organizacionais, as práticas organizacionais apresentam uma estreita relação de influência sobre as identidades (profissionais e organizacionais), na medida em que comunicam sentidos e significados aos sujeitos dos ambientes em que as práticas se desenvolvem (Dupuis, 1996).

A relação já demonstrada entre cultura organizacional e identidade (Dutton \& Dukerich, 1991; Hatch, 1993; Fiol et al., 1998; Schein, 1985), sendo a identidade advinda da cultura, conforme observou Cheung et al. (2011), possibilitou a realização de diversos estudos. Esses estudos investigaram, entre outros aspectos, as relações entre a cultura, ou seus elementos constitutivos, notadamente as práticas, e a identidade (Baruch, 2009; Chang \& Wu, 2013; Prati et al., 2009; Smith, et al., 2013; Tataw, 2012), que acabaram por demonstrar a influência das práticas sobre a identidade.

Novamente, os resultados desta tese confirmam a influência das práticas organizacionais sobre a identidade profissional e organizacional, apoiando os aspectos teóricos e empíricos envolvidos nas investigações dessas relações. De maneira concreta, o instrumento utilizado para se mensurar as práticas organizacionais, quando constituído com suas seis dimensões correlacionadas, apresenta uma influência direta sobre a identidade profissional, com estes dois construtos avaliados de forma isolada, sendo essa relação positiva para a prática de regulação $(\gamma=0,16, p<0,000)$, e negativa para a definição de responsabilidade $(\gamma=-0,11, \mathrm{p}<0,05)$, conforme Figura 42.

Como o instrumento de práticas organizacionais não havia sido validado, psicometricamente, anteriormente a esta tese, decidiu-se verificar a influência dos seis fatores que o constituem, de maneira separada, sobre a identidade profissional (regressão estrutural simples). A parcimônia de um modelo estrutural como o proposto permite conhecer a influência de cada fator separadamente sobre a variável dependente, sem que haja covariância entre os fatores, o que pode acarretar concentração da variância em torno de poucos fatores, como ocorreu no resultado acima.

Este teste possibilitou verificar que o instrumento, de forma isolada, é preditor da identidade profissional, para quase todos os fatores, à exceção de definição de responsabilidade. Este resultado comprova a hipótese de que, quando correlacionados, ocorre o compartilhamento de variância, pois a prática de definição de responsabilidade mostrou que influencia a identidade quando covariada com as outras práticas (ver Figuras 42 e 48).

Especificamente, as práticas de recompensas e punições $(\gamma=0,44, p<0,000$, Figura 43), de regulação $(\gamma=0,65, p<0,000$, Figura 44), de senso de dever $(\gamma=0,48, p<0,000$, Figura 45), 
de relações de autoridade $(\gamma=0,39, p<0,000$, Figura 46), e de qualidade da cooperação $(\gamma=0,50, p<0,000$, Figura 47) tiveram influência direta e positiva sobre a identidade profissional, sendo que a prática de definição de responsabilidade não se mostrou significativa ( $\mathrm{p}=0,146$, Figura 48).

A análise do modelo geral (MEG1, Figura 85) permitiu afirmar que as práticas de regulação (MEG1: $\gamma=0,59, \mathrm{p}<0,000$ ) e definição de responsabilidade (MEG 1: $\gamma=-0,10$, $\mathrm{p}<0,05)$ apresentam relação direta e positiva e direta e negativa sobre a identidade profissional, respectivamente. Para os modelos estruturais gerais parcimoniosos - MEGP (1a, 1b e 1c) - somente a prática de regulação apresentou influência direta e positiva sobre a identidade profissional (MEGP1a: $\gamma=0,59, \mathrm{p}<0,000$, Figura 87; MEGP1b: $\gamma=0,58, \mathrm{p}<0,000$, Figura 88; MEGP1c: $\gamma=0,58, \mathrm{p}<0,000$, Figura 89).

A hipótese de pesquisa elaborada neste trabalho previa que:

H5a: As práticas organizacionais influenciam de forma direta e positiva a identidade profissional.

Os resultados indicam que a hipótese H5a foi confirmada parcialmente. Esperava-se que outras práticas emergissem como explicativas da identidade profissional, o que não ocorreu.

Para a relação entre as práticas organizacionais e a identidade organizacional, os achados da tese apresentam que a relação é positiva para a prática de regulação $(\gamma=0,48$, $\mathrm{p}<0,000)$ e negativa para definição de responsabilidade $(\gamma=-0,14, p=0,005)$, conforme a Figura 49. Esse resultado foi o mesmo da relação entre práticas organizacionais e identidade profissional, o que demonstra que a percepção das práticas da organização são compatíveis ao influenciarem a identidade profissional e organizacional.

A análise isolada de cada uma das práticas sobre a identidade organizacional resultou na influência direta e positiva das práticas de recompensas e punições $(\gamma=0,30, p<0,000$, Figura 50), de regulação $(\gamma=0,45, p<0,000$, Figura 51), de senso de dever $(\gamma=0,33, p<0,000$, Figura 52), de relações de autoridade $(\gamma=0,31, p<0,000$, Figura 53), de qualidade da cooperação $(\gamma=0,39, \mathrm{p}<0,000$, Figura 54), não sendo significativa a relação da prática de definição de responsabilidade $(\gamma=0,45, \mathrm{p}<0,000$, Figura 55), o que, de forma semelhante, ocorreu com a relação entre as práticas e a identidade profissional.

A análise do modelo geral (MEG2, Figura 86) permitiu afirmar que as práticas de regulação (MEG2: $\gamma=0,61, p<0,000)$ e definição de responsabilidade (MEG 2: $\gamma=-0,22$, $\mathrm{p}=0,002$ ) apresentam relação direta, sendo positiva para regulação. Para os modelos 
estruturais gerais parcimoniosos - MEGP (2a, 2b e 2c) - somente a prática de regulação apresentou influência direta e positiva sobre a identidade profissional (MEGP2a: $\gamma=0,39$, $\mathrm{p}<0,000$, Figura 90; MEGP2b: $\gamma=0,41, \mathrm{p}<0,000$, Figura 91; MEGP1c: $\gamma=0,39, p<0,000$, Figura 92). Estes resultados apontam para a percepção dos policiais de que sua identidade é fortemente influenciada pela prática de regulação, quase que exclusivamente.

A hipótese de pesquisa desta relação previa que:

H5b: As práticas organizacionais influenciam de forma direta e positiva a identidade organizacional.

Os resultados indicaram que a $5 \mathrm{~b}$ foi confirmada parcialmente.

Estes achados apontam para a percepção dos policiais de que sua identidade (profissional e organizacional) é fortemente influenciada pela prática de regulação, quase que exclusivamente, o que de certa maneira representa a organização estudada. Para Rodrigues et al. (no prelo), a cultura organizacional da PMDF apresenta-se como avessa a mudanças, regida para manter seu status quo, pelo culto às tradições e com base na hierarquia e disciplina, o que exige regulação (Nascimento, 2010; Nascimento et al., 2013; Sousa, 2009).

A presença da prática de regulação reflete os aspectos de moderação que permeiam as regras da organização, bem como os acordos que regem as atividades dos profissionais, o cumprimento de contratos, a gestão de interesses organizacionais e individuais, presentes na definição do modelo teórico de D’Iribarne (1993). Além disso, a presença dessa prática reflete a resistência às mudanças, similarmente encontrada no estudo de Rodrigues et al. (no prelo), bem como o ritmo definido pelos profissionais nas equipes, o prazer na execução das tarefas, os laços de amizade, a flexibilidade nas relações (Fenili, 2012; Nascimento, 2010; Nascimento et al., 2013; Sousa, 2009). De forma complementar, como os valores antecedem as práticas, o tipo motivacional conservação, relatado com prioridade axiológica da organização, reflete a prática de regulação, pois em ambos os casos, a ênfase recai na manutenção tradicional do funcionamento organizacional.

Para a prática de definição de responsabilidade, os resultados mostram que são possíveis os relacionamentos e interesses pessoais, existindo a percepção de maior distância do poder, com possibilidade de acordos e arranjos e trabalhos individuais, utilização de regras mais formalizadas, deixando de lado ideias e comportamentos alternativos. A influência negativa da prática de definição de responsabilidade sobre a identidade profissional justificase na medida em que esta identidade é entendida numa perspectiva social, em que se articulam o processo cognitivo de categorização e a vinculação social, apresentando-se como 
estrutura psicológica que efetua a ligação entre o indivíduo e o grupo (Baugnet, 1998). Ao possibilitar o desenvolvimento de acordos e arranjos e trabalhos individuais, restringe-se a conexão entre a experiência afetiva proveniente dos relacionamentos e a experiência cognitiva da descoberta (Machado, 2003). Novamente, esta prática está associada ao tipo motivacional igualitarismo, lembrando que sua relação foi inversa nos modelos gerais, o que se traduz no tratamento diferenciado entre os policiais e na realização dos interesses pessoais.

A primazia da prática de regulação vincula-se à forma de como os acordos na PMDF regem as ações dos seus profissionais, especificamente no modo como as relações conflituosas são tratadas nesse ambiente organizacional. Trata-se, portanto, de uma forma de resistência às mudanças que poderia atingir este ambiente, conforme Rodrigues et al. (no prelo), Nascimento (2010), Sousa (2009). Com base nisso, flexibilizam-se as relações, que passam por constantes articulações no ambiente organizacional, com o intuito de impedir mudanças, garantindo que a organização continue tradicional, avessa a inovações, o que poderia comprometer sua coesão e afetar seus status quo. Esses arranjos, engendrados no dia a dia da organização, objetivam aumentar os espaços de poder organizacional (Fernades \& Zanelli, 2006; Machado, 2003), restringindo a identidade profissional e a identidade organizacional.

Desta forma, de acordo com Bedani (2008) e Ferreira e Mendes (2008), a forma como a organização estrutura que suas práticas - no que se refere aos elementos prescritos (formais e informais), à concepção e aos modelos de gestão (de pessoas e do trabalho), à divisão do trabalho, às relações hierárquicas, às metas e aos resultados almejados, aos ritmos, às regras formais, aos controles e às características das tarefas - sejam assumidas mais em função das pressões provenientes dos sistemas de controle interno e do ambiente da organização, como propõem Aycan et al. (1999), Delmas e Foffel (2004) e Verbeke (2000), que em função dos valores organizacionais (Bedani, 2009).

Outros resultados que merecem atenção referem-se às relações entre as práticas organizacionais e a identidade (profissional e organizacional), que foram semelhantes às dos valores organizacionais. Demonstrando a influência da cultura organizacional sobre a identidade profissional e organizacional, como preconizaram diversos autores (Baruch, 2009; Bingöl et al., 2013; Chang \& Wu, 2013; Chen, 2011; Kira \& Balkin, 2014; Prati et al., 2009; Smith, et al., 2013; Tataw, 2012), manteve-se consistente e equivalente ao se examinarem os valores e as práticas da organização, o que reflete a cultura da organização. 
Os resultados apontaram para um maior poder de explicação, proporcionado tanto pelos valores quanto pelas práticas sobre a identidade profissional, comparativamente à identidade organizacional. A explicação para este resultado pode residir no fato de que a identidade profissional apresenta maior força na constituição do autoconceito do indivíduo no trabalho (Ashforth \& Mael, 1989; Dubar, 2005, 2009; Erickson, 1972; Machado, 2003; Pratt, 200; Scott \& Lane, 2000; Tajfel \& Turner, 1979), do que sua identificação com a organização (Ashforth \& Mael, 1989). Como a concepção do autoconceito é gradativa (Machado, 2003), ocorre primeiro uma vinculação com o grupo de pertença, com o trabalho que realiza (identidade profissional) e, por fim, com a organização (identidade organizacional), permeados por aspectos cognitivos e afetivos.

As demais práticas organizacionais (recompensas e punições, senso de dever, relações de autoridade e qualidade da cooperação) não se relacionaram com a identidade (profissional e organizacional) de forma significativa, somente quando investigadas separadas uma a uma, o que não se justifica para fins de teste dos modelos gerais. Estes resultados podem corresponder a diferenças de percepção entre os entrevistados, levando em conta, principalmente seus perfis, no que diz respeito, por exemplo, ao tempo de serviço e ao posto. Essas diferenças, entre outras, podem levar a percepções não compartilhada pelos policiais. Pode-se inferir que por serem estas práticas incorporadas a formação do policial podem estar fortemente enraizadas na doutrina da corporação, não encontrando lugar de destaque entre as características culturais da organização. Como a escala EMC de manifestações culturais foi validada pela primeira vez neste estudo, recomenda-se repetir esses procedimentos em outros grupos de profissionais.

Por essa forma de compreensão, o grupo, o trabalho e a organização constituem-se como bases centrais de representação do eu para o indivíduo (Ashforth \& Mael, 1989; Erickson, 1972; Machado, 2003; Pratt, 200; Dubar, 2005, 2009; Scott \& Lane, 2000; Tajfel \& Turner, 1979). Quanto maior o reconhecimento do indivíduo em todas as esferas, ou seja, no trabalho desempenhado, no grupo ou na organização de pertença, maior é a força desses elementos na constituição do próprio conceito (Dubar, 2005; Machado, 2003; Oliveira, 2008; Van Der Zee et al., 2004).

\section{Discussão da Influência das práticas organizacionais sobre o desempenho profissional}

A relação entre cultura organizacional e desempenho é frequente na literatura, como apontam as revisões de Sackmann (2011), Schneider et al., (2013) e Wilderom et al. (2000). 
A revisão de literatura anteriormente realizada contemplou a relação entre práticas organizacionais e o desempenho no trabalho (Chan et al., 2004; Peltier et al., 2013; TrigueroSánchez et al., 2013). Parte dessas investigações assinalaram para o efeito direto sobre o desempenho profissional, o que é corroborado pelos resultados desta tese.

As práticas organizacionais, quando analisadas com suas seis dimensões correlacionadas, apresentam uma influência direta sobre o desempenho profissional, sendo essa relação positiva para a prática de regulação $(\gamma=0,45, p<0,000)$, e negativa para definição de responsabilidade $(\gamma=-0,18, \mathrm{p}<0,05)$, conforme a Figura 56.

De maneira semelhante ao procedido na relação entre práticas e identidade, verificouse a influência dos seis fatores componentes das práticas que o constituem, de maneira separada, sobre o desempenho profissional (regressão estrutural simples). De maneira específica, as práticas de recompensas e punições $(\gamma=0,19, \mathrm{p}=0,002$, Figura 57$)$, de regulação $(\gamma=0,34, p<0,000$, Figura 58), de senso de dever $(\gamma=0,24, p<0,000$, Figura 59), de relações de autoridade $(\gamma=0,27, p<0,000$, Figura 60$)$, e de qualidade da cooperação $(\gamma=0,24, p<0,000$, Figura 61) tiveram uma influência direta e positiva sobre a identidade profissional, sendo que a prática de definição de responsabilidade não se mostrou significativa ( $\mathrm{p}=0,930$, Figura 62).

A análise do modelo geral (MEG1 e MEG2, Figuras 85 e 86) permitiu afirmar que as práticas de regulação (MEG1: $\gamma=0,18, \mathrm{p}<0,000$; e MEG2: $\gamma=0,17, \mathrm{p}<0,000$ ) e definição de responsabilidade (MEG 1: $\gamma=-0,16, \mathrm{p}<0,05$; e MEG2: $\gamma=-0,22, \mathrm{p}<0,002$ ), apresentam uma relação direta e positiva e direta e negativa sobre o desempenho profissional, respectivamente. Para os modelos estruturais gerais parcimoniosos - MEGP (1a, 1b e 1c) - a prática de regulação apresentou influência direta e positiva sobre o desempenho profissional (MEGP1a: $\gamma=0,21, \mathrm{p}<0,000$, Figura 87; MEGP1b: $\gamma=0,23, \mathrm{p}<0,000$, Figura 88; MEGP1c: $\gamma=0,23, p<0,000$, Figura 89), e influência direta e negativa para a prática de definição de responsabilidade sobre o desempenho profissional (MEGP1a: $\gamma=-0,13, p<0,05$, Figura 87; MEGP1b: $\gamma=-0,15, p<0,05$, Figura 88; MEGP1c: $\gamma=-0,15, p<0,05$, Figura 89).

Para os modelos estruturais gerais parcimoniosos - MEGP (2a, 2b e 2c) - os resultados indicaram que a prática de regulação apresentou influência direta e positiva sobre o desempenho profissional (MEGP2a: $\gamma=0,10, p<0,05$, Figura 90; MEGP2b: $\gamma=0,13, p<0,05$, Figura 91; MEGP2c: $\gamma=0,13, \mathrm{p}<0,05$, Figura 92), e influência direta e negativa para a prática de definição de responsabilidade sobre o desempenho profissional (MEGP2a: $\gamma=-0,13$, $\mathrm{p}<0,05$, Figura 90; MEGP2b: $\gamma=-0,15, \mathrm{p}<0,05$, Figura 91; MEGP1c: $\gamma=-0,15, p<0,05$, Figura 92). 
A hipótese da tese previa que:

H2: As práticas organizacionais influenciam de forma direta e positiva o desempenho profissional por competências.

Estes resultados indicam que as práticas organizacionais apresentam influência direta sobre o desempenho profissional, sendo positiva para o fator regulação e negativa para definição de responsabilidade, o que corrobora parcialmente a hipótese H2. A análise da literatura permite ratificar parte dos efeitos encontrados neste estudo.

A escassez de estudos que relacionam as práticas organizacionais, baseadas no modelo de manifestações culturais de D'Iribarne (1983, 2009b), ao desempenho no trabalho limitam, mas não impossibilitam a discussão dos dados. A esse respeito, Souza (2009) observa que o indivíduo, por intermédio da regulação, comporta-se de acordo com algumas regras da organização, além de aceitar orientações e a gestão das políticas da organização, articulando a forma como os empregados vivenciam seu trabalho e a organização, o que possibilita um efeito positivo sobre o desempenho. Como afirma Dupuis (1996), os indivíduos incorporam suas experiências em suas práticas, resultando em desempenhos superiores, o que de forma similar foi relatado por Sonnentag e Frese (2002).

A prática de regulação, como prioritária da percepção dos sujeitos é internalizada, refletindo as características vigentes na organização em todos os níveis (Zeitz et al., 1999). Essa dinâmica permite o equilíbrio entre a organização e o seu ambiente, envolvendo todos os membros, a tecnologia, aspectos legais e financeiros. A internalização torna-se um processo complexo que envolve muitos fatores da cultura organizacional, exigindo coerência entre os valores partilhados e o uso de recursos, com o objetivo de aprimorar o desempenho.

De acordo com Sonnentag e Frese (2002), a perspectiva de regulação do desempenho refere-se à análise dos processos envolvidos na manutenção do desempenho, vinculando-se ao interesse do indivíduo em sua manutenção, como no caso da prática de definição de responsabilidades, cujo favorecimento dos interesses individuais, frente aos interesses da organização, pode afetar o desempenho. Soma-se a isso o abandono de comportamentos alternativos, como práticas de inovação, que estão associadas com melhor desempenho (Baer \& Frese, 2003; Fay \& Sonnentag, 2010). A instituição policial estudada apresenta aversão à mudança; as práticas que levem à mudança na cultura e na identidade são rechaçadas, como observaram Nascimento (2010) e Sousa (2009).

Estudos como os de Seifert, Yukl e McDonald (2003) sobre a perspectiva da regulação do desempenho sinalizam que o estabelecimento contínuo de intervenções 
planejadas de maneira prévia, relativas à orientação por metas, ações de feedback que estejam vinculadas às tarefas, afetam o desempenho. Estas perspectivas assemelham-se às práticas de regulação e definição de responsabilidade, ao referir-se às ações de moderação e de acordos que regem as atividades dos profissionais, o cumprimento de contratos, gestão de interesses organizacionais e individuais, no caso da primeira, e, relacionamentos e interesses pessoais, com possibilidade de acordos e arranjos e trabalhos individuais, no caso da segunda.

Discussão: comparando a Influência das práticas e dos valores na predição da identidade (profissional e organizacional) e do desempenho profissional

Os achados evidenciam o papel de protagonista, das práticas organizacionais, na predição da identidade (profissional e organizacional) e do desempenho profissional, comparativamente aos valores organizacionais.

Nesta tese, postulou-se a hipótese de que:

H3: As práticas organizacionais têm maior poder de predição sobre o desempenho em comparação com os valores organizacionais.

H6: As práticas organizacionais têm maior poder de predição sobre a identidade profissional (H6a) e identidade organizacional (H6b) em comparação com os valores organizacionais.

Os resultados encontrados confirmam as hipóteses H3, H6a e H6b.

A literatura apresenta-se conflitante na discussão sobre quais componentes (valores ou práticas) constituem o núcleo da cultura organizacional. Parte dos autores (Schein, 1988; Paz \& Tamayo, 2004) preconizam que são os valores organizacionais; enquanto para outros, são as práticas organizacionais (D’Iribarne, 1983; Hofstede et al., 1990), mesmo havendo concordância quanto à proeminência de ambos.

Os achados deste trabalho, considerados de maneira conjunta, evidenciam que as práticas organizacionais são melhores preditoras da identidade profissional, da identidade organizacional e do desempenho profissional em comparação aos valores organizacionais. Como a identidade está intimamente relacionada à cultura organizacional (Cheung et al., 2011), pode-se inferir que as práticas são os elementos mais manifestos da cultura organizacional, ocasionando maior influência sobre a identidade (profissional e organizacional) e sobre o desempenho.

Resultado semelhante foi encontrado por Santos (2012), cujos indivíduos que apresentaram maiores escores nos fatores de identidade expressavam em maior grau o 
desempenho profissional relativo ao contexto. A esse respeito, Sonnentag e Frese (2002) observam que se deve verificar a natureza desta dimensão, conforme o modelo que propuseram. Conforme este modelo teórico, os preditores de desempenhos dirigidos ao contexto estão relacionados de forma efetiva aos constructos de natureza disposicional. Os efeitos encontrados, que ressaltam tanto a importância da identidade profissional quanto da identidade organizacional, podem ter sido aumentados em função do contexto em que esta investigação foi concretizada.

Algumas pesquisas têm demonstrado empiricamente maior predição das práticas sobre determinados construtos do comportamento organizacional. Como exemplo, está a investigação de Veiga (2010), que tratou da influência dos valores organizacionais e de práticas de estímulo e barreiras à criatividade sobre o comportamento proativo. Os resultados indicaram que as práticas apresentaram maior poder de predição. $\mathrm{O}$ mesmo resultado encontrou Bedani (2008), ao investigar a influência de valores e práticas organizacionais na expressão da criatividade organizacional, demonstrando a preponderância das práticas. Todos esses resultados, trazem novas evidências da primazia das práticas organizacionais na expressão da cultura da organização.

De maneira semelhante, Santos (2012) verificou que variáveis de cultura ligadas às práticas de aprendizagem estão predizendo de forma direta o desempenho profissional, em seu estudo medido pelos fatores contexto e tarefas, tanto no nível individual, quanto no organizacional, este último com menor magnitude. A expressão do desempenho profissional pode ser favorecida quando a organização de ações de gestão, que incentivem o compartilhamento e troca de informações, o favorecimento de práticas organizacionais, que se vinculam ao suporte à aprendizagem (Santos, 2012), além do constante investimento nos programas de aprendizagem formal, com o objetivo de se adquirir competências (Abbad \& Borges-Andrade, 20004; Sonnentag et al., 2004).

A constituição e o compartilhamento de um sentimento de pertença e afetividade entre indivíduos num grupo, no ambiente organizacional, apresentaram melhor desempenho em comparação aos grupos em que a formação da identidade não ocorreu ou demorou a ocorrer (Van der Zee et al., 2004). Estudos anteriores também mostraram que a identidade profissional pode influenciar a interação interprofissional (Fitzgerald \& Teal, 2003; Helmreich \& Schaefer, 1994), o que acarreta melhor desempenho, como pode ser verificado no trabalho de Morash e Haarr (2012) sobre a variação de gênero na identidade profissional em policiais e sua influência no desempenho. 
A percepção de valores e o estímulo a práticas organizacionais que favoreçam a expansão do desempenho no trabalho necessita estar vinculada a programas formais, que possibilitem a constante aprendizagem e incentivem as relações sociais. Entretanto, o desempenho no trabalho só ocorrerá em graus mais elevados, caso haja uma percepção do sujeito de que o ambiente organizacional apresente-se como um facilitador para essas ações, favorecendo o reconhecimento do indivíduo em seu grupo, no trabalho desempenhado e na organização, fortalecendo sua identidade profissional e organizacional, e, por conseguinte, o desempenho no trabalho.

\subsection{Discussão da Identidade Profissional e da Identidade Organizacional}

Nesta parte, serão discutidos os resultados referentes à identidade (profissional e organizacional) e suas relações com o desempenho profissional. Posteriormente, cuidam-se das relações de mediação (simples e em cadeia), que as identidades estabelecem entre os valores e práticas organizacionais e o desempenho profissional.

Discussão da Influência da identidade profissional e da identidade organizacional sobre o desempenho profissional

A literatura vem apresentando diversos estudos que comprovam a relação de influência da identidade profissional (Mitchell et al., 2011; Santos, 2012; Van der Zee et al., 2004; Van Dick et al., 2008; Van Knippenberg \& Schippers, 2007) e da identidade organizacional (Ashforth et al., 2008; Rao et al., 2003; Riketta, 2005; Smith, 2011) sobre o desempenho no trabalho. Bem mais do que uma simples relação, a identidade, seja ela profissional, seja organizacional, tem sido reconhecida pelo papel fundamental para o entendimento de questões atreladas ao desempenho no trabalho. Como destacaram He e Brown (2013) e Mitchell et al. (2011), a compreensão da influência da identidade no contexto do trabalho e da organização sobre o desempenho dos colaboradores é uma questão essencial para as investigações científicas.

Os resultados desta tese confirmam o papel da identidade profissional e da identidade organizacional na predição do desempenho no trabalho encontrados em outros estudos revisados. No que se refere à identidade profissional e à sua influência sobre o desempenho profissional, foi encontrada influência direta e positiva $(\gamma=0,44, \mathrm{p}<0,000)$, conforme a Figura 63. De forma análoga, porém com magnitude um pouco inferior, é a relação entre identidade organizacional e desempenho profissional $(\gamma=0,37, p<0,000$, Figura 64). 
A análise do modelo geral (MEG1 e MEG2, Figuras 85 e 86) permitiu afirmar que a identidade organizacional (MEG1: $\gamma=0,21, \mathrm{p}<0,000)$ e a identidade profissional (MEG 2: $\gamma=0,34, p<0,000)$ apresentam relação direta e positiva sobre o desempenho profissional, respectivamente. Para os modelos estruturais gerais parcimoniosos 1 - MEGP (1a, 1b e 1c) a identidade organizacional apresentou influência direta e positiva sobre o desempenho profissional (MEGP1a, b e c: $\gamma=0,24, \mathrm{p}<0,000$, Figuras 87, 88 e 89). Para os modelos estruturais gerais parcimoniosos $2-\operatorname{MEGP}(2 \mathrm{a}, 2 \mathrm{~b}$ e $2 \mathrm{c})$ - os resultados indicaram que identidade profissional apresentou influência direta e positiva sobre o desempenho profissional (MEGP2a, b e c: $\gamma=0,36, \mathrm{p}<0,0000$, Figuras 90, 91 e 92). Nota-se que a identidade profissional apresenta índices de magnitude superiores à identidade organizacional, como ocorrido no teste das relações diretas, destes construtos, com o desempenho no trabalho.

Nesta tese, postulou-se a hipótese de que:

H9: A identidade profissional (H9a) e a identidade organizacional (H9b) influenciam de forma direta e positiva o desempenho profissional por competências.

Os resultados encontrados permitem não só confirmar estas hipóteses, como também os pressupostos teóricos inerentes aos construtos. A relação positiva entre essas variáveis foi também encontrada por Santos (2012) em órgão públicos federais brasileiros. Esse autor demonstrou, em seu estudo, que indivíduos com índices superiores de comprometimento organizacional afetivo e de comprometimento com a carreira (fatores de identidade) expressavam em maior grau o desempenho profissional no trabalho.

Essa tendência foi explicada por Machado (2003), Scott e Lane (2000) e Whetten e Godfrey (2000), que, entre outros aspectos, observaram que a identidade atinge o processo, a atividade e o acontecimento em que a organização se torna presente na mente de seus integrantes, compreendendo as crenças compartilhadas pelos indivíduos da organização sobre o que é fundamental, o que a distingue e é duradouro. Como o indivíduo está envolto nesse ambiente, forma-se uma espécie de mentalidade coletiva, de conformidade, na qual assimilam-se as regras e normas de comportamento e, assim, constitui vínculos afetivos com as pessoas dos grupos de pertença, o que afeta o desempenho de maneira positiva.

De fato, alguns estudos atuais têm descrito uma relação positiva entre identidade e desempenho, tanto nas tarefas quanto no trabalho (Chen et al., 2013; He \& Brown, 2013, Mitchell et al., 2011; Smith, 2011; Walumbwa et al., 2008; Weiseke et al., 2008). Entre esses estudos, o de Hirst et al., (2009) e Madjar et al. (2011) investigaram o efeito da identidade na 
criatividade de funcionários. Os resultados mostraram que a identidade apresenta efeito positivo nos funcionários. Esse efeito origina maior propensão dos indivíduos a dedicar maior esforço criativo, ou seja, maior criatividade ao seu trabalho, devido a um alinhamento entre os seus próprios interesses e o interesse da organização, aumentando o desempenho no trabalho.

O impacto positivo sobre o desempenho no trabalho, que advém de uma alta identificação do indivíduo com o seu trabalho e sua organização, é determinado pelo seu maior esforço, mesmo que não haja capacidade para realizar (He \& Brown, 2013; Mitchell et al., 2011; Riketta, 2005; Xenikou, 2011). Na visão de He e Brown (2013), os possíveis facilitadores dessa relação podem estar relacionados ao grau de crédito que os indivíduos têm de que seu próprio desempenho pode fazer a diferença para o desempenho global da organização, e na medida em que os sujeitos são (ou pensam que são) capazes de terem o melhor desempenho no trabalho.

Discussão da mediação da identidade profissional e da identidade organizacional na relação entre cultura organizacional (valores e práticas) e o desempenho profissional

- Mediação Simples

Os estudos anteriormente apresentados mostraram que a identidade (profissional e organizacional) influencia de forma direta e positiva o desempenho, e é influenciada de maneira direta pela cultura organizacional (medida por valores e práticas organizacionais). Contudo, a literatura vem apontando que outras relações devem verificar a influência direta e indireta quando mais de dois construtos são empregados, como as relações de mediação da identidade na relação entre cultura organizacional e desempenho (Chang \& Wu, 2013; Chen, 2011), ou mesmo relações de moderação (Cheung et al., 2011).

Diante disso, esta tese procurou avaliar, não somente as influências diretas entre as variáveis (independentes e dependente), mas também os relacionamentos diretos e indiretos quando uma terceira variável (chamada mediadora) é colocada no modelo estrutural, para avaliar a redução da magnitude do relacionamento entre uma variável antecedente e uma variável dependente (Abbad \& Torres, 2002), aumentando-se o poder estatístico.

As relações de mediação que a identidade, seja ela profissional seja organizacional, estabelece entre cultura organizacional e o desempenho no trabalho já foi objeto de estudo de diversos trabalhos, como os desenvolvidos por Chang e Wu (2013), Chen (2011) e Cheung et al. (2011). Entretanto, não foram encontrados na literatura estudos que propusessem a 
realização de mediação múltiplas, em que a identidade profissional e a identidade organizacional, de forma conjunta, mediassem as relações entre cultura organizacional e desempenho profissional por competências.

No primeiro momento, a preocupação foi de avaliar as relações de mediação simples da identidade (profissional e organizacional) na relação entre a cultura organizacional (medida pelos valores) e o desempenho no trabalho.

Os resultados da mediação simples tanto da identidade profissional como da identidade organizacional, na relação entre os valores organizacionais e o desempenho profissional, mostraram que os tipos conservação, igualitarismo e harmonia foram mediados parcialmente em sua relação com o desempenho profissional pela identidade profissional, no primeiro teste (conforme a Figura 65), e pela identidade organizacional, no segundo (conforme a Figura 69). Quando os tipos motivacionais foram avaliados por dimensões bipolares, a identidade profissional mediou a relação entre os tipos conservação (parcial) $x$ autonomia (total) (Figura 66), hierarquia (parcial) x igualitarismo (parcial) (Figura 67) e domínio $x$ harmonia (parcial) (Figura 68). Para a relação da identidade organizacional, na relação entre valores, por tipos bipolares, e desempenho, encontrou-se: conservação (parcial) $x$ autonomia (total) (Figura 70), hierarquia (parcial) $x$ igualitarismo (parcial) (Figura 71) e domínio (sem mediação) $x$ harmonia (parcial) (Figura 72).

Para o segundo momento, procurou-se avaliar as relações de mediação simples da identidade (profissional e organizacional) na relação entre a cultura organizacional (medida pelas práticas) e o desempenho no trabalho. Os resultados da mediação simples da identidade profissional e da identidade organizacional, na relação entre as práticas organizacionais e o desempenho profissional, mostraram que a prática de regulação foi mediada parcialmente em sua relação com o desempenho profissional pela identidade profissional, no primeiro teste (Figura 73), e as práticas de regulação e definição de responsabilidade foram mediadas parcialmente pela identidade organizacional, no segundo (Figura 74).

- Mediação em cadeia (múltipla)

Como não foram encontrados estudos de mediação em cadeia da identidade profissional e da identidade organizacional, nesta ordem e na ordem inversa, que influenciassem a relação entre os valores organizacionais, num primeiro momento, e as práticas organizacionais em um segundo, e o desempenho profissional, estas análises foram realizadas. A justificativa para estes testes encontra-se no modelo proposto por Machado (2003), em que existem influências da identidade profissional sobre a identidade 
organizacional, e vice-versa, conforme a Figura 12.

Os resultados da mediação cadeia da identidade profissional que antecede a identidade organizacional, na relação entre os valores organizacionais correlacionados e o desempenho profissional, mostraram que os tipos conservação, igualitarismo e harmonia foram mediados parcialmente em sua relação com o desempenho profissional pela identidade profissional e pela identidade organizacional, no primeiro teste (Figura 75). Quando os tipos motivacionais foram avaliados por dimensões bipolares, a identidade profissional em cadeia com a identidade organizacional mediaram a relação entre os tipos conservação (parcial) $x$ autonomia (total) (Figura 76), hierarquia (parcial) $x$ igualitarismo (parcial) (Figura 77) e domínio (sem mediação) $x$ harmonia (parcial) (Figura 78). Para a relação da identidade organizacional antecedendo a identidade profissional, na relação entre os valores organizacionais correlacionados e o desempenho profissional mostraram que os tipos conservação, igualitarismo e harmonia foram mediados parcialmente em sua relação com o desempenho profissional pela identidade organizacional e pela identidade profissional (Figura 79). Na relação entre valores, por tipos bipolares, e desempenho, encontrou-se: conservação (parcial) $x$ autonomia (total) (Figura 80), hierarquia (parcial) $x$ igualitarismo (parcial) (Figura 81) e domínio (sem mediação) $x$ harmonia (parcial) (Figura 82).

Para o segundo momento das mediações em cadeia, buscou-se avaliar as relações de mediação que a identidade profissional que antecede a identidade organizacional exerce na relação entre a cultura organizacional (medida pelas práticas) e o desempenho no trabalho. Os resultados mostraram que somente as práticas de regulação e de definição de responsabilidade são mediadas parcialmente em sua relação com o desempenho profissional pela identidade profissional e pela identidade organizacional (Figura 83). Quando se inverteu a relação das variáveis mediadoras, ou seja, a identidade organizacional antecedeu a identidade profissional, as práticas de regulação e definição de responsabilidade foram mediadas parcialmente pela identidade organizacional e pela identidade profissional (Figura 84).

Nos testes dos modelos gerais, observou-se que a identidade profissional e a identidade organizacional mediaram em parte a relação entre as práticas (de regulação e definição de responsabilidade) e entre os tipos motivacionais (igualitarismo e harmonia) e o desempenho profissional (MEG1, conforme Figura 85). O mesmo resultado foi encontrado no modelo MEG2, cuja identidade organizacional e identidade profissional mediaram em parte a relação entre as práticas de regulação e definição de responsabilidade e os tipos 
igualitarismo e harmonia e o desempenho profissional (MEG2, conforme Figura 86).

Para os modelos parcimoniosos, os testes mostraram que houve a mediação em cadeia da identidade profissional e organizacional, na relação entre o tipo conservação e a prática de regulação sobre o desempenho (MEGP1a, conforme Figura 87). O teste do MEGP1b (Figura 88), os tipos hierarquia e igualitarismo e a prática de regulação foram mediadas parcialmente pela identidade profissional e organizacional, em sua relação com o desempenho. E, por fim, o teste do MEGP1c (Figura 89), a mediação da identidade profissional e organizacional foi parcial na relação entre o tipo harmonia e a prática de regulação sobre o desempenho profissional.

No MEGP2a, a identidade organizacional e a identidade profissional mediaram parcialmente a relação entre o tipo motivacional conservação e as práticas de regulação e definição de responsabilidade e o desempenho profissional e totalmente entre o tipo autonomia e o desempenho profissional (conforme Figura 90). No MEGP2b (Figura 91), a identidade organizacional e a identidade profissional mediaram parcialmente a relação entre os tipos motivacionais hierarquia e igualitarismo e a prática de regulação e o desempenho profissional. Por último, no MEGP2c (Figura 92), a identidade organizacional e a identidade profissional mediaram em parte a relação entre o tipo motivacional harmonia e a prática de regulação e o desempenho profissional.

As hipóteses postuladas nesta tese diziam que:

H7: A identidade profissional (H7a) e a identidade organizacional (H7b) mediam a relação entre os valores organizacionais e o desempenho profissional por competências. A identidade organizacional antecede a identidade profissional (H7c) na mediação da relação entre os valores organizacionais e o desempenho profissional por competências. A identidade profissional antecede a identidade organizacional (H7d) na mediação da relação entre os valores organizacionais e o desempenho profissional.

H8: A identidade profissional (H8a) e a identidade organizacional (H8b) mediam a relação entre as práticas organizacionais e o desempenho profissional por competências. A identidade organizacional antecede a identidade profissional (H8c) na mediação da relação entre as práticas organizacionais e o desempenho profissional por competências. A identidade profissional antecede a identidade organizacional (H8d) na mediação da relação entre as práticas organizacionais e o desempenho profissional.

Os resultados encontrados demonstram claramente que a identidade profissional e a identidade organizacional exercem, individualmente e em cadeia, uma relação de mediação 
entre os valores e o desempenho e entre as práticas e o desempenho. Tais achados corroboram parcialmente todas as hipótese postuladas para a mediação.

Confirmaram-se parcialmente as hipóteses, pois esperava-se que todos os tipos motivacionais subjacentes aos valores organizacionais e todas as práticas organizacionais fossem mediados pela identidade (profissional e/ou organizacional, e vice-versa), o que não ocorreu. Cabe ainda salientar que esses achados vão de encontro aos resultados de outras pesquisas que testaram relações entre cultura organizacional e desempenho, tendo como mediador simples a identidade, como pode ser observado em Chen (2011), Chang e Wu (2013) e Van Der Zee et al. (2004).

Além disso, respaldam-se os aspectos teóricos encontrados na literatura de que a identidade advém da cultura da organização, ou seja, é predita por esta (Dutton \& Dukerich, 1991; Cheung et al., 2011; Hatch, 1993; Fiol, Hatch \& Golden-Biddle, 1998; Schein, 1985). Somam-se a isso, a maior explicação da relação entre cultura organizacional (medido por valores e práticas) e o desempenho no trabalho, quando da colocação da variável mediadora.

$\mathrm{O}$ efeito indireto sobre o desempenho foi maior estando presente a mediação simples da identidade profissional, comparativamente à identidade organizacional, tanto nas relações dos valores, quanto das práticas. Estes resultados refletem que os valores e as práticas organizacionais, percebidos pelos indivíduos da organização como prioritários, exercem maior influência sobre a identidade profissional. Resultados semelhantes foram relatados em outras pesquisas que envolvem policiais, como em Nascimento (2010), Nascimento et al. (2013) e Sousa (2009), bem como as que envolvem funcionários da administração pública federal brasileira (Santos, 2012).

Outro resultado inerente às análises de mediação simples das identidades profissional ou organizacional, diz respeito à primazia das práticas organizacionais na predição indireta do desempenho, comparativamente aos valores organizacionais. Novamente, esses achados apontam para o papel de proeminência das práticas organizacionais na relação direta com o desempenho ou mesmo em sua relação indireta, sendo, dessa forma, mediada pela identidade, conforme relataram D’Iribarne (1983) e Hofstede et al. (1990), ao apontarem o papel de centralidade das práticas como manifestações da cultura.

Conforme mencionado nesta tese, não se vislumbrou na literatura pesquisas que trabalhassem com a mediação conjunta da identidade profissional antecedendo a organizacional (ou seu contrário), na relação entre cultura organizacional (medida por valores ou práticas organizacionais) e o desempenho no trabalho. A mútua relação entre identidade 
profissional e identidade organizacional foi ressaltada teoricamente por diversos autores (Ashforth et al., 2008; Fernandes \& Zanelli, 2006; Machado, 2003, entre outros), mas não se encontrou um teste empírico dessas relações. Neste sentido, esta tese contribui com a literatura ao testar as relações de mediação múltipla. Percebe-se pelos resultados que, quando a identidade organizacional antecede a identidade profissional, em todos os modelos gerais, aumenta-se a explicação do desempenho competente. Postula-se que, por tratar-se de organização militar, com cultura organizacional bem estabelecida (Nascimento, 2010; Sousa, 2009), a identidade organizacional está presente na mente dos indivíduos (Scott \& Lane, 2000), mesmo dos noviços (Mattos, 2012). Assim, pelo compartilhamento de crenças pelos sujeitos da organização sobre o que é fundamental, o que a distingue e é duradouro (Whetten \& Godfrey, 1998), apresenta-se um ambiente fecundo para o estabelecimento e o desenvolvimento da identidade profissional, cuja construção é realizada diuturnamente, quando o sujeito passa a internalizar a crença de que a organização de pertença é a mesma que era no passado, simbolizando a sua existência temporal (Machado, 2003).

\subsection{Discussão das Variáveis Sociodemográficas}

Esta pesquisa interessou-se igualmente pela influência de variáveis sociodemográficas (idade, tempo de serviço, escolaridade, e área de lotação - atividade meio ou fim, nível hierárquico) sobre o desempenho profissional. Os resultados só apresentaram diferenças significativas para o nível de escolaridade e em função do nível hierárquico do policial.

\section{Discussão da relações entre as variáveis sociodemográficas e o desempenho profissional}

Os estudos revisados mostraram a influência de variáveis individuais sociodemográficas no desempenho no trabalho. A idade tem sido constantemente apontada como variável que influencia no desempenho (Ali \& Davies, 2003; Coelho Jr., 2009); o mesmo tem sido relatado para tempo de serviço (Macedo, 2007; Treadway et al., 2005; West \& Anderson,1996), escolaridade (Coelho Jr. \& Borges-Andrade, 2011b; Santos, 2012), área de lotação (Albuquerque, 2004; Chang \& Lee, 2006; Coelho Jr., 2009; Laros \& Andrade, 2006; Macedo, 2007) e em função do nível hierárquico (gestão ou execução), conforme pesquisas de Brandão et. al (2012a) e Coelho Jr. (2009).

A escolaridade foi codificada e avaliada dividindo-se a amostra em indivíduos que possuíam nível superior (1) e aqueles que possuíam especialização, mestrado ou doutorado (2). Os resultados desta tese confirmaram que existe uma diferença no desempenho 
profissional em função do nível de escolaridade, ratificando a hipótese H12. Assim, policiais que são pós-graduados apresentam, em média, melhor desempenho profissional por competências (técnica e comportamental) se comparados aos policiais que possuem formação até o nível de graduação. Resultados semelhantes foram descritos por Nascimento (2010), Nascimento et al. (2013) e Santos (2012). Diante disso, recomenda-se à organização incentivar o desenvolvimento de seus funcionários por intermédio de cursos de especialização, mestrado e doutorado.

Outra variável que apresentou diferenças significativas sobre o desempenho profissional foi o nível hierárquico, separados pelos indivíduos que estão em função de gestão, os oficiais, e àqueles que se encontram em funções de execução, as praças. Os resultados do teste $\mathrm{t}$ mostram que os oficiais apresentam, em média, maiores escores de desempenho profissional por competências (técnicas e comportamentais) comparativamente aos indivíduos de níveis mais baixos da hierarquia. O que confirma a hipótese H14. Os estudos de Brandão et. al (2012a), Coelho Jr. (2009), Nascimento (2010) e Nascimento et al. (2013) encontraram resultados semelhantes. Ao compararem a diferença entre oficiais e praças relativamente à abertura no trabalho e à percepção do ambiente favorável no trabalho, Nascimento (2010) e Nascimento et al. (2013) encontraram médias maiores para os oficiais.

No que se refere às hipóteses H10 (Existe uma diferença no desempenho profissional em função da idade do policial), H11 (Existe uma diferença no desempenho profissional em função do tempo de serviço do policial) e H13 (Existe uma diferença no desempenho profissional em função da área de lotação - atividade fim versus atividade meio - do policial), todas mostraram-se refutadas. Uma provável explicação para a rejeição das hipóteses reside no fato de as competências analisadas, referentes a aspectos técnicos e comportamentais, serem de natureza geral. Significa dizer que essas competências são de alta importância para a realização da atividade policial, portanto, são aprendidas nos cursos iniciais de formação das carreiras de oficiais e praças, mas também nas constantes atualizações a que estão sujeitos os policiais.

Mesmo que outros estudos tenham mostrado diferenças em termos da atividade que o policial realiza (área meio versus área fim), como nos estudos de Nascimento (2010) e Nascimento et al. (2013), infere-se que, na medida em que a organização possibilita a policiais das áreas meio e fim trabalharem exclusivamente na atividade fim ao realizarem o serviço gratificado voluntário, as competências técnicas ou comportamentais passam a ser 
utilizadas por todos os policiais. Como são competências gerais, não foram encontradas diferenças, em função do nível hierárquico, da natureza da atividade ou do tempo de serviço.

\section{Conclusão do Capítulo VIII}

Este oitavo e último capítulo permitiu a interpretação dos resultados e das hipóteses da pesquisa. Na primeira seção, mostrou-se que as escalas de medida utilizadas apresentaram qualidades psicométricas similares ou melhores do que as escalas originais. Encontraram-se novas evidências de validade de construto da escala de valores organizacionais, por intermédio de análises exploratórias e confirmatórias. Validou-se a escala de medida de práticas organizacionais, construída por Souza (2014), a partir dos estudos de D’Iribarne (1989), configurando-se como um novo instrumento de medida que pode ser empregado para descrever as manifestações da cultura organizacional pelas práticas da organização.

Foi, ainda, traduzido e validado para o Brasil, um novo instrumento de medida de identidade social, que pode ser aplicado para aferir a identidade profissional em diversos contextos de trabalho, com índices satisfatórios e de tamanho reduzido. Nesta tese efetuou-se a validação confirmatória da escala de identidade organizacional, procedimento até então não encontrado na literatura brasileira. E, por fim, foi proposta e validada uma escala bidimensional para aferição do desempenho profissional, podendo ser utilizada em organizações policiais e de outros setores.

Em seguida, os resultados dos modelos preliminares, com relações mais simples e parcimoniosas, as relações de mediação e os modelos mais complexos, que refletem os testes dos modelos estruturais globais finais foram discutidos. Finalmente, os resultados sobre a influência de variáveis individuais (sociodemográficas) foram utilizadas para melhor compreender seus efeitos sobre o desempenho profissional no serviço policial.

Todos estes resultados permitem aos gestores identificarem como se manifesta a cultura da organização, quais são os valores e as práticas que emergem dessa cultura, e que, por conseguinte, influenciam na formação e na transformação da identidade profissional e organizacional, impactando no desempenho profissional no trabalho. Essas informações possibilitam decisões mais adequadas para o aprimoramento do desempenho policial. A conclusão geral deste trabalho apresenta-se como a oportunidade de desenvolver as implicações gerenciais da pesquisa, enfatizar os limites antes de propor direções para pesquisas futuras. 
CONCLUSÃO GERAL 


\section{SÍNTESE DAS RESPOSTAS ÀS QUESTÕES DE PESQUISA}

O objetivo geral desta tese foi identificar e descrever a influência das manifestações da cultura da organização PMDF, em termo de valores e práticas organizacionais, e da identidade organizacional e profissional sobre o desempenho profissional no serviço policial. Para atingir este objetivo foram realizados nove passos e proposto um modelo integrador, que permitiu responder as seguintes questões de pesquisa que deram origem ao objetivo geral:

Questão de pesquisa 1: Os valores e as práticas, como manifestações da cultura organizacional, e a identidade organizacional e profissional são variáveis antecedentes e explicativas do desempenho profissional por cometências no trabalho?

Questão de pesquisa 2: Que dimensões emergem dos valores e das práticas organizacionais para explicar o desempenho profissional por competências?

Questão de pesquisa 3: Que dimensões emergem dos valores e das práticas organizacionais para explicar a identidade profissional e a identidade organizacional?

Questão de pesquisa 4: A identidade atua como mediadora da relação entre as manifestações da cultura e o desempenho profissional por competências?

Questão de pesquisa 5: São encontradas diferenças em função das variáveis biográficas (idade, grau de escolaridade) e profissionais (tempo de serviço, nível hierárquico) em relação ao desempenho?

Para responder às questões de pesquisa, foi elaborada uma revisão de literatura sobre as diferentes variáveis antecedentes e explicativas do desempenho no trabalho (cultura, valores, práticas organizacionais, identidade organizacional e profissional, desempenho no trabalho). Essa revisão da literatura baseou-se em uma abordagem histórica, conceitual e multidisciplinar, que permitiu evidenciar as relações entre as variáveis.

Após a realização da revisão da literatura, foi proposto um modelo teórico integrador das dimensões estudadas, que possibilitou efetivar o estudo quantitativo, conduzido para testar os modelos de mensuração, os modelos estruturais e as hipóteses de pesquisa.

Os parágrafos seguintes resumem a abordagem utilizada e as respostas para cada pergunta.

\subsection{Resposta à Primeira Questão de Pesquisa}

A primeira questão de pesquisa refere-se aos quatro primeiros objetivos específicos deste trabalho (a, b, c, d), que propuseram identificar e descrever a influência dos valores e 
das práticas organizacionais sobre o desempenho profissional, bem como, a influência da identidade organizacional e profissional sobre o desempenho profissional.

Os resultados demonstraram que os instrumentos de medida utilizados nesta tese apresentaram evidências de adequações psicométricas. Além disso, a utilização dos modelos estruturais preliminares e dos modelos estruturais gerais permitiram as seguintes conclusões:

Os valores organizacionais apresentam influência direta sobre o desempenho profissional por competências;

$>$ As práticas organizacionais apresentam influência direta sobre o desempenho profissional por competências;

$>$ As práticas organizacionais apresentam maior poder de predição sobre o desempenho profissional por competências em comparação aos valores organizacionais;

$>$ A identidade organizacional apresenta influência direta e positiva sobre o desempenho profissional por competências;

$>$ A identidade profissional apresenta influência direta e positiva sobre o desempenho profissional por competências.

No geral, estes resultados confirmaram os aspectos teóricos e empíricos concernentes às relações de predição que as variáveis antecedentes (valores, práticas e identidade) exercem sobre a variável critério (desempenho profissional ). Além disso, relatou-se um protagonismo das práticas organizacionais na explicação do desempenho profissional . Este resultado vem somar-se a outros, que procuram identificar qual dos elementos da cultura organizacional (valores ou práticas) apresenta proeminência na explicação de construtos do comportamento organizacional. Assim, esta tese contribui com novas evidências de que as práticas organizacionais apresentam-se como importante construto para identificar as manifestações da cultura da organização, acompanhando, entre outros, os trabalhos de Bedani (2008), D’Iribarne (2009b), Neumann et al. (2012) e Veiga (2010).

\subsection{Resposta à Segunda Questão de Pesquisa}

A segunda questão de pesquisa refere-se a dois objetivos específicos $(a, b)$ desta tese, especificamente, no que corresponde a descrição da influência das dimensões subjacentes aos valores e às práticas organizacionais sobre o desempenho profissional .

A análise dos resultados dos modelos estruturais preliminares e dos modelos gerais possibilitou as seguintes considerações: 
Os valores organizacionais têm influência positiva sobre o desempenho profissional , quando os tipos motivacionais são analisados por dimensões bipolares separadas (domínio x harmonia; hierarquia x igualitarismo; autonomia x conservação) e positiva para conservação e harmonia, assim como negativa para igualitarismo, quando os tipos motivacionais encontram-se correlacionados.

Quando as práticas organizacionais encontram-se correlacionadas, a influência sobre o desempenho profissional é positiva para a prática de regulação e negativa para prática de definição de responsabilidade.

Assim, pode-se dizer que as manifestações culturais representadas tanto pelos valores como pelas práticas organizacionais influênciam no desempenho profissional do serviço policial.

Diferentemente do que é publicado na literatura sobre a influência dos valores e das práticas sobre o desempenho, este estudo junta-se aos poucos que buscam especificar quais tipos motivacionais subjacentes aos valores organizacionais e quais dimensões das práticas organizacionais emergem para explicar determinado construto, no caso o desempenho. Estes resultados permitem que outras organizações possam elaborar estudos semelhantes, com o objetivo de identificar, de maneira particular, qual a prioridade axiológica da organização e qual prática se apresenta como mais percebida. Neste contexto, existe a possibilidade de que políticas sejam aplicadas à organização para modificarem determinadas práticas e transmitirem outros valores, a critério dos interesses organizacionais, e não somente, dizer que os valores e as práticas de forma geral influenciam no desempenho.

\subsection{Resposta à Terceira Questão de Pesquisa}

A terceira questão de pesquisa versa sobre os objetivos específicos (e, f) que buscam descrever: a influência das dimensões subjacentes aos valores e às práticas organizacionais sobre a identidade profissional e sobre a identidade organizacional.

As considerações realizadas com base nos resultados obtidos com as análises dos modelos estruturais preliminares e dos modelos gerais ensejaram os destaques subsequentes:

Os valores organizacionais apresentam influência direta sobre a identidade profissional e sobre a identidade organizacional;

> As práticas organizacionais apresentam influência direta sobre a identidade profissional e sobre a identidade organizacional; 
Os valores organizacionais têm influência positiva sobre a identidade profissional e sobre a identidade organizacional, quando os tipos motivacionais são analisados por dimensões bipolares separadas (domínio x harmonia; hierarquia x igualitarismo; autonomia x conservação) e positiva para conservação e harmonia e negativa para igualitarismo, quando os tipos motivacionais encontram-se correlacionados.

Quando as práticas organizacionais encontram-se correlacionadas, a influência sobre a identidade profissional e sobre a identidade organizacional é positiva para a prática de regulação e negativa para prática de definição de responsabilidade.

$>$ As práticas organizacionais apresentam maior poder de predição sobre a identidade profissional e sobre a identidade organizacional em comparação aos valores organizacionais;

Os resultados apresentados vão de encontro ao que estabelece a literatura revisada, no que se refere às relações estabelecidas entre os componentes da cultura organizacional e a identidade, profissional ou organizacional. Confirmaram-se os aspectos teóricos e as implicações empíricas atribuídas aos construtos.

Novamente, observou-se maior influência das práticas organizacionais na explicação da identidade profissional e da identidade organizacional, comparativamente aos valores organizacionais. Ressalta-se ainda que tanto os valores quanto as práticas exercem maior influência sobre a identidade profissional, comparando-se à identidade organizacional dos policiais. Entretanto, quando se compara a influência dos valores e das práticas organizacionais sobre a identidade profissional e sobre a identidade organizacional, a maior influência recai para a influência das práticas. Infere-se destes resultados que, as práticas, como elementos manifestos da cultura, apresentam maior relação com a identidade (profissional e organizacional) e com o desempenho.

\subsection{Resposta à Quarta Questão de Pesquisa}

A quarta questão de pesquisa refere-se a dois objetivos específicos ( $\mathrm{g} \& \mathrm{~h}$ ) deste trabalho: a identidade organizacional e a identidade profissional atuam como mediadoras da relação entre as manifestações da cultura e o desempenho profissional .

Com o uso da revisão da literatura, foi possível investigar como se comportam as variáveis identidade organizacional e identidade profissional na relação que estabelecem entre valores e práticas sobre o desempenho. Relações de mediação foram relatadas nos 
estudos teóricos e empíricos revisados, confirmando, dessa forma, as relações de mediação da identidade profissional e organizacional foram consideradas.

Os resultados mostraram que a identidade organizacional e a identidade profissional estabelecem relações de mediação (mesmo que parcial) entre os valores e as práticas organizacionais sobre o desempenho. A força das relações estruturais que os valores ou as práticas exercem sobre o desempenho profissional difere em função do construto utilizado como mediador (identidade organizacional ou identidade profissional). Mais precisamente, os resultados obtidos foram os seguintes:

$>$ A identidade organizacional medeia parcialmente a relação entre os valores e as práticas organizacionais sobre o desempenho profissional ;

$>$ A identidade profissional media parcialmente a relação entre os valores e as práticas organizacionais sobre o desempenho profissional ;

> Quando a identidade profissional se apresenta como variável mediadora, a influência, tanto dos valores quanto das práticas sobre o desempenho, é superior, comparativamente à presença da identidade organizacional como variável mediadora.

$>$ Quando a identidade organizacional antecede a identidade profissional na mediação em cadeia, a influência tanto dos valores quanto das práticas sobre o desempenho é superior, comparativamente à mediação em cadeia da identidade profissional que antecede a identidade organizacional.

Conforme descrito na literatura revisada, a identidade, seja profissional, seja organizacional, exerce efeito de mediação simples na relação entre cultura organizacional e desempenho no trabalho. Entretanto, os resultados desta tese, além de confirmarem o efeito mediador simples da identidade, estabelecem que a identidade possa ser verificada em uma dupla vertente (profissional e organizacional) de forma conjunta. Os resultados encontrados demonstram a mediação em cadeia que a identidade profissional e a identidade organizacional (ou vice-versa) exercem na relação os valores e o desempenho e entre as práticas e o desempenho.

Outro resultado interessante refere-se à maior explicação da relação entre cultura organizacional (medido por valores e práticas) e o desempenho no trabalho, quando da colocação da variável mediadora. O efeito indireto da relação entre cultura e desempenho, quando do uso da variável mediadora identidade, demonstra que a proposição do modelo desta tese encontra respaldo não só teórico como também empírico.

De forma similar, ao resultado anteriormente relatado, o efeito indireto sobre o 
desempenho foi maior diante da mediação simples da identidade profissional, comparativamente à da identidade organizacional, tanto nas relações dos valores quanto das práticas. Além disso, as práticas organizacionais mostraram-se superiores na predição indireta do desempenho, comparativamente aos valores organizacionais.

\subsection{Resposta à Quinta Questão de Pesquisa}

A quinta e última questão de pesquisa refere-se ao objetivo específico (i) desta tese, que descreve: as diferenças no desempenho profissional em função das variáveis sociodemográficas.

Para responder a esta pergunta, primeiro, foram identificadas as variáveis individuais relacionadas ao desempenho no trabalho. A revisão da literatura evidenciou a relação de variáveis sociodemográficas analisadas em trabalhos acadêmicos que mantinham relações com o desempenho no trabalho. Emergiram como variáveis, frequentemente relatadas, a idade, o tempo de serviço, o nível de escolaridade, a natureza da atividade (atividade-fim ou atividade-meio) e o nível hierárquico (oficiais ou praças, no caso desta pesquisa).

Diante disso, foram empregadas análises de diferença de médias (teste $t$ e ANOVA) para testar as hipóteses, sendo, também, utilizado, de forma complementar, o teste de Kruskal-Wallis (não paramétrico), quando o teste de Levene rejeitou a hipótese homogeneidade de variância.

Foram obtidos os seguintes resultados:

Não há diferença no desempenho profissional em função da idade do policial;

$>$ Não existe diferença no desempenho profissional em função do tempo de serviço policial;

$>$ Existe diferença no desempenho profissional em função da escolaridade;

> Não há uma diferença no desempenho profissional em função da natureza da atividade (área fim ou área meio);

Existe diferença no desempenho profissional em função do nível hierárquico.

Parte dos resultados encontrados nesta tese difere do que foi encontrado na literatura revisada, especificamente, ao não serem encontradas diferenças significativas quanto a idade, ao tempo de serviço e ao tipo de atividade exercida (atividade-fim ou atividade-meio). Uma possível explicação para estes resultados está no fato de as competências (técnicas e comportamentais) analisadas serem de natureza geral, sendo aprendidas tanto nos processos iniciais de socialização profissional, durante os cursos de formação das carreiras de oficiais e 
praças, quanto, nas constantes atualizações a que estão sujeitos os policiais ao longo da carreira. Cabe salientar que a instituição necessita constantemente investir em qualificações profissionais de alto nível (especializações, mestrados e doutorados), tanto de oficiais quanto de praças, como forma de se aumentar o desempenho no trabalho.

\section{APORTES DA PESQUISA}

Neste ponto, apresentam-se os aportes teóricos (2.1), as contribuições metodológicas (2.2) e as implicações gerenciais (2.3) da pesquisa.

\subsection{Aportes Teóricos}

Esta pesquisa inscreve-se no rol das que buscam uma melhor compreensão dos fatores que explicam o desempenho profissional no trabalho, oferecendo várias contribuições para a teoria.

O primeiro aporte teórico desta pesquisa foi apresentar evidências empíricas para os pressupostos hipotetizados por teorias da administração e da psicologia. Revelaram-se os antecedentes e consequentes da expressão das competências técnicas e comportamentais. Esta última variável é analisada como forma de mensurar o desempenho profissional do indivíduo no contexto organizacional, possibilitando não só o aprofundamento de investigações sobre cultura, identidade, competências e desempenho, mas também como estas variáveis se relacionam e influenciam o desempenho no trabalho. Para tanto, propôs-se um modelo integrador, que colocou em evidência a influência simultânea da cultura organizacional (medida por valores e práticas organizacionais) e da identidade (profissional e organizacional) sobre o desempenho profissional . Com isso, esta tese foi a primeira apresentar uma modelização geral aplicada a uma organização policial no contexto brasileiro.

A segunda contribuição teórica refere-se ao cumprimento de parte das agendas de pesquisa, elaborada por autores como Brandão (2009), Coelho Jr. (2009) e Santos (2012). Neste sentido, cumpriram-se as recomendações de Brandão (2009) e Santos (2012) para a necessidade da concretização de estudos sobre competências relevantes a outras categorias profissionais, que, por exemplo, diferissem do setor bancário ou da administração pública federal brasileira. Além de investigar, como sugerido por Coelho Jr. (2009), outras variáveis do contexto do trabalho, relativas a traços culturalmente compartilhados, como valores e práticas organizacionais, e questões ligadas à identidade social no contexto do trabalho e da organização. De acordo com Coelho Jr (2009), o conhecimento dessas variáveis é 
imprescindível para se verificar os processos de interação social entre os indivíduos na organização, somando-se a influência dos fatores culturais norteadores da construção social da realidade.

A utilização da identidade profissional e da identidade organizacional, empregadas de maneira individual ou em conjunto, como variáveis antecedentes e mediadoras da expressão do desempenho no trabalho, revelou-se a terceira contribuição teórica. Os resultados das análises evidenciaram os pressupostos teóricos acerca da identidade (profissional e organizacional), conforme descrito por Machado (2003), em que a identidade profissional pode anteceder a identidade organizacional, ou o contrário. Contudo, o maior poder de predição ocorreu com a identidade organizacional que antecede a identidade profissional na relação de mediação em cadeia entre a cultura organizacional e o desempenho profissional .

\subsection{Contribuições Metodológicas}

Esta pesquisa apresentou duas contribuições metodológicas principais. De início, no nível dos testes dos modelos estruturais, foram testados, simultaneamente, diversos tipos de efeitos (efeitos diretos e efeitos indiretos), utilizando-se diferentes métodos (teste $\mathrm{t}$ de Student, bootstrap paramétrico e não paramétrico e o teste de significância conjunta). Nos testes dos efeitos mediadores, consideraram-se os efeitos mediadores totais e os efeitos mediadores específicos (em cadeia e em uma etapa). A avaliação de quão robusto são os modelos gerais foi conseguida utilizando-se modelos concorrentes, técnica pouco empregada no contexto brasileiro, o que garantiu a validade satisfatória dos resultados.

Em seguida, no nível dos instrumentos de medida dos construtos, foi desenvolvida uma escala de medida de desempenho baseado em competências específicas para o policial, até então inexistente no Brasil, que seguiu as recomendações de Faiad et al. (2012). Encontraram-se evidências de validade da escala de manifestações da cultura (EMC) desenvolvida por Souza (2014). Foi adaptada e encontraram-se evidências de validade para o Brasil da escala de identidade profissional, baseada no modelo tri-fatorial da identidade social (Cameron, 2004). E, por fim, encontraram-se novas evidências de validade da escala de identidade organizacional de Mael e Ashforth (1992). Todos os instrumentos passaram por validações de juízes e semânticas e utilizaram-se procedimentos de validação exploratória e confirmatória, o que assegura a aplicabilidade dessas escalas em outras organizações e contextos. 


\subsection{Implicações Gerenciais}

Esta tese comporta diversas implicações gerenciais, de maneira particular, para a PMDF, apresenta contribuições de ordem prática. Seus resultados podem facilitar o planejamento de intervenções organizacionais que visem, por exemplo, à indução e à utilização de determinadas estratégias de aprendizagem no trabalho e ao aprimoramento de determinados aspectos do suporte organizacional. Estas operações objetivariam aumentar a identificação dos indivíduos com o trabalho e com a organização, refletindo na otimização, no desenvolvimento e na expressão de competências, resultando em melhores desempenhos do indivíduo e consequentemente da organização.

As implicações para os gestores da polícia refletem-se na identificação de quais fatores da cultura organizacional, notadamente dos valores e das práticas organizacionais, influenciam aspectos da identidade do policial e sua identificação com a organização. Com isso, podem-se desenvolver estratégias e práticas de gestão que apontem para a manifestação dos valores e de práticas consideradas prioritárias para a organização. Os resultados, também, sugerem que o levantamento de competências individuais pode ser utilizado como importante instrumento avaliativo do seu desempenho no trabalho. A identificação dessas competências relevantes propicia que o gestor recomende estratégias de aprendizagem que contribuam para o desenvolvimento dessas competências, e para o crescimento profissional do policial.

Este estudo busca suprir a ausência de ferramentas com comprovação empírica, construídas de maneira específica para o contexto policial, possibilitando os gestores da organização conhecer de forma confiável, o impacto das políticas organizacionais no desempenho dos servidores, tais como o atual e constante investimento dedicado à capacitação dos policiais prática efetiva no desempenho individual, a qual deve ter continuidade.

\section{LIMITES DA PESQUISA}

Como todo empreendimento científico, esta tese apresenta suas limitações. A primeira refere-se à obtenção dos dados sobre medidas utilizadas (valores organizacionais, práticas organizacionais, identidade profissional, identidade organizacional e desempenho profissional ), por intermédio de autorelato. Esse procedimento pode conter imprecisões, erros de halo e outros vieses, ou mesmo, ter sujeitado os resultados ao impacto da variância comum. 
Outro ponto que pode ser levantado como limitação deste estudo é a utilização de amostra circunscrita a apenas uma organização, Por um lado, permite-se a obtenção de validade interna, mas, por outro, restringe-se os resultados à empresa estudada, impossibilitando sua generalização a outros contextos organizacionais.

Tanto em relação à variável dependente como em relação às variáveis independentes, pode-se considerar como limitação a utilização de escalas sem evidências de validade psicometricamente, como no caso da escala de práticas e da escala de desempenho. Mesmo que este trabalho tenha encontrado evidências de validade com índices satisfatórios, sua generalidade fica comprometida o que sugere a utilização destes instrumentos em estudos futuros, a fim de se testar a adequação a contextos diversos.

Acredita-se que essas limitações, embora existam e possam restringir os resultados, não invalidam o presente trabalho, até porque esses entraves são comuns em investigações no campo do comportamento organizacional, conforme relatam Bedani (2008), Coelho Jr. (2009), Santos (2012), Tucker et al. (2005). Soma-se a isso a observação de Sykes (1991) ao relatar que a aderência de forma rígida a um método também pode impor limitações à pesquisa. Assim sendo, esforços que objetivam clarificar a natureza dos fenômenos organizacionais e individuais revelam-se importantes e auxiliam os indivíduos e as organizações a prosperarem (Brandão, 2009).

\section{AGENDA DE PESQUISA}

A despeito das contribuições e limitações da presente pesquisa, torna-se imprescindível a realização de novas investigações sobre o tema. Recomenda-se verificar se os resultados obtidos nesta pesquisa são consistentes em outras organizações policiais, ou mesmo em outras profissões correlatas, como no caso dos bombeiros. Pode-se ainda adaptar o modelo proposto para utilização em outras organizações públicas ou privadas.

Outro ponto que merece aprofundamento refere-se à investigação sobre as competências relevantes e específicas para cada nível hierárquico da polícia. Um estudo como este possibilitaria a avaliação particular e a construção de políticas de gestão específicas para cada nível hierárquico da organização.

Sugere-se investigar outras características do contexto de trabalho, da equipe e da organização que possibilitem ou restrinjam a expressão de competências no trabalho, dentro de uma abordagem de múltiplos níveis de análise. Também seria viável verificar como a 
expressão de competências no trabalho do policial pode influenciar o desempenho da organização.

Recomenda-se, ainda, averiguar como a expressão de competência no trabalho por parte do indivíduo pode introduzir mudanças em sua equipe e na organização, isso é, analisar como a competência propaga-se do sujeito para outros níveis da organização.

Por fim, propõem-se aprimorar e buscar novas evidências de validade da escala de medida de práticas organizacionais, assim como aplicar em outros contextos a escala de medida de identidade profissional, visando verificar sua adequação a contextos diversificados. 


\section{REFERÊNCIAS}

\section{A}

Abbad, G. (1999). Um modelo integrado de avaliação do impacto do treinamento no trabalho - IMPACT. Tese de Doutorado não publicada, Instituto de Psicologia, Universidade de Brasília, Brasília.

Abbad, G., \& Borges-Andrade, J. E. (2004). Aprendizagem humana em organizações de trabalho. Em J. C. Zanelli, J. E. Borges-Andrade, \& A. V. B. Bastos (Orgs.), Psicologia, organizações e trabalho no Brasil. (pp. 237-275). Porto Alegre: Artmed.

Agbényiga, D. L. (2011). Organizational culture influence on service delivery: A mixed methods design in a child welfare setting. Children \& Youth Services Review, 33(10), 1767-1778. doi. 10.1016/j.childyouth.2011.04.035.

Accardo, A. (1991). Initiation à la sociologie: une lecture de Bourdieu. Bordeaux: Ed. Le Mascaret.

Adarves-Yorno, I., Postmes, T., \& Haslam, A. (2006). Social identity and the recognition of creativity in groups. British Journal of Social Psychology, 45, 479-497. doi.10.1348/014466605X50184.

Agbényiga, D. L. (2011). Organizational culture-performance link in the human services Setting. Administration in Social Work, 35(5), 532-547. doi. 10.1080/03643107.2011.614536.

Akerlof, G., \& Kranton, R. (2009). Identity economics: How our identities shape our work, wages and wellbeing. New Jersey: Princeton University Press.

Aktouf, O. (2001). O simbolismo e a cultura da empresa: Dos abusos conceituais às lições empíricas. In J. F. Chanlat (Org,). O indivíduo na organização: dimensões esquecidas. (pp. 39-79). São paulo: Atlas.

Albert, S., \& Whetten, D. A. (1985). Organizational identity. Research in Organizational Behavior, 7, 263-296.

Albert, S., Ashforth, B. E., \& Dutton, J. E. (2000). Organizational identity and identification: Charting new waters and building new bridges. Academy of Management Review. 25(1), 13-17. doi. 10.5465/AMR.2000.2791600.

Albuquerque, A. S. (2004). Bem-Estar subjetivo e sua relação com personalidade, coping, suporte social, satisfação conjugal e satisfação no trabalho. Tese de Doutorado não publicada, Instituto de Psicologia, Universidade de Brasília, Brasília. 
Alge, B. J., Gresham, M. T., Heneman, R. L., Fox, J., \& McMasters, R. (2002). Measuring customer service orientation using a measure of interpersonal skills: a preliminary test in a public service organization. Journal of Business and Psychology, 16(3), 467-476. doi. 10.1023/A:1012833326181.

Ali, H., \& Davies, D. R. (2003). The effects of age, sex and tenure on the job performance of rubber tappers. Journal of Occupational and Organizational Psychology, 76, 381- 391. doi. 10.1348/096317903769647238.

Allaire, Y. \& Firsirotu, M. E. (1984). Theories of organizational culture. Organization Studies, 5(3), 193-226.

Allport, F. (1924). Social Psychology. Boston: Houghton-Miffin.

Allport, G. W. (1955). Becoming. New Haven, CT: Yale University Press.

Almeida, L. F. L., \& Fernandes, N. C. M. (2006). Contribuição da competência de relacionamento para o desenvolvimento de capital social da empresa de base tecnológica. Trabalho apresentado no $30^{\circ}$ Encontro Nacional de Pós-graduação em Administração. Salvador: ANPAD.

Álvaro, J. L., \& Garrido, A. (2006) Psicologia social: perspectivas psicológicas e sociológicas. São Paulo: McGraw Hill.

Alvesson, M. (1993). Cultural perspectives on organizations. Cambridge: Cambridge University Press.

Alvesson, M. (2000). Social identity and theproblem of loyalty in knowledge intensive companies. Journal of Management Studies, 37(8), 1101-1123. doi. 10.1111/14676486.00218 .

Alvesson, M. \& Berg, P. O. (1992). Corporate culture and organizational symbolism: an overview. New York: Walter de Gruyter, 1992.

Amâncio, L. (1993). Identidade social e relações intergrupais. In: J. Vala e M. B. Monteiro (Orgs.). Psicologia Social, Lisboa, Fundação Calouste Gulbenkian.

Anchieta, V. C. C. (2003). "Policial 24 Horas": Um estudo sobre representação social da violência e identidade entre policiais civis do Distrito Federal. Dissertação de Mestrado não publicada. Instituto de Psicologia, Universidade de Brasília.

Anderson, J. C., \& Gerbing, D. W. (1988). Structural equation modeling in practice: a review and recommended two-step approach. Psychological Bulletin, 103(3), 411-423. 
Anderson, C., Spataro, S., \& Flynn, F. J. (2008). Personality and organizational culture as determinants of influence. Journal of Applied Psychology, 93, 702-710. doi. 10.1037/0021-9010.93.3.702.

Angle, H. L., \& Perry, J L. (1986). Dual commitment and labor-management relationship climates. Academy of Management Journal, 29(1), 31-50. doi. 10.2307/255858.

Anselmo, E. (2007). Estratégia planejada versus estratégia emergente e desempenho empresarial: um estudo de casos múltiplos. Trabalho apresentado no $31^{\circ}$ Encontro Nacional de Programas de Pós-Graduação em Administração (Enanpad), Belo Horizonte.

Antaki, C. \& Widdicombe, S. (1988). Identities in talk. London: Sage Publications.

Arbuckle, J. (2009). Amos 18 User's Guide. Amos Development Corporation.

Argote, L., \& McGrath, J. E. (1993). Group processes in organizations: Continuity and change. In Cooper, C. L., \& Robertson, I. T. (Eds.). International Review of Industrial and Organizational Psychology, 8, 333-389, John Wiley \& Sons, New York.

Aristóteles (2001). Ética a Nicômacos. (M. G. Kury, Trad.). 4eed. Brasília: UnB.

Armeli, S., Eisenberger, R., Fasolo, P., \& Lynch, P. (1998). Perceived organizational support and police performance: The moderating influence of socio-emotional needs. Journal of Applied Psychology, 83(2), 288-297.

Ashforth, B. E. (2001). Role transitions in organizational life: an identity-based perspective. Academy of Management Review, v.26, n.4, p.670-672, 2001.

Ashforth, B. E. \& Mael, F. A. (1989). Social identity theory and the organization. Academy of Management Review, v.14, n.1, p.20-39. doi. 10.5465/AMR.1989.4278999.

Ashforth, B. E., \& Mael, F.A. (1996). Organizational identity and strategy as a context for the individual. Advances in Strategic Management, 13, 19-64.

Ashforth, B. E., Harrison, S. H., \& Corley, K. G. (2008). Identification in organizations: An examination of four fundamental questions. Journal of Management, 34(3), 325-374. doi. 10.1177/0149206308316059.

Ashkanasy, N. M., Broadfoot, L. E., Falkus, S. (2000). Questionnaire measures of organizational culture. In: Ashkanasy, N. N., Wilderom, C., Peterson, M. F. (Ed.). The handbook of organisational culture and climate. Newbury Park, CA: Sage.

Ashkanasy, N. M., Wilderom, C. P. M., \& Peterson, M. F. (2011). The handbook of organizational culture and climate. Thousand Oaks, CA: Sage. 2nd ed. 
Asree, S., Zain, M., \& Razalli, M. R. (2010). Influence of leadership competency and organizational culture on responsiveness and performance of firms. International Journal of Contemporary Hospitality Management, 22(4), 500 - 516. doi. 10.1108/09596111011042712.

Austin, J. T., \& Villanova, P. (1992). The criterion problem: 1917-1992. Journal of Applied Psychology, 77, 836-874.

Avolio, B. J.; Waldman, D. A., \& McDaniel, M. A. (1990). Age and work performance in non-managerial jobs: the effects of experience and occupational type. Academy of Management Journal, 33, 407-422. doi. 10.2307/256331.

B

Babin, B. J., \& Boles, J. S. (1996). The effects of perceived co-worker involvement and supervisor support on Service provider role stress, performance and job satisfaction. Journal of retailing, 72(1), 57-75. doi. 10.1016/S0022-4359(96)90005-6.

Bagozzi, R. P., \& Yi, Y. (1988). On the evaluation of structural equation models. Journal of the Academy of Marketing Science, 16(1), 74-94. doi. 10.1007/BF02723327.

Bajdo, L., \& Dickson, M. W. (2001). Perceptions of organizational culture and women's advancement in organizations: a cross-cultural examination. Sex Roles, 45(5-6), 399-414. doi. 10.1023/A:1014365716222.

Bandalos, D. L. (1993). Factors influencing cross-validation of confirmatory factor analysis models. Multivariate Behavioral Research, 28(3), 351-374.

Bandeira-de-Mello, R., \& Marcon, R. (2004). A mensuração multivariada da 'performance' e suas componentes de variância: uma análise dos efeitos do ano, indústria e firma no contexto brasileiro. Trabalho apresentado no $18^{\circ}$ Encontro Nacional da Associação Nacional de Pós-Graduação e Pesquisa em Administração, Curitiba, Paraná.

Bandura, A., \& Jourden, E. J. (1991). Self-regulatory mechanisms governing the impact of social comparison on complex decision making. Journal of Personality and Social Psychology, 60(6), 941-951. doi. 10.1037/0022-3514.60.6.941.

Bansal, P. (2003). From issues to actions: The importance of individual concerns and organizational values in responding to natural environmental issues. Organization Science, 14(5): 510-527. doi. 10.1287/orsc.14.5.510.16765. 
Barbosa, L. N. H. (1996). Cultura administrativa: Uma nova perspectiva das relações entre antropologia e administração. RAE - Revista de Administração de Empresas, 36 (4), 6-19.

Bardi, A. \& Schwartz, S. H. (2003). Values and behavior: Strength and structure of relations. Personality and Social Psychology Bulletin , 29(10), 1207-1220. doi. 10.1177/0146167203254602.

Barley, S. R. \& Kunda, G. (1992). Design and devotion: Surges of rational and normative ideologies of control in managerial discourse. Administrative Science Quartely, 37(3), 363-399. doi: 10.2307/2393449.

Baron, R. M., \& Kenny, D. A. (1986). The moderator-mediator variable distinction in social psychological research: Conceptual, strategic and statistical considerations. Journal of Personality and Social Psychology, 51, 1173-1182.

Barreto, M., Ellemers, N., \& Palacios, M. S. (2004). The backlash of token mobility: The impact of past group experiences on individual ambition and effort. Personality and Social Psychology Bulletin, 30, 1433-1445. doi:10.1177/0146167204264336.

Barrett, P. (2007). Structural equation modelling: Adjudging model fit. Personality and Individual Differences. 45(5), 815-824. doi:10.1016/j.paid.2006.09.018.

Bartram, D. (2000). Internet recruitment and selection: Kissing frogs to find princes. International Journal of Selection and Assessment, 8, 261-274. doi. 10.1111/14682389.00155 .

Bartram, D., Kurz, R., \& Bailey, R. (2000). The SHL competency Framework. Internal SHL memorandum, March 200, Thames Ditton: SHL.

Bates, R. A. (1999). Measuring performance improvement. Advances in Developing Human Resources, 1, 47-67.

Baugnet, L. (1998). L'identité sociale. Dunod: Paris.

Baum, J. R., Locke, E. A., \& Smith, K. G. (2001). A multidimensional model of venture growth. Academy of Management Journal, 44(2), 292-303. doi. 10.2307/3069456.

Beal, D. J., Weiss, H. M., Barros, E., \& MacDermid, S. M. (2005). An episodic process model of affective influences on performance. Journal of Applied Psychology, 90(6), 1054-1068.

Bedani, M. (2006). Clima organizacional: investigação e diagnóstico: estudo de caso em agência de viagens e turismo. Psicologia para América Latina, (7). 
Bedani, M. (2007). Efetividade das equipes de trabalho: clima organizacional como variável preditora do desempenho. Trabalho apresentado no $31^{\circ}$ Encontro Nacional de Programas de Pós-Graduação em Administração, Belo Horizonte.

Bedani, M. (2009). Valores, práticas e criatividade organizacionais: estudo do perfil cultural de uma instituição bancária. Tese de doutorado. Programa de Pós-graduação em Psicologia Social, do Trabalho e das Organizações. Universidade de Brasília, Brasília.

Beersma, B., Hollenbeck, J. R., Humprey, S. E., Moon, H., Conlon, D. E., \& Ilgen, D. R. (2003). Cooperation, competition, and team performance: Towards a contingency approach. Academy of Management Journal, 46(5, 572-590. doi. 10.2307/30040650.

Belasen, A. T. (1997). An application of the competing values framework to self- managed teams. In Rahim, A. M., Golembieski, R. T., \& Pate, L. E. (Eds.), Current topics in management, vol. 2, (79-111). Greenwich, CT: JAI Press Inc.

Benedict, R. (1934). Patterns of culture. New York: Houghton Mifflin.

Bendassolli, P. F. (2012). Desempenho no trabalho: Revisão da literatura. Psicologia Argumento, 30(68), 171-184.doi. 10.7213/psicol.argum.5895.

Bendassolli, P. F., \& Borges-Andrade, J. E. (2013). Meaningfulness in Work in Brazilian and French Creative Industries. The Spanish Journal of Psychology, 16, E109 doi:10.1017/sjp.2013.107.

Bentler, P. M. (1990). Comparative fit indices in structural models. Psychological Bulletin. 107, 238-246.

Bentler, P. M. (2007). On tests and indices for evaluating structural models. Personality and Individual Differences. 42(5), 815-824. doi. 10.1016/j.paid.2006.09.024.

Beugelsdijk, S., Koen, C., \& Noorderhaven, N. (2008). A dyadic approach to the impact of differences in organizational culture on relationship performance. Industrial Marketing Management, 38(3), 312-323. doi. 10.1016/j.indmarman.2008.02.006.

Berger, P. L., \& Luckmann, T. (2002). A construção social da realidade (21. ed.). Petrópolis, RJ: Vozes.

Bernardes, A. G., \& Hoenisch, J. C. D. (2003). Subjetividade e identidades: Possibilidades de interlocução da Psicologia Social com os estudos culturais. In N. M. de F. Guareschi \& M. E. Bruschi (Eds.), Psicologia Social nos estudos culturais: Perspectivas e desafios para uma nova Psicologia Social (pp. 95-126). Petrópolis, RJ: Vozes.

Beyda, T. T. \& Macedo-Soares, T. D. L. V. A. (2010). Identidade Organizacional: Análise Crítica Da Produção Acadêmica Brasileira De 2004 A 2009. Rausp-e, 45, 400-414. 
Beyer, J. M., \& Trice, H. M. (1987). How an organization's rites reveal its culture. Organizational Dynamics, 15, 5-24.

Bingöl, D., Şenerb, İ., \& Çevikb, E. (2013). The effect of organizational culture on organizational image and identity: Evidence from a pharmaceutical company. Procedia Social and Behavioral Sciences, 99, 222-229. doi. 10.1016/j.sbspro.2013.10.489.

Birkeland, S.A., Borman, W.C., \& Brannick, M.T. (2003). Using personal construct theory to investigate 360-degree source effects. $18^{\text {th }}$ Annual Conference of the Society for Industrial and Organizational Psychology, Orlando.

Bishop, J.W., \& Scott, K.D. (1997). How commitment affects team performance. $H R$ Magazine, 107-111.

Bitencourt, C. C., \& Barbosa, A. C. Q. (2004). A gestão de competências. In C. C. Bitencourt (Org.), Gestão contemporânea de pessoas: novas práticas, conceitos tradicionais (pp. 239-264). Porto Alegre: Bookman.

Blackwell, R. D.; Miniard, P. W. \& Engel, J. F. (2005) Comportamento do consumidor. São Paulo: Thomson Learning.

Blau, G. (2003). Testing for a four-dimensional structure of occupational commitment. Journal of Occupational and Organizational Psychology, 76(4), 469-488.doi: 10.1348/096317903322591596.

Block, J. (1978). The Q-sort method in personality assessment and psychiatric research. Palo Alto, CA: Consulting Psychologists Press. (Originally published 1961).

Bloom, B. S., Engelhart, M. D., Furst, E. J., Hill, W. H., \& Krathwohl, D. R. (1979). Taxonomia de objetivos educacionais: domínio cognitivo. Porto Alegre: Globo.

Bloom, B. S., Krathwohl, D. R., \& Masia, B. B. (1973). Taxonomia de objetivos educacionais: domínio afetivo. Porto Alegre: Globo.

Boas, F. (1911). The Mind of Primitive Man. New York : Macmillan.

Boatswain, S., \& Lalonde, R. (2000). Social identity and preferred ethnic/racial labels for blacks in Canada. Journal of Black Psychology, 26, 216-234. doi. $10.1177 / 0095798400026002006$.

Bollen, K. A., \& Long, J. S. (1993). Testing structural equation models. Newbury Park: Sage. 
Borba, A. C., Pagotto, C. P., \& Martins, V. S. (2008). Desenvolvimento de sistema de avaliação de desempenho em Empresa Pública do Distrito Federal. Trabalho apresentado no III Congresso Brasileiro de Psicologia Organizacional e do Trabalho, Florianópolis, Santa Catarina.

Borges-Andrade, J. E., \& Pagotto, C. P. (2010). O estado da arte da pesquisa brasileira em Psicologia do Trabalho e Organizacional. Psicologia: Teoria e Pesquisa, 26(n.spe.), 3750. doi. 10.1590/S0102-37722010000500004.

Borges-Andrade, J. E., Coelho Jr., F. A., \& Queiroga, F. (2006). Pesquisa sobre micro comportamento organizacional no Brasil: o estado da arte. In: II Congresso Brasileiro de Psicologia Organizacional e do Trabalho, 2006, Brasília. Anais do II Congresso Brasileiro de Psicologia Organizacional e do Trabalho. Brasilia: SBPOT.

Borges-Andrade, J. E., Rocha, K. C. P., \& Puente-Palacios, K. E. (2002). Impacto de informações nas dimensões motivacionais, de capacidade e de desempenho dos indivíduos e das suas organizações. Trabalho apresentado no $26^{\circ}$ Encontro da Associação Nacional de Pós-graduação em Administração. Salvador: ANPAD.

Borman, W. C., \& Motowidlo, S. J. (1993). Expanding the criterion domain to include elements of contextual performance. In N. Schmitt, \& W. C. Borman (Eds.), Personnel selection in organizations (pp. 71-98). San Francisco: Jossey-Bass.

Bose, R. (2004). Knowledge Management Metrics. Industrial Management and Data Systems, 104(6), 457-468. doi. 10.1108/02635570410543771.

Bourdieu, P. (1989). O poder simbólico. Rio de Janeiro: Bertrand Brasil.

Bourdieu, P. (2004). A economia das trocas simbólicas. 5. ed. São Paulo: Perspectiva.

Bourdieu, P. (2007). O poder simbólico. Rio de Janeiro: Bertrand Brasil.

Bourdieu, P. (2009). O Senso Prático. Petrópolis: Vozes.

Bourdieu, P., \& Wacquant, L. (1992) An invitation to reflexive sociology. Chicago: University of Chicago Press(2009). O Senso Prático. Petrópolis: Vozes.

Bourne, H., \& Jenkins, M. (2013). Organizational values: A dynamic perspective. Organization Studies, 34(4), 495-514. doi. 10.1177/0170840612467155.

Bourne, M., Mills, J., Wilcox, M., A., \& Platts, K. (2000). Designing implementing and updating performance measurements systems. International Journal of Operations and Production Management, 20(7), 754-771. doi. 10.1108/01443570010330739.

Bowditch, J. L., \& Buono, A. F. (1992). Elementos do comportamento organizacional. São Paulo: Pioneira. 
Boyatzis, R. E. (1982). The competent management: a model for effective performance. New York: John Wiley.

Brandão, C. R. (1990). Identidade e etnia: construção da pessoa e resistência cultural. São Paulo: Brasiliense.

Brandão, H. P. (2007). Competências no trabalho: uma análise da produção científica brasileira. Revista Estudos de Psicologia, 12(2), 149-158.doi. 10.1590/S1413294X2007000200007.

Brandão, H. P. (2009). Aprendizagem, contexto, competência e desempenho: Um estudo multinível. Tese de Doutorado Não Publicada. Universidade de Brasília, Brasília.

Brandão, H. P., \& Bahry, C. P. (2005). Gestão por competências: métodos e técnicas para mapeamento de competências. Revista do Serviço Público, 56 (2), 179-194.

Brandão, H. P., \& Borges-Andrade, J. E. (2007). Causas e efeitos da expressão de competências no trabalho: para entender melhor a noção de competência. Revista de Administração Mackenzie, 8 (3), 32-49.

Brandão, H. P., Borges-Andrade, J. E., Freitas, I. A., \& Vieira, F. T. (2008). Desenvolvimento e validação de uma escala de competências gerenciais. Em Anais do $32^{\circ}$ Encontro da Associação Nacional de Pós-Graduação e Pesquisa em Administração - EnANPAD. Rio de Janeiro: ANPAD.

Brandão, H. P., Borges-Andrade, J. E., \& Guimarães, T. A. (2012a). Desempenho organizacional e suas relações com competências gerenciais, suporte organizacional e treinamento. Revista de Administração, 47(4), 523-539.doi. 10.5700/rausp1056.

Brandão, H. P., Borges-Andrade, J. E., Puente-Palacios, K. E., \& Laros, J. A (2012b). Relationships between learning, context and competency: a multilevel study. BAR. Brazilian Administration Review, 9(1), 1-22. doi. 10.1590/S1807-76922012000100002.

Brandão, H. P., \& Guimarães, T. A. (2001). Gestão de competências e gestão de desempenho: tecnologias distintas ou instrumentos de um mesmo constructo?. Revista de Administração de Empresas, 41 (1), 08-15.

Brandão, H. P., Guimarães, T. A., \& Borges-Andrade, J. E. (2001). Competências profissionais relevantes à qualidade no atendimento bancário. Revista de Administração Pública, 35 (6), 61-81.

Brandão, H. P., Guimarães, T. A., \& Borges-Andrade, J. E. (2002). Competências emergentes na indústria bancária: um estudo de caso. Revista Comportamento Organizacional e Gestão, 8 (2), 173-190. 
Brandão, H. P., Puente-Palacios, K. E., \& Borges-Andrade, J. E. (2008). A análise multinível aplicada ao estudo da competência: em busca de uma compreensão mais integrada e abrangente sobre a noção de competência. Trabalho apresentado no $32^{\circ}$ Encontro da Associação Nacional de Pós-Graduação e Pesquisa em Administração - EnANPAD. Rio de Janeiro: ANPAD.

Brandão, H. P., Zimmer, M. V., Guarçoni, C. P., Marques, F., Viana. H., Carbone, P. P., \& Almada, V. F. (2008). Gestão de desempenho por competências: integrando a avaliação 360 graus, o balanced scorecard e a gestão por competências. Revista de Administração Pública, 42 (5), 875-898.

Bredford, B., Quinton, P., Myhill, A., \& Porter, G. (2013). Why do 'the law' comply? Procedural justice, group identification and officer motivation in police organizations. European Journal of Criminology, 11(1), 110-131. doi. 10.1177/1477370813491898.

Brewer, M. B. (1979). The role of ethnocentrism in intergroup conflict. In: W. G. Austin \& S.Worchel (Eds.). The Social Psychology of Intergroup Relations. Monterey, California, Brooks/Cole.

Brewer, M. B. (1986). The role of ethnocentrism in intergroup conflict. In S. Worchel \& W. Austin (Eds.), Psychology of intergroup relations (pp. 82-102). Chicago: Nelson-Hall.

Brewer, M. B. (1991). The social self: On being the same and different at the same time. Personality and Social Psychology Bulletin, 17, 475-482.

Brewer, M. B. (1997). On the social origins of human nature. In C. McGarty \& S. A. Haslam (Eds.), The message of social psychology. (pp. 54-62). Oxford, UK: Blackwell.

Brewer, M. B. \& Gardner, W. (2004). Who is this "we"? Levels of collective identity and self representation. In: HATCH, M. J. \& Schultz, M. (Ed.). Organizational identity: a reader. New York, NY: Oxford University Press, p.66-88.

Brickson, S. L. (2013). Athletes, best friends, and social activists: An integrative model accounting for the role of identity in organizational identification. Organization Science 24(1), 226-245. doi. 10.1287/orsc.1110.0730.

Bridger, G. V. (2006). Governança corporativa e os efeitos da adesão a níveis diferenciados de governança sobre o valor no mercado de capitais brasileiro. Dissertação de Mestrado, Fundação Getúlio Vargas, Rio de Janeiro.

Brief, A. P., \& Motowidlo, Stephan J. (1986). Prosocial organizational behaviors. Academy of Management Review, 11 (4), pp. 710-725. 
Brislin, R. W. (1970). Back-translation for cross-cultural research. Journal of Cross-Cultural Psychology, 1(3), 185-216. doi. 10.1177/135910457000100301.

Brito, F. D., Bastos, A. V., Oliveira, C. F., \& Sant'anna, G. B. (2008). Implantação de avaliação de desempenho $360^{\circ}$ em Instituição Federal de ensino superior: reflexões sobre desafios e possibilidades. Trabalho apresentado no $3^{\circ}$ Congresso Brasileiro de Psicologia Organizacional e do Trabalho, Florianópolis, Santa Catarina.

Brown, A. (1998). Organizational culture. 2. ed. Harlow: Prentice Hall.

Brown, A. D. (2006). A narrative approach to collective identities. Journal of Management Studies, 43, 731-753. doi. 10.1111/j.1467-6486.2006.00609.x.

Brown, T. A. (2006). Confirmatory factor analysis for applied research. New York, NY: Guilford Press.

Brown, A. \& Starkey, K. (2000). Organizational identity and learning: a psychodynamic perspective. The Academy of Management Review, 25(1), 102-118.

Brown, R., Condor, S., Mathews, A., Wade, G., \& Williams, J. (1986). Explaining intergroup differentiation in an industrial organization. Journal of Occupational Psychology, 59, 279-304.

Browne, M. W., \& Cudeck, R. (1989). Single sample cross-validation indices for covariancestructures. Multivariate Behavioral Research, 24, 445-455.

Bruno-Faria, M. F., \& Brandão, H. P. (2003). Competências relevantes a profissionais da área de T\&D de uma organização pública do Distrito Federal. Revista de Administração Contemporânea, 7 (3), 35-56. doi. 10.1590/S1415-65552003000300003.

Burns, T., \& Stalker, G. M. (1961). The management of innovation. London: Tavistock.

Büschgens, T., Bausch, A. and Balkin, D. B. (2013), Organizational Culture and Innovation: A Meta-Analytic Review. Journal of Product Innovation Management, 30: 763-781. doi: 10.1111/jpim.12021.

\section{$\mathbf{C}$}

Cable, D.M. \& Edwards, J.R. (2004). Complementary and supplementary fit: A theoretical and empirical integration. Journal of Applied Psychology, 89, 822-834. doi. 10.1037/0021-9010.89.5.822.

Cable, D. M., \& Judge, T. A. (1996). Person-organization fit, job choice decisions, and organizational entry. Organizational Behavior \& Human Decision Processes, 67 (3), 294311. doi. 10.1006/obhd.1996.0081. 
Caetano. A. (1996). Avaliação de desempenho: metáforas, conceitos e práticas. Lisboa: Editora RH.

Calori, R. \& Sarnin, P. (1991). Corporate culture and economic performance: A french study. Organization Studies, 12 (1), 49-74. doi. 10.1177/017084069101200104.

Cameron, J. E. (2004). A three-factor model of social identity. Self and Identity, 3(3), 239262. doi: $10.1080 / 13576500444000047$.

Cameron, J. E., \& Lalonde, R. (2001). Social identification and gender related ideology in women and men. British Journal of Social Psychology, 40, 59-77. doi. 10.1348/014466601164696.

Cameron, J. E., Sato, T., Lalonde, R. N., \& Lay, C. (1997). Developing a multidimensional measure of ethnic identity. Paper presented at the Annual Meeting of the Canadian Psychological Association, Toronto.

Cameron, K. S., Quinn, R. E. (1999). Diagnosing and changing organizational culture: based on the competing values framework. Reading, MA: Addison-Wesley.

Cameron, K. S., \& Quinn, R. E. (2011). Diagnosing and changing organizational culture: Based on the Competing Values Framework (3rd ed.). San Francisco: Jossey-Bass.

Campbell, J. P. (1990). Modeling the performance prediction problem in industrial and organizational psychology. In: M. D. Dunnette \& L. M. Hough (Eds.), Handbook of Industrial and Organizational Psychology. Palo Alto: Consulting Psychologists Press.

Campbell, J. Y. (1999), Asset prices, consumption, and the business cycle. In: J.B. Taylor and M. Woodford, eds., Handbook of Macroeconomics, (pp. 1231-1303). Vol. 1, Elsevier, Amsterdam.

Campbell, J. P., Gasser, M. B., \& Oswald, F. L. (1996). The substantive nature of job performance variability. In: K. R. Murphy (Ed.), Individual Differences and Behavior in Organizations, (pp.258-299). San Francisco: Jossey-Bass.

Campbell, J. P., McCloy, R. A., Oppler, S. H., \& Sager, C. E. (1993). A theory of performance. In N. Schmitt, W. C. Borman, and associates (Eds.), Personnel selection in organizations: 35-69. San Francisco: Jossey-Bass.

Canova, K. R., \& Porto, J. B. (2010). O impacto dos valores organizacionais no estresse ocupacional: um estudo com professores de ensino médio. RAM. Revista de Administração Mackenzie, 11(5), 4-31. doi. 10.1590/S1678-69712010000500002. 
Carbone, P. P., Brandão, H. P., Leite, J. B., \& Vilhena, R. M. (2005). Gestão por competências e gestão do conhecimento. Rio de Janeiro: Ed. Fundação Getúlio Vargas, Série Gestão de Pessoas.

Caridade, A. V. S. (2006). Práticas de gestão estratégica e aderência ao método Sigma: Um estudo de caso no setor de celulose e papel . Dissertação de Mestrado, Universidade de São Paulo, São Paulo.

Carlisle, Y., \& Baden-Fuller, C. (2004). Re-applying beliefs: An analysis of change in the oil industry. Organization Studies, 25, 987-1019. doi: 10.1177/0170840604045093.

Carneiro, J. M. T., Silva, J. F., Rocha, A., \& Dib, L. A. R. (2007). Building a better measure of business performance. Revista de Administração Contemporânea Eletrônica, 1(2),114135.

Carrieri, A. P. (2001). O fim do mundo Telemig: A transformação das significações em uma empresa de telecomunicações. Tese de doutorado, Universidade Federal de Minas Gerais, Belo Horizonte.

Carrieri, A. P. (2002). Cultura no contexto dos estudos organizacionais: breve estado da arte. Organizações Rurais e Agroindustriais, Lavras - UFLA, 4(1), 38-50.

Carvalho, F. (2004). Práticas de planejamento estratégico e sua aplicação em organizações do terceiro setor . Dissertação de Mestrado, Universidade de São Paulo, São Paulo.

Cassepp-Borges, V., Balbinotti, M. A., \& Teodoro, M. L. M. (2010). Tradução e validação de conteúdo: uma proposta para a adaptação de instrumentos. In. Pasquali, L., \& Cols. Instrumentação Psicológica: fundamentos e práticas. Porto Alegre: Artmed, 506-520.

Castells, M. (1999). O poder da identidade. São Paulo: Paz e Terra.

Castro, E. C., \& Figueiredo, P. N. (2005). Aprendizagem tecnológica compensa? Implicações da acumulação de competências tecnológicas para o aprimoramento de performance técnico-econômica em uma unidade de aciaria no Brasil. Revista de Administração

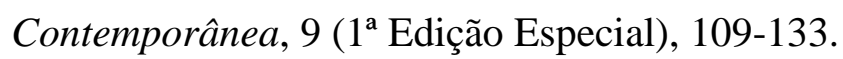

Cattell, R. B. (1966). The scree test for the number of factors. Multivariate Behavioral Research, 1(2), 245-276.

Cavazotte, F. S. C., Humphrey, R. H., \& Sleeth, R. (2004). Competências emocionais e processos intragrupais: o papel da habilidade para expressar emoções e da empatia para a cooperação em grupos de trabalho. Trabalho apresentado no $28^{\circ}$ Encontro da Associação Nacional de Pós-Graduação e Pesquisa em Administração - EnANPAD. Curitiba: ANPAD. 
Cavazotte, F., Oliveira, L. B., \& Miranda, L. C. (2010). Desigualdade de gênero no trabalho: reflexos nas atitudes das mulheres e na sua intenção de deixar a empresa. Revista de Administração (FEA-USP), 45, 1-15.

Cerulo, K. A. (1997). Identity construction: new issues, new directions. Annual Review of Sociology, 23, 385-409. doi. 10.1146/annurev.soc.23.1.385.

Cha, E. S., Kim, K. H., \& Erlen, J. A. (2007). Translation of scales in cross-cultural research: issues and techniques. Journal of Advanced Nursing, 58(4), 386-395.

Chaddad, F. R. (2006). Performance measurement of user-owned organizations: an evaluative survey of the literature. Trabalho apresentado no XXX Encontro Nacional de Programas de Pós-Graduação em Administração (Enanpad), Salvador.

Champy, J. (1995). Reengineering management: the mandate for new leadership. Nova York: Harper Business.

Chan, L. L. M., Shaffer, M. A., \& Snape, E. (2004). In search of sustained competitive advantage: the impact of organizational culture, competitive strategy and human resource management practices on firm performance. International Journal of Human Resource Management, 15(1), 17-35. doi. 10.1080/0958519032000157320.

Chang, C. C., \& Wu, C. C. (2013). Multilevel analysis of work context and social support climate in libraries. Aslib Proceedings: New Information Perspectives, 65 (6), 644-658. doi. 10.1108/AP-05-2012-0051.

Chao, G. T. (2000). Multilevel issues and culture: An integrative view. In K. J. Klein \& S. W. Kozlowski (Eds.). Multilevel theory, research and methods in organizations: Foundations, extensions and new directions (pp. 308 - 346). San Francisco: Jossey-Bass.

Chauchat, H. \& Durand-Delvigne, A. (1999). De l'identité du sujet au lien social. Paris : PUF.

Chen, L. Y. (2004). Examining the Effect of Organization Culture \& Leadership Behaviors on organizational commitment, job satisfaction, \& job performance at small \& middlesized firms of Taiwan. The Journal of American Academy of Business, 5, 432-438.

Chen, Y. S. (2011). Green organizational identity: sources and consequence. Management Decision, 49(3), 384-404. doi. 10.1108/00251741111120761.

Chen, Y., Chi, S. S., \& Friedman, R. (2013). Do more hats bring more benefits? Exploring the impact of dual organizational identification on work-related attitudes and performance. Journal of Occupational and Organizational Psychology, 86(3), 417-434. doi. 10.1111/joop.12017. 
Cheney, G. (1991). Rhetoric in an organizational society, managing multiple identities. Columbia, SC: University of South Carolina Press.

Cheung, G. W., \& Lau, R. S. (2008). Testing mediation and suppression effects of latent variables: bootstrapping with structural equation models. Organizational Research Methods, 11(2), 296-325. doi. 10.1177/1094428107300343.

Cheung, S. O., Wong, P. S. P., \& Wu, A. W. Y. (2011). Towards an organisational culture framework in construction. International Journal of Project Management, 29, 33-44. doi. 10.1016/j.ijproman.2010.01.014.

Ciampa, A. C. (2007). A estória do Severino e a história da Severino: um ensaio de psicologia social. São Paulo: Brasiliense.

Christensen, E. W. \& Gordon, G. G. (1999). An exploration of industry, culture and revenue growth. Organization Studies, 20 (3), 397-422. doi. 10.1177/0170840699203002.

Churchill, G. A. (1979). A paradigm for developing better measures of marketing constructs. Journal of Marketing Research, 16(1), 64-73.

Cieciuch, J., \& Schwartz, S. H. (2012). Assessing the number of distinct basic values and their structure in Poland. Journal of Personality Assessment, 1-8. doi: 10.1080/00223891.2012.655817.

Coad, A. F. (1999). Some survey evidence on the learning and performance orientations of management accountants. Management Accounting Research, 10, 109-135.

Coelho Jr., F. A. (2009). Suporte à aprendizagem, satisfação no trabalho e desempenho: Um estudo multinível. Tese de Doutorado Não Publicada. Universidade de Brasília, Brasília.

Coelho Jr, F. A.; Borges-Andrade, J. E. (2004). Percepção de cultura organizacional: Uma análise empírica da produção científica brasileira. Psico-USF (Impresso), Bragança Paulista, v. 9, n. 2, p. 191-199. doi. 10.1590/S141382712004000200010.

Coelho Jr., F. A., \& Borges-Andrade, J. E. (2011a). Efeitos de variáveis individuais e contextuais sobre desempenho individual no trabalho. Estudos de Psicologia (Natal), 16(2), 111-120. doi. 10.1590/S1413-294X2011000200001.

Coelho Jr., F. A., \& Borges-Andrade, J. E. (2011b). Discussão sobre algumas contribuições da modelagem multinível para a investigação de desempenho no trabalho. Psico-USF, 16(2), 135-142. doi. 10.1590/S1413-82712011000200002.

Coelho Jr., F. A., \& Queiroga, F. (2008). Desempenho no trabalho: introdução aos seus fundamentos teórico/práticos. Curso ministrado no III Congresso Brasileiro de Psicologia Organizacional e do Trabalho. Florianópolis, Santa Catarina. 
Cohen, A. (2003). Multiple commitments in workplaces: an integrative approach. Mahwah, New Jersey: Lawrence Erlbaum Associates.

Cohen, I. J. (1999). Teoria da estruturação da práxis social. (G. C. C. Sousa, Trad.) In: A. Giddens \& J. Turner (Eds.). Teoria social hoje. São Paulo: Editora UNESP.

Cole, B., \& Salimath, M. (2013). Diversity identity management: An organizational perspective. Journal of Business Ethics, 116(1), 151-161. doi. 10.1007/s10551-012-14664.

Collin, A. (1996). Organizations and the end of the individual? Journal of Managerial Psychology, 11(7), pp. 9-17. doi. 10.1108/02683949610148829.

Collins, D. B. (2002). Performance-level evaluation methods used in management development studies from 1986 to 2000. Human Resource Development Review, 1(1), 91110. doi. 10.1177/1534484302011005.

Combs, J., Liu, Y., Hall, A., \& Ketchen, D. (2006). How much do high-performance work practices matter? A meta-analysis of their effects on organizational performance. Personnel Psychology, 59(3), 501-528. doi. 10.1111/j.1744-6570.2006.00045.x.

Conway, J. (1999). Distinguishing contextual performance from task performance for managerial jobs. Journal of Applied Psychology, 84(1), 3-13. doi. 10.1037/00219010.84.1.3.

Cooke, R. A., \& Lafferty, J. C. 1989. Organizational culture inventory. Plymouth, MI: Hum. Synerg.

Cooley, C. H. (1902). Nature and the social order. New York: Charles Scribner's Sons

Cooley, C. H. (1922). Social organization: A study of the larger mind, New York: Charles Scribner's Sons.

Corley, K. G., \& Gioia, D. A. (2004). Identity ambiguity and change in the wake of a corporate spin-off. Administrative Science Quarterly, 49(2), 173-208. doi. $10.2307 / 4131471$.

Corley, K.G., Harquail, C.V., Pratt, M.G., Glynn, M.A., Fiol, C.M., \& Hatch, M.J. (2006). Guiding organizational identity through aged adolescence. Journal of Management Inquiry, 15(2), 85-99. doi. 10.1177/1056492605285930.

Cornelissen, J. P., Haslam, S. A., \& Balmer, J. M. T. (2007). Social identity, organizational identity and corporate identity: Towards an integrated understanding of processes, patternings and products. British Journal of Management, 18, 1-16. doi:10.1111/j.14678551.2007.00522.x. 
Costa, A. T. M., Mattos, M. J., \& Santos, L. (2012). Os novos padrões de seleção na Polícia Militar do Distrito Federal. Desigualdade \& Diversidade (PUCRJ), 11, 115-132.

Coutinho, M. C., Krawulski, E., \& Soares, D. H. P. (2007). Identidade e trabalho na conteporaneidade: repensando articulações possíveis. Psicologia \& Sociedade, 19(spe), 29-37. doi. 10.1590/S0102-71822007000400006.

Cunha, N. C. V. (2005). As práticas gerenciais e suas contribuições para a capacidade de inovação em empresas inovadoras. Tese de Doutorado, Universidade de São Paulo, São Paulo.

Crié, D. (2005). De l'usage des modèles de mesure réflectifs ou formatifs dans les modèles d"équations structurelles. Recherche et Applications en Marketing, 20(2), 5-27.

Cropanzano, R., Howes, J. C., Grandey, A. A., \& Toth, P. (1997). The relationship of organizational politics and support to work behaviors, attidudes and stress. Journal of Organizational Behavior, 18, 159-180.

Cropanzano, R., James, K., \& Konovsky, M. A. (1993). Dispositional affectivity as a predictor of work attitudes and job performance. Journal of Organizational Behavior, 14, 595-600.

\section{D}

Dansereau, F., \& Alutto, J. A. (1990). Level-of-analysis issues in climate and culture research. In B. Schneider (Ed.), Organizational climate and culture (pp. 193 - 236). San Francisco: Jossey-Bass.

Davenport, T. H., \& Prusak, L. (1998). Working knowledge: how organizations manage what they know. Boston: Harvard Buniness School Press.

Davis, S., \& Botkin, J. (1994). The coming of knowledge-based business. Harvard Business Review, 72 (5), 165-170.

Deal, T. E., \& Kennedy, A. A. (1982). Corporate cultures: the rites and rituals of corporate life. Massachusetts: Addison-Wesley.

Deaux, K. (1996). Social Identification. In E. Higgins \& A. Kruglanski (Eds.), Social Psychology: Handbook of basic principles (pp. 777-798). New York: Guilford.

Deaux, K., \& Major, B. (1987). Putting gender into context: An interactive model of genderrelated behavior. Psychological Review, 94, 369-389.

Delery, J. E., \& Shaw, J. D. (2001). The strategic management of people in work organizations: review, sunthesis and extension. In G.D. Ferris (Ed.), Research in personnel and human resources management, (pp. 165-197). Stanford: Jai Press. 
Dellobbe, N., Haccoun, R. R., \& Vandenberghe, C. (2002). Measuring core dimensions of organizational culture: A review of research and development of a new instrument. Unpublished manuscript, Université Catholique de Louvain, Belgium.

Demo, G. (2004). Percepção de políticas de gestão de pessoas: o papel dos valores pessoais $e$ da percepção de justiça organizacional. Tese de Doutorado. Programa de Pósgraduação em Psicologia. Universidade de Brasília, Brasília.

Demo, G., \& Rozzett, K. (2012). Human Resource Management Policies and Practices (HRMPP): Scale Validation in The United States. International Journal of Strategic Management. 12, 41-66.

Demo, G., Neiva, E. R., Nunes, I., \& Rozzett, K. (2012). Human Resources Management Policies and Practices Scale (HRMPPS): exploratory and confirmatory factor analysis. BAR. Brazilian Administration Review. 9, 395-420. doi. 10.1590/S180776922012005000006.

Denison, D. R. (1990). Corporate Culture and Organizational Effectiveness. New York: Wiley.

Deschamps, J. C. \& Moliner, P. (2009). A identidade em Psicologia Social: dos processos identitários às representações sociais. (L. M. E. Orth, Trad.). Petrópolis, RJ: Vozes.

Detert, J., Schroeder, R. G., Mauriel, J. J. (2000). A framework for linking culture and improvement initiatives in organizations. Academy of Management Journal, 25(4), 850863. doi. 10.5465/AMR.2000.3707740.

De Witte, K., \& van Muijen, J. (1999a). Organizational culture. European Journal of Work and Organizational Psychology, 8 (4), 497-502. doi. 10.1080/135943299398122.

De Witte, K., \& van Muijen, J. (1999b). Organizational culture: Critical questions for researchers and practitioners. European Journal of Work and Organizational Psychology, 8 (4), 583-595. doi. 10.1080/135943299398186.

Diallo, M. F. (2011). Les determinants du choix des marques de distributeur: application à um marche émergent, Le Brésil. Thèse de Doctorat en Sciences de Gestion. Université Paul Cézanne, Aix-Marseille Université.

Dias, A.T., Gonçalves, C.A., \& Coleta, K.A.P.G. (2007). Fatores estratégicos e desempenho de empresas em ambientes turbulentos: o caso das companhias brasileiras abertas no período 1996-2001. Revista de Administração Contemporânea Eletrônica, 1(3), 86-106. 
DiMaggio, P. J. \& Powell W. W. (1983). The iron cage revisited: Institutional isomorphism and collective rationality in organizational fields. American Sociological Review, 48 (2), 147-160.

D'Iribarne, P. (1983). La logique d'honneur: gestion des entreprises et traditions nationales. France: Éditions du Seuil.

D’Iribarne, P. (2003). Práticas modernas de gestão inseridas nas culturas do terceiro mundo. Civitas - Revista de Ciências Sociais. 3(2), 327- 337.

D'Iribarne (2009a). Conceptualizing national cultures: an antthropological perspective. European Journal of International Management. 3(2). 167-175. doi. 10.1504/EJIM.2009.02432.

D’Iribarne (2009b). Conceituando culturas nacionais: uma abordagem antropológica. In: L, Barbosa (Ed. ). Cultura e diferenças nas organizações: reflexões sobre nós e os outros. São Paulo: Editora Atlas.

DiStefano, C., Zhu, M., \& Mîndrilă, D. (2009). Understanding and using factor scores: considerations for the applied researcher, practical assessment. Research \& Evaluation, $14,20,1-11$.

Dobni, D. J. R., Brent, R., \& Zerbe, W. (2000). Organizational values: The inside view of service productivity. Journal of Business Research, 47, 91-107. doi. 10.1016/S01482963(98)00058-7.

Dobni, D., Ritchie, J. R. B., \& Zerbe, W. (2000). Organizational values: the inside view of service productivity. Journal of Business Research, 47, 91-107. doi. 10.1016/S01482963(98)00058-7.

Doosje, B., Haslam, S. A., Spears, R., Oakes, P. J., \& Koomen, W. (1998). The effect of comparative context on central tendency and variability judgments and the evaluation of group characteristics. European Journal of Social Psychology, 28, 173-84. doi. 10.1002/(SICI)1099-0992.

Dose, J. J. (1997). Work values: An integrative framework and illustrative application to organizational socialization. Journal of Occupational and Organizational Psychology, 70, 219-240. doi. 10.1111/j.2044-8325.1997.tb00645.x.

Dubar, C. (1994). Identités collectives et individuelles dans le champ professionnel. In M. Coster, F. Pichault (Orgs.). Traité de sociologie du travail. Bruxelles: De BoeckWesmael. 
Dubar, C. (1996). La socialisation: construction des identités sociales et professionnelles. 2.ed. Paris: Armand Colin.

Dubar, C. (2005). A Socialização: Construção de identidades sociais e profissionais. (Silva, A. S. M., Trad.). São Paulo: Martins Fontes.

Dubar, C. (2009). A crise das identidades: a interpretação de uma mutação. (Barros, M. A. L., Trad.). São Paulo: EDUSP.

Dunlop, P., \& Lee, K. (2004). Organizational citizenship behavior and workplace deviant behavior: Are they distinct? Paper presented at the 19th annual meeting of the Society for Industrial and Organizational Psychology, Chicago.

Dupuis , J. -P. (1996). Antropologia, cultura e organização: proposta de um modelo construtivista. In: Chalant, J. F. (Org.). $O$ indivíduo na organização: dimensões esquecidas. São Paulo: Atlas.

Dupuis, J. -P. (2007). Entre as culturas latinas, anglo-saxã e nórdica: os quebequenses em economia, negócios e administração. In: J. F., Chanlat; Fachin, R \& Fischer, T. (Org.). Análise das organizações perspectivas latinas. Porto Alegre: Editora UFRGS.

Dupuis, J. -P. (2008). L'Analyse interculturelle em gestion: décloisonner les approches classiques. In: E. Davel; JP, Dupuis, JF, Chanlat (Org.). Gestion en contexte interculturel: approches, problématiques, pratiques et plongées. Canada: les Presses de l’Université Laval.

Durand, T. (1998). Forms of incompetence. In Proceedings of the fourth international conference on competence-Based management. Oslo: Norwegian School of Management.

Durand, T. (2000). L'alchimie de la compétence. Revue Française de Gestion, 127 (1), 84102.

Durkheim, E. (1897/1964). Suicide. Glencoe, Il.: Free Press.

Durkheim, E. (1912/1954). The elementary forms of religious life. Glencoe, IL: Free Press.

Dutra, J. S. (2004). Competências: conceitos e instrumentos para a gestão de pessoas na empresa moderna. São Paulo: Atlas.

Dutra, J. S., Hipólito, J. M., \& Silva, C. M. (1998). Gestão de pessoas por competências. Trabalho apresentado no Encontro Nacional da Associação Nacional de Pós-graduação em AdministraçAão, 22, Foz do Iguaçu.

Dutton, J., \& Dukerich, J. (1991). Keeping an eye on the mirror: Image and identity in organizational adaptation. Academy of Management Journal, 34(3), 517-554. doi. $10.2307 / 256405$. 
Dutton, J. E., Dukerich, J. M., \& Harquail, C. V. (1994). Organizational images and member identification. Administrative Science Quarterly, 39, 239-263.

$\mathbf{E}$

Eccles, R. G. (1991). The performance measurement manifesto. havard Business Review, 69(1), 131-137.

Eckes, G. (1994). Practical alternatives to performance appraisals. Quality Progress, 27, 5760.

Eiser, J. R. (1987). The expression of attitude. New York: Springer-Verlag.

Ellemers, N., Gilder, D., \& Haslam, S. A. (2004). Motivating individuals and groups at work: A social identity perspective on leadership and group performance. Academy of Management Review, 29, 459-478. doi:10.5465/AMR.2004.13670967.

Ellemers, N., Kortekaas, P., \& Ouwerkerk, J. (1999). Self-categorisation, commitmentto the group and group self esteem as related but distinct aspects of social identity. European Journal of Social Psychology, 29, 371-389.

Ellemers, N., Spears, R., \& Doosje, B. (2002). Self and Social Identity. Annual Review of Psychology, 53, 161-186. doi. 0.1146/annurev.psych.53.100901.135228.

Elsbach, K. D., \& Kramer, R. M. (1996). Members' responses to organizational identity threats: Encountering and countering the Business Week rankings. Administrative Science Quarterly, 41(3), 442-476. doi. 10.2307/2393938.

Erez, M. (1994). Toward a model of cross-cultural I/O psychology. In Triandis, H. M., Dunnette, M. D., \& Hough, L. M. (Eds.). Handbook of industrial and organisational psychology. 2nd edn, 4, 569-607. Consulting Psychologists Press, Palo Alto CA.

Erez, M. \& Earley, P. C. (1993). Culture, self-identity, and work. New York: Oxford Univ. Press.

Erez, M., \& Gati, F. (2004). A dynamic, multi-level model of culture: From the micro level of the individual to the macro level of a global culture. Applied Psychology: An International Review, 53(4), 583 - 598. doi. 0.1111/j.1464-0597.2004.00190.x.

Erickson, E. H. (1994). Identity and the life cycle. London: W. W. Norton \& Company.

Ericson, R. V. (1992). That Strange Word Police. In: McCormick, K. R. E.; Visano, L. A. Understanding Policing. Toronto, Canadian Scholars' Press, p. 151-159.

Evrard, Y., Pras, B., \& Roux, E. (2009). Market: fondements et méthodes des recherches en marketing. (4e édition), Dunod, Paris. 


\section{$\mathbf{F}$}

Faiad, C., Delabrida, Z. N. C., \& Nascimento, T. G. (2011). Survey sobre a qualidade do serviço de segurança oferecido pela Polícia Militar segundo proprietários e funcionários de comércio em Brasília. Psicologia em Pesquisa, 5, 77-85.

Faiad, C., Coelho Jr., F. A., Caetano, P. F., \& Albuquerque, A. S. (2012). Análise profissiográfica e mapeamento de competências nas instituições de segurança pública. Psicologia: Ciência e Profissão, 32, 388-403. doi. 10.1590/S1414-98932012000200009.

Faria, J. H. (2000). Economia do Poder. Texto. Curitiba : UFPR/CEPPAD.

Farias, R. M. C. (2013). Manifestações culturais latentes em práticas de uma organização bancária brasileira internacionalizada. Dissertação de Mestrado em Administração. Universidade de Brasília, Brasília.

Feather, N. T. (1995). Values, valences and choice: The influence of values on the perceived attractiveness and choice of alternatives. Journal of Personality and Social Psychology, 68 (6), 1135-1151.

Fenili, R. R. (2012). Manifestações culturais de uma organização internacionalizada: Um estudo a partir das práticas organizacionais. Dissertação de Mestrado em Administração. Universidade de Brasília, Brasília.

Ferdman, B. M. (2003). Learning about our and others'selves: Multiple identities and their sources. In: Boyacigiller, N. A.; Goodman, R \& Phillips, M. E. (Eds.). Crossing cultures. Routledge, New York.

Fernandes, B. H. R., Fleury, M. T. L., \& Mills, J. (2006). Construindo o diálogo entre competência, recursos e desempenho organizacional. Revista de Administração de Empresas, 46 (4), 48-65. doi. 10.1590/S0034-75902006000400006.

Fernandes, K. R., \& Zanelli, J. C. (2006). O Processo de construção e reconstrução das identidades dos indivíduos nas organizações. Revista de Administração Contemporânea. 10(1), 48-72. doi. 10.1590/S1415-65552006000100004.

Fernandes, M. E. R., Marques, A. L., \& Carrieri, A. P. (2009). Identidade organizacional e os componentes do processo identificatório: uma proposta de integração. Cadernos EBAPE.BR, 7, 688-703.

Ferreira, M. C. (2010). A psicologia social contemporânea: Principais tendências e perspectivas nacionais e internacionais. Psicologia: Teoria e Pesquisa, 26, 51-64. doi. 10.1590/S0102-37722010000500005. 
Ferreira, M. C. (2011). Breve história da moderna psicologia social. In: C. V. Torres \& E. R. Neiva (Orgs.). Psicologia Social: principais temas e vertentes. Porto Alegre: Artmed.

Ferreira, M. C. \& Assmar, E. M. L. (2008). Cultura organizacional. In M. M. M. Siqueira (Ed.). Medidas do comportamento organizacional: ferramentas de diagnóstico e de gestão. (pp. 125-138). Porto alegre: Artmed.

Ferreira, M. C. \& Mendes, A. M. (2003). Trabalho e riscos de adoecimento: O caso dos auditores-fiscais da previdência social brasileira: LPA.

Ferreira, M. C. \& Mendes, A. M. (2008). Contexto de trabalho. In M. M. M. Siqueira (Ed.). Medidas do comportamento organizacional: ferramentas de diagnóstico e de gestão. (pp. 111-123). Porto alegre: Artmed.

Ferreira, M. C., Assmar, E. M. L., Estol, K. M. F., Helena, M. C. C., \& Cisne, M. C. (2002). Desenvolvimento de um instrumento brasileiro para avaliação da cultura organizacional. Estudos de Psicologia (UFRN), 7(2), 271-280. doi. 10.1590/S1413-294X2002000200008.

Ferreira, M. C., Fernandes, H. A., \& Corrêa e Silva, A. P. (2009). Valores organizacionais: um balanço da produção nacional do período de 2000 a 2008 nas áreas de administração e psicologia. RAM. Revista de Administração Mackenzie, 10(3), 84-100. doi. 10.1590/S1678-69712009000300006.

Festinger, L. (1957). A theory of cognitive dissonance. Evanston, II.: Row \& Peterson.

Festinger, L. (1971). Théorie des processus de comparison sociale. In: Faucheux, C. \& Moscovici, S. (Orgs.). Psychologie sociale théorique et expérimentale. Paris: Mouton.

Finegan, J., \& Theriault, C. (1997). The relationship between personal values and the perception of the corporation's code of ethics. Journal of Applied Social Psychology, 27, 708-724. doi. 0.1111/j.1559-1816.1997.tb00655.x.

Fiol, C. M., \& O’Connor, E. J. (2005). Identification in face-to-face, hybrid, and pure virtual teams: Untangling the contradictions. Organization Science, 16, 19-32. doi:10.1287/orsc.1040.0101.

Fiol, M., Hatch, M. J., \& Golden-Biddle, K. 1998. Organizational culture and identity: What's the difference anyway? In D. Whetten \& P. Godfrey (Eds.), Identity in organizations: 56-59. Thousand Oaks, CA: Sage.

Fischer, R., Ferreira, M. C., Leal Assmar, E. M., Baris, G., Berberoglu, G., Dalyan, F., Wong, C. C., Hassan, A., Hanke, K., \& Boer, D. (2013). Organizational practices across cultures: An exploration in six cultural contexts. International Journal of Cross Cultural Management, 14, 105-125. doi. 10.1177/1470595813510644. 
Fitzgerald, A., \& Teal, G. (2003) Health reform, professional identity and occupational subcultures: The changing interprofessional relations between doctors and nurses. Contemporary Nurse 16(1-2), 9-19.

Fleury, M. T. L. (1992). O desvendar a cultura de uma organização: Uma discussão metodológica. In: M. T. L. Fleury \& R. M. Fischer (Orgs.), Cultura e poder nas organizações (pp.15-27). São Paulo: Atlas.

Fleury, A., \& Fleury, M. T. (2001). Estratégias empresariais e formação de competências: um quebra-cabeça caleidoscópico da indústria brasileira. São Paulo: Atlas.

Fleury, A., \& Fleury, M. T. (2004). Alinhando estratégia e competências. Revista de Administração de Empresas, 44 (1), 44-57.

Fombrun, C. J. (1996). Reputation: Realizing value from the corporate image. Boston: Harvard Business School Press.

Fonseca, C. A. M. (2001). Criatividade e comprometimento organizacional: suas relações com a percepção de desempenho no trabalho. Dissertação de Mestrado não publicada, Escola de Administração, Universidade Federal da Bahia, Salvador.

Fornell, C., \& Larcker, D. F. (1981), Evaluating structural equation models with unobservable variables and measurement error. Journal of Marketing Research, 18(1), $39-50$.

Freitas, I. A., \& Brandão, H. P. (2006). Trilhas de aprendizagem como estratégia de TD\&E. Em J.E. Borges-Andrade, G. Abbad, \& L. Mourão (Orgs.), Treinamento, desenvolvimento e educação em organizações e trabalho: fundamentos para a gestão de pessoas (pp. 97113). Porto Alegre: Artmed/Bookman.

Freitas, L. C., \& Medeiros, J. J. (2004). Avaliando desempenho numa aliança estratégica do setor de telecomunicações - um estudo de caso. Trabalho apresentado no $27^{\circ}$ Encontro Nacional de Programas de Pós - Graduação em Administração (Enanpad), Curitiba.

Frese, M., \& Fay, D. (2001). Personal initiative: An active performance concert for work in the 21st century. In. B. M. Staw \& R. L. Sutton (Ed.). Research in organizational behavior (pp. 133-187). Greenwich, CT: JAI Press.

Frese, M., Zapf, D. (1994). Action as the core of work psychology. In. H. C. Triandis, M. D. Dunnette, M. D., \& L. M. Hough (Ed.). Handbook of industrial and organizational psychology (pp.271-340). Palo Alto, CA: Consulting Psychologists Press.

Frost, P. J.; Moore, L. F.; Louis, M. R.; Lundberg, C. C. \& Martin, J. (1991). Reframing organizational culture. London: Sage. 
Fuller, A., Munro, A., \& Rainbird, H. (2004). Introduction and overview. In: H. Rainbird, A. Fuller, \& A. Munro (Eds.). Workplace learning in context (pp. 1-19). London: Routledge. $\mathbf{G}$

Gagné, R. M., Briggs, L. J., \& Wager, W. W. (1988). Principles of instructional design. Orlando, Flórida: Holt, Rinehart and Winston.

Galinkin, A. L. \& Zauli, A. (2011). Identidade Social e Alteridade. In: C. V. Torres \& E. R. Neiva (Orgs.). Psicologia social: principais temas e vertentes. Porto Alegre: Artmed.

Galvão, A. (2009). Os muros (in)visíveis do preconceito: um estudo das representações socias das pessoas que vivem com HIV/AIDS. Dissertação de Mestrado. Universidade de Brasília, Brasília.

Ghantous, N. (2010). Interaction client-personnel et marque-enseigne de services - Impact de l'intensité de l'interaction sur les effets dynamisants de la marque-enseigne. Thèse de Doctorat en Sciences de Gestion. Université Paul Cézanne, Aix-Marseille 3.

García-Zamora, E. González-Bento, O., \& Muñoz-Gallego, P. (2013). Organizational and environmental factors as moderators of the relationship between multidimensional innovation and performance. Innovation: Management, Policy \& Practice, 15(2), 224244. doi: 10.5172/impp.2013.15.2.224.

Gava, R., \& Silveira, T. (2007). A Orientação para o mercado sob a ótica da empresa e dos clientes na indústria hoteleira gaúcha. Revista de Administração Contemporânea, 11(2), 49-69. doi. 10.1590/S1415-65552007000200004.

Gebauer, H., Edvardsson, B., Bjurko, M., (2010). The impact of service orientation in corporate culture on business performance in manufacturing companies. Journal of Service Management, 21(2), 1-43. doi. 10.1108/09564231011039303.

Geertz, C. (1973). The interpretation of cultures. New York: Basic Books.

Geertz, C. (1989). A interpretação das culturas. Rio de Janeiro: LTC.

Geertz, C. (2009). O saber local. Petrópolis: Vozes.

Gelfand, M. J., Erez, M. \& Aycan, Z. (2007). Cross-Cultural Organizational Behavior. Annual Review of Psychology, 58, 479-514. doi. 0.1146/annurev.psych.58.110405.085559.

George, E., \& Chattopadhyay, P. (2005). One foot in each camp: The dual identification of contract workers. Administrative Science Quarterly, 50(1), 68-99. doi. 10.2189/asqu.2005.50.1.68. 
Gerhart, B., Wright, P. M., McMahan, G. C., \& Snell, S. A. (2000). Measurement error in research on human resources and firm performance: how much error is there and how does it influence effect size estimates?. Personnel Psychology, 53, 803-834. doi. 10.1111/j.1744-6570.2000.tb02418.x.

Ghorpade, J., \& Chen, M. M. (1995). Creating quality-driven performance appraisal systems. Academy of Management Executive, 9, 32-40.

Gilbert, T. (1978). Human competence: engineering worthy performance. New York: McGraw-Hill Book Company.

Gillespie, M. A., Denison, D. R., Haaland, S., Smerek, R., \& Neale, W. S. (2008). Linking organizational culture and customer satisfaction: results from two companies in different industries. European Journal of Work and Organanization Psychology, 17(1), 112-132. doi. 10.1080/13594320701560820.

Gioia, D. A. (1988). From individual to organizational identity. In A. D. Whetten, \& P. C. Godfrey (Eds.). Identity in organizations. Building theory through conversations. Sage Publications, USA, pp. 17-31.

Gioia, D. A., \& Thomas, J.B. (1996). Identity, image, and issue interpretation: Sensemaking during strategic change in academia. Administrative Science Quarterly, 41, 370-403.

Gioia, D. A.; Shultz; M. \& Corley, K. G. (2000). Organizational identity, image, and adaptive instability. Academy of Management Review, 25(1), 63-81.

Glisson, C., Schoenwald, S. K., Kelleher, K., Landsverk, J., Hoagwood, K. E., MAYBERG, S., \& GREEN, P. (2008). Therapist turnover and new program sustainability inmental health clinics as a function of organizational culture, climate, and service structure. Administration and Policy in Mental Health and Mental Health Services Research, 35(12), 124-33. doi. 10.1007/s10488-007-0152-9.

Godard, J. (2001). Hight performance and the transformation of work? The implication of alternative work pratices for the experience and outcomes of work. Industrial and Labor Relations Review, 54, 776-805.

Goergen, P. (2005). Educação e valores no mundo contemporâneo. Educação \& Sociedade, 26(92), 983-1011.

Goffman, E. (1959). The presentation of self in everyday life. London: Penguin Books.

Goffman, E. (2011). A representação do eu na vida cotidiana. Petrópolis: Vozes. 
Gomes, A. D. (1990). Cultura organizacional - A organização comunicante e a gestão da sua identidade. Tese de doutoramento não publicada, Faculdade de Psicologia e de Ciências da Educação da Universidade de Coimbra.

Gomes, A. D. (2000). Cultura organizacional: Comunicação e identidade. Coimbra: Quarteto Editora.

Gondim, S. M. G., Melo, L. C. T., Rodrigues, A. C. A., \& Barbosa, L. D. F. (2003). Práticas de inovação e habilidades profissionais: os trabalhadores estão preparados para a mudança organizacional? Trabalho apresentado no $27^{\circ}$ Encontro da Associação Nacional de Pós-Graduação e Pesquisa em Administração - EnANPAD. Atibaia (SP): ANPAD.

Gondim. S. M. G., \& Siqueira, M. M. M. (2004). Emoções e afeitos no trabalho. Em J.C. Zanelli, J. E. Borges-Andrade, \& A. V. B. Bastos (Orgs.), Psicologia, organizações e trabalho no Brasil (pp. 207-236). Porto Alegre: Artmed.

Gondim. S. M. G., Puente-Palácios, K. E., \& Borges-Andrade, J. E. (2011). Performance and Learning in Virtual Work Teams: Comparing Brazilians and Argentineans. Revista de Psicología del Trabajo y de las Organizaciones, 27(1), 31-41. doi.10.5093/tr2011v27n1a4.

Gonçalves, C. A., Dias, A. T., \& Muniz, R. M. (2008). Análise discriminante das relações entre fatores estratégicos, indústria e desempenho em organizaçıes brasileiras atuantes na indústria manufatureira. Revista de Administração Contemporânea, 12(2), 287-311. doi. 10.1590/S1415-65552008000200002.

Gonczi, A. (1999). Competency-based learning: a dubious past - an assured future? In: D. Boud \& J. Garrick (Orgs.). Understanding learning at work (pp. 180-194). Londres: Routledge.

Gonzáles Rey, F. (2009). O social na psicologia e a psicologia social: a mergência do sujeito. (V. L. Mello, Trad.) 2. ed., Petrópolis, RJ: Vozes.

Goris, J. R., Vaught, B. C., \& Petit Jr., J. D. (2000). Effects of communication direction on job performance and satisfaction: a moderated regression analysis. Journal of Business Communication, 37(4), 348-368. doi. 10.1177/002194360003700402.

Greatti, L., \& Previdelli, J. J. (2004). Perfis empreendedores: análise comparativa das trajetórias de sucesso e do fracasso empresarial no Município de Maringá (PR). Trabalho apresentado no $28^{\circ}$ Encontro da Associação Nacional de Pós-graduação em Administração. Curitiba: ANPAD. 
Gregory, B. T, Harris, S. G, Armenakis, A. A, \& Shook, C. L. (2009). Organizational culture and effectiveness: a study of values, attitudes, and organizational outcomes. Journal of Business Research, 62(7), 673-79. doi. 10.1016/j.jbusres.2008.05.021.

Griffim, M. A., Neal, A., \& Parker, S. K. (2007). A new model of work role performance. Positive behavior in uncertain and interdependent contexts. Academy of Management Journal, 50(2), 327-347. doi. 10.5465/AMJ.2007.24634438.

Grote, D. (2003). O Indicador de performance. Perguntas e respostas. Campus: Rio de Janeiro.

Grund, C., \& Nielsen, N.W. (2008). The dispersion of employees' wage increases and firm performance. International Labor Relation Review, 61(4), 485-501.

Guareschi, N. M. F., Medeiros, P. F., \& Bruschi, M. E. (2003). Psicologia Social e estudos culturais: Rompendo fronteiras na produção do conhecimento. In N. M. de F. Guareschi \& M. E. Bruschi (Eds.), Psicologia social nos estudos culturais: Perspectivas e desafios para uma nova Psicologia Social (pp. 2349). Petrópolis, RJ: Vozes.

Guarido Filho, E. R., Machado-da-silva, C., \& Gonçalves, S. A. (2010). Organizational institutionalism in the academic field in Brazil: social dynamics and networks. Revista de Administração Contemporânea, 14(n.spe), 149-172. doi. 10.1590/S180776922009000400003.

Gubbins, C., \& MacCurtain, S. (2008). Understanding the dynamics of collective learning: the role of trust and social capital. Advances in Developing Human Resources, 10(4), 578599. doi. 10.1177/1523422308320372.

Guerreiro Ramos, A. (1966). A Administração e contexto brasileiro. Rio de Janeiro: FGV.

Guimarães, T. A. (1998). Gestão do desempenho em organizações públicas descentralizadas. Em Anais do III Congresso Internacional do Clad. Madri: Clad.

Guimarães, T. A., Nader, R. M., \& Ramagem, S. P. (1998). Avaliação de desempenho de pessoal: uma metodologia integrada ao planejamento e avaliação organizacionais. Trabalho apresentado no $21^{\circ}$ Encontro Anual da Associação Nacional dos Programas de Pós Graduação em Administração (Enanpad), Rio das Pedras, Rio de Janeiro.

Guimarães, T. A., Borges-Andrade, J. E., Machado, M. S., \& Vargas, M. R. M. (2001). Forecasting core competencies in an R\&D environment. R\&D Management, 31(3), 249255. doi: 10.1111/1467-9310.00213.

Günther, H. (1981). Uma tentativa de traduzir e adaptar a escala de valores Rokeach para uso no Brasil. Arquivos Brasileiros de Psicologia, 33, 58-72. 
Gurin, P., \& Townsend, A. (1986). Properties of gender identity and their implications for gender consciousness. British Journal of Psychology, 25, 139-148. doi. 10.1111/j.20448309.1986.tb00712.x.

Gurin, P., \& Markus, H. (1989). The cognitive consequences of gender identity. In Skevington, S. \& D. Baker (Eds.). The Social Identity of Women. Beverly Hills, CA: Sage Publications.

Gregory, B. T., Harris, S. G., Armenakis, A. A., \& Shook, C. L. (2009). Organizational culture and effectiveness: a study of values, attitudes, and organizational outcomes. Journal of Business Research, 62(7), 673-79. doi. 10.1016/j.jbusres.2008.05.021.

Greta, H., \& Elsbach, K. D. (2013). Explaining variation in organizational identity categorization. Organization Science, 24, 996-1013. doi. 10.1287/orsc.1120.0779.

Griffin, M., Neal, A., \& Neale, M. (2000). The contribution of task performance and contextual performance to effectiveness: Investigating the role of situational constraints. Applied Psychology: An International Review, 49(3), 517-533. doi. 10.1111/14640597.00029

\section{H}

Haarr, R. N., \& Morash, M. (2013). The effect of rank on police women coping with discrimination and harassment. Police Quarterly, 16(4), 395-419. doi. $10.1177 / 1098611113489888$.

Hair, J. F., Black, W. C., Babin, B. J., Anderson, R. E., \& Tatham, R. L. (2009). Análise multivariada de dados. (A. S. Sant'Anna, Trad.). Porto Alegre: Bookman.

Hacman, J. R., \& Oldham, G. R. (1976). Motivation through the design of work: test of a theory. Organizational Behavior \& Human Decision Processes, 16(2), 250-279. doi. 10.1016/0030-5073(76)90016-7.

Hall, S. (2000). A identidade cultural na pós-modernidade. (T. T. Silva \& G. L. Louro, Trad.). Rio de Janeiro: DP\&A.

Hall, D. T., Schneider, B., \& Nygren, H. T. (1970). Personal factors in organizational identification. Administrative Science Quarterly, 15(2), 176-190. doi. 10.2307/2391488.

Hampden-Turner, C. \& Trompenaars, A. (1993). The seven cultures of capitalism. New York: Doubleday.

Hambrick, D. C. \& Mason, P. A. (1984). Upper echelons: The organization as a reflection of its top managers. Academy of Management Review, 9, 193-206. doi. 10.1016/j.jm.2004.06.001. 
Hanges, P. J., Schneider, B., \& Niles, K. (1990). Stability of performance: an interactionist perspective. Journal of Applied Psychology, 75, 658-667. doi. 10.1037/00219010.75.6.658.

Harman, H. H. (1967). Modern factor analysis. Chicago, University of Chicago Press.

Hartnell, C. A, Ou, A. Y, \& Kinicki, A. (2011). Organizational culture and organizational effectiveness: A meta-analytic investigation of the competing values framework's theoretical suppositions. Journal of Applied Psychology, 96(4), 677-94. doi. 10.1037/a0021987.

Haslam, S. A., \& Ellemers, N. (2005). Social identity in industrial and organizational psychology: Concepts, controversies and contributions. In G. P. Hodgkinson (Ed.), International review of industrial and organizational psychology (Vol. 20, pp. 39-118). Chichester, UK: Wiley.

Hatch, M. J. (1993). The dynamics of organizational culture. Academy of Management Review, 18, 657-693. doi:10.5465/AMR.1993.9402210154.

Hatch, M. J., \& Schultz, M. (1997). Relation between organizational culture, identity and image. European Journal of Marketing, 31(5/6), 356-365.

Hatch, M. J., \& Schultz, M. (2002). The dynamics of organizational identity. Human Relations, 55, 989-1018. doi:10.1177/0018726702055008181.

Hayton, J. C., Allen, D. G., \& Scarpello, V. (2004). Factor retention decisions in exploratory factor analysis: A tutorial on parallel analysis. Organizational Research Methods, 7(2), 191-207. doi: 10.1177/1094428104263675.

He, H., \& Baruch, Y. (2009). Transforming organizational identity under institutional change. Journal of Organizational Change Management, 28(6), 575-599. doi. 10.1108/09534810910997014.

He, H., \& Baruch, Y. (2010). Organizational identity and legitimacy under major environmental changes: Tales of two UK building societies. British Journal of Management, 21, 44-62. doi. 10.1111/j.1467-8551.2009.00666.x.

He, H., \& Brown, A. D. (2013). Organizational identity and organizational identification: A review of the literature and suggestions for future research. Group and Organization Management, 38(1), 3-35.doi. 10.1177/1059601112473815.

Heene, A., \& Sanchez, R. (1997). Competence based strategic management. Chichester, England: John Wiley\& Sons Ltd. 
Heider, F. (1958). The psychology of interpersonal relations. New York: John Wiley \& Sons.

Helmreich, R. L. \& Schaefer, H. G. (1994). Team performance in the operating room. In: Bogner (ed.) Human Error in Medicine. New Jersey: Lawrence Erlbaum.

Hernandez-Nieto, R. (2002). Contributions to statistical analysis. Mérida, España: Los Andes University Press.

Herskovits M. J. (1955). Cultural anthropology. New York: Knopf.

Hertel, G., Konradt, U., \& Voss, K. (2006). Competencies for virtual teamwork: development and validation of a web-based selection tool form members of distributed teams. European Journal of Work and Organizational Psychology, 15(4), 477-504. doi. $10.1080 / 13594320600908187$.

Hesketh, B., \& Neal, A. (1999). Technology and performance. In. D. R. Ilgen \& E. D. Pulakos, E. D. (Ed.). The changing nature of performance (pp. 21-55). San Francisco: Jossey-Bass.

Hildebrand, D. F. N. (2007). A identificação do consumidor com a empresa: Desenvolvimento de uma escala. Dissertação de Mestrado. Universidade Federal do Rio Grande do Sul, Porto Alegre.

Hinkle, S., Taylor, L., Fox-Cardamone, D., \& Crook, K. (1989). Intragroup identification and intergroup differentiation: A multicomponent approach. British Journal of Social Psychology, 28, 305-317. doi. 10.1111/j.2044-8309.1989.tb00874.x.

Hirst, G., van Dick, R., \& van Knippenberg, D. (2009). A social identity perspective on leadership and employee creativity. Journal of Organizational Behavior, 30(7), 963-982. doi. 10.1002/job.600.

Hodgkinson G. P. (2002). Comparing managers' mental models of competition: why selfreport measures of belief similarity won't do. Organizational Studies, 23, 63 -72.

Hofstede, G. (1980). Cultures's consequences: International differences in work-related values. Beverly Hills: Sage.

Hofstede, G. (1983). The cultural relativity of organizational practices and theories. Journal of International Bussiness Studies, Fall, 75-90.

Hofstede, G. (1986). The usefulness of the organizational culture concept. Journal of Management Studies, 23 (3), 253-257.

Hofstede, G. (1991). Cultures and organizations: Software of the mind. London: McGrawHill. 
Hofstede, G. (1994). Business cultures: Every organization has its symbols, rituals and heroes. UNESCO Courier, April, 12-16.

Hofstede, G. (1998a). Identifying subcultures: A empirical approach. Journal of Management Studies, 35 (1), 1-12. doi. 10.1111/1467-6486.00081.

Hofstede, G. (1998b). Attitudes, values and organizational culture: Disentangling the concepts. Organization Studies, 19(3), 477-492. doi. 10.1177/017084069801900305

Hofstede, G. (2001). Cultures's consequences: Comparing values, behaviors, institutions, and organizations across nations . London: Sage.

Hofstede, G. (2003). Culturas e organizações. Compreender a nossa programação mental. Lisboa: Edições Sílabo LDA. (Trabalho original publicado em 1991).

Hofstede, G. (2005). Cultures and organizations: Software of the mind. London: McGrawHill.

Hofstede, G. H., Neuijen, B., Ohavy, D., \& Sanders, G. (1990). Measuring organizational cultures: a qualitative and quantitative study across twenty cases. Administrative Science Quarterly, 35(2), 286-316.

Hogg, M. A., \& Abrams, D. (1988). Social identifications: A social psychology of intergroup relations and group processes. London: Routledge.

Hogg, M. A., \& Terry, D. J. (2000). Social identity and self-categorization processes in organizational contexts. Academy of Management Review, 25(1), 121-140. doi. 10.5465/AMR.2000.2791606.

Holton, E. F. III, Yamkovenko, B. (2008). Strategic intellectual capital development: A defining paradigm for HRD?. Human Resource Development Review, 7(3), 270-291.doi: $10.1177 / 1534484308321360$.

Homburg, C., Wieseke, J., \& Hoyer, W. D. (2009). Social identity and the service-profit chain. Journal of Marketing, 73(2), 38-54. doi. 10.1509/jmkg.73.2.38.

Houaiss, A. (2001). Dicionário de Língua Portuguesa. Objetiva: Rio de Janeiro.

House, J. S. (1977). The three faces of social psychology. Sociometry, 40, 161-177.

House, R. J., Hanges, P. J., Javidan, M., Dorfman, P., \& Gupta, V. (Eds.). (2004). Culture, leadership, and organizations: The GLOBE study of 62 societies. Sage, Newbury Park CA.

Howard, J. A. (2000). Social psychology of identities. Annual Review of Sociology, 26, 367393. doi. 10.1146/annurev.soc.26.1.367. 
Hu, L., \& Bentler, P. M. (1999). Cutoff criteria of fit indexes in covariance structure analysis: conventional criteria versus new alternatives, Structural Equation Modeling, 6(1), 1-55.

Humphreys, M., \& Brown, A. D. (2002). Narratives of organizational identity and identification: A case study of hegemony and resistance. Organization Studies, 23(3), 421-447. doi. 1177/0170840602233005.

\section{I}

Iacobucci, D. (2010). Structural equations modeling: fit indices, sample size and advanced topics. Journal of Consumer Psychology, 20(1), 90-98. doi. 10.1016/j.jcps.2009.09.003.

Ibarra, H. (1999). Provisional selves: Experimenting with image and identity in professional adaptation. Administrative Science Quarterly, 44, 764-791. doi. 10.2307/2667055.

Ibarra, H., \& Barbulescu, R. (2010). Identity as narrative: Prevalence, effectiveness, and consequences of narrative identity work in macro work role transitions. Academy of Management Journal, 35, 135-154. doi. 10.5465/AMR.2010.45577925.

Ienaga, C. H. (1998). Competence based management. São Paulo: Dextron Consultoria Empresarial.

Isambert-Jamati, V. (1997). O apelo à noção de competência na revista L'orientation scolaire et profissionelle: da sua criação aos dias de hoje. In F. Ropé, \& L. Tanguy (Orgs.), Saberes e competências: o uso de tais noções na escola e na empresa (pp. 103-134). Campinas: Papirus.

\section{$\mathbf{J}$}

Jacobs. R., Mannion, R. Davies, H. T. O., Harrison, S., Konteh, F., \& Walshe, K. (2013). The relationship between organizational culture and performance in acute hospitals. Social Sciense \& Medicine. 76, 115-125. doi. 10.1016/j.socscimed.2012.10.014.

Jacques, M. G. C. (1998). Identidade. In: M. N. Strey et al. Psicologia social contemporânea (pp. 159-167), Petrópolis: Vozes.

Jarvis, C., MacKenzie, S., \& Podsakoff, P. A. (2003). A critical review of construct indicators and measurement model misspecification in marketing research. Journal of Consumer Research, 30(2), 199-218. doi. 10.1086/376806.

Jones, S. E., Buerkle, M., Hall, A., Rupp, I., \& Matt, G. (1993). Work group performance measurement and feedback: An integrated comprehensive system for a manufacturing department. Group and Organization Management, 18, 269-291. doi. 10.1177/1059601193183002. 
Jöreskog, K. G. (1971). Statistical analysis of sets of congeneric tests. Psychometrika, 36(4), 109-133.

Jourden, F. J., \& Heath, C. (1996). The evaluation gap in performance perceptions: illusory perceptions of groups and individuals. Journal of Applied Psychology, 81(4), 369-379.

Judge, T. A., Heller, D., \& Mount, M. K. (2002). Five-factor model of personality and job satisfaction: A meta-analysis. Journal of Applied Psychology, 87, 530-541.

$\mathbf{K}$

Kabanoff, B. \& Daly, J. P. (2000). Values espoused by Australian and US organisations. Applied Psychology: An International Review, 49(2), 284-314. doi. 10.1111/14640597.00015 .

Kabanoff, B. \& Daly, J. P. (2002). Espoused values of organizations. Australian Journal of Management, 27, 89-104. doi. 10.2307/256621.

Kabanoff, B., Waldersee, R. \& Cohen, M. (1995). Espoused values and organizational change themes. Academy of Management Journal, 38, 1075-1104. doi. 10.2307/256621.

Kabanoff, B. (1994). An exploration of espoused culture in Australian organizations (with a closer look at the banking sector). Asian Pacific Journal of Human Resources, 31, 1-29. doi. $10.1177 / 103841119403100301$.

Kabanoff, B. \& Daly, J. P. (2000). Values espoused by Australian and US organisations. Applied Psychology: An International Review, 49(2), 284-3.14. doi. 10.1111/14640597.00015 .

Kabanoff, B., Waldersee, R., \& Cohen, M. (1995). Espoused values and organizational change themes. Academy of Management Journal, 38, 1075-1104. doi. 10.2307/256621.

Kaiser, H. F. (1960). The application of electronic computers to factor analysis. Educational and Psychological Measurement, 20(1), 141-151.

Kalliath, T., Bluerdorn, A., \& Gillespie, D. (1999). A confirmatory factor analysis of the competing values instrument. Educational and Psychological Measurement, 59(1), 143158. doi. 10.1177/0013164499591010.

Kant, I. (2002) Crítica da Razão Prática. São Paulo: Martins Fontes.

Kaplan, R. S. (2012). The balanced scorecard: comments on balanced scorecard commentaries. Journal of Accounting \& Organizational Change, 8(4), 539-545. doi. 10.1108/18325911211273527.

Kaplan, R. S., \& Norton, D. P. (1994). A estratégia em ação. Campus: Rio de Janeiro. 
Karahanna, E., Evaristo, J. R., \& Srite, M. (2005). Levels of culture and individual behavior: An integrative perspective. Journal of Global Information Management, 13, 1-20. doi. 10.4018/978-1-59140-923-6.ch002.

Kärreman, D., \& Alvesson, M. (2004). Cages in tandem: management control, social Identity, and identification in a Knowledge-intensive firm. Organization, 11(1), 149-175. doi. 10.1177/1350508404039662.

Katz, D., \& Kahn, R. L. (1978). Psicologia social das organizações. São Paulo: Atlas.

Kahya, E. (2008). The effects of job performance on effectiveness. International Journal of Industrial Ergonomics, 39 (1), 96-104. doi. 10.1016/j.ergon.2008.06.006.

Keller, R. T. (1997). Job involvement and organizational commitment as longitudinal predictors of job performance: a study of scientists and engineers. Journal of Applied Psychology, 82(4), 539-545. doi. 10.1037/0021-9010.82.4.539.

Kelly, C. (1988). Intergroup differentiation in a political context. British Journal of Social Psychology, 27, 319-332.

Kernis, M. H., \& Goldman, B. M. (2006). A multicomponent conceptualization of authenticity: Theory and research. Advances in Experimental Social Psychology, 38, 283357. doi. 10.1016/S0065-2601(06)38006-9.

Kira, M., \& Balkin, D. B. (2014). Interactions between work and identities: thriving, withering, or redefining the self?. Human Resource Management Review, 24(2), 131-143. doi. 10.1016/j.hrmr.2013.10.001.

Klem, L. (2002). Structural equation modeling. Em L. G. Grimm \& P. R. Yarnold (Orgs.), Reading and understanding more multivariate statistics (pp. 227-260). Washington: American Psychological Association.

Kline, R. B. (2010). Principles and practice of structural equation modeling (3 ed.), The Guilford Press, New York.

Kluckhohn, C. (1951). Values and value-orientations in the theory of action: An exploration in definition and classification. In T. Parsons \& E. Shils (Orgs.), Toward a general theory of action (pp. 469-506). Cambridge: Harvard University Press.

Kluckhohn, C. (1954). Culture and behavior. In Handbook of Social Psychology, ed. G. Lindzey, vol. 2, pp. 931-76. Cambridge, MA: Addison-Wesley.

Kluckhohn, C. (1962). Universal categories of culture. In S. Tax (Ed.), Anthropology today. Chicago: University of Chicago Press. 
Kogut, B., \& Zander, U. (1993). Knowledge of the firm and the evolutionary theory of multinational corporation. Journal of International Business Studies, 24(4), 625-645. doi. 10.1057/palgrave.jibs.8400058.

Kostova, T. (1996). Success of transnational transfer of organizational practices within multinational companies . Tese de Doutorado, Universidade de Minnesota. Disponível em http://proquest.umi.com/pqdweb?index $=0 \&$ did=739308861. Acesso em 05 de março de 2012.

Kostova, T. (1999). Transnational transfer of strategic organizational pratices: A contextual perspective. The Academy of Management Review, 24(2), 308-324. doi. 10.5465/AMR.1999.1893938.

Kotrba, L. M., Gillespie, M. A., Schmidt, A. M., Smerek, R. E., Ritchie, S. A., \& Denison, D. R. (2012). Do consistent corporate cultures have better business performance? Exploring the interaction effects. Human Relations. 65(2), 241-62. doi. 10.1177/0018726711426352.

Krawulski, E. (1998). A orientação profissional e o significado do trabalho. Revista da Associação Brasileira de Orientadores Profissionais, 2(1), 5-19.

Kroeber, A. \& Kluckhohn, C. (1963). Culture: A critical review of concepts and definitions. New York: Vintage Books.

Kroeber, A. L. \& Parsons, T. (1958). The concept of culture on social systems. American Sociological Review, 23, 582-583.

Kruskal, J. B. (1964). Nonmetric multidimensional scaling: a numerical method. Psychometrika. 29, 115-129.

Kull, T., \& Narasimhan, R. (2010). Quality management and cultural values: Investigation of multi-level influences on workgroup performance. Decision Sciences, 41(1), 81-113. doi. 10.1111/j.1540-5915.2009.00260.x.

Kwantes, C. T., \& Boglarsky, C. A. (2007). Perceptions of organizational culture, leadership effectiveness, and personal effectiveness across six countries. Journal of International Management, 13, 204-213. doi. 10.1016/j.intman.2007.03.002.

$\mathbf{L}$

Laing, R. D. (1961). The social and the others. Londres: Tavistock.

Laing, R. D. (1986). O Eu e os Outros: Relacionamento interpessoal. Petrópolis: Vozes. 
Lam, S. S. K., \& Schaubroek, J. (1999). Total quality management and performance appraisal: An experimental study of process versus results and group versus individual approaches. Journal of Organizational Behavior, 20, 445-457. doi. 10.1002/(SICI)10991379(199907)20:4<445::AID-JOB938>3.0.CO;2-J.

Landis, J. R., \& Koch, G. G. (1977). The measurement of observer agreement for categorical data. Biometrics, 33(1), 159-174.

Laros, J. A. (2012). O uso da Análise Fatorial: Algumas diretrizes para pesquisadores. In: Luiz Pasquali. (Ed.). Análise Fatorial para pesquisadores. 1ed. Brasília: LabPAM Editora, 2012, v. 1, p. 141-160.

Laurenti, C. \& Barros, M. N. F. (2000). Identidade: questões conceituais e contextuais. PSI. Revista de Psicologia Social e Institucional. 2(1), 37-65.

Levenson, Alec R., Van der Stede, W. A., \& Cohen, S. G. (2006). Measuring the relationship between managerial competencies and performance. Journal of Management, 32 (3), 360380. doi. 10.1177/0149206305280789.

Le Boterf, G. (1999). Competénce et navigation profissionnelle. Paris: Éditions d'Organisation.

Lee, S. K. J., \& Yu, K. (2004). Corporate culture and organizational performance. Journal of Managerial Psychology, 19(4), 340-59. doi. 10.1108/02683940410537927.

Leite, J. B. D., \& Porsse, M. C. S. (2003). Competição baseada em competências e aprendizagem organizacional: em busca da vantagem competitiva. Revista de Administração Contemporânea, 7 (Edição Especial), 121-144. doi. 10.1590/S141565552003000500007.

Levi-Strauss, C. (1949). Les structures élémentaires de la parenté. Paris-Haia: Mouton \& Co.

Levin, I. M. (2000) Five windows into orgnization culture: an assessment framework and approach. Organization Development Journal, 18(1), 83-94.

Lewin, K. (1942). Field theory and learning. In Cartwright D. (Ed.), Field theory in social science, pp. 60-86. New York: Harper \& Row.

Li, S. K., \& Jones, G. (2010). A study of the effect of functional subcultures on the performance of Hong Kong construction companies. Systematic Practice and Action Research, 23(6), 509-528. doi. 10.1007/s11213-010-9170-8.

Liedtka, J. M. (1989). Value congruence: The interplay of individual and organizational value systems. Journal of Business Ethics, 8, 805-815. 
Lipponen, J., Bardi, A., \& Haapamäki, J. (2008). The interaction between values and organizational identification in predicting suggestion-making at work. Journal of Occupational and Organizational Psychology, 81(2), 241-248. doi: 10.1348/096317907X216658.

Londom, M., \& Mone, E. M. (1999). Continuous learning. In. D. R. Ilgen \& E. D. Pulakos (Ed.). The changing nature of performance (pp. 119-153). San Francisco: Jossey-Bass.

Lucena, M. D. S. (1992). Avaliação de Desempenho. São Paulo: Atlas.

Luhtanen, R., \& Crocker, J. (1992). A collective self-esteem scale: Self-evaluation of one's social identity. Personality and Social Psychology Bulletin, 18, 302-318. doi. 10.1177/0146167292183006.

\section{M}

MacCallum, R. C. (1986). Specification searches in covariance structure modeling. Psychological Bulletin, 100(1), 107-120. doi. 10.1037/0033-2909.100.1.107.

MacCallum, R. C., Roznowski, M. \& Necowitz, L. B. (1992). Model modifications in covariance structure analysis: the problem of capitalization on chance. Psychological Bulletin, 111(3), 490-504.

Macedo, R. B. (2007). Modelo de avaliação de impacto da aprendizagem no nível de resultados organizacionais: preditores relacionados ao indivíduo e ao contexto organizacional. Tese de Doutorado não publicada, Instituto de Psicologia, Universidade de Brasília, Brasília.

Machado, H. V. (2003). A identidade e o contexto organizacional: Perspectivas de análise. Revista de Administração Contemporânea. 7(spe), 51-73.

MacKinnon, D. P., Lockwood, C. M., Hoffman, J. M., West, S. G., \& Sheets, V. (2002). A comparison of methods to test mediation and other intervening variable effects. Psychological Methods, 7, 83-104.

MacKinnon, D., Lockwood, C., \& Williams, J. (2004). Confidence limits for the indirect effect: distribution of the product and resampling methods. Multivariate Behavioral Research, 39(1), 99-128. doi: 10.1207/s15327906mbr3901_4.

MacKinnon, D. P., Fairchild, A. J., \& Fritz, M. S. (2007). Mediation analysis. Annual Review of Psychology, 58, 593-614. doi. 10.1146/annurev.psych.58.110405.085542.

Madjar, N., Greenberg, E., \& Chen, Z. (2011). Factors for radical creativity, incremental creativity, and routine, noncreative performance. Journal of Applied Psychology, 96(4), 730-743. doi. 10.1037/a0022416. 
Mael, F. A. (1988). Organizational identification: construct redefinition and a field application with organizational alumni. Doctoral Thesis, Wayne State University, Detroit, MI, USA.

Mael, F. A., \& Ashforth, B. E. (1992). Alumni and their alma mater: a partial test of the reformulated model of organizational identification. Journal of Organizational Behavior. 13(2), 103-123. doi. 10.1002/job.4030130202.

Maffesoli, M. (2000). O tempo das tribos: o declínio do individualismo nas sociedades de massa. 3a ed. Rio de Janeiro: Forense.

Mair, J. (2005). Exploring the determinants of unit performance: The role of middle managers in stimulating profit growth. Group \& Organization Management, 30(3), 263288. doi. doi: 10.1177/1059601104269113.

Mallak, L. (2001). Understanding and changing your organization's culture. Industrial Management, 43(2), 18-24.

Malhotra, N. K., Sung K.S., \& Ashutosh, P. (2006). Common method variance in IS research: a comparison of alternative approaches and a reanalysis of past research. Management Science, 52(12), 1865-1883. doi. 10.1287/mnsc.1060.0597.

Manning, L. M., \& Barrette, J. (2005). Research performance management in academe. Canadian Journal of Administrative Sciences, 22(4), 273-287. doi. 10.1111/j.19364490.2005.tb00374.x.

Marôco, J. (2010). Análise de equações estruturais: fundamentos teóricos, software e aplicações. Pero Pinheiro: Report Number.

Marôco, J. (2011). Análise estatística com o SPSS Statistics. 5a. Ed. Pero Pinheiro: ReportNumber.

Martins, F. R. (2013). Identidade e estudos organizacionais: em direção a um novo paradigma?. Revista Eletrônica de Gestão Organizacional, 11(1), 62-82.

Martin, J. (2002). Organizational culture: Mapping the terrain. Thousand Oaks, CA: Sage.

Martin, J. \& Frost, P. J. (2002). Organizational culture: Beyond struggles for intellectual dominance. In: R. C. Clegg, C. Hardy \& W. Nord (Orgs.). Handbook of organization studies. (pp. 725-753). London: Sage.

Martins, M. C. F., \& Santos, G. E. (2007). Adaptação e validação de construto da Escala de Satisfação no Trabalho. PsicoUSF, 11(2), 195-205. doi. 10.1590/S141382712006000200008 . 
Martin-Baró, I. (1985). Acción e Ideologia: psicologia social de centroamérica. San Salvador: UCA Editores.

Mathew, J., Ogbonna, E., \& Harris, L. C. (2011). Culture, employee work outcomes and performance: An empirical analysis of Indian software firms. Journal of World Business, 47(2), 194-203. doi. 10.1016/j.jwb.2011.04.006.

Mathur, P., Aycan, Z. \& Kanungo, R. N. (1996). Indian organizational culture: A comparison between public and private sectors. Psychology and Developing Societies, 8, 199-222.

Maslow, A. H. (1959). New knowledge in human values. New York: Harper \& Row.

Maslow, A. (1987). Motivation and personality. Harper \& Row, New York.

MacCallum, R. C. (1986). Specification searches in covariance structure modeling. Psychological Bulletin, 100, 107-120. doi. 10.1037/0033-2909.100.1.107.

McClelland, D. (1973). Testing for competence rather than intelligence. American Psychologist, 28 (1), 01-14.

McCloy, R. A., Campbell, J. P., \& Cudeck, R. (1994). A confirmatory test of a model of performance determinants. Journal of Applied Psychology, 79, 493-505. doi. 10.1037/0021-9010.79.4.493.

McIntosh, C. N. (2007). Rethinking fit assessment in structural equation modelling: A commentary and elaboration on Barrett (2007). Personality and Individual Differences. 42(5), 859-867. doi. 10.1016/j.paid.2006.09.020.

McLagan, P. A. (1997). Competencies: the next generation. Training \& Development, 51 (5), 40-47.

McMillan, A., Chen, H., Richard, O. C., \& Bhuian, S. N. (2012). A mediation model of task conflict in vertical dyads: Linking organizational culture, subordinate values, and subordinate outcomes. International Journal of Conflict Management, 23(3), 307-332. doi. 10.1108/10444061211248994.

McNeely, B. L., \& Meglino, B. M. (1994). The role of dispositional and situational antecedents in prosocial organizational behavior: An examination of the intended beneficiaries of prosocial behavior. Journal of Applied Psychology, 79, 836-844. doi. 10.1037/0021-9010.79.6.836.

Mead, G. H. (1909). Social psychology as counterpart to psichological psychology. The Psychological Bulletin, 1, p. 401-408.

Mead, G. H. (1910). What social objects must psychology presuppose? In: Reck, A. J. (Org.). Selected writings of George Hebert Mead. Chicago: University of Chicago Press. 
Mead, G. H. (1934). Mind, self and society: from the standpoint of a social behaviorist. Chicago: University of Chicago Press.

Mead, G. H. (1937). Co-operation and competition among primitive people. London: McGraw-Hill Publishing Co.

Mead, G. H. (1964). The mechanism of social consciousness. In: Reck, A. J. (orgs.). Selected writings of George Herbert Mead. Chicago: University of Chicago Press.

Melo, C. M. C. (2008). Equipes de trabalho e o alto desempenho. TRabalho apresentado no III Congresso Brasileiro de Psicologia Organizacional e do Trabalho, Florianópolis, Santa Catarina.

Menard, S. (1995). Applied logistic regression analysis: Sage University Series on Quantitative Applications in the Social Sciences. Thousand Oaks, CA: Sage.

Ménard, J., \& Brunet, L. (2011). Authenticity and well-being in the workplace: A mediation model. Journal of Managerial Psychology, 26, 331-346. doi. $10.1108 / 02683941111124854$.

Mendonça, H. \& Tamayo, A. (2008). Valores pessoais e retaliação organizacional: Estudo em uma organização pública. RAC-Eletrônica, 2 (2), 189-200.

Mendes, A. M., \& Tamayo, A. (2001). Valores organizacionais e prazer-sofrimento no trabalho. Psico-USF, 6(1), 39-46.

Messick, S. (1995). Validity of psychological assessment. Validation of inferences from person's responses and performances as scientific inquiry into score meaning. American Psychologist, 50(9), 741-749.

Meyer, J. P., Stanley, D. J., Herscovitch, L., \& Topolnyutsky, L. (2002). Affective, continuance, and normative commitment to the organization: A meta-analysis of antecedents, correlates, and consequences. Journal of Vocational Behavior, 6(1), 2052.doi. 10.1006/jvbe.2001.1842.

Meyerson, D. \& Martin, J. (1987). Cultural change: An integration of three different views. Journal of Management Studies. 24 (6), 623-647.

Mezias, J. M., \& Starbuck, W. H. (2003). Studying the accuracy of managers’ perceptions: a research Odyssey. British Journal of Management, 14(1), 3-17. doi. 10.1111/14678551.00259 .

Michael, J. H., Leschinsky, R., \& Gagnon, M. A. (2006). Production employee performance at a furniture manufacturer: the importance of supportive supervisors. Forest Products Journal, 56(6), 19-24. 
Millward, L. J. (1995). Contextualising social identity in considerations of what it means to be a nurse. European Journal of Social Psychology, 25, 303-324. doi:10.1002/ejsp.2420250305.

Millward, L. J., \& Haslam, S. A. (2013). Who are we made to think we are? Contextual variation in organizational, workgroup and career foci of identification. Journal of Occupational and Organizational Psychology 86(1), 50-66. doi. 10.1111/j.20448325.2012.02065.x.

Millward, L. J., \& Postmes, T. (2010). Who we are affects how we do: The financial benefits of organizational identification. British Journal of Management, 21, 327-379. doi:10.1111/j.1467-8551.2009.00667.x.

Mitchell, R., Parker, V., \& Giles, M. (2011). When do interprofessional teams succeed? Investigating the moderating roles of team and professional identity in interprofessional effectiveness. Human Relations, 64(10), 1321-1343. doi. 10.1177/0018726711416872.

Mohr, A. T., \& Puck, J. F. (2007). Role conflict, general manager job satisfaction and stress and the performance of IJVs. European Management Journal, 25(1), 25-35. doi. 10.1016/j.emj.2006.11.003.

Morgeson, F. P., \& Humphrey, S. E. (2006). The work design questionnaire (WDQ): Developing and validating a comprehensive measure for assessing job design and the nature of work. Journal of Applied Psychology, 91, 1321-1339. doi. 10.1037/00219010.91.6.1321.

Morris, C. W. (2010). Mente, self e sociedade. (Mourão, M. S., Trad.). Aparecida, SP: Ideias \& Letras.

Motowidlo, S. J., Borman, W. C., \& Schmit, M. J. (1997). A theory of individual differences in task and contextual performance. Human Performance, 10, 71-83. doi. 10.1207/s15327043hup1002_1.

Mulaik, S. A. (2007). There is a place for approximate fit in structural equation modelling. Personality and Individual Differences. 42(5), 883-891. doi. 10.1016/j.paid.2006.09.022.

Mulder, M., Lans, T., Verstegen, J., Biemans, H., \& Meijer, Y. (2007). Competence development of entrepreneurs in innovative horticulture. Journal of Workplace Learning, 19(1), 32-44. doi. 10.1108/13665620710719330.

Murphy, K. R. (1989a). Dimensions of job performance. In. R. Dillon \& J. Pelligrino (Ed.). Testing: Applied and theoretical perspectives (pp. 218-247). New York: Praeger. 
Murphy, K. R. (1989b). Is the relationship between cognitive ability and job performance stable over time? Human Performance, 2(3), 183-200. doi. 10.1207/s15327043hup0203_3.

Murphy, K. R. (1990). Job performance and productivity. In. K. R. Murphy \& F. E. Saal (Ed.). Psychology in organizations (pp. 157-176). Hillsdade: Lawrence Erlbaum.

Murphy, P. J., Cooke, R. A., \& Lopez, Y. (2013). Firm culture and performance: intensity's effects and limits. Management Decision, 51(3), 661-679. doi. 10.1108/00251741311309715.

Myers, R. (1990). Classical and modern regression with applications. Boston (MA): Duxburry.

\section{$\mathbf{N}$}

Nankervis, A. R., \& Compton, R. L. (2006). Performance management: theory in pratice? Asia Pacific Journal of Human Resources, 44(1), 83-101. doi. $10.1177 / 1038411106061509$.

Nascimento, D. A. (2012). Concepções de professores da Academia de Polícia Militar de Brasília acerca do aluno policial militar. Dissertação de Mestrado. Programa de Pósgraduação em Educação. Universidade de Brasília, Brasília.

Nascimento, D. A., \& Cerqueira, T. C. S. (no prelo). Concepções de professores da Academia de Polícia Militar de Brasília acerca do aluno policial militar. Educação e Pesquisa.

Nascimento, T. G. (2010). Polícia - Uma identidade em discussão: Construção, validação e aplicação de um instrumento. Dissertação de Mestrado. Programa de Pós-graduação em Psicologia Social, do Trabalho e das Organizações. Universidade de Brasília, Brasília.

Nascimento, T. G., Torres, C. V., \& Pimentel, C. E. (2011). Evidências de validade e precisão da escala de atitudes frente à polícia. Revista Brasileira de Segurança Pública, 9, 42-56.

Nascimento, T. G., Torres, C. V., Souza, E. C. L., Nascimento, D. A., \& Adaid-Castro, B. G. (2013). Identidade no trabalho e a influência de aspectos sociodemográficos: um estudo da diferença entre grupos de policiais militares do Distrito Federal. Revista Brasileira de Segurança Pública, 7, 90-117.

Nascimento, T. G. (2014). Entrevistas realizadas com policiais militares para o levantamento das práticas organizacionais. Manuscrito Não-publicado. Programa de Pósgraduação em Administração, Universidade de Brasília. 
Neiva, E. R., Abbad, G., \& Tróccoli, B. T. (2007). Roteiro para análise fatorial de dados. Manuscrito não-publicado, Instituto de Psicologia, Universidade de Brasília, DF.

Netto, F. S. (2007). Medição de desempenho organizacional: um estudo das vantagens e desvantagens dos principais sistemas sob as óticas teórico-acadêmica e de práticas demercado. Trabalho apresentado no $31^{\circ}$ Encontro Nacional de Programas de PósGraduação em Administração (Enanpad), Belo Horizonte.

Neumann, M., Machado, D. D. P. N., Souza, E. C. L., Neuwiem, A. L. F., Palmeira, E. D. S. (2012). Ambiente de inovação e cultura organizacional em uma organização hospitalar: suas manifestações por meio das práticas organizacionais. Gestão Contemporânea (FAPA), 1, 1-27.

Neves, J. (1996). Clima organizacional, cultura organizacional e gestão de recursos humanos: Portugal no contexto de outros países. Tese de Doutoramento não publicada, Instituto Superior de Ciências do Trabalho e da Empresa, Lisboa.

Neves, J. (2000). Clima organizacional, cultura organizacional e gestão de recursos humanos. Lisboa: Editora RH.

Nicolau, I., \& Musetescu, A. (2012). The Influence of Lifelong Programs on the Organizational Culture and Performance. Procedia - Social and Behavioral Sciences, 46, 1565-1569. doi. 10.1016/j.sbspro.2012.05.341.

Nisembaum, H. (2000). A competência essencial. São Paulo: Infinito.

Nishii, L. H., \& Mayer, D. (2009). Do inclusive leaders help to reduce turnover in diverse groups? The moderating role of leader-member exchange in the diversity to performance relationship. Journal of Applied Psychology, 94(6), 1412-1426. doi. 10.1037/a0017190.

Nohria, N., \& Ghoshal, S. (1994). Differentiated fit and shared values: alternatives for managing headquarters-subsidiary relations. Strategic Management Journal, 15, 491-502. doi. 10.1002/smj.4250150606.

Noriega, J. A. V., Carvajal, C. K. R., \& Grubits, S. (2009). La Psicología Social y el concepto de cultura. Psicologia \& Sociedade, 21(1), 100-107. doi. 10.1590/S010271822009000100012.

Nunnally, J. C. (1978). Psychometric theory (2 $2^{\text {nd }}$ ed.). New York: McGraw-Hill.

\section{$\mathbf{O}$}

Oakes, P. J. The salience of social categories. In J. C. Turner, M. A. Hogg, P. J. Oakes, S. D. Reicher, \& M. S. Wetherell (eds.), Rediscovering the social group: A self-categorization theory. Oxford and New York: Basil Blackwell. 
Oakes, P. J., Haslam, S. A., \& Turner, J. C. (1994). Stereotyping and social reality. Oxford: Blackwell.

Oakes, P. J., Turner, J. C., \& Haslam, S. A. (1991). Perceiving people as group members: The role of fit in the salience of social categorizations. British Journal of Social Psychology, 30, 125-144. doi:10.1111/j.2044-8309.1991.tb00930.x.

Obst, P. L., \& White, K. M. (2005). An exploration of the interplay between psychological sense of community, social identification and salience. Journal of Community and Applied Social Psychology, 15 (2), pp. 127-135. doi: 10.1002/casp.813

Obst, P., Zinkiewicz, L., \& Smith, S. (2002). Sense of community in science fiction fandom, Part 1: Understanding sense of community in an international community of interest. Journal of Community Psychology, 30(1), 87-103. doi. 10.1002/jcop.1052.

Ogaard, T. (2006). Do organizational practices matter for hotel industry employees' jobs? A study of organizational practice archetypical configurations and job outcomes. Hospitality Management, 25, 647-661. doi. 10.1016/j.ijhm.2005.06.003.

Oliveira, A. F. (2008). Identificação organizacional. In M. M. M. Siqueira (Ed.). Medidas do comportamento organizacional: ferramentas de diagnóstico e de gestão. (pp. 179-188). Porto alegre: Artmed.

Oliveira, J. S., Vieira, F. T., Oliveira, L. G. A., Vieira, R. A., \& Brixi, V. P. (2008). Análise do sistema de avaliação de desempenho de um Órgão público do poder judiciário. Trabalho apresentado no III Congresso Brasileiro de Psicologia Organizacional e do Trabalho, Florianópolis, Santa Catarina.

Oliveira-Castro, G. A (1994). Avaliação de desempenho em psicologia: questões conceituais e metodológicas. Psicologia: Teoria e Pesquisa, 10 (3), 355-374.

Oliveira-Castro, G. A., Lima, G. B. C., \& Veiga, M. R. M. (1996). Implantação de um sistema de avaliação de desempenho: métodos e estratégias. Revista de Administração da USP, 31(3), 38-52.

Oliveira, V. I.; Drummond, A. \& Rodrigues, S. B. (1999). Joint venture: aprendizagem tecnológica e gerencial. In: Rodrigues, S. B. (Org.). Competitividade, alianças estratégicas e gerência internacional. São Paulo: Atlas.

Oliveira, W.R., Martins, S., Oliveira; A.C.P., \& Pinto, T.R.G.S. (2012). Análise do processo de institucionalização do Balanced Scorecard no Instituto Nacional do Seguro Social. Anais do Congresso UFV de Administração e Contabilidade. 
Oliveira, O. J., Oliveira, A. B. \& Almeida, R. A. de. (2010). Gestão da segurança e saúde no trabalho em empresas produtoras de baterias automotivas: um estudo para identificar boas práticas. Produção, 20(3), 481-490. doi. 10.1590/S0103-65132010005000029.

Oliveira, S. A., \& Segatto, A. P. (2009). Transferência de Tecnologia e Conhecimento sob a Lente Estruturalista: uma Integração Temática. RAEeletrônica, 8(2), 0-0. doi. 10.1590/S1676-56482009000200003.

Omaki, E. T. (2005). Recursos intangíveis e desempenho em grandes empresas brasileiras: avaliações dos recursos intangíveis como estimador de medidas de desempenho financeiras. Trabalho apresentado no $29^{\circ}$ Encontro da Associação Nacional de PósGraduação e Pesquisa em Administração - EnANPAD. Brasília: ANPAD.

O'Reilly, C., \& Chatman, J. (1986). Organizational commitment and psychological attachment: the effects of compliance, identification, and internalization on prosocial behavior. Journal of Applied Psychology, 71(3), 492-499. http://dx.doi.org/10.1037/00219010.71.3.492.

O’Reilly, C., Chatman, J., \& Caldwell, D. F. (1991). People and organizational culture: a profile comparison approach to assessing person-organization fit. Academy of Management Journal, 34(3), 487-516.

Organ, D. W. (1988). Organizational citizenship behavior: The good soldier syndrome. Lexington, MA: Lexington Books.

Orr, J. E. (1996). Talking about machines: An ethnography of a modern job. Ithaca: Cornell University Press.

Ostroff, C., Shin, Y. \& Kinicki, A. J. (2005). Multiple perspectives of congruence: Relationships between value congruence and employee attitudes. Journal of Organizational Behavior, 26, 591-623. doi. 10.1002/job.333.

Ouchi, W. G. (1980). Markets, bureaucracies, and clans. Administrative Science Quarterly, 25(1), 129-141.

Özan, M. B., \& Şener, G. (2013). Determination of perception level of primary school teachers on organizational identity. Procedia - Social and Behavioral Sciences, 93, 11311137. doi. 10.1016/j.sbspro.2013.10.002.

\section{P}

Paczkowski, S. (2003). Desenvolvimento de um procedimento de avaliação de práticas de responsabilidade social das organizações produtivas. Dissertação de Mestrado, Universidade Federal de Santa Catarina, Florianópolis. 
Pant, P. N., \& Lachman, R. (1998). Value incongruity and strategic choice. Journal of Management Studies, 35, 195-212.

Parker, C. P., Baltes, B. B., Young, S. A., Huff, J. W., Altmann, R. A., Lacost, H. A., \& Roberts, J. E. (2003). Relationships between psychological climate perceptions and work outcomes: a meta-analytic review. Journal of Organizational Behavior, 24(4), 389-416. doi. 10.1002/job.198.

Parsons, T. (1937). The structure of social action. McGraw \& Hill, New York.

Parsons, T. (1951). The social system. Glencoe, IL: Free Press.

Parsons, T. (1960). Structure and process in modern societies. New York: The Free Press.

Parsons, T. (1961). An outline of the social system. In: T. Parsons et al. (Orgs.), Teories of Society. New York: Free Press.

Parsons, T. \& Shils, E. A. (1951). Towards a general theory of action. Harvard: Harvard University Press.

Pasquali, L. (2010). Testes referentes a construto: teoria e modelo de construção. In. Pasquali, L., \& Cols. Instrumentação Psicológica: fundamentos e práticas. Porto Alegre: Artmed, 165-198.

Pasquali, L. (2012). Análise Fatorial para pesquisadores. 1 ed. Brasília: LabPAM Editora.

Payne, R. L. (2000). Climate and culture: How close can they get?. In N. M, Ashakanasy, C.

P. Wilderom, \& M. F. Peterson (Eds.). Handbook of organizational culture and climate (pp. 163-176). Thousand Oaks: Sage.

Paz, M. G. T., \& Tamayo, A. (2004). Perfil cultural das organizações. Em A. Tamayo (Org.) Cultura e saúde nas organizações (pp. 16-38), Porto Alegre: Artmed.

Peinado, J., Fernandes, B. H. R. (2012). Estratégia, competências e desempenho em empresas de pet shop: evidências de um levantamento em Curitiba. Revista de Administração, 47(4), 609-623. doi. 10.5700/rausp1062.

Peixoto, A. L. A. (2008). Performance nas organizações: antecedentes, medidas de desempenho e práticas de gestão. Trabalho apresentado no III Congresso Brasileiro de Psicologia Organizacional e do Trabalho, Florianópolis, Santa Catarina.

Peltier, J., Zahay, D., \& Krishen, A. S. (2013). A hierarchical IMC data integration and measurement framework and its impact on CRM system quality and customer performance. Journal of Marketing Analytics, 1, 32-48. doi. 10.1057/jma.2013.1. 
Peltier, J., Zahay, D. \& Lehman, D. (2013). Organizational learning and CRM success: A model for linking organizational practices. Customer data quality and performance, Journal of Interactive Marketing, 27, 1-13.doi. 10.1016/j.intmar.2012.05.001.

Pema, E., \& Mehay. S. The role of job assignment and human capital endowments in explaining gender differences in job performance and promotion. Labour Economics, 17(6), 998-1009. doi. 10.1016/j.labeco.2010.02.006.

Perin, M. G., Sampaio, C. H., Duhá, A. H., \& Bitencourt, C. C. (2006). Processo de aprendizagem organizacional e desempenho empresarial: $\mathrm{o}$ caso da indústria eletroeletrônica no Brasil. Revista de Administra

Peteraf, M., \& Shanley, M. (1997). Getting to know you:A theory of strategic group identity. Strategic Management Journal, 18, 165-186. doi:10.1002/(SICI)10970266(199707)18:1+<165::AIDSMJ914>3.3.CO;2-R

Peters, G. (2007). Em direção a uma teoria praxiológica da cultura. In: Congresso Brasileiro de Sociologia. Papers. Recife, Sociedade Brasileira de Sociologia.

Peters, T. J. \& Waterman, R. H. (1982). In search of excellence. New York: Harper \& Row. ção de Empresas Eletrônica, 5(2), 51-62. doi. 10.1590/S1676-56482006000200005.

Pilati, R., \& Laros, J. A. (2007). Modelos de equações estruturais em psicologia: conceitos e aplicações. Psicologia: Teoria e Pesquisa, 23(2), 205-216. doi. 10.1590/S010237722007000200011.

Pimenta, A. M. M., \& Paula, P. P. (2012). Avaliação de deempenho por competências: sob avaliação dos empregados. Psicologia em Revista, 18(2), 316-329.

Pires, N. C. M., \& Kato, H. T. (2007). A influência da estratégia na informatização e no desempenho das concessionárias de automóveis brasileiras. Trabalho apresentado no $31^{\circ}$ Encontro Nacional de Programas de Pós-Graduação em Administração (Enanpad), Belo Horizonte.

Plano Estratégico 2011-2022 (2011). Planejando a Segurança Cidadã do Distrito Federal no Século XXI / Polícia Militar do Distrito Federal. Estado-Maior/Seção de Inteligência Estratégica Ciência e Tecnologia. 1 ed. Brasília, PMDF, Rio de Janeiro: Talagarça, 96 p.

Podsakoff, P. M., MacKenzie, S. B., Paine, J. B., \& Bachrach, D. G. (2000). Organizational citizenship behaviors: A critical review of the theoretical and empirical literature and suggestions for future research. Journal of Management, 26(3), 513-563. doi: 10.1177/014920630002600307. 
Polzer, J.T. (2000). Identity in organizations: Building theory through conversations. In D.A. Whetten, \& P.C. Godfrey (Eds.), Thousand Oaks, CA: Sage. Book review.

Poole, M. S. (1985). Communication and organization climates. In McPhee, R. D., \& Thompkins, P. K. (Eds). Organizational communications: Traditional themes and new directions, (79-108), Sage, Beverly Hills CA.

Porto, J. B., Ferreira, M. C., Brandão, H. P., Freitas, I. A., \& Pereira, S. C. M. (2012). Valores Organizacionais: Evidências de adequação da Teoria de Valores Culturais de Schwartz. Manuscrito Não-publicado. Instituto de Psicologia, Universidade de Brasília.

Pozo, J. I. (2002). Aprendizes e mestres: a nova cultura da aprendizagem. Porto Alegre: Artmed.

Prahalad, C. K., \& Hamel, G. (1990). The core competence of the corporation. Harvard Business Review, 68(3), 79-93.

Prajogo, D. I., \& McDermott, C. M. (2005). The relationship between total quality management practices and organizational culture. International Journal of Operation and Production Management, 25(11), 1101-1122. doi. 10.1108/01443570510626916.

Prati, L. M., McMillan-Capehart, A., \& Karriker, J. H. (2009). Affecting organizational identity: A manager's influence. Journal of Leadership \& Organizational Studies, 15, 404-415. doi:10.1177/1548051809331502.

Pratt, M. G. (1998). To be or not to be: central questions in organizational identification. In D. A., Whetten, \& P. C. Godfrey (eds.). Identity in organization, 171-207. Thousand Oaks: Sage.

Pratt, M. G., \& Ashforth, B. E. (2003). Fostering meaningfulness in working and at work. In K. S. Cameron, J. E. Dutton, \& R. E. Quinn (Eds.), Positive organizational scholarship: Foundations of a new discipline (pp. 309-327). San Francisco: Berrett-Koehler Publishers.

Pratt, M. G. \& Foreman, P. O. (2000). The beauty of and barries to organizational theories of identity. Academy of Management Review, 25(1), 141-152. doi. 10.5465/AMR.2000.27711650.

Pratt, M. G., Rockmann, K. W., \& Kaufmann, J. B. (2006). Constructing professional identity: The role of work and identity learning cycles in the customization of identity among medical residents. Academy of Management Journal, 49, 235-262. 
Preacher, K. J., \& Hayes, A. F. (2008). Asymptotic and resampling strategies for assessing and comparing indirect effects in multiple mediator models. Behavior Research Methods, 40, 879-891. doi. 10.3758/BRM.40.3.879.

Prettigrew, A. M. (1979). On studying organizational cultures. Administrative Science Quarterly, 24, 570-581.

Primi, R., Santos, A. A., Vendramini, C. M., Taxa, F., Muller, F. A., Lukjanenko, M. F., \& Sampaio, I. S. (2001). Competências e habilidades cognitivas: diferentes definições dos mesmos construtos. Revista Psicologia: Teoria e Pesquisa, 17(2), 151-159. doi. 10.1590/S0102-37722001000200007.

Puente-Palacios, K., Almeida, R. S., \& Rezende, D. V. (2011). O impacto da interdependência no trabalho sobre a efetividade de equipes. Organizações \& Sociedade, 18(59), 605-623. doi. 10.1590/S1984-92302011000400003.

Pulakos, E. D., Arad, S., Donavan, M. A., \& Plamondon, K. E. (2000). Adaptability in the workplace: Development of a taxonomy of adaptive performance. Journal of Applied Psychology, 85(4), 612-624. doi. 10.1037/0021-9010.85.4.612.

Pulakos, E. D., Schmitt, N., Dorsey, D. W., Arad, S., Hedge, J. W., \& Borman, W. C. (2002). Predicting adaptative performance. Human Performance, 15(4), 299-323. doi. 10.1207/S15327043HUP1504_01.

\section{Q}

Quenneville, N., Bentein, K., Simard, G. (2010). From organizational values to mobilization of human resources. Canadian Journal of Administrative Sciences, 27(2), 122-135. doi. 10.1002/cjas. 114 .

Quinn, R.E., \& Rohrbaugh, J. (1983). A spatial model of effectiveness criteria: Towards a competing values approach to organizational analysis. Management Science, 29, 363-377.

Quinn, R. E., \& Spreitzer. G. M. (1991). The psychometrics of the competing values culture instrument and an analysis of the impact of organizational culture on quality of life. In R. W. Woodman \& W. A. Passmore (Eds.). Research in Organization Change and Development, 5, 115-142. Greenwich, CT: JAI Press.

Quinn, R. et al. (2003). Competências Gerenciais: princípios e aplicações. Rio de Janeiro: Elsevier. 


\section{$\mathbf{R}$}

Rao, H., Monin, P., \& Durand, R. (2003). Institutional change in Toque Ville: Nouvelle cuisine as an identity movement in French gastronomy. American Journal of Sociology, 108(4), 795-843. doi. 10.1086/367917.

Raub, S. P. (1998). A knowledge-based framework of competence development. In Proceedings of the Fourth International Conference on Competence-Based Management. Oslo: Norwegian School of Management.

Ravasi, D., \& Phillips, N. (2011). Strategies of alignment: organizational identity management and strategic change at Bang \& Olufsen. Strategic Organization, 9(2), 103135. doi. 10.1177/1476127011403453.

Reade, C. (2001). Dual identification in multinational corporations: local managers and their psychological attachment to the subsidiary versus the global organization. International Journal of Human Resource Management, 12(3), 405-424. doi. 10.1080/713769627.

Ravasi, D., \& Canato, A. (2010). We are what we do (and how we do it): Organizational technologies and the construction of organizational identity. In Phillips, N., Griffith, D., \& Sewell, G. Research in the Sociology of Organization: Technology and Organization: Essays in honour of Joan Woodward.

Ravasi, D., \& Schultz, M. (2006). Responding to organizational identity threats: exploring the role of organizational culture. Academy of Management Journal, 49(3), 433- 458. doi. 10.5465/AMJ.2006.21794663.

Rebelo, T. M. M. S. D. (2001). Organização, aprendizagem e cultura: Estudo sobre a homogeneidade / heterogeneidade da orientação cultural para a aprendizagem. Dissertação de Mestrado não publicada, Faculdade de Psicologia e de Ciências da Educação da Universidade de Coimbra.

Rebelo, T. M. M. S. D. (2006). Orientação cultural para a aprendizagem nas organizações: Condicionantes e consequentes. Tese de Doutorado. Faculdade de Psicologia e de Ciências da Educação. Universidade de Coimbra.

Reichers, A. \& Schneider, B. (1990). Climate and culture: An evolution of constructs. In B. Schneider (Ed.), Organizational climate and culture. (pp. 5-39). San Francisco: JosseyBass.

Riantoputra, C. D. (2010). Know thyself: Examining factors that influence the activation of organizational identity concepts in top managers' minds. Group \& Organization Management, 35(1), 8-38. doi. 10.1177/1059601109354804. 
Richard, O. C., Murthi, B. P. S., \& Ismail, K. (2007), The impact of racial diversity on intermediate and long-term performance: The moderating role of environmental context. Strategic Management Journal, 28(12), 1213-1233. doi: 10.1002/smj.633.

Riggio, R. E., \& Taylor, S. J. (2000). Personality and communication skills as predictors of hospice nurse performance. Journal of Business and Psychology, 15 (2), 351-359. doi. 10.1023/A:1007832320795.

Riketta, M. (2002). Attitudinal organizational commitment and job performance: A metaanalysis. Journal of Organizational Behavior, 23(3), 257 - 266. doi. 10.1002/job.141.

Riketta, M. (2004). Organizational identification: A meta-analysis. Journal of Vocational Behavior, 66(2), 358-384. doi. 10.1016/j.jvb.2004.05.005.f

Riketta, M. (2005). Organizational identification: A meta-analysis. Journal of Vocational Behavior, 66(2), 358-384. doi. 10.1016/j.jvb.2004.05.005.

Riketta, M., van Dick, R., \& Rousseau, D. M. (2006). Employee attachment in the short and long run. Zeitschrift für Personalpsychologie, 5, 85-93. doi:10.1026/1617-6391.5.3.85

Robertson, I. T., Callinan, M., \& Bartram, D. (2002). Organizational effectiveness: the role of psychology. Chichester, John Wiley \& Sons, LTD.

Robbins, S. P. (1999). Comportamento organizacional. Rio de Janeiro: Livros Técnicos e Científicos Editora.

Rocha, C. B., \& Silva, J. R. G. (2007). Identificação de funcionários com empresa pública no contexto de mudanças: o caso Finep. Revista Brasileira de Administração Pública, 41, 685-706.

Rodrigues, L. G., Nascimento, T. G., \& Neiva, E. R. (no prelo). Valores Organizacionais e Atitudes frente à Mudança: O Caso da Polícia Militar do Distrito Federal. Psicologia: Ciência e Profissão.

Rokeach, M. (1973) The nature of human values. New York: Free Press.

Rokeach, M. (1968/1981). Crenças, atitudes e valores. Rio de Janeiro: Interciência. (Trabalho original publicado em 1968).

Ropé, F., \& Tanguy, L. (1997). Introdução. In F. Ropé, \& L. Tanguy (Orgs.), Saberes e competências: o uso de tais noções na escola e na empresa (pp. 15-24). Campinas: Papirus.

Ros, M. (2001). Psicología social de los valores humanos: Uma perspectiva histórica. In M. Ros \& V.V. Gouveia (Orgs.), Psicología social de los valores humanos: Desarrollos teóricos, metodológicos y aplicados (pp.27-51). Madrid: Biblioteca Nueva. 
Ros, M. (2006). Psicología social de los valores humanos: Uma perspectiva histórica. In M. Ros \& V.V. Gouveia (Orgs.), Psicologia social dos valores humanos: Desenvolvimentos teóricos, metodológicos e aplicados (pp.23-53). São Paulo: Ed. SENAC.

Rotundo, M., \& Sackett, P. R. (2002). The relative importance of task, citizenship, and counterproductive performance to global ratings of job performance: A policy-capturing approach. Journal of Applied Psychology, 87(1), 66-80. doi. 10.1037/0021-9010.87.1.66.

Rousseau, D. M. (1992). Assessing organizational culture: the case for multiple methods. In: Schein, E. H. Organizational culture and leadership. 2. ed. San Francisco: Jossey-Bass.

Roussel, P., Durrieu, F., Campoy, E. \& Akremi, A. E. (2002), Méthodes d'équations structurelles: recherche et applications en gestion. Economica: Paris.

Rousseau, D. M. (1997). Organizational behavior in the new organizational area. Annual Review of Psychology, 48, 515-546.

Rousseau, D. M. (1990). Assessing organizational culture: The case for multiple methods. In: B. Schneider (Org.), Organizational climate and culture (pp.153-192). San Francisco: Jossey-Bass.

Rousseau, D. M. (1998). Why workers still identify with organizations. Journal of Organizational Behavior, 19, 217-233. doi:10.1002/(SICI)10991379(199805)19:3<217::AID-JOB931>3.0.CO;2-N.

Ruano-Borbalan, J. (1998). L'Identité: l'individu, le groupe, la société. Paris: Éditions Sciences Humaines.

Ruas, R., Ghedine, T., Dutra, J. S., Becker, G. V., \& Dias, G. B. (2005). O conceito de competência de A a Z: análise e revisão nas principais publicações nacionais entre 2000 e 2004. Em Anais do $29^{\circ}$ Encontro da Associação Nacional de Pós-Graduação e Pesquisa em Administração - EnANPAD. Brasília: ANPAD.

Ruiz Castro, M. (2012). Time Demands and Gender Roles: The case of a big four firm in Mexico. Gender, Work \& Organization, 19(5), 532-554. doi. 10.1111/j.14680432.2012.00606.x.

Russell, C. J. (2001). A longitudinal study of top-level executive performance. Journal of Applied Psychology, 86, 560- 573.

\section{$\mathbf{S}$}

Sackmann, S. A. (1991). Cultural knowledge in organizations: Exploring the collective Mind. Newbury Park, CA: Sage. 
Sackmann, S. A. (2011). Culture and performance. In N. Ashkanasy, C. Wilderom, \& M. Peterson (Eds.), The handbook of organizational culture and climate, 2nd edn, p. 188224. Thousand Oaks, CA: Sage Publications.

Sackett, P. R. (2002). The structure of counterproductive work behaviors: dimensionality and relationships with facets of job performance. International Journal of Selection and Assessment, 10, 5-11.

Sainsanlieu, R. (1977). Identité au travail les effets culturels de l'organisation. Paris: Presses de la Fondation Nationale de Sciences Politiques.

Sainsanlieu, R. (1995). L’identité au travail: une expérience partagée. In: Francfort, J. et al. Les mondes sociaux de l'entreprise. Paris: Sociologie Économique.

Salgado, J. F. (2003). Predicting job performance using FFM and non-FFM personality measures. Journal of Occupational and Organizational Psychology, 76, 323-346. doi. 10.1348/096317903769647201.

Sanchez, R. (1997). Managing articulated knowledge in competence-based competition. In. R. Sanchez, \& A. Heene (Orgs.). Strategic learning and knowledge management. (pp. 163-187). Chichester, UK: John Wiley \& Sons.

Sansone, C. (1986). A question of competence: the effects of competence and task feedback on intrinsic interest. Journal of Personality and Social Psychology, 51 (5), 918-931.

Santos, A. C. (2001). O uso do método Delphi na criação de um modelo de competências. Revista de Administração da USP, 36 (2), 25-32.

Santos, A. P., \& Borges-Andrade, J. E. (2012). Competências no trabalho: Estado da arte da produção científica portuguesa e estrangeira. Psychologica (Coimbra), 1, 39-59.

Santos, A. P. (2012). Competências, carreiras e contexto: um estudo multinível na administração pública brasileira. Tese de Doutorado Não Publicada. Universidade de Brasília, Brasília.

Sanzi, R. P. (2008). Gestão do desempenho na prática de recursos humanos. Trabalho apresentado no III Congresso Brasileiro de Psicologia Organizacional e do Trabalho, Florianópolis, Santa Catarina.

Sarros, J. C., Gray, J. H., Densten, I. L., \& Cooper, B. (2005). The organizational culture profile revisited and revised: An Australian perspective. Australian Journal of Management, 30(1), 159-182. doi. 10.1177/031289620503000109. 
Sagiv, L. \& Schwartz, S. H. (1995). Value priorities and readiness for out-group social contact. Journal of Personality \& Social Psychology, 69 (3), 437-48. doi. 10.1037/00223514.69.3.437.

Sagiv, L. \& Schwartz, S.H. (2000). Value priorities and subjetive well-being: direct relations and congruity effects. European Journal of Social Psychology, 30(2), 177-198. doi. 0.1002/(SICI)1099-0992(200003/04)30:2<177::AID-EJSP982>3.0.CO;2-Z.

Sagiv, L., Sverdlik, N., \& Schwarz, N. (2011). To compete or to cooperate? Values' impact on perception and action in social dilemma games. European Journal of Social Psychology, 41, 64-77. doi:10.1002/ejsp.729.

Schiehll, E., \& Morissette, R. (2000). Motivation, measurement and rewards from a performance evaluation perspective. Revista de Administração Contemporânea, 4(3), 724. doi. 10.1590/S1415-65552000000300002.

Schein, E. H. (1985). Organizational Culture and Leadership. San Francisco: Jossey-Bass.

Schein, E. H. (1992). Organizational Culture and Leadership. San Francisco: Jossey-Bass. 2nd ed.

Schein, E. H. (1996). The corporate culture survival guide: sense and nonsense about culture change. São Francisco, CA: Josey-Bass.

Schein, E. H. (1999). Culture: the missing concept in organizational studies. Administrative Science Quarterly, 44, 229-241. doi. 10.2307/2393715.

Schein, E. H. (2004). Organizational culture and leadership. San Francisco: Jossey-Bass. 3rd ed.

Schein, E. H. (2010). Organizational culture and leadership. San Francisco: Jossey-Bass. 4rd ed.

Schmitt, N., \& Chan, D. (1998). Personnel selection. Thousand Oaks, London, New Delhi, Sage.

Schneider, B., Ehrhart, M. G., \& Macey, W. H. (2013). Organizational climate and culture. Annual Review of Psychology, 64, 361-388. doi.10.1146/annurev-psych-113011-143809.

Schultz, M. (1994). On studying organizational cultures: Diagnosis and understanding. Berlin: Walter de Gruyter.

Schultz, M., \& Hernes, T. (2013). A temporal perspective on organizational identity. Organization Science 24(1):1-21. doi. 10.1287/orsc.1110.0731. 
Schwartz, S. H. (1992). Universals in the content and structure of values: Theoretical advances and empirical tests in 20 countries. Em M. P. Zana (Org.), Advances in Experimental Social Psychology (pp.1-65). New York: Academic Press.

Schwartz, S. H. (1994). Are there universal aspects in the structure and contents of human values? Journal of Social Issues, 50(4), 19-45. doi. 10.1111/j.1540-4560.1994.tb01196.x.

Schwartz, S. H. (1996). Value priorities and behavior: Applying a theory of integrated value systems. Em C. Seligman, J. M. Olson, \& M. P. Zanna (Orgs.), The psychology of valuesThe Ontario Symposium, (pp.1-24). Hillsdale: Lawrence Erlbaum Associates.

Schwartz, S. H. (1999). A theory of cultural values and some implications for work. Applied Psychology: An International Review, 48 (1), 23-47. doi. 0.1111/j.14640597.1999.tb00047.x.

Schwartz, S. (2005a). Valores humanos básicos: seu contexto e estrutura intercultural. Em A. Tamayo \& J. B. Porto (Orgs.). Valores e comportamento nas organizações. (pp. 21-55). Petrópolis: Vozes.

Schwartz, S. (2005b). Validade e aplicabilidade da teoria de valores. Em A. Tamayo \& J. B. Porto (Orgs.). Valores e comportamento nas organizações. (pp.56-95). Petrópolis: Vozes.

Schwartz, S. H., \& Davis, S. M. (1981). Matching corporate culture and business strategy. Organizational Dynamics , 1. 318-328.

Schwartz, S. H., \& Bilsky, W. (1987). Toward a universal psychological structure of human values: Extensions and cross-cultural replications. Journal of Personality and Social Psychology, 53 (3), 550-562. doi. 10.1037/0022-3514.58.5.878.

Schwartz, S. H., \& Bilsky, W. (1990). Toward a theory of the universal content and structure of values: Extensions and cross-cultural replications. Journal of Personality and Social Psychology, 58 (5), 878-891. doi. 10.1037/0022-3514.58.5.878.

Schwartz, S. H., \& Ros, M. (1995). Values in the west: A theoretical and empirical challenge to the individualism-collectivism cultural dimension. World Psychology, 1, 91-122.

Schwartz, S. H., Cieciuch, J., Vecchione, M., Davidov, E., Fischer, R., Beierlein, C., Ramos, A., Verkasalo, M., Lönnqvist, J.-E., Demirutku, K., Dirilen-Gumus, O., \& Konty, M. (2012). Refining the theory of basic individual values. Journal of Personality and Social Psychology, 103, 663-688. doi. 10.1037/a0029393.

Scott, T. \& Lane, L. (2000). A stakeholder approach to organizational identity. Academy of Management Review, 25(1), 43-62. doi. 10.5465/AMR.2000.2791602. 
Scott-Ladd, B., Travaglione, A., \& Marshall, V. (2006). Causal inferences between participation in decision making, task attributes, work effort, rewards, job satisfaction and commitment. Leadership \& Organization Development Journal, 27(5), 399-414. doi. 10.1108/01437730610677990.

Scroggins, W. A. (2008). Antecedents and outcomes of experienced meaningful work: A person-job fit perspective. Journal of Business Inquiry, 7, 68-78.

Secretaria Nacional de Segurança Pública (SENASP) (2012). Perfil dos cargos das instituições estaduais de segurança pública: estudo profissiográfico e mapeamento de competências. Programa Nacional de Desenvolvimento para as Nações Unidas (PNUD), Brasília: Ministério da Justiça, 71 p.

Seifert, C. F., Yukl, G., \& McDonald, R. A. (2003). Effects of multisource feedback and a feedback facilitator on the influence behavior of managers toward subordinates. Journal of Applied Psychology, 88(3), 561-569. doi. 10.1037/0021-9010.88.3.561.

Selig, J. P., \& Preacher, K. J. (2008). Monte Carlo method for assessing mediation: An interactive tool for creating confidence intervals for indirect effects [Computer software]. Available from http://quantpsy.org/.

Sellitto, M. A., Borchardt, M., \& Pereira, G. M. (2006). Avaliação multicriterial de desempenho: um estudo de caso na indústria de transporte coletivo de passageiros. Gestão \& Produção, 13(2), 339-352. doi. 10.1590/S0104-530X2006000200014.

Selznick, P. (1949). TVA and the grass roots. Berkeley: University of California Press.

Selznick, P. (1971). A liderança na administração: Uma interpretação sociológica. Rio de Janeiro: FGV. (trabalho original publicado em 1957).

Shaffer, M. A., Harrison, D. A., Gregersen, H. B., Black, J. S., \& Ferzandi, L. A. (2006). You can take it with you: individual differences and expatriate effectiveness. Journal of Applied Psychology, 91 (1), 109-125. doi. 10.1037/0021-9010.91.1.109.

Shim, M. (2010). Factors influencing child welfare employee's turnover: Focusing on organizational culture and climate. Children and Youth Services Review, 32, 847 856. doi. 10.1016/j.childyouth.2010.02.004.

Shweder, R \& LeVine, R. (1984). Culture theory: Essays on mind, self, and emotion. London: Cambridge Univ. Press.

Sillince, J. A. A., \& Brown, A. D. (2009). Multiple organizational identities and legitimacy: The rhetoric of police websites. Human Relations, 62(2), 1829-1856. doi. 10.1177/0018726709336626. 
Singh, J., Verbeke, W. \& Rhoads, G. K. (1996). Do organizational practices matter in role stress processes? A study of direct and moderating effects for marketing-oriented boundary spanners. Journal of Marketing, 60, 69-86. doi. 10.2307/1251842.

Silva, G. A. V. (2002). Organizações flexíveis: identidades elásticas? A reconstrução da identidade social em processos de terceirização. Tese de Doutorado - Instituto de Psicologia, Universidade de São Paulo, São Paulo.

Silva, L. A. M. (2010). "Violência urbana", segurança pública e favelas: o caso do Rio de Janeiro atual. Cad. $C R H, 23(59)$, 283-300.

Silva, T. T. (2004). A produção social da identidade e da diferença. In T. T. da Silva (Ed.), Identidade e diferença: A perspectiva dos estudos culturais (3. ed., pp. 73-102). Petrópolis, RJ: Vozes.

Skinner, B. F. (1981). Selection by consequences. Science, 213(4507), 501-504. doi. 10.1126/science.7244649.

Smircich, L. (1983). Concepts of culture and organizational analysis. Administrative Science Quarterly, 28(3), 339-358.

Smith, E. B. (2011). Identities as lenses: How organizational identity affects audiences' evaluation of organizational performance. Administrative Science Quarterly, 56(1), 61-94. doi. 10.2189/asqu.2011.56.1.061.

Smith, P. B. \& Bond, M. H. 1(999) Social psychology: Across cultures. Boston: Allyn \& Bacon.

Smith, P. B.; Bond, M. H; \& Kağitçibasi, C. (2006). Understanding social psychology across cultures: Living and working in a changing world. London: Sage.

Smith, P., Cunha, J., Giangreco, A., Vasilaki, A., \& Carugati, A. (2013). The threat of disidentification for HR practices: An ethnographic study of a merger. European Management Journal, 31(3), 308-321. doi. 10.1016/j.emj.2012.07.004.

Sobel, M. E. (1982). Asymptotic intervals for indirect effects in structural equations models. In Leinhart, S. (Eds). Sociological Methodology, Washington DC, American Sociological Association, 290-312.

Søndergaard, M. (1994). Hofstede's consequences: A study of reviews, citations and replications. Organizations Studies. 15, 447-456.

Sonnentag, S., \& Frese, M. (2002). Performance concepts and performance theory. In S. Sonnentag (Org.). Psychological management of individual performance (pp. 03-25). Chichester, UK: John Wiley \& Sons. 
Sørensen, J. B. (2002). The strength of corporate culture and the reliability of firm performance. Administrative Science Quarterly, 47(1), 70-91. doi. 10.2307/3094891.

Sousa, J. M. (2013). Felicidade no trabalho: impacto de valores laborais e organizacionais. Dissertação de Mestrado não publicada. Instituto de Psicologia, Universidade de Brasília.

Sousa, R. R. (2009). Análise do perfil cultural das organizações policiais e a integração da gestão em segurança pública em Belo Horizonte. Tese de Doutorado não publicada. Instituto de Psicologia, Universidade de Brasília.

Souza, E. C. L. (2000). Formação de gestores e a reforma do aparelho do Estado. In: Violeta Pallavicini Campos; Ferdinando Gomes Ortiz. (Org.). Avances y Desafios de la Administracion de los Recursos Humanos ao Iniício del Tercer Milenio. 1 ed. v. 1, p. 7583. San Jose: Editorial de la Universidad de Costa Rica.

Souza, E. C. L. (2001). Gestão de organizações de aprendizagem. Brasília: Universidade de Brasília - UnB e Serviço Social da Indústria - SESI.

Souza. E. C. L. (2009). La logique culturelle des organisations au Brésil: leurs pratiques de gestion. Actes du Séminaire: Innovation et Internationalisation des Activites de Services. Aix-en-Provence. Université Paul Cézanne Aix-Marseille III et Université de Brasília.

Souza, E. C. L. (2014). Construção da escala de manifestação da cultura pelas práticas organizacionais segundo os estudos de d'Iribarne. Manuscrito Não-publicado. Programa de Pós-graduação em Administração, Universidade de Brasília.

Souza, E. C. L., \& Fenili, R. R. (2012). Internacionalização de empresas: perspectivas teóricas e agenda de pesquisa. Revista de Ciências da Administração. 14(33), 103-118. doi. $10.5007 / 2175-8077.2012 v 14 n 33 p 103$.

Souza, E. C. L., Castro-Lucas, C. S., \& Chaves Farias, R. M. (2013). Latent cultural expressions in practices of an internationalized Brazilian bank. In: 23rd RESER Conference, Aix-en-Provence. 23rd RESER. Aix-en-Provence: Aix - Marseille Université, 1, 1-10.

Souza, E. C. L.; Castro-Lucas, C. \& Torres, C. V. (2011). Práticas sociais, cultura e inovação: três conceitos associados. Faces. vol. 2, n. 2. p. 210-230.

Souza, E. C. L., Castro-Lucas, C., Fenili, R. R., \& Chaves Farias, R. M. C. (2013). Internacionalização de organizações: propostas de análise à luz da cultura. Faces Journal: Revista de Administração, 12(1), 139-151.

Souza, E. R.; \& Lima, M. L. C. (2006). Panorama da violência urbana no Brasil e suas capitais. Ciênc. saúde coletiva, 11(suppl.), 1211-1222. 
Souza, L. (2005). Processos de identidade social: da intolerância e violência à utopia solidária. Simpósio Nacional de Psicologia Social e do Desenvolvimento. Violência e Desenvolvimento Humano: textos completos. Vitória: Programa de Pós-Graduação em Psicologia/PROCAD-CAPES. Vol. 1. pp. 131-138.

Sparrow, P., \& Bognanno, M. (1994). Competency requirement forecasting: issues for international selection and assessment. In C. Mabey, \& P. Iles (Orgs.), Managing learning (pp. 57-69). London: Routledge.

Stainer, A., \& Stainer, L. (1996). Productivity and performance: a value-based approach. Journal of Applied Management Studies, 5(1), 1-13.

Satarbuck, W. H. (2005). Performance measures: prevalent and important but methodologically challenging. Journal of management inquiry, 14(3), 280-286. doi. $10.1177 / 1056492605279099$.

Steel, R. P., \& Scotter, J. R. V. (2003). The organizational performance cycle: longitudinal assessment of key factors. Journal of Business and Psychology, 18 (1), 31-50. doi. 10.1023/A:1025030904021.

Stephan, C. W., \& Stephan, W. G. (1985). Two social psychologies: An integrative approach. Homewood: Dorsey.

Stets, J. E., \& Burke, P. J. (2000). Identity theory and social identity theory. Social Psychology Quarterly. 63(3), 224-237.

Stock, R. M., Oliveira, P., \& von Hippel, E. (2014). Impacts of hedonic and utilitarian user motives on the innovativeness of user-developed solutions. Journal of Product Innovation Management. doi: 10.1111/jpim.12201.

Stryker, S., \& Serpe, R. T. (1994). Identity salience and psychological centrality: equivalent, overlapping, or complementary concepts? Social Psychology Quarterly, 57(1), 16-35.doi: $10.2307 / 2786972$.

Suar, D., Tewari, H. R., \& Chaturbedi, K. R. (2006). Subordinates' perception of leadership styles and their work behaviour. Psychology and Developing Societies, 18(1), 93 - 114. doi. 10.1177/097133360501800106.

Sumner, W. G. (1906). Folkways. A study of the sociological importance of usages, manners, customs, mores and morals. Boston, Ginn.

Sveningsson, S., \& Alvesson, M. (2003). Managing managerial identities: Organizational fragmentation, discourse and identity struggle. Human Relations, 56, 1163-1193. doi. $10.1177 / 00187267035610001$. 
Swanson, R. A. (1996). Analysis for performance: Tools for diagnosing organizations and documenting workplace expertise. Berrett-Koehler, San Francisco, CA.

Swanson, R.A., \& Holton, E. F. III (2001). Foundations of human resource development. Berrett-Koehler, San Francisco, CA.

Szulanski, G. (1996). Exploring internal stickiness: Impediments to the transfer of best practice within the firm. Strategic Management Journal, 17 (Summer special issue), 2743.

\section{$\mathbf{T}$}

Tabachnick, B. G., \& Fidell, L. S. (2007). Using multivariate statistics. Needham Heights, MA: Allyn \& Bacon.

Tajfel, H. (1972). La categorisation sociale. In: Moscovici, S. (Org.). Introduction à la psychology sociale. Paris: Larousse.

Tajfel, H. (1978). Differentiation between social groups: Studies in the social psychology of intergroup relations. New York: academic.

Tajfel, H. (1981). Human groups and social categories. Cambridge: Cambridge University Press.

Tajfel, H. (1982). Grupos humanos e Categorias sociais: Estudos em psicologia social. (L. Amâncio, Trad.). Vol. I, Lisboa, Livros Horizonte.

Tajfel, H. (1983). Grupos humanos e categorias sociais: Estudos em psicologia social. (L. Amâncio, Trad.). Vol. II, Lisboa: Livros Horizonte.

Tajfel, H., \& Turner, J. C. (1979). An integrative theory of intergroup conflict. Em: W. G. Austin e S. Worchel (Org.). The social psychology of intergroup relations, Monterey, Brooks.

Tajfel, H., Billig, M. G., Bundy, R. P. \& Flament, C. (1979). Catégorisation sociale et comportements intergroupes. In: Doise, W. (org.). Expériences entre groupes. Paris: Mouton.

Tamayo, A. (1994). Hierarquia de valores transculturais e brasileiros. Psicologia: Teoria e Pesquisa, 10, 269-285.

Tamayo, A. (1996). Valores organizacionais. In. A. Tamayo, J. E. Borges-Andrade, \& W. Codo (Orgs.). Trabalho, organizações e cultura (pp. 175-193). São Paulo: Cooperativa de Autores Associados. 
Tamayo, A. (2008). Valores Organizacionais. In: Siqueira, M. M. M. (Org.). Medida do comportamento organizacional: Ferramentas de diagnóstico e de gestão. 1 ed. Porto Alegre: Artmed, p. 309-340.

Tamayo, A., \& Borges, L. de O. (2006). Valores do trabalho e das organizações. In. M. Ros \& V. V. Gouveia (Orgs.). Psicologia social dos valores humanos (pp. 397-431). Senac: São Paulo.

Tamayo, A., \& Gondim, M. G. C. (1996). Escala de valores organizacionais. Revista de Administração, 31(2), 62-72.

Tamayo, A., Mendes, M. \& Paz, M. G. T. (2000). Inventário de valores organizacionais. Estudos de Psicologia (Natal), 5 (2), 289-315.

Tamayo, A., \& Schwartz, S. H. (1993) Estrutura motivacional dos valores humanos. Psicologia: Teoria e Pesquisa, 9 (2), 329-348.

Tataw, D. (2012). Toward human resource management in inter-professional health practice: linking organizational culture, group identity and individual autonomy. Int. J. Health Plann. Mgmt., 27: 130-149. doi: 10.1002/hpm.2098.

Tavares, S., Caetano, A., \& Silva, S. (2007). Não há bela sem senão: a identificação organizacional, os comportamentos de dedicação ao trabalho e o conflito trabalho-família. Psicologia, Lisboa, 21(1), 133-149.

Taylor, F. W. (1970). Princípios de Administração Científica. 7.ed. São Paulo: Atlas.

Taylor, F. W. (1980). Princípios de Administração Científica. 8.ed. São Paulo: Atlas.

Taylor, A., MacKinnon, D., \& Tein, J. (2008). Tests of the three-path mediated effect. Organizational Research Methods, 11(2), 241-269. doi: 10.1177/1094428107300344.

Taylor, S., Beechler, S., \& Napier, N. (1996). Toward an integrative model of strategic international human resource management. The Academy of Management Review, 21 (4), 959-985.

Tett, R. P., \& Burnett, D. D. (2003). A personality trait-based interactionist model of job performance. Journal of Applied Psychology, 88, 500-517. doi. 10.1037/00219010.88.3.500.

Tett, R., Jackson, D., \& Rothstein, M. (1991). Personality measures as predictors of job performance: a meta-analytic review. Personnel Psychology, 44, 703-742. doi. 10.1111/j.1744-6570.1991.tb00696.x.

Thompson, B. (2004). Exploratory and confirmatory factor analysis: understanding concepts and applications. Washington: American Psychological Association. 
Tilles, S. (1963). How to evaluate a corporate strategy. Harvard Business Review, 41(4), 111121.

Tindale, R. S., Smith, C. M., Thomas, L. S., Filkins, J., Sheffey, S. (1996). Shared representations and asymmetric social influence processes in samll groups. In E. Witte \& J. H. Davis (Eds.), Understanding group behavior: Consensual action by smaill groups (pp. 81-103). Mahwah, New Jersey: Lawrence Erlbaum Associates, Inc, 1996.

Tomczyk, D., Lee, J., \& Winslow, E. (2013). Entrepreneurs' personal values, compensation, and high growth firm performance. Journal of Small Business Management, 51(1), 66-82. doi. 10.1111/j.1540-627X.2012.00374.x.

Toro, F. (1996). Desempeño y Productividad. Medellin: Cincel Editora.

Torres, C. V. (1999). Leadership style norms among Americans and Brazilians: Assessing differences using Jackson's return potential model. Unpublished doctoral dissertation. San Diego, CA: California School of Professional Psychology.

Torres, C. V. (2009). Do social norms have an infl uence in leadership style preference? Assessing leadership style differences between Americans and Brazilians. London: VDM, 2009.

Torres, C. V., \& Pérez-Nebra, A. R. (2004). Diversidade cultural no contexto organizacional. In: Zanelli, J. C.; Borges-Andrade, J. E.; Bastos, A. V. B. (Orgs.). Psicologia, organizações e trabalho no Brasil. Porto Alegre: Artmed.

Treadway, D. C., Ferris, G. R., Hochwarter, W., Perrewe, P., Witt, L. A., \& Goodman, J. M. (2005). The role of age in the perceptions of politics--job performance relationship: a three-study constructive replication. Journal of applied Psychology, 90(5), 872-881. doi. 10.1037/0021-9010.90.5.872.

Triandis, H. C. 1972. The analysis of subjective culture. New York:Wiley.

Triandis, H. C. 1994. Culture and social behavior. New York: McGraw-Hill.

Triandis, H. C. (1994). Cross-cultural industrial and organizational psychology. In H. C. Triandis, M. D. Dunnette \& L. M. Hough (Eds.), Handbook of industrial and organizational psychology, Vol. 4 (2nd ed.) (pp. 103-172). Palo Alto, CA: Consulting Psychologists Press.

Trice, H. M. \& Beyer, J. M. (1986). Studying organizational cultures through rites and ceremonials. Academy of Management Review, 9(4), 653-669. doi. 10.5465/AMR.1984.4277391. 
Trice, H. M. \& Beyer, J. M. (1993). The culture of work organizations. Englewood Cliffs, NJ: Prentice Hall.

Triguero-Sánchez, R., Peña-Vinces, J. C., \& Sánchez-Apellániz, M. (2013). Hierarchical distance as a moderator of HRM practices on organizational performance. International Journal of Manpower, 34(7), 794-812. doi. 10.1108/IJM-03-2012-0046.

Tseng, S. (2010). The correlation between organizational culture and knowledge conversion on corporate performance. Journal of Knowledge Management, 14(2), 269 - 284. doi. $10.1108 / 13673271011032409$.

Tuomi, K., Vanhala, S., Nykyri, E., \& Janhonen, M. (2004). Organizational practices, work demands and the well-being of employees: A follow-up study in the metal industry and retail trade. Occupational Medicine, 54, 115-121.

Turner, J. C. et al. (1987). Rediscovering the social group: a self-categorization theory. Oxford: Basil Black-Well, 1987.

Turner, J. C., Oakes, P. J., Haslam, S. A., \& McGarty, C. A. (1994). Self and collective: Cognition and social context. Personality and Social Psychology Bulletin, 20, 454-463. doi. 10.1177/0146167294205002.

Ţuţu, A., \& Constantin, T. (2012). Understanding job performance through persistence and job competency. Procedia - Social and Behavioral Sciences, 33, 612-616.doi. 10.1016/j.sbspro.2012.01.194.

Tylor, E. (1871). Primitive Culture. John Murray \& Co. Ed.: New York.

$\mathbf{U}$

Ullman, J. B. (2007). Structural Equation Modeling. Em B. G. Tabachnick \& L. S. Fidell (Orgs.), Using multivariate statistics ( $5^{\mathrm{a}} \mathrm{ed}$.). Boston: Pearson Education.

V

Vallerand, J. R. (1989). Vers une mèthodologie de validation trans-culturelle de questionnaires psychologiques: implications pour la recherche en langue fraçaise. Canadian Psychology, 30(4), 662-680. doi. 10.1037/h0079856.

van den Berg, P. T. \& Wilderom, C. P. (2004). Defining, measuring, and comparing organisational cultures. Applied Psychology: An International Review, 53(4), 570 - 582. doi. 0.1111/j.1464-0597.2004.00189.x.

Vandenberghe, C. (1999). Organizational culture, person-culture fit, and turnover: a replication in the health care industry. Journal of Organizational Behavior, 20, 175-184. doi. 10.1002/(SICI)1099-1379(199903)20:2<175::AID-JOB882>3.0.CO;2-E. 
van der Zee, K, Atsma, N \& Brodbeck, F. (2004). The influence of social identity and personality on outcomes of cultural diversity in teams. Journal of Cross-Cultural Psychology. v. 35 p. 283-303. doi: 10.1177/0022022104264123.

van Dick, R., Wagner, U., Stellmacher, J., \& Christ, O. (2004). The utility of a broader conceptualization of organizational identification: Which aspects really matter? Journal of Occupational and Organizational Psychology, 77, 171-191. doi:10.1348/096317904774202135.

van Knippenberg, D., \& Schippers, M. C. (2007). Work group diversity. Annual Review of Psychology, 58, 515-541. doi. 10.1146/annurev.psych.58.110405.085546.

van Knippenberg, D., \& van Schie, E. C. M. (2000). Foci and correlates of organizational identification. Journal of Occupational and Organizational Psychology, 73(2), 137-147. doi. 10.1348/096317900166949.

van Rijswijk, W., \& Ellemers, N. (2002). Context effects on the application of stereotype content to multiple categorizable targets. Personality and Social Psychology Bulletin, 28(1), 90-101. doi. 10.1177/0146167202281008.

van Dick, R., Wagner, U., Stellmacher, J., \& Christ, O. (2005). Category salience and organizational identification. Journal of Occupational and Organizational Psychology, 78, 273-285. doi:10.1348/096317905X25779.

Van Scotter, J. R., Motowidlo, S. J., \& Cross, T. C. (2000). Effects of task performance and contextual performance on systemic rewards. Journal of Applied Psychology, 85(4), 526535.

Vasconcelos, T. S. (2005). O inventário fatorial dos cinco fatores de personalidade no ambiente de trabalho. Tese de Doutorado não publicada, Instituto de Psicologia, Universidade de Brasília, Brasília.

Veiga, H. M. S. (2010). Comportamento pró-ativo: relações com valores organizacionais, estímulos e barreiras à criatividade nas organizações e normas sociais. Tese de Doutorado não publicada. Instituto de Psicologia, Universidade de Brasília.

Verbeeten, F. H. M., \& Boons, A. N. A. M. (2009). Strategic priorities, performance measures and performance: An empirical analysis in Dutch firms. European management journal, 27(2), 113-128. doi. 10.1016/j.emj.2008.08.001.

Verbeke, W. (2000). A revision of Hofstede et al. (1990) organizational pratices scale. Journal of Organizational Behavior, 21(5), 587-602. doi. 10.1002/10991379(200008)21:5<587::AID-JOB22>3.0.CO;2-5. 
Viswesvaran, C., \& Ones, D. S. (2005). Job performance. In A. Evers, N. Anderson \& O. Smit-Voskuijl (Ed.). The Blackwell handbook of personnel selection (pp. 354-375). New York: Blackwell.

Viswesvaran, C., Ones, D. S., \& Schmidt, F. L. (1996). Comparative Analysis of the reliability of job performance ratings. Journal of Applied Psychology, 81(5), 557-574. doi. 10.1037/0021-9010.81.5.557.

Voss, G. B., Cable, D. M., \& Voss, Z. G. (2000). Linking organizational values to relationships with external constituents: A study of nonprofit professional theatres. Organization Science, 11, 330-347. doi. 10.1287/orsc.11.3.330.12497.

\section{W}

Waldman, D. A. (1994). The constribuitions of total quality management to a theory of work performance. Academy of Management Review, 19(3), 510-536.

Waldman, D. A., \& Avolio, B. (1986). A meta-analysis of age differences in job performance. Journal of Applied Psychology, 71, 33-38. doi. 10.1037/0021-9010.71.1.33.

Wallace, C., \& Chen, G. (2006). A multilevel integration of personality, climate, selfregulation and performance. Personnel Psychology, 59(3), 529-557. doi. 10.1111/j.1744-6570.2006.00046.x.

Wallach, E. J. (1983). Individuals and organizations: The cultural match. Training and Development Journal, 37, 28-36.

Walton, E. J., \& Dawson, S. (2001). Manager's perceptions of criteria of organizational effectiveness. Journal of Management Studies, 38, 173-199. doi. 10.1111/14676486.00233.

Walumbwa, F. O., Avolio, B. J., \& Zhu, W. (2008). How transformational leadership weaves its influence on individual job performance: The role of identification and efficacy beliefs. Personnel Psychology, 61(4), 793-825. doi. 10.1111/j.1744-6570.2008.00131.x.

Watkins, M. W. (2000). Monte Carlo PCA for parallel analysis(computer software). State College, PA: Ed \& Psych Associates.

Weber, M. (1905/1958). The Protestant ethic and the spirit of capitalism. New York: Scribner's.

Weiseke, J., Ahearne, M., Lam, S. K., \& Von Dick, R. (2008). The role of leaders in internal marketing: A multilevel examination through the lens of social identity. Theory Journal of Marketing, 73(2), 123-146. 
Werner, J. M. (2000). Implications of OCB and contextual performance for human resource management. Human Resource Management Review, 10(1): 3-24. doi. 10.1016/S10534822(99)00036-4.

West, M., \& Anderson, N. (1996). Innovation in top management teams. Journal of Applied Psychology, 81, 680-693. doi. 10.1037/0021-9010.81.6.680.

West, S. G., Finch, J. F., \& Curran, P. J. (1995). Structural equation models with non-normal variables: Problems and remedies. In: Hoyle, R. H. (Org.). Structural equation modeling: Concepts, issues and aplications. Thousand Oaks: Sage.

Westbrook, T. M., Ellett, A. J., \& Asberg, K. (2012). Predicting public child welfare employees' intentions to remain employed with the child welfare organizational culture inventory. Children \& Youth Services Review, 34, 1214-1221. doi. 10.1016/j.childyouth.2012.02.010.

Whetten, A. D. \& Godfrey, P. C. (1998). Identity in organizations: Building Theory Through Conversations. London: Sage Publications.

Whiddett, S., \& Hollyforde, S. (1999). The competencies handbook. London: Institute of Personnel and Development.

Wiener, Y. (1988). Forms of value systems: a focus on organizational effectiveness and cultural change and maintenance. Academy of Management Review, 13(4), 534-545. doi. 10.5465/AMR.1988.4307410.

Wieseke, J. M., Ahearne, S. K., Lam, S. K., \& van Dick, R. (2009). The role of leaders in internal marketing. Journal of Marketing, 73, 123-145. doi:10.1509/jmkg.73.2.123.

Wilderom, C. P. M., Glunk, U., \& Maslowski, R. (2000). Organizational culture as a predictor of organizational performance. In N. Ashkanasy, C. Wilderom, \& M. Peterson (Eds.), The handbook of organizational culture and climate, p. 193-209. Thousand Oaks, CA: Sage Publications.

Wilderom, C. P. M., van den Berg, P. T., \& Wiersma, U. J. (2012). A longitudinal study of the effects of charismatic leadership and organizational culture on objective and perceived corporate performance.Leadershio Quarterly, 23(5), 835-848. doi. 10.1016/j.leaqua.2012.04.002.

Williams, L. J., \& Anderson, S. E. (1991). Job satisfaction and organizational commitment as predictors of organizational citizenship and in-role behaviors. Journal of Management, 17(3), 601-617. doi. 10.1016/j.sbspro.2010.07.225. 
Willians, D. W. (2004). Evolution of performance measurement until 1930. Administration \& Society, 36(2), 131-165. doi: 10.1177/0095399704263473.

Windsor, C., \& Ashkanasy, N. M. (1996). Auditor independence decision-making: The role of organisational culture perceptions. Behavioural Research in Accounting, 8 (Supplement), 80-97.

Winter, S. G. (2003). Mistaken perceptions: cases and consequences. British Journal of Management, 14, 39-44. doi. 10.1111/1467-8551.00263.

Wood, S. (1999). Human resource management and performance. International Journal of Management Reviews, 1, 367-413.

Wood Jr., T., Pereira Filho, J. L., \& Picarelli Filho, V. (1997). Remuneração por competências. In V. Picarelli Filho (Org.), Remuneração por habilidades e competências: preparando a organização para a era das empresas de conhecimento intensivo (pp. 121140). São Paulo: Atlas.

Woodward, K. (2004). Identidade e diferença: Uma introdução teórica e conceitual In T. T. da Silva (Ed.), Identidade e diferença: A perspectiva dos estudos culturais (3. ed., pp. 772). Petrópolis, RJ: Vozes.

Wright, P. M., Gardner, T. M., Moynihan, L. M., Park, H. J., Gerhart, B., \& Delery, J. B. (2001). Measurement error in research on human resources and firm performance: additional data and suggestions for future research. Personnel Psychology, 54, 875-901. doi. 10.1111/j.1744-6570.2001.tb00235.x.

Wright, B. E., \& Kim, S. (2004). Participation's influence on job satisfaction: the importance of job characteristics. Review of Public Personnel Administration, 24 (18), 18-40. doi. 10.1177/0734371X03259860.

Wright, B. E., Manigault, L. J., \& Black, T. R. (2004). Quantitative research measurement in public administration. An assessment of Journal Publications. Administration \& Society, 35(6), 747-764. doi. 10.1177/0095399703257266.

\section{Y}

Yarbrough, L., Morgan, N. A., \& Vorhies, D. W. (2011). The impact of product-market strategy-organizational culture fit on business performance. Journal of the Academy of Marketing Science, 39(4), 555-573. doi. 10.1007/s11747-010-0238-x.

Yesil, S. \& Kaya, A. (2013). The effect of organizational culture on firm financial performance: Evidence from a developing country. Procedia - Social and Behavioral Sciences, 81(26), 428-437. doi. 10.1016/j.sbspro.2013.06.455. 
Yeh, R. \& Lawrence, J. J. (1993). Individualism and confucian dynamism: a note on Hofstede's cultural root to economic growth. International Business Studies, Washington, v. 9, n. 3, p. 655- 669. doi. 10.1057/palgrave.jibs.8490191.

Yazici, H. J. (2010). Role of project maturity and organizational culture on project success. Paper presented at the PMI ${ }^{\circledR}$ Research and Education Conference, Washinghton DC, USA.

Yildirim, N., \& Birinci, S. (2012). Impacts of organizational culture and leadership on business performance: A case study on acquisitions. Procedia - Social and Behavioral Sciences, 75(3), 71-82. doi. 10.1016/j.sbspro.2013.04.009.

Yilmaz, C., \& Ergun, E. (2008). Organizational culture and firm effectiveness: An examination of relative effects of culture traits and the balanced culture hypothesis in an emerging economy. Journal of World Business, 43(3), 290-306. doi. 10.1016/j.jwb.2008.03.019.

$\mathbf{X}$

Xenikou, A., \& Simosi, M. (2006). Organizational culture and transformational leadership as predictors of business unit performance. Journal of Managerial Psychology, 21(6), 56679. doi. 10.1108/02683940610684409.

\section{$\mathbf{Z}$}

Zan, A. (2006). Mudanças na contabilidade gerencial de uma organização: Estudo de caso com diagnóstico institucional . Dissertação de Mestrado, Universidade de São Paulo, São Paulo.

Zarifian, P. (1996). A gestão da e pela competência. Em Anais do Seminário educação profissional, trabalho e competências. Rio de Janeiro: Centro Internacional para a educação, trabalho e transferência de tecnologia.

Zarifian, P. (1999). Objectif compétence: pour une nouvelle logique. Paris: Editions Liaisons.

Zehir, C. Ertosun, Ö. G., Zehir, S. \& Müceldili, B. (2011). The Effects of Leadership Styles and Organizational Culture over Firm Performance: Multi-National Companies in İstanbul. Procedia - Social and Behavioral Sciences, 24, 1460-1474. doi. 10.1016/j.sbspro.2011.09.032.

Zeitz, G.; Mittal, V. \& McAulay, B. (1999). Distinguishing adoption and entrenchment of management practices: A framework for analysis. Organization Studies, 20 (5), 741 - 776. doi. 10.1177/0170840699205003. 
Zhao, L., Lynch, J. G., \& Chen, Q. (2010). Reconsidering Baron and Kenny: myths and truths about mediation analysis. Journal of Consumer Research, 37(2), 197-206. doi. $10.1086 / 651257$.

Zohar, D., \& Hofmann, D. H. (2012). Organizational culture and climate. In: The Oxford Handbook of Industrial and Organizational Psychology, ed. S. W. J. Kozlowski. Oxford, UK: Oxford Univ. Press. In press.

Zonatto, V. C. S., \& Lavarda, C. E. F. (2013). Evidências dos efeitos da participação orçamentária na assimetria de informação, estresse ocupacional e desempenho no trabalho. Advances in Scientific and Applied Accounting, 6(1), 92-111.

Zwick, W. R., \& Velicer, W. F. (1986). Comparison of five rules for determining the number of components to retain. Psychological Bulletin, 99(3), 432-442. 


\section{APÊNDICE A}

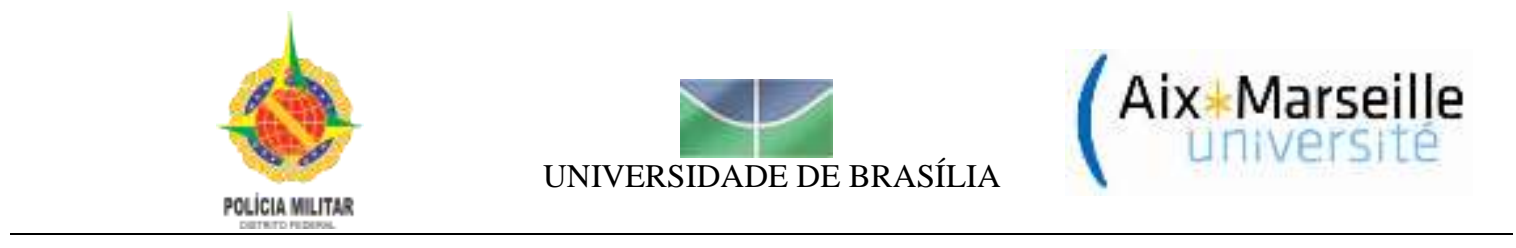

\section{Orientação Geral}

Prezado(a) Policial,

Esta é uma pesquisa da Polícia Militar do Distrito Federal em parceria com a Universidade de Brasília (UnB, Brasil) e com a Université d'Aix-Marseille (AMU, França), financiada pela Coordenação de Aperfeiçoamento de Pessoal de Nível Superior - CAPES, sobre Cultura organizacional (valores e práticas organizacionais), identidade organizacional / no trabalho e desempenho no trabalho. Estamos nos dirigindo a vossa senhoria para solicitar a sua colaboração respondendo ao questionário em anexo. Sua colaboração é fundamental para o sucesso deste trabalho.

O objetivo deste trabalho é conhecer a opinião dos(as) policiais sobre seu ambiente de trabalho. A sua participação é voluntária. Se o(a) senhor(a) decidir participar ou não, isto não afetará a sua relação atual ou futura com a equipe de pesquisa ou com a sua instituição. Queremos que o(a) senhor(a) se sinta inteiramente à vontade para dar suas opiniões. Se o(a) senhor(a) aceitar participar, pedimos que responda os questionários com duração aproximada de $20 \mathrm{~min}$. Os participantes não serão identificados e os dados fornecidos serão utilizados apenas para fins de pesquisa. Não escreva seu nome em qualquer lugar do questionário.

Por favor, responda conforme as instruções e não deixe nenhuma questão em branco.

Qualquer dúvida entre em contato com a Seção de Gestão da Qualidade do Estado-Maior, pelos telefones 3910-1292 e 3910-1293 ou com Thiago Nascimento via e-mail nascimento.g.thiago@gmail.com ou pelo telefone 61-99568925.

Os resultados da pesquisa servirão para subsidiar políticas institucionais, com foco na gestão de pessoas, além de serem divulgados em congressos científicos e revistas científicas, respeitados todos os preceitos éticos de pesquisa.

Agradecemos desde já a sua colaboração!

Atenciosamente,

Equipe de Pesquisa. 


\section{QUESTIONÁRIO I}

Este questionário traz uma lista de competências técnicas e comportamentais necessárias ao Policial Militar. As competências são descritas e direcionadas ao que se é esperado para o bom desempenho no cargo, isto é, comportamentos objetivos e observáveis no ambiente de trabalho. Por favor, avalie quão importantes são essas competências para o desempenho de sua atividade e qual é o seu domínio dessas competências.

\begin{tabular}{|c|c|}
\hline \multicolumn{2}{|c|}{ ESCALA DE RESPOSTAS PARA AS COMPETÊNCIAS } \\
\hline IMPORTÂNCIA & DOMÍNIO \\
\hline $\begin{array}{l}1 \text { = Nenhuma importância (competência irrelevante) } \\
2 \text { = Pouca importância } \\
3 \text { = Média importância } \\
4 \text { = Alta importância (competência necessária) } \\
5 \quad=\quad \text { Extrema importância (competência } \\
\text { imprescindível) }\end{array}$ & $\begin{array}{l}\text { 1 = Não tenho domínio (não possuo a competência) } \\
2 \text { = Tenho pouco domínio da competência } \\
3 \text { = Tenho médio domínio da competência } \\
4 \text { = Tenho alto domínio da competência } \\
\text { (possuo a competência) } \\
5 \text { = Tenho domínio completo da competência } \\
\text { (possuo excelência na competência) }\end{array}$ \\
\hline
\end{tabular}

\begin{tabular}{|c|c|c|c|c|c|c|c|c|c|c|}
\hline Competências Técnicas e Comportamentais & & npo & ortâ & inc & & & & $\mathbf{m}$ & inio & \\
\hline Capacidade de utilizar armas e munições, quando necessário. & 1 & 2 & 3 & 4 & 5 & 1 & 2 & 3 & 4 & 5 \\
\hline $\begin{array}{l}\text { Ser capaz de agir demostrando conhecimentos sobre legislação, normas e regimentos internos } \\
\text { aplicados à função policial militar. }\end{array}$ & 1 & 2 & 3 & 4 & 5 & 1 & 2 & 3 & 4 & 5 \\
\hline $\begin{array}{l}\text { Capacidade de identificar e gerenciar conflitos (identificar pontos de divergência e } \\
\text { convergência, procurando soluções adequadas para resolver o conflito). }\end{array}$ & 1 & 2 & 3 & 4 & 5 & 1 & 2 & 3 & 4 & 5 \\
\hline Ter capacidade de agir com criatividade e inovação. & 1 & 2 & 3 & 4 & 5 & 1 & 2 & 3 & 4 & 5 \\
\hline $\begin{array}{l}\text { Capacidade de visão sistêmica (ter compreensão do todo em uma determinada situação; ser } \\
\text { capaz de combinar partes coordenadas entre si e que formam um conjunto). }\end{array}$ & 1 & 2 & 3 & 4 & 5 & 1 & 2 & 3 & 4 & 5 \\
\hline Ser capaz de trabalhar de forma interdisciplinar. & 1 & 2 & 3 & 4 & 5 & 1 & 2 & 3 & 4 & 5 \\
\hline Capacidade de resposta imediata à sociedade, de acordo com as necessidades da mesma. & 1 & 2 & 3 & 4 & 5 & 1 & 2 & 3 & 4 & 5 \\
\hline $\begin{array}{l}\text { Capacidade de persuasão e argumentação (poder de convencimento; capacidade de argumentar } \\
\text { e contra-argumentar). }\end{array}$ & 1 & 2 & 3 & 4 & 5 & 1 & 2 & 3 & 4 & 5 \\
\hline $\begin{array}{l}\text { Ter capacidade de utilizar a experiência pessoal e profissional ao planejar ações, seguindo } \\
\text { normas, doutrina e legislações pertinentes ao âmbito da PMDF. }\end{array}$ & 1 & 2 & 3 & 4 & 5 & 1 & 2 & 3 & 4 & 5 \\
\hline Capacidade de agir com responsabilidade. & 1 & 2 & 3 & 4 & 5 & 1 & 2 & 3 & 4 & 5 \\
\hline Agir com eficiência no desempenho das atividades. & 1 & 2 & 3 & 4 & 5 & 1 & 2 & 3 & 4 & 5 \\
\hline Capacidade de tomada de decisão. & 1 & 2 & 3 & 4 & 5 & 1 & 2 & 3 & 4 & 5 \\
\hline Capacidade de agir com responsabilidade. & 1 & 2 & 3 & 4 & 5 & 1 & 2 & 3 & 4 & 5 \\
\hline Ter capacidade de manter bom relacionamento com outros servidores. & 1 & 2 & 3 & 4 & 5 & 1 & 2 & 3 & 4 & 5 \\
\hline $\begin{array}{l}\text { Capacidade de gerar resultados efetivos e de qualidade ao desempenhar as tarefas relativas ao } \\
\text { cargo. }\end{array}$ & 1 & 2 & 3 & 4 & 5 & \begin{tabular}{|l|}
1 \\
\end{tabular} & 2 & 3 & 4 & 5 \\
\hline $\begin{array}{l}\text { Capacidade de negociação (buscar consenso de ideias; demonstrar firmeza em seus } \\
\text { posicionamentos, sem ser intransigente). }\end{array}$ & 1 & 2 & 3 & 4 & 5 & 1 & 2 & 3 & 4 & 5 \\
\hline Capacidade de agir proativamente (buscar soluções de problemas demostrando determinação). & 1 & 2 & 3 & 4 & 5 & 1 & 2 & 3 & 4 & 5 \\
\hline $\begin{array}{l}\text { Capacidade de reagir a ameaças e enfrentar situações, com prudência e coragem (dominar o } \\
\text { medo em uma situação difícil; agir com cautela e precaução, procurando evitar riscos e } \\
\text { consequências desagradáveis). }\end{array}$ & 1 & 2 & 3 & 4 & 5 & 1 & 2 & 3 & 4 & 5 \\
\hline $\begin{array}{l}\text { Capacidade de agir com dinamismo (ser ativo e ágil, envolvendo-se em diversas atividades ao } \\
\text { mesmo tempo). }\end{array}$ & 1 & 2 & 3 & 4 & 5 & \begin{tabular}{|l|}
1 \\
\end{tabular} & 2 & 3 & 4 & 5 \\
\hline $\begin{array}{l}\text { Capacidade de agir com senso crítico (ter postura crítica frente à determinada situação ou } \\
\text { evento, após se cientificar das possíveis consequências). }\end{array}$ & 1 & 2 & 3 & 4 & 5 & 1 & 2 & 3 & 4 & 5 \\
\hline $\begin{array}{l}\text { Capacidade de agir com empatia (entender e colocar-se no lugar do outro, compreendendo seus } \\
\text { sentimentos e percepções / crenças gerais). }\end{array}$ & 1 & 2 & 3 & 4 & 5 & 1 & 2 & 3 & 4 & 5 \\
\hline
\end{tabular}




\begin{tabular}{|c|c|c|c|c|c|c|c|c|c|c|}
\hline $\begin{array}{l}\text { Capacidade de agir com persistência e determinação, demostrando interesse e } \\
\text { comprometimento com o trabalho. }\end{array}$ & 1 & 2 & 3 & 4 & 5 & 1 & 2 & 3 & 4 & 5 \\
\hline $\begin{array}{l}\text { Capacidade de agir com preocupação com a própria segurança (primar pela sua integridade } \\
\text { física, de forma precavida). }\end{array}$ & 1 & 2 & 3 & 4 & 5 & 1 & 2 & 3 & 4 & 5 \\
\hline Capacidade de agir com criatividade e inovação. & 1 & 2 & 3 & 4 & 5 & 1 & 2 & 3 & 4 & 5 \\
\hline Capacidade de trabalhar em equipe. & 1 & 2 & 3 & 4 & 5 & 1 & 2 & 3 & 4 & 5 \\
\hline Capacidade de comunicação. & 1 & 2 & 3 & 4 & 5 & 1 & 2 & 3 & 4 & 5 \\
\hline $\begin{array}{l}\text { Capacidade de agir com deferência (capacidade de acatar normas e agir em conformidade com } \\
\text { as mesmas). }\end{array}$ & 1 & 2 & 3 & 4 & 5 & 1 & 2 & 3 & 4 & 5 \\
\hline Capacidade de disciplina. & 1 & 2 & 3 & 4 & 5 & 1 & 2 & 3 & 4 & 5 \\
\hline
\end{tabular}

\section{QUESTIONÁRIO II}

Este questionário traz uma lista de valores organizacionais, que são princípios que guiam as práticas e normas das organizações.

Por favor, avalie quão importantes são esses valores para a organização em que você trabalha. Para isso, considere aquilo que é realmente colocado em prática por sua organização.

Para dar sua opinião, registre para cada item o número que representa a sua percepção, utilizando a escala de 0 a 10 indicada abaixo:

\begin{tabular}{|cccccccccc|}
\hline $\begin{array}{c}0 \\
\text { Nada }\end{array}$ & 1 & 2 & 3 & 4 & 5 & 6 & 7 & 8 & $9 \begin{array}{r}10 \\
\text { Exportante }\end{array}$ \\
impomente \\
importante
\end{tabular}

Lembre-se de que quanto mais próximo do 10, mais importante é o valor para a sua organização.

Ressaltamos que não se trata de uma avaliação dos seus valores pessoais, mas sim dos valores que estão presentes na organização em que você trabalha. Não há respostas certas ou erradas. Responda de acordo com a sua percepção. Não deixe nenhum item sem resposta .

\begin{tabular}{l|l}
\hline \multicolumn{1}{c|}{ A minha organização realmente considera importante... } & Grau de Importância \\
\hline 1. Autorrealização profissional dos policiais. & \\
\hline 2. Busca de novidades. & \\
\hline 3. Centralização das decisões & \\
\hline 4. A opinião dos cidadãos. & \\
\hline 5. Relações transparentes com a sociedade. & \\
\hline 6. Liderança na área de segurança pública pela introdução de ideias criativas. & \\
\hline 7. Cordialidade no relacionamento entre os policiais. & \\
\hline 8. Fidelidade às práticas consagradas da organização. & \\
\hline 9. Reconhecimento pelas outras agências policiais por seus serviços & \\
inovadores. & \\
\hline 10. Posicionamento dominante no setor de segurança pública. & \\
\hline 11. Centralização da definição das normas na alta hierarquia. & \\
\hline 12. Saúde e bem-estar dos policiais. & \\
\hline 13. Respeito à sociedade. & \\
\hline 14. Trabalho em equipe. & \\
\hline
\end{tabular}




\begin{tabular}{l|l} 
15. Obtenção de cada vez mais êxito na sua atuação. & \\
\hline 16. Evitação de erros por parte dos policiais. & \\
\hline 7. Flexibilidade. & \\
18. Respeito às leis. & \\
\hline 19. Favorecimento da PMDF em detrimento do meio ambiente. & \\
\hline 20. Respeito aos costumes da organização. & \\
21. Autonomia dos policiais na realização de tarefas. & \\
\hline 22. Cooperação entre os policiais. & \\
\hline 23. Respeito às regras da organização. & \\
\hline 24. Capacidade de inovar. & \\
\hline 25. Originalidade. & \\
\hline 26. Preocupação com o aumento da prestação dos serviços & \\
\hline 27. Obediência às normas da organização. & \\
\hline 28. Proteção do meio ambiente. & \\
\hline 29. Obediência dos policiais aos padrões de comportamento estabelecidos. & \\
\hline 30. Oportunidades iguais a todos os policiais. & \\
\hline 31. Capacidade de iniciativa. & \\
\hline 32. Subordinação às pessoas com cargos de chefia. & \\
\hline 33. Atuação dos policiais de acordo com a missão da organização. & \\
\hline 34. Ambição nas ações de segurança pública. & \\
\hline 35. Tratamento diferenciado aos ocupantes de cargos de chefia. & \\
\hline 36. Credibilidade frente aos cidadãos. & \\
\hline 37. Desenvolvimento do País e das comunidades em que atua. & \\
\hline 38. Poder concentrado nos níveis hierarquicamente superiores. & \\
\hline 39. Eliminação das ações das organizações policiais concorrentes. & \\
\hline
\end{tabular}

\section{QUESTIONÁRIO III}

Agora você deverá marcar o quanto você concorda com as frases seguintes. Utilize a escala de cinco pontos mostrada abaixo. Quanto mais próximo de cinco, mais você concorda com a afirmativa.

\begin{tabular}{|ccccc|}
\hline 1 & 2 & 3 & 4 & 5 \\
\hline $\begin{array}{c}\text { Discordo } \\
\text { totalmente }\end{array}$ & $\begin{array}{c}\text { Discordo } \\
\text { um pouco }\end{array}$ & $\begin{array}{c}\text { Concordo em } \\
\text { parte }\end{array}$ & $\begin{array}{c}\text { Concordo } \\
\text { bastante }\end{array}$ & $\begin{array}{c}\text { Concordo } \\
\text { totalmente }\end{array}$ \\
\hline
\end{tabular}

\begin{tabular}{|c|c|c|c|c|c|}
\hline Quando alguém critica minha organização é como se estiv & & 2 & 3 & & \\
\hline Tenho muito interesse no que os outros pensam sobre minha organização. & 1 & 2 & 3 & 4 & 5 \\
\hline Quando me refiro à PMDF, normalmente falo nós, ao invés de eles. & 1 & 2 & 3 & 4 & $J$ \\
\hline Quando alguém elogia a PMDF é como se estivesse me elogiando. & 1 & 2 & 3 & 4 & 5 \\
\hline Quando uma matéria na mídia faz crítica à PMDF, eu me sinto constrangido. & 1 & 2 & 3 & + & \\
\hline O sucesso da PMDF é como se fosse o meu sucesso pessoal. & & 2 & 3 & & \\
\hline
\end{tabular}


Agora responda às perguntas abaixo sobre sua identidade no trabalho, entendida como a forma de constituir um sentido para si na multiplicidade de papéis sociais, e de fazê-lo ser reconhecido por seus colegas de trabalho.

Utilize a escala de cinco pontos mostrada abaixo. Quanto mais próximo de cinco, mais você concorda com a afirmativa.

\begin{tabular}{|ccccc|}
\hline 1 & 2 & 3 & 4 & 5 \\
\hline $\begin{array}{c}\text { Discordo } \\
\text { totalmente }\end{array}$ & $\begin{array}{c}\text { Discordo } \\
\text { um pouco }\end{array}$ & $\begin{array}{c}\text { Concordo em } \\
\text { parte }\end{array}$ & $\begin{array}{c}\text { Concordo } \\
\text { bastante }\end{array}$ & $\begin{array}{c}\text { Concordo } \\
\text { totalmente }\end{array}$ \\
\hline
\end{tabular}

\begin{tabular}{|c|c|c|c|c|c|}
\hline Eu estou contente por ser um policial. & 1 & 2 & 3 & 4 & 5 \\
\hline Ser um policial é uma parte importante de minha autoimagem (de quem eu sou). & 1 & 2 & 3 & 4 & 5 \\
\hline Em minha vida diária, eu frequentemente penso sobre o significado de ser um policial. & 1 & 2 & 3 & 4 & 5 \\
\hline Em um grupo de policiais, eu realmente sinto que pertenço a esse grupo. & 1 & 2 & 3 & 4 & 5 \\
\hline Eu encontro dificuldades em formar vínculos de amizade com outros policiais. & 1 & 2 & 3 & 4 & 5 \\
\hline Eu frequentemente me arrependo de ser um policial. & 1 & 2 & 3 & 4 & 5 \\
\hline Eu frequentemente penso sobre o fato de que sou um policial. & 1 & 2 & 3 & 4 & 5 \\
\hline Eu não me sinto "conectado" com outros policiais. & 1 & 2 & 3 & 4 & 5 \\
\hline Eu me sinto bem quando eu penso sobre mim mesmo como um policial. & 1 & 2 & 3 & 4 & 5 \\
\hline Eu não me sinto bem em ser um policial. & 1 & 2 & 3 & 4 & 5 \\
\hline Eu normalmente não estou consciente do fato de que sou um policial. & 1 & 2 & 3 & 4 & 5 \\
\hline Eu sinto que me ajusto bem quando estou entre policiais. & 1 & 2 & 3 & 4 & 5 \\
\hline Eu sinto fortes vínculos com outros policiais. & 1 & 2 & 3 & 4 & 5 \\
\hline Eu tenho muito em comum com os outros policiais. & 1 & 2 & 3 & 4 & 5 \\
\hline Ser um policial tem pouco a ver como eu me sinto sobre mim mesmo. & 1 & 2 & 3 & 4 & 5 \\
\hline O fato de que eu sou um policial raramente entra em minha mente. & 1 & 2 & 3 & 4 & 5 \\
\hline Ser um policial é um importante reflexo de quem eu sou. & 1 & 2 & 3 & 4 & 5 \\
\hline Às vezes tenho sentimentos ruins só de pensar sobre o fato de que eu sou um policial. & 1 & 2 & 3 & 4 & 5 \\
\hline
\end{tabular}

\section{QUESTIONÁRIO IV}

Este questionário traz uma lista de práticas organizacionais, vistas como "ações nas organizações". Agora você deverá marcar o quanto você concorda com as frases seguintes. Utilize a escala de cinco pontos mostrada abaixo. Quanto mais próximo de cinco, mais você concorda com a afirmativa.

\begin{tabular}{|ccccc|}
\hline 1 & 2 & 3 & 4 & 5 \\
\hline $\begin{array}{c}\text { Discordo } \\
\text { totalmente }\end{array}$ & $\begin{array}{c}\text { Discordo } \\
\text { um pouco }\end{array}$ & $\begin{array}{c}\text { Concordo em } \\
\text { parte }\end{array}$ & $\begin{array}{c}\text { Concordo } \\
\text { bastante }\end{array}$ & $\begin{array}{c}\text { Concordo } \\
\text { totalmente }\end{array}$ \\
\hline
\end{tabular}

Em minha organização...

Concordância

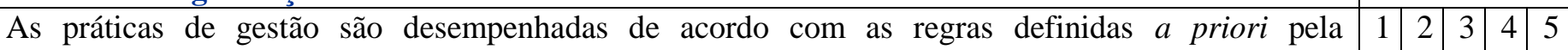
organização, independentemente dos interesse individuais.

Os profissionais envolvem-se no trabalho pelo desafio de solucionar problemas e cumprir as metas.

As equipes trabalham para alcançar resultados.

Os profissionais resistem à mudanças determinadas pela organização.

O ritmo de trabalho das equipes é definido pelos profissionais que as constituem.

Os profissionais sentem prazer nas tarefas que realizam, em seu trabalho 
Os profissionais relacionam-se no trabalho por meio de laços de amizade.

Investe-se continuamente nos profissionais para o desenvolvimento de competências.

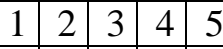

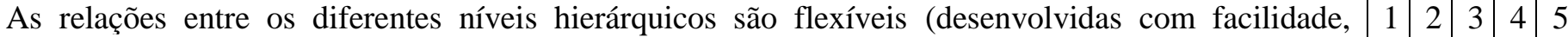
adaptáveis).

Os horários de trabalho são controlados pela organização.

Os profissionais trabalham de forma mais eficiente individualmente do que em equipe.

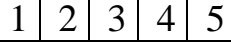

Os profissionais são promovidos de acordo com critérios estabelecidos nas normas da organização.

Os profissionais priorizam interesses pessoais aos organizacionais.

A linguagem utilizada pelas chefias estabelece distância com os demais profissionais.

Profissionais comunicam-se livremente sobre suas atividades com distintos níveis de chefia

As escalas de trabalho são respeitadas pelas chefias.

A comunicação de assuntos profissionais ocorre de maneira informal entre os diferentes níveis hierárquicos.

As relações interpessoais nas equipes de trabalho são conflituosas.

Os profissionais envolvem-se no trabalho pelo sentimento de orgulho e pertencimento à organização.

O planejamento das atividades/rotinas é um processo contínuo.

O planejamento das atividades envolve todos os profissionais da seção/unidade/setor.

A chefia interfere diretamente na forma de trabalhar dos profissionais.

As tarefas e ações são realizadas por meio de acordos e arranjos (maneira informal).

As recompensas concedidas pela organização atendem as expectativas dos profissionais.

A cooperação entre as diferentes áreas de trabalho é encorajada pela organização.

Os prazos para execução das tarefas são cumpridos.

Os profissionais estão comprometidos com o seu trabalho.

A divisão das tarefas é estabelecida mediante critérios claros.

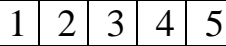

Os conflitos são resolvidos, formalmente, utilizando-se as regras da organização.

Os profissionais são recompensados pelo bom desempenho no trabalho.

Os profissionais trabalham sentindo-se membros de uma equipe.

O ambiente da organização estimula os profissionais a serem mais efetivos no trabalho.

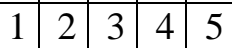



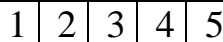

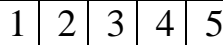

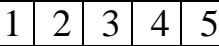

$\begin{array}{llllll}1 & 2 & 3 & 4 & 5\end{array}$

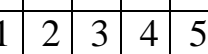

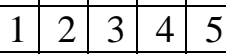

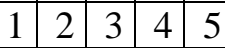

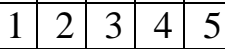

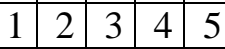

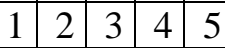

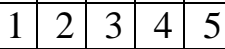

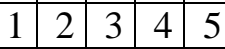

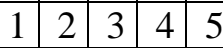



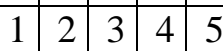

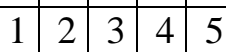

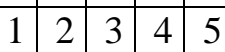

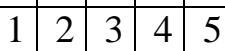

As regras sobre a operacionalização do trabalho são elaboradas com a participação dos profissionais.

Para realizar as tarefas os profissionais são escolhidos pelas competências necessárias à execução das mesmas.

Os profissionais envolvem-se no trabalho visando o alcance de resultados.

Os profissionais concordam com os critérios de controle da execução das tarefas.

As tarefas (atividades) são realizadas por meio das equipes.

Os profissionais são valorizados no trabalho.

Os profissionais criam novas práticas no trabalho.

As chefias delegam autoridade aos profissionais.

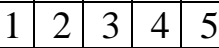

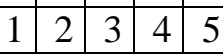

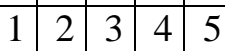

A avaliação dos profissionais é realizada de forma imparcial.

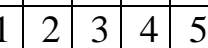

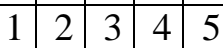

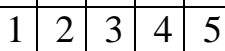

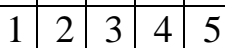

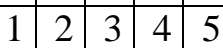

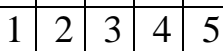



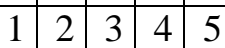

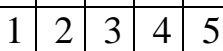

Os profissionais respeitam-se uns aos outros.

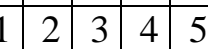

As distintas unidades (departamentos) da organização trabalham de forma integrada.

$\begin{array}{lllllll}1 & 2 & 3 & 4 & 5\end{array}$

Os profissionais aceitam o controle de seu desempenho.

Para finalizar, gostaríamos de pedir-lhe algumas informações demográficas.

Sexo: $\square$ Masculino

Idade: anos

Tempo de serviço:

Feminino 
Tempo no Posto ou na Graduação anos

Unidade em que trabalha

Tempo na Unidade em que trabalha: anos

Tempo desde o último curso feito em sua organização ou pago por sua organização: anos

Quantidade de filhos:

$\square$ Nenhum $\quad \square 1 \quad \square 2 \quad \square 3 \quad \square 4 \quad \square 5$ ou mais

Qual seu grau de religiosidade? Circule a resposta.

Nada religioso(a) 1

$2 \quad 3 \quad 4$

5 Totalmente religioso(a)

Estado Civil:

$\square$ Casado (a)

$\square$ Divorciado (a)

$\square$ Separado (a)

Solteiro (a)

$\square$ União estável

Viúvo

\section{Religião:}

$\square$ Católico (a)

$\square$ Evangélico (a)

$\square$ Protestante

$\square$ Espírita

Religiões afro-brasileiras

Sem religião

$\square$ Outra: 


\section{Escolaridade:}

$\square$ Ensino Fundamental incompleto

$\square$ Ensino Fundamental completo

$\square$ Ensino Médio incompleto

$\square$ Ensino Médio completo

$\square$ Graduação incompleta

$\square$ Graduação completa

$\square$ Especialização incompleta

$\square$ Especialização completa

$\square$ Mestrado incompleto

$\square$ Mestrado completo

$\square$ Doutorado incompleto

$\square$ Doutorado completo

\section{Posto ou Graduação:}

$\square$ Coronel

Tenente-Coronel

$\square$ Subtenente

$\square$ Major

$\square 1^{\circ}$ Sargento

$\square$ Capitão

$\square 2^{\circ}$ Sargento

$\square 1^{\circ}$ Tenente

$\square 3^{\circ}$ Sargento

$\square 2^{\circ}$ Tenente

$\square$ Cabo

$\square$ Cadete

$\square$ Soldado

\section{Quadro:}

$\square$ QOPM $\square$ QOPMA/E/M $\quad \square$ QOPMSM/D/V $\square$ QPPMC $\quad \square$ Outro

Muito obrigado por sua participação! 


\section{APÊNDICE B}

\section{Resultados das Análises Preliminares de Adequação dos Dados para a Análise Multivariada.}

Para cada escala, apresenta-se as estatísticas univariadas (média, desvio padrão, assimetria e curtose), os resultados da análise normalidade dos dados (teste KolmogorovSmirnov e Shapiro-Wilk) e multicolinearidade entre variáveis (VIF).

Escala de Valores Organizacionais

\begin{tabular}{|c|c|c|c|c|c|c|c|c|c|}
\hline \multicolumn{10}{|c|}{ Descriptive Statistics } \\
\hline & $\mathrm{N}$ & Minimum & Maximum & Mean & $\begin{array}{c}\text { Std. } \\
\text { Deviation }\end{array}$ & \multicolumn{2}{|c|}{ Skewness } & \multicolumn{2}{|c|}{ Kurtosis } \\
\hline & Statistic & Statistic & Statistic & Statistic & Statistic & Statistic & Std. Error & Statistic & Std. Error \\
\hline $\mathrm{VOI}$ & 916 & 0 & 10 & 5,75 & 3,307 &,- 144 &, 081 & $-1,258$ &, 161 \\
\hline VO2 & 916 & 0 & 10 & 5,71 & 2,677 &,- 087 & 081 &,- 907 &, 161 \\
\hline VO3 & 916 & 0 & 10 & 6,57 & 2,764 &,- 473 & 081 &,- 630 &, 161 \\
\hline VO4 & 916 & 0 & 10 & 6,16 & 2,599 &,- 272 & 081 &,- 585 &, 161 \\
\hline v05 & 916 & 0 & 10 & 6,41 & 2,649 &,- 275 & 081 &,- 790 &, 161 \\
\hline V06 & 916 & 0 & 10 & 6,15 & 2,625 &,- 279 & 081 &,- 715 &, 161 \\
\hline vo7 & 916 & 0 & 10 & 6,98 & 2,612 &,- 543 & 081 &,- 667 &, 161 \\
\hline VO8 & 916 & 0 & 10 & 6,64 & 2,479 &,- 460 & 081 &,- 487 & , 161 \\
\hline VO9 & 916 & 0 & 10 & 5,92 & 2,703 &,- 290 & 081 &,- 698 &, 161 \\
\hline VO10 & 916 & 0 & 10 & 6,44 & 2,633 &,- 449 & 081 &,- 568 & , 161 \\
\hline VO11 & 916 & 0 & 10 & 6,75 & 2,773 &,- 614 & 081 &,- 527 & , 161 \\
\hline v012 & 916 & 0 & 10 & 6,32 & 3,199 &,- 291 &, 081 & $-1,207$ &, 161 \\
\hline V013 & 916 & 0 & 10 & 7,29 & 2,518 &,- 702 & 081 &,- 284 & , 161 \\
\hline VO14 & 916 & 0 & 10 & 7,22 & 2,481 &,- 651 & ,081 &,- 379 &, 161 \\
\hline v015 & 916 & 0 & 10 & 7,01 & 2,486 &,- 568 & 081 &,- 428 &, 161 \\
\hline V016 & 916 & 0 & 10 & 7,11 & 2,488 &,- 608 & ,081 &,- 389 &, 161 \\
\hline v017 & 916 & 0 & 10 & 6,03 & 2,727 &,- 364 & 081 &,- 760 & , 161 \\
\hline V018 & 916 & 0 & 10 & 7,92 & 2,308 & $-1,217$ & ,081 & ,985 &, 161 \\
\hline V019 & 916 & 0 & 10 & 5,30 & 3,063 &,- 221 & 081 &,- 971 &, 161 \\
\hline VO20 & 916 & 0 & 10 & 6,93 & 2,442 &,- 649 & 081 &,- 205 & , 161 \\
\hline VO2 1 & 916 & 0 & 10 & 6,00 & 2,811 &,- 299 &, 081 &,- 909 &, 161 \\
\hline VO22 & 916 & 0 & 10 & 7,13 & 2,468 &,- 602 &, 081 &,- 436 &, 161 \\
\hline VO23 & 916 & 0 & 10 & 7,46 & 2,314 &,- 872 &, 081 & ,274 &, 161 \\
\hline VO24 & 916 & 0 & 10 & 6,03 & 2,736 &,- 309 &, 081 &,- 767 &, 161 \\
\hline VO25 & 916 & 0 & 10 & 5,85 & 2,717 &,- 230 & ,081 &,- 764 &, 161 \\
\hline VO26 & 916 & 0 & 10 & 6,41 & 2,605 &,- 427 &, 081 &,- 545 &, 161 \\
\hline VO27 & 916 & 0 & 10 & 7,44 & 2,326 &,- 829 & ,081 &, 152 &, 161 \\
\hline VO2 8 & 916 & 0 & 10 & 7,01 & 2,601 &,- 638 & ,081 &,- 399 &, 161 \\
\hline VO29 & 916 & 0 & 10 & 7,25 & 2,334 &,- 725 & ,081 & ,009 &, 161 \\
\hline VO30 & 916 & 0 & 10 & 5,56 & 3,579 &,- 129 & ,081 & $-1,410$ &, 161 \\
\hline VO31 & 916 & 0 & 10 & 6,13 & 2,779 &,- 331 &, 081 &,- 795 &, 161 \\
\hline V032 & 916 & 0 & 10 & 7,48 & 2,340 &,- 955 & ,081 & ,394 &, 161 \\
\hline VO33 & 916 & 0 & 10 & 7,18 & 2,262 &,- 623 &, 081 &,- 117 &, 161 \\
\hline V034 & 916 & 0 & 10 & 6,53 & 2,389 &,- 479 & 081 &,- 237 &, 161 \\
\hline VO35 & 916 & 0 & 10 & 6,59 & 3,022 &,- 676 &, 081 &,- 545 &, 161 \\
\hline V036 & 916 & 0 & 10 & 6,85 & 2,723 &,- 579 & 081 &,- 505 &, 161 \\
\hline V037 & 916 & 0 & 10 & 6,47 & 2,687 &,- 389 &, 081 &,- 615 &, 161 \\
\hline V038 & 916 & 0 & 13 & 6,97 & 2,935 &,- 809 &, 081 &,- 344 &, 161 \\
\hline VO39 & 916 & -3 & 12 & 4,46 & 3,017 &, 040 &, 081 &,- 964 &, 161 \\
\hline Valid N (listwise) & 916 & & & & & & & & \\
\hline
\end{tabular}




\begin{tabular}{|c|c|c|c|c|c|c|}
\hline \multicolumn{7}{|c|}{ Tests of Normality } \\
\hline & \multicolumn{3}{|c|}{ Kolmogorov-Smirnov $^{\mathrm{a}}$} & \multicolumn{3}{|c|}{ Shapiro-Wilk } \\
\hline & Statistic & df & Sig. & Statistic & df & Sig. \\
\hline VO1 &, 128 & 916 & 000 & 913 & 916 & ,000 \\
\hline VO2 & 111, & 916 & ,000 & 959 & 916 & ,000, \\
\hline VO3 & 133, & 916 & ,000 & 923, & 916 & ,000 \\
\hline VO4 &, 123 & 916 &, 000 & ,951 & 916 & 000 \\
\hline vO5 & 113 & 916 & 000 & 941 & 916 & 000 \\
\hline VO6 & 116 & 916 & ,000 & 953, & 916 & ,000, \\
\hline vO7 & , 154 & 916 &, 000 & 912, & 916 & ,000 \\
\hline vO8 & 144 & 916 &, 000 & ,942 & 916 &, 000 \\
\hline vO9 & 113 & 916 &, 000 & ,956 & 916 & 000 \\
\hline VO10 & 133 & 916 &, 000 & ,942 & 916 & 000 \\
\hline V011 & 155 & 916 &, 000 & ,914 & 916 & 000 \\
\hline v012 & , 169 & 916 &, 000 & ,894 & 916 & , 000 \\
\hline v013 & 149 & 916 &, 000 &, 895 & 916 & 000 \\
\hline VO14 & 149 & 916 & ,000 & ,905 & 916 & 000 \\
\hline v015 & 145 & 916 &, 000 & ,922 & 916 & 000 \\
\hline vO16 & , 148 & 916 &, 000 & ,913 & 916 &, 000 \\
\hline v017 & 127 & 916 &, 000 & ,949 & 916 & 000 \\
\hline VO18 & 193 & 916 &, 000 & ,835 & 916 & ,000 \\
\hline vO19 & 110 & 916 & 000 & 941 & 916 & 000 \\
\hline VO20 & 152 & 916 & ,000 & 927, & 916 & 000 \\
\hline VO2 1 & 129 & 916 & ,000 & 946, & 916 & ,000 \\
\hline VO22 & 155 & 916 & ,000 & 914 & 916 & ,000 \\
\hline VO23 & 170 & 916 & ,000 & ,896 & 916 & ,000 \\
\hline VO24 & 114 & 916 & ,000 & 951 & 916 & ,000 \\
\hline VO25 & 101 & 916 & ,000 & 957, & 916 & ,000 \\
\hline VO26 & 138 & 916 & ,000 & 943, & 916 & ,000 \\
\hline VO27 & 163 & 916 & ,000 & ,897 & 916 & ,000 \\
\hline VO28 & 149 & 916 & 000 & 910 & 916 & ,000 \\
\hline VO29 & 154 & 916 & 000 & 914 & 916 & 000 \\
\hline VO30 & 140 & 916 & ,000 & 890 & 916 & ,000 \\
\hline VO3 1 & 123, & 916 & ,000 & ,945 & 916 & ,000 \\
\hline V032 & 196 & 916 & 000 & ,888 & 916 & 000 \\
\hline VO33 & 156 & 916 & 000 & 924 & 916 & 000 \\
\hline VO34 & 130 & 916 & ,000 & 948 & 916 & ,000 \\
\hline VO35 & 157 & 916 & ,000 & ,898 & 916 & ,000 \\
\hline v036 & 134 & 916 & 000 & 913 & 916 & 000 \\
\hline VO37 & 122 & 916 & 000 & 935 & 916 & 000 \\
\hline VO38 & 175, & 916 & ,000 & ,882 & 916 & ,000 \\
\hline VO39 & , 112 & 916 &, 000 &, 950 & 916 & ,000 \\
\hline
\end{tabular}

a. Lilliefors Significance Correction

\begin{tabular}{|c|c|c|c|}
\hline \multicolumn{4}{|c|}{ Coefficients $^{a}$} \\
\hline \multirow{2}{*}{\multicolumn{2}{|c|}{ Model }} & \multicolumn{2}{|c|}{ Collinearity Statistics } \\
\hline & & Tolerance & VIF \\
\hline 1 & $\mathrm{VO1}$ &, 262 & 3,818 \\
\hline & VO2 &, 270 & 3,705 \\
\hline & VO3 &, 572 & 1,750 \\
\hline & VO4 & , 499 & 2,004 \\
\hline & VO5 &, 312 & 3,202 \\
\hline & VO6 &, 251 & 3,991 \\
\hline & V07 & ,266 & 3,754 \\
\hline & v08 &, 424 & 2,361 \\
\hline & VO9 & ,346 & 2,887 \\
\hline & VO10 & ,399 & 2,507 \\
\hline & VO11 &, 457 & 2,187 \\
\hline & vo12 &, 264 & 3,792 \\
\hline & VO13 & ,276 & 3,617 \\
\hline & VO14 &, 288 & 3,478 \\
\hline & VO15 & ,246 & 4,069 \\
\hline & VO16 &, 324 & 3,086 \\
\hline & VO17 & 310 & 3,228 \\
\hline & VO18 &, 526 & 1,901 \\
\hline & vo19 & ,695 & 1,439 \\
\hline & VO20 & ,403 & 2,482 \\
\hline & VO21 & ,323 & 3,100 \\
\hline & VO22 & ,274 & 3,651 \\
\hline & VO23 &, 310 & 3,225 \\
\hline & VO24 & , 172 & 5,805 \\
\hline & VO25 & ,239 & 4,187 \\
\hline & VO26 & ,403 & 2,482 \\
\hline & VO27 &, 276 & 3,622 \\
\hline & VO28 & , 414 & 2,417 \\
\hline & VO29 & ,351 & 2,851 \\
\hline & VO30 & ,246 & 4,063 \\
\hline & VO31 & ,226 & 4,415 \\
\hline & VO32 &, 527 & 1,897 \\
\hline & VO33 & ,357 & 2,803 \\
\hline & vO34 & , 438 & 2,282 \\
\hline & VO35 &, 480 & 2,083 \\
\hline & v036 & ,337 & 2,965 \\
\hline & V037 & ,299 & 3,343 \\
\hline & VO38 &, 412 & 2,427 \\
\hline & VO39 & ,691 & 1,446 \\
\hline
\end{tabular}

a. Dependent Variable: Sujeitos 
Escala de Práticas Organizacionais

\begin{tabular}{|c|c|c|c|c|c|c|c|c|c|}
\hline \multicolumn{10}{|c|}{ Descriptive Statistics } \\
\hline & $\mathrm{N}$ & Minimum & Maximum & Mean & $\begin{array}{c}\text { Std. } \\
\text { Deviation }\end{array}$ & \multicolumn{2}{|c|}{ Skewness } & \multicolumn{2}{|c|}{ Kurtosis } \\
\hline & Statistic & Statistic & Statistic & Statistic & Statistic & Statistic & Std. Error & Statistic & Std. Error \\
\hline $\mathrm{PO1}$ & 916 & 1 & 5 & 2,91 & 1,210 &, 064 &, 081 &,- 795 &, 161 \\
\hline $\mathrm{PO} 2$ & 916 & 1 & 6 & 3,07 & 1,023 &,- 029 &, 081 &,- 333 &, 161 \\
\hline $\mathrm{PO} 3$ & 916 & 1 & 5 & 3,31 & 1,054 &,- 217 &, 081 &,- 480 &, 161 \\
\hline $\mathrm{PO} 4$ & 916 & 1 & 5 & 3,05 & ,969 &,- 104 &, 081 &,- 176 &, 161 \\
\hline PO5 & 916 & 1 & 5 & 3,53 & 1,088 &,- 519 &, 081 &,- 261 &, 161 \\
\hline PO6 & 916 & 1 & 5 & 3,08 & ,963 &, 004 &, 081 &,- 015 &, 161 \\
\hline PO7 & 916 & 1 & 5 & 3,40 & ,923 &,- 335 & ,081 &,- 026 &, 161 \\
\hline PO8 & 916 & 1 & 5 & 2,55 & 1,149 & ,307 &, 081 &,- 733 &, 161 \\
\hline PO9 & 916 & 1 & 6 & 2,60 & 1,121 & ,139 &, 081 &,- 818 &, 161 \\
\hline PO10 & 916 & 1 & 6 & 3,94 & 1,011 &,- 834 & ,081 &, 445 &, 161 \\
\hline PO11 & 916 & 0 & 5 & 2,40 & 1,097 &, 355 & ,081 &,- 640 &, 161 \\
\hline PO12 & 916 & 1 & 6 & 3,33 & 1,306 &,- 355 &, 081 &,- 921 &, 161 \\
\hline PO13 & 916 & 1 & 5 & 3,02 & 1,091 &,- 101 & ,081 &,- 456 &, 161 \\
\hline PO14 & 916 & 1 & 6 & 3,32 & 1,095 &,- 170 & ,081 &,- 611 &, 161 \\
\hline PO15 & 916 & 1 & 5 & 2,70 & 1,112 & ,114 &, 081 &,- 686 &, 161 \\
\hline PO16 & 916 & 1 & 5 & 3,06 & 1,155 &,- 207 &, 081 &,- 743 &, 161 \\
\hline PO17 & 916 & 1 & 5 & 2,79 & 1,043 &,- 038 &, 081 &,- 493 &, 161 \\
\hline PO18 & 916 & 1 & 6 & 3,15 & ,949 &,- 216 &, 081 &,- 173 &, 161 \\
\hline PO19 & 916 & 1 & 5 & 3,05 & ,954 &,- 088 &, 081 &,- 351 &, 161 \\
\hline $\mathrm{PO} 20$ & 916 & 1 & 5 & 3,02 & 1,061 &,- 112 & ,081 &,- 510 &, 161 \\
\hline $\mathrm{PO} 21$ & 916 & 1 & 5 & 2,70 & 1,165 & , 154 &, 081 &,- 834 &, 161 \\
\hline $\mathrm{PO} 22$ & 916 & 1 & 5 & 3,63 & 1,048 &,- 447 &, 081 &,- 280 &, 161 \\
\hline $\mathrm{PO} 23$ & 916 & 0 & 5 & 2,69 & 1,047 &, 067 &, 081 &,- 557 &, 161 \\
\hline $\mathrm{PO} 24$ & 916 & 1 & 5 & 2,41 & 1,096 & ,355 &, 081 &,- 574 & , 161 \\
\hline $\mathrm{PO} 25$ & 916 & 1 & 5 & 2,70 & 1,034 &, 086 &, 081 &,- 501 &, 161 \\
\hline PO26 & 916 & 1 & 5 & 3,14 & 995 &,- 172 &, 081 &,- 268 &, 161 \\
\hline $\mathrm{PO} 27$ & 916 & 1 & 5 & 3,25 & 947 &,- 252 &, 081 &,- 133 &, 161 \\
\hline $\mathrm{PO} 28$ & 916 & 1 & 5 & 2,90 & 1,032 &, 045 &, 081 &,- 392 &, 161 \\
\hline PO29 & 916 & 1 & 5 & 3,17 & 1,013 &,- 148 & ,081 &,- 244 &, 161 \\
\hline PO30 & 916 & 0 & 5 & 2,53 & 1,101 & ,229 & ,081 &,- 615 &, 161 \\
\hline PO31 & 916 & 1 & 5 & 3,04 & ,952 &,- 135 &, 081 &,- 185 &, 161 \\
\hline PO32 & 916 & 1 & 5 & 2,67 & 1,101 & , 175 & ,081 &,- 597 &, 161 \\
\hline PO33 & 916 & 1 & 5 & 2,49 & 1,070 & ,252 &, 081 &,- 635 &, 161 \\
\hline PO34 & 916 & 1 & 5 & 2,57 & 1,141 & ,223 & ,081 &,- 765 &, 161 \\
\hline PO35 & 916 & 1 & 5 & 3,07 & ,972 &,- 096 &, 081 &,- 210 &, 161 \\
\hline PO36 & 916 & 1 & 5 & 2,81 & 909, &,- 034 &, 081 &,- 034 &, 161 \\
\hline PO37 & 916 & 1 & 5 & 3,25 & 902 &,- 211 &, 081 &, 118 &, 161 \\
\hline PO3 8 & 916 & 1 & 5 & 2,46 & 1,123 &, 316 &, 081 &,- 677 &, 161 \\
\hline PO39 & 916 & 1 & 5 & 2,81 & ,987 &,- 013 & ,081 &,- 336 &, 161 \\
\hline $\mathrm{PO} 40$ & 916 & 1 & 5 & 2,98 & 1,027 &,- 098 &, 081 &,- 384 &, 161 \\
\hline PO4 1 & 916 & 1 & 5 & 2,68 & 1,115 & , 186 &, 081 &,- 632 &, 161 \\
\hline $\mathrm{PO} 42$ & 916 & 0 & 5 & 2,58 & 1,160 & ,231 &, 081 &,- 728 &, 161 \\
\hline $\mathrm{PO} 43$ & 916 & 1 & 6 & 3,40 & ,914 &,- 235 &, 081 & ,092 &, 161 \\
\hline $\mathrm{PO} 44$ & 916 & 1 & 6 & 2,75 & 1,058 & ,113 & ,081 &,- 444 &, 161 \\
\hline $\mathrm{PO} 45$ & 916 & 1 & 5 & 2,89 & ,969 &,- 017 &, 081 &,- 108 &, 161 \\
\hline Valid N (listwise) & 916 & & & & & & & & \\
\hline
\end{tabular}




\begin{tabular}{|c|c|c|c|c|c|c|}
\hline \multicolumn{7}{|c|}{ Tests of Normality } \\
\hline & \multicolumn{3}{|c|}{ Kolmogorov-Smirnov $^{\mathrm{a}}$} & \multicolumn{3}{|c|}{ Shapiro-Wilk } \\
\hline & Statistic & $\mathrm{df}$ & Sig. & Statistic & df & Sig. \\
\hline $\mathrm{PO1}$ &, 168 & 916 &, 000 &, 916 & 916 &, 000 \\
\hline $\mathrm{PO} 2$ & ,208 & 916 &, 000 &, 912 & 916 &, 000 \\
\hline $\mathrm{PO} 3$ &, 179 & 916 &, 000 &, 911 & 916 &, 000 \\
\hline $\mathrm{PO} 4$ &, 226 & 916 &, 000 &, 904 & 916 &, 000 \\
\hline PO5 &, 216 & 916 &, 000 &, 895 & 916 &, 000 \\
\hline PO6 &, 242 & 916 &, 000 &, 896 & 916 &, 000 \\
\hline PO7 &, 213 & 916 &, 000 &, 891 & 916 &, 000 \\
\hline PO8 &, 183 & 916 &, 000 &, 905 & 916 &, 000 \\
\hline PO9 &, 179 & 916 &, 000 &, 905 & 916 &, 000 \\
\hline PO10 &, 221 & 916 &, 000 &, 848 & 916 &, 000 \\
\hline PO11 &, 184 & 916 &, 000 &, 898 & 916 & ,000 \\
\hline PO12 &, 182 & 916 & ,000 &, 897 & 916 & ,000 \\
\hline PO13 & ,212 & 916 & ,000 & ,912 & 916 & ,000 \\
\hline PO14 & ,176 & 916 & ,000 & ,915 & 916 & ,000 \\
\hline PO15 & ,183 & 916 & ,000 & ,912 & 916 & ,000 \\
\hline PO16 &, 180 & 916 &, 000 & ,912 & 916 & ,000 \\
\hline PO17 & ,221 & 916 & ,000 & ,908 & 916 & ,000 \\
\hline PO18 & ,211 & 916 & ,000 & ,902 & 916 & ,000 \\
\hline PO19 & ,202 & 916 &, 000 & ,907 & 916 & ,000 \\
\hline PO20 & , 197 & 916 & ,000 & ,915 & 916 & ,000 \\
\hline PO21 &, 165 & 916 &, 000 &, 914 & 916 &, 000 \\
\hline PO22 & , 197 & 916 & ,000 &, 891 & 916 & ,000 \\
\hline PO23 & , 199 & 916 & ,000 & ,913 & 916 & ,000 \\
\hline PO24 & ,173 & 916 &, 000 & ,895 & 916 & ,000 \\
\hline PO25 & 203 & 916 &, 000 & ,909 & 916 & ,000 \\
\hline PO26 & 208 & 916 & ,000 & ,908 & 916 & ,000 \\
\hline $\mathrm{PO} 27$ & ,205 & 916 &, 000 & ,900 & 916 & ,000 \\
\hline PO2 8 & ,203 & 916 &, 000 & ,912 & 916 & ,000 \\
\hline PO29 & ,211 & 916 &, 000 & ,908 & 916 & ,000 \\
\hline PO30 &, 184 & 916 &, 000 & ,906 & 916 & ,000 \\
\hline PO31 & ,222 & 916 &, 000 & ,903 & 916 & ,000 \\
\hline PO32 &, 184 & 916 &, 000 & ,912 & 916 & ,000 \\
\hline P033 &, 180 & 916 & ,000 & ,902 & 916 & ,000 \\
\hline PO34 & ,171 & 916 &, 000 & ,904 & 916 & ,000 \\
\hline PO35 & ,217 & 916 &, 000 & ,905 & 916 & ,000 \\
\hline PO36 & ,247 & 916 &, 000 & ,892 & 916 & ,000 \\
\hline PO37 & ,228 & 916 &, 000 &, 889 & 916 & ,000 \\
\hline PO38 & , 170 & 916 &, 000 &, 898 & 916 & ,000 \\
\hline PO39 & ,220 & 916 &, 000 & ,907 & 916 & ,000 \\
\hline $\mathrm{PO} 40$ & ,213 & 916 &, 000 & ,910 & 916 & ,000 \\
\hline PO4 1 & , 177 & 916 &, 000 & ,911 & 916 & ,000 \\
\hline $\mathrm{PO} 42$ & ,173 & 916 &, 000 & ,907 & 916 & ,000 \\
\hline PO43 & ,220 & 916 &, 000 &, 890 & 916 & ,000 \\
\hline PO44 & , 197 & 916 &, 000 & ,916 & 916 & ,000 \\
\hline $\mathrm{PO} 45$ & ,233 & 916 &, 000 & ,902 & 916 &, 000 \\
\hline
\end{tabular}

a. Lilliefors Significance Correction

\begin{tabular}{|c|c|c|c|}
\hline \multicolumn{4}{|c|}{ Coefficients $^{\mathrm{a}}$} \\
\hline \multirow{2}{*}{\multicolumn{2}{|c|}{ Model }} & \multicolumn{2}{|c|}{ Collinearity Statistics } \\
\hline & & Tolerance & VIF \\
\hline 1 & PO1 & ,673 & 1,487 \\
\hline & $\mathrm{PO2}$ & ,404 & 2,473 \\
\hline & $\mathrm{PO3}$ &, 400 & 2,502 \\
\hline & $\mathrm{PO} 4$ & ,710 & 1,408 \\
\hline & PO5 & 744 & 1,345 \\
\hline & PO6 &, 523 & 1,914 \\
\hline & PO7 & 672 & 1,488 \\
\hline & PO8 &, 480 & 2,083 \\
\hline & PO9 & ,471 & 2,123 \\
\hline & PO10 & ,716 & 1,397 \\
\hline & POII & ,688 & 1,454 \\
\hline & $\mathrm{PO} 12$ & ,743 & 1,345 \\
\hline & PO13 & ,756 & 1,323 \\
\hline & PO14 & ,756 & 1,322 \\
\hline & PO15 &, 599 & 1,669 \\
\hline & PO16 &, 588 & 1,701 \\
\hline & PO17 & ,709 & 1,411 \\
\hline & PO18 & ,683 & 1,465 \\
\hline & PO19 & ,509 & 1,963 \\
\hline & $\mathrm{PO} 20$ & ,476 & 2,102 \\
\hline & PO21 & ,434 & 2,304 \\
\hline & $\mathrm{PO} 22$ & ,786 & 1,272 \\
\hline & PO23 & ,692 & 1,446 \\
\hline & $\mathrm{PO} 24$ & ,413 & 2,420 \\
\hline & PO25 & ,433 & 2,310 \\
\hline & PO26 &, 565 & 1,771 \\
\hline & PO27 & ,485 & 2,060 \\
\hline & PO28 & ,454 & 2,203 \\
\hline & PO29 &, 598 & 1,672 \\
\hline & PO30 & ,402 & 2,488 \\
\hline & PO31 & ,401 & 2,492 \\
\hline & PO32 & ,382 & 2,616 \\
\hline & PO33 & ,345 & 2,902 \\
\hline & PO34 &, 426 & 2,346 \\
\hline & PO35 & ,393 & 2,544 \\
\hline & PO36 & ,383 & 2,611 \\
\hline & PO37 &, 517 & 1,933 \\
\hline & PO38 & ,321 & 3,114 \\
\hline & PO39 &, 578 & 1,731 \\
\hline & PO40 & ,616 & 1,624 \\
\hline & PO4 1 & ,470 & 2,129 \\
\hline & $\mathrm{PO} 42$ & 799 & 1,252 \\
\hline & $\mathrm{PO} 43$ &, 585 & 1,709 \\
\hline & $\mathrm{PO} 44$ & ,440 & 2,271 \\
\hline & $\mathrm{PO} 45$ &, 537 & 1,862 \\
\hline
\end{tabular}

a. Dependent Variable: Sujeitos 
Escala de Identidade Profissional

\begin{tabular}{|c|c|c|c|c|c|c|c|c|c|}
\hline \multicolumn{10}{|c|}{ Descriptive Statistics } \\
\hline & $\mathrm{N}$ & Minimum & Maximum & Mean & $\begin{array}{c}\text { Std. } \\
\text { Deviation }\end{array}$ & \multicolumn{2}{|c|}{ Skewness } & \multicolumn{2}{|c|}{ Kurtosis } \\
\hline & Statistic & Statistic & Statistic & Statistic & Statistic & Statistic & Std. Error & Statistic & Std. Error \\
\hline IP1 & 916 & 1 & 5 & 3,75 & 1,106 &,- 591 & 081 &,- 365 &, 161 \\
\hline IP2 & 916 & 1 & 5 & 3,72 & 1,060 &,- 615 &, 081 &,- 124 &, 161 \\
\hline IP3 & 916 & 1 & 5 & 3,61 & 1,046 &,- 543 &, 081 &,- 175 &, 161 \\
\hline IP4 & 916 & 1 & 5 & 3,81 & 1,010 &,- 597 &, 081 &,- 135 &, 161 \\
\hline IP5 & 916 & 1 & 5 & 2,14 & 1,182 & ,766 & ,081 &,- 406 &, 161 \\
\hline IP6 & 916 & -1 & 5 & 1,85 & 1,129 & 1,111 &, 081 &, 255 &, 161 \\
\hline IP7 & 916 & 1 & 7 & 3,29 & 1,155 &,- 346 & ,081 &,- 462 & , 161 \\
\hline IP8 & 916 & -1 & 5 & 2,15 & 1,173 & ,636 &, 081 &,- 560 &, 161 \\
\hline IP9 & 916 & 1 & 6 & 3,72 & 1,090 &,- 621 &, 081 &,- 266 & , 161 \\
\hline IP10 & 916 & 1 & 6 & 1,92 & 1,212 & 1,122 & ,081 &, 148 &, 161 \\
\hline IP11 & 916 & 1 & 5 & 1,77 & 1,122 & 1,350 & ,081 & ,788 &, 161 \\
\hline IP12 & 916 & 1 & 5 & 3,78 & ,960 &,- 582 &, 081 & ,103 &, 161 \\
\hline IP13 & 916 & 1 & 5 & 3,48 & 1,022 &,- 331 & ,081 &,- 399 &, 161 \\
\hline IP14 & 916 & 1 & 5 & 3,46 & ,971 &,- 325 & ,081 &,- 147 &, 161 \\
\hline IP15 & 916 & 1 & 5 & 2,40 & 1,202 &, 425 & ,081 &,- 798 &, 161 \\
\hline IP16 & 916 & 0 & 5 & 1,85 & 1,097 & 1,105 & ,081 & ,312 &, 161 \\
\hline IP17 & 916 & 1 & 5 & 3,58 & 1,085 &,- 525 &, 081 &,- 282 &, 161 \\
\hline IP18 & 916 & 1 & 5 & 1,92 & 1,215 & 1,097 &, 081 &, 032 & , 161 \\
\hline Valid N (listwise) & 916 & & & & & & & & \\
\hline
\end{tabular}

Tests of Normality

\begin{tabular}{|l|c|c|c|r|r|r|}
\hline & \multicolumn{3}{|c|}{ Kolmogorov-Smirnov $^{\text {a }}$} & \multicolumn{3}{|c|}{ Shapiro-Wilk } \\
\cline { 2 - 7 } & Statistic & \multicolumn{1}{c|}{ df } & \multicolumn{1}{c|}{ Sig. } & Statistic & \multicolumn{1}{c|}{ df } & \multicolumn{1}{c|}{ Sig. } \\
\hline IP1 &, 195 & 916 &, 000 &, 871 & 916 &, 000 \\
IP2 &, 218 & 916 &, 000 &, 878 & 916 &, 000 \\
IP3 &, 227 & 916 &, 000 &, 889 & 916 &, 000 \\
IP4 &, 216 & 916 &, 000 &, 872 & 916 &, 000 \\
IP5 &, 228 & 916 &, 000 &, 839 & 916 &, 000 \\
IP6 &, 316 & 916 &, 000 &, 768 & 916 &, 000 \\
IP7 &, 182 & 916 &, 000 &, 909 & 916 &, 000 \\
IP8 &, 226 & 916 &, 000 &, 860 & 916 &, 000 \\
IP9 &, 225 & 916 &, 000 &, 881 & 916 &, 000 \\
IP10 &, 315 & 916 &, 000 &, 758 & 916 &, 000 \\
IP11 &, 348 & 916 &, 000 &, 716 & 916 &, 000 \\
IP12 &, 226 & 916 &, 000 &, 876 & 916 &, 000 \\
IP13 &, 209 & 916 &, 000 &, 902 & 916 &, 000 \\
IP14 &, 203 & 916 &, 000 &, 897 & 916 &, 000 \\
IP15 &, 179 & 916 &, 000 &, 882 & 916 &, 000 \\
IP16 &, 304 & 916 &, 000 &, 777 & 916 &, 000 \\
IP17 &, 215 & 916 &, 000 &, 891 & 916 &, 000 \\
IP18 &, 324 & 916 &, 000 &, 751 & 916 &, 000 \\
\hline
\end{tabular}

a. Lilliefors Significance Correction
Coefficients $^{\text {a }}$

\begin{tabular}{|ll|r|r|}
\hline \multirow{2}{*}{ Model } & & \multicolumn{2}{|c|}{ Collinearity Statistics } \\
\cline { 2 - 4 } & & Tolerance & \multicolumn{1}{c|}{ VIF } \\
\hline I & IP1 &, 455 & 2,199 \\
& IP2 &, 353 & 2,830 \\
& IP3 &, 502 & 1,993 \\
& IP4 &, 479 & 2,089 \\
& IP5 &, 666 & 1,503 \\
& IP6 &, 455 & 2,195 \\
& IP7 &, 789 & 1,267 \\
& IP8 &, 646 & 1,547 \\
& IP9 &, 527 & 1,896 \\
& IP10 &, 543 & 1,843 \\
& IP11 &, 477 & 2,094 \\
IP12 &, 451 & 2,219 \\
& IP13 &, 377 & 2,649 \\
& IP14 &, 427 & 2,342 \\
& IP15 &, 744 & 1,344 \\
IP16 &, 477 & 2,097 \\
IP17 &, 476 & 2,100 \\
IP18 &, 458 & 2,183 \\
\hline
\end{tabular}

a. Dependent Variable: Sujeitos 
Escala de Identidade Organizacional

\begin{tabular}{|c|c|c|c|c|c|c|c|c|c|}
\hline \multicolumn{10}{|c|}{ Descriptive Statistics } \\
\hline & $\mathrm{N}$ & Minimum & Maximum & Mean & $\begin{array}{c}\text { Std. } \\
\text { Deviation }\end{array}$ & \multicolumn{2}{|c|}{ Skewness } & \multicolumn{2}{|c|}{ Kurtosis } \\
\hline & Statistic & Statistic & Statistic & Statistic & Statistic & Statistic & Std. Error & Statistic & Std. Error \\
\hline $\mathrm{IO1}$ & 916 & 1 & 5 & 3,75 & 1,172 &,- 600 & 9,081 &,- 456 &, 161 \\
\hline 102 & 916 & 1 & 6 & 3,82 & 1,046 &,- 679 &, 081 &,- 075 & , 161 \\
\hline 103 & 916 & 1 & 5 & 4,06 & 1,017 & $-1,057$ &, 081 &, 721 & , 161 \\
\hline 104 & 916 & 1 & 5 & 4,08 & 1,053 &,- 992 &, 081 &, 296 & , 161 \\
\hline 105 & 916 & 1 & 7 & 4,11 & 1,044 & $-1,021$ & 081 &, 486 & ,161 \\
\hline 106 & 916 & 1 & 6 & 3,98 & 1,101 &,- 887 &, 081 &, 077 & , 161 \\
\hline Valid N (listwise) & 916 & & & & & & & & \\
\hline
\end{tabular}

Tests of Normality

\begin{tabular}{|l|c|c|c|c|c|c|}
\hline & \multicolumn{3}{|c|}{ Kolmogorov-Smirnov $^{\text {a }}$} & \multicolumn{3}{c|}{ Shapiro-Wilk } \\
\cline { 2 - 7 } & Statistic & df & \multicolumn{1}{c|}{ Sig. } & Statistic & \multicolumn{1}{c|}{ df } & \multicolumn{1}{c|}{ Sig. } \\
\hline IO1 &, 209 & 916 &, 000 &, 857 & 916 &, 000 \\
IO2 &, 235 & 916 &, 000 &, 873 & 916 &, 000 \\
IO3 &, 233 & 916 &, 000 &, 816 & 916 &, 000 \\
IO4 &, 272 & 916 &, 000 &, 804 & 916 &, 000 \\
IO5 &, 272 & 916 &, 000 &, 806 & 916 &, 000 \\
IO6 &, 249 & 916 &, 000 &, 824 & 916 &, 000 \\
\hline
\end{tabular}

a. Lilliefors Significance Correction

\section{Coefficients $^{\text {a }}$}

\begin{tabular}{|ll|r|r|}
\hline \multirow{2}{*}{\multicolumn{2}{|c|}{}} & \multicolumn{2}{|c|}{ Collinearity Statistics } \\
\cline { 3 - 4 } Model & & \multicolumn{1}{c|}{ Tolerance } & \multicolumn{1}{l|}{ VIF } \\
\hline 1 & IO1 &, 546 & 1,831 \\
& IO2 &, 553 & 1,807 \\
& IO3 &, 531 & 1,883 \\
& IO4 &, 341 & 2,934 \\
& IO5 &, 593 & 1,686 \\
& IO6 &, 382 & 2,619 \\
\hline
\end{tabular}

a. Dependent Variable: Sujeitos 
Escala de Desempenho profissional por Competências (Importância e Domínio)

\begin{tabular}{|c|c|c|c|c|c|c|c|c|c|}
\hline \multicolumn{10}{|c|}{ Descriptive Statistics } \\
\hline & $\mathrm{N}$ & Minimum & Maximum & Mean & $\begin{array}{c}\text { Std. } \\
\text { Deviation }\end{array}$ & \multicolumn{2}{|c|}{ Skewness } & \multicolumn{2}{|c|}{ Kurtosis } \\
\hline & Statistic & Statistic & Statistic & Statistic & Statistic & Statistic & Std. Error & Statistic & Std. Error \\
\hline COMPIIMP & 916 & 1 & 5 & 4,73 & ,562 & $-2,310$ &, 081 & 5,820 &, 161 \\
\hline COMP2IMP & 916 & 1 & 5 & 4,38 & ,771 & $-1,215$ & 081 & 1,497 & 161 \\
\hline COMP3IMP & 916 & 1 & 5 & 4,44 & ,713 & $-1,195$ & 081 & 1,574 & 161 \\
\hline COMP4IMP & 916 & 1 & 6 & 4,11 &, 813 &,- 660 & 081 &, 228 & , 161 \\
\hline COMP5IMP & 916 & 1 & 5 & 4,17 & ,796 &,- 814 & 081 & 647 &, 161 \\
\hline COMP6IMP & 916 & 1 & 5 & 4,21 & ,782 &,- 775 & 081 & ,435 &, 161 \\
\hline COMP7IMP & 916 & 1 & 5 & 4,43 & ,705 & $-1,044$ & 081 & 633 &, 161 \\
\hline COMP8IMP & 916 & 1 & 5 & 4,33 & ,728 &,- 836 & 081 & ,272 & , 161 \\
\hline COMP9IMP & 916 & 1 & 5 & 4,34 & ,757 &,- 913 & 081 & ,382 & , 161 \\
\hline COMP10IMP & 916 & 1 & 5 & 4,73 &, 552 & $-2,303$ & 081 & 6,686 & , 161 \\
\hline COMP11IMP & 916 & 1 & 5 & 4,59 & ,631 & $-1,551$ & 081 & 2,613 & , 161 \\
\hline COMP12IMP & 916 & 2 & 5 & 4,56 & ,627 & $-1,205$ &, 081 &, 830 & 161 \\
\hline COMP13IMP & 916 & 2 & 5 & 4,47 & ,650 &,- 972 & ,081 & ,362 & , 161 \\
\hline COMP14IMP & 916 & 1 & 5 & 4,43 & 643 &,- 872 &, 081 & ,736 & , 161 \\
\hline COMP15IMP & 916 & 1 & 5 & 4,35 & ,710 &,- 809 & 081 & , 179 & , 161 \\
\hline COMP16IMP & 916 & 1 & 5 & 4,42 & 675 &,- 941 & 081 & 686 &, 161 \\
\hline COMP17IMP & 916 & 2 & 5 & 4,57 & ,663 & $-1,452$ & 081 & 1,502 & , 161 \\
\hline COMP18IMP & 916 & 1 & 5 & 4,21 & ,798 &,- 753 & 081 & ,096 &, 161 \\
\hline COMP19IMP & 916 & 1 & 5 & 4,24 & ,771 &,- 884 & 081 & ,778 & , 161 \\
\hline COMP20IMP & 916 & 1 & 5 & 4,26 & 801 &,- 996 & 081 &, 853 & , 161 \\
\hline COMP2 1 IMP & 916 & 1 & 5 & 4,48 & ,673 & $-1,297$ & 081 & 2,227 & , 161 \\
\hline COMP22IMP & 916 & 1 & 5 & 4,35 & ,695 &,- 788 & 081 & ,222 &, 161 \\
\hline COMP23IMP & 916 & 1 & 5 & 4,54 & ,657 & $-1,336$ & 081 & 1,638 & , 161 \\
\hline COMP24IMP & 916 & 1 & 5 & 4,70 & ,571 & $-1,953$ & 081 & 4,017 & 161 \\
\hline COMP25IMP & 916 & 1 & 5 & 4,19 & ,785 &,- 629 &, 081 &,- 252 &, 161 \\
\hline COMP26MP & 916 & 1 & 6 & 4,67 &, 576 & $-1,798$ & 081 & 3,641 &, 161 \\
\hline COMP27IMP & 916 & 1 & 5 & 4,62 & ,611 & $-1,638$ & 081 & 3,022 &, 161 \\
\hline COMP2 8IMP & 916 & 1 & 6 & 4,45 & ,687 & $-1,119$ & 081 & 1,252 & 161 \\
\hline COMP29IMP & 916 & 1 & 5 & 4,42 & ,687 & $-1,023$ & 081 & ,969 &, 161 \\
\hline COMP30IMP & 916 & 1 & 5 & 4,54 & ,649 & $-1,282$ & 081 & 1,543 & , 161 \\
\hline Valid N (listwise) & 916 & & & & & & & & \\
\hline
\end{tabular}




\begin{tabular}{|l|c|c|c|c|c|c|}
\hline \multicolumn{7}{|c|}{ Tests of Normality } \\
\hline & \multicolumn{2}{|c|}{ Kolmogorov-Smirnov ${ }^{\mathrm{a}}$} & \multicolumn{3}{c|}{ Shapiro-Wilk } \\
\cline { 2 - 7 } & Statistic & df & Sig. & Statistic & df & Sig. \\
\hline COMP1IMP &, 466 & 916 &, 000 &, 527 & 916 &, 000 \\
COMP2IMP &, 316 & 916 &, 000 &, 748 & 916 &, 000 \\
COMP3IMP &, 338 & 916 &, 000 &, 728 & 916 &, 000 \\
COMP4IMP &, 227 & 916 &, 000 &, 832 & 916 &, 000 \\
COMP5IMP &, 231 & 916 &, 000 &, 814 & 916 &, 000 \\
COMP6IMP &, 250 & 916 &, 000 &, 810 & 916 &, 000 \\
COMP7IMP &, 335 & 916 &, 000 &, 742 & 916 &, 000 \\
COMP8IMP &, 290 & 916 &, 000 &, 778 & 916 &, 000 \\
COMP9IMP &, 301 & 916 &, 000 &, 774 & 916 &, 000 \\
COMP10IMP &, 461 & 916 &, 000 &, 539 & 916 &, 000 \\
COMP11IMP &, 397 & 916 &, 000 &, 656 & 916 &, 000 \\
COMP12IMP &, 382 & 916 &, 000 &, 688 & 916 &, 000 \\
COMP13IMP &, 345 & 916 &, 000 &, 727 & 916 &, 000 \\
COMP14IMP &, 314 & 916 &, 000 &, 745 & 916 &, 000 \\
COMP15IMP &, 297 & 916 &, 000 &, 773 & 916 &, 000 \\
COMP16IMP &, 319 & 916 &, 000 &, 750 & 916 &, 000 \\
COMP17IMP &, 402 & 916 &, 000 &, 659 & 916 &, 000 \\
COMP18IMP &, 254 & 916 &, 000 &, 809 & 916 &, 000 \\
COMP19IMP &, 254 & 916 &, 000 &, 797 & 916 &, 000 \\
COMP20IMP &, 270 & 916 &, 000 &, 790 & 916 &, 000 \\
COMP21IMP &, 343 & 916 &, 000 &, 714 & 916 &, 000 \\
COMP22IMP &, 294 & 916 &, 000 &, 770 & 916 &, 000 \\
COMP23IMP &, 375 & 916 &, 000 &, 691 & 916 &, 000 \\
COMP24IMP &, 447 & 916 &, 000 &, 576 & 916 &, 000 \\
COMP25IMP &, 250 & 916 &, 000 &, 814 & 916 &, 000 \\
COMP26MP &, 431 & 916 &, 000 &, 609 & 916 &, 000 \\
COMP27IMP &, 406 & 916 &, 000 &, 641 & 916 &, 000 \\
COMP28IMP &, 335 & 916 &, 000 &, 737 & 916 &, 000 \\
COMP29IMP &, 324 & 916 &, 000 &, 744 & 916 &, 000 \\
COMP30IMP &, 361 & 916 &, 000 &, 710 & 916 &, 000 \\
\hline
\end{tabular}

a. Lilliefors Significance Correction

\begin{tabular}{|l|c|c|}
\hline \multicolumn{4}{|c|}{ Coefficients } \\
\hline \multirow{2}{*}{ Model } \\
\hline 1 & & \multicolumn{2}{|c|}{ Collinearity $^{\text {Statistics }}$} \\
\cline { 2 - 3 } & Colerance & VIF \\
\hline COMP1IMP &, 609 & 1,642 \\
COMP2IMP &, 489 & 2,046 \\
COMP3IMP &, 475 & 2,106 \\
COMP4IMP &, 492 & 2,031 \\
COMP5IMP &, 425 & 2,352 \\
COMP6IMP &, 524 & 1,909 \\
COMP7IMP &, 502 & 1,993 \\
COMP8IMP &, 482 & 2,076 \\
COMP9IMP &, 476 & 2,102 \\
COMP10IMP &, 366 & 2,731 \\
COMP11IMP &, 416 & 2,406 \\
COMP12IMP &, 463 & 2,161 \\
COMP13IMP &, 516 & 1,939 \\
COMP14IMP &, 455 & 2,198 \\
COMP15IMP &, 463 & 2,158 \\
COMP16IMP &, 402 & 2,488 \\
COMP17IMP &, 447 & 2,239 \\
COMP18IMP &, 445 & 2,246 \\
COMP19IMP &, 427 & 2,344 \\
COMP20IMP &, 505 & 1,979 \\
COMP21IMP &, 453 & 2,209 \\
COMP22IMP &, 513 & 1,949 \\
COMP23IMP &, 501 & 1,995 \\
COMP24IMP &, 458 & 2,183 \\
COMP25IMP &, 439 & 2,276 \\
COMP26MP &, 388 & 2,579 \\
COMP27IMP &, 399 & 2,504 \\
COMP28IMP &, 409 & 2,445 \\
COMP29IMP &, 402 & 2,488 \\
COMP30IMP &, 462 & 2,166 \\
\hline
\end{tabular}

a. Dependent Variable: Sujeitos 
Descriptive Statistics

\begin{tabular}{|c|c|c|c|c|c|c|c|c|c|}
\hline & $\mathrm{N}$ & Minimum & Maximum & Mean & $\begin{array}{c}\text { Std. } \\
\text { Deviation }\end{array}$ & \multicolumn{2}{|c|}{ Skewness } & \multicolumn{2}{|c|}{ Kurtosis } \\
\hline & Statistic & Statistic & Statistic & Statistic & Statistic & Statistic & Std. Error & Statistic & Std. Error \\
\hline COMPIDOM & 916 & 1 & 5 & 3,77 &, 788 &,- 225 &, 081 &,- 091 &, 161 \\
\hline COMP2DOM & 916 & 1 & 5 & 3,51 & ,767 &,- 009 & 081 &,- 223 &, 161 \\
\hline COMP3DOM & 916 & 1 & 5 & 3,59 &, 816 &,- 123 & ,081 &,- 367 &, 161 \\
\hline COMP4DOM & 916 & 1 & 5 & 3,62 & ,803 &,- 097 & 081 &,- 236 &, 161 \\
\hline COMP5DOM & 916 & 1 & 5 & 3,54 & 841 &,- 143 & 081 &,- 306 &, 161 \\
\hline COMP6DOM & 916 & 1 & 6 & 3,79 & ,792 &,- 223 & ,081 &,- 242 &, 161 \\
\hline COMP7DOM & 916 & 1 & 5 & 3,71 &, 825 &,- 190 & ,081 &,- 329 &, 161 \\
\hline COMP8DOM & 916 & 1 & 5 & 3,71 & ,777 &,- 084 & 081 &,- 377 &, 161 \\
\hline COMP9DOM & 916 & 1 & 5 & 3,66 &, 836 &,- 218 & 081 &,- 054 &, 161 \\
\hline COMP10DOM & 916 & 1 & 5 & 4,42 & ,702 & $-1,030$ & ,081 & ,747 &, 161 \\
\hline COMP11DOM & 916 & 2 & 5 & 4,19 & ,729 &,- 524 & 081 &,- 249 &, 161 \\
\hline COMP12DOM & 916 & 1 & 5 & 4,05 & ,746 &,- 404 & 081 &,- 174 &, 161 \\
\hline COMP13DOM & 916 & 2 & 5 & 4,23 & ,743 &,- 583 & 081 &,- 349 &, 161 \\
\hline COMP14DOM & 916 & 1 & 5 & 4,03 & ,746 &,- 405 & ,081 &,- 091 &, 161 \\
\hline COMP15DOM & 916 & 1 & 6 & 3,86 & ,774 &,- 310 & ,081 &,- 008 &, 161 \\
\hline COMP16DOM & 916 & 1 & 5 & 3,93 & ,791 &,- 494 & 081 & ,297 &, 161 \\
\hline COMP17DOM & 916 & 1 & 5 & 3,93 & ,754 &,- 254 & ,081 &,- 296 &, 161 \\
\hline COMP18DOM & 916 & 1 & 5 & 3,76 & ,803 &,- 172 & 081 &,- 399 &, 161 \\
\hline COMP19DOM & 916 & 1 & 5 & 3,83 & ,778 &,- 241 & ,081 &,- 144 &, 161 \\
\hline COMP20DOM & 916 & 1 & 5 & 3,94 & ,785 &,- 298 & 081 &,- 406 &, 161 \\
\hline COMP21DOM & 916 & 1 & 5 & 4,09 & ,768 &,- 627 & ,081 & , 480 &, 161 \\
\hline COMP22DOM & 916 & 1 & 5 & 3,98 & ,753 &,- 311 & 081 &,- 268 &, 161 \\
\hline COMP23DOM & 916 & 1 & 5 & 4,08 & ,778 &,- 571 & ,081 & , 172 &, 161 \\
\hline COMP24DOM & 916 & 1 & 6 & 4,28 & ,731 &,- 694 & 081 & ,031 &, 161 \\
\hline COMP25DOM & 916 & 1 & 5 & 3,83 & ,766 &,- 161 & 081 &,- 290 &, 161 \\
\hline COMP26DOM & 916 & 1 & 6 & 4,36 & ,713 &,- 928 & ,081 & 800 &, 161 \\
\hline COMP27DOM & 916 & 1 & 5 & 4,27 & ,741 &,- 820 & 081 &, 585 &, 161 \\
\hline COMP2 8DOM & 916 & 2 & 5 & 3,99 & ,783 &,- 277 & ,081 &,- 603 &, 161 \\
\hline COMP29DOM & 916 & 1 & 5 & 4,15 & ,788 &,- 648 & 081 &, 052 &, 161 \\
\hline COMP30DOM & 916 & 1 & 5 & 4,30 & ,771 & $-1,054$ & ,081 & 1,265 &, 161 \\
\hline Valid N (listwise) & 916 & & & & & & & & \\
\hline
\end{tabular}

Tests of Normality

\begin{tabular}{|l|c|c|c|c|c|c|}
\hline & \multicolumn{3}{|c|}{ Kolmogorov-Smirnov $^{\text {a }}$} & \multicolumn{3}{|c|}{ Shapiro-Wilk } \\
\cline { 2 - 7 } & Statistic & \multicolumn{1}{|c|}{ df } & Sig. & Statistic & df & Sig. \\
\hline COMP1DOM &, 257 & 916 &, 000 &, 856 & 916 &, 000 \\
COMP2DOM &, 245 & 916 &, 000 &, 858 & 916 &, 000 \\
COMP3DOM &, 244 & 916 &, 000 &, 872 & 916 &, 000 \\
COMP4DOM &, 234 & 916 &, 000 &, 870 & 916 &, 000 \\
COMP5DOM &, 232 & 916 &, 000 &, 879 & 916 &, 000 \\
COMP6DOM &, 255 & 916 &, 000 &, 865 & 916 &, 000 \\
COMP7DOM &, 242 & 916 &, 000 &, 871 & 916 &, 000 \\
COMP8DOM &, 250 & 916 &, 000 &, 859 & 916 &, 000 \\
COMP9DOM &, 232 & 916 &, 000 &, 872 & 916 &, 000 \\
COMP10DOM &, 324 & 916 &, 000 &, 746 & 916 &, 000 \\
COMP11DOM &, 236 & 916 &, 000 &, 812 & 916 &, 000 \\
COMP12DOM &, 256 & 916 &, 000 &, 834 & 916 &, 000 \\
COMP13DOM &, 252 & 916 &, 000 &, 806 & 916 &, 000 \\
COMP14DOM &, 265 & 916 &, 000 &, 837 & 916 &, 000 \\
COMP15DOM &, 268 & 916 &, 000 &, 852 & 916 &, 000 \\
COMP16DOM &, 268 & 916 &, 000 &, 847 & 916 &, 000 \\
COMP17DOM &, 263 & 916 &, 000 &, 844 & 916 &, 000 \\
COMP18DOM &, 251 & 916 &, 000 &, 864 & 916 &, 000 \\
COMP19DOM &, 256 & 916 &, 000 &, 853 & 916 &, 000 \\
COMP20DOM &, 250 & 916 &, 000 &, 848 & 916 &, 000 \\
COMP21DOM &, 255 & 916 &, 000 &, 826 & 916 &, 000 \\
COMP22DOM &, 261 & 916 &, 000 &, 841 & 916 &, 000 \\
COMP23DOM &, 247 & 916 &, 000 &, 832 & 916 &, 000 \\
COMP24DOM &, 267 & 916 &, 000 &, 798 & 916 &, 000 \\
COMP25DOM &, 255 & 916 &, 000 &, 849 & 916 &, 000 \\
COMP26DOM &, 296 & 916 &, 000 &, 772 & 916 &, 000 \\
COMP27DOM &, 258 & 916 &, 000 &, 795 & 916 &, 000 \\
COMP28DOM &, 238 & 916 &, 000 &, 849 & 916 &, 000 \\
COMP29DOM &, 231 & 916 &, 000 &, 823 & 916 &, 000 \\
COMP30DOM &, 279 & 916 &, 000 &, 775 & 916 &, 000 \\
\hline
\end{tabular}

a. Lilliefors Significance Correction

\begin{tabular}{|ll|c|c|}
\hline \multicolumn{4}{|c|}{ Coefficients $^{\text {a }}$} \\
\hline \multirow{2}{*}{ Model } & & Collinearity $^{\prime}$ & Statistics \\
\cline { 2 - 3 } & & Tolerance $^{\prime}$ & VIF \\
\hline COMP1DOM &, 629 & 1,590 \\
COMP2DOM &, 571 & 1,751 \\
COMP3DOM &, 495 & 2,021 \\
COMP4DOM &, 536 & 1,867 \\
COMP5DOM &, 485 & 2,062 \\
COMP6DOM &, 539 & 1,856 \\
COMP7DOM &, 480 & 2,084 \\
COMP8DOM &, 475 & 2,107 \\
COMP9DOM &, 519 & 1,928 \\
COMP10DOM &, 473 & 2,112 \\
COMP11DOM &, 428 & 2,339 \\
COMP12DOM &, 468 & 2,135 \\
COMP13DOM &, 536 & 1,867 \\
COMP14DOM &, 469 & 2,131 \\
COMP15DOM &, 479 & 2,089 \\
COMP16DOM &, 439 & 2,279 \\
COMP17DOM &, 495 & 2,020 \\
COMP18DOM &, 499 & 2,005 \\
COMP19DOM &, 498 & 2,007 \\
COMP20DOM &, 582 & 1,717 \\
COMP21DOM &, 491 & 2,036 \\
COMP22DOM &, 501 & 1,995 \\
COMP23DOM &, 532 & 1,881 \\
COMP24DOM &, 539 & 1,856 \\
COMP25DOM &, 538 & 1,860 \\
COMP26DOM &, 406 & 2,461 \\
COMP27DOM &, 423 & 2,366 \\
COMP28DOM &, 511 & 1,957 \\
COMP29DOM &, 413 & 2,424 \\
COMP30DOM &, 447 & 2,235 \\
\hline
\end{tabular}

a. Dependent Variable: Sujeitos 


\section{APÊNDICE C}

\section{Resultados das Análises Preliminares de Adequação dos Dados para a Análise}

\section{Multivariada.}

Para cada escala, apresenta-se as estatísticas multivariadas, especificamente as análises de skewness (assimetria) e Kurtosis (curtose) e pelo teste de Mardia.

Escala de Valores Organizacionais

\begin{tabular}{|c|c|c|c|c|c|c|}
\hline \multicolumn{7}{|c|}{ Assessment of normality (Group number 1) } \\
\hline Variable & $\min$ & $\max$ & skew & c.r. & kurtosis & c.r. \\
\hline VO37 & ,000 & 10,000 &,- 326 & $-2,824$ & -659 & $-2,856$ \\
\hline VO36 &, 000 & 10,000 &,- 521 & $-4,513$ &,- 596 & $-2,582$ \\
\hline VO5 &, 000 & 10,000 &,- 276 & $-2,391$ &,- 773 & $-3,350$ \\
\hline VO13 &, 000 & 10,000 &,- 687 & $-5,955$ & -.257 & $-1,114$ \\
\hline VO21 &, 000 & 10,000 &,- 274 & $-2,380$ &,- 942 & $-4,082$ \\
\hline $\mathrm{VO} 24$ &, 000 & 10,000 &,- 252 & $-2,184$ &,- 827 & $-3,585$ \\
\hline $\mathrm{VO} 25$ &, 000 & 10,000 &,- 164 & $-1,426$ & -.834 & $-3,616$ \\
\hline VO12 &, 000 & 10,000 &,- 239 & $-2,070$ & $-1,205$ & $-5,225$ \\
\hline $\mathrm{VO} 22$ &, 000 & 10,000 &,- 663 & $-5,750$ & -.249 & $-1,078$ \\
\hline VO30 &,- 225 & 10,000 &,- 097 &,- 837 & $-1,412$ & $-6,120$ \\
\hline VO23 &, 000 & 10,000 &,- 884 & $-7,667$ &, 254 & 1,099 \\
\hline $\mathrm{VO} 27$ &, 000 & 10,000 &,- 771 & $-6,687$ &, 024 &, 106 \\
\hline VO29 &, 000 & 10,000 &,- 829 & $-7,184$ &, 355 & 1,540 \\
\hline VO26 &, 000 & 10,000 &,- 362 & $-3,135$ &,- 599 & $-2,596$ \\
\hline VO34 &, 000 & 10,000 &,- 451 & $-3,914$ &,- 355 & $-1,538$ \\
\hline $\mathrm{VO} 3$ &, 000 & 10,000 &,- 438 & $-3,798$ &,- 704 & $-3,050$ \\
\hline VO35 &, 000 & 10,000 &,- 603 & $-5,232$ &,- 696 & $-3,018$ \\
\hline VO38 &, 000 & 10,000 &,- 696 & $-6,032$ &,- 629 & $-2,727$ \\
\hline Multivariate (Mardia) & & & & & 85,402 & 33,796 \\
\hline
\end{tabular}


Escala de Práticas Organizacionais

\begin{tabular}{|c|c|c|c|c|c|c|}
\hline \multicolumn{7}{|c|}{ Assessment of normality (Group number 1) } \\
\hline Variable & $\min$ & $\max$ & skew & c.r. & kurtosis & $\overline{c . r}$. \\
\hline$\overline{\mathrm{PO} 6}$ & 1,000 & 5,000 &, 001 &, 011 &, 017 & 9,076 \\
\hline PO19 & 1,000 & 5,000 &,- 002 &,- 015 &,- 253 & $-1,096$ \\
\hline PO18 & 1,000 & 5,000 &,- 209 & $-1,812$ &,- 144 &,- 623 \\
\hline PO4 & 1,000 & 5,000 &,- 142 & $-1,232$ &,- 212 &,- 918 \\
\hline $\mathrm{PO} 12$ & 1,000 & 5,000 &,- 215 & $-1,865$ & $-1,065$ & $-4,619$ \\
\hline $\mathrm{PO} 29$ & 1,000 & 5,000 &,- 149 & $-1,295$ &,- 231 & $-1,001$ \\
\hline $\mathrm{PO} 26$ & 1,000 & 5,000 &,- 162 & $-1,402$ &,- 307 & $-1,332$ \\
\hline $\mathrm{PO} 23$ &, 324 & 5,000 & 037 &, 324 &,- 523 & $-2,267$ \\
\hline PO11 & 1,000 & 5,000 &, 304 & 2,637 &,- 801 & $-3,470$ \\
\hline $\mathrm{PO} 2$ & 1,000 & 5,000 & ,002 & 014 &,- 212 &,- 919 \\
\hline $\mathrm{PO} 3$ & 1,000 & 5,000 &,- 182 & $-1,581$ &,- 451 & $-1,956$ \\
\hline PO37 & 1,000 & 5,000 &,- 173 & $-1,498$ & 049 & .211 \\
\hline PO35 & 1,000 & 5,000 &,- 012 &,- 106 &,- 058 &,- 251 \\
\hline PO45 & 1,000 & 5,000 &,- 064 &,- 558 &, 157 & ,682 \\
\hline $\mathrm{PO} 43$ & 1,000 & 5,000 &,- 215 & $-1,861$ &, 057 & .246 \\
\hline PO38 & 1,000 & 5,000 &, 332 & 2,881 &,- 596 & $-2,585$ \\
\hline PO30 & 1,000 & 5,000 & ,291 & 2,520 &,- 482 & $-2,090$ \\
\hline PO33 & 1,000 & 5,000 &, 227 & 1,964 &,- 633 & $-2,745$ \\
\hline PO34 & 1,000 & 5,000 & ,208 & 1,803 &,- 753 & $-3,266$ \\
\hline PO32 & 1,000 & 5,000 &, 169 & 1,469 &,- 459 & $-1,990$ \\
\hline $\mathrm{PO} 25$ & 1,000 & 5,000 &, 114 &, 985 &,- 424 & $-1,838$ \\
\hline PO9 & 1,000 & 5,673 &, 160 & 1,390 &,- 815 & $-3,533$ \\
\hline PO36 & 1,000 & 5,000 &,- 003 &,- 025 &,- 077 & -333 \\
\hline PO41 & 1,000 & 5,000 & .295 & 2,561 &,- 504 & $-2,183$ \\
\hline $\mathrm{PO} 21$ & , 195 & 5,000 &, 160 & 1,389 &,- 802 & $-3,475$ \\
\hline PO15 & 1,000 & 5,000 &, 043 &, 374 &,- 676 & $-2,930$ \\
\hline Multivariate (Mardia) & & & & & 114,091 & 31,749 \\
\hline
\end{tabular}

Escala de Identidade Profissional

\begin{tabular}{lrrrrrr}
\hline \multicolumn{7}{c}{ Assessment of normality (Group number 1) } \\
\hline Variable & min & max & skew & c.r. & kurtosis & c.r. \\
\hline IP12 & 1,000 & 5,000 &,- 586 & $-5,081$ &, 265 & 1,147 \\
IP13 & 1,000 & 5,000 &,- 224 & $-1,942$ &,- 399 & $-1,729$ \\
IP14 & 1,000 & 5,000 &,- 291 & $-2,523$ &,- 139 &,- 602 \\
IP6 &, 568 & 5,000 & 1,111 & 9,634 &, 345 & 1,494 \\
IP10 &, 858 & 5,000 & 1,073 & 9,306 &, 119 &, 518 \\
IP18 &,- 356 & 5,000 & 1,064 & 9,228 &, 018 &, 078 \\
IP2 & 1,000 & 5,000 &,- 459 & $-3,978$ &,- 366 & $-1,588$ \\
IP3 & 1,000 & 5,000 &,- 458 & $-3,970$ &,- 176 &,- 765 \\
IP17 & 1,000 & 5,000 &,- 412 & $-3,574$ &,- 389 & $-1,687$ \\
Multivariate (Mardia) & & & & & 26,735 & 20,175 \\
\hline
\end{tabular}


Escala de Identidade Organizacional

\begin{tabular}{lrrrrrr}
\hline \multicolumn{7}{c}{ Assessment of normality (Group number 1) } \\
\hline Variable & min & max & skew & c.r. & kurtosis & c.r. \\
\hline IO1 & 1,000 & 5,000 &,- 645 & $-5,596$ &,- 312 & $-1,352$ \\
IO2 & 1,000 & 5,000 &,- 614 & $-5,327$ &,- 205 &,- 889 \\
IO3 & 1,000 & 5,000 & $-1,021$ & $-8,848$ &, 733 & 3,177 \\
IO4 & 1,000 & 5,648 &,- 978 & $-8,482$ &, 361 & 1,566 \\
IO5 & 1,000 & 5,000 & $-1,080$ & $-9,365$ &, 592 & 2,565 \\
IO6 & 1,000 & 6,255 &,- 838 & $-7,267$ &, 114 &, 496 \\
Multivariate & & & & & 14,846 & 16,089 \\
\hline
\end{tabular}

Escala de Desempenho Competente

\begin{tabular}{lrrrrrr}
\hline \multicolumn{7}{c}{ Assessment of normality (Group number 1) } \\
\hline Variable & min & max & skew & c.r. & kurtosis & c.r. \\
\hline COMP29DOM & 1,000 & 5,298 &,- 662 & $-5,736$ &, 056 &, 241 \\
COMP20DOM & 1,000 & 5,000 &,- 390 & $-3,382$ &,- 173 &,- 752 \\
COMP21DOM & 1,000 & 5,000 &,- 557 & $-4,827$ &,- 006 &,- 028 \\
COMP22DOM & 1,000 & 5,000 &,- 359 & $-3,114$ &,- 235 & $-1,017$ \\
COMP23DOM & 1,000 & 5,000 &,- 558 & $-4,839$ &, 108 &, 469 \\
COMP24DOM & 1,000 & 5,000 &,- 795 & $-6,893$ &, 224 &, 971 \\
COMP25DOM & 1,000 & 5,270 &,- 260 & $-2,253$ &,- 202 &,- 875 \\
COMP26DOM & 1,000 & 5,000 &,- 997 & $-8,643$ & 1,293 & 5,607 \\
COMP27DOM & 1,000 & 5,000 &,- 806 & $-6,988$ &, 598 & 2,591 \\
COMP1DOM & 1,000 & 5,000 &,- 108 &,- 933 &,- 054 &,- 232 \\
COMP2DOM & 1,000 & 5,000 &, 005 &, 041 &,- 214 &,- 928 \\
COMP3DOM & 1,000 & 5,000 &,- 198 & $-1,713$ &,- 258 & $-1,118$ \\
COMP4DOM & 1,000 & 5,000 &,- 199 & $-1,723$ &,- 202 &,- 877 \\
COMP5DOM & 1,000 & 5,000 &,- 085 &,- 736 &,- 373 & $-1,615$ \\
COMP6DOM & 1,000 & 5,435 &,- 236 & $-2,049$ &,- 272 & $-1,181$ \\
COMP7DOM & 1,000 & 5,000 &,- 152 & $-1,318$ &,- 342 & $-1,483$ \\
COMP8DOM & 2,000 & 5,000 &,- 010 &,- 084 &,- 420 & $-1,821$ \\
COMP9DOM & 1,000 & 5,000 &,- 184 & $-1,594$ &,- 121 &,- 526 \\
Multivariate (Mardia) & & & & & 54,371 & 21,516 \\
\hline
\end{tabular}

Nota: COMP20DOM a COMP29DOM referem-se às competências comportamentais (DCC) e os demais às competências técnicas (DCT). 